

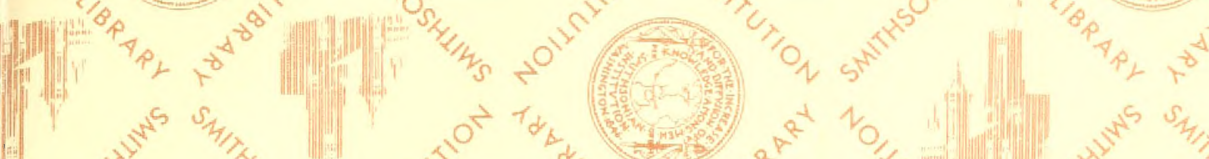

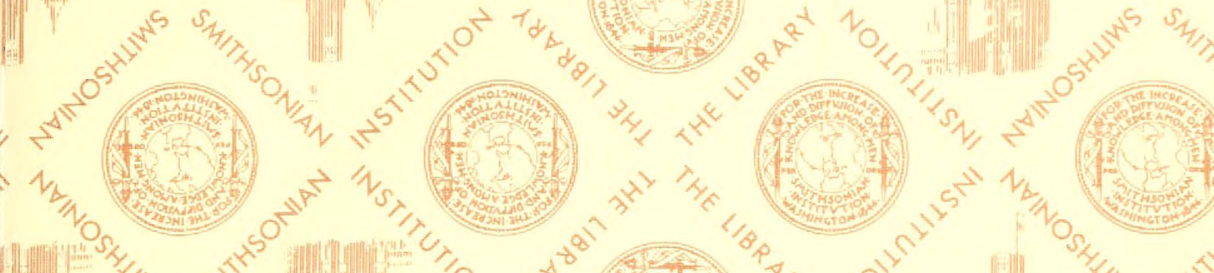
(1)

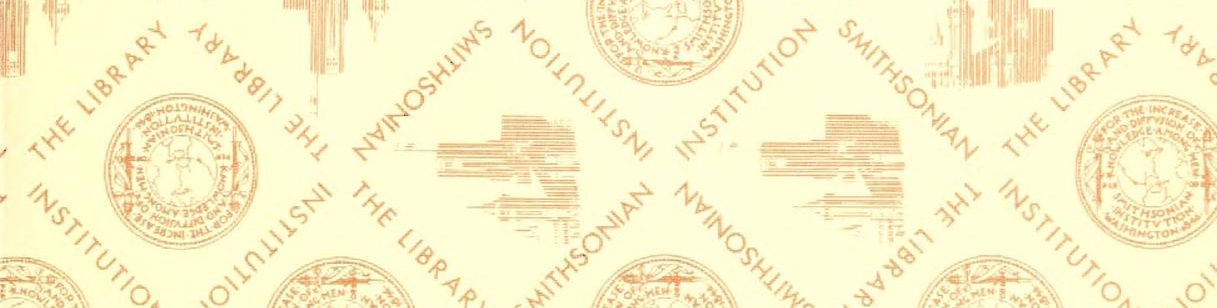
24)

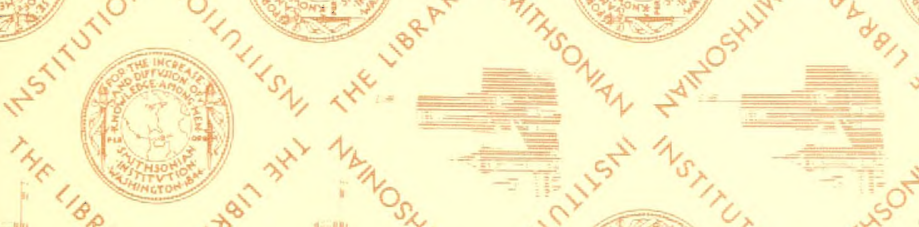
[III) (1.7)

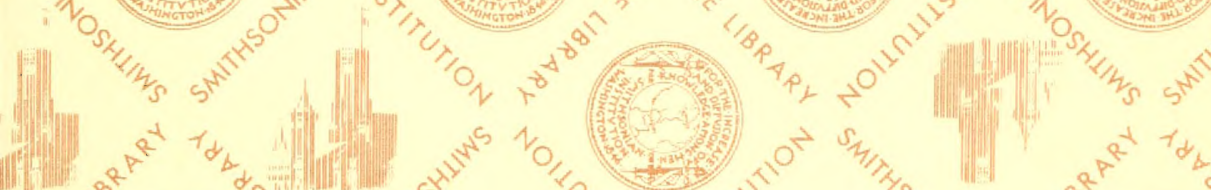

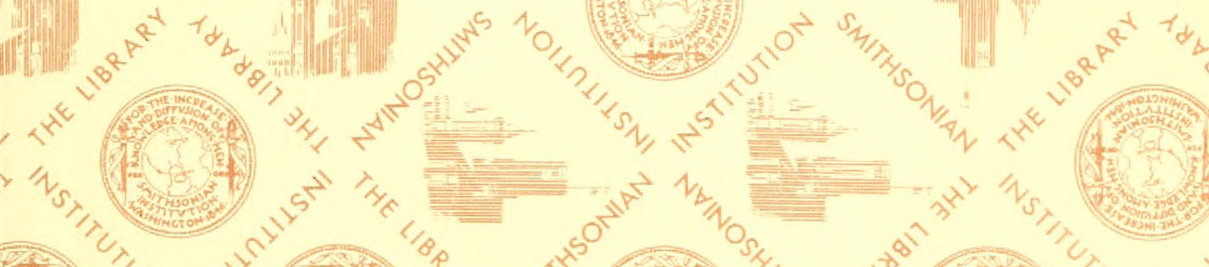

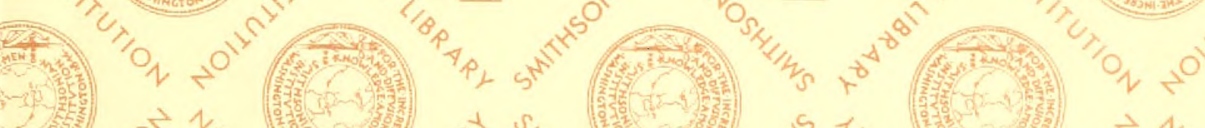
(2iv) 10 (1) 



$$
D-3
$$



ILLUSTRATED MANUAL OF BRITISH BIRDS. 



\section{B R I T IS H B I RDS。}

BY

HOWARD SAUNDERS, F.L.S., F.Z.S., \&C.

EDITOR OF THE THIRD AND FOURTH VOLUMES OF "YARRELL"S HISTORY OF BRITISH BIRDS," FOURTH EDITION.

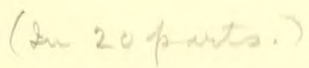

WITH ILLUSTRATIONS OF NEARLY EVERY SPECIES.

\section{LIBRARIES}
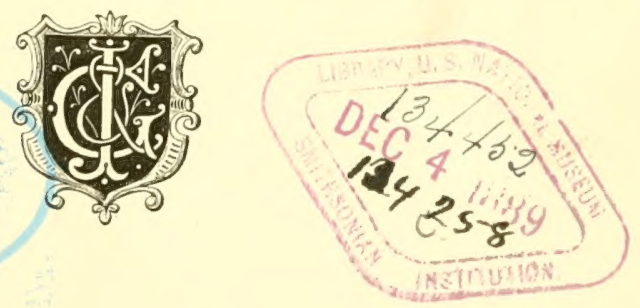

LONDON :

GURNEY AND JACKSON, I, PATERNOSTER ROW. (SUCCESSORs to Mr. Van VOorst.) 1889. 
LONDON :

PRINTED BY WOODFALL AND KINDER, 70 TO 76 , LONG ACRE, W.C. 


\section{PREFACE.}

THE plan of a work in which exactly two pages are devoted to each species, may justly be called Procrustean ; and, unfortunately for the author, the limited space at his disposal has often been encroached upon owing to the leneth of an engraving, whereas extension of the text has rarely been called for. Little idea, for instance, can be formed of the labour involved in an article like that on the Crossbill, wherein the necessary consideration of the distinctive features of several local races increased the difficulty of sketching briefly the history of a remarkable bird. In this and similar cases, when four lines in excess meant as many hours of hard work in condensing, the writer has sometimes been tempted-in the interest of his readers as well as in his own-to deviate from the original scheme; yet any such concession must necessarily have led to an increase in the bulk and the expense of the work. Even now, the low price is due to the fact that the publishers own the blocks from which the illustrations were struck for the four editions of Yarrell's 'British Birds'; though to these have been added wood-cuts of many recent wanderers to Great Britain, such as the Isabelline, Black. throated and Desert Wheatears, the Barred Warbler, Wall-Creeper, Needle-tailed Swift, Lesser Kestrel, Killdeer and Sociable Plovers, and Mediterranean Black-headed Gull; while fresh engravings have taken the place of the unsatisfactory originals of the Marsh-Harrier, Gos-Hawk, Merlin and Great Auk. Great liberality has also been shown by the publishers in placing no restriction on alterations whenever the slightest improvement was thercby attainable. For example, a scrap of information, obtained by mere chance, led to the re-writing of the article on the Blue-throat at the last moment, and that too for reasons which nine in ten of my readers might, perhaps, consider inadequate; the tenth, however, would appreciate the need for strict accuracy, and it is his intelligent approbation that I have striven to deserve. 
Three Maps have been added, as likely to be of use for reference, especially to the traveller. The first of these shows the comparative elevation of the land in the Lnited Kingdom and the depth of the surrounding seas; and, although on a small scale, it will serve as a guide to the relative positions of the various groups of islands, respecting some of which rather rague ideas appear to be entertained. It may also remind the reader that, owing to the indentations of our coast, very few places in the British Islands are fifty miles distant in a straight line from tidal or brackish water : a fact which exercises an inportant influence on our climate-and consequently on our bird-life-during the winter months, and may well be contrasted with the conditions prevailing over Continental areas. 'The North Polar Chart will, I trust, be of assistance in estimating the range of the birds which breed in the Arctic regions. As regards orthography, I have persistently run counter to custom in two instances -Bering for Behring and spitsbergen for Spitzbergen, for the following reasons. Vitus Bering was a Dane, born in Jutland about I680, and the discoveries which have immortalized him were made when in the service of Russia; while Spitsbergen was so written by the Dutch, who were the first to give an account of that island. It seems undesirable to disguise the above facts by copying the spelling of German cartographers.

The study of Migration is now pursued throughout the civilized world, and has already become surrounded by a literature of its own, far too voluminous for notice here; indeed we are now overwhelmed with plausible theories out of all proportion to the scanty amount of solid facts accumulated. Meanwhile it is satisfactory to note the great interest that has been awakened among the keepers of our lighthouses and lightships, owing to the publication of their schedules in the annual Migration Reports, which have been drawn up by a Committee of the British Association for the last ten years; and through them considerable addition has already been made to our knowledge of the habits of wandering species as well as to that of the regular lines of flight adopted by birds in general. The impetus given to this study by the researches of Mr. H. Gätke of Heligoland cannot be orer-estimated, and some valuable papers by various authors have appeared during the last five years in the Austro-Hungarian 'Ornis.'

The birds considered as Eritish in this work are $3^{6} 7_{7}$ in number, exclusive of sereral forms-duly noticed-respecting which there are conflicting opinions. The species which have been ascertained to breed within the United Kingdoni during the present century 
may be taken as 200 ; about 70 non-breeding wanderers have occurred fewer than six times, and 59 others are more or less infreruent visitors: while is species annually make their appearance on migration or during the colder months, in srome portion of our long, narrow group of islands or the surrounding waters.

Owing to the necessity of compression I have had frequent occa sion to regret the imposibility of mentioning the names of many authorities for much and varied information, and even now I fear that some may have been accidentally omitted. My thanks-which cannot be apportioned-are rendered to I.t.-Col. H. M. Drummond-Hay, Col. H. W. Feilden, Lt.-Col. Irby, the Lord Lilford. the Rer. H. A. Iacpherson, Professor Newton, Sir John II. P. Campbell Orde, Col. E. I)elmé Radcliffe, Capt. S. (x. Reid, Messrs. Aplin. R. M. Barrington, E. Bidwell, G. Bolam, E. Booth, Abel and A. C. Chapman, W: Eagle (larke, John Cordeaux, H. E. Dresier, Henry Evans (Derby), William Erans (Edinburgh), H. Giithe, I. H. Ciurney jun., I. E. Harting, R. J. Howard, A. G. More, E. C. Phillips, W. H. St. Quintin, H. Seebohm, R. Service (Dumfries), (i. Sim (.Iberdeen), R. Bowdler Sharpe, Cecil smith. Thomas Southwell, R. I. Ussher. Robert Warren, and John Young: while, in addition to providine many details respecting distribution, Messrs. Harvie-Brown and Buckley (through their courteous publisher. M[r. D). Douglas of Edinburgh) allowed me the great advantage of consulting the adrance-sheets of their "Fauna of the Outer Hebrides. Beyond all, I am indebted to . Mr. A. H. Evans of Cambridge, who has gone over the proof-sheets, arguing and threshing-out points on which our experiences differed, suggesting alterations in phraseology, and rendering infinite assistance. In a work of the present nature an author is necessarily indebted in no small degree to the experiences of others : and, far from captiously criticizing the writings of predecessors, each successive compiler should remember how much is due to previous and often unacknowledged labours.

H. S.

7. Radnor Place, Hyde Park, $W$. Ifth October, ISS9. 



\section{INTRODUCTION.}

THE scientific arrangement followed in this work is mainly in accordance with that of 'The List of British Birds compiled by' a Committee of the British Ornithologists' Lnion,' in which arain the sequence is almost identical with that in Mr. I)resser's 'Birds of Europe. There may be differences of opinion respecting the relatic' position of some of the Families which make up the (Order PAsseres, but nearly all modern systematists in Europe and America are agreed that the highest arian development is attained in that Order; the Passeres therefore-being the most specialized of birds - should occupy the first place in a descendinis arrangement (such as the one set forth by Mr. P. L. Sclater in 'The Ibis' for I 880 and widely adopted in the Old World), or the last in a scheme of ascension from the lowest and most reptilian birds (which finds farour in the Lnited States). Is regards the Order Accipitres-which formerly headed the list - there is strong evidence of its affinity with the Herodiones, and any wide separation of the Tultures from the Storks appears to be inconsistent with the teachings of modern anatomical research; whereas, by following the highly-sanctioned scheme of commencing with the Passeres, we at least make some approach to uniformity of system. To that end I have suburdinated my own views to those of the majority of the B.(). L . Committee respecting the positions of the Alawdide and the Corride in that Order, as well as on some other unessential points.*

* A large portion of a notice of Pts. i.-iv. in 'The Zoologist' is devoted to calling me to account for having departed from the arrangement adopted in the

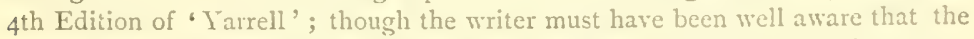
above work-comnenced in $I \$ 7 I$-did not reach my hands until the latter part of $\mathbf{1} 88_{2}$, and that, as editor, I was in a great measure constrained to follow the order adopted by the original author. On the other hand, a very competent critic of my portion of 'Tarrell,' while admitting the dificulties of the position, contended-in 'Nature'-that I ought to have boldly followed up the Picarix with the Steganopodes, Herodiones and Anseres, instead of the Columbr ! 
It must be remembered that this work is merely a Manual, intended to convey as much information up to date as may be practicable in one rolume; and it would be foreign to my purpose to increase its bulk by a treatise on the Orders and Families of Birds: the characteristics of the Genera nevertheless are given at some length below, although as briefly as is consistent with lucidity. The beginner will, however, do well to bear in mind that although systematists may be fairly agreed as regards the components of the Orders and Families, much diversity of opinion exists respecting the validity of many of the Genera which have been proposed and even adopted; nor is this surprising, for, after all, a generic name is mainly - and often purely - a matter of convenience. According to the Rules for Nomenclature-known as the Stricklandian Code - a genus should be based upon some structural character, but pattern of coloration, general habits \&c. have often been allowed to carry weight when anatomical distinctions have proved insufficient to attain the desired end.

The plan of giving a systematic sketch of the Genera in an Introduction, and not in the body of the work, was suggested by the Rev. C. A. Johns' 'British Birds in their Haunts,' an excellent treatise on our commoner species at the time of its publication (1867), though now out of date.

\section{Order PASSERES.}

Family TURDIDE.

Subfamily TURDINÆ.

(Young in first plumage differ from adults in having the upper and under parts spotted.)

TURdus, Linncus. - Bill moderate, straight, convex above; point of the upper mandihle compressed, notched and slightly decurved; gape furnished with a few hairs. Nostrils basal, lateral, oval, partly closed by a membrane. Wings with the first or 'bastard' quill very short; the second shorter than the third or fourth, which are generally the longest. Tail rather long. Tarsus longer than the middle toe; outer toe connected with the middle toe at the base (p. I).

Mon'ícola, F. Boie.-Bill stout, straight, the ridge arched towards the point; gape almost hairless. Nostrils basal, round, partly covered with hairs. Wings moderate; the first quill short, the second a little shorter than the third, which is longest. Feet moderately stout. Tail short and even (p. I7). 
Saxicola, Bechstein.-Bill straight, broad at the base; the upper mandible receding towards the forehead, compressed towards the tip, which is decurved and more or less indented. Nostrils basal, supernal and oval. Gape with a few hairs. Wings with the first quill very short, the third or fourth the longest; coverts and scapulars short. Tarsus long, covered in front by one long scale, to which succeed two or three shorter scutella; the outer toe partly united to the middle toe; hind claw short, strong and curved (p, I9).

Pratricola, K. L. Koch.-Bill shorter and broader than in Saxicola; bristles at the gape strongly developed. Wings and tail rather short (p. 27).

RuTicilla, C. L. Brehm.-Bill slender, compressed towards the point, a little deflected and very slightly emarginated; gape with tolerably large bristles. Nostrils basal, supernal and nearly round. Wings moderate; the first quill short; the second equal to the sixth; the third, fourth and fifth, nearly equal, and one of them the longest. Legs slencler, the tarsus longer than the middle toe, and covered in front by a single scale and three inferior scutelle (p. 3i).

Cyanecula, C. L. Brothm. - Differs from the above in having few and small bristles at the gape, four inferior scutellae on the tarsus, and a short middle toe. Practically this genus is based on the blue colour of the throat, and upon the desirability of separating the members of this little group from the Redstarts (p. 35).

ERITHacus, G. Cuvier:-Bill narrow and depressed at the base, inflected towards the point, the upper mandible slightly notched. Nostrils basal, lateral and oval. Wings rounded; the first quill only half as long as the second, which is shorter than the third; the fourth, fifth and sixth nearly equal and longest. Legs long and slender; the tarsi with a single scale in front and three inferior scutellx; the outer toe a little longer than the inner, and united at its base to the middle toe ; the hind toe longer and stronger than the others. Plumage generally soft (p. 37).

DAUlias, F. Boie.-Bill moderate, straight; the tip slightly deflected and emarginated. Nostrils basal, supernal and round. Wings moderate; the first quill very short, the second longer than the fifth, the third the longest in the wing. Tail rounded. Tarsus long and s!ender, covered in front by a single scale and four inferior scutelle; toes long; claws rather short (p. 39).

\section{Subfamily Sxlviñe.}

(Young on leaving the nest differ very slightly in colour from the adults.)

SyLYiA, Scopoli.-Bill rather stout, short, not very broad at base; upper mandible decurved from the middle towards the point, which is slightly emarginated; nostrils basal, lateral, oval and exposed; gape furnished with bristles. Wings moderate; the first quill very short. Tail of twelve feathers, generally rounded. Legs with the tarsus scaled in front and longer than the middle toe; toes and claws short (p. $4 \mathrm{x}$ ).

REgulus, G. Cuvier.-Bill slender, straight, the edges dilated at the base, compressed towards the point, which is notched. Nostrils basal, supernal and oval, covered by a single bristly feather directed forwards; the internasal ridge stout; the gape beset with hairs. Wings rather long; the first quill nearly half the length of the second, the fourth the longest. Tail of twelve pointed feathers, slightly forked. Tarsus slender and rather long, covered 
in front by a single scale; toes moderate, the outer and middle toes joined at their base; claws much curved (p. 55).

Phylloscopus, F. Boic.-Bill slender, rather short, upper mandible decurved from the middle and compressed towards the tip, which is very slightly notched ; nostrils basal, lateral, oblong and partly operculate, the membrane clothed with small bristle-tipped feathers, the internasal ridge very thin; gape beset with hairs. Wings rather long; the first quill comparatively large, the third or fourth being the longest. Tail of twelve feathers, slightly forked. Tarsus scaled in front and rather long, as are also the toes; claws curved (p. 59).

AÉdos, F. Boie -Bill long and strong, with the culmen curved and much compressed at the tip, hardly notched; nostrils supernal, small and oval; the gape without bristles. Wings with the first quill short, the second nearly equal to the third and fourth, which are longest. Tail long and rounded. Tarsi long, with broad scales in front; toes short, the inner nearly as long as the outer; clars small (p. 67).

Hyolais, C. L. Brehm.--Bill stout, very wide at the base, the edges straight, somewhat compressed towards the tip, which is slightly emarginated. Nostrils basal, oblique, oval and exposed. Wings rather long and pointed, the first quill very short, the third usually the longest. Tail moderate; rounded, square, or slightly forked. Tarsi short; feet small; the claws short but much curved (p. 69).

Acrocephalus, F. A. Naumam.-Bill more or less straight, with the culmen elevated, wide at the base, compressed towards the tip, and slightly emarginated; the edges of the lower mandible inflected; nostrils basal, oblique, oval and exposed; bristles at the gape moderately developed. Forehead narrow and depressed. Wings rather short; the first quill minute, the third generally longest. Tail rounded and rather long. Legs long; feet large and stout, the hind toe strong; claws long and moderately curved (p. 7I).

LocUstella, Kaup.-Differs from the above chiefly in having a more rounded tail and longer under tail-coverts. Prof. Newton states that the tendons of the tibial muscles are strongly ossified in this genus (p. $8 \mathrm{I}$ ).

\section{Subfamily ACCENTORINE.}

ACCExtor, Bechstin.-Bill strong, broad at the base, rather conical ; the upper mandible overlapping the lower and slightly notched near the tip. Nostrils basal, oblique and linear. Wings moderate, more or less rounded; the first feather very short, the third generally the longest. Legs strong; the tarsi feathered at the upper end, and covered in front with several broad scales; the outer toe joined at its base to the middle toe; the claw of the hind toe much the longest (p. $\delta_{5}$ ).

\section{Family CINCLIDE.}

Crxclus, Bechstein.-Bill moderate, slightly ascending, angular and higher than broad at the base; straight, compressed and rounded near the tip; the upper mandible slightly decurving at the point. Nostrils basal, lateral, placed in a depression, cleft longitudinally, partly covered by a membrane. Gape 
very narrow, and without bristles. Wings short, broad and convex; the first quill very short; the second not so long as the third or fourth, which are nearly equal. Tail short. Legs feathered to the tibio-tarsal joint; tarsus longer than the middle toe: the lateral toes equal in length, the outer toe slightly connected with the middle toe. The whole body closely covered with down. sternum with the posterior margin entire (p. 89).

\section{Family PANURIDA.}

Pavurus, K. L. Koch,-Bill short, subconical, upper mandible convex above, decurved from the base, broader and considerably longer than the lower, which is almost straight; the edges of both somewhat inflected and not notched. Nostrils basal, oval, pointed in front and partly covered by reflected bristly feathers. Wings with ten quills, the first almost obsolete, the third longest, but the fourth and fifth nearly equal to it. Tail very long and much gracluated. Tarsus long and scutellated in front; feet stout ; claws not much hooked (p. 9I).

\section{Family PARIDA.}

ACREIULA, K. L. Tóch.-Bill very short, strong, much compressed, both man. dibles curved, the upper considerably longer than the lower. Nostrils basal, round, concealed by the plumage. Eyelids with broad bare margins. Wings with ten quills, gradually increasing in length to the fourth and fifth, which are the longest. Tail very long, narrow and graduated, the outer feathers being only about one-third of the length of the middle pair. Tarsus long and scutellated; feet moderate; the anterior toes united to the second joint, the outer toe longer than the inner, the hind toe stout and armed with a long hooked claw (p. 93).

PARUS, Linncus.-Bill strong, straight, rather conical, slightly compressed, upper mandible hardly longer than the lower and not notched. Nostrils basal, round, covered with reflected bristly feathers. Wings with ten quills, the first short, the fourth or fifth the longest. Tail moderate, even or slightly xounded. Tarsus moderate and scutellated; feet strong; toes as in preceling genus (p. 95).

\section{Family SITTID K.}

SiTTA, Limnaus.-Bill moderate, strong, and slightly conical, the lower mandible ascending from the angle to the point. Tongue short and horny, the tip abrupt and furnished with strong bristles. Nostrils basal, rounded, placed in a deep hollow, covered by hairs and short feathers. Wings rather long; the first quill much shorter than the second, the fourth or fifth the longest. Tail short, flexible, broad and nearly square. Legs short and stout, the tarsi scutellated; toes long and strong-the hind toe especially, the outer toe joined at its base to the middle toe; claws large and much hooked (p. 105).

\section{Family TROGLODYTID $\mathrm{E}$.}

Troglonytes, Vicillot.-Bill moderate, compressed, slightly curved, without any notch, and pointed. Nostrils basal, oval, partly covered by a membrane. Wings very short; concave, rounded; the first quill rather short, the fourth or fifth the longest. Tail generally short; its feathers soft and rounded. Tarsus ather long and strong; the middle toe united at the base to the 
outer toe, but not to the inner toe; hind toe rather long; claws long, stout and curved. Plumage long and soft (p. 107).

\section{Family CERTHIIDE.}

Certhia, Linnceus.-Bill rather long, slender, compressed, curved downwards and pointed; nostrils basal, lateral, elongated and partly covered by a membrane. Wings moderate and rounded; the first feather short, the fourth and fifth longest. Tail of twelve feathers, long, stiff, pointed, and slightly curved downwards. Feet large, the tarsus slender ; the fore toes long and united at the base as far as the first joint, their claws moderate but much curved; the hind toe short, but with a long curved claw. Plumage soft and thick, especially above (p. 109).

Tichodroma, Illiger.-Bill long, slender, slightly decurved and pointed; nostrils elongated. Wings long and broad. Tail of twelve rounded feathers, and square in shape. Tarsi rather slender; toes long; claws much curved, especially the long hind claw (p. I I I).

\section{Family MOTACILLID \&.}

Motacilla, Linnaus. - Bill slender, nearly straight, very slightly notched at the tip; the mandibles nearly equal in length and their edges slightly compressed inwards. Nostrils basal, lateral, oval and partly concealed by a membrane. Wings moderate; the first quill acuminate and nearly obsolete, the second, third and fourth nearly equal and one of them the longest, the fifth considerably shorter; inner secondaries very long, one of them about equal to the fifth primary. Tail of twelve feathers, long and nearly even. Tarsus scutellated in front, much longer than the middle toe, which is joined to the outer toe at its base; toes moderate; claws short, except that of the hind toe which is somewhat elongated (p. II3).

Anthus, Bechstein._Bill and nostrils as in the above genus. Wings moderate; the first primary acuminate and nearly obsolete, the second, third and fourth nearly equal and one of them the longest, the fifth in some species almost as long; outer secondaries short, inner secondaries very long, equal to or occasionally exceeding the fifth primary. Tail of twelve feathers, moderate and slightly forked. Tarsus scutellated in front, about as long as the middle toe, which is joined to the outer toe at its base; toes rather long; claws moderate, except that of the hind toe which in some species is very much elongated (p. 123).

\section{Family ORIOLIDÆ.}

Orrolus, Linncaus.-Bill moderately long, conical and decurving to the point which is notched; nostrils basal, lateral, naked, pierced horizontally in an extended membrane. Wings long; the first quill much shorter than the second; the third the longest. Tail moderate, slightly rounded. Tarsi covered in front with broad plates; toes with large scutelle; claws arched, and laterally grooved (p. 137).

\section{Family LANIIDE.}

LANius, Linnceus. - Bill short, thick and straight at the base, compressed; upper mandible hooked at the point, with a prominent tooth; base of the bill beset with hairs directed forwards. Nostrils basal, lateral, oval. Wings of moderate size; the first quill shorter than the second, the third usually the longest. Tarsus longer than the middle toe, which is united at its base to the outer toe (p. 139). 


\section{Family AMPELID E.}

Ampelis, Limncus.-Bill strong, short and straight; broad at the base; both mandibles slightly hooked at the tip, and the upper one notched. Gape wide, without bristles. Nostrils basal, oval and large, partly concealed by closely-set feathers directed forwards. Feathers of the head forming an elongated erectile crest. Wings long, with ten primaries, the first very minute, the second the longest, but the third nearly equal to it. Tail short and almost even. Tarsus scutellated in front, and shorter than the middle toe with its claw; toes stout. Plumage very soft (P. I47).

\section{Family MUSCICAPIDA.}

Muscicapa, Limnaus.-Bill of moderate length, broad and depressed at the base; compressed and slightly curved towards the point. Nostrils basal, lateral, and partly concealed by the frontal plumes. Gape beset with bristles. Wings long and pointed; the first primary very short, the second rather shorter than the third, fourth and fifth, which are the longest in the wing. Feet small, the tarsus about the same length as the middle toe, which is much longer than the lateral toes (p. I49).

\section{Family HIRUNDINIDA.}

(Wings with nine primaries, long and pointed.)

HiRundo, Limncus.-Bill short, depressed, and very wide at the base, commissure straight. Nostrils basal, oval, partly closed by a membrane. Tail deeply forked, of twelve feathers, the outermost greatly elongated and abruptly attenuated. Legs and feet slender and bare; toes rather long, three in front, one behind; claws moderate (P. I 55).

Chelidon, F. Boie.-Bill short, depressed, and very wide at the base, commissure slightly decurved. Nostrils basal, oval, partly closed by a membrane and opening laterally. Tail forked, of twelve feathers, the outermost not abruptly attenuated. Legs and feet slender, closely feathered above, toes rather long, three in front, one behind; claws moderate, sharp (p. I 57).

Cotile, F. Boie.-Bill short, depressed, and very wide at the base, commissure straight. Nostrils, wings and tail as above. Legs and feet slender, and bare except a tuft of feathers on the tarsus just above the hallux; toes moderate, three in front, one behind; claws strong (p. I59).

\section{Family FRINGILLID E.}

\section{Subfamily FringiLlinæ:}

Ligurinus, $K$. L. Koch.-Bill hard, short, conical, compressed towards the tip, with a scarcely perceptible notch at the point; nostrils basal, concealed by stiff feathers directed forwards; wings rather pointed, the first quill obsolete, the second, third and fourth nearly equal and the longest. Tail rather short, slightly forked. Tarsus scutellate in front; toes moderate; claws arched and laterally grooved (p. I6I).

Coccothraustes, Brisson.-Bill nearly conical, very thick at the base, tapering rapidly to the point; culmen more or less rounded; the mandibles nearly equal, edges inflected and slightly indented. Nostrils basal, lateral, oval, nearly hidden by projecting and recurved frontal plumes. Wings with the 
first quill obsolete, the third and fourth primaries nearly equal, the sixth, seventh, and eighth curved outwards. Tail short, and nearly square. Tarsus scutellate in front, covered at the sides with a single plate, stout and short; claws moderately curved, rather short and strong (p. 163).

CARDUelis, Brisson.-Bill nearly conical but slightly compressed, the point slender and sharp. Nostrils basal, lateral, round, and hidden by projecting and recurved plumes. Wings rather long and pointed; the first primary obsolete; the second, third, and fourth nearly equal, but the second the longest. Tail more or less moderate, and forked. Tarsus short and rather stout, scutellate in front, covered at the side by a single plate; claws moderate (p. I65).

Chrysomitris, $F$. Boie.-Bill rather attenuated, tapering to an acute point. Nostrils concealed by short stiff feathers directed forward. Wings rather long and pointed, the second quill being slightly the longest. Tail rather short and forked. Tarsus slender ; toes covered in front with four plates and three inferior scutellie; claws moderate, curved and acute. Plumage soft, the predominant colour being greenish-yellow (p. 167).

SERINUS, K. L. Kocit.-Bill strong, short, somewhat conical, but very broad at the base and with the distal half suddenly diminishing to the tip; mandibles nearly equal in size, but the upper a little longer than the lower; edges plain. Nostrils basal, supernal, round and hidden by projecting and recurved frontal plumes. Gape straight. Wings with the first primary so small as to seem wanting; the second, third and fourth nearly equal, but the third a trifle the longest. Tail moderate, rather deeply forked. Tarsus slender, and shorter than the middle toe, scutellate in front, covered at the side by a single plate ; claws small and rather weak (p. I69).

PAsser, Brisson.-Bill somewhat conical, but bulging above and below, longer than deep; upper mandible larger than the lower, edges nearly plain. Nostrils basal, lateral, rounded, almost hidden by projecting and recurved frontal plumes. Gape straight. Wings with the first primary small and attenuated but distinctly developed, the third or fourth rather the longest, but the second, third and fourth-sometimes even the fifth-are not very unequal. Tail moderate or short, and nearly square. Tarsus stout, nearly as long as the middle toe, scutellate in front, covered at the sides by a single plate; claws moderately curved, rather short (p. I7I).

Fringilla, Limaus. - Bill hard, straight, somewhat long, nearly conical, but bulging slightly and pointed; mandibles nearly equal, edges plain. Nostrils basal, lateral, oval, partly hidden by projecting and recurved frontal plumes. Gape straight. Wings with the first primary obsolete, the second always shorter than the third, which or the fourth is longest in the wing. Tail moclerately long and decidedly forked. Tarsus stout, shortish, scutellate in front, covered at the sides with a single plate; claws moderately curved, rather short (p. I75).

ACANTHis, Bechstein.-Bill hard, nearly conical, but slightly swollen; the point slender and sharp. Nostrils basal, round, and hidden more or less by projecting and recurved plumes. Gape nearly straight. Wings long, somewhat pointed; the first primary obsolete, the second, third, and fourth nearly equal, and either the second or third the longest in the wing. Tail rather long and forked. Legs short; the tarsus scutellate in front, covered at the side by a single plate; toes stout ; claws moderate, the hind claw rather large (p. 179). 
Pyrrirula, Brisson.-Bill hard, short, broad and thick at the base, bulging at the sides; culmen rounded; upper mandible considerably longer than the lower, and overhanging its point. Nostrils basal, round, hidden by plumelets. Gape slightly arched. Wings rather short; the first primary obsolete, the third or fifth the longest in the wing. Tail moderate, square or forked. Tarsus scutellate in front, covered at the sides by a single plate, stout; claws moderately curved, rather short ( $\mathrm{p} .187$ ).

Loxra, Linnaus.-Bili hard, strong, thick at the base, much compressed towards the tip, the lower mandible curving upwards and its point crossing that of the upper mandible. Nostrils round, basal, hidden by thick projecting bristly plumes. Wings long, pointed; the first primary very small but visible, the second generally the longest. Tail short, forked. Tarsus short and stout, scutellate in front; toes short; claws moderately curved (p. 193).

\section{Subfamily EMBERIZIN E.}

Emberiza, Limous. - Bill hard, conical and short; the upper mandible not wider than the lower, the edges of both inflected and those of the latter gradually cut away (sinuated); the palate generally furnished with a project. ing bony knob. Nostrils oval, basal and placed somewhat near the culmen, partly hidden by small feathers. Gape angular. Wings moderate; first primary obsolete, second, third and fourth nearly equal. Tail rather long and slightly forked. Tarsus scutellate in front, covered at the sides with an undivided plate forming a sharp ricige behind, almost as long as the middle toe : claws considerably. curved, that of the hind toe of moderate length (p. 197).

Calcarius, Bechstein. - Bill with considerably inflected cutting edges (tomia); claws of the front toes short and slightly curved; hind claw nearly straight and elongated; other characters much as in the next genus (p. 2I3).

Plectrophenax, Stijneger. *-Bill hard, conical and short; the upper mandible narrower than the lower, the edges of both inflected and those of the latter sinuated ; the palate furnished with a projecting bony knob. Nostrils oval, basal, and placed somewhat near the culmen, nearly hidden by small feathers. Gape angular. Wings long and pointed; the first primary obsolete, second and third nearly equal and the longest in the wing, but the fourth considerably longer than the fifth. Tail moderate and slightly forked. Tarsus scutellate in front, covered at the sides with an undivided plate forming a sharp ridge behind about as long as the middle toe. Front claws rather long and curved; hind claw considerably curved and elongated (p. 2I5).

\section{Family STURNIDA.}

STURNUS, Linncens. - Bill as long as the head, almost straight, blunt at the tip, depressed so as to be wider than high ; elges of the upper mandible extending over those of the lower, and both quite smooth. Nostrils basal and partly overlaid by an operculum. Gape angular and free from bristles. Feathers

* Dr. Stejneger has shown that the genus I'lectmphanes was instituted by B. Meyer for the Lapland Bunting, and that, consequently, as a mere equivalent of Calcarizs, it cannot be correctly employed for the Snow-Bunting. 
of the head and anterior part of the body pointed and elongated. Wings long, pointed, with ten primaries; the first minute and attenuated, the second and third nearly equal and the longest. Tail short, the feathers diverging at the tip. Tarsus scutellate in front covered at the side by an undivided plate, forming a sharp ridge behind; claws short and moderately curved (p. 2I 7).

PAstor, Timminck.- Bill moderate, convex above, straight beneath, compressed, the upper mandible notched and slightly decurved. Nostrils basal, partly closed by a membrane covered with small feathers. Feathers on the crown pointed and elongated, forming a crest. Wings as above. Tail moderate, the feathers mostly rounded at the tips. Tarsus scutellate in front, covered at the sides by an indistinctly divided plate, forming a sharp ridge behind; claws rather more curved than in Sturnus (p. 219).

\section{Family CORVID E.}

Pyrriocorax, Tunstall.-Beak harl, slender, compressed, arched, and pointed. Nostrils basal, hidden by small, closely-set feathers. Wings long and graduated; the first primary much shorter than the second, and about half as long as the third, the fourth the longest. Tail nearly even. Feet strong; tarsus longer than the middle toe, to which the outer toe is united as far as its first joint; claws strong and much curved (P. 22I).

Nucifraga, Brisson.-Beak about as long as the head, hard, stout and straight, dilated at the base; both mandibles terminating obtusely, the maxilla prolonged and slightly depressed at the tip. Nostrils basal, round, hidden by stiff feathers directed forwards. Feathers of the crown short. Wings graduated, the fifth primary being the longest. Tail slightly rounded. Feet stout; tarsus longer than the middle toe, to which the outer toe is united at the base; claws stout, curved and sharp (p. 223).

Garrulus, Brisson.-Beak shorter than the head, hard, stout and compressed, straight at the base, sharp at the edges, commissure straight. Nostrils basal, hidden by stiff feathers directed forwards. Feathers of the crown long and erectile. Wings moderate, rounded; the first primary short and not attenuated, the fourth, fifth and sixth nearly equal and one of them the longest in the wing. Tail moderately long and rounded. Feet strong, tarsus longer than the middle toe, to which the outer toe is united at its base; claws stout, curved and sharp (p. 225).

PICA, Brisson.-Beak stout and compressed, straight at the base, arched towards the point, sharp at the edges, and slightly notched near the tip of the upper mandible. Nostrils basal, hidden by stiff feathers directed forward. Wings short and rounded; the first primary attenuated for two-thirds of its length and very short, the fourth or fifth the longest. Tail very long and graduated. Feet strong; tarsus longer than the middle toe, to which the outer toe is united as far as its first joint; claws curved and sharp (p. 227).

Corvus, Limncus. - Beak hard, stout, compressed, straight at the base, arched towards the point and sharp at the edges. Nostrils basal, generally hidden by stiff feathers directed forwards. IVings long and graduated; the first primary much shorter than the second, but more than half as long as the third, the fourth the longest. Tail more or less graduated. Feet strong; tarsus longer than the middle toe, to which the outer toe is united as far as its first jcint ; claws strong, curved and sharp (p. 229). 
Family ALAUDIDE.

AlAudA, Linncus. - Bill moderate, slightly compressed at the edges; upper mandible more or less arched from the middle and without notch. Nostrils basal, oval, covered by bristly feathers directed forward. Gape straight. Wings long : first primary short but unmistakably developed; second, third and fourth nearly equal, but the third longest. Tail moderate and slightly forked. Tarsus blunt and scutellated behind as well as before, longer than the middle toe; claws slightly curved and moderate, except that of the hind toe, which is generally elongated and nearly straight (p. 239).

OTOconys, Bonaparte.-Bill rather short, subconic; upper mandible slightly arched and without notch. Head-in the adult male-with a tuft of long, erectile feathers on either side of the occiput. Wings long; the first primary so small as at first sight to seem wanting, the second the longest but the third nearly its equal, the fourth decidedly shorter, outer secondaries short and emarginate at the tip. Tail rather long, slightly forked. Tarsus blunt and scutellated behind as well as before, shorter than the middle toe; claws moderate and very slightly curved, that of the hind toe being comparatively straight (p. 249).

\section{Order PICARI Æ⿸尸}

\section{Family CYPSELIDE.}

Cypselus, Illiger.--Bill very short, wide, triangular at its base and depressed ; culmen and commissure much decurved; gape extending beyond the eyes. Nostrils longitudinal, the edges raised and furnished with small feathers. Wings with ten curved primaries, very long and pointed, the first shorter than the second, but a little longer than the third. Tail, of ten feathers, somewhat deeply forked. Tarsi very short, feathered in front; toes four, all ordinarily directed forwards, the middle and outer with three phalanges only; claws short, large and much curved (p. 251).

ACANThyllis, F. Boie.-Wings very long, narrow and pointed. Tail short, even; the feathers terminated by long sharp spines. Tarsus bare in front and not scutellated; one toe directed backwards. Otherwise much as in preceding genus (p. 255).

\section{Family CAPRIMULGIDA.}

Caprinulgus, Limaus.-Bill very short, flexible, broad at the base, much compressed at the point; gape very wide, extending behind the large eyes; upper mandible decurved at the tip, and beset on each side with a row of moveable bristles directed forward; lower mandible upturned at the tip, so as to meet the upper at the point, leaving an open space further back. Nostrils basal, with a prominent membranaceous rim, clothed with very small feathers. Wings long, with ten primaries; the first shorter than the second, which is the longest. Tail of ten feathers, long and slightly rounded. Legs weak; tarsi short, feathered in front for two-thirds of their length; feet with three toes before, one behind, the anterior united as far as the first joint, the posterior turned inwards at right angles, inner and outer toes equal, the latter with but four phalanges; claws short, except that of the middle toe, which is long and serrated on the inner edge (p. 257). 
Family PICID E.

Subfamily IŸNGIN玉.

IYix, Linnaus. - Bill shorter than the head, hard, straight, nearly conical, sharp at the tip. Nostrils basal, linear, partly closed by a membrane. Tongue capable of protrusion, the tip horny and smooth. Wings moderate; the first primary minute, the third or fourth longest. Tail rather rounded, of ten rectrices, with straight shafts and webs of ordinary character. Tarsi strong, slightly feathered in front above; toes, two before and two behind, the fourth-which is turned backwards-about as long as the third; claws much hooked, grooved and very sharp (p. 261).

\section{Subfamily Picisæ.}

Gecinus, $F$. Boie.-Bill about as long as the head, hard, broad at the base, compressed at the tip; upper mandible slightly arched, ending abruptly, with a shallow groove on each side running parallel to and near the culmen, and Ionger than the lower mandible, which is pointed, and has the gonys nearer the tip than the base and the tomia rounded. Nostrils basal, oval, covered with hair-like feathers directed forwards. Tongue capable of great protrusion, beset at the tip with horny barbs. Wings moderate; the first primary very short, the fourth longest, but the fifth nearly equal to it. Tail of twelve graduated rectrices; the outer pair very short and overlying the next which, with the rest, are pointed and have stiff, decurved shafts, with hard webs. Tarsi strong, slightly feathered in front above; toes, two before and two behind, the fourth-which is turned backwards-equal to the third; claws strongly hooked, grooved and very sharp. Prevailing colour of the plumage greenish (p. 263).

Dendrocorus, $K$. L. Koch.-Bill pyramidal, laterally bevelled at the tip. The fourth toe much longer than the third." Otherwise much as in preceding genus. Prevailing colours black and white, or black and red (p. 265).

\section{Family ALCEDINID E.}

AlCEDo, Linncus. - Bill long, hard, straight, quadrangular and acute. Nostrils basal, oblique, nearly closed by a bare membrane. IVings short and rounded, of ten primaries; the second or third the longest, but the first nearly equal to them and longer than the fourth. Tail very short, of twelve rectrices. Tibir bare below ; tarsi short ; toes, three before, one behind, the middle united to the outer toe as far as the second joint, and to the inner as far as the first joint; hind toe not much shorter than the inner (p. 269).

\section{Family CORACIIDE.}

Coracias, Linnaus.-Bill stout, hard, compressed, with cutting edges slightly inflected; upper mandible decurved at the tip ; gape wide. Nostrils lateral, linear and oblique, partly hidden by a plumose membrane. Lores beset in front by a row of stiff bristles. Post-ocular space bare. Wings long, of ten primaries; the first a little shorter than the second or third-which are the longest-but rather longer than the fourth. Tail of twelve feathers, rather long. Tarsi short, broadly scutellated in front; toes free, three before, one behind; claws stout (p. 27I).

\section{Family MEROPID E.}

Merops, Limncus.-Bill rather long, hard, slightly decurved, and tapering to a point, the culmen elevated. Nostrils basal, lateral, oval, covered by 
hairs directed forwards. Wings long, of ten primaries; the first very short, the second and third longest. Tail rather long, of twelve feathers, the central pair elongated and pointed. Tibire bare below; tarsi short, toes small, three before, one behind, the middle united to the outer toe as far as the second joint, and to the inner as far as the first joint (p. 273).

\section{Family UPUPID E.}

UPUPA, Linncus.-Bill long, slender, slightly arched, sharp and much compressed. Nostrils basal, oval, partly concealed by feathers. Tongue very short and heart-shaped. Head with an erectile crest of oblong feathers set regularly in pairs for the whole length. Wings moderately long, very broad, with ten primaries; the first about half as long as the second, which is nearly an inch shorter than the third, the fourth or fifth longest, but the sixth nearly equal to them. Tail of ten feathers, almost square at the end. Feet with the tarsi scutellated behind as well as before; three toes before, one behind, the outer and middle united as far as the first joint; claws but slightly curved (p. 275).

\section{Family CUCULID玉.}

Cucurus, Linnaus. - Bill short and sub-cylindrical, culmen somerrhat decurved, upper mandible slightly notched near the tip, lower mandible nearly straight beneath ; gape wide. Nostrils basal, circular, with a prominent membranaceous rim. Wings with ten primaries; the first short, the third longest, the innermost three shorter than the first. Tail of ten feathers; the outer three pairs graduated, the middle two nearly equal. Tarsi short, feathered for nearly half their length; toes two before, two behind (p. 277).

Coccystes, Gloger.-Bill moderate, compressed towards the tip. culmen decurved, cutting edge smooth; lower mandible slightly decurved beneath; gape moderate. Nostrils basal, oval, the upper part closed by a membrane. Head crested. Wings moderate, with ten primaries; the first short, the third longest, but the fourth nearly its equal, the ninth as long as, and the tenth shorter than, the first. Tail of ten feathers, long and graduated. Tarsi strong and long, bare behind, slightly feathered in front above; toes two before, two behind (p. 279).

\section{Order STRIGES.}

Family STRIGIDE.

STRIX, Linnaus. - Bill straight at the base, decurved only towards the point; cutting margin of the upper mandible nearly straight, under mandible notched. Nostrils oval, oblique. Facial disk large and complete, narrowing rapidly below the eyes towards the beak. Auditory opening square, large, and furnished with a large and nearly rectangular operculum, stiffened with the shafts of small feathers. Wings long and ample; the first and third quills equal and nearly as long as the second, which is the longest. Tail short. Legs long and slender, clothed with downy feathers to the origin of the toes, which are only furnished on the upper surface with a few bristlelike feathers; hind toe reversible; claws long and grooved underneath, that of the middle toe serrated on the inner edge. Head smooth, not furnished with tufts (p. 28r). 
Asio, Brisson.-Bill decurved from the base; cere large; under mandible notched. Nostrils oval, oblique. Facial disk complete. Conch of the ear extremely large, with a semicircular operculum running the whole length in front, and a raised margin behind; auditory opening asymmetrical. Wings long, the second quill generally the longest. Legs and toes feathered to the claws. Head furnished with two tufts, more or less elongated (p. 28 3 ).

Syrnium, Savigny.-Bill decurved from the base. Nostrils large. Facial disk large and complete; ears large and furnished in front with a large crescentic operculum, broad below and tapering above. Wings short and rounded; the first quill very short, the fourth the longest. Tail long, concave beneath. Legs and toes feathered. Head large, round and without tufts (p. 287).

Nyctala, C. L. Brem.-Bill short, decurved from the base; cere rudimentary; nostrils nearly circular; under mandible notched. Ears large, asymmetrical, and furnished in front with a well-developed operculum. Facial disk large and nearly complete. Wings long, rounded. Tail short. Legs and toes thickly feathered. Head large, the asymmetry of the aural region extending to the skull (p. 289).

Athene, F. Boie.-Bill decurved from the base; cere short and swollen; nostrils oval ; lower mandible sinuated. Auditory conch large, the orifice small and without an operculum. Facial disk not well defined. Wings large, the third and fourth quills nearly equal in length. Legs long, covered with short feathers; toes above with bristles only, instead of feathers. Head round, large and without tufts (p. 29r).

Nyctea, Stephens.-Bill decurved from the base; nostrils large, oval; cere short; upper mandible smooth, lower mandible notched. Facial disk incomplete. Orifice of the ears moderate, without operculum. Wings of moderate size; the third quill the longest, second and fourth nearly equal. Tail rounded and of moderate length. Legs and toes thickly covered with feathers. Head large, round, not furnished with tufts of feathers (p. 293).

SuRnia, Duméril.-Bill decurved from the base and much hidden by feathers; nostrils small and rounded; cere short; upper mandible slightly undulated; lower mandible notched. Facial disk nearly obsolete. Orifice of the ears small, without operculum. Wings short; first quill equal to seventh, second longer than fifth, third and fourth longest and nearly equal. Tarsi rather short and-with the toes-thickly fenthered. Tail long and graduated. Head flat and without tufts (p. 295).

Scops, Savigny.-Bill much decurved from the base, cere small, under mandible notched. Nostrils round. Facial disk incomplete above the eyes; auditory conch small, and without an operculum. Wings long, reaching to the end of the tail ; the third quill generally the longest. Tarsi rather long, feathered in front; the toes naked. Head furnished with two tufts of feathers (p. 297).

Bubo, Duméril.-Bill short, strong, curved, compressed at the point. Nostrils pierced in the cere, large, oval or rounded. Facial disk incomplete about the eyes. Auditory opening, small, oval, without an operculum. Wings rather short, concave; the third and fourth quills generally the longest. Legs and toes covered with feathers; claws long. Head furnished with two tufts of feathers (p. 299). 


\title{
Order ACCIPITRES.
}

\author{
Family VULTURIDE.
}

Gyps, Savigny.-Bill strong, thick, and deep, the sides rather swollen, maxilla rising immediately in front of the cere, forming a culmen curving to the tip, where it is somewhat abruptly hooked. Manoible straight and rounded, becoming narrower towards the point. Nostrils naked and diagonal. Tongue fringed with spines. Head slender and covered with short down, as is most part of the neck; above the shoulders a ruff of elongated feathers. Wings long ; the first quill short, the fourth the longest. Tail of twelve or fourteen feathers. Feet strong; claws slightly hooked; middle toe rather longer than tarsus, and united at base to outer toe by a membrane (p. 301).

Neoprron, Savigny.-Bill straight, slender, elongated, rounded above, encircled at the base with a naked cere, which extends more than half the length of the beak; upper mandible with straight edges, hooked at the tip; under mandible blunt, and shorter than the upper. Nostrils near the middle of the beak, elongated, longitudinal. Head and neck partly bare of feathers. Wings rather pointed, the third quill the longest. Tail of fourteen feathers. Legs of moderate strength and length; tarsi reticulated; feet with four toes - three before, one behind; anterior toes united at the base (p. 303).

\section{Family FALCONID E.}

Circus, Lacépide.-Bill small, bending from the base, compressed and elevated ; cutting edge of the upper mandible with a slight festoon. Cere large. Nostrils oval, partly concealed by the hairs radialing from the lores. Lower part of the head surrounded by a ruff of small thick-set feathers. Wings long; the first quill very short, the third and fourth the longest. Tail long. Tarsi long, slender, and naked; toes rather short, and not very unequal; claws slightly curved, and very sharp (p. 305).

Buteo, Lacépede.-Bill rather small and weak, bending from the base, part of the cutting edge of the upper mandible slightly projecting; cere large; nostrils oval. Wings ample; the first quill short, about equal in length to the seventh, the fourth the longest; the first four feathers with the inner edge deeply notched. Tarsi short, strong, scaled, and occasionally feathered; toes short, claws strong (p. 3I I).

Aquila, Brisson.-Bill strong, of moderate length, curved from the cere, pointed, the cutting edges nearly straight. Nostrils oval, lateral, directed obliquely downward and backward, or circular. Wings large and long, the fourth quill the longest. Tarsi feathered to the junction of the toes; feet strong, the last phalanx of each toe covered by large scales; claws hooked (p. 3I5).

HAliaítus, Savigny.-Bill elongated, strong, straight at the base, curving in a regular arc in advance of the cere to the tip and forming a deep hook, upper ridge broad and rather flattened, edges of the maxilla slightly prominent behind the commencement of the hook. Nustrils large, transverse, lunate. Wings ample, the fourth quill the longest. Tarsi half feathered; the front of the naked part scutellated, and the sides and back reticulated. Toes divided to their origin, the outer one versatile. Claws strong and hooked, grooved beneath; the claw of the hind toe larger than that of the inner, which again exceeds either of the others (p. 319). 
Astur, Lacépide.-Bill short, bending from the base ; cutting edge of the upper mandible produced, forming a festoon. Nostrils oval. Wings short, reaching only to the middle of the tail-feathers, the fourth quill the longest. Legs stout, the tarsi covered in front with broad scales. Toes of moderate length, the middle toe somewhat the longest, the lateral toes nearly equal, but the inner claws considerably larger than the outer (p. $32 \mathrm{I}$ ).

ACCIPITER, Brisson.-Bill bending from the base, short, compressed, superior ridge rounded and narrow, cutting margin of the upper mandible with a distinct festoon. Nostrils oval. Wings short; the fourth and fifth quillfeathers nearly equal in length, and the longest. Legs long, slender, and smooth. Toes Iong and slender, the middle toe particularly; claws curved and sharp (p. 323).

Milvus, Lacépide.-Bill straight at the base, curved from the cere to the point, cutting margin with a slight festoon. Nostrils oval, oblique. Wings long, the third or fourth quill the longest. Tail long, generally forked. Legs short. Toes short and strong ; the outer toe united at its base to the middle toe, but slightly reversible. Claws moderately long and curved (p. 325).

PERNIS, G. Cuvier.-Bill slender, rather weak, curved from the base, the cutting edge of the upper mandible nearly straight ; cere large; nostrils elongated, placed obliquely; lores closely covered with small scale-like feathers. Wings long and large ; the first quill short, the third and fourth the longest ; inner" webs of the first four deeply notched. Tail long. Tarsi short, half-plumed, the rest reticulated; toes of moderate length and strength ; claws slender and only slightly curved (p. 329).

Falco, Limaus.-Bill short, curved from its base; a strong projecting tooth on each cutting edge of the upper mandible. Wings long and pointed; the first and third primaries of equal length, the second longest. Tarsi short, robust; toes long, strong, armed with curved and sharp claws (p. 331).

PANDion, Savigny.-Bill short, strong, rounded and broad; cutting edge nearly straight. Nostrils oblong-oval, oblique. Wings long; second and third primaries longest. Legs strong and muscular; tarsi short, covered with reticulated scales. Toes free, nearly equal, the outer toe reversible ; all armed with strong, curved, and sharp claws; under surface of the toes rough and covered with small pointed scales. Feathers wanting the accessory plumule (p. 347).

\section{Order STEGANOPODES.}

Family PELECANID/E.

Phalacrocorax, Brisson.-Bill moderate, or long, straight, compressed, culmen rounded; upper mandible very much curved at the point, hooked; the base connected with a membrane which extends to the throat. Face and throat naked. Nostrils basal, linear, hidden. Wings of moderate length, the third quill the longest. Tail of twelve or fourteen stiff and rigid feathers. Legs strong, short, abdominal ; three toes in front, and a hind toe articulated on the inner surface of the tarsus, all four united together by membranes; claw of the middle toe serrated on the inner edge (p. 349).

Sula, Brisson.-Bill strong, long, forming an elongated cone, very large at its 
base, compressed towards the yoint, which is slightly curved; edges of the mandibles serrated; angle of the gape behind the line of the eyes. Face and throat naked. Nostrils basal, obliterated. Wings long, first quill the longest. Tail wedge-shape. Legs strong, short, placed rather backward; three toes in front, and a.hind toe, articulated to the inner surface of the tarsus, all four united by membranes; claw of the middle toe pectinated (p. 353).

\section{Order HERODIONES.}

\section{Family ARDEIDA.}

ARDEA, Brisson.-Bill long, strong, straight, compressed in a lengthened cone ; upper mandible slightly channelled, ridge rounded. Nostrils lateral, basal, pierced longitudinally in the groove, and half closed by a membrane. Wings moderate, the second quill the longest. Tail of twelve feathers, short, nearly even. Legs long, slender, naked above the tarsal joint ; tarsi scutellate in front; three toes in front, the outer united to the middle one by a distinct membrane, one toe behind, directed inwards; claws long, compressed, sharp, the middle claw pectinated on the inside (p. 355).

Nycticorax, Stephens. - Bill about the same length as the head, bulky, strong, broad, and dilated at the base ; upper mandible slightly bending and curved at the point; under mandible straight. Nostrils longitudinal, lateral, but little in advance of the base of the beak, nalied, placed in a groove, and partly covered by a naked membrane; lore and orbits naked. Tail of twelve broad and moderately hard feathers. Legs of moderate length, naked for a short distance above the tarsal joint ; tarsus longer than the middle toe, with hexagonal scutellie in front; the outer and middle toe united by a membrane; claws short, that of the middle toe pectinated (p. 367).

Ardetta, G. R. Gray.-Bill longer than the head, slender, pointed, gape-line straight. Nostrils basal, linear, longitudinal ; space in front of the eye bare. Wing broad, rather rounded; the second quill barely longer than the first, and a little longer than the third. Tail of ten soft feathers, short and rounded. Legs rather short, the tibia feathered nearly to the joint; tarsus anteriorly scutellate; toes moderately long and slender, the middle toe shorter than the tarsus and its claw pectinated on the inner edge (p. 369).

BOTAURLs, Stifhens. - Bill rather longer than the head, strong, higher than broat, the mandibles of equal length, upper mandible curved downwards. Nostrils basal, linear, longitudinal, Iodged in a furrow, and partly covered by a naked membrane. Wing long, rather rounded, the first three quills the longest and nearly equal. Tail of ten soft feathers. Legs of moderate length; tarsi scutellate; toes long and slender, all unequal, the middle toe as long as the tarsus; hind toe long, articulated with the interior toe and on the same plane; claws long, that of the middle toe pectinated (p. 371).

\section{Family CICONIID E.}

Cicosis, Brisson.-Bill longer than the head, straight, strong, and pointed. Nostrils pierced longitudinally in the horny substance. Eyes surrounded by a naked skin. Wings rather large, the first quill-feather shorter than the second, the third and fourth quills the longest in the wing. Plumage without 
powder-down tracts. Tail short and slightly rounded. Legs long; feet with four rather short toes, the three in front united by a membrane as far as the first joint; claws short, broad, obtuse, the middle claw not pectinated (p. 375).

\section{'Family IBIDID E.}

Plegadis, Kanp.-Bill long, slender, decurved, large at the base, the point depressed, obtuse, rounded; upper mandible deeply grooved throughout its length. Nostrils on the upper surface and near the base of the beak, oblong, narrow, pierced in a membrane which covers part of the aperture. Face and lores naked, without feathers. Tail of twelve feathers, moderate, even. Wings moderate; the first quill shorter than the second and third, which are the longest. Legs rather long, naked above the tarsal joint; three toes in front, one behind; the anterior toes united by a membrane, hind toe long and resting its length on the ground. Plumage more or less Stork-like, wanting the powder-down tracts of the Herons (p. 379).

\section{Family PLATALEIDA.}

Platalea, Linnceus. - Bill long, and much flattened, dilated at the point and rounded in the form of a spoon; upper mandible channelled and transversely grooved at the base. Nostrils on the upper surface of the beak, near together, oblong, open, bordered by a membrane. Forehead, lores, orbits and chin naked. Wings rather large; the third quill nearly as long as the second, which is the longest. Legs long and robust; three toes in front, united as far as the second articulation by a membrane, the marginal edge of which is deeply concave; hind toe long (p. $38 \mathrm{r}$ ).

\section{Order ODONTOGLOSSÆ.}

\section{Family PHCNICOPTERID E.}

Phanicopterus, Brisson.-Bill longer than the head, abruptly bent in the middle; edges of both mandibles furnished with fine transverse plates (lamellæ). Nostrils, linear, sub-basal. Neck very long and slender. WVings moderately long, the first quill slightly the longest; the inner secondaries longer than, and folding over, the closed primaries. Tail short, even. Legs very long and slender; the chief portion of the tibia bare; tarsus broadly scutellate; toes short, the three anterior ones palmated, with incised webs, hind toe elevated, free and small ; claws flattened and obtuse (p. $38_{3}$ ).

\section{Order ANSERES.}

\section{Family ANATIDE.}

ANSER, Brisson:-Bill nearly as long as the head, sub-conical, elevated at the base, which is covered with a cere or skin; a conspicuous nail (unguis) at the tip ; under mandible smaller than the upper. Nostrils lateral, placed towards the middle of the beak, pierced anteriorly. Wings large, the second quill longest. Tail of sixteen feathers. Legs under the centre of the body; the tarsi moderately long; the hind toe free, articulated upon the tarsus; the three anterior toes united by a membrane (p. $3^{85}$ ). 
CHen, F. Boie-Bill shorter than the head, very robust, and higher than broad at the base; culmen slightly convex, the outline of the lower mandible decidedly so, leaving an elliptical space displaying the lamelle. Nostrils subbasal. Feathers on the neck less conspictously furrowed than in true Anser. Wings long, full, the second quill the longest. Tail rather short and rounded. Tibia feathered to the joint; tarsus moderately long, reticulate; three anterior toes connected by a memlırane; hind toe short and elevated (p. 393)

Bernicla, F. Boie.-Bill"much shorter than the head, sub-conical, higher than broad at the base, narrowing to the end; nail broadly ovate; edges of the bill nearly straight, scarcely showing the margins of the lamellæ. Nostrils oval, placed in the anterior portion of the nasal depression, near the centre of the bill. Feathers on the neck narrow, blended. Wings large, the second quill usually the longest. Tail short, rounded. Legs short and stout, the tarsus reticulate; the three anterior toes long, united by a membrane; hind toe small and elevated; claws small, that on the middle toe broadly rounded (p. 395).

Cygnus, Bechstein.-Bill of equal breadth throughout its length, higher than wide at the base, depressed at the point; both mandibles furnished along the sides with transverse serrated lamellæ. Lores chiefly naked. Nostrils oblong, lateral, near the middle of the beak. Neck slender and very long. Legs short; tarsi reticulated; the three front toes fully webbed, the hind toe small and free. Sexes alike in plumage (p. 401).

TADORNA, Fleming.-Bill about the length of the head, higher than broad at the base, depressed or concave in the middle, breadth nearly equal throughout; under mandible much narrower than the upper, and the latter grooved near the tip; nail decurved, forming a hook; both mandibles furnished with thin transverse lamellæ. Nasal groove near the base of the beak; nostrils oval, lateral, pervious. Wings of moderate length, the second quill the longest. Legs moderate; the tibia naked for a short space above the tarsal joint; three toes entirely webbed in front, and one behind free. Sexes nearly alike in plumage (p. 407).

AnAs, Brisson.-Bill about as long as the head, broad, depressed, sides parallel, sometimes partially dilated; both mandibles furnished on the inner edges with transverse lamellæ. Nostrils small, oval, lateral, anterior to the base of the beak. Wings rather long, pointed. Tail wedge-shaped. Legs rather short, placed under the centre of the body; tarsus somewhat rounded; three toes in front, connected by membranes; hind toe free, without pendent lobe or membrane. The sexes differ in plumage (p. 4II).

Sratula, F. Boie,-Bill much longer than the head, compressed at the base, widening towards the end, lamella projecting conspicuously from the base to near the broadest part. Wing pointed, the first and second quills the longest. Tail short, graduated, of fourteen pointed feathers. Legs very short; hind toe small, free, unlobed (p. 4I5).

DAFila, Stephens.-Bill about as long as the head, the edges nearly parallel, but widening a trifle to the end; lamella not very strongly defined. Neck long and slender. Wings long and pointed, the first and second quills sub-equal and longest, the rest rapidly graduated. Tail sharply pointed, the central rectrices considerably elongated in the ma?e. Legs rather short; hind toe small; margin of web to anterior toes slightly emarginate (p. 4I7). 
Querquedula, Stephens. - Bill about as long as the head, the edges nearly parallel; the extremities of the lamelle exposed along the projecting edge of the upper mandible; nostrils small and oblong. Wings rather long, pointed, the first and second quills sub-equal and longer than the rest; scapulars and inner secondaries elongated and pointed. Tail of sixteen feathers, short and rounded. Legs short; tarsus compressed, anteriorly scutellate; hind toe very small, outer toe much shorter than the third, centre toe rather long; interdigital membrane emarginate; claws small, somewhat curved (p. 419).

MARECA, Stephens.-Bill considerably shorter than the head, higher than broad at the base, gradually depressed and narrowed towards the point; culmen slightly concave; lamellæe only just visible; wings rather long and pointed ; the first and second quills sub-equal and longer than the rest. Tail short and pointed. Legs short, the tibia bare for a short distance; hind toe with a very narrow lobe; feet rather small (p. 425).

Fuligula, Stephesss.-Bill not longer than the head, but slightly elevated at the base, depressed towards the tip, sides parallel; both mandibles laminated, lateral edges of the upper mandible enclosing the edges of the under one. Nostrils at a short distance from the base. Wings rather short, pointed. Legs with the middle and outer toes longer than the tarsus, which is flattened laterally; feet large, webbed; the hind toe with a broad lobe (p. 429).

Clangula, F. Boie.-Bill much shorter than the head, higher than broad at the base, depressed towards the nail, which is elliptical and decurved at the tip ; lamellæ completely hidden by the overhanging edge of the maxilla; nostrils near the middle of the bill. Wings rather short, pointed, the first quill the longest. Tail of sixteen feathers, moderately long, rounded. Legs short, placed far back; tarsi scutellate in front; hind toe small, slender, broadly lobed ; interdigital membranes full (p. 439).

HARELdA, Stephens. - Bill much shorter than the head, its outlines tapering rapidly to the tip, which is occupied by a broad, prominently decurved nail; lamellie slightly exposed along the gape-line; nostrils oblong, sub-basal. Feathering at the base of the bill forming an oblique line, advancing furthest forward on the forehead, and scarcely interrupted by the re-entrant angle so prominent in most Ducks. Wings rather short, pointed; scapulars much elongated and lanceolate in the adult male. Tail of fourteen feathers, short and graduated, except the two central feathers, which are very long and tapering in the adult male. Legs short, placed far back; hind toe small but broadly lobed (p. 443).

CosmonetTA, Kaup.-Bill rather short, converging rapidly to the tip, which is occupied by a large decurved nail; a small lobe on each side at the base of the upper mandible ; lamella concealed ; nostrils oblong, median. Wing short, pointed, the tirst and second quills nearly equal in length. Tail of fourteen rather pointed feathers, much graduated. Legs short and placed far back; hind toe slender, with a large lobe; anterior toes fully webbed (p. 445).

Somateria, F. Boie.-Bill swollen and elevated at the base, extending up on the forehead, where it is divided by an elongated, descending, angular, projection of feathers down the surface. Nostrils lateral, oval, small. Wings 
moderate, with the first. and second quills sub-equal. Tail short, of fourtecn feathers. Legs short; three anterior toes, brcadly webbed; hind toe with a deeply lobated membrane (p. 447).

EDEma, Fleming.-Bill swollen or tuberculated at the base, large, elevaterl, and strong; the tip much depressed, and terminated by a large flat nail, rounded and slightly deflected at the extremity; lamelle broad, strong, and widely set. Nostrils lateral, elevated, oval, placed near the middle of the bill. Wings rather short, pointed. Tail short, graduated, acute. Legs far behind the centre of gravity; tarsi short; feet large; three toes in front and one behind; the outer toe as long as the middle one and much longer than the tarsus, hind toe with a large lobated membrane (p. 453).

MERGUS, Linnaus.-Bill about as long or longer than the head, straight, slender, rather pointed, the base large, forming an elongated and almost cylindrical cone; point of the upper mandible curved and, with the horny nail, forming a hook; edges of both mandibles furnished with saw-like teeth, the points directed backwards. Nostrils lateral, about the middle of the beak, longitudinally elliptic. Wings moderate, the first and second quill-feathers nearly equal in length. Legs short, placed rather backward; three toes in front webbed, hind toe with a pendant lobe or membrane (p. 459).

\section{Order COLUMB正.}

\section{Family COLUMBID E.}

Columba, Limnaus.-Bill moderate, straight at the base, compressed, the point deflected. Base of the upper mandible covered with a soft skin. in which the nostrils are pierced. Wings, long, broad, rather pointed; the second quill-feather longest. Tail of twelve feathers, nearly even. Tarsi short, anteriorly scutellate, posteriorly scurfy ; three toes in front, entirely divided, one toe behind ( $\mathrm{p} .467)$.

Turtur, Selby.-Bill rather slender, the tip of the upper mandible gently deflected, that of the lower scarcely exhibiting the appearance of an angle; base of the upper mandible covered with two soft, tumid, bare substances covering the nostrils. Tail of twelve feathers, rather long and considerably rounded or graduated. Wings rather long and pointed, the first quill a little shorter than the second, which is the longest. Tarsi rather shorter than the middle toe ; inner toe longer than the outer ( $\mathrm{p} .473$ ).

\section{Order PTEROCLETES.}

\section{Family PTEROCLID 1 E.}

SYRiraptes, Illiger.-Bill small, gradually decurved from the base to the point; nostrils basal, hidden in the feathers. Wings very long, pointed, the first primary longest. Tail of sixtcen feathers, cuneate, the two central rectrices long and tapering. Tarsi very short and strong, covered with downy feathers to the toes, which are three in number, all in front, and united by a membrane as far as the claws; hind toe (hallux) obsolete; soles rugose; claws broad and obtuse (p. 475). 


\section{Order GALLIN丑.}

Family TETRAONID Æ.

TETRAo, Linncus. - Bill short, strong ; upper mandible convex, and arched from the base to the tip. Nostrils basal, lateral, partly closed by an arched scale, and hidden from view by small closely-set feathers. Space above the eye naked, the skin with red papillæ, and fringed. Wings short and rounded; the fifth quill the longest. Tail of eighteen feathers. Tarsi feathered to the junction of the toes, which are naked; the three in front united as far as the first joint; one toe behind, short; the edges of all pectinated.

LAGopus, Brisson.-Bill very short, clothed at the base with feathers ; the upper mandible convex, and bent down at the point. Nostrils basal, lateral, partly closed by an arched membrane, and nearly hidden by the small closely-set feathers at the base of the bill. Eyebrows naked, as in Tetrao. Wings short, concave, with the third and fourth quills the longest. Tail of sixteen feathers, generally square at the end. Tarsi and toes completely feathered; hird toe very short and barely touching the ground with the tip of the nail; claws long and nearly straight.

\section{Family PHASIANIDE.}

Phasianus, Brisson.-Bill of moderate length, strong; upper mandible convex, naked at the base, and with the tip bent downwards. Nostrils basal, lateral, covered with a cartilaginous scale; cheeks and the skin surrounding the eyes destitute of feathers, and with a verrucose red covering in the male. Wings short; the first quill narrow towards the tip, the fourth and fifth feathers the longest in the wing. Tail of eighteen feathers, long, wedgeshaped, graduated. Feet with three anterior toes united by a membrane as far as the first joint ; the hind toe articulated upon the tarsus, which is furnished with a horny, conical and sharp spur in the male (p. 485).

PERDIx, Brisson. - Bill short, strong, naked at the base ; upper mandible convex, deflected towards the tip. Nostrils basal, lateral, the orifice partly concealed by an arched naked scale. Wings short, concave, rounded in form; the first three quills shorter than the fourth or fifth, which are the longest in the wing. Tail with sixteen feathers in the same plane, short, rounded. Feet with three toes in front and one behind, those in front united by a membrane as far as the first joint (p. 487).

CACCABIS, Kaup.-Bill short, stout, naked at the base; upper mandible decurved to the tip. Nostrils basal, lateral, partly covered and closed by an oblong horny scale. Wings short, rounded; the first three feathers shorter than the fourth and fifth, which are the longest. Tail of fourteen feathers, short, rounded. Tarsi anteriorly scutellate, and-in the male-armed with blunt spurs; three toes in front united at their bases by a membrane; one toe behind (p. 489 ).

CoTURnix, Bonnaterre.-Bill strong, shorter than the head, upper mandible curved. Nostrils basal, lateral, half closed by an arched membrane. Wings moderate, the first quill the longest. Tail short, rounded, recumbent, almost hidden by the tail-coverts. Tarsi unarmed. Feet with four toes, those anterior connected by a membrane as far as the first joint (p. 49I). 


\title{
Order FULICARIÆ.
}

\author{
Family RALLIDAE.
}

Crex, Bcchstcin.-Bill shorter than the head, thick at the base, compressed; the culmen gradually deflecting from the forehead to the point of the bill; lateral furrow of the upper mandible broad, and occupying more than half its length; angle of the under mandible bending upwards; both mandibles of an equal length. Nostrils concave, lateral, linear, ovoid, pierced in a membrane occupying the furrow in the middle of the bill. Wings armed with a spine, and having the second and third quills the longest. Legs strong, of moderate length, with the lower part of the tibia naked. Feet with three anterior toes, long, slender, and cleft to their base without any lateral membrane; the hind toe resting almost wholly on the ground; claws arcuate, compressed and sharp (p. 493).

Porzana, Vieillot.-Bill shorter than the head, slightly higher than broad at the base, compressed, tapering towards the point. Nostrils linear and oblong, the nasal groove reaching to the middle of the bill. Wings shorter than in Crex ; the second quill the longest. Tail short, rounded, the feathers narrow, weak, and slightly curved. Tibix bare on the lower part; tarsi short, scutellate in front; toes long and slender; claws long, curved, and acutely tapering (p. 495).

RAllus, Brisson.-Bill longer than the head, slender, slightly decurved, compressed at the base, cylindrical at the point; upper mandible grooved at the sides. Nostrils pierced longitudinally in the lateral groove, partly covered by a membrane. Wings moderate, rounded; the first quill much shorter than the second, the third and fourth the longest. Legs long and robust, with a small naked space above the tarsal joint; the three anterior toes divided to their origin, the hind toe articulated upon the tarsus (p. 50r).

Galimula, Brisson.-Bill thick at the base, compressed, slightly swollen towards the tip, subconic, as short as the head. Upper mandible convex, with the culmen extended and dilated, forming a naked, oblong frontal plate or shield ; lateral furrow wide ; mandibles of nearly equal length ; angle of the lower one ascending. Nostrils lateral, pervious, pierced in the membrane of the furrow in the middle of the bill, longitudinal and linear. Wings short, concave, rounded; armed with a small, sharp, recumbent spine. Legs long, naked for a short space above the tarsal joint, scutellated in front, reticulated behind. Toes, three before and one behind, long, divided and bordered through their whole length by a narrow entire membrane (p. 503).

Fulics, Brisson.-Bill and frontal plate much as in Gallinula. Wings of moderate size; the first quill shorter than the second or third, which are the longest in the wing. Tail short. Legs rather long, naked above the tarsal joint; three toes in front, one behind; all the toes long, united at the base, and furnished laterally with extensions of the membranes, which form round lobes (p. 505). 


\section{Order ALECTORIDES.}

Family GRUID正.

Grus, Bechstein.-Bill longer than the head, straight, strong, compressed and pointed. Nostrils placed longitudinally in a furrow, large, pervious, closed posteriorly by a membrane. Wings moderate and rounded; the first quill shorter than the second, the third the longest in the wing. Legs very long, robust, naked above the joint; three toes in front, middle toe united to the outer toe by a membrane, hind toe articulated high up on the tarsus (p. 507).

\section{Family OTIDIDE.}

OTIs, Linnaus. - Bill moderate, straight, depressed at the base, the point of the upper mandible curved. Nostrils a little removed from the base, lateral, oval and open. Wings of moderate length, rather rounded in form; the third quill the longest. Legs long, naked above the tarsal joint. Toes three ; all directed forward, short, united at the base, and edged with membranes (p. 509).

\section{Order LIMICOL画.}

\section{Family CEDICNEMID在.}

CEDicrent's, Timminck.-Bill stout, strong, and straight, a little depressed at the base ; ridge of the upper mandible elevated, under mandible with a sharp angle at the gonys. Nostrils in the middle of the beak, extending longitudinally as far forward as the horny portion, open in front, pervious. Wings moderate, the second quill longest. Tail much graduated. Legs long, slender; three toes only, directed forwards, united by a membrane as far as the second joint (p. 515).

\section{Family GLAREOLID E.}

Glareola, Brisson.-Bill short, convex, compressed towards. the point, the upper mandible curved throughout the distal half of its length. Nostrils basal, lateral, pierced obliquely. Wings very long, the first quill the longest. Tail forked. Legs bare for a short space above the tarsal joint, long and rather slender; three toes in front, one behind; the middle toe united by a short membrane to the outer toe; the inner toe free; the hind toe articulated upon the tarsus; claws long and subulate (p. 5 i I $^{2}$ ).

\section{Family CHARADRIID底.}

Cursorius, Latham. - Bill a trifle shorter than the head, straight to the end of the nasal furrow, then decurved to the tip, which is pointed. Nostrils oval. Wings long, rather pointed; the first and second quill the longest in the wing. Tail rounded. Tarsi long and slender; three toes, only, all in front, the middle toe almost as long again as the lateral toes (p. 5I9).

Eudromias, C. L. Brelmm.-Bill rather slender, compressed, shorter than the head; nasal furrow extending about half the length of the upper mandible, which is horny and slightly decurved to the tip. Nostrils sub-basal, lateral, linear. Tail rather long, slightly rounded. Wings of moderate length, pointed, the first quill the longest; the inner secondaries very nearly as long 
as the primaries. Legs of moderate length, scutellate, rather slender, naked for a short distance above the tarsal joint. Toes three only, all directed forwards, the outer and middle toes comected at the base by a slight web; claws short, curved, slender (p. 52I).

Egialitis, F. Boie.-Bill much shorter than the head, rather slender; straight to the end of the nasal furrow, which extend's beyond the middle of the bill, then slightly raised, but bent downwards at the tip. Nostrils small and linear. Wings long, pointed, the first quill the longest; the inner secondaries attaining the tip of the third primary. Tail broad, slightly rounded. Leegs moderately long, slender, bare for a short distance above the tarsal joint; tarsi reticulated. Toes three only, slightly webbed at the base (p. 523).

Cinaradrius, Limuzus. - Bill shorter than the head, straight, rather slencler, the upper mandible straight to the end of the nasal furrow, then slightly raised, and decurved to the pointed tip. Nostrils sub-basal and linear. Wings long and pointed, the first quill the longest ; inner secondaries much shorter than in Eudromias and somewhat shorter than in isialitis. Legs of molerate length, slender, bare for a short distance above the tarsal joint ; tarsi reticulated. Toes three only, all directed forwards, slightly webbed at the base (p. 531).

SoUATAROLA, Leach.-Bill nearly as long as the head, rather strong, upper mandible straight to the end of the nasal groove which is long and wide: then raised and decurved to the tip. Nostrils sub-basal, linear. Wings long, pointed, the first quill the longest. Legs moderate, slender; lower part of the tibia naked, tarsi reticulated. Toes four in number; three directed forward, and slightly webbed at their base, the fourth behind, rudimental but distinct and elevated (p. 535).

VANEllus, Brisson.-Bill shorter than the head, straight, slightly compressed; the points of both mandibles horny and hard. Nasal groove wide, and reaching as far as the horny tip. Nostrils basal, linear, pierced in the membrane of the nasal groove. IVings large, tuberculated or spured in front of the carpal joint ; the first and second quill-feathers shorter than the third and fourth, which are about equal, and the longest in the wing. Legs slender, with the lower part of the tibire naked; tarsi reticulated behind, scutellated in front. Feet with three anterior toes united at the base by a membrane, and a short hind toe, articulated upon the tarsus (p. 539).

S'TREPILAS. Iliger.-Bill as short as the head, strong, thick at the base, tapering gradually to the point, forming an elongated cone ; upper mandible the longer, rather blunt at the end. Nostrils basal, lateral, linear, pervious, partly covered by a membrane. Wings long, pointed, the furst quill-feather the longest. Feet with three toes in front, united by a membrane at the base and furnished with narrow rudimentary interdigital membranes; a hind toe articulated upon the tarsus and just reaching the ground ( $\mathrm{p} .5+\mathrm{I}$ ).

Himatores, Limuens.-Bill longer than the head, straight, strong, the point much compressed, forming a wedge; culmen of the anterior part slightly convex; upper mandible with a broad lateral groove, extending one-half the length of the bill; mandibles nearly equal in size and length, with the thin ends truncated. Nostrils basal, lateral, linear, pierced in the membrane of 
the mandibular groove. Legs of moderate length, maked for a short space above the tarsal joint ; tarsi strong. Feet with three toes only, all directed forward, united at their base by a membrane : claws broad (p. $5+3$ ).

\section{Family SCOLOPACID.E.}

RECURTIROSTRA, Limisus.-Bill very long, slender, weak, depressed throughout its whole length, flexible, pointed, and curving upwards ; the upper mandible grooved along the upper surface, under mandible grooved along the side. Fostrils near the base of the upper surface of the beak, linear, long. W'ings pointed, the first quill the longest. Legs long and slender, a great portion of the tibia naked : three toes in front, united as far as the second joint by a membrane, the margin of which is concave; hind toe minute, articulated high up on the tarsus $(p .5+5)$.

Himaxtopus, Brisson.- - Bill long, slender, slightly recurved at the tip, cylindri$\mathrm{cal}$, flattened at the base, compressed at the point, both mandibles grooved on the sides along the basal half of their length. Nostrils lateral, linear, elongated. Wings very long, the first quill considerably the longest. Legs very long and slender; three toes only, all in front, the middle united to the outer toe by a membrane of considerable size, and to the interior toe by a smaller membrane; claws small and flat (p. $5+i)$.

l'lli.ARopts, Brisson.-Bill rather long, weak, straight, depressed, and blunt; both mandibles grooved throughout their whole length; the upper mandible slightly curved at the point. Nostrils basal, lateral, oral, with an elevated margin. Wings long and pointed, the first quill the longest. Legs rather short, slender. Tarsus compressed; three toes in front, furnished with an extension of the membrane laterally, forming lobes slightly serrated at the edges; a small hind toe articulated on the inner side of the tarsus (p. 549).

scolopAx, Brisson,-Bill long, straight, compressed, slender, snft, slightly curved at the point; both mandibles grooved over the basal half of their length: point of the upper mandible extending beyond that of the lower mandible, the curved part forming a slight crook; superior ridge elevated at the base, prominent. Nostrils lateral, ibasal, pierced?longitudinally near the edges of the mandible, covered by a membrane. Wings moderate, the first quill the longest. Tail short, rounded. Legs rather short, tibia feathered nearly to the tarsal joint; three toes before and one behind, the anterior toes almost entirely divided (p. 553).

Galtisago, Lackin-Bill very long, straight, slender, flexible, slightly elevated towards the tip of the upper mandible, mhich is decurved at the point and projects beyond the lower; both mandible; groored orer the basal half of their length. Nostrils lateral, linear, basal, coverecl by a membrane. Tail slightly rounded. Wings moderate, pointed, the first quill the longest; inner secondaries very long. Legs rather long and slender; naked space on the tibia short; trreus scutellate; three toes before, long, slender, divided to the base ; hind toe slender, elevated ; claws slender, acute (p. 555).

Macrorhauphus, Liach.-Bill long, straight, rounded, rather slender in the middle, the tip dilated, slightly incurved and rugose. Nostrils lateral, basal. Wings long and pointed. Tail of twelre feathers. Lorrer part of the tibia naked; toes four in number, those on the outside connected at their base by a membrane; the hind toe touching the ground only at the tip (p. 56r). 
Lrmicot.A, $K$. L. Koch. - Bill much Ionger than the head, nearly as broad as high at the base, very flat and wide up to the tip, where it is gradually rounded to an olotuse point, with the terminal point slightly decurved; nostrils oval, oblique, placed in a depressed membrane. Wings long, pointed, the first quill the longest; inner secondaries long and pointed. Tail moderate, doubly emarginate. Legs rather short, slender, bare on the lower part of the tibia; tarsus scutellate; the three anterior toes long and slender, slightly webbed at the base; the hind toe moderate (p. 563).

Tri:Ma, Brisson.-Bill rather longer than the head, sometimes decurved, rather flexible, compressed at the base, depressed, dilated, and blunt towards the point, both mandibles grooved along the sicles. Nostrils lateral, placed in the membrane of the groove. Wings moderately long, pointed, the first quill the longest. Legs moderately long, slender, lower part of tibia raked ; three tces in front, divided to their origin; one toe behind, small, and articulated upon the tarsus (p. 565 ).

CAlidris, Illiger.-Bill as long as the head, straight, slender, flexible, compressed at the base, with the point dilated and smooth. Nostrils basal, lateral, narrow, longitudinally cleft in the nasal furrow, which extends to the smooth point of the beak. Wings of moderate length, pointecl, the first quill the longest. Tail of twelve feathers. short, doubly emarginate. Legs rather short, naked for some distance above the tarsal joint. Feet with only three tois, all directed forwards, with a very small connecting membrane at their base $\left(p .58_{3}\right)$.

Macnetes, G. Cucier.-Bill straight, rather slender, as long as the head, with the tip dilated and smooth; upper mandible laterally sulcated for four fifths of its length; culmen rounded. Nostrils basal, lateral, linear, placed in the commencement of the groove. Wings long and pointed, the first quill the longest. Legs moderate, the tibia naked for a considerable space above the tarsal joint. Toes, three before and one behind; the outer toe united to the middle one by a small web; hind toe short, barely touching the ground. During the breeding-season the head and neck of the male are adorned with long plumes, which, when raised, form a large ruft around the head, and the face is covered with small fleshy warts or papille (p. $5 S_{5}$ ).

Trysites, Cabanis,-Bill shorter than the head, slender, straight, decurved, acute and hardened at the tip ; nasal groove long; nostrils basal, linear, rather large. Gape extensive. Wings pointed, the first quill the longest. 'Tail rounded, with projecting central feathers. Legs moderate, slender, the tibia bare for a considerable distance ; tarsus compressed, slender, scutellate, anterior toes cleft nearly to their bases; hind toe small, elevated ; claws small. arched, slender, slightly acute ( $\left.\mathrm{p} .5 S^{7}\right)$.

BARThAmi, Lesson. - Bill scarcely longer than the head, moderately slender, straight, the nasal groove extending nearly to the tip, which is narrowed but obtuse; nostrils linear, basal. Gape very wide and deep. Wings not reaching to the end of the tail, pointed; the first quill the longest, the inner secondaries rather elongated. Tail of twelve feathers, long, much rounded. Legs rather loug and slender, the tibia bare for a considerable distance: tarsus scutellate; toes, three in front, long and slender, a slight web between the outer and the middle ones; hind toe elevated (p. 5\$g).

Tordxus, Bichstim.-Bill longer than the head, stmight or very slightly re- 
curved, soft at the base, hard, solid and cutting at the point, compressed throughout the whole length, ending in a sharp point; both mandibles grooved at the base, the extreme end of the upper mandible slightly bent towards the under one. Nostrils lateral, linear, pierced longitudinally in a groove. Wings moderate; the first quill the longest; inner secondaries elongated. Tail rather short; somewhat rounded. Legs moderate or long, slender, naked above the tarsal joint: three toes in front, one behind; the middle toe united to the outer toe by a membrane (p. 59I).

Lrmosa, Brisson.-Bill very long, rather thick at the base, compressed, slightly curved upwards; both mandibles grooved laterally to within a short distance of the point, which is somewhat dilated and blunt; tip of the upper mandible projecting beyond the lower one. Nostrils basal, placed in the lateral groove, narrow and longitudinal. Wings pointed, of moderate length, the first quill the longest. Tail short and even. Legs long and slencler, a great part of the tibia naked. Feet four-toed, three in front, one behind; outer and middle toes united at the base by a mombrane, the inner toe nearly free; middle claw dilated, recurved, and pectinated; hind toe short, and articulated upon the tarsus (p.607).

Numenius, Brisson.-Bill long, slender, and decurved to the point, which is hard; upper mandible rather longer than the lower, rounded near the end and grooved along three-fourths of its whole length. Nostrils lateral, linear, pierced in the groove. Wings moderate, the first quill the longest. Legs rather long, slender; tibia partly naked; three toes in front, united by a membrane as far as the first joint; one toe behind articulated upon the tarsus and touching the ground (p. 6Ir).

\title{
Order GAVIÆE.
}

\author{
Family LARIDA. \\ Subfamily STERNINT.
}

IydrocheLIDON, Boie.-Bill about as long as the head, nearly straight, tapering. Nasal groove rather long; nostrils basal, direct, oblong. Wings long and pointed, the first quill the longest. Tail short, very slightly forked. Legs short; the tibia bare for some distance; the tarsus compressed, anteriorly scutellate; three toes in front connected by deeply scalloped webs; hind toe small and elevated; claws long, slender, curved (p. 6I 7).

Sterna, Brisson.-Bill longer than the head, nearly straight, compressed, often slender and tapering, with the edges sharp, and the end pointed; the mandibles of equal length, the upper one slightly decurved. Nostrils near the middle of the beak, pierced Iongitudinally, pervious. Wings long, pointed, the first quill-feather the longest. Tail distinctly forked in varying degrees. Legs slender, naked for a short space above the tarsal joint; tarsi short. Toes four; the three in front united by intervening membranes concave in front, or semi-palmated; the hind toe free; claws curved (p. 623).

Anoüs, Slephens.-Tail moderately long, rounded, slightly emarginate. Three anterior toes united by a very full web, hind toe small; claws strong and curved. Otherwise much as in Sterna (p. 639). 


\section{Subfamily LARINE.}

XEMA, Leach. - Bill rather shorter than the head, moderately stout; the upper mandible decurved from beyond the nostrils to the tip, the gonys angulated and advancing upwards. Nostrils basal, lateral, linear. Wings Iong, the first quill the longest. Tail distinctly forked. Legs moderately long; the lower part of the tibia bare for some distance; tarsi tolerably strong; three toes in front entirely webbed, hind toe small, elevated (p. 64I).

RHodostethia, Macgillizray.-Bill very short, rather slender; the upper mandible decurved towards the tip, the lower mandible with the intercrural space narrow, the knob slight, the dorsal line concave, and the tip narrow. Wings long, pointed, the first quill the longest. Tail cuncate, the central fiathers much longer than the lateral ones. Legs rather short, the tibia bare for a short distance; tarsus anteriorly scutellate, rough posteriorly; hind toe very distinct, with a large curved claw; the three anterior toes entirely weblod; claws rather large, and curved (p. 643)

LARUS, Limacus.-Bill of moderate length, strong, harci, compressed, cutting, slightly decurved towards the point, lower mandible shorter than the upper, the symphisis angular, prominent. Nostrils lateral. near the middle of the beak, pierced longitudinally, pervious. Wrings long, the first and second quills varying slightly in their relative length, but nearly equal. Tail square at the end. Legs moderately slender, lower part of the tibia nalied, the tarsus long, three toes in front entirely palmated, the hind toe free, short, but not rudimentary, articulated high up on the tarsus above the line of the other toes (p. 645).

Rissa, Stephens.-Bill rather short and stout, the uppor mandible considerably de. curved to the tip, the lower mandible compressed, with the intercrural space long and narrow. Nostrils median, linear, oblong. Wings long, pointed, the first primary slightly exceeding the second. Tail slightly but perceptilly forked in the young, nearly square in the adult; tarsus very short in propor. tion to the foot; hind toe mimute and usually obsolete; claws rather small, slightly curved (p. 667).

Pagophild, Kaup.-Bill shorter than the head, rolust, compressed, straight, the upper mandible decurved towards the tip, lower mandible narrower. Nostrils basal, linear, oblong, wider in front, covered above and behind with a sloping thin-edged plate. Wings long, pointed, the first quill longest. Tail rathe' lons, slightly graduated. Legs short, bare for a short distance above the tilia; tarsi broadly scutellate in front, and minutely at the sirles and back; interdigital membranes emarginated and serrated; claws strong and curved; hind toe furnished with a large clase, and connected on the inside with the tarsus by a well-defined web (p. 669).

\section{Subfamily STERCORARINA:}

Stercorarius, Brisson. - Bill strong, harl, cylindrical, formec for cutting : compressed, curved, and hooked at the point; base of the upper mandilib covered with a cere. Nostrils situated towards the point of the beak, diagonal, narrow, closed behind, pervious. Tail slightly rounded, the two middle feathers elongated, sometimes consiclerably. Wings moderate, the first quill the longest. Legs strong, naked above the tarsi, which are mather long : three toes in front, palmated; the hind toc small; claws large, strong; very much curved (p.67I). 


\section{Order PYGOPODES.}

Family ALCID R.

ALCA, Linncus. - Bill straight, large, compressed, very much decurved towards the point, basal half of both mandibles covered with feathers, grooved towards the point, the superior mandible hooked, the under one forming with it a salient angle. Nostrils lateral, marginal, linear, near the middle of the beak, the aperture almost entirely closed by a membrane covered with feathers. Wings short. Tail pointed. Legs short, very far back; only three toes, all in front, entirely webbed; claws but slightly curved (p. 679).

URIA, B'risson. - Bill of moderate length, strong, straight, pointed, compressed ; upper mandible slightly curved near the point, with a small indentation or notch in the erlge on each side. Nostrils basal, lateral, concave, pierced longitudinally, partly closed by membrane, which is also partly covered with feathers. Wings short, first quill the longest. Tail shorter than in Alca. Legs short, slender, placed behind the centre of gravity in the body ; feet with only three toes, all in front, and entirely webbed (p. 683).

Mergulus, Vieillot.-Bill shorter than the head, thick, broader than high at the base; culmen arched; upper mandible indistinctly grooved, under mandible with the symphysis very short and oblique, the tips of both notched ; commissure arched. Nostrils lateral, round, situated at the base of the bill, and partly covered with small feathers. Wings and tail short. Legs far back, short ; feet with three toes, all directed forwards and united by a membrane (p. 689).

IRATERC'IA, frison.--bill higher than long, much compressed ; both mandible: arched, transversely grooved, notched towards the point. Nostrils lateral, naked, almost entirely closed by a membrane. Wings and tail short. Legs very far back; feet with three toes only, all in front and fully webbed; claws curved (p.69I).

\section{Family COLYMBIDA.}

Colymis, Linncus. - Bill about as long as the head; strong, straight, rather compressed, pointed. Nostrils basal, lateral, linear, perforate. Wings short, the first quill the longest. 'Tail short and rounded. Legs thin, the tarsi compressed, placed very far backwards, and closely attached to the posterior part of the body; toes three in front united by membranes, one toe behind with a small membrane, articulated upon the tarsus; the claws flat (p. 693).

\section{Family PODICIPEDIDA.}

Podicrpes, Latham.-Bill of moderate length, straight, hard, slightly compressed, pointed, forming an elongated cone. Nostrils lateral, concave, oblong, open in front and perforate, closed behind by a membrane. No true tail. Wings short, first three primaries nearly equal, and the longest in the wing. Legs and feet long, attached behind the centre of gravity; tarsi very much compressed; three toes in front, one behind; anterior toes very much flattened, united at the base, surrounded by a lobated membrane; hind toe also flattened, articulated on the inner surface of the tarsus; claws large, flat (p. 7OI). 


\title{
Order TUBINARES.
}

\author{
Family PROCELLARIID \&.
}

Fulmarus, Stephens.-Bill not so long as the head; the upper mandible composed of four portions, divided by lines or indentations, the whole together large and strong, curving suddenly towards the point; the under mandible grooved along each side, bent at the end, with a prominent angle beneath; the edges of both mandibles sharp and cutting; those of the lower mandible shutting just within those above. Nostrils prominent along the upper ridge of the upper mandible, but united, enclosed, and somewhat hidden within a tube with a single external orifice, within which the division between the two nasal openings is visible. Wings rather long, the first quill the longest in the wing. Tarsi compressed, feet moderate; three toes in front united by membranes, hind toe rudimentary, with a conical claw (p. 7 II ).

Gstrelata, Bonaparte.-Bill rather shorter than the head, stout, compressed, straight for some distance, then ascending at the commencement of the unguis, which is sharply decurved, with an acute tip; nasal tubes moderately long, elevated, conspictous, the dorsal outline straight, the orifice subcircular. Wings long and pointed, extending beyond the tail when folded; the first quiil a trifle longer than the second. Tail moderately long and graduated. Tarsi reticulated; feet and front toes of moderate size; hind toe small and elevated (p. 713)

Puffrnus, Brisson. - Bill rather longer than the head, slender; mandibles compressed and decurved. Nostrils tubular, with two separate orifices. Wings long and pointed, the first quill slightly the longest. Tail graduated. Tarsi compressed laterally; three toes in front, rather long, webbed throughout ; hind toe rudimentary (p. 7 I5).

Bulweria, Bonaparte.-Bill about as long as the head, stout at the base, compressed, rising at the nail, which is large; nostrils tubular, dorsal, rather short. Wings long, pointed, the first quill slightly the longest. Tail long and cuneate. Legs slender, the tibia bare for a short distance above the joint; tarsi reticulated; hind toe minute, elevated; feet fully webbed, the inner toe shorter than the middle and outer toes, which are about equal ; claws curved (p. 723).

Cynocitores, Coues.-Bill shorter than the head, moderately stout, compressed, rising slightly at the nail, then decurved; nostrils tubular, dorsal. Wings long and narrow; the first quill-feather shorter than the secondwhich is the longest-and also than the third, and about equal to the fourth. 'Tail long and deeply forked. Legs short, slender; tarsi anteriorly reticulate; hind toe minute, front toes long and slender; webs slightly emarginate (p. 725, as OCEANOI)ROMA).

Procellaria, Linnceus.-Bill small, robust, much shorter than the head, straight to the nail, which is decurved; nostrils dorsal. Wings long, narrow: the second quill-feather the longest, slightly exceeding the third; the first quill shorter than the fourth. Tail of moderate length, slightly rounded. Legs moderate, the tarsi anteriorly reticulate, and a little longer than the feet: webs emarginate; claws rather short ( $p .727)$. 
OCEANites, Keyserling \&o Blasizes.-Bill small and weak, the nail gradually decurved; nasal tubes perfectly horizontal. Wings exceedingly long, the second quill much the longest, the first quill being shorter than the fourth, and slightly exceeding the fifth. Tail almost square. Legs long and slender, bare for a considerable distance above the tarsal joint; feet nearly as long as the tarsi, membranes emarginate, hind toe absent (p. 729).

In answer to correspondent, it may be stated that :-

I. Round brackets indicate that the original describer of the species did not employ the generic name now adopted.

2. The omission of Mr. or any other prefix to a proper name signifies (in the present work) that the person mentioned is dead. 


\section{E R R A T A.}

Page I, line 2, and throughout the article, for Missel-Thrush read Mistle-Thrush. "2 216, , 40, for Rustic read Rusty.

", 3I8, , 2, ,, Ayrshire, Dumfries and Galloway mad Ayrshire and Kircud. brightshire.

, 359, "15, delete or 1882.

, 367, , 5, for $1872 \mathrm{read} 1782$.

,, 397. , I6, delete coast.

$, 429,,$, I 8, , and in Fifeshire.

,, 436, , 21, for of the Blackburn Corporation rad Woodfold.

$, 504,, 2$, , salatea read galeata.

,, 608, ,, 26, ,, winter read autumn.

.645, ,, 12, ,, Jannary read January.

, 681, , 13, , $1812 \mathrm{rad} 1813$.

, 725, , 3, , Oceanodroma read Cymochorea. 



\section{BRITISH BIRDS.}

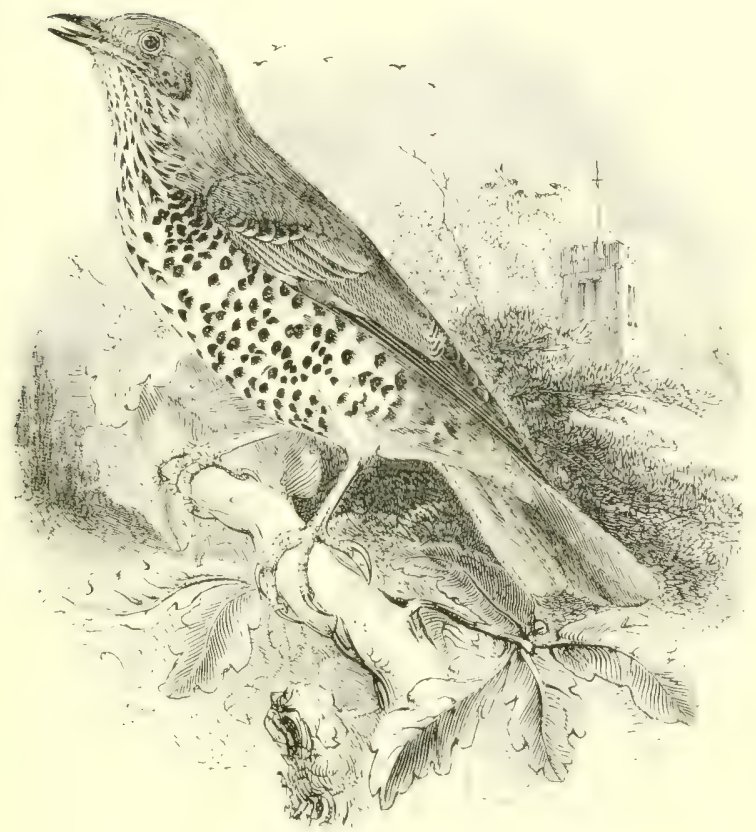

THE MISSEL-THRUSH.

TURdUs viscívorus, Linnæus.

The Missel-Thrush, the largest indigenous species of the genus, has, owing to the increase of plantations during the present century, extended its breeding-range northward to Caithness and Sutherland, and to most of the Hebrides; though to the Orkneys it is only a straggler, and has not yet been recorded from the Shetlands. Unknown in Ireland until about the year $\mathrm{I} 800$, it is now a resident and increasing species there; while in England and Wales it is of general distribution, being commoner in the wooded districts. Migration takes place from the colder portions of our islands in autumn and winter, when large flocks arrive from the Continent.

It breeds from Bodö in Norway southward, throughout the suitable portions of temperate Europe to the extremity of the Spanish Peninsula, and even in Northern Africa; eastward, in 'Turkey, the Caucasus, the mountain forests of Asia Minor, Turkestan, 
and the north-western Himalayas up to 9,000 feet: in the latter it attains its palest colour and largest dimensions, and was formerly distinguished as $T$. hodgsmi. In temperate Siberia it is found eastward to Lake Baikal; migrating in winter to Northern India, Persia, and Africa north of the Sahara.

In the south of England the Missel-Thrush sometimes begins to brecd in February, and even in the north it frequently has eggs in March. The nest, which when placed in a wide fork of a tree has a considerable foundation of mud, is lined with dry grasses and composed externally of bents and lichens, but although the colour of the latter may resemble that of the branch on which the structure is placed-bushes being seldom resorted to-there is often no attempt at concealment. The eggs, $4-5$ in number, are greenish to tawny-white, blotched with reddish-brown and lilac: measurements about $\mathrm{I}^{\circ} 25 \mathrm{in}$. by $8_{5} \mathrm{in}$. In the south two broods are generally produced annually, but in the north the fine weather is too short for more than one. From its habit of singing early in the year in defiance of rough weather, the Missel-Thrush is often called the 'Storm-cock'; also the 'Holm-screech,' from its partiality to the berries of the Holm or Holly, and its harsh churr-ing note. Its trivial name is probably a contraction of Mistletoe-Thrush, owing to a widely-spread belief in its predilection for the berries of that parasite; but in Great Britain its food consists rather of berries of the yew, holly, mountain-ash, hawthom, ivy, \&c., fruit when obtainable, worms, snails and insects. Although shy of man, except when its nest is approached, the Missel-Thrush is bold and tyrannical towards other birds, fearlessly attacking Magpies, Jays, and other species superior to it in size; and occasionally it has even been known to carry off nestlings. Its fight is rapid but jerky, and on the wing its large size and generally sry appearance serve to distinguish it from any other Thrushes.

Adult male: upper parts ash-brown; under parts buffish-white, with bold fan-shaped spots, snsaller and more arrow-shaped on the throat; under wing-coverts and axillaries pure white; bill hornbrown, yellowish at the base; legs pale brown. Length about I $\mathrm{x}$ in. ; wing from the carpal joint $5^{\prime} 75 \mathrm{in}$. The female is slightly paler than the male. In the young the arrow-shaped markings on the throat and breast are more pronounced; the upper wing-coverts broadly tipped with white, and the under parts, especially the flanks, suffused with golden-buff. In this plumage it has been mistaken for the rare White's Thrush, but its twelve tail-feathers distinguish it. 


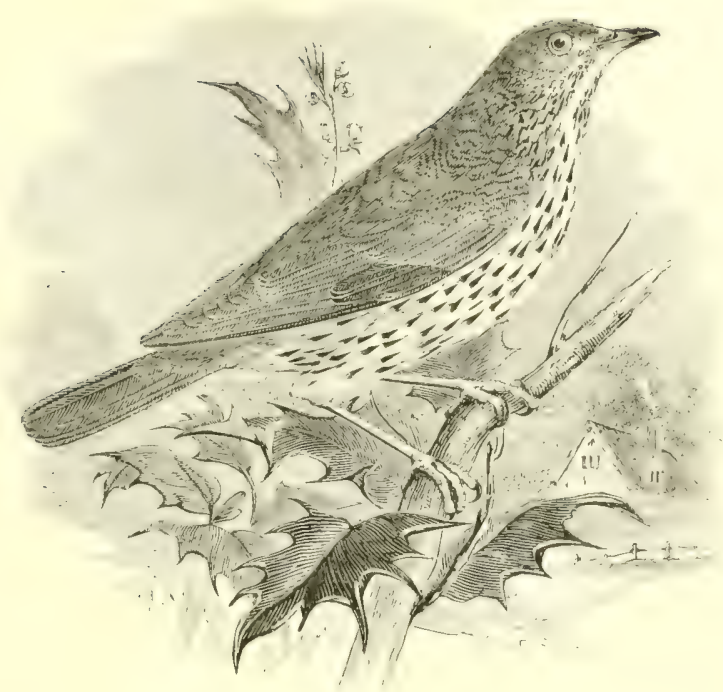

THE SONG-THRUSH.

TURdus Músicus, Linnæus.

The Song-Thrush-known in the North as the Throstle or the Maris-is generally distributed throughout the British Islands; and in summer it appears to be equally at home in the cultivated rewions of the south, or amongst the storm-swept, surflashed rocks of the Outer Hebrides (where the birds are small and dark). In the shetlands, however, it is of very rare occurrence, and has not yet been known to nest. Especially in the north, a migratory movement takes place in autumn among our native birds, while consiclerable numbers then visit us from the Continent. Northwards the SongThrush las straggled to the desolate island of Jan Mayen, between Iceland and Spitsbergen; and southwards to Madeira. From within the Arctic circle in Norway its breeding-range extends across Europe and Asia up to about $60^{\circ} \mathrm{N}$. lat., as far east as the Pacific ; and southwards, throaghout temperate kurope-sparingly and at increasing elevations in the south-down to the P'yrencan chain, the north of Italy, and the Caucasus. In winter, abandoning the colder regions, it migrates in great numbers as far as Northern Africa, Nubia, Asia Minor, and Persia.

The song-Thrush is an early breeder, and young birds may some- 
times be found by the end of March. The well-known nest, with its smooth water-tight lining of rotten wood and dung, is generally placed in the middle of a thick bush or among ivy, and not unfrequently in a moss-covered bank; occasionally, but rarely, on level ground. The eggs, 4-6, are of a shining greenish-blue, blotched with black or rusty-brown: spotless varieties being not uncommon: average measurements $I$ in. by ${ }^{7} 78$ in. The female sits very closely, and is assisted to some extent by the male in the task of incubation, which lasts about a fortnight; two and sometimes three broods being produced in the season: the young, presumably of the first, aiding in rearing the second. It is not a pugnacious bird. The much-admired song, characterized by a distinct repetition of its three or four component notes, may be heard on a warm bright day very early in the year; continuing until the moulting season, and being often resumed in autumn: it is frequently uttered on fine nights. For nine months of the year the Song-Thrush feeds on wild berries, insects, worms, and snails, the shells of the latter being broken against some convenient stone; but when fruit is ripe, the bird undoubtedly varies its diet, and in the vine-countries it feeds largely on grapes. On the sea-coast whelks and other "shell-fish" are eaten, and this may have something to do with the dark colour of the Hebridean birds. Nigration takes place at night, when flocks of this species drop suddenly and almost perpendicularly into wooded places, where numbers are frequently snared for the table; and an interesting account of the tindiries am Griats in Belgium, is to be found in Gould's 'Birds of Great Britain.' It may be mentioned that although the Song-Thrush is called "Maris" in Scotland, yet the French Manvis is the Redwing. As regards the duration of life in the Song-Thrush, Mr. J. H. Gurney, jun., informs me that Mr. Bilham of Cromer, kept one for fifteen years.

Adult male: upper parts olive-brown, the wing-coverts tipped with buff; under parts whitish; tawny on the breast and sides, which with the ear-coverts and cheeks are streaked and spotted with dark brown; axillaries and under wing golden-buff; bill hornbrown, yellowish at the base of the lower mandible; legs pale brown. Length about 9 in.; wing $4^{.6} 5$ in. Female: rather smaller and paler on the under parts than the male. Young before first moult, mottled above with buff; afterwards like the parents, but more golden-tinted. Albinism in varying degrees is not uncommon in this species. 


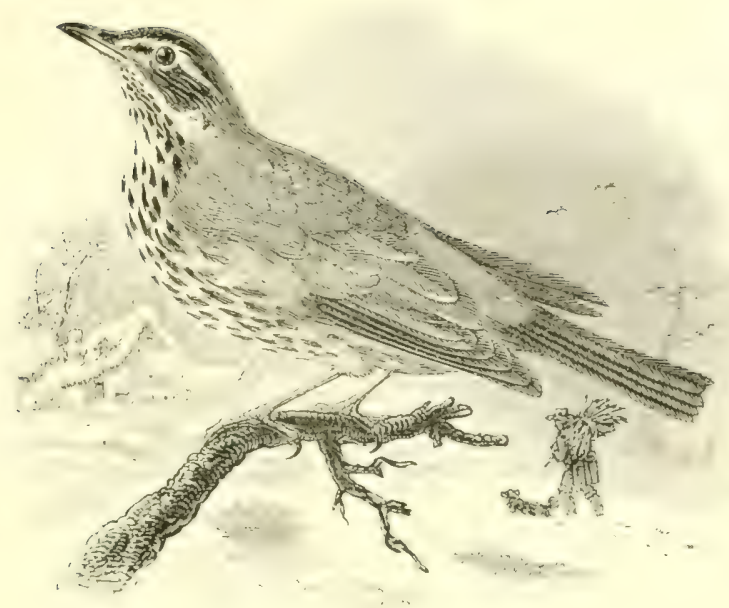

THE REDWING.

Turdus ilíacus, Linnæus.

The Redwing resembles a small Song-Thrush, but it may easily be distinguished by the broad whitish streak wer the eye, and by the rich orange-red of the flanks and under-feathers of the wing: whence the bird's trivial name. The Redwing has been obtained in this country on striking against lighthouses, from the beginning of August onwards, but being less numerous and less gregarious than the Fieldfare its arrival is not so soon noticed. Although the most delicate of the European l'hrushes, the Redwing can resist a con. siderable amount of frost, but should this be followed by a heary fall of shou', such a combination of hardships proves very destructive. In winter, therefore, large numbers go past our shores to suitable situations, as far eren as the south of Europe and the north of Africa, to which this species is a more abundant and regular visitor than the fieldfare. Wistward the Redwing has straggled to the Canaries and Madeira : its winter range castward extending to the lower regions of the Caucasus, Persia, 'Turkestan, Northern India, and siberia as far as Iake laikal. In the latter country its breeding-range does not aplear to reach much eastward of that portion of the valley of the lenesei which lics within the Arctic circle; but westward it extends through Russia north of about $5 \%$ N. lat. to Scandinavia. The nest is also said to have been found in 
Poland, Austrian Galizia, and even in Anhalt near the Harz Mountains. In our islands there is no satisfactory proof that this species has ever bred, although individuals have been known to linger throughout the summer; and the late Dr. Saxby asserted that in May, 1855 , he watched a Redwing brooding on four eggs in North Wales, but the bird was not obtained. Nor has it been proved to breed in the Orkneys or the Shetlands; but its nest has been found by Herr Müller in the Færoes, which are annually visited on its migrations to and from Iceland. There the Redwing is generally distributed during the short summer, being the only Thrush which breeds in that island; whence it occasionally straggles to Greenland.

In Norway, where owing to the Gulf stream the climate is comparatively warm, the Redwing sometimes breeds early in May, but elsewhere later. In the forest-region the nest is placed on bushes or low trees, and a colony of Fieldfares will frequently have a nest or two of Redwings on the outskirts; but in the barren districts, sloping banks, hollows between stones, and low fences are selected. The structure is composed of twigs and earth, lined with dried grasses, and is frequently ornamented externally with lichens, especially reindeer-moss. The eggs, generally 6 , are of a peculiar and evanescent green, closely streaked with fine reddish-brown, resembling small varieties of the eggs of the Blackbird, but without the bold markings of those of the Fieldfare: average measurements $98 \mathrm{in}$. by 75 in. Two broods are frequently reared in the season. The parents show great anxiety when the nest with young is approached, snapping their bills angrily as they flutter round the head of the intruder. The song, which has been much, and perhaps unduly eulogized, consists of several clear flute-like notes which may be syllabled as trui, trui, trui, tritritri. The food consists of insects, small snails, and berries, but to the latter the Redwing seems to be somewhat less addicted than are its congeners. Its flight is remarkably rapid.

Male : upper parts clove-brown; wing-feathers rather darker, with paler edges; over the eye a conspicuous whitish streak; under parts dull white, broadly streaked with dark brown on the throat, breast and part of the flanks, the inner portion of the latter being of a rich orange-red; under wing-coverts and axillaries somewhat paler. Bill dark brown above, lighter at lower base; legs pale brown. Total length about $8 \cdot 75$; wing $4{ }^{\circ} 4$ in. Female: slightly duller than the male. Young: spotted on both upper and under parts, and, after the first autumn moult, with well-defined pale tips to the wing-coverts. 


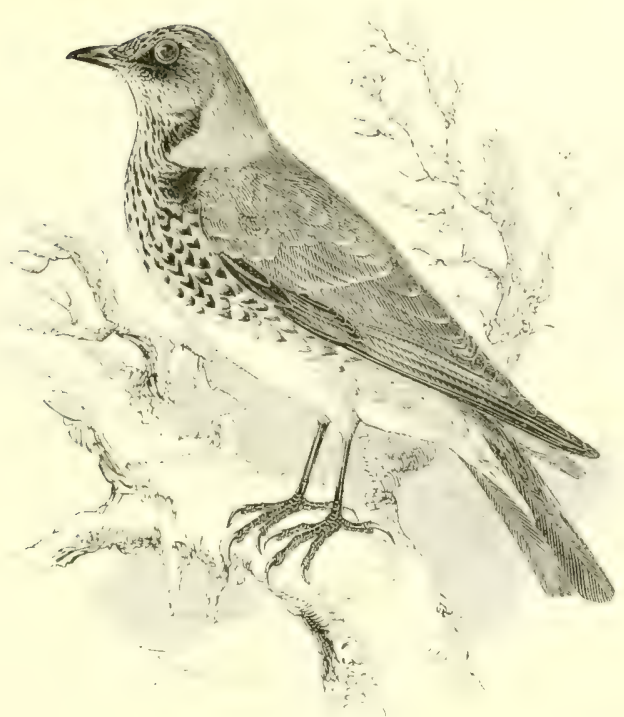

THE FIELDFARE.

\section{Turdus piláRIS, Linnæus.}

The Fieldfare is one of the regular visitors to our islands, the date of its arrival depending upon the autumnal temperature in those northern regions of Europe which form its principal breeding-ground. In Scotland and in eastern England its appearance has been recorded from the middle of September onwards, but on the west side and in Wales it is usually later, often coinciding with the arrival of the Woodcock. Every one must be familiar with the large flocks of lelts, "Blue Felts," or "Felfers," which during the winter are generally distributed throughout the United Kingdom, seeking their food over the fields and pasture-lands during open weather, and resorting to the berry-producing hedges when frost hardens or snow covers the ground. In backward springs the fiieldfare remains until the middle of May, and, exceptionally, till the beginning of June; but there is no proof that it has ever nested in this country.

An irregular visitor to the Faroes, it has straggled two or three times to Iceland, and once even to the island of Jan Mayen. It breeds abundantly in Scandinavia, Finland, Northern Russia, and Siberia as far as the Lena; in smaller numbers in Central Russia, the Baltic provinces, and P'olind; and of late in MLoravia, Bohemia, and Bavaria; while increasing colonies have established themselves in Central Germany, especially near Halle on the Saale, and in Prussia. 
There are even grounds for believing that it nests in the wooded portions of the Alps and the Pyrenees, but as yet proof of this is wanting. Its migrations extend to the African side of the Mediterranean, Asia Minor, Palestine, Persia, Turkestan, and Northern India.

In the forest regions of Northern Europe Fieldfares often breed in large colonies, and in the midst of such an assemblage Mr. A. C. Chapman found a nest with three eggs of the Merlin! In birch and fir woods the nest is in a fork between the trunk and a large branch; but further north, where the birds become less gregarious, heaps of fire-wood, fences, shepherds' huts, \&c., are utilized; while on the treeless tundrus of siberia the nest is placed on the ground, on the edge of a rock or a bank. In Poland breeding com-

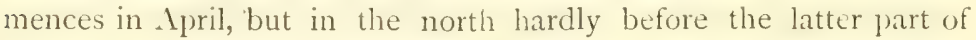
May. The eggs, +6, sometimes 7 , resemble very handsome Blackbird's, but they vary greatly, some being boldly blotched with reddishbrown like Ring-Ouzel's, while others have a light blue ground colour: average dimensions $\mathrm{I}^{\prime} 2$ by ${ }^{\circ} 85 \mathrm{in}$. 'T'wo broods are generally produced in the season. The old birds are very noisy when the breeding-place is approached, uttering their harsh cries of tsak, tsak; the call-note or love song, uttered by the male when on the wing, is a softer warbling qui, qui. The food of the young consists principally of insects, until the wild strawberries and other fruits are ripe; and owing to its fondness for the juniper, this species is known in Germany as the 'Wachholder-drossel.' It generally roosts in trees; sometimes in reed-beds; also on the ground in stubble-fields.

The young Fieldfare on leaving the nest is spotted on the back like the young of other Thrushes, moulting again, as do the parents, before migration. The birds arrive in this country with broad margins to the feathers of the lower parts, but by the following spring these edges have disapueared and the spots become more clearly defined, leaving the bird in its nuptial dress. This is slate-grey, streaked with black on the head; mantle chestnut-brown; rump slate-grey; wings and tail dark brown; throat and breast goldenbrown streaked with black, the flanks boldly marked with very dark brown; centre of the belly white; under wing-coverts and axillaries pure white; bill, which was darker in winter, is now yellow; legs and toes very dark brown. The female is somewhat duller in colour than the male. Length fully ro in. ; wing $5^{\circ} 7^{\circ}$ in. Albinisms of this Thrush are comparatively rare. I ike many of its congeners, it exhibits a few slender hair-like filaments projecting from the nape, and to the accident of their being especially noticed in this species the name pilaris is probably due. 


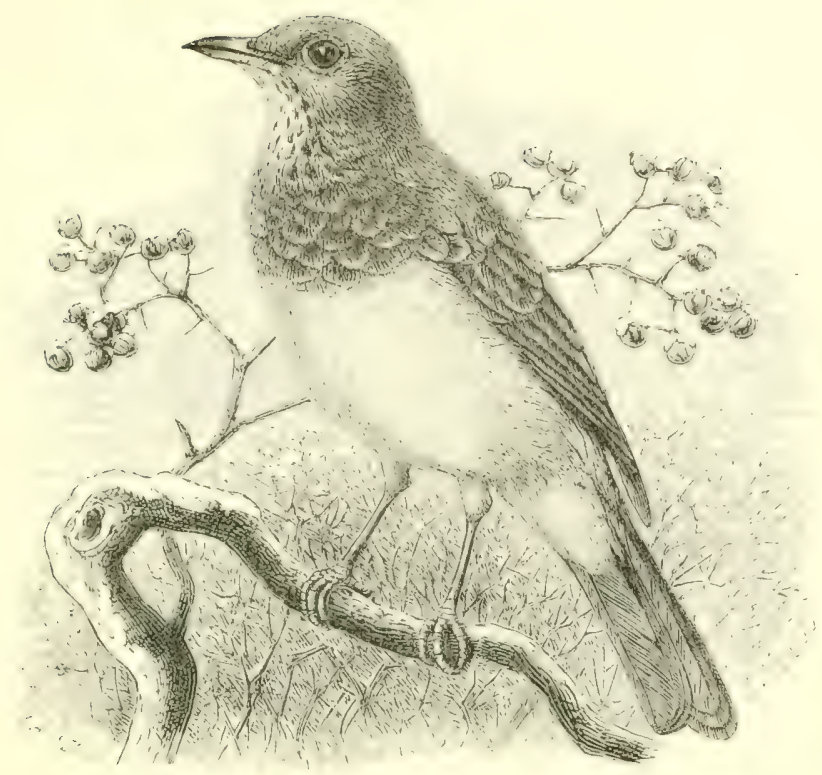

THE BLACK-THROATED THRUSH.

'I'Urdés Atriguláris, Temminck.

A young male of this eastern species was obtained in the flesh by Mr. T. J. Monk of Lewes, shot near that town on December 23 rd, I 868 ; and it is not improbable that other stragglers to this country may have been overlooked, for the species has several times occurred at no great distance from our shores. In l eecumber, 1886 , an example was obtained in Norway; one has been taken in Denmark, two in Heligoland, several in Northern (iermany, liclgimm, and firance, and at least three in Tyrol and Northern Italy. In Central and Eastem Europe its occurrences, as might naturally be expected, become more frequent in proportion as its Siberian home is approached; nevertheless it has only once been obtained in the Caucasian district, near I enkoran. lieyond the I ral Vountains it becomes more abundant, breeding in Fiastern 'lurkestan up to an elevation of t,000 feet, and probably in the valley of the ()bb; and although too late for eggs, Mr. Seebohm obtained three young not fullyfledged in the valley of the Yenesei between $60^{\circ}$ and $63^{\circ} \mathrm{N}$. lat., early in lugust. Herr Tancres's collectors have obtained a series of eggs in the Altai Mrountains which "exhibit the same variation in 
colour as the eggs of the Blackbird, and measure from $I^{\prime} 2$ to I'I 5 in. in length, and from ' 8 to $75 \mathrm{in}$. in breadth" (Seebohm). Crossing the lofty Pamir range in October, it winters in Western Turkestan, Baluchistan, and India as far south as Assam; its range extending eastward to Lake Baikal. There it meets-and perhaps inter-breeds with-the Red-throated Thrush, $T$. ruficollis, a species which has straggled to Heligoland and Saxony.

The food of this species is stated by Dr. Scully to consist in winter chiefly of the berries of the Eleagmus, called "jigda" in Turkestan, whence its name of "jigda-chuk," i.e. "jigda-eater"; a diet varied with insects and worms. Favourite haunts in the cold season are sandhills, low scrub, and trees bordering watercourses. In summer Mr. Seebohm found that the Black-throated Thrush showed a marked preference for pine-trees, and frequented the neighbourhood of the banks of the river where the forest had been cut down for fuel. The parents of the young which he obtained showed great anxiety, making the woods resound with their alarmnote. The song of this species, if it has any, appears to be undescribed.

The adult male in breeding-plumage has the throat and breast black; belly white, turning to greyish-brown on the sides and flanks; upper parts olive-brown, darker on the wings and tail. In winter the throat-feathers have light margins, and the general plumage is duller. Young males resemble the adult female, in which the feathers of the throat and breast are not completely black, but have merely dark centres, forming a streaked gorget; under parts dull creamy-white. In both sexes the under-wing and axillaries are golden-buff. Bill dark brown above, pale below; legs and feet pale brown. Length about 95 in., wing $5^{\circ} 45$ in.

The American Nigratory 'Thrush, Turdus migratorius, commonly called in its native country 'the Robin,' owing to its ruddy breast, has been obtained at Dover (Zool. I877, p. I 4 ); but like the Wydahbird and other exotic species obtained in that locality, it had probably escaped from some ship passing through the narrow seas, and the species cannot be considered to have a claim to a place in the British list. It has occurred once at Heligoland, which is on the high road of vessels for Bremen and Hamburg; and it is not unfrequently brought to Europe as a cage-bird. 


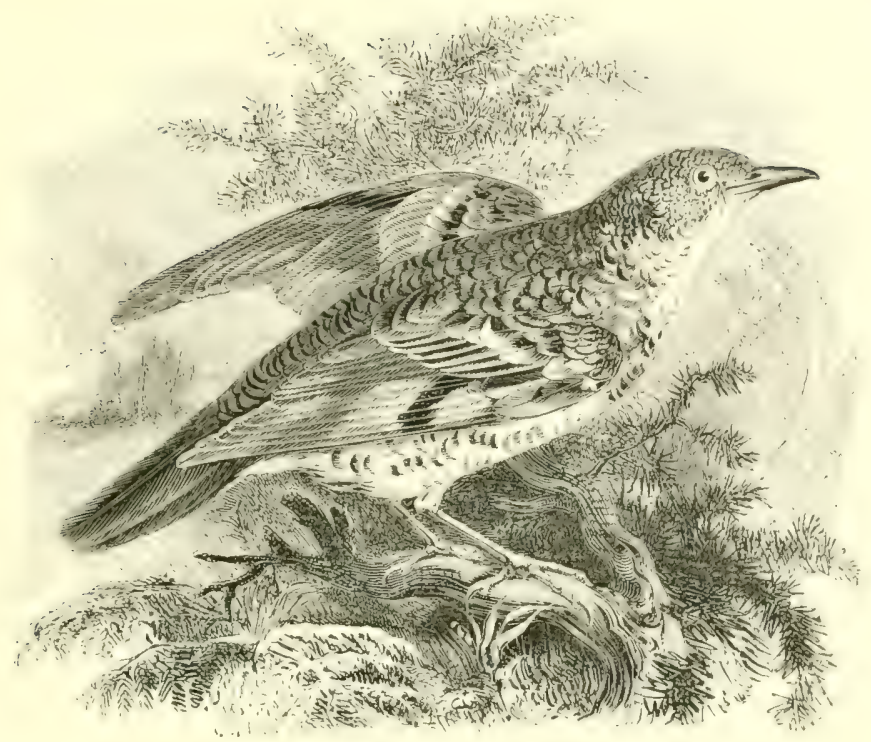

\section{WHITES'S THRUSH.}

\section{Turdus várius, Pallas.}

This boldly-marked species, rather larger than the Missel-Thrush, belongs to a group known as the 'Ground' 'Thrushes (Geocichla), characterized by a partiality for woodland glades, where insects, their principal food, are obtained among the dead leaves on the humid soil. Owing to this habit, their large size, mottled plumage, and low undulating flight, several of the White's Thrushes obtained in this country have at first been mistaken for Woodcocks. 'The earliest recorded Jiritish example was shot in January, i $\$ 2 \$$, in Hampshire; receiving a scientific as well as a trivial name in honour of White of Selborne, from Eyton, who supposed the species to be undescribed. Others have since been obtained in Cornwall, I)evon, Somerset, Gloucestershire, Suffolk, Norfolk, Yorkshire, and I)urham ; once in Berwickshire; and in Ireland in counties Cork, I ongford, and Mayo. Most of these occurrences have been in the winter, and only one in October; but on Heligoland about a dozen have been recorded: in September and October, and on the return migration up to the 23 rd of $A_{\text {pril. }}$ On the Continent, stragglers have been obtained, mostly in autumn, from Norway and Sweden southwards to Italy and the foot of the Pyrences. 'The true home of White's, or as it 
might be more appropriately called the "Golden" Thrush, extends eastward through Siberia from about the line of Krasnoiarsk on the Yenesei to Lake Baikal and Northern China ; the winter migrations reaching to Southern China, the Philippine Islands, and even Sumatra. In Japan Captain Blakiston says that the 'Nuyejinai,' as it is called, is common in Yokohama market in winter, and having been obtained in July on the volcano of Fuji, it was probably breeding there. A nest built on a pine-branch, close to which a pair of birds were seen, was obtained by Swinhoe near Ningpo, and one of the eggs figured by Mr. Seebohm ('British Birds,' pl. 8) has a greenish-white ground with minute reddish spots: measurements $\mathrm{I}^{\circ} \mathrm{2}$ by ${ }^{\circ} \mathrm{in}$. Although White's Thrush is mostly insectivorous, in China banyan and other berries are consumed. Its note is a soft plaintive see, audible at a long distance.

In the adult the bill is brownish; legs and feet yellowish.brown; upper plumage yellowish-brown tipped with black, darker on the wings; under parts white tinged with buff, and boldly marked with black crescentic spots; a distinct light-coloured fatith in the middle of the underside of the wing; tail of fourteen feathers, the central four yellowish-brown and the rest dark brown, all tipped with white. Length 12 in.; wing 6.45 in. An Australian species, T. lumulatus, with only twice tail-feathers, has not unfrequently been passed off as White's Thrush.

An example of the Siberian Thrush (T. sitivicus, Pallas), said to have been shot in Surrey in the winter of $\mathrm{I} \$ 60-6 \mathrm{I}$, and originally supposed to be a melanism of the Redwing, is in the collection of Mr. F. Bond; and I fully beliere that another was picked up exhausted at Bonchurch, I. of Wight, in the winter of 1874 ; but the evidence is not sufficient to warrant the introduction of this species into the British list. Like White's Thrush, it has the light-coloured patch on the underside of the wing, characteristic of the genus Gocicilia. The adult male is dark slate-grey, with a conspicuous white eye-streak, and white abdomen; the female is olive-brown above, and whitish-buff barred with brown beneath; both sexes haring white patches at the tips of the tail-feathers. Stragglers have occurred as near our shores as Germany, Belgium and France. 


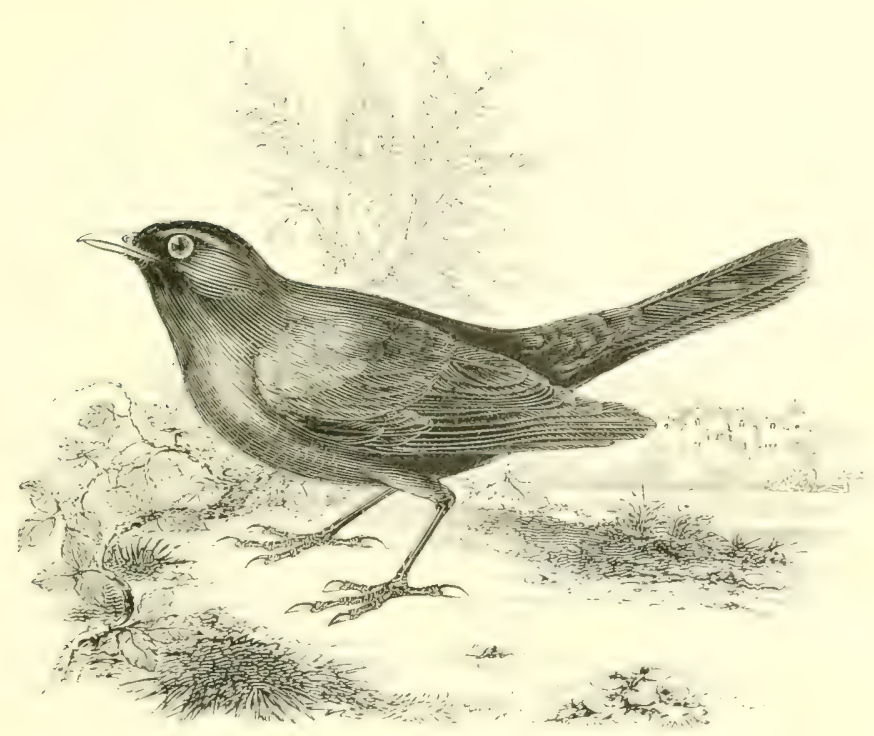

THE BLACKBIRD.

TURDUS MÉRUla, Linnæus.

The Blackbird, "the Ouzel-cock so black of hue" of Shakespeare, is of general distribution throughout the Pritish Islands, where it may be considered as a resident, excepting in some of the Outer Hebrides and the Shetlands, to which it is chiefly an autumn and winter visitor. Like the Missel-Thrush and probably for the same reasons, the Blackhird has spread northward and westward of late years; in some places, as at Gairloch in Ross-shire, supplanting the Ring-()uzel : while in addition to our native-bred birds, some of which are, perhaps, partially migratory, large flocks visit us in autumn and winter.

In the Froes the Blackbird has occurred in spring; it undoubtedly straggled to Iceland in the winter of $1 \$ 77$, and once to the island of Jan Mayen. About $67^{-}$N. lat. in Norway appears to be its highest breeding-range: south of which it is found nesting down to the Azores, Madeira, the Canaries, both sides of the Mediterramean, Asia Minor, and even in the sultry depths of the Ghor in Palestine. In Russia it does not appear to range further north or east than the valley of the Volsa: being represented in Turkestan, Afghanistam. and Cashmere by a larger resident species or form, which MIr. 
Seebohm calls Mirula maxima. In winter its numbers in southern countries are considerably increased by migrants from the nortl.

The usual nesting-places selected by the Blackbird are bushes, especially evergreens and hedge-rows; occasionally the ground; but the nest differs from that of the Thrush in being lined with dried grasses. The eggs, $4_{-6}^{-6}$, are of a greenish-blue, spotted and streaked with reddish-brown: average measurements $I^{\prime}{ }^{\prime}$ by ${ }^{8} S_{5}$ in. Blue varieties resembling eggs of the starling are sometimes met with, but it is well known that the Blackbird and the Song-Thrush occasionally inter-breed, and these blue eggrs may be the result of such a union, upon which Mr. R. M. Christy has a valuable paper (Tr. Norw. Soc. iii. p. 5SS). Several broods are hatched during the season, the first often by the end of March. The old birds are much more shy during the breeding-season than the Song-Thrush, but the cock, especially at pairing-time, is very quarrelsome. The food consists of worms, insects and their larve, slugs and snails, with seeds, hawthorn- and other berries in winter, and fruit in summer. The Blackbird's powerful song makes it a favourite for the cage, and it is further gifted with a considerable power of mimicry; while its noisy, rattling alarm-note, as it flits from the hedge-rows or copses to which it is partial, must be familiar to every one. A peculiarity by which the Blackbird may be recognized, even in a bad light, is its habit of sharply raising its tail the moment it perches. As in the case of the Song-Thrush, the young of this species sometimes assist the parents in feeding the second brood.

Adult male: entire plumage glossy-black; bill and edges of the eyelids yellow; legs and feet brownish-black. I ength about ro in. ; wing +9 in. Female: umber-brown, pale and more rufous on the throat and breast, with darker streaks - some mountain forms being exceptionally light-coloured; bill and legs brawnish. roung males can be distinguished in the nest by their stouter bill and darker hue, especially along the carpal joint; and if a few of the first brown feathers of the breast be pulled out, they will be reproduced of a black colour. Later, the plumage is blackish-brown above, with pale shaft-streaks; under parts lighter. Even after assuming the adult plumage, young males of the year have blackish bills. Albinos and pied varieties of the Blackbird are by no means uncommon. 


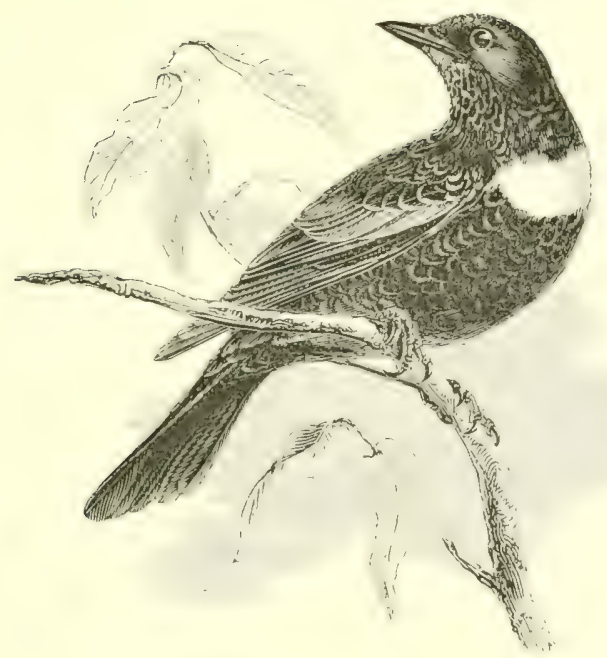

THE RING-OUZEL.

TuRdus TORQUUÁtus, Linnæus.

The Ring-Ouzel is the only Thrush which is entirely absent from our islands during the winter; for although, in exceptionally mild years, individuals have been known to remain as late as Christmas, the majority leave in September and October the wilder and more elevated districts in which they have passed the summer; and, after a comparatively short stay in the lowlinds to feed upon the autumnal berries, they depart for the south. In April the Ring-Ouzel returns, and pairs are said to have nested occasionally in Hampshire, Suffolk, Norfolk, Warwickshire, and similar counties, but as a rule its breeding-places are in the wild and hilly districts of Cornwall, Deron, Somersetshire, the Pennine backbone of England and its spurs; Wales; and the greater part of Scotland, including most of those islands which present suitable features, except the Orkneys and the Shetlands, to which it is comparatively a rare visitor. In Ireland it frequents the mountainous districts in limited numbers durmg the summer.

In Scandinavia it breeds from alout 5 S N. lat. northward, while eastward it is found in suitable localities as far as portions of the Ural Mountains, beyond which the steppes appear to act as a barrier. It is said to breed sparingly in the south of Holland 
and Belgium; and undoubtedly does so in the elevated districts of France, Switzerland, Germany, Austria, and Southern Russia, frequenting the rhododendron-region of the Caucasus nearly up to the snow-line, and, according to Radde, remaining even in winter at a lower elevation in that chain; also in Asia Minor. It likewise nests in the Pyrenees, where, from the date of its spring arrival, it is known as the 'Pie de Mars'; and in the Sierra Nevada in the south of spain. On migration it is found in varying numbers over almost the whole of Europe and in Northern Africa; visiting Lower Egypt, Syria, and P'ersia. Birds which breed in the mountains of Central and southern Europe have more white on both upper and under wing, and have been segregated as T. altestris (C. I. Brehm).

On our moors the Ring-()uzel begins to breed in the latter part of April, making a nest similar to that of a 13lackbird, in the tall ling and heather, on the ledges of rocks, or in broken banks; sometimes at a moderate distance underneath fallen rocks; the sides of a stream or watercourse being a favourite locality; occasionally stunted bushes are selected. The eggs, 4 , scldom 5 , are greenishblue, flecked and spotted with reddish-brown; bolder and handsomer as a rule than those of the Blackbird, and more like those of the Fieldfare: average measurements I'I by 85 in. Not unfrequently a second brood is produced in July. Few birds are bolder when their young are approached, the parents flying round the intruder, uttering their sharp alarm-note of tac-tac-tac; tac-tac-tac; but the song is somewhat monotonous and derives its principal charm from the scenery in which it is heard. The food consist:s of worms, slugs, and insects: the bird beins also partial to moorland berries and those of the rowan or mountain-ash. It frecuently descends to gardens in the vicinity of its haunts, and is extremely bold in its attacks upon the fruit: while in the vine countries it feeds largely on grapes.

Adult male: upper parts brownish-black, the outer margins of the wing-feathers grey; under parts also blackish, except a broad white gorget: under wing-coverts and axillaries mottled with grey and white; bill black at the tip, the rest yellowish; legs and feet brownish-black. Length about I I in.; wing $5{ }^{\circ}$ in. Adult female: lighter and browner, with a narrower and duller gorget, scarcely perceptible in young fomales. A cock, little more than a nestiing, in the British Nuscum, shot in Nairnshire on Ist September, is blacker than any adult. In autumn both sexes have the feathers conspicuously margined with grey. 


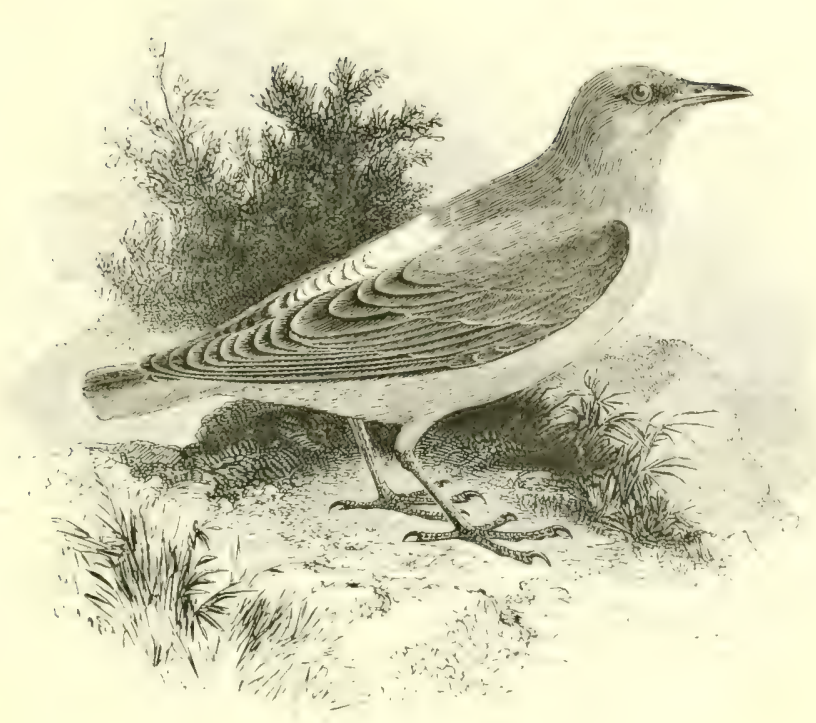

THE ROCK-THRUSH.

\section{Montícola saxátilis (Linnæus).}

The claim of the Rock-Thrush to a place in the liritish iist rests upon an example shot on the igth May, I $S_{+3}$, at Therfield, in Hertfordshire, and figured as above by the late Mr. Varrell, who examined it before it was skinned. Some other occurrences are recorded, but are not authenticated. The bird in question had no doubt deviated on its spring migration to the westward of its usual course; but some of its regular haunts are at no great distance from our shores; the species being a yearly summer-visitor to the centraland side-valleys of the Rhine, Moselle, Upper Meuse, and some portions of Alsace. It also breeds sparingly in the IIart/. Mountains, Thuringia, and other suitable situations in Germany: while it has straggled to Belgium, and six times to Heligoland. In Switzerland and southwards it is generally distributed throughout suitable rocky districts, although often local; and where, as in Southern Spain and Northern Africa, its congener the Bilue Rock-Thrush (Monticolar cyanus) predominates, it retires to higher ground. From the Carpathians castward it breeds in Greece, 'Turkey, Southern Russia, Asia Minor, Persia, Turkestan, Southern Siberia, Mongolia, and North 
China; its migrations extending to the Gambia on the west coast of Africa, Egypt, Nubia, Abyssinia, and the south of Arabia; also to Thibet, Northern India, and Upper Burma.

The nest is placed in a hole among rocks, vineyard-walls, fortifications or ruins, and occasionally in a tree-stump. MLss, roots, and dried grass - without any clay-with a finer lining of bents, are the materials employed; and the eggs, $4-5$, are pale greenish-blue, sometimes slightly specked with light brown: average measurements I in. by 75 in. Two broods are often reared in the year, incubation commencing in Nay; and the parents display considerable anxiety when the nest is approached. The Rock-Thrush has a sweet and varied song, and being also an excellent mimic, it is highly esteemed as a cage-bird. During courtship the male from time to time rises singing into the air; then drops down almost vertically, and travels for some distance along the rocks. In fact all the Rock-Thrushes in their mode of nesting and in many of their actions resemble the Wheatears or Chats, thus forming a link with the true Thrushes, from which they differ in the comparative shortness of the legs and tails. The food consists of earth-worms, snails, insects and their larvæ, and wild berries.

Adult male: head, neck, and throat greyish-blue, passing into blackish-blue on the upper back; a. white patch covers the centre of the back and dorsal scapulars; wings dark brown; lower back bluish-slate, mottled with grey ; tail-feathers chestnut, the two centre ones brown; under parts bright chestnut; bill black; legs and feet brown. Length $7.5 \mathrm{in}$. ; wing to end of the $3^{\text {rd }}$ and longest primary +75 in., the bastard primary being very small. In winter the white patch is less conspicuous, and the feathers have lighter margins. The young male, late in September, is much mottled with light brown and slate-grey on the upper parts; no white patch on the back; wing-feathers and coverts broadly tipped with buffishwhite; breast and abdomen chestnut barred with black, and with broad whitish edges which gradually wear off.

Female: spotted brown above, with but little grey about the head and back; chin and throat whitish; lower parts orange-buff marbled with brown; tail chestnut.

The Blue Rock-Thrush (Monticola cyanus) was erroneously recorded by Mr. Blake-Knox as having occurred at Westmeath in Ireland: for complete refutation of the statement, see 'The Zoolngist,' I 880, p. 67. 


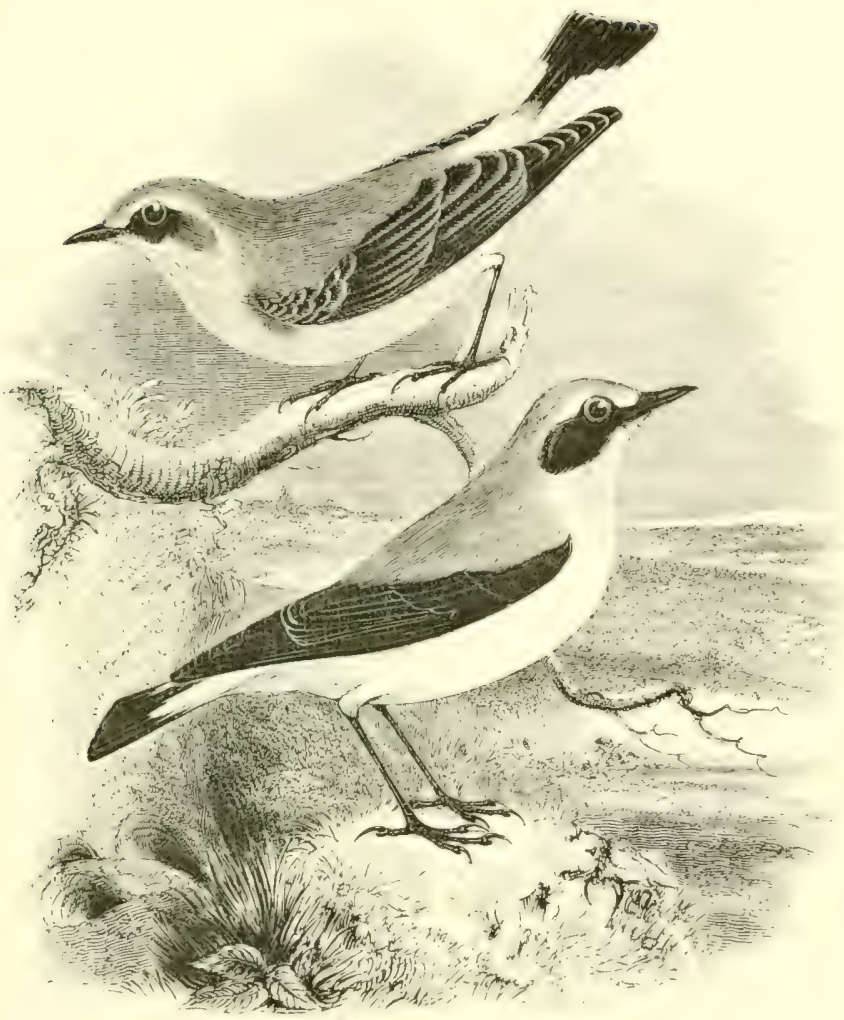

THE WHEATEAR.

\section{Saxícola enánthé (Linnæus).}

The Wheatear, one of the first of our spring-visitors, usually arrives in the second week in March : any hirds seen earlicr being probably those which, as exreptions, have wintered in mild portions of our islands. From early spring onwards the Wheatear is to be seen, jerking its white tail as it flits along uttering its sharp chack, chack, on open downs, warrens, and the poorer land; ascending the moun. tains almest to the highest summits. Numbers still frequent our South Downs, especially on migration in August; but by the beginning of ()ctober nearly all have left us. In summer it is very widely distributed, ranging to the livroes, Iceland, Jan Maven and Cireenland; while it has straggled to so $\mathrm{N}$. hat. (Feilden), and to 
$9 \mathrm{I}^{\circ} \mathrm{W}$. long. Greenland appears to be the breeding-place of a large race which passes through our islands from the middle of April onwards, and seems to be somewhat addicted to perching on trees. Our ordinary form breeds throughout Europe, Siberia, Mongolia, and, at suitable elevations, in Asia Minor and Algeria; it has also, of late years, established itself in the Azores. The smallest examples are found in Syria. Its winter migrations extend to a little south of the Equator; crossing Bering's Sea from Kamschatka it visits Alaska; while as a straggler it has occurred in Colorado, the eastern portions of the United States and Canada, and the Bermudas.

About the middle of April the loose nest of dry grass, lined with rabbits' fur, hair, and feathers, is placed in rabbit-burrows, crevices of stone walls, peat-stacks on the moors, or under rocks and fallowclods; the eggs, 5-6, often 7 , being of a very pale blue, sometimes minutely dotted with purple: average measurements $S$ by 6 in. Two broods are produced in the season. The old birds are wary and do not easily betray the situation of their treasure. The song of the male, often uttered on the wing, is rather pretty; and the bird also displays considerable powers of imitating other species. Its food consists of small spiders, insects-often captured flyingand their larva.

The name has no connection with wheat, but is a corruption of zithit, and of the Anglo-Saxon irs, for which the modern equivalent is "rump"; and in fact as "white-rumps" this species and its congeners are known in every European language.

Adult male in summer: forehead and eye-streak white; lores and ear-corerts black; head, neck and back grey; wings nearly black; rump white; the two central tail-feathers black nearly to the base, the others white with broad black tips; under parts white, with only a faint tinge of buff on the throat in old birds; under wing-coverts and axillaries mottled with dark grey and white; bill, legs and feet black. In autumn the new feathers are so broadly margined with rufous-brown that the male much resembles the female; and even on the spring arrival many of the upper feathers still retain buff margins. Length $6 \mathrm{in}$; wing to tip of 3 rd and longest quill, $3.75 \mathrm{in.}$ The female differs in having the ear-roverts dark brown; upper parts hair-brown; under parts buff : not unlike the south-eastern $S$. isabcllina, in which, however, the under wing-coverts are white. The young are slightly spotted above and below, with buff tips and margins to the tail- and wing-feathers. 


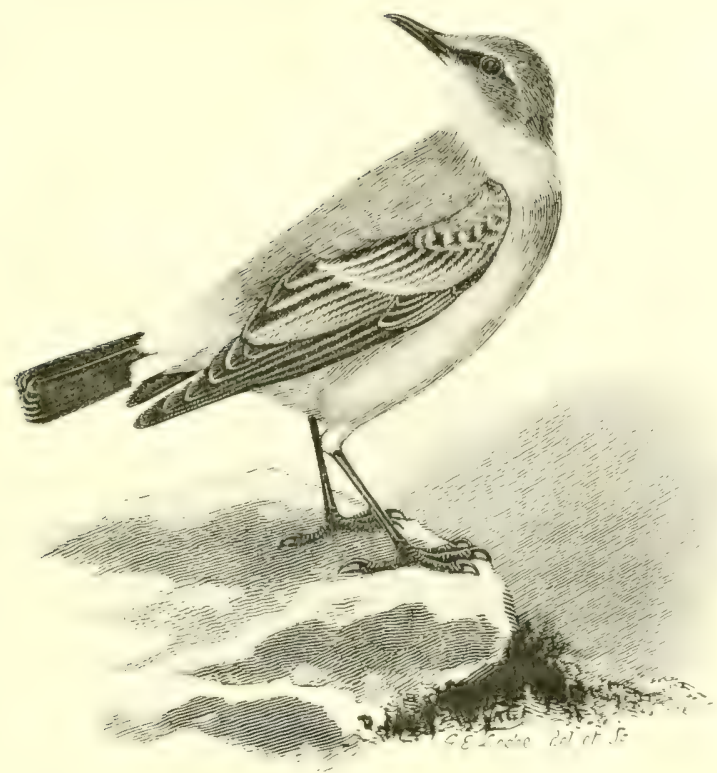

THE ISABEILINE WHEATEAR.

Saxícola isabellína, Rüppell.

While the above sheets were in the press, my friend the Rev. H.A. Nacphierson brought to me in the flesh for identification a bird shot by Mr. Thomas Mann, on a ploughed field, quite alone, at Allonby, Cumberland, on irth November i $\$ \$ 7$. It proved to be the Isabeiline Wheatear, and was exhibited at a meeting of the Zoological Society on 6th I)ecember. This south-eastem bird had not previously been recorded from Heligoland or any part of Western kurope, but it so closely resembles the female of the previous species that it might easily escape notice. When I mentioned (1) 20) one of its distinguishing characteristics as being the white under wings, I had no presentiment that the test would so soon be invoked. The bird, a female, is figured above.

The Isabelline Wheatear is an early spring-visitor to South-eastern Russia, especially the province of Astrachan and the arid plains of the Caspian, and to Asia Minor; whence, after breeding, it takes its departure in autumn; but in Palestine, Egypt, Eastern Africa down to Somali- and Masai-land, Abyssinia, and Arabia, it appears 
to be a resident. Eastward it is found in summer across Siberia south of $56^{\circ} \mathrm{N}$., and Central Asia up to ro,000 feet above sea-level,

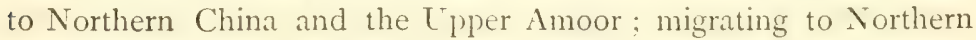
India, \&c.

The nest is generally placed in burrows; those of such rodents as Lagomy's ogrotona and Spermoptuilus cirrsmanni being utilized on the steppes of Daiiria; while near Smyrna the extensive tunnels formed by the Asiatic mole-rat (Spalux typhlus) afford a convenient retreat. The eggs are pale blue, similar to those of the Common Wheatear, but a trifle larger: measurements $8_{2}$ by $6_{5}$ in. Breeding commences in February in Abyssinia; while by the middle of May young are to be found nearly fledged in Asia Ninor. 'Two broods are probably reared in the season, as Canon Tristram found eggs in Palestine in June. Mr. Lanford, who observed this Wheatear frequenting barren ground, bushy hillsides, and cven fir-woods in Asia Minor, where it arrived March $9^{\text {th }}$, lescribes its notes as very peculiar, "the most striking being a cry resembling that of a Sandpiper, which is uttered as the bird descends, after its hovering flight and lark-like song." The call-note is zri, zri, zri.

Adult male : upper parts pale sandy-brown; a buffish-white streak from the base of the bill upwards to the back of the eye; lores black; ear-coverts pale brown; upper tail-coverts white; the two central tail-feathers blachish-brown almost to their bases which are white; the remainder white for the basal third of the length, and blackish-brown, narrowly tipped and margined with buff, on the lower two-thirds; wings brown, edged with buff, especially on the secondaries and coverts: under parts buffish-white, deeper on the neck and breast; under ains-iverts and axillaries athite; the undersiti of the quills being also conspicuously faler than in the Common Wheatear. Bill and legs black. Length 6.5 in.; wing to the tip of the $3^{\text {rd }}$ and longest quill, $3^{\circ} 9 \mathrm{in}$; tarsus $I^{\circ} 2$ in. Female: duller in plumage and slightly smaller than the male. Young: streaked with dark brown on the head, neck and breast; wings and tail broadly margined with rufous-buff. In autumn, as with other Wheatears, the buff margins to the wing-feathers are very pronounced.

The distinguishing characteristics of the Isabeiline Wheatear may be thus summed up :- it is larger, more tawny, and has more black in its comparatively short tail than any Common Wheatear; the colour of the under-wing is much lighter, and the bill and tarsi are longer. 


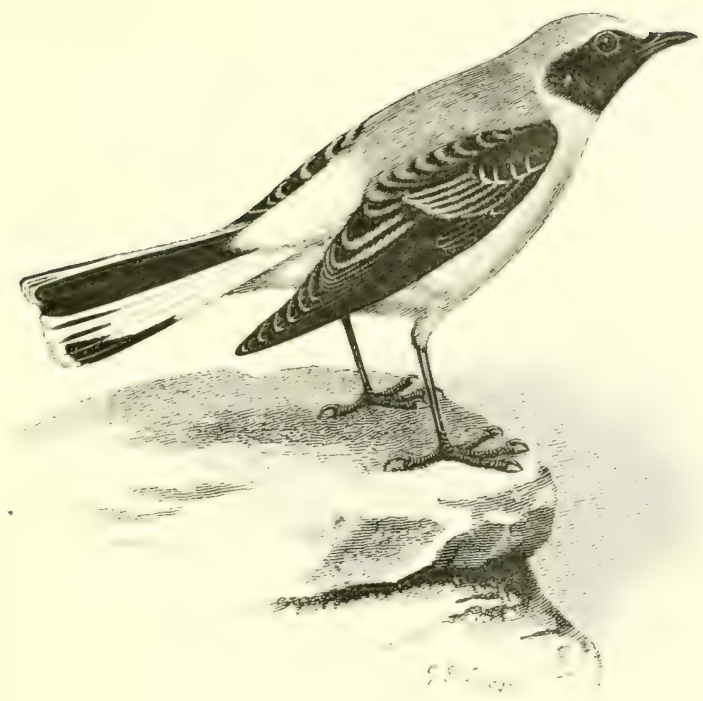

THE BLACK.THROATED WHEATEAR.

Saxícola stapazína, Vieillot.

A specimen of this handsome South-European species was shot about the Sth of May 1875 , near Bury in Lancashire, and subsequently recorded by Mr. R. Davenport, who, as should always be done in the case of such rare visitors, sent the specimen for exhibition at a meeting of the Zoological Society (P. Z. S. I 878 , pp. 88 $\mathrm{I}, 977)$. It was a male in adult plumage.

Although some occurrences formerly recorded under this name in Heligoland were really those of the Desert Wheatear, yet the present species has since been obtained there once, and observed oftener. In France it breeds regularly about as far nortl as the line of the I.oire; southward, in the Spanish l'eninsula, Morocco, Algeria and Italy. In the latter country it meets with S. melanolenca, Guildenstidt : a form which some ornithologists consider to be specifically distinct, characterized by a whitur back and litrger anount of black on the throat. This form occupies Greece, South Russia, Asia Minor, Palestine and Persia; both races migrating wholly or partially to more southern regions in winter. The extremes of each are distinguishable in adult males, but there appear to be numerous intergradations, and I have therefore treated the hird under one heading. 
The Black-throated Wheatear is very common in Southern Europe from the middle of March : making a loose nest of bents and grass in holes and crerices, especially in old ruins : and Mr. Seebohm found it brecding in the Parnassus up to an elevation of 3.000 feet. The erges, rather elliptical-ovate in shape, are of a pale sea-green colour, freckled with brown: measurement;, 75 by 6 in. In song, habits and food, it resembles the Common Wheatear. The name stapazina refers to its noisy scolding note.

The adult male in spring has the forehead white, the crown and upper back zolden-buff, becoming paler as the season advances; throat, lores and ear-coverts black; wings nearly black; lower back white: the two central tail-feathers biack almost to their bases, the rest white. margined with an amount of black which is subject to sreat diminution and partial disappearance with age ; under parts

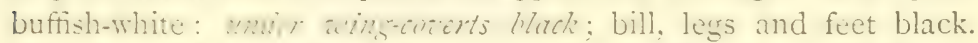
In July and lugust. when the autumn moult takes place, the crown, nape. upjer back and breast are rich buff; the wing-coverts and secondaries broadly margined with gale bufi. Length 5.6 in. ; wing 3.6 in. The female differs in having the throat merely mottled with black; the head streaked with hair-brown: upper back sandybrown: wings dark brown; under parts dirty buff. The young resemble the fumale in general, but are rather more rufous; and they have less white in the tail than the adults of the ripective sexes.

To obviate the perpetuation of confusion, I may remark that the species here described is the one which Mr. I)resser in his "Birds of Europe" called "Savianir mufa (Russet Chat)"; but the bird was re-instated under its old and well-known name by the Committee of the British Cimithologists 'Lnion. L'nfortunately Mr. Dresser has transferred the specific name staptsiva to the Eared Wheatear, S. allivalis (Vieill.), S. aurita ( $\mathrm{Temm}$ ) : another southern species, which has nt stragrgled to our islands, although erroneously entered in the British list by Mr. II. E. Clarke (Cat. Yorkshire Tertebs. p. I9); a mistake copied by Messrs. Harvie-Brown and Buckley in their recent 'Fauna of sutherland, Caithness and West Cromarty:' 


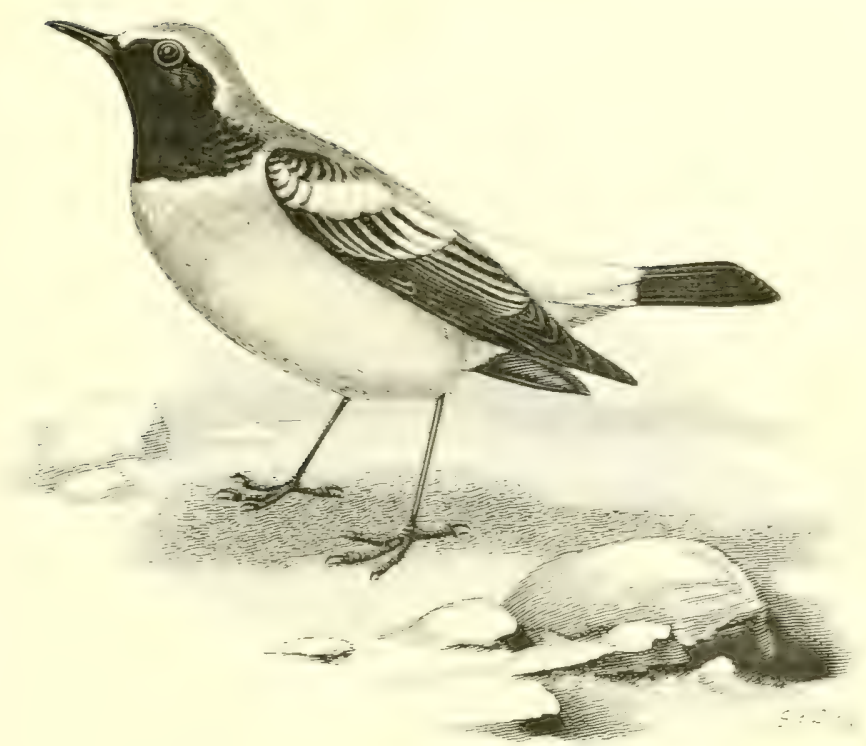

THE DESERT WHEATEAR.

SAXícola DESÉRTI, Rüppell.

Although the Desert Wheatear has a still more southern habitat than the preceding species, it has undoubtedy been obtained on two occasions in Great Britain. The first example, a male in autumn plumage. shot on the zoth November isfo, near. Allua in Clackmannanshire. was sent for exhibition at a meeting of the Zoulogical Society (P. Z. S. ISSI, P. 453), by its omner, MIr. J. J. Dalgleish: the second, a lirel in female plumage obtainet on the Holderness coast, lorkshire. I th October I ss 5 , was sent for exhibition ly Mr. W. Eagle Clurke (I. Z. S. ISS5. I, S.3.). Three stragerlers have been obtained on Helicoland: a male on zoth OCtober I $S 56$ : a female on fth ()ctolver i 557 (these being originally and erroneously recorded as S. stahatimal): and an adult male in full breeding-plumase, zard June rsio. The above appear to be the only records of its occurrence in Europe.

As implied by its name, the home of this species is to be found in the dry. sandy regiuns of North Lifrica, Esypt, Nubia, Arahia, Palestine, Persia, the plains of Turkestun up to an clevation of orer $\mathrm{I} 2.000$ feet, and the mountain ranges to the north of Cashmere. 
In winter it occurs in North-western India, Scind, Baluchistan, Southern P'ersia, Somali-land and Abyssinia. Mr. J. H. Gurney, junr., describes it as the most universally distributed species of the genus in the Algerian Sahara.

The nest of the Desert Wheatear is placed in crevices of rocks, walls of wells, in burrows, or under bushes. The eggs are of a greenish-blue, paler than those of the Black-throated Wheatear, with liver-coloured spots round the larger end: measurements 75 by 5 in. The food appears to be ants and other insects; the stomach of the one shot at Alloa contained small flies. In its movements it is even more restless than the Common Wheatear; and its song is said to be short and pleasing. The individuals observed by Mr. J. H. Curney, junr., were estimated by him as being in the proportion of about eight in male plumage to one in female dress.

The maie in spring has the crown sandy-grey, shading into buff on the back and lower wing-coverts; secondaries, brown in the centre, with pale margins: primaries blackish, with light margins to the inner webs, rery conspicuous on the underside; under wing-coverts and axillaries black tipped with white; tail-coverts white; tail llack almost to the base; under parts white, washed with buff on the breast: throat and sides of neck to shoulders black; a whitish streak above and behind the eye. Bill, legs and feet black; the latter small for the size of the bird. Length 6 in.; wing to the tip of 3 rd and longest quill 3.85 in. The female is duller and greyer on the upper parts; wings brown, the under surface buff; and the black throat is absent. The young is like that of S. stapazinu, except for its characteristic blackish-brown tail, and larger size.

The members of this group are frequently denominated 'Chats,' but I have used the term "Wheatear' to emphasize the difference between the longer-tailed, white-rumped species, and the shortertailed, streaked-rumped 'Bush-chats' of the genus Pratincola. 'The latter are considered so distinct by Mr. R. B. Sharpe that he has even gone the length of placing them among the Flycatchers (Muscicapidce). 


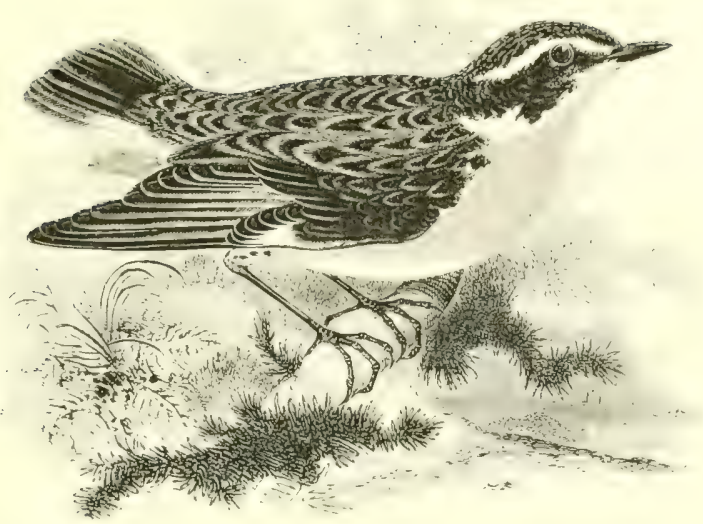

THE WHINCHAT.

PRATÍNCOLA RUBÉTRA (Linnæus).

The Whinchat generally arrives in the southern portions of our islands by the middle of April, but it seldom reaches the north before the beginning of May; after which, until its departure for the south in the early part of October, it is fairly distributed throughout lingland and Wales, although somewhat local in the west; becoming rare in Cornwall, and only occurring in the Scilly Islands during the autumnal migration. In Scotland, although absent in some districts, it may be said to range from the border counties to Caithness, and is very common in Sutherlandshire ; it occurs in the Outer Hebrides and the Orkneys; and Mr. A. H. Evans identified it in the summer of 1887 in the Shetlands. To Ireland it is a rare and local summervisitor.

A very rare straggler to the Færoes, the Whinchat breeds from about $70 \mathrm{~N}$. lat. in Scandinavia southwards, in suitable localities, in many parts of Northern and (ientral Europe; and, seeking in the mountains appropriate climatic conditions, it nests as far south as Sicily. In the countries bordering the Mediterranean it is, however, principally a migrant; wintering in Africa down to fiantee on the west side, and Abysinia on the east; also in Arabia, Asia Minor, and Northern Inclia. The Ural Mountains appear to form its castern boundary in European Russia.

The breeding-season is from the beginning of May: the nest is on the ground, or at most a few inches above it, among the stems of 
a thick furze-bush, or in coarse herbage and thick meadow-grass. It is a loose structure of dry grass and moss, with a lining of finer materials; the eggs, usually 6 in number, being greenish-blue, sometimes dotted or zoned with rust-colour : average measurements, 72 by 6 in. The call-note is a sharp it-tick, and the bird has also an agreeable song, uttered on the wing or while sitting on some low branch, accompanied with a fanning movement of the tail. Although, like the Stonechat, it frequents heaths and commons, the two species are seldom abundant in the same neighbourhood; and, when obtainable, the Whinchat exhibits a partiality for pastures, whence its local name of ' 'irasschat.' Its food consists of bectles, flies, and other insects-often sought for late in the evening; worms, especially the wire-worm, and small mollusks. It roosts on the ground.

The adult male has the lores, ear-coverts and cheeks dark brown; a clear white streak above the eye; crown and upper parts mottled with about equal proportions of sandy-buff and dark brown, more rufous on tail-coverts; base of tail white (except the two central feathers, which are dark brown), terminal-half dark brown, tipped and margined with buff; wing brown, the upper part showing a conspicuous white patch contrasted against a nearly black outer portion of the coverts; a smaller white patch on spurious wing; bastard primary smaller than in the Stonechat; under parts buff, turning to bright fawn-colour on the breast and throat; chin white, with a streak of the same running below the blackish checks to the sides of the neck. Bill black (stouter than in the Stonechat), legs and feet black. I.ength $5.25 \mathrm{in}$; wing to the end of the $3 \mathrm{rd}$ and longest primary $2^{\circ} 9$ in.

The female is duller in colour, the speculum smaller; the eyestreak buff; the upper breast slightly spotted. The young have the feathers margined with rufous and buff; the breast much more spotted than in the female, which otherwise they resemble. By September the young males have the wing-patches well defined.

In autumn the Whinchat assumes a duller plumage, leading to confusion with the Stonechat; and to this, perhaps, may be ascribed the records of the occurrence of the former in winter in the British Islands. In spring, according to Herr Meves and other observers, it not only loses the paler tips of the feathers by abrasion, but has a distinct moult. This is an exception to the rule among the Turdince. White and pied varieties of this bird have been obtained. 


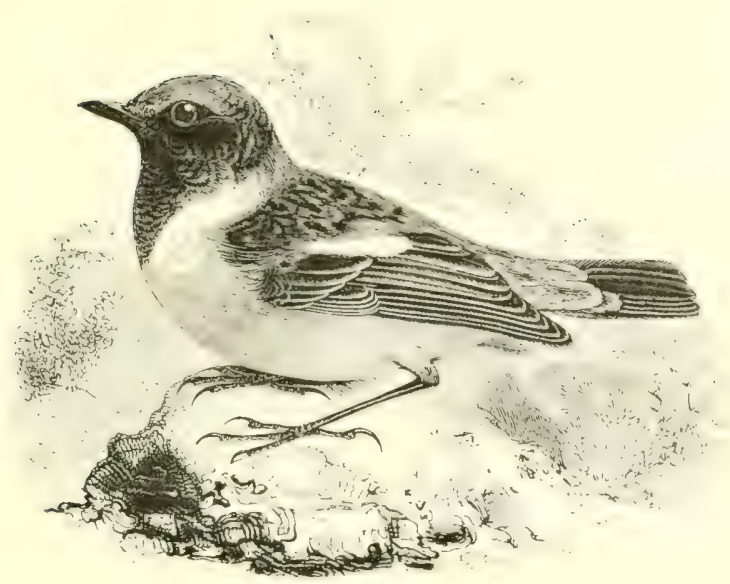

'THE STONECHA'T.

\section{Pratíncola RUBícola (Linnæus).}

Unlike the preceding migratory species, the Stonechat is a resident in the greater part of our islands, although a partial migration takes place from the colder to the more sheltered situations in winter; at which season there is an influx of visitors from those parts of the Continent where the climate is too severe to allow of a stay. It is somewhat local in its distribution, and also crratic; frequenting a place for a few seasons, and then suddenly abandoning it. Although rare in the Orkneys and Shetlands, it is found to the extreme limits of the Outer Hebrides, for I observed it on St. Kilda in August 1886 . In Ireland it is common and resident.

The northern range of the Stonechat in Europe is not nearly so extensive as that of the Whinchat, and scarcely reaches to the south of Sweden; while in the north of Germany the bird is uncommon and of irregular distribution. Even in Central Europe it is unaccountably local, but in the south it is common, breeding in Spain even in the hot plains below Seville. Migrants from the north go down in winter to the shores and islands of the Mediterranean, North Africa, Asia Minor and Palestine; and examples have been obtained to the south of Senegal. In South. Ifrica the representative species is $P$. torquatit, with white rump and deeper chestnut on the breast ; North-eastern Africa is inhabited by $P$. himprichi, with morc white than black in the tail; while east of the valley of the Tolga the place of our species is taken by $I$ ?. maura, characterized by a 
white rump and the predominance of black in the under wingcoverts and axillaries.

The nest, constructed early in April, is concealed amongst the herbage on broken ground, or at the foot of some thick furze or other bush, and is composed of dry grass and moss with a lining of bents, hair, and feathers. The five or six eggs are of a bluish-green (greener than those of the Whinchat), spotted and zoned with pale reddish-brown : arerage measurements 7 by $5 . \mathrm{in}$. The parent birds display considerable anxiety when the nest is approached, flitting from bush to bush and uttering a sharp chack, but it repuires great patience to eye the female to her nest. Two broods are produced during the season. The sone, commenced early in the spring, continues until the latter part of June, and, although short, is rather pleasing; but the scolding note, h-aitet, jur, jur; uttered by the male as, conspicuous by his black head, white neck, and ruddy breast, he darts from spray to spray on some furze-covered moor, is the most familiar indication of the presence of this sprightly bird. The insert-prey of the Stonechat, including small moths and butterflies, is often taken on the wing; grubs, worms and beetles forming its principal diet, with the addition of a few seeds.

Adult male in May:-the head, throat, nape and back, black; the feathers of the latter edged with frown: tail-coverts white, spotted with dark brown; tail and wings dark brown; a conspicuous white patch on the wing corerts: sides of the neck white; breast bright rufous, lighter on the aldomen; under wing-coverts and axillaries mottled black and white; bill, leers and feet black. In autumn the under parts are paler, and the upper feathers are margined with reddish-brown. In young males the crown of the head is streaked brown and black. Female: - striped brown upper parts; throat merely mottled with black: rump reddish-brown; the white wing-patch smaller than in the male and under parts much duller. Young :- throat buffish-white; feathers of the upper parts much tinged and margined with rufous-brown; otherwise as in the female. Length $5: 25 \mathrm{in}$; wing to the end of the th and longest primary $2 \cdot 7$ in. 


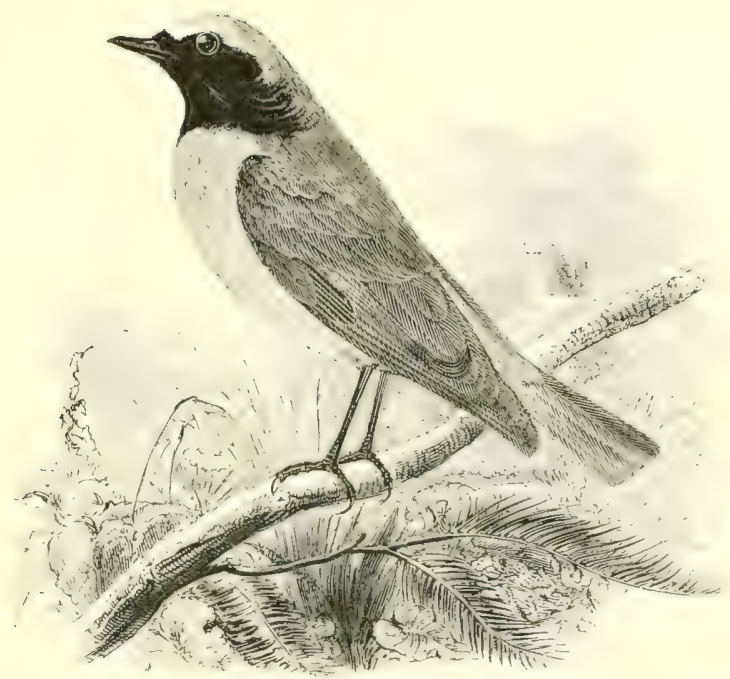

THE REDSTAR'T.

\section{Ruticílla phenicúrus (Linnæus).}

The date of the arrival of the Redstart is to some extent influenced by the prevailing temperature in the early spring; but as a rule the males, which precede the females by several days, attract our attention by their conspicuous plumage about the middle of April, as they flit, with lateral movements of the tail, from one low branch to another, along the skirts of woodlands. Although generally diffused throughout Great Britain, especially in the south, the Redstart is often unaccountably partial in its distribution, being uncommon to the west of Exeter; a rare breeder in Cornwall : and only an autumnal visitor to the Scilly Islands. In Wales it is common as far as Breconshire. In Scotland, where, although not rare it is local, it has of late years spread northwards, and it is now found breeding in Sutherland and Caithness: but it seldom visits the Orkneys or the Shetlands, and in the Hebrides it is as yet un. recorded. In Ireland, only two or three occurrences are known.

On the Continent the Redstart is found in summer from the North Cape to the wooded regions of Central, and even southern Europe, although better known in the latter on its spring and autumn migrations. Lastward it stretches in summer as far as the valley of the Yenesei; its winter migrations extending to North 
Africa, the Canaries and Madeira, Senegal, Abyssinia, Arabia, Palestine, and Persia. In Cyprus, Asia Minor, Persia, and the Caucasus-straggling to Turkey and Greece-the representative species is $R$. mesolenca, the male of which has a white patch on the wing, like the Black Redstart; from the Lebanon eastward we find the Indian Redstart, R. rufizentris, with biack throat and mantle and chestmut under wing; while the under wing is black in $R$. ochrurus of the Caucasus and Armenia.

The nest is generally placed in hollow trees or in the holes of walls; exceptionally in such localities as the inside of an inverted flower-pot, or in the gable-ends of inhabited buildings. It is rather loosely constructed of moss, dry grass, and fine roots, with a lining of hair and feathers; the eggs, usually 6, being of a light bluepaler than those of the Hedge-Sparrow-occasionally speckled with reddish: average measurements 7 by 55 in. Nesting commences early in May, and while the female is sitting the male is conspicuous in the vicinity, uttering his slight but pleasant song, or, when alarmed, a plaintive whict. The food consists of flies, gnats, small butterflies, and other insects, spiders \&c. ; the young being fed largely on caterpillars. Departure for the south takes place in September. In many parts of the country this bird is known as the 'Firetail'; the second syllable of the name Red-start being derived from the Anglo-Saxon steort, a tail.

Adult male: forehead and eye-streak white; crown, nape and upper back slate-grey, wings brown with pale outer edges; rump and tail chestnut, cxcept the two central feathers, which are brown; chin, throat and cheeks jet-black; breast and axillaries chestnut; abdomen buff; bill black; legs and feet dark brown. Total length $5^{\circ} 25$ in. ; wing to the end of the 3 rd and longest primary $3 \cdot 15$ in. The female has no bright colours on the head, being greyish-brown above, and lighter on the under parts, while the chestnut of the tail is less brilliant. Occasionally, however, a plumage resembling that of the male is assumed, and a bird exemplifying this was caught on her eggs in June ISS2 (Tr. Norw. Soc. iv. P. I82). Birds of the year resemble the female; the nestlings are spotted above and below, and, but for the chestnut tail, are rather like young Redbreasts.

In autumn the new feathers of both sexes are broadly tipped with white, producing a greyish appearance, but these edges disappear by the following spring. 


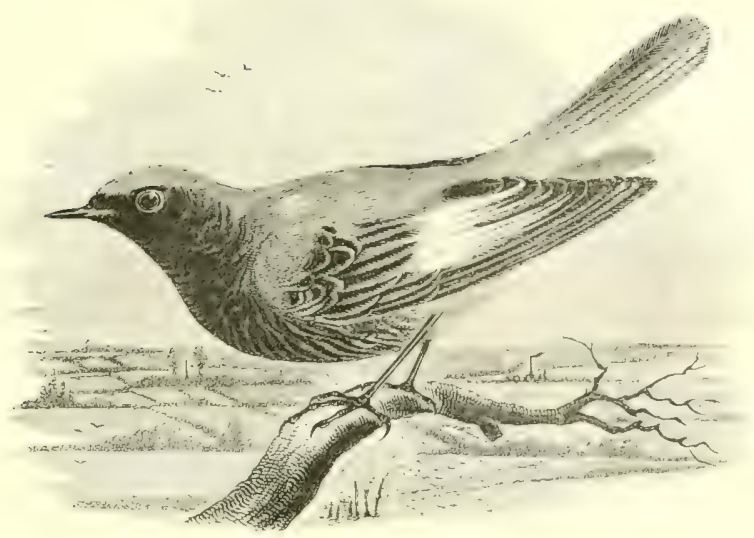

THE BLACK REDSTAR'T.

Ruticílla Títys (Scopoli).

The Black Redstart, formerly considered a rare bird, is now a well-known visitor to many parts of our coasts in autumn and winter; being in fact tolerably common at those seasons in the southern counties, especially in Devon and Cornwall. It has also occurred in summer, and I saw an adult male at Frpingham, Nor folk, on May $15^{\text {th }} 1872$; but as yet there is no really satisfactory evidence that the species has ever bred in this country. In Scotland it is of rare occurrence, the latest and most northerly instance being on the Pentland Skerries, March 3 Ist I $\$ S S_{4}$. To Ireland it is an unfrequent winter-visitor, chiefly on the east and south coasts.

As a straggler the Black Redstart has been recorded in Iceland, the Firoes, Southern Scandinavia and Dummark: but, although extending its range, it is not yet a common bird in the north-eastern districts of Germany: From Holland southward it is, however, abundant in summer; migrating from the countries on the north of the Alps in winter; but becoming more or less resident in Southern Europe, and even in the mountains of North Africa, where it breeds at a considerable elevation. Eastward its range appears to extend to the Ural, Asia Minor, and Palestine; and, in winter, to Nubia.

Breeding begins early in May; the nest, compused of dried grass, moss and fine roots, with a lining of hair and feathers, being placed, with little attempt at concealment, in sheds. holes of walls, chatlets, or clefts of rocks. The eggs, 5-6, are of a pure shining white, 
sometimes with a faint tinge of blue, and occasionally speckled with brown : average measurements 75 by ${ }_{5} 8 \mathrm{in}$. Two broods are often produced in the season. The male commences his rich song very early in the morning: and from his familiar habits the Black Redstart is one of the most conspicuous species on the Continent, as, jerking his tail, he flits along the roofs in large cities, or the sides of ravines in the country. Even in London one frequented the grounds of the Natural History Museum, South Kensington, from November i $\$ 85$ until the snow-fall of January 6 th i 886 . Refuseheaps and sea-tangle seem to have great attractions for this bird. Its food consists principally of insects, caterpillars, and, on our seacoasts, of small crustaceans.

Adult male: frontal band and lores black; crown, nape and back dark slate-grey : wings brownish, with broad white margins to the secondaries forming a conspicuous white patch; rump and tail, except the two brown central-feathers, bright bay; chin, throat, cheeks and breast black, passing into grey on the belly; vent buff; bill, legs and feet biack. In younger males the wing-patch is less pronounced. After the autumn moult the black feathers of the under parts have grey margins, which so soon wear off that I have seen old males in splendid black plumage by the end of November. Length $5.75 \mathrm{in}$. : wing to the tip of the 4 th and longest primary, 3.4 in.

Female: greyer on both upper and lower parts than the female Common Redstart, and her axillaries and under wing-coverts are grey instead of buff. The young resemble the female. Young males often breed in their immature grey plumage; and owing to this a supposed distinct species, since withdrawn, was described by Gerbe under the name of R. aririi. The full black plumage is not attained by the male until the second autumnal moult, and even then the intensity of the colour is considerably modified by the long grey margins of the feathers. 


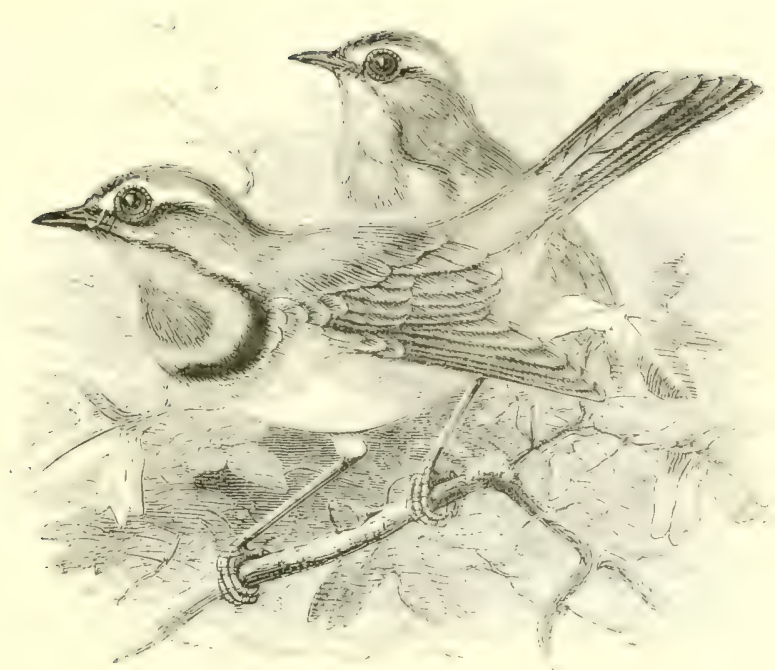

THE BLUETHROAT.

Cyanécula suécica (Linnæus).

It may be well to commence by stating that there are certainly two, and perhaps three, forms of the Bluethroat. The first, which has its breeding-grounds in Arctic and sul--Irctic Furope and Asia, exhibits a red spot in the centre of the blue gorget of the adult male; whereas the second form, which breeds south and'west of the Baltic, has the spot zolite. In the third and much rarer form, the gorget is unspotted blue; but as the feathers, on being raised, show white at their bases, it seems probable that this last is an intensified development of the white-spotted form, with which alone it is associated as regards its geographical distribution. I am not aware of any distinctive characters by which the females and young of these forms may be separated. 'The red-spotted form is the only' one which has been proved to visit this country; for although an entirely blue-throated bird is said to have been observed by Capt. Hadfield in the Isle of Wight, it was not obtained: and an eximple with a white spot, supposed by Mr. Hancock to have been taken near London in May $\mathbf{I} 845$, was purchased from a dealer whose traffic with Holland was notorious. An adult male from Moscow belonging to Mr. Secbohm exhibits an apparently white wirror; but on minute examination a few red feathers are discernible in the centre of the white; indicating that the bird belongs to the red- 
spotted form: The question of specific distinctness must remain a matter of opinion. If segregated, the red-spotted bird is C. suecica, and the white-spotted one is C. leucocyana; while the third, if separated from the second, is $C$. wolf.

The Red-spotted Bluethroat has been recorded since $\mathbf{I}_{2} 6$ at irregular intervals; mostly on the eastern and southern coasts of England, at the spring, and especially at the autumn migration. In September i $S_{3}$, considerable numbers were observed on our east coast, chicfly in Norfolk, where a much larger flock dropped in the same month of $188+$. Three are recorded from Scotland; but none as yet in Ireland. It breeds in the northern portions of Scandinavia and Russia, the elevated Pamir region, and Siberia as far as Kamschatka (whence it has straggled to Alaska); migrating to China, India, Arabia and North-eastern Africa. From Egypt westward the White-spotted Bluethroat appears, and predominates in North-western Africa and South-western Europe : breeding in France, Belgium, Holland, and Northern Germany as far as the Vistula.

The nest, similar to that of the Redbreast, is placed in the side of a hummock among swampy thickets; the eggs, 5-6, laid about the middle of June, are palc olive with minute rufous spots: measurements 75 by $55 \mathrm{in}$. The food consists of insects-especially mosquitoes-and their larre; earth-worms and small seeds. The song, as heard during the nightless summer of the Arctic regions, is described as rivalling that of the Nightingale in richness, ending with a metallic tingr ting. The cock bird is frequently bold and conspicuous, while the female skulks among the undergrowth. In its habits it resembles the Redbreast rather than the Redstart.

Adult male: lores dark brown; a white stripe above the eye; upper parts clove-brown; bright bay tail-coverts and basal part of tail-feathers, except the two central ones which are dark brown like the lower half of the tail; chin, throat and gorget ultramarine-blue, with a large central spot of red bay; below the blue successive bands of black, white and bay; remaining under parts buffish-white; wing-coverts and axillaries golden-buff; bill black; legs and feet brown. Length 6 in.; wing to ends of 3 rd-4th and longest primaries, 2.9 in. Female: differs in having the whole of the under parts tawny-white, except a dark brown band across the chest; but old females show some blue and bay feathers there. Young: like the female; the nestiing streaked with black, similar to a young Redbreast, but the base of the tail is bay. In autumn the new feathers have grey tips which are shed by the following spring. 


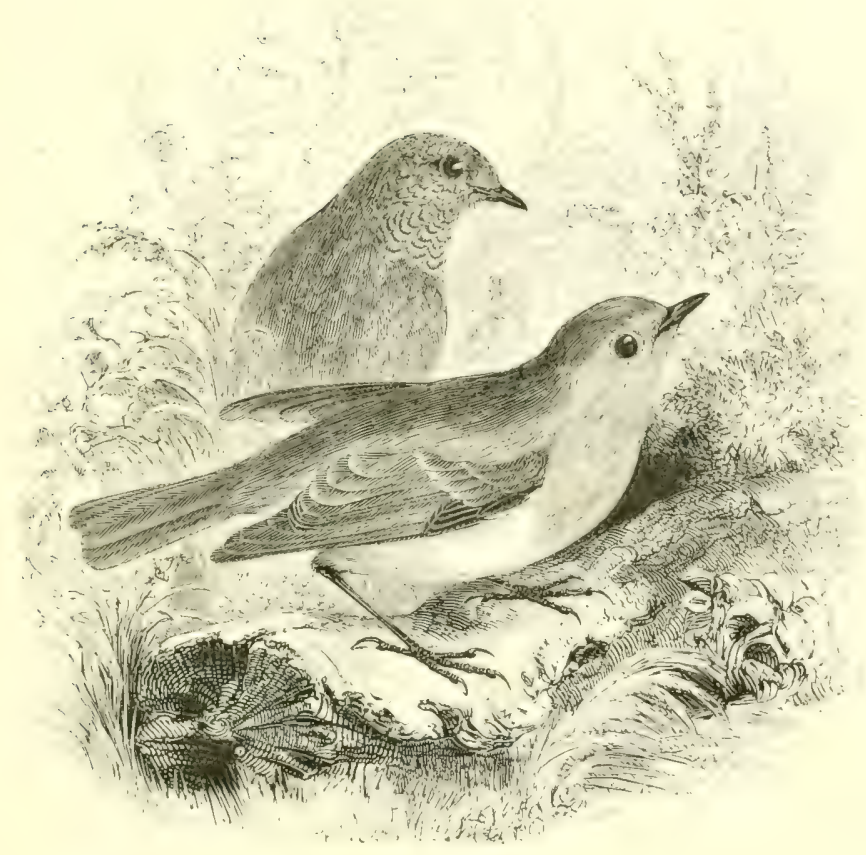

THE REDBREAST.

\section{ERÍTHACUS RUBÉCULA (Linnæus).}

The Redbreast, familiarly known as the Robin, is probably the most characteristic of our British species; for, in addition to the early and legendary associations which combine to render it a favourite, it is also a resiclent species, consplicuous from its bright plumage. Generally distributed throughout the British Islands, it has undoubtedly increased in the north with the spread of plantations, and it is now found breeding in the Hebrides and the Orkneys, although not as yet in the shetlands. In autumn the young are driven away and forced to migrate by their parents, who, in their turn, when pressed for food in winter, resort to the vicinity of our dwellings, where they are almost universally welcome. It this season numbers arrive from the Continent: shumning the cold of the northern regions where they have passed the summer, even within the Arctic circle.

The Redbreast has been observed in May on the islind of Jan 
Mayen, but it has not yet been recorded in Iceland, although it visits the Færoes in autumn. Southwards it breeds throughout Europe down to the south of Spain-where it is very localNorth-western Africa, the Canaries, Nadeira and the Azores; castward, across Russia-where it is not abundant-to the Ural Mountains. Its winter migrations extend to the Sahara, Egypt, Palestine, Asia Minor, North-western Turkestan and Persia; but in the last-named country we also find E. hyrcanus: a somewhat larger form-of doubtful specific validity with ruddier breast, and chestnut margins to the upper tail-coverts. On migration the Redbreast is by no means treated with the same consideration as with us, being snared in large numbers for the table in the south of Europe.

The nest, made of dead leaves and moss, lined with hair and a few feathers, is placed in banks, holes of walls, amongst ivy, and in hollow trees; while pages might be filled with details of the extraordinary sites sometimes selected. The eggs, 5-6, often 7 , are usualiy white with light reddish blotches, but sometimes they are pure white: arerage measurements, $\cdot S$ by $\cdot \sigma \mathrm{in}$. Nesting begins in March, and two, or even three broods are produced in the year. Its song is nusical, but of little compass. The food is mostly insects and worms. but berries and fruit are by no means despised, and in winter, as is well known, bread-crumbs, meat \&c. are acceptable. A more pugnacious and domineering species than the Redbreast it would be difficult to find.

In the adult male the upper parts are olive-brown; frontal band, jores, chin, throat and upper breast reddish-orange, bordered with bluish-grey on the sides of the neck and shoulders; lower breast and belly dull white; flanks and lower tail-ceverts pale brown; bill black; legs and feet brown. Length $5{ }^{*} 75$ in.; wing to the end of the $5^{\text {th }}$ and longest quill 3 in. The female is usually duller than the male, but I have seen carefully sexed examples which were quite undistinguishable. The nestlings have a spotted appearance, the smaller feathers of the upper and under parts being yellowishbrown in their centres with blackish tips; but after the first autumn moult young birds are like the adults, except that the orange colour of the breast is paler. Albino, grey, and mottled varieties of the Redbreast are on record. 


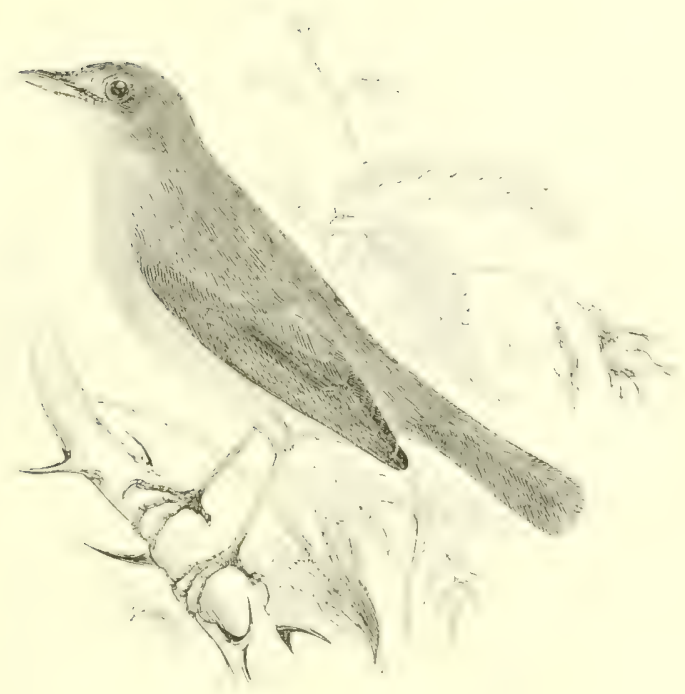

THE NIGHTINGALE.

Daúltas luscínia (Linnæus).

This noted songster usually comes to us about the end of the second week in April; the males preceding the females by several days. Although generally distributed over the greater part of England, it becomes rarer in the west, until in Devonshire a line is reached beyond which the bird is absolutely unknown; and the same may be said of Wales, except Glamorganshire and Brecon. A straggler to Cheshire, its occurrence in Lancashire is questionable, while it is unknown in Westmoreland, Cumburland, Northumberland, and Durham. In Yorkshire, where its range is increasing, it has recently bred near Scarborough. There is as yet no proof that it has visited Scotland or Ireland.

On the Continent, Northern (iermany appears to be the hieghest authenticated latitude for our Nightingale; south of which, exrept where systematically molested by bird-catchers, it is generally dis tributed throughout Central Europe. In such southern countries as Portugal, spatir, Italy, (ireece and 'Turkey, it is very abundant in suitable localities; breeding also in North Africa, Palestine and Asia Minor. Its north eastern limit in Europe appears to be the valley of the Vistula; and in Russia it is confined to the southern provinces. From the Caucasus castward to Turkestan and Persia, is found a closely allied form, D. golsii-rather more olive-coloured, 
with longer bill and tail; while in Scandinavia, Denmark and Eastern Europe, our bird is replaced - and from Asia Ninor to the Rhine over-lapped--by the rather larger "Sprosser" or Northern Nightingale, $D$. phitomela : a perfectly distinct species, less russet in hue, slightly spotted on the breast, and with a mimule bastard primary. In autumn our Nightingale leaves Europe and Asia Minor; wintering at least as far south as Abyssinia.

The nest, commenced early in May, is composed of dead leaves of the oak and other trees, with a scanty lining of roots and bents; and is usually placed on or near the ground in low underwood and close hedge-row bottoms-always on the warmer side-or in the banks of coppices. In Spain I have found it fully five feet from the ground, in the tojs of broad hedges and the sides of clipped cypress and myrtle trees. 'The eggs, 4-6, are mostly of an olive-brown, but some birds, which annually return to the same place, lay eggs of a bluish-green mottled with reddish-brown, somewhat resembling those of the Bluethroat: average measurements ' $s$ by 6 in. The young are hatched in June; after which the male discontinues his melodious song, uttered hitherto by day' as well as by night in genial weather, and merely retains a harsh croak. Spiders, ants, and small green caterpillars are the food of the nestlings, and in July and August the young frequent fields planted with peas and beans; the adults live on worms, insects, ants'-eggs, fruit and berries, especially those of the elder. Favourite resorts are small woods at no great distance from water and the coppices bordering damp meadows. Although the Nightingale does not bear captivity well, yet birds have been kept through the winter, and a pair has even bred and reared three young in confinement. Its well-known song needs no description; the call-note being a watc, wate, cur-cur. In August the young take their departure, the old birds remaining till September, completing their moult. Nigration is supposed to be performed singly and not in flocks; but Mr. Monk states that on April $3_{3}$ th I 872 , there were Nightingales under the bathing-machines along the whole length of the shore at Brighton.

In the adult the upper parts are russet-brown shading into reddishchestnut on the tail-corerts and tail, the colour of the latter being very noticeable on flight; under parts greyish-white, turning to buff on the flanks and breast; bill, legs and feet brown. The sexes are alike in plumage. Length $6{ }^{\circ} 5 \mathrm{in}$.; wing to tip of the $3^{\text {rd }}$ and longest primary 335 in. The young in first plumage are darker, with yellowish-brown shaft-streaks to the upper feathers and greyish-brown bars on the under parts. 


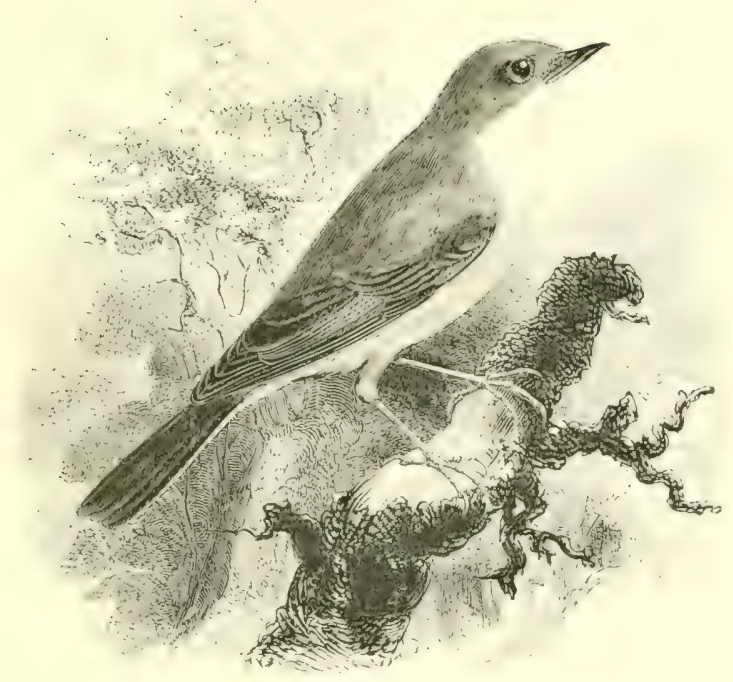

THE WHITE'THROAT.

Sýlvia cinérea, Bechstein.

The Whitethroat arrives about the second week in April, remaining until the beginning of september. Throughout Fngland, Wales and Ireland, it is the most generally distributed and plentiful of the Warblers; while in Scotland it is also common, except in the northern counties, and even there it is extending its range, breeding regularly as far as the Dornoch Firth. In the Outer Hebrides it appears to be as yet unrecorded; and it is only a rare visitor to the Orkneys and Shetlands.

The Whitethroat breeds up to about $65^{\circ} \mathrm{N}$., in Scandinavia, and southwards throughout Europe down to the Mediterranean; but sparingly in the basin of that sea, the majority of the birds found there being migrants and winter-visitors. In . Isia Minor it is only found in summer, although said to be resident in Palestine. The Canaries and Northern Africa are frequented in winter; the migrations of this Warbler extending down the west coast to Damaraland. Eastward, it breeds in Turkestan and South-western Siberia, wintering in Egypt, Abyssinia, and Arabia ; its place being taken in the Altai and 'Iian-Shan Mountains, and North-western India, by a larger, darker and greyer form, distinguisined as S. fuscifilia. 'To the north of the Caspian, the arid steppes beyond the Urai 
Mountains appear to form the eastern boundary of our Whitethroat.

Hedge-rows and thickets overgrown with brambles are favourite resorts of this lively bird, and owing to its predilection for beds of nettles it is generally known by the name of "Nettle-creeper." The slight but rather deep nest, made of fine grass-stems and lined with bents and horsehair, is placed low down in almost any kind of coarse vegetation, or in straggling hedges; the eggs, $4^{-6}$, are greenishwhite or stone-colour, blotched and sometimes zoned with violetgrey and light brown: average measurements 7 by 55 in. The food consists largely of insects, especially Tipulce; also fruit and berries during the season. The alarm-note is harsh and scolding: the male showing considerable annoyance at the presence of an intruder on his domain, and often following the pedestrian for some distance along a hedge-row, flitting from branch to branch with every feather on the throat and crest extended, agitating his outspread tail ; anon shooting almost perpendicularly into the air. The female is less demonstrative and generally skulks amongst the herbage. The sweet but somewhat monotonous song of the male, uttered in snatches with great energy, is frequently to be heard by night as well as by day in May and June.

Adult male in spring: head and neck smoke-grey; mantle and wings brown, with broad rufous margins to the secondaries; tailfeathers brown, except the two outer ones which are mostly dull white, the next pair having broad white tips; chin and throat white, passing into vinous-buff on the breast; abdomen brownishwhite, darker on the flanks; under wing smoke-grey; bill brown, lighter on lower mandible; legs and feet pale brown. Length 5.5 in.; wing to end of 3 rd and longest quill $2 \cdot 75$ in. The female is duller, and has the head brown like the back, while the vinous tint of the breast is absent. 'The young are rather more tawny-brown and rufous.

Those Whitethroats which breed in the south of Europe, and which migrate only a short distance southwards, are rather small in size and brilliant in the contrast of their colours. A further step in the process of evolution has produced a perfectly recognizable species in the shape of Sylvia conspicillata, much smaller, with more pronounced ear-coverts, and far brighter colours; but otherwise, in habits, colour of eggs \&c., a miniature reproduction of our bird. Every one of ornithological tastes who has visited Gibraltar, Malta, or almost any place in the Mediterranean basin, will remember the Spectacled Warbler, and appreciate the force of the comparison. 


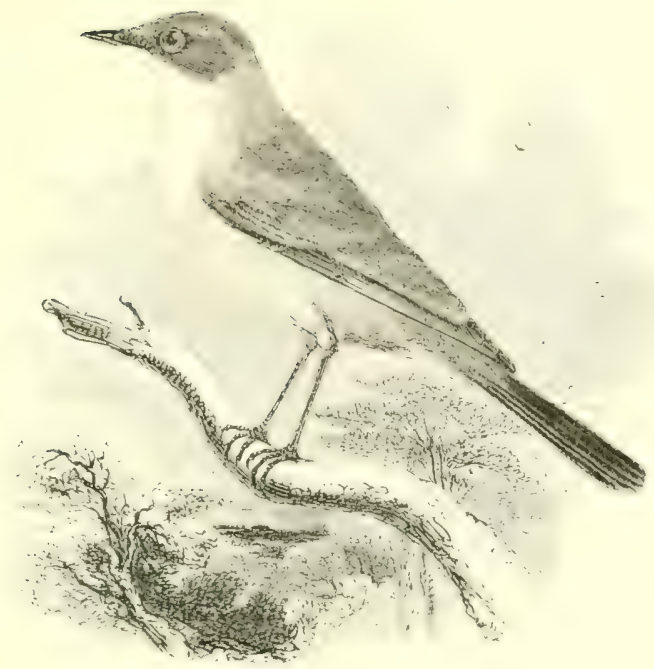

THE LESSER WHI'TETHROAT.

Sylvia CURrúcA (Linnæus).

The Lesser Whitethroat, as its name implies, is a smaller bird than its congener; and although it arrives in England about the same time, its distribution in our islands is decidedly less extensive. Tolerably abundant in the southern, eastern and midland counties, it becomes rarer in the west; only visiting Cornwall on migration, and having been recorded for the first time as breeding in Breconshire in I886. To Cheshire and Lancashire it is a well-known though not very numerous summer-visitor, and it is generally distributed in Yorkshire; but scarce in Durham, Westmoreland and Cumberland. In Scotland, Mr. R. Service informs me that it is seldom met with in Kirkcudbrightshire, although better known in the eastern part of Dumfriesshire and down by the Borders, and he has only twice found its nest; it is said to breed sparingly and locally as far as Stirlingshire; but in the northern counties, and in the outlying islands, the evidence, so fiar as I have been able to collect any of a trustworthy nature, tends to show that it is at most a rare straggler. One is stated in the 'Scottish Naturalist' to have been shot by Mr. G. Sim in Aberdeenshire, on November $4^{\text {th }}$ ISSo; and Saxby says that be observed it in september on Lnst, shetland. From Ireland there are as yet no records of it.

In Scandinavia the Lesser Whitethroat breeds up to about $65^{\circ}$ 
N. lat. ; while southward it is found in summer over the greater part of temperate Europe. It is, however, almost unknown or very rare, even on migration, in Portugal and the western part of Spain, but a few pass the winter to the east of Málaga, and in some years the species is fairly common on migration about Valencia and Murcia. In Italy it is very local; but eastward it becomes more abundant, and in Transylvania its numbers far exceed those of its relative. Beyond the valley of the Lower Volga the doubtfully distinct Siberian form S. affinis, replaces it; in Cashmere, the Himalayas and the north-west of India comes S. althur; while the Afghan S. minuscula, Hume, makes yet a fourth subdivision. Our typical bird winters in Northern and Central Africa, Arabia, Palestine and Persia.

The nest is a shallow structure of dried grasses, lined with hair, and is frequently placed in brambles or small bushes; a predilection being shown for hazel- and thorn-hedges, whence the bird's Lancashire name of 'Hazel Linnet.' 'The eggs, 5-6, laid in May, are creamy-white blotched with brown, and with under-spots of grey: average measurements $6_{5}$ by 5 in. The female sits very close. The song of the male is continued very late into the summer, and has been syllabled as sip, sip, sip, frequently uttered in sultry weather. The food consists of insects and their larva, and fruit in the season. The autumn departure generally takes place in the latter part of September, but exceptional captures up to November are on record.

Adult male: crown smoke-grey; lores and ear-coverts dark brown; nape, back and tail-coverts brownish-grey; wing-feathers ash-brown, with paler tips and margins, but without the rufous edgings to the secondaries which are so conspicuous in the larger species; outer tail-feathers greyish-brown with white outer webs; the rest of the feathers dark brown; under parts white, with a faint rosy tinge, fading into buff on the flanks; bill blackish ; legs, which are short and stout, slate-colour ; iris white. Length 5.25 in. ; wing to the tip of the 3 rd and longest primary $2.5 \mathrm{in}$. The female is rather smaller and generally duller in colour. The young are like the female, except that the pale margins of the wing-feathers are more pronounced, and the irides are reddish-brown.

Sundevall states that this species, the Greater Whitethroat, and the Barred Warbler, all have a spring moult. Mr. J. Young, who has kept the I.esser Whitethroat for several years, confirms this as regards some, but not all, of the quill-feathers. 


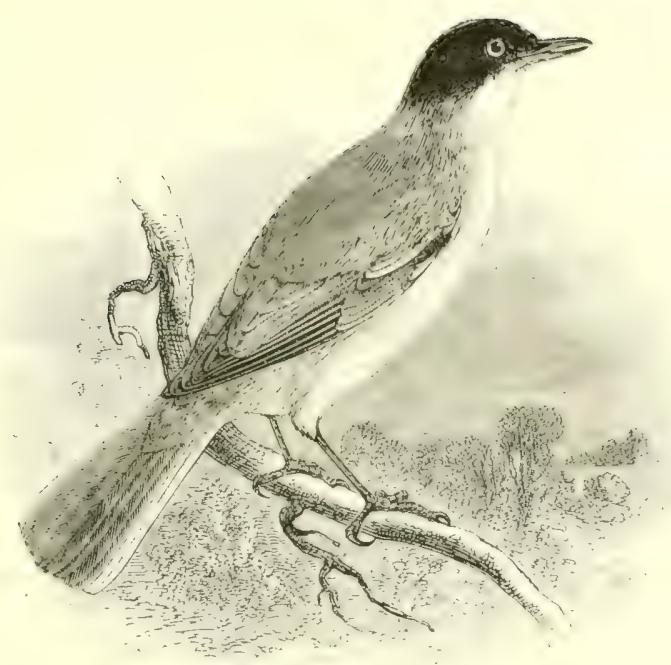

\section{THE ORPHEAN WARBLER.}

SYlYia ÓRPHEA, Temminck.

According to the late Sir William M. E. Milner a female Orphean Warbler was shot, and her mate observed, on July 6 th 1848 , in a small plantation near Wetherby, Yorkshire; and from the state of her plumage she was believed to have been incubating. Virtually, however, the authority for this statement was Graham of York, a bird-stuffer and purveyor of rarities : but the bird is correctly named. In June $\mathrm{I} 866$, as recorded by Mr. J. E. Harting, a young bird unable to fly was caught near Holloway, in Middlesex, and having been kept alive by sergeant-major Hanley for nearly six months, it was identified as an Orphean Warbler by the late Mr. E. Blyth. Nests and eggs supposed to be those of this species bave been taken, but no other birds have as yet been authenticated.

In France the Orphean Wirbler breeds sparingly in the Jienne distric monly in the southern provinces. In Portugal and Spain it is abundant wherever the olive grows, and aise among woods of conifers. It visits Savoy in summer; is local on the mainland of Italy, and very rare in the islands; passes annually up the valley of the Rhone to the Vosges, the vicinity of Metz, and Luxembourg; and straggeles to Belgium and to Heligoland; calst of which it is unknown. Rare in Tyrol, it occurs regularly in Dalmatia, Greece, Southern 
Russia, Turkey, Asia Minor and Palestine; a form known as S. jerdoni, with a somewhat larger bill and brighter coloration, being found in Persia, Turkestan and Northern India. South of the Mediterranean the Orphean Warbler breeds in Morocco and Algeria; visiting Egypt, and pushing its winter migrations as far south as Nubia. None remain in Europe during the winter.

The nest, a tolerably compact structure of dry grass, lined with finer bents, thistle-down and the down of the cotton grass, is generally placed in bushes, such as tamarisks, or in young cork-trees about twelve feet from the ground. The eggs, usually 5, are greyish-white, blotched and slightly scrolled with various shades of brown; much resembling those of the Lesser Whitethroat, but as large as those of the Garden Warbler: average measurements $S$ by $\cdot 6$ in. Nests which I obtained near Málaga often contained one, and sometimes two eggs differing from the others in their abnormal size, and microscopic examination of the texture of the shell by Mr. Sorby, F.R.S., subsequently proved them to be eggs of the Cuckoo. Incubation begins late in April, and while the female is sitting the cock-bird utters his song, louder and harsher than that of the Blackcap, from some neighbouring branch. The food, like that of many other Warblers, consists principally of insects, varied by fruit in the season. I am not aware of any distinctive features in the habits of this species.

Adult male: head to below the eyes black, paler on the nape; upper parts dark brownish-grey, with paler margins and tips to the secondaries; the outside pair of tail-feathers white on the outer half ; the second and third pairs spotted with white at the tips; the remainder of all the feathers blackish-brown; throat white; breast and flanks buffish-white; under tail-coverts buff; bill nearly black, paler at the base; legs and feet dark brown; iris straw-yellow. The female differs merely in having less contrasted and browner tints. The above descriptions are taken from a pair of birds obtained with their nest at Málaga on May 23rd I869. Young birds resemble the female. Length 6 in. ; wing, to the tips of the $3^{\text {rd }-4 \text { th and longest }}$ primaries $3^{*} \mathrm{I}$ in.

The white on the outer tail-feathers will always serve as a distinction between this species and the Blackcap. 


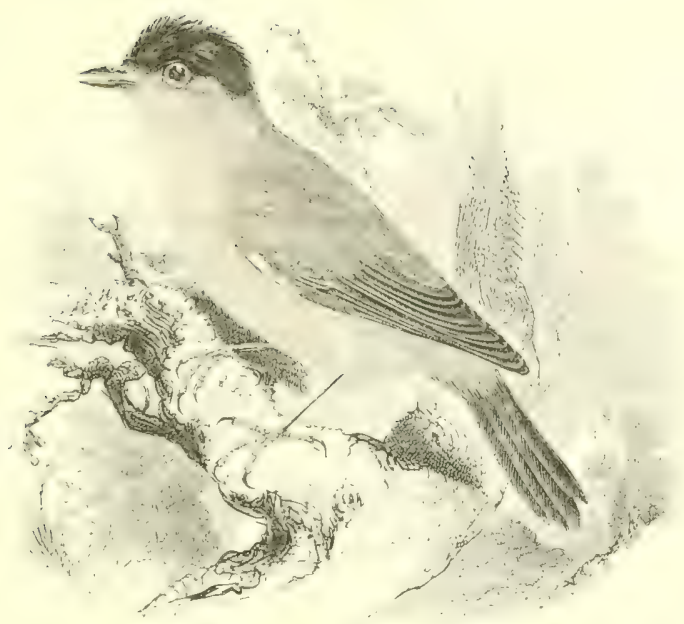

THE BLACKCAP.

\section{Sylvia ATRICAPÍlla (Linnæus).}

The principal arrival of this songster, hardly inferior to the Nightingale, takes place about the middle of $\mathrm{A}$ pril ; but occasionally some Blackcaps remain with us through the winter, and are consequently noticed on warm days in early spring. The majority take their departure for the south in September. Although somewhat local, the Blackcap appears to be of tolerably general distribution throughout England and Wales. In Scotland it becomes scarce as a breeder beyond the Firths of Clyde and Forth, but its nest has been found as far north as Ross-shire: while a pair attempted to establish themselves in a garden in the shetlands, to which, as well as to the Orkneys, Caithness, and Sutherland, the bird is a visitor during the autumn migration. In the mild, moist climate of the south-west it remains until late in the year, and Mr. R. Service captured one near I umfries on November egth isSi. In Ireland it occurs sparingly in summer, the nest having been found in the counties of Dublin, Wicklow, Tipperary, and Milyo; while in winter its presence has been recorded several times, especially in the south.

From scandinavia below $66^{\circ}$ N. lat., the Blackcap is found breeding in every country of Europe, as well as in North Africa and Palestine; in fact, allowing for individual migration, the Iblackcap appears to be a resident species in the basin of the Mediterranean. 
In the Cape-Verd Islands it breeds in January, but it is later in the Canaries. In Madeira and the Azores, where it appears to be resident, a variety with much more black on the head and shoulders of the male bird is not unfrequent. Its winter migrations have been traced to the Gambia, Abyssinia and the Red Sea; Omsk in Siberia being its somewhat doubtful eastern limit at any season.

The small but tolerably compact nest, built of dry grasses and lined with horsehair, is generally placed a few feet from the ground, among bushes; a privet hedge being rather a favourite site. The eggs, 4-5, are sometimes light yellowish-brown blotched with a darker shade, resembling those of the Garden Warbler, although a little smaller; in another variety the ground-colour and the blotches are suffused with a beautiful reddish hue: average measurements 73 by 58 in. Two broods are reared in the season, and the male takes his turn at incubation. The food consists of insects, often taken on the wing; rowan-, elder- and other berries; and fruit, especially raspberries and red-currants, for the sake of which the nest is often placed in or near orchards and gardens. In the south the bird also eats figs, oranges, and the berries of the pepper-tree.

Adult male: upper part of the head jet-black; nape ash-grey; back, wings and tail ash-brown; chin greyish-white; throat, breast and flanks ash-grey; belly white; bill horn-brown; legs and feet lead-colour. Length $5^{\circ} 75$ : wing to the end of the $3^{\text {rd }}$ and longest quill $2 \cdot 75$ in. The female has the top of the head bright reddish-brown and the remainder of the plumage browner than in the male. The young at first resemble the female, but the males acquire the black head, with merely brownish margins, during the first autumn.

It has been stated that in winter the males assume the plumage of the females; but I have seen hundreds of birds with black heads in the markets of Southern Europe at that season; and Mr. John Young, who has kept a jair of Blackcaps alive for four years, assures me that the male never changes colour after the first autumn moult. In spring some, if not all, of the tail-feathers are said to be renewed, but Mr. Young states that this is not his experience. 


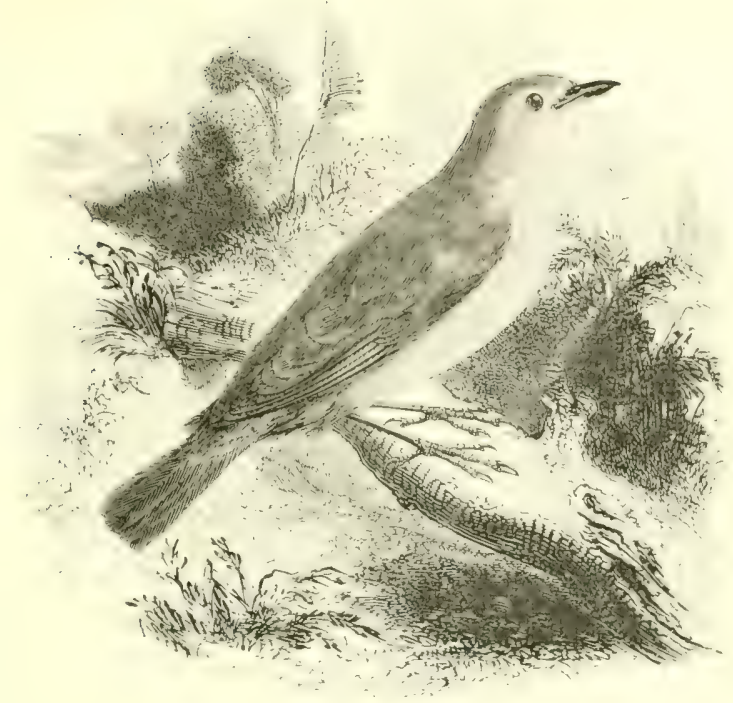

THE GARDEN-IVARBLER.

Sylvia HORTÉNSIS, Bechstein.

Iater in its arrival than the Blackcap, the Garden-Warbler seldom comes to us before the beginning of May, and although generally distributed over the greater part of England it is far more local than that species. It is not known to breed in the western portion of Cornwall; nor in Wales beyond Pembrokeshire and Ireconshire. In Scotland, Mr. R. Service informs me that it is more abundant in the Solway district than the Blackcap; and although it does not appear to be generally distributed, it has been recorded in Iianffshire, and has been obtained in the Shetlands on its attumn migration. In Ireland, where it is somewhat rare and very local, it has been found breeding in cos. Antrim, lemmanash, Tipperary, and perhaps in Cork. It generally leaves our islinds about the end of September.

The Garden-Warbler is only a straggler to the Færoes; but south of $70^{\circ} \mathrm{N}$. in Norway and about $65^{\circ} \mathrm{N}$. in Finland and Russia, it is found breeding throughout Europe down to the shores of the Mediterranean ; it is, however, partially distributed, and although common in Southern Spain, it is not kmown to breei in sicily or Greece; yet it does so in Palestine. On its autumn migration it 
leaves Europe by the middle of October, and passing through Asia Minor and Northern Africa, it winters in the oases of the Sahara, pushing on to Damaraland, the Transvaal and Cape Colony. Eastward its range appears to be bounded by the Caspian, and the Ural Mountains; possibly it may extend as far as Omsk, on the Irtisch, in Siberia.

The nest, lightly though firmly constructed of dry bents and fine roots, with only a slight lining of hair, is generally placed in low brambles and thorn-bushes; sometimes among peas or in gooseberry-bushes in a garden. The eggs, 4-5, are white, marbled and blotched with shades of buffish-brown; a good deal like one variety of those of the Blackicap, but never, like the other phase of the latter, suffused with a reddish tint: they are also on the average a trifle larger and the shell is less glossy: medium measurements 75 by 6 in. Only one brood is, as a rule, reared in the season. The nestlings are fed largely on insects, particularly on the caterpillar of the white cabbage-butterfly; but later, peas, fruit of all kinds and berries, are largely consumed. From its partiality to figs it has acquired its Italian name of Peccafico, which is however a comprehensive term for many other small species. Its song is continuous and mellow, though softer and less rich than that of the Blackicap; the call-note being a harsh teck, resembling the sound made by knocking two small pebbles-together. In its habits the Garden-Warbler is rather more shy and skulking than most of its congeners; and it appears to be intolerant of rivalry, for it is generally scarce in those districts where the Blackcap abounds, and common where that bird is scarce, as for instance, in Lincolnshire.

Adult male in May: entire upper parts olive-brown, with a paler eye-streak: quill-feathers darker brown with narrow whitish tips and margins; under parts mostly buffish-white, jurer in the centre of the belly, and darker on the flanks; bill brown, paler at the base; legs and feet lead-colour with yellowish soles to the latter; irides hazel; eyelids white. Length 5.5 in.; wing to the tip of the 3 rd and longest primary $3 \mathrm{in}$. The female is slightly paler than the male. The young are rather more greenish-olive than the adults, and have well-defined pale margins to the secondaries. 


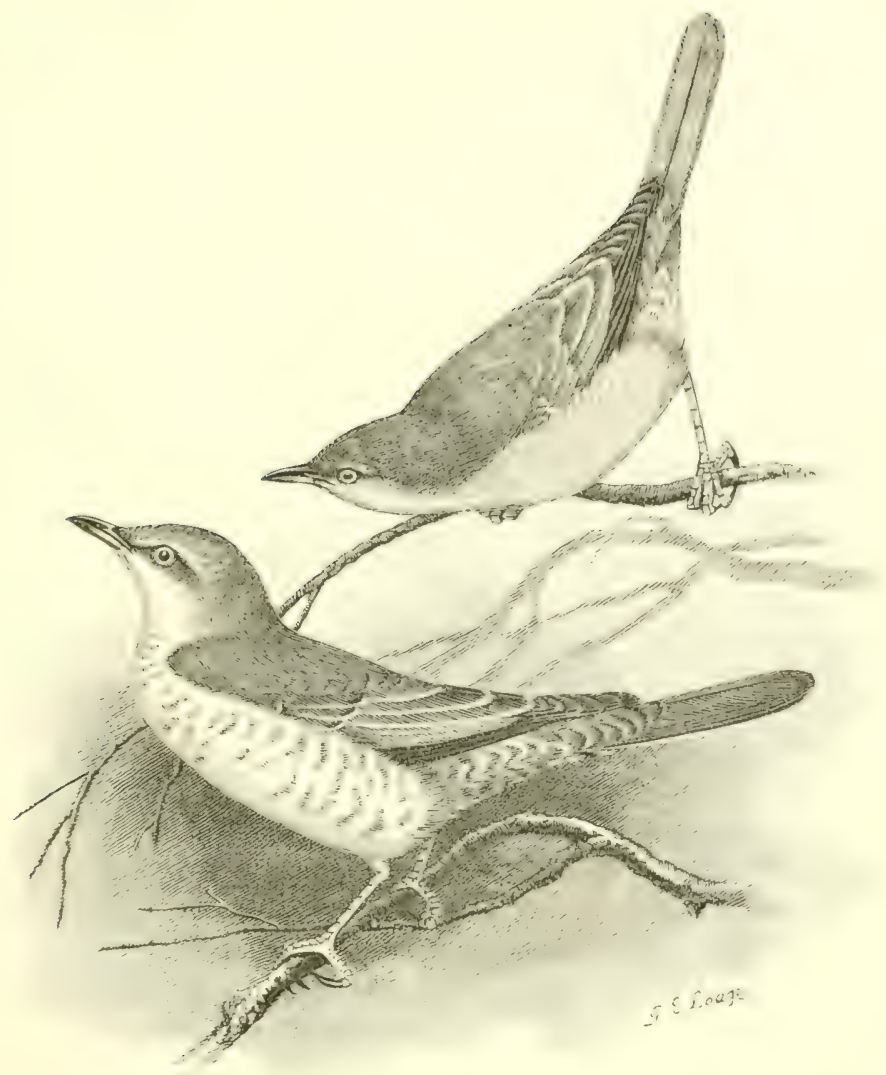

THE BARRED IVARBLER.

\section{Sylvia Nisória (Bechstein).}

On Narch 4th 1879 , Professor Newton exhibited at a meeting of the \%oological Society a sperimen of the liared Warhler which had been shot many years previously in a garden near Queen's College, Cambridge. Attention having heen drawn to this specics as a straggler to Great Britain, a second example, an immature female, was shot and recognized by the Rer. H. I S. Slater, as it was skulking in an clder-hodge by a potato-garlen in some sand-hills on the Yorkshire coast, on lugust 2sth r SS.f. On september fth of the same year, Mr. F. D. Power shot another immature female in some scrub at the base of Blakency sand-hills, Norfulk. Botl: these 
specimens were exhibited (P. Z. S. I $S S_{4}, 1$ ). 477 ). Lastly, on August I6th, still in I884, a young bird was shot by Mr. G. D. Lees near Broadford, Isle of skye, and subsequently identified by Mr. Dresser. It seems probable that this species has occurred more frequently, while from its skulking habits it may have escaped notice.

The Barred Warbler is a summer-visitor, for the purpose of breeding, to the southern portions of Sweden, Demmark, Germany east of the Rhine valley, and Central Europe generally in suitable localities; but so far as I know, Nice is its western limit on migration, and in Italy it appears to be restricted to the northern and north.castern provinces. It also breeds in Bulgaria, Turkey, Southern Russia, Persia and Turkestan; in the latter up to an altitude of from 6,000 to 10,000 feet. In October or November it leaves Europe, and probably winters in Central and Nortl-castern Africa, having been met with in Nubia and Northern Sennaar, among thorn-hedges and thickets along the Nile.

Towards the end of May the nest, which is more neatly and firmly constructed than is usual among the Warblers, is placed in a bush, or on the branch of a tree near the ground in a plantation; occasionally however at the height of some twenty-five feet. The eggs, generally 5, are buffish-white marbled with grey, not unlike those of the Grey Wagtail : average measurements 85 by $\cdot 62$ in. Only one brood is reared in the season. Its food is principally insects, but in summer and autumn fruit and berries are freely eaten. The song is said to be little inferior to that of the Garden-Warbler; the call is a sharp chek and the alarm-note a rattling rhar. Plantations, thickets and thorn-growth are its favourite resorts.

Adult male in spring: upper parts ashy-grey, brighter on the head and rump, browner on the wings; upper tail-coverts barred with dark slate and white; upper wing-coverts slightly barred and tipped with white; broad white tips to inner secondaries; tailfeathers tipped and margined on the inner webs with white, except the two central ones, which are ashy-grey with faint darker bars; under parts greyish-white with numerous grey transwerse bars, deeper on the flanks; axillaries and under wing-coverts mottled white and grey; bill brown, paler at the base; legs and feet brownish; iris pale yellow. Length 6.15 in ; wing 3.5 in. Female: browner and less barred. The young exhibit very few markings on the under parts, and, except on the rump, are hardly barred at all. 


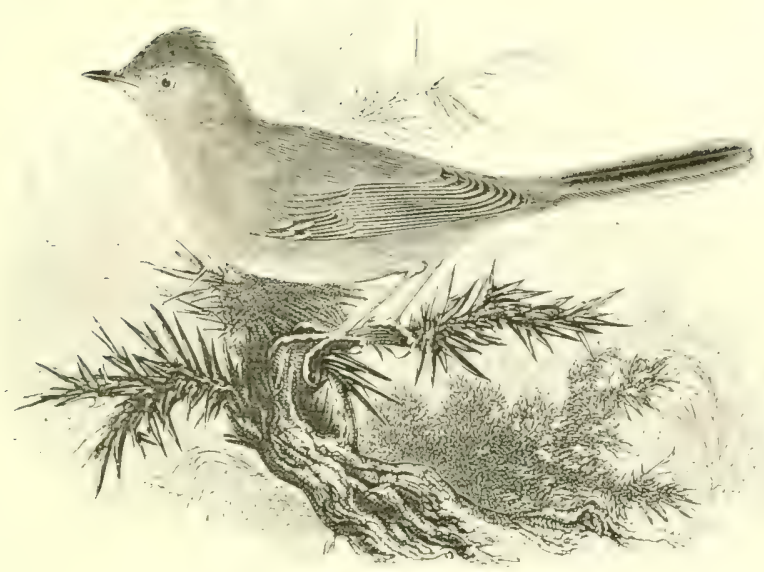

THE DARTFORD WARBLER.

\section{Sylvia undáta (Boddaert).}

'This Warbler derives its trivial name from the fact that it was first obtained near Dartford in I773, by Latham; but subsequent research has shown that, although local, it is more generaliy distributed in England than was for a long time supposed. Allowing for a little wandering, it may be described as a resitent southern species, chiefly frequenting furze-covered commons; and, apparently, extending its range both westward and northward of late years. It is now known to breed in nearly all the southern counties, from Cornwall to Kent, especially in Hampshire (including the Isle of Wight), surrey and Sussex; sparingly in the valley of the 'Thames; perhaps in some of the midland counties; and, on the sole authority of Mr. C. Dixon, in the Rivelin valley, in the extreme south of Yorkshire. It has been olserved in Cimbrigeshire and Norfolk; while in Suffolk a fuw probably breed. ()nly those who have studied its habits are aware what a skulking little bird it is, esperially in dull rainy weather ; or how easily a patch of gorse holding two or three pairs may be passed over, eren by a careful ob-erver, as untenanted.

Although as a rule a non-migratory species, the l)artford Warbler has been observed in Ifeligoland; but it is unkmown in Northem Germany, Holland, or Belgium. Rather rare in the Channel Islands, it is found throughout France in suitable localities, especially from the foot of the Western Pyrenees to Provence. In many parts of P'ortugal and sirain it is common, and I have watched 
it singing among the orange-gardens of Murcia; while it nests in the sierras of the almost tropical south coast at elevations of from I,, 00 to 3,000 feet. In Morocco and Algeria it is also resident, and it has been recorded from Lower Egypt and Palestine; but in Europe its eastern range is not known to extend beyond Italy and Sicily, the bird seldom reaching Malta. In Liguria, Corsica, Sardinia, and the Balearic Islands, it is to a great extent replaced by a close ally, S. sarda, of a nearly uniform grey tint.

'The nest in this country is placed among the lower branches of the thickest furze; but on the Continent, especially in the south, broom and heather are selected. The materials are principally goose-grass and the softer branches of furze, with a little wool and moss; the second nest of the season being generally more flimsy than the first; but on the whole the structure is tolerably compact. The eggs, 4-5, are greenish-white, with olive or reddish-brown markings-bolder than on those of the Whitethroat: average measurements 68 by ${ }^{5} 5$ in. The first nest is made in April; the second in June or July. The food of both old and young consists principally of insects; but in autumn blackberries and probably other fruits are added. In its habits the I)artford Warbler is a restless bird, flitting from the top of one furze bush to another, with a quick and very undulating flight; alighting in an abrupt manner as if the action were the result of an after-thought: the tail being spread for an instant as if to aid the bird in an effort to retain its balance. On the wing the adult looks very dark : in fact like a Dlack long-tailed Wren. The note which I have most frequently heard uttered is a fit-it-ihou, whence the French name Pitchou; but a scolding cha-cha is emitted when the bird is irritated. In severe winters its numbers are liable to be greatly reduced.

Adult male: upper parts dark slate-grey; wings dark brown with paler margins to the secondaries; the long dark fan-shaped tail with white outer margins and tips to the two exterior feathers; chin, throat, breast and flanks rufous-chestnut in spring, but streaked and spotted with white in autumn; lower breast and belly dull white; bill horn-brown at the tip, yellowish at the base; legs and feet pale brown; irides and eyelids orange-yellow. Length $5^{\circ} \mathrm{I}$ in. ; wing to the tip of the $4^{\text {th }}$ and longest primary, $2^{\prime} 25$ in. The female is rather smaller and browner, and shows less chestnut on the breast. The young are still paler than the female, and have more white on the lower parts; irides brown. 


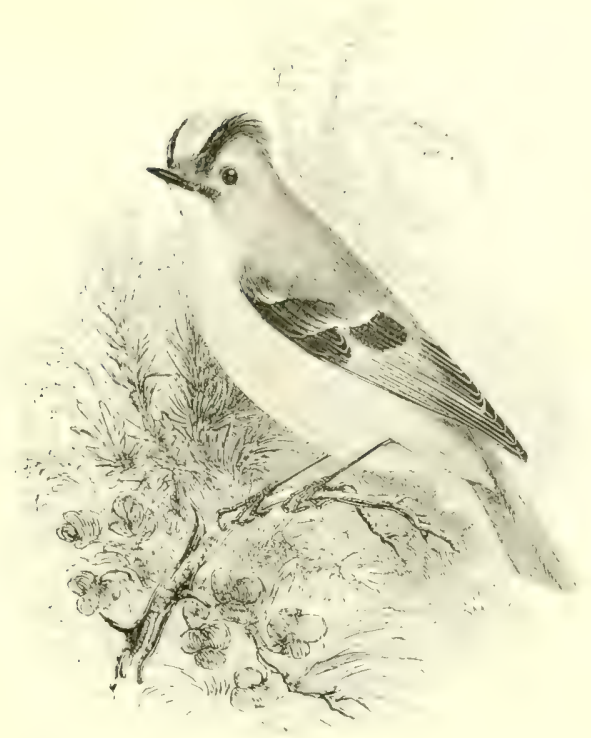

THE GOLDEN-CRESTED IVREN.

RÉgulus cRistatus, K. L. Koch.

This tiniest of British, and indeed of European birds, is generally distributed throughout our islands, breeding as a rule wherever it is found, with the exception of the Outer Hebrides, Orkneys and Shetlands, in which there are as yet few or no coniferous plantations suitable to its requirements. Even on the mainland of Scotlind there has been a marked increase in its numbers of late years, owing to the cultivation of firs and larches. In autumn immense flocks sometimes arrive on our east coast, extending quite across England, and the Irish Channel, and into Ireland. In i 88 a migration-wave of this description, commencing on August 6th and lasting 92 days, reached from the Channel to the Froes; in $188_{3}$ the migration lasted $S_{2}$ days; and again, in $188_{4}$, for a period of 87 days. Similar 'waves' passed over Heligoland, with the exception of the last year when, strange to say, the numbers were below the areraige. An unusual spring 'rush' took place in March and April I882. On such occasions bushes in gardens on the coast are covered with birds as with a swarm of bees; crowds flutter round the lanterns of lighthouses; and the rigging of fishing-smacks in the North sea is thronged with weary travellers. In April a return migration occurs. 
From the limits of the fir-woods in Scandinavia, and from Archangel and the Ural Mountains in Russia, the Golden-crest is generally distributed over Europe down to the Mediterranean and Black Seas; it is also a regular migrant to Malta in spring and autumn, on its way to and from North Africa. Eastward, it stretches across Asia to the Amoor; examples from Asia Minor, Turkestan, and the Himalayas, being intermediate between our form and $R$. cristatus var. jutonlicus, with a greyish-brown nape, resident in Japan. At the other extremity of its range, a local race named by Mr. Seebohm R. cristatus var. asoricus, distinguished by its much larger bill, stouter legs, and longer tail, is found in the Azores; but the Canaries appear to be frequented by the ordinary form.

The beautiful nest of the Golden-crested Wren is generally placed beneath the extremity of a branch of a fir, yew, cedar, or other evergreen; the almost spherical structure being supported by the lateral twigs. Occasionally it has been found upon the upper surface of a branch, and eren in a low bush. Built of the softest moss, felted with spiders' welss, wool and a few lichens, and with a lining of small feathers, it is frequently ready for eggs by the latter part of March. These, 5- 8 and even $\mathrm{o}$, are of a pale ochraceous-white, minutely mottled, especially at the larger end, witl reddish-brown : average measurements 52 by 4 in. The female sits very close. The song of the male. uttered almost incessantly in fine weather, is often commenced in February; but although sweet, it is weak, and rather difficult to decribe. Insects seem to form the food of this little bird, which may often be seen searching for the means of subsistence in the woods and groves, together with 'Tits and Creepers, for it is very sociable in its habits.

Adult male: base of the bill to above the eye, greyish-white; followed by a dark brown frontal streak decpening into a black line on each side of a crest which is bright yellow in front and rich orange further back; neck and back yellowish olive-green; tailfeathers ash-brown, with yellowish margins; wings ash-brown, with white tips to the secondaries, and a black bar across the upper part, contrasting with the white margins of the median and greater wing-coverts; under parts greenish-buff, whiter on the belly; bill very dark brown; legs and feet brown; irides hazel. Length 3.5 in.; wing to the tip of the 5 th and longest primary $2 \mathrm{in.}$ The female is duller than the male, with narrower black streaks below the crest, which is only lemon-yellow. The young have no crest, but merely a crown rather darker in colour than the back. 


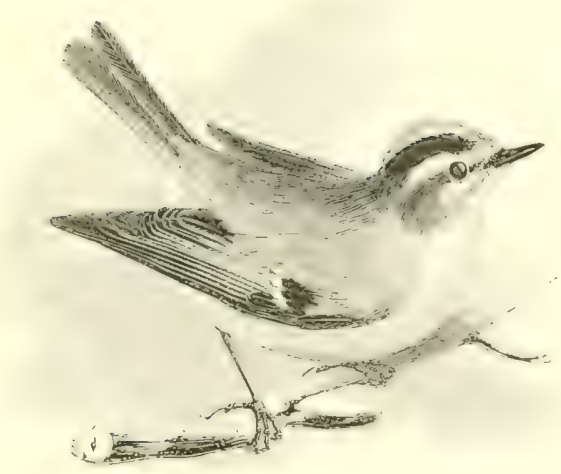

THE FIRE-CRESTED WREN.

Regulus ignicapíllus (C. L. Brehm).

Although the Fire-crested Wren can only be considered as a straggler to our shores, yet its authenticated occurrences have been far more numerous than is generally supposed. Since the first recognized British example - a bird of the year obtained near Cambridge in August $1 \$ 32$ - many visitors of this species have been obtained -almost invariably in winter: rarely in Cumberland, Lancashire, Yorkshire and Durham; twice in, and once off the coast of Norfolk; once in Kent; over twenty times in Sussex; occasionally in Hampshire and the Isle of Wight; sparingly in I)evonshire; more frequently in Cornwall and the Scilly Islands than in all the rest of England; and once in North Wales. In Ireland it is as yet unknown; while in Scotland, the records of its occurrences in East Lothian and the Shetlands require confirmation.

The Fire-crested Iren has a much less cxtended range northward than its congener, and although it appears to have straggled to the Feroes, it is unknown in scandinavia; barely reaches I)enmark; and does not occur to the north-east of the Baltic Provinces of Germany. To some parts of the khine district it is rather partial in summer; and, although locil in its distribution, it breeds in France, Spain, Italy, swit/erland, Central and Southern Gemany, (ireece, Turkey, and Southern kusial. In the Taurus range of Asia Ninor, it is more abundant than the Gold-crest. In the mountainforests of Algeria, and in some parts of Southern Europe, the firecrest is resident throughout the year; its numbers being augmented 
in winter by migrants from the north. In Madeira it is represented by $R$. maderensis, with dull-gold crest, dark grey nape and no black streak behind the eye ; while a form with greyish-white lores found in the Canaries is distinguished by Mr. Seebohm as $R$. tencriffie.

The nest of the Fire-crest is similar to that of the Golden-crest; but the eggs, 7-ro, may always be recognized by the much redder tinge of their ground-colour and dots: measurements 52 by $4+2$ in. In Germany the branches of a fir-tree are almost invariably selected; the nest being seldom found in pines or larches; and the same trees are frequented year after year. In the above country nesting does not begin before May; but in the south of Spain the young are able to fly by the middle of that month. Insects and spiders constitute its food. In the Pyrenees, with excellent opportunities for observing the habits of both species, I noticed that the Firecrest was much more restless and erratic in its movements, darting away suddenly after a very short stay upon the gorse bush or tree where it was feeding, and being often alone or in parties of two or three at most; whereas the Golden-crests, five or six together, would work steadily round the same bush, and, if I remained quiet, would stop there for many minutes. The note of the Fire-crest is a soft zit, zit.

The adult male has a yellowish frontal band prolonged into a white streak passing above and behind each eye, and separating a parallel black line through and behind the eye, from the broader and blacker upper bands on each side, which enclose the rich orangeyellow crest. This black line through the eye is one of the principal features which distinguish the Fire-crest from the Gold-crest; another important characteristic being the sulphur-green tint on the sides of the neck and shoulders. From the gape runs a third black streak which may be called the moustache. Mantle olivegreen; wings and tail brown, margined with yellowish-green; the former doubly barred on the upper parts with brown and white; under parts dull buffish-white; bill black; legs and feet brown. The female differs in having a paler crest; while the young have no crest at all until after the first moult, but the characteristic triple band is always present. Length $3^{\circ} 8$ in. ; wing 2 in.

An example of the American Ruby-crowned Wren, R. calendula, now in the British Nuseum, is said to have been shot near Loch Lomond in $18_{52}$, by the late Dr. Dewar, in whose cabinet this very conspicuous bird lay unrecorded for six years, when it was recognized by the late R. Gray! 


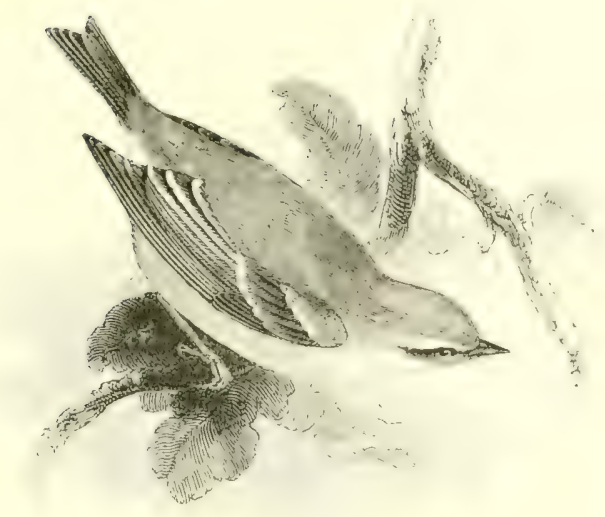

THE YELLOW-BROWED WARBLER.

Phyllóscopus superciliósus (J. F. Gmelin).

This rare little straggler was introduced to the British list by Mr. John Hancock, who shot an example on September 26 th ${ }_{1} \delta_{3} s$, on the sea banks near Hartley, Northumberland, about four miles north of the Tyne. It was catching insects on the tops of the taller herbage; and its actions were so like those of the (iolden-crested Wren that he mistook it at first for one of that species. This specimen is now in the Museum at Newcastle. A second example, recorded by (sould as having been obtained near Cheltenham on October I th I 867 , by Mr. I. 'T. White, passed into the collection of the late Sir John Harpur Crewe. Iastly, a third specimen was taken at the lantern of Sumburgh Head lighthouse, Shetland, by Mr. James Youngclause, on September 25 th 1886 , as recorded by Mrr. Harvie-Brown, to whom it was sent in the flesh.

On the Continent identified examples have heen obtained, at rare intervals, near Berlin, Vienna, and Leyden; but on Ifeligoland the Yellow-browed Warbler has been taken or seen at least eighty times between 18,46 and the end of $188 ;-$ on its autumn migrations, with the exception of two in $\lambda_{\text {pril }}$ and May (Gritke). Its summerhome appears to be in the pine-forests of North-eastern Siberia, from the valley of the lenesei castward to the Pacific, and from the mountains of Lake Baikal northward to the Arctic circle. The bird passes through Mongolia and North ('hina on migration, and winters in South (hina. Assam, Burma and North-eastern India 
(Seebohm). Canon Tristram obtained it at Jericho; and Severtzoff found it nesting in Turkestan up to about 8,500 feet.

The finding in Cashmere of a nest and eggs supposed to be those of this species, was described by MIr. W. E. Brooks in 'The Ibis' for 1872 ; and reproduced in the 4 th Edition of 'Yarrell's British Birds,' as well as in Mr. Dresser's 'Birds of Europe'; but the parent bird subsequently proved to be $P h$. humii, a distinct species. Mr. Seebohm had the good fortune to find the first authenticated nest of the Yellow-browed Warbler, on June 26 th 1877 , in the forest between the Kurayika and the Yenesei. It was built in a slight tuft of moss and bilberries, semi-domed, exactly like the nest of our Willow-Wren, and composed of dry grass and moss, with a lining of reindeer-hair. The eggs, 6 in number, are described as pure white, thickly spotted at the larger end with reddish-brown; measurements 6 in. by ' $45 \mathrm{in}$, and one of them is figured by Mr. Seebohm on P'l. Io of his 'Mritish Birds,' a work which contains the best account extant of this Warbler. In its habits, says Mr. Gätke, this bird has little affinity with the restless Golden-crests, which it only resembles in size and the double bar across the wings; and in Heligoland it is universally known as the 'Barred Willow Warbler.' When it alights on a tree, it begins at the lower branches and works steadily up to the top, searching for its insect food. Mr. Gätke describes the note as hyiif, a little drawn out; while a bird observed by Mr. Scebohm-also on Heligoland-uttered a plaintive zeest.

The bird in autumn-plumage has the whole of the upper parts a greenish-yellow; on the centre of the crown of the head a pale line; a yellowish stripe over the eye from the base of the bill to the occiput; a short streak of the same colour beneath the eye, and a narrow dusky band passing through the eye to the ear-coverts; under parts pale yellow; the ridge of the wing bright lemon-colour; wing-feathers dusky, edged with pale yellow, becoming broader on the secondaries; two conspicuous bands of lemon-colour across the coverts : bill brown, paler at the base; mouth yellow; legs and toes brown, with the under surface of the toes inclining to yellow. In summer the green and yellow have largely suffered from abrasion, and the general tints are olive-grey. Length 4 in. ; wing $2^{\circ} \mathrm{I}$ in.

The Yellow-browed Warbler was formerly known as the 'Dalmatian Regulus,' Resulus motistus, of Gould, described and figured in his 'Birds of Europe'; but this proved to be Ph. proregullus (Pallas), an Asiatic species which has straggled to Heligoland, but is otherwise unknown in Europe. 


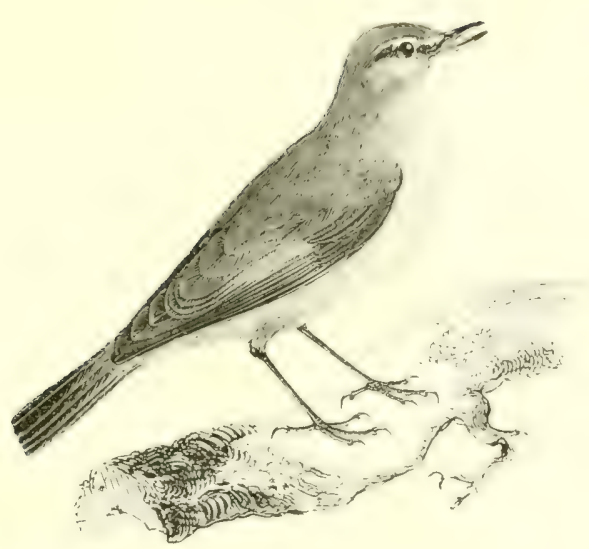

THE CHIFFCHAF.

Phylloscopus Rufus (Bechstein).

The Chiffchaff is the earliest visitor among our spring migrants, the familiar note, from which its name is derived, being frequently heard by the middle of March, lefore the trees have put out their leaves; while a comparatively small number occasionally pass the winter in various sheltered portions of our islands, especially in Cornwall. Tolerably abundant in summer in our southern counties, and particularly so in the south-west and midlands, the Chiffchaff is somewhat rare, or local, in Norfolk, Iancashire, and the north-west of Yorkshire; but more frequent in Cumberland, Westmorland, 1)urham and Northumberland. In Scotland it has been observed as far north as Caithness, and is stated by Mr. J. H. Dixon to be common at Gairloch, Ross-shire; but it is much scarcer everywhere than the Willow-Wren, and is merely a straggler to the Outer Hebrides and Orkneys. To Ireland, according to Mr. A. G. More, it is a frequent summer-visitor.

In Northern Europe the Chiffchaff ranges in summer up to the Arctic circle, and as far east as the valley of the Volga; beyond which it is replaced by the siberian Chiffehaff, P'tullescrofus trisis, a rather smaller bird, browner and duller in coloration. Southward, our Chiffchaff is generally distributed in suituble localitie's as far as the shores and islands of the Mediterranean, and is more or less resident beyond the Pyrenees and the Alps; its numbers being largely augmented at the times of migration and in winter. At the latter season, it is abundant in some parts of Africa duwn to 
Abyssinia; also in Arabia, Palestine, Asia Minor and Persia. In the Canary Islands it is a resident, and there, according to Capt. S. G. Reid, R.E., its song has become longer and more desultory.

The nest of the Chiffchaff is usually placed near to, but a little above, the ground, in rank regetation and ferns; occasionally in ivy against a wall, at an elevation of a couple of feet or so, while instances are on record where-in England and in the Canariesthe nest has been found from three to five feet up, in laurel, holly, and other bushes. In this country nidification begins about the end of April ; the oval dome-shaped nest, with a hole rather nearer the top than the middle, being composed of dry grass, leaves and moss, with an abundance of feathers as a lining. The eggs, commonly 6 in number, are normally of a pure or a creamywhite, spotted with purplish-brown, and sometimes with underlying blotches of violet-grey; occasionally spotted with pale red : average measurements 6 in. by 45 in. The song, if such it may be called, is continued throughout the summer, and by it the presence of the bird is often betrayed, while the owner of the voice is invisible; for the Chiffchaff frequents the branches of loftier trees than the Willow-Wren does; groves of tall elms being peculiarly attrac. tive. Its food consists of insects and their larvæ. By October the autumn-migration from our islands may be said to have terminated, except for those individuals which, as already stated, occasionally remain till December or even through the winter, and, if severe weather sets in, pay the penalty for running such a risk.

The adult in spring:-olive-green on the upper parts, rather yellower on the rump; a pale yellow streak above the eye, passing into white behind the ear-coverts; wing-coverts, quills and tailfeathers dull brown, edged with olive-green; chin, throat, breast, belly and lower tail-coverts duil white, tinged with greenish-buff; under wing-coverts pale yellow; bill brown; iris hazel; legs and feet very dark brown, Length $4^{\circ} 75$ in. ; wing 2.4 in ; tarsus ${ }^{\circ} 6$ in. The plumage is alike in both sexes. The young are slightly greener than the adults and the eye-streak is fainter. After the autumn moult the yellow tint in the plumage is much more pronounced.

The Chiffchaff may be distinguished from the Willow-Wren by its smaller size, duller hue, darker legs, and more rounded wing. The 2 nd quill is equal in length to the 7 th, and the outer webs are sloped off, or emarginated, up to the 6th inclusive. In the WillowWren this emargination only reaches to the 5 th, and the and is equal in length to the 6th quill. 


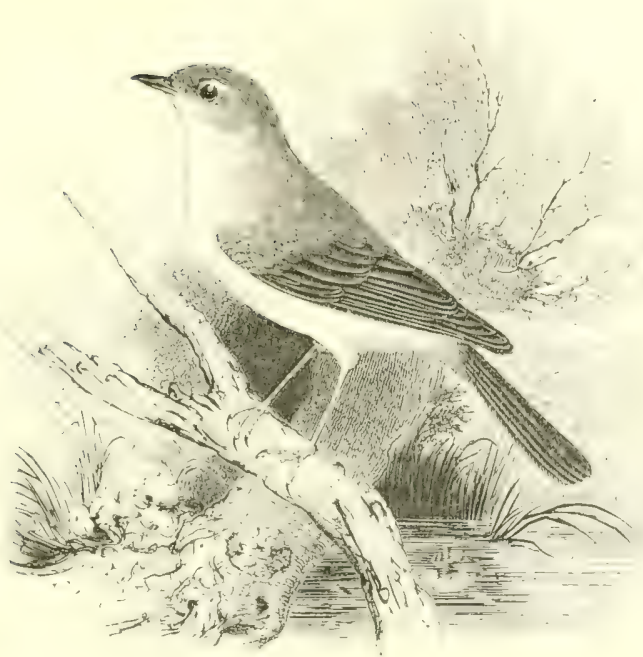

THE WILLOW-ITREN.

\section{P’Hylloscopus tróchilus (Iinnæus).}

The IVillow-Wren makes its appearance in the southern portions of this country about the first week in April, and from that time until the middle of September it is by far the most abundant of the three species of small greenish-yeliow Warblers which annually visit us. In England it is generally distributed, although somewhat local in Cornwall : and it seems to be only fairly common in some parts of Wales. To Scotland it is a regular and abundant summervisitor, and in the northern districts its numbers have considerably increased of late years; but to the Orkneys, shetlands and Feroes it appears to be only a stragerler. In Ireland it is common in suitable localities. Occurrences of this little bird in winter, in the milder districts of our islands, have often been recorded.

In summer the Willow-Wren ranges nearly as far as the northern extremity of the Continent, and southward we find it breeding throughout the greater part of Europe down to the Straits of Gitraltar. Eastward it certainly nests in Transylvania; but in South Russia, Turkey, (Greece, Asia Minor, l'ersia and Palestine it is only known to occur in winter and on migration. Its summer range extends over Northern Russia and sileria to the valley of the Yenesei; while its winter quarters may be said to begin in the south of France, but the majority pass on to the oases of Africa, and 
some even to about $32^{\circ} \mathrm{S}$. lat. in Kaffraria. It is not improbable that a limited number pass the summer in suitable localities in Northern Africa.

The domed nest, loosely constructed of dry grass, and always lined with feathers, is generally placed among long herbage on the ground, but often at the foot of a bush, occasionally some feet from the ground, or even in a hole in a wall. The shape of the nest has procured for this species and its congeners the name of "Oven-birds"; while in many places the Willow-Wren is also knuwn as the "Hay-bird," from the dry materials employed, and also from the fact that the nest is often found in the corner of a hay-field. The eggs, 6-8, are white, blotched and speckled with much lighter red than is the case with the eggs of the Chiffchaff, but exceptionally they are pure white: average measurements 62 by 46 in. The first brood is hatched about the end of May, a second being generally produced in the season. The merry song of the Willow-Wren, consisting of a few often-repeated notes, may be heard during the season in every coppice; and sometimes calls attention in our I.ondon parks to a begrimed songster which would otherwise be almost unrecognizable. When the bird is aware that its nest is approached, or when calling its young together, its usual note is a plaintive whit, and at such times the greatest solicitude and disregard of danger are displayed: Its food consists almost entirely of flies, affides, and other insects; but although its utility to the gardener is undeniable, it must be allowed that it does peck and damage currants and other fruit to an unimportant extent.

The adult male in spring has the upper parts olive-green, yellower on the rump; a yellowish streak over the eye and earcoverts; wings and tail olive-brown, margined with greenish-yellow; under parts yellowish-white, more sulphur-coloured on the flanks; under wing-coverts brimstone-yellow; bill, legs and feet brown. Length 4.9 in. ; wing 2.6 in. ; tarsus 7 in. The sexes are alike in plumage. In autumn the general tint is yellower, especially in young birds. There is a spring as well as an autumn moult.

The Willow-Wren may be distinguished from the Chiffchaff by its larger size, generally yellower tinge, paler tarsi, and by having the outer margins of the primaries sloped off as far only as the $5^{\text {th }}$ inclusive; whereas in the Chiffchaff the 6th is also emarginated.

Varieties of the Willow-Wren are uncommon; but in May I86 I a primrose-coloured bird was shot in Surrey (Harting), and in August of the same year a similar bird was shot in Suffolk (Stevenson). 


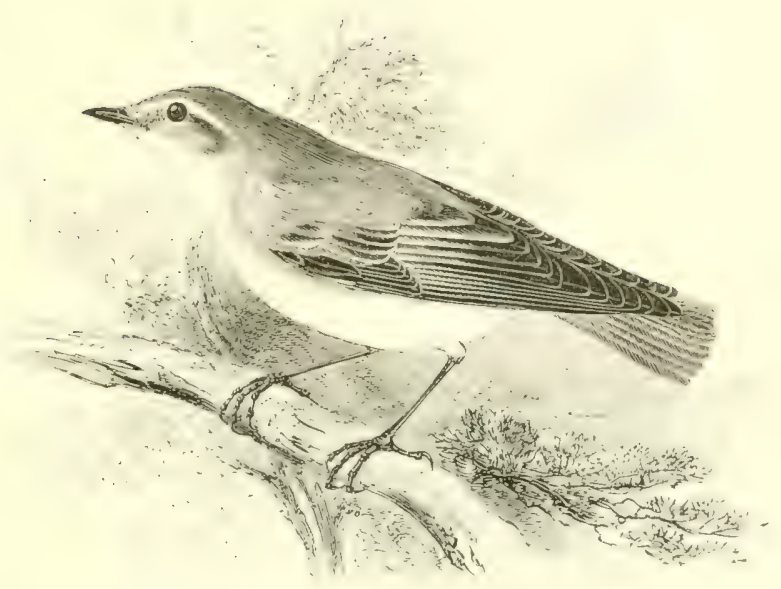

THE WOOD-WREN.

Phylloscopus sibilátrix (Bechstein).

The Wood-Wren, the largest of the three members of the genus which habitually visit us, is the latest to arrive; seldom appearing even in the south of England before the middle of April ; while in September it departs for the winter. Owing to its marked preference for woods, especially of beech, it is more local in its distribution than the two preceding species: for example, although very common in some of the eastern parts of Cornwall, it is of rare occurrence in the west of that courity. It is to be found in suitable localities throughout England, and, more sparingly, in Wales; while in st. Leonard's and 'Tilgate Forests in Sussex, the New Forest, Sherwood Forest, and the woodlands of Cumberland, Westmorland, Yorkshire, I) urham and Northumberland it may be called abundant. In Scotland it is fairly distributed, and has apparently spread northward of late years; being recorded by Messrs. I Iarvie-Iirown and liuckley as breeding in the south-east of Sutherlandshire, and as having been identified at Dunbeath in Caithness. Mr. A. C. Chapman recornized it on North Uist, in the Outer I Iebrides. To Ireland it is as yet a rare visitor, having only been obtained in cos. Fermanagh, I onegal and Dublin, and observed for sereral successive summers in Wicklow.

The Wood-Wren has not yet been proved to visit Norway, but it is found in sweden as far north as Upsala; while it is very common 
in the Baltic provinces, rarer in South Finland, and a straggler to Archangel. Eastward it can be traced to Kazan, the lower valley of the Volga, the Caucasus, and the western shore of the Caspian. In Palestine, Asia Minor and Greece, it occurs on migration; but it breeds in Turkey, Transylvania, and Europe generally, although rarely in the extreme south; while in Portugal the bird seems to be almost unknown. It appears probable that a few remain during the summer in the mountain forests of the Atlas; the winter migrations extending to the Gold Coast on the west side of Africa, and to Abysinia on the east. Notwithstanding its comparatively long wings, the Wood-Wren appears to hug the land on passage far more closely than is customary with the Willow-Wren and the Chiffchaff, thousands of which annually risit Heligoland on their migrations; whereas the Wood-Wren is seldom met with there.

Like its congeners, this species makes a domed nest of dry grass with a little moss, but there is no lining of feathers. Sloping wooded banks are favourite situations for the nest, which often is not merely on the ground, but is actually set in some natural hollow, well concealed by herbage. The hen at times sits very close: when fairly beaten out, she will feed in an unconcerned manner, uttering a low pi-ó for a quarter of an hour or more; after which she works round to a branch above her nest, drops down abruptly, and enters it in an instant. The eggs, 5-7, are white, thickly spotted and frequently zoned with purplish-brown and violet-grey : average measurements ${ }^{6}{ }_{5}$ by $\cdot 55$ in. Ph. bonellii, a miniature Wood-Wren, common on the Continent, especially in the south, lays similar but much smaller eggs. The food is principally flies -often taken on the wing-and other insects; but in the season it eats berries, and probably fruit. Its call-note is dee-ur, dee-ur; dic-ur; and the shivering song may be syllabled as-chit, chit, chit, ihit, chitr, tr-tr-tr-tr-tr-tre, accompanied by rapid vibrations of the wings and tail.

In spring the adult has a broad and characteristic sulphur-yellow streak above and behind the eye ; the upper parts yellowish-green; wings greyish-brown, edged with yellowish, turning whiter on the inner secondaries; tail greyish-brown; belly and under tail-coverts white; breast and throat sulphur-yellow; bill, legs and feet brown. Length 5.9 in. ; wing, to the tip of the 3 rd and longest quill, 3 in.; the first or bastard quill being very short; tarsus ' 7 in. In plumage the sexes are alike; the young differ in being rather yellower than the adults. The coloration, larger size, and proportionately long wing suffice to distinguish this species from its allies. 


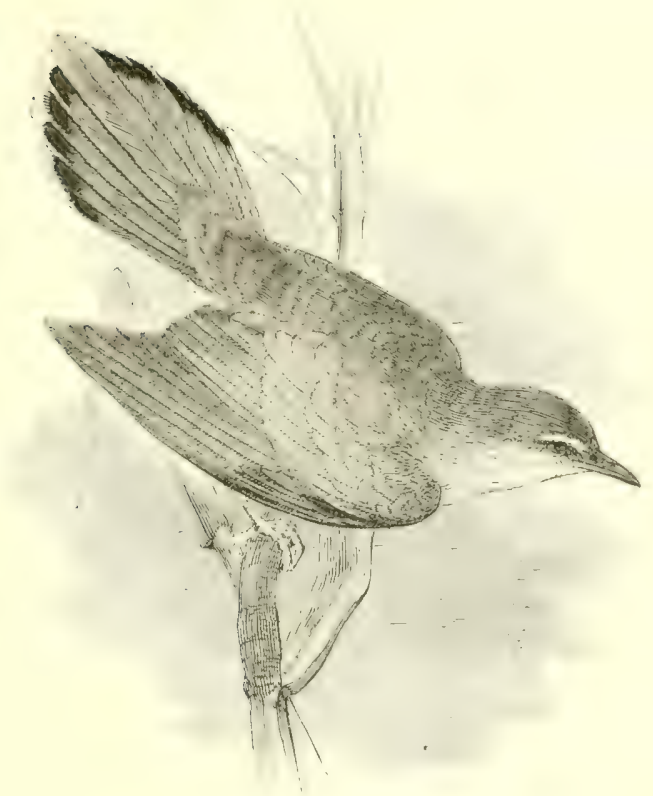

THE RUFOUS WARBLER.

AËDN GALACTódES (Temminck).

The Rufous Warbler is a southern species, which has been obtained in England, as a straggler, on three occasions. The first example was shot by Mr. Swaysland near Irrighton on September I6th I854, and according to Mr. IV. Borrer of Cowfold, who recorded it, the bird was a male preparing to moult. On September 25 th i 859 , after the prevalence for a week of a strong southerly wind, a very thin bird, which had lost its tail, was shot at the Start in I cevonshire by Mr. W. D. Llewellyn, who presented it to the liritish Museum. A third was obtained in a turnip-field near Slapton, Devon, on October I 2 th 1876 , as recorded by Mr. H. Nicholls (Zool. s.s. p. 5I79). These occurrences, all in autumn, show that the individuals in question were merely wind-driven waifs from the south; nor is it likely that many others have escaped observation, the bircl being conspicuous by its plumage and habits. It may be briefly described as a pale-coloured Nightingale, with white tips and black spots on a broad fan-shaped tail.

The Rufous Warbler does not appear to visit France, or even the northern portions of the Peninsula; but in Southern P'ortugal and 
Spain it is abundant from the third week in April until the end of September. To the mainland of Italy it is a somewhat rare straggler; visiting Malta on its migrations to and from Northern Africa, where, from Morocco to Egypt, it is generally distributed throughout the greater part of the year. In winter it goes as far south as Abyssinia, ascending the mountains of that country in May to an elevation of 3,500 feet. In April, according to Canon Tristram, it arrives in Palestine, and breeds to the south of Beyrout; but north of the Iebanon we meet with a very closely-allied species, Aidon familiris: much less rufous on the upper parts, and with the central pair of tail-feathers brown instead of chestnut. The latter breeds in Asia Minor, Persia, Turkey, Greece, the Caucasian district, and Turkestan; straggling, strange to say, across the line of didon salactodes, to Italy and Nice, and even to Heligoland.

Breeding begins by the end of May; the rather bulky nest being often placed, without any attempt at concealment, at some distance from the ground, on a branch or in a fork of a tamarisk bush; sometimes between the roots of a tree in a bank-side; and frequently in the cactus-hedges which border vineyards. Wool, hair, feathers and any soft materials are used for the lining, amongst which a piece of snake's-skin is generally to be found. The eggs, usually 5 in number, are pale grey, streaked and blotched with ash-brown and dull violet, much resembling those of the Tawny Pipit: average measurements $98 \mathrm{in}$. by $6_{3} \mathrm{in}$. In its habits this bird is lively and restless, constantly flirting its expanded tail ; whence its Spanish names of 'Alza-cola,' and 'Alza-rabo.' I have not found it to be at all shy, until it becomes conscious of being watched and followed : a proceeding which it naturally resents, as do most birds. The original English name of Rufous Sidge Warbler is remarkably inappropriate, as the bird is never seen in sedges, and is rather partial to arid places. Its food consists of insects. The song is said to resemble that of the Redbreast.

Adult male: upper parts chestnut-brown; a broad whitish streak above the eye to the nape; quills brown with reddish-buff margins; tail rich chestnut with a narrow blackish terminal band on the two central feathers, and a broad sub-terminal black band with increasingly large white tips from the centre to the outer feathers; under parts sandy-white, deeper on the breast and flanks; bill, legs and feet brown. Length $6.75 \mathrm{in}$. ; wing to the end of the $3 \mathrm{rd}$ and longest quill 3.5 in. The female is slightly, if at all, paler than the male. 


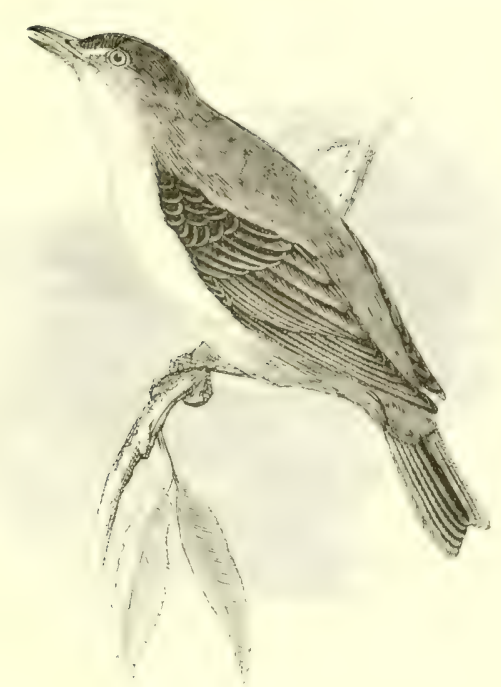

THE ICTERINE IVARBLER.

Hypoláis icterína (Vieillot).

Although common on the Continent, even within sight of our own shores, this member of a well-marked genus not remotely allied to the group of Reed-Warblers is only a very rare straggler to the British Islands. The first example was killed on June I 5 th is 4 s, at Eythorne, near Dover; a second (now in the I)ublin MLuseum), on June Sth 1856 , at Dunsinea on the banks of the Tolka, co. Dublin; and a third was shot by Mr. F. 1). Power on September I Ith ISS +, near 13lakeney, Norfolk. All three examples have been examined and identified by competent authorities : the significance of which will be apparent hereafter.

In Norway the Icterine Warbler reaches the Arctic circle, although in Sweden, Finland and Russia, its northern range is less extensive. Eastward, the Ural and the valley of the 'Tobol form its known limits, and further south it has been obtained at I.enkoran on the western side of the Caspian. In Asia Minor, and South-eastern Europe as far as Malta, it is only known on its migrations to and from Africa-where it winters down to about $25 \mathrm{~S}$. lat. : lut in sicily and on the mainland of Italy it arrives in April and remains to breed; though Sardinia and Corsica are seldom, if ever, visited. In Central and Northern Europe, up to the Baltic provinces, 1)emmark, 
Germany, Holland and Belgium, it is common from the middle of May until autumn. In the north-east of France it is very abundant, and extends westward as far, perhaps, as the mouth of the Somme; to the west of which we find a very closely allied species, H. polyglotta, often confounded with our bird both as regards specimens and nomenclature. H. polyglotta is common round Paris and generaily west of the line of the Seine, as well as in the southern provinces; it is also the only one of the two found, as yet, in Portugal, Spain, and North-western Africa. As its appearance in this country, sooner or later, is highly probable, its distinctive characters are pointed out below.

The nest, generally placed in the fork of a small tree or lilac bush in a slightly moist locality, is a firm, deep, and often beautiful structure of dry grass, wool, thistle-down, lichens \&c., lined with horsehair. The eggs, usually 4-5, are dull rose-pink, blotched, and sometimes scrolled with dark purplish-brown : average measurements 72 by 55 in. In Holland incubation begins about the end of May or early in June. Almost every garden contains a pair, and the presence of an intruder of his own, or any other small species, is promptly resented by the male. The song has been much admired for its variety, and its supposed imitation of the notes of other birds-whence the German name Spottregel or Mocking-bird; but Mr. Seebohm, who is gifted with a fine ear for notes and who has enjoyed considerable experience, can see no reason for supposing the bird to be more of a mocker than the Song-Thrush or the Nightingale. When the nest is approached a soft fi-ti-u-y is uttered; the alarm-note being an angry tck, tck, tck. The food of the Icterine Warbler is principally insects and small snails, but in summer and autumn fruit and berries are freely consumed.

The adult male in spring has the lores and a streak over the eye yellow; upper parts greyish-olive; quills brown, broadly margined and tipped with buffish-white on the secondaries; tail brown, slightly tipped with buff; under parts lemon-yellow; bill, brown above, yellowish below; legs and feet slate-brown. Length 5 in.; wing $3 \cdot r$ in. The female is a trifle paler; the young browner, with wider pale margins to the wing-feathers.

Its western representative $H$. polyslotta is decidedly smaller, the wing measuring only $2{ }^{\circ} 5$ in.; the inner wing-feathers have much narrower, and indeed hardly any, pale margins; and the bastard primary is larger. 


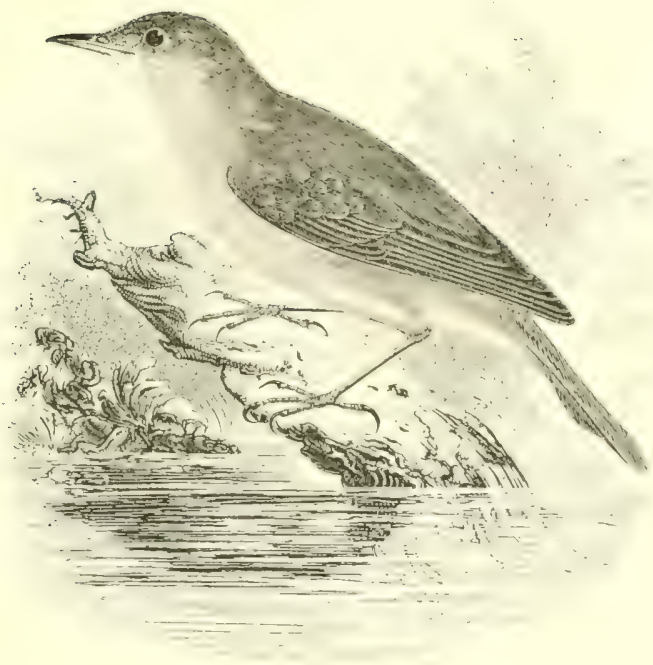

THE REED-IVARBLER.

\section{Acrocéphalus stréperus (Vieillot).}

The Reed-Warbler arrives in England regularly in the latter part of April ; and from that time until September it is common in most, but not all, the localities apparently suited to its habits, in the southern, midland, and eastern districts. In the extreme south-west it is rare, seldom visiting Cornwall or the Scilly Islands: but in Wales it is fairly common, at least as far west as Breconshire, and especially about Llangorse Lake, where there is abundance of reeds (Phillips). It is plentiful in such situations in Cheshire (Nicholson); but in Lancashire, where suitable spots are few, it is naturally local, and in cumberland it is rare. In Torkshire it breeds as far north as the vicinity of Ripon, and also near Iceeds, while at Hornsea Mere, in the East Riding, it is abundant. Mrr. R. Fortune asserts that he has found its nest and exgs at Ravensworth on the Durham side of the Tyne. In Fastern Scotland it is said to have been observed in Forfarshire, and even to breed on the Tay in P'erthshire, but proof is as yet wanting; and in the Scottish Solway district Mr. R. Service has never heard of it. In Ireland it is said

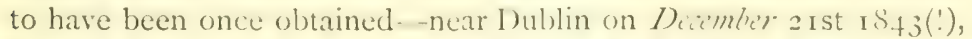
but not since; and certain wings attributed to this species, recently sent by lighthouse-keepers, have proved to be those of the Blackcap and the Garden-Warbler. 
The south of Sweden, and ahout $58^{\circ} \mathrm{N}$. lat., mark the northern limits of the Reed-Warbler in Europe; but below this line the bird has been found breeding in suitable localities down to the extreme south of Spain and Italy, and perhaps in Algeria. Large numbers pass the winter in the basin of the Mediterranean, whilst others go down to Central Africa. Eastward, it is found as far as the countries between Baluchistan and the south-western portion of Siberia

In the breeding-season the Reed-Warbler is by no means restricted to reeds, or even to the immediate proximity of water; and Mr. R. H. Mitford has given an account of the nesting of several pairs annually in lilac-trees in his garden at Hampstead. On the Thames and elsewhere the slender branches of willows and alders are frequently selected; the nest being often ten feet above the ground or water, and sometimes at a far greater elevation. Exceptionally nests have been found in hedges fringing a river. Where reeds are abundant, as in the Eastern Counties, they are usually preferred; and in every case the nest is supported by from two to four reeds or twigs, as the case may be, woren into the sides of the nest, which is so deep that the esrrs will not roll out in the strongest wind. Begun when the reeds are quite short, the nest is often a full yard above the water by the time that the young birds are hatched. The materials employed are dry grasses and moss, with a little sheep'swool, feathers, and horsehair for a lining, but occasionally there is so much wool that the nest seems to be made of it. The eggs, $4-5$, are greenish-white, clouded, blotched or freckled with dark olive, ash-colour, and black: average measurements 72 by 53 in. The Cuckoo is partial to the nest of this Warbler, and I have more than once found two eggs of that parasitical bird in the same home. Incubation begins very carly in June. During the summer the varied song of the Reed-Warbler may be heard at intervals during the day, except in windy weather ; but it is loudest and most attractive during the long twilight of evening. The food consists of aquatic insects-especially small dragon-flies-and their larve, spiders, slugs and worms, varied in the season by fruit and berries.

The adult male has a pale buff streak over each eye; upper parts brown, tinged with chestnut, especially on the rump; under parts white, turning to buff on the sides, thighs, and under tail-coverts. In autumn the chestnut and buff are much stronger. Bill hornbrown above, yellowish-brown below; legs and feet purplish-brown. Length $5^{\circ} 5$ in. ; wing to end of $3^{\text {rd }}$ and longest quill $2^{\circ} 5$ in. The female, according to my experience, is decidedly less rufous during the breeding-season. The young are very tawny underneath. 
THE MARSH-WARBLER.

\section{Acrocephalus palústris (Bechstein).}

The Marsh-Warbler is not figured here, for no wood-cut could adequately show the points of diffurence between this species and the Reed-Warbler; nor, for that matter, can much be said in favour of many of the coloured illustrations which are supposed to represent the former. Some English ornithologists have even been unable to recognize, in presurved specimens, the distinctions in plumage between species which, in life, differ still further in their nesting-habits, eggs, and song ; and it is evident that the eyes of many persons are incaprable of appreciating the somewhat subtle differences of tint. Others, again, have started under the disadvantage of not possessing genuine specimens of the Marsh-Warbler, for only ten years ago it was by no means easy to obtain them. Gould's coloured plate in the 'Birds of (ireat liritain' undoubtedly represents the Reed-Warbler; so does, in my opinion, the one in Lord Lilford's 'Birds of the British Islands'; while in Mr. Dresser's plate of the two species in his 'Birds of Europe' the respective tints are inadequntely rendered, and the legs of the Marsh-Warbler are wrongly coloured stone-grey, althoush accurately described in the letterpress. The legs of the Marsh-Warbler are pale brownish fleshcolour; the general hue of the upper parts is at all times less rufous than in the Reed-Warbler, and more distinctly greenish olive-brown; while, except when much abraded, the wing-feathers are more markedly tipped and margined with pale buff; the under parts are tinged with sulphur-buff, not rufous-buff as in the Reed-Irarbler.

The Marsh-Warbler is a regular spring-visitor in small numbers to Somersetshire, particularly to the neighbourhood of Taunton; the nest has also been found by Mr. C. Young near liath; and last year, I believe, one was taken in (iloucestershire. The only satisfactory British-killed specimens of the bird I have been able to examine are those obtained near 'Taunton; and all of them were, to my eye, quite unmistakable, although some of them had been preserved for years. My friend, Mr. F. Bond, has an undoubtedly genuine nest and egess of this species, taken some years ago in Cambridgeshire, but a pair of hirds oltained at the same time and place are, in my opinion, simply Reed-Warblers. 
Denmark, and Revel in Esthonia, appear to be the northern limits of the breeding-range of the Marsh-Warbler; while eastward it extends across Russia to South-western Siberia, Turkestan and Persia; the bird wintering in many parts of Africa, as far south as Natal. South of the Baltic it is generally distributed in suitable localities throughout Europe, except in the extreme west, respecting which further information is desirable. The 'Verderolle,' as it is appropriately named in French, undoubtedly breeds as far as a longitudinal line drawn through Normandy; but as yet no specimens are forthcoming from the Spanish Peninsula. In May I 870 I shot, near Aranjuez, a bird, too much shattered for preservation, which I then believed to be a MIarsh-Warbler; and my friend Mr. Dresser has identified as Marsh-Warblers several specimens now or formerly in my collection, obtained near Málaga; but with every wish that they should be so, I have always dissented strongly from this view, and consider them to be well-marked Reed-IVarblers.

The Marsh-Warbler does not frequent reeds, but confines itself principally to swampy thickets and osier-beds, where the nest can be reached dry-shod, although the ground may be somewhat moist owing to the vicinity of a stream. The nests never overhang the water, although often close to it, in low bushes, or among the rank meadow-sweet, cow-parsnip and nettles. Those which I have examined were composed of fine round grass-stalks and lined with horsehair. The eggs, $5-7$, are much whiter in their ground-colour than those of the Reed-Warbler, with spots and blotches of olivebrown and violet-grey: average measurements 73 by ${ }^{\circ} 55$ in. Only one brood is reared in the season; but if the nest be taken, another is soon built, and fresh eggs have been found in the beginning of July. The male bird is often conspicuous at some distance from the nest; not skulking like the Reed-Warbler, but boldly pouring out a song far more melodious than that of its congener. Its food is similar to that of the Reed-Warbler.

The adult is olive-brown above, with a faint buffish-white streak over the eye; under parts white tinged with sulphur-buff; wingfeathers olive-brown, tipped and margined with pale buff; bill hornbrown above, paler below; legs and feet brownish flesh-colour. Length $5{ }^{\circ}$ in. ; wing to the end of the $3^{\text {rd }}$ and longest primary 2.7 in., longer than in the Reed-Warbler. In fresh and fully moulted birds the and quill infinitesimally exceeds the $4^{\text {th }}$ : the reverse being the case with the Reed-Warbler. 


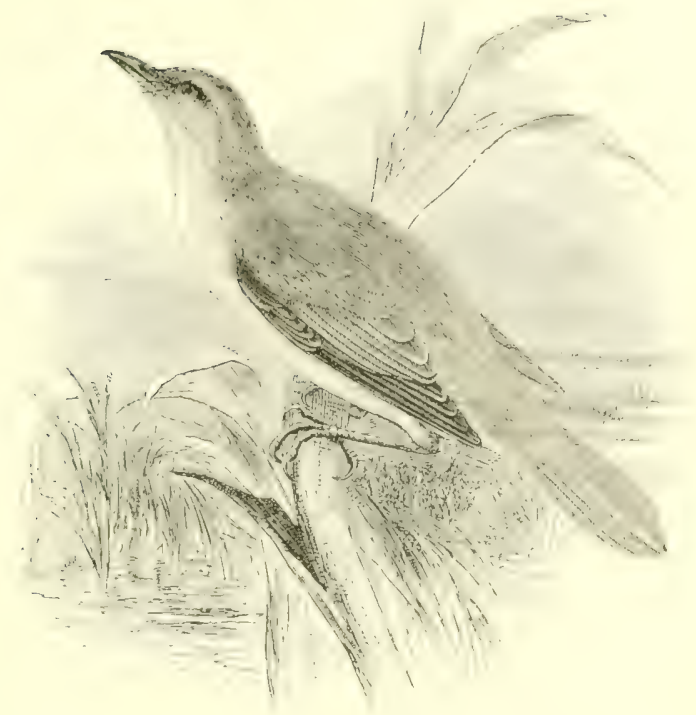

THE GREA'T REED-IVARBLER.

\section{Acrocephalus turdoídes (Meyer).}

The Great Reed-Warbler is another species which, like the Icterine Warbler, is so common on the Continent that it is a marvel its visits to our shores are so few and far between. Nor is the present a species likely to escape notice: on the contrary, its powerful chattering song and large size would at any time attract attention. The fact, however, remains that it has been very rarely obtained in England. The first on record was oftained near Newcastle on May 2 Sth I 847 , by Mr. Thos. Robson (afterwards well known as a collector at Ortakoi, near (onstantinople); three ale stated, on the authority of a dealer whose traffic with Holland was notorious, to have been obtained in Essex and Kent; later, Mr. Goodchild informs me that an example shot near sittingloume is in the collection of Mr. G. Thomas; Mr. W. O. Hammond shot one near Wingham, Kent, on september r.fth rssi; and one was obtained near Ringwood, Hampshire, on Junc , jre is $\$ \&_{4}$. I believe that a few summers ago an individual of this species frequented one of the Norfolk Broads, which it is unnecensary to name. Statements as to the finding of egess supposed to belong to this bird are not wanting, 
but none of them are authenticated. In Yarrell's 'British Birds', until the 4 th Edition, this species was called the Thrush-like Warbler; and by some authors it is termed the Great Sedge-Warbler.

The Great Reed-ITarbler is only a rare straggler as far as the south of Sweden, and the islands at the mouth of the Gulf of Riga appear to be its extreme northern limit. South of the Baltic it is abundant in summer, in suitable localities, throughout Europe down to the Mediterranean, Palestine, Asia Minor, and the shores of the Caspian, while in Morocco and Algeria it is to a great extent resident: its winter migrations extending almost to the extreme south of Africa. In Egypt, Arabia, Persia, and eastward to India, it is replaced by $A$. stcntoris, a close ally. The Great Reed-Warbler breeds annually as near to us as Calais, and is common in Belgium and Holland ; only a few hours' journey from London.

In the breeding-season the Great Reed-Warbler need only be looked for in reed-beds, whether on the banks of streams and lakes, or on small ponds. The rest, seldom finished before the end of May, is a compact cup-shaped structure, some five inches deep, composed of dry reeds and grass, with a lining of the finer portions and the flowers of the same; the whole being closely bound to and suspended from several upright reed-stems. The eggs, $4_{-5}$, often 6 , are pale greenish-blue, blotched and speckled with ash-grey, russet-brown and dark olive : average measurements 9 by $6_{5} \mathrm{in}$. Only one broor is reared during the season, and by the beginning of September the southward migration has taken place. In its habits the bird is generally bold, and is conspicuous from its large size $e_{\gamma}$ as it flits from one clump of reeds to another, or sits high upon one of the upper stems, uttering its loud harsh song, karra-karra-karra, karec-karce-karee, charra-charra-charra; it has also a croaking note when alarmed. It sings from early morning till late at night. Its food consists principally of insects and their larva; but in autumn it is said to eat berries, especially those of the elder.

The adult male has a dull whitish streak from the nostrils over each eye; the upper parts warm olive-brown, with paler tips and margins to the feathers of the wings and graduated tail ; under parts warm buff, whiter on the throat and belly; bill brown, yellowish at the base; inside of the mouth orange-yellow; irides brown; legs pale horn-colour. Length $S$ in.; wing to the tip of the 3 rd and longest quill (the first or bastard being very small) $3.5 \mathrm{in}$. The female is slightly smaller. The young are more fulvous on the under parts, and are slightly striated on the sides of the neck and throat. 


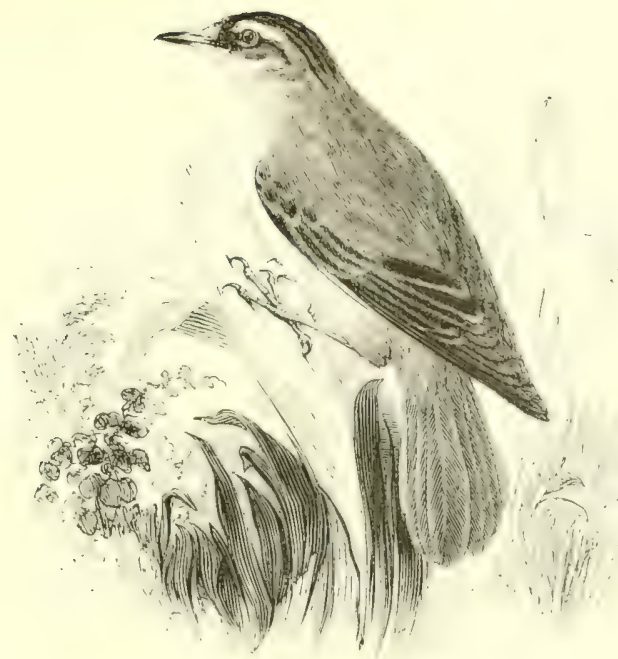

'THE SEDGE.WARBLER.

Acrocephalus phragiŕtis (Bechstein).

The Sedge-Warbler or Sedge-bird arrives in our islands during the latter half of April, and from that time until the latter part of September it is the most abundant and generally distributed member of the genus; while occasionally examples have been observed late in October and even in winter. It breeds in every county of Great Britain; although somewhat locally in the extreme north, and very sparingly in the Isle of Skye; west of which I do not trace it. Mr. T. E. Buckley observed about three pairs frequenting a garden, in summer, on Rousay in the Orkneys; but it is not yet recorded from the shetlands. 'To Ireland it is a regular and widely distributed visitor in surnmer.

In Norway the Sedge-Warbler is found as far north as lat. $70^{\circ}$; and eastward, it can be traced across sweden, North Russia, and Siberia to lat. $67^{\circ}$ in the valley of the Yenesei. Southward, its breeding-range extends to North-western Turkestan, Palestine, Greece, and the central part of Italy : but in sicily and throughout the greater part of the Mediterranean basin as far as Spain it is principally known as a migrant. In the latter cuuntry I obtained examples in spring and autumn, and, although not found breeding, I have adults shot at Mrilaga on fuly 25 th. Throughout the rest of Europe it is tolerably abunclant in suitalle situations, especially in 
the north, although sometimes rather unaccountably local. In winter it visits Africa and Figypt, migrating as far south as Damaraland and the Transvaal.

Although partial to the banks of streams, lakes and ponds, where beds of rushes and osiers abound, the Sedge-Warbler is by no means restricted to such or even to less moist situations; indeed it may often be found among copses and hedge-rows far from water. The nest is never suspended, like that of the Reed-Warbler, but is concealed among the lower branches of a willow, or in the rank herbage by some stream or ditch, or even in a mossy hollow in the ground. Mr. A. H. Evans and I found one in the middle of a gooseberry bush in a garden by Hickling Broad; and Mr. M. Browne has recorded another which was placed quite ten feet up, at the top of a 'bullfinch' hedge, in Leicestershire. The foundation of moss is surmounted by grass and coarse bents, with a slight lining of horsehair and seed-tufts of plants, and occasionally feathers. The eggs, $5^{-6}$, are of a yellowish clay-colour, clouded or mottled with a brownish shade, and often streaked and scrolled at the larger end with black hairlines (much like those of the Yellow Wagtail): average measurements .68 by 52 in. The young are hatched early in June. Aquatic insects and their larve, small slugs and worms, form the principal food of the Sedge-IVarbler; but in autumn, like its congeners, it appears to be partial to elder-berries. Its babbling song is loud and merry, although some of the notes are harsh (for which reason the bird is known as the 'Chat' on the Thames); and in the summer it sings day and night; being more often heard than seen, for it is skulking and restless.

The adult male in spring has the lores and ear-coverts brown, surmounted by a broad yellowish-white streak above each eye; crown streaked with dark brown on a paler ground, forming a sort of cap; neck, back and wing-coverts reddish-brown clouded with darker brown; rump and tail-coverts tawny brown; tail dark brown, with paler edges; wings nearly the same; chin and throat white; breast and under parts buff; bill dark brown above, lighter below; legs and feet pale brown. Length +75 in.; wing to the end of the $3^{\text {rd }}$ and slightly longest primary $2 \cdot 5$ in.; the bastard primary being very small. The latter character serves to distinguish the SedgeWarbler from the Moustached Warbler (Lusciniula melanoposon), found in the south of Europe, and very similar in general appearance, but with a long bastard primary. The female Sedge-Warbler is less rufous on the rump, and is generally of a duller brown than the male. The young are distinctly spotted with pale brown upon the throat and upper part of the breast. 


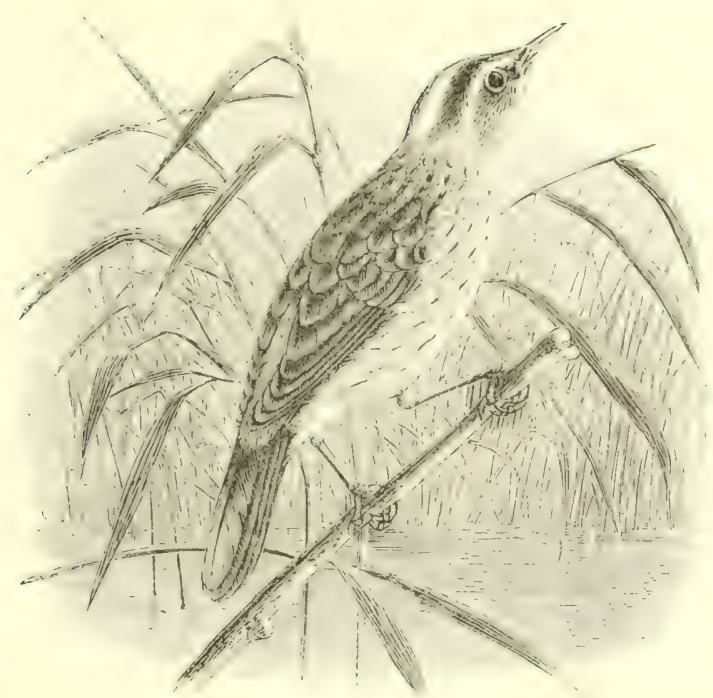

THE AQUATIC WARBLER.

\section{Acrocephalus aquáticus (J. F. Gmelin).}

Owing to its similarity to the preceding species, all the examples of the Aquatic Warbler hitherto obtained in England appear to have been originally overlooked. I'rofessor Newton was the first to recognize a specimen in the collection of Mr. W. Borrer, who said that it had been shot on October Igth I $S_{53}$, while creepings alout among the grass and reeds in an old brick-pit near Hove, Sussex. This example having been exhibited before the \%oolugical society (P. Z. S. r866, p. 210), it was subsequently examined by $\mathrm{Mr}$. Harting, who announced (Ibis $1 \$ 67,1$ ) $f^{6}(9)$ that he also possessed an Aquatic Warbler, obtained near J oughborough, in I eeicustershire, in the summer of $\mathrm{I} S 6_{4}$, and forwarded to him. by a friend, under the impression that it was a (imsshopper-llarler. In February r87 I, Mr. J. H. Gurney, jun. detected in the Museum at Dover a third example, which the Curator, Mr. C. Cordon. stated that he had shot near that town. Mr. (iurney has further pointed out that the bird figured as a Sectege-Warbler in Munt's 'liritish Ornithology" was undoubtedly an Aquatic 11 arbler, in all probability obtaincel in Norfolk about the year isi5. The conspicuous buff streak down the middle of the crown in the Aquatic Marbler is an unfailing mark of distinction between this species and the Sedge-Warbler. 
The Aquatic Warbler is only a rare straggler to Heligoland; although it breeds sparingly in the southern part of Denmark, SleswigHolstein, and on the southern side of the Baltic. In Holland and Belgium it is of uncommon occurrence; but in France, according to Degland and (ierbe, it is of 'annual passage' in the departments of Somme and Nord. In the Brenne, and beyond the Loire, it arrives about the third week in April to breed; while further south, in the Camargue and similar marshy districts, it is not uncommon. Eastward, it is fairly clistributed throughout Northern Germany, becoming abundant in silesia and some parts of Poland; nor is it uncommon in Southern Germany. It breeds in many parts of Italy, Sicily and Sardinia; but in the Spanish Peninsula I have only obtained it in the month of September. In Algeria it is probably resident. In the eastern portion of the basin of the Mediterranean it appears to be merely a migrant or a winter-visitor; and the marshes of the Southern Lral form its boundary in that direction.

According to Naumann, the nest is placed in more open localities than that of the Sedge-Warbler, and generally about a foot from the ground, in a bunch of sedge, or amongst dwarf willow-growth; but never among reeds overhanging the water. It is similar to that of the Sedge-Warbler, and the eygs, $4-5$ in number, are slightly less yellow in their ground-colour than those of that bird: average measurements 65 by $5 \mathrm{I}$ in. Breeding commences in the middle of May. In its habits this species is remarkably shy, concealing itself on the least alarm and running like a mouse along a branch or on the ground. Its fond consists of insects. The song, uttered from the end of April to July, is shorter and less varied than that of the Sedge-Warbler.

In the adult the forehead is reddish-buff; lores and ear-coverts pale brown, surmounted by a buff stripe above and behind each eye; above this, on each side, is a broad blackish stripe, followed by a conspicuous buff streak along the middle of the crown; nape and back tawny-brown striped with black; rump rufous-brown, striped with black; tail-feathers brown, darker along the shafts; under parts yellowish-buff, darker on the flanks, which, with the neck and throat, are more or less striated; bill brown above, yellowish below; legs and feet yellowish-brown. In the autumn the buff tint becomes more intense. Length 4.5 in.; wing to tip of the 3 rd and longest primary 2.5 in. ; the bastard quill being very small. 


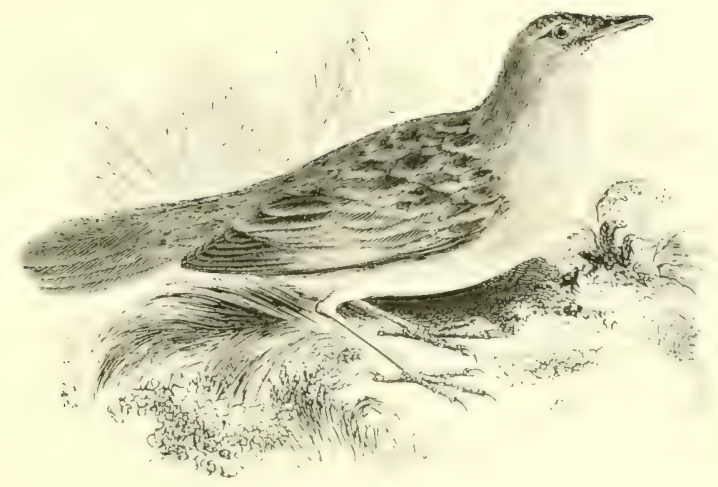

THE GRASSHOPPER-WARBLER.

Locustélla Nívia (Boddaert).

This Warbler owes its trivial name to its rapid trilling song, which resembles the chirping noise made by the grasshopper or the molecricket: but in many parts of England it is also known as the 'Reeler,' from a fancied imitation of the noise of the old-fashioned implement used by wool-spinners, or of the running out of the line on a fisherman's reel. The bird arrives from the south about the end of April; departing in September. Between those months it is of tolerably general distribution in suitable localities throughout England and Wales; but owing to its skulking habits, it is often supposed to be rarer than is really the case. Fens and partially reclaimed land are favourite situations, but heaths, commons, and tangled hedge-rows are also frequented; while the moist shoulders or 'dips,' near the summits of some of our highest hills, such as the Cheviots, are situations to which it seems to be partial ; Northumberland and Durham being two of the counties in which it is especially abundant in summer. In Scotland, we trace it, in diminishing numbers, to Arisaig, below the sound of Sleat; and, across that water, to the Isle of Skye. In Ireland it is a somewhat local summer-visitor, breeding in the eastern and southern districts, especially in co. Waterford, and in co. Fermanagh.

The Grasshopper-Warbler is only a rare visitor to Heligoland, and is not known to cross the lialtic, but it is found in Russia as far north as St. Petersburg. Over the greater part of Lurope it seems to be generally distributed, although seldom common; but it 
is not improbable that it may often be overlooked. In Italy it is said to be rare; but in the south of Spain I found it fairly abundant in autumn and winter; and in the latter season it appears to visit Morocco and Algeria. Eastward, it can be traced in Europe to Transylvania and to the south-west of Russia; but beyond the Ural Mountains its place is taken by allied species:- $L$. lanceolata in Siberia, and L. straminea in Turkestan; there is, however, still much to be learnt respecting the eastern limits of our bird.

The nest may be looked for in clumps of dry fen-grass, the bottoms and sides of thick hedge-rows, rank herbage on hill-sides, or in young plantations. When flushed from her nest the bird flies off with a very peculiar drooping movement of her outspread tail, and, if not immediately pursued, she will usually not fly far. On her return she will, doubtless, come stealing back again with the mouse-like action so often insisted upon as a characteristic by various writers, but neither Mr. A. H. Evans nor I have noticed this performance on her leaving the nest. The compact and rather deep structure is principally composed of moss and dry grass, with a finer lining of the latter; the eggs, $5-7$, are pale pinkish-white, freckled and zoned with darker reddish-brown: average measurements 7 by $5 . t$ in. Two broods are sometimes reared in the season; the first ergs being laid about the third week in May; while they have been taken fresh in the first week of August. The song, already described, may be heard to advantage on a still summer's evening, or during the two or three hours after dawn; the bird perching on the topmost spray of a bush or the point of a tall reed to utter it, but taking refuge in the herbage on the smallest alarm, although perhaps only for a moment. The alarm-note is a sharp tic, tic, tac. The food consists of dragon-flies-taken on the wing-and other insects, with their larve. It appears to migrate in large parties, for Mr. Booth has observed several hundreds at daybreak early in May, all congregated on a small patch of some dozen or twenty acres of mud-banks covered with marsh-samphire and other weeds, near Rye in Sussex, and evidently making their way inland.

The adult above is greenish-brown, with darker striations down the centre of each feather; quills and tail brown, with faint bars on the latter; under parts pale brown, with darker spots on the neck and breast; under tail-coverts very long, and streaked along the shaft with dark brown; bill brown; legs and feet pale yellowish-brown. Length 5.5 in.; wing to tip of 3 rd and longest quill 2.5 in. The sexes are alike in plumage. The young are more suffused with buff on the under parts, and have larger bastard primaries. 


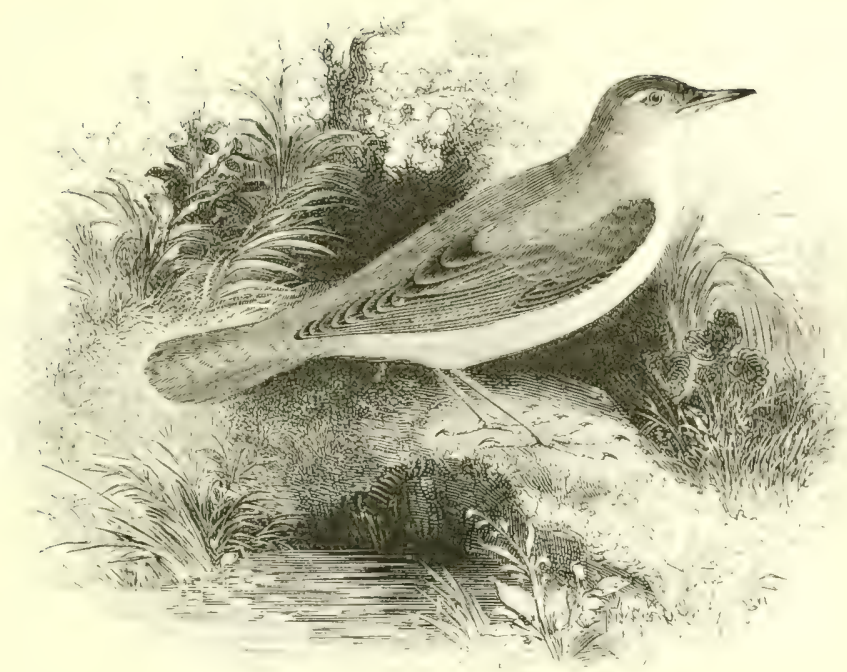

SAVI'S WVARBIER.

\section{Locustella LUSCINioídes (Savi).}

As Professor Newton says, in the best account extant of Savi's Warbler (Yarrell's British Birds, th Ed., i. 1). 389 ), there can be little doubt that this bird was a regular, though never a very abundant, summer-visitant to England, until the drainge of the fens and meres of the Eastern Countics unfitted large districts for its habitation. The first example ever brought to the notice of naturalists - still at the Norwich Muscum - was shot in Norfolk during the month of May, in the early part of this century; but having been submitted to Temminck it was pronounced by him to be a variety of the ReedNarbler; and subsequently some confusion in his mind was, cloubtless, the cause of his wholly crroneous statement that Citti's Warbler (a very distinct species, with only ton tail-feathers) had been killed in England. 'The specific distinctness of Savi's Warbler was first recognized in $\mathbf{1} \$ 2+$ by the Italian ornithologist after whom it is named. In after years about six examples of the bird, and one or two of its nests, were taken in Norfolk: while in ('ambridgeshire and IJuntingdonshire a larger number of both were obtained in fens which are, at the present day, with two exceptions, completely drained. The last British specimen was obtained at Surlingham, Norfolk, in June $\$_{5} 6$; and none are known to be in existence except those 
from the Eastern Counties, where the bird used to arrive about the middle of April, and at its first coming was not shy.

In Holland, Savi's Warbler has become rarer of late years, owing to drainage; so that at the present time it appears to be very local, and almost restricted to the reed-beds of the Maas district. It is also found in summer in similar localities in the Camargue, at the mouth of the Rhone; in some parts of Andalucia in Spain; the swamps of Massaciuccoli in Tuscany; Austrian Galizia ; Poland; Southern Russia as far as the Caspian; and Western Turkestan. It has been obtained once in Palestine; and appears to pass the winter in Egypt, where Capt. Shelley found it tolerably abundant and generally distributed, frequenting the most luxuriant growth of the cornfields, as well as the reedy marshes. Canon Tristram observed it in the oases of the Sahara as far south as $32^{\circ} \mathrm{N}$. lat. ; while northward, in Algeria, Mr. Salvin met with it breeding in the marshes of \%ana; and it las occurred in Morocco. In the islands of the Mediterranean it appears to be rare, even on migration.

The deep cup-shaped nest, placed in sedges and reed-beds, or in a tuft of the spiky rush which flourishes in wet ground, is composed of interwoven sedge-blades, and may be compared to that of a Crake in miniature. The eggs, $4^{-6}$, are white or pale buff in ground-colour, thickly freckled, and generally girdled with ashy-brown and violetgrey spots: average measurements 78 by 57 in. In Andalucía nesting begins early in May, but in (jalizia and Holland not until the end of that month; both sexes taking part in the duties of incubation. Count Wodzicki says that in the breeding-season the male is excitable and quarrelsome, displaying also much curiosity on the appearance of an intruder; he sings all day in calm clear weather, but seldom at night, and generally at the top of some commanding reed. From its monotonous note this Warbler was formerly known to our fen-men by the names of 'red craking reed-wren' and 'reel-bird'; while in Holland it is called Steorr and in Germany Schirriosel. The callnote is a short krr. The food consists of insects and their larvæ.

In the adult the upper parts are reddish-brown; the fan-shaped tail (of $\mathrm{I} 2$ broad feathers) shows in certain lights some faint transverse bars; throat and centre of abdomen white; upjer breast, flanks, and under tail-coverts buff; bill brown above, paler below; legs and feet pale brown. Length 5.5 in.; wing to the tip of the and and longest primary 2.5 in. The young are said to be paler on the under parts. Mr. Seebohm states that the few examples which he has been able to examine from the drier regions east of the Black Sea are of a more pinky earth-brown than western examples. 


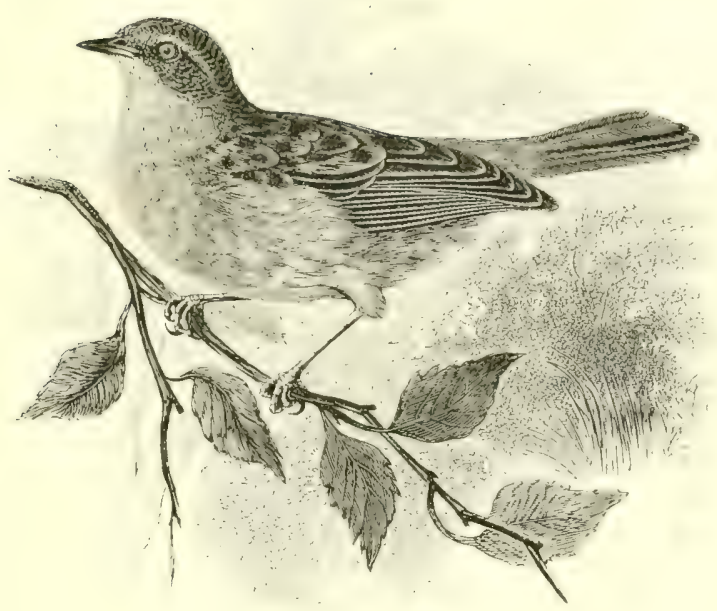

THE HEDGE-SPARROW.

\section{ACCÉNTOR MODTJLÁRIS (LinnæUS).}

The Hedge-Sparrow is resident and generally distributed throughout the British Islands: the exceptions being the bleakest of the Hebrides; the Orkneys, to which it appears to be only a wintervisitor; and the Shetlands, where Saxby states that he only saw it once-in the month of October. In Sutherland and Caithness it is extending its range wherever plantations are springing up); while in winter it comes nearer to houses, where a more plentiful supply of food is attainable. On the east coast it is a regular migrant, extraordinary numbers sometimes arriving on the const of Lincolnshire and Yorkshire in September and Octoher: and return parties have been noticed in spring. The Hedge-Sparrow is known by a variety of names, such as 'I unnock,' 'I ykie,' 'Smokie,' and 'Shufflewing' (the last from its peculiar action), while some well-meanng writers call it the Hedge-Accentor, to show that it is no relative of the pert and obnoxious House-Sparrow.

In Norway the Hedge-Sparrow breeds as fur north as the limit of forest growth, and eastward it occurs sparingly up to $60^{\circ} \mathrm{N}$. lat. in the Ural Mountains; but from the greater part of these northern regions it migrates southwards in attumn; large numbers passing by Heligoland. Throughout Europe south of the Baltic, it is generally 
distributed in summer, down to the northern districts of Spain; and Mr. Tait found it nesting in the valley of the Douro, in Portugal; but in Southern Spain its familiar eggs have not yet been seen. In the latter country, and, in fact, along the northern shores of the Mediterranean, it is a winter-visitor-straggling to the islands and to Algeria ; Canon Tristram says that it is resident in the Lebanon; and Von Heuglin found it in winter in Arabia Petrea. Its southeastern breeding limit appears to be the Caucasus.

The nest is seldom far from the ground, and is generally placed in hedge-rows and in tangled bushes, or among heaps of dry sticks; less frequently in ivy. In a wet cave on Ailsa Craig the late Mr. R. Gray found one placed on a ledge of rock at the root of some hart's-tongue fern. Roots and green moss, with hair and wool for the lining, are the materials employed; and the blue eggs, usually measuring about $5^{\prime} 78$ by ${ }^{\circ} 6$ in., may frequently be fourd early in Narch; two, and sometimes three broods being reared in the season. An old and popular belief, alluded to by Shakespeare, is that the Hedge-Sparrow is usually selected by the Cuckoo as a foster-parent for its young; and the observations of Jenner and others on the behaviour of nestling Cuckoos, have tended to strengthen the idea; for, owing to the situations adopted, the nests of the Hedge-Sparrow are easily found and watched; yet it may be doubted whether the nests of the Meadow-Pipit, Reed-Warbler, and Pied Wagtail are not equal favourites. The food consists of spiders, small beetles and other insects, worms, seeds, and, in severe weather, any crumbs and sweepings that may be picked up in the neighbourhood of habitations. Its short song is commenced, even in our islands, as early as February, and in the south of Europe it may be heard all through the winter.

The adult male has the head and nape bluish-grey, streaked with brown; ear-coverts brown; back and wings reddish-brown, with blackish streaks; the lower wing-coverts tipped with buffish-white, forming a narrow but distinct bar; quills and tail dusky brown; chin, throat and upper breast bluish-grey; belly dull white; sides and flanks pale reddish-brown, with dark streaks; bill brown, lighter at the base ; legs and feet yellowish-brown. Length, $5{ }^{\circ} 5$ in. ; wing to the tips of $3 \mathrm{rd}, 4^{\text {th }}, 5^{\text {th }}$ and longest primaries $275 \mathrm{in}$. The female is somewhat less in size and duller in colour, and the streaks about the head, neck and shoulders are smaller and more numerous. The young have no slate-grey on the head and throat, and are browner and more spotted than the adults. 


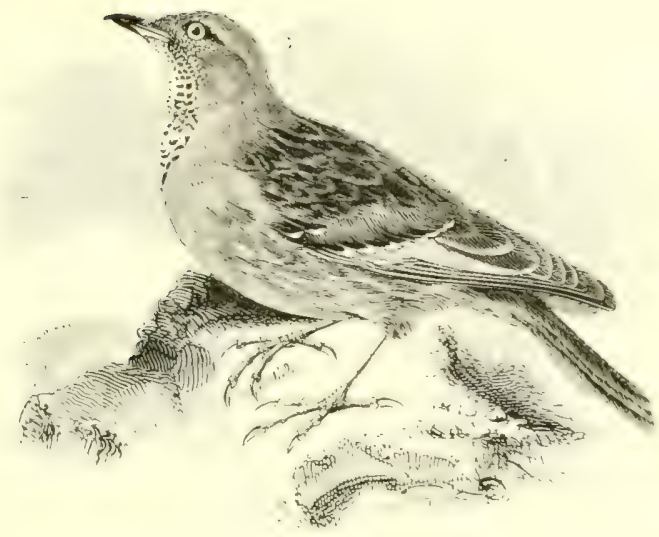

THE ALPINE ACCENT'OR.

Accentor collíkis (Scopoli).

As might be expected, this mountain-loving species is only a rare straggler to England. Its first recorded occurrence was at Cambridge, where two of these birds were noticed climbing about the buildings or feeding on the grass-plots in King's College, one of them being shot on November and i 822. Previously, however, an example had been obtained near Walthamstow, Essex, by Mr. Pamplin, in August $\mathrm{I}$ I $\%$. Subsequently several birds have been taken-or their occurrence recorded by competent observers: one near Lowestoft, Suffolk; one at Wells, Somerset; four in South Devon; one near Cheltenham; one near Scarborough; two near Lewes, Sussex; and one on the Llanberis side of Snowdon, on August 2oth i 870 . The last bird was exceedingly tame, hopping about a small stone-enclosure, where I watched it as long as I dared, being fearful of attracting the attention of the man who accompanied a pony ridden by one of the party.

As a straggler the Alpine Accentor has occurred in Heligoland, Northern Germany, Belginm, and the north of France; while along the cliffs of the I.oire it is to be found with tolerable regularity in autumn (Bureau). Its home is, however, in the mountains of savoy, and the ranges which, under various names, streteh from the $\mathrm{Dl}_{1}$ s to the Carpathians, inclusive; the Appenines; Sicily : Sardinia; the Pyrenees and their Cantabrian continuation; the (inadarrama and other Spanish ranges down to the Sierra Nevada; (ireece; Isia Ninor; the Caucasus, and Northern Persia. Fastward, the distri- 
bution of this bird can with difficulty be traced, owing to a chain of forms of questionable distinctness, leading, of course, to wellsegregated species in those highlands of Asia which form the headquarters of the Old-IVorld genus Accentor.

The nest, constructed towards the end of May, is placed on the ground, among crevices of rocks, or under some small bush; it is round, compact, and somewhat shallow, the materials consisting of dry grass-stems, with a slight lining of fine moss, and sometimes a few feathers of the Ptarmigan (Wilson). The eggs, 4-5, are of a pale blue, like those of the other members of the genus: average measurements 95 in. by 68 in. In summer it is to be found up to the beginning of the snow line, and seldom below the altitude of 4,000 feet: while on the Tatra Mountains of Galizia, Count Wodzicki met with breeding colonies of from twenty to forty pairs; a gregariousness unusual, although in autumn small flocks collect. Beetles and other insects form the food of this bird in summer, while in autumn it gets as fat as a Bunting on the seeds of Alpine plants; nor does it leave the mountains until the snow covers the seeds, and forces it downwards to the villages and even to the coast. It creeps about in the same sly way as our Hedge-Sparrow does; like that bird, it undoubtedly hops, and does not run, as some writers have asserted; nor does it duck its head and jerk up its tail every time it utters its note, after the manner of the Chats. Mr. Seebohm saw it at least fifty times without perceiving anything of the habit alluded to, and the same is my own somewhat less extensive experience. He describes the song as a rich liquid chich, $i c h, i c h$, ich. The call-note is said to be a plaintive tri, tri, tri.

The adult has the head, nape, and ear-coverts greyish-brown with darker streaks ; back rather browner, with broader streaks down the centre of each feather; wing-coverts dark brown, tipped with white spots, forming a double bar; secondaries margined and tipped with rufous; primaries dark brown; tail dark brown, with buffishwhite tips, which are larger on the inner webs and almost absent on the central feathers; chin and throat white, spotted with black; breast and centre of abdomen greyish-brown; flanks mottled with dark chestnut; bill black above, yellowish at the base; legs and feet pinkish-yellow, in life. The sexes are alike in plumage. The young have the feathers of the back edged with rufous; the white patch on the throat is entirely absent; and the under parts are of a very dusky yellowish-brown. Length 7.5 in.; wing to the tip of the $3^{\text {rd }}$ and longest primary $4^{\circ} \mathrm{I}$ in. ; the bastard primary being very minute. 


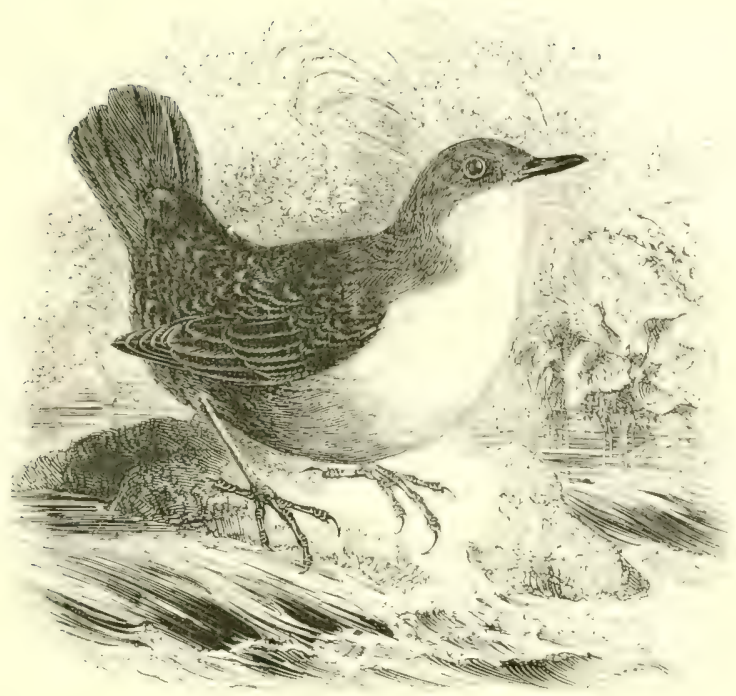

THE DIPPER.

Cinclus aquáticus, Bechstein.

It may fairly be said that the Dipper, Water-Ouzel or "WaterCrow' is found in the British Islands wherever there are rapidly running rivers or brooks rippling over rocks and stones; while, as a straggler, it occurs on the margins of more sluggish streams. Localities suitable to its habits present themselves in Cornwall, Devon and Somerset (where the bird is known as the "Water-Colly" i.e. Water-Blackbird), Wales and the bordering counties, and, northwards, to Scotland, where every river or Highland burn of any consequence is frequented by several pairs; the range extending to the Outer Hebrides. In Ireland it is resident in the mountainous districts. In winter the mouths of tidal rivers, and the sea-shore are favourite resorts.

Our Dipper is of rare occurrence in the eastern counties of England, which are, however, sometimes visited in winter by the Jilack-bellied I)ipper, Cinclus milnnesastir, lirehm; a form which some naturalists consider entitled to specific rank. The latter has little or no chestnut colour in the breast-band, and is found in its distinctive coloration in Scandinavia, and in Northern Russia: visiting I enmark, Heligoland, Northern (scrmany and Holland. After examining a considerable number of Dippers, including the 
fine series in the British Museum, it appears to me that $C$. melanogaster is merely a dark form which inhabits the northern countries of Europe, and the higher mountain regions of the south. Even in Derbyshire, Dippers from the Peak district at I,500 feet are darker than birds from I, 000 feet lower down; and examples from the upper portions of the narrow valleys of the Pyrenees above Luz, and from the lofty Cantabrian Nountains, in North-western Spain, are undistinguishable from Scandinavian specimens. Lower down, and also on the river Genil near Granada, the Dippers have a broad chestnut band, and belong to a race intermediate between our British form and another, paler on the back, called by separatists C. allicollis; the latter inhabiting the Alps, the Carpathians, Italy and Greece. From the Caucasus and Asia Minor eastward to Tibet, intergraduating races lead to the browner-backed $C$. cashmiriensis; while in the Atlas Mountains is found yet another form, distinguished by Canon Tristram as $C$. minor. Under these circumstances I have considered it advisable to treat both the forms of Dipper which occur in our islands under one heading, while admitting that the extremes of each race are recognizable.

The nest is a large oval ball of moss, grass, or leaves, with an entrance low down in the side; lined with dry grass and dead leaves. It is placed in a recess under a bridge, in the wall of a mill dam, in a bank, or on a ledge of rock, often behind a cascade of water; sometimes in the boughs of trees overhanging a river. The eggs, 4-6, are of a dull white: average measurements $\mathrm{I}$ in. by 75 in. Fully fledged young have been found on March 2 Ist; and not only are two and even three broods reared in the season, but a second clutch of eggs is often deposited in the same nest. The song, begun in autumn, may frequently be heard throughout the winter, and always early in spring. The food consists of soft-shelled molluscs, spiders, aquatic beetles and other insects, with their larva; many of which are known to be destructive to the spawn of trout and salmon. In the pursuit of its prey, the bird employs both legs and wings, using the latter like oars; while the young are able to swim freely as soon as they leave the nest.

Adult: head and nape umber-brown; upper parts mottled with dark grey and brown; tail and wing-feathers dark brown; chin, throat and upper breast white; lower breast dark chestnut-brown, passing into black on the flanks and lower belly; bill brownishblack; legs and feet brown. Length 6.5 in.; wing 3.75 in. The sexes are alike in plumage. The young are greyish-brown above, and have no chestnut-brown on the under parts. 


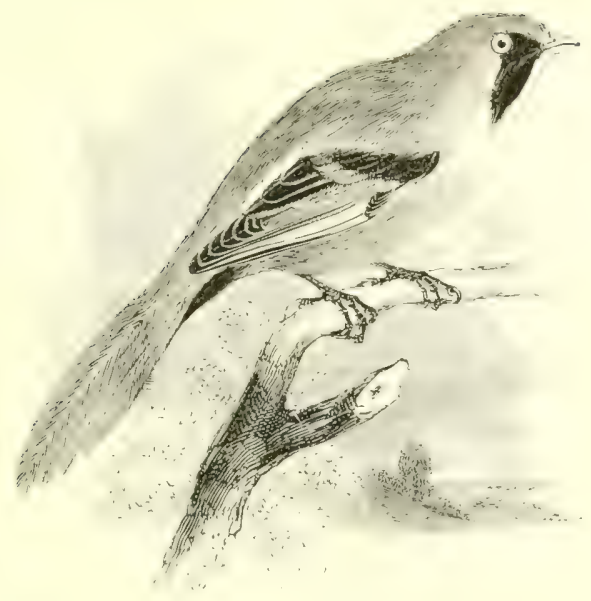

THE BEARDED TITMOUSF.

\section{Panúrus biármicus (Linnreus).}

The drainage of the reedy fens and meres has destroyed the former breeding-grounds of the Bearded Tit in Sussex, Kent, Essex, Cambridgeshire, Huntingdonshire and Lincolnshire; perhapsaided by the greed of collectors-even in Suffolk. The places where it can now be observed in the nesting-scason are mostly in the Broad-district of Norfolk, and in one locality, which need not be revealed to the exterminator, in I evonshire. As a straggler it has twice occurred in Cornwall; it has been recorded in Dorset, and up the Thames valley to Gloucesters!nire; also in Nottinghamshire and Staffordshire. It is a resident species in Lngland, seldom wandering far from its usual haunts: and if our indigenous birds should be exterminated, there is little hope that their place would be supplied by migrants from the Continent.

A mere straggler to Heligoland, and rare in Holstein and Germany east of the Moselle, it becomes comparatively common in the great reed-beds of Holland; visiting Belgium in autumn and Luxembourg in winter, to escape the severity of the weather. In France it is principally found in the valley and the delta of the Rhone, and in the marshes below Narbonne. In Spain I obsersed it in considerable numbers on the Mlbufera lake, near Valencia, where it is resident; as it is also in the marshes of Italy and sicily. It is found in suitable situations in Poland, Austro-Hungary, south 
Russia-especially in the marshes of the Black and Caspian Seas-Turkestan, Yarkand and Southern Siberia: the coloration of specimens becoming gradually paler from England eastward to Central Asia. The bird has also been observed in Albania, Greece and Asia Minor.

On the Norfolk Broads the 'Reed Pheasant,' as it is called, often begins to lay early in April; the nest being placed near the water, in sedge, crushed-down reeds, or aquatic plants-never suspended from the stems - and composed of flat grasses, sedges, and dead flags, with a lining of the flower of the reed. The eggs, 5-7, are shining cream-white, sparingly streaked with short wavy lines of reddish-brown: average measurements 7 by 55 in. Sometimes two hens occupy the same nest, each laying an egg daily until a total of $\mathrm{s} O$ is reached. 'Two broods are produced in the season, fresh eggs being obtainable up to the early part of August. The note is a clear, ringing pins, fing: and when the nest is approached a plaintive ec-ar, $a-a r$ is uttered. Even in the winter the birds are lively and musical, and at that season they may be seen in flocks of forty or fifty together; often roving from the frozen inland waters to those which are kept open owing to the influence of the tide. The food consists largely of the seed of the reed in winter; but in summer the crops of some individuals have been found closely packed with such small shell-bearing molluscs as Sucinea amphiticr. In its digestive organs and other points of internal structure this bird shows no real affinity to the Tits; and some writers have advocated its relationship to the Finches; it is, however, as Professor Newton remarks, a perfectly distinct form, with no very near relations, and entitled to be regarded as the representative of a separate family, the Panurida.

The adult male has the crown bluish-grey; a black loral patch descends diagonally from below the eye and terminates in a pointed moustache; nape, back and rump orange-tawny; wings longitudinally striped with buffish-white, black and rufous; quills brown with white outer margins; tail mostly rufous; chin and throat greyish-white turning into greyish-pink on the breast; flanks orangetawny; under tail-coverts jet black; bill yellow; legs and feet black. Length 6.5 in. ; wing 2.25 in. The female has the head brownish-fawn, and no black on the moustache or under tailcoverts; in other respects she is merely duller than the male. The young are like the female, but the crown of the head and the middle of the back are streaked with black. 


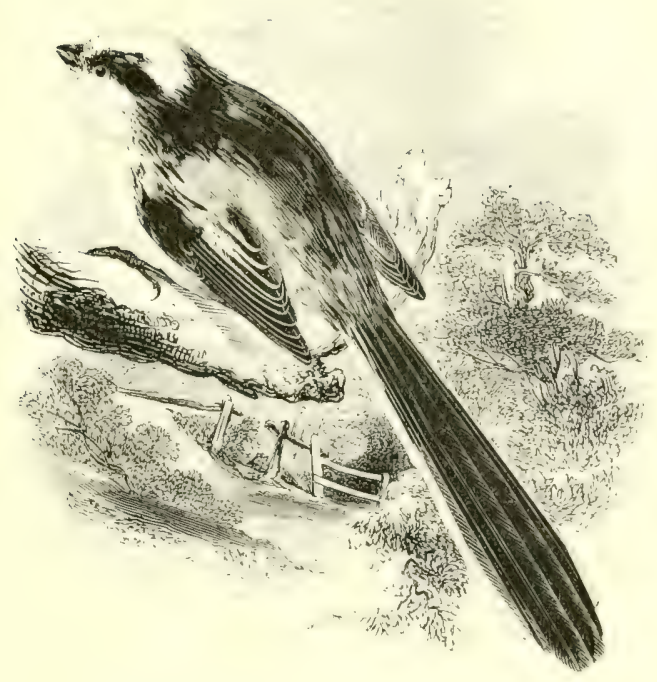

THE LONG-TAILED TITMOUSE.

\section{Acrédula caudáta (Linnæus).}

The Long-tailed Titmouse is one of those species which exhibit a strong tendency to variation under climatic or other conditions; and ornithologists must exercise their individual discretion in classing each form as a race, a sub-species, or a completely segregated species. In the bird found in Scandinavia, Northern Germany, Austria and Russia - extending across Siberia to Japan-when fully adult the head is white; the purity and extent of that colour attaining their maximum in the far north. This is the true A. candata, as restricted by some authors; an example of which has been obtained in Northumberland, while others, as well as various intergradations between this and the next form, have been observed. In the Netherlands, Germany west of Cassel, and part of France, it meets and interbreeds with the form which represents it in the British Islands, distinguished by its duller tints and by having the white on the head restricted to the crown. If separated specifically, this is $A$. rosea. In the south of France and the north of Italy, this latter form meets and intergrades with the greyer-backed A. irlii, which becomes the representative form in Sicily and spain. Although it is difficult to separate any but adult examples of these 
two forms, yet Herr Lorenz has not hesitated to describe A. irbii var. caucasica! Space fails for the enumeration of the Siberian, Chinese and Japanese forms of Long-tailed Tit upon which specific names have been conferred; but I may observe that from the Balkan Peninsula to Persia occurs a really distinct species, $A$. tephronata, with a black patch on the throat.

Our form of the Long-tailed Tit is resident and tolerably abundant throughout England and Wales, wherever the localities are suited to its habits; and, although somewhat more partial in its distribution in Scotland, it is by no means uncommon there; ranging as far west as Skye, and occurring as a straggler in the shetlands. In Ireland, according to Mr. More, it is resident and common.

The nest is oval, with a snuall hole in the upper part of the side, and is composed of silvery lichens, green moss, wool and spiders' webs felted together, and lined with a profusion of feathers and hair. Its form has procured for its maker the name of 'Bottle-Tit'; while, owing to the materials, the bird is frequently called the 'Feather-poke.' The nest is often placed in the middle of a thick whitethorn, holly, or furze-hush: sometimes in ivy, or high up in the lichen-covered branches of a tree ; occasionally in tangled masses of brambles and creepers. The eggs are white, generally more or less speckled and streaked with light red, but sometimes merely suffused with that tint: average measurements 53 by 42 in. In number they are usually 7 to $S$; but i6 young birds have been found in the same nest, without any evidence of their being the production of more than one female. When sitting, the long tail of the parent-bird is iurned over her back, and projects above her head through the entrance-hole. 'Two broods are often reared in the season, and subsequently the family may often be seen flitting in single file from one hedge-row to another with a remarkably dipping motion. The usual note is a shrill zee, zee, zee. The food consists of insects and their larvæ.

Adult male: front and crown white, bordered on each side by a black line running from the base of the bill over the eye, and joining the nape and upper back, which are also black; scapulars and lower back dull rose; wings dark brown, margined with white on the secondaries; tail-feathers black, the three outer pairs broadly tipped and margined with white; cheeks and throat dull white; upper breast white with a few black streaks; belly and flanks dull rose; bill, legs and feet black. Length 5.5 in. ; wing 2.5 in. The female has rather more black about the head; the young are duller in colour and have no rosy tint on the upper parts. 


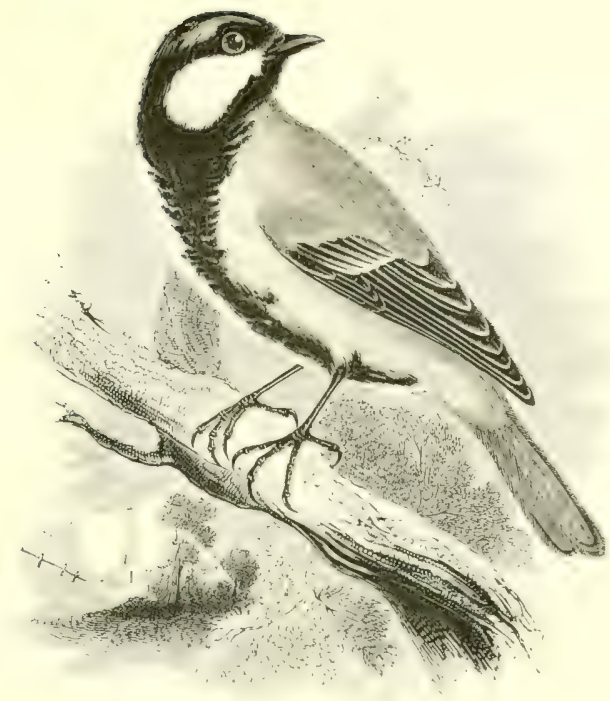

THE GREAT 'TTMOUSE.

\section{PARUS MAJOR, Linnæus.}

This species, often called the Ox-eye, is resident and generally distributed in suitable localities throughout Fngland and Wales, Ireland, and the greater part of Scotland; but in the northern and western portions of the latter it becomes rare; being only a casual visitant to the Isle of Skye, and a straggler to the Shetlands.

In the comparatively mild climate of Norway the Great Titmouse is found as far north as the Arctic circle; but in Russia it has not been recorded beyond $64^{\circ} \mathrm{N}$. lat., while in the valley of the Yenesei Mr. Seebohm did not find it beyond $5 S^{\circ} \mathrm{N}$. Eastward it is met with in the wooded districts of Siberia as far as the Pacific coast and the Amoor. In Mongolia, China and Japan, its representative is $P$. minor: a slightly smaller bird, with the under parts buffish-white instead of yellow. Our bird is common over the whole of Europe; being migratory in the more northern countries, but resident in the temperate and southern ones, down to the Mediterranean. In most of the islands of that sea it is also found, although but rarely in Malta: it occurs in the (anaries; is resident throughout a great part of North Africa; and abounds in Isia Minor, Palestine and Persia.

The nest is often commenced in March; a hole in a tree or wall 
being usually selected; but many curious situations are on record, such as the inside of a pump in constant use, a shelf in a threecornered cupboard, and the interior of an inverted flower-pot; one of the latter in the British Museum containing three new nests! Sometimes the foundations of old abodes of other birds, such as Crows, Rooks and Magpies, or squirrels' dreys, are utilized, but more frequently on the Continent than in this country. The structure consists of soft moss, surmounted by a warm bed of hair, wool and feathers, felted together. The eggs, 6 9, are white, spotted and blotched with light red: average measurements, 7 by 55 in. Two broods are produced in the season. The Great Titmouse may often be seen roving from tree to tree in our gardens and sheltered districts; sometimes hanging back downwards by its strong claws, while searching for insects, its principal food. No doubt the bird destroys many buds ; but it is in many cases certain, and always probable, that such buds already contained grubs which would not only have put a stop to the growth of the sprouts, but would have inflicted further damage upon the trees. In the autumn and winter it cracks and eats nuts and hard seeds, but on the whole its predilections are decidedly for 'animal' food. In cold weather the lover of birds may enjoy watching the actions of this and allied species, by suspending a piece of raw meat, a bone, or a lump of suet, from some bough or iron standard outside the windows. The Great Titmouse will attack small and weakly birds, splitting their skulls with its powerful beak in order to get at their brains; and it has even been known to serve a Bat in this manner. Its usual note in spring resembles the sound produced by sharpening a saw with a file, and may be heard at a considerable distance; its call-note is a low zee; and some individuals display great power of imitating other birds.

Adult male : crown of the head bluish-black; a band of the same colour descends each side of the neck, behind the white cheeks and ear-coverts; on the nape is a small spot of whitish, passing into yellowish-olive which pervades the mantle; wing-coverts bluishgrey, with white tips which form a transverse bar; quills dark brown with paler margins; tail-feathers slate-grey, the outer pair tipped and margined with white; chin, throat, and a stripe down the centre of the breast to the vent, black; sides and flanks dull sulphur-yellow; bill black; legs and feet lead-colour. Length 5.75 in. ; wing to the tip of $4^{\text {th }}$ and longest primary 3 in. The female is duller in colour than the male; the young have a tinge of yellow on the cheeks. 


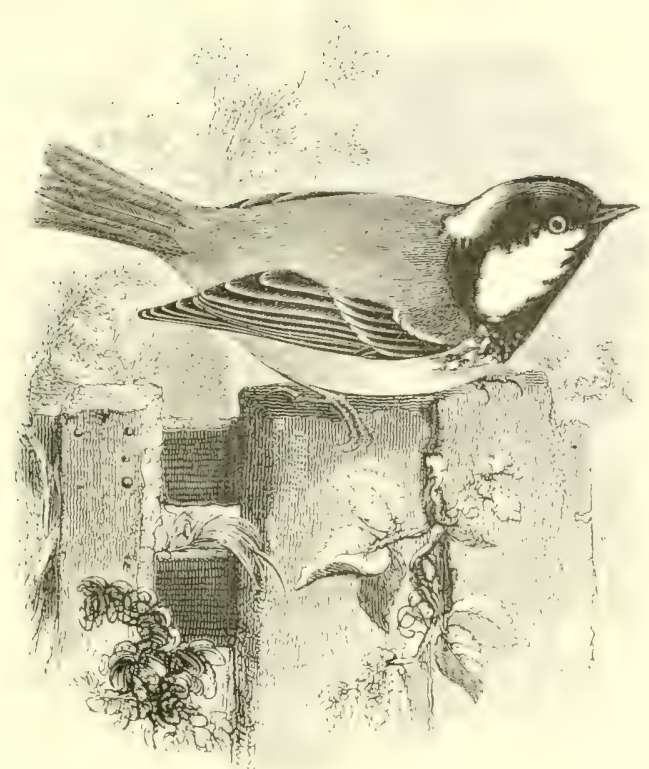

THE COALATTMOLSE.

Parus ater, Linnæus.

In the Coal-Titmouse, as in the Long-tailed Titmouse, there are successive variations, the extremes of which become, in the opinion of some ornithologists, entitled to specific distinction. As Parms britamicus, Messrs. Sharpe and I resser have separated our race from that of the Continent, because the upper back is olive-brown in the British bird, and slate-grey in the Continental form; but, while I admit that a difference in tint is often recognizable, there are intergradations, especially noticeable in specimens from the old pineforests of Scotland. Examples from Norfolk, indistinguishable from those of the c'ontinent, may', of course, be of forcign parentage: and so may specimens in the British IIuseum, from Perthshire, which are identical with birds from the Vosges, although less purely grey than those from Japan. Against the migration-hypothesis must be set the experience of Mr. (iurney, jun., and Mr. Booth, who never observed the Coal.Tit at sea off the cast coast, nor received a wing of it out of thousands sent from the light-ships: as well as the fact that it seldom visits I Ieligoland. I have therefore treated these 
forms as climatic races and under one specific head, as done by Dr. Gadow (Cat. Birds Brit. Mus. viii. p. 40).

The Coal-Tit is a resident species in Great Britain and Ireland, and appears to have increased during the present century: although it is still, as a rule, less numerous than the Great and Blue Tits. In Scotland, while somewhat local, it is fairly distributed; except in the Outer Hebrides, Orkneys and Shetlands. On the Continent the greyer-backed race is found in summer as far north as lat. $65^{\circ}$ : a partial migration taking place in winter; but in the central and southern portions of Europe the bird is generally distributed as a resident. In Algeria it is represented by $P$. ledouxi, with cheeks, nuchal spot and under parts yellow-much like the young of our bird. In the mountains of Cyprus Dr. (iuillemard obtained a form described by Mr. I)resser as P. cypriotes (Ibis I 888 ); distinguished by a tint on the back even browner than in British specimens, a nearly obsolete nuchal patch, and a greater amount of black on the throat. In the Caucasus a larger form, $P$. michalozeskiz, occurs, intermediate in tint between that of our islands and the typical race of the Continent : and under various other names, as the bird increases in brightness of colour and length of crest, the Coal-Tit is found across Asia to China and Japan.

The nest, commenced early in April, is placed in a hole in a tree, a crevice in a wall, and not unfrequently a mouse's burrow in a bank or the level ground; while Mr. Bond found one on the branch of a fir-tree, close to the bole. Noss and wool, rabbits' fur or deer's hair, are the materials ; the eggs, $6-9$, being white, spotted with light red: average measurements 6 by 45 in. The note is rather more shrill than that of its congeners. The young of the Coal-Tit are fed largely upon green caterpillars; but besides insects, nuts, as well as seeds-especially those of the Scotch fir, are eaten.

Adult male : crown and nape glossy blue-black, with a white nuchal spot; cheeks and sides of the neck white; back grey, tinged with olive in most British specimens; rump brownish-fawn; quills ashbrown, with dull white margins to the secondaries; wing-coverts tipped with white, which forms two bars; tail ash-brown; throat black; breast dull white, passing into fawn on the belly and flanks; bill, legs and feet dark horn-colour. Length $4^{\circ} 2$ in.; wing $2^{\circ} 5$ in. Female: slightly duller in colour. Young : no gloss on the head; cheeks, nape-spot and under parts suffused with sulphur-yellow; upper feathers tinged with olive. The white nape of the Coal-Tit readily distinguishes this species from the Marsh-Tit. 


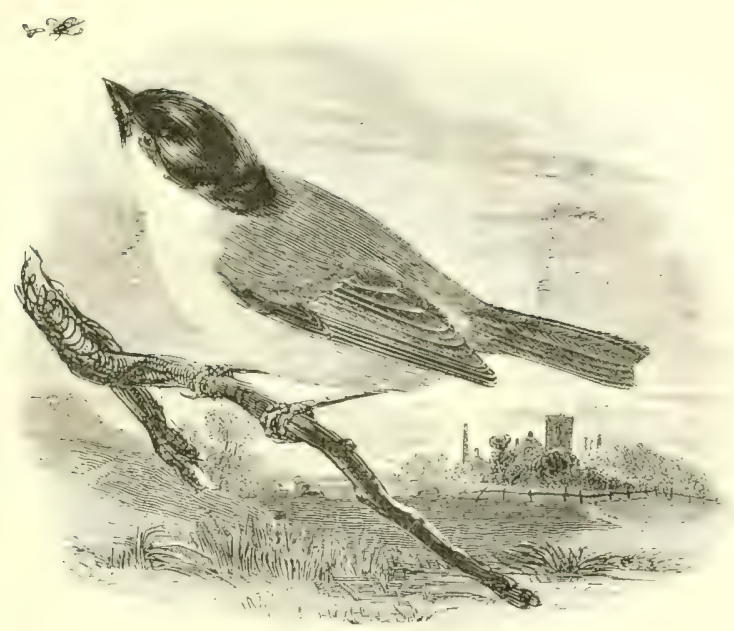

THE MLRSH-TITMOUSE.

\section{PARUS PALÚSTRIS, Linnæeus.}

The Marsh-Titmouse is another of our resident species; but with the exception of the Crested Titmouse it is the least plentiful and the most local of the genus. Its name is somewhat misleading, for the bird may often be seen in orchards and gardens, and even in pine-woods; but it is partial to the vicinity of rivers, and to the alders and pollarded willows which flourish on swampy ground. In England, and in suitable parts of Wales, it is fairly common; but in Scotland it is very local, and is not known to breed to the north of the valley of the Forth, where Mr. William Evans obtained a nest in $\mathrm{I} S S_{+}$, at Dunipace. In Ireland it is only recorded from cos. Antrim, Kildare, and Dublin.

British examples are somewhat browner on the upper parts and flanks than Continental specimens, and, according to I)r. Stejneger, they have also shorter tails. Nevertheless the ornithologists who have described the British Coal Tit as a distinct species, have not been equally courageous as regards the British Marsh-Tit, in which the differences between the dull insular and the bright Continental forms are quite as marked. I)r. Stejneger has emphasized his opinion of this omission by naming our bird $P$. palustris dresseri; and, as I agree with him that it is inconsistent to recognize specific distinctness in the former case and to reject it in the latter, I have treated the variations in both as merely those of race. In Scandinavia 
north of lat. $6 \mathrm{I}^{\circ}$, Northern Russia, the Alps and the Carpathians, the Continental form itself is represented by a larger and still greyer sub-species or race, $P$. bomalis, variations of which are found across Asia to Japan. The typical form is distributed throughout Central and most of Western Europe down to the Pyrenees; but in Portugal it has not yet been identified: in Spain, I only observed it at Granada and Córdova ; it is rare in Southern Italy, and uncommon in Greece. In the latter, as well as in the rest of Southeastern Europe, Asia Minor, and Northern Persia, it is mainly replaced by $P$. lugubris, a larger, heavy-billed bird, with a dark brown head.

The Marsh-Titmouse makes its nest in holes in trees-especially willows and alders-in decayed stumps near the ground, or behind loose bark, or in burrows made by rats and mice in banks. The bird has been observed to hew out its own abode, carefully removing in its bill the chips of wood that would otherwise betray the site, and it leaves a very narrow entrance, although the hole is often of considerable size inside. The nest itself is composed of moss, wool, rabbits' fur and hair felted together, and is often lined with willowdown ; the eggs, $5^{-8}$, are white, spotted with dull red-almost livercolour: average measurements $6 \mathrm{I}$ by $47 \mathrm{in}$. The call-note is a rapidly uttered tay', tay', farl, tay; the song being a simple sis, sis, sis, see. The food consists largely of insects, in pursuit of which the bird has been seen to thrust its bill under the scales of the rough bark of a Scotch fir, and to prize them off with a forcible jerk; in the autumn and winter however, seeds--especially those of the sunflower-beech-mast and berries are consumed; the bird holding them in its claw like a parrot, while getting out the edible parts. Its habits during the breeding-season are more retiring than those of other Tits.

Adult : upper part of head and nape glossy black; cheeks dull white, turning to buff on the sides of the neck; back olive-brown, inclining to grey in Continental specimens; rump rather browner olive; quills and tail ash-brown with the outer margins paler; chin and throat black; remaining under parts dull white, turning to buff on the flanks; bill black; legs and feet lead-colour. Length 4.4 in.; wing to the tips of the $4^{\text {th }}, 5$ th, and longest quills 2.5 in. The sexes are alike in plumage: in the young the colours are duller and more olive-brown. 


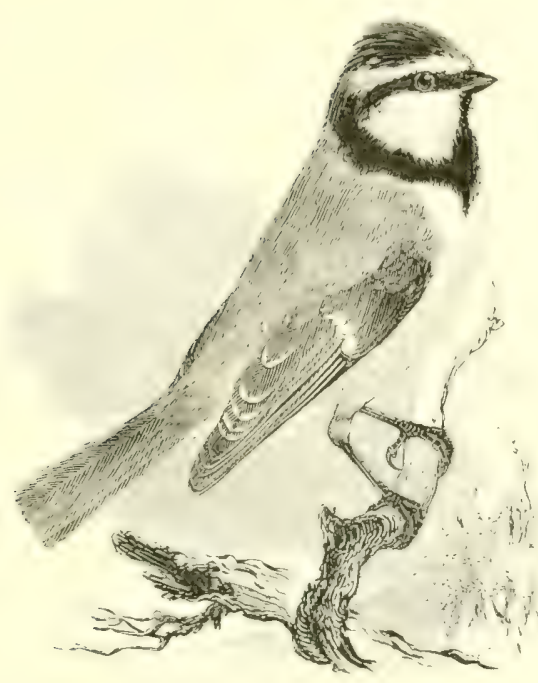

THE BLUE TITMOUSE.

\section{PARUS CARÚleUS, Linnrus.}

The Blue Titmouse is one of the best known of our british birds, and is generally distributed throughout the greater part of our islands. In Scotland, however, it does not appear to reach the Hebrides, and it is rare and very local in the north-west, although resident in sutherland and Caithness: while in the ()rkneys and shetlands it is only known as a mere straggler. In Ireland it is the commonest of the genus. In autumn considerable numbers of Blue and (ireat Tits arrive on our east coast: and still larger flocks pass by Heligoland.

In Norway the Blue Titmonse breeds as far north as lat. $64^{\circ}$, but further east its range does not extend beyond 6 I N., nor is the bird found to the east of the Urals. It is gencrally distributed over the remainder of Europe, except in some of the (ireek islands; and it is common in Asia Minor; but in Persia it is replaced by $F$. persicus, a much paler bird, with broaler white margins to the greater wing-coverts. Continental specimens of the Blue Titmouse are brighter than those of our islands, and attain the maximum of brilliancy in the south of Spain; while on the other side of the Mediterranean (which this species has never been known to cross), in 'Tunisia, Algeria and Norocco, we find $P$. ultramarinus, and in the Canaries the insular form I'. lineriffe; birds with the 
same pattern, but with bluish-slate back, blue-black crown, and more intense coloration. In Central Russia our Blue Titmouse meets with $P$. pleskii, a blue-backed pale form, with the belly pure white, and only a pale yellow spot on the breast; while in Siberia, Russia, Poland, and casually in Eastern (iermany, we find the larger and very beautiful Azure Titmouse, P. clanus, in which pale blue and white are the prevailing colours. I mention this bird because live specimens are not unfrequently brought to Lngland, and, sooner or later, there will probably be an attempt to add it to the British list.

The Blue 'Titmouse makes its nest in April, and generally selects a hole in a wall or a tree; but, exceptionally, many curious sites, too numerous to mention, have been recorded. The bird defends her nest with great pertinacity, hissing like a snake, and pecking at the fingers of the intruder in a way which has gained for her the name of "Billy-biter." The nest is composed of wool and moss, with feathers and hair in varying proportions. The eggs, usually $7-8$ (but as many as 18 are on record), are white, spotted with light red-more minutely than those of other Tits: average measurements ${ }^{\circ} 8$ by 45 in. Mr. Norgate says that this species and the Great Titmouse may be encouraged to almost any extent by hanging up suitable nesting-boxes. The young are fed largely with larvæ of the gooseberry- and winter-moths, Aphides and other insects; while the old bird also preys on the grubs of the wood-boring beetles, the maggots from oak-galls, spiders, \&c. In autumn it may perhaps damage fruit to a small extent; while in winter a meat-bone hung up will always prove an attraction. Its note is a harsh chee, chee, chee.

Adult male: forehead, and a line which runs backward over each eye and encircles the head, white; crown cobalt-blue; a blueblack band runs through the eye to the nape, where it meets a dark blue band which, crossing the nape and encircling the white cheeks, joins the bluish.black throat; mantle and rump yellowish.green; tail and wings blue; the coverts and tertials of the latter tipped with white; breast and abdomen sulphur-yellow, with a bluish-black streak down the middle; bill blackish; legs and feet bluish-grey. Length, $4^{\circ} 2$ in. ; wing to the tips of $3 \mathrm{rd}, 4^{\text {th }}$, and longest quills $2^{\circ} 4 \mathrm{in}$. The female is somewhat duller. The young exhibit less blue and more yellow in their comparatively dingy plumage. 


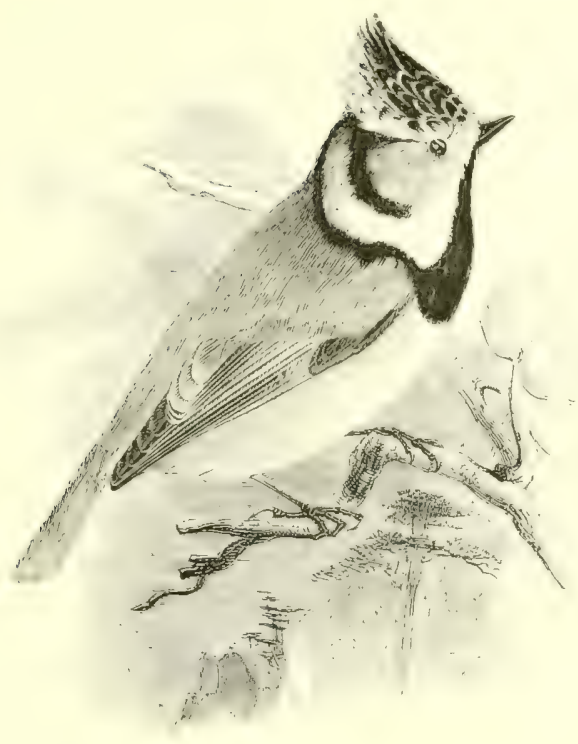

\section{THE CRESTED TITNOUSE.}

PARUs CRISTÁtus, Linnæus.

The Crested Titmouse is a resident in a few of the oldest forests of Scotland, which have not lost their natural growth of firs and oaks; and these, it may be sufficient to say, exist principally in the valleys of the spey and some neighbouring rivers. The bird is also said to have been observed in summer in the Pass of Killiecrankie, and it has undoubtedly occurred in Perthshire in winter; but it wanders little from its usual haunts, and one example in Argyleshire and another near Dumbarton, appear to be the only authenticated instances of its occurrence in the south-west of Scotland. In England few of the cases on record can be substantiated, but a bird in the Museum of Whitby, lorkshire, was obtained in that vicinity in March IS72; one, examined by Mr. E. I'. I'. Hutturfield, is said to have been shot in August I887 near Keighley, in the same county; and one appears to have been taken in Suffolk-about 1847 . Notwithstanding Mr. Blake-Knox's circumstantial assertions that at least two had been obtained in Ireland, Mr. A. G. More classes this with the Blue Rock-Thrush and other "excluded species" in his latest list.

The Crested Titmonse inhabits the pine-forests of Scandinavia 
and Russia to about $64^{\circ} \mathrm{N}$. lat. ; and eastward it can be traced as far as the valleys of the Don and the Volga. In (iermany, wherever conifers are plentiful, and in the higher districts of France, the bird is to be found in tolerable abundance; it also breeds in Dutch Brabant, principally in oak-trees, for it is by no means restricted to firs; and in the Alps, Carpathians, and other ranges of Central Europe, it is generally distributed. In some parts of the Higher Pyrenees I found it the most abundant of the genus; while in the south of France and in Spain it may often be observed among trees close by the sea. In the latter country it breeds in the corkwoods in the vicinity of Gibraltar, as well as on higher ground; and it is also common in Portugal. It is not yet known in Morocco or indeed any part of North Africa, Greece, or Asia Minor.

The nest of the Crested Titmouse is, in Scotland, generally placed in the rotten stump of a fir broken off by the wind; a hole being bored in the tree, from two to eight feet above the ground; or in old stumps of very large trees within six inches of the soil. In Germany, however, the deserted nests of Magpies, Crows, and squirrels are also utilized; and the bird has been seen by an excellent observer to occupy nests built in bushes, apparently those of the Wren and the Long-tailed Titmouse. The usual materials are moss, wool and fur, felted together; the eggs (laid in Scotland towards the end of April or early in May), from 58 in number, are white, boldly spotted and zoned with light red: arerage measurements 62 by 48 in. Two broods are frequently produced in the season. The food of this bird consists of insects and their larve, small seeds, and berries. The note is a ptur, re, re, re, ree (Seebohm). The bird is very lively in its habits, flitting rapidly from one pine to another, and it may often be seen during winter in company with Creepers, (ioldencrested Wrens and Tits.

In the adult male the feathers of the head are dull black, broadly tipped with greyish-white, and prolonged so as to form a conspicuous crest; a black streak runs from the bill, through the eye, to the back of the head, whence it descends behind the cheeks, which are mottled black and white; below this a white band, followed by another black crescentic line; back and wings olive-brown; quills and tail hair-brown; throat and upper breast black; abdomen dull white, turning to buff on the flanks; bill black; feet and legs leadcolour. Length $4.5 \mathrm{in}$; wing, to the tip of the 4 th and longest primary, $2.5 \mathrm{in}$. The female has a shorter crest and less black on the throat; and the young are like her, but with hardly any crest. 


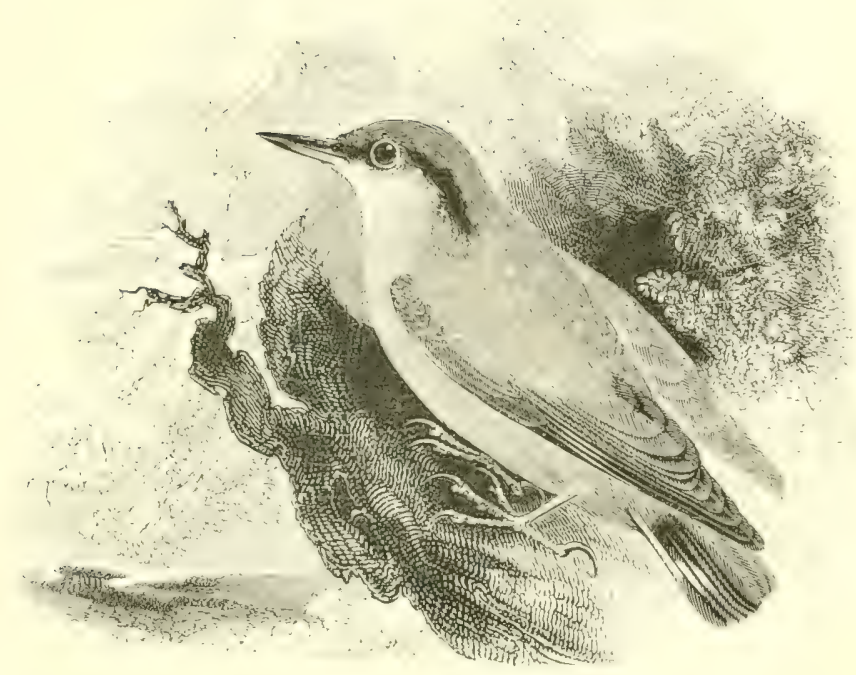

\section{THE NUTHATCH.}

SITIA CX́SIA, Wolf.

The Nuthatch is tolerably conmon in most of the districts in the south-east and centre of England which contain old timber. In the west it is rarer, although perhaps increasing; as it is in Breconshire and some other parts of Wales, where it was formerly considered a very uncommon bird. In Lancashire it is seldom seen; in Yorkshire it is mostly restricted to the liurge old parks: while in the more northern counties it seems to have decreased during the present century, and is now very rare. In Scotland it bas been obtained in Berwickshire and Hadelingtonshire, and otserved in Skye; while the late R. Gray records its reported occurrence on Bressay, in the Shetlands. In Ireland it is as yet unknown.

On the Continent the northern limit of this species appears to be the peninsula of Jutland, where it meets its close ally with nearly white under parts, S. curepere, which replares S. cirsir in Scindinavia, Northern Russia and Siberia. From the Baltic southwards to the Mediterranean and Black Seas, our species is gencrally distributed: Loche records it from Algeria and Capt. S. G. Reid from Northwestern Morocen; and it has beenolstained in . sia Minorand l'alestine. Eastward, it cannot with certainty be traced, owing to the 
presence of such questionable species as S. rupicold in Persia and S. cashmirensis in Northern India. Our bird is absent from Malta, Sardinia and Corsica; but in the last-named island it is represented by a distinct species, $S$. whiteheadi, with white under parts, and, in the male, a jet-black head, named by Mr. R. B. Sharpe after its discoverer.

The Nuthatch begins to breed about the middle of April ; generally making its nest in some hole in a branch of a tree, and occasionally between the buttresses of the trunk, close to the ground. A hole in a wall is sometimes selected; and, in every instance, the aperture is filled up with clay and small stones, leaving only a narrow orifice for entrance. An extraordinary nest in the British Museum, presented by MIr. F. Bond, was placed in the side of a haystack, and measured thirteen inches by eight, the weight of the clay being eleven pounds. Some distance inside the nest is a bed of dry leaves or the scales of the Scotch fir, on which the eggs, 5-7, are deposited. These are white, spotted with reddish-brown-larger and more boldly blotched than those of the Great Titmouse : average measurements 77 by $56 \mathrm{in}$. In spring the male utters a loud and shrill tui-tui-tui; the bird has also a bubbling or churring note. The food during a portion of the year consists largely of hazel-nuts, which the bird fixes in some crevice, and then proceeds to hammer with its bill until the shell is broken, each stroke being delivered with the full strength and weight of the body, working from the hip-joint; whence the names of Nuthatch, i.e., Nuthack, and Nutjobber. It is partial to beech-mast, and will eat many kinds of hard seeds, with acorns, and even corn in times of scarcity; but during a considerable portion of the year it feeds on insects, for which it searches on trees and on the ground. At such times its motions resemble those of a mouse rather than of a bird, being conducted upwards, sideways, or downwards with equal facility; and it is stated on good authority that, when sleeping, the head and back are downwards.

Adult male: the upper parts generally of a bluish-slate colour; wing-quills greyish-brown; centre tail-feathers slate-grey, the remainder black at their bases, barred and tipped with white and grey; a black streak runs from the base of the bill through the eye to the side of the neck; above the eye a narrow white streak; chin and cheeks white; throat and belly rich buff; flanks and under tailcoverts streaked with dark chestnut; bill horn-colour, lighter at the base; legs and feet brown. I.ength $55^{\circ}$ in.; wing $3{ }^{\circ}+$ in. The female is rather duller in colour, and the young are conspicuously so. 


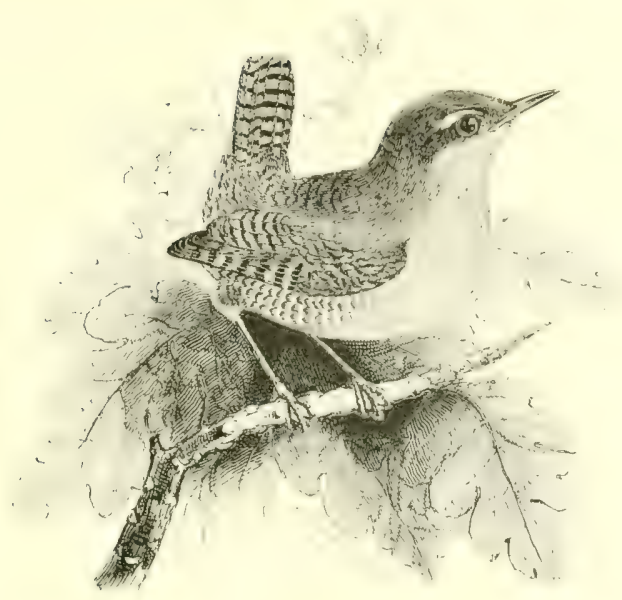

THE WREN.

'Tróglonytes pÁrvulus, K. I. Koch.

The Wren, a bird as familiar in our traditional associations as the Robin Redbreast, is generally distributed througho: th the British Islands; being a resident even in the Shetlands. A single example from St. Kilda has been described by Mr. Seebohm as a new species, T. hirtensis (Zool. I 884,1 ). 333); but Mr. Dresser, who subsequently examined seven examples, considers that the supposed points of difference are all to be found in specimens from various parts of Europe, and that the bird is not worthy of specific rank (Ibis a $S \& 6$, 1. 43). Iny this time the few pairs which inhabited the island have probably been extirpated. Although the Wren is a resident species with us, its numbers are largely increased by autumnal immigration : many being found in October, according to Mr. Cordeaux, on and near the treeless coasts of Lincoinshire and the south of Yorkshire, and, perhaps less abundantly, in Norfolk.

Iceland and the Færoes are inhabited by a larger and darker Wren, more barred beneath, which has been separated as T. horealis. I)r. Stejneger has distinguished the Wren found in the south-west of Norway as $T$. hergensis; but with this exception the typical form inhabits the whole of Europe, ranging to $6 .+\mathrm{N}$. in Sweden, and nearly as high in Finland and Russia. Eastward, the Ural Mountains appear to be its boundary, and in the Volya district it is chiefly observed in winter. Statements respecting its occurrence in the Canaries and Madeira require confirmation; but it is found in 
Morocco and Algeria, although ausent from Egypt ; and it has been met with in the Caucasus, Northern Persia, Asia Minor and the north of Palestine. The representative species in Central Asia is T. pallidus, beyond which it is unnecessary to sketch the distribution of the genus, Mr. Sharpe having already done so in the 'Catalogue of Birds in the British Museum,' vol. vi. pp. 268-280, where our bird bears the name of Anorthura troglodytes.

The Wren is a very early breeder; making its nest in shrubs, bushes overgrown with brambles, hedges, banks, the sides of walls covered with ivy, trees, hayricks, thatched roofs and other situations. The materials employed are principally leaves and moss, although dry grass is often used; sometimes with a lining of feathers. The structure, which is comparatively large, is domed above, and has a small hole in the side; the eggs, about $6-S$ (though i 6 young have been found in one nest), are white, generally spotted with red: average measurements 67 by $5 \mathrm{in}$. Two broods are produced in the season. It is a common belief, and one not to be rashly discountenanced, that if the inside of a W'ren's nest is touched the bird will desert it; but if care be used such is by no means invariably the case. Imperfect nests are frequently found near an occupied one, and owing to the notion that they are built by the male bird for his lodging at night, they are commonly known as " cocks' nests." In winter, however, old nests and holes in walls or thatched roofs are undoubtedly resorted to by Wrens in some numbers for warmth and shelter. The song, loud for the size of the bird, may be heard during the greater part of the year; the callnote is a sharp clicking chit. The food consists principally of insects, for which search is made in all sorts of crannics, but in winter the bird will eat seeds and any odd scraps.

The adult has a dull white streak over the eye; upper parts reddish-brown, with narrow transverse darker bars ; outer quills umberbrown, barred with buff and dark brown on the exterior webs; under parts buffish-white on the chin and throat, becoming browner on the belly and flanks, the latter being somewhat barred; bill dark brown above, paler below, legs and feet light brown. Length 3.5 in. ; wing I.9 in. The female is smaller, duller above and browner beneath, and has paler legs. The young are less distinctly barred. 


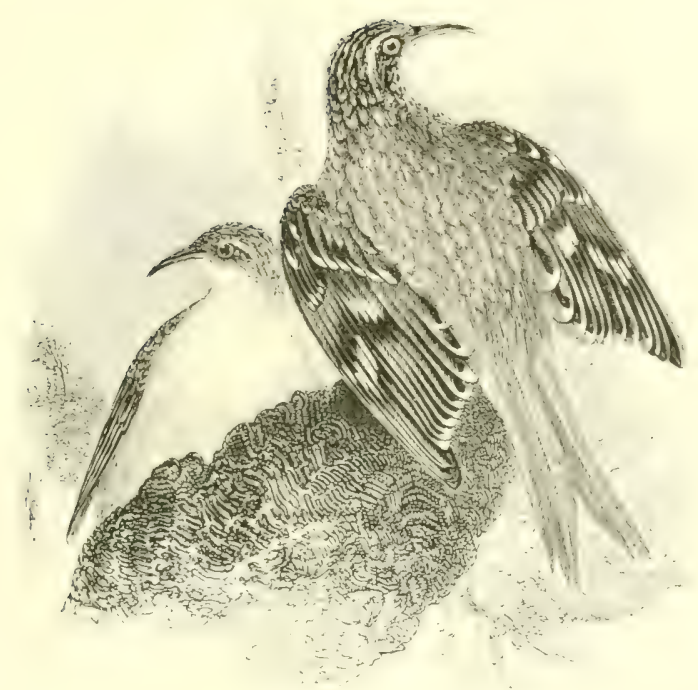

THE TREE-CREEPER.

\section{CÉrthiA FAMILÁRIS, Linnæus}

Although tolerably numerous, the Tree-Creeper is not very frequently observed, owing to its small size, modest colours, and the quickness with which it shifts its position on the trunk or branch of the tree whereon it is seeking for spiders and other insects, which lurk in the crevices of the bark. It is generally distributed throughout Creat Britain from Cornwall to Caithness, straggling to the Orkneys and Shetlands, and being resident in sikye, although not found in the Outer Hebrides. In Ireland it is common in those districts where old timber prevails.

In Norway the Tree-Creeper is abundant in all the lower coniferwoods up to the Trondhjems-fiord, and eastward it occurs in Sweden, Russia, and across Siberia to the Pacific, as far north as trees flourish. Southward, it is found in Japan, Northern China, and Asia north of the Himalayas-in and south of which several distinct species replace it; and. turning westward, in P'ersia, Asia Minor, Ageria, the basin of the Mediterranean generally as far as the Spanish Peninsula, and northwards throughout Europe wherever suitable localities present themselves. I few ornithologists dis-

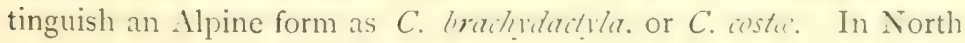


America, from $50^{\prime} \mathrm{N}$. lat. to Mexico, is found a very close ally which trinomialists designate $C$. familiaris americana.

Towards the end of April the Tree-Creeper makes its nest ; usually selecting for it a crevice between the partially detached bark and the trunk of a tree, or a narrow cleft in the bole; not unfrequently it is behind the loose plaster, or under the straw eaves of a shed or dwelling; sometimes in the foundation of the nest of a large bird of prey, and in piles of timber or bricks. Fine straw and twigs, roots, grass and moss are the materials employed, with a lining of wool, feathers, and fine strips of inside bark, often that of the birch-tree. The eggs, 6-9, are white, spotted and blotched with reddish-brown and dull purple, especially towards the larger end: average measurements 62 by 47 in. Incubation is assiduously performed by the female, who is, however, rather shy, slipping off her nest on the approach of an intruder. Two broods are generally reared in the season. The food, as already observed, consists principally of insects, and occasionally of seeds of the Scotch fir. The song of this littie bird is shrill, but rather pleasing; and I have noticed that in the bright climate of the south of Europe, in the gardens of the Alhambra at Granáda, for instance, it is much more prolonged and joyous than in the north. The call-note is a feeble chup, chctp. When climbing, the stiff-pointed feathers of the tail are depressed; the bird ascending by their assistance and by that of its long curved claws, with a short jerking movement, and generally in a spiral direstion. In winter the Tree-Creeper may often be observed in company with several species of Titmouse, or Goldenand Fire-crested Wrens.

The adult has a dull white streak over the eye; feathers of the head, neck, and back dark brown with pale centres; lower back rufous-brown; wing-quills dark brown, barred and margined exteriorly with buffish-white; tail of twelve stiff-pointed feathers, dull reddish-brown, with paler shafts; chin, throat, breast and belly silvery-white; flanks and vent suffused with buff; the rather long, slender, curved bill dark brown above, yellowish below; legs and feet, light brown. Length from the forehead to the tip of the tail about 4.5 in. ; wing 2.5 in. The sexes are alike in plumage. The young have a more rufous-yellow tinge than the adults, and the bill is very short and almost straight. 


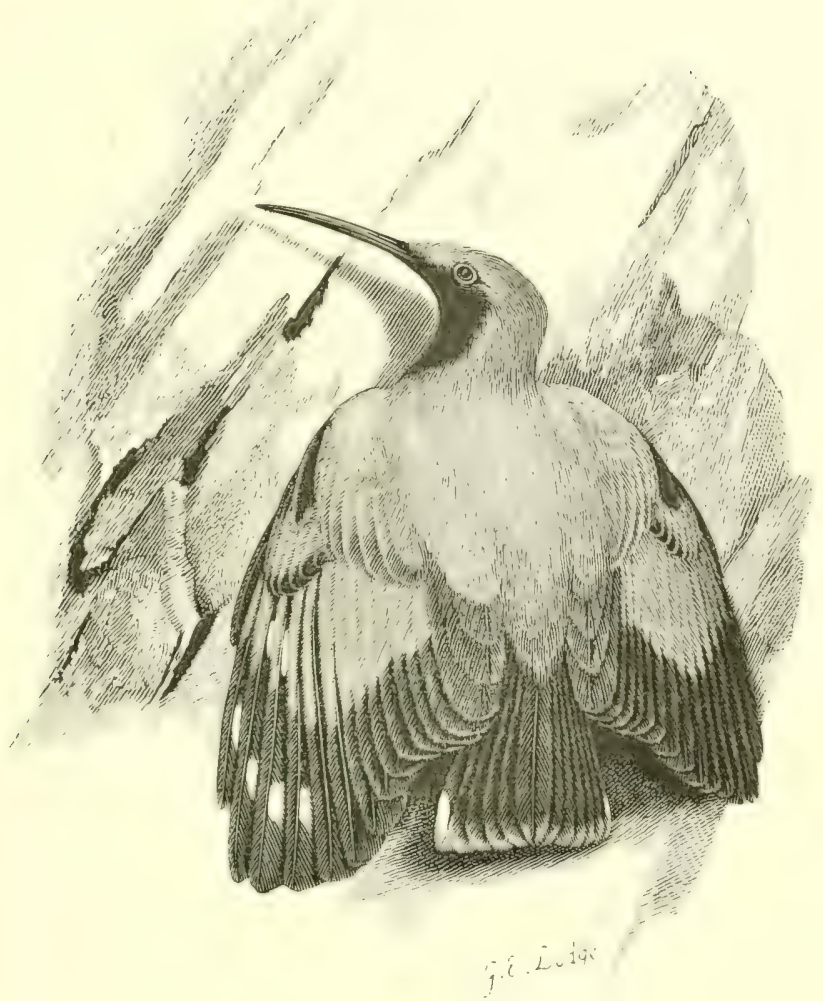

THE WALL-CREEPER.

Tichódroma murária (Linnaus).

This inhabitant of the mountainous regions of Europe and Asia is a very rare straggler to England. The first authenticated instance was furnished by the late Thomas Bell, who published (\%ool. s.s. p. 4664, and Tr. Norfolk and Norw. Nat. Soc. ii. p. I So) a letter from Robert Marsham of Stratton-Strawless, Norfolk, to Gilbert White of Selborne, dated Uctober $30 \pm$ h 1792 , containing an accurate description of a Wall-Creeper which had just been shot whilst flying about his house. Eighty years later Mr. F. S. Mitchell stated (\%ool. s.s. p. 4839 ) that one, now in his possession, was shot on May Sth 1S72, at Sabden, at the foot of Pendle Hill, in I ancashire, when flying around a tall chimney, and attracting the attention of the mill-hands by its crimson-banded wings. 
The Wall-Creeper breeds sparingly in suitable localities in the Vosges and the Jurn; while stragglers have occurred on the Rhine as far north as Coblentz, and in the valleys of the Moselle and the Meuse. Along the Loire it is not very uncommon, and seven or eight examples have been obtained as far west as Nantes; most of them on the walls of the old châtean which overlooks the busy wharves. In the mountains of Savoy and Switzerland it is generally distributed, being perhaps more abundant in the Grisons than in any other district; it is also resident in the Basses-Alpes, Provence, the mountainous regions of the mainland of Italy, Sicily, Sardinia and Elba; while Professor Giglioli has observed it climbing about walls in Florence. Throughout the Pyrenees and the Cantabrian chain, and in the loftier ranges of Portugal and Spain down to the Sierra Nevada, it is comparatively abundant. East of the Alps we find it in 'Tyrol, Styria, the Carpathians, Greece, Asia Minor, the Caucasus, and the mountains of Asia as far as China ; while Rüppell has recorded it from Egypt and Abyssinia.

The nest, composed of moss, straw, and grass, lined with hair, wool and feathers, is placed in some crevice of the rocks; and the eggs, $3-5$, are white, very finely spotted with reddish-brown : average measurements 78 by ${ }_{5} 6$ in. Two broods are sometimes produced in the season; the task of incubation devolving upon the female. The call-note is a shrill pli-pli-pli-pli-pii, like that of the Lesser Spotted Woodpecker. The food consists of ants' eggs, spiders, and insects and their larva generally; in search of which the bird may be seen climbing up the face of a cliff by successive bounds, and moving its wings like a butterfly, which indeed, from the red and white markings displayed, it much resembles. Its course is generaliy zig-zag, and the tail is not used as a means of progression.

Adult male in breeding-plumage: slate-grey above, darker on the head, and darkest on the rump ; wing-coverts mostly crimson; quills blackish-brown, tipped with dull white, the and to 5 th each with a basal and a sub-apical white spot on the inner web, from the 6th inwards only a basal spot; outer webs of nearly all the primaries rich crimson, forming a bar; tail black, tipped with grey and white; throat and breast black; remaining under parts dark grey; bill, legs and feet black. The female has rather less black on the throat. In winter that part becomes greyish-white in both sexes: the head is browner and the upper parts are paler. The young bird at first exhibits less crimson and has a shorter bill, but the black throat is acquired the first spring. 


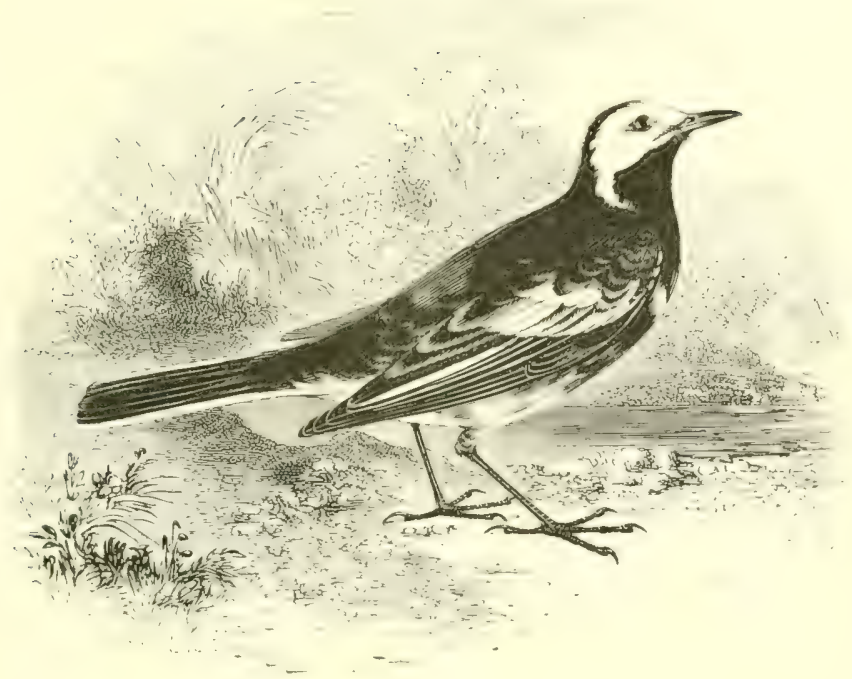

THE PIEI) WAG'TAIL.

\section{Motacílla lúgUbRIS, Temminck}

The Pied Wagtail was first distinguished from the White Wagtail of the Continent by 'Temminck, who conferred upon it the above scientific name; in ignorance of which, Gould, seventeen years later, called our bird M. farrelli. Throughout the British Islands it is a common and generally distributed speries: visiting the extrente north of Scotland in March and remaining to breed, but migrating southwards, as a rule, on the approach of winter. It nests, sparingly, in some of the Ilebrides and Orkneys: but in St. Kilda and in the Shetlands it is only known to occur on the spring and autumn migrations. In Ireland it is common and on the whole resident, but is partially migratory as regards the northem districts: and even in England there is a general movement southward in autumn, and northward in spring. The late Mr. Knox observed large flocks early in september, mainly composed of young of the year, travelling along the coast of sussex in the direction of Kent, whence the transit to the Continent is shortest; while from the middle of March numerous small parties. consisting of old males (the females being later), have been seen to arrive from the sea where the Channel is wider.

On the Continent the Pied Wagtail is almost restricted to the 
western portion. It occurs and probably breeds sparingly, in the south west of Scandinavia ; visits Denmark : passes over Heligoland in considerable numbers; and is found in Holland, Belgium and the north of France. In the north-west of the latter country it appears to breed regularly; in the south-west I observed that males of this species and of the White Wagtail were in full plumage from the latter part of December to the end of Narch, after which both disappeared. It arrives in Portugal about October soth, leaving in Narch; in the latier month I obtained an adult male at Seville : and it occurs near Tangier in Morocco. Eastward, the Pied Wagtail has been met with in autumn from Nice to Sardinia, Sicily, and Malta.

Breeding generally begins early in April ; the nest--of moss, dry grass and roots, lined with hair and feathers-being in some cleft of a bank, wall, rock or quarry, a decayed tree, the thatch of a building, a faggot stack, or even in an open turnip-field; and the Cuckoo often places her egg in it. The eggs, +6 , are greyish-white, closely speckled with ash-brown: average measurements 8 by $\cdot 6$ in. Two broods are often reared in the season. The bird feeds principally on insects obtained in the meadows, moist ground, and shallow water, to which it is partial: on the coast it eats the flies \&.c. which it finds amongst the sea-drift; Mr. Tait observed it hovering over the water to pick up the floating ova of a small crab: and Mr. Booth says that it is fond of glow-worms. The call-note is a sharp chis-sic; the song, seldom heard except in spring, is short but agreeable. The quick running movements of this pretty bird, and the lively agitation of its long tail, must be familiar to every one.

Adult male in breeding-plumage: forehead and sides of the head and neck pure white, contrasting strongly with the deep black of the crown, nape, throat and breast ; mantle, rump and wing-coverts, black; the latter margined with white, which forms a double bar; quills blackish, the inner secondaries-nearly as long as the primaries-margined with white on the outer edge; tail-feathers black, except the two outer pairs which are mainly white; belly white; sides and flanks blackish; bill, legs and feet black. Length $7+4$ in.; wing 3.5 in. The female has a shorter tail; the back is lead-grey with somewhat darker streaks; and the black on the crown and breast is less extensive. After the autumn moult both sexes lose the black chin and throat, and become greyer on the back. The young are like those of $M$. alba, next to be described, but darker on the upper parts. 


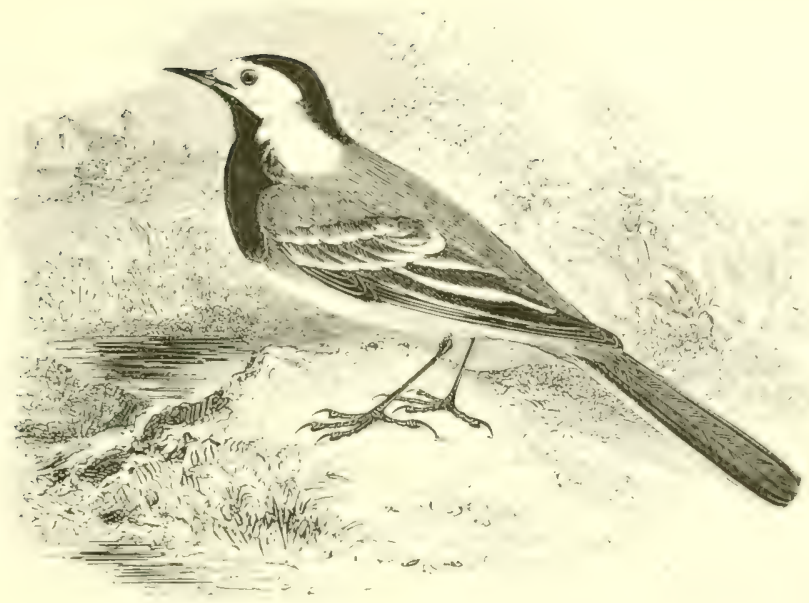

THE WHITE WAGIALL.

Motacilla ALBA, Linnæus.

This Continental representative of the familiar species already described was first recognized in England by Mr. F. Bond, who found two pairs at Kingsbury Reservoir, Middlesex, in the latter part of May i84i. Since that date it has occurred in a good many counties of England, being not uncommon in Cornwall in spring; and it is said to have nested in Devonshire, the Isle of Wight, Kent, Middlesex, Cambridgeshire and Huntingdonshire. Mr. Upcher observed two in September $\mathbf{I} 88_{3}$, on his lawn at Feltwell, Norfolk; while of a pair of birds obtained with their nest and young in that county, presented to the British Museum by Lord Walsingham, the male is a White and the female is a Pied Wantail. Dr. Günther has informed me of a similar case of interbreeding in Suffolk. Mr. Cordeaux mentions several occurrences in Lincolnshire, in spring; competent observers have noticed it in Nottinghamshire, lorkshire, Iancashire and Cumberland : and on May 24th I88.5 I watched an adult, probably a male, by some lead-mills near Langley (astle in Vorthumberland. In scotland it has been observed in some of the southern counties; while pairs have been noticed at (iairloch, in Ross-shire. Mr. Rooth saw several pairs in April feeding on the river hank at Inverness, and he also observed a number on the island of Lewis, early in May $1 \$ 7 \%$, after rough weather. Saxby says that he obtained it in shet. 
land. In Ireland it is of very rare occurrence, and perhaps the only authenticated example is that shot by Mr. R. Warren in co. Mayo on April 25th I 85 I.

The White Wagtail is a summer-visitor to the Frees and Iceland, straggling to the island of Jan Mayen and the south of Greenland. On the Continent it is found over the whole of Europe and of Northern Asia ; Siberian birds being of a purer grey un the upper parts, and wintering in India and Burma; while the ordinary form occurs in Asia Minor, Palestine and Northern Africa, in summer and winter, visiting Senegambia on the west and Zanzibar on the east in the latter season. It is one of the earliest species to return to the northern summer quarters from which cold and want of food force it to migrate at the end of autumn; the males arriving about a week before the females. It has recently been found in Madeira.

The situations selected for its nest are similar to those chosen by its congener; but the White Wagtail has further been known to breed in the burrow of a Sand-Martin, and also to make its nest in an open place in the middle of a strawberry-bed. The eggs, 57 , are sometimes of a rather bluer grey, with bolder ashy markings, than those of the Pied Wagtail ; but frequently they cannot be distinguished, and their average measurements are identical. In general habits, food and haunts, the White Wagtail hardly differs from our indigenous bird; and in spite of assertions that it does not follow the plough, I have scen flocks whitening the furrows in spain and the south of France, as Mr. (iurney jun. has in Ageria.

The adult male in breeding-plumage has the forehead and the sides of the head and neck white; crown and nape black; back, rump and upper wing-coverts ash-grey, the latter and the median ones tipped with white; quills blackish, the long inner secondaries edged outside with white; tail-feathers black, except the two outer pairs which are mainly white; chin, throat, and breast black; abdomen white; flanks grey; bill, legs and feet black. Length 7.5 in.; wing 3.5 in. The female has a shorter tail; her colours are less pure, and the black portions are more restricted. After the autumn moult the chin and throat are white, and the black is reduced to a crescentic band. In the young the white forehead, checks and throat are tinged with yellow, and the head and mantle are olive-grey, but males soon show white on the forehead and a little black on the crown. By the following spring the olive tint has disappeared, and the young have a remarkably light appearance. 


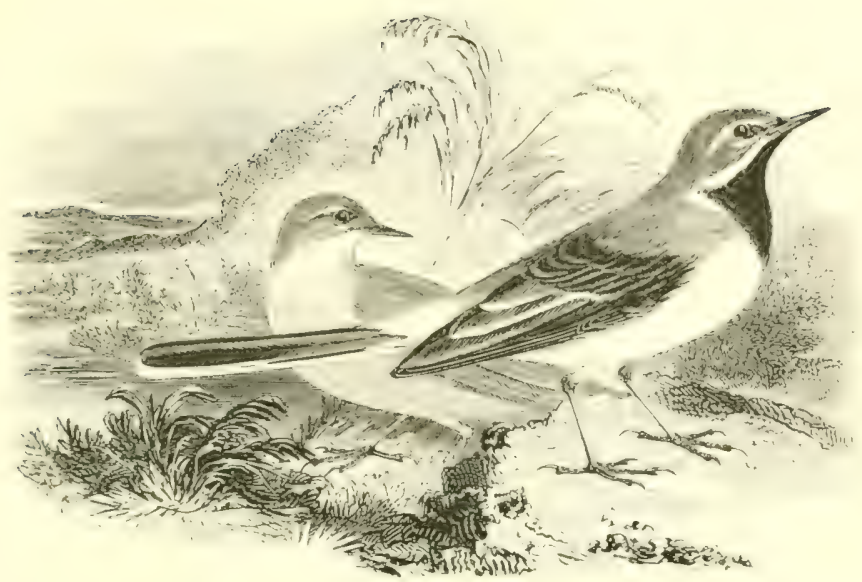

THE GREY WAGTAIL.

Motacilla melanópe, Pallas.

This beautiful species, easily recognizable by its yellow tints and exceptionally long tail, is resident or partially migratory throughout those portions of the British Islands where rapid streams are found in the vicinity of mountains, or even hills; but to the flat country and the sea-coast it is only a visitor on migration and in winter. It breeds regularly in Ievon, somerset, Dorset and Wilts: sparingly in Hampshire, Sussex and Kent ; and, as an exception, it has been known to nest once at Chenies in liuckinghamshire, according to Gould. In Wales and the neighbouring counties, and along the Pennine range on both sides, it is common, increasing in numbers to the northward; while in Scotland it is generally distributed, although not very abundant in Sutherland and Caithness. It breeds sparingly in skye, and is a visitor to the ()rkneys and the Shetlands. In Ireland, according to Mr. More, it is resident in small numbers, but local.

On the Continent the Grey Wagtail barely reaches the extreme south of Sweden, and is very rare in Northern Germany, while in Russia it is hardly found beyond the latitude of MLscow; but in the mountainous and even rolling ground of the central and southern parts of Europe it is farly common ; breding as fur south as the basin of the Nediterranean, where it is a resident, as it is also in the Canaries, Narleira and the Vores. Eastward, it is found 
in summer across Asia, south of about $67^{\circ} \mathrm{N}$. lat., to Persia, Turkestan, the Himalayas, Northern China and Japan; wintering in India, Burma, the Indo-Malayan islands, Palestine and Northern Africa.

The nest is usually near a stream, in some rugged portion of a bank, occasionally among the stems of a shrub; very frequently in a rough stone wall or some crevice of the rocks. In the Pyrenees, where the Grey Wagtail is very abundant, I observed a nest behind a pair of votive crutches at the entrance to the grotto at Lourdes. The materials employed are moss, soft grass and fine roots, with abundance of hair for a lining. The eggs, usually 5 in number, are greyish-white, mottled with pale clay-colour, and sometimes marked with a. few black hair-streaks at the larger end: average measurements 75 by 55 in. Two broods are occasionally reared in the season; the first eggs being laid in the latter half of April in England, but earlier in the south of Europe: and the male takes his share in the task of incubation. The food consists of aquatic and other insects, and small molluscs; and at the baths of Dax in the Landes, a pair of birds which frequented the courtyard of the hotel used to enter the open windows of the corridors with the utmost familiarity, in search of flies. Its call-note is a sharply-uttered $\approx i s \approx i$. In its constant and rapid movements this species resembles its allies, but it is decidedly more addicted to perching on trees by the side of streams.

The adult male in breeding-plumage has the crown and earcoverts slate-grey, with a narrow white streak abovt the eye; bclow the lore, which is black, a broad white line runs to the neck, which is slate-grey, as are the mantle and rump; wing-feathers brownishblack, the long secondaries margined whth buffish-white; upper tailcoverts greenish-yellow; the outside pair of tail-feathers white, the next two pairs also white with a black stripe along part of the outer web, the remainder brownish-black; chin ard throat black; breast to lower tail-coverts sulphur-yellow; bill dark brown; legs and feet pale brown. Length, from 7 to $7.5 \mathrm{in}$., depending upon the length of the tail, which is often shorter than the average in specimens from the Azores, Turkey and Siberia; wing $3 \cdot 3$ in. The female has a shorter tail than the male; her tints are duller and more greenish, and she has less black on the throat. That part becomes white in both sexes in autumn, when a buff tint appears on the breast. The young are browner than the female, and the eye-stripe is buff. This species has bred, in captivity, with the Pied Magtail, and the hybrids proved fertile. 


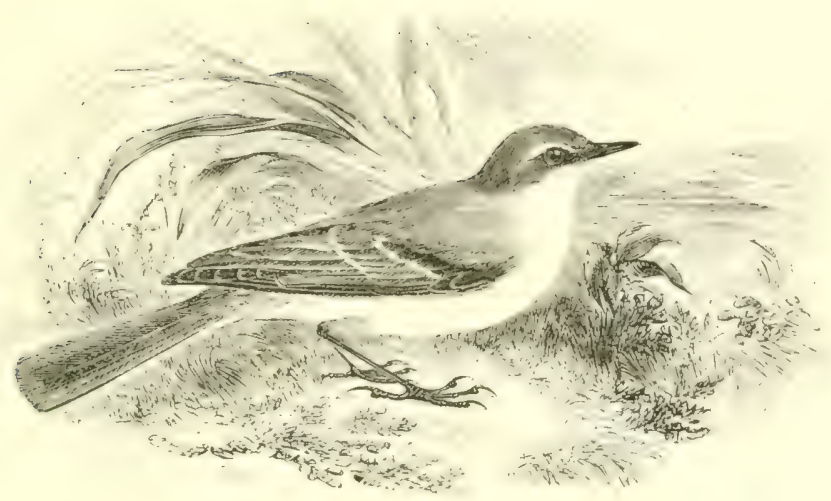

THE BLUE-HEAIED WAGTAI.

\section{MotacilLa FLAVA, Linnæus.}

In ${ }_{1} \delta_{32}$ it was pointed out by Gould that the Blue-headed Wagtail of the Continent was distinct from the Vellow II agtail, which is a regular visitor to our islands; and two years later loubleday shot an example of the former at Walton-on-the-Naze. Since that date a considerable number have been obtained or observed; mostly in the south-western, southern, and eastern counties of England ; while the bird has undoubtedly nested on several occasions near Gateshead in Durham, as certified by Mr. John Hancock. As a rule, however, the Blue-headed Iragtail can hardly be considered as more than an irregular-though perhaps overlooked-visior on migration : senerally in spring, but not unfrepuently in autumn. In sicotland it has been shot near Edinburgh and I umbar: and saxhy states that he obtained it on migration in shetlanel. Mr. Blake-Knox has asserted that it occurs in Ireland, but Mr. More excludes it from his list.

The Blue-headed Wagtail has straggled to the Froroes; and I have examined a specimen in the British Museum obtained by Gould in summer as far north in Norway as the Dovre Fjeld. couthward, it is found throughout Europe: breeding in the west down to the shores of the Mediterranean, where it is partially resident, and pushing its migrations in winter te) the south of Africal. lastward, it is found across. Isia to the Pacifre : and also in . laska, where it breeds up to $64^{\circ} \mathrm{N}$. lat. 'This Wagtail runs to varicties which are, in the opinion of some omitholosists, cntitled to take rank as species; but upon this intricate question I must refer my readers 
to Mr. Sharpe's views (Cat. Birds Brit. Mus. x. pp. 516-532). I have only room for the broad statement that in Upper Scandinavia. Northern Europe and Siberia, migrating as far as the south of Africa and India, there is a form, the male of which has a nearly black crown and no eye-streak, known as $M$. viridis of Gmelin, or better as $M$. burealis of Sundevall : two examples of which are said to have occurred at Penzance. (the basin of the Mediterranean is found a close ally, $M$. cinereica " $/ a$ of Savi, with grey crown but very little eye-streak; while in South-eastern Europe and Central Asia there is an easily recognizable form with a very black head and no eye-stripe, known as $M$. feldeggi or $M$. melanocephala. When, as in Hungary, this black-headed bird exhibits a narrow white eye-stripe, it is MI. paradova; when, as at I.enkoran on the Caspian, the stripe is pale yellow, the bearer is $M$. xanthophry's.

Breeding commences in the latter half of May; the nest being placed on the ground among herbage in meadows and corn-fields. It is composed of fine roots. grass and moss, lined with horsehair and a few feathers; the eggs, $4-6$, being yellowish-white, clouded with paic brown, and sometimes scrolled with black at the larger end: average measurements 78 by ${ }^{\circ} 56$ in. The food consists of insects and their larrx: and the bird is very partial to small flies, in pursuit of which it may be seen strutting and fluttering within a few inches of the muzzles of grazing cattle or horses. The call-note is a shrill chit-up.

The adult male in breeding-plumage has the crown and nape bluish-grey: lores and ear-coverts dark slate-grey; over each eye and ear-covert a white streak; mantle olive, tinged with yellow; wingcoverts dark brown, tipped with yellowish-white, forming a double bar: secondaries margined with the same colour; quills dark brown; tail-feathers blackish-brown, except the two outer pairs, which are white with black edges to the inner webs; chin and a line below the lores white; throat, breast and tail-coverts bright gamboge-yellow; bill, legs and feet black. Length 6.25 in. ; wing $3^{\circ} 2$ in. The female is rather shorter: the head has a more olive tint, and the yellow of the under parts is less pronounced. In autumn both sexes acquire an olive-brown tinge. The young are greenish-brown above, with a rough $\bigvee$-shaped line of brown spots from the nape to the breast, and the under parts are only pale yellow; but the white eye-stripe which serves to distinguish typical examples of this species from our Vellow Wagtail is always present. Young males often display in their first spring some dark mottlings on the throat, grey patches on the head, and a considerable amount of yellow on the shoulders. 


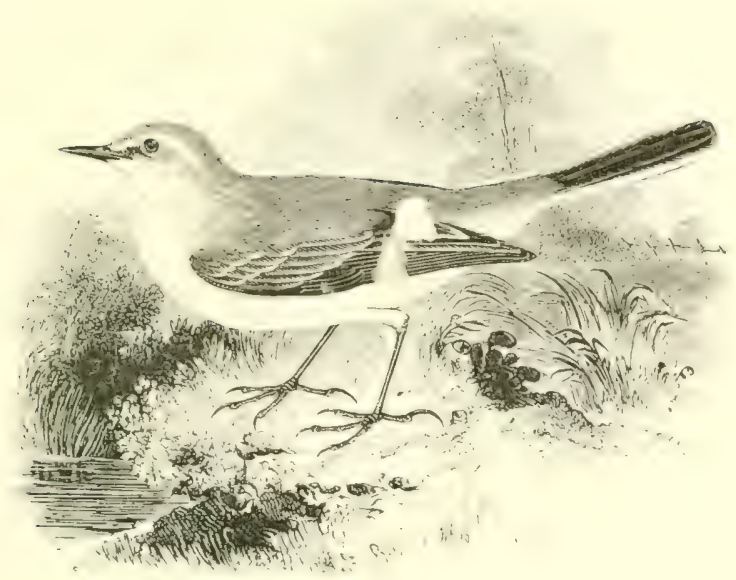

THE VELI,OW WAGIIJ.

Motacllat Rail (Bonaparte).

The Yellow Wagtail is a regular summer-visitor to the British Islands, arriving early in $A_{p}$ ril, and leaving again in september. In Cornwall and Devon it is usually seen on migration; but from Somersetshire onwards, it is generally distributed as a breeding species throughout England and Wales, in suitable localities. In Srotland it is locally distributed as far north as the Firths of Forth and Clyde, and it is said to breed in Inverness- and Aberdeenshire; but recent observers have failed to verify its reported occurrences in sutherlandshire, the Orkneys, or the Shetlands. To Ireland it is a summer-visitor in small numbers, but is very local; the district about Lough Neagh, and the vicinity of Dublin, being the only parts in which it is known to breed up to the present time.

Nithough the Vellow Wagtail has been obtained as a straggher on Heligoland, Borkum, and the coast of Ifolland, it is only westward of Belgium that it is known as a regular migrant, and the Blue-headed IVagtail is still the prevailing species in the loreeding. season as far as Dieppe, west of which our Yellow Wagtail is said to predominate. On migration, it visits the south of firance and both sides of the Iberian Peninsula with great regularity; but it is only of rare and accidental occurrence in Italy, Sicily, and Malta. Southward, its migrations extend down the coast of 11 . Ifrica as far as the (jaboon. A large and isolated colony is said to inhabit 
the valley of the Lower Volga, the Caspian region, and Turkestan as far east as the Altai Mountains; the migrations of this section reaching along the eastern side of Africa as far as Natal. In Eastern Asia it is represented by $M$. taivana.

The nest, built in the latter part of April and generally well concealed, is placed in a depression or a small furrow of the ground in a meadow or corn-field; sometimes in a bank, or at the foot of a wall among the long rank herbage. Even in the same locality there is considerable variation in the materials employed; moss and dry grass being generally used for the exterior, while the lining may be of feathers, hair, rabbit's-down, or fine roots. The eggs, 4-6, are greyish-white mottled with clay-brown, and have often some black hair-streaks : average measurements 78 by 56 in. By the end of May the young are able to $\mathrm{fly}$, and a second brood is sometimes reared in the season. The food consists of the small thin-shelled molluscs which the bird finds among the water-meadows, and various kinds of insects; and it is as partial as the I3lue-headed Wagtail to the proximity of grazing cattle. In its note and in the bold curves of its flight, it also resembles that species.

Adult male in breeding-plumage: lores, ear-coverts and back, greenish-olive; the forehead yellower: a sulphur-yellow streak over the eye and ear-coverts on each side; wing-coverts and quills duskybrown, tipled and margined with pale buff; tail-feathers blackishbrown, except the two outer pairs which are white, merely edged with black on the inner webs; under parts rich sulphur-yellow; bill, legs and feet black. Length about 6 in. ; wing $3{ }^{\circ} \mathrm{I}$ in. The female is browner on the upper parts, and the eye-streak and under parts are less yellow. In autumn the adults of both sexes become much paler. The young in the first and nestling-plumage, which is only worn for a short time, are greenish-brown on the upper parts, and buff on the breast, much resembling young Pipits; later they become yellow on the rent and under parts, and gradually assimilate themselves to their parents; but the sides of the neck and the breast are spotted with dark brown for some time.

For the Wagtails which exhibit a prevalence of yellow in their plumage and have also a longer hind-claw than the Black-and-white Wagtails, Cuvier established the genus Budltes; and as the (irey Wagtail presented intermediate characters, Kaup invented for it the genus Calobates. 


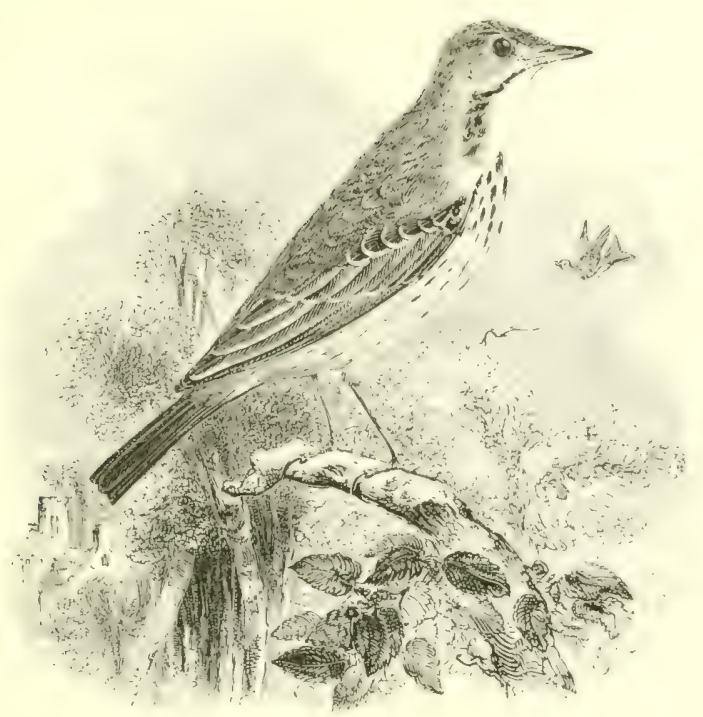

'THE TREE-PIPIT.

\section{ANTHUS TRIVIÁlis (Linnæus).}

The Pipits present a superficial resemblance to the Larks, but from these they differ considerably in structure, moulting, and some of their habits; while they agree with the Wagtails in almost every respect, except in the coloration of the plumage of the adults. Like Wagtails, Pipits moult twice in the year-partially in spring-and they are equally fond of hathing; while I arks have only an autumnal moult, and dust themselves over, instead of washing.

The Tree-Pipit generally arrives in the southern portions of England early in April ; and, except in the west of Cornwall and in Wales, where it is scarce, the bird is fairly distributed throughout the country in summer, becoming more numerous in the wooded districts suitable to its habits. In tootland it is common in the Western Solway district (Service), and around (Blasgow; and. although local, it appears to be fairly diffused in other parts of the country; but in the north it is rarer, and it has only been detected breeding in Sutherlandshire since 1875 . It is said to be a straggler in the ()rkneys. In Ireland it has not yet been obtained. The majority depart for the south during the month of september, but in the 
west Mr. Cecil Smith observed a flock of about a score preparing to migrate from the cliffs near Exmouth on the 26 th of October.

A specimen of the Tree-Pipit is said to have been brought by the Austrian Expedition from Jan Mayen! On the Continent it breeds as far north as Tromsö in Norway, and southward, to the Pyrenees, the higher grounds of Northern Italy, and the Crimea. South of this it is principally known as a migrant in spring and autumn, or as a resident in winter; as it is also in the northern portion of Africa, from Morocco, on the west, to Egypt, Nubia and Abyssinia on the east; while it has been recorded from about $25^{\circ} \mathrm{S}$. lat. It occurs in Sibcria in summer as far cast as Krasnoiarsk in the valley of the Yenesei, where it meets with $A$. maculatus, a closely-allied form, of a more olive-green colour with but few dusky streaks on the upper parts; and in winter it is found as far to the south-east as Assam.

The nest, placed on the ground among herbage, is constructed of moss, dry grass and roots, lined with fine bents and a little hair. The eggs, 4-6. are subject to much variation; some being greyishwhite, mottled with deep brown; others are rich reddish-brown; some are almost lilac-pink; and again a not uncommon variety resembles the egg of the Reed-Bunting: average measurements $S_{2}$ by 6 in. Two broods are sometimes reared in the season. The food consists principally of insects, with small seeds. The song of the male-somewhat like that of the Canary -is generally begun on the topmost branch of a tree, after which the bird hovers in the air and descends, still singing, to his perch.

Adult male: eye-stripe buff; upper parts clear sandy-brown with distinct dark brown streaks; wing-coverts and secondaries dark brown with paler edges; primaries dull brown; the outer pair of tail-feathers white, with a dark brown stripe on part of the inner webs; the second pair merely tipped with white, but otherwise, like the remaining feathers, dark brown ; chin dull white; throat buff, with a dark line on each side from the bill to the gorget; sides of the neck, breast and flanks buff, with elongated spots and streaks of dark brown ; belly dull white; bill brown above, lighter below; legs and feet pale flesh-colour in life, but yellowish-brown in preserved specimens. Length 6 in. ; wing $3^{\circ}+$ in. The female is slightly smaller, and less distinctly spotted on the breast. In autumn the buff tint is more pronounced; and in young birds the spots and streaks are smaller in size, but more numerous. The Tree-Pipit may always be distinguished from the Neadow-Pipit by its somewhat larger size, tint of a warmer buff, paler legs, and much shorter and more curved hind claw. 


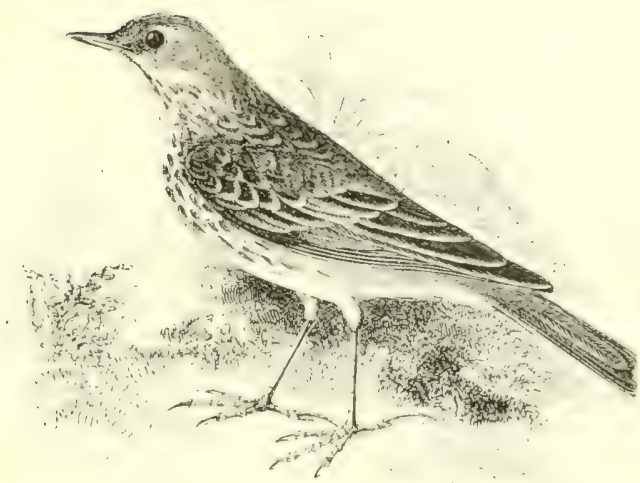

THE MEAIDOW-PIPIT.

ANTHUS PRATÉNSIS (Linnæus).

The Meadow-Pipit, generally known as the Titlark, and locally by the names of Titling. Moss-cheeper, Ling-bird \&c., is the smallest and most abundant member of the genus throughout the British Islands. During summer it is equally at home on lowland pastures and elevated moors; but in winter the higher and bleaker situations are deserted for milder and more sheltered localities, especially those in the vicinity of the sea-coast. In autumn considerable numbers leave our shores altogether; a return migration taking place in spring.

In the Færoes and Iceland the Meadow-Pipit is common in summer, and in Greenland a single straggler was obtained in 1845 . Its breeding-range extends from the North Cape over the greater part of Europe to the Pyrenees, the northern portions of Italy and the Carpathians, and perhaps to some of the elevated regions still further south ; but in the basin of the Mediterranean the bird is principally known as a visitor on migration and in winter. Eastward, it is found in Asia Minor, Palestine, Western 'Turkestan, and the valley of the $\mathrm{Ob}$ in Siberia; while its southern wanderings reach North Africa, from Morocco to Egypt. In the Canary Islands and Maleira there is a resident insular form known as $A$. bertheloti, smaller in size, with paler and less marked upper parts, narrowly striated under parts, and no green tint in its plumage.

The resident Meadow-Pipits begin to breed carly in the spring, hut the migratory individuals which arrive from the south in Ipril 
are somewhat later. The nest, placed in a depression of the level ground or the side of a bank among sheltering herbage, often in ling, is constructed of dry grass with a lining of finer materials; the eggs, usually +6 in number, being greyish-white-sometimes with a green tint-thickly mottled with different shades of brown, and, occasionaliy, with a few hair-streaks at the larger end : average measurements 78 by 57 in. Two broods are generally reared in the season. In many districts, especially of moorland where other small species of birds are comparatively scarce, the Cuckoo commonly deposits its egg in the nest of the Meadow-Pipit. The song, feeble but rather shrill, is generally uttered on the wing, but sometimes from a stone or low bush. The food consists of insects, worms, small snails and molluscs, with seeds in winter; and in search of these the bird may be seen working its way among grass or heather with a slow creeping movement, varied by an occasional quick run. Its flight is jerky and wavering. The scent emitted by the Titlark is very strong, and dogs 'point' it more frequently than they do any other ground-bird.

Adult male: eye-stripe narrow and dull white; upper parts olivebrown, with dark stripes down the centre of the feathers; quills dark brown, with a greenish-yellow tint on the margins of the outer webs; wing-coverts and secondaries-the latter shorter than the primaries brown, edged with dull white; tail dark brown, except the outer pair of feathers which are white on the lower part, while the second pair have a white spot near the tip) under parts dull white, streaked with brownish-black on the throat, gorget and flanks; bill dark brown above and at the tip, the rest paler; legs and feet pale brown; hind claw longer than the hind toe, and only slightly curved. Length $5^{\circ} 75$ in.; wing 3 in. The female is less richly spotted below. After the autumn moult, the upper and the under parts are suffused with a yellowish-buff tint; and in spring this hue is very noticeable on the throats of fresh arrivals from the Continent.

The young are even more buff-coloured, but the streaks on the under parts are smaller and browner than in the adults. 


\section{THE RED.THROATED PIPIT.}

\section{Anthus cervínus (Pallas).}

On March I 3 th $x S_{4} 4$ a Red-throated Pipit was brought by a birdcatcher to Mr. Swaysland, the well-known bird-stuffer at Brighton, and was examined in the flesh on the following day by Mr. J. H. Gurney jun., who recorded the occurrence in 'The Zoologist' for that year (P. I92). In the same volume (p. 272) Mr. Walter Prentis stated that, in April I880, he shot an example of this species at Rainham in Kent, whilst it was feeding and singing along the freshly-turned furrows behind his plough, and sent it, as merely a bright-coloured Meadow-Pipit, to Dover for preservation. Both these examples were forwarded to Mr. R. 1). Sharpe, who exhibited the former-now in the possession of Mr. T. J. Monk of Lewesat a meeting of the Zoological society, April ist ISS.4. Up to that year no thoroughly authenticated British-killed example was known, although Mr. Bond possessed a genuine specimen of the bird, labelled "Lnst, May fth i $\$ 54 "$, purchased at the sale of the late Mr. Troughton's collection, and proceeding, as shown by Mr. Gurney jun., from a previous sale which had obtained a notoricty of a certain kind. Iet, as was prophetically remarked by Professor Newton, the migratory habits and wide range of this species made it very likely to occur, and probably rendered its recognition in these islands only a matter of time and observation. It has not been considered necessary to figure it here, because the coloration and other characteristics could not be rendered in a woodcut.

The Red-throated Pipit is a species which, throughout the year, enjoys the maximum of sunshine; and under the continuous daylight which reigns in summer to the north of the Aretic circle, it breeds in many parts of Scandinavia, especially in Fast linmark; while castward, we find it in increasing numbers, heyond the limit of forestgrowth, across Siberia to Kamschatka and liering Island. It is even said to have straggled acrosis the I'acific to I.ower California : but be this as it may, the migrations of this Pipit undoubtedly extend to Southern China, Borneo, Burma, India, I'ersia and Exygt. In the latter and in Nubia, the bird is exceedingly abundant in winter. and 
up to the month of April ; by which time it has assumed full breeding-plumage. Westward, in North Africa it becomes rarer, but it is found on migration throughout the basin of the Mediterranean, from Asia Minor to Gibraltar; and it passes through the greater part of Europe on the way to and from its northern breeding-grounds, although it is scarce to the west of Heligoland.

The Red-throated Pipit makes its nest in the sides of the tussocky ridges of the bogs or tundras of the north; dry grass being the material employed, with a finer lining of the same. The eggs, $4^{-6}$ in number, vary from a nearly uniform rich mahogany colour to a greenish-grey with dark brown mottlings: average measurements 75 by ${ }^{\circ} 5 \mathrm{in}$. In late springs breeding does not commence before the last week in June, so that only one brood can be reared in the season. Its note is louder and more full than that of the MeadowPipit. The food consists principally of insects and their larvæ, small worms, molluscs and grass seeds. In its winter quarters the Red-throated Pipit is gregarious; and frequents planted fields where there is cover.

The adult male, in breeding-plumage, is distinctly more rufousbrown on the upper parts than the Meadow-Pipit, and the black streaks are more pronounced; the eye-stripe is broad and of a rufous-buff; the tail as in the Meadow-Pipit; the inner secondaries nearly equal to the primaries and longer than in the above species; the chin, throat, sides of the neck and breast vinous-chestnut; the gorget with fewer and smaller spots than in the Meadow-Pipit, but the flanks with larger ones; abdomen buff; bill dark above, yellowish below; legs and feet light brown. Length 5.8 in.; wing $3.5 \mathrm{in.}$ In the female the vinous-chestnut only extends to the throat, and her breast and flanks are more streaked with black; she is also smaller in size. In winter the red throat is only found in very old birds, and at that season the feathers of the mantle are margined with white; the general tint being greyish-brown, without the olivegreen of the Meadow-Pipit. Birds of the year are very buff-coloured on both upper and lower parts; while even in December there is a little rufous round the $\epsilon y e$ and on the cheeks, and that tint is slightly apparent on the throat. 


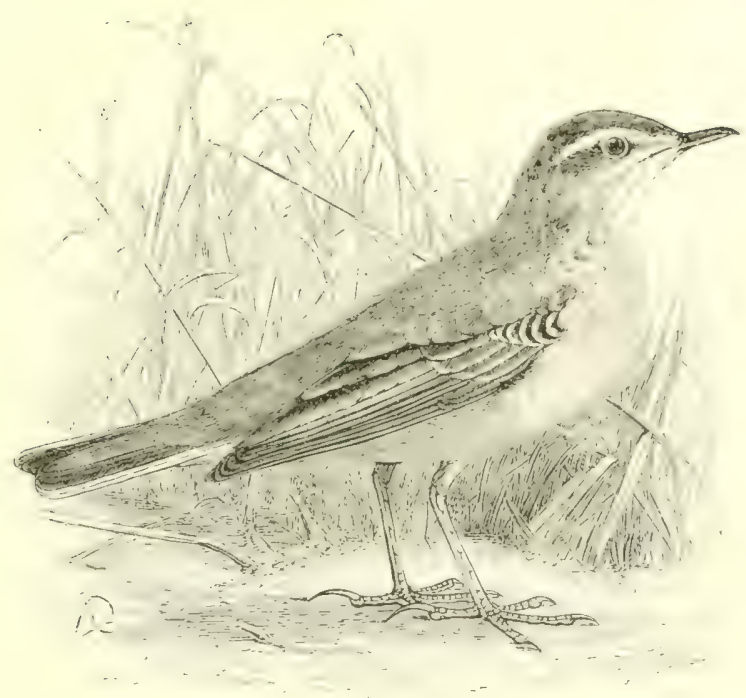

THE TAIINY PIPIT.

ANTHUS CAMPéstris (Linnæus).

The Tawny Pipit was first noticed as a straggler to our islands by the late Mr. (i. I)awson Rowley, who recognized two examples shot in autumn near Irrighton; one of which had previously been taken for a Richard's Pipit (Ibis 1863, p. 37). Since that time, up to I 886 , thirteen or fourteen have been obtained, at the same season of various years, in that vicinity ; one at Trescoe, Scilly Islands, in September I 868 ; and one at Bridlington, Lorkshire, on November 20 th I 869 ; while other occurrences may have been overlooked.

It is somewhat remarkable that the Tawny l'ipit should not have been noticed on our shores in spring, for it is an annual visitor, for the purpose of breeding, to the sandy dunes of the north of lirance and Holland, and to suitable dry wastes inland. Rare in I lenmark, it passes over Heligoland on migration, and is not uncommon in the south of Sweden; while on the islinds and the south-eastern side of the Baltic as far as Riga it is enencrally distributed in summer. Southward it occurs, either breeding or on passage, in most of the stony and arid districts of Europe, down to the Mediterrancan ; north of which it is not found in winter. In Northern Africa it is probably a resident species; whilst its migrations are known to extend to I amaraland on the west side, and to the I alie districts on 
the east. From Palestine and Asia Ninor we trace it to Turkestan and the plains of North-western India; while from Central Asia to Eastern Siberia it is represented by a smaller race of doubtful specific distinctness. It is essentially a desert-loving species, and will seldom be found, even when migrating, on fertile or wellwatered soil; but on sterile plains sprinkled with a little coarse herbage it is usually abundant, up to an elevation of about 3,000 or 4,000 feet in Europe. It crosses the Mediterranean from the end of March onwards, reaching the shores of the Baltic late in April ; while the return migration takes place in August and September.

The nest is placed at the foot of a shrub or bush - on the lee-side where there is a prevalent wind-and sometimes among growing barley; the materials being roots and dry grass, with a lining of horsehair. The eggs, 5-6 in number, are of a greyish-white, blotched and streaked with darker grey and purplish-brown; resembling, as already observed (p. 68), those of the Rufous Warbler; average measurements $S_{5}$ by $\theta_{2}$ in. The food consists of small insects, but seldom or never of seeds. This species does not collect in large flocks, like other Pipits; but it is said to be fond of bathing. The call-note is a short whit; and the song, usually uttered during a brief fluttering flight, is poor and monotonous.

The adult male in spring is sandy-brown tinged with grey on the upper parts, with dull darker centres to the feathers, more marked on the crown, but almost obsolete on the rump; over the eye a buffishwhite streak; ear-coverts ash-brown; wing-coverts dark brown with buff edges; quills and secondaries umber-brown, with tawny margins; the outer pair of tail-feathers dull white, with a large portion of the margin of the inner web brown; in the second pair the brown extends nearly to the shaft which is also brown, as are the remaining tail-feathers; from the base of the bill a faint dusky stripe ; chin and throat tawny-white; breast warmer buff slightly striated with brown; lower parts paler; bill brown above, yellowish below; legs and feet yellowish-brown. Length 6.5 in. ; wing 3.6 in. The female is slightly smaller than the male, and is said to be often without the streaks on the breast, but the least spotted bird in the series before me is a male. From the autumn moult to the early part of the following spring the tints are much more tawny, and, in young birds, are very pronounced on the margins of the wing and tailfeathers, while the brown markings of the upper parts and of the breast are much inore intense. 


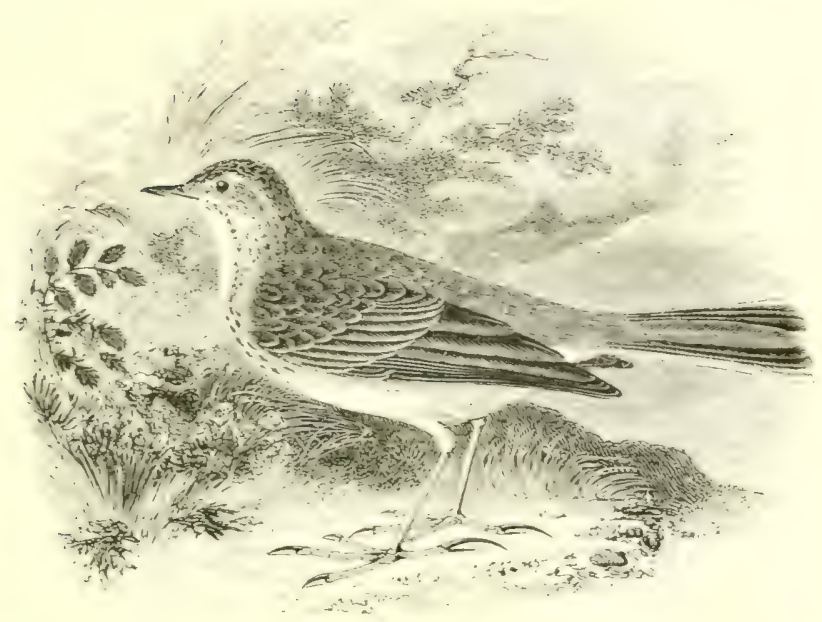

RICHARD'S PIPIT.

ANTHUS RICHÁRDI, Vieillot.

This large Pipit, distinguishable by its length of limb and extremely long hind claw, is an Eastern species which visits Western Europe irregularly on migration, generally in autumn : and at least sixty occurrences are on record in Great Britain - but none in Ireland-since i $\delta_{24}$, when Vigurs announced it as a visitor to our shores. The majority of these have been in the southern districts of England, especially on the Sussex coast: but six examples have been obtained near Yarmouth in Norfolk, three in Northumberland, one in shropshire, one-in summer-near llectwood in I ancashire, two in Cumberland, and recently, two in Warwickshire. In Scotland the only authenticated example is one obtained by Mr. I. (i. Millais, near Dunkeld, on August 2nd i $88 \circ$.

On the Continent, Richard's Pipit has been met with. as a rare straggler, in the southern districts of Norway and Sweden : but on Borkum, Heligoland, and along the coasts of Holland, lielgium and France, it is not uncommon on migration. In Central Europe it is rare, though in the south of France, especially in P'rovence, it is not unfrequent; near Mailaza and throughout the south of spain it is in some years tolerably common from November to . 1pril : while it occurs irregularly in Italy and in the basin of the Nediterrancan, occasionally visiting North . Africie. Its usual breeding-grounds are not to be found west of Turkestan; in the valley of the lenesei 
Mr. Seebohm found both old and young in August, up to $58^{\circ} \mathrm{N}$. lat.; and it nests abundantly on the elevated steppes of Eastern Turkestan, the Lake Baikal district and Mongolia. In winter it visits South China, Burma and the Indian region.

The nest is built, during the eariy part of June, in some depression in a meadow or grass-ficld; and the eggs, which, judging from the clutches obtained by Dybowski, are generally 5 in number, are greyish-white blotched with various shades of brown: average measurements $\$ 6$ by $68 \mathrm{in.}$ In Daüria the Cuckoo frequently deposits her egg in the nest of this Pipit. Two broods are sometimes reared in the season; and in September the southward migration commences. In winter it is described by Mr. Brooks as frequenting paddy-grounds and retch-nelds in Bengal, where it is very wary, keeping a sharp look-out, with head erect and outstretched neck; but Col. Legge found it very tame in the wet pastures of Ceylon. Its usual call-note is loud and calculated to attract attention, while it has also a soft double chirp like that of a Bunting. The ordinary flight is very undulating and strong. Col. Legge says this bird feeds on worms and grasshoppers, and often seizes a passing butterfly or insect on the wing. The name was conferred in honour of M. Richard, of Lunéville in Lorraine.

The male in breeding-plumage has the feathers of the upper parts sandy-brown with dark centres, jroducing a mottled Lark-like appearance; rump nearly uniform brown, tail-coverts striated; wingcoverts tipped with reddish-buff; secondaries broadly - and primaries faintly-margined with buffish-white; outer pair of tail-feathers nearly white, with only a narrow dusky margin to the inner web; in the second pair the dusky margin extends nearly to the tip, and the shaft also is brown; remaining tail-feathers very dark brown, with pale and often buffish margins to the central pair; chin white; a dotted line of brown spots from the base of the bill down each side of the neck to the grorget, which is still more spotted on a buff ground-colour extending down the flanks; abdomen dull white; bill dark brown above, yellowish below; legs and feet yellowishbrown; hind claw generally longer than the toe. Length $7^{*} 25$ in.; wing 375 in. The female is smaller, but alike in plumage. In autumn a more rufous tint pervades the upper and, still more, the under parts. In the young the pale margins to the upper feathers and the streaks on the under parts are more pronounced. A specimen in my collection, obtained at Málaga on March I 5 th, and which I take to be a bird of the previous year, is renewing its tailfeathers. 


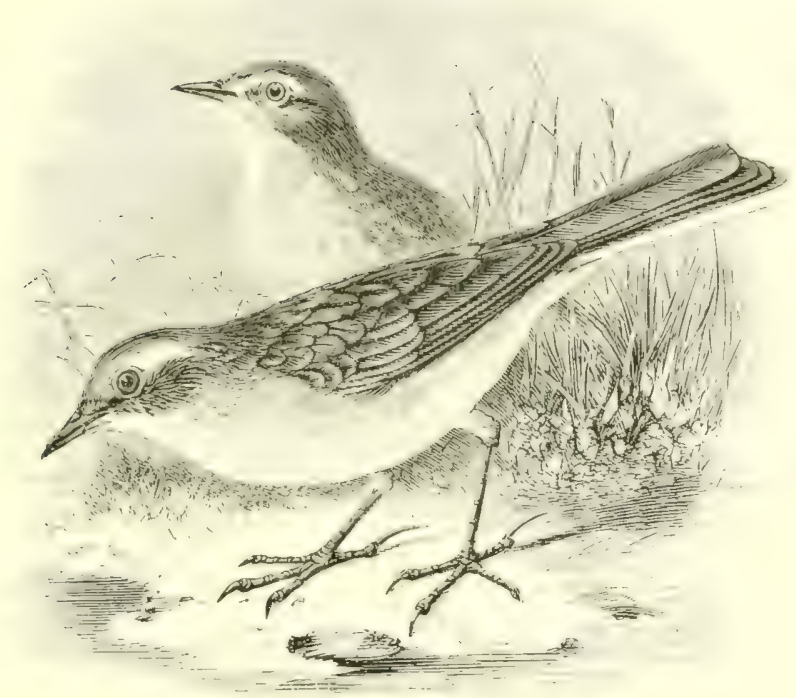

THE WATER-PIPIT'.

\section{ANTHUS SPIPOLÉTTA (Linnæus).}

The true Water-Pipit is a very rare straggler to England, but its occurrences have been estimated as more frequent than was reaily the case, owing to a confusion with the Scandinavian form of the Rock-Pipit, which occasionally visits us. The first authenticated examples of the Water-Pipit were recorded by Mr. P'ratt of Brighton, in 1864 , when one killed near that town, and another taken near Worthing, were sent to (rould for identilication. On Octoler 26 th 1868, a third was shot at Shoreham, and in March I877, one-in the collection of Mr. F. Nicholson-was obtained at Lancing. Sussex is therefore the only county in which this species has yet been recognized. It may always be distinguished from the RockPipit by the distinctly white colour of the outer part of the exterior pair of tail-feathers, and the white tips to the second pair; and, although in young birds this white is not so pure as has been asserted, it is sufficiently so to distinguish the species from even the Scandinavian form of the Rock-Pipit, which, in its turn, is brighter than our resident bird.

During the breeding-season the Water-Pipit is to be found on 
the Alps and the mountain ranges of Central Europe, the Pyrenees, and some of the higher regions in the Spanish Peninsula, even in the extreme south. On migration it occurs in Heligoland, Holland, Belgium, France, and Europe generally, down to the Mediterranean and Black Seas. In Russia it breeds in the Ural Mountains up to $64^{\circ} \mathrm{N}$. lat., and in the Caucasus; as it does in the high ranges of Asia Minor, Persia, Beluchistan, Turkestan, and in the Altai. In winter it visits the North of Africa, Egypt, Palestine, and the lower districts of Asia to Western India; being replaced to the eastward by a smaller form, A. blakistoni, which inhabits Eastern Siberia, Mongolia and China. In Japan the representative is a subspecies, $A$. japonicus, doubtfully distinct from $A$. pennsylianicus - also known as A. ludvicianus-which is found throughout North America and in Greenland; the latter has also been identified in Heligoland, and is said, but on insufficient evidence, to have occurred in Great Britain.

The Water-Pipit returns to its breeding-quarters as soon as the elevated regions are sufficiently free from snow; and early in May I observed large numbers in the Val de Lys above Luchon. The nest, loosely composed of dry grass, bents and stems, lined with a few hairs and feathers, is placed on the ground among stones, or under the shelter of a low bush; the eggs, usually 5 in number, are greyishwhite mottled with brownish-olive : average measurements 8 by 6 in. In some localities two broods are reared in the season. The song of the male is an often-repeated tit, tit, tit, uttered in the air or from the top of some tree. The food consists of insects, minute snails, and small seeds.

The adult male in breeding-plumage has a white stripe over the eye and the greyish-brown ear-coverts; upper parts greyish-brown, turning to brown on the rump; wings dark brown with pale edges to the coverts and secondaries; the exterior pair of tail-feathers white on the outer portion, the second and third pairs brown tipped with white, the remaining feathers brown; chin white; throat and breast warm vinaceous-buff; belly paler, and flanks rather browner, with a few dark streaks; bill, legs and feet brown. Length 6.25 in. ; wing $3^{\circ} 6 \mathrm{in}$. The sexes are alike in plumage. Jn autumn the vinous tint is lost, and the sides of the neck and breast are spotted with dark brown. The young bird is still more spotted, and the outer webs of the exterior pair of tail-feathers are pale brown. 


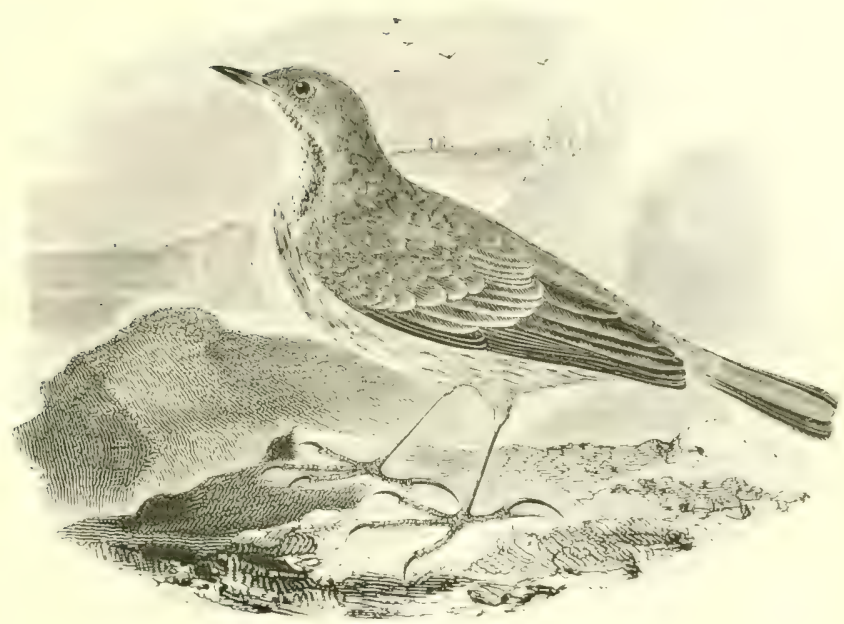

THE RUCK-PIIT.

Anthus obscúrus (Latham).

The Rock-Pipit is a resident species in the Lritish Islands, where it is essentially a shore-bird ; gencrally frequenting, during tile breeding-season, those portions of the sea-coast which are of a rocky nature-conditions which are not found between the 'Thames and Humber; although during autumn and winter it is found on salt-marshes and in the muddy estuaries where there is sea-weed. Along the east coast a migration southwards has been noticed in October. In Scotland it is abundant in suitable lucalities, especially in the west; and it is equally common in Ireland.

The Rock-P'ipit inhabits the Fieroes, but his not been obtained in Iceland or Greenland. Along the western side of Scandinavia, and in Denmark, is found a race which, in the breeding-season, exhibits a vinous tint on the breast, approaching the lue of the Water-Pipit; and birels belonging to this form have been distinguished as $A$. rupestris. Mr. Booth says that the latter used to arrive in Sussex in considerable numbers from March to April, though it never remained to breed, but of late years it seems to have changed its line of migration; it has also occurred on the east coast of Great Britain; Mr. Hancock says that he has an example shot from the nest at Chepstow, Monmouthshire, on April I8th I 854; and Mr. J. H. Gurney, jun., has one which he obtained near the Land's End. A woodcut of this form is given 
below. Our dull-coloured race is found in the Channel Islands and along the northern and western shores of France; while it is represented by the Scandinavian form to the eastward of our islands and in the Baltic. There is as yet no evidence of the occurrence of either in the Mediterranean.

The nest, generally in a clump of sea-pink, a grassy bank, or a crevice of the rocks on the sea-shore, is made of dry grasses and seatang; the eggs, $4-5$, are usually greenish-grey mottled with olivebrown, but I have seen some reddish ones, like those of a TreePipit: measurements $\cdot 8$ by $6 \mathrm{in}$. Two broods are produced in the season. The food consists of marine insects, flies, small molluses and crustaceans, for which the bird may be seen searching among the heaps of sea-weed on the shore at low water.

The adult is olive-brown with darker streaks above; the under parts dull ochreous-olive streaked with brown on the breast; much like the Water-Pipit in winter, but more olive, and the outer tailfeathers with smoke-coloured outer webs, so that the under side of the tail seems nearly uniform brown. The young are more striated. Length 6.25 in. ; wing 3.5 in.

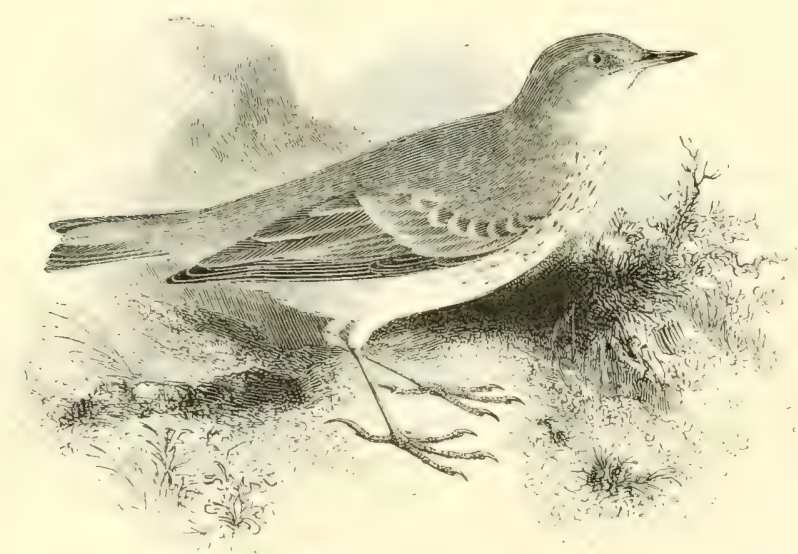

PyCnonotide. - An example of the South-African Bulbul or 'Gold-vented Thrush,' Pycnonotus capensis, was shot near Waterford, Ireland, in January ${ }_{1} \delta_{3} 8$, and skinned by Dr. R. Birkett. Considering the natural habitat of the bird, and the time of year, it is only reasonable to suppose that it had escaped from confinement. 


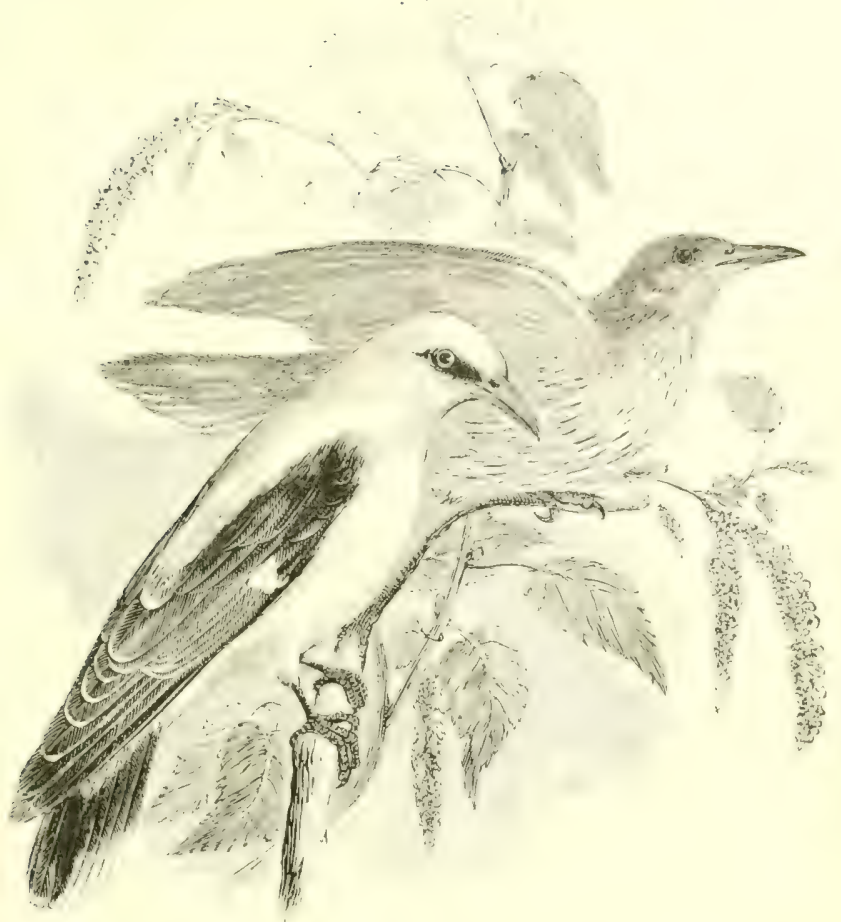

\section{THE GOLDEN ORIOLE.}

\section{Oriolus gálBula, Linñis.}

This bright-plumaged bird is an annual spring-migrant to Cornwall and the scilly Islands, where as many as forty have been seen in a single April, and it is an irregular but not unfrequent visitor to the southern and castern counties of England ; while nests have heen found - or the birds seen under circumstances which left little doubt that they were breeding - in Norfolk, Essex, Northamptonshire, Surrey, and especially in Kent. The most recent instances have been at I umpton I'ark, Isle of 'Thanet, where a pair of birds, protected by the proprictor, Mr. Bankes Tomlin, reared a brood (Harting, 'Our Summer Migrante,' p. 268) in 1874 , and again in ${ }^{1} 8_{75}$. As a rule, however, the bright plumage of this bird attracts the attention of the destroying collector, and the species is thus prevented from nesting with us annually, as it would otherwise do; for migrants generally return to the localities in which they were 
hatched. In Scotland its occurrences have been few, and mostly in the southern districts; but one is recorded from Lerwick, Shetland, in October I882. In Ireland it has occurred in the southern and eastern counties, and once in Donegal.

The Colden Oriole is a mere straggler to the south of Sweden, and has only visited Heligoland once in the last thirty years; but it breeds regularly in Finland, and in Russia rather further north than St. Petersburg. In (iermany, Holland, France and Europe generally, it is a common species during the summer in suitable localities; except, perhaps, in the eastern half of the Mediterranean basin, where, as well as in Asia Minor and Palestine, it is better known as a migrant. Eastward it is found in Asia-north of the great mountain ranges-as far as Irkutsk; but in the Indian region it is represented by $O$. Funtoo, in the adult male of which the black loral streak cxtends behind the eye, and the outer tail-feathers are entirely yellow. In North Africa the Golden Oriole breeds sparingly, and winters regularly; its migrations extending to I amaraland, Natal and Madagascar. As a straggler it has been found in Madeira and the Azores; but Kjwerbolling's assertion that one was picked up dead in the north of Iceland in December I 843 , is incredible.

The nest is placed in, and suspended from, the horizontai fork of a small branch of some tree-frequently an oak or fir-in a shady grove or thick wood, and is made of strips of pliable bark, wool, slender grass stems \&c., carefully woven together; the eggs, 4-5, are glossy white, blotched with reddish-purple: average measurements $I^{*}=b_{y} \cdot S_{+}$in. Although fond of shade, the Oriole is not a shy bird, and I have seen its nests in the avenues of trees in Ltrecht. Its food consists of insects and their larve, the young birds being principally fed on caterpillars; but fruits, especially cherries, are also eaten. The French name 'Loriot' indicates the flute-like call of the male; the alarm-note being a harsh khrr.

Adult male: most of the plumage golden-yellow; lores black; quills and wing-coverts black, tipped and margined with yellowishwhite; tail-feathers yellow at the tips and black at the bases, except the central pair which are mostly black; bill dull red; iris bright red; legs lead-grey. Length 95 in.; wing 6 in. The mature female certainly has a blackish loral streak, but the yellow is far less intense than in the male, and the under parts are striated with greyish; in less mature birds the upper parts are only greenishyellow; but I have tried in vain to obtain any proof of Blyth's theory that the mature female assumes the plumage of the adult male. 'The young are browner and greener than the female. 


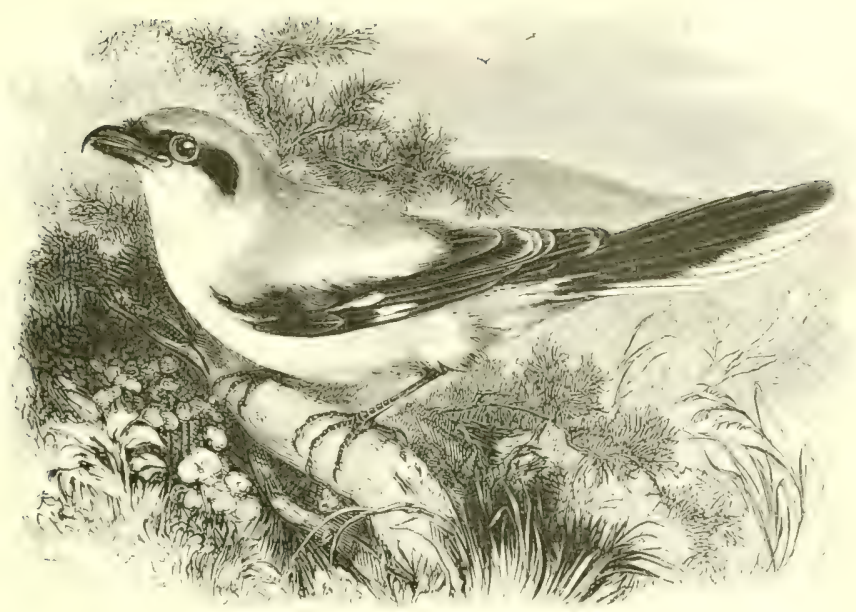

THE GREAT GREY SHRIKE.

\section{LÁNIUS ExcúbITOR, Linnæus.}

The Great Grey Shrike is a reguiar, conspicuous, and fairly abundant visitor from the Continent to the British Islands in autumn and winter; while in England it has occasionally been observed in summer, although there is no evidence that it has ever bred there. It is naturally more frequent on the eastern side than on the west, but though records are wanting from the I lebrides, it has occurred in the Orkneys and was seen by Sixby in the Shethands. To Ireland, according to Mr. More, it is a rare and uncertain visitor in winter.

Many of the specimens obtained in winter have a white bar on the primaries only, the bases of the secondaries being black; whereas in the typical $L$. cxcubitor the bases of the secondaries are white, and the wing cabibits a clouble bar. The form with only one bar is the L. major of Pallas, and, as shown by Prof. Collett (Ibis I886, pp. 30-40) it meets and interbreeds with $L$. excubitor in Scandinavia, typical examples of both races being actually found in the same brood, while intermediate forms are not uncommon. Where the sexes have been determined, the double-harred bird has generally proved to be a male, and the single-barred a female. Typical I. ciculutur breeds as for cast as st. l'etersburis, beyond which, in Siberia, L. major becomes the representative form. In the valley of the lenesei the latter meets, but does not interbreed with, the whiter-winged I. likneftrms; the last ranging through 
Turkestan to Southern Russia, where, by its union with the typical $L$. excutitor, it seems to have produced an intermediate race, known as $L$. homeyeri. Space will not allow me to say more.

A Grey Shrike of some kind was seen in Iceland in 1845 by John Pell the falconer; and, as already shown, two forms occur and interbreed in Northern Europe, up to the Arctic circle. In winter they are forced to leave the high north, but even in Central Germany the typical L. cucubitor often remains throughout the winter, and comparatively few of either form extend their migrations to the shores of the Mediterranean, although in the Black Sea region they are more numerous. The south-east of France and the Spanish Peninsula are occupied by a distinct and resident species, L. miridionalis, with vinous-coloured breast, while in Morocco and Algeria we find L. alsiriensis; these two species never crossing the Mediterranean. The (ireat Grey Shrike with the double white bar, breeds in considerable numbers in the north of France, Pelgium, Holland, Germany and Central Europe.

From the middle of Nay onwards the rather bulky nest of twigs, roots and moss, lined with wool, hair and feathers, is built at the top of a fir, or high up in some other tree. The eggs, 5-7, are greenish-white, spotted and zoned with olive-brown and violet-grey : average measurements $I$ ' $\mathrm{I}$ by $S \mathrm{in}$. The food consists largely of lizards, mice, shrews, small or young birds, frogs and insects, especially beetles and grasshoppers; the indigestible portions being thrown up in pellets. Like other members of the family, this species impales its prey on long sharp thorns; whence the name of 'Butcher-bird'; while its fondness for sitting, like a sentinel, on a lofty and conspicuous perch has earned for it the name of cxcubitor. The alarm-note is a sharp shake, shake; the call-note truii.

Adult male: forehead and a line over each eye white; lores, cheeks and ear-coverts black; upper parts pearl-grey, turning to white on the scapulars; wing-feathers black with white bases to the primaries, and in the typical L. excubitor; also to the secondaries, which, with the inner primaries, are tipped with white; outer tail-feathers white; in the others the black at their bases increases until the central ones are entirely black; under parts white; bill, legs and feet blackish. Length 9.5; wing 4.5 in. Female: duller, and the breast faintly marked with greyish semilunar bars. Young: dull greyish-brown above, and more barred on the under parts. 


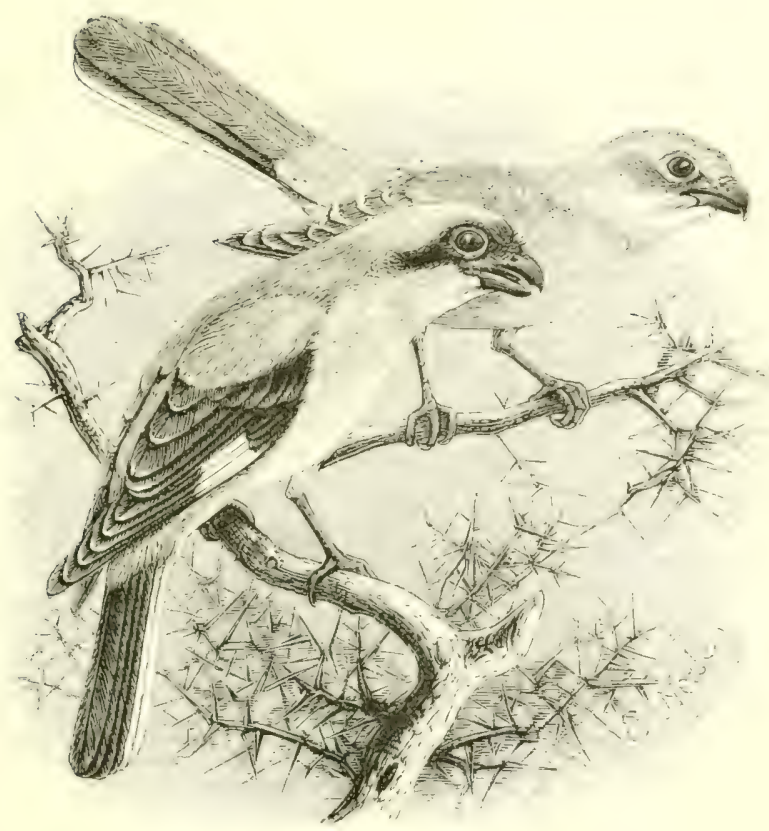

THE LESSER GREY SHRIKE.

LANiUS MiNOR, J. F. Gmelin.

The Lesser Grey Shrike is an annual summer-visitor to the southern and central portions of Europe, and, on migration, it occasionaily wanders to England. Early in November I85 I, a female was killed in the Scilly Islands; in the spring of I869 the Rev. Murray A. Mathew received one from Great Yarmouth, where another was taken in May 1875 ; and on September 23 rd I876, a bird of the year, identified by the late Mr. Gatcombe, was taken alive near Plymouth.

It is doubtful if the Lesser Grey Shrike hos occurred in the south of Sweden or in Denmark; while it is distinctly rare on passage in Heligoland, as well as in Holland, liclgitm and the north of France. Eastward, it is not uncommon along the southern shores of the Baltic, and it has even wandered to Finland; while in the south it is generally distributed over Europe as far west as the valley of the Rhone and Provence. It may perhaps visit Catalonia on the east side of Spain, but it is unknown in the south and west. It is common in Italy, Sicily, Dalmatia, Greece, Turkey, Asia 
Minor and Palestine, where it frequents the outskirts of cultivation on the lower ground; but does not ascend to the elevated regions. In all the above countries it is only known in summer or on migration; and its winter quarters appear to be in Africa, where it goes as far south as Damaraland on the west, and the Orange Free State on the east. In Asia it is found from Persia to Omsk in $57^{\circ} \mathrm{N}$. lat., and eastward, to Lake Zaisan in long. $84^{\circ}$. It arrives in Germany between April 24th and May 7 th; remaining till between August ISth and September Ioth (Rey); but in Southeastern Europe it stays until October.

The nest, commenced about the middle of May, is generally placed at least ten feet from the ground, in an oak, wild pear or crab, and, in Greece, frequently in an olive-tree. It is composed of twigs, dry roots, aromatic field-flowers and green grasses, with a lining of wool, hair and feathers ; the eggs, $5^{-7}$ in number, are pale bluish-green, blotched with olive-brown and ash-colour: average measurements 98 by 77 in. Incubation, shared by both sexes, lasts fifteen days, and during the breeding-season the birds are very quarrelsome, driving even Crows and Magpies from the vicinity of their nest. Like most Shrikes, this species is fond of perching on the topmost branch of a tree or other elevated position, whence it darts with rapidity upon its prey, sometimes gliding with extended and unmoved wings for a short distance. Its food consists of beetles and other insects, seldom impaled on thorns, but devoured while held in the bird's foot: in the season, however, cherries, figs and other fruits are eaten. The note is described by Naumann as a harsh kjuick, kjick, but the song of other birds is often imitated.

Adult male: forehead, eye and ear-coverts black; cheeks white; nape and back grey, rather paler on the rump; wings black, slightly tipped with white on the secondaries, and with white bases to the primaries, forming a broad single bar; central tail-feathers black; in the others the bases and tips are white, which gradually encroaches upon the black until the outside pair are entirely white; under parts white, suffused with a rosy blush on the breast and flanks; hill, legs and feet blackish. Length 8.5 in.; wing $4^{.6}$ in. The female and immature male have less black on the forehead. The young bird-the upper figure in the woodcut-has no black on the forehead, and the under parts are dull yellowish-white, mottled with grey transverse lines. This species may be distinguished from all other Grey Shrikes by its wing formula; the ist or bastard primary being very short, while the and nearly equals the 3 rd and longest primary. 


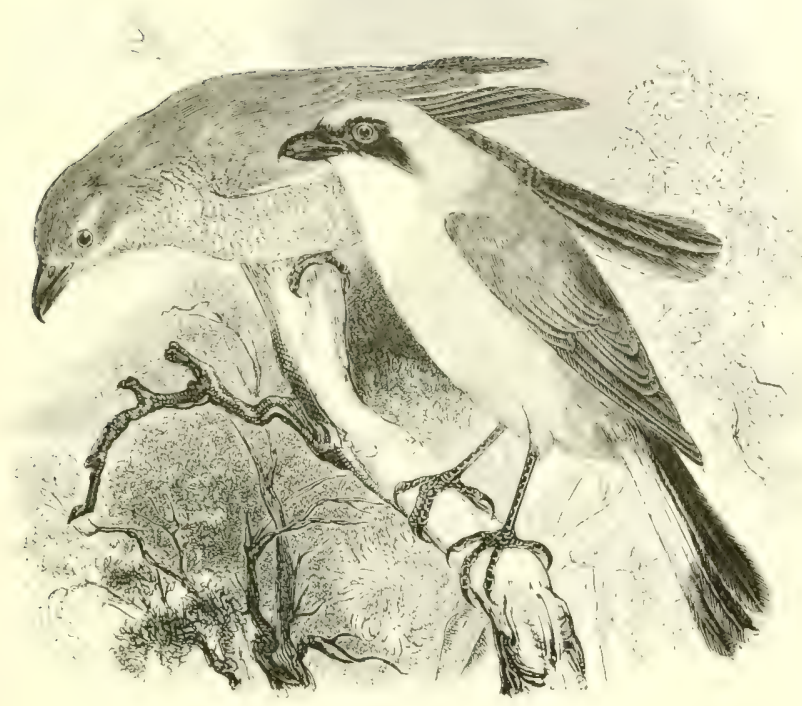

THE RED-BACKED SHRIKE.

\section{LANiUS COLLÚRIo, Linnæus.}

This Shrike, by far the commonest of our British species, arrives in the south of England very early in May, being, as a rule, generally distributed during the summer throughout the wooded districts of the southern and central counties, and in Wales. In Norfolk, however, it appears to be decreasing; in I.incolnshire it is almost unknown; while in Yorkshire, and northward, it is of irregular occurrence, and is said to be rarer than in former years. In the south-east of Scotland it has occasionally been known to breed, but it is very rare in the south-west, and an exceptional visitor to the north. In the Shetlands, however, Saxby says that he shot a young male on Octoler 5 th 1866 , and that on $F$ mene gth I 870 , he saw a female Red-backed Shrike followed by three young birds already tolerably strong on the wing : a remarkable experience, seeing that even in the south of England eggs are hardly laid by the middle of May, and require a fortnight's incubation! In Ireland the only example on record was shot on lugust ioth is 78 , near Belfast. 
In summer the Red-backed Shrike is found in Scandinavia and Northern Europe as high as about $64^{\circ} \mathrm{N}$. lat., and southward, throughout the greater part of the Continent; but in the south-west it appears to be rare, for Mr. Tait only once obtained it - with its nest -in the north of Portugal; while one, shot by Mr. Abel Chapman on April roth, is the only specimen recorded from Southern Spain. Comparatively few, in fact, remain to breed in the basin of the Mediterranean, although the bird is common in some parts on passage ; but eastward it is found nesting on the high grounds of Hermon and Lebanon, and through Asia Minor, Northern Persia, and Turkestan, to the Altai Mountains. In winter its migrations extend along both sides of Africa to Natal and Cape Colony, and it has even been said to breed in the southern districts.

The nest, large for the size of the bird, is usually placed about five or six feet from the ground, in a thick thorn-bush or strong hedge, and is made of stalks of plants, moss and roots, with a lining of bents, wool and hair. The eggs, 4-6, vary considerably, some having the ground-colour of a greenish-white, others of a yellowishclay, and some of a salmon tint spotted and zoned with brown, olive, or lilac, and blotched with two shades of light red and violet-grey: average measurements 88 by $65 \mathrm{in}$. Only one brood is reared in the season; the majority taking their departure in August in family parties, and before their moult; although the capture of a young bird is recorded on November 11 th 1869 , when in pursuit of a Wren. This Shrike feeds on mice, lizards, beetles, humble-bees, wasps and other insects; there is evidence that it will attack and kill almost any bird up to its own size; and like its congeners, it impales its prey on thorns. The alarm-note is a harsh chack, but the male has a rather sweet song, and is also a good mimic.

The adult male has the frontal band, lores and car-coverts black; crown and nape srey; mantle chestnut-brown; wing-feathers dark brown edged with rufous; tail-coverts grey; tail-feathers-except the central pair which ore mostly black-white at their bases and black on the distal portion, the whole with black shafts and narrow white tips; chin white; under parts rose-buff; bill, legs and feet black. Length 7 in. ; wing 3.7 in. The female ordinarily has the upper parts and tail russet-brown with faint crescentic bars on the mantle, and the under parts buffish-white with greyish-brown semilunar bars; but instances are on record of the assumption of a plumage similar to that of the male. The young bird is whiter on the forehead, duller and less rufous-brown on the upper parts, more barred both above and below, and the legs are iron-grey. 


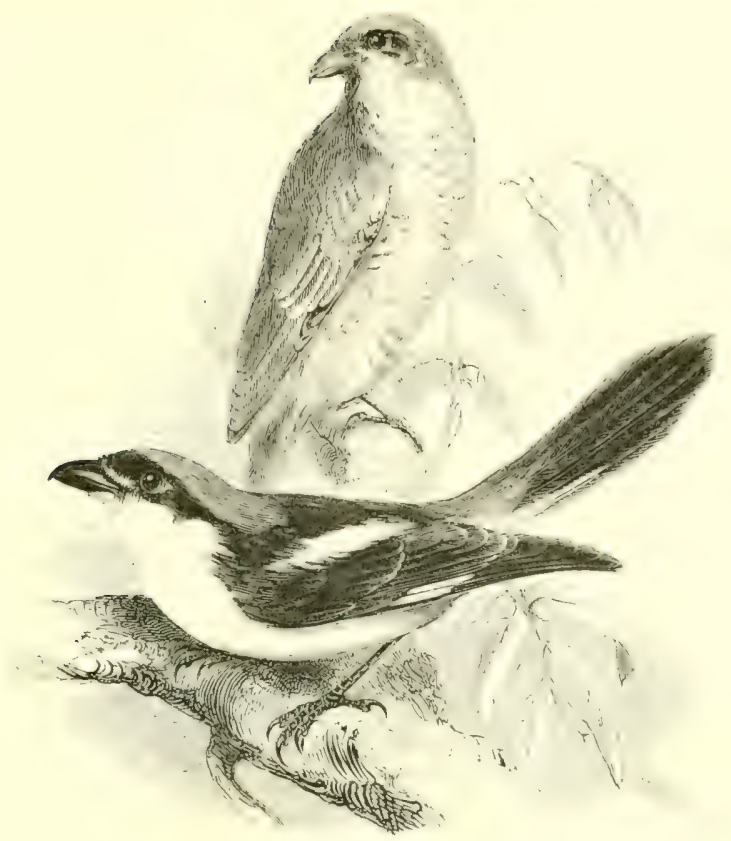

THE WOODCHAT.

LANIUS POMERÁNUS, Sparrman.

Although a common species during the breeding-season on the opposite shores of the Continent, the Woodchat Shrike only crosses the narrow seas at irregular intervals, and not more than thirty examples are known to have been obtained in England during the last hundred years. The majority of these have been noticed in the southern and eastern districts, and gencrally at the time of migration; but there is evidence that the bird has nested twice near Freshwater in the Isle of Wight, and westward, it has been known to occur as far as ('ornwall. Northward, it has been identified on rare occasions up, to Vorkshire, Lancashire, Cumberland and Northumberland; but there is no proof that it has risited Scotland or Ireland.

On the Continent the Woodchat breeds as far to the north-east as the line of the Baltic and the valley of the Vistula, beyond which it is of accidental occurrence; while southward it is generally distributed throughout Europe, and in the countries bordering on the Mediterranean is very abundant. Lien there, however, it is 
only a visitor; arriving about the end of Narch, or early in April, and leaving again between August and October. Eastward, it breeds in South Russia, Turkey, Asia Minor, Palestine and Persia; while in winter it occurs in Arabia, and down the East African coast to about $5^{\circ} \mathrm{N}$. lat., also on the west side to the Gambia and the Gold Coast. Throughout Northern Africa it is abundant in summer, arriving from the southern side of the Sahara in March.

The nest, composed of a variety of materials and frequently adorned with the flowers of aromatic plants, is placed in the fork of a branch of almost any kind of tree, without the slightest attempt at concealment. The eggs, usually 5 in number, are, as a rule, rather larger than those of the Red-backed Shrike, but similar in colour; the exception being the red variety, which, although not unknown, is very rare: average measurements 92 by 68 in. In its habits and its food this species resembles other Shrikes, though insects of various kinds, especially grasshoppers and beetles, appear to form a larger proportion of its diet; it is also very fond of bathing. The note usually heard is a harsh krall kacis krah; but the male has also a low and rather pretty song in spring, and shows great capacity for imitating the notes of other birds.

The adult male, represented in the lower figure, has an elongated white spot above each nostril ; forehead, lores, ear-coverts, sides of neck and back black; crown and nape chestnut-red; scapulars conspicuously white; wing-feathers blackish, with white bases to the primaries, forming a single bar; coverts and secondaries tipped with buffish-white; lower back grey; tail-coverts nearly white above, turning to grey telow; tail-feathers chiefly black with white tips and with white outer webs and bases to the exterior pair; under parts buffish-white, darker on the flanks. Length $7^{\circ} \mathrm{I}$ in.; wing $3^{*} 9$ in. The female has all the colours less bright and the upper parts tinged with rufous and buff. The young bird, represented in the upper figure, is russet, streaked and mottled with darker brown and dull white on the upper parts, and with wide rufous margins to the quills; under parts much barred with brownish; bill yellowish-horn.

Vireonid ж.-Mr. Edwin Brown (Mosley's Nat. Hist. of Tutbury, pp. 94 and $3 S_{5}$, pl. 6) has described and figured a male of the American Red-eyed 'Flycatcher,' Vireo olizaceus, which a Derby bird-catcher known as 'Hatter Dick' asserted that he had captured, with a female not preserved, at Chellaston in May 1859 . Several species have been admitted to the British list on no better evidence! 


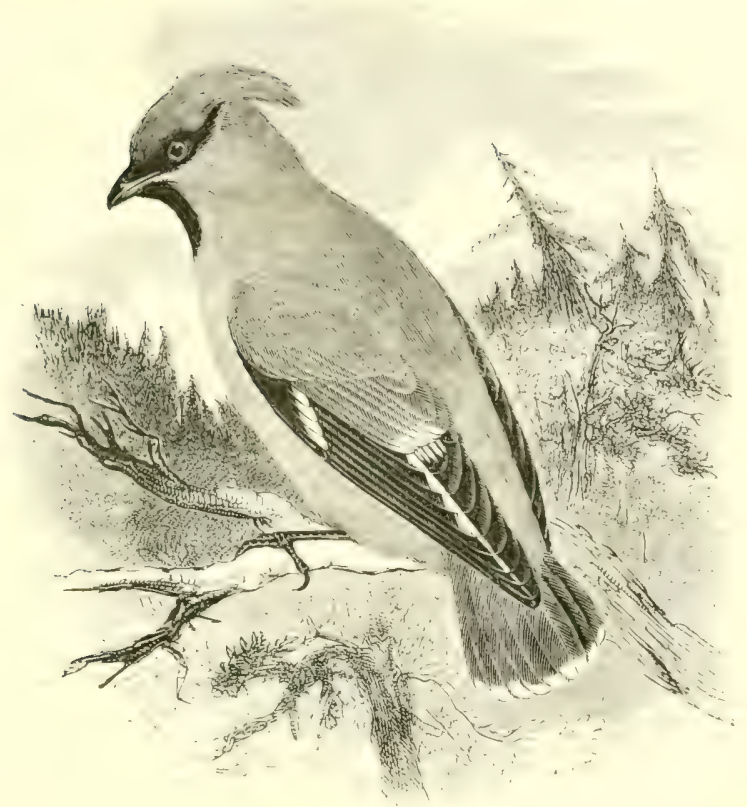

THE WAXWING.

Ámpelis gárrulus, Ijinnæus.

For upwards of two centuries this beautiful bird has been known to visit our islands at irregular intervals, and sometimes, as in the winters of $\mathrm{I} 686$, I830-3I, I8 $34-35$, I849-50, I866-67, and $1872-3$, in considerable numbers. As might be expected in the case of an inhabitant of the Arctic regions, the visits of the Waxwing have been more frequent in the northern and eastern portions of Great Britain than on the western side, and do not appear to have extended to the Outer Hebrides; while to Ireland they have been few and far between. In England it has been obtained in almost every county, including the south and the extreme south-west ; and on the spring migration, in Norfolk up to the first week in Nay. Its visits depend on the severity of the weather on the Continent, but it does not follow that the same winter should be rigorous in the British Islands

The wanderings of the Waxwing are not known to extend in a south-westerly direction as far as the lyrences or the Spanish Peninsula; but from Provence, in the south-east of France, we can trace them across the northern districts of Italy to Turkey. In 
summer the bird inhabits the Arctic regions, within the limits of tree-growth, in Europe and Asia; but it is very erratic, nesting for some seasons in large numbers in certain districts and then suddenly abandoning them. Its breeding-range extends across Bering Strait to Alaska and the Rocky Mountains, while in winter the United States-exceptionally as far south as $35^{\circ} \mathrm{N}$. lat.-are visited. The representative species in temperate North America is the Cedarbird, $A$. cedromm, which is rather smaller, without any white or yellow on the wings, and is erroneously stated to have visited Great Britain. Our Waxwing occurs in winter in Japan and Northern China, but there the resident species is A. flu'nicoftera, which has red markings on the wings and tail, but no wax-like tips.

The account of the discovery of the breeding of the Waxwing, with which the name of Wolley will always be associated, has been given by his friend and sometime companion Professor Newton, in 'The Ibis' for I86I (pp. 92-106), and in the 4th Edition of 'Yarrell's British Birds.' My limits will only allow me to say that the first nests and eggs were found in ${ }_{1} S_{5} 6$ in Russian Lapland, since which a great many have been taken; and the breeding-range is now known to extend westward to the north-eastern portion of Norway, and southward to about $65^{\circ} \mathrm{N}$. lat., on the shores of the Gulf of Bothnia. Open portions of the forest appear to be preferred; the rather large nest being placed on a branch of a spruce, Scotch fir, or birch, and mainly composed of the lichen known as tree-hair, on a platform of dead twigs. The eggs, $5-7$, are pale purplish-grey, blotched and streaked with sereral shades of brown and lilac: average measurements 97 by 68 in. In summer the food of the Waxwing consists of crane-flies and other insects, but later on hips, juniper and other berries are eaten roraciously. The only note of this almost silent bird is a low cir-ir-ir-ir-re (Seebohm).

Adult male: frontal band, lores, eye-region and chin black ; forehead and sides of the crest chestnut-brown; general plumage light greyish-brown, shading into ash-grey on the rump and abdomen; wing-corerts black, tipjed with white; secondaries spotted with white at the end of the outer web, and with tips like red sealingwax; primaries black, with $\mathrm{V}$-shaped white and yellow borders; tail blackish, terminated by a broad yellow band, and, in mature birds, with small red wax-like tips; under tail-coverts chestnut; bill, legs and feet black. Length 7.5 in.; wing 4.5 in. Female: rather duller, with fewer wax-like tips and generally without the white edges to the imner webs of the primaries. Young : browner and without the black throat. 


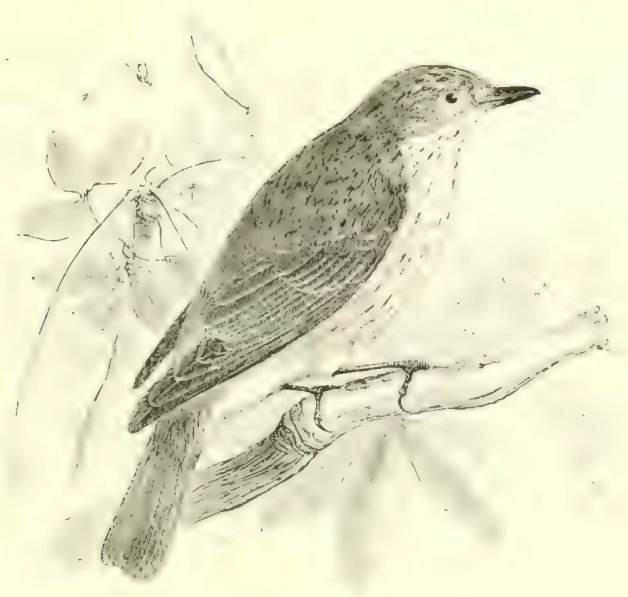

THE SPOT'TEI) FLYCATCHER.

Mt'scicapa grísola, Linnæus.

The Spotted Flycatcher is often said to be one of the latest spring-visitors to our islands; nevertheless it has been observed exceptionally in our castern counties as early as $A_{p}$ ril $23 \mathrm{rd}$, and at Carlisle one day earlier, while the usual date of its appearance in the south is about the first week in May; and even in this remarkably cold backward spring of ISSS, I watched an evidently new arrival feeding in Kensington (iardens on the ist of that month. During the summer it is generally distributed throughout Great Britain, becoming rarer towards the north; although even there it has been found nesting in Sutherland and caithness, and to as far westward as Skye. At present it appears to be merely a wanderer to the Orkneys and shetlands. Mr. More states that it is a regular summer-visitor to Ireland, but on the west side it does not arrive before the latter half of May.

The Spotted Flycatcher breeds as far north as Tromsio in Norway and Archangel in Russia; while southwerd it is tolerably abundant throughout Europe, nesting down to the northern shores of the Mediterranean; also on the African side, and in M lia Minor, Palestine, Persia, Turkestan, and Siberia as far as Irkutsk. In winter it visits India, Arabia, and Africa to the Cape of Good Hope. It leaves our islands and the northern portion of Europe in September, but in the south the abundance of insect food enables it to 
remain later; and in Asia Minor it has even been obtained late in November.

The nest is frequently placed among creepers, or in a hole in a wall or a tree; occasionally behind loose bark; often on a beam in an outbuilding, whence the name of 'Beam-bird'; and sometimes in such odd situations as the top of a door-hinge, the inside of a lamp or of a stove, \&c. The structure, which is rather neat and well assimilated to its surroundings, is generally of moss and lichens, warmly lined with wool, hair and feathers. The eggs, $4^{-6}$ in number, vary from bluish-white to pale green in ground-colour, which is spotted and clouded with rusty-brown: average measurements 75 by 55 in. Incubation is said to devolve entirely upon the female, who is fed by the male; and two broods are not unfrequently produced in the season, the first being hatched by the middle of June. The Spotted Flycatcher is one of the few species which still nest in some of our London parks and gardens. Its food consists principally of insects, and the bird may often be scen sitting on a fence or branch, whence it darts upon some fly or gnat, returning with a graceful sweep to the spot it has just quitted. It can even manage a tolerably large moth, such as the yellow underwing; and in the autumn, it has been known to feed on berries, especially those of the mountain-ash, to which so many species of birds are partial. The song is very faint and low, and the call-note is a zt-chick.

The adult has the crown light brown, with dark streaks down the centre of the feathers; upper parts hair-brown, slightly darker on the wings and tail, and paler on the margins of the wing-coverts and secondaries; chin and under parts dull white, with brown streaks on the throat, breast and flanks; bill dark brown; legs and feet blackish. The sexes are alike in plumage. Length 5.6 in.; wing 3.3 in. The young are very much spotted; the feathers of the upper parts have pale centres with broad dark margins, and the wing- and tail-coverts are conspicuously tipped with buff, as are also the secondaries. 


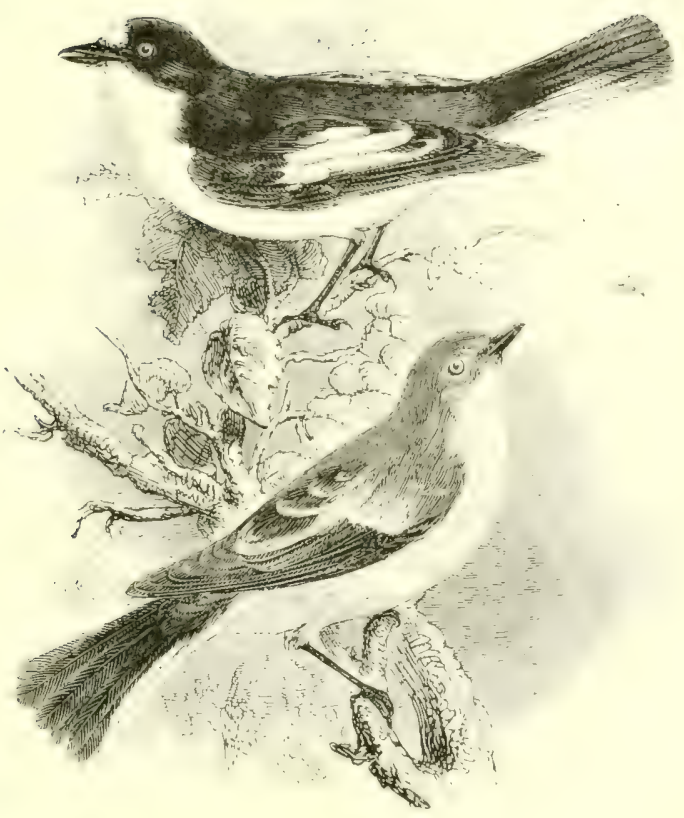

THE PIED FLYCATCHER.

MUSCICAI'A ATRICAPÍLLA. Linnæus.

Although far less numerous than the preceding species, the I'ied Flycatcher is a regular visitor to (ireat Britain, arriving in the latter part of April and returning southward in autumn. Large numbers have sometimes been observed during the first week in Miay on the Pentland Skerries, the Isle of May, and Flamborough and Spurn in Vorkshire; and a return migration has been noticed in August and September; while in the latter month immense flights have passed over Heligoland. During the breeding-season it is a very local species, and although nests are said to have been found occasionally in Devon, Somerset, Dorset, IIants, Surrey, Middlesex, Oxford, Gloucester and some of the other southern countics, its farourite haunts are rather in the north and west. In portions of Wales, such as Brecon, Denbigh and Merioneth, and in the English counties of the Welsh border, it nests annually; also in Lancashire, some parts of Yorkshire, I)urham and Nothumberland: but its head-quarters are in Westmoreland and Cumberland, where it ap- 
pears to be on the increase. In Scotland it is much rarer, but it is said to have bred as far north as Inverness-shire, and it has occurred in the Orkneys on migration. In Ireland an adult female was shot by Mr. R. Warren at Moyview, co. Sligo, on April Igth I 875 , and in the autumn of I 886 two examples were killed by striking against lighthouses.

A wanderer to the Freroes, the Pied Flycatcher breeds regularly up to $69^{\circ} \mathrm{N}$. lat. in Scandinavia, $65^{\circ}$ in Finland, and about $60^{\circ}$ in Northern Russia to the Ural Mountains; southward, in suitable wooded localities, throughout the greater part of Europe down to the centre of Spain; and eastward, as far as Palestine; while it has been met with in Northern Persia. In Algeria it is said to be a resident species, its migrations extending to the Canaries, and down the west side of Africa to the Cambia, as well as on the east side to Egypt.

The nest is generally placed in a hole in a tree in rather thin groves of old oaks, birches or aspens, the same spot being resorted to in successive seasons; occasionally holes in walls are utilized. It is made of dry grass and roots, with a lining of hair ; the eggs, 6-9, laid from the middle of May to the first week in June, are pale blue, with, occasionally, a few fine specks of reddish-brown : average measurements 68 by 52 in. Like its congener, the Pied Flycatcher feeds principally upon insects, but it does not so often catch them on the wing, preferring to take up its position at the extremity of a dead bough, whence it can dart upon them in the grass beneath; and it is frequently to be seen among the highest branches of forest trees (Macpherson). The song resembles that of the Redstart.

The adult male in breeding-plumage is black on the upper parts, with a white frontal band, conspicuous white outer margins to the secondaries, and an obscure band of grey across the rump; under parts white; bill, legs and feet black. Length 5 in.; wing $3 . \mathrm{I}$ in. Less mature males show some white on the outer margins of the two exterior pairs of tail-feathers. After the autumn moult the upper parts are somewhat browner, but the white frontal patch is always present. In the female the frontlet, wing-patches and under parts, are buffish-white, and the upper parts are olive-brown. The young bird in nestling-plumage is mottled on the back like the spotted Flycatcher, but the white on the wings is very conspicuous in the male. The upper figure represents a male in breedingplumage; the lower one a young male killed in September.

The White-collared Flycatcher, $M$. collinis, was introduced by Gould to the British list, but there is no proof of its occurrence in England. The male has a white frontlet and collar. 


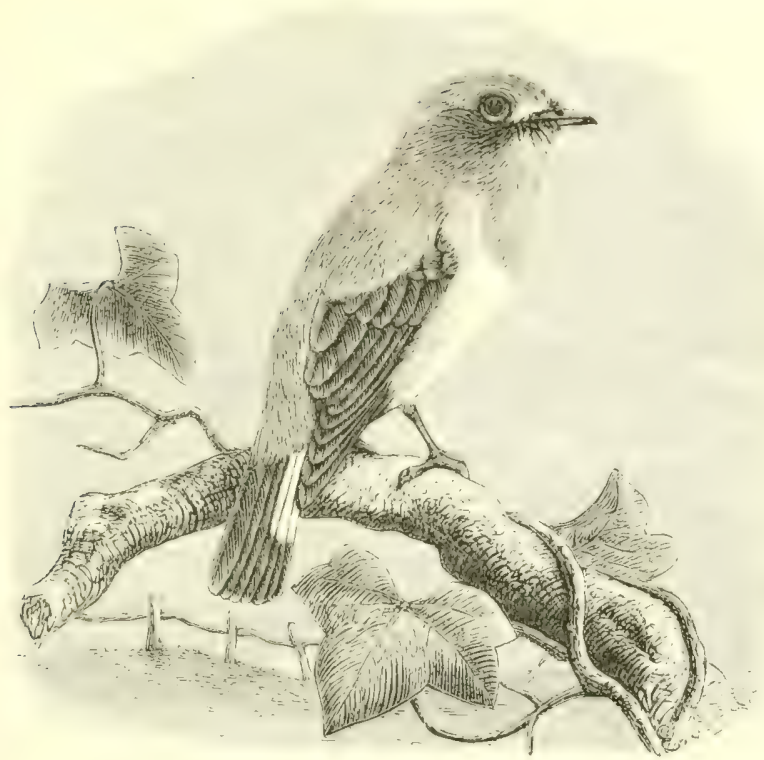

THE REI-BREASTEI） FLYCATCHER.

Muscicapa PARVA, Bechstein.

This small Flycatcher is one of those species which, like the Isabelline and 1)esert Wheatears, have their usual habitat to the east of our island, but in autumn and winter often migrate in a westerly direction. Its orcurrence in England was first noticed near Falmouth, where two cxamples were seen for several days, and one-a female - was shot on January 24 th 1863 . In the October following, a young male was oltatined on one of the Scilly Islands; and on November $5^{\text {th }}$ i $86_{5}$, a bird so damaged by shot that its sex could not be determined, was taken on Trescoe. On October $5^{\text {th }}$ I $88_{3}$, a young male was killed by $\mathrm{Mr}$. G. Bolam in his garden at Berwick-on-Tweed.

As a straggler the Red-breasted Flycatcher has been taken in Denmark and off the south coist of sweden, and two examples have been obtained in atumn on I teligoland. It breeds sparingly in North-eastern (iermany and in the St. Petershurg district, soutl of which, in Central Jurope, it becomes more plentiful in summer, though very local. To the south-east of france it is an occasional risitor; and, from the accurate description of a careful olsserver, I 
have no doubt of its irregular occurrence, during winter, in the south-west of sprain. Though only a migrant in Italy, the islands of the Mediterranean, Greece, and the Black Sea region, it breeds in Southern Russia, the Caucasus and Northern P'ersia; while eastward, it occurs in 'Turkestan, and in Siberia as far as Lake Baikal, where it probably nests, as it visits Northern India and China in winter; but in that direction its range can with difficulty be traced, owing to the intrusion of a doubtfully distinct species. The winter migrations of our bird extend to Nubia. It arrives in Northern Germany in May, generally leaving early in September; and it appears to be partial to beech-woods, or those where beech and fir are intermixed.

The nest, built about the beginning of June, is rather deep and cup-shaped, neatly formed of moss and a few lichens, with a lining of dry grass and hair. It is ustrally placed in a hole in the trunk or some rotten branch of a beech-tree, but occasionally in a fork against the stem, from six to ten feet from the ground. In appearance the eggs, $5^{-7}$ in number, are intermediate between those of the Redbreast and the Spotted Flycatcher; having a very pale greenish ground-colour, with mottlings of rusty-brown: average measurements $6_{3}$ by ${ }_{5}$ in. The young are hatched by the end of June, and their food, like that of the adults, consists of insects, in search of which the birds soon leave their breeding-grounds in the forests for the gardens and orchards of the vicinity. The habits of this species are lively and active, and in pugnacity, as in plumage, the male resembles our Redbreast. It has a pleasant song, resembling the syllables tio' $i$ several times repeated, while the alarm-note is a clear pink, pink.

The adult male in breeding-plumage has the cheeks ash-grey; crown and nape browner grey; upper parts in general wood-brown; tail (of twelve feathers) rather darker brown, with conspicuous white bases to all except the central pair; chin, throat and upper breast reddish-orange ; belly white ; sides and flanks pale buff; bill brown ; legs dark brown. Length $4 \cdot 5$ in.; wing $2 \cdot 8 \mathrm{in}$. The female has no ash-grey on the head and her throat is merely reddish-buff. The young have a spotted nestling-plumage, and afterwards the wingcoverts and secondaries are tipped with buff; otherwise they resemble the female. The male breeds in the immature plumage of the first year, while the orange-red on the throat does not extend to the breast until after the third moult. 


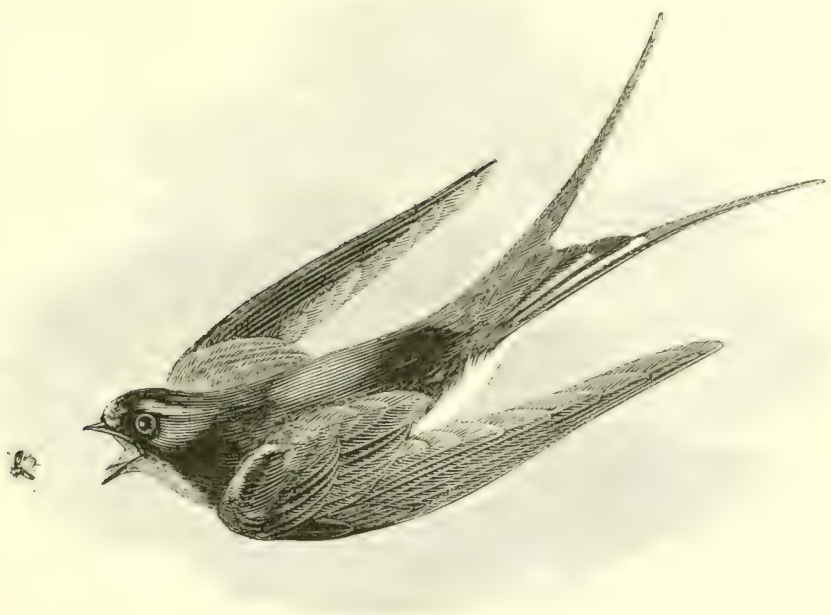

THE SIVALLOW.

HIRÚNDO RÚSTICA, Linnæus.

This well-known summer-visitor usually arrives in the southern portions of our islands during the first half of April, and thenceforward it is generally distributed, although somewhat scarce and local in the extreme north, and decreasing in the north-west. It visits the Outer Hebrides, and will probably be found to breed there, exceptionally, as is the case in the Orkneys and Shetlands.

The Swallow occurs in the Froes in Nay, and has been known to stray to Iceland, Spitsbergen and Novaya Zemlya. It nests in Scandinavia up to $70^{\circ} \mathrm{N}$. lat., but not quite as far as the Arctic circle in Russia : eastward and southward, its breeding-range extends over Europe, Asia north — as a rule - of the great mountain ranges, and Northern Africa; while during winter it is found throughout the Indian region as far as liuma and the Malayan peninsula, and all over Africa. My space will not permit a discussion of its allies, and I must refer my readers to Mr. R. B. Sharpe's excellent remarks in the 'Cat. Birds Brit. Mus.' vol. x., especially those on pp. 126-I27; merely observing that, by way of Asia, a connection appears to be established near lake Baikal with the Xorth American Swallow, II. aythergaster of Boddacrt, better known as $I I$. horreomm. The latter, although found in (ireenland, does not cross the Atlantic to us, nor has our bird been observed further west than 
about 180 miles beyond the Azores. In Egypt there is a resident subspecies, $H$. sarizmii, with the under parts nearly as ruddy as the throat.

The nest was, no doubt, originally built in caves, and even now these are sometimes resorted to, but at the present day it is usually placed about human habitations or buildings of some kind; often it is in chimneys, though almost any ledge or projection will serve; while exceptionally it has been found in forks of boughs of trees, and in even more remarkable sites. Mud, with a mixture of short straws, and a lining of feathers and fine grasses, is the material employed, and the structure has generally the shape of half a saucer; the eggrs, usually $+^{-6}$, are white, blotched and speckled with several shades of grey and brown: average measurements $S_{2}$ by $5+$ in. Two broods are produced in the season, but I have known even three hatched by the same pair of (marked) birds, although I believe that the last brood, still in the nest on October 23 rd, was not reared. Belated individuals are said to have been observed in England during the winter months. To the extreme south of Europe the Swallow returns by the end of January, and below seville I found many broods hatched by April I 6th. Large flocks collect together in autumn, prior to their departure for the south, and are then conspicuous on roofs, trees and telegraph-wires, especially in the vicinity of water. The food mainly consists of gnats and crane-flies in spring, and small beetles in summer. The soft, low twittering song can hardly be described; the alarm-note may be syllabled as fictafeetfeetafeetit.

The adult male in spring has the forehead and throat chestnut; crown, upper parts and a pectoral band deep metallic blue; quills dark bluish-green; tail bottle-green, with white patches on the inner webs of all except the central pair of feathers, the long outside streamers exceeding the next pair in length by fully two inches; belly and under wing-coverts buff; under tail-coverts pale chestnut; bill, legs and feet black, and very small. Length 7.5 to 8 in.; wing $4^{\circ} 8$ in. The female has a shorter tail, the forehead less chestnut, and the under parts whiter. The young are duller in colour; the frontlet and throat are pale chestnut, and the spots on the tail are tinged with rufous. The moult takes place in winter, and I noticed that the birds which were breeding in the south of Spain in April had not then attained the warm buff tint on the under parts, which I observed later. 


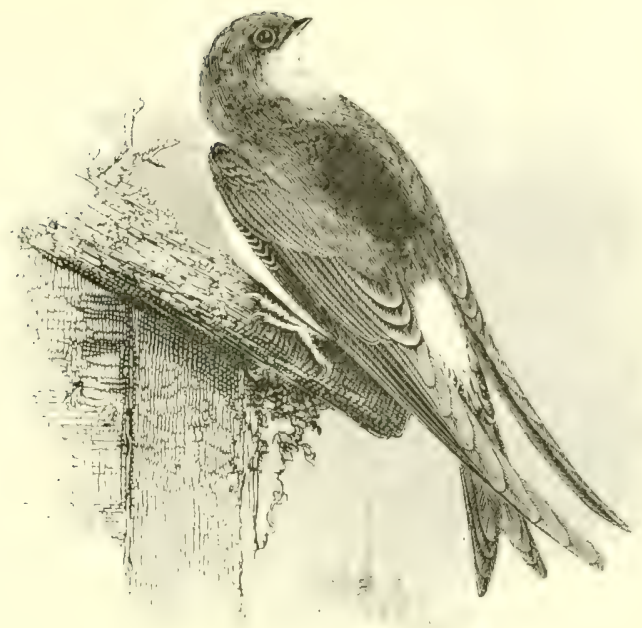

THE MARTIN.

\section{Chelídon úrbica (Linnaus).}

The Martin, sometimes called the House-Martin to distinguish it from the Sand-Martin, usually arrives a few days later than the Swallow, and is of general distribution during the summer throughout the British Islands. In the north, however, it is rather local and even of irregular occurrence, while in some parts of the north-west it has hecome decidedly scarcer of late years. It does not appear to visit the Outer Hebrides, and only breeds sparingly in the Orkneys and shetlands. By the middle of October the bulk of the Martins have left this country, but considerable flocks have been noticed up to the middle of November, and birds-generally young-have been obtained in lecember. Mr. MIore says that in Ireland it is less common than the Swallow.

The Martin is a rare visitor to Iceland, but in the Farees it is not uncommon on the spring migration. In scandinavia it breeds in colonies, in the rocks as well as under the eares of dwellings, as far as about lat. $70^{\circ} \mathrm{N}$., but in Russia its range in that direction is less extensive; while eastward our bird is not known beyond the valley of the $\mathrm{Ob}$, its place being taken in siberia by $C$ h. lagofoda, a well-defined species, with a shorter and squarer tail, and entirely white upper tail-coverts. In the IImalayas the representative species, Ch. cashmiriensis, is smaller, with shorter and less decply- 
forked tail; but our bird is found during the breeding-season in North-western India, Turkestan, Persia, Palestine, Asia Minor, and throughout Europe, except in the Basque Provinces, where, for some mysterious reason, it is almost unknown. It also breeds abundantly in North Africa; visits the Canaries and Madeira; and probably winters in Central Africa, inasmuch as examples have heen obtained in Abyssinia on the east side, and off the coast of Guinea on the west.

The nest, constructed of mud, is not open at the top like that of the Swallow, but is shaped like the quarter of a cup, and is fixed against a wall, bridge or rock, beneath eaves or other projections; the hole for entrance being in the top or corner of the side. On rocky coasts, and in mountain districts, especially those where lime stone prevails, the nests are often placed in large numbers against the cliffs. Upon a lining of fine straws and feathers, the eggs, $4-5$, of a pure white, are deposited: average measurements 79 by $52 \mathrm{in.}$ Incubation lasts a fortnight, and two or even three broods are produced in the season; the same spot being occupied year after year. The food of the Martin consists entirely of insects, and it is a pity that this beneficial bird should be dispossessed and driven from its home, as it often is, by the almost useless House-Sparrow. This has lately happened to several colonies in the West-end of London. The note is a low twitter, something like the word spritz.

The adult has the upper parts of the head, nape and back glossy bluish-black : rump white, as are the upper tail-coverts, except those next the tail, which are bluish-black; wings and the forked tail dingy black; under parts white, as also the feathers which cover the legs and toes; bill black. Length 5.25 ; wing 4.2 in. The sexes are alike in plumage. 'The young bird is sooty-brown above, with hardly any gloss; the rump and under parts are dull white; the tail is shorter and less forked; and some dark feathers on each side of the neck form an incipient collar.

An American Purple Martin, Progne purpurea, said to have been shot near Kingstown in $\Sigma_{39}$ or I $S_{40}$, is in the Nuseum of Science and Art, Dublin. An American Tree-Swallow, Tachycinćta bicolor, said to have been killed at Derby in $18_{5}^{\circ}$, is now in the Museum at Norwich. There are no other instances of the occurrence of these species in Europe; and, even assuming the correctness of the statements, the birds had probably received "assisted passages." 


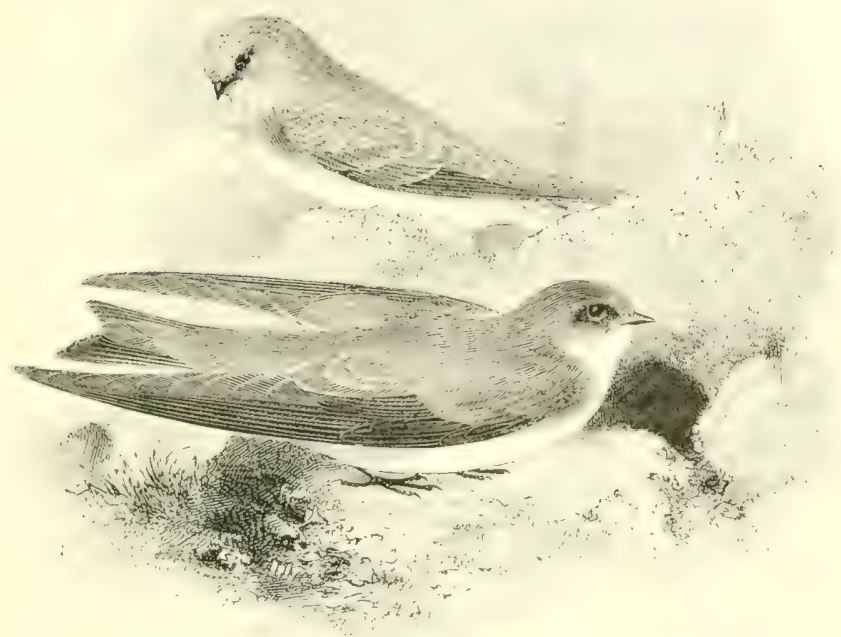

THE SAND-MARTIN.

\section{Cótile ripária (Linnæus).}

The Sand-Marim, the smallest member of the family which visits our islands, is one of the earliest species to arrive in spring, often making its appearance during the last week in March. It is also one of the first to quit our shores, its southward migrations commencing in August and terminating in (October ; but, exceptionally, it has been known in co. Limerick as late as November $z=$ th $[1859]$. Owing to the nature of its haunts it is somewhat locally distributed throughout the British Islands, but upon the whole it is widely diffused; and, in $\mathrm{r} 887$, Mr. A. H. Evans ascertained that it nested near Lerwick in the shetlands, where it had not previously been known to breed. In Ireland, according to Mr. Nore, it is not so numerous as the House-Martin.

In the Faroes and Iceland the Sand-Martin has not yet been obtained, but on the Continent it is generally distributed from $70^{\circ}$ $\mathrm{N}$. lat. to the Mediterranean in summer; while it also breeds sparingly in the northern districts of Africa, and abundantly in Egypt and Palestine. Eastward, it is found across Asia ; on the American continent it breeds in large colonies in Alaska and up to $68^{\circ} \mathrm{N}$. lat. on the Nackenzie River; and we trace it to Newfoundland. In 
winter it visits Mexico, Central America and the valley of the Amazon; and-in the Old World-China, the Indian region, and South-eastern Africa down to Zanzibar. Occasionally it wanders to the Canary Islands.

The nest is generally made in banks-whether natural, such as earth-cliffs by the sides of rivers and lakes, or artificial, such as railway-cuttings, sandpits and gravel quarries-or even in huge heaps of half-rotten sawdust. In such situations galleries slanting slightly upwards are bored, and, in a somewhat wider chamber at the end, the nest is formed of a little dry grass with an abundance of feathers. The eggs, usually $4-6$, are pure white: average measurements 7 by +8 in. In some parts of Norway the Sand-Martin burrows into the turf-covered roofs of the peasants' houses, and in this country holes in old walls are not unfrequently utilized. Small colonies are often ousted by the overbearing HouseSparrow, but where large numbers congregate, they are able to defy intruders. Two broods are generally produced in the season, and after leaving their flea-haunted nest, the young betake themselves to the vicinity of water, where they feed all day upon the abundance of insects produced in such localities, and roost at night in large numbers in the reed-beds and plantations. Gnats and other insects form the food of this species. The male has a low twittering song, but the alarm-note is rather harsh.

The adult male is hair-brown above, slightly darker on the crown and lighter on the rump; wings and tail blackish-brown; under parts white, except a mottled brown pectoral band; bill black; legs dark brown, with a tuft of pale buff-coloured feathers above the hind toe. Length $4^{.8}$; wing 4 in. The female has a rather narrower band across the throat. The young bird, shown in the upper figure of the woodcut, has the feathers of the upper parts tipped with dull white, and the under parts tinged with buff.

In the rocky goiges and mountainous regions of Central and Southern Europe many of my readers may have noticed a rather larger bird, resembling our Sand-Martin in the colour of its upper parts, but displaying white spots on its outspread tail. This is the Crag-Martin, Cótile mupéstris, a bird which has not yet been found in the British Islands, but which may possibly stray to our shores, as it breeds regularly no further off than Switzerland. This species has not the small tuft of feathers on the tarsus, and its eggs are spotted, like those of the Swallow. 


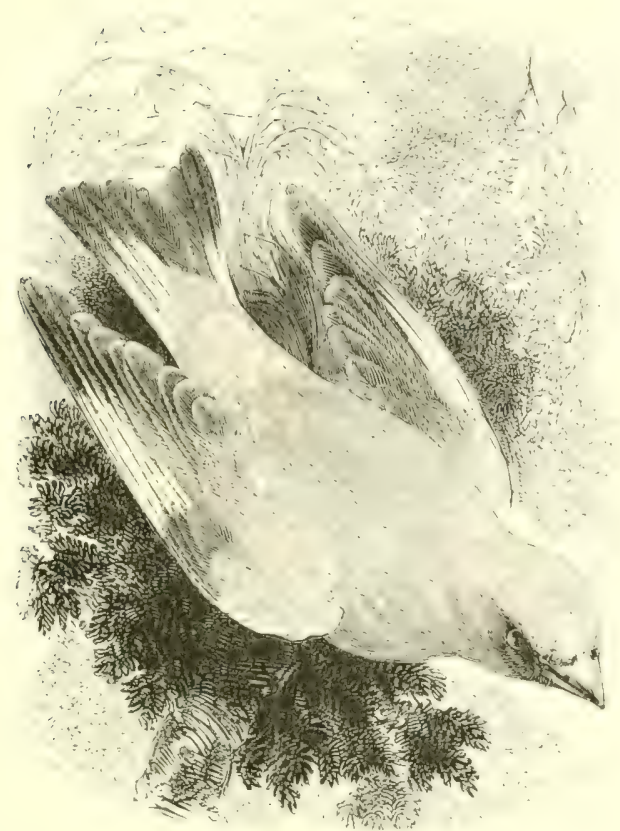

THE GREENFINCH.

LiguRínUS CHLóRIS (Linnæus).

The Greenfinch, sometimes called the Green Linnet, is a common and well-known resident species in the cultivated and wooded districts of Great Britain and Ireland. In the hleaker portions of our islands it is, naturally, less abundant; but it has spread with the increase of plantations of late years, and even in the Orkneys it now breeds sparingly, although to that group, the Hebrides and the shetlands, it is chiefly a visitor in autumn and winter. I arge flocks annually arrive on our east coast in October.

To the Freroes the Greenfinch is only a rare wanderer; but south of $65^{\circ}$. N. lat. in Norway and $60^{\circ}$ in the Ural Mountains it is more or less sedentary in suitable localities throughout Europes. In spain, Northern Africa, Palestine and Asia Minor, our comparatively large and dull-coloured bird is only observerl during the winter months, and the race which breeds is distinctly smaller, and -especially on the forchead-more brishtly coloured. Extremes of this form have been named $L$. chloroticus; while intermediate 
examples have been styled $L$. aurantiiventris. Eastward, the Greenfinch is found as far as the north-west of Persia and Turkestan; but in Eastern Siberia, China and Japan, the representative species is L. sinicus, with greyish head, brown mantle, and yellowish-brown under parts. As a straggler the Greenfinch has occurred in Madeira, and as an introduced species in the United States.

The nest is placed in hedges, shrubs and evergreens, or sometimes in tolerably tall trees, frequently amongst ivy, and occasionally in such unusual situations as a cavity in a tree or a hollow at the top of a gate-post. It is a rather loose and slovenly structure, built, without any attempt at adaptation to the surroundings, of coarse fibrous roots, moss and wool, with a lining of finer materials, hair and feathers. The eggs, $4^{-6}$ in number, are pale greenish-white, blotched, spotted, and often zoned with reddishbrown and purplish-grey: average measurements $s_{3}$ by $\cdot 55$ in. Not unfrequently several nests may be found in close proximity. The first laying takes place about the end of April, and two broods are often reared in the season. The young are fed upon caterpillars and other insects, and soft seeds; later, berries of various kinds are also consumed; and in autumn flocks may be seen on the stubbles. The song is poor, while the call-note is a long-drawn true-e-e, often repeated by the male as he sits on the top of a hedge or bush. In confinement the Greenfinch is easily domesticated, and shows a moderate capacity for learning the songs of other birds; it also interbreeds freely with several species of Finch, and, in a wild state, with the Linnet.

The adult male has the lores dusky black; forehead greenishyellow; a golden-yellow stripe over each eye; crown, neck and mantle olive-green, turning to yellow on the rump; secondaries brownish-grey, darker on the shafts and inner margins; quills greyishbrown with yellow outer webs; central tail-feathers and terminal portion of the rest blackish-brown with greyish edges, the basal portions yellow; under parts greenish-yellow, greyer on the flanks; bill dull flesh-colcur, darkest at the tip; legs and feet pale woodbrown. Length of the large form about 6 in., and wing 3.5 in.; but a brilliant specimen of the smaller race, now before me, measures rather less than $5 \mathrm{in.}$ and the wing barely $3^{\circ} 2 \mathrm{in}$. The female is somewhat smaller and far less brightly coloured than the male, the head and mantle being greenish-brown with darker striations, and the under parts generally dusky, with very little yellow. The young are dull brown, tinged with yellow, and spotted and streaked with darker brown. 


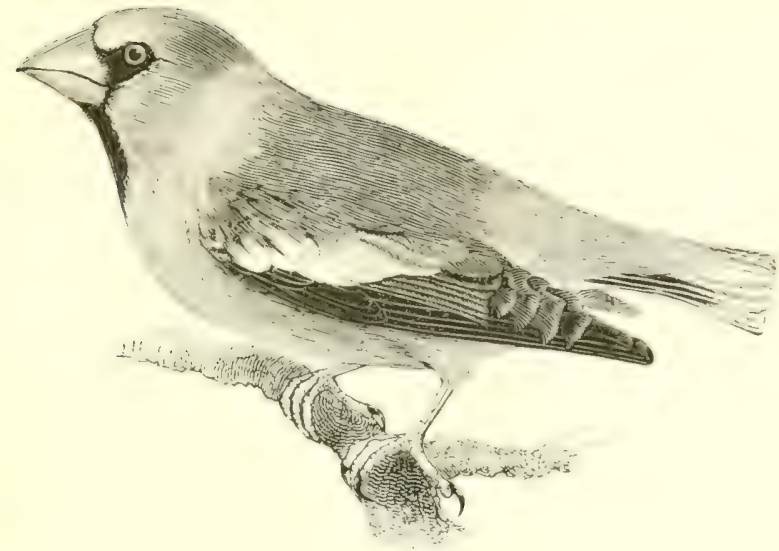

THE HAWFINCH.

Coccothróustes vulgáris, Pallas.

The Hawfinch is a bird of shy and retiring habits, and unless attention be attracted to it by the shrill and-when once heard-unmistakable whistle, its presence riny easily escape detection. There can be no doubt that its numbers have been steadily increasing during the last fifty years; and, though its distribution is local, its nest has perhaps been found in every county in England, excepting Cornwall, as far north as the Lake district, where the bird becomes rare. To Wales its visits - even to Brecon-are exceptional, although it breeds sparingly in Herefordshire. In spite of the extension of the metropolis, the Hawfinch is not yet banished as a lureeding-species from the county of Middlesex, and it is comparatively common in Essex, Herts, Bucks, lierks and Surrey, while in some portions of Kent it may almost be called abundant. In scotland it has been obtained accidentally in winter, both in the solway district and as far north, possibly, as Banff; but Messirs. Harvie-1irewn and Buckley have not found it in Sutherland, and are evidently sceptical as to its reported occurrence in Caithness. To Ireland, according to Mr. More, it is a rare and irregular migrant in winter.

Even in the south of Scandinavia the Hawfinch is only a wintervisitor, but in Russia it has been found nesting as far north as the St. Petersburg district. Over Central Europe, in suitable localities, it appears to he generally distributed, althumb nowhere very common; but in the south, from Spain to Turkey, and in Asia 
Minor, it is a more abundant resident species. In North-western India we find Mr. Sharpe's new and paler species, C. Ium slightly different suhspecies, C. jafonicus, inhabits Eastern Siberia, North China and Japan. In Morocco the Hawfinch is rare; but it breeds sparingly in Algeria, and has wandered to Egypt and Palestine.

The nest, built early in May, is generally placed in trees overgrown with grey lichens, such as old hawthorns, apple- and peartrees: the horizontal branches of oaks, beeches and spruce firs, the heads of pollarded hornbeams, and holly bushes are also selected. It is a rather flat structure, built of twigs mixed with more or less grey lichen, and lined with fine roots and a little hair. The eggs, + $^{-6}$ in number, are pale olive- or bluish-green, spotted and streaked irregularly with dark olive- and greyish-brown: average measurements 98 in. by 72 in. Only one brood is reared in the season, but if the first nest is interfered with, another is built. The young are fed largely on caterpillars, but afterwards the food of this species consists of peas, the kernels of cherry-stones (which are crushed by the powerful bill), and especially of the seeds of the hornbeam and other trees, beechmast, haws and similar berries. In winter small parties and even flocks are formed, and a certain amount of movement-hardly to be called migration-takes place. The song is short and poor; the call-note is a prolonged whistle repeated four times.

Adult male in summer: lores and a narrow frontal line connect. ing them, and also the throat, deep black; head orange-brown; nape grey; back dull brown, paler on the rump and tail-coverts; upper wing-coverts blackish, followed by a line of white which turns to brown on the secondaries; quills black, with white patches on the inner webs and with steel-blue tips, which, from the fifth inwards, are jagged; tail-coverts orange-brown, and very long; tail-feathers black at the bases and dark on the outer webs, ends white; under parts vinous-brown: bill dull black at tip, leaden-blue at base; legs and feet flesh-colour. Length 7 in. ; wing nearly 4 in. Female : less orange-brown on the head and duller in colour. In winter the bill in both sexes is pale horn-colour. The young bird has the head and cheeks yellowish-brown; mantle mottled-brown; under parts dirty white, spotted and barred with dark brown; throat white, tinged with yellow; bill olive. By August black feathers appear on the throat. 


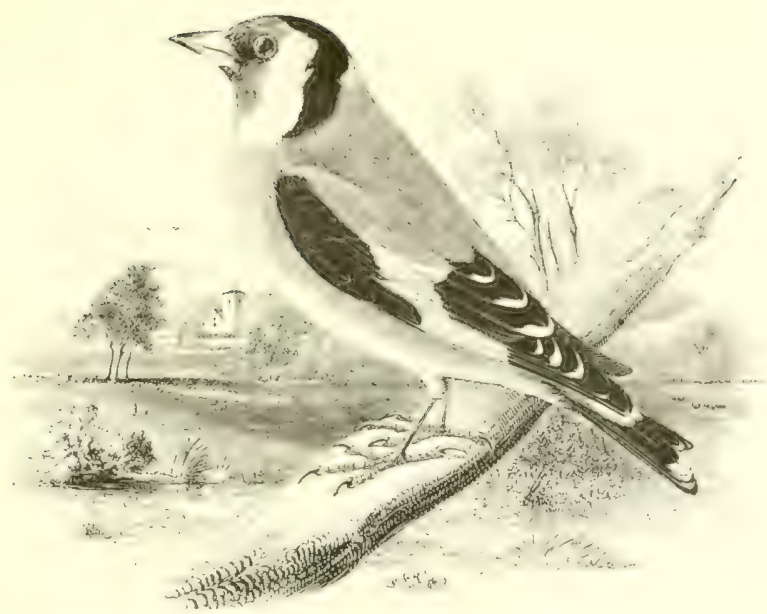

THE (BOLIINCH.

Cardetéls Élegans, Stephens.

Owing to the arts of the bird-catcher, and also to the improvements in cultivation, which have done away with many of the tracts formerly covered with thistles and other weeds, the (indinch has undoubtedly decreased in numbers during the last half century; although the Wild Birds' I'reservation Act, and perhalps the present agricultural depression, have somewhat operated in its ficour during the past few years. Though local, and principally to be found during the breeding-sea-on in the neighbourhood of gardens and orchards, it still nests in every county in England-not evecpting Northumberland, where it has bred at Greenhead; while it is tolerably common along the Eden valley in Cumberland, although in the northern and western counties a comparatively rare bird. Beyond the Border it has almost disappeared from the I othians, owing to the influence of hish farming; but I am informed by Mr. R. Service that, after a marked diminution, it is again on the increase in the Solway district. It is said to breed sparingly as far north as Caithness, and on one occasion it has nested in the south of Skye, while as a straserler it has occurred in Mull and Eiger ( Macpherson). In Ireland it is common in suitable localities. A large proportion of the foldtinches which inhabit bingland during the summer, as well as flocks which have arrived from the Continent, migrate southward across the ('hannel in ()etoluer, and return northward in April. 
South of about $64^{\circ} \mathrm{N}$. lat. in Norway, and $60^{\circ}$ in the Ural Mountains, the (ioldfinch is found breeding throughout Europe, although rare in the north: while in Spain and other southern countries it is exceedingly abundant and very bright in colour. It is a resident in Madeira, the Canaries and Northern Africa; visits Egypt in winter: and ranges eastward to Persia. There, and generally to the east of the line of the Urals, we find a larger form, known as $C$. major, with nearly white rump and flanks; and in Southern siberia this meets and interbreeds with $C$. caniceps, which has no black on the crown and nape, but more white on the wing.

The compact nest-like that of the Chaffinch, but smaller, neater, and of finer materials, and without the conspicuous lichens-is built about the middle of May, and is generally placed in a fork of a fruittree, though often in a hedge or evergreen shrub. The eggs, 4-5, are greyish-white, spotted and streaked with purplish-brown : average measurements 66 by $5 \mathrm{in}$. Two broods are produced in the year, and youns have been found in the nest in September. At first they are fed with insects and larvæ; but the principal food of the Goldfinch consists of seeds of the thistle, knapweed, groundsel, dock and other plants. The song of this favourite cage-bird is well known; its call-note is a sharp twit. In captivity it breeds with several other species of Finch.

Adult male: feathers at the base of the bill and lores, black; forehead and throat glossy crimson-red; cheeks and lower throat white; crown and the parts behind the cheeks black; on the nape a narrow line of white; back wood-brown; wings black, tipped with white on the inner quills and barred with bright yellow; tail-coverts white with black bases: the three outer pairs of tail-feathers black with white central spots, the remainder black, tipped with white; breast white, banded with brownish-butf, with a yellow tint beneath; flanks buff; belly and under tail-coverts white; bill whitish with a black tip; legs and feet pale flesh-colour. Length 5 in. ; wing 2.85 in. In less mature males, only the ist and and pairs of tail-feathers have white spots. The female has a more slender bill, the crimson of the throat is less extensive, and she shows no yellow tint in the breast. 'The yourig, known as 'grey-pates,' 'baldpates' and 'branchers,' are greyish-brown on the upper parts; the wing-tips are buffish-white, and only the outer pair of tail-feathers show the white spot. Some birds, known as 'cheverels,' have the throat white; examples from Morocco have the back isabelline, and there are several other variations. 


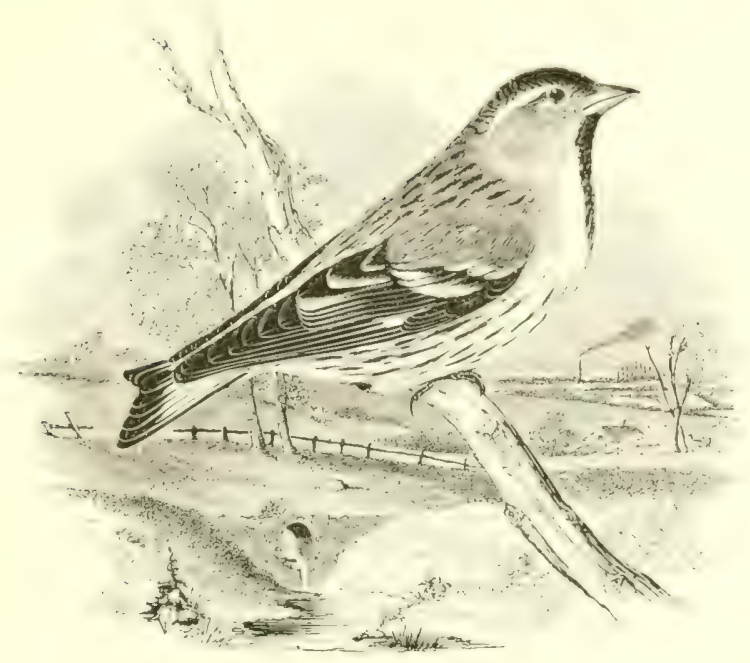

THE SISKIN.

\section{CHRYSOMÍtris sPínus (Linnæus).}

The Siskin, or Aberdevine as it has been called since the time of Albin, is principally known in England and Wales during winter and on its migrations to and from its more northern breedingquarters; but there is evidence that it has bred, exceptionally, in Surrey, Sussex, and perhaps some other southern counties. In the north, where fir-woods are more abundant, it has nested in the county of Durham; while a few pairs breed regularly in some parts of Cumberland, and in the Solway district in Scotland. From Perthshire northward, it nests freely in some of the old fir-woods and in other suitable localities up to Caithness; in East Sutherland it is said to be resident, and it also breeds in Ross-shire; but on the western side generally it is only a somewhat rare winter-visitor, and I do not trace it to the Hebrides or the Orkneys, although it wanders to the Shetlands. In Ireland it is resident in cos. Wicklow and Waterford, and nests in Down, Antrim, and probably in other localities where pine-trees flourish; while in winter it is tol rably common over a much larger area.

In Northern Europe the breeding-limit of the Siskin coincides with that of conifer-growth; and southward, the bird nests in some of the fir-woods of Germany, South Holland, France, Switzerland, Northern Italy as far as the vicinity of Florence, Austria, and 
the Caucasus; while elsewhere it is found on migration down to the Mediterranean. No recent visitors to the Canaries have found it there; but in severe winters it is said to cross to Morocco and Algeria. Eastward it has been met with in Asia Minor, Northern Persia, and across Siberia to China and Japan, being a favourite cage-bird in the latter. In the Indian region, from Cashmere to Western China, the representative species is Ch. spinoides.

The Siskin generally produces two broods in the year, and St. John found well-fledged young near Nairn as early as April 26 th. Firs of some kind or birches are the trees usually selected, and the nest, while occasionally placed at the top against the main-stem, is generally high up and at the end of a long lateral branch; but sometimes it is built in gorse and other bushes. Fir twigs, fine roots and green moss are the materials employed to form a tolerably neat structure, which is lined with horsehair and a few feathers. The eggs, usually 5, are slightly smaller than those of the Goldfinch, rather bluer in ground-colour, and speckled with dull lilac and reddishbrown : average measurements $6_{5}$ by 47 in. Siskins not unfrequenily breed in captivity, but there is a difficulty in rearing the young, as in the earlier stages they appear to require Aflides, such as infest the leaves and green shoots of the alder. Later in the year, beechmast, and seeds of rag-weed and other plants are eaten. The call-note is loud and clear, resembling the word slec-or zeisig, whence the bird's German name-and the song is pretty and varied.

The adult male has the chin, lores and top of the head black; cheeks and ear-coverts dusky-greenish; above and behind each eye, to the nape runs a broad streak of yellow, which unites with the upper breast of the same colour ; mantle greenish-olive, streaked with dusky-black; rump, yellow; the central pair of tail-feathers dusky-black, the others black near the tips, yellow at the bases and on the inner webs; wing-coverts black tipped with yellow; quills blackish, with yellow margins and bases forming two irregular bars; belly white; flanks jellowish, streaked with black; bill pale brown; legs dull brown. Length 4.6 ; wing $2.8 \mathrm{in}$. In autumn the colours are duller, and there is hardly any black on the chin. The female is streaked with dusky on the crown, and has very little yellow on the rump, wings and tail; the under parts are yellowish-white, streaked with dusky. The young are still duller and greyer in appearance. 


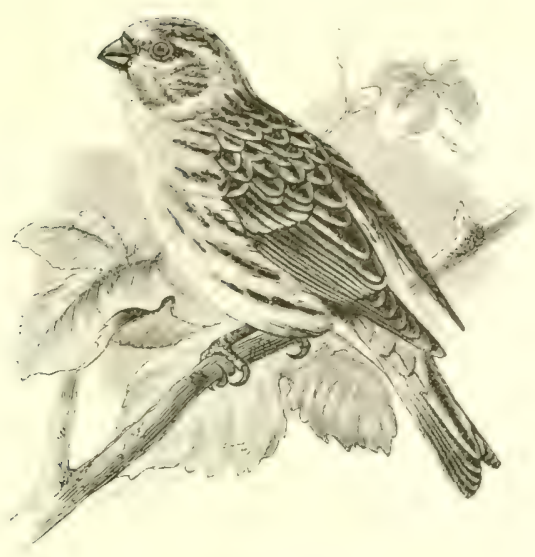

THE SERIN.

Serínes hortuláxus, K. L. Koch.

The occurrence of the Serin in England was first recorded from the neightourhood of Portsmouth (Naturalist, 1853, p. 20), ly Mr. IV. Hazel, of notorious grood fortune in obtaining exotic Finches in this country. Subsequently, about eight examples have been obtained by bird-catchers in Sussex-most of them near Brighton; one or two near London, one in Norfolk, and one in Somersetshire. Almost all of these were noticed either in spring or in autumn ; and although the Serin is a very common cage-bird abroad and likely to be inported, yet, considering that it breeds no further off than Luxemburg, it may possibly be a genuine visitor to our shores.

The Serin has wandered to Sleswick, and at least a dozen examples have been obtained on Heligoland; its northern breedingrange extending to Larmstadt and the upper portions of the khine and Moselle vallers. Southward, it is found-generally at the foot of mountains skirting the plains-ihroughout the greater part of Europe, and on both sides of the Mediterranean; in Asia Minor, it Is resident and extremely alundant : and castward it can be traced to Egypt and sinai. It visits the coast of Palestine in winter, but in the higher regions of that country tlec representative species is $S$. cammizes, a larger, paler and much yellower lird; while in the I.ebanon, Taurus and other mountain ranges, reaching to North-western India, is found $S$. pusillus, the male of which has a red forehead and black throat and cheeks. As an introduced species the Serin has occurred in the United States. 
The nest of the Serin, placed in the fork of some tree or about breast-high in a bush, is built of fine roots, bents, lichen and grey moss, with a lining of softer materials. The eggs, 4-5, are pale greenish-white, with light reddish-brown spots and a few darker blotches: average measurements $6 \mathrm{I}$ by 47 in. The food consists of various kinds of seeds. The song resembles the word $z i-z i$ often repeated, and a flock of birds settled in a tree produces a peculiar buzzing or almost hissing sound.

Adult male in breeding-plumage: forehear, a line over each eye, rump, throat and breast, bright yellow; cheeks and upper parts olive, with dark brown streaks; great wing-coverts and secondaries edged with dull white; quills and tail brown, margined with pale yellow; belly white; flanks boldly streaked with brown; bill horn-brown; legs pale brown. Length 4.5 ; wing 2.6 in. Female much less yellow and more striated. In winter both sexes are duller in colour; while the young in their first autumn exhibit hardly any yellow tint.

Examples of the subspecies Serinus canaria, peculiar to the Canaries, Madeira and the Azores, have been obtained in England: and, although cages-full are known to be imported, there are persons who wish to believe that the individuals captured are not escaped birds, but stragglers from a warm to an inhospitable climate. While upon the subject, it may be mentioned that the above-named Mr. W. Hazel has stated (Nat. I853, p. 20) that the African Serimus icterus (Crithagre chrysopyga of Swainson), was taken ncar Portsmouth. AIr. Lanselon recorded (Zool. ISS6, P. 490) that, among the many rarities obtained by the late Mr. Swaysland of brighton, there was a Citril Finch taken alive on October I th ; but on examination the bird proved to be a freely-imported South African species, Sirinus anticollis, another specimen of which has since been captured. Montagu mentions an example of the American Cyanospiza ciris, taken near Portland in $\mathrm{I} 802$, which he, with his accustomed good sense, naturally presumed to have escaped from confinement. Another American species, the "White-throated Sparrow;' Zonotrichic albicollis, (which is really a Bunting) having been obtained near Aberdeen, was included and figured by the late R. Gray in his 'Birds of the West of Scotland,' and a second example has been taken near Brighton. 


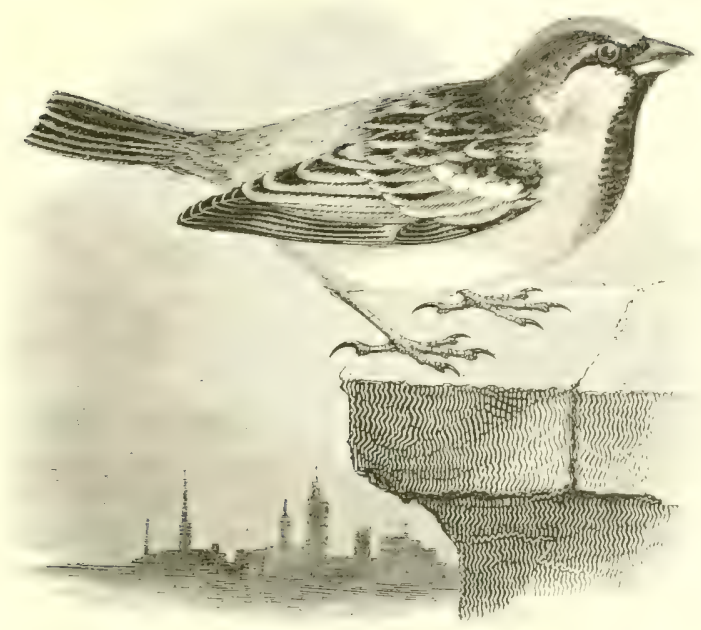

THE HOUSE-SPARROW.

PÁsser domésticus (Linnæus).

The House-Sparrow is generally distributed throughout Great Britain and Ireland wherever human habitations are to be found, except near some of the high moorland farm-houses and a few of the most elevated villages. In proportion as land is brought under cultivation, the Sparrow makes its appearance and rapidly increases, so that it is now established in the: ()uter Hebrides and other places where it was formerly unknown. As yet it does not appear to have reached the Freroes, but in Scandinavia it occurs, in suitable localities, up to and a little beyond the Arctic circle; while eastward, we trace it across Russia, and along the inhabited portions of Siberia to Irkutsk; but not to China or Japan. A smaller and paler race (known as $P$. indicus, but not considered by the best authorities as entitled to specitic distinction) inhabits ciam, liuma and the Indian region, as far west as Southern Persia; thence gradations lead back to the typical bird, which is found almost all over Europe where grain will grow. In Italy, and on the island of Corsica, the representative species is $P$. ifulie, the male of which has the crown chestnut instead of grey; but although this species has been found for a considerable distance up the Irenner l'ass, it has not yet infringed upon the territory of our bird, which, on the northern side, reaches Innsbruck. In Sardinia, Sicily and 
Malta we find only $P$. hisfaniolensis, also with a chestnut head, but much blacker on the throat and flanks. In Spain our bird keeps to the towns, and does not seem to clash with $P$. hispaniolensis, which there breeds in the woods, often occupying the foundations of inhabited nests of large birds of prey. Westward, the HouseSparrow occurs in Madeira, but apparently not in the other Atlantic islands. In Africa it is found from Morocco in the north to the Albert Nyanza near the Equator. Introduced, like the rabbit, through officious ignorance, into Australia, New Zealand, and also the United States, it has become such a curse that special legislation is being loudly invoked for its destruction.

The well-known nest, of straw, hay, dry grass and all sorts of odd materials, thickly lined with feathers, is placed indifferently in trees, among climbing plants, under the eaves of roofs, in the spouts of water-pipes, in holes in walls, and those in banks originally excavated by the Sand-Martin; in fact almost everywhere. The eggs, 5-6, are pale bluish-white, blotched, speckled or suffused with ash-and duskybrown: average measurements 9 by $\cdot 6$ in. Three broods are frequently reared in the season. The young are fed upon caterpillars and the larva of various destructive insects, and in this respect the sparrow is beneficial to the farmer; but the voluminous evidence collected on the subject shows that during the greater part of the year an enormous amount of grain $\& c_{i}$, is devoured, and the consensus of opinion appears to be that, while extermination is not advocated, the increase of this species must be checked. By deferring the destruction of the insect-fed young until they are fledged, the greatest amount of usefulness may be extracted from this bird, which further causes incalculable harm by dislodging and driving away the House-Martin and other purely insectivorous species.

Adult male : lores black; a narrow streak of white over each eye ; crown, nape and lower back ash-grey; region of the ear-coverts chestnut; back chestnut-brown streaked with black; wings brown, with a bar of white on the middle coverts; tail dull brown; throat and breast black, sometimes suffused with bright chestnut; cheeks and sides of the neck white; belly dull white; bill bluish-black; legs pale brown. Length 6 in.; wing 3 in. In winter the colours are duller and the bill is yellowish brown. In the female the upper parts are striated dusky-brown; there is no black on the throat or grey on the pate, and the under parts are brownish-white. The young bird is deeper brown both above and below; the middle wing-coverts are tipped with buff; the bill is dull yellow. 


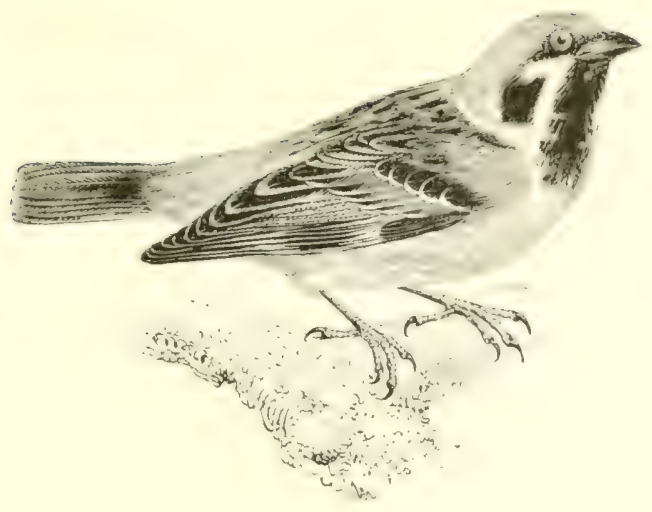

THE TREE-SPARROW.

\section{Passer montánus (Linnæus).}

The 'Tree-Sparrow is rarer and more local than the preceding species, but it is undoubtedly extending its range, having recently been found in the Hebrides, including st. Kilda, and in many other places where a few years ago it was unknown. In the south-west of England it is as yet uncommon, and although in Wales it breeds in Brecon, it is not abundant there: while it is at most very local in Lancashire and Cumberland. It is probably more abundant in Cambridgeshire and some of the eastern and midland counties than elsewhere; but it is difficult to sketch its distribution with accuracy, owing to the strong probability that, from its resemblance to the House-Sparrow, it has often been overlooked. Large numbers arrive from the Continent upon our east coast in autumn. In Scotland its settlements are mostly along the eastern side, from the Border to Sutherland. Unknown in Ireland until I 852 , it is now a resident and increasing species near Dublin; and its range is eridently spreading, as Mr. H. M. Wallis found a pair in May rsso on North Aran Island, off the Rosses, co Donegal.

About I 869 the Tree-Sparrow reached the Færoes, where it has multiplied exceedingly: and in Norway, although still local, it hats now spread beyond the Arctic circle. Throushout the rest of northcrn and temperate Europe it is generally distributed: in IIungary and Slavonia it is more abundant than the lIouse-Sparrow: and. although local, it may be said to be common in most parts of the south, except in the islands of the Mediterranean. I have speci- 
mens from Valencia and Málaga in Spain, but it has not yet been obtained in Portugal. It is rather common in the south of France, and it breeds in many towns, and even in the city of Paris, as may be seen by inspecting the thatched roofs in the Jardin des Plantes. In Algeria it is rare, but it is said to visit Egypt and Arabia. It is found throughout the greater part of Asia, south of about $5 \mathrm{~S}^{\circ}$ N. lat, down to the Philippines and the Malay Peninsula; and in Java, where it was introduced less than a century ago, it has already varied so much from the type as to be named var. malaccensis by MI. Dubois. Imported specimens have been obtained in North America.

The nest is often placed at some distance from habitations, in the soft rotten wood of pollard-willows and other trees : but in many districts it is built in the outer side of the thatch of barns and outhouses, and beneath the tiles of roofs, as well as under the coping of old walls and in sea-cliffs; in fact almost any hole will serve. The materials employed are mostly dry rass and feathers; the eggs, +-6, smaller and more glossy than those of the House-Sparrow, are greyish-white, grencrally freckled all over with rich hair-brown : average measurements 78 by 54 in. Two, and even three broods are reared in the season; the first being hatched about the middle of April. The young are fed on caterpillars and other insects, suft vegutables \&c., but later, both they and their parents live principally upon small seeds; while in winter both young and old frequent rick-yards, highroads and even streets of towns, for the horse-droppings. The male has a slight, though somewhat pleasant song, but the ordinary call-note is a shrill chirp. In captivity this species has bred with the House-Sparrow.

Unlike the precting species, the sexes are alike in plumage. The adult has the lores and a streak under each eye black; crown and nape warm reddish-brown; cheeks and ear-coverts white, with a triangular black patch; mantle, wings and tail much as in the male House-Sparrow, but both upper and lower wing-coverts tipped with white, forming two distinct bands; chin and throat to upper breast black : under parts greyish-white, brownish on the flanks; bill black ; legs and feet pale brown. Length $5^{\circ} 6$ in.; wing $2^{\circ} 75$ in. In the young bird the plumage is duller, and the bands on the wings are tinged with buff. As shown by the above measurements it is a decidedly smaller species than the House-Sparrow. 


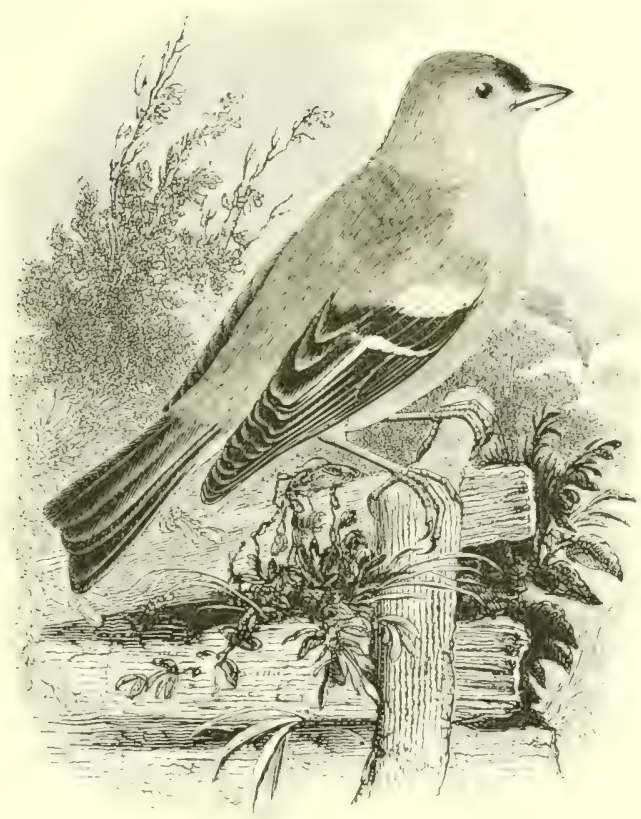

THE CHAFFINCH.

Fringílla c(Élebs, Linnæus.

The Chaffinch is a common and generally distributed species throughout the cultivated or wooded portions of the British Islands: it may even be found nesting in low bushes in some of the treeless Outer Hebrides, and also at a corsiderable elevation in the mountains of Scotland, where it is undoubtedly increasing. Is yet it has not been recorded as breeding in the Shetlands, although it visits them in winter; at that scason large flocks arrive from the continent on our east coast, while other bands, from the north of our island, spread themselves over the inland provinces. Owing to a partial and temporary separation of the sexes at this time, the name culctis, or bachelor, was used by linneus in reference to the deserted males.

As a straggler, the Chaffinch has heen obtained in the Faroes, and in summer it occurs, in comparatively small numbers, nearly up to the North (ape; while south of the Arctic circle it is generally distributed during the breeding-season throughout the temperate regions of Europe down to the Iediterranean. Colonel Irby found it breeding near (ibraltar, but in the south of spain it must be very 
local; for I neither obtained its nest, nor had its well-known eggs brought to me, although in winter the bird is very common. Captain S. G. Reid obtained it on the coast of Morocco ; but in that country and in Algeria the representative inland species is F. spodiogeny's, the male of which has a bluish-grey head and nape, greenish back, and under parts of a vinaceous white, while the female is much greyer than our bird. Mr. R. B. Sharpe distinguishes the Madeiran Chaffinch as $F$. maderensis, and those of the Azores ( $F$. morcleti) and the Canaries (F. tintillon) as merely subspecies; but the dark grey $F$. teydea, found on the Peak of Teneriffe, is perfectly distinct. In winter our Chaffinch occurs in Egypt ; it breeds on Hermon and Lebanon, and in the forest region of Persia: while it has been found as far east as Omsk in Siberia.

The nest, almost too well known to need description, is generally placed at a moderate height from the ground, in a fork of the lower branches of a tree or in a bush, and is artfully composed of wool, green moss, lichens and other substances felted together, with a lining of hair and feathers. The eggs, $4^{-6}$ in number, are usually of a pale greenish-blue, clouded with reddish- and spotted with purplish-brown, but occasionally they are unspotted blue: average measurements $S$ by $\cdot 6$ in. Two broods are generally reared in the season. The call-note is the familiar spink, spink, spink, to which the bird owes one of its many local names, but the song varies much in different lccalities, one of the commonest renderings being toll-toll, fretty-little, dictr. Both young and old feed largely on insects and on the seeds of weeds, so that in spite of a little pilfering of fruit, vegetables and newly-sown seeds, the Chaffinch may be considered as one of the gardener's best friends.

Adult male in spring: forehead black; crown and nape bluishgrey; back reddish-brown; rump yellowish-green ; upper wing-coverts white, greater coverts black, tipped with yellowish-white, forming two conspicuous bars; quills dull brown, slightly fringed with greenishwhite; central tail-feathers dark grey, the rest black, with broad white patches on the two exterior pairs; cheeks, throat and under parts rich reddish-brown, paler on the belly; bill bluish-lead; legs dull brown. Length 6 in.; wing 3.4 in. In autumn the bill is brownish, and the head is tinged with rufous. Female: head and back light yellowish-brown; breast pale yellowish.grey. Young: similar to the fumale, but with paler tints at first; the males, however, begin to show brighter colours within a fortnight. 


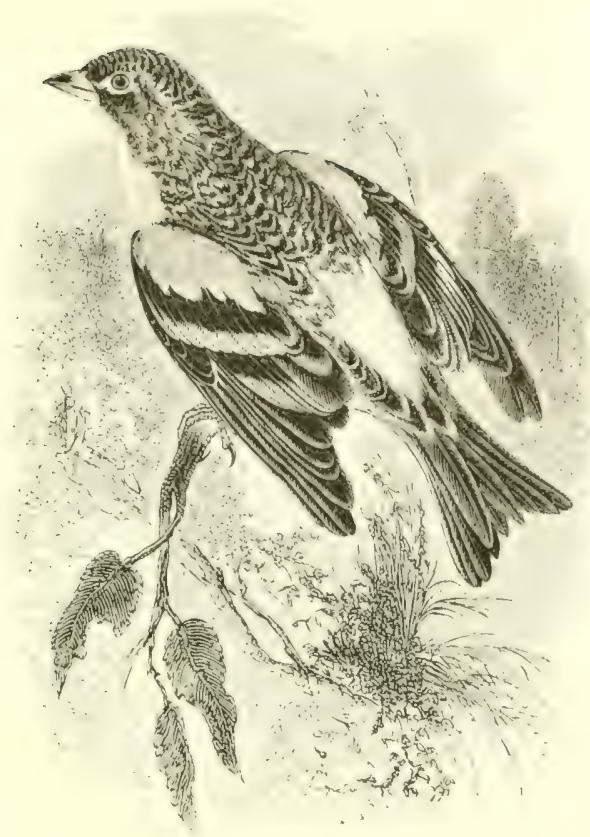

THE BRAMBLING.

FringILLA MoNTIFringílla, Linnæus.

This species is a tolerably regular autumn- and winter-visitor to many parts of Scotland, and migrants from Scandinavia may be found in small parties among the Highland glens lones before their arrival is noticed in England, where their presence and relative abundance depend upon the severity of the weather on the Continent. In hard winters the Brambling -or Mouritain-Finch as it is sometimes called - is very numerous, especially in the vicinity of beech-woods; but in other years it is not noticed, and in Cornwall and the west its appearance is very uncertain. By the middle of March almost all have returned to their northern breeding-grounds, but exceptionally a few pairs have been known to remain behind: and Mr. E. T. Booth states that in June isoo, while frshing in the river I,yon, l'erthshire, he had occasion to climb a beech-tree to disentangle his line, when he disturbed a female brambling from her nest with three eggrs. To Ireland this bird's visits are very irregular. and it is little known there, but at long intervals lare flocks have 
been observed in the beech-woods of Armagh and the north-eastern districts, and also in co. Cork.

To the Faross the Brambling is only an exceptional visitor. On the mainland it breeds throughout the sub-Arctic pine and birch forests, from Norway to the valley of the Amur; while on migration it occurs in Japan, China, Northern India, Asia Minor and the whole of Europe; but it is only in very severe winters that it pushes its wanderings to the African side of the Mediterranean. Immense flocks sometimes visit Belgium, Holland, Germany and Heligoland; but statements that this species has nested in the Pyrenees, the Alps, or the Ardennes, are as yet unconfirmed.

As a rule, the Brambling breeds at higher altitudes than those frequented by the Chaffinch : and its nest, usually placed where a branch meets the stem of a birch-or fir-tree, but sometimes in small juniper bushes, is bulkier, less compact, and largely composed of birch-bark. Several pairs gencrally breed in company. The eggs, 6-7 in number, laid late in May or early in June, are, as a rule, rather greener than those of the Chaffinch and have more defined markings, but many of each species are quite indistinguishable: average measurements .8 by 6 in. The Brambling has bred several times in captivity. Its food consists of insects, small seeds-especially those of the knot-grass, beechmast, and the kernels of nuts. The call-note is a harsh chirp, but the song of the male during the breeding-season consists of several flute-like notes, resembling those of the Redwing.

The adult male in breeding-plumage has the head, cheeks, nape and back glossy blue-black with white bases to the feathers, which sometimes show in the form of an irregular collar; upper wingcoverts orange-buff, tipled with white; greater coverts black, margined with white, which forms a conspicuous bar: quills mostly brownishblack, with whitish exterior margins; rump white, mottled with black; tail-feathers black, with a little white at the base of the outer pair; throat and breast reddish fawn-colour; belly dull white; flanks spotted with black; under wing-coverts bright yellow; bill bluish-black; legs brown. Length $6 \mathrm{in}$.; wing $3.6 \mathrm{in}$. In autumn and winter the black feathers of the head and back have long margins of reddish-brown, as represented in the woodcut, which are shed in spring; a warm orange-brown pervades the wing-and tail-coverts, breast and flanks; and the bill is yellow, with a black tip. The female is dull brown on the upper parts and has none of the rich black and chestnut markings of the male. The young at first resemble the female, but the males soon show signs of black on the head and back, and the under parts are brighter fawn-colour. 


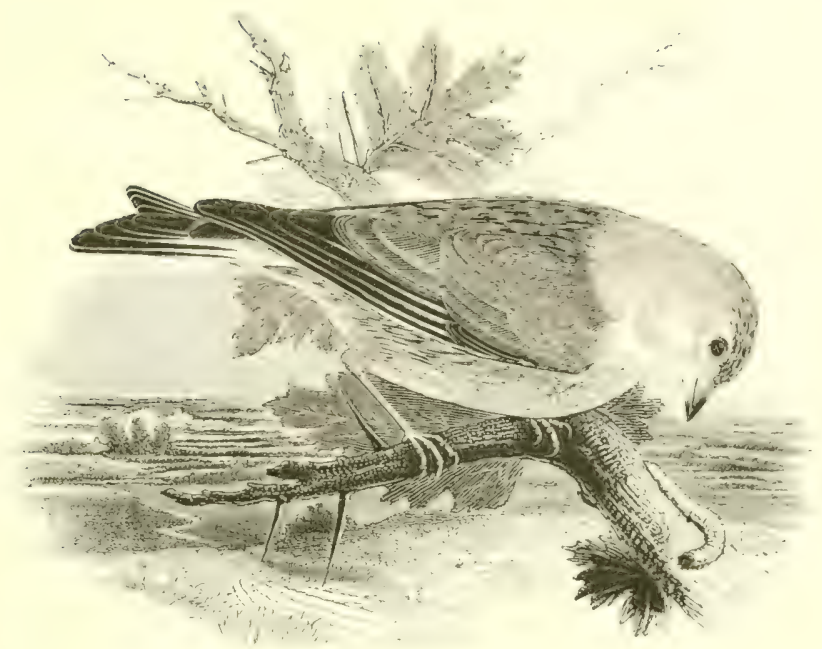

THE LINNET?

\section{Acánthis canxíbina (Linnæus).}

Owing to its seasonal changes of plumage this species is often known as the Grey Linnet; also as the Red or Brown Linnet, to distinguish it from the (ireenfinch, which is frequently styled the (ireen Linnet. It is widely distributed throughout the greater part of the British Islands, especially on uncultivated lands and fur/e-covered tracts: but in the mountain-regions of Scotland it is replaced by the Twite. Near Gairloch in Ross-shire it is almost unknown, and it appears to be local in the Hebrides, although common enough on some of the islands; while from Shetland it is as yet unrecorded. In autumn large floclis from the Continent arrive on our east coasts, at the same time that a general migration southward occurs among our home-bred birds.

The Linnet does not breed north of lat. $64^{\circ}$ in Scandinavia, nor beyond $60^{\circ}$ in East Russia. Southward, it is found as a resident all over Lurope; also in North-westem Africa, the Canaries and Madeira. Eastward, it appears to range as far as the Altai Mountains: but in Asia Minor, Hermon and I etanon-breeding nearly up to the snow-line-and in P'ersia and Northern India, the representative race is more ash-coloured, with bright scarlet on the breast, and more defined coloration; this form is known as 
A. fringillirostris or A. bella. In winter one or both of these forms visit Egypt and Abyssinia.

Breeding begins in April; the nest being made of fine twigs, moss and grass-stalks, and lined with wool, hair, vegetable-down and sometimes a few feathers. It is generally placed in gorse or juniper bushes, though often in hedges, and sometimes in low trees. The eggs, $4^{-6}$ in number, are bluish-white, blotched, speckled and streaked with reddish-brown and purplish-red : average measurements 7 by 53 in. Two broods are often reared in the season. The food consists of soft seeds, especially those of an oily nature, such as the various species of flax and hemp; grains of charlock, knotgrass and other weeds are also largely consumed, while in winter various kinds of berries and even oats are devoured. In autumn the different families unite in large flocks, which may be seen crossing the stubbles with swift dipping flight, uttering their musical and rapidly-repeated trit, twit. At this season large numbers are taken by bird-catchers, as the birds then adapt themselves more easily to captivity than if captured in the spring. The natural song is sweet, although somewhat irregular, but it is the capacity for learning the notes of other birds which makes the Linnet so great a favourite for the cage. In our cold, dull climate, captive males seldom acquire in spring the fine crimson tints on the head and breast; but abroad, under the influence of warmth, bright sunshine and good food, Mr. J. loung has known them do so, and in Madeira the wild males appear to undergo hardly any eclipse.

The adult male in breeding-plumage has the forehead and centre of the crown crimson; rest of the head, nape and sides of the neck mottled brownish-grey; mantle chestnut-brown; wing-feathers dull black, with white outer edges which form a conspicuous elongated bar; upper tail-coverts dark brown, with broad whitish margins; tail-feathers black, narrowly edged with white on the outer and broadly on the inner web; chin and throat dull white, striped with greyish-brown; breast crimson, occasionally with a decided yellow tinge; belly dull white; flanks fawn-brown; bill horn-colour, legs brown. Length $5{ }^{\circ} 75$; wing $3^{\circ} 5$ in. In autumn the bill is brownish, the crimson feathers are concealed by wide grey margins, and the under parts are more striated. The female is rather smaller and duller in colour, with no crimson on the head and breast, and little white on the wings, while both upper and under parts are much streaked with dark brown. The young at first resemble the female. 


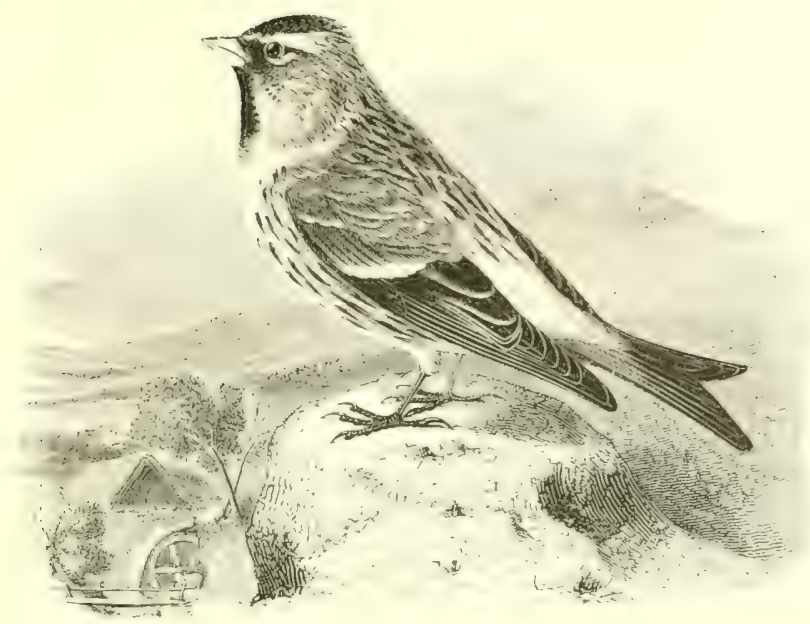

THE MEALY REIPPOLL.

\section{ACANTHIS LináRIA (Linnæus).}

The logical separation of the various species or races of Redpolls is one which presents unusual difficulties. The latest worker on the subject, Mr. R. B. Sharpe, considers (Cat. Birds Brit. Mus. xii. pp. 245-257) the Mealy Redpoll, Acanthis linaria, as a main stem, if I may use the term, with three subspecies, viz.: $A$. holhoelli, rather larger and with a very much longer bill, found " in Northern Europe from Scandinavia to Eastern siberia," and. as a rare stragsler, twice in Norfolk; A. restrata, "only distinguishable by the coarser striping of the under parts and by the stouter and more obtuse bill," inhabiting (ireenland and North-eastern . Imerica : and our smaller and ruddier Lesser Redpoll, 4 . rufiscens, of which more hereafter. A. exilipes, with greyer rump, Mr. Sharpe considers to be a good species, with a range extending from Northern Scandinavia across Siberia, and throughout Northern America: while he puts down as a subspecies of $A$. exilipes the rather larger A. homemanni, of Fastern North America, Greenland, Iccland and spitsbersen, one example of which has been recorded by IIr. John IAncock, under the name of Linaria canescins, as having been olutained near Whitburn, Northumberland, on April 2 th 1855 . The whole question is incrusted by a voluminous literature, in which hardly two authors agree as regards specific value or srnonymy : but, for the sake of conrenience. I propose to treat the Mealy Redpolls under 
one heading, and to take our small, dark Lesser Redpoll separately.

The typical Mealy Redpoll is a regular winter-visitor to Shetland from September onwards, and the track of its migration appears to be principally along the east coast in Scotland and the north of England, for the bird is rarer and of more uncertain occurrence on the west side. South of Durham its visits become irregular; in the Eastern Counties it has occasionally been obtained in spring, and exceptionally in summer; and in some years large flocks have been noticed down to the Channel; but in Cornwall it is as yet unknown. In Ireland an example was taken in co. Kildare, in February i $S_{7} 6$.

In Europe and Asia the Mealy Redpoll extends as far north as the limits of birch-growth, but southward, it may be doubted if it reaches below $58^{\circ} \mathrm{N}$. lat.; for the bird found breeding in the mountain-regions of Central Europe is, probably, our Lesser Redpoll. On migration it is irregularly abundant in the northern portions of Europe, but rare in the south of France, Italy, (ireece and Southern Russia. As already stated, one or two races breed in Arctic America, and a large form in (ireenland, Iceland and Spitsbergen.

The nest, neatly built of bents, lichens and shreds of bark, with a lining of catkins, hair and feathers, is usually placed in the low fork of a tree, and sometimes in a tuft of grass. The eggs, $5^{-6}$, are greenish-blue, spotted with reddish-brown: average measurements 7 by 5 in. The young feed on insects and their larva; afterwards on seeds, like the parents. Authorities differ widely as to the song.

Adult male in spring : lores black; forehead blood-red; upper parts dark brown, mottled and streaked with grey:sh-white, especially on the rump, which is tinged with pink; tail dark brown, with paler edges; chin black; throat and breast carmine; lower parts dull white, streaked with dark brown on the flanks; bill horn-colour, yellowish at the base; legs dark brown. Length $5^{\circ} 2$ in.; wing 2.9 in. Female: smaller; darker on the upper parts, and more streaked on the lower; no red on the breast. The young have the upper feathers margined with buff and have no red on the forehead, but are otherwise like the female. After the autumn moult the new feathers have broad yellowish-grey margins, which, in the male, conceal the carmine, and the general appearance is very pale; whence the name 'mealy,' and, perhaps, that of 'Stone-Redpoll.' The Greenland form, as already observed, is larger than any of the other races, paler, and with less carmine colour. 


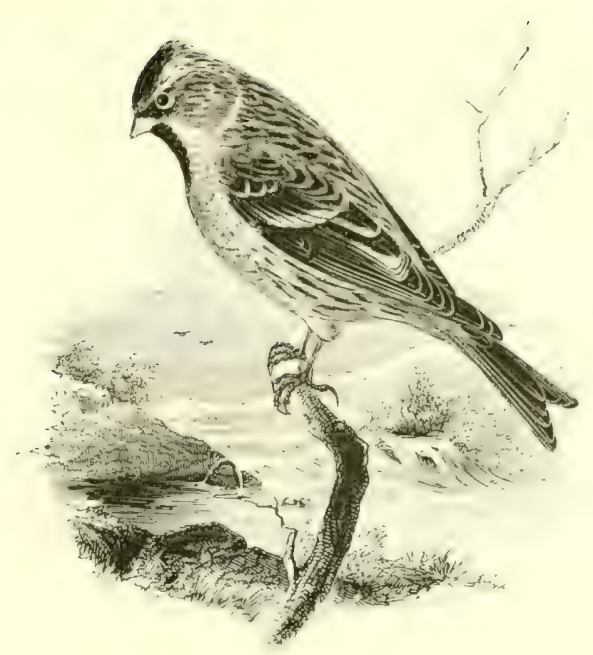

THE LESSER REDPOLL.

\section{ACANTHIS RUFÉSCENS (Vieillot).}

The Lesser Redpoll, the smallest of our British Finches, may be distinguished from the preceding by its size, and by its darker and more rufous colouring. Throughout the greater portion of the year it is generally distributed over the British Islands, and large numbers are taken by bird-catchers from autumn to spring; but in the breedinsseason it is rather local. Its distribution at that time in Scotland appears to be somewhat dependent upon woods and plantations, and is consequently irregular, nor does it extend to the ()uter Hebrides: but in winter the bird is generally dispersed and partially migratory. In England it nests, more or less commonly, north of a line drawn through Shropshire, I cicestershire and Norfolk; locally in Suffolk and Cambridgeshire; sparingly in (iloucestershire and along the upper part of the Thames valley; and more frequently than is generally supposed in the counties of Middlenex, surrcy and kient, in the immediate ricinity and exen in the suburbs of I.ondon. In Hants, Wilts, Dorset and Devon, it is a very local breeder, and in the extreme south-west it is rare at any time. Mr. Booth says that he has never obtained it on migration from any of the light-ships on the east coast of England. It nests commonly in many parts of Ireland, and large flocks are sometimes seen in winter.

On the Continent the Lesser Redpoll is unknown to the north of 
the Baltic, but it visits Heligoland (where it has once nested), Western (iermany, Holland, Belgium, and France down to the Pyrenees. Bailly's long-doubted statement as to its breeding in Savoy has recently been confirmed by the fact that Mr. S. B. Wilson found it nesting on the Engstlen Alp (6,100 feet) and in other parts of Switzerland, while Professor Giglioli had already done so on the Italian side; and it now appears probable that this species inhabits the greater part of the mountain-ranges of Central Europe. In severe winters it occasionally pushes its migrations to the south of Spain.

In the southern half of England the nest is often built in April, but nearly a month later in the north. The situation selected varies a good deal :; in Norfolk, for instance, a small fruit-tree is often chosen, while a good many pairs may be found breeding in low alders and willows, down in the marshes; again, small plantations of conifers, shrubberies, and hazel-hedges are much frequented. Fine twigs and grass stems, with a little moss and wool, are the materials employed for the exterior, the inside being beautifully lined with vegetable-down (principally from the catkins of the willow), hair and feathers. The eggs, 4-6 in number, are pale blue, spotted with reddish-frown : arerage measurements $\sigma_{3}$ by ${ }_{4} 8 \mathrm{in}$. Two broods are often reared in the season, and unfledged young have been found in the nest as late as September I4th. In autumn the various family parties unite to form large flocks, and rove about in search of food, which, like that of other members of the family, consists mainly of seeds. At all times of the year the Lesser Redpoll is a remarkably tame and confiding bird, allowing a near approach; and it is aiso eminently sociable, being frequently found in the comjany of Siskins and other species. The usual note is a continuous twitter, but the love-song of the male is rather loud and clear.

The adult male in spring has the lores and throat black, forehead and crown blood-red; upper parts of a darker and warmer brown than in the Mealy Redpoll-especially the pink-tinted rump, while the bands on the wings are rufous-buff, not white; breast carminered, and plumage otherwise as in the Mealy Redpoll; colour of soft parts the same; but the dimensions less, our bird measuring only $4^{\circ} 25$ in., and wing $2 \cdot 75$ in. After the autumn moult the red tints are generally less brilliant, owing to the pale edges of the new feathers; but I have seen old males with plenty of crimson in October. The female is smaller than the male, and has no red on the rump or breast, but only on the forehead; while the young bird is even duller in colour, inasmuch as it has no red on the head. 


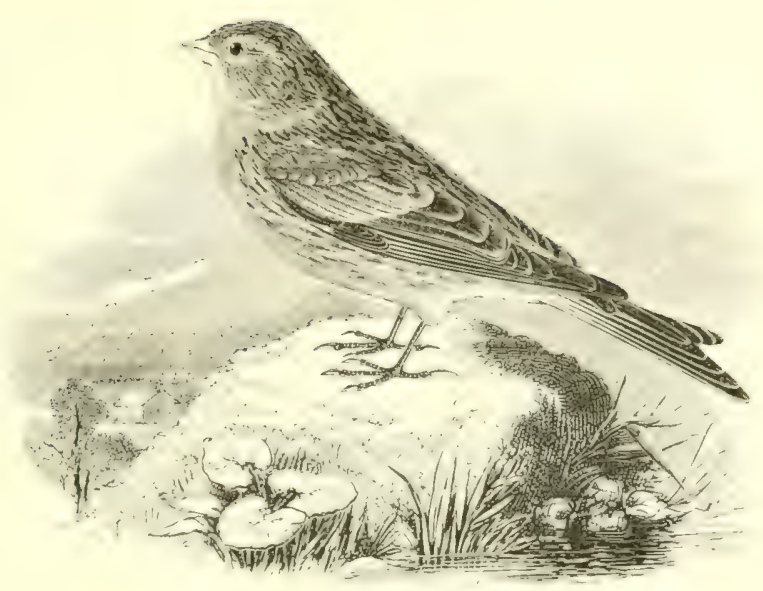

THE 'TWITE.

\section{ACANTHIS FLAVikóstris (Linnæus).}

The 'Twite, or Mountain-Linnet as it is often called, may be clistinguished from the Redpolls by its longer tail, more slender appearance, and the absence of any crimson tint on the head or breast. During the breeding-season it is an inhabitant of most of our moorlands from the Midlands northward, and although more frequent in the hilly districts, it mests at the lower level of the mosses in Lancashire and elsewhere. It is, however, rather local ; and in Cumberland it has, for some unaccountable reason, decreased during the last thirty years. On the mainland of Scotland the "Hill J intie" or 'Yellow-neb Lintie,' as it is called, becomes more abundant, especially where there is a sufficiency of long rank heather: and in the neighbourhood of the shore, on the long arms of the sea so numerous on the west coast, and in the Hebrides, Orkneys and shetlands it is extremely numerous. In Ircland it breeds commonly, both on the mountains and on the coast, from Waterford in the south to Donegal in the north. (On the apuroach of cold weather the more elevated districts are alsandoned, and gradually increasing tocks descend to the sea-shore, spreading themselves over the country: but in the south and east of Eneland their appearance is somewhat irregular as regards numbers, while in Comwall the species is, like the Lesser Redpoll, extremely rare.

On the Continent the fwite is found in summer amoner the islands 
and along the coast of Norway up to about $70^{\circ} \mathrm{N}$. lat., but in sweden it is scarce even in the sub-alpine districts, and it is somewhat doubtful if it nests in Northern Russia. On migration it visits Denmark and Northern Germany - sometimes passing in large numbers over Heligoland-Holland, Belgium and France ; but it seldom goes far south, and its occurrences in Spain, Italy and Southern Russia, are few and far between. In the east, however, from the Caucasus and Asia Minor to Tibet, it is represented by A. brizirostris, whicn is little more than a much paler form.

The nest is often placed in heather, or in low fruit and other bushes, sometimes in iry; one favourite position in Scotland is among the yrass growing on rocks by the sea-shore, and another is beneath a strip of turf which has been nearly reversed in ploughing or roadmaking; while on Rathlin Island I found one on the ledge of a high cliff, while seeking eggs of the Manx Shearwater. Fine roots for the outside, with an ample lining of wool, a little hair and a few feathers, are the materials employed; the eggs, usually $3^{-4}$, but sometimes 6 in number, being pale greenish-blue, blotched with reddish-brown, and rather more inclined to streakiness than those of the linnet: average measurements 7 by 5 in. Nidification commences about the middle of May, and two bronds are sometimes produced in the season. The food consists largely of the seeds of charlock and other weeds, but in the Shetlands the bird is said to be somewhat destructive to the newly-springing turnips and cabbages. Its callnote is indicated by its monosyllabic name. The Twite is usually far more shy than the Lesser Redpoll.

The adult male in spring has the lores, cheeks and throat reddishbuff: crown, nape and mantle hair-brown with paler edgings; wings dark brown, with whitish margins to the greater coverts, inner primaries and some of the secondaries-very noticeable in flight; rump rose-red; tail-feathers brown, with whitish inner edges to the three outer pairs: breast and flanks buffish-white streaked with hair-brown; belly dull white; bill pale yellow; legs dark brown. Length 5.25 ; wing 3 in. In winter the general appearance is greyer, and the bill is less yellow. The female has no red on the rump; the bar on the wing-corerts is buff; and the bill is dusky brown at the tip. The young are somewhat duller in colour. 


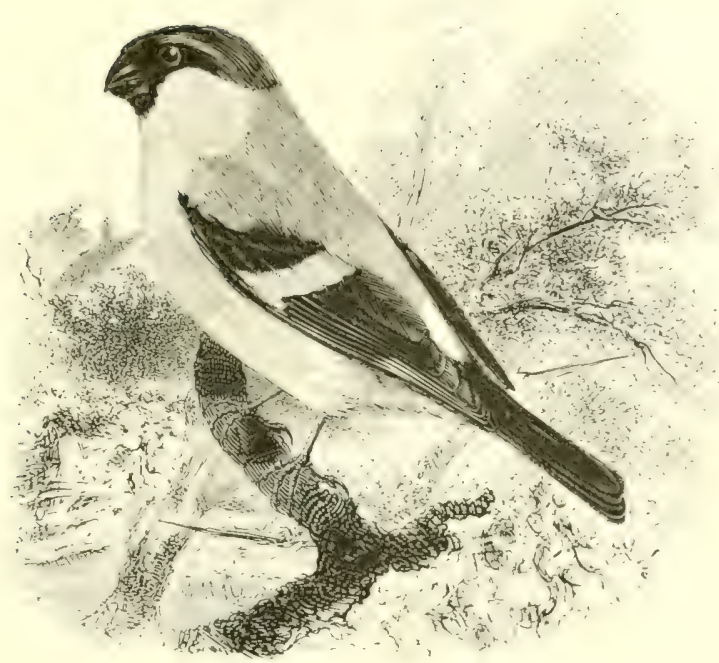

THE BULLFINCH.

PÍrRhula EURopía, Vieillot.

1) uring the greater portion of the year the Bullfinch is a frequenter of wooded districts; and unless the white rump and, in the male, the bright colour of the breast should happen to catch the eye, the bird may often, by escaping notice, be considered far rarer than is really the case. In spring, however, it frequently attracts the attention of the gardener by its visits to his fruit-trees, and although the damage (lone to the young buds may sometimes be orerestimated, it cannot be denied that there is apparent ground for complaint. Throughout suitable iocalities in England and Wales the Bullfinch is generally distributed; and althoush rather more local in Scotland, it has of late years spread to some of the Hebrides, especially to the south-eastern part of skye, but to the (Orkneys and Shetlands it is a rare visitor. In Ireland it is common, except in treeless districts, and in the south is increasing.

In Northern and Eastem Furope and in Siburia, misrating southward in winter, is found a large and brilliant race, which has been segregated as $I$. majer of Irehm; but our smaller and duller bird inhabits the countries south of the Baltic and west of Central Russia, as far as the northern portions of the Spanish Peninsula 
and of Italy, and reaches to Naples and Sicily ; wandering occasionally to other islands in the Mediterranean, and even to Algeria. In the mountainous portions of St. Michael's, one of the Azores, is found a large insular species, $P$. murimus, the sexes of which are nearly alike in plumage, both of them being of a dull grey without any white on the rump; a remarkable development, as no connecting link is known in the Canaries or in Madeira.

The unmistakable nest of the Bullinch is a platform of fine twigs of the birch, beech, fir \&c., surmounted by fine roots and a little hair woven into a shallow cup to receive the eggs. These, 4-6 in number, are of a clear greenish-blue, speckled and streaked with purplish-grey and dark brownish-purple, especially at the larger end: average measurements 73 by 55 in. A white-thorn hedge, or a fork near the extremity of a branch in some leafy tree or evergreen, are among the sites usually selected; and two broods are frequently reared in the season, the first eggs being laid in the latter half of April. The duties of incubation devolve upon the female. The young are fed partly on insects and their larvæ, and partly on seeds softened by the parent; but later in the year I have seen both old and young birds feeding upon the berries of the rowan-tree, dog-rose, hawthorn \&c., while the seeds of such weeds as the dock, thistle, ragwort, groundsel, chickweed and plantain, are largely consumed. It may even be doubted whether the Bullfinch's destructiveness to buds in spring may not originate in a search for concealed insects, but in any case it is certain that a charge of shot fired into the tender branches of a fruit-tree does far more damage than the depredations of the bird. The call-note is a soft diu, diu.

The adult male has the forehead, lores, throat, and head above the eyes, glossy blue-black; mantle smoke-grey; larger wing-coverts black, tipped with white, which forms a conspicuous bar; quills dark ash-colour, with narrow whitish edges to the emarginate portions of the $2 \mathrm{nd}, 3^{\mathrm{rd}}$, $4^{\text {th }}$ and 5 th ; secondaries glossy blue-black; rump pure white; tail glossy blue-black; cheeks and under parts bright brick-red ; vent white; bill black ; legs and feet dark brown. Length $6 \mathrm{in}$; wing 3 in. The female is of a browner grey on the upper parts, and the under parts are vinous-brown. The young differ from the female in having no black on the head, and the bar on the wing buffish-white. An entirely black nestling, found with three other young birds of the ordinary colour, attained after moulting the plumage of the female. 


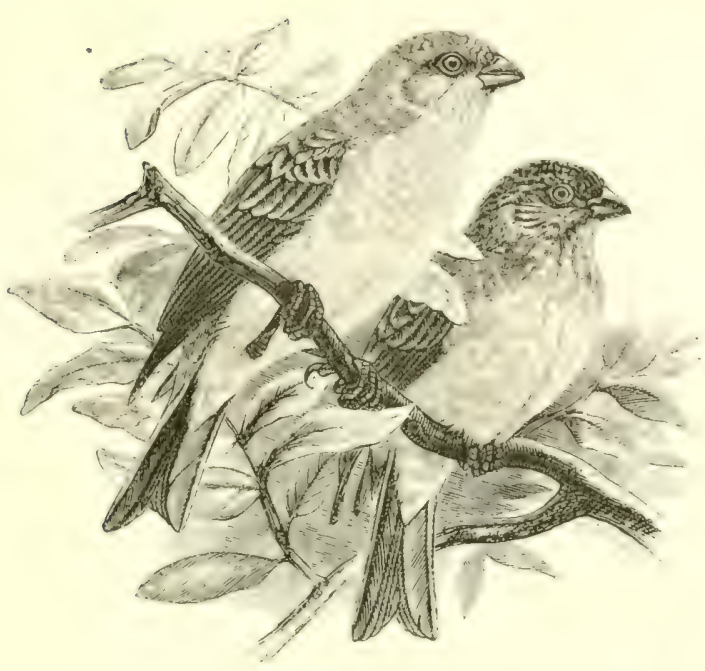

THE SCARLET GROSBEAK.

Pyrrhula erthirína (Pallas).

The Scarlet Grosbeak is an Eastern species which has noticeably extended its range in a westerly direction of late years, and on two occasions has been known to stray to England. The first instance on record was that of a female, captured on the downs near Brighton in September I869, which subsequently lived until June I 876 in the aviary of Mr. T. J. Monk of Lewes, in whose collection it is now preserved. On October $5^{\text {th }} 1870$, another female, now in the collection of Mr. F. Bond, was taken near Caen. Wood, Hampstead. ()ther examples have probably occurred from lime to time, and have been overlooked; for young birds or females of this species might easily be mistaken for Greenfinches.

As a straggler, the Scarlet Grosbeak has visited South Sweden, Sylt, Sleswick, Heligolankl, Belgium, lirance, the south of spainwhence I possess a specimen, killed on November I $_{5}$ th IS $_{74}$, and have seen another-Italy and Malta. In North-eastern Germany it is not uncommon on migration, and on one occasion it has been known to nest in Silesia ; but the westem limits of its usual breedingrange appear to be Finland, the Baltic Provinces of Russia, and Polanel. Fastward, it nests throughout the marshy torests of Forthern Siberia to the Pacific, and further south, in the elevated regions of the Caucasus, Isia Minor. Turlictan, and through Contral Isia 
to Northern China. In winter it is very common throughout the greater portion of the Indian region. It is rather late in returning to its northern breeding-quarters in Europe, and near Warsaw it does not arrive until about the middle of May; but in the drier climate of Siberia it is earlier.

The nest, which is rather deep, and is slenderly constructed of dry grass-stalks with a lining of horsehair, is placed in the fork of a small bush, generally in the neighbourhood of water. The eggs, $4^{-6}$ in number, are of a deeper greenish-blue than those of the Bullfinch, sparsely marked with reddish-brown and almost black spots : average measurements 75 by 57 in. The food consists of seeds, grain and berries, and Col. E. A. Butler says that the bird is partial to the watery nectar in the flower of the Indian coral-tree, while Jerdon observed it eating bamboo-seeds; but the young are probably fed on insects. 'The song, generally uttered from the top of a bush or low tree, is a loud clear whistle, tu-whit, tu-tu-i, several times repeated in rapid succession, whence the Hindoo name 'Tuti.'

The adult male has the top of the head glossy carmine-red; mantle warm brown with a reddish tinge; quills and tail dark brown, with paler buffish margins; rump and upper tail-coverts carmine-red; chin and throat rich rose-red; loreast rose-pink, fading to brownish on the flanks; bill yellowish-brown; legs reddish-brown. Length 5.75 in.; wing 3.25 in. The female has no red tints, the general colour of the upper parts being dull striated olive-brown, but the wingcoverts and inner secondaries are much more conspicuously edged with dirty white than in the male; the lower parts are dull white with a buffish tinge on the throat and breast, and numerous hairbrown streaks from the latter to the flanks; a brown stripe descends from either corner of the lower mandible. The young are at first rather greyer in tint than the female, but cock birds soon begin to show a distinctly yellowish tinge on the ear-coverts, rump, and outer margins of the wing- and tail-feathers. It seems probable that the rosy hue is not assumed until after the second moult.

This species has been separated by some modern authors from Pyrrhula, under the generic name Carpodacus of Kaup; but the distinctions are very fine, consisting mainly in the shape of the bill and in the smaller amount of covering to the nostrils. 


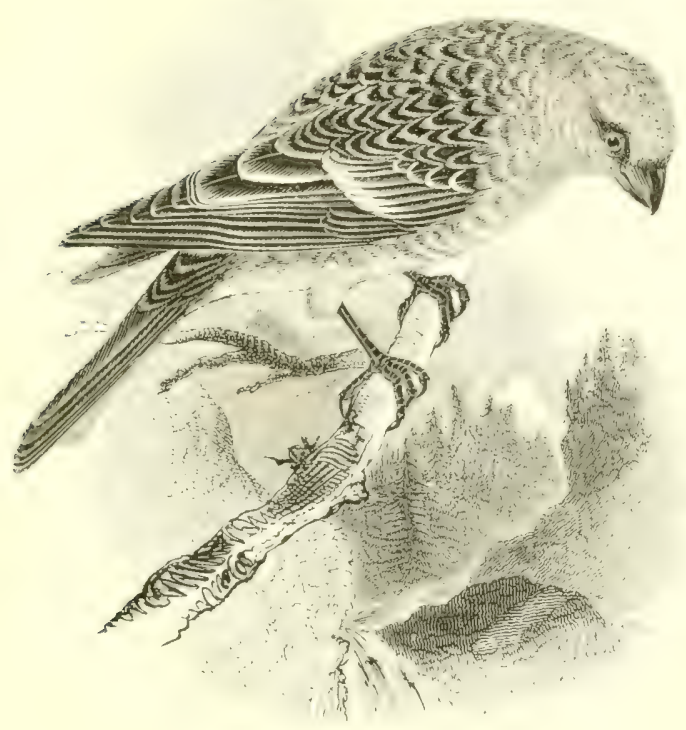

THE PINE-GROSBEAK.

Pyrrhula enucleátor (Linnæus).

The Pine-Grosbeak is, at most, an exceedingly rare visitor to the British Islands, and although some five-and-twenty so-called occurrences' are on record, critical examination by Mr. J. H. Gurney jun. (Zool. I887, pp. 242-250), and Professor Newton (4th Ed. Yarrell's B. B.), has disposed of all but five as unworthy of belief; while, to my mind, few even of these sifted records are entitled to acceptance. The specimens still existing are undoubtedly authentic, but the unsatisfactory nature of the evidence of their having feen obtained in a wild state in this country will hardly be credited by those who have not read Mr. Gurney's paper. If, as he observes, the Pine-Grosbeak were now to be installed for the first time as a British bird, the evidence would scarcely warrant such a step ; but. all things considered, I do not feel justified in summarily rejecting a bird which has for so long occupied a place in our list.

Exen in Heligoland, that wonderiul resting place for wats, and so much nearer it; home, the l'ine-(ircosbeak has only once been obtained; it is a rare winter-visitor to I emmark, and its occurrences, even in the suitable conifer-woods of North-eastern Germany, 
Silesia, and I'oland, are irregular. Accepting the records without criticism, it has strayed at long intervals to Belgium, France and Southern Germany; while, probably following the line of the mountain pine-Hoods, a solitary example appears to have crossed the Alps to the Trentino in the winter of 1876 . Its home is principally in the conifer region near the Arctic circle; but sometimes, as at Pulmak in Lapland, it extends to the birch-woods as far as $70^{\circ} \mathrm{N}$. lat.; while eastward, the bird is plentiful in Northern Russia, across Siberia to Kamsclatka, and as far south as Lake Baikal; as a straggler it has also been obtained in the Kuril islands to the north of Japan. In America it occurs throughout the Arctic and sub-Arctic forests, migrating southward in winter to California, Colorado and the northern portions of the Eastern States.

For a knowledge of the nesting habits and eggs of the PineGrosbeak, Englishmen are indebted, as in so many other cases, to the ardent researches of the late John Wolley, who discovered its breeding-haunts in Lapland. The nest, similar to that of the Bullfinch, consists externally of interlaced birch-twigs, with a lining of fine stiff grass, and is usually placed on the horizontal branches of a fir or a birch-tree, near the bole. The eggs are deep greenish-blue, spotted with brownish-purple: average measurements I in. by 72 in. The food consists partly of insects, but mainly of buds, birchcatkins, seeds and various berries. The song has been described as loud and flute-like; the flight is undulating.

The adult male has the feathers of the head, back and rump suffused with rich rose-red, upon a ground-colour of slate-grey; wings ash-brown, with broad pinkish-white tips to both sets of wingcoverts, and white margins to the secondaries; tail dusky-brown; under parts rose-red, turning to grey on the flanks and vent; bill dark brown, paler at the base of the lower mandible; legs blackishbrown. Length 8 in.; wing 4.25 in. In the ferrale the rose tint is replaced by a more or less golden-yellow, except on the back, which is slate-grey. The young have a greyish-green tinge. Mr. A. C. Chapman found a pair of birds breeding in this greyish-green plumage, the male having rather more of the yellow colour than the female; another nest belonged to a couple of greyish-green birds; while at a third nest a male in full ros; plumage was paired with an ash-grey female.

Many authors have accepted the genus Pinicole of Vieillot for this species. 


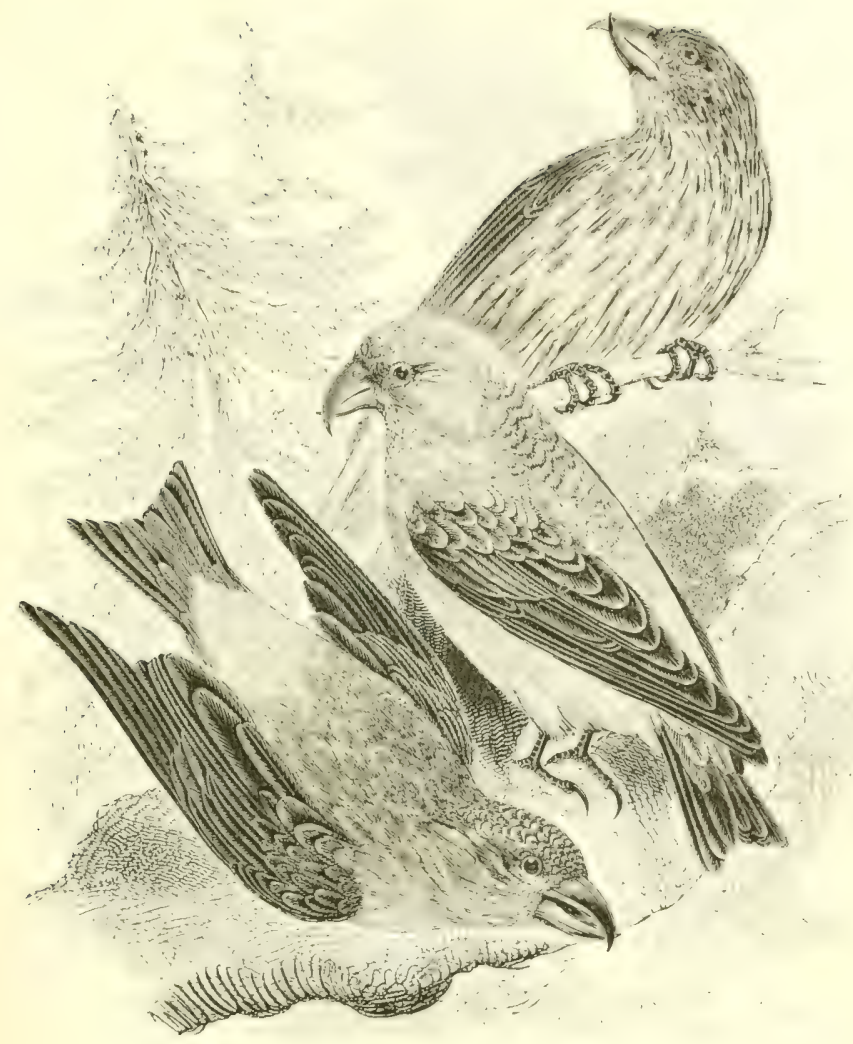

\section{THE CROSSBILL.}

\section{LóxiA CURVIRÓSTRA, I inneus.}

The Crossbill is generally noticed in England from autumn to spring, when wandering about the country in family-parties which sometimes unite to form flocks; but numerous instances are known in which it has remained to breed among the conifers of the southern counties, although such situations as its habits require are less frequent there than in the north. Across the Solway, and northward, it nests in many districts, chiefly in the old pineforests; but it does not appear to stray to the Outer Hebrides, although it is an uncertain visitor to the Orkney's and Shetlands. In Ireland it has occasionally bred in cos. Down, Meath, Kildare, Wicklow and Tipperary, and occ!rrs irregularly on migration. 
The Crossbill nests throughout the pine-forests of Europe, from Lapland to Spain, the Balearic Islands, and (ireece, as well as in the Atlas Mountains of Africa ; the southern residents having noticeably weaker bills than northern examples; and it equally frequents the conifer growths of Siberia as far as Kamschatka, wintering in North China. The pine-woods of Scandinavia, Northern Russia and the Baltic provinces are also inhabited by a large stout-billed race, formerly distinguished as the PARROT Crosiblll, Lowia pityopsittacus, but now esteemed by modern authorities as merely one of several forms which Mr. R. B. Sharpe (Cat. Birds Brit. Mus. xii. p. 439) "does not consider to be worthy of even subspecific rank." I have deemed it unnecessary to give a separate figure or description of this extreme phase, which merely differs from the type in its varying size, and in the fact that its food consists largely of the seeds of the Scotch fir, whereas the smaller common form also feeds on the spruce, larch, stone-pine $\mathcal{S}_{\mathrm{c}}$. The large-billed birds are occasionally obtained in our islands and in Central Europe, but they do not migrate far to the south. Forms slightly smaller than the ordinary Crossbill are found in the Himalayas and Tibet, Japan, and North America, but the highlands of Mexico produce a rather larger race.

The nest, frequently built in February or March, is generally placed on the horizontal branch of a fir, often close to the stem, and is formed of twigs, surmounted by a cup-shaped structure of dry grass, moss, wool and lichen, with a lining of similar but softer materials. The eggs, usually 4 , rarely 5 in number, are greyishwhite, sparsely spotted with several shades of reddish-brown; like those of the Greenfinch, but larger: average measurements 9 by .66 in.; those of the so-called Parrot-Crossbill hardly exceeding these dimensions. In summer both young and old birds eat caterpillars and the larve of insects, but later their food is obtained from fir cones, while rowan and other berries, apple-pips and buds are also consumed. The note is a gip, gip, chi, chi.

The adult male has most of the upper and under parts dull crimson, which is brightest on the rump; wings brown, with a pale bar along the edges of the coverts; tail brown; bill, legs and feet dark brown. Average length 6.5 ; wing 4 in. In the female the red is represented by greenish-orange, and her plumage is more striated, especially before maturity. Young birds are greenish-grey, with a little yellow on the rump; in the nestling stage the general colour is ash-brown, and at three weeks old the bill is still straight, the lower mandible shutting within the upper. 


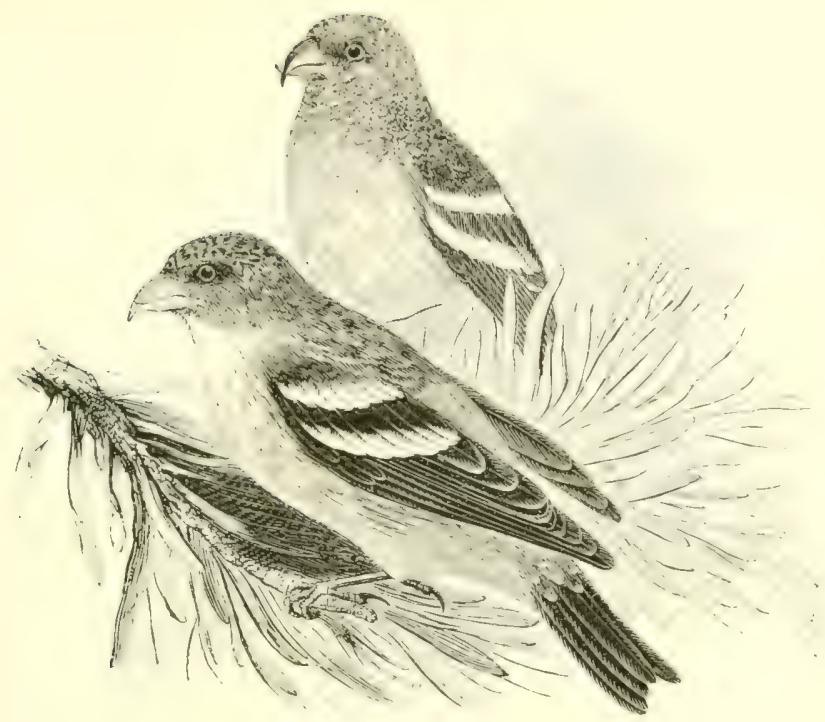

THE 'TIVO-BARRED CROSSBILL.

\section{Loxia bifasciáta (C. L. Brehm).}

This species, sometimes called the European White-winged Crossbill, to distinguish it from the American form, inhabits the coniferous forests of Northern Russia and Siberia as far as the Pacific; wandering in autumn and winter to South Sweden, Denmark, Heligoland, North (iermany, Holland, Helgium, the north of France, North Italy, Austria and Poland. In our islands the first recorded specimen was obtained near Belfast, Ireland, on May i th 1802, and in July or August I868 a second was obtained in co. Dublin. A few years prior to 18.43 one was killed in Cornwall; in the autumn of 1845 a flock appeared in the neighbourhood of Brampton in Cumberland, and ten or eleven were shot, six of them being in female plumage; in May I 846 two or three were killed from a flock near Bury St. Edmund's, Suffolk; and about the same time the late H. I oubleday shot a bird in his sarden at Epping. Others have been olserved in various prarts of the ( nited Kingdom.

The northern forests of America, from Alaska to Labrador, are inhabited by a bird known as the White-Winged Crossbili, Loxia leucoptera, which Mr. R. B. Sharpe considers to be only entitled to subspecific distinction; and after examining a good many speci mens, including those in the british 1 lusem, I agree with him that 
the only difference of any moment between the European and American forms consists in the darker scapulars of the latter; to which I may add that the red in the male has a pinker tint, and the bill in both sexes is weaker. A hen bird ascribed to the American form. and still in the strickland collection at Cambridge, was killed near Torcuster in 1835 : a red male was picked up dead at Exmouth on September $\mathrm{I}-\mathrm{th}$ is +5 : and a female, which lived in Mr. Stevenson's aviary at Norwich till December $r 874$, was stated by the dealer of whom it was purchased by Mr. J. H. Gurney jun. in $I_{7}{ }_{2}$, to have been captured-it is not said where-on the rigsing of the presumably American ressel "Beecher stowe," which arrived at Great Yarmouth in October 1870. Even in Greenland only five occurrences are on record during nearly sixty years; it has not been known to visit Iceland or the Færoes; and I have Mr. Gätke's authority for stating that it has never been obtained on Ieligoland. It is noturious that - American White-winged Crossbills, captured at sea comparatively near their own coast, have been brought to the British Islands, and have then escaped or been let louse: and I do not consider that the species has a claim to a place in the British list.

A nest of the Two-barred Crossbill sent to MIr. Dresser, with the parent birds, from the Archan rel district, is described as rather smaller and slighter than that of the common Crossbill, while the ezgs are somewhat darker in colour and less in size. In food and habits this bird resembles its congener, but its song being of a superior quality, it is a greater favourite as a cage-bird.

Adult male: head, neck, mantle and rump, carmine-red, slightly mottled, owing to the protrusion of the black bases of the feathers; wings black, with white tips to the inner secondaries, and broad pinkish-white edges to the greater and median wing-coverts; tail-feathers brownish-black, narrowly edyed with reddish-white; under parts carmine-red, which fades into white on the belly; bill horn-colour, lighter on the lower mandible; legs dull brown. Length 6.25 in.; wing 37 in. In 'ess mature birds the pink tinge on the wing bands is wanting, and the flanks are striated. Female: upper parts greenish-grey, whith a yeliow tint, and dusky-brown streaks; rump Iale yellow; under parts greyish-yellow; paler on the throat and abdomen, and streaked with dusky-brown. loung bird in August: much striated on a greyish ground, with hardly any trace of yellow: white upper wing-bar very narrow; quills and tailfeathers distinctly margined with grcenish-white. 


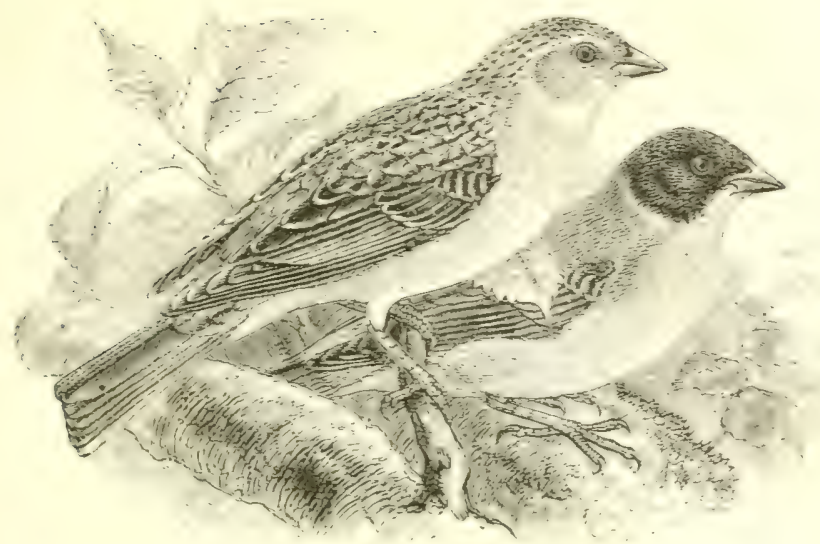

BLACK-HEADED BL'NTING.

Emberíza malayocéphala, Scopoli.

The Black-headed Bunting - not to be confounded with our common Reed-Bunting, which is sonetimes called by this name-is an inhabitant of the south-eastern protions of Eurofe: but from time to time it wancers in a westerly direction, and, owing to the increisud attention now paid to ornithology; its presence has already been detected on three occasions in Great Britain. The first example, an adult female, identified by the late Mr. Gould, and now in the collection of Mr. T. J. Monk of Lewes, was shot near Brighton while following a lluck of lellow Buntinss. about Nurember ind r868. The Rer. J. R. Ashworth has recorded (Zool. r\$86, p. 73), the acquisition of an identified specimen in June or July IS\&4, stated to have been shot in Nottinghamshire. The third example was said by the dealer from whom it was purchased to have been

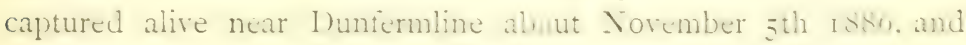
was recognized by the Rev. H. A. Macpherson at the Bird Show of February I $5^{\text {th }}$ ISS $\boldsymbol{7}$, held at the Crystal Palace (Zool. ISS 7 , p. I93), where I saw it again in the present year (ISSS), when in nearly adult male pluma-ce. The fact that the icmales and yound are dull-coloured birds, not likely to be imported, farours the assumption that these histories are substantially correct.

On Heliguland the IBlack-headed Iunting has been obtained as Mr. Githe informs me. "Wwarks of niteon times-in May and I une. and also in September and October; but, strange to say, I do not find it recorded from Authem (iermany: although it anctine: 
visits Austria. It has also occurred near Marseilles, and along the Riviera to Liguria : while in Verona and along the east side of Italy it is, naturally, not uncommon, inasmuch as it breeds abundantly in Dalmatia, on the further side of the Adriatic. To Sicily and Malta it is only a rare visitor, nor does it cross the Mediterranean to Africa. In Cireece, Turkey, the Danubian Provinces, Southern Russia, Asia Minor, Palestine, and Northern Persia, it is common from the end of April to autumn, after which it leaves for its winter-quarters in North-western and Central India, where immense flocks are found during the cold season.

The Black-headed Bunting seldom ascends the mountains to any great elevation, preferring the flat ground planted with vines, olivetrecs, pomegranates $\mathrm{Lic}_{\mathrm{c}}$, near the sea-shore. The nest is generally in climbing plants, rose-bushes or brambles, and, in Turkey, often among peas, which are allowed by the gardeners to stand until the young are fledged. It is rather loosely constructed of the stalks of small flowering plants, with a lining of dry grass, roots and hair. The eggs-different in appearance to those of any other Europan Bunting - are pale greenish-blue, speckled with ash-brown, and are $4^{-6}$ in number : average measurements 85 by 7 in. In summer both young and old feed on grasshoppers and other insects, and on fruit: but in India, during autumn and winter, considerable haroc is made in fields of grain. Canon Tristram says that this bird has nothing of the Bunting in its habits or character, whereas Mr. Seebohm asserts that in its habits and song it is a typical Bunting: The call-note of the male is a ribrating monotonous ihirivir.

The adult male has the head and ear-coverts black: back and rump, orange-brown: wings hair-brown, with dull whitish margins to the coverts and secondaries: tail hair-brown, with a narrow white streak to the inner web of the outer pair of feathers; under parts and sides of the neck bright gamboge-yellow; bill greyish horncolour; legs and feet pale brown. Length $6{ }^{\circ} 75$; wing $33^{\circ} 7$ in. After the autumn moult the bright tints, although perceptible at the bases of the feathers, are obscured by the new dull brown edges. The female is sandy-brown on the upper parts, with darker striations on the head and back, and buffish-white margins to the wingcoverts and quills: rump slightly tinged with yellow: tail-feathers hair-brown with paler margins; throat and belly dull white; breast and flanks sandy-buff with narrow brown streaks: under tail-coverts pale yellow. The young resemble the female. 


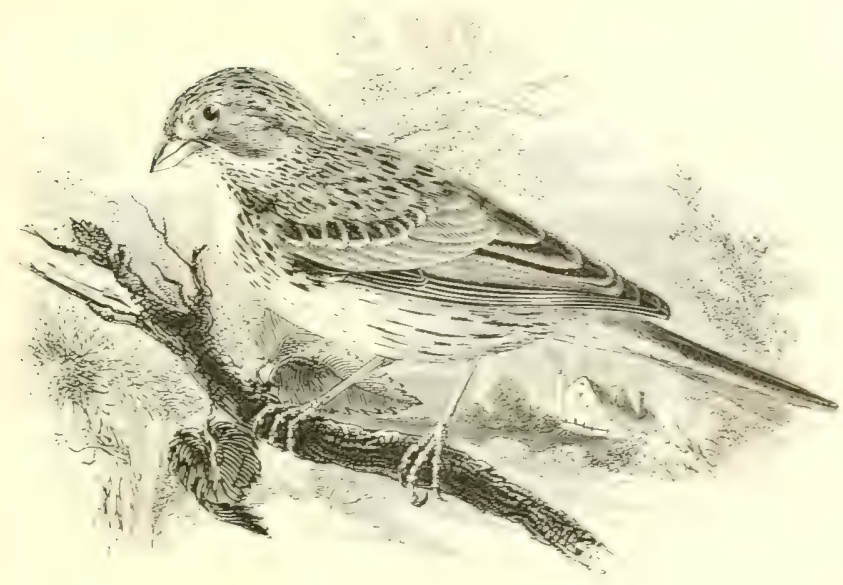

THE CORN-BUNTING.

Eimeriza milí́ria, Linnaus.

This species is frequently called the Bunting-Iark, and by many authors it las been styled the Common Bunting: but the lise of the latter name is hardly to be encouraged, as the bird, although widky distributed throughout the British Islands, is decidedly Loal and not nearly so common as the Yellow Bunting. It is principally to be found where grain of some kind is grown, and when arable land is turned into grazing ground the Com-Bunting becomes scarce. or even disappears. Low lands and the vicinity of the sea are the districts most affected in scotland and its islands, where it ranges as far west as St. Kilda: while northward it is found breeling on the Shetlands, although not yet obtained in the Fierces. In Ircland it is common in suitable districts, but local. In autumn our home. bred birds become gregarious, and to a certain extent mirrants: at the same time considerable accessions are made to their numbers, especially on our east coasts, by visitors from the Continent.

In Scandinavia the Corn-Bunting is only known in the extreme south: but from Inemmark and the hither side of the Baltic it is generally distributed over the open lortions of Europe in summer. though in winter it is partially migratory in the northern and central districts. In the spanish l'eninsula and other steat comproducing countries of the suth, as well as in Jorth . Arica and the Canaries, it is resident and extremely numerous: it is also found in 
Palestine, Asia Minor, Persia and Western Turkestan; and in winter as far south as Nubia, Arabia Petræa, Bushire and Sind. In all forest and mountain regions it is practically unknown.

The Corn-Bunting is a late breeder, and in this country it is useless to search for its eggs before the latter part of May. The nest may sometimes be found in rough herbage, or at the foot of a low shrub, but it is generally placed well towards the middle of a field of clover or pease, or under a clod among young corn; and some umbelliferous plant, sufficiently strong to afford a perch for the bird, will probably be at no great distance from it. Straw, a little moss, roots and dry grass, with hair for a lining, are the materials employed to form the somewhat loose structure; the eggs, $4-5$ in number, are of a dull purplish-white, or sometimes of an ochreous ground-colour, blotched and streaked with dark purple-brown : average measurements 98 in. by 7 in. The hen sits closely, whilst the male utters his harsh and monotonous tic-tic-teese on a perch, which varies in elevation from the top of some tall tree or a hedgerow to a clod in the fallows. The flight is heavy and laboured, the legs of the bird hanging down at first, as if broken. The young are fed on insects; the adults have been seen to eat cockchafers, and they undoubtedly devour numbers of small beetles; but in autumn and winter grain is largely consumed, and the birds become so fat that, in the south of Europe, they are much in request for the table. Many are taken in nets, together with Larks, owing to their habit of roosting on the gronnd, and Mr. Booth says that near Shoreham numbers resort in the evening to the beds of marine weeds which grow on the mud-flats above high-water mark.

Adult male: lores, and a line above and behind the eye buffishwhite: ear-patches, head, neck, mantle and upper tail-coverts pale hair-brown, streaked with darker brown down the middle of each feather; wing-coverts dark brown with buff margins; quills duskybrown : tail rather lighter brown with pale margins; throat buffishwhite, with brown spots at the side which form a moustache-like streak; remaining under parts buffish-white, freely spotted on the breast and streaked on the flanks with brown; bill yellowish-brown, with a dark stripe along the ridge of the upper mandible; legs pale flesh-colour. Length 7 in. ; wing $3^{\circ} 6$ in. The sexes are alike in plumage. The young bird is darker, with broad fulvous margins to the wing-coverts and secondaries, and the under parts are tinged with buff. Some Continental specimens - especially those from the east-are very pale in colour; while albinistic varieties are not uncommon. 


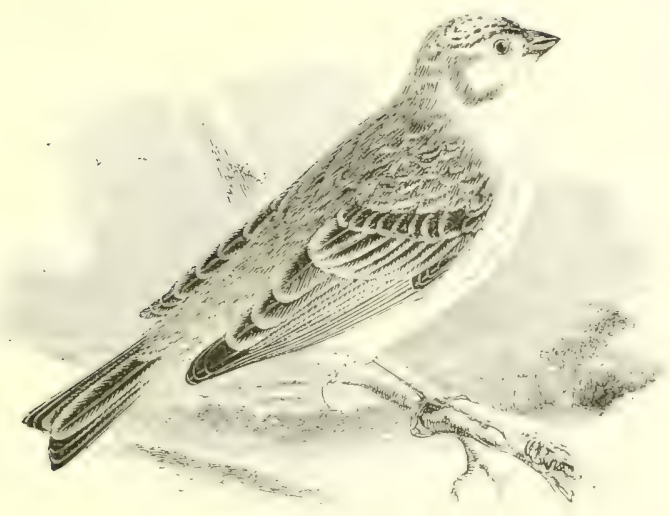

THE YELLOW BUNTING.

EMberiza citrinélia, Linnæus.

The Yellow Bunting is familiarly known as the Yellow Hammer, the latter portion of the name having, no doubt, a common origin with 'Ammer,' the modern German word for a Bunting; but our form of spelling has now been in print for upwards of two centuries, and few, even among purists, will risk the imputation of a solecism by omitting the aspirate. Throughout the British Islands this handsome bird is in most parts common and resident; it even nests in the Outer Hebrides, and sparingly in the Orkneys, but as yet is not known to do so in the Shetlands, although a visitor to that group.

In Norway this species is found breeding up to about $70^{\circ} \mathrm{N}$. lat., but as we proceed eastward, its northerly summer-range gradually decreases to only $64^{\circ}$ on the Ob, in Siberia. South-eastward, it reaches as far as the upper valley of the lenesei: while, turning southwestward, we find the bird in Turkestan, Persia and Asia Minor. In temperate Europe it is generally distributed. and, except in the northern districts, is resident; but its breeding range does not appear to extend south of the Pyrences and ('antalirian Yountains, and the northern portions of Italy; while, even in winter, the bird is almost unknown in the islands of the Mediterranean, in Southern Italy, and the South-west of Spain, though said to occur in the Canaries. In Palestine, according to Canon Tristram, its place is taken by a very distinct species, E. casia, which occasionally wanders to Heli- 
goland; where, by the way, the Yellow Bunting is common on migration in spring and autumn.

The nest, somewhat slightly made of dry grasses and a little moss, with a lining of finer material and hair, is usually placed on or near the ground, in the side of a bank, or among tangled herbage, but sometimes it is built in a bush, and in the north often in young spruce plantations; exceptionally at an height of seven feet. The well-known eggs, $4-5$ in number, are subject to considerable variation in shade of colour, but as a rule they are purplish-white, streaked, spotted and clouded with reddish-purple, and scrolled with long hair-like markings, from which, in some parts, the bird has acquired the name of 'Writing-lark' : average measurements 85 by 63 in. Incubation, in which the male takes part, lasts fourteen days, and at least two broods are produced in the year; the first eggs being laid about the middle of April, while nestlings are not unfrequent in September. The familiar song, often rendered as "Little-bit-of-bread-and nó chēese," may be heard from morning tili night during the hottest weather, and even on a bright day in winter. In summer both young and old feed largely on insects; in autumn they are partial to blackberries and other wild fruits; while seeds and grain form their principal sustenance in winter, at which season large flocks frequent stubble-fields and even farm-yards. In severe weather Mr. Booth observed a flock feeding on the carcase of a horse hung up at some kennels, in P'erthshire.

Adult male: head and throat bright lemon-yellow, spotted and streaked with dusky-brown; mantle reddish-brown with blackish streaks; quills dusky-brown with narrow yellowish margins; rump and tail-coverts chestnut; tail-feathers chiefly dark brown, with elongated white patches on the two outer pairs; under parts lemonyellow, with dusky chestnut streaks on the breast and flanks; bill bluish; legs light brown. Length $6.5 \mathrm{in}$. ; wing 3.25 in. In autumn the colours are duller, owing to the pale margins of the new feathers. The female is less yellow and more streaked with greyishbrown, while the chestnut-brown tints are nearly absent. The young show no yellow until after their first moult. 


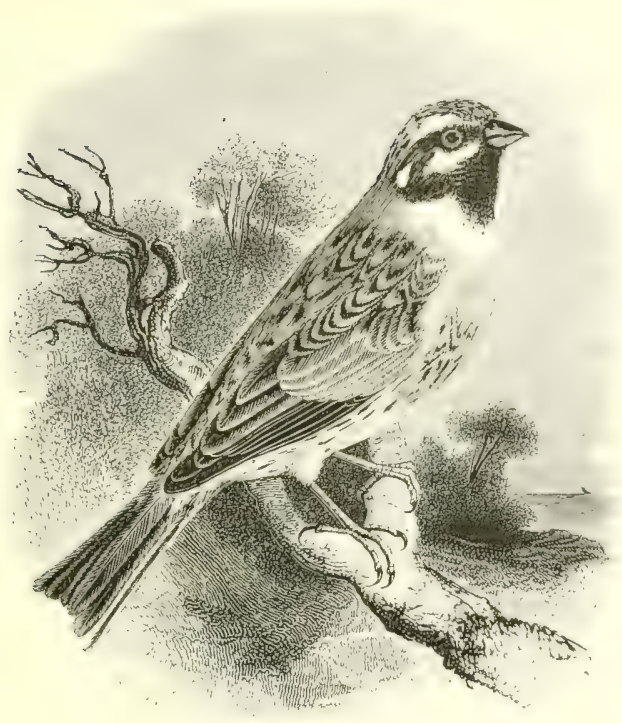

THE CIRL, BUNTING.

EMieriza círlus, Linnæus.

The Cirl Bunting is a resident southern species, which was added to the British list by Montagu, who found it breeding in I)evonshire. Subsequent observations have considerably extended our acquaintance with its range, and the bird is now known to be fairly common, although very local, from Cornwall to Kent, and along the valleys of the Thames and its tributaries up to Gloucestershire; also on the chalk-hills of Hertfordshire and Bedfordshire, especially in the neighbourhood of Tring. Mr. Booth obtained two by chance in Norfolk in the autumn of 1875 ; in Northamptonshire and the Nid. land counties it is of accidental occurrence, and to Yorkshire it is a rare visitor; while in 1)urham, Northumberland and Cumberland it is unknown, though it has strayed to Lancashire. It has been found breeding in Warwickshire, Worcestershire, Herefordshire and Salop; but it was, I believe, unknown in Wales until Mr. E. C. Phillips obtained a male on $15^{\text {th }}$ March I 888 , near Brecon. In Scotland, at long intervals, three stragglers have been taken; one near Edinburgh, one in Aberdeenshire, and one in Roxburghshire. Mr. A. G. More classes it among the species erroneously included in the Irish list.

The Cirl Bunting has only twice been obtained (in spring) on 
Heligoland, and is of rare occurrence in Holland and Belgium. In summer it is found from France on the west to Bohemia on the east: while southward, it is resident from the Spanish Peninsula to Greece, Southern Russia, Turkey, Asia Minor, and the islands of the Mediterranean; it is also found on the northern slopes of the Atlas Mountains in Africa. To other European Bunting has nearly so restricted a range.

The nest, similar to that of the Yellow Bunting, but often containing rather more moss, is placed in a bank among the stems of a hazel or other bush, though sometimes in furze or juniper at a little distance from the ground. The eggs, $4-5$ in number, are purplish-grey with almost black markings, bolder, as a zule, than on those of the preceding species and with fewer hair-lines: average measurements 86 by .64 in. The first clutch is laid in May, the second in July; and on the chalk-hills of Surrey, where the bird is not uncommon, I have found that the Cuckoo is rather partial to its nest. The young are fed chiefly on grasshoppers and other insects; but later, principally on grass seeds and grain; and in the south of France during snowy winter weather I have seen small flocks feeding, along with Sparrows and other Finches, on the refuse in the streets. Although unobtrusive and inconspicuous, my experience is that it is anything but a shy bird; on the contrary it will at all seasons allow a very near approach and close inspection, and even when disturbed it does not fly far. The note is like that of the Yellow Bunting, but without the "no cheese," and, if long drawn out, is nearly expressed by the French name for the bird, 'zizi.' In the bright climate of the south the song may be heard throughout the greater part of the year, except when the bird is actually moulting.

The adult male has a lemon-yellow streak from the forehead over each eye; lores and ear-coverts black; crown and nape olive streaked with black; upper wing-coverts greenish-grey; mantle and secondaries more distinctly chestnut-brown, and rump decidedly less rufous than in the Vellow Bunting; quills and tail-feathers about the same as in that species; throat black, followed by a pale sulphurcoloured collar, below which is an olive-grey band succeeded by chestnut-brown stripes that run down the flank; belly sulphur-yellow; bill dark horn above, bluish below; legs yellowish. Length 6.5 in.; wing 3.25 in. The female has the throat pale buff and hardly any yellow on the breast and under parts, which are streaked with dark brown; upper parts less rufous than in the male. The young are rather duller than the female. 


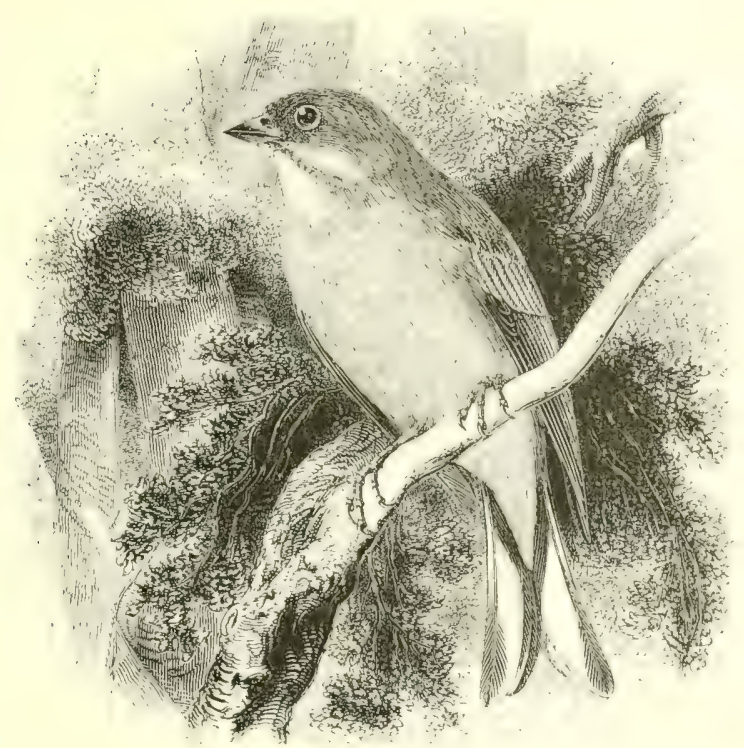

THE ORTOIAN.

EMBERIZA HORTULÁNA, Linnæus.

This Bunting was first described as a visitor to England from a bird taken alive in Mary-le-bone Fields, a little before I 776 ; which, with another specimen caught on board a collier off the Yorkshire coast in May I822, is now in the Museum of Newcastle-on-Tyne. In November 1827 , a male was killed near Manchester. In Sussex four or five examples have been taken in spring and autumn since I $84 \mathrm{I}$; and an immature bird was killed in the Scilly Islands early in October IS 5 I. Several have been captured near London since I 837 , but from that time onwards such increasingly large numbers of Ortolans have been annually imported from the Continent that occurrences in the home-counties are open to suspicion. In June, a few years ago, I saw an adult male in Hyde Park Street, which had undoubtedly escaped from a neighbouring poulterer's, where at the time there were cages full of these birds. One was killed on Lowestoft Denes in May I859; and MIr. F. D. Power shot an immature male from among some Linnets, at Cley, Norfolk, on September I 2 th 1884 , about the time that enormous numbers were seen on Heligoland. On May zrd I883, Mr. J. Cordeaux watched with his binoculars a female feeding on the scattered grain in a newly- 
sown oatfield on the Lincolnshire side of the Humber. In Scotland two examples were obtained in November $\mathbf{I} \mathrm{6}_{3}$, near Aberdeen. Mr. A. G. More states that in the Museum of Science and Art, Dublin, there is a specimen said to have been taken in co. Clare previous to May 1852 .

The Ortolan is found in summer as far north as the Arctic circle in Scandinavia; but eastward, its northerly range gradually recedes to about $57^{\circ} \mathrm{N}$. lat. in Russia. South of the Baltic it is irregularly distributed throughout Europe, and, although extremely local, it is common at no greater distance from this country than some districts in the north of France, Flanders, Dutch Brabant \&c. Even in the south of Europe, where it is rather partial to low bushes on stony hill-sides, it is only a summer-visitor; and in Northern Africa, where it breeds in comparatively small numbers, it does not remain for the winter, but migrates southwards as far as Abyssinia. In Palestine, Asia Minor, Persia, Turkestan, and Siberia as far as the valley of the Irtish, it only passes the summer, visiting North-western India during the cold season. I have known the Ortolan arrive on the French side of the Pyrenees as early as March $23^{\text {rd }}$; the return migration begins in August.

The nest, built in the latter half of May, of dry grass and roots with a lining of fine bents and hair, is always on the ground, and generally in open fields, though sometimes among coarse herbage or under small bushes. 'The eggs, 4-6 in number, are pale purplishgrey, distinctly spotted and very little scrolled with purple and black : average measurements 8 by 62 in. The food consists of beetles and other insects as much as of seeds, but in confinement the bird feeds greedily upon oats and millet, until it attains the fatness which is proverbial. The note, which is rather metallic, may be syllabled as tsee-ah, tsee-ah, tsee-ah, tyur.

Adult male: head and nape greenish-grey with faint yellow streaks from the forehead to below the ear-coverts; back, wingcoverts and secondaries fulvous-brown, with dark stripes down the centre of the feathers; rump reddish-brown; tail-feathers brown, with oblong patches of white on the three outer pairs; throat sulphur-yellow; pectoral band olive-grey; lower breast, belly and under tail-coverts pale chestnut; bill reddish-brown; legs brownishorange. Length 6 in. ; wing 3.25 in. In less mature males the rump is dull striated brown, there is no white on the third inner pair of tail-feathers, and the under parts are paler. The female has the head greener and more streaked; upper parts duller; gorget yellowish-buff streaked with brown; under parts yellowish-buff. 


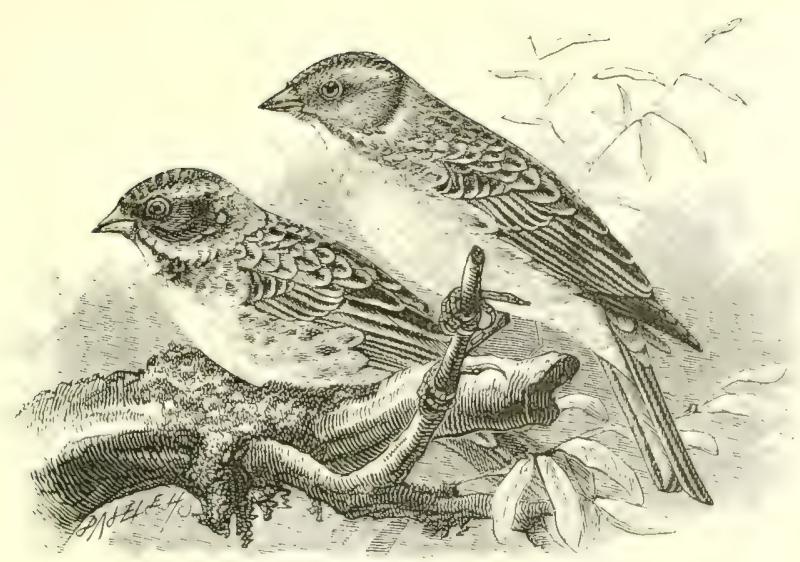

THE RUSTIC BUNTING.

Emberiza rústica, Pallas.

The first example of the Rustic Bunting known to have occurred in England was caught near Brighton, on October 23 rd IS67, and was shown alive to the late Mr. G. D. Rowley; it is now in the collection of Mr. T. J. Monk of Lewes. A second, identified and recorded by Mr. W. E. Clarke (Zool. ISS I, P. 465), and exhibited at a meeting of the Zoological Society, was shot on the Holderness coast, Yorkshire, on September I 7 th $188 \mathrm{I}$, the same day on which a young bird of this species was obtained at Heligoland by Mr. Gätke. Lord Lilford states (Zool. I 883 , p. 33) that a young male was sent to him in the flesh, which had been taken by a bird-catcher at Elstree reservoir, near London, on November Igth I882.

The Rustic Bunting is an eastern species which is gradually extending its range westward, and is now known to wander to Sweden and to occur annually in East Finland. Mr Gïtke informs me that he possesses eight specimens taken on Heligoland, while more have been obtained there: and stragglers have occurred from time to time in Germany, Austria, the south of France, the north of Italy, and once near Constantinople. From Archangel eastward it ranges across Siberia to Kamschatka; D)r. von Middendorff found it paired and apparently nesting in the Stanovoi Mountains; southward, it is abundant on passage in Mongolia; and, according to Captain Blakiston, it is common in the southern part of the main island of Japan in winter, and at Yeso in summer. In the cold scason it is found in China as far south as shanghai; and 
it is supposed to breed in the mountainous regions to the north of Mongolia, and in Turkestan, as well as in Northern Siberia. In Western Siberia it appears to be very local.

Nothing is really known of the nesting habits of this Bunting; and although Mr. I)resser has described a nest and egsss sent to him from Archangel, stated to belong to this specics, while Mr. Secbohm has figured two egys--unlike each other -from the Altai and Archangel respectively, none of them are really authenticated. The bird arrives in Northern Russia about the beginning of May, and frequents the open portions of swampy fir-woods, where it is supposed to breed, as in such situations Herr Meves met with two broods in July. The young are said to feed upon oats and other grain. 'The song is described by I)r. von Middendorff as rich and melodious, while the call-note is a sharp cry, not unlike that of the Redwing.

Adult male in breeding-plumage: crown of the head, lores and ear-patches black; above and behind each eye a broad white stripe, and a small patch of the same colour on the nape; mantle, upper wing-coverts and rump chestnut-brown, with some blackish streaks on the upper back; greater and middle wing-coverts broadly tipped with white, which forms two conspicuous bars; secondaries with dark brown centres and reddish-buff margins; quills ash-brown; tailfeathers chiefly dark brown, but the exterior pair with the greater part of their webs white, and the second pair with a long white streak from near the base to the tip of the inner web; throat and belly white; breast broadly banded with chestnut, and flanks streaked with the same; bill dark brown above, yellowish below; legs pinkish-yellow. Length $5^{\circ} 4$ in. ; wing $3^{\circ} 2$ in. In the female the head and ear-patches are brownish, mottled with black, and the chestnut tints on the back and chest are less pronounced. The young bird in August has the upper parts warm tawny-brown with blackish streaks; under parts dull white, streaked with dark brown, and suffused with rufous-buff, with a faint chestnut tinge on the breast and flanks. 


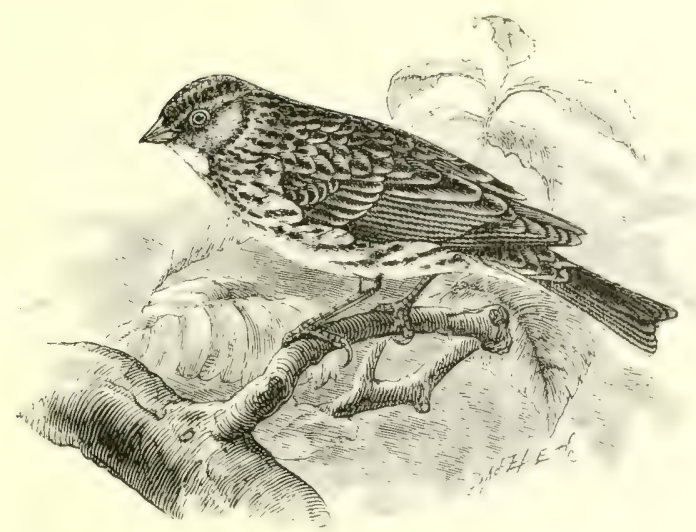

THE LITTLE BUNTING.

Emeeriza pusílla, Pallas.

The only British example yet recorded of this smallest of European Buntings was brought, on November and I 864 , to the late Mr. Swaysland of Brighton, and was identified alive by the late Mr. G. D. Rowley. It was subsequently exhibited before the Zoological Society, and now forms part of Mr. T. J. Monk's fine collection of Sussex birds. Others have probably occurred and been overlooked.

The Little Bunting has only once been obtained in Sweden, namely near Lund, on the spring migration of $\mathrm{x} 8 \mathrm{I} 5$; at long intervals four or five specimens have been taken in Holland in autumn; and on Heligoland, as Mr. Gätke informs me, more than thirty have been captured, chiefly in September and October In the south-east of France it is said to occur almost every autumn, and along the Riviera to Liguria and Northern Italy it is not very uncommon on passage; while stray examples have been obtained in (Fermany, Austria, the neighbourhood of Constantinople, Smyrna and lieyrout, as well as twice in Algeria. In summer it is found in Northern Russia as far west as Onega; and from Archangel and the valley of the I)wina eastward it is abundant, crossing siberia to the Pacific, and reaching as far as the mountains beyond Lake lBaikal, and the Amoor district. In winter it visits China, Burma, the Andaman Islands, and India generally.

Mr. Seebohm, who found the Little Punting extremely abundant 
in the valley of the Yenesei from June ist onwards, before the snow had sufficiently melted to make the forest penetrable, discovered the first nest on the $23^{\text {rd }}$ of that month. He was scrambling amongst the tangled underwood and fallen tree-trunks on the south bank of the Kuraika, a tributary of the Yenesei, when a Little Bunting started from the grass at his feet and flitted from branch to braich at a short distance. He soon found the nest, which was nothing but a hole made in the dead leaves, moss and grass, carefully lined with fine dry bents, and containing 5 eggs; two other nests afterwards obtained were lined with reindeer-hair, and contained respectively 5 and 6 . Those of the first clutch are described as almost exact miniatures of Corn-Bunting's eggs; being of a pale grey groundcolour, with bold twisted blotches and irregular spots of very dark grey, and equally large underlying shell-markings of paler grey; the others were redder cr browner in ground-colour : average measurements $6_{3}$ by 56 in. In every instance the bird was remarkably tame; though in winter Mr. Davison found it excessively wild in Tenasserim, when in flocks; in summer it appears to be partial to the younger woods composed of a mixture of pines, firs, alders and birches. All travellers, who have had the opportunity of observing it, describe its song as low and sweet, more like that of a Warbler than of a Bunting, while the call-note resembles the words tick, tick, tick. The food consists of insects in summer and of seeds in winter.

The adult male in breeding-plumage has the crown and sides of the head chestnut, with a broad black stripe from above each eye to the nape, behind which is a dull whitish collar; mantle and rump reddishbrown with blackish streaks; wing-coverts brown, tipped with buffishwhite; quills ash-brown; tail-feathers the same, with longitudinal white patches on the two outer pairs ; chin and throat pale chestnut ; upper breast and flanks white, thickly streaked with black; belly white; bill horn-brown; legs pale brown. Length 5 in.; wing $2^{\prime} 75$ in. In the female the black on the head is duller, and the chestnut paler. In the young bird the central stripe on the crown is buff, and the two side stripes are reddish-brown with dark streaks; the secondaries are broadly edged with rufous-brown, and the under parts are more streaked and mottled with black. 


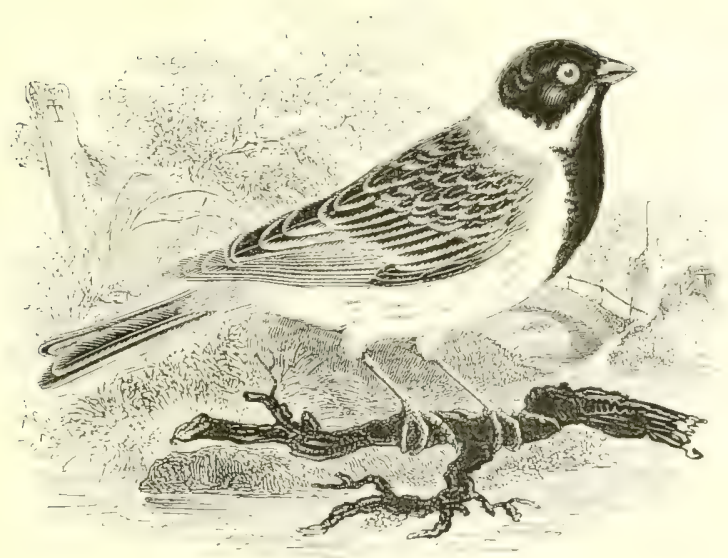

THE REED-BUNTING.

Emberiza schcéniclus, Linnæus.

This bird is often called the Reed-Sparrow, and unfortunately has also been known as the Black-headed Bunting, which has led to a confusion with the totally different species already described (p. 197). It is resident and generally distributed throughout Great Britain and Ireland, breeding sparingly even in the Outer Hebrides and the Orkneys, though only an occasional visitor to the Shetlands, In summer it frequents damp spots, whether on the banks of sluggish streams bordered by alders, osiers and sedge, or rush-grown places on swampy moorlands. In winter, however, it sometimes assembles in flocks, and Mr. Booth has found from forty to fifty birds roosting on patches of reeds by small marsh dykes; at that season also it often shifts its haunts, in search of food, to places at some distance from water. In autumn large numbers cross the North Sea from the Continent and visit our east coast, while a similar migration has been noticed on the shores of Ireland.

The Reed-Bunting inhabits suitable localities in Europe from the vicinity of the North Cape to the Mediterranean, though in the northern portions it is partially migratory, quantities crossing Heligoland; in Spain and the extreme south, however, it is most abundant during the winter, and comparatively few remain to breed. It occurs in North-western Africa, yet in the North-east and in Egypt it is decidedly uncommon, and to Asia Ninor it is only a winter-visitor. Eastward, it is found across Siberia to Kamschatka; but South. 
eastern Siberia, Mongolia and China are inhabited by a smaller race, with the black and white colours intensified, which has been called E. passerina. In Southern Spain, Southern Italy and Sicily, we find a resident form with a larger bill, which has received the name of $E$. palustris; while further east, from Astrachan to Turkestan and Yarkand, a bird with a still larger bill, and also paler in colour, is distinguished as E. pyrrhuloides. Few authors agree as to the nomenclature of these supposed species, or where the lines of distinction between them are to be drawn; nevertheless Mr. R. B. Sharpe (Cat. Birds Frit. Nus. xii. p. 473) has placed the two last with a Japanese form in a separate genus, Pyrrhulorhyncha, which Professor Giglioli invented as long ago as I $\$ 65$, and fondly hoped was forgotten!

The nest, commenced in the latter part of April, is usually placed upon the ground, at the foot of a tuft of rushes or of the stems of young willows and shrubs; frequently in herbage on the side of a bank; occasionally it has been found on young spruce-firs or on bunches of reeds, at varying elevations. The materials employed are dry grass, moss and withered flags for the exterior, with bents, hair and the feathery tops of reeds for the lining. The eggs, $4^{-6}$ in number, are purplish-grey-sometimes with a buffish tinge-boldly spotted and streaked with darker purple-brown: average measurements 77 by 59 in. Two, and occasionally three broods are reared in the season. The hen sits very close, and both she and the male feign lameness and practise other devices to divert attention from the brood. In summer the food consists of insects, such as caterpillars and small white moths, also of small fresh-water crustaceans and molluscs; later in the year seeds and grain are consumed. The song of the male is loud and stammering, ending with a long-drawn zississ; the call-note resembles the word tschee.

The adult male has the head and throat deep black; from the base of the bill a moustache-like white line connects the collar and breast of the same colour; mantle, wing-coverts and secondaries warm reddish-brown, with dark centres to the feathers; quills dull brown; tail-feathers blackish, with oblique white patches on the two outer pairs; flanks dusky, streaked with brown; bill and legs dull brown. Length nearly 6 in. ; wing 3 in. In autumn the black on the head and throat is obscured by the buffish-brown tips of the feathers. The female is rather smaller and much duller in colour, and has a reddish-brown head with darker streaks, while the eyestripe is buffish-white. The young resemble the female. 


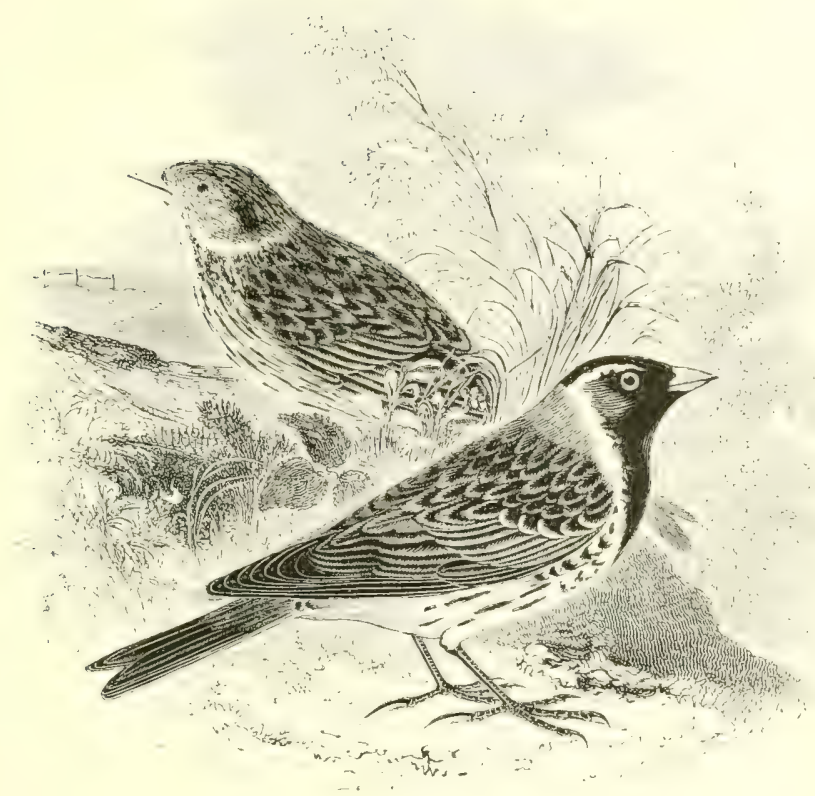

THE IAAPLAND BUNTING.

Calcárius tappónicus (Linnaus).

The Lapland Bunting was first recognized as a visitor to our islands by Selby, early in 1826 , when one was sent up from Cambridgeshire with some Larks to I,eadenhall Market. Subsequently, at long intervals, six or seven examples have been obtained near London, four in Iancashire, one in Westmoreland, one in Durham, one near Whitby on the spring migration, three in I,incolnshire, five -all males-in Norfolk, two near Shrewsbury, and a good many on the coasts of Kent and Sussex, but as yet the bird has not reached Cornwall. On the whole, some forty specimens have been taken in England; many of them alive, associating with I arks, and almost all on the autumn migration. In Scotland two are said to have been obtained, in Caithness. In Ireland this species was unknown, until Mr. Barrington received a female, found dead at the foot of the light-house on the Fastnet Rock, on October r6th I 887 .

In summer the Lapland Bunting inhabits the greater part of the circumpolar regions, with the exception of Iceland - to which it is only an occasional straggler from Greenland and spitsbergen and 
Novaya Zemlya, whence it has not yet been recorded. It is only at considerable elevations, such as the Dovre-fjeld in Norway, that it is found breeding to the south of the Arctic circle; but east of the North Cape it is common in Lapland, while in Northern Siberia it is extremely abundant, being, according to Mr. Seebohm, not only the commonest but also the most widely-distributed bird on the tundras. In Asia it migrates further southwards than in Europe, reaching to about $30^{\circ} \mathrm{N}$. lat. in China; whereas it is rare in the south of Russia and in Northern Italy, and as yet unknown in Spain. In Centrai Europe its occurrences are accidental, but further north they are naturally more frequent, and are regular on Heligoland in autumn. In America this species breeds throughout the far north; wintering in South Carolina, Kansas and Colorado.

Swampy moorlands-beyond the limit of forest growth-with their tussocks of grass and stunted willows or birches, are the favourite summer-haunts of the Lapland Bunting, but occasionally it inhabits dry and bushy spots. The nest, built early in June, is placed in a hollow of some little mound or grass-clump, and is made of dry bents and roots, with a thick lining of feathers, which at once serves to distinguish it from those of the Red-throated Pipit and other birds frequenting such localities. The eggs, +6 in number, are pale greyish- or reddish-brown, spotted, blotched and slightly scrolled with darker shades of brown: average measurements $S_{\text {I }}$ by ${ }_{5} 8 \mathrm{in}$. The song of the male is generally uttered on the wing; the bird rising from his perch on some low bush, and hovering above it, like a Tree-Pipit; but all song ceases as soon as the young are hatched. The food consists of insects as well as seeds in summer, and of the latter, with maggots \&c., in winter.

The adult male in summer has the crown black; a broad white streak extending backwards over each eye down the sides of the neck; hind neck broadly banded with bright chestnut; back, rump, wing-coverts and secondaries tawny-brown, with blackish centres and paler margins to most of the feathers; quills dull brown; tailfeathers dark brown, with long white patches on the inner webs of the two outer pairs; throat, cheeks, and breast deep black; remaining under parts white, with broad black streaks on the flanks; bill yellow, with the point black; legs black; hind claw nearly straight, and longer than the toe. Length $6 \cdot 25$ in. ; wing $3 \cdot 6$ in. The female has the crown, ear-coverts and chestnut collar streaked with brown and black; the upper parts are paler; throat white, with an irregular blackish gorget. The young bird is still duller in colour. In winter both sexes have pale rufous margins to the upper feathers. 


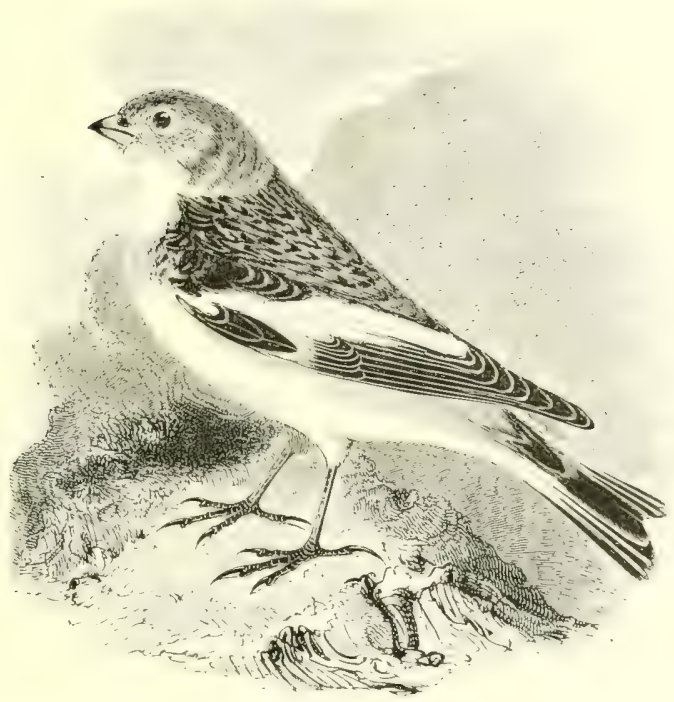

THE SNOIT-BUNTING.

\section{Plectró́phenax nivális (Linnæus).}

The Snow-Bunting is principally a cold-weather visitor to the British Islands, seldom making its alpearance on the east coast of England until October, and generally returning northwards in Narch or April. For more than a century, however, paired birds have been noticed from time to time on several of the higher mountains of the Scottish mainland, and there could be no reasonable doubt that they were breeding; though absolute proof was wanting, until, in July r886, Messrs. Peach and Hinxman discovered the nest and young in Sutherlandshire. In Unst, the most northern of the Shetlands, Saxby, who had frequently observed the birds in summer, obtained a nest with three eggs on July and I86r, and others have since been taken in Yell.

In the Froes a considerable number of Snow-Buntings remain to breed, and in winter the species is abundant there, as it is in Iceland throughout the year; while northward, Col H. W. Feilden found it nesting on Grinell Land in $\delta 2^{\circ} 33^{\prime}$, nearly as far as man has penetrated. In spitsbergen, Novaya \%emlya, Siberia, and the Aretic: regions generally, it is widely distributed in summer; migrating southwards in winter down to Georgia in North America, Japan, Northern China, Turkestan, South Russia, the northern shores of 
the Mediterranean, Malta, Tangier in Morocco, and occasionally to the Azores. In the northern portions of Europe it is of annual occurrence, but its visits to the south are exceptional.

Near the southern extremity of its breeding-range the SnowBunting builds on the rugged sides of mountains, but in the Shetlands, Freroes, and the high north the nest is often but little above sea level; generally in some crevice behind rocks and boulders, or among the piles of drift-wood which fringe the shores of the Arctic Sea. It is formed of dry grass and moss, with a lining of a few hairs and a good many feathers-especially those of the Ptarmigan; the eggs, $4^{-6}$ in number, are greyish-white, spotted and blotched with brownish-red and purplish-black: average measurements $\$ 6$ by $62 \mathrm{in}$. While the female is sitting the male utters a low and melodious warble, often hovering in the air; the call-note is a longdrawn tsee. In summer both young and old feed principally on insects, but in autumn and winter they live on seeds, and do some damage to newly-sown corn. On the ground the Snow-Bunting runs with rapidity, but it also hops, and has frequently been observed to perch on trees.

The adult male in breeding-plumage has the mantle, scapulars, inner secondaries, terminal part of primaries, and the six central tail-feathers, black; the rest of the plumage mostly white; bill, legs and feet black; hind claw shorter than its toe. Length 6.55 in.; wing 4.4 in. In the female the head and neck are mottled with greyishblack; the upper parts are greyish-black, except the secondaries, which are chiefly white. In autumn the bird, as figured, has the feathers of the upper parts broadly edged with dull chestnut; bill yellow with black tip: in this state it has been called the "Tawny Bunting.' In winter the chestnut margins gradually become white. The young bird is greyish-brown, with darker spots on both upper and under parts; a specimen is figured in Messrs. Harvie-Brown and Buckley's ' Fauna of Sutherland \&c.'

ICTERIDE.-Males of the introduced American Red-winged Starling, Agelceus pherniceus, have been captured in this country, but it is significant that the females, which are dull-coloured and therefore seldom imported, have never been taken! Attempts have been made to swell the British list by including in it escaped examples of the American Meadow-Starling, Sturnella magna; the American Rustic Grackle, Siolicophagus fermentineus; and the Indian Mynah, Gracula reiziosa. 


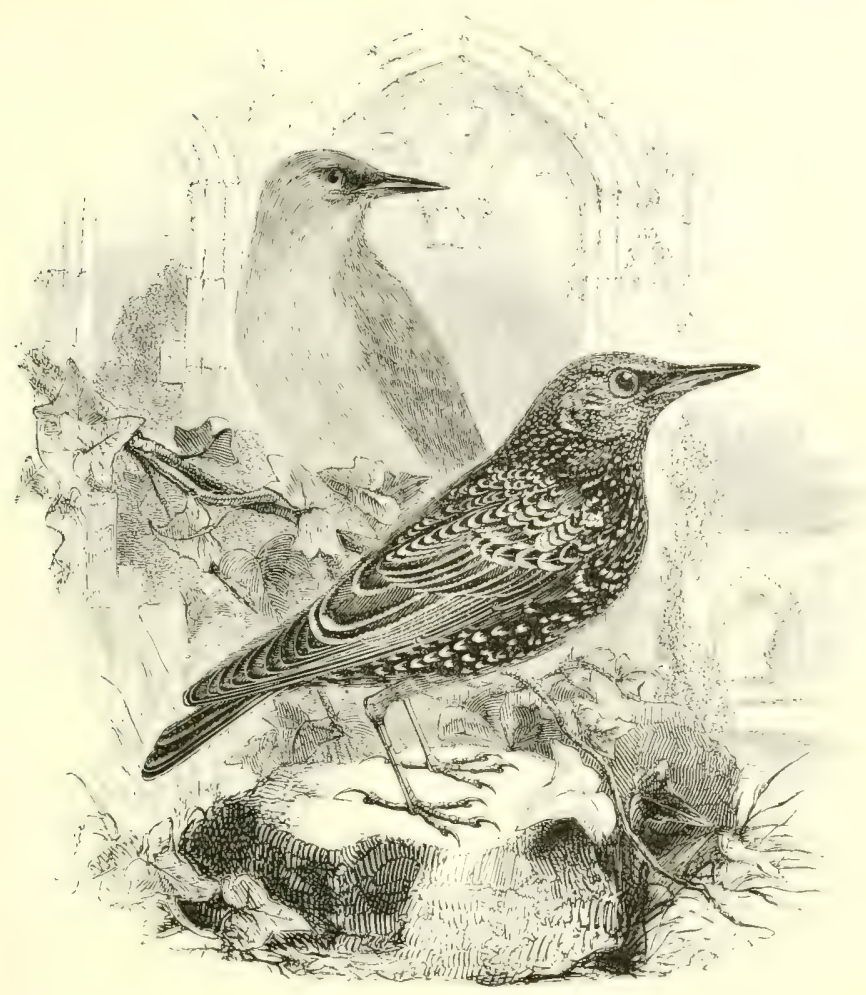

THE STARLING.

STÚRNUS VULGÁRIS, Linnæus.

The Starling, which is now so generally distributed throughout Great Britain and Ireland, has during the last thirty years materially increased both in numbers and range in Wales and the west and north of England. In many parts of Scotland where it is now common it was either rare or unknown within the memory of persons hardly past middle-age, though in some of the islands it had long been a resident. Large flocks arrive on our east coasts in autumn, at which season there is also a marked migration westward, localities in the interior of this country which have been frequented during the summer being then almost deserted, while great numbers visit the south of Ireland.

Examples from the Froes, where this species is common and resident, have, as a rule, large and particularly broad beaks. In Iceland a solitary specimen was obtained in I)ecember is $\$ s$, and as 
long ago as 1 \& $5 \mathrm{r}$, Holböll obtained one in (ireenland. In Norway it occurs as high as Tromsë, but proceeding eastward we find its northerly extension gradually diminishing, until in the Urals and across Siberia it does not exceed $57^{\circ} \mathrm{N}$. lat. Throughout Europe our Starling is, with few exceptions, generally distributed ; its breeding-range reaching as far as the northern provinces of Italy; but in the south and throughout the greater part of the Mediterranean basin it is only a cold-weather visitor, although at that season it occurs in almost incredible numbers. In the Spanish Peninsula, Southern Italy, Sicily, Sardinia \&c., the bird found in summer is the beautiful unspotted $S$. unioler; while from Asia Minor to the Altai range and North-western India it is represented by $S$. purpurasuens, and some other closely-allied specics, including two lately described by Mr. Sharpe.

The nest is usually built in some hole in a tree, cliff or bank, or, as many persons know to their cost, in chimneys, water-pipes, and under eaves; but exceptionally it has been found open to the sky in a tree. In places where suitable timber is wanting, holes in peat-stacks and even in the turf itself, heaps of stones for mending roads, rabbit-burrows $\mathbb{S c}$, are selected. A large untidy mass of dry grass or straw, with a little moss, wool and a few feathers for lining, forms a receptacle for the +7 pale biue eggrs, which measure about $I^{\prime} \cdot 2$ by $\cdot S_{5} \mathrm{in}$. Where the eggs are successively removed, as many as forty have been obtained from the same nest in the season. The Starling feeds principally unon worms, slugs, small molluscs, flies, beetles, ticks and other insects, but it also eats berries of various kinds, and it has been accused of destroying fruit and the eggs of other birds. Its song, imitative powers, habit of congregating in large flocks at roosting time, and aerial evolutions have often been described elsewhere with a fulness which is here unattainable.

In summer, the adult male has almost the whole plumage glossy black, with rich metallic purple and green reflections; the feathers of the upper parts with triangular buff-coloured spots at the tips; wing-and tail-feathers dark brown, with buffish margins; bill lemonyellow; legs and feet reddish-brown. After the autumn moult the feathers of the upper parts are deeply margined with buff, and those of the under parts are tipped with white. Length 8.5 in.; wing $5^{\circ} \mathrm{in}$. The plumage of the female is less brilliant and the terminal spots are larger. The young bird is uniform greyish-brown above, clouded with white below; in which plumage it is the 'Solitary Thrush' of some of the older authors. 


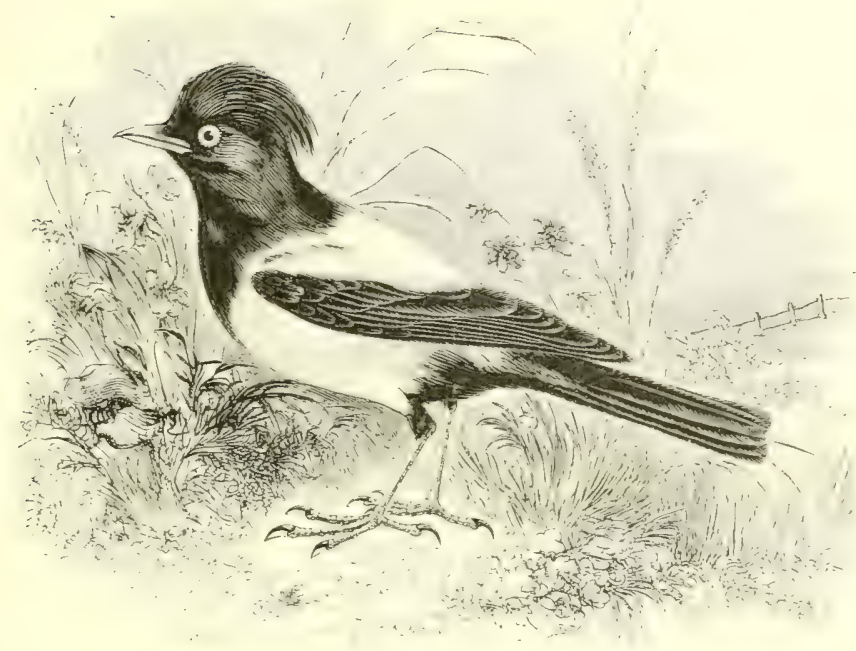

THE ROSE-COLOLIRED STARLINC.

$$
\text { PÁstor róseus (Linnæus). }
$$

This handsome species, which was first recognized as a visitor to the British Islands in $I_{7+2}$, when Edwards figured an example killed near Norwood, has subsequently occurred in most parts of the kingdom, although, naturally, more often on the eastern side. As a rule its arrival has taken place in summer and autumn, and the visitors to our shores appear to have been birds which, accidentally separated from flocks of their own species, have joined those of Starlings \&c. In Scotland, the Rose-coloured Starling has been obtained in every district except the Outer Hebrides : and in Ireland its wanderings have extended to the extreme west.

As might be expected in the case of a bird which has visited the Shetlands, the Rose-coloured Starling has strayed yet a little further and has reached the Froes; but up to the present time it has not been found in Iceland. In Norway the only occurrence on record is that at Trondhiems-fiord on Sejtember 30 th i $\$ \$ 5$, but several examples have been obtained in sweden, Finland and I)enmark: while to Heligoland its visits have been numerous. Over the rest of Europe it is well known as an irregular migrant, increasing in frequency as we proceed southward; and, although rarer in the extreme west, it has been found as far as Seville in Spain. Until June 3 rd 1875 , it was merely known as an almost annual summer- 
visitor to Italy, but on that day commenced an irruption of flock after flock, following up large fights of locusts; and the ruined castle of Villafranca in the province of Verona was soon occupied by some twelve or fourteen thousand Rose-coloured Starlings, which speedily ejected the original feathered inhabitants. The first eggs were laid about June $\mathrm{I}$ th ; by July ioth the young were fledged; and by the I t th all had taken their departure. In Bulgaria, the Dobrudscha, Southern Russia, the vicinity of Smyrna in Asia Minor, and other places, similar large colonies have been found breeding, but not regularly; and localities inhabited by thousands in one year may be absolutely deserted the next. Eastward, the Rose-coloured Starling extends through Turkestan to Lake Saisan; numbers winter in India ; vast flocks traverse Palestine in spring; and on migration the bird has occurred at intervals in North Africa.

The nest, composed of dry grass with a few feathers, is generally placed in some suitable crevice in ruins, raiway-cuttings, quarries and cliffs, or among loose stones on the side of a ravine, while in the latter case it is occasionally open to the sky. The eggs, 5-6 in number, are glossy bluish-white : average measurements $\mathbf{I} \cdot \mathrm{I}$ by 83 in. The female sits very closely, and is fed by the male with locusts, which appear to be the favourite food of old and young; for this reason the bird is protected in the Caucasus and other districts. In India, however, it is very destructive to grain during the cold season, and it also devours large quantities of mulberries; in confinement it will eat cockroaches. The note is a harsh and continuous babble, which, when uttered by dense flocks in rapid flight, is described by Canon Tristram as quite deafening. Although so conspicuous by their colour when on the ground or perched upon a tree, yet a small party of birds will suddenly become almost invisible by dropping among oleander bushes, the pink flowers of which exactly match the colour of the breast.

The adult male has the long crest, head, neck and throat glossy violet-black; wings and tail metallic greenish-black; back, shoulders, breast and belly rose-pink; bill yellowish-pink, black at the base; legs yellowish-brown. Length 8.5 ; wing 5 in. The female is less brightly tinted and has a smaller crest. The young bird in first plumage is greyish-brown above, with buff margins to the wing- and tail-feathers; the throat is white, while the lower parts are striated buffish-white; the bill is brown; but in September the moult into the adult plumage commences. 


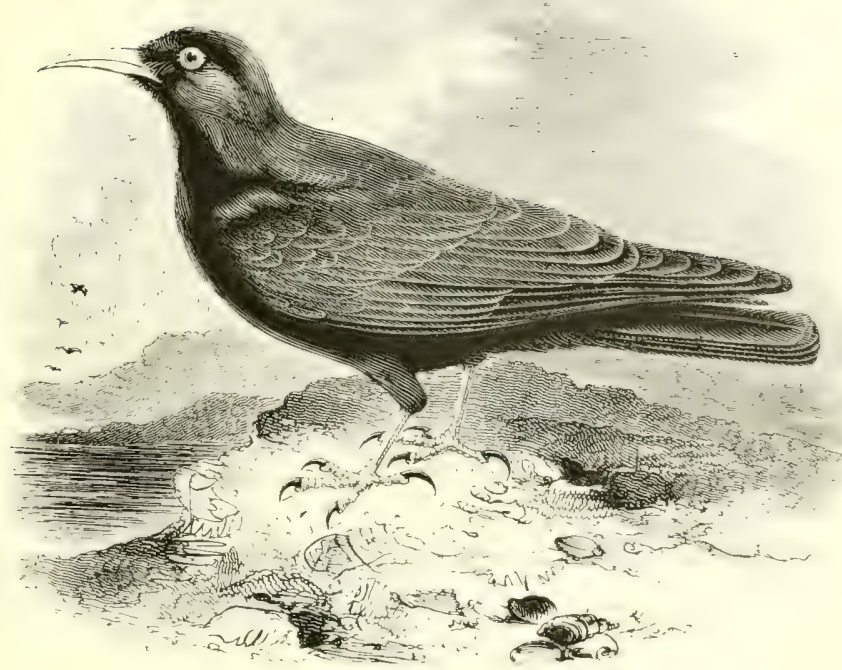

THE CHOUGH.

PyrrhóCORAX GráCUlus (Linnæus).

The Chough is not only a local but also, apparently, a very capricious species; localities formerly inhabited by it being abandoned, sometimes without any assignable reason. In Fingland at the present day it is not known to breed to the eastward of the cliffs of Dorsetshire, while westward as far as Cornwall its distribution is by no means general. In North Devon there are a good many small colonies; but in ${ }_{1} 88_{7} Y$ found that it had almost disappeared from Lundy Island, where it was formerly abundant, owing in a great measure to the ravages of the Peregrine, which, in default of Pigeons, is very partial to Choughs-especially the young. On the sea-cliffs and also in some inland localities of Wales it is not unfrequent; and it is resident in the Isle of Man, whence a pair or two occasionally visit Cumberland and attempt to nest there. From the Wigtonshire coast it has almost vanished, but it still breeds on Islay, Jura, Skye, and other islands of Scotland, as well as on the mainland. On the east side of (ireat Britain and inland it is chicfly of accidental occurrence. In Ireland it is by no means rare on the coast of Waterford and Cork, very abundant on the cliffs of Kerry, 
and decidedly numerous on those of Wayo, Donegal and Antrim; but the east side of the island affords few favourable sites.

In the Channel Islands, especially Guernsey, the Chough is tolerably common, and it breeds in some of the rocky portions of the north-western and west coasts of France, as well as in those of Portugal. It is, however, in inland mountainous situations, such as some parts of the Alps, the Carpathians, the Parnassus, the Urals, the Apennines, the Pyrenees, and the south of Spain, that it is most abundant, while on the rocky islands of the Mediterranean it is plentiful; it is also resident in the hill-regions of Northern Africa, Abyssinia, Arabia, Asia Minor, the Caucasus, and Persia, and throughout the mountain ranges of Asia as far as North-eastern China. As'a rule this bird is little given to wandering.

The nest, built from the latter part of April to the middle of May, is composed of long wiry stems of heather, or of some deciduous plant, and is well lined with wool and hair. It is frequently placed in some cavity in the roof of a cave; but sometimes in vertical fissures, holes of ruins, or disused lime-kilns. The eggs, $3-5$ in number, are greyish-white with occasionally a yellow or greenish tinge, spotted and streaked with several shades of dark grey and pale brown : arerage measurements $1 \cdot 5$ by $I \cdot I$ in. When flying, the Chough performs a series of curves in the air, alternately rising with a scream, and then suddenly dropping with almost closed wings; but on the ground its movement is a short and very quick run. The usual cry is a clear metallic 'kling,' but in autumn I have heard flocks uttering 'chough-chough' very plainly. The food consists of insects and their larvæ, and occasionally of grain.

In the adult male the plumage is glossy bluish-black, with a slight green tint on the primaries; bill, legs, and feet cherry-red. Length 16 in. ; wing $10 \% 7$ in. The female only differs in being somewhat smaller. In the nestling the beak and legs are dull orange, but by September those parts have become as red as in the parents.

A yellow-billed Alpine Chough, $F$. alpinus, shot near Banbury, Oxfordshire, on April Sth ISSI, and examined in the flesh by Mr. O. V. Aplin, is now in the collection of Mr. Whitaker. The species is eminently sedentary, and it is unlikely that an individual should have wandered so far from its home in the mountains of Central and Southern Europe. I believe that Lady I)orothy Nevill, who has been successful in inducing our species to breed in confinement, has purchased importations from the Continent, and it is probable that the bird in question had escaped. 


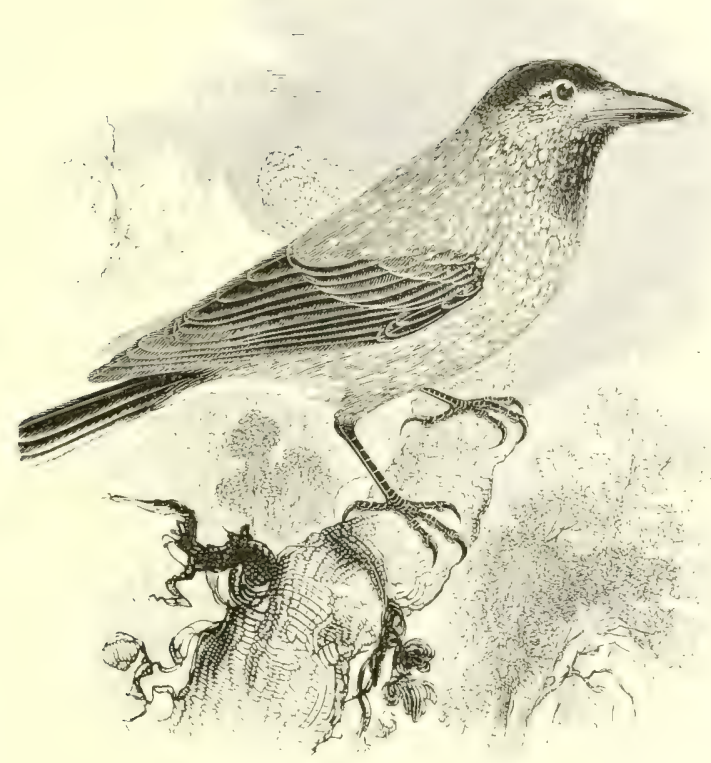

THE NUTCRACKER.

\section{Núcifraga caryocatácles (Linnæus).}

The Nutcracker is a very irregular visitor to England and Wales, but altogether about twenty fairly authenticated occurrences are on record; principally in the southern half of our island, and all of them, so far as is known, in autumn. In Scotland one was shot at Invergarry in October 1868 , and one in Orkney (Buckley); but as yet there is no evidence that the bird has visited Ireland. It is a forest-loving species, and does not, as a rule, wander much from its usual haunts; but in autumn large flocks are sometimes formed, and in search of food considerable migrations take place, to which we are indebted for its erratic appearances.

This conspicuous bird frequents districts in which conifers preponderate; breeding south of lat. $67^{\circ}$ in Scandinavia, in some of the islands of the Baltic, the Black Forest, the French, Swiss, and Italian Alps, the Carpathians, and the mountains of Hungary. It is also said to nest in some of the pine-clad valleys of the Pyrenees, on both sides of which it undoubtedly occurs; and, as it has been observed in Estremadura in Spain, it is not improbable that it may inhabit the 
elevated fir-woods in the sonth of that country: but upon these points further information is much to le desired. Its southward migrations have extended to Sardiria and Sicily, but not as yet to Creece or Turker: nor does it appear to be found in the Caucasus. Eastward, it occurs throughout a great part of the forest region of Siberia as far as Kamschatka; also in the Kuril Islands, Iapan, Corea and Northern China. In Cashmere it is represented by the closely-allied species .1. multifunctatu, and in the Himalayas by the larger and browner 1: himisfila. Examples from Northern Asia have the bill deeper from the angle of the gonys to the ridge of the upper mandible than specimens from Europe, and it is almost needless to add that they have been separated specifically or subspecifically by C. L. Brehm and nthers.

In Europe the Nutcracker often begins to breed early in March, while the forests are still difficult of access owing to the snow; and although eggs were obtained in the French Alps by the late Abbé Caire in $S_{+} 6$, it was not until after i $S_{2} 2$ that English ornithologists became acquainted with them. The rather bulky nest is placed from fifteen to thirt: feet from the ground in a pine-tree, close to the stem; and is composed of twigs, with grass, roots, and a little moss and lichen for a lining. Sometimes the bird will sit upon only two eggs, but $4-5$ are usual; they are pale bluish-green, spotted with ash-brown, like some light varieties of those of the Magpie: average measurements $\mathrm{I}_{3}$ by 95 in. In Arctic Siberia the Nutcracker does not appear to breed before the middle of June, for Mr. Seebohm, who found it absurdly tame on the Tenesei--allowing of close approach, and congregating upon bushes round the houses and on the rigging of his ship, for scraps of meat and refuse-noticed that it remained until the $;$ th of the above month; after which it was not seen until August. The seeds of fir-cones are i's favourite food, especially those of the arolla pine (Pinus cimbra) in Switzerland, but the bird is almost omnivorous. Its flight is slow and undulating; the note is a grating $k r, k r, k r$.

The adult male is umber-brown abcre and below, profusely spotted with drop-shaped white markings on the back and breast, and more sparingly on the throat; wing-feathers glossy black; tail-feathers greenish-black, with broad white tips to all except the central pair; under tail-coverts white; bill and legs black. Length about 12 in.; wing 75 in. The female generally shows a rather browner tint on the wing-feathers. The nestling is dull dirty brown with small greyish-white spots; the quill-feathers have a brownish tint, and the under tail-coverts are dusky. 


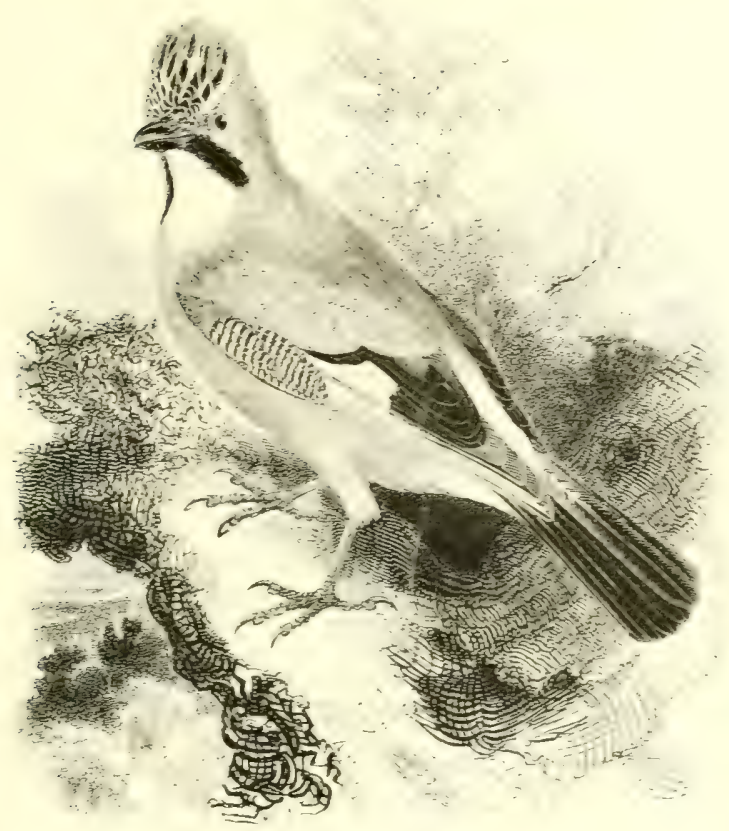

THE JAY.

Gárrulus glaxdárius (Linnæus).

The Iay is less abundant than furmerly, owing chiefly to the dislike entertained for it by game-keepers, but partly to the esteem in which its blue wing-feathers are held for making artificial flies. Being, however, an inhabitant of woodlands and a very wary as well as a wandering bird, it manages to hold its own in spite of persecution, and is still tolerably common throughout Ensland and Wales. In Scotland its numbers have decreased, but its range has extended northward with the spread of plantations, and now reaches to Glengarry, Inverness-shire: though Mlessrs. Harvie-Brown and Buckley have not found it in Sutherland or Caithness, nor does it risit the Hebrides. Saxby asserts that he once saw it in the shetlands, but no one else has observed it there. In Ireland it seems to be a diminishing and very local species, almost confined to the eastern and southern districts. In our islands the Jay is resident, but large flocks from the Continent sometimes visit our eat coasts in autumn: and this was especially the case in ISSz, in the district eastward of a line drawn from the Firth of Forth to Portland Bill in D)orset. 
South of the Arctic circle in Scandinavia, and of about $63^{\circ} \mathrm{N}$. lat. in Russia as far as the valley of the Volga, the Jay is found throughout the suitable wooded portions of Europe, down to the Mediterranean and Black Seas. In North Africa it is represented by $G$. cerricalis, a species with a black crown, white ear-coverts, and a deep rufous nape; while forms to which specific rank has been accorded by some authorities and denied by others are found intergrading from the Urals, the Caucasus, Asia Minor and Persia eastward, until the extreme of differentiation is reached in Southern Siberia and Northern China in G. brandti. The race found in the south sland of the Japanese group differs from the European bird in having some black on the lores.

The nest, often commenced early in April, and fairly well concealed, is an open, cup-shaped structure of short twigs, neatly lined with fine roots and grasses; it is usually not more than twenty feet above the ground, in the branches or the outgrowth of the side of a tree, or in some high thick bush. The eggs, 5-6 in number, are greenishgrey, thickly speckled and often zoned towards the larger end with olive-brown, sometimes scrolled with a few black hair-lines: average measurement $\mathbf{r}^{\prime} 2$ by 9 in. The young at first go about in family parties, but subsequently they often unite with others and form bands which at times migrate in large streams, chiefly in a westerly direction. Thus in the autumn of 1876 , and again in that of $188_{2}$, immense numbers, apparently coming from the great forest regions of Eastern Germany, were observed crossing Heligoland during three consecutive days. The food of the Jay consists chiefly of worms, insects, berries, nuts, beechmast, acorns and fruit, but also to some extent of the eggs and young of other birds. The natural note is a harsh screech, but, as is well known, the bird possesses considerable imitative powers.

The adult male has the head covered with a whitish crest, each feather tipped or striped with black; ear-coverts, nape and back light vinous-brown; rump white; tail-feathers black, the exterior pair brownish; primaries dull black with white margins to the outer webs; secondaries deep black with long white basal patches, the innermost feather rich chestnut tipped with black; wing-coverts barred alternately with black, white and pale blue; chin pale buff; from the base of the bill backwards a black streak; under parts buffish-white, turning to rufous on the flanks; bill dark horn-colour; iris bluish-white; legs and feet pale brown. Length about $\mathrm{I}+225$ in.; wing $7.2 \mathrm{in}$. The female resembles the male, and the young differ little from the adults except in having brown irides. 


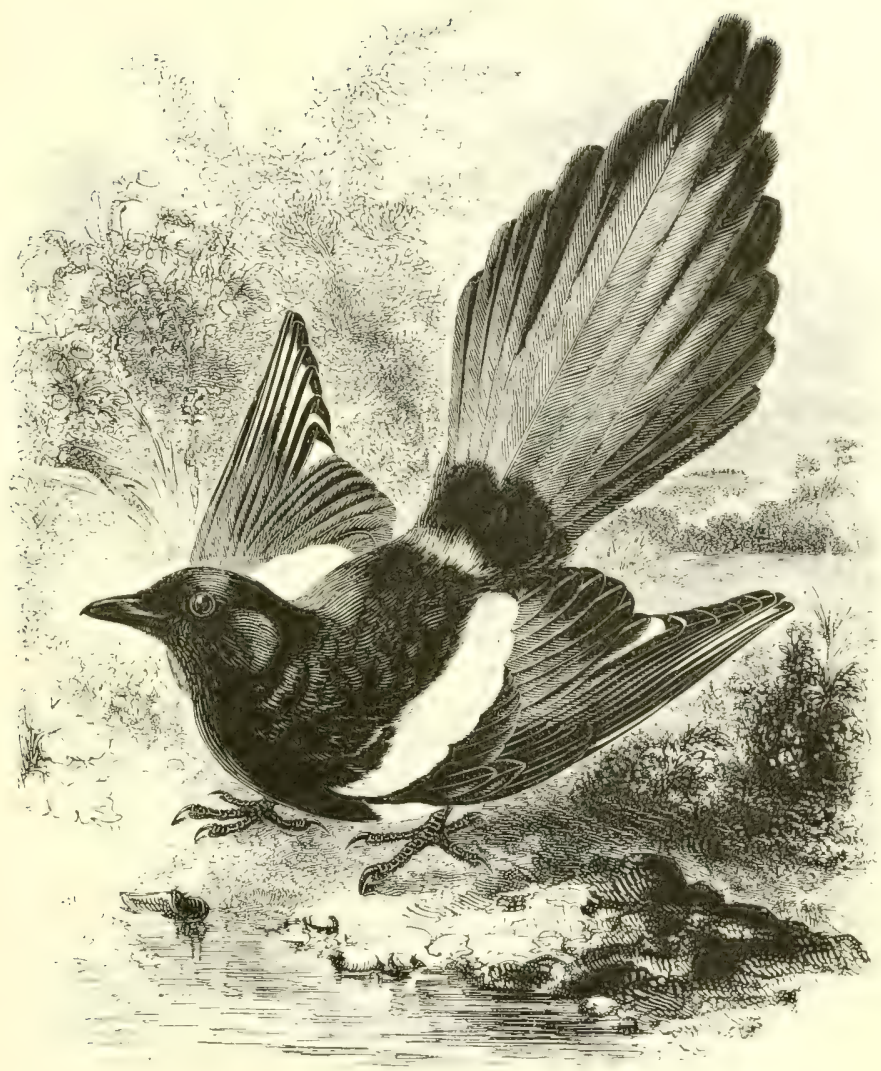

THE MAGPIE.

\section{Píca rústica (Scopoli).}

In many parts of Great Britain game-preservers have been more successful in diminishing the numbers of the Nagpie than of the Jay, but it is still widely distributed throughout the island; while in Ireland it is now an extremely common and increasing species. From the North Cape in Scandinavia southward, it is found, more or less plentifully, throughout Europe, except in the islands of Corsica and Sardinia; but it does not occur in Pallestine, although found in Asia Minor. Eastward-subject to a variation in the amount of white in the plumage, which has led to the creation of several bad species-the Magpie is found across Asia to India, China and Japan, and also in the northern portion of America from 
the Pacific to Michigan; but in California it is represented by $P$. nuttalli, with yellow bill and ear-patch. Algeria and Morocco are inhabited by $P$. manritanica, which has a bare blue ear-patch and no grey on the rump; but it is interesting to note that though in Spain specimens from any part down to Seville are identical with those from Norway, yet examples from the Alpujarras, where a geologically-recent connection with Africa existed, are distinctly intermediate between the typical and the African species.

The nest, large and domed, is often begun towards the end of March, and is made of thorry sticks cemented together with clay at the foundation, with fine roots and dry grass as a lining. It is generally placed at some height in the fork of a tree, but often in tall-and sometimes in very low-hedges and thorn-bushes; while in Norway it is occasionally under the eaves of houses or on the ground. Lord Lilford found several nests in the papyrus reeds of the Anapo, near Syracuse. The eggs, usually 6 but sometimes 9 in number, are bluish-green or yellowish-white in ground-colour, closely freckled with olive-brown : average measurements I'35 by I in. As regards its food, the Magpie is almost omnivorous; the benefits it confers by devouring slugs, snails, worms, rats and mice probably counterbalancing its destructiveness to the eggs and young of poultry and game; while, as showing its boldness, Lord Lilford has recorded (Zool. I 888, p. I 84) an instance of fourteen or fifteen Magpies attacking a sore-backed donkey in severe snowy weather, and after its death from natural causes, several were shot in the act of feeding upon its body. The note is a harsh chatter, kept up incessantly as long as any obnoxious person or animal remains in its haunts; while the manner in which the bird will hover over and swoop at an exhausted fox must be a familiar sight to many sportsmen, and frequently conveys to them the earliest intimation that the quarry is sinking.

The adult has the head, neck, back and breast black, glossed with green and violet; rump grey; scapulars and belly white; secondaries black, with violet lustre; primaries black, glossed with green, and having an elongated patch of white on their inner webs; tail black, iridescent with greenish-bronze; bill, legs and feet black. Average length 18 in., of which the longest tail-feathers measure sometimes I I in. ; wing $7.75 \mathrm{in}$. The female is slightly smaller and less brilliant in plumage; while the feathers of the young have comparatively little sheen. 


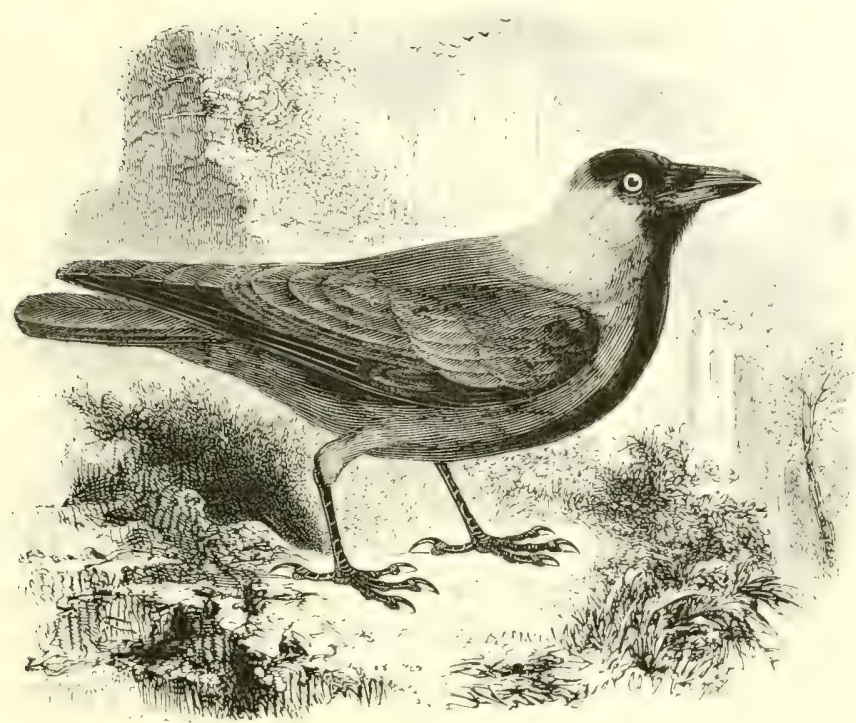

THE JACKDAW.

Córvus monéduta, Linnæus.

The Jackdaw is a familiar resident bird throughout England and Wales: it is also common over the greater part of scotland, but in the north-west it is somewhat rare; and although it breeds sparingly in Skye it has not yet been noticed in the Outer Hebrides; Mr. Buckley informs me that there are now several colonies in the Orkneys, but to the Shetlands it is only an accidental visitor. In Ireland it is, as a rule, abundant; but in Kerry, Donegal, and other wild portions of the coast its place is taken by the Chough, and it is only exceptionally that the two species are found breeding within the same area. The same holds good of Guernsey in the Channel Islands, and on Lundy Island there are no Jackdaws; in fact, although generally distributed along our coasts as well as in town and country, this bird is sometimes unaccountably absent. Iarge numbers arrive on our east coast in autumn, and a similar migration occurs at Heligoland.

To the Froes and Iceland the Jackdaw rarely wanclers, and in Norway it is not found breeding north of 'Trondhjems-fjord; though in Russia it occurs at Mezen, near the Arctic circle. It is, found and, as a rule, is resident throughout the rest of Europe; lnut in 
the south of France. Sian. Italy. (ireces and some other poritums of the Mediterranean basin. induding Moroces and Algeria, it is extremely local. Aiter heary gales from the south-east it has beeis found in the Canaries. Between Easte:n Europe and Turkestan. Cashmere and the valley of the lenesei in siberia, the example' obtained have remarkably white and well-defined collars: but from the Altai Mountains to Eastern Siberia and China, the representative species is C. dairicus, which has the nape, sides of the neck, lower breast anci belly ashy-white.

For its brecdingllace the Iacklaw chooses holes and cavities in rocks, churches and castles-ruined or not, the chimneys of inhabited houses, rabbit-burrows and hollow trees: while sometimes the nest is anmong stalks of coarse ivy on cliffs, open to the sky. It is usually a substantial, and sumetimes a monstrous, pile of sticks, warmly lined with woul, rabbits-fur and other soft materials. The eggs, 4-6 in number, laid towards the end of April, are of a pale bluish-green. Loldly spoted and blotehed with black, olive-brown and violet-grey : sometimes the ground-colour is gregish-white and the markings are very scanty : average measurements $\mathrm{I}^{\circ}+$ by $\mathrm{I}$ in. The warm lining is often pulled orer the eggs, so as to conceal them; and Mr. C. B. Wharton found a clutch smeared and apparentil disguised with a coating of clay, taken from a lump which was in the nest. At cambridge great inconvenience was formerly caused by the appropriation of the labels from the old Botanic Garden ly the Tackdaws: no less than eighteen dozen being discovered in one chimner. The food consists chiefly of insects and their larre. worms, and the parasiies found on sheep, upon the backs of which the bird may often be seen perched. The Hight is rapid but warerins. numerous erolutions being performed in the air to the accompaniment of a short clcar note. sounding like atc. Although it generally flies in pairs the Jackdaw is at all times more or less gregarious, but especially so in winter.

The adult male has the lores and crown of the head glossy purplisin-black: ear-coverts, nape and sides of the neck grey, in clining to white. and producing the effect of a collar: rest of the upper parts glossy black: under jarts dusky-black: bill, legs and feet black. Length about I 3 in.; wing $9.25 \mathrm{in}$. The female is somewhat smailer and the grey collar is less defined. The young are dull black, with wery little grey on the head and nape. The iris is white at all ages. 


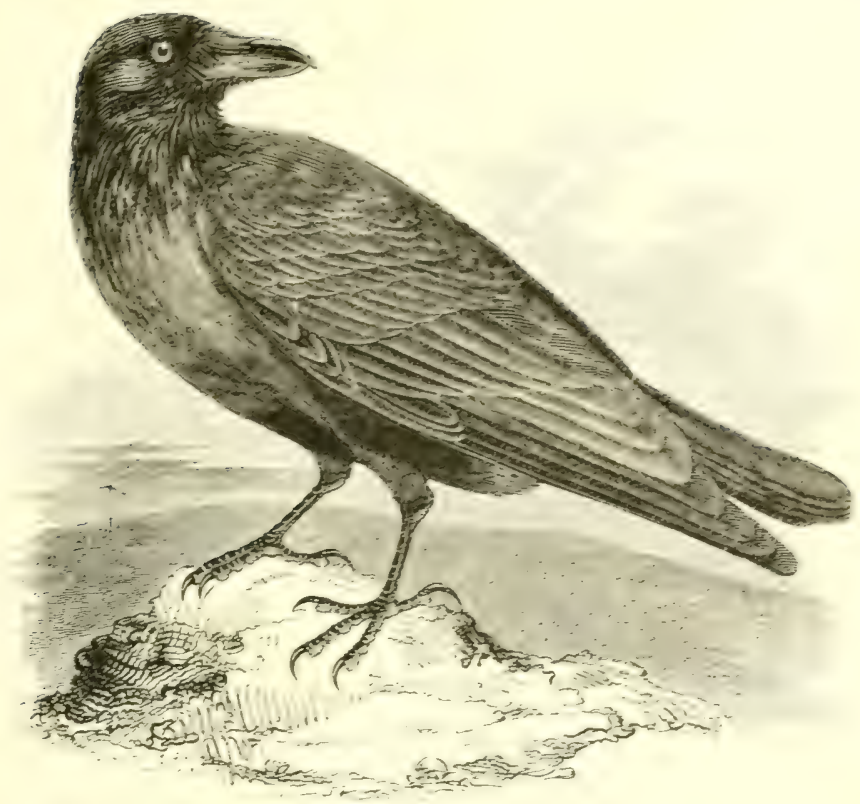

THE RATEN.

CORTES CóRAX. Linnæus.

Although a diminishing species, in consequence of the hatred entertained for it by sheep-farmers and the ease with which it can be trapped, the Raven still maintains itself in the British Islands. In the south its numbers are chiefly kept down by the prices paid for young birds; but even now, from Kent to Cornwall, and along the rucky coasts of North Devon and Wales there is hardly a suitable headland in or near which a pair does not at least attempt to breed

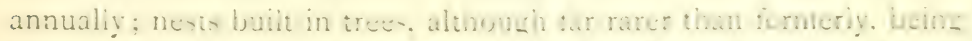

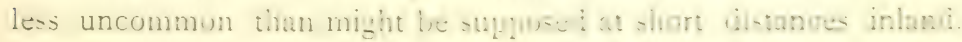
Not long ago several pairs bred in Essex; but in the eastem counties and throughout the inserion of krgland the Koven :s non. rare. On the hills and fells of the north and west it is still to be found; while in Scotland, and especially in the islands, it is by no means uncommon where there are suirable cliffs for its protection. In Ireland it is still resident in the wilder parts, but its numbers have decreased of late years.

In the Freroes the Raven is stationary, and pied birds, oc 
sionally met with in the British Islands and elsewhere, are there rather frequent. In Iceland and Scandinavia the bird sacred to Odin is abundant, and, as a straggler it has been observed in Spitsbergen; while southward, it is distributed all over Europe, especially in the wooded and mountainous districts, and along the sea-coast. It inhabits the northern half of Asia down to the Himalayas; but in Palestine and North-eastern Africa it is represented by the smaller Brown-necked Raven, C. umbrimus, and also by C. affinis, which has the nasal bristles pointed upwards, and very long secondaries; while North-western Africa, the Canaries and Madeira, are inhabited by another small species, C. tinsitanus. In America the Raven is found across the continent from the Pacific to (ireenland, and southward to (iuatemala, but it is local and not common to the east of the Mississippi.

The nest, often built or repaired towards the end of February, though later on the fells, is generally a bulky structure when placed in a crag, but when in trees is, according to my experience, smaller and more compract. The foundation is a mass of sticks, stems of heather \&c., while the lining is of wool, rabbit's-fur, deer's-hair and other soft substances. The eggs, $3-5$, rarely 7 in number, are bluishgreen, flecked with olive-brown, sometimes sparingly, but at other times so thickly as to produce an almost uniform ash-brown appearance; exceptionally they are reddish-white, blotched with rufousbrown : average measurements $\mathrm{I}^{\circ} 9$ by $\mathrm{I}^{\prime} 32 \mathrm{in}$. In the south of Spain the Raven has eggs in April, but there perhaps it breeds twice in the year. In defence of its nest it is very bold, attacking even an Eagle; while its harsh, defiant, barking whoti', whow', when once heard, will never be forgotten. It has, however, softer and more musical notes, generally uttered early in the year, while the bird is performing aerial evolutions and frequent somersaults; and its imitative and linguistic powers in confinement are well known. There is a bold sweep in its flight unrivalled by that of any other Corvine bird. In its food it is omnivorous; and where its depredations among lambs, weakly ewes and game are, naturally, resented, it is shy and difficult of approach ; but in other parts it is very tame, and in Majorca I have seen pairs following the peasants closely when ploughing the ground under the olive-trees, just like Rooks. It is a great destroyer of rats.

The plumage of the adult is black, glossed with purplish-blue on the upper parts and the acuminate feathers of the throat; tail slightly rounded; bill, legs and feet black. Length about 25 in.; wing $\mathbf{r} 7$ in. The female is slightly smaller than the male, and her plumage, like that of the young, is less lustrous. 


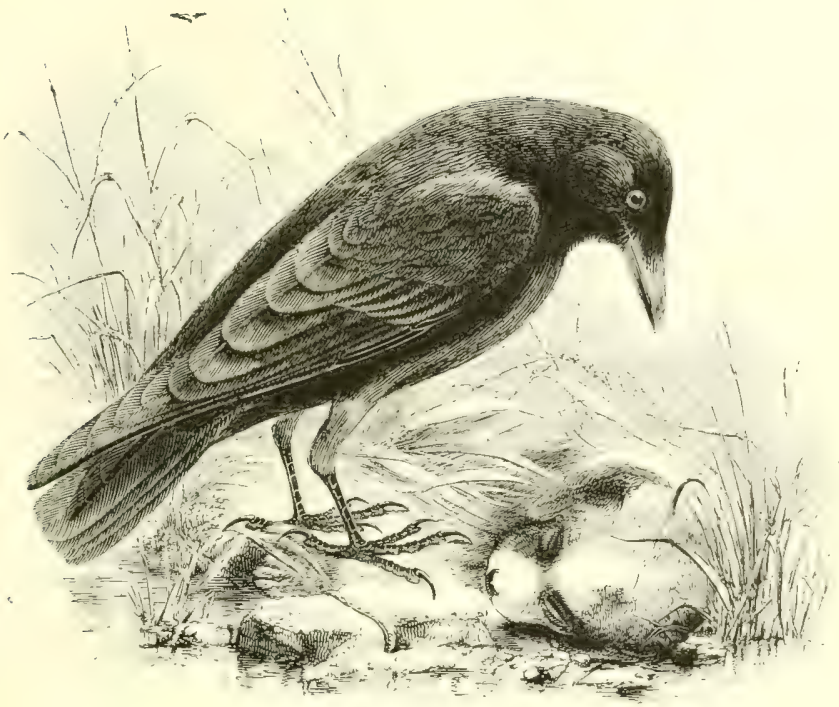

THE CARRION-CROIV.

Corvus coróne, Linnæus.

In spite of the constant persecution which this species undergoes from those interested in the preservation of game, it is still fairly common in most of the wooded districts of England and Wales; especially in the neighbourhood of low-lying coasts, estuaries, lakes, and somewhat sluggish rivers. Near London, where it is comparatively unmolested, it is by no rieans rare, and a pair has nested this year (I888) in one of the Parks. In the north of England, especially in the Lake district and on the Cheviots, it is common; and in the south of Scotland and as far north as Perthshire, it is abundant; beyond which, and in the west, the prevailing form is the Hooded Crow : the two not unfrequently interbreeding. Its asserted occurrence in the Orkneys and Shetlands requires confirmation, but it is resident, though scarce, in skye, and is said to stray to the Outer Hebrides. In Ireland it is extremely rare, its place being taken by the Hooded Crow. Considerable accessions to its numbers take place on the east coast of Great Britain in autumn.

Even to the southern portions of Scandinavia the Carrion-Crow is a very irregular visitor, and its reported existence near Archangel is open to question; while in the interior of Russia it is decidedly 
uncommon, although frequent in the Caucasus, the Black Sea district, the valley of the Danube, Greece, and Southern Germany. In Northern Germany its eastern summer-limits are approximately indicated by the valley of the Elibe; while to the west and south it is found breeding as far as France, the Spanish Peninsula, the northern districts of Italy, Corsica and Sardinia. In Asia it nests in Turkestan, and, sparingly, in Cashmere; in Western Siberia it meets and interbreeds freely with the Hooded Crow; but in the forest district between the Yenesei and the Pacific, as well as in Northern China and Japan, the Carrion-Crow again prevails. Its occurrence in North Africa is doubtful, but it is said to visit Madeira.

This species seldom makes its nest before the middle of April, generally selecting for the purpose some moderately tall tree which affords a good look-out, or a ledge of rock; but, where these sites are not available, it will build in a low bush, and even on the ground. The structure is composed of sticks, fine twigs $\& c_{\text {., }}$ with a warm lining of wool and other soft materials; the eggs, usually $4-5$ in number, are bluish-green, spotted and blotched with olive-brown : average measurements $I^{\circ} 7$ by $I^{\prime} 2$ in. The Carrion-Crow probably pairs for life, and is generally to be seen in couples, quartering the ground carefully, with somewhat heavy and laboured flight, in quest of food. Carrion, weakly lambs, poultry, the eggs of game and witer-fowl, leverets, moles, rats, fish, mussels and the refuse of the shore-nothing comes amiss to it ; but it will also eat insects, grubs, grain and fruit, like the Rock, and I have seen it on the hill-sides in the Pyrenees in similar flocks. Its ordinary note is a hoarse croak, but it sometimes emits sounds which may almost be called musical; while in confinement it develops some capacity for imitation.

The adult has the entire plumage black, glossed on the upper parts with purple, tinged with green on the head, neck and throat; nostrils covered with thick bristly feathers, directed forwards; bill, legs and feet black. Length about 19.5 in.; wing 13 in. The female is less glossy, and has sometimes a browner tinge on her plumage than the male. The young bird is still duller in colour. The inside of the mouth is always pale flesh-colour: in the young Rook it is dark flesh-colour, soon turning livid, and afterwards slatecolour. Albinisms and varieties are not very common; the Rev. H. A. Macpherson has recorded one of a reddish-fawn, the rest of the brood being in normal plumage. 


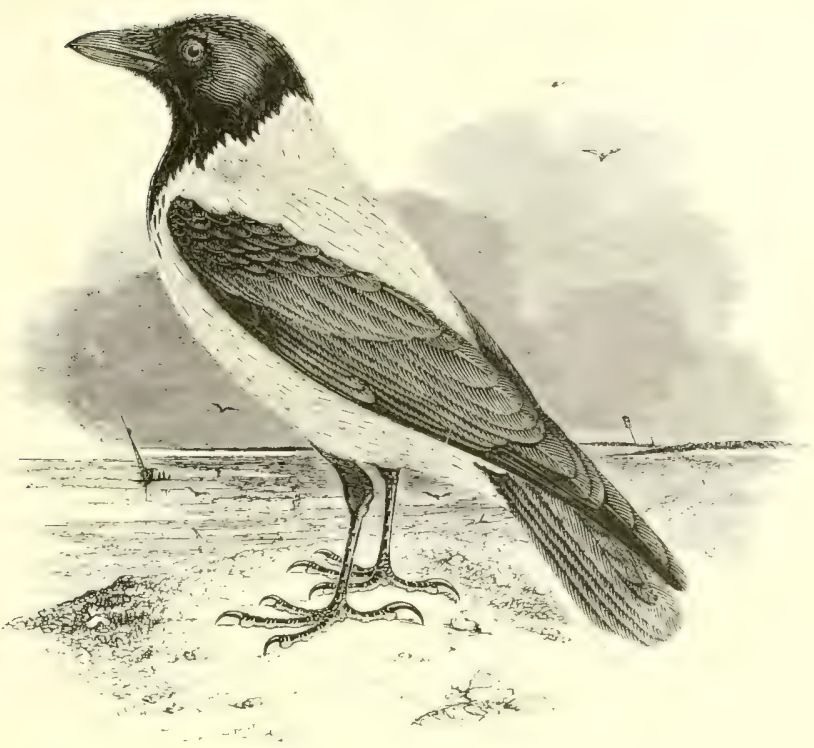

THE HOODED CROW.

CORvus CórNix, Linnæus.

This bird, often called the Grey or Royston Crow, is a regular and numerous visitor to England and Wales from October onwards: while a few instances are on record of its having remained to breed, and cases of hybridism with the Carrion-Crow are not unfrequent in the north. In the Isle of Man it is said to nest annually. On the mainland of Scotland it is only too abundant, predominating in the north and west, and becoming the representative form in the Outer Hebrides, Orkneys and Shetlands. In Ireland also it is common and increasing, especially in the south. The majority of the large flocks found in our eastern districts arrive from the continent.

In the Froes the Hooded Crow is resident, and it occasionally visits Iceland. In Scandinavia, Finland and Northern Russia it is common, migrating from the higher latitudes in winter, at which season large flocks are found in Northern Germany west of the Elbe; but these, as a rule, take their departure in March, although some occasionally remain to interbreed with the Carrion-Crow. Colonies of the pure-bred bird are dotted about Central (icmany and are frequent in (ializia; but to Switzerland, lrance and spain, it is only a winter-visitor, though it nests in the isiands of Majorca, 
Corsica and Sardinia; in Italy also, and Sicily, as well as in the Cyclades, it is resident. To North-IVestern Africa it is only a visitor, but in Egypt it is very abundant where there are trees, breeding in February and March; it is also found in Syria, and it swarms in Southern Russia; while eastward it can be traced through Asia Minor and Persia to Afghanistan; and northward, through Turkestan and Siberia as far as Tomsk. Between that place and Krasnoiarsk - about $35^{\circ}$ miles east-the area is occupied by hybrids between this bird and the Carrion-Crow, the latter becoming, as already stated, the representative form in Eastern Siberia (Seebohm).

In the south of Ireland the Hooded Crow sometimes has eggs by the middle of March (Zool. I883, p. 337), but in Scotland it is later in breeding. According to circumstances, the nest is placed on inland rocks, sea-cliffs, tall trees, low bushes, on the ground among heather, or even on the roofs of huts. The materials are similar to those employed by the Carrion-Crow, and the eggs, 4-5 in number, cannot with certainty be distinguished, but they are often slightly larger, paler, and of a brighter green ground-colour. The call-notes are similar, and so are the habits and food, although perhaps the Hooded Crow is rather the bolder robber. I have seen a young one greedily devouring the carcase of a recently shot member of the same brood.

The thoroughbred bird has the head, throat, wings, tail and thighs black, glossed with greenish-purple; the rest of the body ashy-grey, with a few dark streaks down the centres of the breastfeathers; the remainder as in the Carrion-Crow, the grey colour forming the sole distinction. To some extent the hybrids are fertile, and Mr. Seebohm found every intermediate state of plumage between the two forms. A large case of specimens illustrating these gradations has been presented by him to the Natural History Museum at South Kensington. Northern examples of the Hooded Crow are rather larger than those resident in the south of Europe, and also, as a rule, than Carrion-Crows from Scotland; the latter apparently attaining its fullest development in the centre and south of Europe. Professor Newton has expressed with his usual perspicacity the reasons for not admitting their specific distinctness; but, without entering into argument, it has seemed expedient to treat them under separate headings in the present work. 


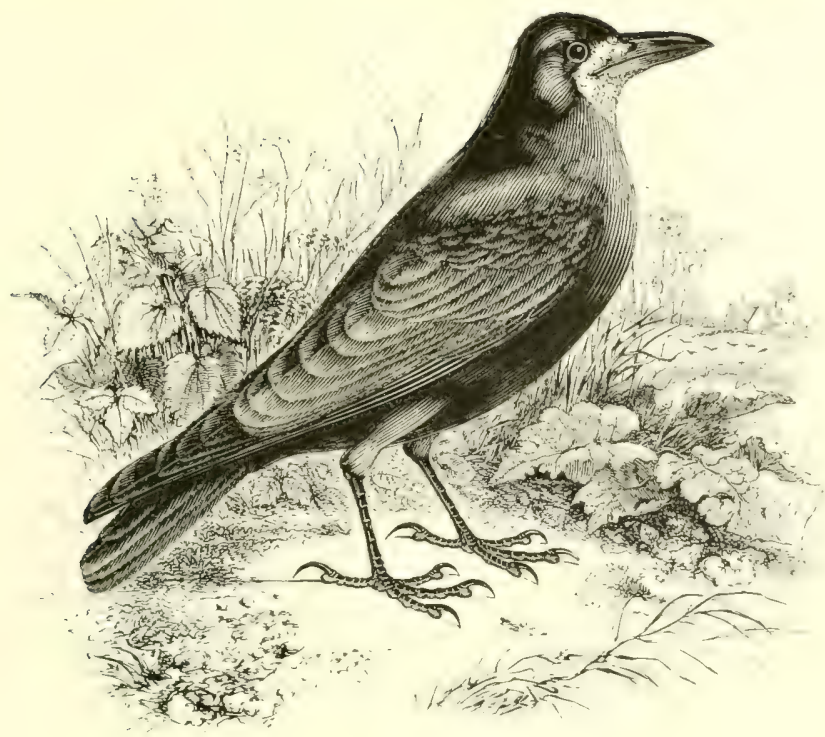

THE ROOK.

Corvus Frúgilegus, Linnæus.

The Rook is even better known than the Jackdaw, owing to its custom of living in noisy flocks throughout the year, and its tendency to select the vicinity of human habitations for its breeding-places. The rookeries still existing in London have often been enumerated, but unfortunately their number is diminishing: and the same must be said of other large cities and towns. As regards the country, the Rook is generally distributed throughout England and Wales; while in Scotland it has for some years been increasing in numbers and northward range, breeding in Sutherland and Caithness, and even at Kirkwall, Ieerness and Melsetter, in the Orkneys. In Skye there are now two large rookeries near Dunvegan, and two that are smaller; but throughout Scotland generally the increase of the Rook is not regarded with favour, for in default of other food it undoubtedly pilfers eggs. To the Outer Hebrides, Shetlands and Faroes it is as yet only a straggler. In Ireland it is common. Numbers visit our east coast in October and November from the Continent, and a considerable return migration has been observed early in the spring.

Large flocks of Rooks made their appearance towards the end of 
November $\mathbf{1} 880$ in Iceland; and in Scandinavia---whence, as a rule, it emigrates in winter-it breeds below the line of the fells; as it also does in Finland on the frontier of the St. Petersburg district, and sparingly as far as Archangel. During summer it is genera!ly, though somewhat irregularly, distributed throughout the rest of Northern and Central Europe; nesting southward down to the vicinity of Biarritz in France, Iodena and Venetia in Italy, the Dobrudscha, and the Crimea. It is probable-but on this point information is desirable - that it also breeds in the exceptionally moist province of Galicia, in the north-west of Spain ; but otherwise it is only known as a winter-visitor to the Peninsula and the countries in the Mediterranean basin, where, during summer, the soil is usually too hard to be bored for grubs \&c. It nests in the wooded districts of Northern Persia, Turkestan, and Siberia as far as the valley of the Irtish; visiting Afghanistan, Cashmere, North-western India, and Palestine in winter, at which season it is also found in Egypt down to Memphis, and occasionally in Algeria. In Eastern Siberia, China, and Japan the representative species is $C$. pastinator, in which the throat is feathered, and the plumage purplish-black.

The nest, built about the middle of March, and composed of twigs and turf, with a lining of roots and straw-but seldom, if ever, any wool-is generally placed in tall trees, but sometimes in pollard willows, firs, laurustinus and holly-bushes; occasionally on chimneytops and ornaments of church-spires, and exceptionally on the ground. In the Orkneys dry tangle and fish-bones are used as building-material. The eggs, $3-5$ in number, are like those of the Carrion-Crow, bluish green blotched and streaked with olive-brown, but rather smaller: average measurements $I \cdot 6$ by I'I 5 in. The food consists chiefly of insects and their larvæ, but practically the Rook will eat anything, and in dry seasons or localities it not only takes eggs if the occasion offers, but hunts for them, like a Crow. Its note is the well-known care.

In the adult the general plumage is black with a blue gloss; the forehead, lores and throat are bare of feathers, and show a greyishwarty skin; bill, legs and feet black; inside of mouth slate-coloured. Length about 19 in.; wing $12^{\circ} 75$ in. In the young, until the second moult, the base of the bill is bristly, as in the Crow, but the bill itself is more slender, and the inside is deep flesh-colour ; the feathers have greyer bases, and the plumage has a bluish tint. The bird does not breed until it is nearly two years old. White and piebald varieties are not uncommon, and curious malformations of the bill have been noticed. 


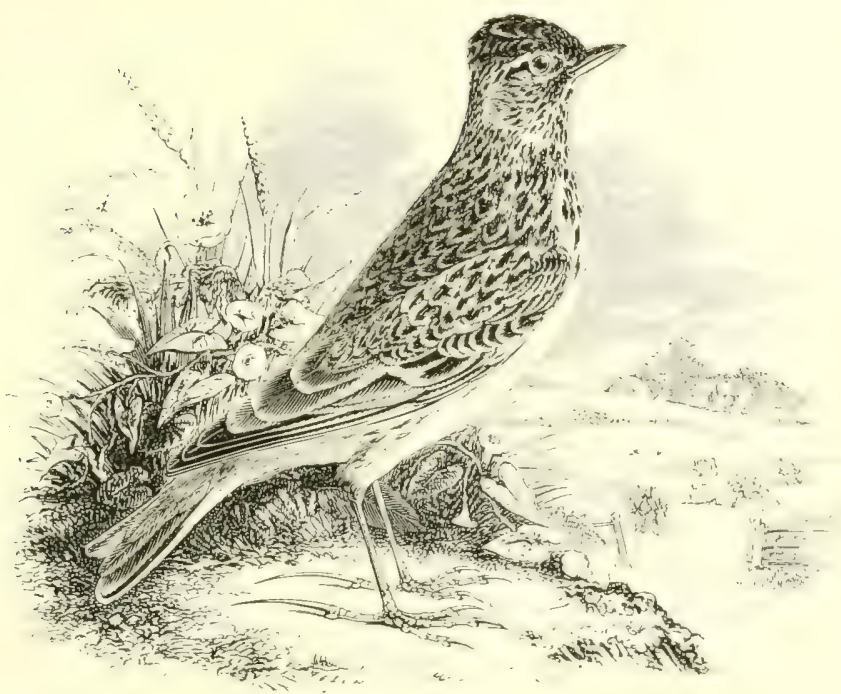

THE SKYLARK.

Alauda arvensis, Linnæus.

This favourite songster is of general distribution throughout the British Islands, being especially abundant in the vicinity of arable or pasture land. A considerable emigration takes place from the northern districts in autumn; and at that season the flocks of our home-bred birds are augmented by, hordes from the Continent, which are sometimes observed arriving on our east coast for days in succession; while in Ireland a similar invasion from England takes place.

The Skylark only breeds in small numbers in the Froes, although large bands visit that group of islands in autumn. In Scandinavia it nests as far north as lat. $70^{\circ}$, but is comparatively rare beyond the Arctic circle; while eastward it is found, in suitable localities, across Russia, Siberia, and Asia generally north of the Himalayas, as far as the coast of the Pacific, the Kuril and other islands, and Japan. In winter it visits China. North-western India, Afghanistan, Persia, Asia Minor, Palestine and Egypt. During the summer it is found throughout Europe, though comparatively few breed in the southern portions of the Spanish Peninsula, where it has been noticed that the examples resident on the higher grounds are rather dark in colour. In autumn a general 
movement southward takes place, few, if any, remaining on the northern side of the Baltic; and on Heligoland as many as r 5, 000 have been caught in a single night, while immense numbers are taken both on passage and in winter in the south of Europe. The Skylark also visits Northern Africa, where a few breed on the slopes of the Atlas; its wanderings sometimes extending to Madeira. It is even said to have strayed to Greenland, but Reinhardt has expressly denied any knowledge of such an occurrence. It is well known to have been introduced to the United States, and on June 12 th 1850 , an example was shot at Hamilton, Bermudas. Its importation to Australia and New Zealand is notorious.

The nest, often commenced in the first half of April, and placed on the ground in a hollow among growing crops, or under the shelter of some tuft, clod of earth \&c., is made of dry grass with a finer lining of the same. The eggs, 3-5 in number, are dull grey, thickly mottled and often zoned with olive-brown: average measurements 92 by 68 in. Incubation lasts fifteen days, and two broods are generally produced in the season. The food consists of insects and worms, with a considerable quantity of seeds of various kinds during the colder portion of the year, and a certain amount of grit to aid digestion. Every one must be familiar with the rapturous trill of the Skylark, as, rising from the ground, it soars, still singing, until almost lost to sight; but it sometimes utters its song while on the ground, and, exceptionally, I have seen a bird-unmistakably of this species and not a Tree-Pipit-giving forth its joyous carol while swaying in the wind on the topmost branch of a tree some twenty feet in height. Like other members of the family, the Skylark is fond of dusting itself to get rid of insect parasites; and, contrary to the custom of the Pipits, it does not bathe in water.

The adult in spring has the general plumage of the upper parts warm yellowish-brown, streaked with dark brown, especially on the crown and back; over the eye a buffish-white streak; quills dark brown, with buff outer margins and greyish-white tips; tail-feathers with dark brown centres and tawny edges, except the outer pair, which are chiefly white, and the second pair which have white outer webs; under parts buffish-white, distinctly spotted and streaked with dark brown on the throat, breast and flanks; bill dark brown above, paler below; legs yellowish-brown. The dimensions vary greatly: average length 7 in.; wing $4^{.25}$ in. The sexes are alike in plumage. In the young bird the feathers are broadly tipped with buff; while in autumn both young and old have a tawny tint. 


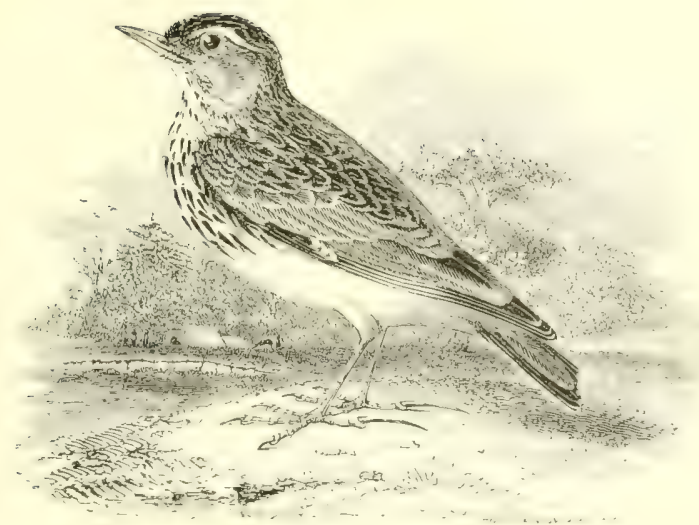

THE WOODLARK.

Alauda arbórea, Linnæus.

The Woodlark is a locally distributed species in England and Wales, and during the breeding-season it is chicfly to be fornd om warm, dry, light soils, especially on undulating ground studded with copses or plantations. Although nowhere plentiful, it is most frequent in some of the southern counties, such as I levon, I)orset, Wilts, and Gloucestershire; it is also fairly distributed along the dry, wooded and rising ground on both sides of the valley of the Thames, and over the line of the chalk formation which runs from Buckinghamshire to West Norfolk. In the midland counties it is very local, and northward it gradually becomes scarce: comparatively few breeding in Yorkshire, Lancashire, Cumberland and the Lake district. Up to that point, however, it appears to be a resident which has suffered considerably from the persecutions of birdcatchers and to some extent from severe winters; but in scotland it is only a rare and local visitor in summer as far as Stirlingshire, where its nest has been taken by Mr. Harric-lirown; though on migration examples are said to have been oltained much further north, and once even in Orkney. Many of these records require corroboration, and it may be well to remember that the term 'Woodlark' is often misapplied to the Tree l'ipit hy lird-catchers and others. In winter considerable numbers are sometimes found in the southern districts of England, especially in snowy weather. but there does not appear to be any consideralice immigration from the Continent. In Ireland it is resident in a few suitable localitics. 
In summer the Woodlark inhabits the southern portions of Scandinavia, and Russia below about $60^{\circ} \mathrm{N}$. lat., as far east as the Ural Mountains, while in Northern Germany it is common. Southward, it is found in places suited to its habits-especially in Central Francedown to the Mediterranean, Black and Caspian Seas; its numbers being increased by accessions from the north in winter, at which season it also visits Northern Africa and Palestine, and in the latter it is said to breed on the high ground.

The nest, rather firmly constructed of grass and a little moss, with fine bents for a lining, is generally placed in a depression of the ground, sheltered by a low bush or a tuft of grass, but sometimes in smooth turf. The egrgs, $4^{-5}$ in number, often laid by the middle of March, are white or pale greenish-white, finely spotted and often boldly zoned with warm-brown and violet-grey : average measurements $\cdot \delta_{3}$ by $\cdot_{3}$ in. They are quite unlike Skylark's eggs, resembling rather some varieties of those of the Crested Lark. At least two broods are produced in this country, but on the Continent the bird does not appear to nest so early as with us; while in autumn young and old rove about in family parties. The food consists principally of insects, supplemented by small seeds and tender herbage. The sweet and flute-like song, fairly indicated by the French name ' Lu-lu' repeated several times, is very attructive, and is uttered by day, and not unfrequently by night, almost throughout the year, except during the moulting season; the bird hovering in the air and descending spirally with half-closed wings.

The adult male resembles the Skylark in the general mottledbrown colour of its upper parts and in its crest, but it may always be distinguished from that species by its smaller size, much shorter tail, more slender bill, and by a very broad buffish-white stripe which runs backward over each eye to the nape, and shows up the dark ear-coverts; the bastard primary is much longer, and there is a conspicuous triangular patch of dark brown tipped with buffishwhite on the larger wing-coverts; the tail-feathers are chiefly brownish-black with triangular white tips; the throat and breast are yellowish-white streaked with dark brown; belly yellowish-white; legs and feet flesh-brown. Length 6 in. ; wing 3.6 in. The female is slightly smaller and shows less crest; the young are more rufous and have light buff tips to their feathers. 


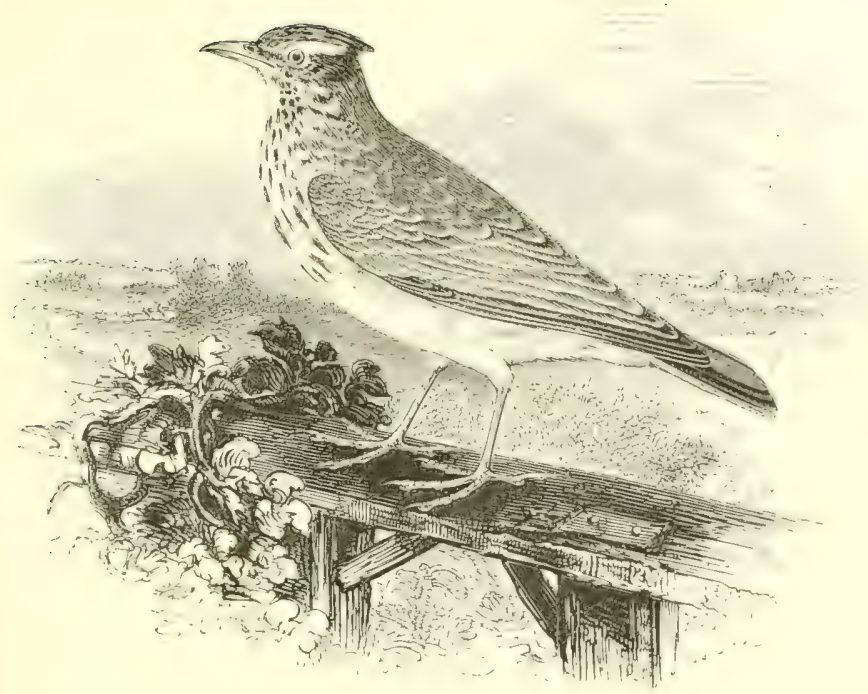

THE CRESTED LARK.

\section{Alauda cristáta, Linnæus.}

Although the Crested Lark is a tolerably common bird on the opposite side of the Channel, yet authenticated specimens have seldom been obtained even in the south of England; a Skylark with a well-developed crest having often been fondly ascribed by its owner to this very distinct species. Mr. Bond has a genuine example obtained at Littlehampton, Sussex, previous to I $8_{+5}$, and another was taken alive near Shoreham on October 2oth I 863 , while at intervals five have been killed in Cornwall-all of them in autumn and winter, with the exception of one shot on June I 2 th I S8O. Capt. Hadfield asserts that one was captured in the Isle of

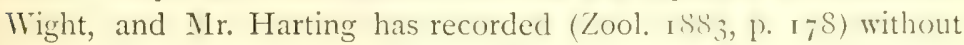
seeing the specimen, the statement by a bird stuffer that one had been taken from the nest near Cambridge. The species is not known to have visited Scotland, and its supposed occurrence in Ireland rests upon an anonymous paragraph in a newspaper.

The Crested Lark flourishes best in warm countries, but it can bear cold well, although snow interferes with its means of subsistence; and it is resident in small numbers as far as $60^{\circ} \mathrm{N}$. lat. in Sweden and Russia. In I)enmark, Northern Germany, Holland and Belgium, it becomes more frequent; in the nortl of France 
it is fairly common; while in Central and Southern Europe it is abundant, especially on dry sandy soils, except in Corsica, Sardinia and Malta, in which it is nearly unknown. It is numerous in North Africa, and as far south as Senegal on the west; but there and elsewhere an approach to the desert is generally accompanied by a more sandy tint, and sometimes by an increase of size and a greater development of bill. Allowing for these and other climatic variations, which have led to the fabrication of some thirty species and subspecies, the Crested Lark may be said to range eastward from Morocco to Abyssinia, and from Arabia to Northern China.

The nest, often commenced early in March, is usually placed in some such depression of the dry ground as a hoof-print, or amongst herbage, but sometimes on an old wall or bank of earth, or even on the ridge of a low thatched shed in the fields; the matcrials employed being dry grass and roots. The eggs, $4^{-5}$ in number, vary from greyish-white distinctly spotted with brown and violet-grey, to greenish-grey mottled with olive-brown : average measurements 95 by 68 in. Incubation, in which the male takes part, lasts a fortnight. The Crested Lark is a tame and conspicuous bird, frequenting sandy roads - in which it is fond of dusting itself - and running with great rapidity, while I have often seen it glide beneath a horse when at a slow walk, rather than take wing. Its flight is undulating and resembles that of the Woodlark. It is not gregarious, and is generally seen singly, or in pairs and family parties. The short but rather liquid and melodious song of the male is generally uttered on the ground, though often during a short flight, and occasionally from a bush; the note may be syllabled as 'coo-hai.' The young are fed on insects and their larve, but seeds and grain form the principal food of this species, and in snowy weather it may be seen examining horse-droppings \&c.

The general colour of the upper parts is greyish-brown with darker streaks, and often with a sandy tint; while the under parts are buffish-white, with dark streaks on the gorget, and pale brown markings on the flanks. The characteristics of this species are the long, pointed crest, larye bastard primary, orange-taminy hue of the under side of the wing and inner portion of the quill-feathers, and the absence of white from the tail - the feathers of which are tawny-brown and black. Owing to the shortness of its tail and wings the dimensions-length 6.75 in., wing $4^{\circ} \mathrm{I}$ in.-are less than those of the Skylark. The female is slightly smaller and darker than the male; the young have the feathers of the upper parts broadly margined with white and buff, and fewer spots on the breast. 


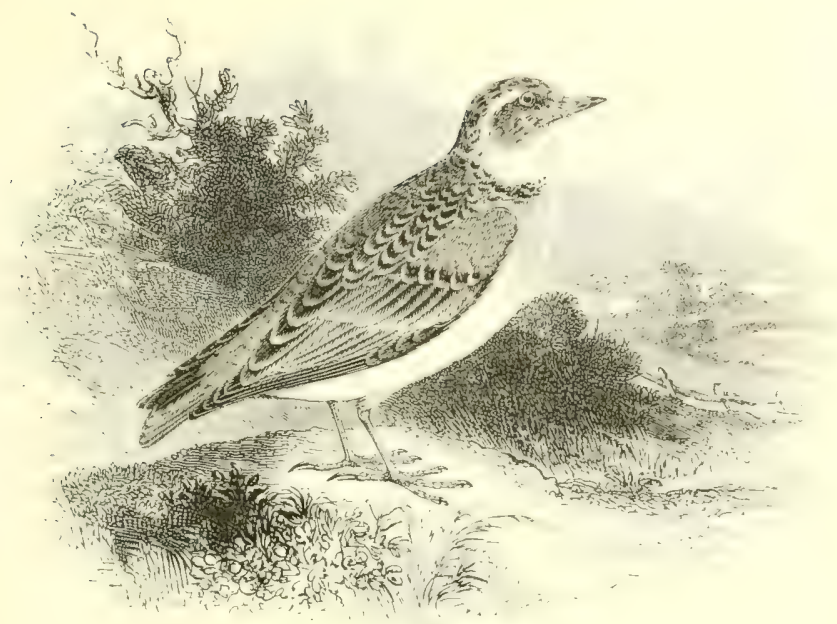

THE SHORT-TOED LARK.

AlAUdA BRACHYDÁCTY゙LA, Leisler.

The Short-toed I ark is a rare wanderer to England at the seasons of migration, and the authenticated instances of its occurrence appear to be:-one near Shrewsbury, two near Brighton, one near Southampton, one on the Scilly Islands, and one near Cambridge -all in autumn; while a bird was killed near Irighton in April 1858 by a person who saw it alight and begin dusting itself in the road. On July a 7 th I $8 S 8$, Mr. Cooper, the taxidermist, of Radnor Street, E.C., showed me a live bird said to have been taken at Amberley, Sussex, on the i 8 th of that month.

Although this species has been recorded from Heligoland, it can only be considered a straggler to Northern or even Central Germany; to Belgium, and to France north of Paris; but at Blois Sir Edward Newton found it breeding, and it is a regular summer-visitant to the districts further south, although said to emigrate in winter. In the Spanish Peninsula it is abundant and-in the southern portions. at least-stationary; it is so also in North-western Africa, but in the north-east, as far south as Abyssinia, it is only found in winter and on passage, when it is very numerous and in large flocks. To Italy, again, it is only a summer-visitor, a'though abundant in the south, but in Malta it is a resident, and it is found more or less throughout the year in Greece, Turkey, Southern Russia, Asia Minor and Palestine; while further east we trace it to Persila. 
Turkestan, and the northern half of India. This Lark is one of a group of nearly allied species which have been justifiably placed in the genus Calandre?la, characterized by the absence of crest, a stout conical bill, straight and short hind-toe, and by the infinitesimal-almost invisible-bastard primary. I have not, however, considered it expedient to use this genus at the head of the present article, when treating of a mere wanderer in a work for British readers. Several of its congeners are found over part of the same area as the typical Short-toed Lark; for instance, Calandrella botica in the extreme south of Spain, C. minor in North Africa and the Canaries, and $C$. pisfoletta in the steppe-region between the Volga and China; but these three are still more closely related to one another than to our bird, being distinctly marked with numerous dark brown streaks on the throat and breast, as the Skylark is ; their eggs, moreover, are creamy-white with bold spots.

The nest is placed on the ground in any slight cavity, very often in a deep hoof-print; dry grass, with a few feathers and hair as a lining, forming the materials. The eggs, $4-5$ in number, are dull white, mottled and freckled with greyish-brown: average measurements 75 by 57 in. During the breeding-season the bird frequents dry and sandy soil, and plains where the herbage is somewhat scanty; while its tameness is such as often to cause difficulty in shooting a specimen for identification without blowing it to pieces, and $I$ have seen a bird cut down with a whip in the road. The male utters his short and rather feeble song while perched on some clod or low wall, or during a brief, undulating, and somewhat jerky flight. In autumn and winter large flocks are formed, and in India, according to Jerdon, they quite darken the air. The food consists principally of small seeds.

The adult has the upper parts pale rufous-brown with darker streaks; a white line over each eye; central tail-feathers duskybrown, the rest blackish-brown, except the outer pair which are broadiy margined with buffish-white; under parts white, with a few brown spots and streaks on the sides of the neck, and a buffish tinge on the breast and flanks. After the moult both upper and under parts have a warm rufous tint, which is sometimes retained until the middle of the following May. Length $5^{\circ} 5$ in. ; wing $3{ }^{\circ} 4$ in. The sexes are alike in plumage; the young bird has the feathers of the upper parts, including the tail, broadly margined and tipped with buff. The short and conical bill is yellowish-brown; the legs pale brown; the hind claw straight and, as a rule, short, but it is subject to considerable variation. 


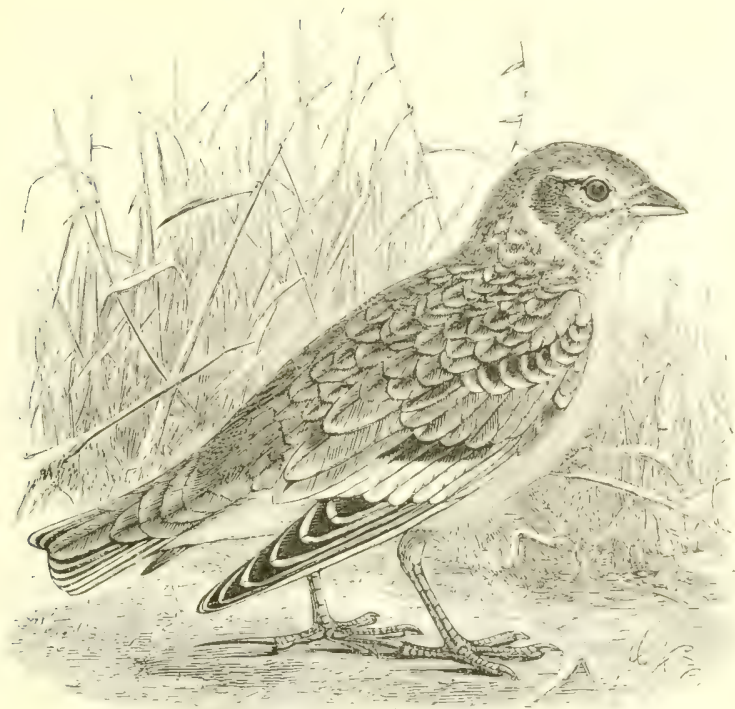

WHITE-WINGED LARK.

Alauda sibírica, J. F. Gmelin.

An example of this Eastern species, which had been captured alive on Nov. 22nd $\mathrm{x} 869$, when associating with a flock of SnowBuntings, was recognized the same day by the late Mr. (i. I awson Rowley and subsequently exhibited at a meeting of the Zoological Society. It proved to be a female, and is now in the collection of Mr. T. J. Monk of Lewes.

An occasional visit from the White-winged I ark is not surprising, for three specimens have already been obtained in Iielgium: onc in October 1855 near Liège, another at Malines (or Mechlin) in I 856 , and a third more recently near Namur. (In I Idigoland one was taken on August 2nd ISSI; and although its occurrence is not yet authenticated in Northern Germany its visits to P'oland and Galizia are not unfrequent, while stragglers have been recordedalways on the autumn migration-from Irent in Tyrol, and Teroma and Bergamo in Italy. ()n the black-earth plains of Russia as far north as Saratov on the Volga it is a common breeding species, visiting Southern Russia and portions of Turkey in winter; while eastward we trace it throush the Kirghis steples as far as the Mltai Mountains, and up to Omsk on the Irtish in Siberia; it is also found in Turkestan. 
The nest, generally built early in May, is placed on the ground under a tussock of grass, and the eggs, $3-5$ in number, are yellowishwhite, spotted and mottled with several shades of brown and violet grey : average measurements 95 by 65 in. In Russia the bird does not arrive until the grass is green, and, according to Eversmann, prefers those portions of the steppes which are most clothed with herbage; while Pallas, who was the first to observe this species on the banks of the Irtish, describes it as frequenting the road-sides and uttering its song--similar to that of the Skylark but shorter-when hovering at a moderate height from the ground. During the cold season it is found in large flocks and is very tame. The food is probably similar to that of other Larks.

The adult male has the top of the head and ear-coverts pale chestnut; lores and eye-stripe dull white; back tawny-brown with dark stripes down the centre of each feather; upper wing-coverts chestnut, the greater rufous-brown: outer primaries dark brown, the inner ones and the secondaries chicfly white, forming a large and conspicuous bar or patch; tail-coverts, and the central tail-feathers broadly edged with chestnut, the outer pair of tail-feathers white, the rest dark brown with white or pale margins; under parts white, with brown and rufous spots on the throat, gorget and flanks; under wing-coverts white; bill horn-colour; legs yellowish-brown. Length 7.5 in. ; wing 4.6 in. The female is rather smaller and exhibits hardly any tinge of rufous on her brown-streaked crown, and but little on the wings, tail or breast. After the autumn moult the plumage is tinged with buff. The young resemble the female. The stout bill, chestnut tint, white wing-patch, and white under wing-coverts are sufficiently distinctive of this species.

Two examples of the Calandra Lark, Alauda calandra, said to have been killed in England, have been recognized in the shops of bird-stuffers at Devonport and Exeter respectively; but the evidence is not sufficient to warrant the introduction to the British list of a species which is very tolerant of confinement, and is one of the commonest cage-birds in Spain and Italy.

The White-winged, Calandra, and other stout-billed Larks have been placed in several genera, the favourite one being Melanocorypha; but that name is, at best, misleading, for the Calandra, which is the type, has not a black crown, nor would it be easy to define the characters which distinguish the genus from Calandrella. 


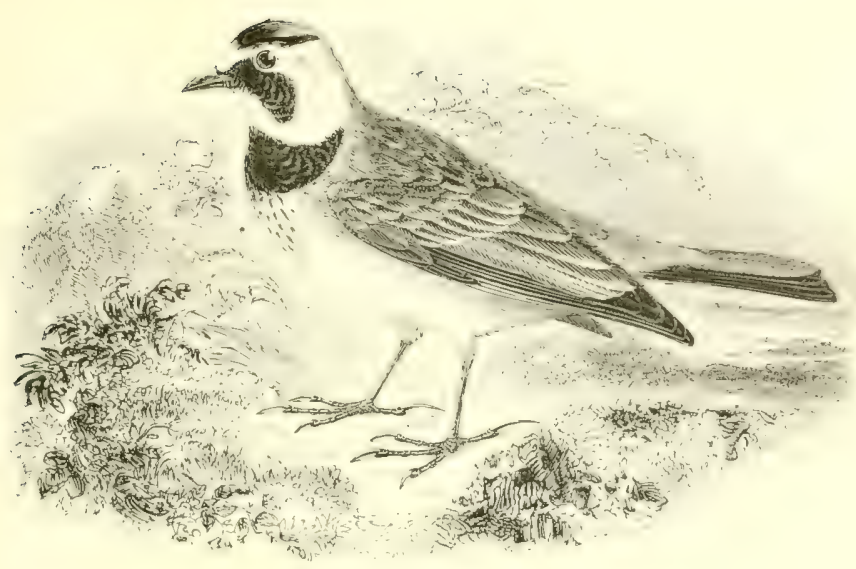

THE SHORE-LARK.

\section{OTÓCURYS ALPÉSTRIS (Linnæus).}

The Shore-Lark was first noticed as a visitor to England in March $1 S_{3}$, when one was obtained on the coast of Norfolk; since which date it has occurred at irregular and sometimes long intervals on the eastern and southern shores of England, but seldom on the west side. In the winter of $1869-70$ a considerable visitation took place, chiefly along the east coast; and from that time onwards, especially in $18 \$_{2}-8_{3}$, its numbers have considerably increased. The majority have been observed in autumn and winter, but examples have been obtained on the spring migration northward as late as April 2and (Aplin). In Scotland, where it was not noticed until I 859 , it has occurred as far north as St. Andrews on the east coast, but not on the west; while from Ireland it is as yet unrecorded.

The present species-a member of a well-defined and widelydistributed genus-inhabits during the summer the northern, or the elevated regions above the limits of forest-growth, in Scandinavia, Finland, Russia (including Noraya \%emlya), and Siberia beyond the Arctic circle, reaching as far east as Rering Straits. ()n migration it occurs irregularly throughout the ircater part of Europe, and occasionally down to the Black and IIediterranean Seas, although it is not recorded up to the present from the Spranish l'eninsular; eastward it is found in Turkestan, southern siberia and Northern China. The district between Asia Minor and the Mltai Mountains is inhabited by a recognizathe species, $O$. fincillatu. in which the black 
on the ear-coverts joins the black on the throat; while a paler Tibetan form has been distinguished as O. lonsirostris. In the desert region between Morocco and Arabia Petrea, we find a resident, well-marked, tawny species, $O$. bilopha. Our bird is found in Greenland and the eastern portions of Arctic America, but the remainder of that continent is distributed by American trinomialists among no fewer than seven subspecies; and O. peremina inhabits the high lands of Bogotá, Colombia.

The nest, slightly made of grass and plant-stalks, with willowdown and reindeer-hair for a lining, is placed in some hollow of the ground, or among stones on a hillside. The eggs, 4-5 in number, are greenish-white, minutely freckled and often boldly zoned with olive-brown, and occasionally scrolled with black hairlines : average measurements 9 by $6_{3} \mathrm{in}$. In Norway and Lapland breeding often begins by the middle of May, two broods being produced during the season. In autumn small flocks are formed, which rove about in search of food, principally seeds, though in summer beetles and other insects are eaten; the Shore-Lark is also partial to the small molluscs and crustaceans found on the sea-shore. It is a tame and confiding species, frequently entering the streets of towns and villages in the north of Europe, and up to the end of June it utters its pleasant and rather mellow song from some post, rail or barn-top, or while hovering in the air.

The adult male has the lores and cheeks black; forehead, throat, and a broad stripe above the eye and enclosing the ear-coverts yellowish-white; across the front of the crown a black band, terminating in an erectile tuft of black feathers on each side of the head; nape and mantle pinkish-brown; wing-coverts tipped with white, quills brown; middle tail-feathers warm brown, the rest nearly black, with whitish margins to the outer pair; upper breast broadly banded with black; under parts duil white with brown streaks on the flanks; bill greyish-black; legs black. Length 6.5 to 7 in.; wing about $4^{\circ}+$ in. The female is smaller, with less black on the head; the erectile tufts are wanting; and her general colour is duller. The young male resumbles the female; the nestling is dark brown mottled with buff, but the black ear-patches are conspicuous. After the moult the feathers on the head in the adults are much tinged with yellow. 


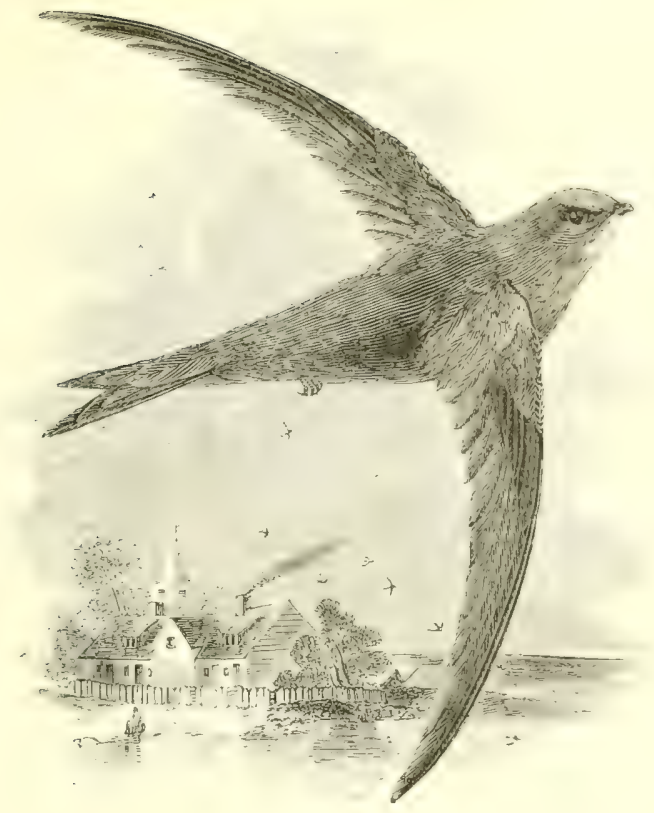

THE SWIFT.

CÝPSELư ÁPus (Linnæus).

The Swifts, with which we enter upon the Order PICARIE, were formerly placed among the Passeres, united with or close to the Swallows; but it is now generally admitted that in spite of a certain similarity in habits and appearance, the swifts have as little structural affinity with the latter as with any other Passerine family, their nearest allies being the Humming-Birds. Having no true song-muscles their note is a harsh scream ; and their powerful wings are so long-while the feet with the four toes directed forwards and well adapted for clinging, are so small - as to render walking difficult; but, contrary to the popular be'ief, the birds are alble to raise themselves from the ground.

The swift, often called 'screecher' and 'I cuiling,' is a common summer-visitor to the British Islands, making its alpearance in the south towards the end of April, and in the north somewhat later. The majority have taken their departure by the cul of August, but even so far north as Nairn I noticed that many remained until the 2 Ist of that month, and laggards have becn recordcel in the south-west as late as October and even November. To the 
extreme north of Scotland it is somewhat irregular in its visits, and it is only seen occasionally in the Orkneys and Shetlands; while on the west side it is of rare occurrence in Skye and in the Outer Hebrides, including St. Kilda. To Ireland it is a regular visitor, and though said to be rare in some parts of the west, it is common in Mayo and Sligo,

To the Firoes the swift is only a straggler, but it is found in Scandinaria up to $70^{2} \mathrm{~N}$. lat., and in Russia as far as Archangel ; in siberia it has occurred at Omsk, and breeds regularly in Daïria, Mongolia, Northern China, and Asia generally to the north of the Himalayas and other great ranges. On migration it visits the Punjab and even the Andaman Islands, but from India westward to the Jordan valley the resident species is the white-rumped $C$. affinis: while in Northern Ifrica our bird is either associated with or represented by $C$. pallitus, also found in southern spain and in the Canaries; the latter group being further occupied by the smaller and darker $C$. miculor. Throughout Europe the Swift is abundant in summer, often arriving in the sunny south early in March, though not till June in Lapland; while its migrations extend to the extreme south of Africa.

Holes in thatch under the eaves of cottages and other buildings, in church towers, crevices in sea-cliffs, quarries, chalk-pits, and even trees, are the sites selected by the swift for its breeding-place, to which it returns year after year. I few bits of straw and grass, with feathers, collected on the wing, and glued together by the viscous secretions of the bird, form its usual nest, but it sometimes robs Martins, House-Sparrows and even starlings of their dwellings. The eggs, laid early in June, are 2 in number, and when more are found in the same nest, they are probably the produce of two females; they are oval, rough in texture, and dead-white: average measurements $I$ in. by $\sigma_{5}$ in. Incubation lasts eighteen days, and as a rule only one brood is produced during the season; backward young being abandoned by their parents when the time arrives for emigration. Insects taken on the wing form the food, and the indigestible portions are rejected in the shape of pellets. The wild, screeching note is sometimes quite startling, when uttered by a flock of birds sweeping by at lightning speed, and often in the worst of weather, for the Swift seems to revel in the storm.

The plumage of the adults is a bronzed blackish-brown, with a small greyish patch under the chin; bill, toes and claws black. Length to the tip of the tail $6 \cdot 5$ in.; wing $z$ in. The young have more white on the throat, and paler margins to the feathers. 


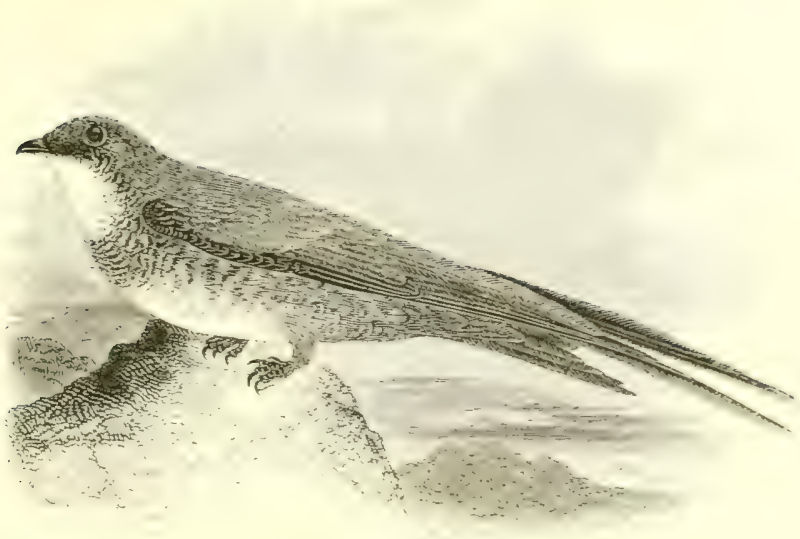

THE ALPINE SWIFT.

\section{Crpselus mí́lba (Linnæus).}

This large Swift was first noticed as one of our occasional risitors about midsummer I 829 , when one was shot off the coast of Ireland: and since that time three or four more have been obtained, at long intervals, in that island. Nearly a score of instances are on record from various parts of England-mostly from the southern half, but though one of them occurred as far north as. Alnmouth in Northumberland, no captures have as ret bein made in scotland. With the exception of one taken near Dublin in March Is,3, the occurrences noted have been between June and (lotobur, and for sereral reasons, coupled with the fact that I have obtained it in the Bay of Biscay early in August, I think that most of uur visitors are from the Pyrenees or the Cantabrian range.

The Alpine Swift is a very rare visitor to Heligoland, Ciemany. and the north of France, although it breeds no further off than the cliffs at Nolay on the western frontier of bursundy : also in the Vosges and Saroy. Throughout switkerland it nests amnually, in high crags and in lofty towers-notably in the cathudral at licme: arriving at the end of April and leaving in suptember or October. All the high mountain ranges of Central and suthern Eurepe are frequented by it during the summer; while castwarl we trace it, through Asia Minor, Palestine, P'ersia and l'urkestan, to many larts of India. In the cold season, and indeed during a consicirable portion of the year, it is found in Ceylun : also in staitable situations 
down to the extreme south of Africa, where it is supposed, though not yet proved, to breed.

Mr. S. B. Wilson has described the nests in the cathedral at Berne as placed on the ledge which goes round the tower about four feet below the main floor; sometimes there were three or four in the space of three yards, all placed on the same beam. The structure itself is very shallow, and is made of dry leaves, bits of paper, grass stems, fir-bark, and a few feathers; the whole being made fairly solid by the mucous fluid which the bird emits. I believe that the eggs are normally 2 in number, but as 3 and 4 are sometimes found, perhaps two birds lay in the same nest; the colour is deadwhite: average measurements $1 \cdot 2$ by 77 in. The Rev. H. A. Macpherson says that he noticed some green grass in many of the nests. Mr. Wilson considers that the male and female take turns in the duties of incubation, for as he was watching a bird on its nest another suddenly dashed in under the roof and began to caress it, and after both had twisted their heads about and rubbed each other's cheeks with open bills, the sitting bird rolled itself off the nest and vanished, while the other took its place. Only one brood is reared in the season. The food consists of insects. The note is louder than that of the Common Swift, and the flight is more powerful; while the large size, browner colour and white belly are distinctive characters.

Excepting a blackish patch in front of the eye, the upper parts, sides of the neck, gorget, and under tail-coverts are of a nearly uniform mouse-brown, with a metallic lustre on the wing-and tailfeathers; throat and belly white; bill black; feet yellowish-brown; length from bill to end of tail nearly $S$ in.; wing $S \cdot 5$ in. The sexes are alike in plumage. In the young the feathers are slightly margined with greyish-white.

The vignette below represents the breastbone and foot of the Common Swift.
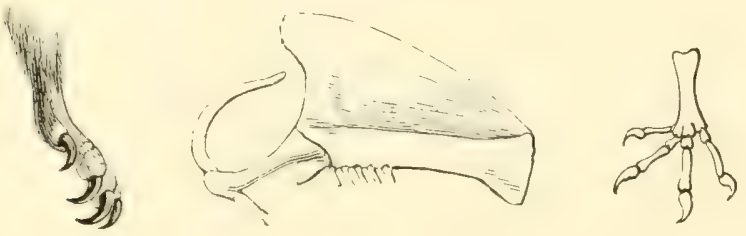


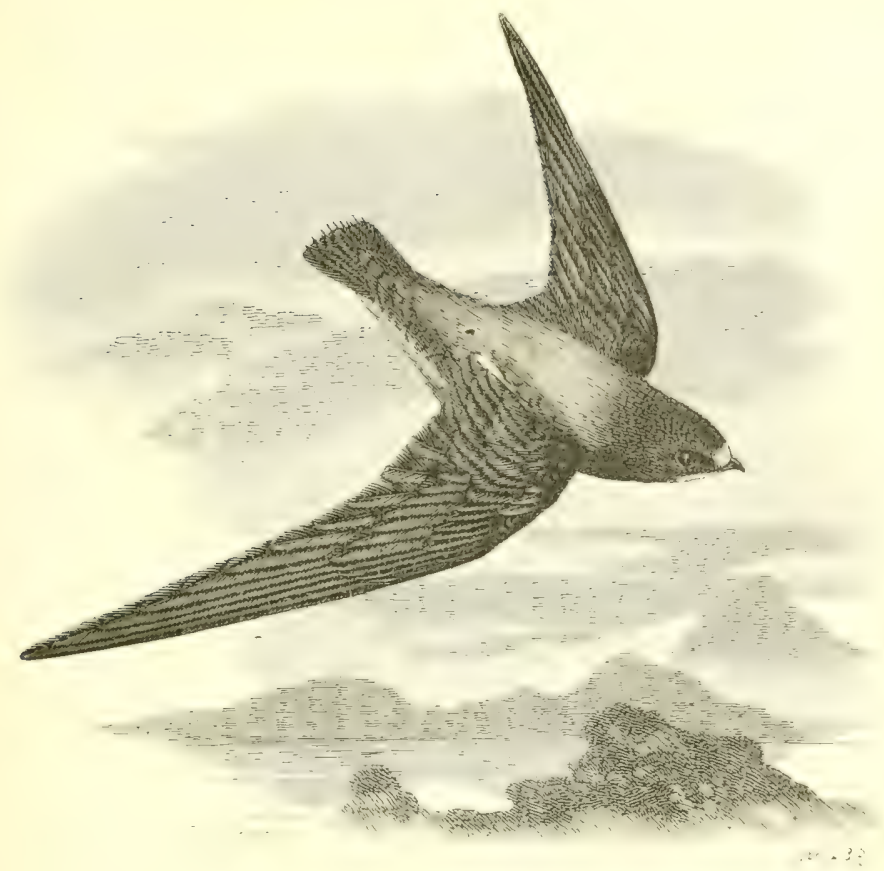

THE NEEDLE-TAILED SWIFT.

Acanthýllis CaUdacúta (Latham).

An example of this Asiatic species was shot at Great Horkesley, near Colchester, on July Sth is 86 , having frequented that nejghbourhood for two days, and was examined in the flesh by Dutibleday and Yarrell. The latter, however, did not include it in his "Irritish Birds,' being probably under the impression-then generally prevalent-that the species was a native of Australia, to which it is now known to be merely a winter-visitor. On July 26 th or 27 th, I 879 , another was obtained near Ringwood, in I Iampshire, having for a few days before been seen flying with a companion over the river Avon by Mr. Corbin, on whose behalf the specimen was exhibited by Professor Newton at a meeting of the \%oological Society.

This fine Swift has not yet been noticed in any other part of Europe, and its western breeding-limits are probably in the moun tains to the south of Krasnoiarsk in the upper valley of the lenesci, whence Mr. Seebohm has received specimens. I) uring the summer it inhabits South-eastern Siberia, Mongolia, Manchuria, Japan, and 
the mountainous regions of China, Tibet, and the eastern Himalayas; while in the cold season it migrates southwards as far as Eastern Australia and Tasmania. It is said to return to its breedingquarters about the end of April or early in May; departing for the south in August and September; and General Prjevalsky has described its bands as passing over-head in an almost incessant stream at the time of the autumn migration in Mongolia.

Several pairs are stated by the above-mentioned Russian explorer to breed in close proximity, the nests being placed in cliffs and in hollow trees; but nothing is as yet known of its eggs, which are probably white. The food consists of insects; the note is described as feeble; while all observers agree in eulogizing the unrivalled vigour of the bird's flight. Gould remarks that the keel of the breast in this species is more than ordinarily deep, and that the pectoral muscles are more dereloped than in any bird of its weight with which he was acquainted.

The adult has the forehead dull white; crown, nape and sides of the head dusky-black with a greenish gloss; back dusky-brown, paler in the middle; wing-cnverts and secondaries bottle-green; inner secondaries chiefly white on the inner webs; primaries blackish; tail-feathers bottle-green with projecting spinous shafts; throat, breast and under tail-coverts white; belly sooty-brown; lower flanks white, mixed with glossy blue-black; bill black; legs and feet dark brown, with one claw directed backwards, in which respect birds of this genus differ from the true Swifts. Iength $8 \cdot 5$; wing $8 \cdot 1$ in.

The rignette below represents the head and foot of the Nightjar, the next species.
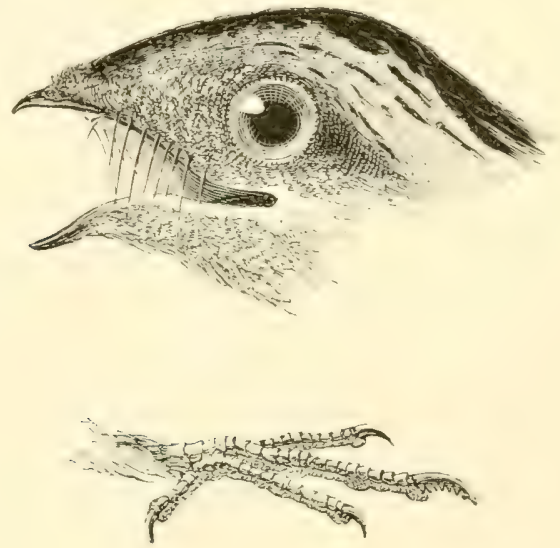


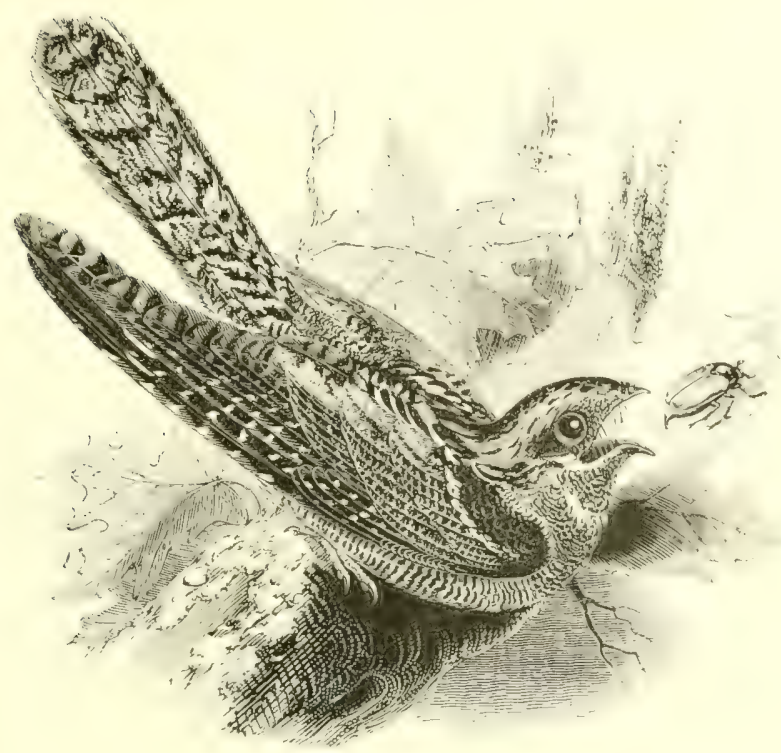

THE NIGHTJAR.

Caprimúlgus europétes, Linnæus.

The Nightjar is the latest of our regular summer migrants in its arrival, being seldom noticed before the middle of May; and it usually leaves us in September, although in the mild south-west of England it has been known to remain until November. Uncultivated ground more or less covered with ferns, and the cool shade of woodland glades, are its favourite haunts, and it is conseguently. somewhat local; but it is generally distributed as far as the northern extremity of the mainland of Scotland, and also in the western islands, except the Outer Hebrides, to which, as to the Orkneys and Shetlands, it is only a straggler. In Ireland it is rather common in some of the southern and central counties, but less frequent in the north and west.

The Nightjar sometimes visits the Fieroes, and in Scandinavia it has been found nesting up to about $6,3 \mathrm{~N}$. lat.; but in Russia its range is less extensive, while eastward it does not reach beyond Irkutsk in Siberia. This bird is found throughout the summer over the greater part of Europe, down to the high grounds of Central Spain; but in the south of that country, although common on passage, I do not think that it remains to breed, its place being taken 
by the Red-necked Nightjar, C. mficollis. One of its lines of migration from Africa crosses Malta, where large numbers are shot for the table in spring. It also visits Asia Minor, Palestine, Persia, Turkestan-where its plumage shows a tendency to paleness-and North-western India. Small numbers are said to remain in North Africa during the winter, at which season it occurs in Arabia, and, apparently, throughout South Africa down to Natal.

The eggs, 2 in number, are placed on the bare ground or short moss, and often on dead gorse-needles in open patches among furze. They are oblong, equally rounded at each end; and are creamywhite, marbled and veined in endless variety with brownish-black and purplish-grey : average measurements $I^{*} \cdot 2$ by $\delta_{5}$ in. Fresh eggs have been found as late as August 12 th. The nestlings are at first covered with a thick greyish down and have been known to display a precocious activity approaching that of the young of Gallinaceous and other ground-breeding birds; but they are dependent upon their parents for food, and do not attempt to feed themselves in confinement. The Nightjar lives entirely upon insects, which it may be seen to take upon the wing in the twilight or when the moon is shining, though it hawks for them on dark nights as well; it is not, however, averse to light and is fond of basking in places where the rays of the sun fall. The whirring which accompanies its twisting flight is caused by the wings, which are sometimes brought into contact and produce a loud noise; but the well-known, vibrating 'churr' is believed to be uttered by the male only, and while the bird is stationary. When reposing on a branch it sits lengthways, with the head lower than the body. The use of the serrated claw has yet to be determined. From early times and in almost every European language the Nightjar has been stigmatized by some name equivalent to 'Goat-sucker,' while in England the equally unfortunate designation of 'Night-hawk' brings it under the ban of the gamekeeper; it is also called 'Fern-owl,' and 'Churn-owl.'

In the adult male the general plumage is ashy-grey, streaked, spotted and barred with dark brown and reddish-buff; on the throat are some white patches; near the centre of each of the three outer primaries are well-developed white spots; and the two lateral pairs of tail-feathers are broadly tipped with white. These white spots on the wings and tail are wanting in the female, and her tints are less rufous. Length about ro in.; wing $7 \cdot 25$ in. In the young the serration of the claw of the middle toe is not pronounced, and the wing- and tail-spots in the male have a buffish tint. 
THE RED-NECKED NIGHTJAR.

Caprinulgus Ruficóllis, Temminck.

A freshly-killed example of this southern species was recognized in the flesh by that eminent ornithologist Mr. John Hancock, in the shop of Mr. Pape, at Newcastle, on October 6th I $8_{5} 6$. It was stated to have been shot the previous day at Killingworth, and is now in the Newcastle Museum.

$\mathrm{Up}$ to the present time the Red-necked Nightjar has not been noticed elsewhere in Northern Europe, but in I anguedoc and I'rovence, in the south-east of France, it has several times been obtained. Though not yet recorded from the mainland of Italy, one was taken at Spalato, in Dalmatia, in March $\mathrm{IS} 75$, and MIr. C. A. Wright has mentioned two captures in Malta during May, in different years. In summer it is common in the southern half of the Spanish Peninsula, where it frequents the cool chequered shade of the woods during the greater part of the day; it is also said to be a regular visitor to some of the Canary Islands, while eastward it is found throughout North Africa as far as Tunis.

The eggs, 2 in number, are placed on the bare ground, and resemble those of our Common Nightjar; on an arerage they are less boldly marked, and a trifle larger, as might be expected from the superior size of the bird. I am not aware of any distinctive points deserving of mention as regards the food and habits.

In general pattern of coloration the Red-necked Nightjar resembles the preceding species, but its tint is paler, and more rufous on the wings and under parts; a conspicuous tawny collar encircles the head, and the throat exhibits large white patches; tle white spots on the three outer primaries increase in size with the are of the bird, and are small and tinged with buff in the youns. They are found in both sexes, and I cannot perceive any difference in plumage between the male and female; the outer pairs of tail-feathers are broadly tipped with white. Length nearly 12 in. ; wing 7.8 in.

It has not been considered necessary to give an illustration of this species, as a wood-cut would fail to render its distinctive chara. ters. There are coloured illustrations of it in Gould's 'Birds of Great Britain,' and in Mr. Dresser's 'Birds of Europe.' 


\section{THE EGYPTIAN NIGHTJAR.}

\section{Capriaulgus ÆGÝPtius, Lichtenstein.}

On June 23 rd $\mathbf{I} 883$ a gamekeeper in the employ of Mr. J. Whitaker, of Rainworth Lodge, near Mansfield in Nottinghamshire, shot a Nightjar, the light colour of which attracted his attention; and on his mentioning the fact to his master who takes a special interest in albinisms and pale varieties, the bird, which had meanwhile undergone very rough treatment and then been thrown aside, was carefully inspected. When submitted to competent authorities it proved to be an example of the Egyptian or Isabelline Nightjar (Zool. I 883 , p. 374 ).

The occurrence of this south-eastern species in Europe is not unprecedented, Mr. Secbolnm having discovered in the shop of the principal bird-stuffer in Heligoland, a specimen (now in the collection of Mr. Giitle) shot on June 22 nd 1875 , which had been passed over as a pale variety of the Common Nightjar. Subsequently Professor Giglioli recognized three examples in the Museum of the University of Malta, obtained in 1876 ; and in Sicily a bird which was probably an Egyptian Nightjar was shot at Girgenti, while an undoubted specimen was obtained at Modica in 1879 . Its breeding-places are the sandy parts of Turkestan, Baluchistan, Egypt and Nubia ; its winter-quariers appear to be still further south.

The eggs, 2 in number as is usual in this family, are described by Von Heuglin as smaller, paler and more yellow in tint than those of our well-known species, and are placed in a mere depression in the sand or under a low, stunted bush. The old bird sits very closely and rises unwillingly, often running along with puffed-out throat from one bush to another, uttering meanwhile a curious note. Captain shelley found flocks in Egypt in spring and autumn, and it would appear that the sexes separate on migration.

The plumage of the adult is sandy-grey finely marked with black, the pattern being generally the same as in the Common Nightjar; there are, however, no white spots on the upper surface of the tail or wings, but the inside webs of the primaries are pure white. Length $10^{\circ} 5$ in. ; wing $8{ }^{\circ} \mathrm{i}$ in.

For the reasons mentioned on the preceding page, I have not considered it expedient to give a wood-cut of this species; it is well figured in Mr. Dresser's 'Birds of Europe,' vol. iv. pl. 262. 


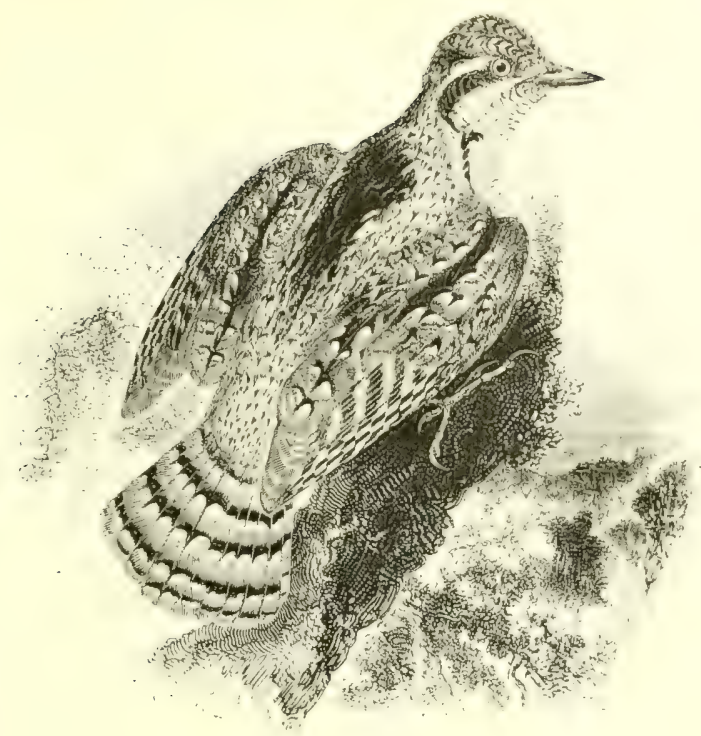

THE WRYNECK.

IŸNX TORquílLA, Linnæus.

This bird resembles the Nightjars in its delicately pencilled plumage, though allied to the Woodpeckers by its anatomical structure. It is a regular spring-visitor to England, sometimes arriving in the south by the middle of March, though usually about the first half of April; for this reason it is often called 'Cuckoo's-mate' or '-leader': names which have their equivalent in several Luropean languages. In the south-eastern counties it is more numerous than in the west, and it is rare in Wales; Lancashire has seldom been visited by it of late years, and to Cumberland it is now merely a straggler; in Yorkshire and Durham it is very local, and it becomes rare in Northumberland. Statements that it has nested in scotland require confirmation, but at intervals it has been known to wander as far north as Caithness, the Orkneys, and the Shetlands; also to the Færoes. In Ireland it was taken in co. Waterford in the summer of 1878 , and on the Arran Islands, off (alway Bay, on October 6th 1886 . By the latter part of September it has usually left England for the south, but Mr. A. H. L peher assurts that he saw and heard one in Norfolk on January Ist I 884.

In Scandinavia and Finland the Wryneck has been found up to 
about $64^{\circ} \mathrm{N}$. lat., and in Russia it visits Archangel; but across Siberia to Kamschatka its range does not extend so far north. In summer it inhabits the Japanese islands, as well as suitable localities on the mainland of Asia down to the Himalayas and the Altai Mountains; while in the cold season it visits India and Burma. In Africa its winter-quarters extend to Kordofan, but it appears probable that a limited number go no further than Algeria; some may even remain in the south of Europe, where, however, the bird is chiefly known on jassage; while in summer it is generally distributed over the rest of the Continent.

Unlike the Woodpeckers, the Wryneck does not excavate a nesting-place for itself, but about the middle of May it makes use of any convenient hole in a tree, at no great height; occasionally in an earth-cutting or sandbank. The eggs are usually from 7-10 in number, but the bird has been induced to go on laying, until in a case recorded by Mr. Frank Norgate, the maximum of $4^{2}$ was reached; they are pure white, rather larger, less glossy, and thinner in shell than those of the Lesser Spotted Woodpecker: average measurements 8 by 6 in. When disturbed, the sitting bird makes a loud hissing, calculated to induce the belief that a snake is concealed in the hole-a practice which has led to the popular name of 'Snake-bird'; it also erects the feathers of the head, twisting its neck about in a way which is equally characteristic of the above name, and when taken in the hand it will often feign death. Its loud note, which somewhat resembles that of a Kestrel, and may be syllabled as qui, qui, qui, or pay, pay, pay, is heard from the time of the bird's arrival until midsummer. The food consists almost entirely of insects-many of them obtained on the trunks and branches of trees-but chiefly of ants and their pupæ, which the bird seeks on the ground, shooting with marvellous velocity its long, retractile, vermiform tongue (covered with a glutinous secretion) into ant-hills; in autumn it is said to eat elder-berries. In its habits the Wryneck is skulking and unobtrusive; its flight is short and undulating.

The general colour of the upper parts is greyish-white, mottled with brownish-grey, and streaked on the nape, back and scapulars with brownish-biack; wing-feathers dark brown with buff bars on the outer webs; tail-feathers soft at the tips, greyish-brown barred with black; throat warm buff with narrow black bars; breast and flanks dull white with small spots and bars. Length 7 in.; wing $3+$ in. The female is rather smaller and duller in plumage than the male : the young are more strongly marked with blackish-brown on the under parts. 


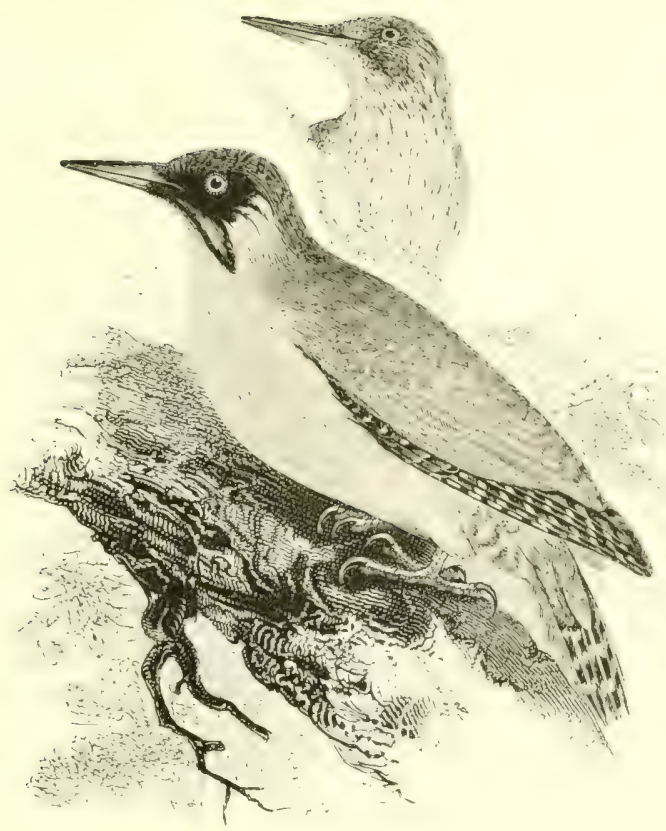

THE GREEN WOODPECKER.

\section{GÉCINUS víridis (Linnæus).}

This largest and best known of our British Woodpeckers occurs in most of the wooded districts of England as far as Derbyshire and the south of Yorkshire, north of which it becomes rare: and is only occasionally found breeding in I.)urham, Northumberland and Cumberland. Across the Solway it is said to have been killed in Kirkcudbrightshire, but other records from Scotland require confirmation. In Ireland-where all the Woodpeckers are uncommon-this species has only twice been obtained up to the present time. Even in England it is often unaccountably local; and while in some districts it has decreased of late years without any assignable reason, it has, on the other hand. recently become diffused in every direction alsout the land's-Bnd district in the extreme west of Comwall, without reference to tree or woodlands (Rodd).

In Norway the Green Woodpecker breeds in the forests up to about $63^{\circ} \mathrm{N}$. lat.; but in sweden and in the islands of the lialtic it does not range so far north; again in Rusia it is very rare aluout 
St. Petersburg, nor is it common in the forests of the central provinces, but this or a subspecies is abundant in the Caucasus. In Denmark it is scarce, and in Heligoland it has only once been taken; but southward it is generally distributed throughout the rest of Europe down to Turkey, as well as in Asia Minor and North Persia ; in Greece, however, it is very local ; in Sardinia and Corsica it is unknown; and in sicily it is rare, although common on the mainland of Italy. In the Pyrenees it is abundant, but in Portugal and the southern half of Spain-and probably throughout the whole of the Peninsula - the representative species is the grey-faced $G$. slarpii, which unites our bird to $G$. a'aillanti of North Africa (with no red on the moustache of the male), and, less closely, to $G$. camus of the Continent (the male of which has little red on the head, while the fernale has none).

Early in April a neat circular hole is hewn in a trunk or branch, generally of some tree whose wood, like that of the beech, is soft, though not necessarily decayed; the excavation running horizontally till the heart is reached, and then turning downwards for a short distance, when it is enlarged to form a suitable receptacle for the eggs, from $5-7$ in number. These are of a pure glossy white, slightly pyriform in shape: average measurements $I^{\prime} 3$ by $8 S$ in. The discarded chips of wood are rarely removed from the vicinity, and often serve to indicate the position of the nest; new holes being usually made every season, while those of former years are used as sleepingplaces. 'The note most frequently heard is the loud laughing pleu, pleu, pleu, popularly supposed to foretell rain, for which reason 'Rainbird' is a common name in some parts; as are 'Yaffle' and 'Woodweele.' In search of timber-haunting beetles, spiders and other insects, this Woodpecker may be seen climbing obliquely up some trunk or branch with short jerking movements, assisted by the stiff-pointed feathers of the tail, until, on arriving at the top, it passes with dipping flight to some other tree; it also feeds to a great extent on ants in summer, and on other ground-insects during the great part of the year, while it has been said to eat nuts and acorns.

The upper plumage of the male is chiefly olive-green, shading into yellow on the rump; under parts pale greyish-green ; crown, nape and moustaches crimson; lores and cheeks black. Length $\mathrm{I} 2$ in.; wing 6.4 in. The female has less crimson on the head, and the moustaches are black. In the young the under parts are barred; the nestling is mottled on the back and profusely spotted with arrowheaded markings on the under parts. 


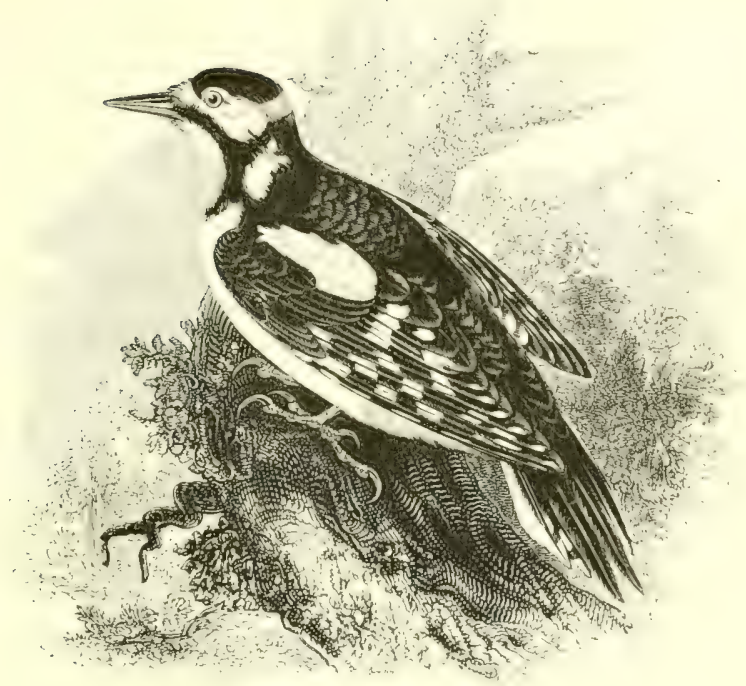

GREAT SPOTTED WOODPECKER.

DÉNDROCOPUS MAJOR (Linnæus).

The Great Spotted Woodpecker is often supposed to be rarer than it really is, in consequence of its retiring nature and its habit of confining itself to the higher branches of trees, but nowhere in the British Islands can it be considered abundant. It is, however, fairly distributed throughout the wooded portions of England, and though naturally rare in the treeless parts of Cornwall, and scarce in Wales, it is not unfrequent in many of the southern and midland counties. North of Yorkshire it becomes rare as a breeding species, and there is little evidence that it nests in scotland at the present day; but from the Shetlands southward, especially along the cast coast of Great Britain, it occurs irregularly on the autumn migration, sometimes in considerable numbers, as in I $86 \mathrm{I}, 1862$, I $\$ 68$ and r886. In Ireland it is not known to breed, but it has been obtained at long intervals; several were taken in the autumn of r $\$ S 6$ and one in February I 887 .

This Woodpecker has wandered to the Faroes, and is the only member of the family which regularly visits I Ieligoland in autumn; doubtless on its migration from sicandinavia, where it breeds as far north as the Arctic circle. In Russia it is common up to about 
$64^{\circ} \mathrm{N}$. lat.; and-subject to an increase in the extent or purity of white in its plumage which has given rise to the creation of several questionably valid species-it can be traced across Siberia to the Pacific and Japan. Between the Persian Gulf and the Mediterranean other forms are observed, which show in addition a tendency to develop a crimson band on the breast-a coloration which reaches its highest point in D. mumidicus of North Africa; but it should be mentioned that Continental and even British examples sometimes exhibit distinct signs of a red pectoral band. In the Canaries our northern form was obtained by Mr. Godman.

The nesting-hole, smaller than that made by the preceding species, is generally hacked out in a similar manner; but, according to good authorities, a natural cavity in a dead branch is sometimes prolonged and utilized, and several holes are often cut out before the bird is satisfied. The eggs, laid on the bare wood about the middle of Nay, are 6-7 in number, creamy-white in colour, and in shape rather less pyriform than those of the Green Woodpecker: average measurements 98 by 75 in. Incubation, in which both parents take part, lasts about a fortnight. In captivity it has been noticed that this bird descends by a series of jerks with the tail downwards, but the mode of progression usually observed in the wild state is diagonally or spirally upwards. The food consists of insects and their larra, but in autumn the berries of the mountainash, nuts, acorns \&c. are eaten. The note is a sharp tchick, and sometimes a low, reiterated $t r a$, but the male often makes a loud vibrating noise by rapidly hammering with his bill on the bark of a tree.

In the male the general plumage of the upper parts is black; the forehead dull white; cheeks and ear-coverts white; nape crimson; scapulars white; wing-feathers barred with white on the outer webs; under parts dull white; vent crimson. Length $9^{\circ}+$ in.; wing $5^{\circ} 5$ in. The female is slightly smaller and has no red on the head. The young of both sexes have the croin of the head red, and ignorance of this fact has led to the supposition that the Middle-spotted Woodpecker, D. medius, had occurred in the British Islands.

A bird, supposed to be a specimen of the White-backed Woodpecker, D. leuconotus, was obtained in the Shetlands during the migration of I86I, and figured by Gould; but Professor Newton and other authorities have pronounced it to be merely a slightly albescent Great Spotted Woodpecker. An example of the American Hairy Woodpecker, D. aillosus, is said to have been obtained in Yorkshire more than a century ago, and another in 1849 . 


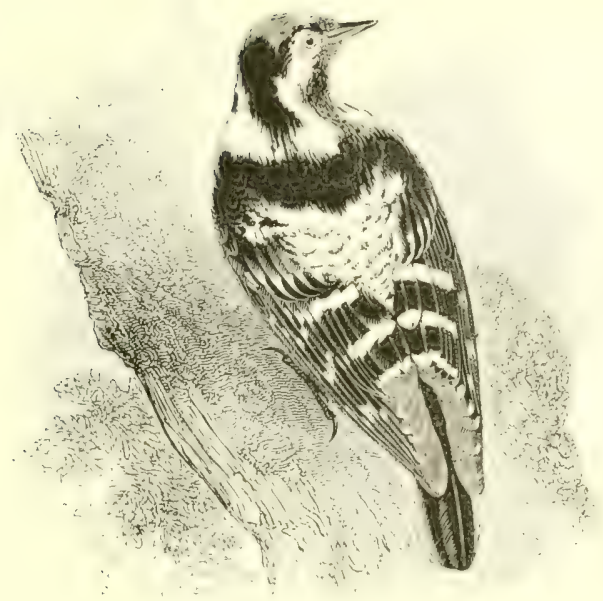

THE LESSER SPOT'TED WOODPECKER.

DÉNDROCOPUS MINCR (Linnæus).

Owing to its small size and its partiality to tall trees, such as elms and poplars, this little Noodpecker frequently escapes observation; but, though less widely distributed than the preceding species, it is the more numerous of the two in many parts of the southern half of England, being, in fact, rather common near London and along the valley of the Thames, as well as in the westerm midlands. In Jorkshire it becomes scarce and very local, while in Lancashire and the northern counties it is extremely rare. In the Solway district Mr. Service informs me that three examples have been obtained, at long intervals, since $\mathrm{I} \$ 60$, but in the rest of Scotland it is almost unknown. In Ireland only six or seven instaices are on record; none of them recent.

In Scandinavia the I.esser Spotted Woodpecker breeds as far north as lat. $70^{\circ}$, while in Russia it is found up to Archangel and to lat. $67^{\prime}$ in the valleys of the Petchora and the ()b; though eastwird, to the Pacific, its northerly range is rather less extensive. Forms which vary slightly from the type are found in Kamschatka, Japian, and Northern China, but their southern limits in Isia are as yet unclefined; while in Asia Minor another occurs, and yet another in . Nereria. Throughout the greater part of Europe our race is generally distributed, but though common in siouthern Kussia and lurkey, yet 
in other parts of the south it is either comparatively rare or has been overlooked. There also it is to a considerable extent a migrant, but in the Azores, strange to say, it is a resident species.

The nest-hole is often made in the highest branches of poplars and other tall trees, but sometimes at very moderate elevations in oaks, chestnut- and fruit-trees, or even in pollard willows. The eggs, laid about the middle of May, and usually $6-7$ in number, resemble those of the Wryneck; but their texture is more ivory-like, and their colour more creamy-white, while in size they are slightly smaller: average measurements 75 by 57 in. The food consists almost entirely of timber-haunting insects. The usual note is an often repeated kiek, but the male further produces a vibrating noise like that made by the preceding species. In its flight and general habits this bird hardly differs from its congener, except perhaps in its extreme restlessness.

The adult male has the forehead buff; crown of the head pale crimson; nape and moustache black; cheeks white; upper parts black broadly barred with white; central tail-feathers black, the rest black barred with white; under parts buffish-white, with black streaks on the flanks. Length about 5.5 in. ; wing 3.75 in. In the female the crown is whitish instead of crimson, and the under parts are more striated. The young male has a crimson crown as in the adult, but it is said that in the female only the fore part of the head is red, and the black and white chequerings of the back are less pure.

The Rev. O. Pickard-Cambridge has a specimen of the North American Downy Woodpecker, $D$. pulescens, supposed to be a bird which he shot at Bloxworth in Dorset, in December 1836 ; and an example of this species has also been killed near Elbeuf, in Normandy ; American 'Spotted Woodpeckers' are, however, known to have been brought to Europe and turned loose more than a century ago ( $C f$. Yarrell, th Ed., ii. 1. $4 S_{5}$ ). An American Golden-winged Woodpecker, Colaptes auratus, is said to have been shot at Amesbury, Wilts, in $\mathrm{I}_{3} 6$. As regards the Black Woodpecker, Picus martius, Mr. J. H. Gurney jun. and Professor Newton have, I think, conclusively shown that, in spite of its numerous recorded occurrences in the British Islands, there is not one sufficiently authenticated to justify insertion. Donovan's statement in $\mathbf{I} 809$, that an example of the Three-toed Woodpecker, Picö̈les tridactylus, had lately been shot in the North of Scotland is unsubstantiated. 


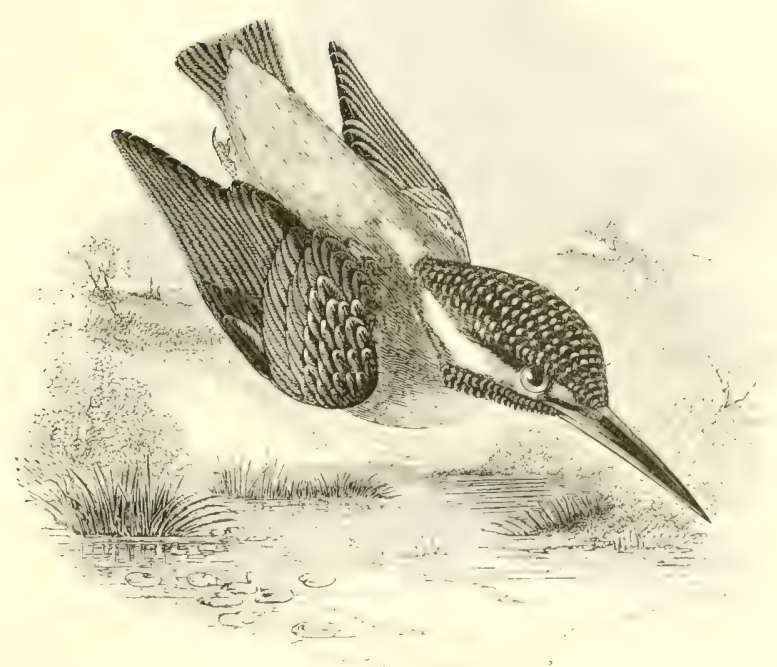

THE KINGFISHER.

Alcédo Íspida, Linnæus.

The Kingfisher is resident and generally distributed throughout Great Britain as far north as Sutherland, to which it is only a rare visitor; it also occurs casually as far west as Skye. In Ireland, according to Mr. More, it is found throughout the year, but chiefly: in the lowland districts. In few places can it be considered an abundant species; mainly owing to the fact that it is often shot on account of its bright plumage, but partly to the value of its feathers for dressing artificial flies. The banks of lakes, ponds, and streams of all sizes-provided the current be not too rapicl--or even the seashore, especially on a rocky coast, are its usual haunts; and there it may frequently be seen darting in a straight line crer the water, or sitting patiently on some convenient ierch, where it waits the opportunity for the sudden plunge by which it secures its prey.

Even in the southern portion of Scandinavia the Kingfisher is of accidental occurrence, though known to have nested there on one occasion; and to Denmark it is merely a visitor, while in Russia it is rarely found as far north as St. Petersburg. In Northern (iermany - where, from its habit of congregating on the ice round any open water, it is known by the name of 'Eisrogel'-it is uncommon ; but 
southward we find it in suitable localities throughout Europe down to the Mediterranean. It occurs in the Canaries and Madeira; in Morocco and Algeria it is said to breed; and it inhabits Egypt during the winter. Further east, variations from the type are noticed: examples from between Asia Minor and South-western Siberia have been named $A$. pallasi, while those from further south, as far as the Malay Archipelago, have been called A. hingalcnsis; but the differences are very trifling.

For the nesting-place a hole in a bank is either bored or selected; generally near water, but sometimes in a dry sand-pit, and occasionally in some crevice in a wall. It usually slopes upward from the entrance, and at the end, upon the bare earth or upon a layer of small fish borres, the roundish glossy-white eggs, $6-\$$ but sometimes I $\mathrm{O}$ in number, are deposited: average measurements 9 by 75 in. The young are known to have been out of the nest by March i Ith, and they have been found inside as late as July 24 th, so that two broods are probably produced in some seasons. The food consists of small crustaceans, insects such as dragon-flies and water-beetles, minnows, sticklebacks, and the small fry of other fishes; the quantity consumed being extraordinary. In autumn the young are driven by the parents from the nesting-place and become partially migratory. The note is a shrill tit, tit, tit, somewhat like that of the Common Sandpiper. The legends and superstitions relating to this bird are too numerous for mention here.

The adult male has the moustache, head and wings dark greenishblue, slightly mottled; lores and ear-coverts chestnut; back azureblue; tail dark blue; throat white; under parts chestnut ; bill black, orange at the base; feet reddish-brown. Length 7.5 ; wing 3 in. The female is slightly greener and duller; the young bird further differs in having a wholly black bill.

Two examples of the North-American Belted Kingfisher, Ceryle alcyon, are, respectively, in the Museum of Science and Art, and in Trinity College, Dublin. One of these is said to have been shot in co. Meath on October 26 th I $S_{45}$, and the other in co. Wicklow the following November. No other instance of the occurrence of this species in Europe is known, nor has it been obtained in Greenland or Iceland; it seems, therefore, inexpedient to admit to the British list an American bird which-assuming the accuracy of the records - had probably escaped from confinement. 


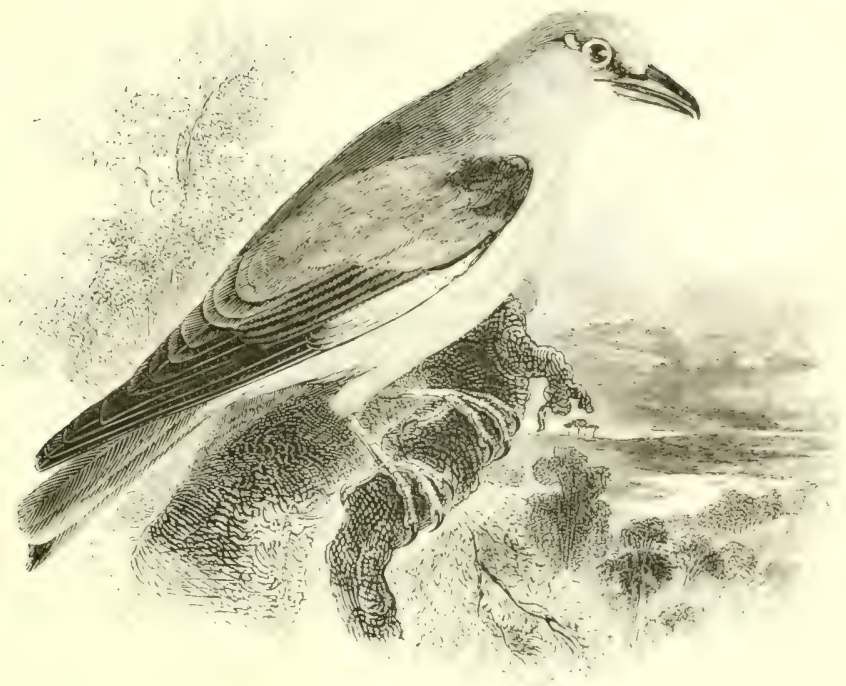

THE ROLLER.

CorÁcias gárrulus, Linnæus.

This bright-plumaged bird was first recorded as a visitor to our islands by Sir Thomas Browne, who described a specimen obtained in Norfolk in May I644. Since then, upwards of a hundred examples have been noticed, chiefly on the southern and eastern coasts of England and Scotland; however, some have visited the Orkneys and Shetlands, while on the west one has even reached St. Kilda. In Ireland there have been five or six occurrences, at long intervals. The majority of its appearances in the British Islands have been in the autumn, but a fair proportion during the spring migration.

To the Færoes and the north of Norway the Roller is only a straggler, and it is scarce in any part of the latter country; but in Sweden it breeds annually up to about $6 \mathrm{I}^{\circ} \mathrm{N}$. lat., and in Russia. sparingly, as far north as St. Petersburg. In Northern Germany it is not uncommon in summer, though rare in l)enmark, Holland, Belgium and Northern France; in Central Furope it is tolerably abundant; while in Spain and other countries bordering the Mediterranean it is very numerous, arriving in the Peninsula from the middle of March onwards, and leaving by November at the latest. Eastward, it is plentiful in Turkey, southern Russia, 
Asia Minor, Palestine, Persia, and temperate Asia generally, as far north as Omsk in Siberia. Southward, we find it in Cashmere and North-western India, where it meets with the closely-allied $C$. indicus, the breast of which is vinous-purple instead of blue. In the north of Africa it is common in summer, but eren there it does not pass the winter; nor does it breed in Egypt, which it traverses on its way to and from South Africa. During the cold season it inhabits the lower half of that continent down to Cape Colony and Natal.

In wooded districts the nesting-place selected is some hollow in a tree, but quite as often in the wall of a ruined fortress, or in a high bank; in the two latter a bedding of roots, grass, feathers and hair is accumulated, but in trees the bare wood or at most a few chips suffice. The eggs, often globular, but sometimes elongated, are glossy white and usually $5^{-6}$ in number: average measurements $I^{\circ}+$ by $I^{*} I$ in. Incubation lasts nearly three weeks, commencing early or late in May, according to the country. During the breeding-season the male indulges in some extraordinary tumbling antics, turning somersaults in the air, and uttering a harsh cry which the Germans syllable as 'Racker-racker' and the Spaniards as 'Carlanco-carlanco'; at other times the bird is merely restless, flying from branch to branch with flapping, uncertain flight; like the Bee-eater, it may frequently be seen sitting on telegraph-wires. The food consists of beetles and other insects captured on the ground. On migration the Roller is observed in large flocks.

The adult has the head and nape greenish-blue; mantle chestnutbrown; upper wing-coverts dark blue; greater wing-coverts and bases of primaries light blue, quills black; tail-feathers dark blue at the bases and in the middle, and pale blue on the lower portions; chin white; under parts light blue; bill dark horn-colour; legs and feet yellowish-brown. Length $\mathrm{I} 2 \mathrm{in}$; wing $7.8 \mathrm{in}$. The sexes are alike in plumage; the young bird is much more dingy and less pronounced in colour.

The late Dr. Bree has stated that a male of the Abyssinian Roller, C. leucociphalus, was killed near Glasgow about $\mathrm{I} 8_{57}$, and a female later, some forty miles off; the former was preserved by Mr. Small of Edinburgh, and is said to be in the Paisley Museum. The story is given, like many others, for what it is worth. 


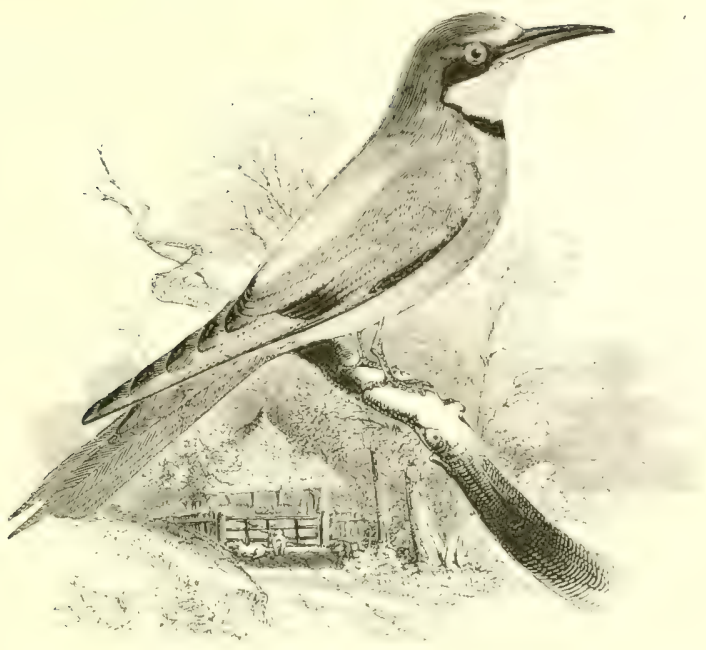

THF, BEE-EATER.

\section{MÉrops APIÁSTER, Linnæus.}

The first British-killed Bee-eater on record was obtained in Norfolk in June 1793 , and since that time orer thirty examples have been noticed south of Derbyshire in England, and Pembrokeshire in Wales--chiefly on the spring migration. Further north its visits have been very rare; Mr. IV. E. Clarke mentions a bird picked up exhausted near Filey in Yorkshire on June 9th ISSc; and in Scotland one was captured in October $1_{832}$ near the Mull of Galloway, while two or three are said to have been taken in the north-east of the country. In Ireland it has occurred five or six times, chiefly in the south.

On the Continent its northerly range is not, as a rule, so extensive as that of the Roller; and although it has been known to push its excursions to Muonioniska, within the Arctic circle, yut its visits to Sweden, Denmark, and Northern Crermany, are few and irregular, and on Heligoland it has only once been obtained. It is said to have bred in Central and Southern Germany, and near Abterille in the north of France, while it nests not unfrequently in Iansuedos: and Provence; but north of the Alps and the Carpathians, and of about lat. $55^{\circ}$ in Russia, it only does so exceptionally. In touthern Russia, Turkey, Creece, along the ralley of the 1)anuhe, and in Southern Italy, the Bee-eater is abundant; and in the spunish 
Peninsula it swarms from the beginning of April until the latter part of August. It visits the Canaries and Madeira, and is common throughout the basin of the Mediterranean and in North Africa, while in winter it is found as far south as Cape Colony. In Egypt, though it is abundant on migration, comparatively few remain to breed, the representative species being the Blue-cheeked Bee-eater, $M I$. persicus. Eastward it ranges to North-western India during the cold season, and through Turkestan to the Altai Mountains in summer.

The Bee-eater generally breeds in colonies, like the Sand-Martin, and banks by the side of rivers or dried-up watercourses may be seen honeycombed with its excavations, commenced soon after arrival; the bill of the bird being sometimes worn down by the operation. In the great plains below seville holes are often bored diagonally or even vertically in the ground; and as the shafts vary from three or four to eight or nine feet in depth, the eggs, placed in a small chamber at the end, are not obtained without labour. These, generally $5^{-6}$ in number, are laid upon the bare earth, though afterwards surrounded by castings and the wing-cases \&c. of coleopterous insects: they are fure glossy white, nearly globular in shape: average measurements $\mathrm{I}$ in. by 9 in. Though sometimes found by the end of April, the middle of May is the usual time, and only one brood appears to be reared in the season. Sacksfull of birds are taken in Spain by spreading a net over the face of an occuppied bank and pouring water into a parallel trench cut at some distance back; for the Bee-eater is hated by the peasants, owing to the ravages inflicted upon their numerous hives, although it also destroys large numbers of wasps, locusts, grasshoppers, beetles and other insects. The flight is light and undulating; the note is a sharp quilp.

The adult male has the lores and ear-coverts black; forehead white followed by a pale green band; head, neck, upper back, and a broad bar on the secondaries, chestnut-brown; remaining wing-feathers chiefly bluish-green; lower hack tawny-yellow; tail green, the two elongated central feathers tipped with black; throat bright yellow followed by a black band; under parts greenish-blue; bill black: feet reddish-brown. Length $10 \mathrm{in}$; wing 6 in. The female is greener on the back, duller in colour, and has the central tail-feathers shorter. In the young the latter scarcely project; the upper parts are greenish-brown, and there is no black gorget.

An identified adult example of the Blue-tailed Bee-eater, $M$. thilitfinus, is said to have been shot near Seaton Carew, Northumberland, in August I 862 . 


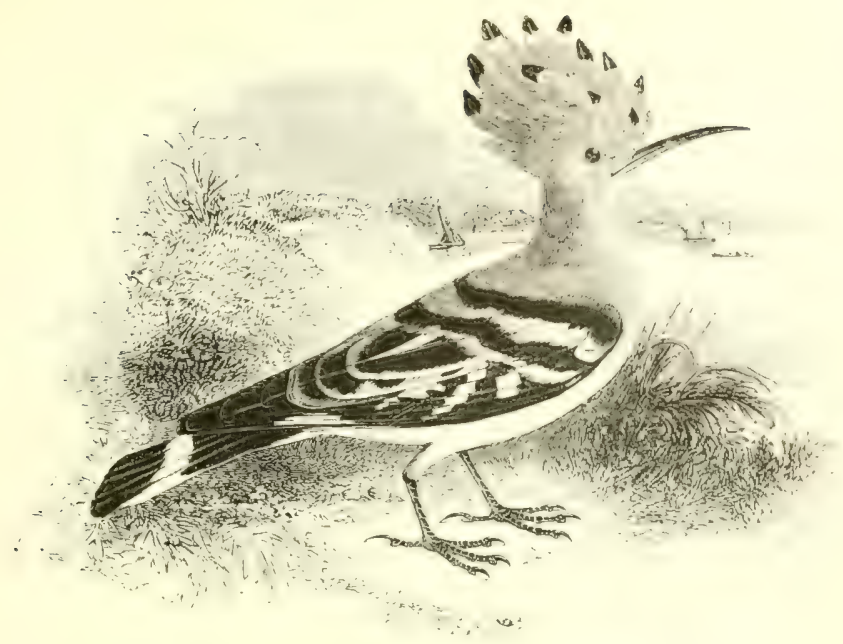

THE HOOPOE.

UP'́PA ÉPOPS, Linnæus.

The Hoopoe has been noticed for more than two centuries as a visitor to Great Britain, and in spring it arrives so frequently on our southern and eastern coasts that if unmolested it would soon become one of our regular breeding species. The appearance of this tame and conspicuous bird is, however, the signal for its persecution unto death, and some years ago the head-keeper at Ashburnham Park, in Sussex, destroyed no fewer than seven in one week, while I am afraid to say how many have been slain near a certain spot in Kent where they alight after crossing the: Channel. In spite of their inhospitabie reception a few pairs manage to escape, and have bred from time to time in I)evon, I) rset, Wilt., Hants, Surrey, Sussex, Kent, and probably in some other countics. The bird also visits us in autumn-sometimes in toicralle numbers on the east coast after gales---and even in winter: while as a wanderer it has been found in most of the counties of lingland, though seldom in the north. In scotland it has occurred irrexularly ass far as Sutherland and Caithness: also in the ()rkneys, Shetlands, and Outer Hebrides. 'To Ireland it is an almost annual visitor in small numbers, principally to the southern portion.

Accidentally the Hoopoe has been taken in the Furues, Spitsher gen, and the north of Norway and Russia: while in the south of 
Sweden and in Denmark it breeds sparingly, though in the latter its numbers have diminished owing to the eradication of the old hollow trees in the forests. Southward it is generally distributed throughout Europe, wherever there are swampy wonds and timber-fringed meadows suitable to its habits: while in the countries bordering the Mediterranean and Black Seas it is abundant and almost ubiquitous, being especially numerous at the periods of migration. It is found in the Azores and Madeira, and is common in the Canaries (where some are resident), Northern Africa, Egypt, Nubia, and eastward throughout the greater part of Asia to China and Japan; its most southern winter-quarters being, as far as is known, in Abyssinia and Senegal.

A hole in the decared wood of some hollow tree-frequently a willow or ash-is usually selected; and the slight materials of which the nest is composed are generally surrounded or cemented by ordure of some kind. causing an intolerable stench, which is subsequently increased by the droppings of the female and of the young. Sometimes a crevice in a wall or rock is made use of; in China holes in exposed coffins are occupied; and Pallas found a nest in the chest of a rotting corpse loosely covered with stones. The eggs, $t_{-7} \rightarrow$ in number, are pale greenish-blue when first laid, but later they become greenish-olive: arerage measurements $\mathrm{I}$ in. by 7 in. The food consists of worms, insects and their larvæ-especially those which are found in dung-and flies, which are taken on the wing. The morements of the Hooploe are graceful, particularly at the time of courtship, when the bird struts about with crest erect, uttering a note resembling a soft lin-l"n (whence the Spanish term "abubilla") or hoof-hoop, to which, and not to the crest, it owes its English and French names. The flight is undulating.

The general plumage of the adult is pale cinnamon on the head, shoulders and under parts; the long, erectile crest-feathers richer in tint and tipped with black: wing-feathers black, broadly barred with white, and striped with buff on the inner secondaries; lower back barred with black, white and buff; tail black, with a broad white bar across the centre, and descending. towards the tips on the outer pair of feathers: the long, slightly decurved bill is black, flesh-coloured at the base ; feet dusky-brown. Length from base of bill nearly ro in.; wing 6 in The female is rather smaller, duller in plumage, and has less crest. The young bird has a shorter bill, and the colours are not so rich. 


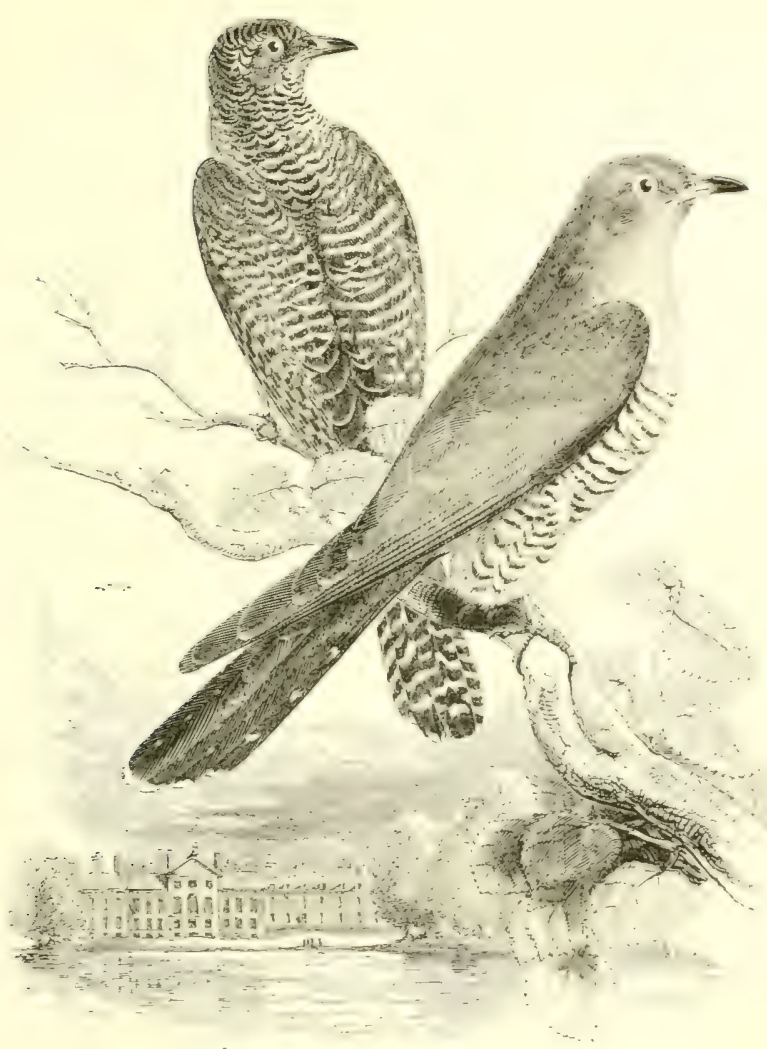

THE CUCKOO.

Cúculus CaNóRUs, Linnæus.

The male Cuckoo, which precedes the female by a few days, seldom arrives even in the south of England befure April Gth, and immediately announces his presence by the well-known alki-re note, often uttered at night as well as by day. In June, according to the familiar adage, he "changes his tune," and becomes hoarse, while by August most of the old birds have taken their departure, though the young sometimes remain until Octolur. In summer the Cuckow is found throughout the Lnited Kingdom, inclusive of the outlying islands; and, though only an accidental visitur to the Fieroes, it ranges almost to the North Cape in Norway; nearly as far in Russia; and across Northern Asia-except on the siberian tundras -to the Pacific. Over Europe it is generally distributed, thoush 
comparatively few remain to breed in the countries bordering the Mediterranean, or in Northern Africa; while to the Canaries and Madeira it is only an irregular visitor. In Asia its southern breeding limits appear to be in the Himalayas; but in winter it goes down to the Philippines, Celebes, Burma and Ceylon: and in Africa to Natal. Closely-allied species occur in both the above continents.

The female, which resorts to the same locality year after year, deposits her egg on the ground, and then conveys it in her bill to the nest of some bird destined to act as foster-parent. In this country the latter is generally the Meadow-Pipit, Pied Wagtail, Hedge-Spar row or Reed-Warbler, and less frequently the Yellow- and Cirl-Buntings; with many others, especially on the Continent. An interesting list of these has been compiled by Mr. Bidwell (Tr. Norw. Soc. iii. pp. 526-53I). The egg, which arerages about 85 by 75 in.. varies considerably, and, though usually of a greenish- or reddishgrey with darker cloudings and spots, sometimes, but not always, resembles the eygs of the foster-bird. For instance, Cuckoo's eggs placed in the nest of the Orphean Warbler are chiefly distinguishable by their size (suprit. p. 46 ) ; while eggs of a pale blue have been found, though not invariably located in nests of the Hedge-Sparrow or the Redstart. From 5-S are produced by the female in the season; the same bird sometimes depositing two, and even three eggs in a nest. When the young Cuckoo is nine or ten days old, it ejects the other nestlings by the aid of a cavity in its back which fills up after the twelfth day: and, where there are two Cuckoos in the same nest the struggle for existence is sometimes severe. The food consists of insects and their larve, especially hairy caterpillars; the indigestible portions being thrown up in pellets. The female utters a water-bubbling or whistling note. The superficial resemblance of the Cuckoo to a Hawk undoubtedly proves deceptive to other birds; also to ignorant peasants and gamekeepers, who frequently assert that "Cuckoos turn to Hawks in winter."

The adults of both sexes are greyish-ash above and on the throat, with small white spots on the darker grey tail, and dusky bars on the white under parts; irides, legs and feet yellow. Length $\mathrm{I} 2$ in. ; wing 8.5 in. The female sometimes shows a slight rufous tinge on the breast. The young are clove-brown on the upper parts; there is a white spot on the nape, and the irides are brown. Birds of both sexes are sometimes found in spring of a rich chestnut-brown, like a female Kestrel, and this form has been distinguished as $C$. hepaticus. 


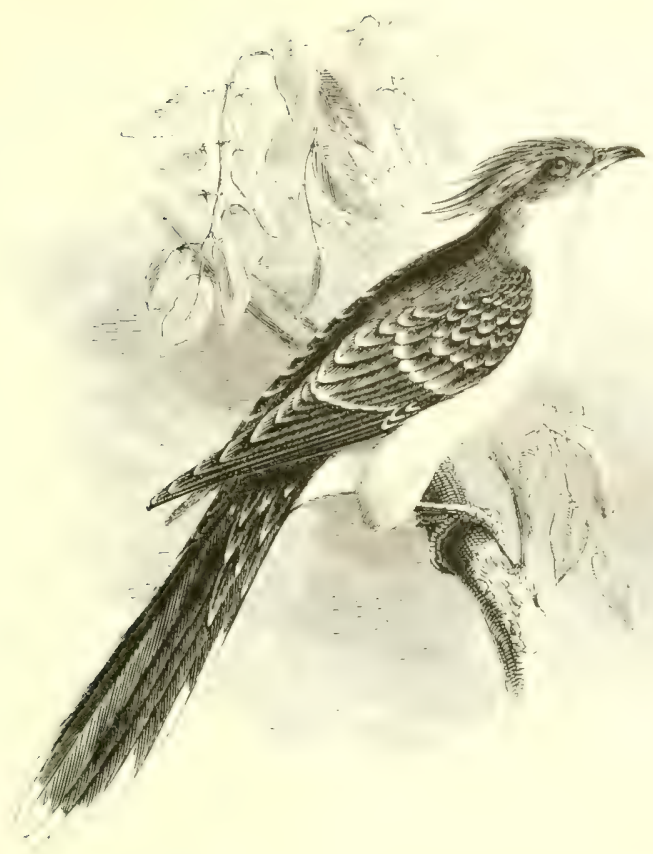

'THE GREAT SPOTTED CUCKOO.

Coccústes (gllandárius (Linnæus).

An example of this southern species was captured alive in a fatigued and emaciated condition on the island of ()mey (crroneously printed (Omagh), off the coast of Connemara, jrobably in March 1842. It was subsequently obtained for the Museum of Trinity College, I)ublin, where it still remains, although said to have perished; and, on examining it a short time ago, I found that it was in immature plumage. Another, shot near licllinsham, Northumberland, on August 5 th 1870 , is now in the Newcastle Museum.

As a wanderer the Great Spotted Cuckoo has occurred in Northern Germany, Southern France, and Northern Italy, while in the south and in Sicily it is tolerably frequent on passage, though rare in Malta, and unrecorded from Sardinia or Corsica. In . Indalucia I found it had arrived by March and, and it is common throughout the summer in the Spanish Peninsula as far north as the vicinity of Madrid, wherever there are woods suited to the habiti of the Magpie, in the nests of which this Cuckoo deposits its eggs. It is not known to breed in any other part of lurope, 
though it visits Greece and Southern Russia; in Asia Minor, Palestine, and Northern Persia, however, it occurs on migration and in summer. It is common and resident in Egypt and Nubia, and breeds throughout the wooded districts of Northern Africa, occasionally wandering to the Canaries; while in the cold season it goes as far south as Damara-land and Kaffraria.

In Spain, as already mentioned, it generally selects the Magpie as foster-parent, and I have found as many as four of its eggs, with six of those of that bird, in the same nest; occasionally a Raven's or Blue-winged Magpie's is made use of. In Egypt the Hooded Crow's is chosen, and in Algeria the Moorish Magpie's. The Cuckoo takes the egg in her bill, and after placing it in the nest, often ejects an egg of the foster-parent to make room for her own. So common is the bird at Aranjuez that my man and I took forty-four eggs in the course of two mornings, but we climbed to at least two hundred Magpies' nests. The egg is pale green, streaked and spotted with russet and dull lilac, sometimes closely resembling that of the IIagpie, but of a much firmer and smoother texture : average measurements $I^{\circ} 2$ by 96 in. A female shot on April 6th had a well-formed egg in her oviduct, but early in May is the usual time for laying. The food consists of insects. The note of the male is a harsh kark-kark; that of the female burroo-burroo. Col. Irby gives August 7 th as the latest date for Spain.

The adults of both sexes have the crown grey with a long-pointed crest; upper parts greyish-brown with white tips to most of the feathers; tail-feathers, except the central ones, largely tipped with white; neck buffish-white; under parts dull white. Length 15 in. ; wing $S$ in. The young bird is much handsomer, having a nearly black head and nape, buff neck and breast, and the upper parts of the primaries chestnut.

An example of the American Yellow-billed Cuckoo, Coccyzus americamls, was shot in co. Cork in the autumn of 1825 ; another near Dublin in $\mathrm{I}_{32}$; a third in Pembrokeshire, also in the autumn of 1832 ; and a fourth near Aberystwith in October I870. On the Continent, one was obtained in Belgium in October 1874 , and another near Turin in $188_{3}$. Admitting that all these have occurred at the time of migration, I cannot believe that they have crossed the Atlantic without human assistance; and the same remark applies to the American Black-billed Cuckoo, C. erythropthalmus, a specimen of which was shot near Belfast about September $25^{\text {th }} 187$ I while in Italy one was killed near Lucca in 1858 . 


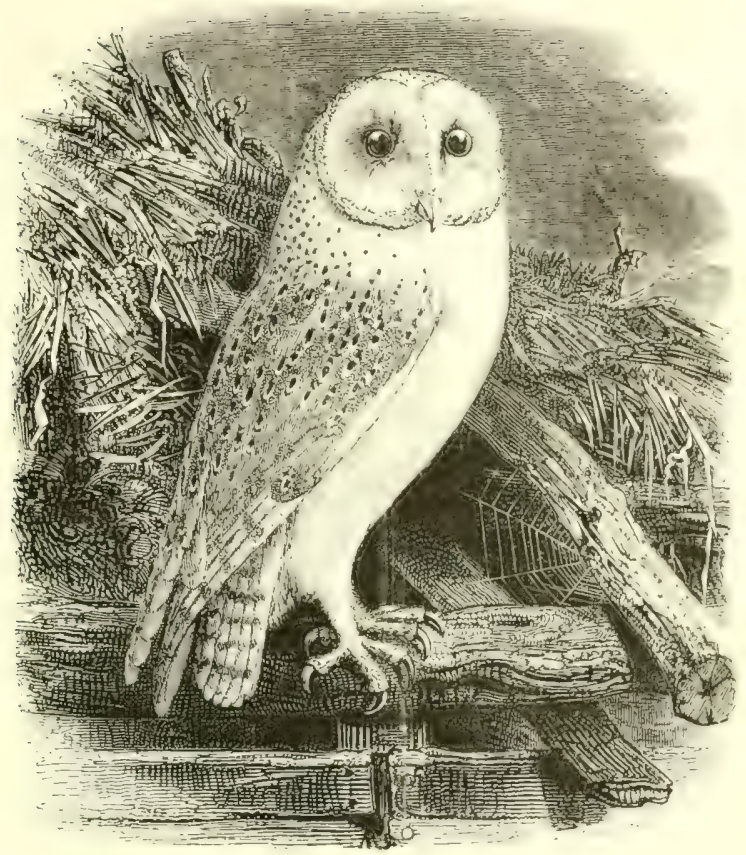

\section{THE BARN-OWL.}

STRIX FLÁNMEA, Lirnæus.

This species, often known as the White or Church-Owl, is generally distributed throughout England, Wales and Ireland; it would even be common but for the persecution it suffers from gamekeepers and ignorant farmers, as well as from dealers in plumes for ladies' hats, fire-screens dic. In Scotland it is not often found beyond the lowlands, though it breeds in small numbers as far north as Caithness, and in the Inner Hebrides, including sive; in the Orkneys it is now almost unknown, though it has recently occurred in the Shetlands.

On the Continent the Barn-Owl has a more restricted range northward, and is not known to nest beyond the suuth of sweden. to which it has recently spread from Denmark, where the bird is tolerably common. It is resident in Courland and not scarce in Poland, while in Central Russia it is found sprangly as far east as Toula and Orel, becoming abundant in the southern provinces of Podolia and Bessarabia. In Austro-Hungary and the sereater part 
of Crermany it is fairly numerous, though somewhat local in its distribution; and throughout Western Europe it is a well-known species. It is found in the Azores, Madeira, the Canaries, and the Cape Verd Islands, also in Northern Africa to Egypt, and in Palestine; in the north-eastern portion of the Mediterranean basin, however, it is seldom met with, although occurring in Mesopotamia and down to the head of the Persian Gilf. Over the above-mentioned area both light and dark phases are found; and, making allowance for climatic varieties which Mr. R. B. Sharpe and other authorities do not consider entitled to specific distinction, this Owl may be described as ranging over the African region inclusive of Madagascar, the Indian, Malayasian, Australian and Polynesian regions, and throughout America and its islands from about $40^{\circ} \mathrm{N}$. lat. to $40^{\circ} \mathrm{S}$. lat.

The Barn-Owl takes up its abode in church-towers and belfries, farm- and other buildings, hollow trees, dovecotes, and clefts in walls or cliffs. It makes no nest, though its castings may be found round the eggs, sometimes laid in pairs ; six, nearly fresh, have been found alongside of three nestlings, while two or three distinct stages of the latter are not unknown. Incubation, which occasionally begins about the end of April, but usually in May, has been known to take place up to November and December. The eggs are dull white: average measurements $\mathrm{I} \cdot 6$ by $\mathrm{I} \cdot 2$ in. There is no evidence that this species does any harm to eggs or pigeons in the dovecotes which it often inhabits, and it feeds chiefly on field-mice, thereby entitling itself to protection on the part of the agriculturist; it also eats rats, shrews, bats, small birds, insects, and occasionally small surface-frequenting fish. I) uring the daytime the Barn-Owl generally remains concealed, though when disturbed I have seen it flitting in no uncertain manner in the brilliant sunshine of the south; but it seeks its food in the dusk of evening and at nights. Its cry is a loud weird shriek, and a snoring sound is emitted by young and old.

In the adult male the upper parts are orange-buff, ninutely variegated with brown, grey and white; facial disk white with a brownish rim ; under parts white. In the dark form the upper parts are grey, with darker spots and vermiculations; the facial disk is tinged with orange, and the rim is blackish; the under parts are warm orange-buff with clearly-defined blackish-grey spots. Bill white; operculum (or skin which covers the orifice of the ear) large;

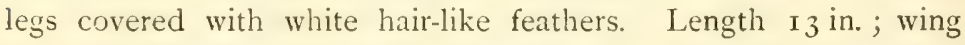
$1 \mathrm{I} \cdot 2$ in. The female is slightly larger than the male. The young bird, at first covered with white down, hardly differs from the adult in its feathered plumage. 


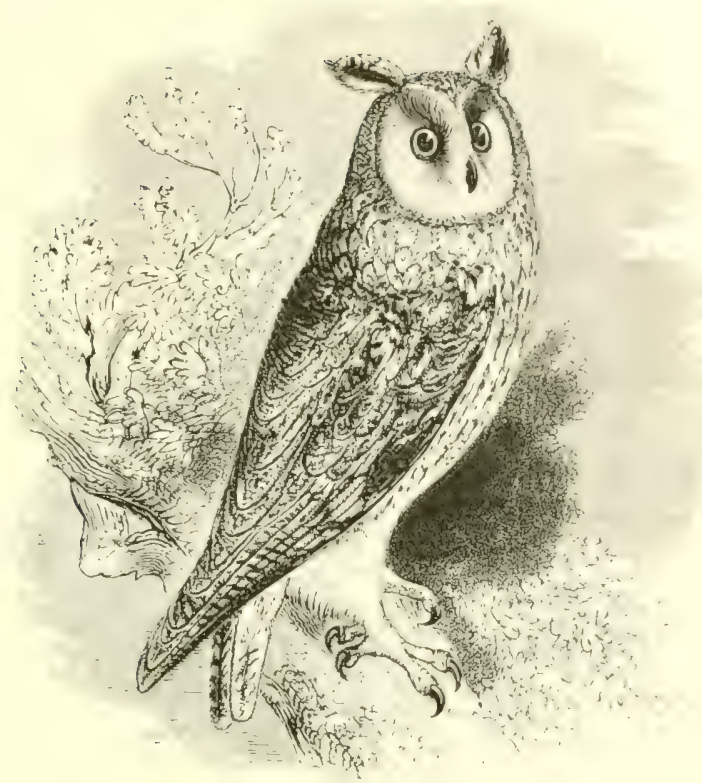

THE IONG-EARED OWL.

Asio ótus (Linnæus).

The Long-eared Owl is more abundant than is generally supposed, and in the wooded districts of Cireat liritain - cspucially in fir-plantations-this handsome bird is found throughout the year: its numbers being increased in autumn by considerable micrations from the Continent. Where suitable cover is available it breeds in the Hebrides, and it has vinited the (irkneys, Shetlands and livroes, though there the conditions are not favouratile for a joulunged stay: In Ireland it is common and resident.

To Iceland this Owl has strayed on one occasion; and it is found breeding in Scandinavia and Russia as far as $63^{\circ} \mathrm{N}$. lat., though rare and local at the northern extremity of its rance. suth of $59^{\circ}$ in the Ural Mountains, it is more or less numerous down to the northern slopes of the Caucasus; while westward, we find it generally distributed throughout the woullands of limuge. In the south it is more abundant in winter than in summer, and the birds which breed in sioain and Italy semerally ascend to the 
wooded mountains. Mr. Godman obtained a nestling in the Azores; it occurs in Madeira; in the Canaries it nests in the palm-trees of the warm valleys as well as in the mountain forests; and it is found in North Africa from Morocco to Egypt. Eastward it has been recorded from Arabia; and it inhabits the temperate portions of Asia north of the Himalayas as far as the Pacific and the Japanese Islands. In North America it is represented by a subspecies, A. wilsonianus of Lesson, which has darker upper parts and more closely barred under parts.

The Long-eared Owl deposits its eggs in an old squirrel's drey, or on the last year's nest of a Ring-Dove, Magpie, Crow, Rook, Heron, and, on the Continent, of a Buzzard, Kite \&rc; a little lining of small thin sticks and rabbit's fur being often added. It lays very early in the season, and even in Northumberland clutches of eggs have been taken by February 22nd. These, 4-6 in number, are white, with a rather smooth but not glossy surface: average measurements $\mathrm{I}^{\circ} \mathrm{C}$ by $\mathrm{I}$ ' 3 in. Several pairs may be found in close proximity, and I knew of eight broods being destroyed in a long fir-plantation which stretches along a commanding ridge in surrey, by orders of an ignorant plutccrat who hoped that by exterminating every bird of prey he would ensure the biggest head of game ever known in the neighbourhood: in which he was signally disappointed. This Owl is almost entirely nocturnal or crepuscular in its habits, and during the daytime it is seldom to be found in the open fields, except at the time of migration. The pellets which I have examined show that it feeds principally upon field-mice, rats, and birds up to the size of a Blackbird, while it is said that beetles and other insects are sometimes eaten. The young utter a loud mewing, and the old birds occasionally make a barking or 'quacking' noise, both while on the wing and also when perched; but as a rule this species is rather silent, and certainly does not 'hoot' like the Tawny Owl.

The adult male has the upper parts buff, mottled and vermiculated with brown and grey, and streaked with dark brown, especially on the long erectile ear-tufts; facial disk buff, with a greyish-black margin and outer rim, and dark markings round the eyes; under parts warm buff and grey, with broad blackish longitudinal streaks and minute transverse bars; bill blackish ; operculum senicircular; legs covered to the toes with fawn-coloured feathers. Length 15 in.; wing 12 in. It has been stated that the female is more rufous in tint than the male. In the young the facial disk is yellower and the markings on the under parts are more defined. 


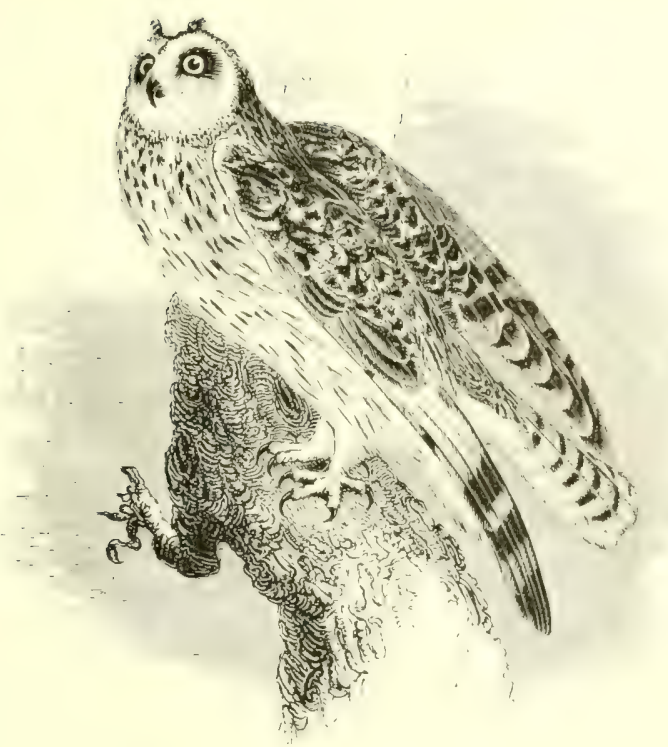

THE SHORT-EARED OWL.

\section{Asio accipitrínus (Pallas).}

Unlike the preceding arboreal species, the Short-eared Owl is an inhabitant of the open country, especially upland moors, fens, heather and furze on hillsides, and more or less damp places; while in the latter part of the year it is often met with in turnip-ficlds and stubbles. Owing to the fact that large numbers arrive regrularly from the Continent in autumn, and remain for the winter, it is frequently flushed by sportsmen, and is often called the Woodcock-Owl, from the coincidence of the time of its appearance, and, perhaps, from its twisting flight; in some years it is much more plentiful than in others. Notwithstanding the drainage of the fens a few pairs still breed in the eastern counties, and northward its nesting-places, though widely scattered over our moorlands, become more frepuent; while in sicotland and the islands they may almost be called numerous. In Ireland this species has not yet been recorded as breeling, but it is as common there in winter as it is in the rest of the Lnitcd kingdom.

Though the Short-eared Owl sometimes nests in the Shetlands, it is only a wanderer to the Feroes, and its occurrence has not heen authenticated in Iceland. From $70 \mathrm{~N}$. lat. down to the shores of the Mediterranean, Black and Caspian Seas, it is generally distributed 
throughout Europe, breeding in suitable localities down to the south of Russia, Italy, Sicily and Malta. In the Spanish Peninsula it has not yet been known to nest, though abundant there in winter; but in Morocco it is said to pair with an African species, Asio capensis (which visits Spain), and it is found in Africa as far south as Natal. Its range extends all over the temperate portions of Asia and even as far south as Singapore; in the Pacific it has been obtained in the Sandwich, Ladrones and Caroline groups; while on the continent and islands of America it occurs from Greenland to the Straits of Magellan. No other species of $\mathrm{Owl}$ has so wide a range, but its breeding-limits in the south are as yet imperfectly defined.

In the fens the nest is a mere hollow formed on the top of a clump of sedge or in the side of a mass of mown reeds; but on the moors the eggs are laid in tufts of heather: they are often 6 or even $S$ in number, rather smooth in texture, and creamy-white in colour: average measurements $\mathrm{I} \cdot 6$ by $\mathrm{I}^{\prime} 25 \mathrm{in}$. They are generally laid early in May, though the young are sometimes unable to fly by the beginning of August. At one nest visited by Mr. A. H. Evans, Mr. Seebohm and myself, the parent birds uttered no sound, but hovered high in the air and circled round, occasionally fluttering their wings in a manner indicative of anxiety; at another the sitting bird flapped away after onc harsh scream. The food consists of rats, field-mice, lemmings, and other rodents, birds from the size of a Lark to that of a Plover, and occasionally of bats, fish, reptiles, and large insects. This Owl is often seen pursuing its prey in daylight, and it has been known to pick up and carry off wounded birds.

The plumage of the upper parts in the adult is similar to that in the preceding species, but it is more blotched than streaked, the buff tint is more pronounced, the facial disk and the rim are browner, and the ear-tufts, though erectile, are short and invisible except when the bird is excited; the under parts are streaked longitudinally with blackish-brown, but not transversely barred or vermiculated ; bill black; operculum senicircular. Length I $4-15_{5}$ in. ; wing about $\mathrm{I}_{2} \mathrm{in}$; the female being slightly larger than the male. The young bird is browner and darker, with bolder markings, and is very tawny on the under parts, while the iris is pale sulphur instead of rich yellow. Pallid forms are not uncommon, and specimens from different parts of the enormous area inhabited by this Owl vary considerably in tint. 


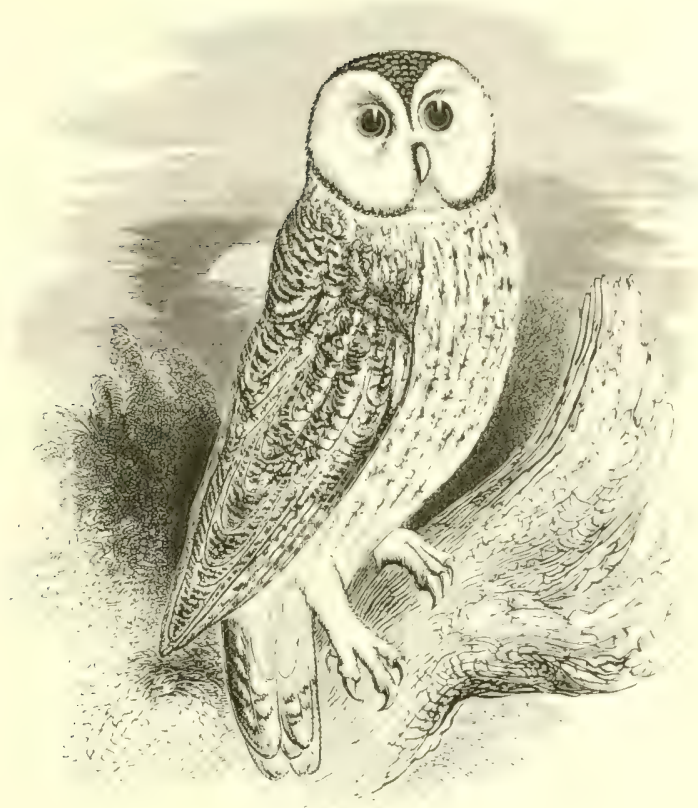

THE TAWNY OWL.

\section{SÝrNiUM ALÚCo (Linnæu:).}

The Tawny, Brown, or Wood-Owl is still, in spite of molestation, tolerably abundant in England and Wales wherever there are woods or crags suited to its habits; it is in fact much commoner in some places than the White or Barn-Owl, though in others rapidly decreasing. In the south of Scotland it is a well-known species, and of late years it has extended its range on the mainland to Caithness and Sutherland, while in the west it occurs in Skye and some of the Inner Hebrides. In Ireland, strange to say, its presence has not yet been authenticated.

From the Faroes this species was recorded in January and again in March IS $7 \mathrm{r}$; on the latter occasion it was migrating in company with some Long-eared Owls. In Norway it is numerous up to the Trondhjems-fjord, above which it becomes rare; but in sweden its northern range is, as usual, less extensive, though the bircl is very common in the southern parts of that country. Below $60^{\circ}-61^{\circ} \mathrm{N}$. lat. in Russia it is generally distributed as far as the western slopes of the Ural Mountains, but on the eastern side it is scarce, and in 
Siberia is as yet unknown. Throughout temperate Europe the Tawny Owl is found in suitable localities, but in the south it is very local, being almost confined to the higher wooded districts in the Spanish Peninsula, and to the northern portion of Italy, while it has not yet been obtained in Corsica or Sardinia. In North Africa, however, it is known to breed in small numbers, as also in Asia Minor, and Canon Tristram met with it among the cedars of Lebanon. Eastward it can be traced through Turkestan to Tibet; but a form resident in the Himalayas, with bolder and darker mottlings, has been separated specifically as $S$. niricolum, while opinions differ respecting birds from China.

The Tawny Owl breeds early in the year, often having eggs by the middle of March in the south of England, though rather later in the north of Scotland. A hollow in the trunk of some decayed tree, especially when covered with ivy, is a favourite site; but old nests of Rcoks, Crows, Magpies and other birds are often occupied, and ruins, barns and out-buildings, disused chimneys \&c. are occasionally resorted to; while instances of eggs being laid in rabbit-burrows, on ledges of root-trellised crags, or on the bare ground under shelter of fir-branches, are by no means uncommon. As usual, the eggs are white, rather smooth in surface and nearly round in shape: average measurements $\mathrm{I} \& \mathrm{~S}$ by $\mathrm{I}_{5} 5 \mathrm{in}$. The clicking note of the young resembles the word kitalik; the old birds may be heard to utter their loud hwo-hoo, or the th-ithit, to-who as rendered by Shakespeare, chiefly in the evening and shortly before dawn. During the day this Owl remains concealed, and it appears to dislike the sunlight more than any other British member of the family. Some bold individuals resent an approach to their nest, and cases are even known of distinct aggressiveness. The food consists of voles, rats, mice, shrews, squirrels, moles, small birds, insects, and surface-swimming fish.

The adult male has the upper parts of varying shades of ash-grey mottled with brown, with large white spots on the outer webs of the wing-coverts; tail barred with brown and tipped with white; under parts buffish-white, mottled with pale and streaked with dark brown; facial disk greyish, with a dark brown border; operculum large; legs feathered to the claws. Length about 16 in.; wing i i in. The female is larger, and often more rufous in plumage, but there are two phases - a red and a grey - of this species, the colour of which is independent of sex, the ruddy form being the more common in this country. The nestlings are covered with greyish down; afterwards the plumage is generally more rufous than in the adults. 


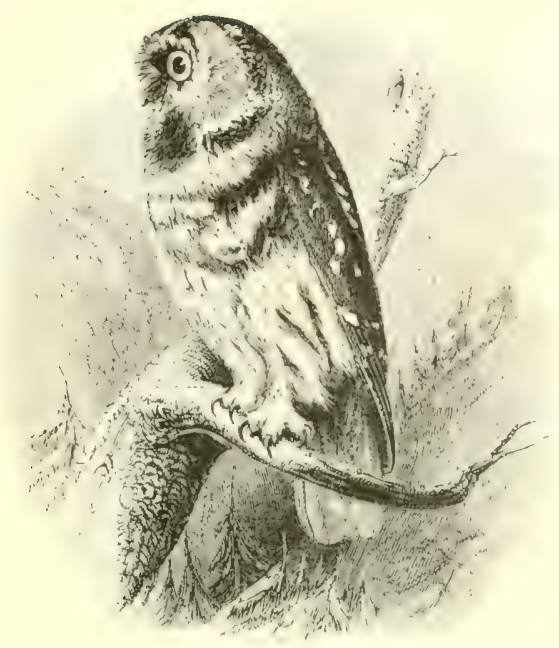

TENGMALM'S OWI.

Nýctala tengmálmi (J. F. Cimelin).

As indicated by its thick and downy plumage, this small Ow' is an inhabitant of northern regions, whence it migrates southward in severe weather; wandering, at long intervals, to Great Britain in autumn and winter, and in spring on its return northwards. Since the beginning of this century about fifteen examples have been obtained in England-chiefly in Northumberland, Vorkshire, Norfolls and Suffolk; specimens have, however, been obtained as far south as Kent and Somerset (though the so-called susiex example proves to be a Little $\mathrm{Owl}$ ) : also in shropshire, near l'reston in I ancashire. and once in Cumberland. With regard to Scotland, one has been captured in the Orkneys, and one in the Firth of Forth. As yet there is no record from Ireland.

Tengmalms Owl inhabits scandinavia, 1aplund, Finland and Russia, almost up to the northern linit of the torests: its southem breeding-range in the latter country coinciling with the growth of Pinus sylvestris, and reaching as far as Saratov and Orenburg. In winter its migrations extend to (iuricy, where the l'ral River emptic: itself into the Caspian Sica; but I)r. Mcnshicr, the eninent Russian authority, does not believe in its asserted existence in the (rimes. It breeds in the higher forests of the varioun branches of the (arrathians. 
and in those of the $\mathrm{Al}_{\mathrm{p}}$ s, from Styria and the Tyrol westward to the Vosges, the Jura, and the mountains of Ibauphine ; while there is evidence that it inhabits the Prrenees, though it is not found further south in Spain. In other parts of Europe-including Heligoland - it is chiefly a migrant. Eastward, it appears to range across the pine-forests of Siberia to the Pacific; and in the woods of Arctic America it is represented by a slightly darker form of very doubtful specific distinctness, known to separatists as $N_{y c t a l a}$ richardsoni.

Our earliest knowledge of the breeding-habits of this, as of so many other Arctic species, was derived from Wolley, who found that in Lapland it occupied the tyllas or unt-nest-boxes formed of logs hollowed out at either end, with a hole cut in the side-set up by the inhabitants for the use of the (rolden eye I)ucks; it also deposits its eggs in holes in trees, often in some former abode of the Black Woodpecker. 'The eggs, laid between the beginning of May and end of June, are $f^{-6}$, and exceptionally ro, in number; they are smooth, and white in colour: average measurements $I^{\circ} 28$ by $\mathrm{I}$ in. The food-consisting of lemmings, mice and other rodents, with large beetles and small birds-is generally procured during the latter half of the day; but it is hardly necessary to add that sunshine does not incommode a bird which passes the summer in the continuous light of the high north. The call-note is described by Wheelwright as a soft whistle, only uttered in the evening and by night.

The adult male has the upper parts chocolate-brown, with small white spots on the top of the head, and larger white patches on the back and wing-coverts; facial disk nearly complete, dull white with a dark outer ring; under parts greyish-white, irregularly barred and streaked with brown; legs and toes thickly covered with whitish brown-speckled feathers (in the Little Owl the feathers on the legs are short and the toes have merely bristles); bill yellowish-white. Length $S .5$ to $9 \mathrm{in}$. The female is slightly larger than the male and has the white spots less pronounced; while the young are much darker than the adults, and are chiefly spotted on the wings and tail. A remarkable characteristic of this Owl, as shown by Professor Collett of Christiania, is that the ear-regions in the skull itself, as well as the orifices, are unequal in size.

The late Sir William M. E. Milner recorded (Zool. p. 7104) the occurrence of the North American Saw-whet Owl, Nyctala acadica, near Beverley in Iorkshire. He was probably mistaken or, as frequently happened, imposed upon. 


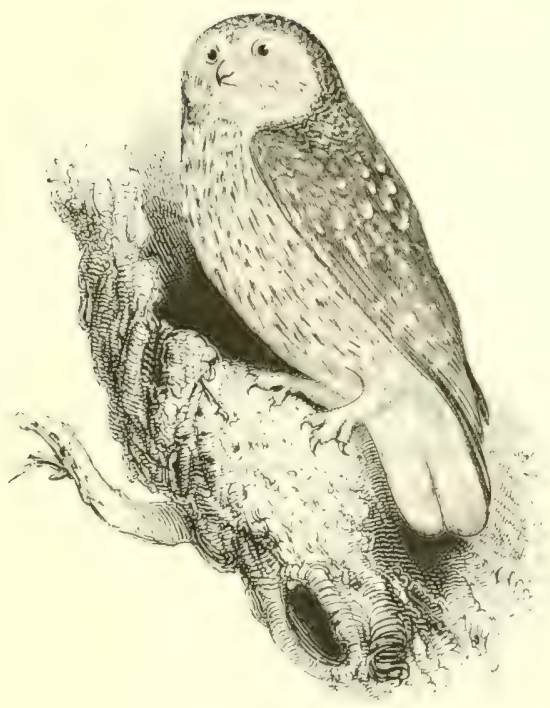

THE LITTLE OWL.

\section{ATHÉNe nóctua (Scopoli).}

More than twenty examples of this common European species have been obtained in England since i $75 \$$, when Elwardi figured a bird caught alive in a chimney near the Tower of London; but so many are known to have been imported from the Continent and intentionally liberated-to say nothing of those which have excaped from confinement-that it is impossible to say whether any of our visitors have been really wild. In May i 843 Waterton turned out five Little Owls near Wakefield, which he hat bromsht from It ly the previous year; while recently Mr. St. Quentin in Yorkshire, and Mr. Meade-Waldo in Hampshire, have introduced others, which have bred at large though in sradually diminishing numbers. Cages-full brought from Holland may often be seen in I.eudenhall Market; and, without disputing the claim of this speries to a ylace in the British list, it must be said that in the countries it inhabits, it is certainly not addicted to migration. As yet it has not been recorded from Scotland or Ireland.

The Little Owl is of exceptional occurrence in Sweden, and in Russia the Baltic P'rovince of (ourlanel marks its northem hroceling-limit; but south of lat. $56^{\circ}$ it is a generally distributed resilent 
in Europe, especially in the countries washed by the Mediterranean. Examples from Greece are paler than those from Western Europe; and an increase in sandy tint has led to the separation of the form which inhabits North Africa and Egypt, as A. glaux or A. meridionalis: other variations in tint are found in South Russia and in Asia Minor; while between the Ural Mountains and Northern China there is a fairly distinct species, A. bactriana, with the toes covered with feathers instead of hairy bristles.

In April or Nay the Little ()wl deposits its eggs in holes in ruins, farm out-houses and other buildings, hollow trees, or rocks; they are white, and are $3-5$ in number: average measurements $\mathrm{I}_{4} 4$ by I' ${ }_{5}$ in. Mr. Meade-Waldo informs me that incubation lasts twentyeight days; that the bird feeds largely on insects, and frequents lawns in the evening to collect earth-worms; while in winter it catches birds at roost, and devours a large number of Thrushes; eating also mice and other small mammals. Early in the spring the male is very noisy; repeating its note of cu and sometimes cu-cil, with exasperating monotony. This Owl is comparatively diurnal, and is therefore liable to be mobbed by small birds; for which reason it is often used as a lure by Continental bird-catchers. Its habit of alternately ducking down and drawing itself up to its full height is extremely grotesque.

The upper plumage is greyish-brown, striped on the head, spotted on the head and wings, and barred on the tail with white; under parts dull white streaked with brown; facial disk ill-defined; no operculum ; irides yellow ; toes corered with hairy bristles. Iength about $8 \mathrm{in}$, the female being rather larger than the male. The young have a more rufous tinge than the adults.

If we follow the least elastic interpretation of the often disregarded laws of nomenclature, the generic name Athene is inadmissible, as having been previously employed in Entomology, and Carine should be adopted: but many will agree with me that the point should be conceded, to preserve an association with Pallas Athéné, to whom this bird was sacred. The specific name passerina, sometimes employed, is inadmissible; for the Strix fasscrina of Linnæus is the Pigmy Owl, a bird hardly larger than a sparrow, and one which has never occurred, or is likely to occur, in the British Islands.

The I,ittle Owl, and, I believe, all others, usually keep two toes in front and two behind, when perched. The late Mr. Yarrell and his draughtsman were probably unaware of this, which is a thing by no means generaliy known, even now; and in this respect the attitudes of several of the Strigidæe are not happy. 


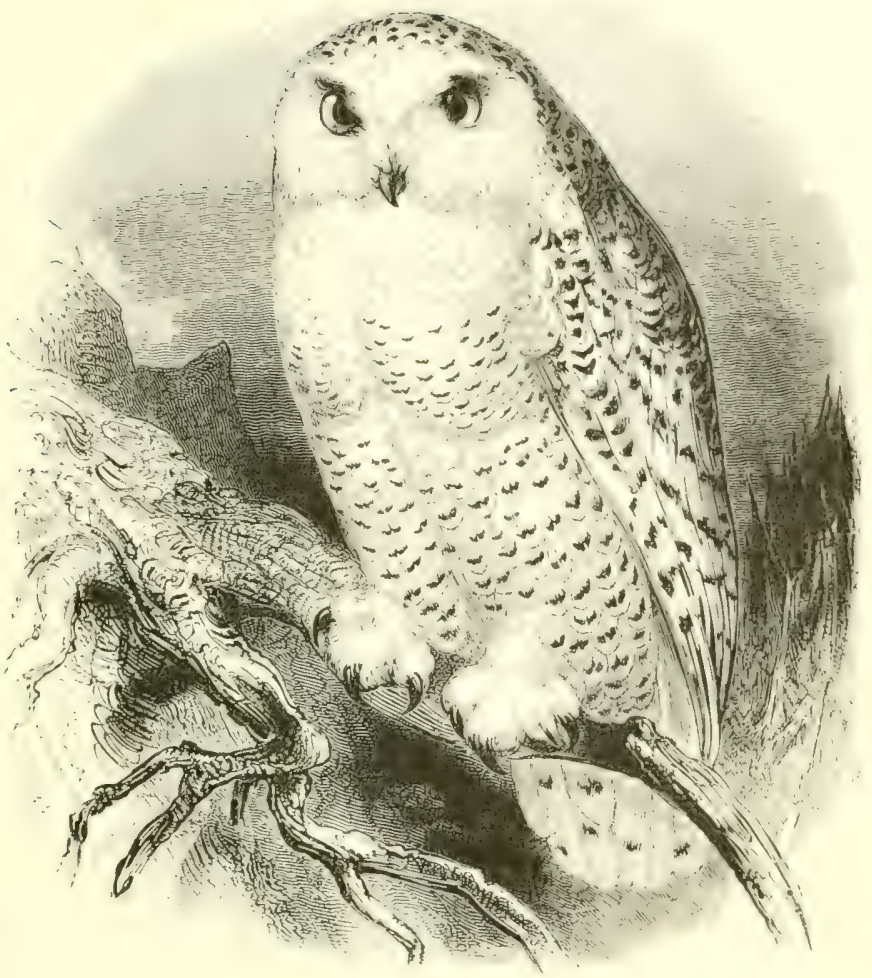

THE SNOWY OWL.

\section{NÝctea scándiaca (Linnæus).}

This conspicuous bird was first noticed in Britain by the late Dr. Edmondston, who recognized it in $\mathrm{s} \mathrm{S}_{\mathrm{i}} \mathrm{i}$ in the shetland Islands; to which, and to the Orkneys, it is now known to be an almost annual visitor in the cold season, especially after northerly gales. Its occurrence in the Outer and the Inner Hebrides, as well as on the mainland of Scotland, is by no means unusual; while in England it has been obtained on several occasions in Vorthumberland and Yorkshire, nine times in Norfolk, once in Suffulk, and once in South I levon. 'To Ireland its visits have been kess fretuent, but it has been observed, at considerable intervils, in several counties during the winter months. It has never been known to breed in a wild state-though it has done so in captivity - in any part of the British Islands. 
To the Feroes, Iceland and Spitsbergen, the Snowy Owl is only a straggler; but it is common and partially resident on Novaya. Zemlya, Waigatz, and throughout the Kola Peninsula. On the fells of Norway and Sweden it follows the lemmings on their migrations, and of late years has been found breeding in many places where it had previously been unnoticed. In Russia it inhabits the tundras; nesting, exceptionally, down to the Governments of St. Petersburg and ILivonia; and in winter it is distributed over the whole country down to the Caspian and the Sea of Azov. As regards the western half of Europe, it visits Pomerania, the north of (iermany, and Tenmark, in some numbers during cold weather; while its wanderings have extended to Holland, France, and Lower Austria. In Asia, it is found across Northern Siberia in summer, and in winter an txample has been obtained at Murdan in the Indus valley. On the Imerican continent it breeds on the barren-grounds and the rerge of the wooded districts, from Alaska to Labrador: also in (ireenland, where-or, strictly speaking, in Grinnell-Iand-Col. H. W. Feilden found it nesting as far north as $\delta z^{\circ} 33^{\prime}$, though it abandoned those high latitudes at the end of August, reappearing on March $29^{\text {th. }}$. In winter it has occurred as far south as Texas, and in the Bermudas; while a flock has been known to perch on the spars of a vessel and accompany it from Labrador half way across the Atlantic towards Ireland.

The Snowy Owl deposits its eggs on the bare ground or in a mere hollow scraped in the reindeer-moss, generally on some slight eminence. The eggs are often laid in pairs and at intervals, and Io have been found together; they are, like most Owls' eggs, white, but rather more elongated than usual: average measurements $2 \cdot 3$ by $x^{\prime} 75$ in. Prof. Collett says that the female and young are fed by the male, which exhibits great boldness and even ferocity when the nesting-place is approaclied. The food consists of lemmings and other rodents, Arctic hares, Ptarmigan and WillowGrouse-wounded birds being often picked up before the sportsman can reach them; carrion is also eaten, and the bird is an expert catcher of fish. Its own flesh is highly esteemed by the inhabitants of the Arctic regions. The cry is a loud and repeated krau-au.

The plumage of the Snowy Owl is white, barred and spotted with an amount of black or dark brown which varies greatly in different individuals; it is said that the female is more profusely marked than the male, and she is certainly much larger. Small but almost invisible tufts exist; there is no operculum ; bill black ; iris orangeyellow. Length from 22 to 27 in. 


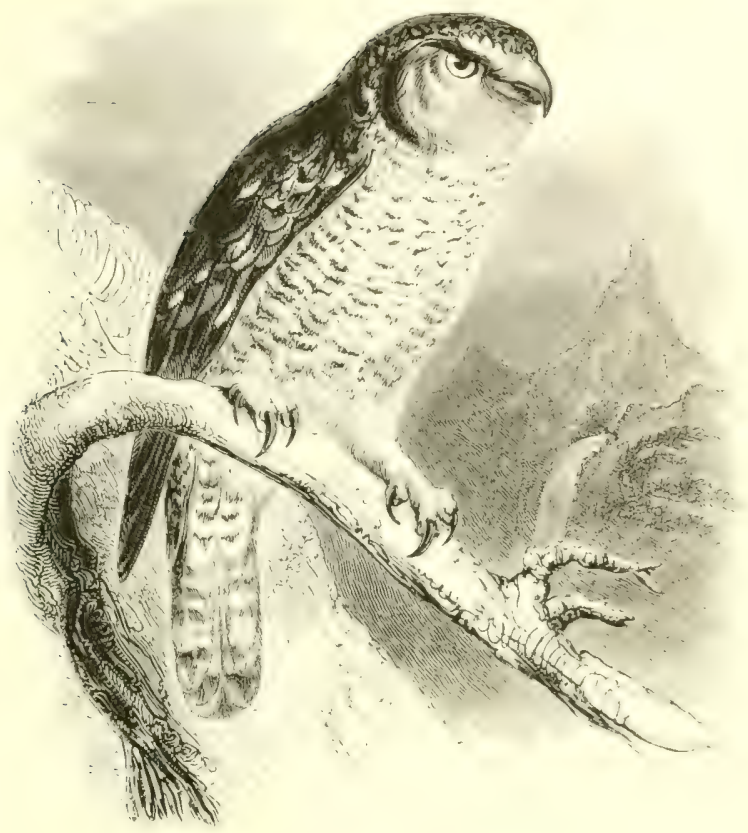

THE HAWK-ONIL.

SÚRNIA FUNÉREA (Linnæus).

An example of this rare wanderer to Great Britain was taken in an exhausted state off the coast of Cornwall in March I $\$_{3} 0$; a second was shot near Yatton, in somersetshire, while lrawking for prey on a sunny afternoon in August I847; a third on Unst, in the Shetland Islands, in the winter of r\$60 6 i ; a fourth near (ilassow in December 1863 ; and a fifth near cireenuck in November isos. Of the above, I believe that all which are now awailable for critical examination belong to the North Imericin form--elistinguished by trinomialists in the United states as. S. uluhe afuroth in which the dark transverse bands of the under parts are more rudely than in the European, and the white on the upper parts is rather more pronounced. There can be little doubt that the American visitors hacl received aid from vessels for Bristol and the Clyde; a genuine example of the European form has, howerer, been olutaned near Amesbury, Wilts, and identified by Mrr. R. B. Sharpe (P. Z. S., I876, p. 334); while the Shetland bird (destroyed by moth) was also, judging by the description, from the Old World. 
Neither variety of the Hawk-Owl is found in Greenland or Iceland; but the European race inhabits the pine-forests of Scandinavia and Northern Russia. In the latter it is found up to $68^{\circ} \mathrm{N}$. lat., and though only breeding occasionally in the Baltic Provinces, it does so regularly as far south as the Governments of Moscow and smolensk, and in the mountain forests of the Ural down to Orenburg. In winter it occurs in Poland and Northern (iermany; less frequently in Denmark, Belgium, Northern France, Lorraine, and Alsace; rarely in Austria. In examples from between the Ural Mountains and the Pacific, the colours are purer and more strongly contrasted-as in the case of many other species; and this NorthSiberian form, distinguished by Pallas as $S$. doliata, is said to inhabit Alaska. There it meets with the American race already mentioned, which ranges eastward to I abrador, and as far south as Pennsylvania in severe winters.

The Hawk-Owl begins to breed by the middle of April; and Wolley, to whom we owe the earliest details respecting its habits, found that it occupied holes in trees, and the nesting-boxes set up by the peasants for the use of Ducks, in which it lays from 5 to 8 white eggs: average measurements 155 by $\mathrm{r} \cdot 2$ in. In Arctic America these are said to be deposited in nests built of small sticks and twigs, in pine-trees: doubtless the deserted habitations of other birds, such as are utilized by the I.ong-eared Owl. The male bird fiercely attacks any intruder upon its domain, and both sexes appear to take part in the task of incubation. The cry is similar to that of a Hawk, which, from its long tail, sharp wings and quick flight, this species much resembles in appearance. It flies much in the daytime and has been seen to strike down the Siberian Jay on the wing; its food consists of lemmings and other rodents, large insects, and birds up to the size of Ptarmigan or a Willow Grouse; to obtain the latter of which it will sometimes attend upon the sportsman.

The general colour of the upper parts is dark browil, spotted with white; facial disk incomplete; tail long and graduated, narrowly barred and broadly tipped with white; under parts white, barred with dark reddish-brown; feet covered to the claws with greyishwhite feathers; bill yellowish-white; irides straw-yellow; no operculum. Length 15 to 16 in.; the female being larger than the male, and having the dark bars on the under parts slightly broader and more rufous. 


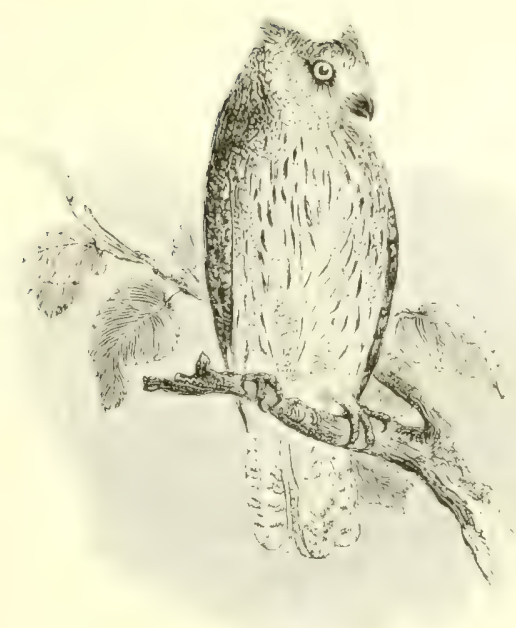

THE SCOPSOWL.

Scóps giú (Scopoli).

This, the smallest Owl which occurs in the British Islands, was first noticed as a visitor in the spring of 1805 , when specimens were obtained in Yorkshire. Since that time examples have been recorded from Essex, Middlesex, Bucks, licrks, Wilts, Cornwall, Pembrokeshire, Lancashire and Cumberland; but the often-repeated story of the breeding of the sicops-()wl at CastleEden I)ene in I)urham is untrue, while as regards the five or six occurrences ascribed to Norfolk, Mr. I. H. (iumey jun. considers only one-that of November I86I-can be implicitly relied on. The statement that one was shot in Sutherland late in May I $S_{54}$, is accepted by Messrs. Harvie-Hrown and Buckley. In Ircland one was killed in co. Neath in 1837 , one in Wexford in the spring of 1847 , and a third near Belfast in November $188_{3}$.

The Scops-Owl is only a summer-visitor even to the temperate portions of Europe, seldom extending its migrations as far north as Holland, Beigium, Northern France, or (isalpine switzurlanel. Beyond the $A l_{p}$ s and the Carpathians it is not uncommon; while in the south of France, the Spanish Peninsula, and Italy, and thence eastward to Greece, Turkey and Southern Russia, it becomes abundant. In fact, it is found in summer as far north as 
the grape annually ripens, but it is most numerous in those countries in which the olive-tree grows, although it may ascend there to elevations far above the oil-producing zone. In the Mediterranean basin it appears to be to some extent resident, as it is also in portions of Northern Africa; but large numbers pass onward and winter in Abyssinia and Senaar. It is common in summer in Asia Minor, Palestine, Persia and Turkestan; but in the Indian and African regions it has several representatives of more or less specific distinctness.

About the middle of May the Scops-Owl lays its white eggs (5-6 in number and measuring about $\mathrm{I}^{2} 25$ by 1 in.) in some hollow tree or in a hole in a wall; in the south of France it is said to make use of old Magpies' nests, but confirmation of this statement is required. It is partial to cork-woods and to groves of trees on the banks of rivers; while its note may frequently be heard in the gardens of large cities, such as Seville and Florence. To my ear its cry is a clear, metallic, ringing ki-ou - whence the Italian names Chiil or Ciil-but Mr. Seebohm renders it by ahp. This Owl is particularly nocturnal, and, except when disturbed, I never saw it on the wing in the day-tine, during which it remains perched across a branch, often close to the stem; resembling, beneath the shady foliage, some snarled stump or knot, which, on a tap being given to the trunk, will be seen to shoot up to double its former height and exhibit a pair of ear-tufts. So abundant is it on the wood-fringed banks of the Tagus and the Jarama that I have found over a score in an afternoon's ramble. It feeds on beetles, grasshoppers, large moths and other insects, mice, and small birds.

The general colour of the plumage is grey, with a dark centre to each feather and vermiculations of various shades of brown; facial disk incomplete above the eyes; car-tufts conspicuous when erected; legrs feathered, but feet bare; beak black; irides yellow ; no operculum. Length about 7 in. The female is often rather more rufous than the male, while the young are decidedly so.

Examples of the American Scops asio are said to have been obtained in Yorkshire and in Norfolk, but no credence need be attached to these statements. 


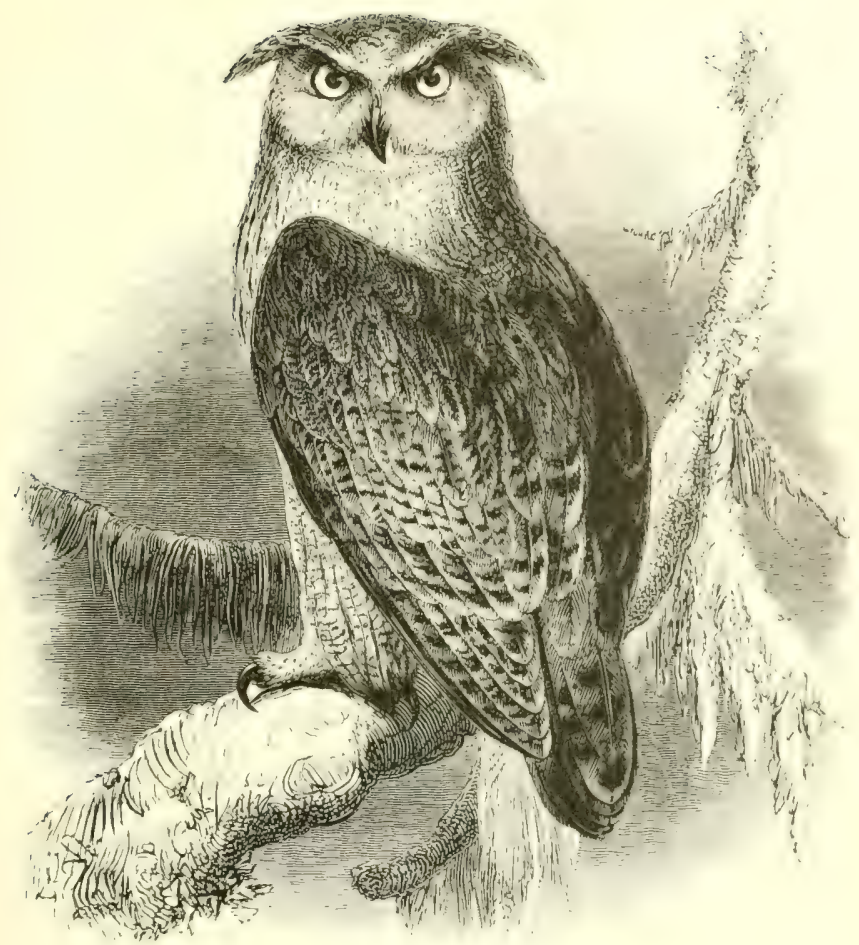

THE EAGLE-OWL

Búbo ignávus, 'T'. Forster.

Occurrences in Great Britain of this large and handsome speries have from time to time been recorded; but some of these are known - while others may be suspectud- to refor to examples which have escaped from that semi-captivity in which this (Owl is often kept. Birds which were probably genuine migrants from Xortherm Europe have, however, been obtained, at long intervals, in the Orkney and shetland Islands and on the mainland of scotland: while in England, besides other records, a female which showed no sign of having been in confinement was shot near Stamford in Lincolnshire, in April is 79 . There is no evilence that the lixigleOwl has ever visited Ireland. In the collection of Dr. Birkett, however, is, or was, a 'Horned' Owl said to have been shot in co. Waterford on January 27 the is 5 I though only lalrelled in 1 sisz: it 
was afterwards wrongly identified (Zool. ISS I, pl). 262, 30S) as the American $B$. itrginianus, and subsequently proved to be $B$. maculosus (Zool. I 882, p. +60 ), a native of South Africa, like Dr. Birkett's 'Gold-vented Thrush,' also said to have been shot in co. Waterford, in winter!

The Eagle-Owl inhabits the forest-covered, rugged and mountainous districts of Europe, from Scandinavia, Lapland and Northern Russia to the Mediterranean; as well as Africa north of the Atlas Mountains. Specimens from beyond the Volga are pale in colour, while east of the Ural Mountains and across Siberia a still paler form, B. sitivicus, is found; though birds from China and the south of Japan are identical with those from Europe. In Central Asia the representative varicty is the rather smaller B. turcomanus, which appears to connect the European race with the shorter-eared and fairly distinct species, $B$. ascalaflucs, inhabiting Egypt and Northeastern Africa. America is occupied by $B$. rirginianus and its subdivisions.

In the forest regions the Eagle-Owl deposits its eggs in some wide fork or other convenient place in a large tree, sometimes making use of an old nest of another bird; but in the mountains it lays them on slightly overhung ledges, or on crags, among the roots of trees; it is rather partial to the sides of narrow gorges, and is not averse to the proximity of a cottage. Incubation often commences early in April; the eggs being 2 and never more than 3 in number, nearly round in shape, and creamy-white in colour: average measurements $2 \cdot 3$ by I $_{9} 9$ in. No nest is originally made, but the young are often found upon an accumulation of castings and the fur of rats, rabbits, hares and other mammals; which, with birds, form the food of this predatory species. In Spain and the Pyrenees the peasants make a practice of robbing its nest of the game supplied daily to the young by the parent birds and substituting any available offal; for which reason the position is seldom revealed until the young are nearly ready to fly. The Eagle-Owl seeks its prey by day as well as by night. Its cry, chiefly uttered early in the spring, is a loud hoot. In confinement this species breeds freely and has been known to live to a great age.

The general colour of the upper parts is dark brown or black, mottled with tawny-yellow; wings and tail transversely barred; under parts yellowish-brown with dark streaks and bars; head with long ear-tufts; no operculum; legs thickly feathered to the toes; irides bright orange. Length of the male about $24 \mathrm{in.}$; of the female 28 in. 


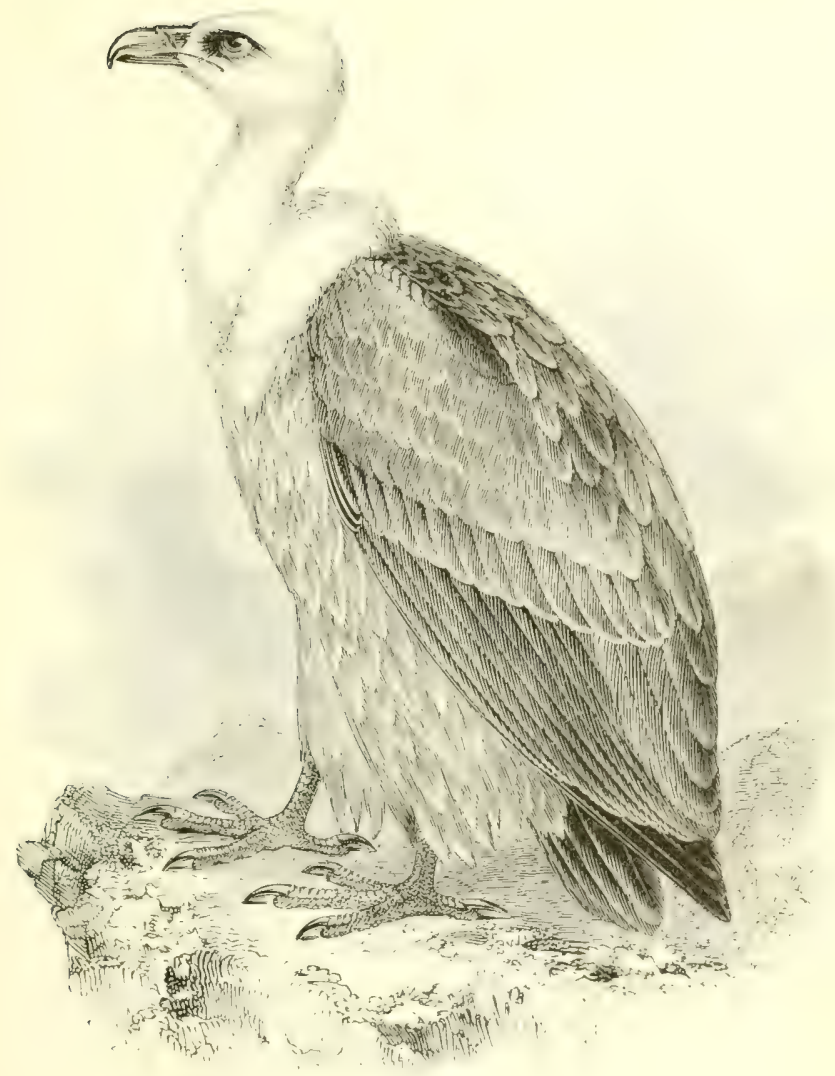

THE GRIFFON-VULTURE.

Gíps fúluus (J. F. Gimelin).

In the spring of 1843 a bird of this species was caught alive (presumably gorged or injured), on the ruchs near Cork Hartwur, and is now preserved in the coilection at Trinity College, 1)ublin. It was described by Thompson as being in adult plumage; but, after examination, I have no hesitation in saying that it is immature. There is no other instance of the capture of this Vulture in the british Islands; though an eminently cautions omithelegire, who must have seen thousands of Griffons, but who will not allow his name to be mentioned, informed me a few years since that he had recently watched one soaring around, near Southampton Water. 
The Griffon-Vulture breeds in small numbers not far from Biarritz, and in several localities just within the French frontier on the northern side of the Pyrenees; also in the Departments of Hautes and Basses Alpes and Alpes Maritimes. Throughout the mountainous portions of the Spanish Peninsula it is common, as it is in most of the situations suitable to its habits in Southern Europe and along the basins of the Mediterranean, Black and Caspian Seas; but north of the Alps and the Carpathians it is of very rare occurrence, although it has been obtained in Germany and Poland. In Russia it is found up to about lat. $50^{\circ}$, and along the Ural Mountains it has considerably extended its range northward during the last thirty years. In Asia it can be traced to Turkestan and Northern India, where, however, it meets with a larger form which has been separated as G. himalayensis; while in Africa it is resident as far south as Nubia, though represented by G. kolli in the South.

Towards the end of January the Griffon-Vultures may be seen building or repairing their nests with branches of trees and clawsfull of grass torn up by the roots. Their usual resorts are overhung ledges, cavities and fissures, such as are especially frequent in limestone ranges, and are seldom accessible from above without a rope : while owing to thick scrub the base of the cliff is often unattainable. In the latter part of February, though sometimes not till the end of March, I and not unfrequently 2 eggs are laid; they are rough in texture, and usually white in colour, but some are more or less marked with genuine blotches of a rusty-brown, as well as with blood-stains: arerage measurements $3 \cdot 7$ by 2.8 in. A strong and unpleasant musky smell pervades the eggs, the nest, and the whole dung-splashed ledge. Like other Vultures, this species hunts by means of its keen sight; the alteration in the flight of the nearest bird, on the discovery of a carcase or other carrion, being quickly noticed and followed-up by more distant individuals. During the lambing season I have seen it on the ground, assiduous in its attendance upon the ewes; but it is an arrant coward and I never knew of its touching any living thing. It is at all times somewhat gregarious.

The general colour is buffish-brown, with black on the wings and tail ; the head and neck are covered with whitish down; and there is a broad ruff, which is composed of long whitish filaments in the adult, but of brownish acuminate feathers in the young; under paits striated buff in the adult; warm fulvous in the young. Length about 42 in, 


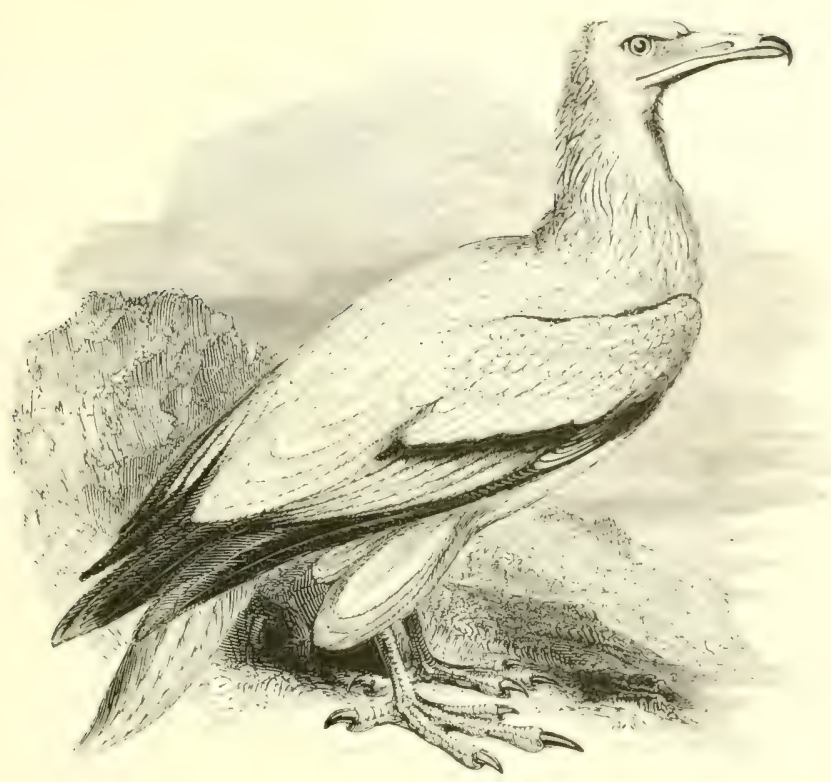

THE EGYPTIAN VULTURE.

\section{NÉophron perCNópterus (Linnæus).}

In October 1825 two birds of this species are said to have been observed near Kilve, on the shores of liridgewater lay in somersetshire, and one, gorged with the carcase of a sheep, was shot. It proved to be in immature plumage; as was another example killed on September 28 th 1868 , in a farm-yard at l'eldon, Essex, to which it had been attracted by the blood of some geese.

The Egyptian Vulture has wandered to Norway and (icrmany, but its nearest nesting-place is in the cliffs of 11 ont salive (just within French territory), near Geneva; though further south it is not uncommon in suumer, arriving in P'rovence and the l'yrences carly in March. It is usually seen in pairs, and never breeds in colonics; but a couple or two are to be seen near almost every mountainrange in the Spanish P'eninsula and in Southern Eunope sencrally, especially in the basins of the Mediterrancan, llack and ('isplian Seas. It inhabits Madeira, the Canaries, the Cape Verd Islands, and North Africa from Morocco to Egypt and the Red Sea ; while in winter it goes down to Cape Colony. From Asia Ninor and 
Palestine we trace it to Persia and Turkestan, but the smaller Indian form has been distinguished as $N$. ginginianus.

The nest, built of branches and rubbish, sometimes on a former abode of the Bearded Vulture, Raven or other large bird, is usually placed on a ledge of rock; but in Turkey it is often in cypress and other trees. The eggs, 2 in number, are seldom laid in Europe before April roth; they are creamy-white, blotched and often richly suffused with chocolate-red or claret colour: measurements $2^{\circ} 5$ by 2 in. This Vulture feeds on the lowest animal and vegetable refuse and dung of all kinds; it may also be seen following the plough, with long, slow strides, for what it can pick up. But though its habits are repulsive, it is a magnificent bird on the wing, circling round without a flap of its outspread pinions, or at times sweeping low over the ground, like a Harrier.

The adult is white, with black primaries; the fore part of the head and neck yellow and devoid of feathers; irides crimson; legs and feet flesh-colour. Length $25^{-27}$ in. The young bird, represented in the vignette, is dark brown, with greyish head and neck: irides brown. The full plumage is not obtained until tlie fourth year.

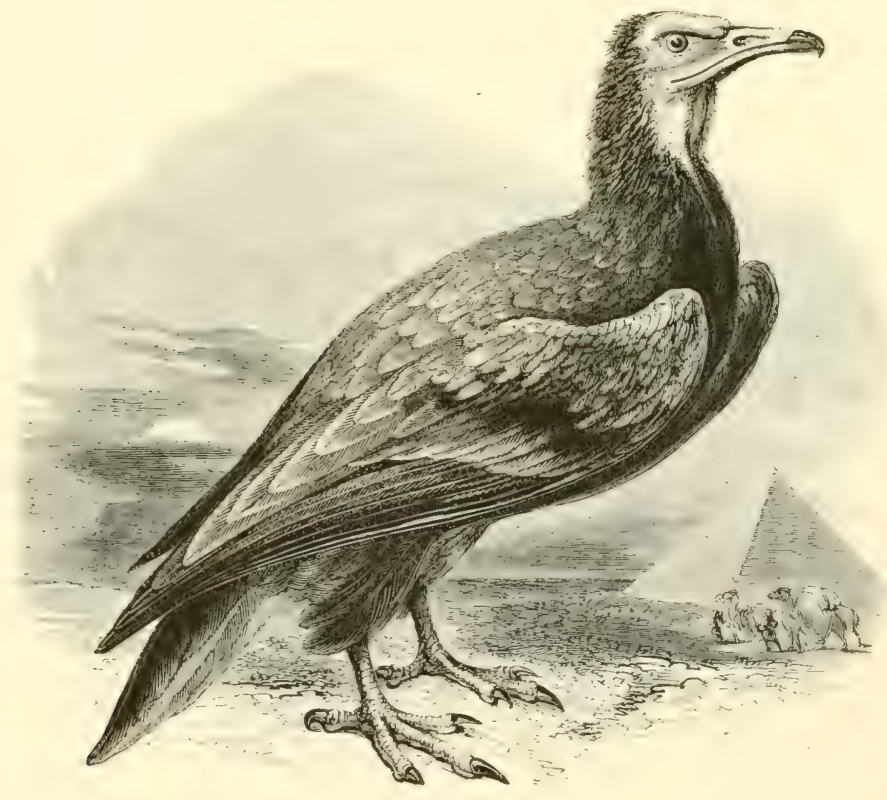




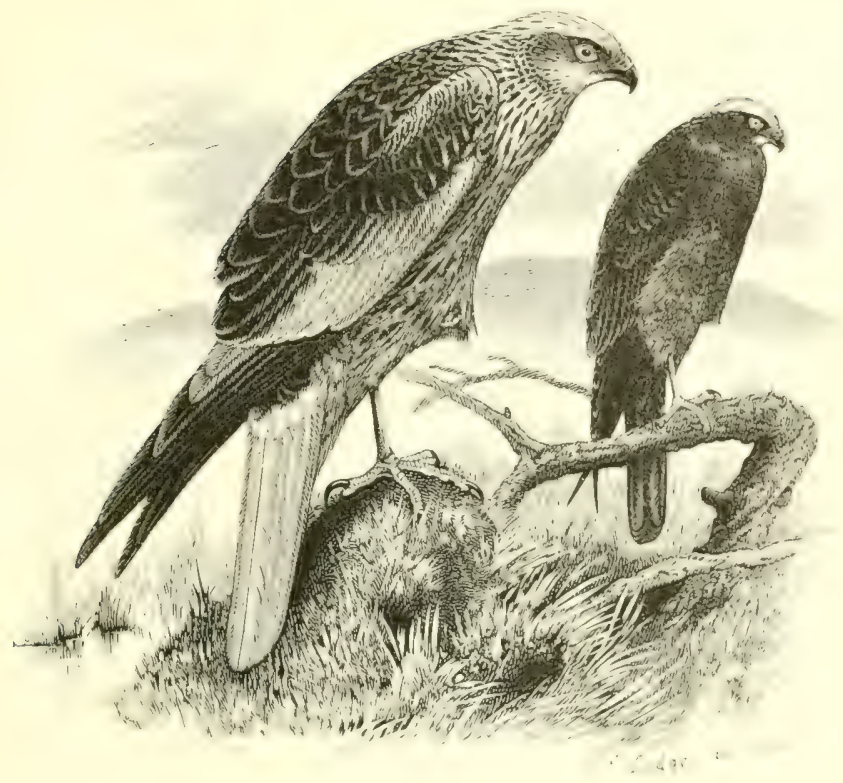

THE MARSH-HARRIER.

\section{Círcus æreuginósus (Linnæus).}

This species-better known as the Moor-Buzzard, while 'moor' retained a signification allied to 'mire' or 'marsh' - is now all but banished from the number of our indigenous birds. The principal cause of its decrease in England has been the drainage of the fens in the eastern districts, and the reclamation of the marshy: wastes in Somerset, Dorset, Shropshire, I ancashire, Vorkshire and some other counties, where it used to breed until within the last twenty or thirty years. At the present day a pair or two, probably colonists from Holland, almost annually attempt to rear their brools in the Broad district of Norfolk, but are rarely; if ever, allowed to succeed; and I know of no other county in which this Harricr has recently nested, though migrants from the Continent occur in spring and autumn. In Scotland it is very rare, even in the solway district, which is not altogether unsuited to its habits; the only example Mr. Booth ever saw was an immature bird in East Lothian; single instances are on record from I)umbartonshire and from scolpa, near Skye; Mr. Macleay of lnverness has recived but one in all his long experience; and Mr. (;. Sim of Mherdecn tells me that 
only a solitary male, shot May izth i $S S$ I, has passed through his hands in thirty years. Statements respecting its breeding in Aber. deenshire, Banffshire $\mathbb{N}$., are simply incredible. Ireland offers many more congenial situations; and the bird was formerly common about Lough Erne in co. Fermanagh, along the valley of the Shannon, in co. Cork, and other districts; but since is 8 o the keepers have nearly succeeded in exterminating it by the use of poison.

In Norway the Marsh-Harrier is of accidental occurrence, but it nests in the soutl of sweden, and in Russia is found in summer up to Archangel, though not abunclant north of the Volga. In Middle and Southern Russia it is common, and, in the latter, resident; but from the northern districts it migrates in the cold season, as it does-at least partially-from Poland, I)enmark, (iermany, Holland, lielgium and the north of France. In the marshes of the Spanish Peninsula, Italy, and the rest of Southerr Europe it is abundant throughout the year, as it is also in some parts of North Africa, from Morocco to Egypt; while in winter it has been observed in Ahyssinit and even in the Transvaal. Eastward it is found from Asia Minor to Northern (hina and Japan; migrating in the cold season to 'Turkestan, Southern Siberia, India, and Ceylon.

The nest, built of reeds and dry grass, is a large firm structure, usually placed on a mass of sedge, and occasionally on the lower branches of a tree standing in or on the confines of a marsh. The eggs, $3^{-5}$ in number, are pale bluish-white, seldom-if ever-with genuine brown markings: average measurements 2 in. by $\mathrm{I}^{\circ} 5 \mathrm{in}$. In the season the Marsh-Harrier is a sad destroyer of the eggs and young of waterfowl; but during the greater part of the year it feeds on small mammals, birds, frogs and reptiles; the scarcity of the two latter in winter being one cause of its departure from the north of Europe.

Old males have the head creamy-white, streaked with umber; mantle brown; primaries blackish; rest of wings, and tail, silverygrey; under parts buff, striped with brown on the breast and chestnut on the belly and thighs; under-wing white. In the female the nuantle, tail and under parts are brown. Young birds are chocolatebrown, but the males have the entire crown of the head buffishwhite, while the females have a yellowish patch streaked with brown, on the nape only; in subsequent stages the plumage of this species varies greatly. Length: male $2 \mathrm{I}$ in.; female 23 in. 


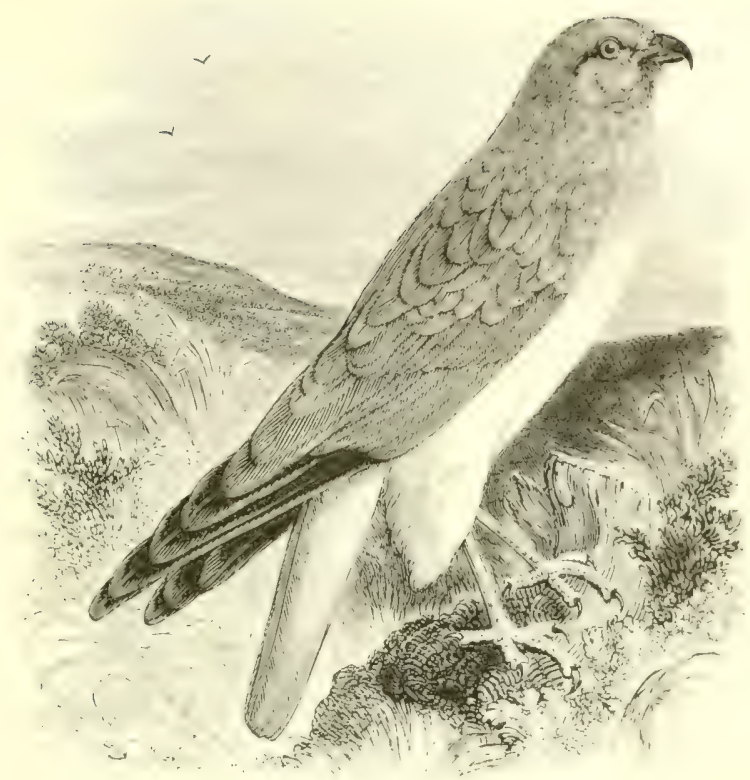

THE HEN.HARRIER.

\section{Circus cyáneus (Linnæus).}

The Hen-Harrier frequents higher and less marshy ground than the preceding species, and although it undoubtedly used we ned in the fen-district of Eastern England before the spread of drainage and agricultural improvements, it was probably not common there: Montagu's Harrier being often taken for it. Of late years its numbers have been so far thinned by game-preservers that it is now only to be found nesting on a few of the wildest and most extensive moorlands and wastes in England and Wales. Even in Scotland, where it was formerly numerous, it is rapidly decreasing as a breclingspecies; but in autumn young birds are sometimes very alumetant. while the adults also come down from the moors to the lowlands and the male attracts especial attention, owing to his pale grey plumage. These remarks apply equally to Ireland. Few-and those old birds-are to be met with in any purt of the liritint l-hamls during the colder months of winter.

In Norway, Lapland, and Northern Russia, the Hen-Harrier is found in summer about as far north as lat. $69^{\circ}$, though rare near that limit; and it is only south of $62^{\circ}$ that it becomes at all 
numerous in the last-named country. From March or April until autumn it is to be found in suitable localities in Denmark, Holland, Germany, \&c. down to the $\mathrm{Al}_{\mathrm{l}}$ s and the Carpathians ; in Francewhere from its abundance on migration in November it is called Busart Saint-surtin-comparatively few breed below the central provinces : and although a limited number are resident in the north of the Spanish I'eninsula and in Italy, yet throughout the basin of the Mediterranean it is chiefly known in winter and on passage, when it also visits MLorocco, Algeria, and North-Eastern Africa as far south as Abysinia. Eastward it is found across Asia-down to Canton in winter, and a little above the Arctic circle in summer. Over the northern half of America it is represented by a closely-allied species, $C$. mudsonius.

When placed on the bare hill-side the nest is often a slight structure, though, if in deep heather or a dried-up marsh, it is frequently a mass of roots and plant-stems a foot or so high; in Germany a grain-field is a favourite site: whence the name Korn-aith. The eggs, $4^{-6}$ in number, are bluish-white, exceptionally with genuinc yellowish-brown or rusty markings: average measurements $\mathrm{I} \&$ by $\mathrm{I}+\mathrm{in}$. Incubation, which devolves upon the female, seldom commences before the latter part of May, and lasts three wceks. Like other Harriers, this species quarters the ground with great regularity in search of the small mammals, birds and reptiles, which form its food; but though destructive to game, there is no evidence that it is an especial scourge of the poultryyard, as might be inferred from its vernacular name. The flight is particularly buoyant, and generally low; but, when soaring or hovering, the light-coloured rump is very noticeable.

The adult male has the upper parts pale slate-grey; rump white; throat and breast bluish-grey; remaining under parts white. In younger males there are five ashy bars on the tail, and brown streaks on the flanks, thighs and nape; cere, irides and legs yellow. Length I 9 in. The female is brown above, streaked with white on the nape and on the edges of a distinct facial ruff; rump white, marked with rufous; tail brown, with five darker bars-whence this sex was formerly called the Ring-tail, and was considered a distinct species; under parts buffish-brown, with darker stripes. Length $2 \mathrm{I}$ in. The young resemble the female, and, like her, have brown irides, but their plumage is more rufous in tint.

In these two species-and, I believe, in all except Montagu's and the Pallid Harrier-the outer webs of the primaries to the $5^{\text {th }}$ inclusize are notched or emarginate. 


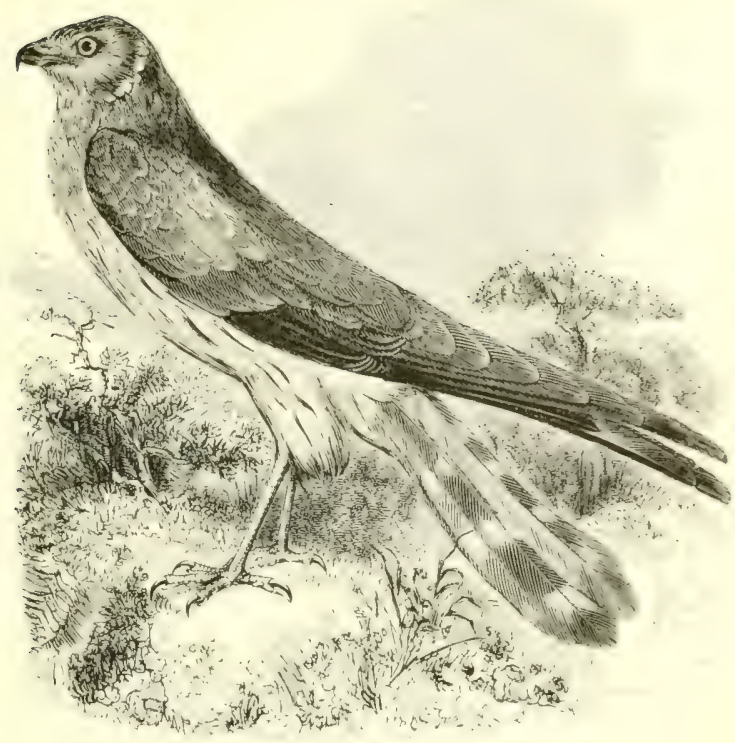

MONTAGU'S HARRIER.

\section{Circus cineráceus (Montagu).}

This species, first distinguished from the Hen-Harrier by Montagu, is smaller and more slender, with proportionately longer wings: and in any stage of plumage it may infallibly be recognized by the outer web of its $5^{\text {th }}$ primary having no notch or emargination. Montagu's Harrier was never a resident in the british Islands, as erroneously stated by a recent author; on the contrary, it is mercly a spring and summer visitor to the northern half of Europe, nor is its range in that direction extensive. To us it cones in $A_{p}$ ril, and a pair or two make a nest-often fruitlessly-almost every year in Norfolk; while instances are on record of its having bred of late years in Devon, Somerset, I)orset, Hants-including the Isle of Wight-and other counties of linglund, as well as in Wales; and it even reaches to Yorkshire, beyond which it is rare. In the Solway district a female, which had cridently been sitting, was shot, according to Mr. R. Service, on June $15^{\text {th }} 1882$, and there have been a few other occurrences: but except in the south it is unknown in Scotland, and statements that it has bred in sutherland or visited Caithness are unfounded. In Ireland only thece examples have been obtaincel, 
namely in October $1 \delta_{4} S$, October $1 \delta_{49}$, and in $1 \delta_{77}$; all near Bray; co. Wicklow.

The st. Petersburg district and the Gulf of Finland appear to mark the extreme northern breeding-limits of this Harrier; but it is abundant in summer in Central and southern Russia, and on the steples of the latter a few remain throughout the winter. In J)enmark and in the north of Germany it is not numerous; but to the central and southern districts of the latter it is a regular visitor, arriving in March and leaving in October: while in Holland, Belgium, and many parts of France it is common, large flocks often congregating at the time of migration. A considerable number are resident in suitable localities in the Spanish Peninsula and other parts of the south of Europe, a large increase taking place in winter; and many are killed in Malta on their passage to and from Africa. In the cold season Montagu's Harrier occurs in the Canaries, Morocco, Algeria, Egypt, Ibyssinia and as far south as Cape Colony; while in Asia its range extends to 'Turkestan and the south-west of Siberia in summer, and in winter to India, Ceylon and Burma.

The nest is often a mere hollow lined with dry grass and bordered with twigs, in the middle of a small clearing in gorse or heather, and, on the Continent, in a field of grain; but in the fens it is mere substantially built of sedge. The eggs, laid at intervals of two or three days, about the end of May, are usually pale bluish-white, but sometimes spotted with reddish-brown: average measurements, I*7 by $I^{\prime} 3$ in. I never found the male bird on the nest. Like other Harriers, this species eats small mammals and birds, but its food consists principally of grass-snakes, vipers, lizards and other reptiles, large insects, such as grasshoppers and locusts, and, during the season, eggs of other birds. From the crop of a male I once took two unbroken eggs of the Crested I ark, and the crushed remains of others. The flight is very light and elegant; the young sometimes circle and hover with out-spread wings and tail, like Kestrels, though less steadily, and the white colour of the rump distinguishes them.

The adult male has the upper parts slate-grey, with a black bar across the secondaries; throat and breast ash-grey; lower parts white streaked with rufous. Varieties reaching to an entirely sootyblack are not uncommon in this sex, but are rare in the female. The latter is usually brown above, and buffish-white streaked with rufousbrown below; the young are similar, but almost chestnut on the under parts. Length : male about i 8 in.; female i 9 in. 


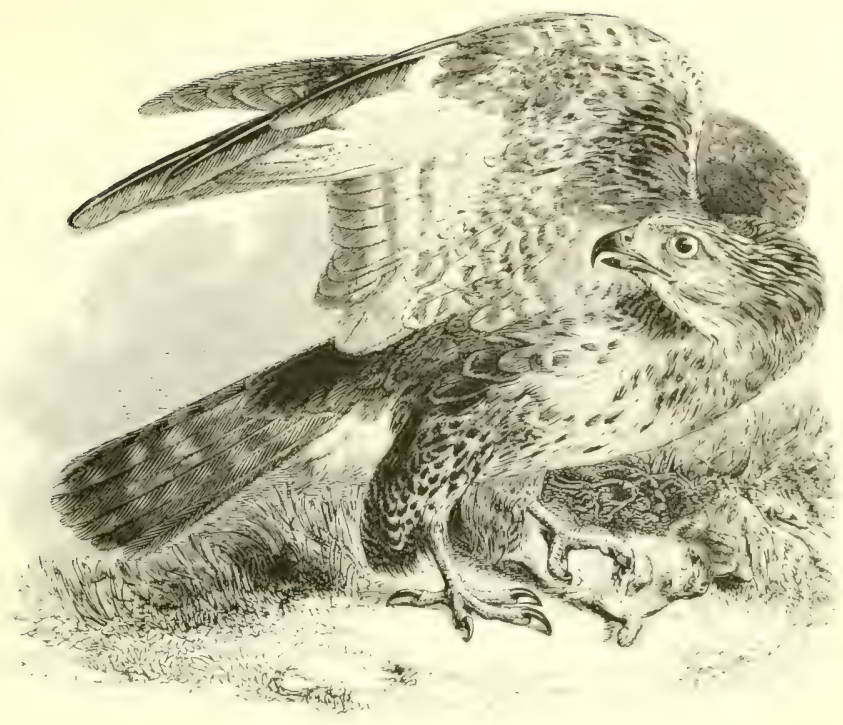

THE COMMON BUZZARI).

Búteo vulgáris, Leach.

As regards the British Islands, the epithet 'common' is annully. becoming less and less applicable to this species; but there are wild and wooded districts in England-especially on the western side - and in Wales, where the bird may still he seen circling high in air, and be heard uttering its plaintive mewing cry. Fifty years ago it used to breed in Norfolk and in other counties abounding with Partridges and ground-game, without being considered incompatible with their existence; but with the increase of Pheilsant-worship the doom of the Buzzard was sealed, for the larger the 'Hawk,' the worse it must necessarily be: In sicotland it is less persucuted and more widely distributed, though only a visitor to the ()uter l lebride: Orkneys and Shetlands. In Ireland, according to Mr. More, it still nests in small numbers, but it usually occurs as a migrant in autumn.

The northern breeding-limit of the (ommon buzard appears to be about lat. $66^{\circ}$ in Sweden : but in Russila, according to Mr. Mem/bier, it is seldom found to the east of the baltic I'rosincess or of the Vistula; beyond which its place is taken hy the more rufous . Ifrican Buzzard (B. desertorum of manyauthers): and he thinks that where the two forms or species meet they interbreed. From l'oland 
westward, the Common Buzzard is generally distributed throughout Europe; migrating to some extent from Northern Germany during the colder months - when immense flights have been observed over Heligoland-but residing in the central districts. In the south of Europe, though sometimes seen on passage in very large numbers, it is rather local as a breeding-species; while in North Africa, Egypt, and Western Asia, the resident form is the aforesaid $B$. desertorum. It is, however, the Common Buzzard which inhabits the Canaries and Madeira, while the Azores owe their name to its abundance in that group when discovered by the Portuguese.

Cliffs, especially those covered with ivy or scrub, are favourite resorts in Wales, the Lake country, and Scotland; but in wooded districts the nest is usually built in a tree, and, when placed in a fork, is frequently a deep, bulky structure of sticks, with a slight cavity on the top, which is lined and surrounded with green leaves; these being renewed from time to time, until the young have attained considerable size. The eggs, $3^{-+t}$ in number, are greyish-white, more or less blotched and streaked with reddishbrown and pale lilac: average measurements $2 \cdot 25$ by $1^{\prime} 75$ in. Both birds take part in incubation, which usually begins about the middle of April and lasts three weeks. Not long ago the Buzzard was still common in the New Forest, but the bark-strippers are at work in April, when the nest is easily seen through the scanty foliage; and by the offer of five shillings for a well-marked egg the collector of 'Britishtaken' specimens has done his best to destroy the remnant which have escaped the gamekeeper. There is no evidence that this species is destructive to Partridges or Pheasants, its ordinary food consisting of field-mice, moles and other small mammals, frogs, reptiles, grasshoppers \&c.; it also takes small birds when it can pounce upon them unawares, but it never attempts to fly them down. Unless pressed by hunger, it is decidedly sluggish in its habits, and will remain perched for hours; though when on the wing its spiral gyrations are remarkably graceful.

The plumage varies greatly, irrespective of sex or locality; very old birds are dark bluish-black above, and have only a few light markings on the breast; tail brown, with twelve darker bars; legs bare of feathers and yeilow in colour. Length: male 20 in.; female $22 \mathrm{in}$. Very handsome varieties-ranging from cream-colour mottled with brown to pure white-are often found on the Continent. The young bird has the throat brown, streaked with white; breast spotted with brown on a white ground; tail greyish-brown, with only ten dark bars. 


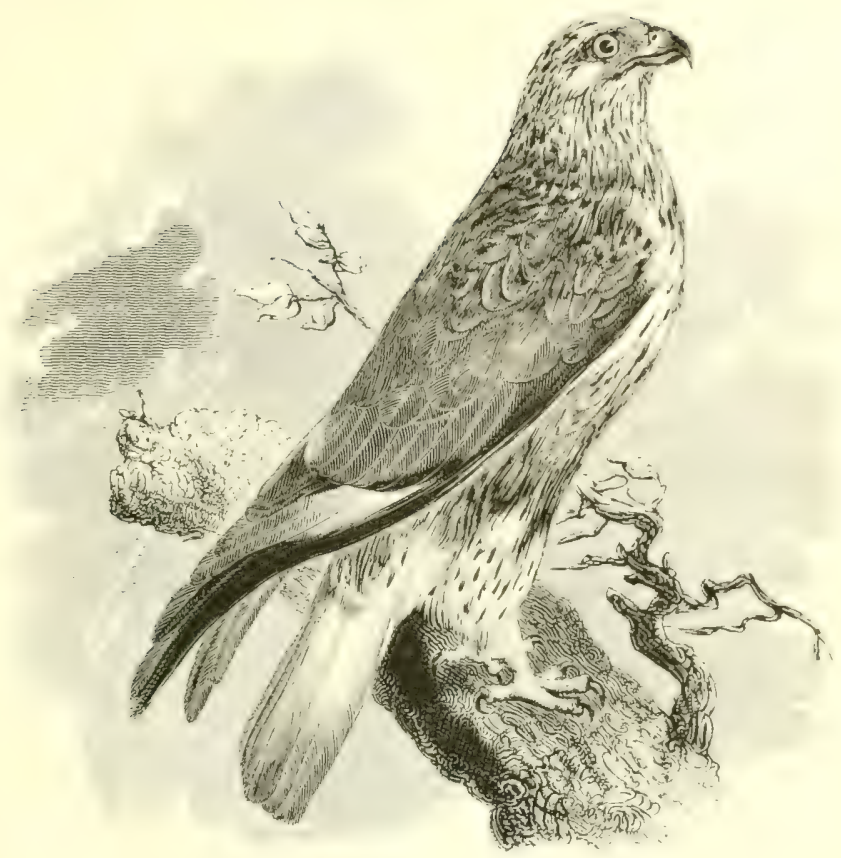

THE ROUGH-LEGGED BUZLARI).

Buteo lagópes (J. F. (imelin).

The Rough-legged liuzzard-distinguishable at a slance from the preceding species by having the front and sides of the legs feathered to the toes - is an irregular autumnal visitor to England: considerable numbers, chiefly immature birds, sonctimes making their appearance in the eastern counties, and, if unmolested, remaining for the winter. In the southern and western districts it is less frequent; but it is not rare in the midlands, and its line of migration appears to follow the l'ennine rance. In some of the northern and eastern parts of scotland it is of almost annual occurrence: and in the winters of $1875-76$ and $1880-8 \mathrm{r}$, it was very numerous in the south. To Ireland, however, its visits have only been recorded some six or seven times. The often-repeated statement that the Rough-legged Buzard nested "year after year, on the ground, amongst the heather, in the moor-dells," near Harkness, in Yorkshire, rests upon a gamekecerer's recollections of twenty-four years back, and is so contrary to the known halvits of the bird, that 
it is amazing to find it has been seriously accepted. The assertion by Thomas Edward that the nestlings were taken from a wood near Banff in $\mathbf{1} S 6_{4}$, is far less unlikely, though probably as incorrect as many of his other records of rarities.

The Rough-legged Buzzard is the commonest bird of prey in the higher districts of Scandinaria, and-beyond the wooded region-in Russia : in the latter it breeds, irregularly, as far south as lat. $56^{*}$, as well as in the Baltic Provinces; while in winter it goes down to the northern shores of the Caspian and to the Asiatic side of the Black Sea. Eastward it is found in siberia as far as the watershed of the Venesei and the Iena in summer (seebohm), and in Turkestan during the cold season. Wanderers have occurred in Malta and other islands of the Mediterranean, as well as on the mainland of Italy; but the bird recorded under this name by Spanish authors is the Booted Eagle, Aquila pinnata: the Rough-legged Buzzard is, however, an occasional winter-visitor to the P'yrenees; though only frequent to the north of the. $\mathrm{l}_{\mathrm{l}}$ s and the Carpathians. In North America it is represented by the more rufous and darker $B$. sanctijohannis, fondly believed to visit Fngland by owners of deep-coloured examples of the European bird.

The nest is built of sticks when placed in trees, but is a slighter structure lined with grass when on a crag. The eggs, often laid by the middle of May, are from $3^{-5}$. in number, and similar to those of the preceding species: though the average dimensions are a trifle larger, and the markings are sometimes very handsome. This Buzzard feeds, to some extent, on frogs, reptiles and birds, but largely on such small mammals as lemmings, moles and mice; it can eren manage an Irctic hare, while its partiality for rabbits has often proved fatal to it on the warrens of Norfolk and Suffolk. Open or marshy moorlands are more to its taste than wooded districts, in which respect it differs from the Common Buzzard: its flight is bolder: and in the air the white on the tail forms a good distinction. By some authorities this and other species with feathered legs have been placed in a separate genus, Archibuter.

The general colour of the adult is buffish-white, variegated with several shades of Lrcwn, darkest on the back and rump; basal part of tail white. and the remainder with two or three dark brown bars on a mottled ground; legs feathered to the toes on the front and sides. Length $23^{-26}$ in.; the female being larger than the male. The immature bird, represented in the woodcut, is browner in plumage and has less white on the tail : the under parts are striakd -not barred - with brown. 


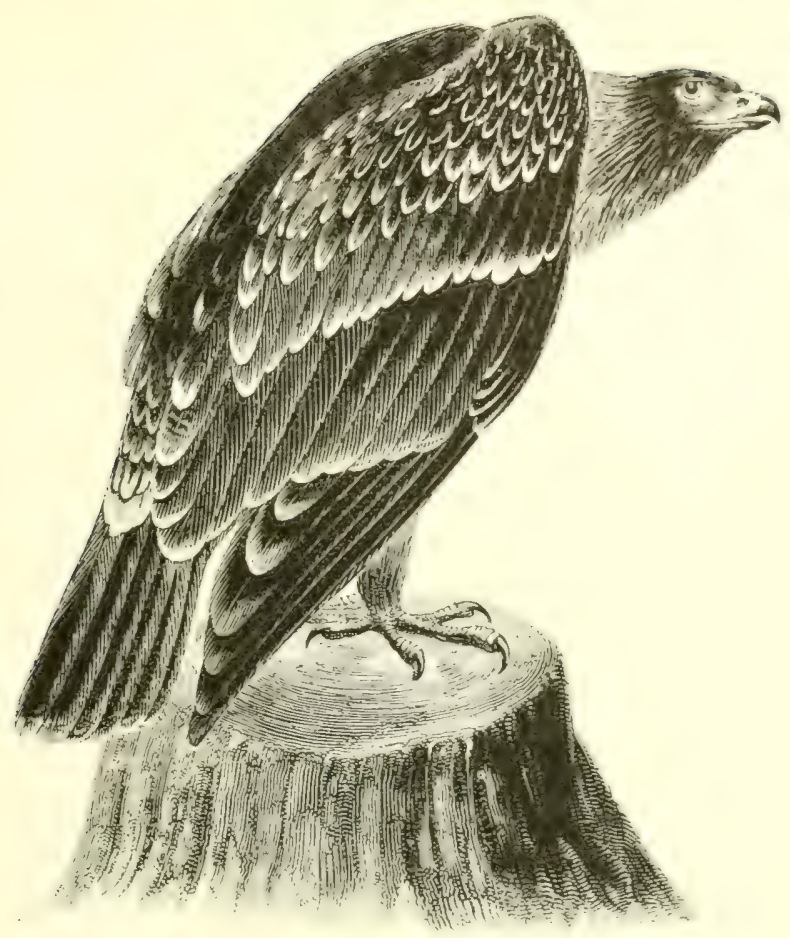

THE SPOTTED EAGLE.

\section{Aquila N.tita (J. F. Gmelin).}

In January is +5 two examples of this rare wanderer to the liriti-h Islands were shot near loughal in Ireland, and one of them-an immature bird-is preserved in the Museum of Trinity College, Dublin. On December $4^{\text {th }}$ I 860 , and early in November IS6I, two young males were shot in Cornwall, as recorded by the late E. H. Rodd; Mr. Durnford states that one was picked up dead

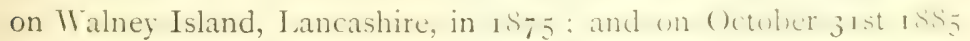
an example was obtained in Northumberland.

It is probable that the specific name generally employed was originally intended for a small form which lirceds in the formets e.1 Northern (iermany, and becomes numerous in l'omerania and the Baltic Provinces of Russia, though rare on the casicm sicle of liec Gulf of Bothnia, and only a straggler to Sweden and Lapland. Southward this can be traced through Poland and the marshy womh 
to the west of the Dnieper, down to Bessarabia; as well as to the Caucasus. A larger form (winich slightly intrudes on this area) occupies the forest-region to the eastward and southward as far as the steppes; beyond which it extends across Turkestan and Central Asia to Northern China; and to some parts of India, Persia and Asia Minor. It nests in Turkey, the districts watered by and south of the Danube, and suitable localities in Italy and the islands of the Mediterranean; also, sparingly; in North Africa. In the south of Spain it is not common, but I frequently saw and heard it in the Pyrenees; in France and Belgium it is rare, except on the wooded south-eastern frontier, towards Switzerland and Luxemburs. In winter both races migrate entirely from their northern, and partially from their southern haunts in Europe; numbers ascending the Nile valley to Abyssinia. Is regards the adults, the only difference is that of size; an average male of the larger form being equal to a female of the smaller, so that the races can only be separated on dissection. In the young of the smaller form there is usually a more defined buffish patch on the nape, but the pale spots of the upper parts are limited to the secondaries and wing-coverts: whereas in the larger form these spots are also found on the scapulars and rump. If entitled to specific distinction, Mr. J. H. Gurney refers all the Iritish examples which he has examined to the larger form, the A. clangit of Pallas; a name which has, unfortunately, been freely applied by ornithologists, especially on the Continent, to a larger and distinct species, the Steppe-Eagle, A. orientalis.

The nest, almost invariably built in a tall tree, is a large flat structure of sticks, with a slight lining of fresh twigs, leaves or grass; the eggs, laid early in May, and usually 2 but sometimes 3 in number, are greyish-white, streaked and often boldly blotched with ruddy-brown and blood-red: average measurements 2.5 by $2^{\circ} \mathrm{I}$ in. Nests found on the ground in the Dobrudscha and South Russia, and formerly ascribed to this species, prove to be those of the Steppe-Eagle. The food consists largely of frogs; also of reptiles, grasshoppers, small birds and mammals. The cry, loud and shrill, is repeatedly uttered in spring.

The general colour of the adult is warm coffee-brown or greyishbrown, according to the age of the feathers. The young bird is dark purplish-brown, with pale edges to the upper feathers-as is well shown in the cut-and ochreous streaks on the under parts. Length of wing from 18 to $20 \mathrm{in}$. in the male; 19 to $22 \mathrm{in.} \mathrm{in}$ the female. The nostril is round, not oval; the legs, feathered to the toes, are rather long and slender. 


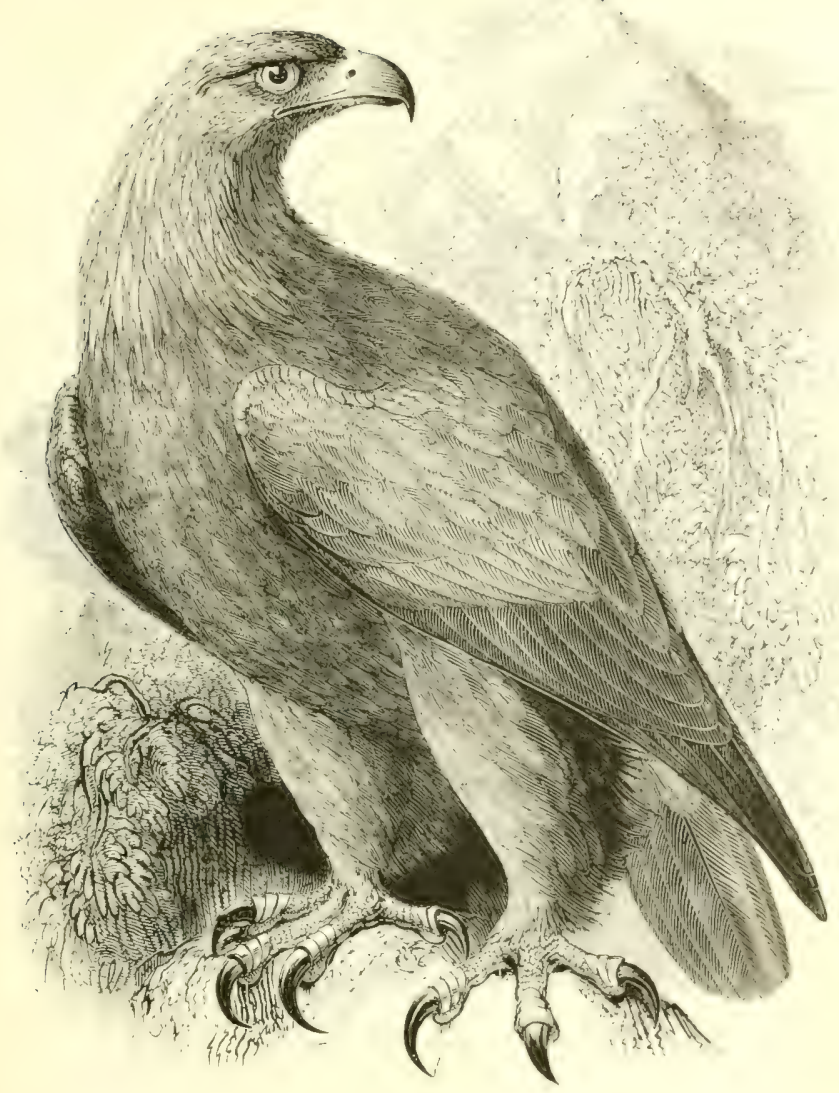

THE GOLDEN EAGLE.

AQuila chrysáetus (Linnæus).

Authenticated occurrences of this fine species in the south of England are exceedingly rare, for the birds recorded as ciolden Eagles generally prove to be examples of the White-tailed or sinEagle in the tawny-brown plumage of immaturity; the two can, however, be infallibly distinguished by their feet, as pointeul out on p. 320. Single specimens have been obtained in Norfolk and lincolnshire; while northward in England the visits of this speries are not much more frequent, although about two centuries itst it bred in Derbyshire and Wales, and almost within the last humber years in the Cheviots and the Lake district. Across the Border, as Mr. R. Service informs me, there were eyries up to $18_{33}$ in the 
Moffat Hills, and for some years after is $S_{5} \circ$ in Ayrshire, Dumfries and Galloway. 'To the Lowlands of Scotland the (iolden Fagle is, even now, not an unfrequent visitor in the cold season; but its breeding-places are confined to the Highlands and the islands on the western side, where, owing to the protection afforded by many of the proprietors of deer-forests, its numbers, severely thinned in former years by grouse-preservers and sheep-farmers, have to some extent recovered; it no longer, however, nests in the Orkneys, and has never been known to do so in the shetlands. In Ireland only a few pairs remain, in the north and west.

The (iolden Eagle inhabits the mountainous and some of the forest regions of Europe, from Lapland to the Mediterrancan; of North Africa; of Asia as far west as Kamschatka, the Amoor and Japan, and southward to the Himalayas: and of North America; but it is unknown in Greenland. Over this vast area considerable variations in size and plumage are observed:-examples from IIistern Europe being darker than those from the Central and Southern portion; adults as well as young from the eastern half of Russia have a great deal of white at the base of the tail; and the maximum of size appears to be attained in the lofty ranges of Central Asia and the Himalayas. Four distinct species, one of which is divided into five varieties, are recognized by the Russian naturalists.

The nest-generally placed on a crag in mountainous regions, but often in a tree, and occasionally on the ground-is a large platform of sticks, lined with softer materials, such as the coneshaped tufts of Lusulu syliatica. The egos, laid early in April, are usually 2 , and sometimes 3 in number, though an instance of 4 is recorded by Sir I. W. P. Campbell-Orde. Some are dull greyishwhite or mottled-buff, while others are streaked and blotched, and often richly suffused with every shade. of reddish-brown and lilac: average measurements 2.9 by $2 * 3$ in. In Scotland the "Black" Fagle, as it is called, feeds to a great extent upon mountain-hares. and on the Continent upon marmots and sinilar animals; it also takes lambs, grouse and other birds; occasionally fawns, and the 'calves' of red deer; nor does it despise carrion. Its note is a shrill squeal, ending in an abrupt bark.

The general colour is dark brown, tawny on the nape; the tail is mottled with dar's grey in the adults; but the basal half is white in the young, in which also the body-feathers are white at the base; thighs dark brown; legs feathered to the toes. Length $32-36$ in., the female being larger than the male. 


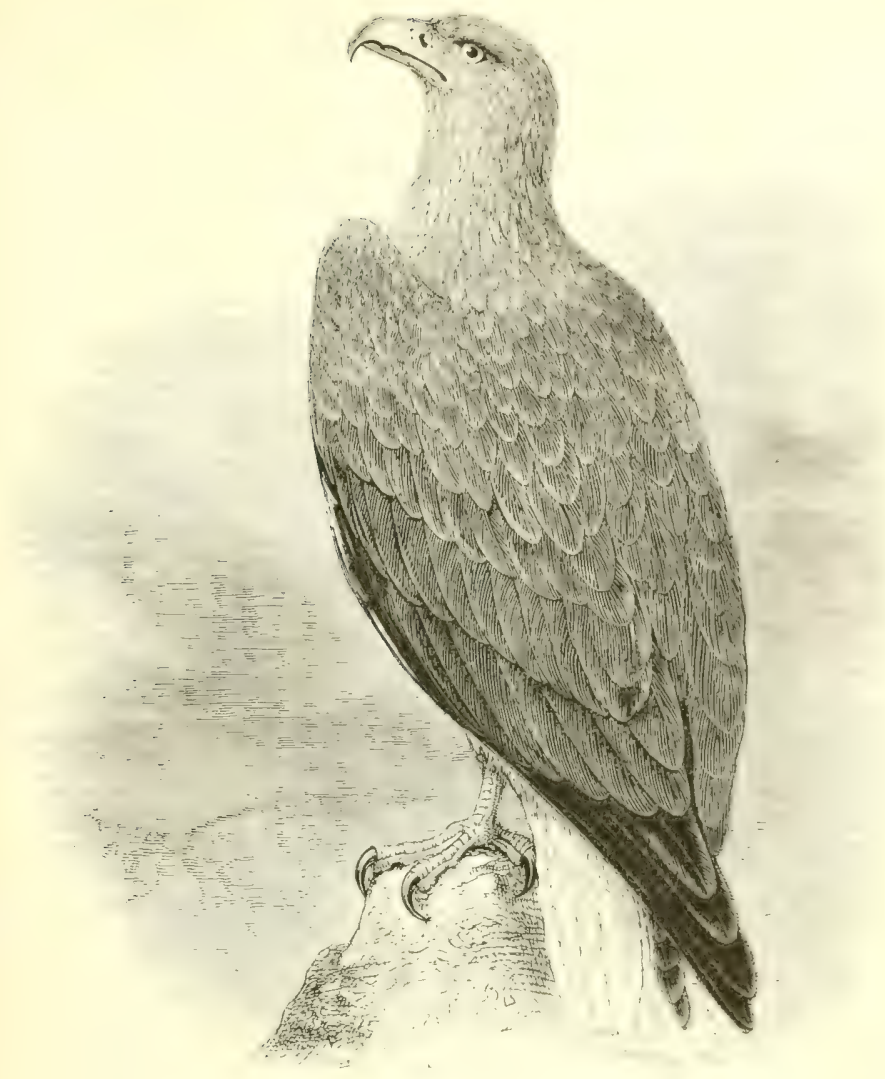

THE WHITE-TAILED EA(ILE.

Haliáërus albicílla (I innæus).

Immature examples of this species - also called Eme, Cinereous or Sea-Eagle-are not unfrequently observed in the maritime counties of England in autumn and winter, when the birds reared in the northern parts of Europe are on their migration sonthwird: aluhare, however, of very rare occurrence. Within the last hundred years the White-tailed Eagle bred in the Isle of Man, the Lake district, and Galloway, I)umfriesshire and ther phare in the south of Scotland; but now its eyries are confined to the western and northern coast, and the islands, including the shetlands. In Inelmet, where it was formerly more numerous than the Golden Eagle, its propensities for carrion have led to its destruction by poison, and only on the west coast can a pair or two be found. 
The White-tailed Eagle is now only a visitor to the Froes; but it is a resident in Iceland, and also in the south of Greenland, though a migrant from the northern districts in winter. In North America it is represented by the Bald Eagle, H. lemociphalus, a species with a pure white head and neck, which has erroneously been supposed to occur in Iceland and Scandinavia, and even in Ireland. On the Continent it inhabits the neighbourhood of salt or fresh water, in Scandinavia, Denmark, Northern Germany, Russia, the valley of the Danube, and Turkey; while on migration it visits the rest of Europe, the Canaries, and Northern Africa. It breeds in the reed-beds of Lake Menzaleh in Lower Egypt; and eastward we trace it across Asia - to Kamschatki and Manchuria in summer, and to Japan, China and India in winter. Though it wanders to the Commander Islands, the only species known in the long Aleutian chain is the American Bald Eagle.

The nest, similar to that of the Golden Eagle, is, in Scotland, often placed on a sea-cliff, but sometimes on an inland rock; frequently in a tree or wide-spreading bush on some small island in a loch, and occasionally on the ground. One found by the Hon. Nurray Finch-Hatton (now I ord Winchilsea) in the marshes of Lower Fgypt. resembled a gigantic nest of the Marsh-Harrier, being raised to a considerable height above the deep mud by which it was surrounded. The eggs, usually 2 in number, dull white in colour, and measuring about 2.85 by $2.2 \mathrm{in}$., are laid in Scotland in April ; but as early as February or March in the southeast of Europe. and January in Egypt. Few kinds of fish, flesh, fowl, or carrion come amiss to this species. The cry is a loud yelp.

The head and neck are ash-white in very old birds; upper parts brown; primaries nearly black; tail wedge-shaped, and white in colour; under parts dark brown; beak, cere, irides, legs and feet yellow. Length: male 28 in.; female 34 in. The young bird is dark brown, mottled with fulvous on the mantle and wings; tail dark brown; beak black; cere and irides pale brown. The full plumage is not attained till the fifth or sixth year. Varieties of a uniform bluish-grey, yellowish-grey, and silvery-white are on record.

In the White-tailed Eagle the lower part of the tarsus is bare of feathers, while the whole length of each toe is covered with broad scales. In the foot of the Golden Eagle the tarsus is clothed with feathers, and each toe is covered with small reticulations as far as the last joint, beyond which there are three broad scales. 


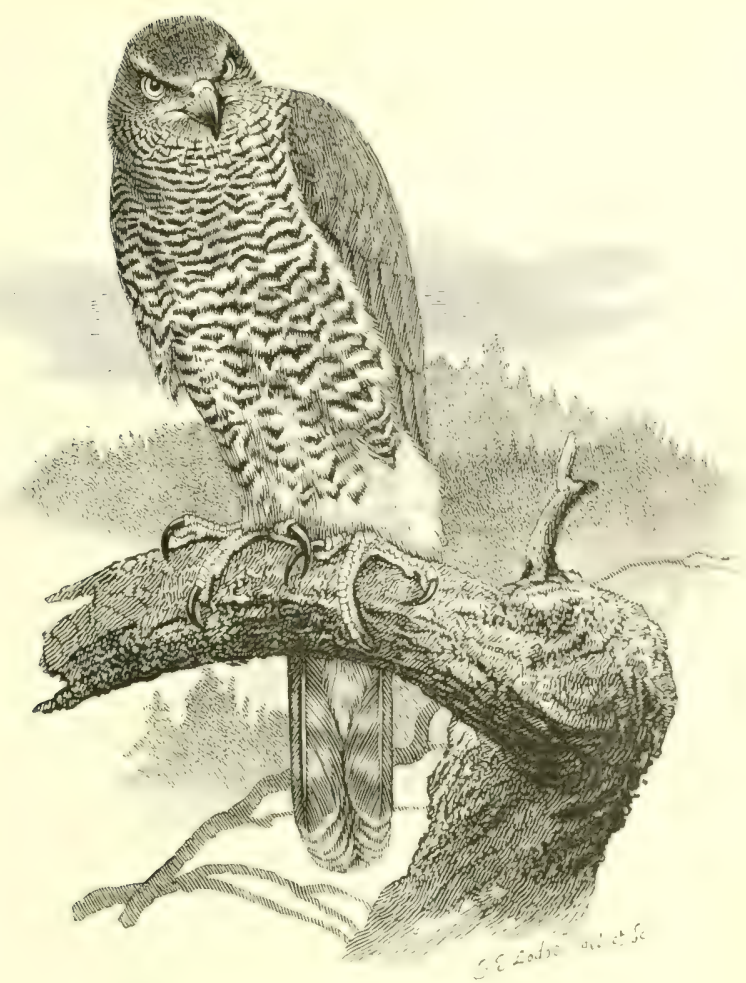

THE GOS-HAWK.

Ástur palumbárius (Linnzeus).

Adult examples of the Gos-Hawk (i.e. Goose-Hawk) are rarely obtained in the British Islands; but in autumn and winter, and sometimes in spring, immature birds have occurred, though at loner intervals. These visitors are, naturally, most frefuent on the cast coast ; but instances are on record from the vicinity of I.ondon, the southern, the midland, and even the western counties. In ticotland, the celebrated Colonel Thornton received at nestlmeg from the forest of Rothiemurchus, and saw some cyries in the old fir-woods in the valley of the Spey, prior to $1 S_{0}$; but there is no later proot that it has bred in any part of Great Britain. Against an assertion that it has nested in recent times in Kirkcudbrightshire, must le set the fact that neither Mr. R. Service nor the veteran taxiclermist Mr. Hastings have ever met with an example anywhere in the Solway district; and it must be remembered that in many parts of 
Scotland the Peregrine Falcon is called the 'Gos-Hawk.' It is unknown in Sutherland, and nearly so in Caithness and the Shetlands. In Ireland only three occurrences are authenticated.

The Gos-Hawk is common in the forest-regions of Scandinavia, and in those of Russia down to the Black and Caspian Seas; it is also abundant in the wooded districts of Germany and Central Europe generally, nor is it rare in many parts of France. In Italy and the Spanish Peninsula it is rather scarce and local, though it breeds as far south as Andalucia, and even in Morocco; while in winter it visits Egypt and Palestine. Eastward it ranges across Asia to China and Japan. The young are the clief migrants southwards from the northern districts; the adults only do so in very severe weather, when food becomes scarce.

Though the old nest of some other species is occasionally repaired, the bird frequently builds its own, which is a large structure of sticks, placed in a tree-generally on the outskirts of a forest or near a clearing. The eggs, laid in April or early in May, are usually 4 in number, and are pale bluish-grey, but when incubated they become dirty greenish-yellow, and occasionally show a few rusty or olive markings : average measurements 2.3 by $\mathrm{I} \cdot 8$ in. The same nest is used year after year. The Gos-Hawk is a bold and rapacious species, preying upon hares and smaller mammals, gamebirds and poultry; the shortness of its wing and the steering power given by its comparatively long tail enabling it to follow with marvellous rapidity every turn of its quarry, which it takes in a style called by falconers trussing. Its hearing is very acute.

The adult has a narrow white line above the eye and ear-coverts; upper parts ashy-brown; tail with four broad darker bars; under parts white, thickly barred with ashy-brown; cere, iris, and legs yellow. Male: length 20 in., wing 12 in.; female: length 23 in., wing $I_{t}$ in. The young bird has the upper parts brown, and five dark bands on the tail; under parts warm buff, with numerous drop-shaped markings of dark brown; iris pearl-white.

A specimen of the American ('js-Hawk, Astur atricapillus, saidon somewhat slight evidence-to have been obtained in Perthshire in 1869 , is in the Edinburgh Museum; and another, shot in Tipperary in 1870 , is in the Dublin Museum, where I have examined it. This distinct though nearly allied species, distinguishable by its closely freckled-not barred-under parts, is not likely to be a genuine visitor to the British Islands. 


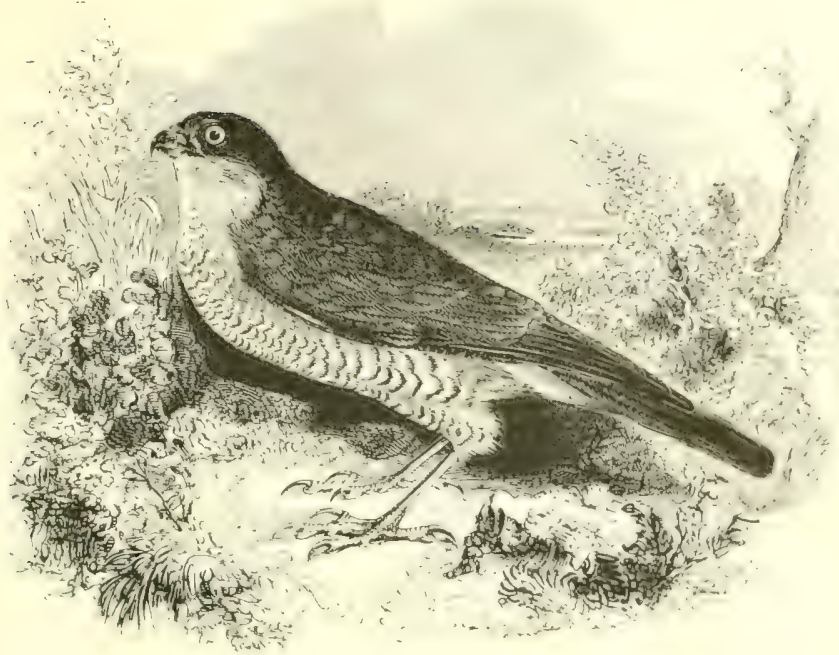

THE SPARROW-HAWK.

\section{AccípIter nísus (Linnæus).}

The Sparrow-Hawk is generally distributed in (ireat liritain from Sussex to Sutherland, and also in Ireland, wherever there are woodlands suited to its tastes. It is emphatically an arboreal species, and is, naturally, of rare occurrence in the ()rkness, shetlands, and Outer Hebrides, where the long-winged Kestrel often lears the name-as elsewhere it suffers for the delinquencies-of this dialing short-winged species.

In autumn the Sparrow-Hawk is frequently observed at our lishtships and stations on the east coast; and immense numbers some. times cross Heligoland on their way from higher lutitules-the young passing first, and the adults following. The loreding range extends as far north as the limits of foresterrowth, and southward it reaches to the Mediterranean; comparatively few. how ver. remain to nest in Spain or Italy, where this species is chiefly noticed on passage, when following the flocks of small lirds on which it preys. It is resident in the Canaries, North Africa, and Egypt as far as Assouan, and occurs as a migrant in Kordotan. In A tia it is foumel across Siberia to the l'acific and Japan. and coen hoceds, sparingly, as far south as Cashmere and the Himalayas, while in winter its range extends to the latitude of Canton. There are at least five members of this genus, all of which possess a well-derined gerstiph hi 
cal range; but the only one which need be noticed is the Levant Sparrow-Hawk, A. breitipes, which inhabits the area between Central Russia and Syria, and appears to be extending its range in a westerly direction; it may be recognized by its much shorter legs.

Like the Gos-Hawk, this species usually builds its own nestcomposed of sticks with a slight lining of twigs-and invariably places it in a tree, often on the branches close to the bole, or at the top: sometimes, however, it adapts and adds to the deserted abode of a Crow, Wood-Pigeon, or other bird. The eggs, $4^{-5}$ and occasionally 6 in number, are pale bluish-white, blotched, mottled. and often zoned with various shades of reddish-brown: average measurements $I \cdot 6$ by $I^{\circ} 25$ in. In this country they are generally laid early in May, at intervals of two days; and Mr. Montanu lirowne has recorded the case of a bird which was robbed of fourteen cyss in one season and fifteen in another, after which she was left unmolested. When urged by the necessities of a clamorous brood the Sparrow-Hawk is even more bold and rapacious than at other times, and is then especially dangerous to the young of game and poultry ; but the food consists principally of small birds, which it snaps up in an instant, as it glides with rapid though stealthy flint along hedges or the skirts of woods. Like all the other short-winged species, it feeds on the ground-usually under shelter of a bush or hedgerow, and the small close heap of feathers unmistakably marks the spot where it has dined; for, unlike the Falcons, the Hawks reçuire both feet to secure their quarry, and do not seem to know where its life lies, so that perching is awkward for them (I)elme-Radcliffe). In India and Japan it is still prized by the native falconers: and in this country it has been trained to take Quails, Partridges, \&c.

The adult male has the upper parts slate-blue, mottled with white on the nape: tail greyish-brown, with from three to five dark bars; cheeks and ear-coverts bright rufous; under parts buff, barred with reddish-brown : cere greenish-yellow; irides orange ; legs and feet yellow ; middle toe very long and slender. Length about $\mathrm{I} 2 \mathrm{in}$. The female is much larger. measuring about $\mathrm{s}$ in.; her breast is usually greyish-white, barred with brown, and there is a rufous patch on the flanks; when very old, however, she attains the plumage of the adult male. The young are brown above, with rufous edges to the feathers; and the under parts are white, with rufous-brown bars, so broad on the throat as almost to deserve the name of spots; iris pale yellow. Few birds however, vary so much in plumage and in size as the SparrowHawk. 


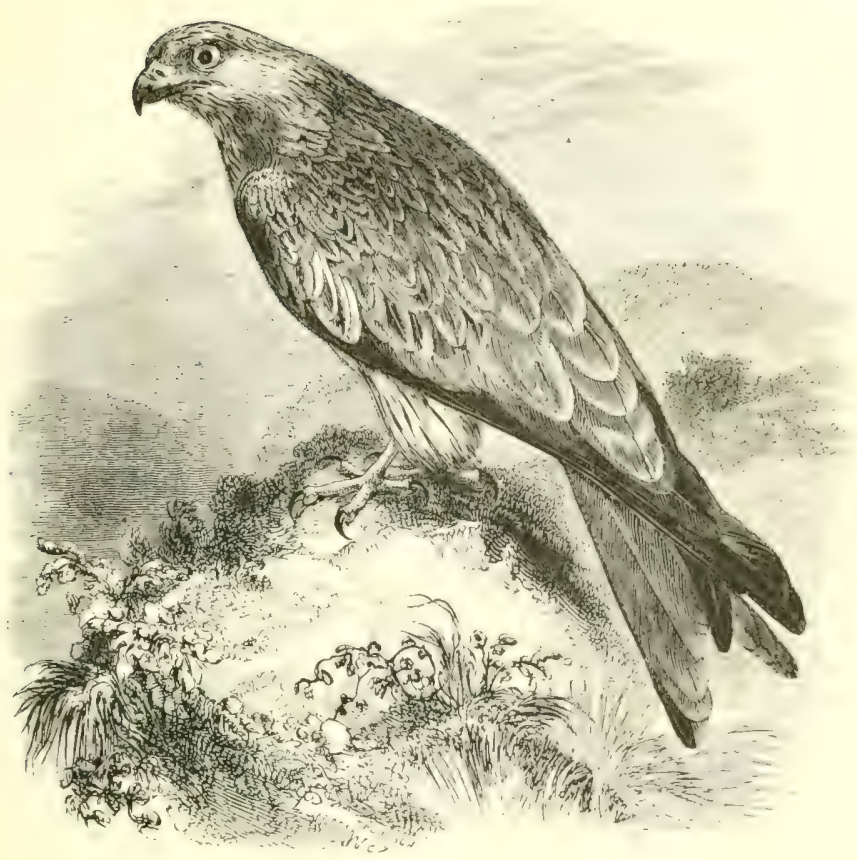

THE KITE.

\section{Mílvus icrínus, Savigny.}

This species-formerly known by the old Anglo-Saxon name of Gled or Glead, in allusion to its gliding flight -may. from the colour of its tail and upper plumage, be called the Red Kite, whencter the necessity arises for distinguishing it from its conseners. In the fifteenth and sixteenth centuries the Kite was so abundant as a scavenger in the streets of London as to attract the attention of foreign visitors, and within the recollection of living persons it was tolerably common in many of the wooded districti of Fnyland, Wales and scotland; but for many years it has not hecen known to breed in the southern counties. The last nest known in l.incolnshire -a former stronghold-was in I870; and in the few spots still inhabited in Wales and the Marches, it will soon be culcminated by the collector of Pritish specimens unless the srenteve caution is observed. In Scotland it survives in a few localities; but there the value of its tail-feathers for salmon-flies adds to the risk which it elsewhere incurs from the gameleeper. At long intervals single birds or pairs--wanderers from the fintinent-are 
observed on the eastern side of Great Britain; but as the Kite does not often migrate in a westerly direction, the gaps left by the destruction of our indigenous birds have little chance of being filled. In Ireland, according to Mr. More, it has only been observed five or six times.

In Scandinavia the Kite is not known to breed north of lat. $61^{\circ}$, whence it emigrates on the approach of cold weather; as it does also from Ienmark and Germany, where it is common in summer. In Russia it is not found to the east of the Governments of Tula and Orel, or of the river Dnieper. Over the rest of Europe it is generally distributed, and in most of the countries washed by the Mediterranean it is common and resident in suitable localities; as it is also in the Canaries, Madeira and the Cape Verd Islands. It is not rare in North Africa as far east as Tunis, though in Egypt it is represented by $1 /$. cerptius ; it breeds, however, in Palestine and Asia Minor, while most abundant there in winter.

The nest, which is almost always placed in a tree-though in North Africa it has been found in rocks-is composed of sticks, mixed with a rariety of rubbish - such as bones, fragments of newspaper, old rags, and the "lesser linen" for which the Kite exhibits a predilection well known to Shakespeare. The eggs, laid in April or early in May, and rarely more than 3 in number, are dull white or very pale blue, spotted, blotched, and sometimes streaked with reddish-brown: arerage measurements $2 \cdot 25$ by $1 \cdot 75$ in. Its food is offal, small mammals, birds, reptiles, frogs, and fish; but though the Kite is destructive to very young game and poultry, especially when it has to satisfy a brood, and is, at times, bold enough, it is not a powerful species; and the old Grouse which have been found in its nest in scotland, were probably sickly birds, or had been robbed from the Peregrine. On the wing the wide circles of its flight are remarkably graceful; either side of the outspread forked tail being raised or depressed at will, and serving to govern the bird's course. In the search for prey a large extent of ground is daily covered. The cry is a shrill whéw, heh-heh-hich.

The adult has the head and neck white, striped with black; mantle rufous-brown; primaries blackish; tail rufous and much forked; under parts rusty-red, striped with dark brown on the breast; under side of wings whitish with a dark patch (very conspicuous in flight); legs and feet yellow; iris yellowish-white. Length about 24 in. The male is a little smaller than the female, but his colours are brighter and his tail is longer and more forked. The young are paler and more mottled on both upper and under parts. 


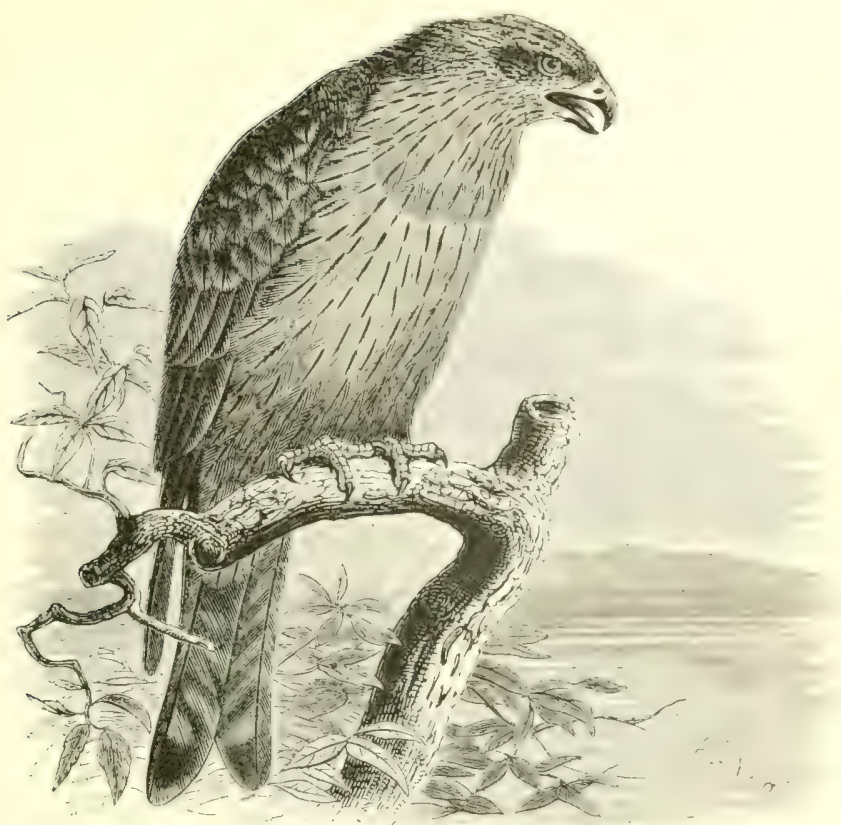

THE BIACK KITE.

\section{Milvus MíGRANs (Boddaert).}

The term 'Black' is by no means inapplicable to this bird as observed flying, when the dark under-surfaces of the wings and the general sombre hue of the plumage are very noticeable; the tail is also much less forked than in the Red Kite. Although a regular summer-risitor to the valleys of the khine and the Mosille, and other districts of the Continent at no grent distance from our shores, yet the Black Kite has only once occurred in Great Britain. This was an adult male, now in the Newcastle Muscum, which had been taken in a trap in the deer-park at . Mnwick, and wals brought in a fresh state to Mr. John Hancock on May I Ith i 866.

In Scandinavia this species has not been obtained, but it arrives on the southern side of the Baltic about the end of March, and leaves again in September; while, on migration, it occurs annually on Heligoland. (Owing to its partiality for marslay forent. open valleys and the vicinity of water, it is somewhat local in its distribution; but it breeds regularly, in suitable Jucalities, in (icrmans. Switzerland, and the southern half of France. In Spain it is very 
abundant from the beginning of March until October, but it is not numerous on the mainland and islands of Italy and in Greece, though it is generally distributed over Central Europe and found in Russia from Finland and the province of Archangel down to the Caucasus and the Caspian Sea. East of the Ural Mountains the representative species is $M$. melanotis, in India it is $M$. goolinda, and in Egypt the resident bird is the yellow-billed M. agyptius; but the Black Kite appears to pass through the latter country on its migrations, which extend to the south of Africa, and even to Madagascar. It breeds, and probably remains throughout the year, in Africa north of the Atlas, where it frequents more arid and rocky districts than in Europe.

The eggs, seldom laid before the beginning of May, are usually 2 in number, similar in appearance to those of the Red Kite, but rather smaller. In Algeria the nest-made of materials similar to those used by its congener-is frequently placed in a crag, particularly one studded with bushes or shrub; but in Europe towers, ruins, and especially trees, even in populcus towns like Pera, are selected, and I have found ten or more nests in a small patch of marshy wood. At Bayonne the Black Kite may be seen crossing the streets, steering its way carefully among the telegraph wires, and picking up from the river offal or small fish. The latter, which it often devours while on the wing, form a favourite article of diet; reptiles, frogs, small birds and mammals are also consumed; but the bird is chiefly a scavenger and does little harm. I have seen it feeding greedily on grasshoppers.

The adult has the head and throat whitish, streaked with black; upper parts dark brown; under parts rufous-brown; bill black. Length about $22 \mathrm{in}$. The young bird is duller in colour, and the upper feathers have pale edges.

An undoubted example of the American Swallow-tailed Kite, Elanoides furcatus, was taken alive during a heavy thunderstorm, near Hawes in Yorkshire, on September 6th $\mathrm{I} 805$, but afterwards made its escape. There is no other authentic record of the occurrence of this species in Great Britain, or in any part of Europe; it chiefly inhabits the tropical portions of America, and there is reason to suppose that the bird in question had been in confinement.

I have examined an immature specimen of the little Black-winged Kite, Elanus carulcus, said to have been shot about 1862, in co. Meath; but it was unrecognized for ten years, and the evidence is not wholly satisfactory. The species is semi-tropical. 


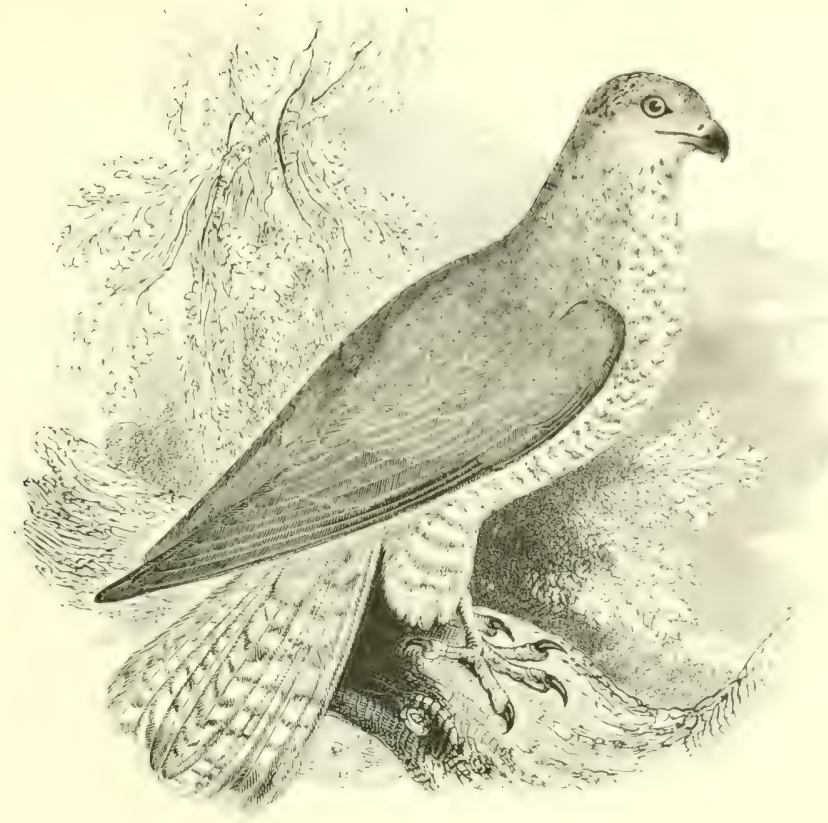

THE HONEY-BUZZARD.

Pérnis APÍVORUs (Linnrus).

The Honey-Buzzard is a regular visitor for breeding purposes to those wooded districts of Europe which lie between $43 \mathrm{~N}$. lat. and the Arctic circle. A certain number visit Great Britain in May and June, and the fact that some remain to nest with us has leen known since the days of Willughby; while, on the return passage in autumn, examples, mostly young, have been obtained in Ensland up to the latter part of November; and on the east coast of Scotland according to R. Gray-instances have even occurred in the depth of winter. To Wales and the neighbouring side of Fngland it rarcly wanders. but it has bred as far west as Ifereforelshire, and its nests have been found at intervals in various counties, from I Iampsisire to Aberdeenshire. About i 860 it was known that ecveral pairs annually resorted to the New Forest; f $_{5}$ soon became the standiard price which collectors of 'British' specimens were willing to pay for a couple of well-marked eggs; and to these inducenents were aciled such extravagant sums as nearly $E_{4} 0$ for the pair of old birds. liy about I 870 the birds which had not been killed were driven away ; and it 
any have since returned, the persons acquainted with the fact have exercised a becoming reticence on the subject. To Ireland this species is a very rare visitor.

In Norway the Honey-Buzzard does not range beyond the southeastern districts; but in Sweden, Finland and Russia it extends its migrations up to, and a little beyond, the Arctic circle. Southward it is distributed throughout Europe during the summer, down to Bulgaria, the northern portions of Italy, the Pyrenees, and the mountain forests of the north of Spain; but in the rest of the Peninsula, and, in fact, throughout the Mediterranean region, it is principally, if not entirely, a migrant. Very large flocks have been observed traversing the Straits of Gibraltar from Morocco early in May, and repassing in September; but in Algeria, and eastward to Egypt, it is of uncommon occurrence, though it has been obtained in winter as far south as Natal and Madagascar. Nor is it abundant in Arabia or Palestine, though numbers cross the Bosphorus to and from Asia Minor. Eastward it can be traced through Turkestan and Sideria to Northern China and Japan; its representative in the Indian region being the Crested Honey-Buzzard, $P$. ptilorhynchus.

The nest, usually placed upon the remains of that of some other large bird, and often in the main fork or an oak or a beech, is well lined, and sometimes sheltered, with fresh twigs and leaves of the latter. The eggs, laid in June, are generally 2 , sometiues 3 , exceptionally 4 in number, and are round and glossy; their colour is creanywhite or buff, blotched and often deeply suffused with rich brown or red: average measurements $1^{\circ} 9$ by $\mathrm{I}^{\circ} \mathrm{T}$ in. Both male and female incubate, the sitting bird being regularly fed by the other. Wasps, wild bees and their larra form the principal food of this species in summer, but other insects are also eaten, as are, occasionally, birds, mice and other small mammals, slugs and worms. Owing to the thickness of the foliage at the time of its risits, and the fact that its prey is chiefly obtained on the ground, this species is by no means conspicuous, except on passage. Its cry, seldom uttered, is a shrill kee, kee, kee.

The adult male has the head ash-grrey; upper parts brown; three conspicuous blackish bars on the tail; under parts white, barred and spotted with brown on the breast. The female is slightly larger, but has no grey on the head. Length from 22 to $25 \mathrm{in}$. The young bird has a whitish head and pale edges to the upper feathers; the under parts being white streaked with brown: a dark brown form, however, frequently occurs. 


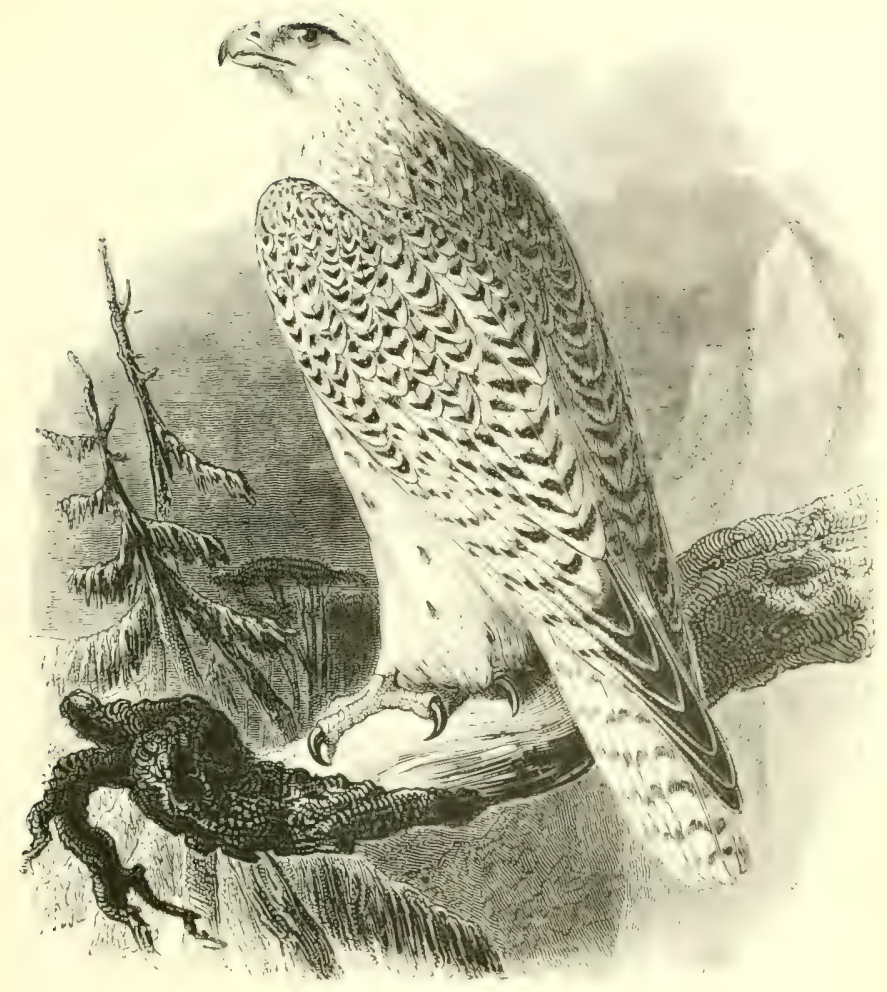

THE GREENLAND FALCON.

Fálco cándicans, J. F. Gmelin.

Considerable difference of opinion still exists respecting the specific distinctness of the large Northern lalcons, for which some systematists have adopted the genus Ilierofalco; but Mr. John Hancock was the first to show that in the present species the prevailing ground-colour is white at all ages, whereby the Greenland Falcon may always be distinguished from the Iceland fiaken, or any other member of the group. For a long time all these members were included under the title of 'Gyr' Falcon; it is therefore impossible to say how many of the earlier records refer to the true Greenland Falcon; while sone of the lirels respecting the speritis identity of which there can be no doubt, are suspected of having escaped from establishments deroted to fithonry. There is, howerer. ample evidence that wild examples of the (ircenlund Falcon have 
from time to time been taken in the British Islands, in winter; naturally, with greater frequency in scotland and the northern districts of England than in the south, though an immature bird, the subject of the present figure and now in the British Museum, was shot in Pembrokeshire, and examples have been obtained in Sussex and Cornwall. Ireland, as might be expected from its geographical position, has not been unfavoured, and no fewer than eight specimens were obtained at different points along the west coast in the winter of $188_{3}-4$.

The Greenland Falcon breeds in the northern portion of the country from which it takes its name, and Mr. Chichester Hart, the naturalist to H.MI.S. 'I)iscovery,' saw a pair nesting on Grinnell Land, in $79^{\circ}+\mathbf{1}^{\prime} \mathrm{N}$. lat. ; while westward it can be traced to Alaska, and across Bering Straits to the winter quarters of the 'Vega' on the Asiatic side; and in spring to the Amur. The record is defective as regards Arctic Siberia, and no example has been obtained from Novaya Zemlya, although this species occurs on Spitsbergen. Turning to Europe, the difficulty of distinguishing the 'Gyrs' recorded on migration becomes extreme; but undoubted examples of the Greenland bird have been obtained as far south as the French side of the Pyrenees.

The eggr, sometimes + in number, are pale reddish-orange in ground-colour with darker mottlings and spots, measuring about $2^{\cdot} 2$ by I' $S$ in., and are placed on a bare ledge of rock, or on the old nest of some other bird. This species is said to visit Iceland in winter, though Mr. B. Gröndal has never met with it there; thence, however, were brought the 'white falcons,' accepted as tribute or as gifts worthy of royalty in the Xidd?e Ages. The food consists of Ptarmigan and Willow Grouse, lemmings and other mammals; but owing to the scarcity of prey in the high north, this species is necessarily forced to migrate southward more often than its congeners.

The adult is white with blackish bars or blotches on the upper parts, the under parts being pure white or only slightly spotted; but the individual variation is very great. In the first plumage the markings are brownish and very broad above, but drop-shaped below, the tail being more or less barred. The adult dress is assumed at the first moult, and never varies afterwards. Length of the male $2 \mathrm{I}$ in. ; of the female 23 in.; wing ${ }^{5-I} 6$ in. Cere, legs and feet pale yellow in the adult; light bluish-grey in the young. In this, as in all true Falcons, the irides are dark hazel-not yellow, as in the Hawks. 


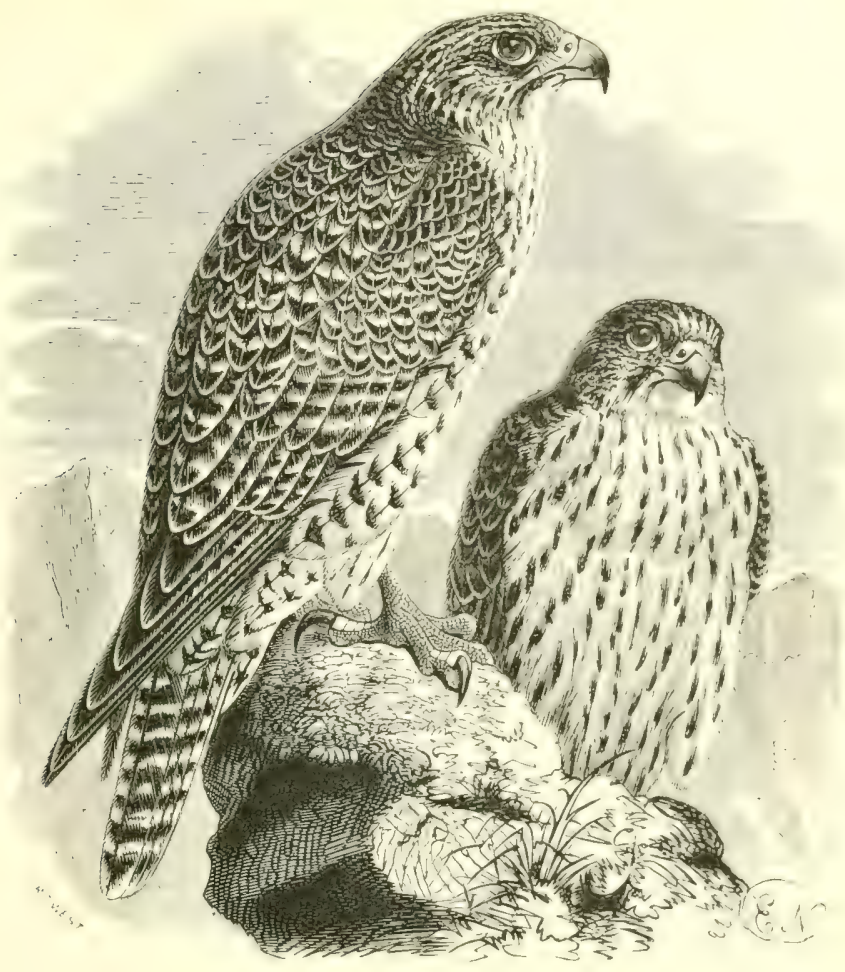

THE ICELAND FALCON.

Falco islándus, J. F. Gmelin.

In the Iceland Falcon the prevailing colour is either brown or grey, according as the bird is young or old. The occurrences of this species in the British Islands appear, so far as cridence gres, to be less frequent than those of the Greenland Falcon : but identi. fied specimens have been obtained in several localities on the mainland of Scotland, and in the Hebrides, includings skye and Islity; also in Northumberland, Yorkshire, and on Iferm in the Channel Islands. In Ireland genuine examples have been captured in Ionegal, Antrim, and near lisimullet and Ilestport in co. Maye - the last in 1883 .

The typical form of this Falcon inhabits Iceland, where it brecels in the precipitous cliffs above the numerous lakes-especially near My-vatn, whence the late W. Proctor of Durham used to receive eggs and a few skins almost crery year. after his visit to that locality. 
It also frequents the southern portion of Greenland, where a paler form is distinguished by Mr. Sharpe as F. holhoelli. In Labrador the representative species is a very dark brown bird, and easily recognizable. The fells of Norway and Sweden are occupied by a smaller form, identical in pattern of plumage, but somewhat greyer and darker with more defined moustache, and this Scandinavian bird is the true $F$. grrfolco of Linnaus; yet with immature examples, and sometimes with adults, it is in many cases difficult to draw the line of demarcation, and I have known an old female, shot from her nest in a pine-tree on the Dovre-fjeld, pronounced to be a 'typical Icelander' by an eminent authority. In the collection of Mr. W. Borrer is a bird shot in Sussex in January $18+5$, and originally recorded by MIr. Ellman as immature, but which has been identified by Mr. Gurney as a fully adult F. Elyfalco; to this form, also, Mr. Seebohm refers a young example obtained at Orford, Suffolk, in October i $\$ 67$. In Northern Siberia yet two more 'species,' which are, in my opinion, identical with the Iceland form, have been dis. tinguished by some of the Russian ornithologists; while in Alaska the Grey Falcons have been referred by Mr. (iurney to F. islandus, and subsequently to $F$. grrfalco, or even to possible hybrids between F. syrfalco and $F$. holboelli.

In Iceland the eggs, $3^{-4}$ in number, and similar in size and appearance to those of the Greenland Falcon, are deposited on the ledge of a cliff, or on the former abode of some other bird, frequently a Raven; in Norway, according to Prof. Collett, an old nest in a tall fir-tree is generally selected; while in Lapland most of the eggs obtained by Wolley were from rocks. The food consists of water-fowl and other birds-largely of various Arctic species of Grouse, which are captured on the wing. All these Northern Falcons were formerly esteemed for hawking, as they still are by the Mongol races; their style of flight is magnificent-much swifter than that of the Peregrine--and both are deadly 'footers' (i.e. tenacious of grip), but they lack spirit and dash.

The adult is represented by the front figure in the engraving; the prevailing colour of the upper parts being brownish-grey on a creamy ground, while the under parts are of a purer white; the bill is horn-colour, the legs and feet are bluish. The young bird (in the rear) is ashy-brown above, while the under parts are marked with dark drop-shaped spots. Length of the female 25 in., of the male $2 \mathrm{I}$ in. There is great individual variation; moreover the Iceland and the Greenland Falcons interbreed at times, and a remarkable hybrid belonging to Col. E. Delmé-Radcliffe is in my care. 


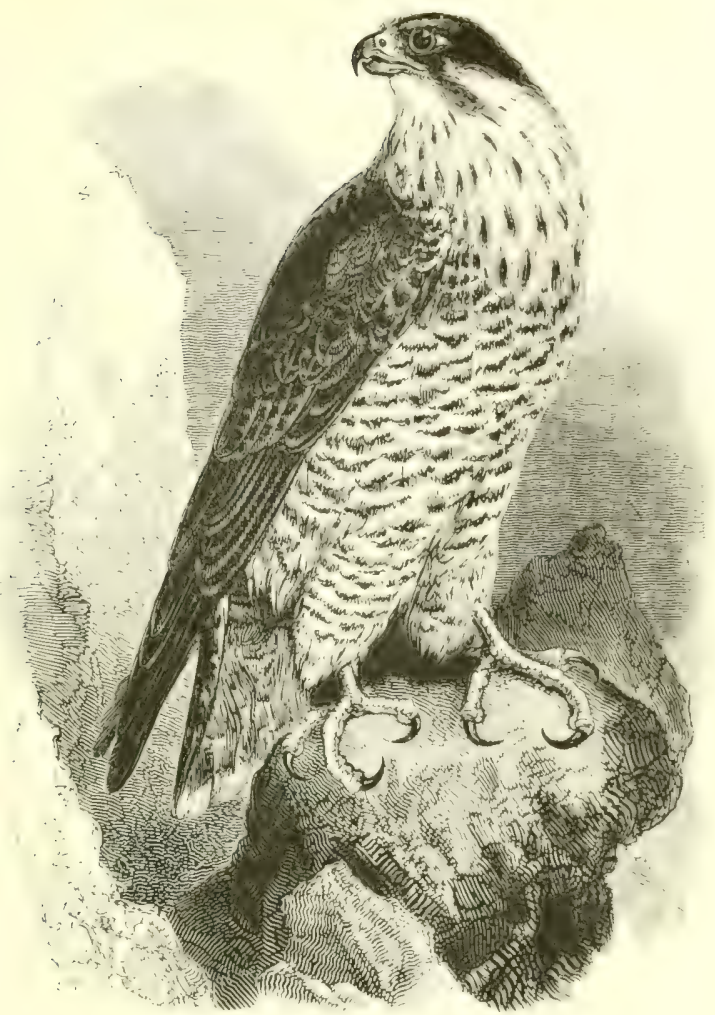

THE PEREGRINE FALCON.

Falco peregrínus, Tunstall.

This fine species, the Falcon, par excellence, of those devoted to the ancient sport of hawking, is still one of the most abundant of our diurnal Accipitres: and considerable numbers of immature birk. technically known as Passage- or Red Hawks, annually occur throughout our islands-especially on the eastern side-between autumn and the following spring. From some of its former breeding-places it has undoubtedly heen hanished; but eyries may still be found-though many of them are yearly robbed-from Kent to Cornwall, and, more frequently, along the west coast and in Wales; while in the mountainous districts of the north of England they are on inland-rocks as well as sea-cliffs. In Scotland, although much persecuted on account of its iestructiveness to game, the Peregrine is gencrally distributed throughout the 
mainland and the islands, as far as the Shetlands. In suitable localities in Ireland it may be considered a common bird; and though, as a rule, each pair asserts its supremacy over a tolerably wide area, yet eyries may there be found in proximity.

To the Froroes the Peregrine is a rare visitor, and it does not occur in Iceland, though it breeds regularly in Greenland up to about $70^{\circ} \mathrm{N}$. lat., and on Cumberland Island, across Davis Strait. On the mainland of North America it is represented by F. anatum, a closely-allied species with ruddier breast. In Europe it is found from Scandinavia and Novaya Zemlya down to the Mediterranean; but in the basin of that sea our larger form is only known in winter; the residents being of a small race, F. punicus, and in North Africa the still smaller red-naped F. barlanus. Across Asia the Peregrine-allowing for sub-divisions which some authors consider species-is found as far east as Kamschatka, the Kuril Islands, and Japan: in fact, under one form or another, it is met with almost all over the world.

This Falcon never builds a nest for itself, but deposits its eggs, usually in April, on some overhung ledge of a cliff covered with a coating of earth, in which a hollow is scratched; or on the old nest of a Raven, Crow, Heron \&c., in rocks or trees; also in churchtowers and steeples, and on the ground in Lapland and Siberia. The eggs, $2-4$ in number, vary from freckled orange-brown to rich brick-red: average measurements ${ }^{\circ} 9$ by 1.6 in. The same spot is resorted to year after year, and should one of the birds be killed the survivor soon finds another mate. The young are driven away by their parents in August, and in autumn numbers used to be captured on the moors near Valkenswaard in Holland, for hawking. The Peregrine varies its diet according to locality and individual taste; preying on ducks, waders, sea-fowl, pigeons, grouse, partridges, and even Kestrels, Choughs, Magpies, Jays \&c. ; while it sometimes sweeps rabbits off the side of a cliff. In many districts it is known as the 'Hunting-Hawk,' and, erroneously, as the 'Gos-Hawk'; by falconers the male is called the Tiercel (corruptly Tassel), and the female the Falcon. The cry is a loud and repeated hek, hek, hek.

Adult: crown, cheeks and moustache blackish; upper parts slate-grey (paler on the rump) with darker bars; under parts buffishwhite to warm rufous, barred with a very variable amount of black;

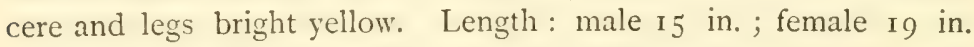
Young: upper feathers brown with buff margins; under parts ochreous, with dark brown streaks; cere and legs livid. 


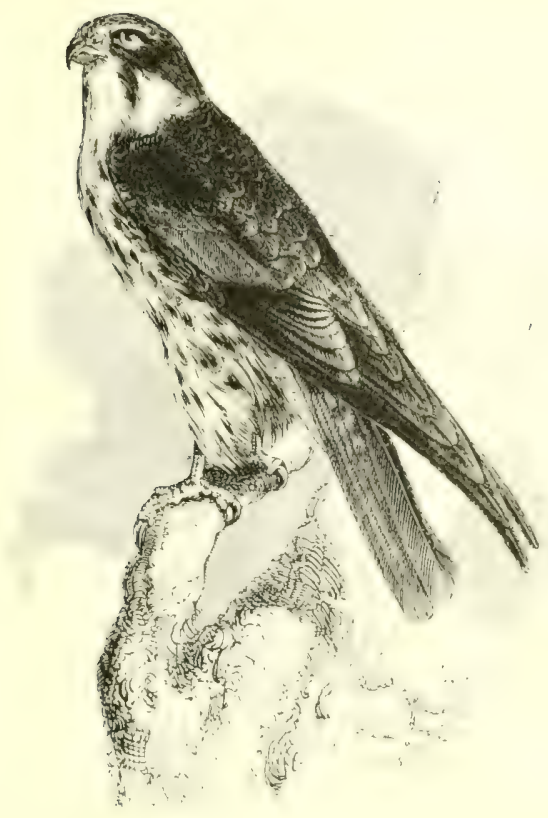

THE HOBBY.

Falco subrúteo, Linnæus.

The Hobby belongs to a group of Falcons (Hypotriturhis of man! authors) characterized by remarkably long wings, comparatively short tail, and soft plumage. It is a regular summer-visitor to the north of Europe, arriving in England in small numbers about the latter half of May: and at irregular intervals it has been found breeding in most of the southern counties, especially in Hampshire : at one time with tolerable regularity in Essex; less frepuently in Cambridgeshire and Suffolk; not uncommonly in Norfolk and Lincolnshire; occasionally in the midlands, and exceptionally in lorkshire: while in Cornwall, Wales, and the west it is scarce. In Scotland it is rare and has never been known to nest, though on migration it hals been taken as far north as Caithness and sutherland. In Ireland six examples have been obtained, five of them in May or June.

The Hobby has been recorded as far north as the Arctic circle in Lapland, and in Russia it is found throughout the wooded districts from $65^{\circ} \mathrm{N}$. lat. down to the mouth of the Volga; but in no part of the Continent does it remain during the cold seaton. 
South of Scandinavia it is generally distributed over Europe to the Mediterranean, though most numerous from Bulgaria eastward; it nests in the pine-woods in the extreme south of Spain, and visits the Canaries, Morocco, Algeria and Egypt, though rare in the last. From Asia Minor we trace its summer-range eastward to Kamschatka, and southward to Cashmere; while in winter it occurs in China, North India, and South Africa down to Damara Land; in the Indian region, however, the resident species is F. sererus, and in South Africa F. cuiveri.

The Hobby is a very late breeder, seldom having eggs before the early part of June, and often not till the end of that month. It never makes a nest for itself, but occupies one which has been built in a tree by a Crow, Magpie, or other bird. The eggs, usually 3 and exceptionally 5 in number, are often yellowish-white, closely freckled with rufous, and can then be easily distinguished from those of the Kestrel; but sometimes they are suffused with reddishbrown and are therefore not so recognizable: average measurements $I^{\circ} 6$ by $I^{\prime 2} 5$ in. Previous to laying, the female is much addicted to brooding on an empty nest or upon eggs of the Kestrel ; and careful observers, who were unaware of this fact, have been led to believe that a nest from which the Hobby had been seen to fly really belonged to that bird, when it did not. Although it can seldom be kept in captivity for any length of time, I have known an instance of one, taken as a nestling in 1849 , which lived for fifteen years. Dragonflies are a favourite food, and these, with cockchafers and other insects, form its principal prey in summer; but it also devours small birds. It is the terror of Swallows and Martins, which its dash and rapidity of flight enable it to capture on the wing; Larks (for the pursuit of which it was used by falconers) are especially subject to its harassing attacks in autumn, when it leaves the woodlands and frequents the more open country; and it will also accompany sportsmen and seize Quails in front of them.

The adult has the upper parts dark slate-grey, with a black moustache-like streak; cheeks and throat white; under parts buffish-white, broadly striped with black; vent and thighs r!nsty-red; cere, orbits and legs yellow. The sexes are alike in plumage, but the female is less vivid in colour, though larger in size. Length: male 12 in.; female $r_{4}$ in. The young bird has the crown of the head mottled with buff, and a decided tinge of that colour on the cheeks and under parts; the upper feathers are brown, edged with ochreous-white, and the tail has a broad pale tip; while the vent and thighs are only pale rufous. 


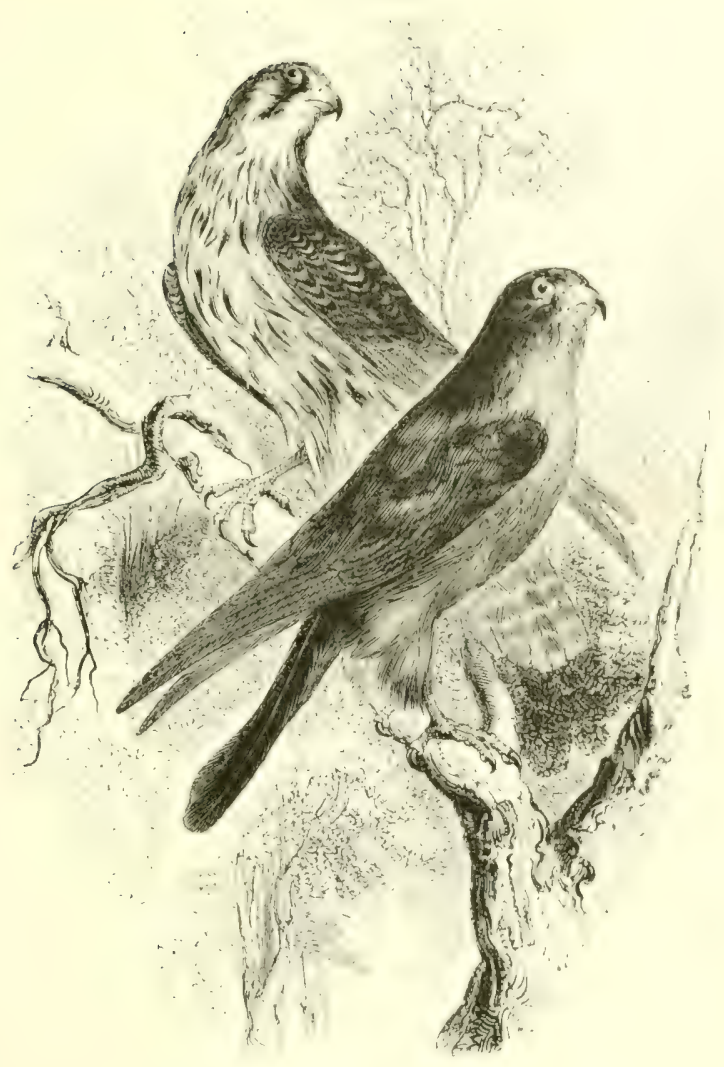

THE RED-FOOTED FAI,CON.

Falco vespertínus, Linnicus.

This small species, otherwise known as the Orange-legged Hobby, is, like its predecessor, a summer-visitor to liurope: in the eastern portions of which it has an extensive northern range. though in the west its appearance is irregular. Upwards of twenty examples have been recorded in the British lslands since I8 3 , when its appearance was first noticed in Norfolk, where. up to the present time, seven specimens have been olitained: suffoll. Berks, Surrey, Kent, Sussex, Hants, Wilts, I)von, ('ormwall, I len bighshire, Salop, Yorkshire, I)urham and Northumberland have each been visited by it ; in Scotland one was shot in . Merelemshire in May IS66; and in Ireland another, now in the I)ublin Muscum. 
was taken in co. Wicklow during the summer of I $_{32}$. MIost of the authenticated occurrences have been in spring or summer, with a few in autumn.

The Red-footed Falcon has been found in the south of Sweden, and as far north as lat. $65^{\circ}$ in Finland; while in Russia, below that parallel, it is generally distributed, though Dr. Menzbier thinks that it has only extended its migration to the northern provinces within the last forty or fifty years. During the same period a gradual diminution in its numbers-as a breeding species--has taken place in the south: where, especially near Odessa, immense flocks used to arrive early in April and afterwards disperse, reuniting in autumn, previous to departure. On the steppes of Orenburg this decrease partially coincides with a remarkable immigration of the Lesser Kestrel, previously a very rare bird there. The Red-footed Falcon is found in Siberia as far as Krasnoiarsk; but to the eastward our bird is represented by $F$. amuronsis, the adult male of which is white beneath the wing instead of grey. On migration the Redfooted Falcon is found in Asia Minor, Turkey, Greece, Nalta and Italy; in the I)anubian provinces and Hungary it breeds in considerable numbers; but westward it is only a straggler, and in Spain it is rare. In winter it is found in Africa down to Damara Land.

In May or June this species appropriates the nest of a Crow, Magpie or Rook, in which it deposits +6 eggs, of a yellower red than those of the Kestrel and smaller in size: average measurements $I^{\circ} 45$ by $I^{\prime} I 5$ in. Five or six nests so occupied may be found in one tree; and in its general habits also this Falcon is remarkably gregarious, numbers roosting close together. The food consists chiefly of dragonflies, large moths, beetles, grasshoppers and other insects; also of lizards and field-mice. The flight resembles that of the Kestrel, and lacks the dash of that of the Hobby; the note is a clear, shrill $k i$, often repeated, especially towards evening, at which time it usually seeks its prey.

The plumage of the male adult is nearly uniform lead-grey, except the thighs, vent and under tail-coverts, which are rich chestnut; under wing-coverts dark grey; bill dark horn-colour; cere, orbits, legs and feet reddish; claws nearly white. Length i I 5 , wing 97 in. In the female the head, nape and under parts are dull chestnut; upper parts ash-grey, barred with black on the mantle and tail : length $\mathrm{I} 2 \mathrm{in}$, wing $\mathrm{Io}$ in. The young bird resembles the female, but the throat is whitish, and the rufous tint is less pronounced; the under parts are streaked with brown, and the outer tail-feathers are barred on both webs. 


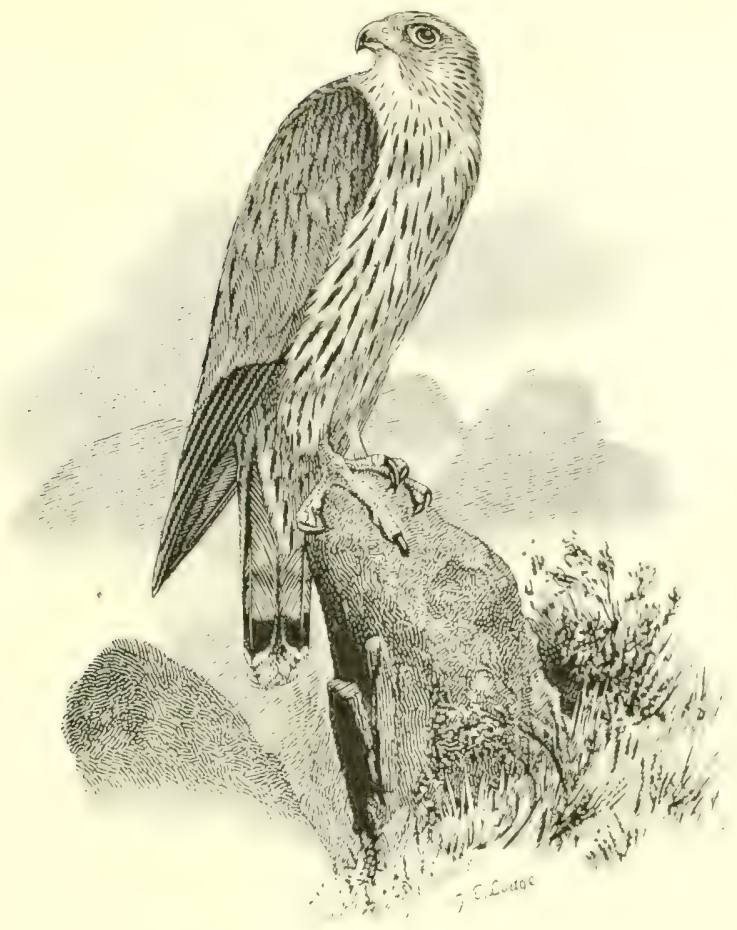

THE MERLIN.

FaLco ésalon, Tunstall.

The Merlin, the least of the British lialcons, breeds annitally on our moorlands; and though these are few and restricted in the south, there can be little doubt that a few pairs nest on Lixmoor. while in many parts of Wales its nest has often been found. Beyond Derbyshire it is generally distributed, in suitable lucalities, up to the Shetlands, where it is common; and in Ireland it is tolerably frequent in the mountainous districts. In autumn it descends to the low grounds, hays and coasts, where snipe. I hunlins and other waders, with small birds, form an abundant juey : while during the winter it is generally distributed throughout the british Islands, but the examples then obtained are chichly immature:

The Merlin is a resident in the Færoes, but only a summervisitor to Iceland; yet an example has been taken at sea not far from the coast of Greenland, and one actually at Cape larewell, in

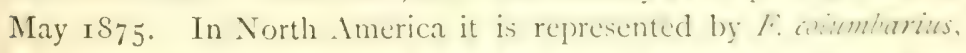
with fewer bars on the tail-a figure of which apyears to hawe heen 
given, in error, for that of the Old World species in Yarrell's 'British Birds.' In Scandinavia, where it arrives in April, the Merlin is common in the northern districts until October; and in Russia it has been found as far as Novaya Zemlya, though in the Ural Mountains it is not known to breed north of lat. $57^{\circ}$. It nests in Central Russia, the higher regions of Germany, the Alpine districts of Central Europe, and the Pyrenees; but elsewhere it is only known on passage, and in winter; the proportion of adults to immature birds being unusually great in the basin of the Mediterranean, from Spain to Greece, During the cold season it inhabits North Africa and abounds in Egypt, its migrations extending to Nubia and Sennaar. Eastward, it frequents the northern portions of Asia in summer, wintering in Northern India and Southern China.

In the British Islands the nesting-place is usually a mere hollow scratched in the moorland, often in the side of a bank, and it is but seldom that even a few twigs of heather are found as a border. In the Froes, and also in the Pyrences, ledges of precipitous cliffs are resorted to; while in Scandinavia frequently, and in scotland occasionally, an old nest of some other species, built in a tree, is utilized. The eggs, laid in May, are 4-6 in number; their usual colour is deep reddish-brown or purplish-red, without gloss : average measurements $I^{\circ} 5$ by $I^{\prime} 2$ in. Mr. Booth says that he has never known the Merlin take unfledged birds of any kind, and although it has been asserted that its brood is fed with young Grouse, its chief prey consists of Iunlins, Meadow-Pipits, Thrushes, Larks dic. It has been seen in pursuit of a swallow, whose rapid evolutions it followed as if mored by the same impulse; while by falconers it was, and still is, used for flying at Iarks; in swiftness, however, it does not approach the Hobby, or even the wild l'eregrine. Owing to its habit of perching on rocks, it is known in some parts as the 'Stone Falcon.'

Adult male: crown and upper parts slate-blue, with black shaftstreaks; throat white; nape and under parts rufous, striped with dark brown; tail bluish-grey, broadly banded with black near the end and tipped with white; cere, legs and feet yellow. Length Io in. ; wing 7.5 in. Female : upper parts dark liver-brown; tailfeathers brown, crossed with five narrow paler bands and tipped with white; nape, cheeks and under parts dull white, streaked with brown. Length $\mathrm{I}_{2}$ in.; wing $85_{5}$ in. Old females sometimes attain the male plumage. The young resemble the female, but are more rufous in tint. 


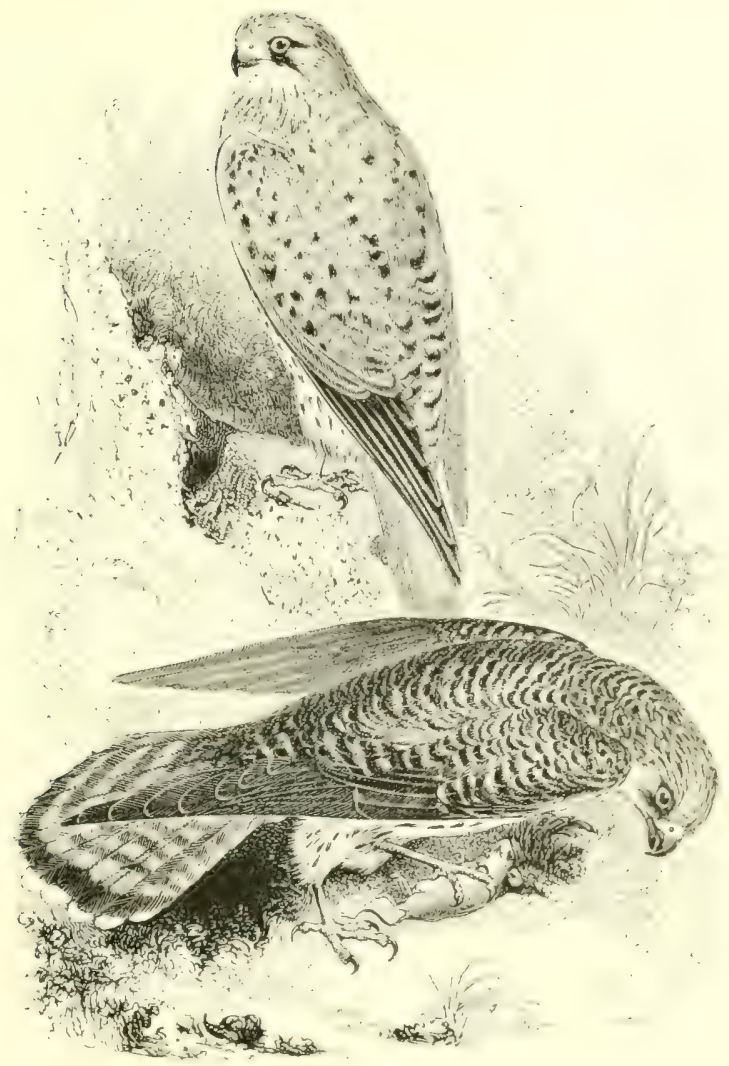

THE KESTREL.

\section{Falco tinnúnculus, linneus.}

The Kestrel-also familiarly known as the Wind-hover, from its habit of hanging almost motionless in air, against the wind-is the most abundant of the British birds of prey : and would l $x$ still more numerous than it is, but for its irrational persecution by persons who ought to be aware that it feeds principally upon mice, and is, therefore, one of the best friends of the agrieulturist. It is sencrally distributed throughout the United Kinglom: but in sondund, where its harmiessness and utility are now recosniced by the more intelli gent gamekeepers, it migrates, as a rule, from the monthern district in winter; at which season its numbers in lingiand are still furthel increased by visitors from the Continent. 
To the Freroes the Kestrel is only a wanderer, and it has not been obtained in Iceland; but on September 27 th I $S 87$ a female was shot near Nantucket, Massachusetts, and examined in the flesh by Mr. C. B. Cory. In Scandinavia its eggs have been found even as far north as lat. $68^{\circ}$; but there, and in Finland, it is rare near the limit of its range, while in Russia its occurrence at Archangel is accidental ; throughout the rest of Europe, however, it is common, migrating more or less from the northern districts in winter, but residing during the entire year in the south. Nowhere is it more abundant than in Spain, and swarms may be seen, especially towards sunset, circling round the lofty church-towers of Córdova and Seville; while above the great plains watered by the Guadalquivir many hundreds are often visible at the same moment, alternately hovering and dropping down on their prey, which there consists principally of beetles. The Azores, Madeira, and Northern Africa as far as Abysinia, are inhabited by a slightly smaller and darker race; while southward, the range of the Kestrel extends to the latitude of the Cape of Good Hope. In Asia it reaches from the Mediterranean to the Pacific, and from Siberia to Burma; the birds inhabiting the northern portion being paler than those found in and to the south of Japan. In America the representative species is F. sparicrius, an example of which is said, though on very incomplete evidence, to have been shot in Yorkshire in May 1883 .

The Kestrel seldom, if ever, builds a nest, but either makes use of the former dwelling of a Crow, Magpie, Woodpigeon \&c., or else deposits its eggs in cavities in cliffs, chalk-pits, quarries, buildings, and hollow trees, or even on the ground. The well-known eggs, often laid in April, and +6 in number, are yellowish-white, mottled, or often deeply suffused, with brownish-red: average measurements I 6 by $\mathrm{I}^{\prime} 3$ in. In northern countries mice form its chief food, birds being seldom taken; in the south it feeds largely on beetles, grasshoppers and other insects. Its graceful flight and shrill cry are too familiar to need description.

The adult male has the head, neck, lower back and tail bluishgrey, the latter tipped with white below a broad black band; back pale chestnut, with small black spots; under parts buff, streaked and spotted with black; cere, legs and feet yellow. Length ${ }_{3} 3$ in. The female has the upper parts rufous, barred with black; and, on the tail, several narrow bands of black, with a broad one near the tip. Very old hens partially assume the male plumage, and have more or less blue on the rump and tail. Length ${ }_{15}$ in. The young resemble the female, but are somewhat lighter in colour. 


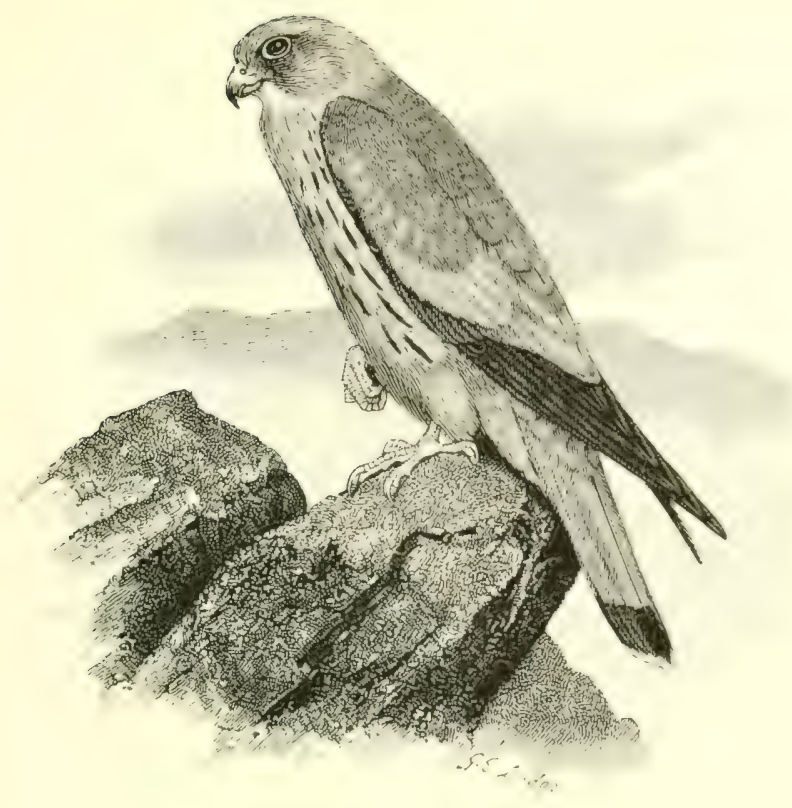

THE LESSER KESTREL.

\section{FALCo CÉNChris, Naumann.}

The claim of this small species to a place in the British list rests upon two occurrences. An example, now in the York Museum, was shot in the middle of November $1 \$ 67$ by Mr. John Harrison of Wilstrop Hall, who noticed the bird flying about his farm ; and in May 1877 an adult male, with one leg injured, was captured alive near Dover, and presented by Mr. E. I'. Robinson to the Museum of that town, where I have examined it.

It will not appear so remarkable that the lesser festrel should occasionally visit England, when we consider that it is a regular migrant to Europe, and has been obtained in May on Heligoland; while it has twice occurred as far north as. Inhalt, in (iermany. It is, however, a southern species, and the northern limit of its brecting range appears to be in Styria, where it arrives carly in April, departing in August. To Savoy, and even to the south of France, it is only an occasional visitor, and statements respecting its breeding on this side of the Pyrenees require confirmation: nor is it common on the mainland of Italy, though alumdant, and partially resilent, in Sicily and some other islands of the Neditermancan. In the sirmish 
Peninsula it is very numerous, especially in Andalucia, where a few remain through the winter, though the majority arrive in February and leave in October. In (ireece and the south-east of Europe it is common in summer, and since 1877 thousands have annually invaded the Orenburg district, where, either as a consequence or a coincidence, the Red-footed Falcon has become rare. Eastward it is found as far as Bokhara, and a nearly allied species, F. pekinensis, breeds in China and winters in India. Asia Minor, Palestine, Egypt and North Africa are regularly visited by the Lesser Kestrel in summer, while its migrations in the cold season extend to Cape Colony.

No nest is built, but the eggs are deposited in holes in cliffs, walls or roofs of inhabited buildings as well as ruined towers, churches $\mathbb{E c}$, and sometimes in trees. Dr. Krüper found a complete clutch by the end of April in Greece, but my experience is that the middle of May is the usual time for laying. The complement is $4 \sim 5$, exceptionally 7 ; the colour yellowish-white, mottled with reddishbrown, much paler than in eggs of the Common Kestrel: average measurements $I^{\prime}+h y^{\prime} r^{\prime}$ in. The food consists of insects, especially cockchafers and other beetles, and grasshoppers; the stairs and other approaches to the towers frequented by this and the larger species being often corered with an accumulation of wing-cases and ejected pellets of indigestible matter; small lizards are also eaten. The cry has been syilabled as i'ti-ai, and also as psche, psich, psche, zische.

The Lesser Kestrel much resembles our common species, but is smaller in size and has white deri's. The male has no black spots on the back, and the innermost secondaries are slate-grey instead of chestnut. Length 12 in.; wing 9 in. The female can only be distinguished from the Kestrel by her smaller size and her white claws; length 13 in.; wing 9.3 in.

From the walls of the cathedral of Seville, I took an unusually large hen bird off a clutch of much incubated eggss of the Common Kestrel, and, rashly assuming that she was necessarily their rightful owner, I hinted--in print-that the two species might possibly interbreed. This was nearly twenty years ago, and I have regretted it ever since, for there is no evidence that such is the case. 


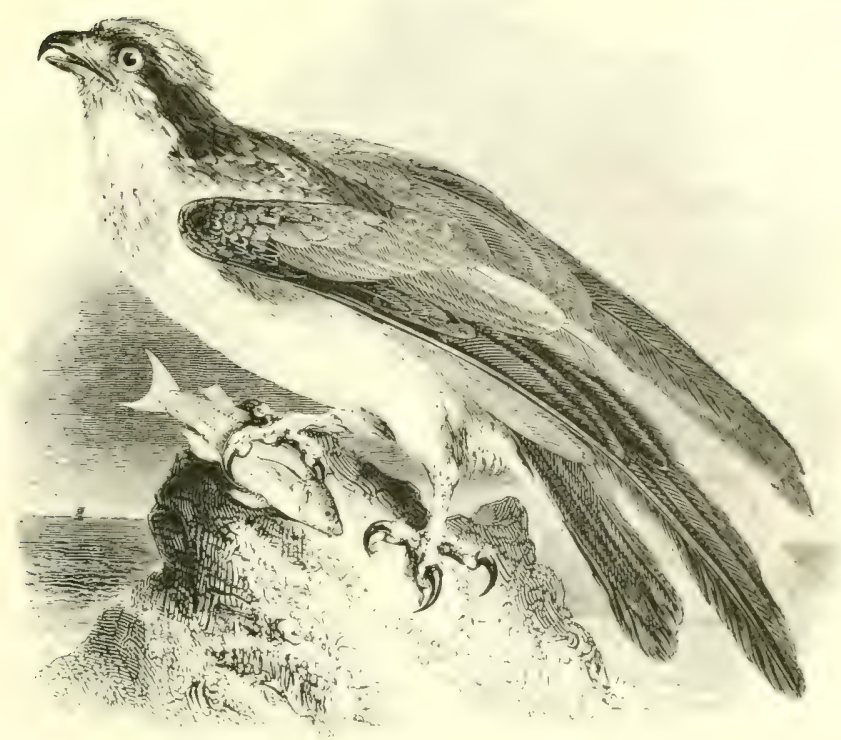

'THE, (ST'RIV.

\section{Pandíon haliä́TUS (Linnæus).}

The Osprey is not uncommon as a visitor to the sea-shores and inland waters of our islands, especially in autumn; and no fewer than ten were recorded between the Tyne and the Thames in the months of September and October isSr; hut the majority of these visitors are immature birds, some of which remain on our coasts until the beginning of June. Estuaries are favourite haunts, and in those of Sussex and Hants it is known as the Mullet-Hawk, owing to its partiality for that fish. Tradition states that it formerly bred on the south coast of lingland, and according to Hersham it did so near Ullswater until the end of the list century : in (ialloway there were at least two eyries up to about 1860 , but at the present day those which are known to exist in seotland are confined to the Highlands, where their safety depends upon protertion and secresy. To the Hebrides, Orkneys and. Shetlands, the Osprey is only an accidental visitor ; while in Ireland, where it occurs on migration, it has never been known to breed, although many of the inland waters appear to be suited to its habits.

This species does not occur in Iceland or Greenland, though very 
abundant in North America; while it is so generally distributed southwards to Australia and northwards again to Japan, that it may almost be termed cosmopolitan. In Europe it breeds-either in forests near lakes, or on sea-cliffs, as in the Mediterranean-from Lapland to Spain, and eastward to (ireece and Southern Russia; as is also the case along the coast of North Africa to the Red Sea, and in suitable localities throughout Asia. Its distribution is, in fact, restricted by two conditions only: the bird must always be near waters inhabited by fish which swim sufficiently near the surface to supply it with food, and the close proximity of man is a decided objection.

The nest is a bulky structure of sticks, sometimes mixed with turf ; and on the top is a small cavity lined with moss, for the reception of the eggs. These, $2-3$ in number, are often very beautiful, having the ground-colour of white or buff, with rich blotches of chestnutred or claret-colour, and underlying blurs of purplish-grey : average measurements 2.5 by $\mathrm{r} \cdot S \mathrm{in}$. In the northern hemisphere they are usually laid towards the end of April or early in May. In wooded districts trees are gencrally preferred, and Mr. Booth says that all the nests he has recently visited in the Highlands have been in Scotchfirs ; but formerly rocky islets in lochs, and ruined castles, were much in vogue. In North America the Osprey is gregarious, and as many as three hundred pairs have been seen nesting on one small island. Lntil taught caution by molestation, it is a very unsuspicious bird, and every one who has read St. John's 'Tour in Sutherland,' must be aware of the ease with which it can be butchered at its breeding-place. The food consists entirely of fish, upon which the bird plunges, often from a considerable height, and which it bears away in its claws; these are remarkably curved and sharp, the outer toe being reversible and the soles of the feet very rough.

The adult male has the head and nape white, streaked with brown; upper plumage umber, with a purplish tinge; under parts white, with a band of brown spots across the breast; cere, legs, and toes greenish-blue. Length $22 \mathrm{in}$; wing 19 in. The female is larger, and more marked with brown on the breast. I ength $24 \mathrm{in}$; wing $2 \mathrm{I}$ in. The young bird has pale edges to the upper feathers and the tail is distinctly barred. The adult plumage is not attained until the third or fourth year. The irides are yellow in young and old. 


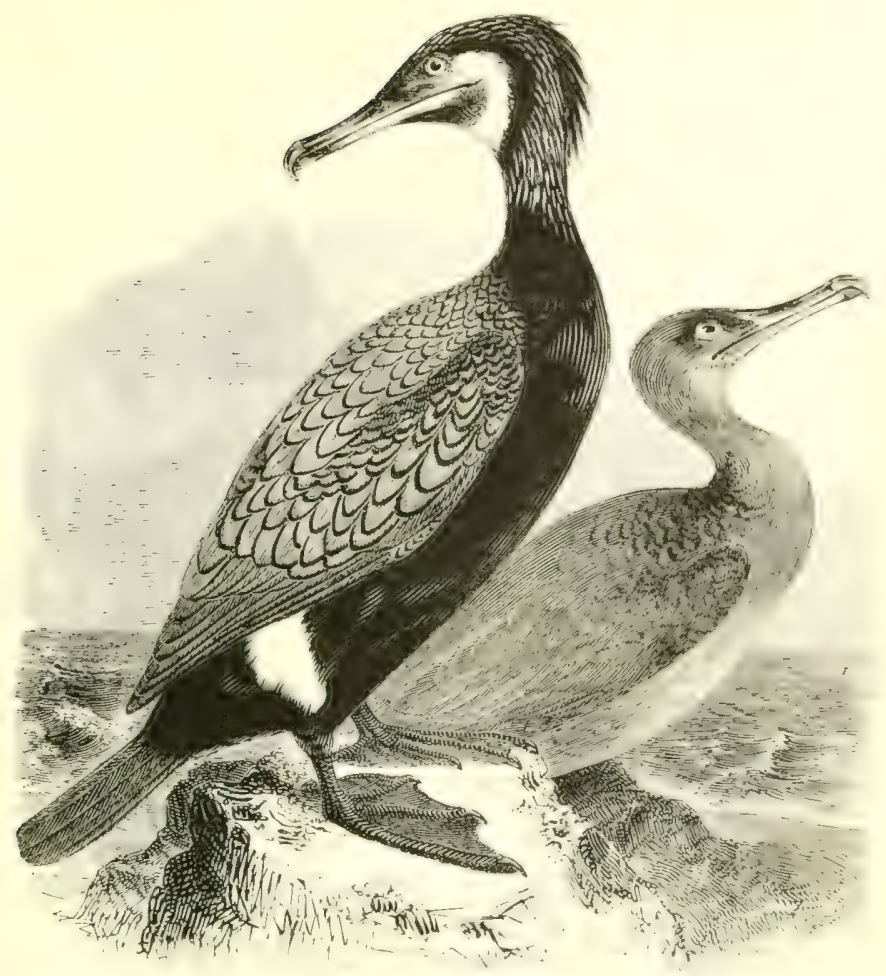

THE COMMON CORMORAN'T.

\section{Phalacrócorax CÁrbo (Linnæus).}

The Great, or Black Cormorant, as it is sometimes called, to distinguish it from the Green Cormorant or Shag, is found in considerable numbers along the greater part of the British coast, except between the Thames and the Ifumber: while from Flamborough northward to Caithness it is more abundant than its congener. In the shetlands. (Orkneys, Hebrides, and along the open coast of the western side of Scotland, it is, as a rule, in a minority; and the same may be said of Wales, the south coast of England, the Channel Islands, and some parts of Ireland. (On the other hand, the Cormorant has many nesting places inland: notably the bold rock near Towyn known as Craig-y-deryn, (astle Martyr in co. Cork, and Lough Attymas in co. Mayo.

This species is found in the Foroes. Iccland, and (ireenland uy 
to about $70^{\circ} \mathrm{N}$. iat.; while over Europe it is generally distributed, and breeding-colonies are to be found in situations as widely different in character as lofty cliffs, the swampy meres of Holland, and the inundated forests of the valley of the Danube. With the exception of the high north it is found all over Asia, where it usually nests on trees; in Australia and New Zealand we find a doubtfully distinct form, $P$. noita-hollandie; and even in South Africa our bird is said to have occurred, while it is common in the north of that continent. In America it inhabits the Atlantic coast from Hudson Bay to New Jersey, but it has not yet been noticed on the Pacific side.

The nest is a large structure composed of sticks and long coarse grass, mixed, when near the coast, with masses of sea-weed; the eggs, laid in this country in the latter half of April or in May, and usually 3 , but sometimes as many as 6 in number, are oblong, rough in texture, and have a pale blue under-shell incrusted with chalkywhite: average measurements $2^{*} 75$ by $1 \cdot 6$ in. Many birds usually congregate at the same breeding-places, which, as already indicated, are to be found on high cliffs, low islets, swamps, bushes and trees. In 1882 a pair hatched two young in the Zoological Gardens, Regent's Park; and it was then observed that after the male had been fed and retained the fish for about an hour, he mounted the side of the nest and opened his capacious mouth, which the young bird entered as far as its outstretched wings would allow, and helped itself to the macerated food in the old one's crop. The parents had been trained by Capt. F. H. Salvin for catching fish, a sport pursued in this country in the time of the Stuart sovereigns; while, as a business, it has been followed in China and Japan from time immemorial.

The adult has the upper head and neck black, with many hairlike white feathers; those on the occiput being elongated and forming a crest in spring; throat white ; gular pouch yellow ; mantle bronzebrown and black; quills, and tail of fourteen feathers, black; under parts rich bluish-black, except a white patch or the thigh, assumed very early in spring and lost in summer; irides emerald-green. The sexes are alike in plumage, but the female has the longer crest and is brighter in colour as well as larger in size. Length about 36 in. ; wing 14.5 in. The young bird is dark brown above; dull white mottled with pale wood-brown below; irides brown the first year, then pale bluish-green, changing to emerald at the end of the second year. Varieties exhibiting tendencies to albinism, and even pure white birds with light-coloured bilis and feet, have been recorded. 


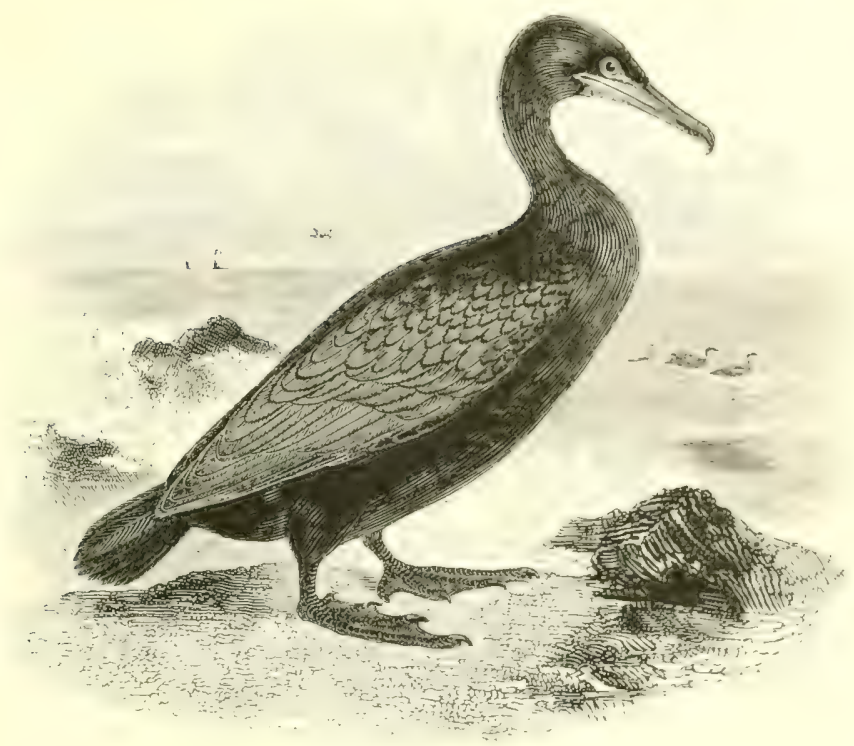

THE SHAG, OR GREEN CORMORANT.

Phalacrócorax gráculus (Linnæus).

The Shag, also known as the Scart, Sicarf, or Crested Cormorant, may be distinguished from the preceding species by its smaller sice. and, when adult, by its prevailing green colour; while the crest-assumed in spring, and not shown in the illustration, which is taken from a bird in winter-plumage---is tuft-shaped and curved forwards. The young, not so easily recognized on the wing, may always be distinguished on examination by the tail-feathers, which, in this species. are only twelee in number. The shas is essentially marine, and seldom wanders inland, or to fresh water ; its favourite haunts being rugged coasts honeycombed with caves, or islands margined with fallen rocks and large boulders, amongst which it often makes its nest. In such situations--which predominate on the west coast of Scotland and in its islands, and along a great extent of Ireland, as well as in Wales and the west of England-it is, on the whole, more abundant than the Cormorant; but it is well to remember that by fishermen and seaside folk the trivial names are frequently interchanged, while the term 'Iliver' is sometimes applied to butt birds. 
Westward of Iceland the Shag has not yet been found, and, although it is common in the Froes and on the coast of Norway, it is scarcely known to enter the Baltic, and is rare on the German shores of the North Sea. It breeds in the Channel Islands, and along the north-west and west coasts of France; also on the Atlantic coast of Spain, Portugal, and Morocco; while a somewhat brighter form, found throughout the Mediterranean and known as $P$. desmaresti, does not appear to me to be distinct.

The nest, formed of sea-weed and grass, matted and plastered together and emitting a horribly fotid smell, is often placed in cliffs or among fallen rocks and large boulders; but frequently it is on a ledge near the roof of a cave, and so far in that the sitting bird can scarcely be discerned amidst the gloom and spray-mist. The eggs-like those of the Cormorant in colour and texture, but smaller, and more variable in shape-are from $3-5$ in number, and are usually laid during May; though Mr. Ussher has found young birds as early as the IIth of that month. The nestlings, at first bare and purplish-black in colour, are afterwards partially covered with down of a browner black than that of the young Cormorant; the mode of feeding is identical in the two species. The Shag lives principally upon sea-fish, for which it dives by making a spring out of the water; and it has the power of descending to a considerable depth, for it has been caught in a crab-pot fixed at twenty fathoms below the surface. Macgillivray states that in deep water he has frequently seen Shags rapidly wending their way beneath a boat by the aid of their outspread wings as well as their feet, and such is also my experience; but in tanks or small ponds, to which the observations of some authors have been restricted, the movements of the bird would naturally be different.

In the adult the bill is black, the base of the under mandible chrome-yellow, and the naked skin about the gape black, thickly studded with small round yellow spots; the irides are green; the forehead bears a crest curved forward, assumed very early in spring and lost by the end of May; the crown, neck, and under parts are rich dark green with purple and bronze reflections; feathers of the mantle dark green with blackish margins; quills and the twelve tail-feathers black, as are also the legs, toes, and their membranes. Length 27 in.; wing $10^{\circ} 75$ in. The sexes are alike in plumage. The young bird has a very slender bill, with yellow lower mandible; the upper parts brown, tinged with green; the under surface brownish-ash, mottled with brown. 


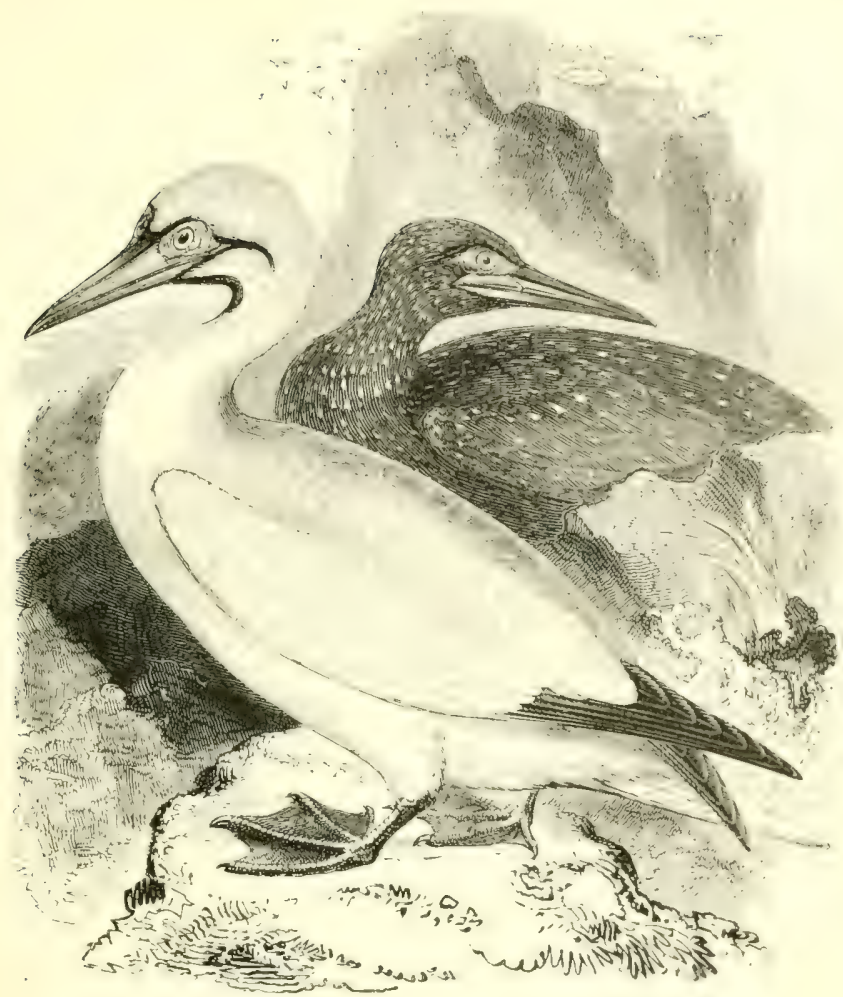

THE GANNE'?

Súla Bassína (Linnæus).

The Gannet, or Solan Goose, is a resident within British waters, though its abundance in different localities varies with the season of the year. The only breeding-place in Fngland is on Lundy Island, where, however, few birds are allowed by the egres cullectors to reir their young; while in Wales there is a larger colony on (irassholm, off the coast of Pembrokeshire. In Scotland there are well-known stations on the Bass Rock, on the east, and Ailsa Craig on the west side; also at Boreray in the St. Kilda group; Sulisgeir, or North Barra, on which from 2,000 to 3,000 birds are sometimes taken in a season; and the stack of Suleskerry, ubut forty miles west of Stromness. In Ireland there is a large colony on the Bull Rock, off Dursey Head, co. Cork, and a small onc on the Little Skellig: but the statement that the Cxammet nests on the Fastnet is crroncous and it has cortainly mot dunc 
so for many years on the 'Stags' (i.c. Stacks) of Broadhaven, off the crast of Mayo.

In the Freroes this species breeds on Mrggenxs, the most western island of the group; in Iceland it has several colonies; and thousands nest on the Magdalene Islands and some other rocks in the Gulf of st. Lawrence. In winter it ranges over the Atlantic, down to North Africa and Madeira on this side, and the Gulf of Mexico on the other; but it seldom enters the Baltic or goes far up the Mediterranean, though after stormy weather it has occasionaliy been taken at a considerable distance inland. In Africa, from Angola southward, our bird is represented by $S$. capensis, which has a nearly black tail; while it is in the Southern Hemisphere that the genus is most abundant.

The nest is a mass of sea-weed and grass, on which is deposited a single egg : this is at first of a pale blue overlaid with chalky-white, but soon becomes soiled: average measurements $3^{*} 25$ by $\mathrm{I}^{*} 9$ in. When unmolested, (iannets are very tame during incubation, and will allow themselves to be stroked by the hand without any sign of impatience except a low guttural srog, gros; but at times they are very vociferous, and as they are continually interfering with each other. or taking advantage of the absence of their neighbours to pilfer the materials of their nests, a constant noise is keppt up, which may be syllabled as carra, crac, cra. The immense numbers which throng Stack-an-Armin and Stack Lii, off Boreray, form a sight never to be forgotten. The food consists of surfaceswimming fish, such as herrings, pilchards, sprats and anchovies, upon which the (iannet plunges perpendicularly with closed wings from a considerable height: and as it fishes in company, considerable numbers often become entangled in the meshes of the fishermen's long sea-nets. The young are collected in August, and, having been plucked, cleaned and half-roasted, are sold, in Scotland, for food; the fat is boiled down into oil, and the feathers are used for stuffing beds.

The adult has the head and neck buff-colour; all the rest of the plumage white, except the primaries, which are black. In the bird of the first year, the under plumage is mottled with dusky-ash and buff, while the upper parts are blackish-brown flecked with white. In each successive year the dark markings diminish until the sixth, when the adult dress is attained. Length 34 in.; wing 19 in. The nestling, at first naked and black, is afterwards covered with down, which is most persistent on the head and neck, giving the bird the appearance of wearing a long wig. 


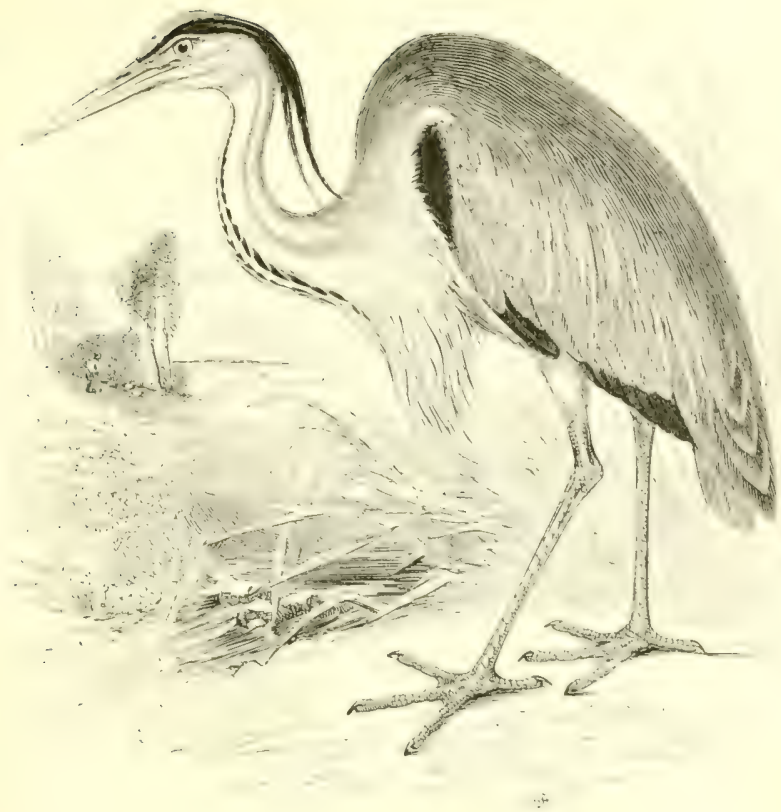

THE COMMION HERON.

Árdea CINÉrea, Linnæus.

Though no longer protected, as in the days of falconry, the Common Heron is generally distributed throughout the liritish Islands; and in England the number of its colonies has suffered no diminution, though many of them are seriously reduced in size as compared with former times. In sicotland there never wore many large heronries, but small ones are scattered over the greater part of the country, except the outlying islands; and the latter remarli applies to Ireland, where, however, some important assemblages in trees are to be found in cos. (ork, IVaterford, I)ublin, 1),wn, I) mengal and Mayo.

The Heron sometimes visits the Faroes and Iectand, and a young bird was picked up dead in south (ircenland in 1856 . () n the coast of Norway it ranges to $68 \mathrm{~N}$. lat., though it docs not reach lecond $57^{\circ}$ in Sweden and Russia: while southward it is found, in suitable localities, over the greater part of Europe, and considerable mumbers breed in colonies in the marshes of Northern and (entral Italy, the valley of the I)anule, and southern kussia. In France, henwever, 
there is only one heronry-a very large one-at Écury-le-grand, near Champigneul, in Marne; though scattered pairs are found in many districts. To the Spanish Peninsula, the Canaries, Madeira and the Azores, it appears to be chiefly a winter-visitor; as it is also to the basin of the Mediterranean, Africa down to the Cape, Madagascar, Mauritius, Australia, and the southern portions of Asia; but in the latter it nests from Ceylon northward, as far as China and Japan.

In January, if the season is very mild, but as a rule in February, the Herons resort to their breeding-places-often occupied for years in succession-and, like the Rooks, in whose proximity they often build, they nest in company, in varying numbers, on high trees; sometimes, however, on precipitous sea-cliffs or among crags covered with ivy and shrubs, as well as on the bare hill-sides or the walls of ruins. The nest, flat and rather broad, is formed of sticks, and lined with small twigs, roots and dry grass; the eggs, $3^{-4}$ in number, are uniform bluish-green: average measurements 2.5 by $\mathrm{r}^{\prime} 75$ in. Incubation lasts about twenty-eight days; and a fortnight later a second clutch of eggs is sometimes laid and hatched off, with the young birds in the nest. On the Danube breeding appears to be in May or June. The heronries are occupied from spring to August, and are occasionally visited in the winter, but during that season the bird is often solitary and rather shy. Its food consists of reptiles, molluscs, crustaceans, worms, insects, small mammalssuch as water-rats and field-mice, and still more largely of eels, pike and other coarse fresh-water fish, but trout and the young of waterfowl are not neglected. Young Herons are excellent eating, and were formerly esteemed for the table. The alarm-note is a loud frank, frank, which is especially startling to other birds, but at the nest it is a prolonged kronk or kraak. When flying, this species is easily recognized by the slow flapping of its rounded wings.

The adult male has the crest bluish-black; upper parts chiefly slate-grey ; forehead, cheeks and neck white, the latter streaked with dark bluish-grey, and terminating in long white feathers; under parts greyish-white; bill yellow. Length $3^{6}$ in.; wing i $S$ in. In the female the colours are less bright and the plumes are shorter; as they are also in the young birds, in which the under parts are ash-colour, and there are no long feathers at the bottom of the neck. Varieties are sometimes obtained.

The members of this family have the breast and lower flanks furnished with well-developed powdery tufts of decomposed feathers, the use of which is not known. 


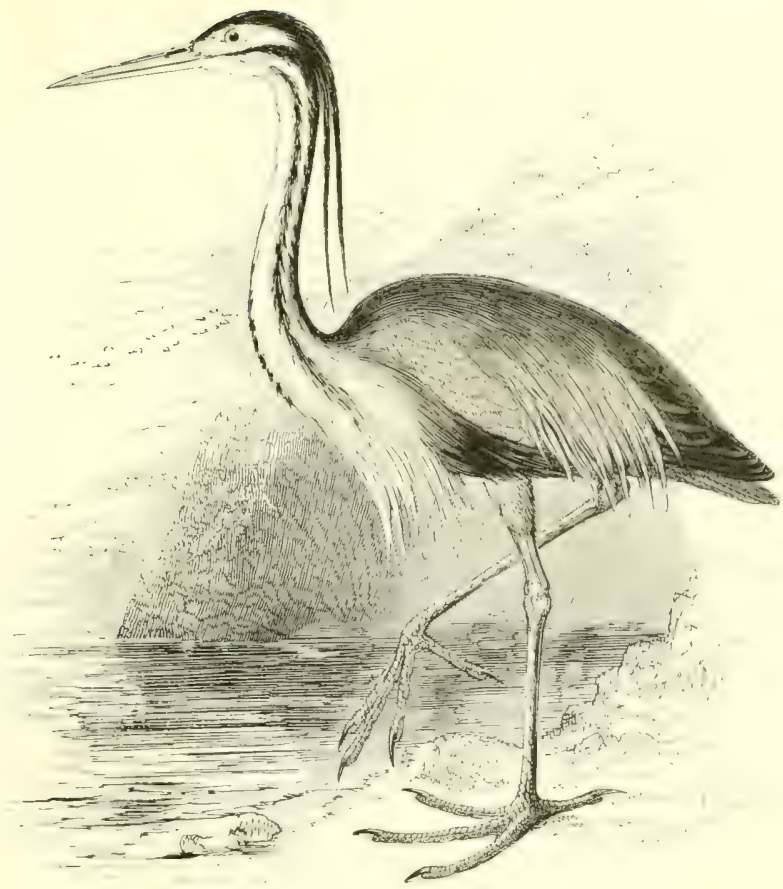

THE PURPLE HERON.

ArdeA PURPÚREA, Linnæus.

Although the Purple Heron is comparatively abundant on the neighbouring shores of the Continent, it is only of irregular occurrence on the east coast of England, and is even less frequent in the south, from Sussex to the Scilly Islands. In Wales, and along the west side, it has seldom been noticed ; while, as regards Ireland, the only example on record is that killed at Carrickmacross in is 3.4. and now in the Warren collection at the Dublin Museum. In Scotland it is said to have occurred in Caithness and Aberdeenshire, more than forty years ago. Altogether nearly fifty specimens have been obtained in the British Islands, the majority being in immature plumage.

The Purple Heron is only a wanderer to the south of Norway and Sweden, Northern (iemany and Poland. Its nearest nestingplaces are in Holland, where it is still by no means uncommon. though lately interfered with by drainage; but, while principally a visitor on passage to Belgium and the north of lirance, it hreeds in considerable numbers in the marshy districts of the Loire. 
and in some parts of the sonth and east. In the Spanish Peninsula it nests in reed-beds, as it does also from Central Germany eastwards to the swampy parts of Southern Russia; the majority, however, migrate in the cold season from all the countries on the northern side of the Mediterranean. It is found in Madeira, and in Northern Africa, whence it departs in winter, though resident in Egypt: in Abyssinia it has been obtained at an elevation of $9,000 \mathrm{ft}$.; it inhabits suitable localities down to Cape Colony, and has occurred in Madagascar. Across Asia it is distributed as far as China, the Philippines, and the Indian Archipelago

Its breeding-places are usually difficult of access, being situated in flooded swamps, or in the midst of clense masses of reeds, where wading is almost impossible. Mr. Mhilip Crowley describes the nests at the Naarden Meer, near Amsterdam, as placed about three feet above the water, and made by bending down twelve or fifteen reeds to form a j latform, on which some smaller pieces were arranged crosswise, and this agrees with my experience in Spain; but in Ceylon this species breeds on trees, forning flat and rather bulky nests. The eggs, usually 3 in number, are of a bluish-green colour, smaller than those of the Common Heron : arerage measurements $2^{\prime} 2$ by $\mathrm{I}^{*} 5$ in. In its habits the Purple Heron resembles the Bittern, being shy and, to a considerable extent, crepuscular, or even nocturnal, in its time of feeding. From the thinness of the long snake-like neck, the birds, even though numerous, are with difficulty distinguished when they are standing in a reed-margined lake, nearly up to the belly in water; their bodies, in the shimmering sunlight, exactly resembling tussocks of rushes. The flight is similar to that of its congener, but the note is more guttural. The food consists of small mammals, reptiles, fishes and aquatic insects.

The adult has the cromn and long plumes glossy purplish-black; cheeks and sides of the neck fawn-colour, streaked with bluish-black; back and wing-coverts dark slate-grey; elongated filamentous dorsal feathers, chestnut; tail grey; neck reddish-buff with a line of black down each side, terminating in a mass of chestnut, grey and black elongated feathers; under wing-coverts chestnut; breast rich maroon-red; thighs rufous; bill yellow. Length from point of bill to end of tail about $3^{6}$ in.; wing, $14^{2} 25$ in. The sexes are alike in plumage, but the male is the larger. The young, until their second moult, are usually without the occipital crest, as well as the elongated feathers at the base of the neck and on the scapulars; the general colour above is rust-1ed, and the under parts are brownish-white. 


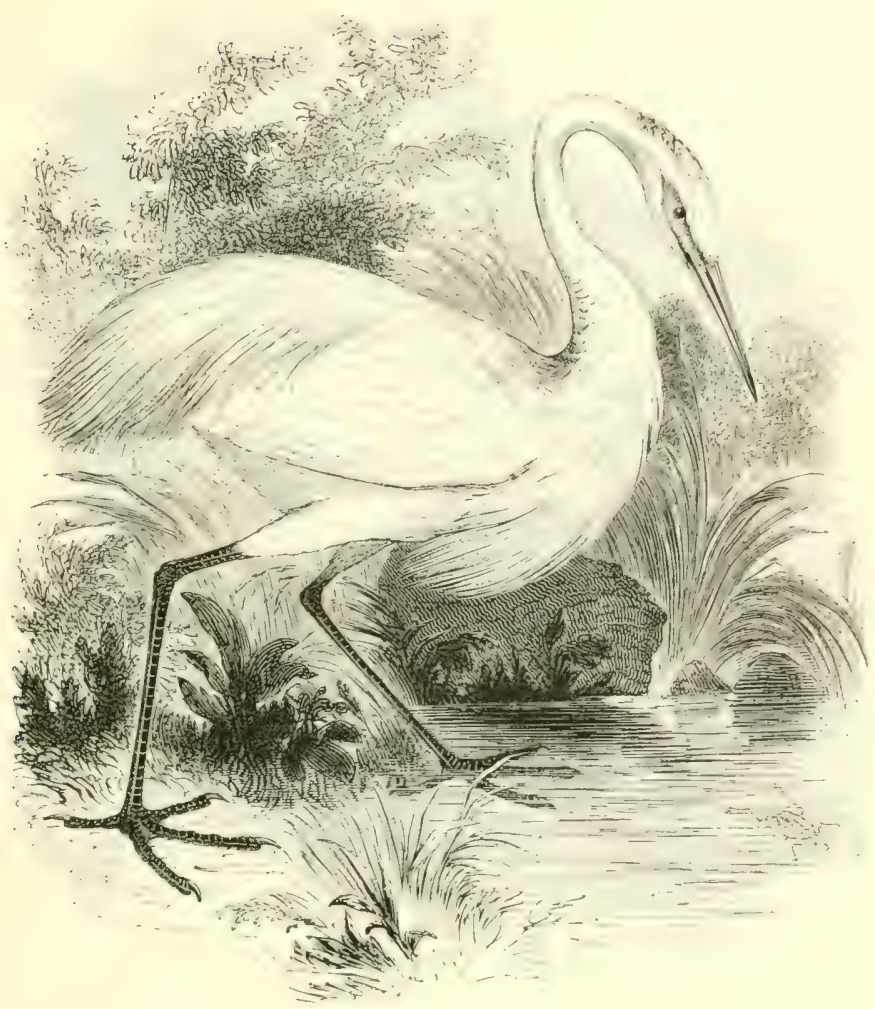

THE GREAT WHITE HERON.

ARDEA ALBA, Limnaus.

The Great White Heron is a rare visitor to Great Britain, and only eight examples appear to be authenticated or avaliahle for examination. Three of these were obtained in Yorkshire, and two of them are in the Museum of the county city; one, from near Worksop in Nottinghamshire, is in the Foljamixe collection, at Osberton; one was shot on the Isis in ()xfordshire, in september I 833 ; one, killed in the Frith of Forth on June gth IS. 0 . is in the collection of the Earl of Haddington at 'Tyninghame Heuse : one (with the long back-plumes) shot on Thorney Fen, Cambriclgeshire, is now in the possession of Mr. Charle's Isham Strong, of Therpe I Lall, Peterborough; and one, killed at Loch Katrine, Scothand, in May or June I $S S \mathbf{I}$ or $\mathbf{1} 8 \$ 2$, and rccorded in 'The scottish Niaturalist' as a Little Egret, is in the Edinburgh Museum. Others are said to have 
been observed, but some of them were probably Spoonbills; while several records are unworthy of serious consideration.

The Great White Heron occasionally visits the south of Sweden, and the north-east of Prussia, but is of very rare occurrence in Poland; although near Glogau, in Silesia, a pair was found breeding by $A$. von Homeyer in $\mathrm{I}_{56}$. Over a great part of the area drained by the Danube and its tributaries it was formerly plentiful in summer, but owing to persecution for its plumes, its numbers have been much reduced of late years; in the Black Sea district however, and the south of Russia, it is still common. Throughout the basin of the Mediterranean, and in the marshy parts of Italy it is not unfrequent, especially in winter; it visits the south of France and the east of Spain; and sometimes wanders to the Azores. Across Asia it is met with in suitable localities as far east as Manchuria and Japan, migrating from the northern districts in autumn; while in the Indian region there is a rather smaller resident form. In North Africa, from Morocco to Egypt, it principally occurs in winter, and it has been found, like the Purple Heron, on the high table-lands of Abyssinia ; while southward, identified specimens have recently been obtained in the Orange Free State. Its representative in Australia and New Zealand is said to have the bill yellow throughout the year; whereas our bird has the bill black in sumner, and yellow at other times. In America there is a closely-allied species, A. egretta, which has the bill yellow and the tarsi and tibire black at all seasons.

The nest found by Honeyer was slightly built and placed in an old fir-tree, and three recently hatched birds were found in it on June $2 S$ th. In India, where the breeding-time depends upon the rains, the nests are built from October to February, in half-submerged groves; while in Ceylon Col I,egge found them in the same trees with those of other Herons, Spoonbills \&c. The eggs, 3-4 in number, are pale greenish-blue: average measurements $2^{\prime} 5$ by I. 5 in. The food consists of small fish, reptiles, molluscs and aquatic insects.

The adult has the whole plumage white; the feathers at the back of the head very slightly elongated, but those at the bottom of the neck in front more so; dorsal feathers very long and filamentous in spring, but absent in autumn; bill black during the breeding-season, but afterwards yellow; lores and orbits pale green; irides yellow; legs and feet blackish; tibir paler. Length about 40 in. ; wing $17-18$ in. The males are the larger, and have more developed plumes. In the young bird the bill is yellowish, the legs are paler, and the elongated feathers are not acquired until the second spring. 


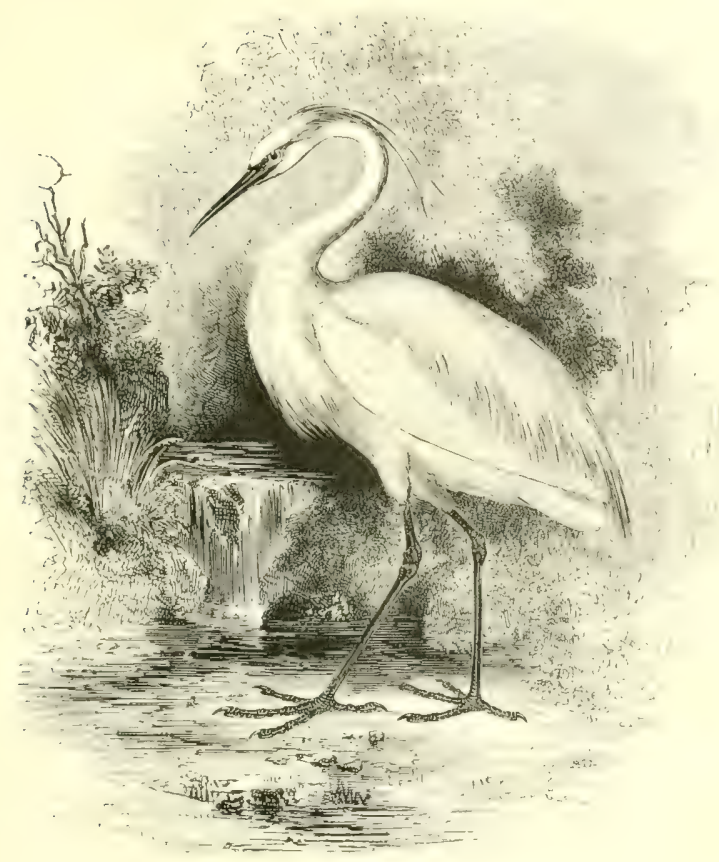

'THE LI'TTLE EGRET.

\section{ARdea garzétTA, Linnæus.}

The Little Egret has a more southern halsitat than the preceding species, and, as might be expected, its risits to the liritish Islands are very unusual. When subjected to critical examination almost all the records of its occurrence are more or le'ss unsatiffactory ; and, as far as I can learn, the only example about which there can be no doubt, is an adult examined and recorded by the late Mr. J. Gatcombe, killed at Countess Weir, on the Fxe, on June 3 rd $18 ; 0$, and then belonging to Mr. E. H. Harbottle, of Toprham, near Exeter. It is not improbable, however, that one has been obtained in Sussex; but the bird recorded under this nime as obtained near Beverley, lorkshire, in $\mathrm{I} s_{4} 0$, is probably one of the (ireat thite Herons already mentioned. There is no specimen in existence to prove Thompson's assertion that it has visited Ireland on three occasions.

This species has not been found to the north of the Baltic, and it seldom wanders to Cermany, Holland, or the morth of France, 
though not uncommon in the southern and eastern portions of the latter; while it is tolerably abundant in suitable localities in the Spanish Peninsula, Italy, Sicily, Sardinia, Cyprus, and generally throughout the Mediterranean region. The northern limit of its breeding-range appears to be in the wooded swamps of Slavonia, where MIr. W. E. Clarke found it nesting towards the end of May I $88_{3}$ on the Obedska 'bara,' a marsh on the river Save, not far from Semlin. In the same year Messrs. Seebohm and Young found it breeding in colonies on the Inwer Danube; and it is common during the summer in Turkey and Southern Russia. Across Asia it is distributed as far east as China and Japan; in India and Ceylon it is resident; and it visits the Philippines, Malacca \&c., down to the northern districts of Australia. To the west, it occurs in the Azores, Canaries, and Cape Terd Islands; while in Africa it is found as far as Cape Colony. Its representative in the warmer districts of America is $A$. candidissima, a bird of about the same size, but distinguishable by the large bunch of occipital feathers, and by the yellow basal portion of the bill. A. culcphotes, found in South China and Formosa, has also a thick tuft, but is a smaller bird, and has a yellow bill.

The nests of the Iittle Egret are usually placed in bushes and trees, in company with those of other swamp-loving species; the material consisting of sticks and a few reeds, on which are deposited the eggs, $3^{-6}$ in number, of a pale bluish-green : averaging $\mathrm{I} 75$ by I.25 in. I)r. H. ( bird on the I 7 th April I884, round an isolated rock on the south coast of P'ortugal, on the inaccessible summit of which it appeared to be breeding, in company with some Gulls. Mr. Seebohm describes this Egret as being very noisy, and uttering a note of alarm or defiance resembling the syllables $a k$, ark, and ork. Its food consists of small fishes, aquatic insects, frogs and worms.

The adult in spring and summer has the beak black; lores lavender; irides varying from yellow to pale lavender; the entire plumage pure white; crest of two long narrow feathers; some elongated plumes at the bottom of the neck in front ; dorsal plumes greatly lengthened and filamentous; legs mostly black, yellowish on the lower portions of the feet. For some time after the autumn moult the dorsal and occipital plumes are absent, and the legs and feet are nearly black. Length 25 in.; wing $\mathrm{I}^{\circ} 25$ in. Females are rather smaller than males : but Mr. J. H. Gurney jun. says that the plumes are sometimes equally developed. Young birds have a greyish tinge, and no elongated plumes. 


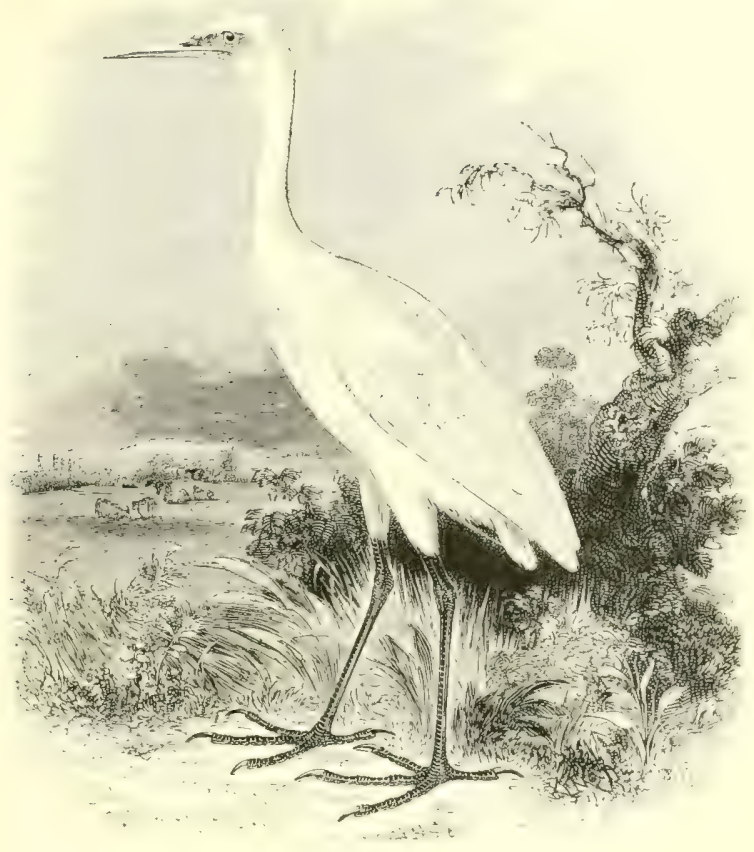

THE BUFF-BACKED HERON.

ArdeA bubúlcus, Audouin.

A young Buff-backed Heron, which proved on dissection to be a female, was shot towards the end of October I $\mathrm{SO}_{5}$ near Kingsbridge in Devonshire, where it had been seen for several days in the same field, following some cows, and picking up insects : it was by no means shy, and was fired at a second time before it was secured. The occurrence was recorded by Montagu, to whom the specimen was presented by Nicholas Luscombe, of Kingsbridge, and it is still (ISSS) preserved in the Natural History Museum at South Kencington. No other authenticated British-killed example is known to exist.

The Buff-backed Heron is essentially a southern bird; and an adult male, shot on the Obedska 'bara,' on May 29 th I883, is recorded by Mr. W. E. Clarke as the first instance known in Hungary; while on the Danube, as in l'oland and Southern Russia, it is extremely rare. Even in the south of France. Italy, Sicily. Malta and Greece it is seldom found, though not unfrequent in 
Cyprus. Its only known breeding-haunts in Europe are in the sonthern portions of the Spanish Peninsula, and from March to autumn it is very common in the marshes of Andalucia, where thousands may be seen amongst, or on the backs of cattle, picking off ticks; whence the name 'Purga-bueyes,' a corruption of 'Espulgabueyes,' meaning 'cattle-cleaners.' It is said to have occurred in Madeira and the Canaries, and in suitable localities from Morocco to Egypt it appears to be resident; while southward, it is found over Africa down to Cape Colony, and also in Madagascar, where it is believed to breed in September. At the Caspian begins the range of a closely-allied species, $A$. coromanda, in which a rich orangecolour pervades the head and neck; and this representative extends across the warmer parts of Asia to South Japan. Two examples of this bird are said to have been shot near Turin in May I862, and one of them has been identified by Prof. Giglioli.

Like its congeners, the Buff-backed Heron breeds in colonies, making a nest of dry sticks and twigs in reedy swamps, or on trees, and sometimes in gardens. Mr. J. H. Gurney jun. describes a colony in the Faioum, consisting of about five hundred birds, the nests of which were in a large bed of dead tamarisks, from two to five feet above the water; none of these contained young in June, while many were in course of building. The eggs, usually 3 in number, are very pale blue, almost white: average measurements $\mathrm{I} \&$ by $\mathrm{I} \cdot 3$ in. The food consists of cattle ticks (Acari), beetles and other insects turned up by the plough, grasshoppers, locusts, and frogs. The note may be syllabled as grah. In Egypt this species is often made to do duty for the Sacred Ibis with the tourist, and is to some extent respected by the peasants.

The adult in summer has the crown, nape, occipital and dorsal plumes and those hanging from the lower neck in front, rufousbuff; the rest of the plumage white, a trifle creamy on the wingcoverts; lores, orbits, and irides golden-pink; beak reddish at the base, yellow at the tip; legs yellowish-red. Length about 20 in.; wing $9.5 \mathrm{in}$. The female is rather smaller than the male, and her plumes are less developed. After the autumn moult, and until the following spring, the elongated buff feathers are wanting, and the bird is almost pure white. In the young bird the skin about the base of the bill is very dark; the plumage shows little buffcolour, and the legs are dull olive. 


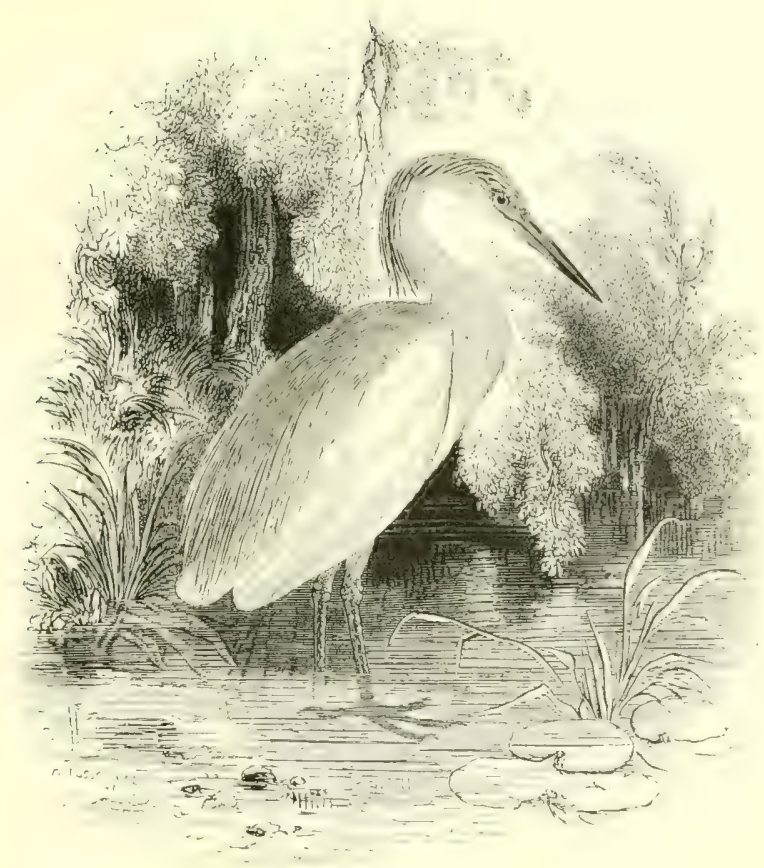

THE SQUACCO HERON.

Ardea ralloídes, Scopoli.

More than forty examples of this little Heron have been taken in the British Islands since $\mathbf{I} 775$, when a specimen was killed in Wiltshire. The other counties visited by it are Hants (and the Isle of Wight), l)orset, Somerset, I)evon, Cornwall (about a dozen instances), Brecon, Salop, Notts, Suffolk, Norfolk, Lincolnshire, Yorkshire and Cumberland. In sicotland one has been shot on the Glasgow Canal, and another at I)almahoy. In Ireland, three have been obtained in cos. Cork and Waterford, one each in Kerry and King's County, and one in Londonderry on November $23^{\text {rd }}$ I88I : an unusually late date. With very few exceptions, however, these visitors have arrived in spring or summer, and have been in immature plumage.

On the Continent the Squacco Heron is only a straggler to l'oland, Northern Germany, I)enmark, Holland, lielgium and the north of France; but it is not uncommon in the valley of the Loire, where I believe it breeds. South of that line and of the Alpine ranges, it 
is generally distributed in suitable localities throughout Central and Southern Europe, from spring to autumn. In Spain it arrives in April, though in the valley of the Danube it does not do so before the middle of May. From the Canaries eastward we find it numerous and resiaent in North Africa-including Egypt, and it inhabits that vast continent as far south as Namaqua Land on the west, and the Transvaal and Natal on the east; while Sir Edward Newton obtoined it in Madagascar. Persia appears to be its eastern limit in Asia.

The Squacco Heron breeds in colonies, in company with other members of the family; building a slight nest of sticks, on bushes or trees in flooded marshes. Mr. IV. E. Clarke in Slavonia, and Messrs. Seebohm and Young on the Lower Danube, found eggs by May 26th, but in dry seasons laying does not become general until at least a week later. The eggs, 46 in number, are greenish-blue--smaller than those of the Buff-backed Heron: average measurements I 5 by $I \cdot I$ in. In its breeding-haunts this species is very pugnacious towards its congeners. The food consists largely of water-beetles and other insects, small crabs, molluscs, frogs, minute fish, and occasionally small mammals, an entire shrew having been found in the crop of cne examined by the late Mr. Rodd. In its habits this bird is somewhat inactive, passing the greater portion of the day in one position, the head being drawn in between the shoulders like that of a Bittern; and in Spain Col. Irby noticed that it did not frequent the grazing-grounds, after the manner of the Buff-backed Heron. It is usually very silent, but occasionally utters a harsh rarr. In dry seasons the nuptial dress is sometimes not assumed until late in the spring, and in Andalucía in I 868 I found that even on May 2 ist some birds were rather bare on the neck.

The adult in breeding-plumage has the head and hind neck pale buff, streaked with dark lines; the occiput furnished with eight or nine long lanceolate plumes, which are pure white in the centre and margined with black; sides and front of the neck warm buff; back darker, the dorsal plumes elongated and filamentous; wing-coverts pale buff ; rest of plumage white; bill cobalt-blue at the base, black at the point ; lores naked and green; irides yellow ; legs yellowish-pink; soles yellow. I.ength $9 \mathrm{in}$, wing 9 in. In the immature plumage - more frequently seen in this country-the streaks on the neck are longer and broader, and the-ground-colour is mixed with ashybrown; the back, and the ends of the inner secondaries are woodbrown; and, the younger the specimen, the darker are the feathers along the middle of the back. 


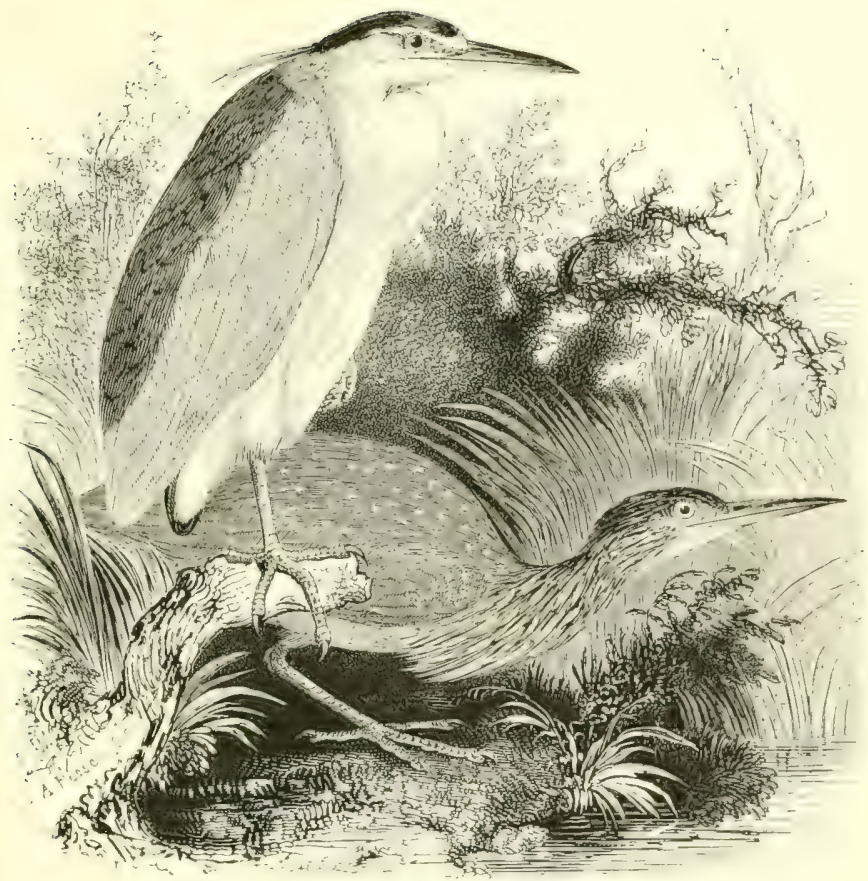

THE NIGHT-HERON.

\section{Nyctícorax gríseus (Linnæus).}

The first specimen of the Night-Heron recorded in England was shot near London in May I 872 ; since which more than sixty examples have been obtained in the liritish Islands, and the species may be considered as an almost annual visitor in spring and autumn. In the south-western counties it would probably have bred, if unmolested; for in 'The Zoologist' (p. 2528), a Mr. C. J. Bulteel has recorded in detail his success in destroying eight adult birds-four males and four females-in Devonshire, between May $23^{\mathrm{rd}}$ and June 22nd I849. Both old and young have been taken along the south coast as far west as Cornwall; more than twenty in the eastern counties, and a good many inland; fewer from Vorkshire northwards; while to the western side of the island its visits have been unfrequent. In scotland three occurrences in the somin, and one each in Argyllshire and Aberdeenshire are on record: and in Ireland ten or twelve examples have been obtained in various localities, from Cork in the south to Donegal in the north. 
Although a visitor to the Froes, South Sweden and Denmark, the Night-Heron is rare even on the southern side of the Baltic, and of late years has gradually been driven from many of its nestingplaces in the northern portions of Germany and Holland; while in France it is chiefly known on migration, though it breeds sparingly in the south. It nests in the Spanish Peninsula, and on the mainland of Italy-which it leaves in autumn, though resident in Sardinia ; on passage it visits the coasts and other islands of the Mediterranean. Iarge colonies are found on the Danube, and throughout the districts of the Black and Caspian Seas. Eastward, it is distributed throughout temperate and southern Asia, as well as over the whole of Africa; in fact it is almost cosmopolitan, inasmuch as slightly varying forms inhabit America, from the Fur Countries down to the Falkland Islands. In the Malayo-Australian region, however, we find a distinct species, $N$. caledonicus, which has the upper parts of a bright cinnamon-colour.

The Night-Heron breeds in colonies, usually building a nest of small sticks radiating from the centre, on trees or bushes in swamps: but in China, where it is held sacred, large groves are selected, and Swinhoe has described a vast assemblage round the great Honam Temple at Canton, where the nests are placed thickly in some venerable banyans. In some parts reeds are chosen, and in the swamps of Lake Nichigan dead rice-stalks are built up into a structure so solid that a man could stand on them without doing any perceptible injury. The egrs, from $3^{-5}$ in number, are pale greenish-blue: average measurements 2 by $\mathrm{I}_{4}+$ in. Judging from Swinhoe's experience, the bird commences sitting at once, and there is an interval of two days between the laying of each egg. In Europe incubation takes place in May. The food consists of water-insects and their larræ, worms, snails, small fish and frogs. The note is a mournful qua-a, seldom uttered in the daytime, though after dark the birds are very noisy.

The adult male has the crown, nape, and middle of the back greenish-black; neck, wings and tail grey; under parts greyishwhite; a crest of from three to ten long white feathers; bill blackish above, lower mandible and lores lead-colour; iris brick-red; legs and feet yellow. Length about $23 \mathrm{in}$.; wing I 2 in. The female is duller in colour and has shorter plumes. The young bird has the upper plumage umber-brown, with paler streaks and white spots; under parts striped with white, buff, and brown; no crest. Young males are capable of reproduction while still in immature plumage. 


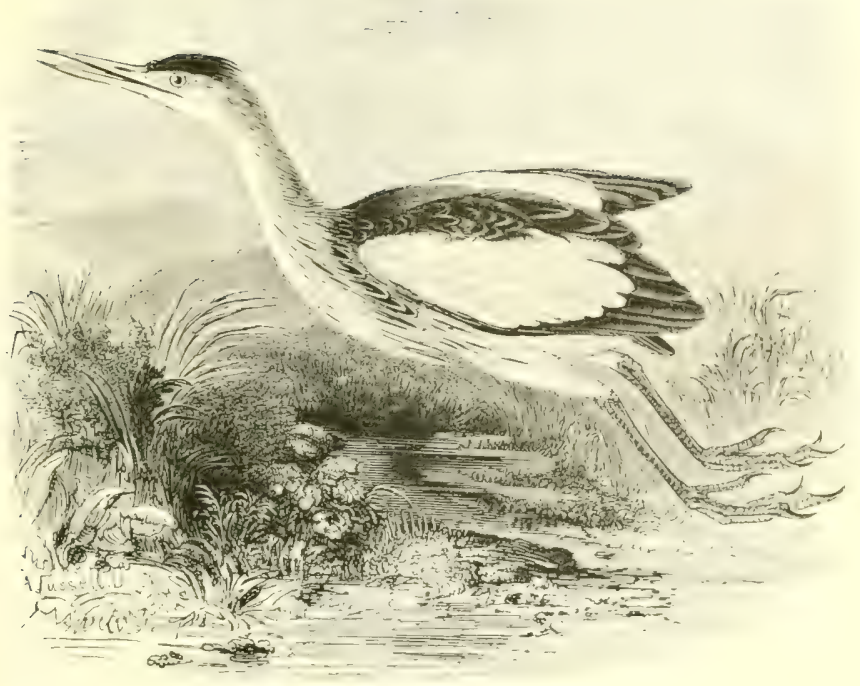

THE LITTLE BITTERN.

ARdétTA minúta (Linnæus).

This small species has been obtained in nearly every county of England, especially in the eastern and southern districts: and there can be little doubt that - even recently - it has bred on some of the Broads of Norfolk, and formerly did so in other localities. In Wales, and on the west side of the island, it is of rare occurrence, as it is also to the north of Yorkshire; while to Scotland its visits are very irregular, though extending as far as the Orkneys and Shetlands. About ten examples have been obtained in Irtand on passage; the latest on October 2 nd I 887 . Most of the instances recorded in England have been between spring and autumn, but a few in the depth of winter.

The Little Bittern is only a rare wanderer to the Ireroes, Iceland, Norway and Sweden: and although it has lecen olnained on several occasions in 1)emmark, as well as the district of it. P'ctershure in Russia, its usual migrations do not extend beyond the Baltic. Southward, it is found during summer in suitable situations throughout Europe; but even from Spain, Italy and Greece it takes its departure in autumn, returning in Ipril. It appears to le resident in the Azores and Madeira, as well as in North Africa, where its 
numbers are augmented by migrants from the north in winter-at which season it visits Egypt and Nubia. In the Transvaal,and, in fact, south of the parallel of the Gaboon, it is represented, according to Mr. J. H. Gurney, by the smaller and more rufous Ardetta policipes. In Asia our Little Bittern is found breeding from the shores of the Caspian to Cashmere, and occurs in Nepal and Northwestern India; but eastward it is represented by $A$. sinensis, the back of which is brown instead of black: while nearly allied species inhabit Australia and America.

The nest is often a solid structure of flags and bits of grass, attached to upright growing reeds, and very little above the water; but sometimes it is built in the heads of pollarded willows, and occasionally the bird makes use of the former abode of a Magpie, in bushes or hedges near a swamp. The eggs, normally 4-5 in number, though o are said to have been found, are uniform dull white: average measurements $\mathrm{I}_{4}+$ by $\mathrm{I}$ in. They are usually laid in the latter half of May, and incubation lasts sixteen or seventeen days. When disturbed from her nest the female utters a sound like sctt, gett; but the male emits a peculiar grunting ziof, woof. The food, obtained chiefly by night, consists of small fish and their fry, frogs, reptiles, molluscs and aquatic insects. During the day the Little Bittern skulks in reed-beds, plantations of osiers, and other moist situations; and, when disturbed, climbs among the branches and threads its way through the tangled vegetation with great celerity. It often escapes notice by remaining motionless, with outstretched neck and bill pointing upwards-resembling a dry stick or reed, whence its appropriate Dutch name IVoud-aapje, meaning 'Wood-ape.'

The adult male-represented in the illustration-has the crown, nape and back greenish-black; primaries and tail browner black; cheeks and neck warm buff, wing-coverts paler; throat and under parts buff, with a few dark streaks on the breast and flanks; bill yellow; legs and feet greenish-yellow. I.ength about I 3 in. ; wing 6 in. The female is a trifle smaller, and differs in having a brown tinge on the head, the cheeks and hind neck rufous, back brown, wing-coverts brownish-buff; under parts buff, much streaked with wood-brown and umber. The young at first resemble the female, but the upper parts are duller in colour.

The members of the genus Ardetta resemble the true Bitterns in having only ten soft tail-feathers and two pairs of powder-down tracts, whereas the Herons have three pairs of the latter and twelve tail-feathers. 


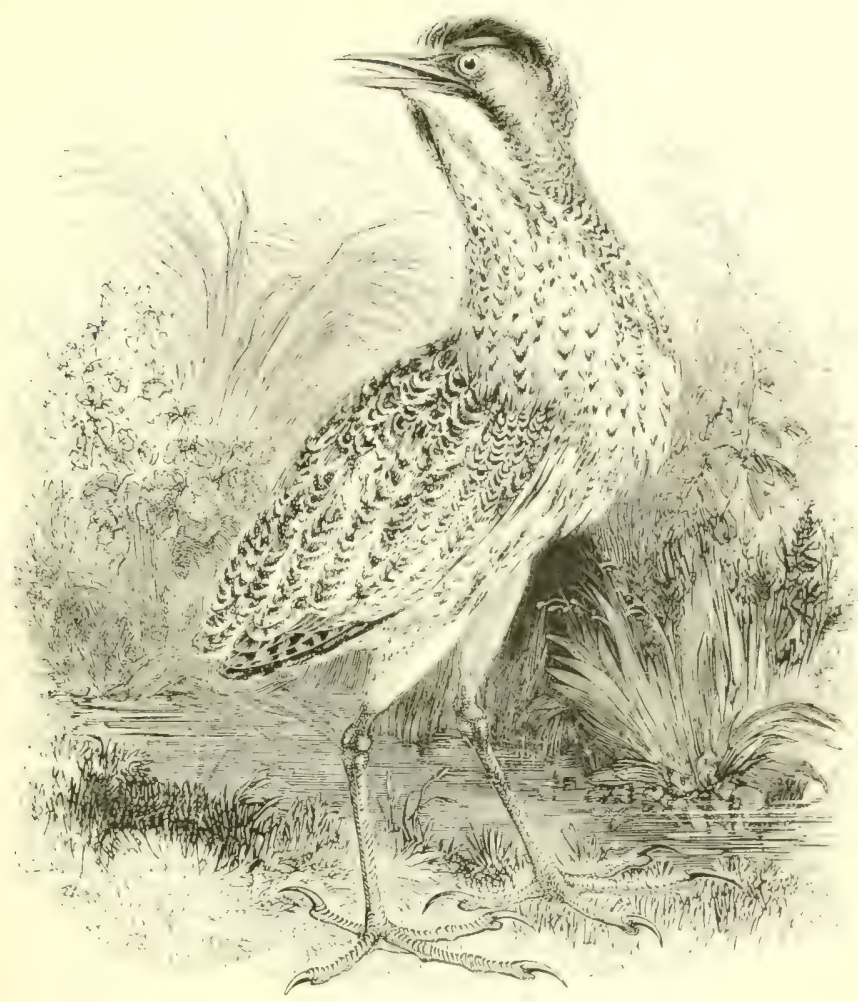

\section{THE COMIION BITTERN.}

\section{Botáurus stelláris (Linnæus).}

The extensive reed-swamps and marshes, to which the Bittern resorts cluring the breeding-season, have greatly ciecreased of hitc years in Fngland, owing to drainage and cultivation: ncturthelest, its eggs were occasionally found in the litoad-district of Norfolk down to March 3 oth I868, and as recently as August rSS6 a young bird with down still adhering to it was obtained there. Beforc the reclamation of the East Anglian fens the "Butter-bump, is it was called from its note, bred in them annually, as it did also in other suitable portions of Lingland and Wales; while aren at the present day so many of the birds which regularly visit us are shot in spring, that, if a little forbearance were exercised, the 'beon' of the Bittern might again be heard in our land. To Scotland it is an irregular visitor, though widely diffused, except in the outer islands: 
while in Ireland it is now chiefly found in winter, though it used to breed in the south up to the first quarter of this century.

The Bittern is not yet known in Norway, but it is a springmigrant to Sweden up to about $60^{\circ} \mathrm{N}$. lat.; while in Russia its range can be traced to $57^{\circ}$, and in Siberia to $64^{\circ}$. Southward, its summer distribution extends throughout the entire Palrarctic region from China and Japan to the Azores, and it is resident in the warmer portions of Europe, where its numbers are augmented in winter by visitors from the north. It is found in suitable localities throughout Africa, breeding as far south as Cape Colony.

Extensive reed-beds, such as still remain in Holland and other parts of Europe, are the usual nurseries of this skulking species; but sometimes it selects swamps on the margins of unfrequented lakes. The nest, placed on the ground amongst the thickest herbage, is composed of dry reeds heaped together; the eggs, often laid in Narch or April, and usually 4 in number, are of a uniform brownish-olive colour, sometimes with a green tint when fresh: average measurements $2^{\circ} \mathrm{I}$ by $\mathrm{I}^{\circ} 5$ in. They are laid at intervals of several days, and incubation lasts more than three weeks; while the young are fed by the parents until fully fledged, and do not quit the nest till nearly able to provide for themselves. The Bittern usually feeds at night, and is seldom seen on the wing in the day, during which it remains with head erect in thick beds of reeds or sometimes in trees, whence it is with difficulty made to rise; the flight is dull and flagging, and seldom sustained to any great distance, except on migration. In the breeding-season, the male makes a loud booming or bellowing noise, whence, probably, the term Butaurus; but at other times the bird utters a sharp, harsh cry. When wounded it throws itself on its back, like a Hawk, and fights desperately with claws as well as bill. The food consists of small mammals, birds, fish, lizards, frogs, and, in fact, almost anything that can be swallowed whole. The Bittern has been described as a solitary bird; but a flock of forty to fifty has been observed on the wing, and in Lower Egypt Capt. Shelley got close to about a score reposing among the reeds.

The adult has the crown and nape black; general colour buff, irregularly barred abore and streaked below with black; feathers of the neck long and forming a ruff; tail of ro soft feathers; primaries chestnut barred with blackish; bill greenish-yellow; legs and feet grass-green. I.ength $2 S$ to $30 \mathrm{in}$. : wing $\mathrm{I}_{4} \mathrm{in}$. The sexes and young resemble each other in plumage. 


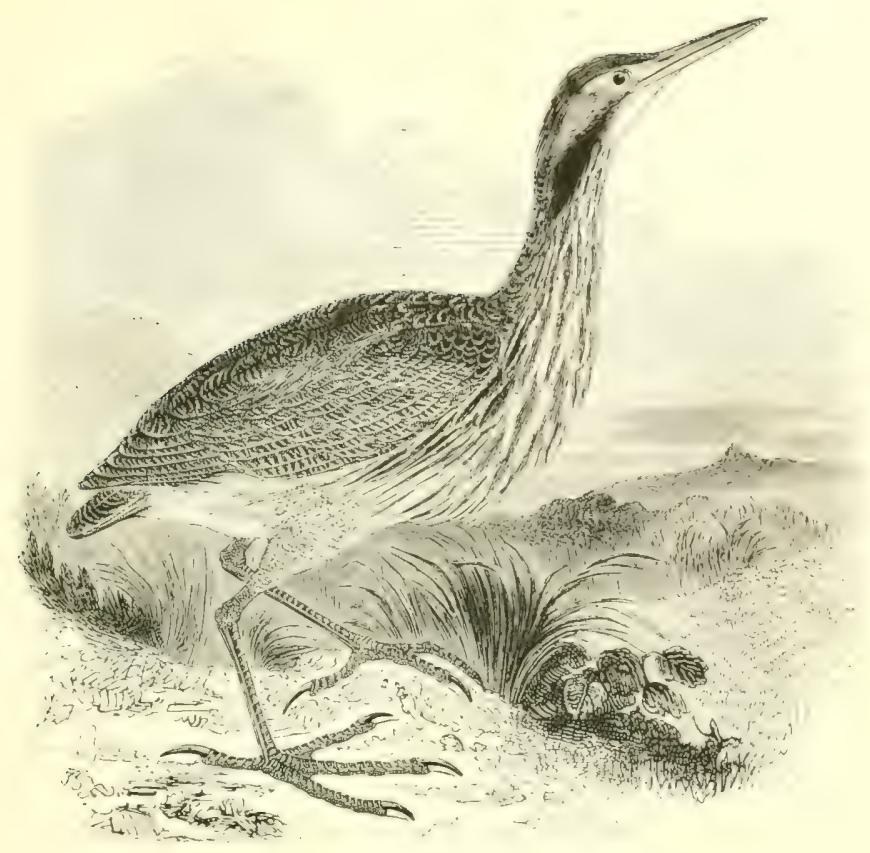

THE ALERICAN BITTERN.

\section{Botaurus lentiginósus (Montagu).}

It is difficult to refuse a place in the Iritish list to a bird which, although an inhabitant of America, has been obtained on more than twenty occasions in our islands, and was first distinguished as a new species by Montagu, from a specimen killed in I) orsetshire in 1804 . Since that date others have been recorded from Kent, sussex, Hants, I)evon, Pembrokeshire, Inglesea, Iancashire and Vorkshire; in Scotland, from the Pentland Hills, I)umfriesshire, Islay, Aberdeenshire and Caithness; in Ireland, from cos. Down, Irmagh, Louth, Tipperary and Cork. As far as is known, all these have heen obtained between October and January, with the exception of one shot in Dumfriesshire on March 25 thi i $S 7, S$ : dates which cuincide with those of its well-known annual migrations. Although an example was killed in (juernsey on ()ctober 2 ; th is $; 0$, the American Bittern has no yet occurred on the Continent; and this may be accounted for by the fact that the greater part of the trade across the North Atlantic is to the British Islands, which are, also, the nearest land. There can be little doulst that many, and probalsly 
most of our visitors, have been aided on their passage by being able to rest on the yards of vessels; especially on those of steamers, the square sails of which are seldom set, so that a bird might easily remain unobserved and undisturbed by day as well as by night, while each twenty-four hours would find it some 300 miles further on its way across. It could probably exist without food for far longer than is necessary for such a transit; moreover, its long slender feet would enable it to alight on patches of sargasso and other strong floating sea-weeds found in the (iulf Stream, and upon these it would also find small fish, crustaceans, and other sustenance.

As a straggler, an exhausted example of this species was captured by dogs at Egedesminde in Greenland, in $\mathrm{r} \$ 69$; and in America its range on the Mackenzie River extends even to the Arctic Ocean, though the bird is probably rare so far north, and is not recorded from Alaskia. South of the 5 Sth parallel in the Fur-countries, it is found, as a breeding-species, down to Texas; while on its autumnal migration it is a regular and sometimes an abundant visitor to the Tiermudas, where it also occurs, though with less frequency, on its passage northward in March. In winter it visits the West Indian Islands and Guatemala.

When situated on dry ground, the nest is a slight structure of reeds and grass; but in places liable to inundations it is sometimes considerably elevated. The eggs, $7_{-7}$ in number, are equally obtuse at either end, and are of a uniform brownish-olive colour : average measurements $\mathrm{I}^{\circ} 9$ by $\mathrm{I}^{\circ}+5$ in. This Bittern usually feeds on frogs, lizards, and small mammals; but as an instance of its omnivorous habits, Mr. Hurdis, of Bermuda, mentions that the stomach of one contained an eel six inches long, a mouse, a dragon-fly, a grasshopper, and a portion of a small golden carp. The note of the male in the early part of the breeding-season is a deep choking croak, resembling the syllables fomp-au-gir; or like the noise made by driving a stake in boggy soil, whence its common name of "Stake-" or "Post-driver." Dr. Coues says that it has another abrupt. explosive cry, something like quark or hauk, uttered when the bird is surprised while feeding, or when its haunts are invaded; ordinarily, however, it is silent.

This species resembles our Old World bird in general plumage, but is smaller in size; its bill, legs and feet are more slender; the feathers of the upper parts are more finely vermiculated; and the primaries are uniform leaden-brown. Length about 27 in.; wing II'5 in. The young have a ruddier tinge and coarser mottlings. 


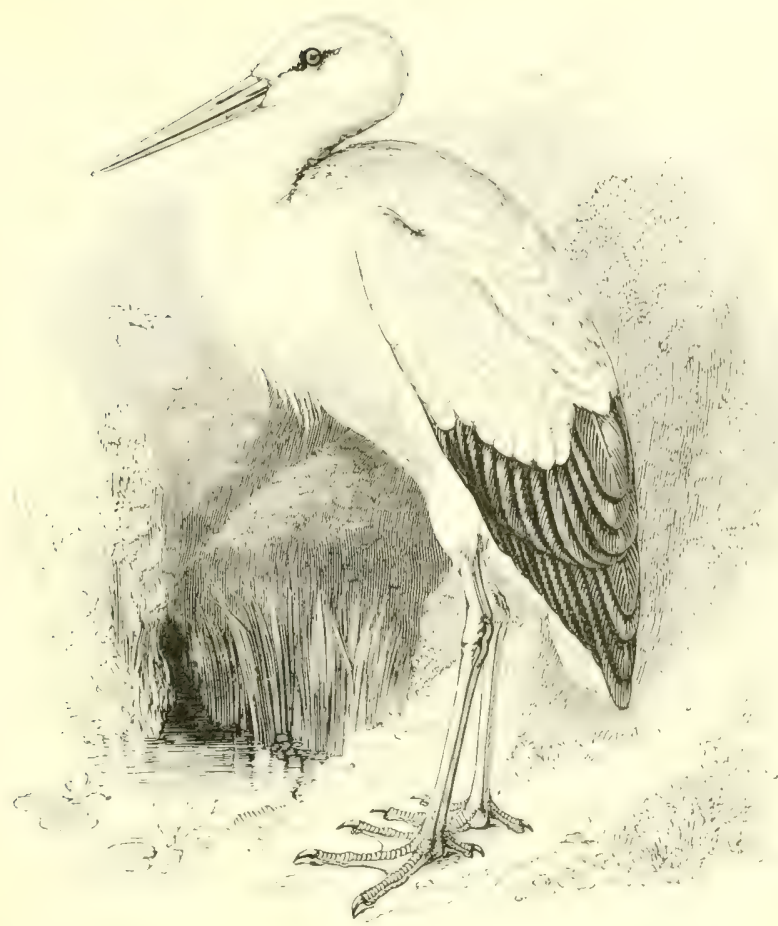

'THE WHITE STORK.

Cicónia Álba, Bechstein.

It does not appear that the White Stork has ever been more than an irregular wanderer to the British Islands: and even in $15 .+1$ )r. William Turner, writing at Cologne, expresses his surprise that a bird so common in Germany should be unknown in lingland. Later, by Merrett, Willughby and Ray it was considered a very rare visitor, but Sir Thomas Browne remarked its not unfrequent occurrence in the fens and marshes of Noriolk, where, from its proximity to Holiand-in which the species has long leen protected-more examples have since been obtained than in all the rest of (ircat Britain. An adult female, shot about May 1 th 1861 at Woodbastwick, contained an eggr ready for exclusion, which was cratced by the fall of the bird; and fully thirty specimens must have been recorded from Last Anglia, chiefly in the springe. Several have heen noticed in our more southern countics, and on . Ipril z 2 rd 1 sist at flock of six passed over the town of Newhury in licrkshire, flying 
in a north-easterly direction. Northward, the occurrences of this species become less frequent, and in Scotland they are rare, though extending to the Shetiands; still fewer are known on the west side of Great Britain; while in Ireland only two are on record, both from co. Cork.

In Norway the White Stork has been found as far north as Bergen, and is a yearly visitor to the south; where, however, it is not encouraged to breed as it is in sweden, Denmark, (iermany, Holland and the greater part of Central Europe. In France, Italy, Sicily, Sardinia and Malta it is of irregular appearance; but in the Spanish I'eninsula it nests freely on the towers and belfries of churches in towns, and on the 'almiares' or stacks of the farm-houses. It is equally abundant in Slavonia and the l anubian Provinces, although not specially protected there; also in Turkey and Southern Russia; but in Greece and the Archipelago it is less common. It breeds in Asia Minor, and sparingly in l'alestine, which it visits in great numbers on migration; while in summer it ranges through Persia to Central Asia, and in winter to India as far south as Calcutta. In China and Japan the representative species is C. boliciana, with black bill and red lores. In the west, the White Stork is a wanderer to the Canaries, and is numerous from early spring to autumn in North Lfrica, where a few remain during the winter; but the majority pass southward-immense numbers migrating through Egypt-as far as Natal and Cape Colony, where a few pairs are said to breed when locusts are abundant.

The nest, built of sticks, and added to year by year, is usually placed on buildings, or on cart-wheels set up for the use of the bird, in Holland and other parts of the Continent; but trees and the ledges of cliffs are also utilized. The eggs, $3^{-5}$ in number, are pure white: average measurements 2.8 by 2.1 in. The yolk is of a very deep orange-colour. Incubation, which lasts a month, begins in April or May, according to season and locality. The old bird feeds the young by inserting its beak within the mandibles of the nestling, and then passing from its stomach the half-digested food. 'This consists of frogs--especially Rana esculenta, reptiles, fish, grasshoppers and other insects, worms, small mammals and young birds. During the breeding-season Storks keep up a constant clattering with their bills.

The adult has the bare skin round the eye black; plumage white, except the quills, which are black frosted with grey; bill, legs and feet red. Length $42-44$ in.; wing 23 in. In the young the quills are dull black, while the feet and legs are brownish-red. 


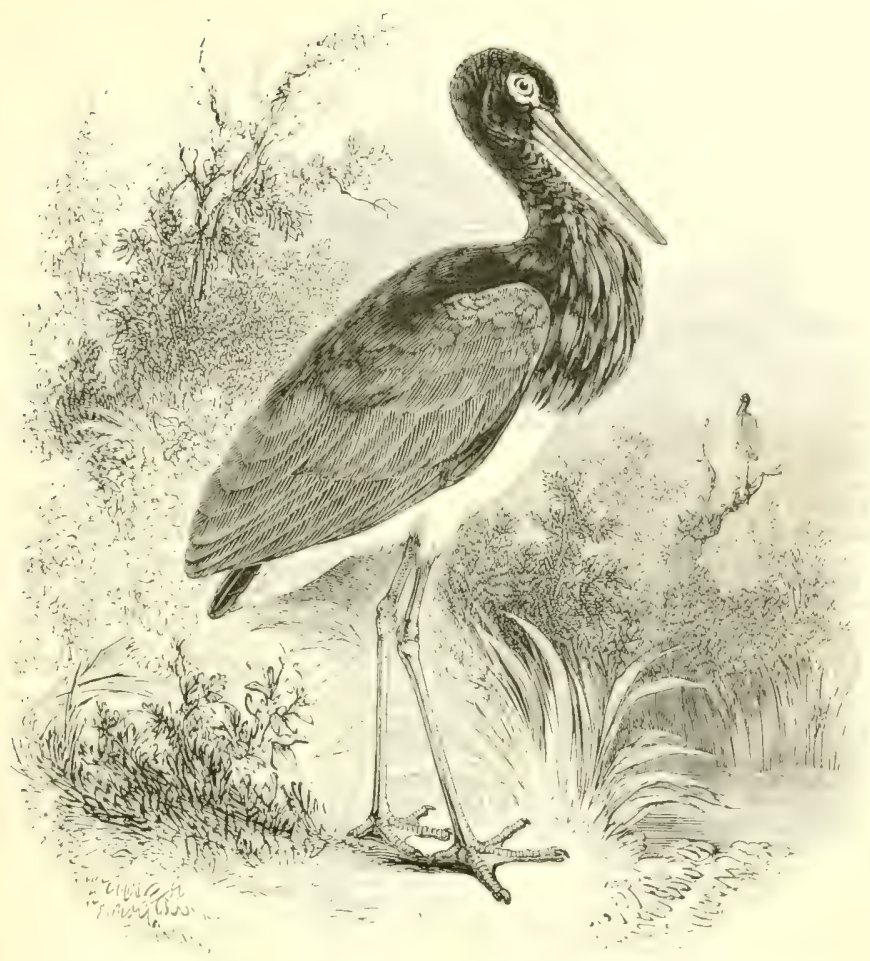

THE BLACK S'IORK.

\section{CICONIA Nígra (Linnæus).}

The Black Stork is a far rarer visitor to England than its congener, and there is no authentic record of its occurrence in Scotland or Ireland. In May ISIt a bird, disabled by a slight shot-wound, was captured on West sedgemoor, somersetshire, and lived in the possession of Montagu for more than twelve months; it is now in the British Museum. Since that time examples have been obtained, at long intervals, between the months of May and November, in Devon (I), Dorset (2), Kient (2), Oxfordshire (I), Essex (I), Suffolk (I), Norfolk (2), Vorkinire (I), and I)urham (1).

This species is only a straggler to Norway; but it breeds sparingly in the forests of the south of swerlen, I enmark. Brunswick, Hanover, Pomerania, and some other partiof (icmany : also in Poland, Central and Southern Rusia, the l)anubian I'rovinces. Turkey and Spain. In the rest of Europe it occurs as a migrant, 
and is even said to visit Madeira. Eastward, it breeds in Palestine, and can be traced - through Persia, 'Turkestan, Siberia up to $55^{\circ} \mathrm{N}$. lat., and Mongolia-to China, where it nests on cliffs in the mountains near Pekin; while it winters as far south as Central India. It is found throughout Northern Africa, from Morocco to Egypt, Nubia, and Abyssinia; and appears to be generally distributed in cold weather down to Cape Colony.

Unlike the White Stork, which frequents the society of man, the Black Stork has its breeding-haunts in the most secluded spots, and generally in marshy woods, where it builds its nest in high trees. Mr. H. J. Elwes describes one in Jutland as a large and heavy mass of sticks, lined with tufts of green moss, and situated about thirty-five feet from the ground, in a good-sized beech; another was on an old nest of the White-tailed Eagle in a smaller tree, overlooking a wide swampy valley in the forest; and Mr. Seebohm found similar structures in oaks and firs. In Spain, Bulgaria and Turkey clefts and ledges of cliffs are also used. The eggs, $4-5$ in number, are coarse in texture and of a dull greyish-white colour, while when the shell is held up to the light the lining membrane shows sreen, whereas it is yellowish in the egg of the White Stork; the average dimensions also are smaller, being about 2.6 by $2 \mathrm{in}$. The male stands by the female whilst she is sitting, and little fear of intruders is shown. Incubation commences in the latter half of April, and, as a rule, the Black Stork arrives at its northern breeding-stations rather earlier than its congener; while it leaves later in the autumn, and has once been obtained in Sweden in winter. It.s food consists chiefly of fish; but frogs, reptiles, small mammals, and aquatic insects are also eaten. The young birds utter a peculiar guttural note; the adults, however, merely making a clattering noise with their bills. The illustration was taken from a specimen which lived in the gardens of the Zoological Society in the Regent's Park for about thirty years.

The adult has the head, neck and upper plumage glossy-black with blue, purple, copper-coloured, and green reflections; under parts below the neck white; bill, neck, skin round the eye, legs and feet scarlet. Length 40 in.; wing $2 \mathrm{I}$ in. The sexes are alike in plumage. In the young bird the upper feathers are dull metallicbrown, margined with dirty-white; and the bill and legs are olivegreen, afterwards turning to orange-red.

The Storks have no powder-down tracts, neither have the Ibises or Spoonbills any. 


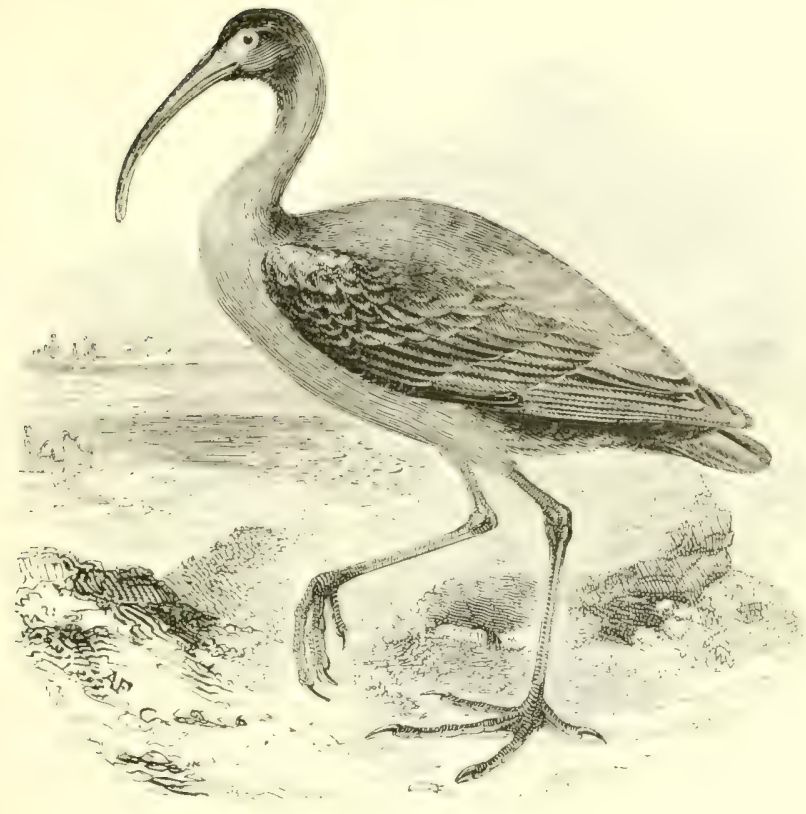

THE GLOSSY IBIS.

Plégadis falcinḱllus (Linnæus).

The Glossy Ibis is now only of accidental occurrence in the British Islands, but towards the end of the last century its visits appear to have been more frequent, and near I,ynn in Norfolk it was known to sunners and fishermen as the "Black ('urlew: In the eastern counties and on the estuaries of the south coast it has, naturally, been observed more often than in the west, though it is popularly and erroneously supposed to be the bird called the Liver, figured in the arms of Liverpool; while northward it is decidedly rare, only six examples having been obtained in scotland. one of them at Unst, in the shetlands. In Irelanel it has occurred. either singly or in small flocks in the southern and casterm countien, and once near Belfast. As a rule this species visits us in autumn or early winter, but occasionally in spring.

To the Faroes, Iceland, Scandinavia, lenmark, and the lialtie Provinces the (ilossy Ibis is a rare straggler; and anywhere north of the Alpine ranges of Central Europe its appearance can only be considered irregular. Southwards it becoms common, and is 
believed to nest in the Camargue near the mouth of the Rhone, as it undoubtedly does, in wet seasons, in the marshes of Southern Spain. Its great European colonies, however, commence in Slavonia, and are to be found along the valley of the Danube, and thence throughout the Black Sea district to the Caspian. In Asia it ranges to $48^{\circ} \mathrm{N}$. lat., and breeds as far south as Ceylon; while in winter it passes down the Eastern Archipelago to South Australia. It nests in suitable localities in North Africa, and on the east side of that continent its migrations extend to Natal. According to the latest authorities our Glossy Ibis is found in the Eastern United States and the West Indies, but the representative species in North America is $P$. suarauna, which has a white margin of feathers surrounding the bare space on the forehead.

Mr. W. E. Clarke found the (Hlossy Ibis breeding by thousands in the great bird colony on the Obedska 'bara' in Slavonia; its nests being constructed of sticks and a few reeds, placed among the lower branches of sallow-bushes, and either on the surface of the water or very little above it. The eggs, $3^{-4}$ in number, are oval, and are of a beautiful greenish-blue pitted with slight indentations: average measurements 2 in. by $\mathrm{I}_{5} 5$ in. In India and Ceylon the nests are built in trees, and Col. Legge describes the young as climbing actively among the branches, and clinging so firmly with their feet as to be removed with difficulty. The food consists of small reptiles, crustaceans $\&$ c., obtained on the muddy banks of rivers and estuaries; and, in Africa, of locusts, scorpions and beetles. In its flight the pinions are first moved rapidly, and produce a whizzing sound, after which the bird skims for some distance.

The adult has the head, neck and under parts deep reddish-brown; back, wings and tail brownish-black, glossed with metallic-green and purple; bill dark brown; bare skin round the eyes greenish-grey; irides hazel; legs and feet bronze-brown. Length about 22 in.; wing 10.75 in. The sexes are alike in plumage. The young bird has no glossy tints; and the head, cheeks and neck are streaked and patched with greyish-white.

The family of the Ibises, of which Pligadis forms a somewhat outlying genus, has no real affinity to the Curlews, with which, owing to a superficial resemblance in the shape of the bill, it was formerly associated. On the contrary, its relationship is with the Storks (Ciconiidic), and, more closely, with the Spoonbills (Plataleida). The egg of the Sacred Ibis is similar to that of the Spoonbill, and so are, probably, the eggs of the other typical species. 


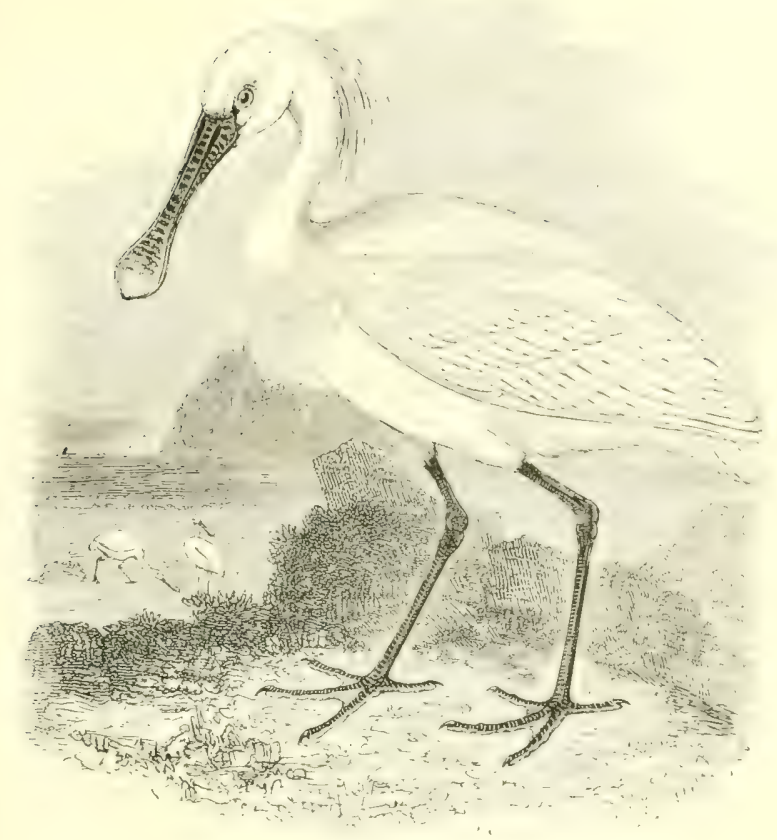

THE SPOONBILL,

Plataléa leucoródia, Linnæus.

In the days of Willughby and Sir Thomas Browne the Siponbill used to nest on trees-in company with Herons-in Norfolk and Suffolk; and Mr. J. E. Harting has drawn attention to earlier breeding-places near Goodwood in Sussex, and even at fulham in Middlesex (Zool. I877, p. $425 ;$ r 886, p. 8I) : its usual name in the sixteenth and seventeenth centuries being 'Shovelur,' or 'Shovelard.' Even now the bird is by no means unfrequent in East Anglia, and along the south coast it is found from time to time, especially in Cornwall; while occasionaliy it wanders up the Thames valley, and even to Wales, though on the west side of England it is rare. Nine specimens have been recorded from Yorkshire, but northward it is of rare occumence; stragglers hate, however, been obtained in the Helrides, ()rkneys and shetlands. To Ireland it is a very irregular visitor, and principally to the southern districts.

In Scandinavia and Northern Russia the Spoonbill is uncommon, 
but south of $56^{\circ} \mathrm{N}$. lat. it breeds in suitable localities, even as near as Holland, where, however, its haunts are rapidly being drained. Its arrival is usually in April, and it remains till September, or a little later. To France it is now merely a wanderer, though in the time of Belon it used to nest on trees in Brittany and Poitou; but it breeds in the south of Spain, as well as along the I) anube and in the Black Sea district, whence it emigrates in winter. Eastward, its summer range extends from Asia Minor to India, Ceylon, and Northern China; while in Africa our Spoonbill appears to be resident at least as far south as the Dahalac Archipelago in the Red Sea. In the south of that continent the representative species is $P$. tomirostris, while other members of the genus are found in Australia and South-eastern Asia. Our bird can be traced to the Canaries, Madeira and the Azores; but the Roseate Spoonbill of America belongs to a structurally different genus, Ajaja.

'The nests, usually formed of piled-up reeds, are placed on the mud among rushes, as in Holland; on the submerged branches of willows, as in Slavonia \&c. ; or on trees, as already mentioned; the last being a favourite site in India and Ceylon. In Europe laying begins late in April or early in May, the eggs, 4 in number, being deposited at consideralle intervals; they are rough in texture, and are dull white, streaked and spotted with reddish-brown in colour: average measurements 2.5 by $1 \cdot 8$ in. The food consists of small fish, frogs, molluscs, aquatic insects and crustaceans, obtained in shallow pools; and Wolley noticed that the bird, while feeding, kept its bill immersed, upon which, as on a pivot, a movement in a semicircle was rapidly maintained by the whole body. In captivity the Spoonbill is inoffensive to other species, and will eat any sort of offal. It is said to emit a grunting note, but it has no true vocal muscles; in old birds of both sexes, however, a singular figure-of8 -like convolution of the windpipe is found, though this is absent in the young.

The adult male in spring has the plumage white, with a tinge of yellow on the occipital crest and at the bottom of the neck; bill yellow at the tip, the rest black, barred with yellow; gular region orange; irides red; legs and feet black. Length 32 in. ; wing $14^{\prime} 5$. The female is slightly smaller and has less crest than the male. In the young bird the bill is narrower at the tip, more flexible, and of a livid flesh-colour; the irides are ash-colour, the shafts and ends of the quill-feathers are black, and the occipital plumes are wanting. 


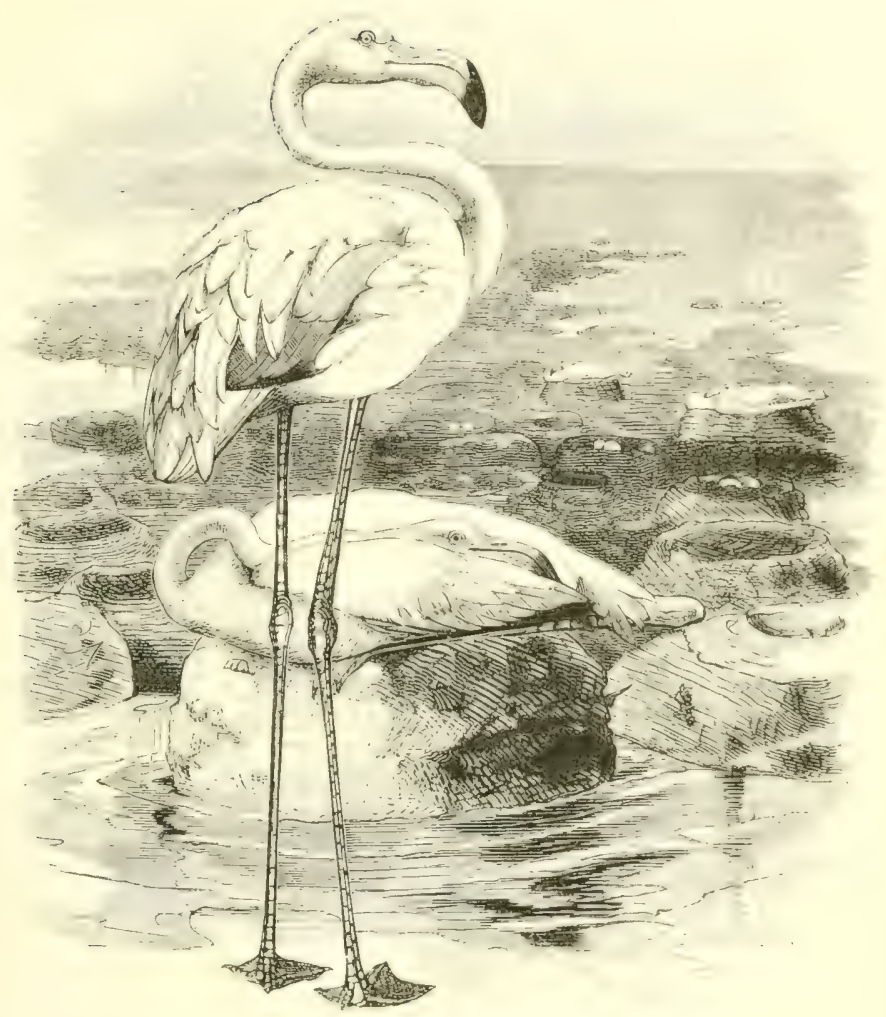

THE FLAMINGO.

Phenicópterus róseus, Pallas.

Early in September i SS I an adult Flamingo was seen for a week or so on the estate of the late Sir John H. Crewe, in the northern part of Stafiordshire; but having crossed the river Manifold to another property, it was captured and taken to the owner of the land, by whom it was kept alive for a few days, and then killed. Another adult bird recorded by Lord Henry Scott (\%ool. iss. p. 338), was shot on November 26 th 1883 , on the mud banks outside the Beaulieu river, Hampshire, which it had frequented for about a fortnight after a great gale from the south-west. Capt. (;. F. Shelley has informed me that on August reth 18.8 . When waiting near New Romney for the evening flights o: Curlews, an adult litaminger hew past him, having been put up by his two nephews, who grot within 
about fifty yards of it. Inquiries failed to show that any bird of this species had escaped from menageries about the above dates; but one which was shot in the Isle of Sheppey on August I6th I873, may have been an individual which escaped from the London Zoological Gardens on July r 9 th.

The visits of the Flamingo to England are not nearly so remarkable as are those of many other southern species, for stragglers have been obtained in Pomerania and Hesse-Darmstadt; single birds, and even flocks, have been observed from time to time along the Rhine; and varying numbers almost annually ascend the valley of the Rhone, visiting the lakes of Savoy, and the étangs of $\mathrm{La}$ Brenne in Central France. Flocks of from one to two thousand resort to the extensive salt marshes of the Camargue in years when there is plenty of water, and in 1870 i saw baskets-full of eggs which had been taken there; while still larger communities are found at the mouth of the Guadalquivir in the south of Spain, and at Tunis and other suitable places in the basin of the Mediterranean; also in the Caspian district. Its range extends from the Canaries and Cape Terd Islands on the west, over the whole of Africa ; and over Asia as far north and east as Lake Baikal.

It had long been known that Flamingoes bred in colonies, depositing their eggs on nests built of mud, and raised to heights varying from a few inches to about two feet, according to the liability of the soil to inundation; but Mr. Abel Chapman was the first to prove, from personal observation (Ibis, I $8 S_{4}$, pp. S6-89), that the birds sit with their long legs doubled under their bodies, and do not stand astride of their nests, as popularly supposed and erroneously pictured. The eggs, laid about May 24 th, are 2 in number, and of a very chalky-white surface, beneath which the shell is greenish-blue: arerage measurements 3.6 by 2.25 in. The food consists of aquatic plants and grass, frogs \&c. Like Grey Geese, Flamingoes feed by day; their cry, formations in flight, and moult are similar, and they also swim with ease.

The adult has the general plumage rosy-white, with scarlet wingcorerts and black quills; irides and bare skin next the eye yellow; bill rosy at the base, black at the tip; legs and feet pinkish-red. The length varies, irrespective of age or sex, from 60-70 in.; the wing averages 16 in. In the young of the first year the pink is absent, except a slight trace of it on the wings; the secondaries are irregularly barred with black, and the bill, eyes, legs and feet are dull lead-colour. 


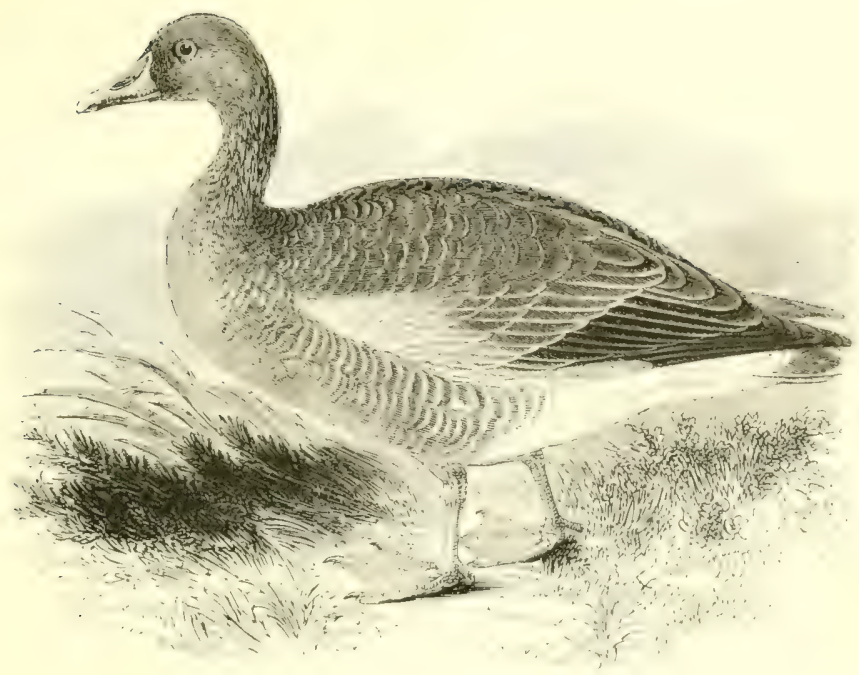

THE GREY LAG-GOOSE.

Ánser cinéreus, Meyer.

This species is generally supposed to be the principal source from which our domestic race has sprung, and, according to I'rof. Skeat, the trival name indicates that it is the Grey (ioose which in former days lagged behind to breed in our fens, when its congeners had betaken themselves to more northerly regions. Early in this century, however, it ceased to nest in Lincolnshire, and below the Humber it is now of rare occurrence; while further north it is almost unknown along the east coast. Even in winter it is uncommon in the south, and also along the west coast, while in the Solway district and throughout the greater part of Scotland it is seldom met with ; but it still breeds, though in rapidly decreasing numbers, in Ross, Caithness, sutherland, and, more abundantly, in the Hebrides, especially the outer islands. It is, in fact, the only kind of Wild Goose which nests in Scotland, for the statements by Selby as to the breeding of the liean (ioose in Sutherland and by Macgillivray of the Pink-footed (ioose in the Hebrides have never been confirmed. 'To the Orkneys and Shetlands it is only an accidental visitor. In Ireland a colony of semi-domesticated birds has for many years been resident on the lake at Castle Coole (Lord Belmore's), and from autumn till late spring flocks are 
found in Wicklow and some of the central counties, and below Limerick, on the Shannon; but the species is very local.

Though now only a risitor to the Feroes, the Grey Lag-Goose has been known to breed in Iceland, and is tolerably numerous during summer in Scandinavia and Russia. In the latter it nests as far south as the Caspian: as it does also in the Black Sea district and along the valley of the Danube, and, occasionally, in the south-west of spain. In the Mediterranean basin however, as well as over the rest of Europe, it is chiefly observed in cold weather; though a limited number breed in lenmark, and-very locally -in Holland and Northern Ciermany. In Asia its northern range seldom reaches the Arctic circle, while southward it extends to Canton in China, to Central India, and probably to Ceylon; birds from the eastern parts are, however, rather larger in size, with more black on the under parts and less grey on the wing-coverts, and have been distinguished as $A$. nubrirostris of Hodgson.

The nest, generally placed among coarse grass or rank heather, though sometimes on a ledge of a crag, is composed of bents, reeds, or moss, without any lining until the female has laid her eggs, which she then surrounds with down plucked from her breast. These, usually $5^{-6}$ in number, though 12 are said to have been found, are dull yellowish-white: average measurements 3.5 by $2^{\circ}+$ in. In Scotland incubation generally begins about the middle of April, and after the females begin to sit the males leave them and collect in flocks at the nearest water. This Goose feeds on grass and other regetable substances which are found inland, and--unless very much harassed-always by day; at night it betakes itself to promontories, sandbanks, and other spots difficult of access. On long flights, a changeable but more or less wedge-shaped formation is often assumed by flocks of all the 'Grey' species, whence the term 'a skitin of Geese'; while old sportsmen usually spoke of a 'gaggle': the latter term having reference, no doubt, to the noise made by the birds.

The adult has a few white feathers round the base of the bill; the general plumage of the head, neck and upper parts greyishbrown; lower breast and abdomen dull white with a few black spots. The distinguishing characteristics of the species are the bluishgrey rump and wing-coverts, flesh-coloured bill with a white nail at the tip, and flesh-coloured legs and feet. Length: male 35 in., wing 175 ; female 30 in., wing 16 in. The young are darker than the adults. 


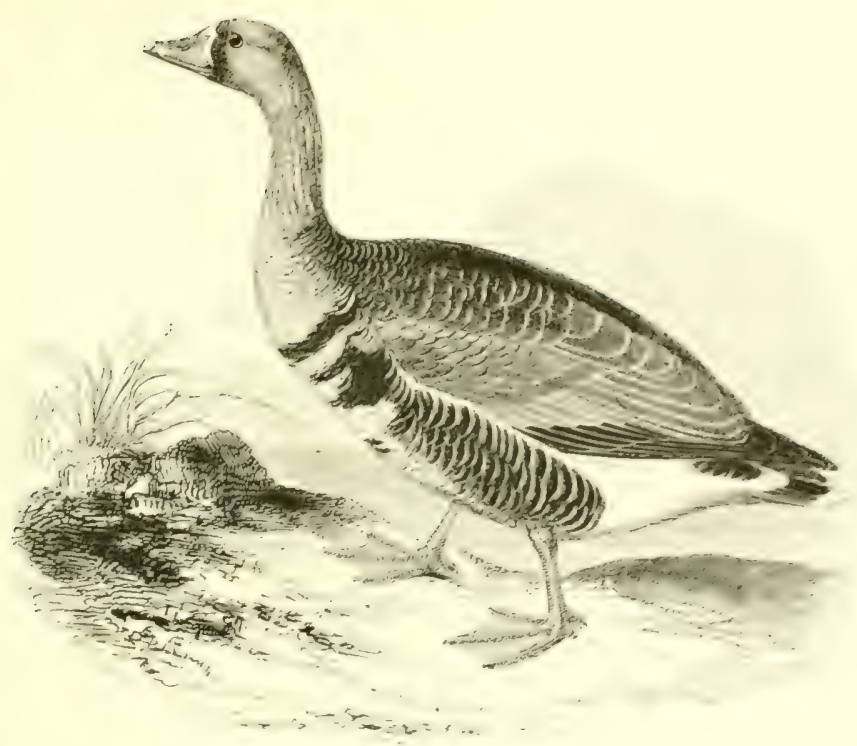

'THE WHITE-FRON'TED GOOSE.

\section{ANSER Álbifrons (Scopoli).}

The White-fronted -or, as it is sometimes called from its hoarse note, the Iaughing--(joose, is a smaller bird than the preceding species, which, however, it resembles in having a white nail at the tip of the bill. It is an annual winter-visitor to the Jiritish Islands, and, should the weather be severe on the Continent. very large flocks occasionally arrive in England, esperially in the south and southwest; but, strange to say, it is not numerous on the east coast, and everywhere appears to be remarkably local in its distribution. It is uncommon on the east side of the mainland of Scotland, except near the Moray Firth; while on the west it occurs but sparingly in the Outer Hebrides, though in Islay it is the commonest of 'Grey' Geese, arriving early in October, and remaining till the middle of April. In Ireland it is aloundant in the southern, western and north-western counties, and large numlers were observed during the severe winters of $1879-80$ and $1880-81$.

The true White-fronted Goose has occurred in the liveres and the southern part of Iccland; and although it is not known to nest in Norway or sweden, yet in winter it visits their coasts, as well as those of Denmark and Western Furope as far as the Meditemanean. 
It is also found inland, and from its breeding-places in Arctic Russia it migrates down the Volga and other great river-valleys to Syria, Egypt and Nubia. This species is supposed to have had a share in the origin of our tame stock, for it was domesticated by the ancient Egyptians, as shown by its admirable portraiture in paintings on a slab from Meydoun, and on others in the temple of Amada in Nubia, as well as in the British Museum. Its chief nestinggrounds are in siberia, where Dr. von Middendorff found it to be the commonest species of Goose in the Taimyr district, while in the cold season it migrates as far as Shanghai and Northern India.

The bird which breeds in the northern districts of Scandinavia and on its fells, is characterized by smaller size, somewhat darker plumage, and short bill, straight-ridged from the tip to the forehead, on which the white extends beyond the line of the eye. By those who admit its claim to specific rank this is known as the LESSER White-fronted Goose, Anser erythropus of Linnæus; a young male was shot by Mr. A. C. Chapman at Holy Island in Northumberland, on Sept. I6th I 886 . Mr. Seebohm obtained this form -as I consider it - on the Yenesei, and the area which it visits on migration appears to be nearly identical with the range of the larger and more numerous bird. The White-fronted Goose found in Greenland, and in America up to $72^{\circ} \mathrm{N}$. lat, has been distinguished by the name of $\mathrm{H}$. gamleli; it is a very large bird, with a great deal more black on the breast, abdomen, and flanks, and much darker under wing-coverts; it occurs as far west as Alaska, but is not known to visit the Aleutian Islands or the Asiatic coast.

The nidification of the White-fronted Goose is like that of its congeners; the eggs, 5-7 in number, and creamy-white in colour, average in measurement 3 in. by 2 in. For its feeding-grounds this species appears to prear fields of grass and clover to stubbles. It breeds in captivity, and has been known to produce a brood by union with a Bernacle Goose.

The adult male has a large amount of white on the forehead and at the base of the upper mandible; upper plumage brcwnish-ash ; breast and belly brownish-white, broadly barred with black; bill orange-yellow, with a $w^{\prime}$ hite nail at the tip; legs, toes and webs orange. Length 27 in. ; wing 16 in. The female is rather smaller and has less black on the breast. The young are darker and more uniform in colour; the feathers at the base of the upper mandible are not white, but dark brown; there are no black markings on the breast in females; and the nail is light brown. 


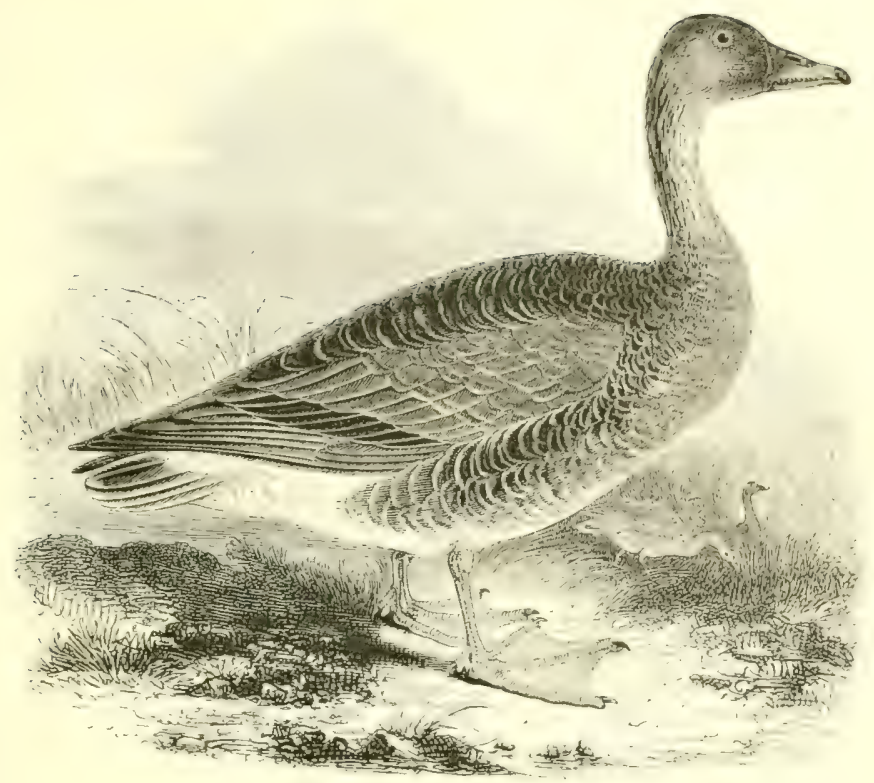

THE BEAN GOOSE.

Ansef. ségetudi (J. F. Gmelin).

This and the nearly-allied Pink-footed Goose next to be considered, may readily be distinguished from the two preceling by the black nail at the tip of the bill. As already observed, the bean Goose does not breed in any part of the British Islands, but it comes to us in autumn, and many frequent our coasts during the winter ; a return migration being observalle early in the spring. ()n the eastern side, and also in Iancashire, it is less aluundant than the Pink-footed Goose; but elsewhere. and especially in Cornwall, it predominates. (In the mainland of Scotland and in some of the islands it is common in cold weather, but its reported occurrence in the Outer Hebrides is unsubstantiated, and to the ()rkneys and Shetlands it is only a straggler. In Ireland, from autumn to spring, it is generally distributed, and is, as a rule, the most abundant of the 'Grey' Geese which feed inland.

The Bean (ioose is only a visitor to Iceland, but it breerls in considerable numbers in Scandinavia to the north of lat. 1.4 , and also in North Russia. Messrs. Seebohm and Harvie-Brown found it nesting on the 'tundras' of the l'etchora: and at lwoinik, on Iuly 


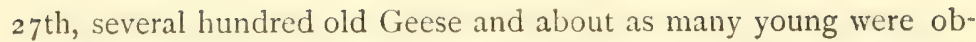
served marching like a regiment of soldiers, most of them being in full moult and unable to fly. Capt. A. H. Markham, R.N., brought specimens from Novaya Zemlya, where he found this-but no other 'Grey' (Goose-very abundant at the end of July and early in August. Eastward we trace it in summer across Arctic Siberia, and through the mountains further south as far as Amurland; while large flocks visit Japan and China in winter. The birds found to the east of Lake Baikal have very large bills and feet, and some of the males exhibit a tawny colour on the head and neck, like that in the Chinese Goose, A. cysnoides, found in the same regions. The winter range in Asia does not extend to India, but the bird visits Palestine and the basin of the Mediterranean, and is said to have been obtained in Madeira. On the Continent generally it is abundant during the colder months, except in Spain ; and in France it is well known by the name of Oic des moissons, or Harvest-Goose, from the time of its arrival and its partiality to stubbles.

The nest, built early in June, is a hollow in a tussock of sedge or upon a hillock in an islet; the eggs, 3-4 in number, are dull creamywhite, measuring about $3^{*} 2$ by $2^{*} 2$ in. : smaller and much lighter in weight than those of the Grey Lag-Goose. The Bean Goose feeds by day, inland; and its name is probably attributable to the bird's partiality to pulse, grain, and néwly-sown beans in early spring. Sir R. Payne-Gallwey says that Bean Geese are the slaves of weather; when frost sets in they are driven to the neighbourhood of tidal-waters; continued rain and wind keep them inland; a north wind unsettles them; a north-east wind, again, will bring them to the coast in anticipation of frost; a change, and they are on their travels once more. He adds that Geese are not very wary at night, nor do they appear to possess the power of vision of other wild-fowl. In confinement, this species has bred with the Pink-footed Goose.

The adult is characterized by its somewhat slender shape, long bill-orange in the centre, and black at the base and on the nailorange-yellow legs and feet, and the absence of any black on the breast; the general plumage is darker than in the two preceding species, and there is no bluish-grey on the shoulder of the wing. Length of the male 34 in. ; wing long in proportion, and averaging nearly 19 in. The female is rather smaller. Young birds are generally darker, their markings are less distinct, and the neck has a tawny tinge. 


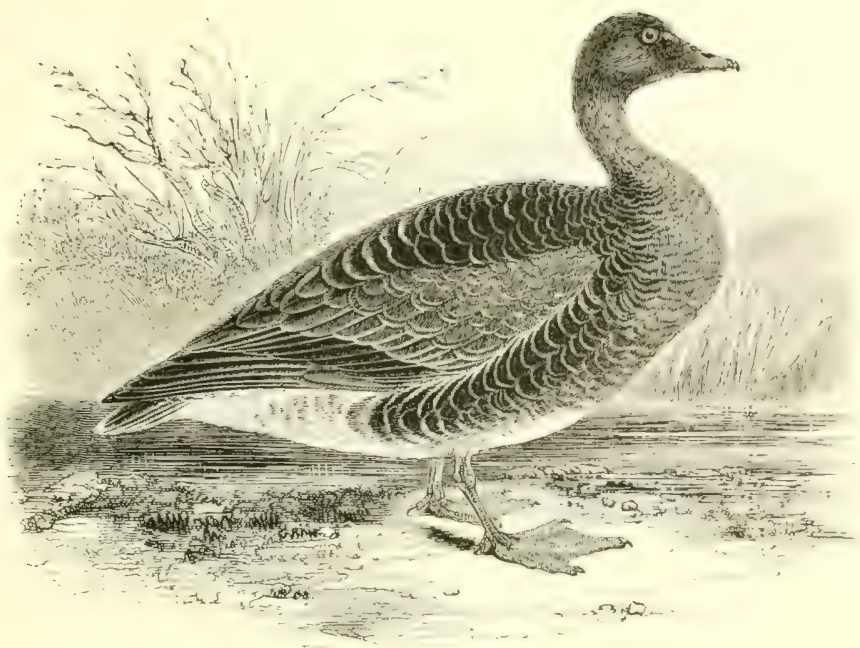

THE PINK-FOOTED GOOSE.

ANSER bRACHYRHínCHUS, Baillon.

Mr. A. D. Bartlett was the first to call the attention of British ornithologists to the distinguishing marks of this species, in a paper read before the Zoological Society of London on January Sth I839; although the name which he then proposed had to give way to one previously conferred by Baillon of Abbeville, in an obscure French periodical. Subsequent observation has shown that the Pink-footed rivals the Bean (roose in abundance during the colder months of the year, and that nearly all the large flocks of '(irey' Geese which frequent the marshes and uplards of Holkham and Burnham in Norfolk are of this species. Similar testimony has been sent to me respecting the Humber district by Mr. Cordeaux, the eastern part of Yorkshire by Mr. W. Eagle Clarke, Northumberland by Mr. Abel Chapman, and Lancashire by Mr. Mitchell; in the south of England, however, its occurrences are less frequent, or pass unnoticed. It is found in winter on the east coast of Scotland; as also on the west side, and sparingly in the ()uter Hubrides. In Ireland it is said to have been recogni\%ed, but has not yet been obtained.

The Pink-footed Goose occurs in Iceland, and the late Mr. Proctor several times received birds together with eggrs said to belong to them. It appears to be the only " (irey' (ioose found breeding in 
Spitsbergen, and may perhaps be the 'Goose of some kind' observed by Mr. Leigh Smith's party on Franz-Josef Land; but on Novaya Zemlya the species found l,y Capt. A. H. Markham was the Bean. It visits Norway, but assertions that it breeds there have not been absolutely confirmed by Prof. Collett's subsequent experience. Accurate information is scanty respecting its distribution in Sweden, Denmark, Russia and the greater part of Europe; but examples are known to have been obtained on passage in Holland, Belgium, and France. Authenticated specimens have been taken in winter in Northern India, but not in Siberia or China, and the bird recorded by Swinhoe under this name from Japan has proved to be A. crythropus.

The nest is said to be placed in situations commanding an extensive view, and the male is constantly on the watch to warn his mate of any approaching danger. Messrs. Cocks and Chapman found three pairs with goslings in the yellow downy state at Magdalena Bay, Spitsbergen, on the egth July, by which date the adults had recovered the use of their wings, being more advanced in their moult than the Brent Geese. The eggs are rather less than those of the Bean Goose, of a pure white colour, and measure $3^{\prime} 15$ by $2^{\circ} 15$ in. In captivity the P'ink-footed Goose is said to keep apart from its congeners. Its voice differs from that of the Bean Goose in being sharper in tone, and the note is also repeated more rapidly.

Mr. Cecil smith has set forth the characteristics of this species so clearly and tersely that I cannot do better than copy his words. He says, "The Pink-footed (ioose has the upper manditle of the bill pink in the centre, base and edges black, nail black, legs and feet pink. This colour does not appear to me to be constant, as some I have kept in a state of semi-domestication and bred from for several years, have, in some instances, had the light parts of the bill and the legs and feet orange, as bright and decided an orange as the orangelegged species; in this state they are very like, and if shot would no doubt be recorded for, Bean Geese. They are slightly different in plumage, however, having the white markings on the tail broader; and the shoulder of the wing is more of a blue grey, in this respect resembling the Grey Lag-Goose, though the blue is darker than in that bird." To this I may add that the Pink-fouted Goose is smaller than the Bean, the length being about 28 in., and the wing 17.5 in.; while the bill is shorter in proportion. Mr. Bartlett has pointed out that the formation of its sternum more closely resembles that of the White-fronted than of the Bean Goose. 


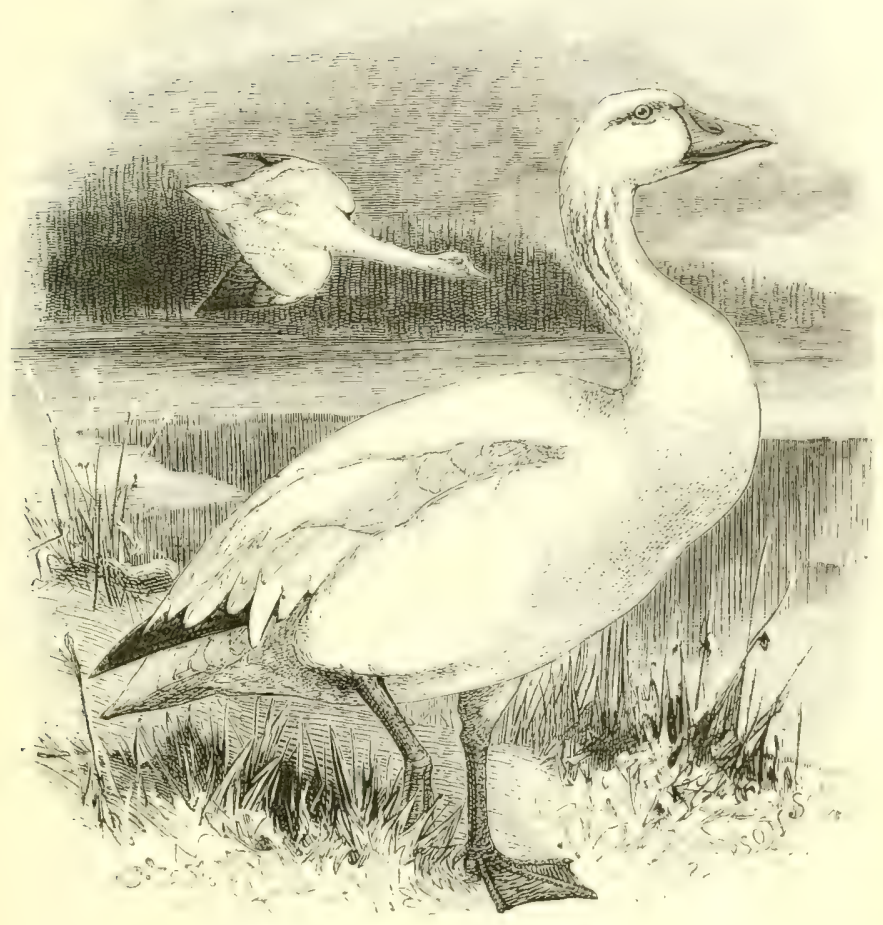

THE SNOIV-GOOSE.

Chen hyperbóreus (Pallas).

On Norember gth 187 I my attention was called to two immature Snow-Geese in Leadenhall Narket; and subsequent investigation, with the assistance of Sir Victor lirooke, showed that these two birds had been shot a few days before, on the lake of Tacumshane, co. Wexford, while a third was killed soon after in Wevford harbour; but not preserved. In October $i_{777}$, as recorded by Mr. I Iarting (Zool. is;8, p. 4I9), a flock of seven were seen near liclmullet, co. Mayo, two of which were captured, and one, a gander, paired with a Common Goose and had young. Having met with its death by an accident in the spring of $18 \$_{4}$, it was presented by Mr. I. R. Crampton to the Museum of Science and Art, I ublin, the athorities of which courteously sent it to me to be figured, and its portrait ly 
Mr. Whymper is at the head of the present article. There is some evidence that three birds sold at the dispersal of the Knowsley menagerie (Lord Derby's) had been obtained in Ireland. On August 2and 1884 the Rev. H. A. Macpherson and others identified an adult bird on the coast near Allonby in Cumberland.

The home of the Snow-Goose is in North America, where two forms are found, distinguishable only in size. The larger breeds in the Hudson Bay region, migrating southward along the Atlantic coast in winter. The smaller, to which-strange as this may appear-the specimens obtained in Ireland clearly belong, is the only one which breeds in Western Arctic America and Alaska, visiting the country between the Pacific and the Mississippi valley during the cold season. It is this race which occurs in Japan and is found in North-eastern Siberia, where it was obtained and described by Pallas under the specific name hyperboreus (Chen albatus of Cassin); and to this probably belong the Snow-Geese which have from time to time been noticed in the Ural district, Greece, Germany down to Silesia, and Heligoland; while in the south of France two have been obtained out of flocks. One or perhaps both forms go as far as the Bermudas, Texas and Cuba.

Mr. MacFarlane describes the nests as being placed near lakes, in hollows formed in the sandy soil, and well lined with down; the eggs, usually 5 in number, are dirty chalky-white: average measurements 3.4 by 2.2 in. The young fly in the middle of August, and by the end of September all have departed south. The food in sumuer consists of green rushes, insects \&c., and in autumn of berries, especially those of Empetnum nigrum. Another member of this genus, $C$. cerulescens, differs only in having a varying amount of lead-coloured markings irregularly disposed over its plumage; and it has been suggested that this and the SnowGoose may be, respectively, coloured and white phases of the same bird, like those that exist in the case of some of the American Herons. There is a third white species, C. rossi, a very small bird.

The adult has the quill-feathers black, greyish at the base, as are also the coverts ; remaining plumage pure white, the forehead sometimes stained with orange-rust colour; bill red, commissures black, nail whitish; legs and feet red. Length: male $28-30$ in., wing $17^{-18}$ in. ; female $23^{\circ} 3^{-24}$ in., wing $15^{-1} 6$ in. The young bird has the upper parts dull brownish-grey with darker centres to the feathers of the back and wing-coverts; under parts greyish-white; bill black; legs and feet lead-colour. 


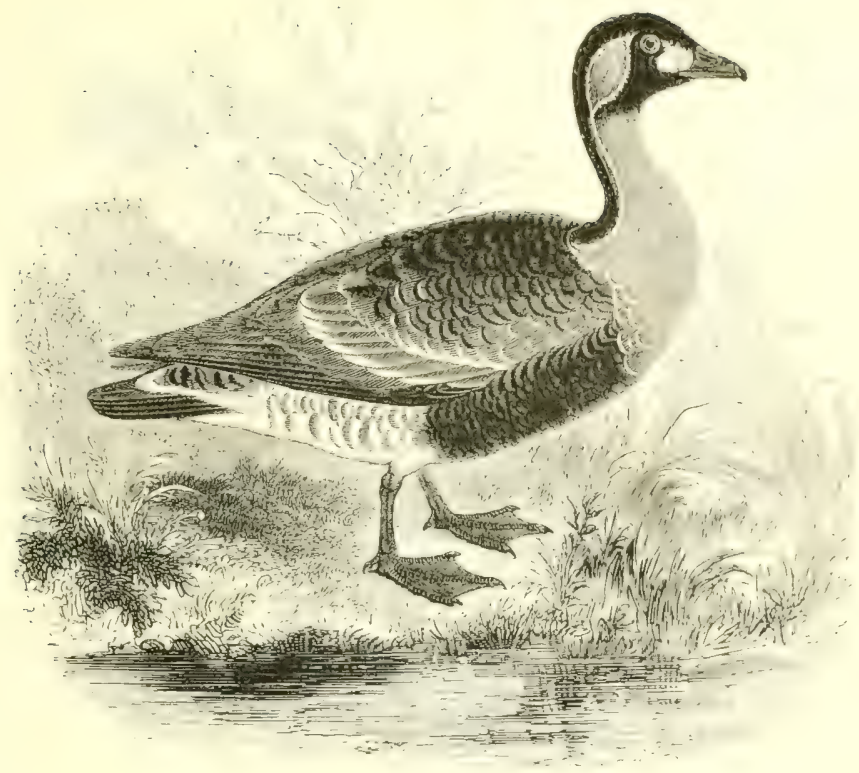

THE RED-BREASTED (¿OOSE.

Bernícla RUficóllis (Pallas).

This small and richly-coloured (ioose is a very rare wanderer as far west as (ireat britain, and almost all the authenticated specimens in existence have been obtained on the east side of the island. 'The first recorded occurrence is that of a bird shot near 1 ,ondon during a severe frost early in 1776 , and now in the Museum of Newcastleon-Tyne; while another, taken alive near Wycliffe in Vorkshire about the same time, lived until i 785 . ()ne, killed near Berwick-on-Tweed in $\mathbf{I} 8 \mathbf{I} S$, is in the British Nuseum (Natural History): and a fine example sent from Maldon in Essex, on January 6th $187 \mathrm{I}$, is in the collection of Mr. John Marshall of Taunton. Two are said to have been obtained in South Leron, and one in Norfolk; while the remains of a bird killed in Caithness are - or were--in the Sinclair collection, now at Thurso. There are other records, but unsubstantiated.

During the summer the Red-breasted (ioose inhabits those districts of Siberia which lie to the north of the limit of forest-growth, from the lower valley of the $\mathrm{Ob}$ to that of the Boganida. In the former I)r. Finsch found it not uncommon; Mr. Secbohm sceured a bird which had been shot from the nest in $70^{\circ} 30^{\prime} \mathrm{N}$. lat. on the 
Yenesei, along the banks of which he afterwards saw adults with their broods; while on the Boganida Dr. von Middendorff obtained the first authenticated eggs. As a straggler this species has occurred as far east as Irkutsk, but its main line of migration in autumn appears to be in a south-westerly direction, to the Caspian. There, according to Dr. Radde, large numbers are often caught in nets or shot on some grassy islands near the south-western shore, during the winter. The ancient Egyptians were well acquainted with this handsome cioose, for it is accurately portrayed in colours on the Meydoun slab already mentioned (p. $38 S$ ), and repeatedly, according to Mr. E. C. Taylor, on the 'tombs of the kings' at Thebes. Lord Lilford has a specimen labelled by the late Mr. S. Stafford Allen, "Alexandria, I)ecember 2 nd i 874 " and skins, said to be from Algeria, were offered for sale in $\mathbf{1 8 8 4}$. Three examples have been obtained in Italy, five or six in France, several in Holland, and a few in Northern Germany, Denmark, and Sweden; while in Russia the bird is said to visit Archangel in spring and to pass through the Central Provinces, in small numbers, on its way to the Caspian.

An egg procured by Mr. Seebohm on July ist is of a dull creamy-white, and measures $2^{\prime} 7$ by $\mathrm{I}^{\circ} 8 \mathrm{in}$. The call-note may be syllabled as shak-iel', whence the local name at Obdorsk, according to Dr. Finsch. 'The food consists of grass and green vegetables, and water is frequently taken. In a wild state this species is exceedingly gregarious, while in confinement it is very tame and sociable; and a female, which lived in the Gardens of the Zoological Society from $185 S$ to 1870 , paired with a lirent (ioose. Its skin, now preserved in the British Museum, shows conclusively that the plumage is quite as brilliant in this sex as in the male, though the contrary has been stated.

The adult has a white patch in front of the eye; the crown, throat, hind-neck, and lower part of the breast, black, bordered by narrow lines of white; ear-patches and breast rich chestnut; upper parts almost black, with greyish-white edges to the wing-coverts; tail black; belly white, barred with black on the flanks; bill, legs and feet very dark brown. Length $2 \mathrm{I}-22$ in.; wing $14^{\circ} 5$ in. In the young bird the ear-patch is whitish with rufous in the centre; the chest is merely tinged with reddish; and the rest of the upper and under parts are dusky-brown, except the abdomen and the tailcoverts, which are white. 


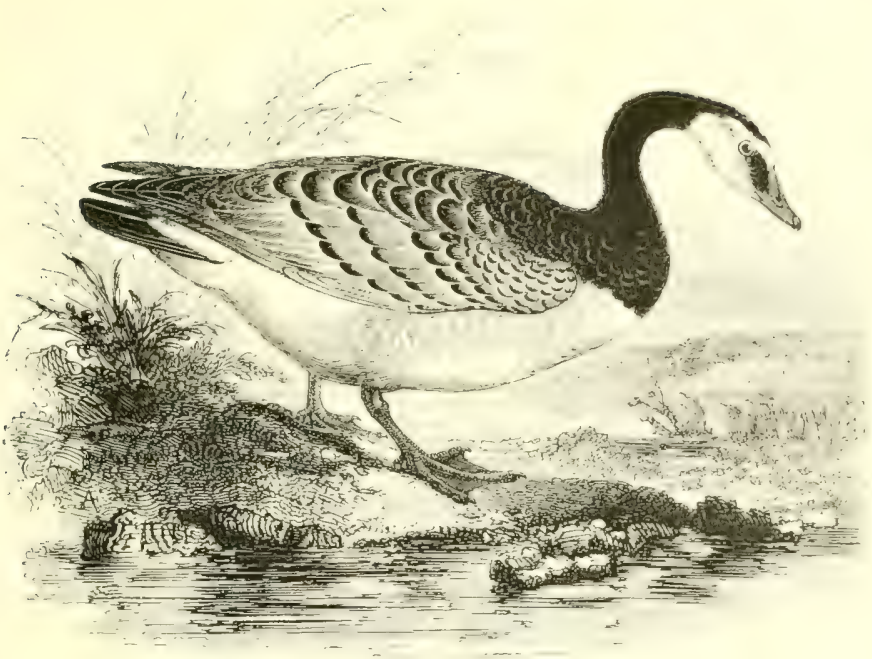

'THE BERNACLE GOOSE.

BerNicla leucópsis (Bechstein).

The Bernacle ( Boose is a winter-visitor to the British Islands, but all competent observers agree that it is comparatively uncommon on the east coasts of England and Sicotland, and only occurs there when the weather is very severe on the Continent; while on the shores of the English Channel, and inland, it is decidedly rare. On the west side, from Cornwall northwards it is not unfrequent. and it is of regular occurrence in Lancashire and Cumberland. In the upper part of the Solway thousands are sometimes seen between the end of September-when they arrive from the north-west and the latter part of March ; while throughout the Hebrides, and on the neighbouring mainland, the bird is numerous in suitable localities. In Ireland it is very local, but rather abundant in the north and north. west, and at Dundalk and I.urgan on the east coast. It is, howerer, difficult to trace its distribution, inasmuch as the Brent coose is often misnamed 'Bernacle.'

To the Shetlands and the Froes this species is only a rare straggler; and although it occurs in Iceland and (ireenland, it has not yet been proved to breed there. No recent explorers have met with it on the western side of Spitsbergen, though Mr. I eigh Smith's party is said to have obtained seven examples (not preserved) in the northern part of that island. Capt. I. H. Mark- 
ham did not find it in Novaya Zemlya, and although Baron Nordenskiöld alludes to its (supposed) occurrence on that island, it is a significant fact that no specimens were brought thence by the 'Vega' expedition, nor indeed from any part of Arctic Siberia ; where, moreover, it has not been observed by any other travellers. The real breeding-haunts of the Bernacle Goose may be surmised, indeed, but are as yet unknown, for the nesting by a pair for several successive years on Borgever, one of the Lofoten Islands, off the coast of Norway - as recorded by Prof. Collett-must be looked upon as exceptional. On migration this species risits Russia, Scandinavia, Denmark, and the northern coasts of Europe; while accidental visitors have been obtained as far south as the mouth of the (iuadalquivir in Spain, and near Foggia in Italy. Except as a very rare wanderer to the south end of Hudson Bay, it is absolutely unknown in any part of Arctic America.

liggs laid in confinement are white, and measure $2^{\prime} 75$ by $\mathrm{I}^{\circ} 9$ in. Many instances of the breeding of this bird in captivity are on record, and Mr. R. I.loyd Patterson states that several broods produced near Belfast did not desert the place, although not pinioned. As already stated, the Bernacle has bred with the Whitefronted Goose. It feeds on the grass found in marshes near the sea-shore, and to some extent upon animal food obtained in the mud-flats; always at night, except when very much harassed by gunners during moonlight. While feeding, the flocks are very noisy, keeping up a constant cackling, and sentinels are regularly posted to give the alarm. Some interesting details respecting this species are to be found in 'The Birds of Cumberland,' by Messrs. Macpherson and Duckworth. Its name is attributable to the vulgar belief that this species and the Brent were hatched from bernacles (Lepadide) attached to logs of wood floating in the sea, as described in Gerard's 'Herbal' ( 1597 ), as well as in a paper published by the Royal Society in 1678 .

The adult has a black stripe between the eye and the bill, while the head, neck and throat are also black; forehead, cheeks and chin white; mantle lavender-grey, barred with bluish-black and white; quills and tail-feathers almost black; breast and belly greyish; vent and tail-coverts pure white; flanks barred with grey; bill, legs and feet black. Length about 25 in.; wing 16 in. The female is slightly smaller than the male. The young bird has the white of the cheeks varied with black, rufous edges to the feathers of the mantle, darker bars on the flanks, and paler legs. 


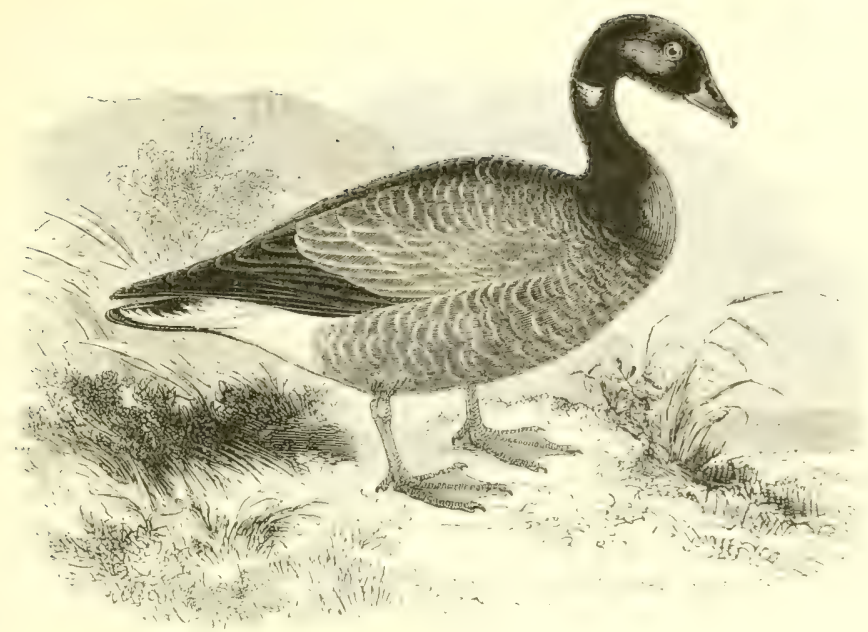

THE BRENT GOOSE.

BERNICLA BRÉNTA (Pallas).

The Brent is the most numerous and generally distributed of the Geese which visit us; and, in varying numbers, is found on our coasts-particularly the east and south-throughout the cold months of the year. Unless wounded, it is seldom seen on inland waters, and it passes a great part of the day and night at sea; while at other times it frequents the extensive mud-flats and sand-bars on the shore which are exposed at every ebb-tide. I arge flocks resort to the vicinity of Holy Island on the Northumbrian const, and multitudes have been observed in some seasons on the Cromarty and Dornoch Firths. In the Orkneys and Shetlands, howerer, it is unfrequent; while in the Hebrides and along the west side of scotland it is far less abundant and less regular in its visits than the Bernacle. Vast quantities occur in many places on the shores of Ireland.

In cold weather the Brent Gonse migrates to the Fierous, the coasts of Scandinavia, and the shores of Europe generally; occasionally reaching the African and Asiatic sides of the basin of the Mediterranean. It is not improbable that it hreeds sparingly in some parts of Iceland; and considerable numbers nest on spitsbergen, Novaya \%emlya, and the coasts and islands of Irctic Siberia as far north as man has yet penetrated. On the P'acific side of North America it is represented by $B$. Mirricans, in which the white 
on the neck forms a nearly complete collar and the black extends to the lower breast; this species visits Japan. Eastward of Alaska, however, and as far as Greenland, our bird is found; but in American examples the under parts are somewhat lighter than in birds obtained in Novaya Zemlya \&c. Both forms visit the British Islands, but the darker usually predominates on the east coast south of the Humber.

Col. Feilden says that the nest is composed of a good foundation of grass, moss, and stems of saxifrage, with a warm bed of down for the eggs, which are laid by June 2 Ist, and are usually 4 in number, smooth, and creamy-white in colour: average measurements $2^{\circ} 7$ by I $\cdot S$ in. Both sexes are assiduous in their care of the young. The Brent Goose is a day-feeder; never diving, but searching on the ooze, or with head and neck extended below the surface of the water in shallow places, for aquatic plants, especially grass-wrack (Zistera marina) and laver (Ulia latissima); whence the local names 'Ware ('ioose' and 'Road Goose,' i.c., Root Goose ; small crustaceans and marine insects are also eaten. The call-note is a loud cronk, or honk, audible at a considerable distance.

The adult has the bill, head, throat, and neck black, except a small white patch on each side of the latter; mantle brownish-black: with paler edges, which in August after the moult are tinged with rufous-brown; quills, rump and tail black, coverts white; upper breast black; lower part and belly slate-grey; legs black (exceptionally reddish). Length $22-23$ in.; wing 13 in. Females are rather smaller than males. The young bird has little or no white on the sides of the neck, and the colours are less pronounced.

The Canada Cioose, Bernicla canadénsis, has been domesticated in this country for more than two centuries, and stragglers are occasionally shot out of the hundreds of unpinioned birds now in existence; there is, however, no evidence that wild American birds visit us, and it is significant that, although Ireland is the nearest land, its occurrences there are far rarer than in England. The Egyptian Coose, Chenalopex cegyptiaca, is another introduced species, examples of which often wander and are killed: though in a wild state it is not known to cross the Mediterranean. The Spurwinged Goose, Plectropterus gambensis, was introduced prior to I $67 \mathrm{~S}$, and two examples have been killed in this country; but there can be no duubt that these had escaped from confinement, for this species is not found wild in Africa to the north of the tropic of Cancer. 


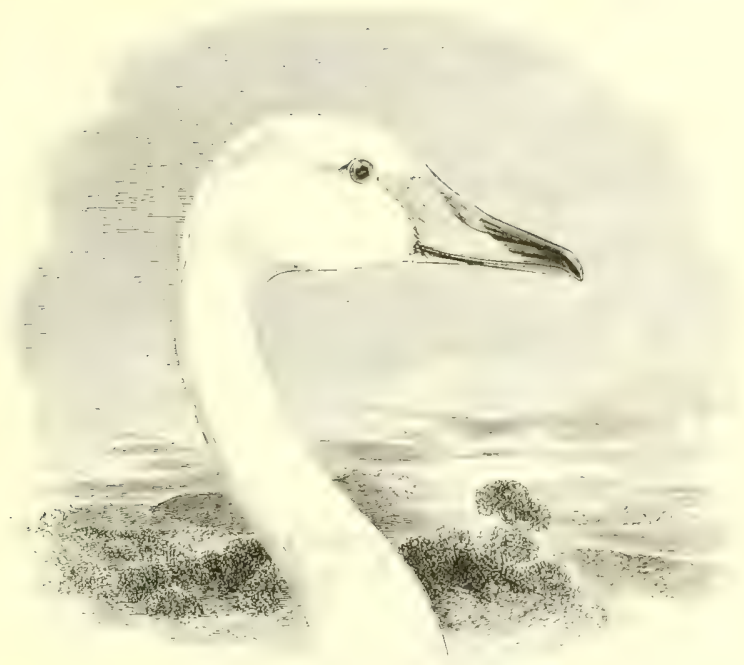

THE WHOOPER.

CÝGnus músicus, Bechstein.

This species is also called the Whistling Swan, both names referring to the peculiarity of its note; while by way of distinguishing it from its larger domesticated congener the prefix 'Wild ' is frequently. employed. Little more than a century ago this fine bird used to nest in the Orkneys, but at the present day there is no part of the British Islands to which it is more than a migrant during the cold season. In numbers which vary according to the mildness or severity of the weather prevalent in Northern Furope, it annually visits the coasts and islands of Scotland from November onwards. and on the return passage in spring individuals out of passing flock: have been observed to linger until May about the old breding. haunts. In hard frosts Whoopers are often abundant on the shores of England as far south as the Channel, where l'oole Harbour and other suitable localities are favourite resorts. On the coast of Ireland. according to Sir Ralph Payne-Gallwey, it is far less common than the smaller Bewick's Swan, and he has seldom met with a doren of the former together, whereas the latter are sometimes seen there in hundreds.

The Whooper is now only a visitor to the Freroes, but is gener ally distributed during the breeding-season in Iceland : and thence. 
according to Reinhardt, it occasionally wanders to Creenland, where it used to nest as far north as Godthaab, until exterminated by the natives. In Norway it is seldom known to breed below the Arctic circle, but in Sweden, Finland, and Northern Russia it is found in summer down to $62^{\circ} \mathrm{N}$. lat. On migration it visits the estuaries and inland waters of Europe as far south as the Mediterranean, Black and Caspian Seas, while in severe winters it ranges to the lakes of Algeria, Lower Egypt, and Palestine. From May to autumn it inhabits Arctic Siberia, and is common during cold weather in Japan and China; it is also said to have occurred in Nepal, and passes through Turkestan on migration.

The nest is a large structure of coarse herbage, and is generally placed on an island in a lake, concealed in willow- and other scrub where such covert is available. The eggs vary in number from $2-5$, though a mature female will sometimes lay 7 ; their colour is pale yellowish-white, average measurements $4^{\circ} 5$ by $2^{\circ} 9$ in. Incubation, which lasts forty-two days, often begins in the latter part of May; and I)r. Palmen states that the young grow so slowly as to be unable to fly until the end of August, or even later. The food consists of the roots and stems of aquatic weeds, and of grass. The note is loud and trumpet-like, and, when uttered during flight, often forms a rhythmical accompaniment to the strokes of the pinions.

The adult has the entire plumage white, with occasionally an chreous tint (probably adventitious) on the feathers of the head; the legs, toes, and their membranes black. The distinguishing external characteristic of this species lies in the beak, the anterior part of which is depressed and black, while the basal portion is quadrangular and lemon-yellow; this latter colour extending forward beyond the openings of the black nostrils. Whole length of a male 60 in. ; wing $25^{\circ} 5$ in. ; weight 24 lbs. The female is smaller. The young bird has the beak of a dull flesh-colour, tipped and margined with black; the upper plumage ash-brown, and the under parts paler, as far as the flesh-coloured legs, the vent being white. Adult plumage is attained by the second winter.

The Whooper and all the other species of the genus found in the northern hemisphere-except the Mute or Tame Swan-have a remarkable cavity in the keel of the sternum, along which the tube of the trachea passes. In the Tame Swan the keel is single and unprovided with a cavity. Some further remarks will be found at the end of the next article. 


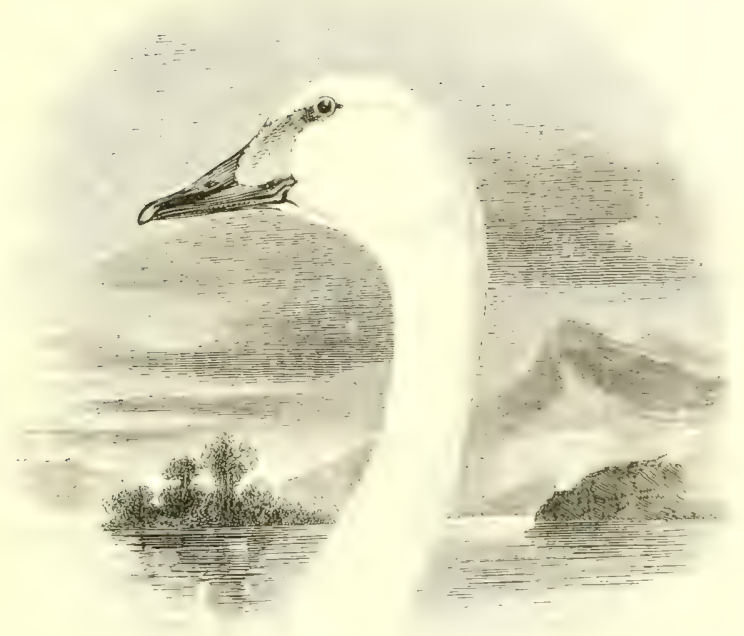

BEWICK'S SIVAN.

Cygnus BéwiCki, Yarrell.

This Swan-which is one-third less than the Whooper, and presents noticeable differences in the smaller size and distribution of the yellow patch at the base of the bill-was recognized as a visitor to this country by Yarrell in 1829 , and almost simultaneously by R. Wingate of Newcastle. Subsequent experience has shown that, although much rarer than its larger congener, Bewick's Swan is of fairly frequent occurrence in severe winters on the coasts of lingland; while in Scotland it is sometimes abundant-especially in the Outer Hebrides; and in Ireland, as already remarked, it is far more numerous than the Whooper. Mr. R. Warren writes that on I)ecember I 7 th I 880 more than two hundred were seen together on I.ough Cullen, co. Nayo ; and during the unexampled frost of i $\$ \& 1$ eight hundred were observed at one time on the lake of Castle Gregory in co. Kerry; while even thousands are said to have been counted in other localities. Sir R. Payne-(xallwey states that there is a strong feeling in Ireland-especially in the west--against slaying a Swan, and the majority of fowlers cannot be induced to fire at one.

Bewick's Swan has not been found in (ireenland or Iceland, and only 
nine occurrences are recorded from Norway, though in Finland it is rather more frequent. Its summer habitat is more easterly than that of the Whooper, no nesting-places being known to the west of the White Sea, and it was only near the mouth of the Petchora that Messrs. Seebohm and Harvie-Brown obtained the first identified eggs on record. On the Arctic portions of the mainland of Siberia and in the islands to the north, it appears to be the most numerous of the Swans; Mr. Seebohm observed no other species on the Yenesei, and its breeding-range probably extends to the Pacific. In the cold season it visits Japan and China ; while in Europe it has occasionally been found as far south as the Mediterranean.

The nest resembles that of the Whooper, but the eggs are smaller than those of that bird, and have rather less gloss : average measurements 3.9 by $2.6 \mathrm{in}$. The note sounds like the word tong quickly uttered, and is very different from the whocp, whoop-zihoop, whoop of the larger species. The food consists chiefly of aquatic plants.

The adult is pure white; the irides dark; legs, toes and webs black; the distribution of black and orange-yellow on the beak is shown in the illustration. The young bird is greyish-brown, but the white plumage is acquired in the second winter, when the irides are yellow. Length from $46-50 \mathrm{in}$; wing about $2 \mathrm{I}$ in.

An immature Swan shot near Aldeburgh in October I 866, and now in the Ipswich Museum, is, in the opinion of Professor Newton, an example of the American Trumpeter Swan, C. buccinator, a larger species than the Whooper, with a black bill. It has long been naturalized in this country and has repeatedly hatched its young in captivity, so there is always a strong probability of the cygnets escaping before they can be pinioned. Another North-American species which has been stated-but on far weaker evidence-to have been found, at long intervals, in the shops of Edinburgh poulterers, is $C$. americanus, a bird which is smaller than the Whooper, though larger than Bewick's Swan, which it resembles in having patches of small size at the base of the bill, but of a deep orange-colour. In the adults of our Whooper and the American Trumpeter Swan the loop of the trachea between the walls of the keel takes a vertical direction, whereas in Bewick's Swan and in C. americanus the bend is horizontal ; but in immature birds these distinctions are less marked and are not absolutely invariable. 


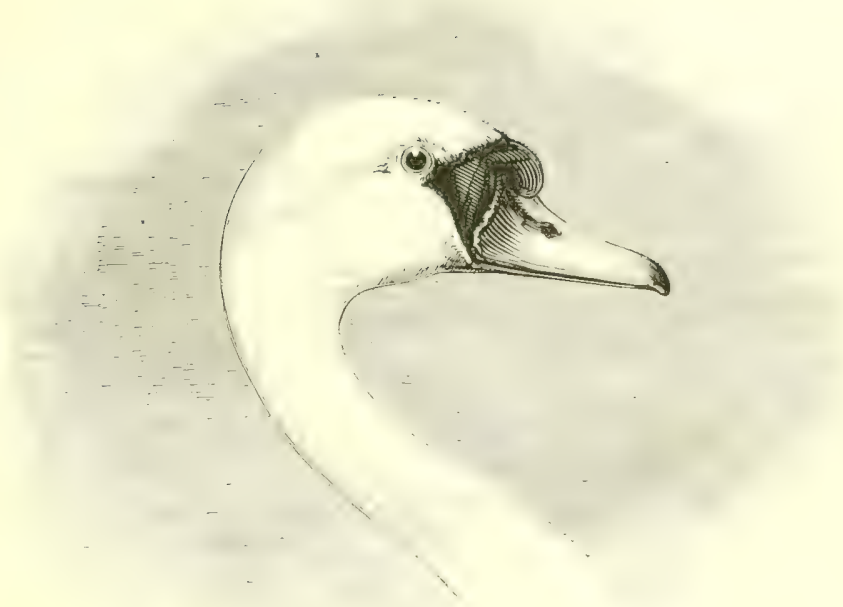

THE MUTE SIVAN.

Cygnus ólor (J. F. Gmelin).

The Mute or Tame Swan is said to have been brought to England from Cyprus by Richard I.; but be this as it may, the species is now generally distributed throughout the British Islands in a semidomesticated condition. Of late years it has even been introduced in some of the Outer Hebrides, where it breeds annually, and the birds fly about as if wild (Harvie-Brown). There is a celebrated ancient swannery at Abbotsbury, near Wreymouth in Dorsetshire; large numbers inhabit the streams and broads of Norfolk; and the presence of this handsome bird on the Thames and other rivers must be familiar to every one.

The individuals which are occasionally shot during winter in Britain are often assumed to be some of our birds which have strayed from their usual haunts; but such is not necessarily the case, for the Mute Swan still breeds in a perfectly wild state at no greater distance than Denmark and the south of sweden, whence it is forced by cold to migrate in winter; while in a free as well as in a half-protected condition it is found in many parts of (iermany: Thoroughly wild birds nest in considerable numbers in (entral and Southern Russia, and on the Iower I lanube; also, sparingly, on 
some of the lakes in Greece; more abundantly in the vicinity of the Black and Caspian Seas, and in Turkestan. In winter Mute Swans occur on the waters of the greater part of Europe, down to the basin of the Mediterranean, and are regular visitors to the lakes of Algeria and Egypt. The range can be traced through Asia to Mongolia, and down to the north-west of India.

According to the late Mr. H. Stevenson, Swans pair for life, and build a fresh nest each season; this is generally on a small island or peninsula, and is a large structure of reeds and coarse herbage. The females do not lay till their second year-some not until the third or fourth-and commence with 3-5 eggs, but when in their prime the clutch sometimes consists of $10-12$; they are dull greenishwhite, averaging 4 in. by 2.9 in. With wild birds incubation begins in May, but earlier in a state of semi-domestication. The young are hatched in 36-39 days and are carefully tended by their mother, who frequently carries the cygnets on her back, to which she sometimes raises them with her foot, at the same time sinking her body low in the water. The food consists of water plants (such as Chara), aquatic insects \&c., also of grain and bread. The note of the wild bird in pairing time is loud and trumpet-like, but in tame individuals it is little more than a feeble hiss.

The adult male has the greater part of the bill reddish-orange, the nail, nostrils, lores, and the basal tubercle, or 'berry' black; plumage pure white; legs and feet black. Length 56-60 in.; weight about 30 lbs. The female is smaller and has far less tubercle. The cygnet is sooty-grey above, and paler below, with lead-coloured bill and legs.

In the so-called 'Polish Swan,' C. immutatilits of Yarrell, the cygnets are white, while the adult is said to have a less developed tubercle, with ash-grey legs and feet; but neither Mr. Bartlett nor I could find these distinctions in old birds in the Zoological Gardens which had been white as cygnets, and were considered typical examples by Mr. J. H. Gurney. With the exception of a bird obtained in Holland in December I 840 , no specimen of the 'Polish Swan' is known to exist outside the British Islands ; and it is now generallythough not universally - considered by ornithologists to be a mere variety as regards the colour of the young, while the supposed distinctions in the adult may depend upon the age of the bird. As pointed out by Prof. Newton, white cygnets were noticed on the Trent 200 years ago, while in I 885 , I 886 , and I 887 a pair of Swans at Cambridge produced broods in which some of the young were abnormally white (Zool. 1887, p. 463; I888, p. 470). 


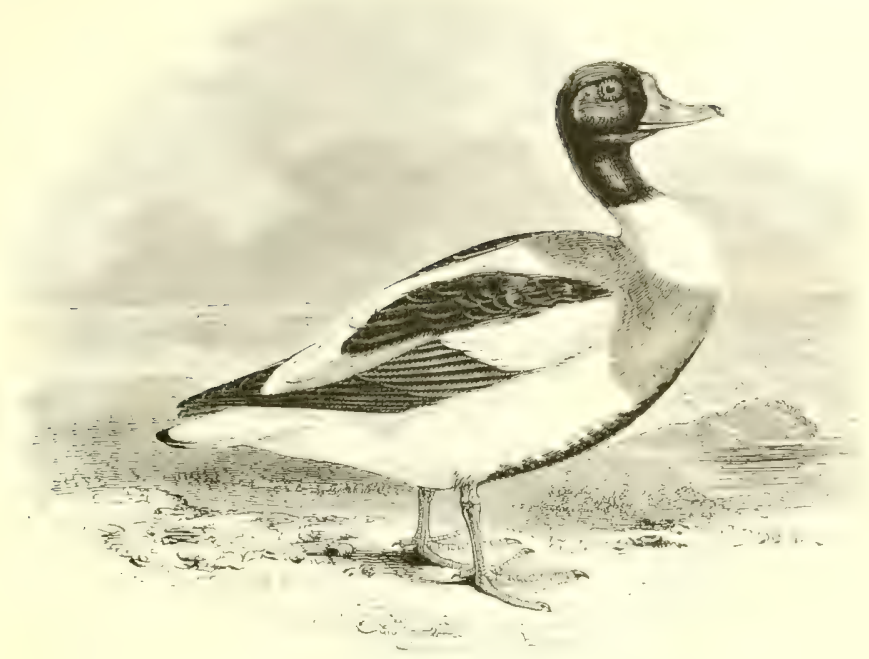

\section{THE COMMON SHELD-DUCK.}

TAdóRna CORnĹtia (S. G. Gmelin).

'This handsome species is rarely seen far from salt water, and some are to be found on the coast during the whole year, especially on flat shores, sand-bars and links. Localities suited to its habits are to be found along the east of England, and also on the west of the island, although the increase of population and commerce has interfered with its haunts in Cheshire and Iancashire: while in the south a limited number nest in I)evon, Somerset and Dorset. On the east side of scotland it is not uncommon, especially in winter, when large flocks cross the sea to escape the cold of Northern liurope: and, though somewhat local on the west and in the islands, it is tolerably numerous during the summer in most of the Hebrides. In Ireland it breeds sparingly among the sand-hills near the sua, especially in cos. Mayo, Waterford and Wexford, becoming more plentiful in winter.

To the Freroes the Sheld-I)uck is only a rare wanderer, but it breeds along the coast of Norway up to abont $70 \mathrm{~N}$. lat., and is abundant in Sweden, Denmark, the Baltic, the North Frisian Isliands and Holland. It also nests on the shores of France, and, sparingly: in the Spanish Peninsula; but throughout the basin of the Mediter. ranean it is chiefly.a winter-risitor, and in the southern and eastern 
portions the representative species in summer is the Ruddy Sheld. Duck. In the interior of Europe it is only of accidental occurrence ; but it is a resident in the basins of the Black and Caspian Seas, and is found on the salt-lakes of the temperate-or the elevateddistricts of Asia as far as Japan; while its winter-range extends southward to the tropic of Cancer.

The nest, made of bents with a lining of fine soft down, is placed at distances varying from a few to ten or twelve feet inside a rabbitburrow-whence the name 'Burrow-Duck,' or at the end of a tunnel (made by the bird) which occasionally forms a nearly complete circle; but sometimes it is in holes in bridges, or among rocks near high-water mark, and, exceptionally, in a very dense covert of furze. The eggs, laid in May, are of a smooth creamy-white, and measure about $2 \cdot 75$ by 1.9 in. In the Frisian Islands artificial burrows are made by the natives, the eggs being taken up to June i 8th, after which the birds are allowed to sit. Incubation lasts from twenty-eight to thirty days, and when the young are hatched they follow their parents, being sometimes carried by the female on her back to the water. The feeding-grounds are mussel-scalps and sandy shores, where the bird obtains minute bivalves and univalves. sand-hoppers, marine insects \&c., with sea-weed; but in captivity grain, soaked bread, and vegetables are eaten. The note of the male is a shrill whistle, but the female, which is far more noisy, utters a harsh bark, sometimes followed by several distinct quacks. The flesh is dark in colour and unpleasant in smell and flavour. In confinement the natural habits of this species must be consulted, or else it will not breed readily. 'The prefix 'Sheld' is given by Ray (I674) as an East Anglian equivalent for particoloured.

The adult male has the beak and basal knob bright red; head and upper neck dark glossy-green, followed by a white collar, below which is a rich chestnut band; wing-coverts white; speculum green; scapulars, part of the secondaries and the primaries nearly black; rump, upper tail-coverts and tail-feathers white, the latter tipped with black; lower central line of the breast and belly dark brown, the rest of the under parts white; legs, feet and webs flesh-pink. Length 24-26 in.; wing 13 in. The female is rather smaller, duller in colour, and has no knob at the base of the bill. The young bird has the head and neck brown; face, neck, wing-coverts and all the under parts white; inner secondaries white, edged with chestnut, and with little green on the speculum; beak flesh-colour; legs and feet livid lead-colour. 


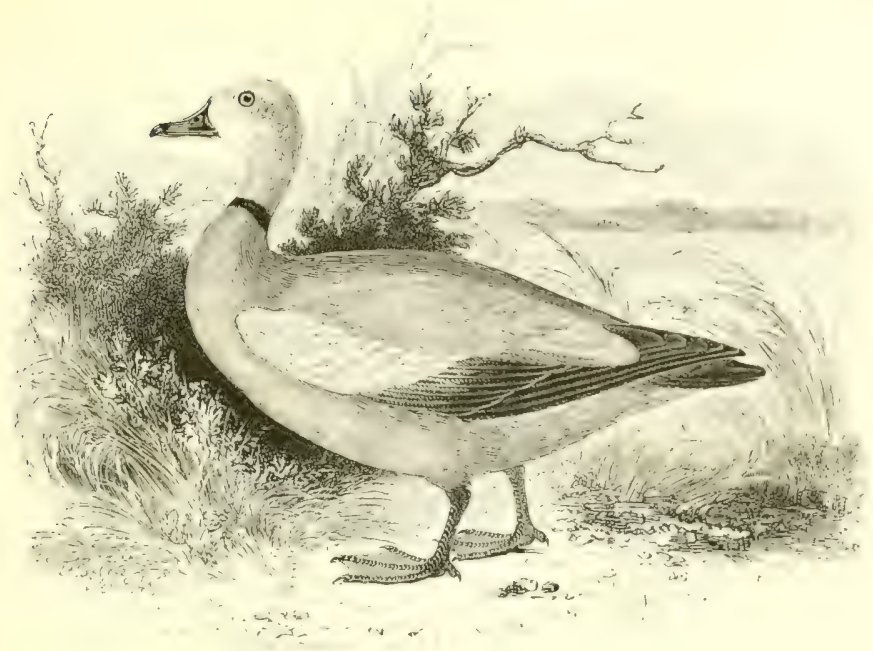

THE RUDIYY SHELD-1)UCK.

TADORNA CASÁRCA (Linnæus).

The Ruddy Sheld-Duck is a native of warm dry countries, and was first recorded as British from a specimen now in the Newcastle Museum, killed near Blandford in Dorsetshire during the severe winter of 1776 . The species was long ago introduced on many of our ornamental waters, and birds shot in Norfolk, Northamptonshire and other places are either known, or are strongly suspected, to have escaped from semi-captivity; some records, too, are unwortliy of credence. There can be no doubt, however, that an example war; shot from a party of four in Romney Marsh, Kent, on september sth I 884; while in Ireland one (in the I)ublin Museum) was oltained in co. Wicklow on July 7 th $1 \$ 47$, a young male in co. Kerry on August i 7 th $\mathrm{x} 869$, another in co. Waterford in March $1.5 \mathrm{r}$, and two were procured on the Shannon in the summer of 1886 . As regards Scotland, occurrences have been noted in Caithness and f'erthshire: and a bird which proved to have escaped from Auchencairn House, Kircudbrightshire, was shot, as Mr. R. Survice infurms me, on August 3 rd 1888.

Solitary wanderers have been recorded from siweten, fiomholm in the Baltic, and Lake Ladoga; but with these exceptions the Ruddy wheld-I)uck is amost unknown to the north of the Ilps and the Carpathians. Individuals have heen olstrined noar Toulouse in 
France, and it breeds in small numbers in the extreme south of Spain, but otherwise it is rare in the Mediterranean to the west of the Adriatic. Eastward it becomes more abundant, nesting in Macedonia, the I anubian and Black Sea districts, Southern Russia, and across the temperate portions and elevated districts of Asia as far as China and Japan. In India, where it is known as the 'Brahminy Duck,' it is very common during the cold season; and it is resident in suitable localities throughout Northern Africa from Egypt to Moroccu. In South Africa the grey-headed T. cana is the representative species: while three others are found, respectively, in the Malay Archipelago, Australia, and New Zealand.

The nest, well lined with down, is placed in almost any sort of hole: sometimes in the middle of a corn-field, or in a marmot's burrow on the plains, sometimes in clefts of precipitous rocks, amongst-and even in-the deserted abodes of birds of prey; also in hollow trees, the fireplaces of abandoned Mongol villages \&c. The eggs, 9-1 6 in number, are similar to, but a triffe smaller, than those of the preceding species: average measurements 2.6 by 1 . $S$ in. When uttered on the wing the call may be syllabled as $i$-oung; but the usual note is kark or kafe, several times repeated. The Ruddy sheld-Duck differs from its congener in being partial to fresh water. Though usually found in pairs during the summer, it is very gregarious at other times, thousands being mentioned by Jerdon as frequenting the Chilka Iake in April. In its style of walking it resembles a (joose; and it feeds in a similar manner, grazing in the fields of young corn and eating grass freely. It has often bred in confinement, and has also produced offspring with the Egyptian (ioose (Chenaloper asyptiaca). That genus is, in fact, the most nearly allied to Tadorna, as shown by the formation of the trachea.

The adult male in summer has the beak lead-colour; irides yellowish-brown; head, cheeks and chin buff-colour, darkening to orange-brown on the neck-which is encircled by a black ring (absent from autumn to spring); back, breast and under parts orange-brown ; wing-coverts buffish-white; primaries dark lead-grey; secondaries paler, with a brilliant bronze-green speculum; rump and tail leadcolour; legs, toes and webs blackish. Length $25^{-2} 2 \mathrm{in}$; wing about ${ }^{4}+5$ in. The female is rather smaller and has a whitish forehead; she never has a black collar; and this ornament is also absent from the young male. The young are like the female, but duller in colour. 


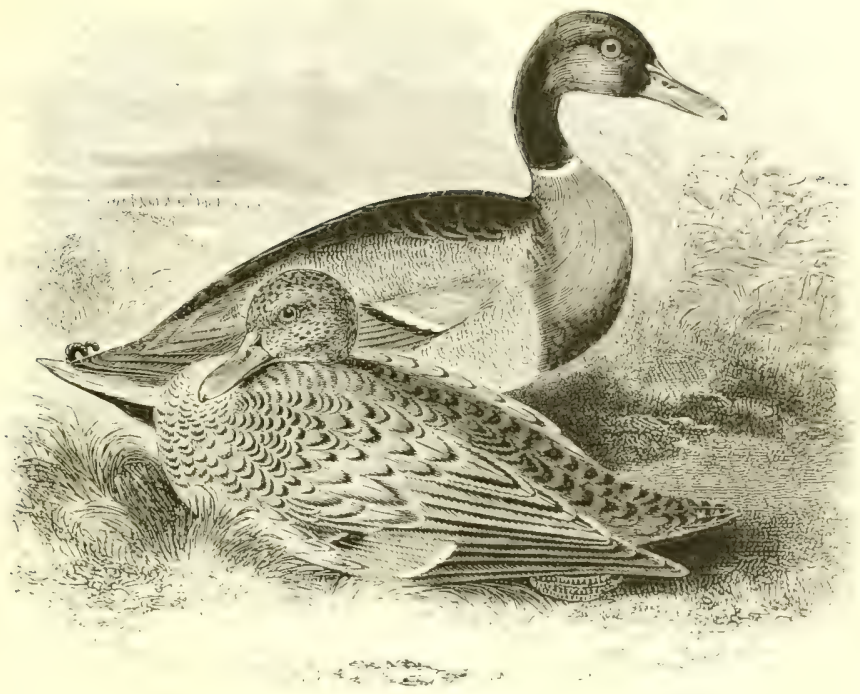

THE MALI,ARI).

Anas bóscas, Linnæus.

The Mallard, or Common Wild I luck, was formerly more numerous in the British Islands than-owing to the progress of drainage and the consequent extension of agriculture - it is at present; though still by far the most abundant of our fresh-water species. In winter it is partially or entirely absent from the northern districts and islands of Scotland; but, with this exception, it may be described as resident during the year in suitable localities throughout the Cnited Kingdom. The birds which breed with us are, however, few in pro. portion to the numbers which annually arrive from the (ontinem during the cold months; and there are still places where decoys are worked with profit, as shown by Sir R. Payne-( iallwey in his "Rook of I)uck Decoys' (I886), to which the reader is refurred for the latest information on this interesting subject.

This species visits (ireenland, and is abundant during the summer in Iceland; while it is generally distributed throughout Europe south of the Arctic circle; breeding in suitable localities down to the Mediterranean, and also in Northern Africa. The range of the migrants from the north extends to the Canaries, Madeira, and the Azores, a few pairs remaining to nest in the last-named group). In Asia it is found-wherever the water does not free for any lensth 
of time--from Turkestan to China and Japan; it breeds as far south as Cashmere, and visits India in the cold season. It inhabits the temperate portions of North America, wintering as far south as Panama; but in the north-east of that continent its place is in some degree taken by the closely-allied I)usky Duck, Anas obscura, both sexes of which much resemble the female of our bird.

Incubation often begins as early as March in the southern counties of England, and by the middle of April even on the bleak moors of Northumberland. The nest, made of grass and lined with down, is usually on the ground, near fresh water, though not unfrequently at a distance from it ; but grain-fields, hedge-rows, stacks of faggots, forks or hollows of trees, and even the deserted nests of other birds are more or less resorted to. The eggs, $8-I_{2}$ in number, are pale greyish-greein or greenish-buff: average measurements 2.25 by i 6 in. Two months or ten weeks clapse before the young can fly. In the wild state the Mallard is monogamous, but the domestic forms which have sprung from it are all polygamous; and, as remarked by that keen observer Mr. C. M. Adamson, the half-wild breeds get duller in colour, and have coarser feet, while the wings, which in a really wild bird reach nearly to the end of the tail, become shorter in proportion to the body. In its food the Mallard is almost omnivorous, and it is strictly a night-feeder

The male in full plumage has the bill yellowish; head and neck glossy-green, followed by a narrow white ring; hind-neck and breast dark chestnut; across the secondaries a greenish-purple speculum, fringed above and below with white; rump and upper tail-coverts bluish-black, as are the four middle up-curled tail-feathers, the rest being greyish; belly and flanks greyish-white; under tail-coverts velvet-black; legs, toes and webs orange-red. Length $24 \mathrm{in}$. ; wing I I 5 in. Towards the end of May the assumption of female plumage by the male commences, and the quills are cast simultaneously, so that he is incapable of flight; but by the middle of October he has again acquired his full dress. Tery old drakes, in semicaptivity at least, lose the white collar, and half-bred birds often do not show it at all. The female is smaller; has a greenish bill; crown dark brown; general plumage mottled-brown and buff; alar speculum dark green. The drake's plumage is occasionally assumed. The young at first resemble the female. In a wild state the Mallard not unfrequently breeds with the Pintail, and in captivity with almost any Duck; varieties are not uncommon, but wild albinoes are rare. 


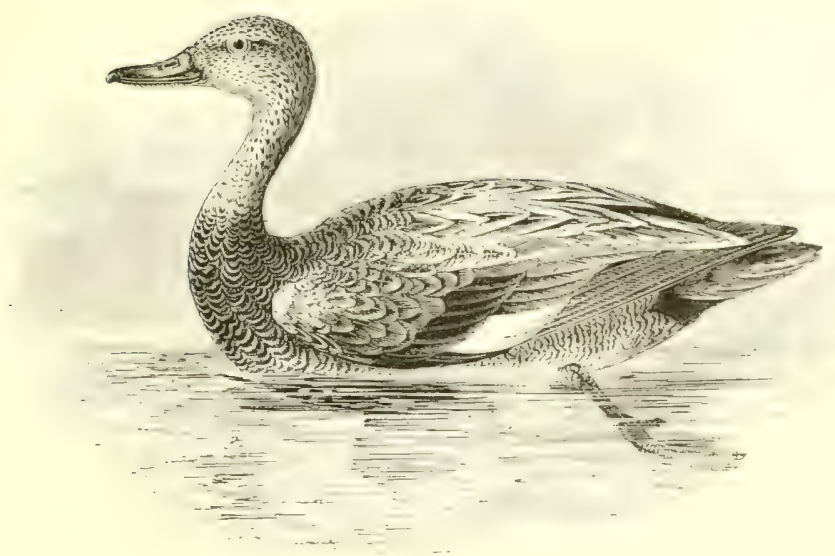

THE GADWALI.

Anas strépera, Linnæus.

This species is a comparatively rare visitor to the British Island.; but in Norfolk, on the carefully preserved estates of Mr. A. Fountaine at Narford Hall, Lord Walsinghom at Merton, and others, the descendants of a pair of pinioned birds, introduced some thirtyfive years ago, have so far multiplied and induced perfectly wild Gadwalls to remain and breed, that, at the present time, the numbers on one property alone are roughly computed at fifteen hundred. Except in the above county and one or two spots in the Midlands, this Duck is, however, uncommon; and when found in the I.onton markets it is usually in spring, though occasionally in autumm. Its occurrence in August has been recorded in Radnorshire and lireconshire, but in the west of England it is rare at any time of year. In Scotland it has been met with on the east, while on the west, as well as in the Hebrides, it is not unfrequent; it is also an irregular visitor to the Orkneys. Sir R. Payne-Gallwey considers that it is far more numerous than is generally supposed in Ireland.

The Gadwall breeds sparingly in the My-ratn district of Icclind: and, though not known to nest in Xorway, it does so rather frecty in the south-east of sweden, nor is evidence wanting that it has been found in Russia as far north as Archangel in summer. In Holland, Belgium and France it chiefly cccurs on migration and in winter: but in Spain it undoubtedly nests near the mouth of the Gualaliquivir. and throughout the basin of the Ifediterranean it is not uncommons 
during the cold season in suitable localities, such as rush-grown lakes and pools; its migrations extending to the inland waters of Northern Africa and up the Nile valley to Nubia. To Northern Germany it is chiefly a summer-visitor, becoming more abundant in Central and Lastern Europe; while in the temperate regions of Asia it is met with as far as the Pacific, and is one of the most plentiful species in India during the cold season. Across North America it is generally distributed, passing southward to the West Indies and Mexico in winter.

The nest, made of grass and lined with down, is generally in a dry place at some little distance from the water; and the eggs, S-1 3 in number, are of a buffish-white, tinged with evanescent green when fresh : average measurements $2 \cdot 1$ by $1 \cdot 5$ in. The Gadwall is a lover of fresh-water, and much addicted to concealing itself among thick reeds and aquatic herbage. Its migrations are nocturnal, and it also feeds by night chiefly on seeds, grain, rice, and other vegetable matter; consequently its flesh is excellent. The call-note resembles that of the Mallard, but is rather more shrill and freguently repeated: whence the bird's specific name of strepera.

The adult male in spring has the beak lead-colour; irides hazel; head and upper neck light brown with darker mottlings; back marked with crescents of light grey on a dark ground; median wingcoverts chestnut, greater coverts almost black; primaries brown; secondaries brown and black-the outer webs forming a white spculum; inner secondaries pointed and of two shades of brownishgrey, the darker colour occupying the centre of each feather, the lighter colour forming the margin; rump and upper tail-coverts bluish-black; tail-feathers dark brown, with paler edges; lower neck dark grey, each feather with lighter crescentic margins; breast and belly white; flanks and vent marbled with two shades of grey; under tail-coverts bluish-black; legs, toes and webs dull orange. In summer the female plumage is assumed. I.ength $2 \mathrm{I}$ in. ; wing $10^{\circ}+$ in. The female has the head and upper neck spotted with dark brown, on a paler surface; the crescentic bands on the lower part of the neck alternately dark and light brown, but broader than in the male; under parts white; feathers of the lower hind-neck and upper parts brown, with paler margins; speculum zohite, as in the male; tail-feathers dark brown, with pale edges. The young are of a more uniform reddish-brown colour above, speckled with dark brown; the middle of each feather also is dark brown; and the characteristic white speculum is always present. 


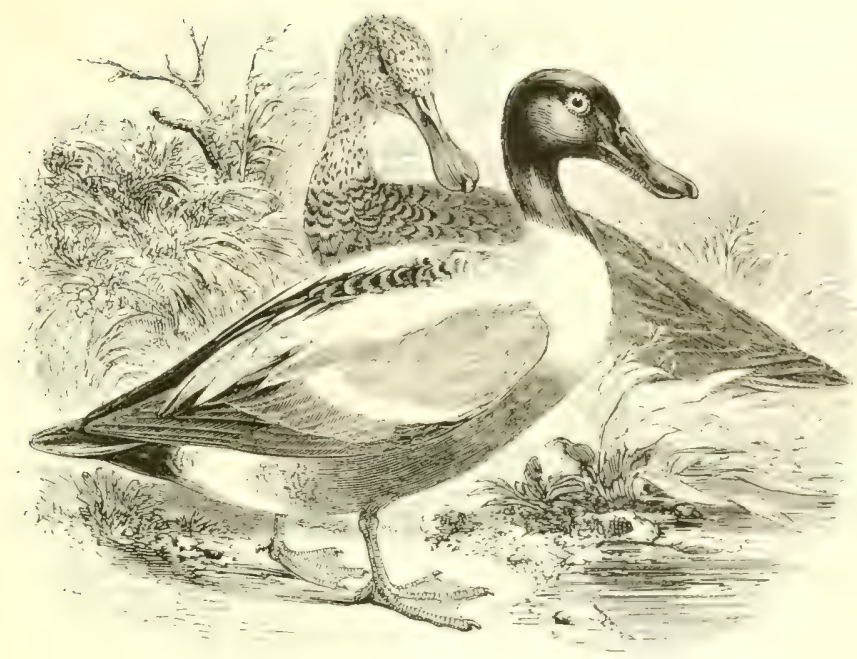

THE SHOVELER.

\section{Spátula clypé́ta (Linnaus).}

This species-sometimes called the spoon-bill or Broad-billis chiefly a visitor to this country during cold weather; but a tolerable number remain to breed with us, though seldom in our southern and western counties, where localities suited to their habits, combined with due protection, are few. In some parts of Norfolk and Lincolnshire it nests regularly, and it does so, sparingly, in Yorkshire, Jurham, and Northumberland; while near Rainworth in Nottinghamshire it is decidedly increasing. In Wales, and on the west side of England, it is rarer; though probably a few pairs inhalit the marshes on the Cumberland side of the solway, inasmuch as the bird is known to nest in Kircudbrightshire, and some of the other southern counties in Scotland. Col. Irby has recently informed me that it breeds on 'Tiree in the llebrides; but it is almost unknown in the Outer islands or in the Orkneys, thoush found in summer on the mainland near lilgin, and in other localitics as far north as Sutherlandishire. In Ireland it is not uncommon in the south, and nests at Ableyleix in (yueen's (i)., l.ough l)erg on the Shannon (not the smaller lake of that name in l)onegral), Lough Portmore in co. Antrim, co. Dublin, and a few other localities.

In summer the Shoveler barely goes as far north as the Arctic 
circle, but from I)enmark, the Baltic, and even Archangel southward, it nests down to the African side of the Mediterranean, where numbers of migrants appear in winter. At that season it is abundant in Egypt and Nubia ; and in the elevated regions of Abyssinia it is said to be resident. Across temperate Asia it is found in suitable localities, visiting South China and India during cold weather: Could states that he examined a single example obtained in Australia : and in America this widely-distributed species breeds from Alaska to Texas, wintering as far south as Panamá.

The nest is usually on dry ground in rank vegetation, or tufts of rushes, and is made of fine grass, with a lining of down plucked by the female from her body after she begins to sit. The eggs, 8-I 4 in number, are of a pale greenish-buff colour: average measurements 2 by $\mathrm{I}_{4}$ in. Mr. J. Whitaker states that on June 2 and I 886 he found the male sitting upon three eggs, though as a rule incubation devolves upon his mate. The note in pairing-time may be syllabled as took, tock: otherwise the bird is comparatively silent. It feeds on grasses, worms, slugs, snails, aquatic or even winged insects, and small crustaceans; its flesh is well-flavoured, rivalling that of the (adwall or the American Canvas-back. Diet, however, is an important factor in this matter, as regards all Ducks; and even a Canvas-back, when it has not been feeding on the succulent Tallisneric so abundant in the Chesapeake river, is a very ordinary bird for the table. In confinement the Shoveler has bred with the Garganey Teal.

The adult male has the bill lead-colour, dilated towards the tip; irides yellow; head and upper neck green; lower neck and scapulars white: feathers of the middle-back dark brown with paler margins; shoulders pale blue; greater wing-coverts white; secondaries dark brown with a steen speculum; primaries, rump, upper tail-coverts and tail-feathers almost black; breast and belly rich chestnut; flanks freckled with dark brown on a paler ground; vent white; under tail-corerts black; legs, toes and webs reddish-orange. Length $20 \mathrm{in}$; wing $10 \mathrm{in}$. In summer the male moults into the plumage of the female. The latter has the head and neck mottled with two shades of brown; the feathers of the upper parts dark brown in the centre, with lighter edges; under parts pale brown. The young male at first resembles the female. The nestling has a proportionately longer, narrower, and more slender bill than the young Mallard or Gadwall, but at the age of three weeks there is an obvious increase in length and breadth, especially in drakes. 


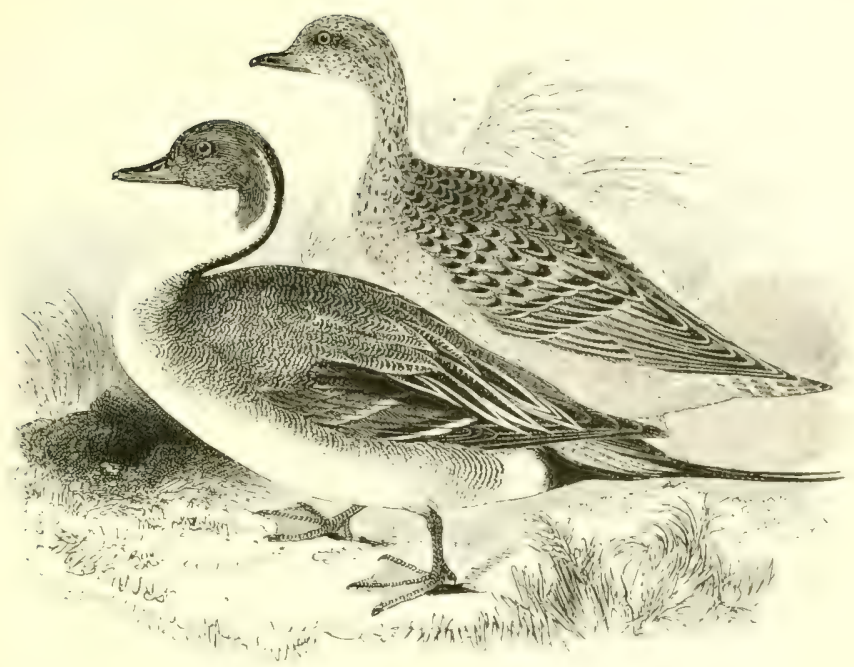

THE PINTAIL DUCK.

\section{Dáfila acúta (Linnæus).}

This slender and elegant Duck-locally known from the length of its tail as the 'Sea Pheasant'-is a regular visitor to the British Islands, from October onwards. In the northern districts it seldom lingers long, its numbers on the east coast are subject to considerable variation, and on the west it is rather uncommon; its principal resorts being our southern shores and estuaries, though its appearance on inland waters is also not unusual. It can hardly be called abundant on the east side of Scotland, and is decidedly rare on the west and in the Hebrides; yet Mr. Harvie-Brown obtained eggs with the down from the low basaltic island of Hysgeir, off Canna : and on July i 7 th i $8 S 6$, when an exceptional opportunity was afforded us for landing on that surflashed reef from the yacht of Mr. Henry Evans, we found, swimming in a pool and at no time more than thirty yards distant, three young birds which were unmistakably l'intails. To the southern part of Ireland this species is a regular winter-risitor, and Sir R. Payne-Gallwey considers that a few pairs remain to breed at Abbeyleix in Queen's County, as well as on some loughs in Galway; but in the north it is comparatively scarce. In spring its numbers are increased by migrants from the south.

The Pintail has nested in the Furoes, and during the summer months is generally distributed in Iccland, sometimes wandering 
to Greenland. It breeds abundantly in the northern portions of Europe, and, in gradually decreasing numbers, down to lat. $50^{\circ}$; while during the cold season it is found over the rest of the Continent, as well as in Northern Africa, Egypt, Asia Minor, the Indian region as far south as Borneo, China and Japan. Returning northward, we find its summer-range extending over Northern Asia, up to and even beyond the Arctic circle. In America it has been met with up to $72^{\circ} \mathrm{N}$. lat. in Alaska, and thence eastward to Labrador; its winter migrations reaching to the West Indies and Panamá.

The nest-generally placed among coarse herbage in a dry situation, and often at a little distance from water - is deep and well lined with down; the eggs, 7 -ro in number, being pale buffish green in colour and rather elongated in form : average measurements $2^{\circ} \mathrm{I}$ by $\mathbf{I} 5 \mathrm{in}$. Incubation commences in May or June, according to the locality. In winter this species resorts to salt-water estuaries; or to large open sheets of fresh-water. in the shallow portions of which it finds plants \&c. - especially Equisetum and wild rice, as well as insects and their larve, and small molluscs; its flesh is therefore excellent in flavour. It feeds with its head below the water, its long tail being then raised in the air, and it is notoriously partial to the company of Wigeon. Rather a silent bird by day, it utters a lowtoned quack at night. In confinernent it breeds freely, and has been known to pair with the Wigeon; an interesting case is also on record of a male Pintail and a Common Duck producing young half-breeds which had offspring again by the father, while the three-quarter birds bred again with the pure species. Its frequent hybridization with the Mallard in a wild state has already been mentioned; the halfbred drake being a remarkably handsome bird.

The adult male in spring has the head and neck bronze-brown, shading into black on the nape, with a white stripe down the neck on each side, meeting the white breast and under parts; back and flanks mottled grey; greater wing-coverts buff, followed by a green speculum, margined with black and white; tail black, the two central feathers much elongated; under tail-coverts black; bill, legs and feet chiefly slate-grey. In July the plumage of the female is assumed, and is retained until October. Whole length, somewhat influenced by the tail-feathers, $26-28 \mathrm{in}$; wing $10^{\circ} 5 \mathrm{in}$. The female is mottledbrown above and greyish-white below ; the long slender neck, green colour of the speculum, and the oblique bars on the tail sufficing to distinguish her from any other species. The young are like her in their first plumage. 


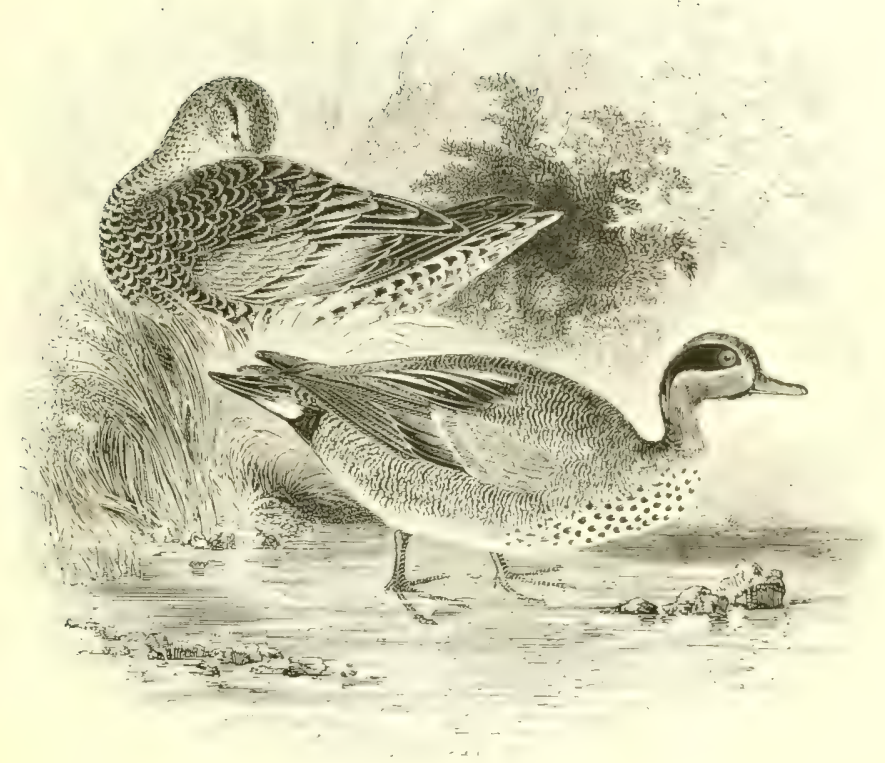

THE TEAL.

\section{Queroquédula crécca (Linnæus).}

It is chiefly between september and the following spring that this, the smallest of our indigenous Ducks, is really abundant throughout the British Islands; but it nests, sparsely, throughout the south of England, and occasionally along the valley of the Thames. In the eastern counties it is a fairly numerous breecler. and north of the Trent it becomes more frequent; while it finds suitable retreats in the Welsh bogs, as well as in the mosses of Lancashire and Cumberland. Except in the Outer Itebrides. where it is rare even in winter, it is a widely distributed breeding. species in Scotland, though scarce in the ()rkncys and shetlands. It is resident in many parts of Ireland, and is abundant there during the cold season.

During summer the Teal is common in Iccland and the north of Europe, while a few pairs nest locally as far south as the Mediter ranean, and even in the Azores. In cold weather it is found all over the Continent, wherever fresh-water does not freeze for any length of time; it visits Madeira, the Canaries and North Africa: is 
numerous in Egypt, and goes as far south as the highlands of Abyssinia. It is distributed throughout Asia, from the Arctic circle in summer to Siam in winter; in all probability it breeds on the islands of the Aleutian chain, and it has been obtained in Alaska in June; but generally throughout North America its representative is $Q$. carolincnsis, the subject of the next article. To the eastern seaboard, however, from Labrador down to North Carolina, our Teal is a rare straggler, and it has been obtained in Greenland.

The nest-placed in tufts of heather, or under low bushes on the borders of morasses and pools - is composed of dry grass and leaves, to which a lining of down is added during the progress of incubation. The eggs, usually laid early in May, are from 8-ro and even up to 15 in number; their colour is buffish- or creamy-white, with a tinge of green: average measurements $\mathrm{I}^{\circ} 8$ by $\mathrm{I}^{\circ} \mathrm{2}$ in. Many instances are on record of the affection of this bird for its brood, and a female has even been known to follow her ducklings into captivity. The food, obtained by night, on or near fresh-water, consists chiefly of the seeds of aquatic grasses, grain, rice (in warm countries). worms, slugs and insects. The Teal has repeatedly bred in the Gardens of the Zoological Society and elsewhere; while in the wild state hybrids between it and the Wigeon are sometimes produced; one of these being the so-called 'Bimaculated Duck.'

The adult male has the bill blackish; crown, nape and cheeks rich chestnut; round and behind the eye an elongated patch of glossy-green enclosed within narrow lines of buff, while a stripe of the latter colour runs from the forehead to the base of the bill; upper parts delicately vermiculated with black and white; on the secondaries a speculum of black, green and purple, tipped with yellowish-white; rump and tail-coverts almost black; tail-feathers ash-brown; chin black; throat chestnut; front of neck spotted with black on a warm buff ground; breast and belly white; flanks delicately barred with black and white; under tail-coverts black in the centre and warm buff on each side; legs and toes brownish-grey. Length $14^{\circ} 5$ in.; wing $7 * 25$ in. From the middle of July till October the drake is in female dress, and I have found brown feathers on the back as late as December. The female is mottled with brown on the upper parts, and has little or no purple in the speculum; the young resemble her.

The North American Summer-Duck, Aix sponsa, is kept and breeds freely on many ornamental waters, and wanderers are sometimes shot. 


\section{THE AMERICAN GREEN.IVINGED TEAL.}

\section{Querquedula carolinénsis (J. F. Gmelin).}

An adult male of this species was shot on November 23 rd 1879 on an arm of the Kingsbridge estuary, South Itevon; and was exhibited by me on behalf of its owner, Mr. H. Nicholls, at a meeting of the Zoological Society on Iecember th isSS. In "The Zoologist' for I $85^{2}, \mathrm{Mr}$. (now Colonel) John Evans recorded the occurrence of an adult male near Scarborough in November $185 \mathrm{I}$; this specimen is now in the collection of Lord Hill. Mr. Arthur Fellowes states (Zool. 1S80, p. 70) that he possesses an example shot by his father 'more than forty years ago' at Hurstbourne Park, Hants, and he correctly describes the essential feature of its plumage. The species has never been kept in the Gardens of the Zoological Society of London, nor, as far as I am aware, in any other part of Europe.

The Green-winged Teal, so called to distinguish it from the Bluewinged representative of our Garganey in America (the subject of the next article), is generally distributed over the northern portions of the New World in summer, and also visits (ireenland; while in winter its migrations extend to the Bermudas, West India Islands, Mexico and Central America. Its nidification and general habits resemble those of our Common 'Teal; but owing to the superior quality of its food, which consists of rice, wild oats, fallen grapes \&c., its flesh is remarkably delicate. Eggs in the Smithsonian Institution, from Fort Simpson, are described as being of a pure irory-white: average measurements $I^{\circ} 8$ by $\mathrm{r}^{\prime} 3$ in.

The adult male differs from our bird in having a broad crescentic band of finely vermiculated greyish-white feathers on each side of the breast, in front of the folded wing; while the buffish-irhite lines which run from the beak to and round the green eye-patch are very slightly defined; the pencilling of the whole plumage also is more minute. Length about $\mathrm{I}_{4} \mathrm{in}$; ; wing about $7 \mathrm{in}$. The female so closely resembles that of our 'Teal that I am unable to sive any specific characters. 


\section{THE BLUE-IVINGED TEAL.}

\section{Querquedula díscors (Linnæus).}

In 'The Naturalist, viii. ( $\$_{5} 8$ ), p. I68, Mr. W. G. Gibson, writing from Dumfries, says, without naming any month, "a specimen of the Blue-winged Teal (.tnas discurs) was shot here a few weeks ago." This bird, erroneously stated by the late Mrr. R. Gray to have been killed in January $1 \$ 6_{3}$, afterwards passed into the collection of Sir William Jardine, and has recently been acquired by the Edinburgh Iuseum; it is a male and undoubtedly genuine. The same cannot be said for the bird recorded under this name in 'The Zoologist' for $18 S_{2}$ (p. 92), which is an immature male of our Garganey. Until recently the American bird was not known as an introduced species on European ornamental waters, but in November $188_{4}$, as Mr. Bartlett informs me. one was sent to the Zoological Gardens by the late M. Cornély of Tours, who probably had others. An adult male was shot near Siby in I) nnmark, about the middle of April r886 (Oluf Winge).

The Blue-winged T'eal is a more southern species than the preceding, and more restricted in its distribution, being seldom met with north of lat. $60^{\circ}$; while it is very local on the Pacific coast. It breeds, in suitable localities, from Labrador to Florida, and from the Saskatchewan to Mazatlan, as well as abundantly in the Mississippi valley; and in winter its migrations extend to the Bermudas, Mexico, the West Indies, and Guatemala. The eggs, $8-\mathrm{I} 2$ in number, are described as of a clear ivory-white, without the slightest tinge of green : average measurements $\mathrm{I}^{\circ} 9$ by $\mathrm{I}^{\prime} 3$ in. Its food and habits do not differ materially from those of its American congener.

The adult male has the throat, forehead and crown dark leadcolour ; in front of the eye a long crescentic patch of white; cheeks and neck dull lavender-grey; back mottled with reddish-buff; lesser wing-coverts lapis-lazuli blue (far more vivid than in our Garganey); on the wing a white bar, followed by a bronze-green speculum; under parts pale reddish; bill black ; feet yellowish. Length 16 in.; wing $7^{\circ} 25$ in. The female is mottled with dull brown and buff, and has only an indistinct eye-stripe. 


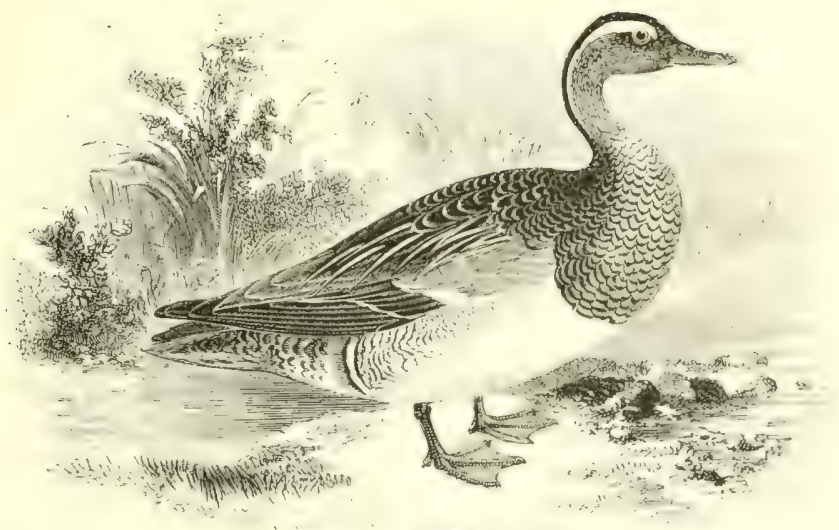

THE GARGANEY.

Querquedula cíkcia Linnæus).

This very local species visits England early in the spring, and, if unmolested, remains in suitable spots to breed (whence it is often called the Summer-Teal); while it is again observed on the migration southward in autumn. It nests regularly in the 'broad' district and other parts of Norfolk-where, owing to protection, it is on the increase, and sparingly in Suffolk; it visits Lincolnshire in April, and used to breed in Northumberland before the drainage of Prestwick Car. Elsewhere its occurrences are irregular, and on the west coast it is decidedly uncommon. The same may be said of the mainland of Scotland, and although recorded as al straggler to the Orkneys and Shetlands, it is as yet unknown in the Outer Hebrides. In Ireland, according to Sir R. Payne-(iallwey, it is the rarest of the well-known I ucks, appearing to be almost confined to the southern half of the island, where it has been founcl as early as March, and even in winter.

The Garganey seldom visits the Froes or Norway, but breeds rather plentifully in I enmark, Sweden, finland, and Russia as far as Archangel; while it is generally distributed in summer throughout the rest of Europe, down to the Caspran, libak and Mediterrancan Seas, though rare in the western portion of the spanish P'eninsula. It is, however, during the cold season that it is most atumdant in the south; its winter migrations reaching to North Africa, Egytt, 
and portions of Arabia. In Asiatic Siberia it does not go far north, but it is common in summer down to the Himalayas, and very abundant during winter in India (where it is known as the Bluewinged Teal), China, and the Malay Archipelago.

The nest is placed among rough herbage in boggy situations, and often in sedge (Cladium mariscus) intermixed with coarse grass. In the $4^{\text {th }}$ Ed. of 'Yarrell' I inadvertently wrote reed-for sedse-beds. Laying begins in the latter half of April or early in May, and the eggs, usually 8 , though sometimes as many as $\mathrm{I} 3$ in number, are more creamy-white than those of the Common Teal, with no tinge of green : average measurements $\mathrm{I}^{\circ} 9$ by $\mathrm{I}^{\circ} 3$ in. The food is similar to that of its congeners, but, strange to say, this Duck is not, as a rule, a good bird for the table. Its usual note is a harsh knack, but in spring the drake makes a peculiar jarring noise, like a child's rattle; whence the name of 'Crick' or 'Cricket Teal' in East Anglia. In its flight this bird is rapid, and when swimming it sits very high in the water.

The adult male in March has the forehead, crown and nape of a dark brown colour, which tapers to a point half way down the neck; from the eye and ear-coverts to the back of the neck a stripe of white; cheeks and neck nutmeg-brown, varied with short hair-like lines of white; back dark brown; scapulars elongated and black with a central stripe of white; ainin-coverts bluish-grey; speculum green between two bars of white; primaries and tail dull brown; chin black; breast pale brown, with dark crescentic bands; belly white; flanks varied with transverse black lines bounded by two broad bands ; under tail-coverts mottled black and white; bill black; legs, toes and webs greyish-brown. Mr. J. H. Gurney jun. states that the male (iarganey remains for an unusually long period in the plumage of the female. Length 16 in. ; wing 775 in. The female is smaller, and has the head brown with darker spots and lines; over the eye a light yellowish-white band; mantle dark brown with rufous edges; wing.coverts greyish-brown; speculum dull metallicgreen between two bars of white; chin white; breast varied with two shades of brown, on a surface of greyish-white; sides and flanks pale brown, varied with darker brown. Young males, as usual, re. semble females in their first plumage; they may be distinguished from the Common Teal by their larger size, bluish-grey wing-coverts, and green speculum. 


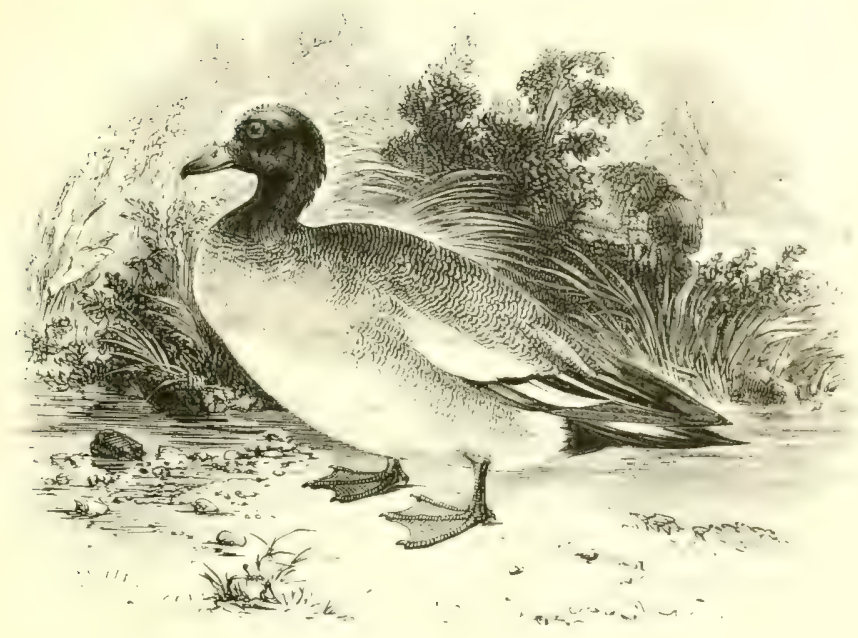

\section{THE WIGEON.}

Maréca penélope (Linnæus).

The Wigeon usually arrives on our coasts from the end of September onwards, and immense numbers are often to be found in sheltered bays and tidal waters during the winter; while in March and April the return migration from the south sets in. During the summer males have occasionally been observed in Norfolk, though the nest has never been found there, or in any other part of England; but in Scotland the species is partially resident, and is known to breed in some numbers over the greater part of sutherland, and sparingly in Ross, Caithness, and Cromarty; ugges are a'so said to have been taken in the Orkneys and shetlands, though not as yet in the Outer Hebrides. In Ireland it is common during the colder part of the year, and Mr. A. G. More states that a few pairs nest in cos. Antrim, Armagh, Tyrone, Mayo, and probably on the lakes of the Shannon.

This Duck is a summer-visitor to the Faroes and lculand, occasionally wandering to Greenland; it is very abundant in scandinavia, Finland, and Russia as far south as Ekaterinburg; and breeds sparingly in I)enmark, Holland, and Northern (iermany. On passage it visits the rest of Europe, eroing as far west as the Azores; and in Africa it is found down to Myssinia. In Asia its 
range in summer extends from the Arctic circle to Mongolia, and in winter over the rest of that continent and its islands down to Borneo; and a specimen has even been obtained in the Marshall group, Polynesia. From Siberia we trace this species across Bering Sea, by way of the Aleutian Islands, to Alaska, and it is not unfrequent on the coast of California; while on the east side of Americil it occurs almost every winter, especially between Virginia and the Carolinas.

The nest, placed in a tuft of rushes, coarse herbage or heather, is warmly lined with down, and usually contains from 7-10 eggs of a rich cream-colour: arerage measurements $2 \cdot 3$ by 1.5 in. The food-procured by day when the birds are undisturbed, but otherwise by night--consists chictly of grasses, with other vegetable matter found on oozy shores. The call-note of the male is a shrill whistling wherell, whence the local names 'Whew Duck' and 'Whewer'; but the female utters a low purr-ing growl; both sexes, however, rise in silence. Although it does not dive for food, the Wigeon can submerge itself easily when wounded and pursued, turning rapidly under water. No other species offers such attractions to the punt-gunner; it is also taken in large numbers in those of our decoys which, as in Essex, and also in Pembrokeshire, are situated near the sca, though flocks seldom resort to pools at a distance inland. In confinement it breeds occasionally, though not very freely; and has been known to cross with the Pintail, Mallard, and Teal.

The adult male has the forehcad and crown cream-white; cheeks and hind neck chestnut, minutely spotted with bottle-green; chin black; throat and upper neck chestnut; breast white, passing into grey on the under parts, the flanks being pencilled with dark grey; mantle chiefly of a finely vermiculated grey; shoulder white with a terminal bar of black, followed by a green speculum tipped with black below; quills and tail dark brown; bill bluish-lead colour: legs and toes dark brown. Early in July female plumage is assumed, but the tints of the drake are always the brighter. Length I 8 in.; wing 10.5 in. The female is generally mottled with greyishbrown on the upper parts, and the shoulders are nearly white; the speculum is greyish-green, and the under parts are mottled buffishwhite. As usual, the young resemble the female, which occasionally assumes nearly full male plumage. 


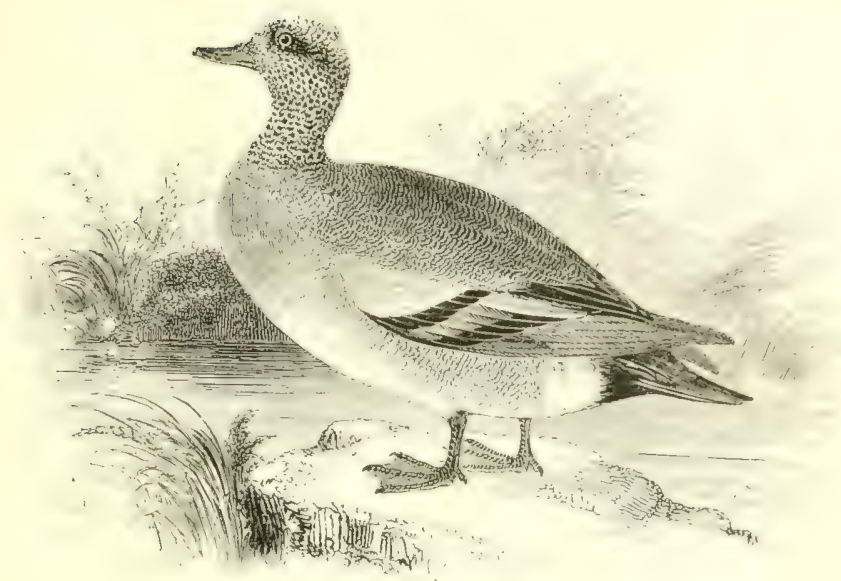

THE AMERICAN WIGEON.

Mareca americána (J. F. Gimelin).

The occurrence of this bird in a London market during the winter of $I_{37} 8$ was thus noticed by Blyth, in the third volume of N. Wood's 'Naturalist,' p. 4I7 :- "The American Wigeon is a novelty which was obtained by Mr. Bartlett. He selected it from a row of Common Wigeons, deeming it, at the time, to be only an accidental variety of the species; there was a female along with it. which, after some hesitation, he unfortunately left, considering it only as a variety, but insufficiently diverse to be worth preserving : he has since, however, positively recognized the female of the American Wigeon to be identical with the hird he thus passed orer hesitatingly in the market." This specimen-a male-is now in the collection of Mr. J. H. (iurney ; and assuming, as we may fairly do, that it was really killed in this country, it is the only liritish-taken example in existence. Thompson believed on hearsay evidence that one, not preserved, was killed in lebrtary is +t. on Stransfort Lough near Belfast; and among his many unauthenticated rarities, Thomas Edward, of Banff, has enumerated another, shot on the Burn of Boyndie in January is 4 , but afterwards thrown away ! 'Two other records in 'The Zoologist' are so utterly unsubstantiated as to be unworthy of serious consideration.

In France, according to MM. Marmottan and Vian, a female, now in the collection of the former, was taken at I ce Crotoy. Somme. 
on April I 3 th I 875 . As strengthening the probability of its wandering to Europe from America, I may mention that Mr. O. H. Howarth informs me of a specimen in a collection at St. Michael, Azores. Up to the present time this species is not known to have been introduced upon ornamental waters in England or any part of the Continent.

In North America this Wigeon is found in summer from Alaska eastward throughout the Fur-countries to Hudson Bay; and on migration it occurs over the greater part of that continent, being numerous on the Chesapeake, where, like the Canvas-back, it feeds on the callisniria. Audubon says that it is abundant during winter at New Orleans, where it is much esteemed on account of the juiciness of its flesh, and is best known by the name of 'Zinzin.' In the western country, and in most parts of the Eastern and Middle States, it is called the Bald P'ate. It frequents the rice-fields of the South, wanders to the Bermudas, and is an annual winter-visitor to Mexico, the West India Islands and Central America.

The nest of this species is stated by Kennicott to be always on high dry ground, among trees or bushes, at a considerable distance from water; it is a comparatively small depression among the dead leaves, lined with down, and contains from 7 -10 ivory-white eggs, averaging in their measurements $2^{\circ} 2$ by $\mathrm{I}_{5} 5 \mathrm{in}$. 'The note is a soft, gentle whistle.

The adult male has the forehead and crown dull white; a broad grecn streak passing backward from the eye; cheeks and neck whitish, freckled with black; mantle brownish-grey vermiculated with black; lesser wing-coverts white, and the greater ones tipped with black; on the secondaries a green speculum; tail greyishbrown; upper breast to flanks mottled reddish-brown; belly and vent white; bill black at the tip, the rest grey; legs and feet bluish. In younger males the plumage is duller, and the soft parts are darker in colour. Length 19 in.; wing $10^{\circ} 5$ in. The female has the head and neck yellowish-white speckled with black, little rufous on the breast, and a dark brown back. The young are much like the females in the first season, but the wing-pattern is better defined, and the colours are more pronounced in the drakes. 


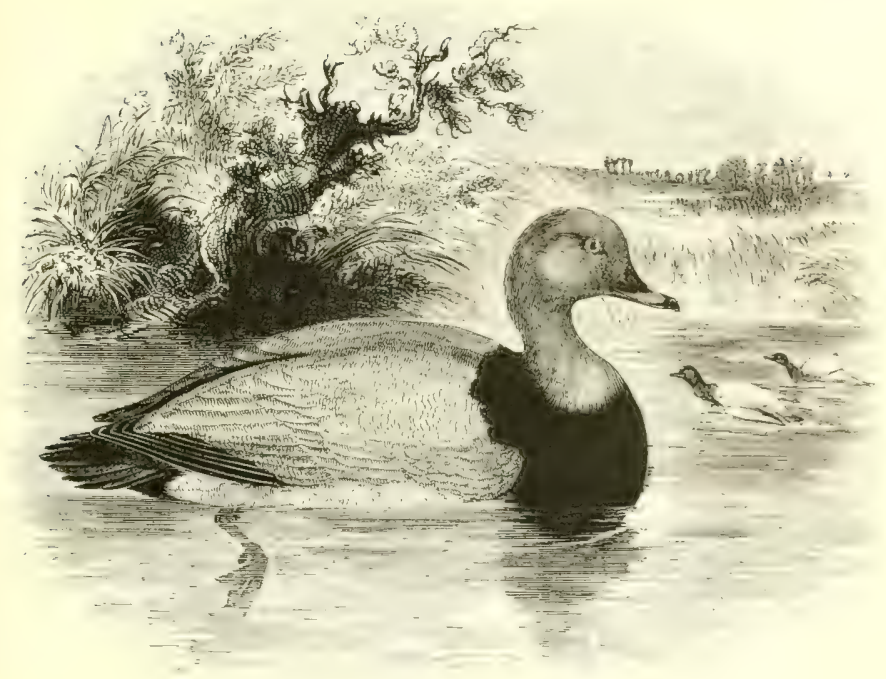

THE POCHARI).

Fulígula ferína (Linnæus).

With this species we begin the Fuligulinu or Diving Ducks: a tolerably natural sub-family, consisting of species which have a conspicuous membranous lobe to the hind toe; most of them being inhabitants of salt-water during a great part of the year, while all obtain their food by diving. The Pochard-also known by the names Dun-bird, Red-headed or Red-eyed Poker--is in the main a coid-weather visitor to this country, appearing early in Octoluer and leaving again in spring; but a tolerable number remain to breed on some of our inland waters, where, owing to efficient protection, they appear to be on the increase. Such is the case at Merton and in other parts of Norfolk, at Hornsea Nere in Yorkshire, in Lancashire, I)orsetshire, and some localities which need not he named. In Scotland it is generally distributed, except in the (utur Hebrides; and Mr. Harvie-Brown informs me that it nests on a loch near Doune, and in Fïfeshire. In Ircland it is abundant in winter, while it has nested in cos. Sligo and Antrim, as well as on Loughs Derg and Beg.

The Pochard is a rare wanderer to the Froes and Iceland, nor is it common in any part of Scandinavia; though in Russia it 
breeds as far north as Lake Ladoga, and southward to the Caspian. A tolerable number nest in Denmark, Germany, Poland and suitable localities throughout Europe, down to the Mediterranean; to which, as well as to North Africa, large flocks resort in winter. Eastward, its range extends in summer across temperate Asia to the Baikal district, but not further north; and southward in winter to Japan, China, and many parts of India. In America the representative is a closely-allied species, $F$. americana, with no black at the base of the bill, greyer back, and whiter belly. The famous Canvas-back belongs to this genus, and not long ago an unfortunate West-end poulterer who had received that bird in ice from America, was prosecuted by bold-swearing meddlers for selling Pochards during close-time.

The nest is placed among rushes, sedge, or other coarse herbage on the margins of meres and pools; the eggs, $7-10$ or even 13 in number, being greenish drab in colour: average measurements $2^{\circ} 3$ by $\mathrm{I} \cdot 6 \mathrm{in}$. So long as the Pochard eats the plants which grow below the surface of our inland waters, it is excellent for the table; but when on the sea it becomes coarse, owing to a diet of crustaceans and molluscs. It feeds principally towards dark, at which time large numbers are captured in nets set for the purpose, but from decoys its diving-powers often enable it to escape. The usual note is a low whistle, but the alarm-cry is a rough croak. In captivity it has been known to breed, but not freely. Wild birds have several times been obtained which appear to be hybrids between it and the Ferruginous I)uck ; and one of these is the so-called 'Paget's Pochard' described by Mr. W. R. Fisher (Zool. pp. I I 37, I 778), shot on Rollesby Broad, Norfolk, and now in the possession of Mr. J. H. Gurney, who has a second example, shot in the same county in February 1859. This hybrid has been named $F$. homeyeri and $F$. ferinoïdes.

The adult male has the head and neck chestnut-red; breast and upper back black; mantle finely freckled with black and white; speculum inconspicuous and grey; under parts greyish-white; tailcoverts black; bill black with a broad band of blue across the middle; iris red; legs and toes bluish-grey. Length 19.5; wing $8 \cdot 25$ in. The female has the head, neck and breast dull brown, and the chin white; the rest of the plumage being browner than in the male. The young at first resemble her, and the black breast is not assumed by the drake during his first year. 


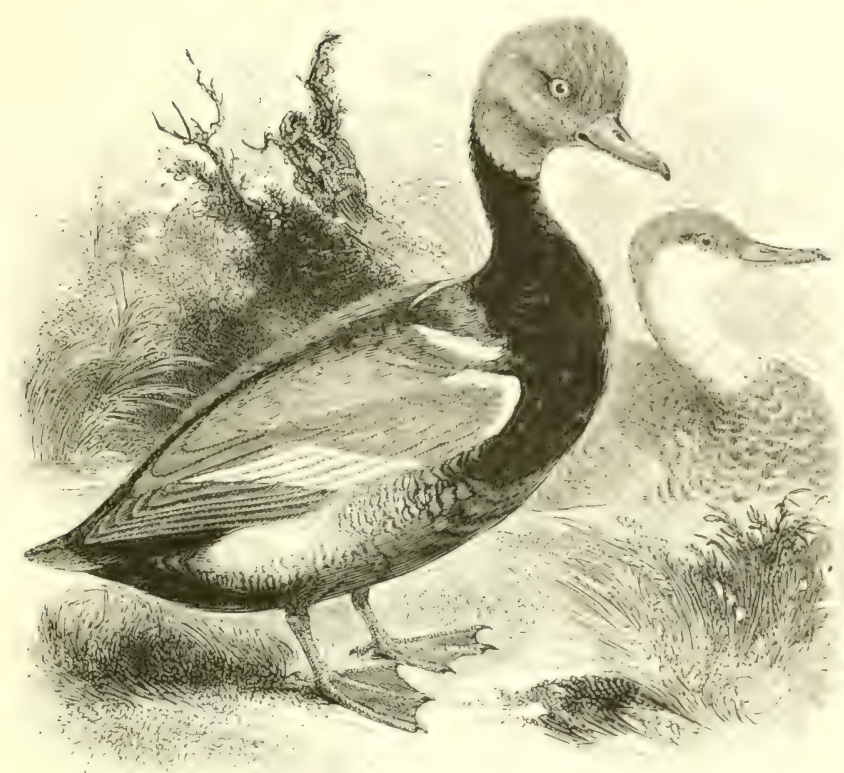

THE REI-CRESTED POCHARI).

Fuligula rufína (Pallas).

The Red-crested Pochard is a southern and eastern speries which was first noticed as a wanderer to the british Ish ind by I. I Iunt, who figured a female killed in Norfolk in July is 1 \&; and eight or nine examples have since been obtained in that county, chiclly in winter. Others have been taken along the cast coast, from a little south of Berwick-on-Tweed to the mouth of the Thames; I eron and Corn wall have each contributed one; and there is a specimen in the British Nuseum from P'embrokeshire. In Scotland one was shot in Argyllshire in January 1802 ; and in Ireland one, in co. Kerry, on January I 8 th 188 I.

This Pochard has only once occurred in I emmark, and seldom visits the waters of Holland, lielgium, France or switzerland: it is even very local in the Spanish P'eninsula, being almost contined to the lakes on the east side and those in the lialearic Islands, mo-t of which are gradually being drained. In the southern half of Italy it is not uncommon, and readers of Willughlyy's 'Ornithology' will remember that more than two centuries ago our countryman obtained 
it in the market at Rome; it is also resident in Sicily and Sardinia. It breeds in small numbers in Central and Southern Germany; more frequently along the valley of the Danube, and abundantly in some parts of South Russia; while in winter it is found throughout the basins of the Mediterranean, Black and Caspian Seas. In Africa it nests in many of the lakes to the north of the Sahara, though very rare in Egypt: in Asia its summer-haunts are in Northern Persia and Turkestan, but do not reach Siberia; its winter-range extending to Northern and Central India, where thousands are sometimes seen on large sheets of water. A young male, probably introduced, was found in the New York market on February and I 872 .

Toward the end of April or the beginning of May the nest is built among rushes or on reedy islands in pools of moderately deep water; the eggs, 7-9 in number, being of a brilliant green colour, which soon fades after they are blown : average measurements $2^{\circ} 3$ by $\mathrm{I}^{\circ} 6 \mathrm{in}$. The food-obtained almost entirely by diving - consists of waterweeds, frogs, small fish, insects \&c.; and the flesh of this bird is generally held in high estimation. The call-note, seldom heard by day, is a deep grating kur); but occasionally the male utters a sort of whistle. Col. E. A. Butler says that this is one of those wary birds which severely try the sportsman's patience, taking wing on the slightest indication of danger, and flying up and down the tanks, invariably out of gunshot. In confinement it does not breed freely, but in 1879 , although several birds of both sexes which were kept in the same enclosure in the Zoological Society's Gardens had refused to pair, yet hybrids between this species and the Antarctic Rosybilled Duck were produced.

The adult male in spring has the beak crimson, with a white nail ; irides reddish ; head, erectile crest, and upper neck chestnut ; lower neck, breast, centre of abdomen, and lower back brownishblack; flanks white, with a tinge of salmon-pink; mantle yellowishbrown; lesser coverts and a small speculum on the secondaries, white; inner secondaries grey; quills and tail-feathers ash-brown; legs and toes vermilion-red; webs almost black. In less mature birds the soft parts are duller in colour. Length 22 in. ; wing Io'5 in. The female has no crest, and the top of the head is dark brown; the cheeks and neck are greyish-white; the upper and under parts pale rufous to greyish-brown; the point of the shoulder and speculum dull white; beak and legs dull red. Young drakes at first resemble the females, but the crest and the red colour of the bill soon become apparent. 


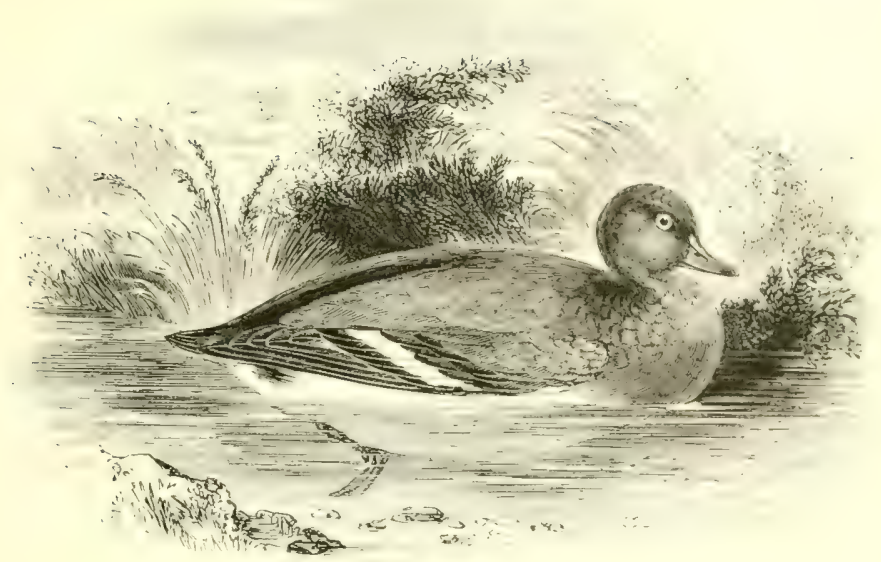

THE FERRUGINOUS DUCK.

Fuligula nyróca (Güldenstädt).

This species-also called the White-eyed Duck, from the colour of its irides-is an irregular visitor, principally in winter and spring. About twenty examples have been obtained in Norfolk, a few in Suffolk, Cambridgeshire, Yorkshire, and along the Trent valley up to Nottinghamshire; and Northumberland, Cumberland and I ancashire are each credited with one. Those exposed for sale in the London markets are open to the suspicion of having leen brought from Holland (whence also live birds are sometimes sent); but four have been killed near Oxford, and one each in l)orset and Devon; while a remarkably tame bird was observed on a pond in Radnorshire during the latter part of 1858 and up to March 1859. In Scotland this Duck has been obtained near linburgh on two occasions in winter; and in Ireland four occurrencess have becen noted from the east and north-east coasts.

The Ferruginous Dúck is not known to breed to the north of Holland, Schleswig-Holstein, the (ieman side of the Baltic, or Moscow in Russia; but in Poland, Hungary, and slawonia it is very abundant from April to autumn, and it is a resident of general distribution in the southern portions of liurope, from spain to the Volga. It visits the Canaries, nests in North Africa, and is found in large flocks on the lakes of Egypt in winter. In the temperate and 
elevated regions of Asia it is generally numerous, and Mr. Hume says that boat-loads of its eggs are brought into the market of Srinugger, in Cashmere. During cold weather it is found over India as far east as Arrakan; Père David states that it is common in spring near Pekin; and it is said to have been obtained in Japan.

A nest found in Spain by Lord Lilford was placed amongst high rushes, at a short distance from the water, and was composed of dry water-plants with a lining of brownish-white down and a few white feathers. The eggs, 7-12 in number, are pale buff-colour with a faint evanescent greenish tinge: average measurements $2{ }^{\prime} \mathrm{I}$ by I' 5 in. The food, sought by day, consists of vegetable matter, varied with insects and their larvæ, small molluscs, crustaceans \&c.; and there is great difference of opinion as to the fitness of this Duck for the table. Its diving powers can hardly be surpassed, but it rises somewhat heavily, striking the water repeatedly with its feet, like a Coot; and it is not remarkably rapid when on the wing, at which time it has a very dark appearance (whence its Spanish name 'Negrete'), by which fact and by its white wing-bar it may easily be recognized. It is seldom seen on large open sheets of water, but prefers weedy lakes and ponds, where it can find reeds and other cover suited to its skulking nature; in fact its habits are very similar to those of a Little (inebe. The note is a harsh kirr, kere, kirr. Mr. J. H. Gurney has known a bird live in captivity for fifteen years.

Adult male: bill bluish-black; irides white; head, and the neck all round to the upper part of the breast and the sides, rich chestnutbrown; on the middle of the neck a narrow brownish ring; back and wing-coverts umber-brown, with a tinge of green; quills dusky-black, part of the inner webs white; on the secondaries a white speculum, tipped with black; tail brownish-black; on the chin a small triangular spot of white; lower breast and belly white; flanks brown; rent greyish-brown; under tail-coverts white; legs and toes bluishblack, webs darker. Length 16 in. ; wing 7.75 in. The female is rather smaller; her irides are not so white; the head and neck are of a darker brown, less rich in tone; and the lower breast and belly are seldom-though occasionally-as pure white as in the male. The young bird of the year has even less of the chestnut tint than the adult female. 


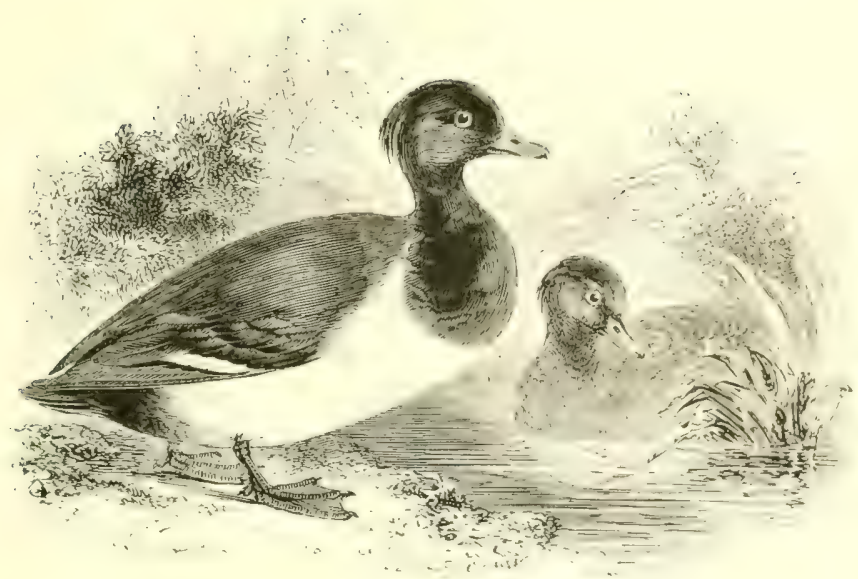

THE TUFTED DUCK.

Fuligula cristáta (Leach).

The Tufted I)uck is best known as occurring between autumn and spring on our low-lying coasts, estuaries and lakes, where it is often found in company with Pochard, Scaup, (iolden-eye, and other diving-ducks. A tolerable and increasing number remain to breed with us, and nowhere more abundantly than in Nottinghamshire, especially on the ponds at Newstead. Clumber, Nelbeck, Rufford and Rainworth; the last--the property of MIr. J. Whitaker-having been visited by many ornithologists. Nests have also been found in Yorkshire, Lancashire, Northumberland, Norfolk, Sussex, I)orset, and some other counties which afford suitable resorts. In ficotland it is evidently on the increase, and breeds on Yetholm Loch in Roxburghshire, Butterston and I)upplin Iochs in I'erthshire, and on Loch Leven, as well as in Aberdeenshire. In Ireland it annually frequents Loughs Neagh and lieg, and some waters in co. Monaglsan in summer, being generally distributed in winter.

This species is said to have bred in the Froes, and is found in small numbers on the rivers and lakes of Norway in the wamer months, becoming more abundant in sweden, Finlunel and Russia : though beyond the Arctic circle it is compratively rare. Southward, it nests in suitable localities down to abuent lat. 50: while over the rest of Europe it is fourd on migration and in winter: at which sealson it ranges through Africa as far as Abysinia. In summer it frequents 
the temperate regions of Asia, and during cold weather large numbers visit Japan, China, and the northern half of India.

Incubation takes place towards the end of May or the beginning of June, the nest being concealed under a bush or in a tuft of sedge ; and the eggs, $8_{-I_{3}}$ in number, are of a greenish-buff colour : average measurements $2{ }^{\prime} 3$ by $\mathrm{I} \cdot 5$ in. The call-note on alighting is rendered by Mr. Whitaker as curmugh, cumugh, uttered gutturally; and, when at Rainworth, he called my attention to the fact-which he believed to be invariable - that the female is the first to rise when both birds are together on the water. They dive freely and frequently. For the table this species is tolerably good when it has been eating aquatic plants, but as soon as it has taken to animal food, either from fresh or salt water, the result is not satisfactory. Feeding takes place soon after twilight, and also in the early morning. Pinioned birds have bred on the ponds in the Zoological Gardens, and on other ornamental waters; and at the former a Tufted crossed with a Ferruginous I)uck in $18+9$, the hybrids afterwards breeding either inter se or with one of the parents till r86r. In the British Museum there is a hybrid presented by Mr. R. J. Howard from a brood produced in 1886 on the reservoir of the Blackburn Corporation Park between the Tufted Duck and the Pochard; and a cross-bred bird of this description is in the Belfast Museum.

The adult male has the crest, head and neck glossy purplishblack; breast, and the upper parts generally, duller black, with a green tinge on the secondaries; alar speculum white; belly and flanks white, washed with grey towards the vent; under tail-coverts black; bill pale blue; nail black; irides brilliant golden-yellow; legs and toes dark blue, webs black. Length 17 in.; wing 8 in. $\mathrm{Mr}$. Whitaker says that a paired male began to change into female plumage in May, but an unattached drake was as bright as ever until the end of August, when he became less white on the flanks. It is a fact, though one which is perhaps not generally known, that the drakes of many other species retain full, or nearly full, dress throughout the summer, when they have not found a mate in spring. The female is dark brown on all those parts which are black in the male, the under surface being brownish-grey; and old females, as well as young males-which in first plumage resemble the mother - sometimes have the forehead sprinkled with white. 


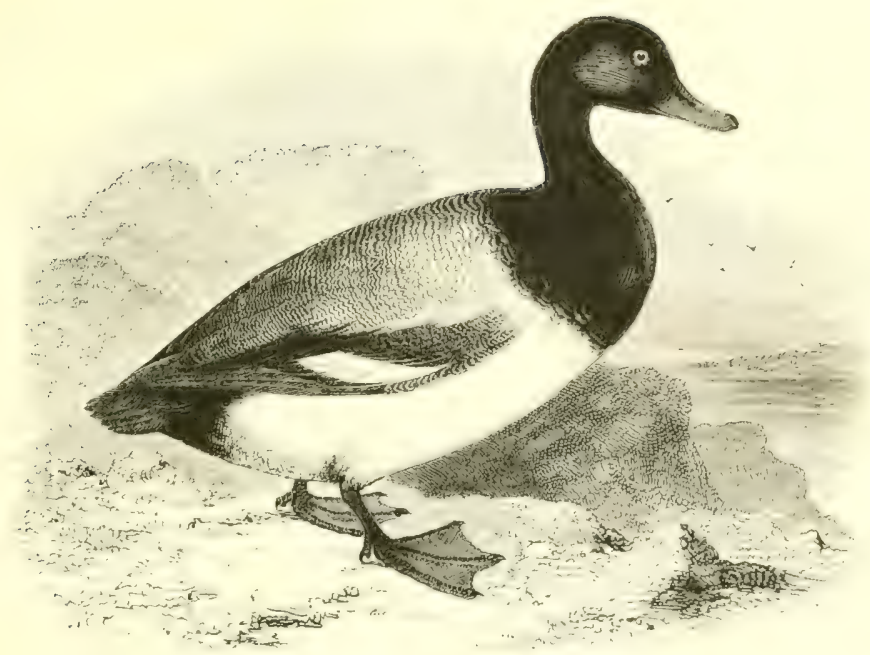

THE SCAUP IUUCK.

\section{Fuligula maríla (Linnæus).}

The Scaup I)uck seldom makes its appearance on our southern coasts till the end of October or beginning of November, though somewhat earlier in the north; and it is common during the winter on low oozy shores as well as in sheltered rocky bays. IBy spring the great majority take their departure, but Mr. A. C. Stark says that on Loch Leven in Scotland, on May i 5 th, he saw about forty, all paired; on June $5^{\text {th }}$ five couples remained, and the following day he flushed a female from a nest containing eleven fresh eggs in a clump of rushes close to the side of the loch; the bird alighting on the water and affording a good opportunity for cxamination through a telescope. This species is not numerous in the ()uter Hebrides, or on the south coast of Ireland; but with these exceptions it seems to be generally distributed along the shores of the United Kingdom.

In the Froes, where the Scaup is common in autumm and winter, a few remain through the summer; and in Iceland it hreeds in great abundance; as it does up to $70 \mathrm{~N}$. lat., in Scandinavia, Irctic Russia, and Asiatic Siberia as far as the Pacific. According to Blasius it nested on one occasion at the Hiddensece in lirunswick: but as a rule it is only found south of the laaltic in winter and on passage; while it is rare in the western prortion of the Mculiter- 
ranean, though not uncommon in the east, as well as on the Black and Caspian Seas. Iluring the cold season it also frequents the coasts of Palestine, Egypt, and Northern Persia, but is unknown in Turkestan and extremely rare in Northern India; the mountains and elevated table-land of Central Asia diverting its line of migration to the east of the meridian of Lake Baikal, whence we trace it southward to Japan, China, and Formosa. Across North America, from the Pacific to the Atlantic, it is distributed north of lat. $50^{\circ}$ in summer, and down to Mexico and the West Indies in winter; but in Greenland it is of rare occurrence. There is also a smaller form -of doubtful specific distinctness-known as the American or Lesser Scaup, F. affinis of Eyton ( $F$. mariliides of Vigors); but the example figured as the above in the earlier editions of 'Yarrell,' and now in the collection of Mr. F. Bond, appears to be a hybrid between the Scaup and the Pochard, and is certainly not the American bird.

The nest is placed in rough herbage or among stones in the vicinity of water, and the eggs, clay-buff in colour, are usually 6-I I in number, though as many as 22 have been found together, the united produce of more than one female: average measurements 2.6 by $I \% 75$ in. The note is remarkably hoarse and discordant, resembling the word scaut, and its utterance is accompanied by a peculiar toss of the bird's head. 'The food consists chiefly of molluscs and sea-plants during winter, obtained by diving, over beds of oyster- and mussel-shells known as 'scalp' or from reefs on which tangle grows; the bird is therefore almost uneatable, and, not being an object of pursuit, is, as a rule, rather tame.

The adult male has the head, neck, upper breast and back glossyblack; mantle finely vermiculated with greyish-brown and white; on the secondaries a white speculum terminated with greenish-black; quills, rump and tail-feathers brownish ; belly white; bill pale blue; nail black; irides straw-yellow; legs and toes dull blue. Length I 8 in.; wing 8.5 in. The female has a broad white band round the base of the bill, which is lead-coloured; head and neck dark brown; upper breast and mantle rather lighter brown with greyish vermiculations; belly dull white; flanks and under tail-coverts mottled with brown. The young drake at first resembles the female, and does not attain the full glossy-black head until he is more than three years old. 


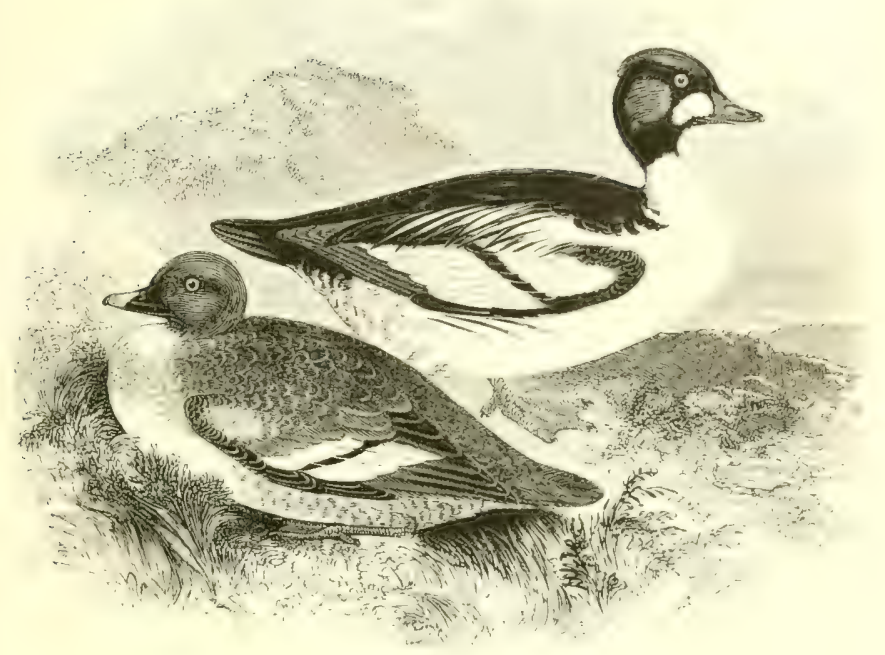

THE GOLI)EN-EYE.

\section{Clángula graúcion (Linnæus).}

The Golden-eye grenerally arrives on our coasts about the middle of October, and so long as the inland waters are not frozen it frequents many of our lakes, as well as rivers and tidal estuaries; immature birds sometimes remaining until the end of May. The Rev. H. A. Macpherson saw a year-old male in North Uist, on July roth 1886 , but as a rule the species is comparatively scarce in the Outer Hebrides; while a statement that its nest had been found in a hollow tree on Loch Assynt, sutherlandshire, has not yet received confirmation. In Ireland this bird is well known on the coasts, and especially on the fresh-water loughs; the young and the females being often called 'Morillons,' and considered by' many fowlers as quite distinct from the far rarer mature males.

In the Faroes this species is of rare occurrence, while in Iccland and Greenland it is represented by the larger Barrow's (iolden-eye (C. islandica), the male of which has a sreater development of crest and a more purplish gloss on the heal. The female of the latter is barely recognizable by her average superiority in sice yet an assertion-unsupported by evidence - that one had leen obtained at the mouth of the Derwent, has found believers. In ficandinavia 
our Golden-eye is common in summer as far north as lat. $70^{\circ}$, even where the trees-in which it makes its nest - are hardly large enough to provide holes suitable for occupation; while in Russia it breeds regularly down to about lat. $58^{\circ}$; and also, though sparingly, in Holstein, Mark Brandenburg and East Prussia. Southward it is found in cold weather on the inland waters and along the coasts of Europe, but only severe winters drive it to the western portion of the Mediterranean or to North Africa, though it is not unfrequent in Greece, the Black Sea, and the Caspian district. Throughout Asiatic Siberia it remains as long as it can find open water, and it also inhabits the lakes, up to an elevation of 10,000 feet, of the Pamir steppe, Kashgaria and Mongolia; while on migration it visits Japan, China, and, occasionally, Upper India. In North America a larger form, identical in plumage, is found.

The nest, when in a hollow tree or a hole previously tenanted by a Black Woodpecker, often has the external opening so small that a man's hand can with difficulty be inserted; but in order to obtain the eggs with greater ease the Lapps and Finns place boxes or hollowed logs in convenient situations, especially in the neighbourhood of falls and rapids, to which this bird seems partial. The eggs, usually $10-12$ or exceptionally 19 in number, are bright green when unblown, though the colour fades: arerage measurements 2.4 by I. 6 in. The food, obtained by diving, consists of crustaceans and molluscs, as well as sea-grass which is brought to the surface and then eaten. The Golden-eye rises from the water with great rapidity, and, from the noise produced during its flight, is often known by the names of 'Rattle-wing' and 'Whistler.' Wild hybrids between it and the Smew have been obtained.

The adult male has the head and neck glossy-green, the feathers on the crown being slightly elongated; a conspicuous white patch at the base of the bill ; back black; all the lower neck, scapulars, alar speculum, and under parts white; thighs dark brown; legs and toes yellow with blackish webs; bill bluish-black; irides goldenyellow. In summer a plumage similar to that of the female is assumed, but a little white remains at the base of the bill, and a good deal on the speculum. Length 19 in. ; wing 9 in. Females and young males have no white spot on the face; the head is dark brown and separated by a white collar from the greyish-brown neck and shoulders; the wing-coverts are tipped with black, so that the white alar speculum is divided into three portions; the back and flanks are dark brown, and the belly is white. 


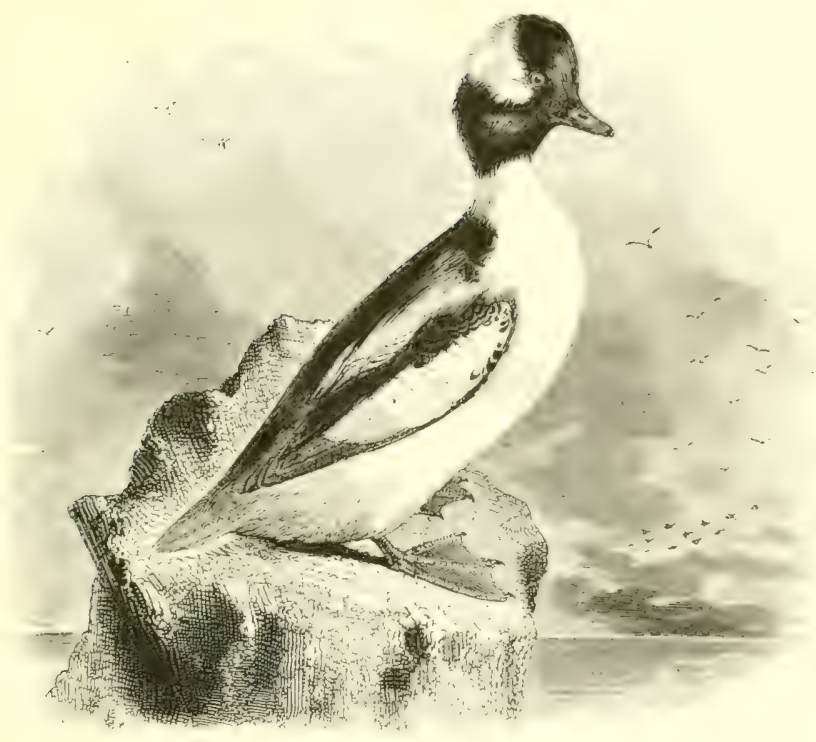

THE BUFFEL-HEADED DUCK.

Clangula albéola (Linnæus).

About the winter of $\varepsilon_{3} \circ$ an adult male of this North-American species was shot near Yarmouth, and is now in the Norwich Museum, having been purchased at the dispersal of the late Mr. Rising's collection. In 'The Birds of the West of Scotland' (I). 396), the late Mr. Robert Gray stated that he had examined a male shot on the Loch of Loriston, Aberdeenshire, in January I 865 , as well as a bird of the same sex in the Banff Inseum, obtained many years previously on the Loch of Strathbeg; while a bird--also a mature male - from Bridlington, Torkshire, in the winter of $186+65$. is now in the collection of Mr. J. Whitaker of Rainworth. Some other records are unauthenticated, while one of them is known to be essentially untrue. The Buffel-headed I)uck is not known to have occurred on the shores of the Continent, and even in fircenland Reinhardt was only aware of the occurrence of a fumale at Godthaab, about 1830 .

In America this Duck is found during the summer as far south as the States of Maine and Wisconsin, and across the Fur-countries to the Pacific, though rare in Northern Alaski. A single specimen was obtained by Dr. Stejneger in January $18 s_{3}$, on liering Island. 
off Kamschatka, being the first recorded instance from the Asiatic side of Bering Sea. Its migrations extend to California-where it is very abundant between October and April-Texas, Mexico, the West Indies, and occasionally to the Bermudas.

So far as is at present known, the nest is, like that of the previous species, placed in the hollow of a tree, and lined with down. One found by Mr. Lockhart on the Yukon River was in a poplar, about twenty feet from the ground, and on July 7 th contained ro eggs ; their colour was of an ivory-white with a faint tinge of green: measurements 2 by $\mathrm{I}_{5} \mathrm{in}$. Mr. A. C. Stark describes a nest from which he shot the female on May 27 th 1882 , in West Minnesota, as being in a hole in an oak-tree, which was only a few inches deep and partly filled with decayed wood, whereon lay 8 eggs nearly buried in down. The stomach of this bird was crammed with small red worms, but snails, leeches, grasses and aquatic plants are also eaten, while on the sea-coast shrimps and molluscs are obtained by diving. From its fatness this species is generally known in the United States by the name of 'Butter-ball'; and it is also called the 'Spirit-Duck,' owing to the alacrity with which it disappears beneath the water. Its note is a mere croak, like that of the Golden-eye, but more feeble. It is very tolerant of cold, and has been seen on the Ohio when that river was thickly covered with floating ice.

The adult male has the forehead metallic-green, a dash of the same colour on the back of the neck, while the crown and throat are iridescent purple; from behind the eye to the nape extends a large triangular white patch which terminates in a sort of crest; below the purplish-green neck comes a narrow white collar which meets the under parts of the same colour; back, rump and inner secondaries, black; outer secondaries, speculum and coverts chiefly white, variegated with black; tail slate-grey; bill bluish; irides dark brown; legs and feet yellowish-pink. Length I 5 in.; wing 6.75 in. The female is srnaller; her head and neck are ash-brown, with a white patch behind the eye; the upper parts are chiefly greyish-brown; the white on the wing is less defined, and the under parts are tinged with brownish-grey on the sides. The young at first resemble the female. 


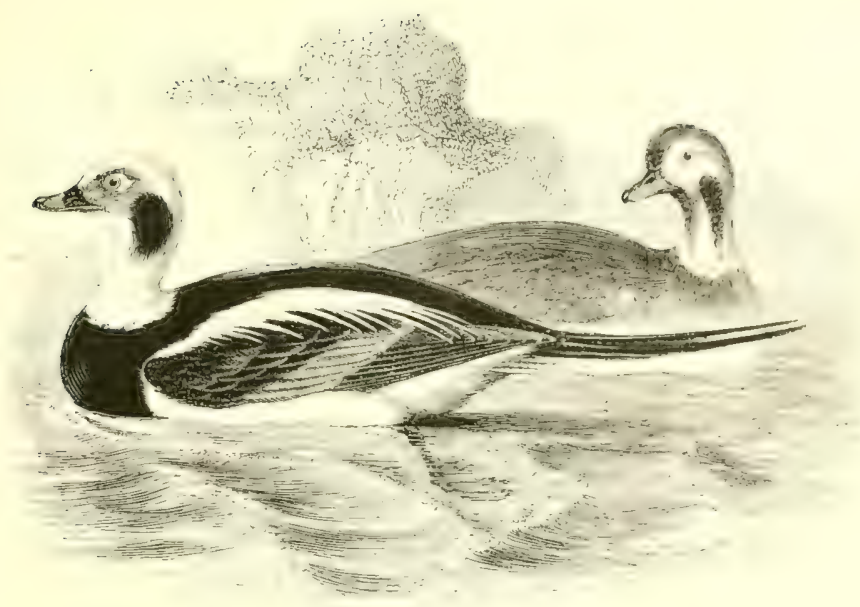

THE LONG-TAILED DUCK.

Harélda gLACIÁLIS (Linnæus).

This species is comparatively uncommon in the south and southwest of England, though it was exceptionally numerous in the winter of $1887-88$; while on the west coast it is decidedly rare. On the east side young birds are not unfrequent, and, strange to say, two adult males in full breeding-plumage have been shot on the 'broads' of Norfolk; while, proceeding northward, we find this Duck tolerably abundant from November to April. In Scotland small flocks are to be met with from Berwickshire to Caithness, and on the west side it is very common in the Outer and Inner Hebrides. In the Orkneys and Shetlands, where it is well known by the name of 'Calloo,' from the loud musical note of the male, it is to be met with on all the inlets or voes. I have little doubt that it breeds on some of the unfrequented lochs of Yell and Mainland in the latter group, though absolute proof is still wanting. To the north and west of Ireland its visits are irregular, and in the south they are exceptional.

It is probable that the Long-tailed I uck nest: though sparingly; in the Froes, and in Iceland it does so in comsideralle numbers. In Scandinavia it breeds on the streams and lakes of the fells an fur south as $60^{\circ} \mathrm{N}$. lat., though it only becomes numerous to the north of the Arctic circle: while in winter it is very abundant along the coasts. It also breeds in Jan Mayen, Siptsherem, Nowiya \%emlya, 
North Russia, Siberia, and throughout Arctic America, as well as in Greenland; in fact its summer-range is circumpolar. In cold weather its migrations extend to the Italian lakes and the Adriatic, though not, as far as is known, to the African side of the Mediterranean; in Asia, to Japan and North China ; while in America it is found down to about lat. $37^{\circ}$, and is widely known as the 'Southsoutherly' and 'Old Squaw,' from its gabbling note. In this connection it may here be mentioned that in many parts of Scotland the call-note is rendered by 'Coal an' can'le licht.'

The nest, generally placed among low bushes by the side of fresh-water, is composed of a few stems of grass, with a thick lining of down which is little inferior to that of the Eider. The eggs, of a somewhat elongated oval form, are pale greyish-green, and measure about $2^{\circ} \mathrm{I}$ by $\mathrm{I}^{*} 45$ in. On a small flat island in My-vatn, Iceland, Messrs. Shepherd and Tpcher counted more than twenty nests, and observed a Long-tailed Duck and a Scaup sitting together on one which contained several eggs of the two species. The food consists of animalcula which swim at various depths, and of small molluscs, crustaceans \&c., chiefly picked off sea-weed; or in summer of fresh-water plants and insects.

The adult male in spring has the cheeks brownish-grey; below, on each side of the neck, an oval patch of dark brown; forehead, crown, nape and all round the neck pure white; back, rump and tailfeathers ( $\mathrm{I}_{4}$ in number, the central ones being sometimes 9 in. long), blackish; elongated scapulars, inner secondaries, and short outside tail-feathers white; breast, wing-coverts and primaries brownishblack; belly and flanks white; bill pale rose-colour in the middle, when fresh, nail and the basal-half black; irides varying from yellow to hazel and red; legs and toes pale lead-colour, webs blackish. Length inclusive of the tail-feathers $22-26$ in.; wing 9 in. In the summer-plumage, assumed by the end of May, the space round the eye is pale buff mixed with a little white, the rest of the head, neck, back and breast being dark brown, while the feathers of the scapulars and the secondaries have broad rufous margins with black centres. In the depth of winter there is more white about the head than in spring, and every intermediate stage between these plumages is to be found. The female has the crown and upper parts dark brown; a dull white stripe behind the eye; cheeks, throat and upper breast ash-brown; under parts white; no long tail-feathers. The young male resembles her, but soon becomes darker on the back. 


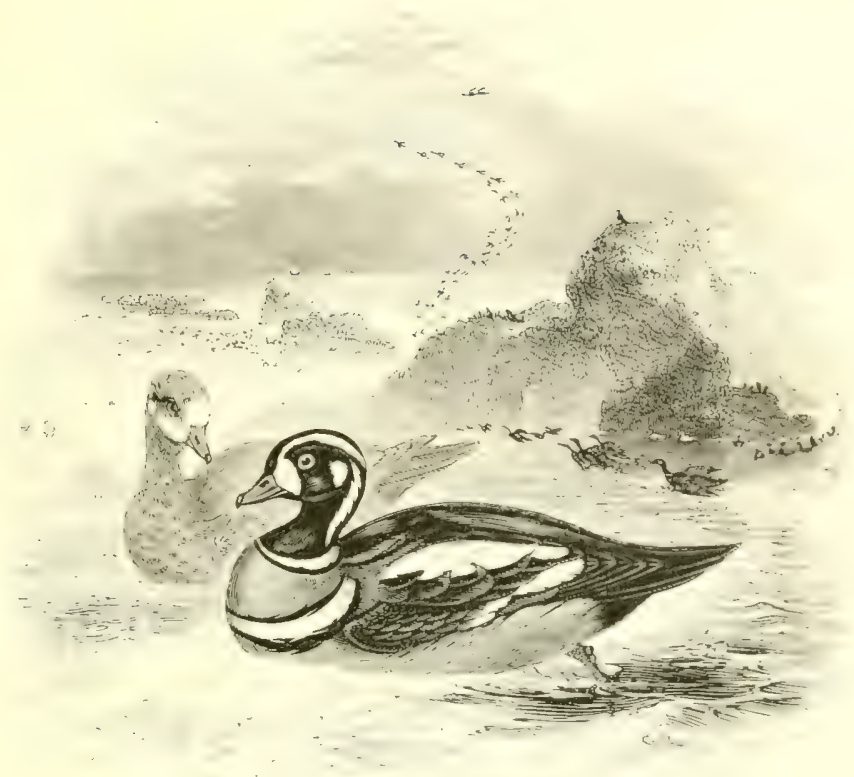

THE HARIEQUIN DUCK.

CosmonétTa histriónica (Linnæus).

As shown by Prof. Newton in 'The Ibis,' I 859, pp. I62-I66, and also by Mr. J. H. Gurney jun., in his 'Rambles of a Naturalist,' pp. $263-269$, the majority of the birds which have from time to time been recorded as Harlequin I)ucks obtained in (ircat Britain have been proved-where proof was pousible - to be I ong-tailud l lucki, American ilood-I)ucks, or some other species. It appears probable, however, that the specimens figured by James Sowerby in his 'British Miscellany' (ISO6), were procured in sicotland: and the collection of Mr. J. Whitaker of Rainworth contains a male bird obtained by Mr. Roberts of Scarborough from some fishemen whe had found it dead on the shore at Filey in the autumn of $\mathrm{x}_{\mathrm{S}} \mathrm{z}_{2}$. On December and I886, three were observed near the Farne Islands, off the coast of Northumberland, and two youns males which were secured are, respectively, in the collections of Mr. R. W. Chase and the Rev. Julian Tuck.

There are no authenticated instances of the occurrence of the 
Harlequin Duck in any part of the Continent of Europe, though a male in the Upsala collection is supposed to have been obtained on the Swedish coast. It has not been observed in Spitsbergen, Novaya Zemlya, or Siberia as far as the Lena delta; but eastward it is found on the waters of the highlands from Lake Baikal and the Amoor to Kamschatka, the Stanowoi Mountains, and the Sea of Okhotsk; whence, by way of the Kuril Islands, we trace it to northern Japan in winter. It inhabits the Aleutian Islands, Alaska, California down to the head-waters of the Stanislaus at about 4,000 feet elevation, the Fur-countries and Newfoundland; migrating as far south as the Middle States in winter. In Greenland it has been observed on both coasts, principally between $62^{\circ}$ and $65^{\circ} \mathrm{N}$. lat.

Iceland is the nearest point to the British Islands where the Harlequin I lack is to be found: and there it appears to be resident, migrating from the northern to the southern districts in the winter. Mr. Shepherd observed it in considerable numbers in the north-west, frequenting the Laxì and other rapid streams, and making its nest in holes in the banks, and, near My-vatn, in the lava, or under stones. The eggs are of a warm creamy colour: average measurements $2^{\prime} 2$ by $1^{\prime} 7$ in. The food consists of small molluscs, crustaceans and marine insects, in winter ; and in summer Mr. L. Belding found the crop and gizzard of one he dissected full of insects. Young and old tumble orer and through rapids and cascades in an astonishing manner.

The adult male has a large white patch on each side of the base of the bill, separated by a black line which runs backward to the nape, and is margined at first with white and afterwards with chestnut; behind each eye is a white spot, and lower down a stripe of the same colour; rest of the head, throat and neck bluish-black, terminated by an imperfect collar of white margined with black; in a line with the bend of the wing is a broader but much shorter crescentic half-band of white (the collar and bands are far too extensive in the wood-cut); upper parts chiefly bluish-black with some white stripes and spots on the scapulars, secondaries and wing-coverts; speculum purple; breast and abdomen dark greyishbrown; flanks rich chestnut; a small white spot on each side of the tail-coverts; bill bluish-black; irides orange; legs and feet leadcolour. Length $\mathrm{I}_{7}$ in.; wing 8 in. The female is smaller, of a nearly uniform brown-colour above, mottled on the front of the neck; at the base of the bill and behind the eye are patches of white, varying in purity; belly dull white. 


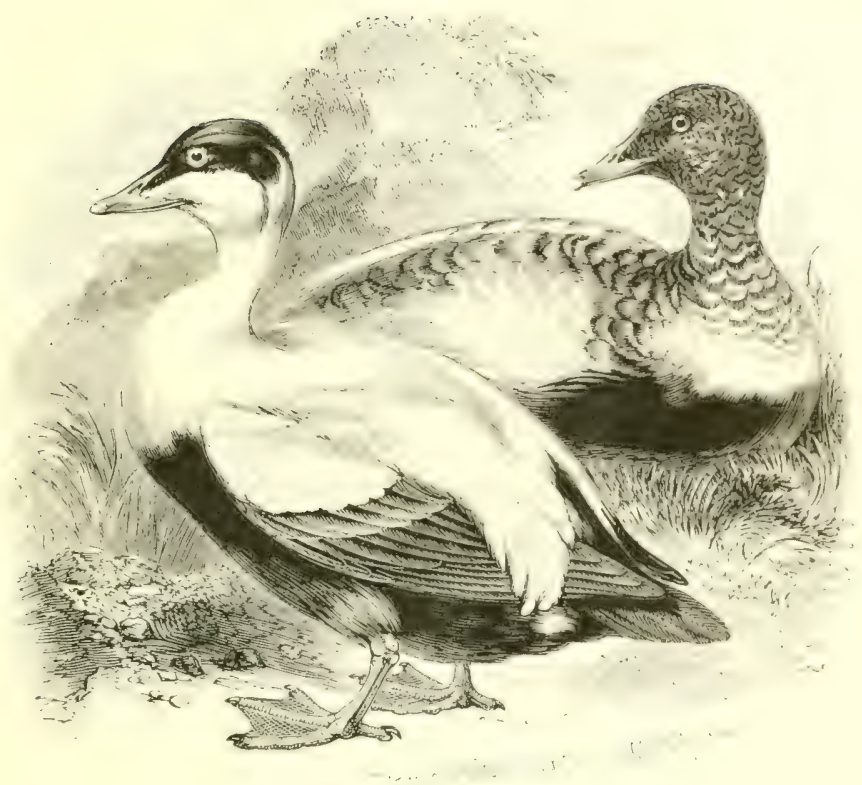

THE EIIER I)UCK.

Somatéria mollíssma (Linnaxus).

The Eider Duck is only a winter-visitor in comparatively small numbers to the western and southern coasts of lingland, but along the east side it gradually becomes more abundant as we proceed northwards. (On the Farne Islands, and along the coast of Northumberland, it has been known for centuries as a breeding bird: while in Scotland it is found in suitable localities up to the ()rkneys and Shetlands, though local in Sutherlandshire. In the Outer Hebrides it is decidedly on the increase, and is very common about Colonsay and Islay; but it is not known to breed on the mainland of Argyll, Ayr, or Wigton. On the Irish coast it is very rare, even in cold weather, and only from twelve to fifteen examples have been obtained.

This species is abundant in the Faroes and Norway, where it is protected by law; and northward it can be traced to Jan Mayen, Spitsbergen and Franz-Josef $I$ and. It also breeds in Noraya \%emlya, but to the eastward it is not known to extend beyond ( apre Chetyuskin, for it has not been found by recent travellers at the mouth of the Lena or in Kamschatka; while lering sea is inhahited by a larger 


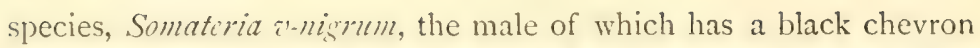
under the chin. Our Eider is met with in Greenland up to $\delta_{1}{ }^{\circ} \mathrm{N}$. lat., and westward as far as the Coppermine River in Arctic America ; but on the Atlantic coast from Labrador to Maine it is represented by $S$. drisseri of Sharpe, a slightly different form, which will be probably exterminated by the Indians and fishermen at no distant date. In winter the Eider occurs irregularly on the coasts of Europe, and exceptionally as far south as the Mediterranean: sometimes also, though rarely, on inland waters.

The nest is usually placed among coarse herbage and rocks on low sloping islands, and at no great distance from water; but it has occasionally been found a mile or two inland, and also at more than I,, 00 feet above sea-level. The materials are grasses and fine seaweed, and to these the celebrated down is gradually added during the progress of incubation, which lasts a month; the eggs, $5^{-8}$ in number, vary from greenish-grey to a somewhat bright green : average measurements $3 \mathrm{in.} \mathrm{by} 2$ in. Towards the end of May, when the ducks begin to sit, the drakes leave them and are found in small parties. Where protected, the birds are extremely tame, and the females may even be stroked by the hand while sitting on their nests, which are frequently in close proximity. In Iceland the average production of down by each bird is one-sixth of a pound. The food, obtained by diving, consists of mussels - some of which, swallowed entire, are $2.2 \mathrm{in}$. in length - and crustaceans; while in confinement worms, slugs, and the raw flesh of other birds are greedily devoured. Several broods have been hatched in the Zoological Gardens.

Adult male in very early spring: bill greenish; down its centre halfway to the nostrils is a wedge of feathers which, like those of the sides of the bill, forehead and crown, are black; the latter bisected by a white line running to the pale green nape, and divided by another white line from a green patch on each side of the neck; cheeks, back, smaller and median wing-coverts white; long sickleshaped secondaries yellowish-white; quilis, rump and tail nearly black, with a patch of white on each side of the latter ; breast rosybuff; abdomen black; legs and toes dull green. In summer the white feathers are shed, and the back becomes nearly black, but the plumage of the female is not assumed. Length $25 \mathrm{in.}$; wing I I in. The female is chiefly pale rufous-brown, with darker bars-similar to, but far less ruddy than the female of the King Eider; quills and tail-feathers dull black.

The front figure in the wood-cut represents an old male, and an immature bird of the same sex is in the background. 


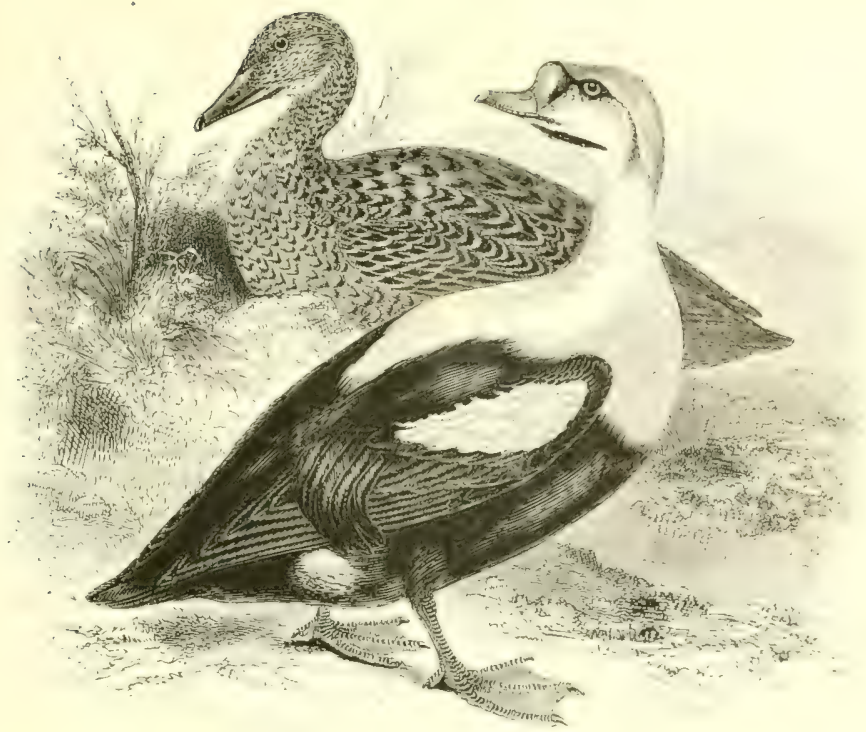

'THE KING-EIDER.

\section{SOMATERIA SPECTÁBitis.}

The King-Eider is an inhabitant of the Arctic regions, and its visits to our coasts are extremely rare, though naturally more frequent in the north than in the south. Mr. J. H. Gurney jun. has a female which was purchased-freshly killed-in I,adenhall Market by the late Mr. Gatcombe, who had previously seen an immature bird at Plymouth ; and one was killed at Irridlington in lorkshire in August 1850. At the Farne Islands two-apparently a pairwere observed throughout the summer of 187,3 , an adult male being secured there in the following Norember ; another pair are said to have been seen in May I880; Mr. H. M. Wallis informs me that he had a good view of an old drake at the end of May 1882; and lastly, a mature male was shot on April 25th 1885 , off that peculiarly attractive group of islands. In Scotland birds have been obtained or identified by competent oloservers off I Iadkingtonshire, the Isle of May in the Firth of Forth, and the mouth of the Tay; while in the Orkneys three have been taken (one of them in spring), and in Shetland one of a pair was killed by Robert Dunn on the 2oth April I 846 . There is, however, no satisfactory' evidence that this species has bred in any part of the liritish Istand. 
In Ireland, Kingstown Harbour, Derrynane in co. Kerry, Tralee Bay and Belfast Lough have each yielded a specimen; all of them in winter and at long intervals.

There is a King-Eider in the museum at Boulogne, the most southern locality on record; but even on the coasts of Holland, Denmark and the Baltic this species is of very rare occurrence. It is only a visitor to the Færoes and the coast of Norway, and there is no proof of its breeding in Iceland or Spitsbergen; yet it nests on Novaya Zemlya, and along the Arctic shores of Siberia as far as Bering Sea. Crossing to the American side, it has been found in summer nearly as far north as man has penetrated, and it breeds as far south as the Province of Quebec. In Greenland it nests near Godhavn and Upernavik, though by no means so plentiful there as the Common Eider; while in winter it occurs on the coast and also on the great fresh-water lakes down to the latitude of New York, and has recently been recorded from California.

The nest is similar to that of our Eider, and the eggs, which are not known to exceed 6 in number, present the same varied shades of green; but they are decidedly smaller, measuring about $2 \cdot 6$ by $I^{\circ} 9$ in. The food consists chiefly of crustaceans and molluscs.

The adult male las the bill and the naked basal tubercle orangered, the latter margined with black; cheeks white, with two green patches; top of the head and nape bluish-grey; lower neck, upper back, scapulars, and wing-coverts white; the ends of the elongated scapulars and inner secondaries falling in curves over the wings; lower back and upper tail-coverts black; quills and tail-feathers dark brown, with a rufous tinge on the inner webs; under the chin a black chevron; front of neck and breast white, the latter tinged with creamy-buff; lower breast, belly, and under surface black, except a white patch on each flank; legs and toes orange-red, webs darker. Length 24 in.; wing $\mathrm{Ir}_{5} 5 \mathrm{in}$. The female has the beak greenish; the entire plumage of two shades of brown, the darker colour occupying the centre of each feather of the back, while the margins are bright rufous; the brown on the head and neck rather lighter. She is smaller and much ruddier than the female of the Common Eider, and the central line of feathers on the upper mandible runs down to the nostrils, whereas in the Common Eider it hardly reaches half way. The plumage of the young drake is at first like that of the female, but later the head and neck become yellowish-grey, spotted with black, and a great deal of the latter colour appears on the upper as well as the under parts. 


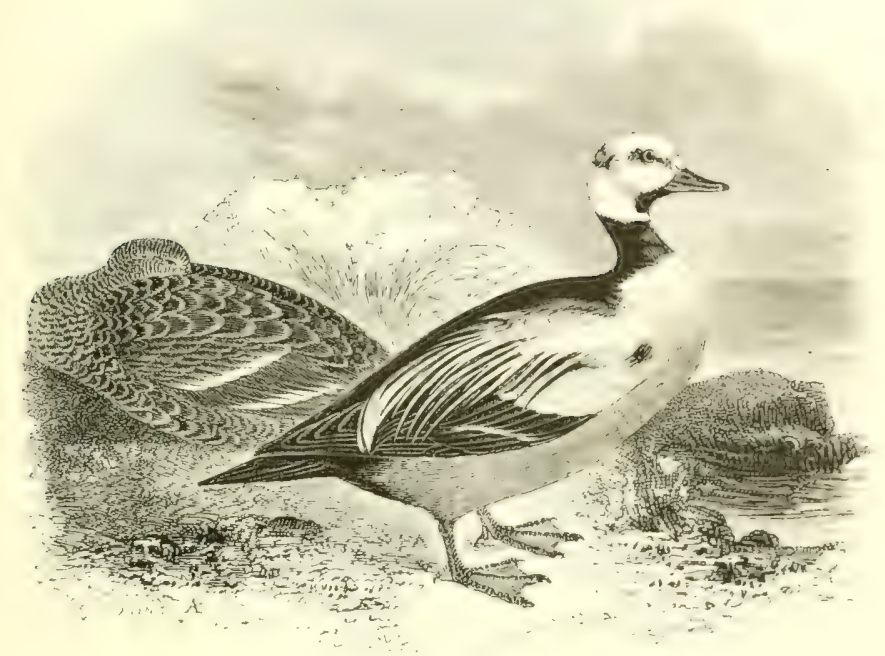

\section{STELLER'S EIDER.}

\section{Somateria Stélleri (Pallas).}

This species, formerly called Steller's Western Duck, is an inhabitant of the Arctic regions which occasionally wanders to the temperate portions of Europe in winter, and has twice occurred in England. The first example, a male in nearly adult plumage, was killed on February Ioth I $8_{30}$, at Caistor in Norfolk, and having been afterwards presented to the Norwich Museum by the Rer. George Stewart, formed the subject of Yarrell's illustration. The second was shot while sitting alone on the sea off Filey lirigr. Yorkshire, on August i 5 th $18+5$, by the late Mr. (i. N. C'ur/on, and is in the collection of his brother, Lord scarsilule, at Kedleston, where I have examined it. This bird was beginning to moult, the white feathers on the head and the black marks on the chin and neck-characteristic of the male-being just visible: but the upper parts are still in the immature plumage, which resembles that of the female.

Steller's Eider is said to have been obtained in 1855 between Calais and Boulogne; it has been observed on sever.al wecasions at Heligoland, and twice in Ienmark; while in the Ialtic it is not uncommon. To the unfrozen waters on the coast of Norway it 
is an annual visitant, and its most westerly breeding-place is on the Varanger Fjord, just round the North Cape; thence eastward it nests on the coast of Russian Finmark, and eggs and down were taken at Petschinka in $S_{70}$. There is no record of it on Novaya Zemlya, or along the Arctic coast of Siberia west of the Taimyr Peninsula, where Dr. von Middendorff found the bird common and breeding on the 'tundras'; Dr. A. Bunge saw flocks in June at the mouth of the Lena, and had two eggs brought to him on July 4 th; the 'Vega' expedition procured specimens in July close to Bering Strait, north of which it is common; and its range can be traced down the coast of Kamschatka - where the species was first obtained by Steller-to the Kuril Islands in winter. In the Aleutian Islands and the north of Alaska it is very abundant, but eastward it is only sparsely distributed along the American shores of the Arctic Sea to Davis Straits; while it is very rare in Greenland.

Dr. von Middendorff describes the nest as cup-shaped and lined with dowri, placed in the moss on the flat 'tundras'; the eggs, 7-9 in number, are of a pale greenish-grey colour: average measurements $2^{\circ} 2$ by 1.6 in. The food consists of marine insects and molluscs. Is far as is known, the bird only frequents deep clear sea-water; and in winter it is found in small flocks, which are sometimes joined by a single King-Eider, the only Duck with which this species has been seen to associate. The call-note is said to be similar to that of the Teal, but somewhat harsher.

The adult male has the head and upper neck chiefly satin-white; lores and crescentic tuft across the occiput dull green, the latter tipped with black; chin black; round the neck a collar of bluishblack, ending in a broad stripe which passes down the middle of the back to the upper tail-coverts; quills and tail-feathers brown; secondaries partly white, with a rich dark blue speculum; the decurved inner secondaries and long falcated scapulars white on the inner and rich blue on the outer webs; below the point of the wing some white feathers tipped with black; middle of breast and belly rich chestnut-brown, passing into warm buff on the front, sides and flanks; vent and under tail-coverts dark brown; bill, legs and feet dark grey. Length 19 in. ; wing $S_{5} 5$ in. The female is dark brown, mottled with rufous, especially about the neck and breast; the greater coverts and the secondaries have white tips, forming two bars, which enclose between them a bluish-black speculum. The plumage of the immature drake has already been noticed. 


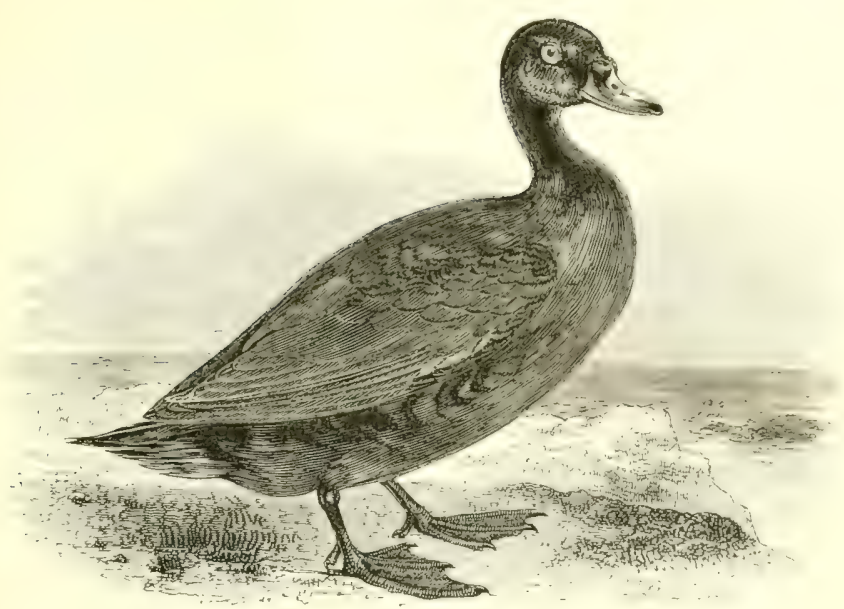

THE COMMON SCOTER.

CÉdémia NígRA (Linnæus).

A comparatively small number of immature Common or Black Scoters may be observed on our coasts during the entire summer, but the autumn and winter months are those in which this species is abundant, and nowhere more so than along the eastern sicle of Great Britain. At times its flocks blacken the sea between this country and Holland, and are also very plentiful throughout the English Channel; not many enter the bays, except in coarse weather, though storm-driven birds occasionally take refuge on inland waters. On the west coast of England and Scotland it is less plentiful, except on the shallow waters of Morecambe Bay in Lancashire, and on the Solway, where thousands are sometimes seen. In spring the majority take their departure for the north of Europe, but a few remain to breed in Caithness, Sutherland, and the north-west of Rosshire. In Ireland it abounds every winter on the northern marine loughs, especially near liclfast and Dundalk, but in the south and west it is comparatively uncommon.

The Scoter visits the Faroes and nests sparingly in Iceland, while in the northern portions of Scandinavia, Kussia, and siineria as far as the Boganida, it is generally distributed during the summer. Along the Atlantic sea-board of Europe it is of regular occurrence in winter, reaching as far to the south-west as the lzores, and aleo 
for a little way up the Mediterranean, but it is very rare on the shores of Provence and Italy. On the inland waters of the Continent it is far less frequent than the Telvet-Scoter, but an important line of migration appears to run along the valley of the Volga to the Caspian (where it is abundant), and Canon Tristram found it on the coast of Palestine in winter. Throughout North America the representative is a closely-allied species, $C$. americana, in which the entire protuberance at the base of the bill is orange-yellow; and this form ranges across the Pacific to the northern shores of Asia, visiting Japan in winter.

The nest, usually placed on an island in a fresh-water lake or among the heather and boys in the vicinity, is composed of grass and moss with a lining of down; the eggs, laid during the first half of June, are 6-9 in number, and yellowish-white in colour: average measurements 2.5 by $\mathrm{I} \cdot \mathrm{S}$ in. The food consists chiefly of molluscs, which the bird obtains by diving, and it generally approaches the shore with each flood-tide for the purpose of satisfying its appetite; its flesh is oily and seldom eatc $\mathrm{n}$ in this country. Like the rest of the genus, the Common scoter dives well, and remains a considerable time under water. The call-note of the male during the breeding-season is rendered by Faber as tu-tu-tu-tu, the female responding with a harsh re-re-re-re-re.

The adult male has the central ridge of the upper mandible orange, and the rest of the bill black; irides dark hazel; upper plumage deep glossy-black, under surface duller; legs, toes and webs black. Length 20 in. ; wing 9 in. The female has the upper parts dull blackish-brown, the margins of the wing-coverts a little lighter; chin dirty white; cheeks and sides of the neck greyishbrown; lower part of the neck, breast, abdomen, vent and under tail-coverts dark brown; legs and toes dusky-olive; webs almost black. Young birds of the year, at the approach of their first winter, have the cheeks, chin, sides and front of the neck dull greyish-white, while the under surface of the body is mottled with white and brown.

Without special reference to the Scoter, advantage may be taken of a little available space to remark upon the perceptible increase that has taken place in the numbers of the various species of Ducks which bred in the British Islands, since the passing of the Wild Fowl Protection Act in $S_{7} 6$. This is particularly roticeable in those suitable for the table. 


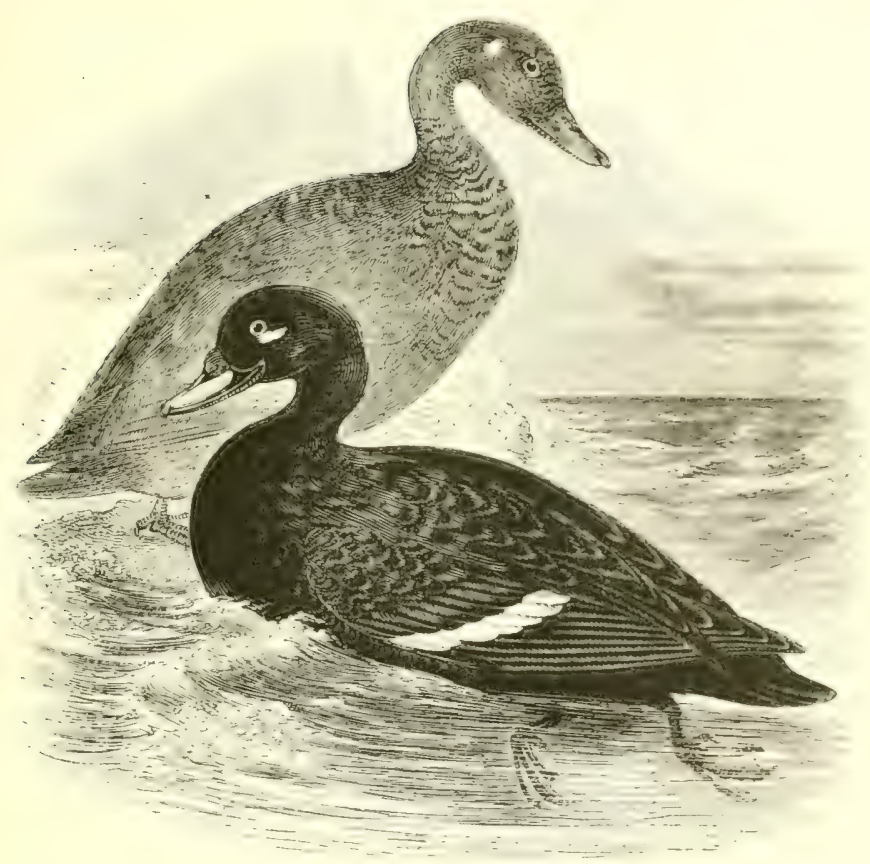

T'HE VELVET-SCOTER.

\section{Edemia fúsca (Linnæus).}

The Velvet-Scoter, casily distinguished from the preceling species by its larger size and the conspicuous white patch on the wing, is far less numerous on our coasts in autumn and winter; but MIr. Cordeaux has observed that in Lynn and Hoston 'deeps' a prair or two are found associating with almost every flock of Common Scoters, and I noticed the same off Southport in Lancashire. Along the south of England it is not unfrequent, though never very plentiful; and it sometimes visits inland waters. ()Ii Northumberland it is of irregular occurrence in winter, while Mr. George Bolam has recorded an instance of a solitary male bird which frequented the ricinity of the jicr at lierwick-on-liwecl throughout the summer and until the mideile of september 1s;\%. (On the cast side of Scotland it is more abundant than on the west : and, though said to be common in the Orkneys, it is an unusual visitor to the Shetlands, and rare in the ()uter Hebrides. Mr. lieoth has rearons for believing that a few pairs have bred in parts of the northem 
Highlands, but the evidence, though strong, is not yet conclusive. On the east and south coasts of Ireland this species is not un. common, but on the west side it is almost unknown.

To the Froes the Telvet-Scoter is a very rare wanderer; while it has not yet been obtained in Iceland, and only once in Greenland. In Scandinavia and Northern Russia it is common on the lakes of the interior during the summer, and Naumann states that it occasionally breeds as far south as Mecklenburg. It visits the Baltic and the waters of Western Europe in winter, and Lord Lilford observed a small flock off Santander, in the north of Spain, throughout May i 876 ; while some of its lines of migration southward appear to run towards the Adriatic, the Black Sea, and the Caspian. Our knowledge of its distribution in Asiatic Siberia is imperfect, but it inhabits the eastern portions, and descends the coast as far as the Yang-tse in winter. A single example has been obtained in Alaska, but there and throughout North America the representative species is $Q$ E. relictinu-a rather smaller bird, the male of which presents some differences in the form of the bill.

The nest, seldom made before the end of June, is placed in a dry spot under some bush or tree, often at a considerable distance from fresh water, and is lined with leaves and down. The eggs, 8-ro in number, are rather large and of a clear creamy-white: average measurements $2 \cdot 75$ by I 9 in. From its habit of diving in soundings for the molluscs and crustaceans which form its principal food in winter, the Velvet-Scoter is sometimes taken in the meshes of sea-nets and also in those set for salmon.

The adult male has the plumage velvet-black, except a small white patch behind each eye and a conspicuous white bar across each wing (which gives the bird when flying the appearance of an old Blackcock); bill apricot-yellow, with an elevated black basal tubercle, from which a narrow dark line runs diagonally above each nostril to the nail and is continued backwards to the gape; irides white; legs and toes orange-red, webs black. Length 22 in.; wing $10^{\circ} 75$ in. The female has the upper plumage sooty-brown, and the under parts lighter; a large dull white patch before-and a smaller one behind-each eye; the white alar speculum less defined than in the male, and the bill dark lead-colour with a smaller basal tubercle; legs and toes dull red. The young are like the female. 


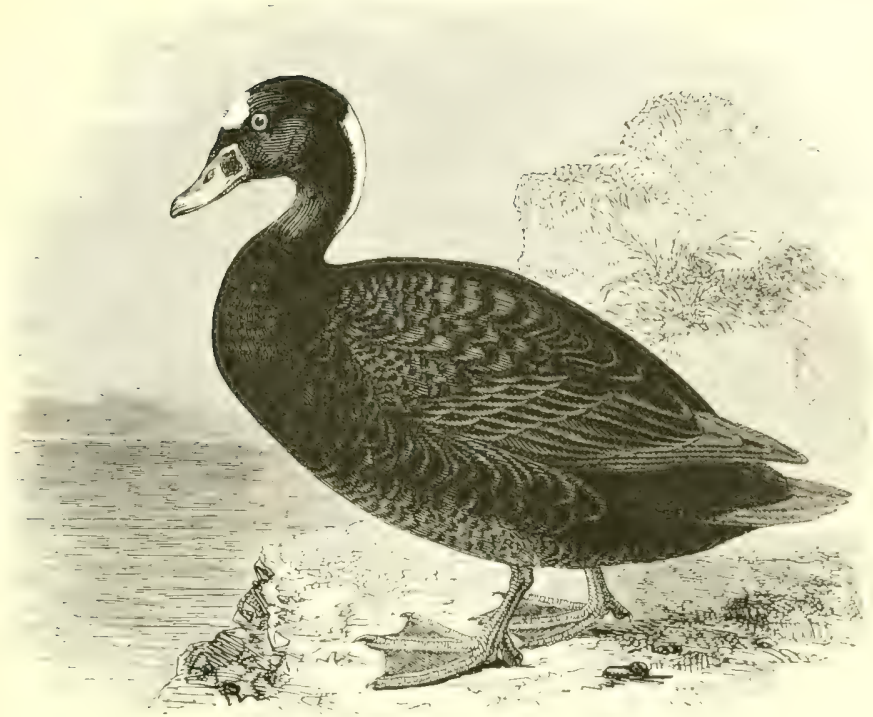

THE SURF-SCOTER.

\section{EDenia PERSPICILLÁta (Linnæus).}

The Surf-Scoter is a North American bird which has not unfrequently wandered to our coasts-especially to the western side, where the influence of the Gulf Stream predominates. Its occurrence was first recorded by Blyth in $I_{3} S$; and since that year two examples have been obtained near Weymouth, one in Cornwall, two in the Scilly Islands, one off I ytham in Lancashire on I)ecember gth i $S S z$, one at Crofton in Cumberland, one near Stornoway in the I Iebrides during the winter of 1865 , and one in the Firth of Forth in 1852 Between autumn and spring its farourite haunts appear to be in the Orkneys, where at least six specimens have been obtained during the last twenty years, while a far larger number have been identified by thoroughly competent observers. In the shetlands it has not yet been procured, but Robert I)unn has stated that he made unavailing attempts to get within shot of a male in Rocness Voe in June 18.7 . In Ireland several were seen on Iielfist I.ough during September i $S_{4} 6$, one of them being now in the museum of that town; and a bird was obtained at Clontarf, co. Dublin, in October r SSO. While this was passing through the press, Mr. R. 
M. Barrington recorded (Zool. 1 889, p. 32) the capture of a female or young male in Crookhaven Harbour, co. Cork, on November $5^{\text {th }}$ I 888.

This species has occurred once in the Færoes, and several times in Swedish Lapland, as well as at Aland in the Baltic ; a bird killed off Heligoland is in the collection of Mr. Gätke, and many examples have been obtained in various winters along the north coast of France. To Greenland the Surf-Scoter is only a straggler. During the summer it is found throughout America to the north of about lat. $45^{\circ}$, from the Atlantic to the Pacific; and in the cold season it descends to Lower California and the Great Lakes, following the eastern sea-board as far as Florida, and occasionally visiting the Bermudas, or even Jamaica.

The nest is usually built on the margin of a lake, or concealed beneath the lower branches of a stunted pine-tree; and the eggs, from 6-8 in number, laid in the latter part of June, are of an ivory-white colour: average measurements $2 \cdot 3$ by $\mathrm{I}^{\circ} 6 \mathrm{in}$. The food consists chiefly of small bivalves, for which the bird dives with great assiduity amidst the tumbling surf to which it is partial; while it seldom, if ever, visits inland or sheltered waters. Exceptionally, the Surf-Scoter has been known to fly against the lanterns of lighthouses in America. By the gunners and fishermen in New England it is, like many other Sea-Ducks, known as 'Coot,' with such distinguishing prefixes as 'skunk-headed,' 'hollow-billed,' or 'spectacled.'

The adult male has the general plumage deep black, the under parts somewhat sooty in their tint; on the forehead a broad patch of white, with another of the same colour on the nape; bill chiefly orange-red-deeper above the nostrils - with a square patch of black on each side of the upper mandible ; iris straw-yellow; legs and feet orange-red, webs dark olive. Length $2 \mathrm{I}$ in. ; wing $9{ }^{\circ} 5 \mathrm{in.}$ The female differs in having the plumage of a dull brown colour, lightest about the cheeks-on which two white spots are sometimes present-and on the under parts, while the white patch on the nape is less defined; bill dark olive ; legs and toes yellowish-orange, webs greyish-brown. In the young the white patches on the cheeks are said to be more pronounced than in the adult female, but there is great individual variation in the plumage of this species. An albino has been recorded by Dr. C. Hart Merriam. 


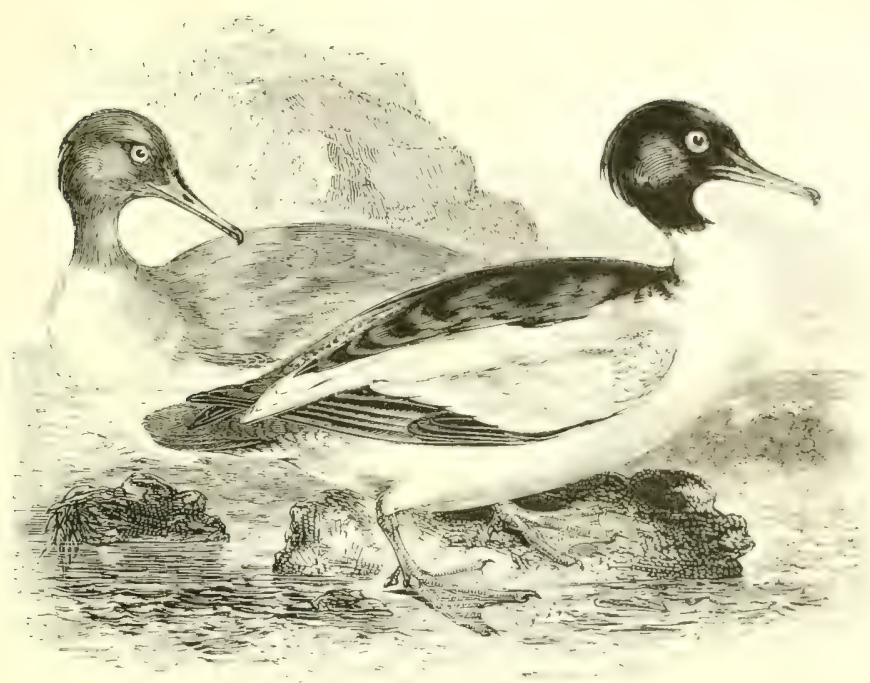

THE GOOSANDFR.

\section{Mérgus Mergánser, Linnæus.}

This species, the largest of the British Mergansers or 'Siaw-bills," is chiefly a visitor to our estuaries and fresh-water lakes during the cold season; but of late years it has been found breeding in sutherland, Argyll, Perthshire, and elsewhere in the Highlands. In the Shetlands it is rare, even in winter, and confirmation of saxby's assertion that it is of regular occurrence in the Orkneys is clesirable ; while the investigations of many competent ornithologists cast great doubt upon the report of its nesting in the ()uter Hebrides (On both sides of the mainland it is tolerably frepuent, and, passing southward, we find it more abundant than the Red-breasted Merganser in some parts of the east of Fngland; but its appearance in the Channel is somewhat irregular, and on the west coist it is comparatively uncommon. To Ireland it is only a somewhat rare wintervisitor, though during the severe frost of January ssis it was ciceptionally numerous.

The Goosander is seldom seen in the Frocos, but breeds and is said to be resident in Iceland, though not yet recorded from (ireenland. It is common throughout the summer in sicandinavia, Finland, and Northern Russia down to the Lral and ('entral Vielira districts : and nests sparingly in hollow trees where the forests come down to the water in I)enmark, as well as in the north-eastern provinees of 
Germany, and-formerly - in Poland. In winter it is found in small numbers along the coasts of the Continent, and more frequently on the inland waters as long as they remain unfrozen; while its migrations extend to the south of Spain, as well as to North-western Africa: it is, however, uncommon in the Mediterranean, though tolerably plentiful in the Black Sea. Eastward, we trace it across Siberia to Japan and China, its breeding-range reaching as far south as the elevated lakes of Central Asia, inclusive of the northern side of the Himalayas; and in the cold season the bird is found down to about $22^{\circ} \mathrm{N}$. lat. North America is inhabited by a closely-allied subspecies, the adult males of which show a distinct black band about half-way across the alar speculum.

Incubation commences toward the end of April in Denmark, but is sumewhat later in Scandinavia, where the Goosander avails itself to a great extent of the nesting-boxes set up by the natives for various species of I lucks; while a hole in the trunk or a recess beneath the gnarled roots of a tree, and sometimes a sheltered ledge of rock, are the localities selected in Scotland. The eggs, $8-\mathbf{I}_{3}$ in number, are of a creamy-white, very different from the greenish-drab of those of the Red-breasted Merganser: average measurements 2.7 by $\mathrm{I} \cdot 8$ in. Mr. Booth remarked that until the young arrive at the age of a month or five weeks, the female usually keeps them in the shallows, where there is less danger of their falling victims to their great enemy, the pike. He also noticed that although the young birds had no pinion-feathers, they appeared, on rising after a dive, to flap along the surface for a yard or two, striking the water with their feet. The note is a low plaintive whistle, not unlike the cry of some young Hawks. The food consists almost entirely of fish.

The adult male has the greater part of the bill blood-red; irides red; head and upper neck glossy bottle-green; lower neck and the entire under parts white, tinged with salmon-pink; upper back and scapulars black; wing-coverts chiefly white; primaries and some of the secondaries ash-brown; lower back and tail ash-grey; legs and toes orange-red. Length 26 in. ; wing i I in. The female has the head-with its small crest - and the upper neck reddish-brown; chin dull white; upper parts chiefly ash-grey, with dark brown inner secondaries and quills, and a white alar speculum; under parts buffish-white, mottled with ash-grey on the sides; bill, legs and feet duller than in the male. Length 24 in.; wing 10 in. The young at first resemble the female, but a rudimentary dark collar soon makes its appearance in the drakes, which do not attain their full plumage until the second year. 


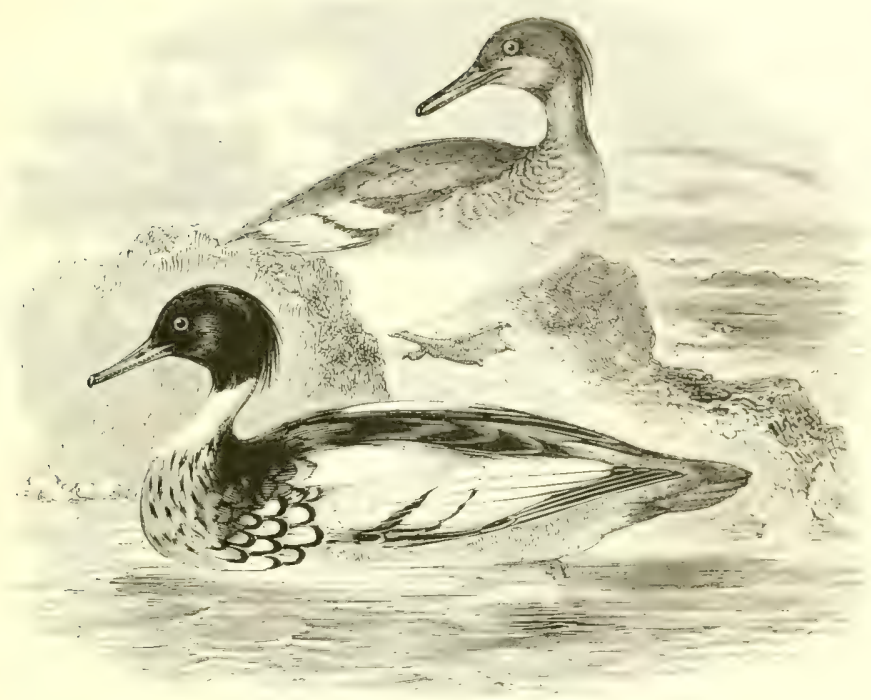

THE RED-BREASTED MERGANSER.

Mergus SERrÁtor, Linnæus.

The Red-breasted Merganser is generally distributed during the winter along the shores of England, but is less partial than the Goosander to inland waters, though sometimes observed far up tidal rivers. In Scotland it is resident, and breeds in comsiderable numbers on the lochs as well as on the coasts of the northern and western districts of the mainland, especially in Ross and sutherland; while it is equally abundant in the Hebricles, though less frequent in the Orkneys and Shetlands. In Ireland, where it is known as 'Sheld-Duck, and occasionally as 'spear-W'igeon,' from the sharp serrated bill, it nests regularly on most of the large loughs, and in many localities along the sea-board; becomins much more plentiful in severe weather, when hundreds have sometimes been seen together.

This species breeds in the Feroes, Ictand. (ireenland. somdinavia, Northern Russia, and-sparingly-on the islands of the Baltic, as well as along its southern shore. In winter it visits the lakes and large rivers of the Continent, though less plentiful there than the (ioosander: but on the coasts it is more numerous, and it is by no means rare throughout the Meditcrancan : its migration. 
extending to the lakes of Algeria, and to Egypt. It ranges across Northern Siberia to the Pacific in summer, and to Japan and China in winter; but in India, where the Goosander is common during the cold season, the Red-breasted Merganser is either exceedingly rare or has been overlooked, for only a single example, obtained off Kurrachi, is on record. In America it inhabits the northern districts from the Pacific to the Atlantic, reaching as far south in summer as about lat. $45^{\circ} \mathrm{N}$., while its winter-range extends to the Bermudas.

The nest is well concealed in heather, brushwood or long grass, and is often at the end of a small tunnel which leads to the middle of a thick growth of briars; sometimes it is in the burrow of a Sheld-Duck, or, in Iceland, among broken lava; exceptionally it is almost open to the sky. The lining consists of a light grey down with a bluish tint, and the eggs, usually laid in the latter part of May and seldom more than $\mathrm{I} O$ in number, are drab-colour with a greenish tinge: average measurements 2.6 by $\mathrm{I}^{\prime} 7$ in. After the young are hatched the male may often be seen at no great distance from the female and brood, but if approached he soon takes wing; the mother, on the contrary, remaining with the young, and diving and doubling in the water with marvellous rapidity. The Merganser swims very low; on land, according to Mr. A. C. Chapman, it sits nearly upright. It feeds by day, chiefly on small fish, and its flesh is extremely unpalatable.

The adult male has the bill and irides red; head, long filamentous crest and upper neck dark glossy-green; below this a white collar, divided on the nape by a narrow black line running to the back, which is also black; near the point of the wing a conspicuous tuft of white feathers broadly edged with black; the long falcated inner scapulars black, and the outer ones chiefly white; speculum white, barred with black; rump, flanks, and tail-coverts vermiculated with grey; lower neck pale chestnut-brown, streaked with black; under parts white; legs and toes reddish-orange. Length 24 in.; wing Io in. The female is smaller and has the head and neck of a reddish-brown, like the hen Goosander-which she somewhat resembles, though her back is much browner; there is a very distinct black bar across the alar speculum; and her dimensions are much less, the length of her wing being only 9 in. The young resemble her in plumage, but males may be recognized by a perceptible enlargement at the base of the trachea. They do not attain their full dress till after their second autumn moult; and the old drakes lose their bright colours in summer. 


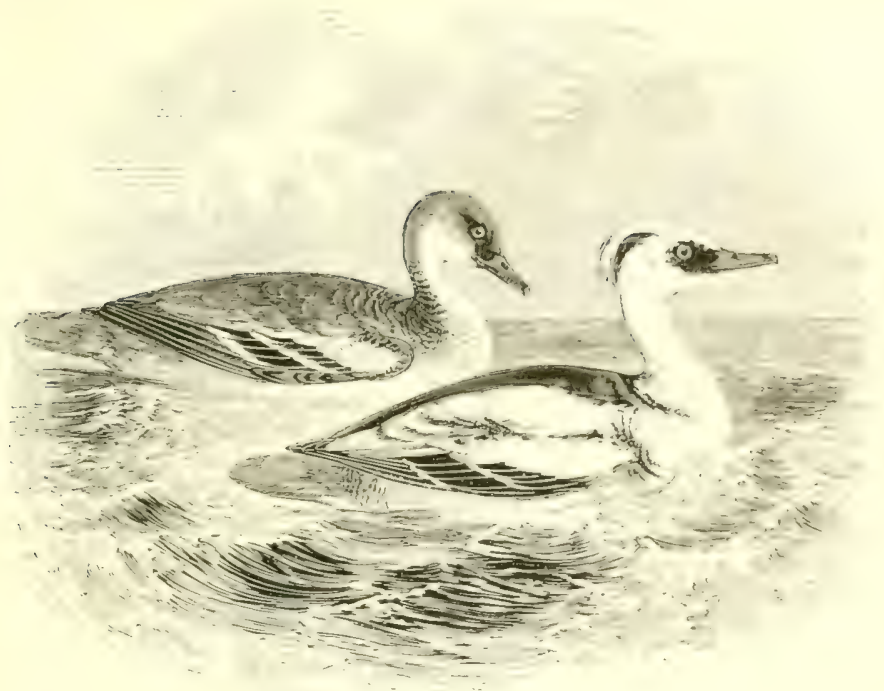

THE SMEIV.

Mergus atbéllus, Linnæus.

The Smew, or Smee-sometimes called Nun, from the sharply contrasted plumage of the male is the smallest nember of the genus, and the least numerous of the three 'Saw-bills' which frequent our islands. Young birds and females, known to fishermen as Reilheaded Smews, are not uncommon in winter along the eastern sicle of England and Scotland, but males in full dress are seldom met with, as they keep further out at sea, and rarely approach the shore, except in very severe seasons. In the south it is of tolerably regular occurrence on the sheltered estuaries and inland waters: though along the west coast of England, and also of Scotland, it is comparatively scarce, and in the Outer Hebrides is decidedly rare. To Ireland it is an irregular visitor in cold weather.

This species is not known in the Faroes, Iceland, or freenland, and even in winter is seldom found on the coast of Norway or of that portion of sweden which lies outside the baltic: through on its south-westerly migrations it skirts the Atlantic sea-hurd of Europe, and goes as far as Morocco. The extensive lakes of Switzerland and Central Europe prove attractive to a t lerable number, and many pass down the Rhone valley to the Mediterranean, where the lirel 
is generally distributed in winter. Its western breeding-limit appears to be in Finnish Lapland, and there Wolley obtained the first authenticated eggs on record; it also nests in Northern Russia and for a considerable distance southward along the Ural Mountains; while lines of migration run down to the Grecian Archipelago, the Black Sea, and the Caspian. In summer it is found across Asiatic Siberia up to the limit of forest-growth, and in cold weather it visits Japan, China, and Northern India; there is, however, no evidence of its occurrence in any part of America.

It was only after four years of arduous research, and persistent inquiry respecting the breeding habits of the 'Uinilo,' as the Finns call the Smew, that Wolley succeeded in obtaining three eggs, which, with the female bird, had been taken from a hollow in an old rotten birch-stump, on June Sth IS57; while four more belonging to the same clutch were afterwards sent to him. In i 875 Messrs. Seebohm and Harvie-Browne had four eggs brought to them at Habariki on the Petchora, a little south of the Arctic circle, and they afterwards procured from the nest some of the down, which is white. The eggs are cream-coloured, like those of the Wigeon, but they have a close-grained and smoother surface, and are much heavier, though slightly smaller: arerage measurements 2 in. by $\tau_{4}+5$ in. The food consists of fish, crustaceans \&.c., and Mr. J. H. Gurney jun. found a frog in the gullet of a bird which he purchased in Leadenhall Market in January r 867 . The Smew, like the rest of the genus, is an excellent diver, but it walks with difficulty, owing to the backward position of its legs.

The adult male in spring has the bill bluish-lead colour, with a white nail; irides reddish-brown; before and below the eye a large black patch; forehead, crown, and elongated crest satin-white, the latter set off by a triangular patch of greenish-black; throat, neck, and under parts white; back black, with a crescentic mottled band of the same colour stretching orer each. side of the shoulders, and another in front of each wing; scapulars white margined with black; lesser wing-coverts white; greater coverts black, with two narrow white bars; quills and tail-feathers blackish-brown; flanks finely vermiculated with grey; legs and toes lead-colour. In June the female plumage is assumed and is retained until the autumn. Length $\mathrm{I}_{7}$ in.; wing $7^{\circ}+5$ in. The hen-bird is much smaller; she has a black patch on the lores (not assumed till the second moult); head reddish-brown, with a nuchal stripe and collar of ash-grey, upper parts much as in the male; under parts pure white. In the young the upper surface is mottled with grey. 


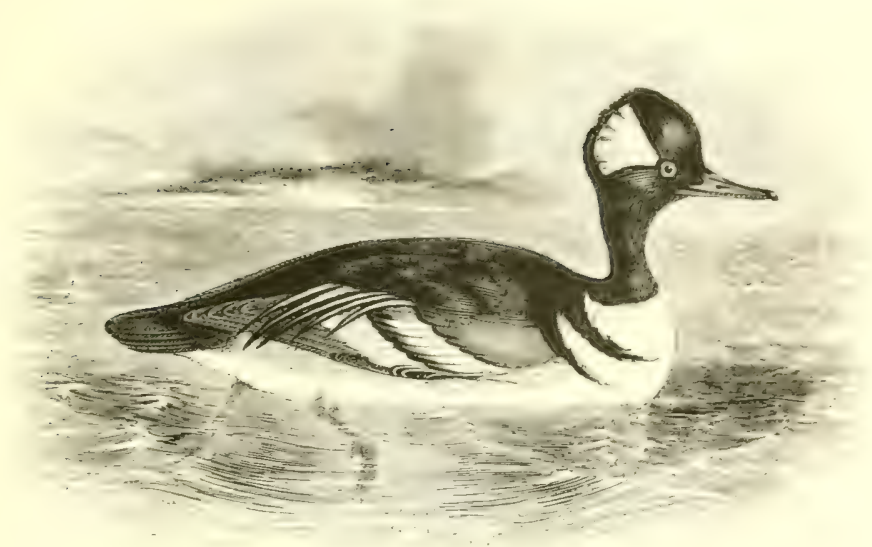

THE HOODED MERGANSER.

Mergus cucullátus, Linnæus.

There are several unauthenticated records of the occurrence of this North American species in British watcls, lut those upon which reliance can be placed are very few in number. Eyton, in his 'History of the Rarer British Birds' (p. 75), has described and figured a Hooded Nerganser which he obtained in the Menai Straits, North Wales, in the winter of $\mathbf{1} 830-3 \mathrm{I}$. In Ireland, a specimen killed in Dingle Bay, co. Kerry, about $18_{40}$, is, or was, at Chute Hall, Tralee; an immature bird is stated by Watters to have been shot in co. Meath; and Sir R. Payne-(rallwey says ('Fowler in Ireland,' p. I $2 \mathrm{I}$ ) that he has had the good fortune to secure no less than three. Of the latter, a pair haunted a creek in Cork Harbour during the severe frost of December 1878 , in company with some Red-breasted Mersansers; but though the writer had ample opportunities of olserving through a glass their motions when feeding and flying, they were $(1 x)$ wild to allow of his approach within range, until one d.1! when they were descrted by their companions. He killed the third bird during the yet more severe weather of January ISS I, on the north crast of Kerry : while he heard of a solitary individual being shot near sligo the same winter, but believes it was not preserved. From what he saw of those he procured, they appeared to fly faster and with a more darting motion than their other congenurs, hlough divins with equal facility : 
though on one occasion a crippled Hooded Merganser made no effort to submerge itself, but swam low in the water like a wounded Teal, with the crest laid flat; the head looking small and black, very unlike its usually bushy aspect.

There is no authenticated instance of the occurrence of the Hooded Merganser on the Continent, or, so far as I can discover, in Greeniand, to which it is stated by the authors of "The Water Birds of North America' to be an occasional visitor. In winter it visits Mexico, Cuba and the Bermudas, while it is abundant in the Carolinas, which form the southern limit of its breeding-range; and northward it is found within the limits of forest-growth up to the St. Lawrence on the east, and Alaska on the west.

As far as our present knowledge goes, the Hooded Merganser invariably makes its nest in the hollows of trees, and lines it with down, which, according to Mr. G. A. Boardman, as quoted in the above-mentioned work, is dark-coloured-not white, as the down of birds which nest in holes usually is. The eggs, from $5^{-8}$ in number, are of a pure ivory-white, and of an oval or almost globular form: average measurements $2 \cdot I$ by $I \cdot 7$ in. This species feeds on fish; the localities it affects being fresh-water ponds in summer, and deep creeks rather than open water on the sea-coast in winter.

Adult male: bill black; irides bright yellow; head and upper neck black, ornamented with a semi-circular crest in which the posterior half is white edged with black; back and wing-coverts black; quills, rump and tail-feathers dark brown; scapulars and inner secondaries white edged with black, elongated and slender; lower neck in front white, with two black crescentic bands descending from the upper part of the back and directed forwards; belly, vent and under tail-coverts white; sides waved with yellowish-brown; legs and feet dull red. Length about 19 in.; wing 7.5 in. The female is rather smaller in size, and has an elongated reddish-brown crest; head, hind neck, back, and wings dark brown; chin white; neck in front pale brown, the edges of the feathers lighter in colour; under parts white; bill, irides and feet, as in the male. The young resemble the female for the first year, but during the second the black and white about the head appears in the drakes, and in the third spring their plumage is complete. 


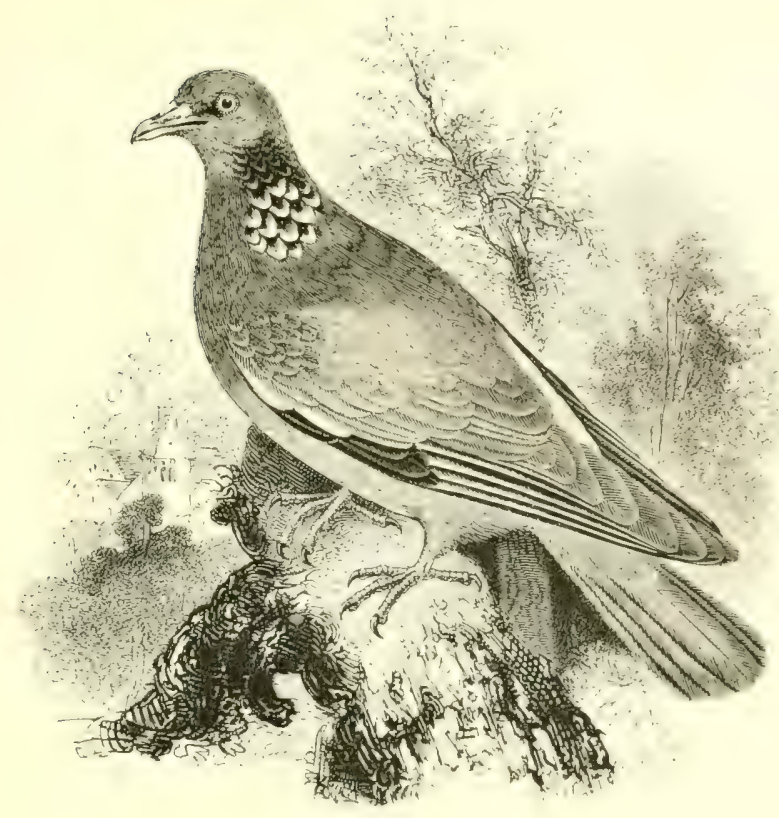

THE RING-DOVE OR WOOD-PIGEON.

Colúmba palúnibus, Linnæus.

The Ring-Dove-so called from the white feathers which partially encircle the neck-is also well known in many parts of England as the Wood-Pigeon, and in the North as the Queest or Cushat. Owing to the large amount of land now under turnips and other green crops, which supply food during the inclement months, as well as to the increase of coverts and the destruction of all the large birds of prey, the numbers of this voracious species have so far been augmented as to cause serious loss to agriculturists, especially in the Lothians, where the bird was unknown a century ago. Immense flights sometimes arrive on the cast const from the Continent, and in October and November iss.t the country between Berwick-on-Tweed and Yarmouth was inferted by hungry hordes. On the west side it is less numerous, though pushing northwards, and annually becoming more freguent in the Outer Ifebrides, Orkneys and Shetlands, while it has several times wandered to the Faroes. In Ireland, as in Great Britain, it is gencrally distributed, and its numbers receive additions in winter. Even in the I.ondon 
Parks ten pairs now nest for one which did so five or six years ago, and this, at least, offers no cause for regret.

In summer the Ring-Dove is found over the wooded districts of Europe up to $65^{\circ}-66^{\circ} \mathrm{N}$. lat., but the northern-bred birds migrate from the colder regions in winter, and join those which are resident in the central and southern districts, as well as in Northern Africa. Its western limit appears to be in the nearer islands of the Azorean group; while eastward its range cannot be traced with certainty beyond $60^{\circ} \mathrm{E}$. long., a meridian which skirts the Ural Mountains and the Persian Gulf.

Breeding begins in March or early in April, and a second clutch of eggs is usually laid in June, while a third brood is often produced in October. The nest, slightly built of twigs laid cross-wise, is placed in almost any kind of tree: frequently in thick ivy on cliffs and old walls, commonly in bushes or hedge-rows, and sometimes on former habitations of other birds or squirrels. The eggs, usually 2 , but exceptionally 3 in number, are oval, and of a pure glossywhite: average measurements $I^{\circ} 6$ by $I^{\circ} 2$ in. They are laid at intervals of two or three days, and incubation lasts from sixteen to eighteen: the male, as a rule, sitting in the day-time. The young are blind and helpless until about the ninth day, and remain in the nest until able to fly: being fed with a half-digested curd-like substance, regurgitated from the crops of their parents. Grain of all sorts, peas, young clover, the leaves and bulbs of turnips, beechnuts and berries, with a good many plants and their seeds form the chief articles of dict. The Ring-Dove is strictly monogamous, and in summer is generally seen in pairs, but in cold weather becomes gregarious. Exceptionally it has been known to breed in confinement, and also to produce a hybrid with the domestic Pigeon. Its note is the well-known coo rōos, coo coo.

The adult male has the head bluish-grey; sides and back of the neck glossed with violet and green, bounded on each side by a patch of white; mantle brownish-grey; wing-coverts grey, broadly edged with white, which forms a conspicuous bar; lower back slate-grey; tail-feathers nearly black, except at their bases; breast rich vinouspurple, belly paler, flanks and vent ash-grey. Length $\mathrm{I} 7$ in. ; wing Io in. The female is smaller and somewhat duller in colour. The young before their first moult have no white on the sides of the neck, and their tints are less pure, but the adult plumage is assumed the first year. Varieties more or less spotted with white, and even perfect albinoes, are sometimes met with. Weight, from i 7-26 ozs. 


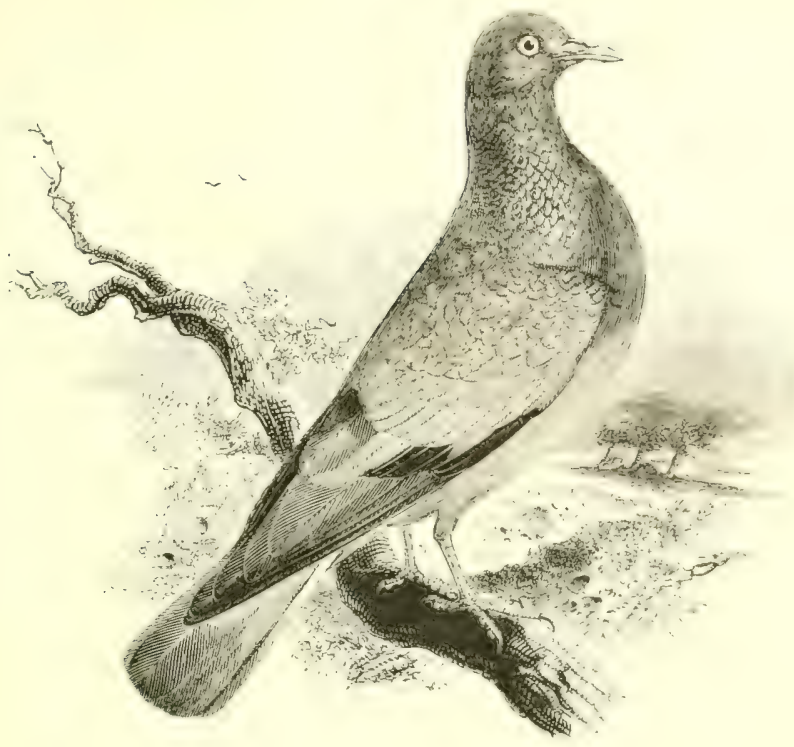

THE STOCK-DOVE.

Columba cenas, Linnæus.

The Stock-Dove has often been confounded with the whiterumped Rock-Dove, and even its name has erroneously been supposed to signify that it was the origin of our domestic breed, though really referring to its habit of nesting in the "stocks" of trees: whence also the Danish 'Huldue,' and the (icrman 'Hohltaube, both meaning Hole-I)ove. In the south of England it has greatly. increased in numbers of late years, and, though somewhat local, it is tolerably frequent in most districts where old timber exists : for instance, in the remains of our ancient forests, and in our parks, even when close to London. It is this species - and not the RockDove-which inhabits the wooded crags near lentnor in the Isle of Wight, as well as the cliffs of I)orset and some parts of Levon: it even nests in the rocks at Flamborough Head in Yorkshire, though there its white-rumped congener is also found. In sandy soils, such as are met with in Suffolk, Norfolk, Lincolnshire, the East Riding of Yorkshire, I ancashire. Cumberland ac.. it depusits its eggs in rabbit-burrows, or under the shelter of dense fur 2 ; while in many places it is persistently misnamed 'Rock-Dove' or even 'Blue Rock' by the inhabitants. Its range northwards is rapielly. 
extending, and whereas its breeding as far as Stirlingshire was considered remarkable a few years ago, it has been known since I 885 to nest in the sandhills along the Moray and Dornoch Firths; while as a wanderer it has reached the Orkneys and Hebrides. In Ireland it was first recognized in 1875 by the late Lord Clermont, but up to the present appears to be confined to the north-east, where it is resident.

The Stock-1)ove is found in Scandinavia, and in Russia as far east as the Ural Mountains, up to about $60^{\circ}-6 \mathrm{I}^{\circ} \mathrm{N}$. lat.- the limit of oak-growth; while in many parts of Central Europe it is even more abundant than the Ring-Dove. In the south, as well as in Northern Africa, it is resident in limited numbers, though chiefly observed in winter, on its migration from the colder regions; while eastward we trace it in Asia as far as the Tigris, beyond which it is represented by $C$. ciersmanni, which has a pale grey band across the rump.

As already mentioned, rabbit-burrows, pollard-tops, holes in trees, cliffs \&c., are used as nesting-places, to which may be added crossbeams in old churches, matted ivy, former abodes of other birds, and squirrels' dreys. The eggs - usually 2 in number, though 3 have been found-are of a more creamy tint than those of the Ring- or the Rock-Dove: average measurements $I^{\circ} 5$ by $I^{*} I$ in. They are often laid in March, usually in April, and have been found as late as October. In length of incubation and general habits this species resembles the Ring. Dove, but its note is shorter and less distinct, and may not inaptly be described as grunting; while for its food the Stock-Dove consumes a larger proportion of the seeds of charlock and other weeds. Its flight is lighter and far more rapid than that of its heavier and larger congener. A bird which appeared to be a hybrid between a Stock-Dove and a domesticated Pigeon has been shot in Nottinghamshire (Zool. i $88_{5}$, p. 150 ).

The Stock-Dove differs from the Ring-Dove in having no white on the sides of the neck, and the nuchal patch is of a greener tint; the vinous-purple on the breast hardly comes below the line of the shoulders, and the lower parts are bluish-grey as in the Rock-Dove; there is no white on the wings, but some black spots on the inner secondaries and wing-coverts form an imperfect bar; the axillaries and under wing coierts are grey. The whole length is only 13.5 in.; wing $8.8 \mathrm{in}$. The female is slightly smaller than the male and the colours are less brilliant. The young have no shining metallic feathers on the neck before their first moult, and the dark spots on the wing-feathers are scarcely visible. Weight, about I 3 ozs. 


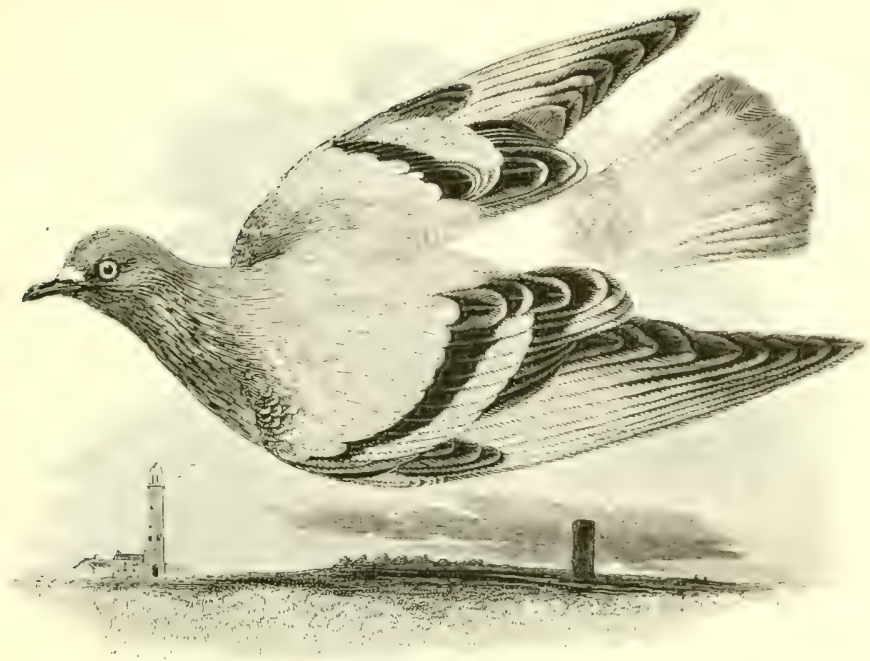

THE ROCK-DOVE.

Columba lívia, J. F. Gmelin.

The Rock-Dove is, I believe, only to be found in a truly wild state in localities where caves or deep fissures exist, and these are few and far between in the east and south of England. Even in some places which appear to offer the rerjuisite conditions--such as the Channel Islarids - this species is little known; while it is very local in Devonshire, and only a few frequent the cliffs of Cornwall. It can be traced along the coast of Wales, and to one spot in Cumberland, as well as to the Isle of Man; while on the eastern seitboard it is found at Flamborough Head and in Northumberland. Birds-apparently wild-sometimes frequent holes in cliffs inland as well as on the coast, but they are open to the suspicion of being partially domesticated individuals which have reverted to a wilk state, or the descendants of such. Along the coast of Scotland, from the Bass upwards, the wild Rock-1)owe is generally distributed: while in the Shetlands, Orkncys, Hebrides, and on the west side, almost every district has its 'Ua' Caloman,' or 'doo-cave.' In Ireland, especially among the rugged wave-hollowed cliffs facing the Atlantic, it is abundant, and there the breed is found in all its purity.

In the Færoes this species is plentiful, but in Scandinavia it is very local, and in the rest of Europe decidedly uncommon, 
except in mountainous regions, such as the Pyrenees and the various ranges of Spain and Italy; while even there a considerable admixture of semi-domesticated birds is apparent. Individuals from the Canaries and the coasts and rocky islands in the west of the Mediterranean have generally a distinct band of white on the crcup, but as we proceed eastward this has a tendency to become less pure and narrower than in northern examples, until in specimens from the Jordan valley that part is grey. Birds identical with our own have, however, been obtained as far east as Cashmere, while in Gilgit both white- and grey-rumped forms are found; the distribution of these and allied species or races in Asia is, however, too complicated for notice within the space at my disposal. "There seems," says. Darwin, "to be some relation between the croup being blue or white, and the temperature of the country inhabited by both wild and dorecot pigeons; for nearly all the dovecot pigeons in the northern parts of Europe have a white croup like that of the wild European rock pigeon; and nearly all the dovecot pigeons of India have a blue croup like that of the wild C. intermedia of India."

In the British Islands the favourite resorts of the Rock-1)ove are deep caverns, on the ledges of which a slight nest is constructed, sometimes as early as March; while young and even unhatched eggs have been found in september, so that two broods must be reared in the year. The 2 white eggs measure about ${ }^{\circ} 5$ by $\mathrm{I}^{\prime} \mathrm{I} 5$ in. Iike other members of the family, this species is partial to grain, but it makes amends by eating the roots of the couch-grass (Triticum repens), and the seeds of various troublesome weeds, as well as considerable quantities of snails. It drinks frequently, and both wild and tame Pigeons have been seen to settle on the water like Gulls and drink whilst floating down stream. It has a marked objection to settling on trees-a peculiarity which is still shared by its domesticated relatives.

In size and general hue the Rock-Dove much resembles the Stock-Dove, but the green on the neck is prolonged to the throat; the mantle is of a paler grey; two very distinct black bars cross the wing-coverts and the secondaries: the rump is white and the black bar near the tip of the tail-feathers is much narrower; the upper breast is dark grey with hardly any tinge of vinous; and the axillaries and unaer. aing-coicrts are white-a very conspicuous distinction in flight. As usual, females are slightly smaller and duller than males; while in the young the metallic tints are wanting. 


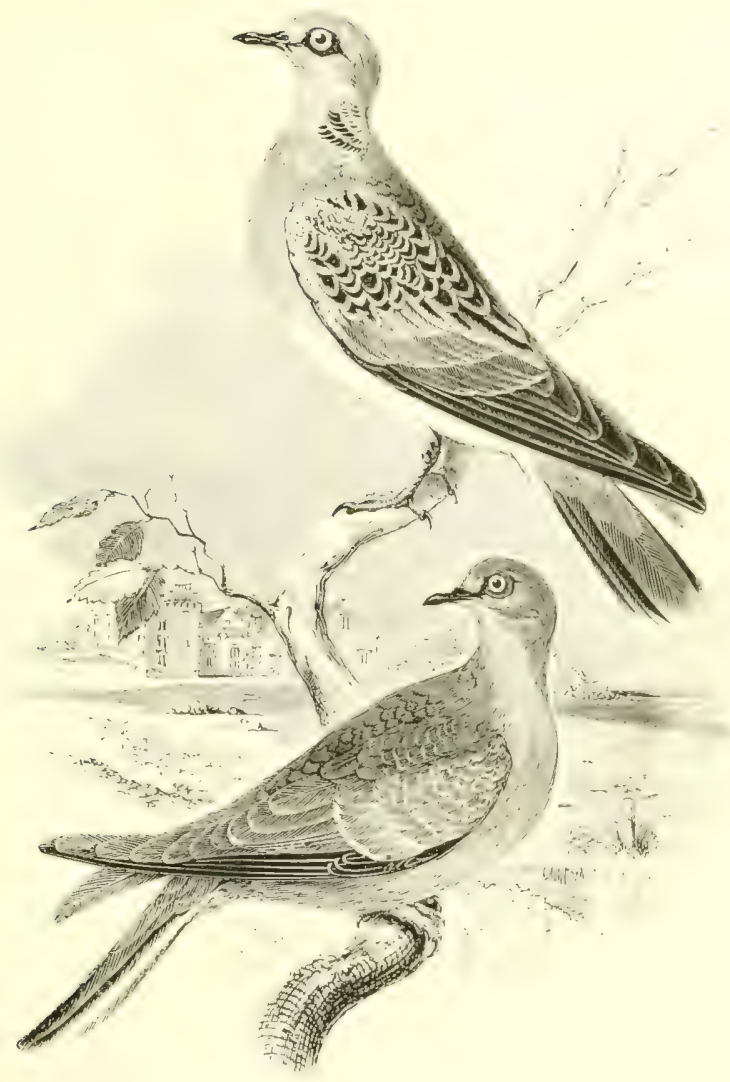

'THE 'TUR'TLE-IOVE.

Túrtur comiúnis, Selby.

The Turtle-Dove is only a summer-visitor to the British Islands, arriving in the southern districts about the end of April or carly in May, according to the nature of the season. In Cornwall, Wistern Wales, and Lancashire it is unfrequent, but otherwise it is of more or less regular occurrence up to alout the line of sheftield, north of which it is rare; though known to have bred in Iurham and Cumberland, while Mr. Fortune asserts that he has found the nest near Alnwick in Northumberland. It probahly brocels in the south-west of Scotland, while its migrations have cotended as har north as the Shetlands (also to the lixroes). In Ireland it is 
generally distributed over the wooded districts, except in the west, to which its visits are irregular. Departure for the south usually takes place in September, but in sheltered situations many birds remain later, and one has even been obtained on the 18 th of November.

During the warmer months of the year the Turtle-Dove is found as far north as Quickiock in Lapland, and throughout Europe; being especially abundant in the south at the periods of migration, at which time it is also plentiful in Asia Minor, Palestine and Persia, and has been obtained as far east as Yarkand. Its Asiatic representative is T. orientalis, while the Collared Turtle-Dove, T. risorius, so often seen in confinement, has its western limit in Turkey. Our bird occurs in Madeira, the Canaries, and Northern Africa, as well as in Egypt, where it breeds - though the more abundant species there is T. isabellinus; its migrations extending to about $12^{\circ} \mathrm{N}$ lat. in the Red Sea and the highlands of Abyssinia.

The nest, very slightly constructed of slender twigs, is usually at no great height from the ground, on the branches of a tree or a thick bush. The z eggs, laid late in May or early in June, are of a somewhat creamy-white and rather pointed at one end : average measurements $I^{\prime} 2$ by 9 in. The parents take turns in the task of incubation, which lasts about a fortnight, and two broods are sometimes reared in the season. The Turtle-Dove is partial to grain, pulse, and seeds-including those of numerous weeds-and, like other members of the family, it drinks regularly. Its flight is rapid, and, when amongst trees, remarkably tortuous; the note is a low plaintive coo, uttered more especially by the cock bird.

The adult male has the head, nape, outer wing-coverts, rump and flanks bluish-ash; a conspicuous patch of white and black feathers on each side of the neck; mantle chiefly cinnamon-brown; tail-feathers broadly tipped with white; throat and breast pale vinous; belly white. Length $\mathrm{II}^{\prime} 5$; wing $7 \mathrm{in}$. The female is rather smaller, and her tints are browner. The young before the moult in September have no mottled patches on the neck, and their upper plumage is suffused with brown.

Five examples of the American Passenger-Pigeon, Ectopistes migratorius, have been shot in the British Islands, but it may reasonably be doubted whether any of them had crossed the Atlantic in a wild state, inasmuch as one at least had evidently been in captivity, while it is notorious that, from 1830 onwards, many have been brought over and turned loose in this country. 


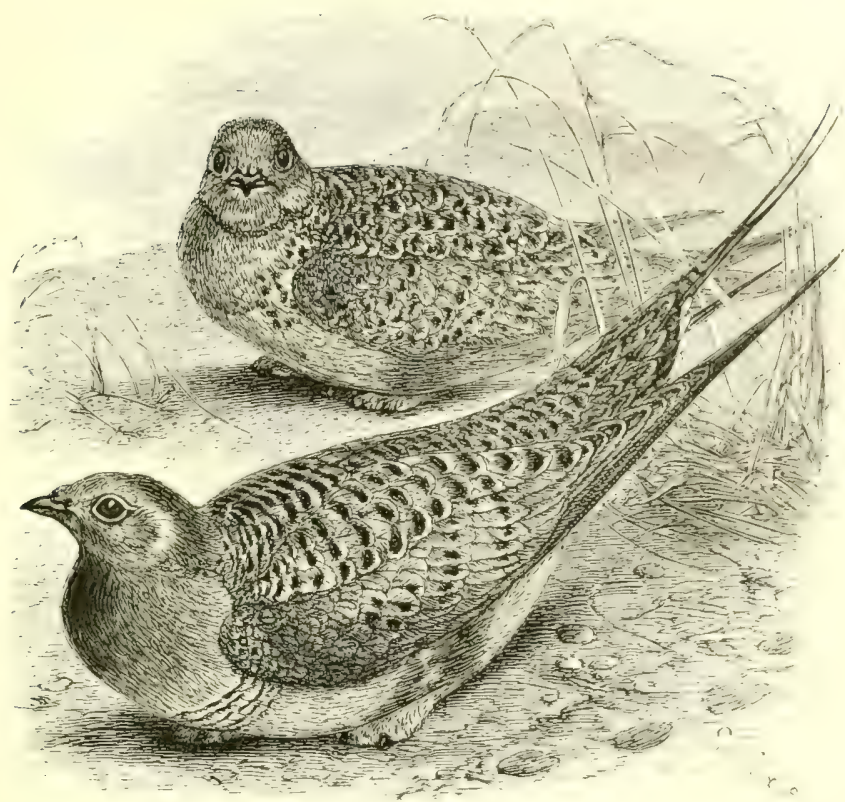

PALLAS'S SAND-GROUSE.

Syrrháptes PARAdóxus (Pallas).

No event in the annals of ornithology has excited more interest than the irruptions of Pallas's Sand-Crouse, which, as regards the British Islands, were first called to notice by a few appearances in Norfolk, Cardigan and Kent, in July and November I\$59; while: several examples were obtained on the Continent during the same year. In $186_{3}$ the ripples of a far larger wave of invasion spread westward over Europe; Heligoland being reached by May zist. the date on which our first visitors of that year were shot in Northumberland, out of a flock of fourteen. Next day about twenty reached staffordshire, and numbers were sulsecpuently found in many parts of the British Islands; the majority on the castern side, from Kent to Caithness, though a few alighted in the shetlands. Inland, as well as in the south of Fingland, occurrences were net wanting; and, while less plentiful in the west, it was in Pembrokeshire that the last survivor was shot, in lethruary $1 \$ 64$. (Onc bird even wandered to Benbecula in the ()uter Heloricles, and several were killed in Ireland, some of them ats far west as co. 1)omezil. . 1ll 
these, however, were merely the skirmishers of a larger army which arrived in Galizia and Moravia on May Gth, and rolled westward to the Atlantic; spreading southward as far as Rimini in Italy and the Pyrenees, northward to the Froes and about lat. $62^{\circ}$ in Norway; while a few eggs were taken among the sand-hills of Denmark and Holland. In $18 ; 2$ small flocks were observed in Northumberland and Ayrshire; in 1876 a pack was seen in May near Winterton in Norfolk, and in October two birds were shot in co. Kildare, Ireland. In I $\$ S S$, from February onwards, it was noticed that another and larger horde was passing over Germany and Poland; by May $\mathbf{1}_{5}$ th it had reached the British Islands, and from June of that year to February iSS9 'The Zoologist' and other journals hare been filled with records from all parts of the Lnited Kingdom. As in $\mathrm{r} S 6_{3}$, Sand-Grouse were especially plentiful along the cast side of Great Britain - and in Norfolk and Yorkshire their coggs appear to have been taken: but a novel feature was their abundance in the Hebrides and other western localities of Scotland, while in Ireland some eren reached co. Mayo. On the Continent this great visitation has reached spain in the south and Norway in the north, but for details we await a paper from Prof. Newton, the able historian of former irruptions. Many birds are still with us [February i889].

'This species, also known as the 'Three-toed Sand-Grouse,' inhabits the sandy steppes of Asia in summer from the eastern shore of the Caspian Sea to Iake Baikal, migrating in winter to Mongolia and Northern China: but on the high table-lands of Thibet the representative is the larger $S$. thilictanus, its sole congener. The eggs, usually 3 in number, are laid in April or Nay, in a hollow scratched in the sandy soil; they are elliptical in shape, and stone-buff blotched with purple-brown in colour: average measurements $\mathrm{r}_{5} 5$ by $\mathrm{I} \cdot \mathrm{r}$ in. The food consists of seeds of plants; the flight is rapid, like that of the Golden Plover.

The adult male may be briefly described as having the head dull yellow; upper parts warm buff, barred with black; quills bluish grey, as are the long and pointed central tail-feathers; neck and breast greyish-buff, crossed by a mottled black gorget; belly banded with black; feathers of the rent and of the feet down to the toes dull white. Length ${ }_{5} 5$ in.; wing 10 in. In the female the head and sides of the neck, and the upper parts generally, are striped and spotted with black, a band of the same colour crossing the upper throat; the general hue is duller, and the central tail-feathers are shorter. 


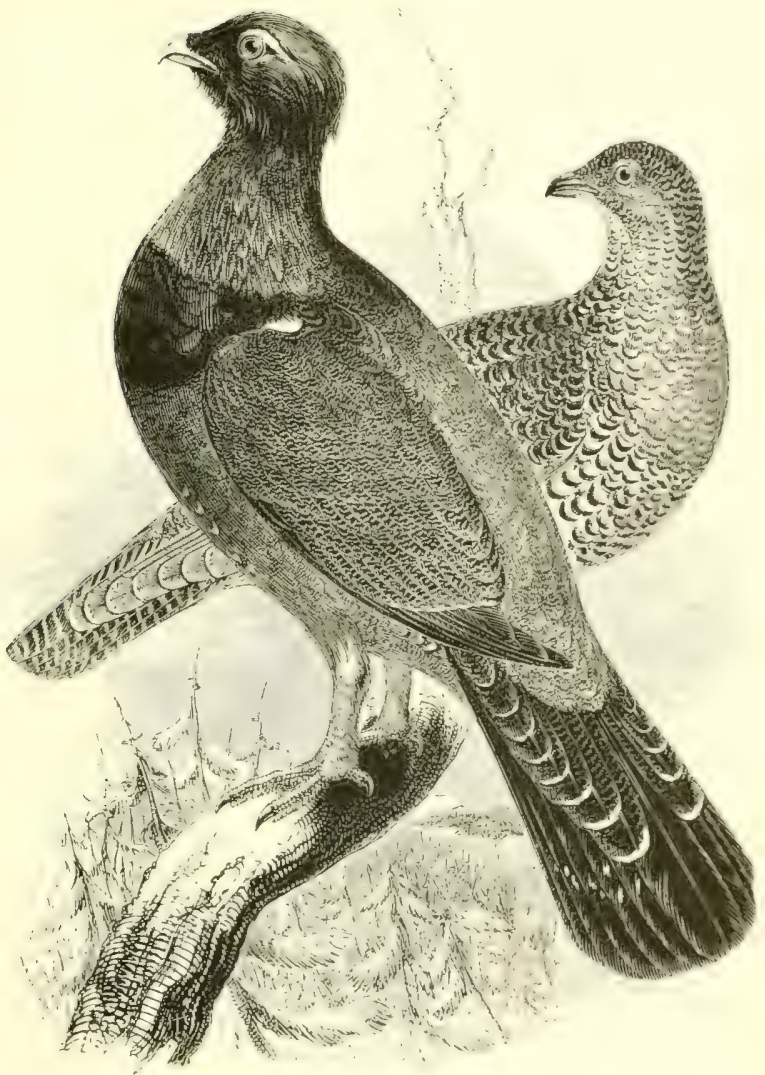

THE CAPERCAILLIE.

\section{'Tetráo urogállus, Linneus.}

The Capercaillie-also known as the Wood-Grouse, and the male as the Cock of the Wood-was formerly an inhabitant of the pine-forests of the British Islands; but at some remote period it became extinct in England and Wales, while in Scotland and Ireland the same fate appears to have overtaken it in the second half of the last century. In 1837 its re-introduction from Sweden was successfully accomplished in l'erthshire, from which county, Forfarshire, and some other centres of distribution, it has now spread over the central districts as far as sirlingshire, and its c... tension further south is chiefly a question of time. Already the coniferous woods have proved too small, and it is now often found 
in oak-and birch-coverts. The females precede the males by one or two years in the search for new quarters, and under these circumstances they often breed with the Black-cock; the male hybrid being a remarkably handsome bird, with plum-coloured breast and a slightly forked tail.

The Capercaillie inhabits the pine-forests of Scandinavia up to lat. $70^{\circ}$, and in Denmark its remains are found in the kitchenmiddens of the prehistoric races who lived before the fir-woods had given way to the oak and the birch. It is abundant in the northern forests of Russia, but is decreasing in Poland, Northern and Central Cermany, and the various branches of the Alps and Carpathians; while from Auvergne and the French side of the Pyrenees it has almost disappeared, though not uncommon on the Spanish slope and in the Cantabrian range. In the Caucasus it is unknown. It is found from $67 \mathrm{~N}$. lat. in Asiatic Siberia down to the Altai Mountains and north-eastern Turkestan, and as far as Iake Baikal; east of which its counterpart is T. urgaglloide's of Middendorff (not of Nilsson), a more slender bird, with head and neck of a rich purple.

Early in spring the male Capercaillie begins his love-song of peller, feller, peller, to attract the hens, at the same time erecting his tail and drooping his wings in a sort of ecstasy; and this proceeding, known as his 'play' or 'spel,' is repeated for a short time about Michaelmas. The nest is a mere hollow scraped in the ground under a tree or bush, the eggs, 6-I 2 in number, being pale reddish-yellow, with brown spots and blotches: average measurements $2 \cdot 2$ by $r_{5} 5$ in. Incubation lasts about a month, and the young are usually hatched early in June. The food of the adults consists of tender shoots of the Scotch fir (rarely of the spruce), with various berries in summer; the young eat insects, worms \&c. The name Capercaillie is, I believe, derived from the Celtic sabur a gont - with allusion to the elongated chin-feathers of the male and his amorous behaviour in spring - and coille a wood: i.e., 'goat of the wood'; but some authorities prefer cabhar an old man, or gobur a horse.

The adult male has a strong hooked bill; upper plumage chiefly dark slate-grey, nearly black on the tail; chest dark glossy-green; lower parts almost black; legs covered with hair-like brown feathers, short in summer, but overhanging the toes in winter. There is great variation in size, but the average length of the wing is 16 in. The female is much smaller, and the general colour of her upper plumage is brown mottled with buff and white; the neck and breast are orange-buff, barred with black and spotted with white. 


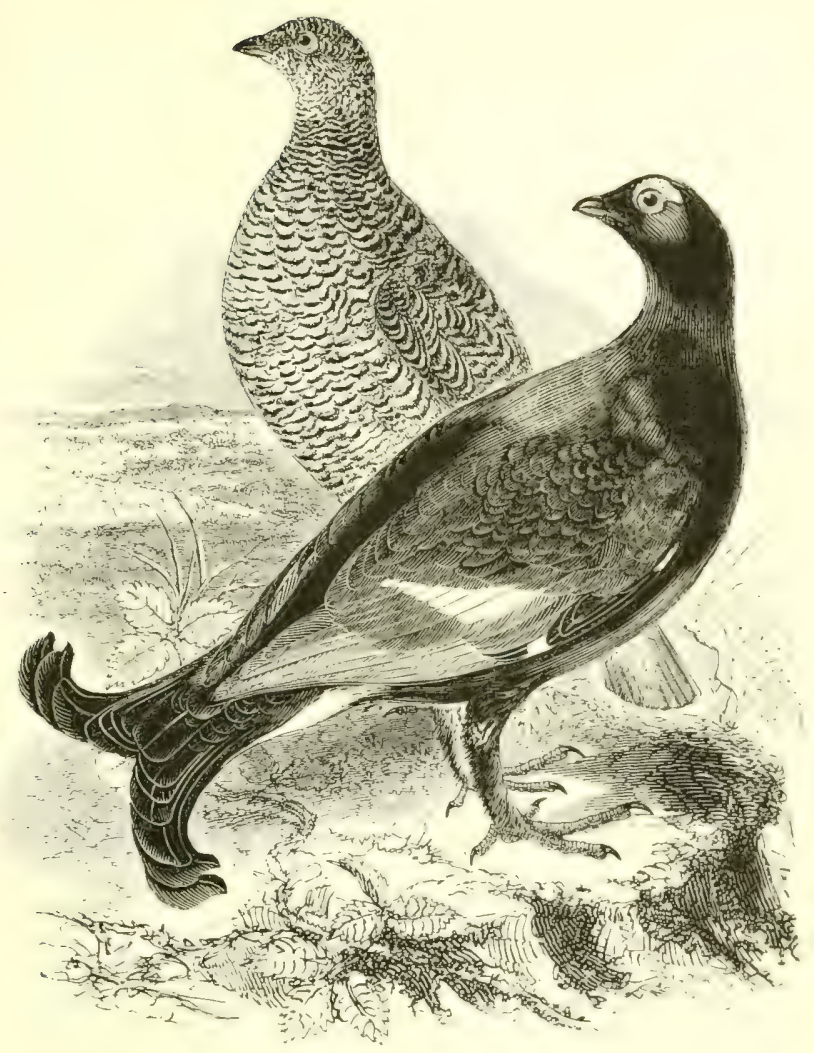

THE BLACK GROUSE.

Tetrao tétrix, Linnæus.

Birds of this species are generally known collectively as lilackgame, and in I)evon and Somerset as Heath-poults; the sexe's leing distinguished as the Black-cock and the (irey-hen. They are found, in small numbers and locally, in Cornwall and south I)evon, and are tolerably plentiful on Exmoor as well as on the Prendons and the Quantocks in Somersetshire, while they still maintain themselves in Dorset, Wilts, and the New Forest district. In Sussex, Surrey and Berkshire their presence is the result of rintroduction early in the present century, and none are now to be found in kint, where. however, the species existed in the time of Henry riii. : and it is in an ordinance for the regulation of the royal hemechold dated from Eltham that the word 'Grouse' makes its first appearance in 
our language as 'Grows.' A small colony exists near Sandringham in Norfolk, and locally the species is scattered over the wilder portions of the Midland counties, the Marches, and many parts of Wales; while north of Sherwood Forest it is found in every English county. In Scotland it is generally distributed on the mainland and in many of the Inner Hebrides, but attempts at introduction in the Outer islands, the Orkneys and the Shetlands, have not been successful. In Ireland it was never indigenous.

The Black Grouse inhabits Scandinavia, Russia, the heath-clad wastes of the cast of Holland, the hilly districts of Germany and Central Europe, and the northern Apennines. There is some evidence that by way of the Cevennes it has found its way to the Eastern Pyrenees, but it is not found in the rest of that chain; while in the Caucasus it is represented by a smaller and more slender species, the male of which has a deep glossy-black plumage and a remarkably developed tail. Beyond the Ural Mountains the Black Crouse stretches across the wooded regions of Siberia, and as far as South Manchuria.

Black-cocks are polygamous, and in spring they assemble before dawn to fight for the hens, performing the most extraordinary antics in order to prove attractive. When this lek is over they retire with the females they have secured, and the latter make a slight nest on the ground in which they deposit 6-10 eggs of a yellowishwhite spotted with orange-brown: average measurements 2 by $1{ }^{\circ} 4$ in. The males have also a short spil in autumn, when they separate from the females and flock together. The young feed largely on ants' eggs and other insect food, while whortleberries \&c., barley, the juicy brown seeds of rushes, and the tops and buds of many other plants are farourite articles of diet with the adults; abundance of moisture being at all times essential. Interbreeding with the Capercaillie has already been noticed; it is not unfrequent with the Pheasant, and occasionally takes place with our Red Grouse, the Scandinavian Willow-Grouse and the Hazel-Grouse.

The general colour of the Black-cock is bluish-black; the wingbar and the under tail-coverts being white. Length 22 in.; wing 10.5. The Grey-hen is chiefly pale chestnut-brown, barred and freckled with black; wing 9 in. 'The latter breeds in her first spring, but the young males are liable to be driven away by the older and stronger cocks. The dark plumage of the male is nearly assumed by December, though the full development of the forked tail-feathers is not attained till the third year. 


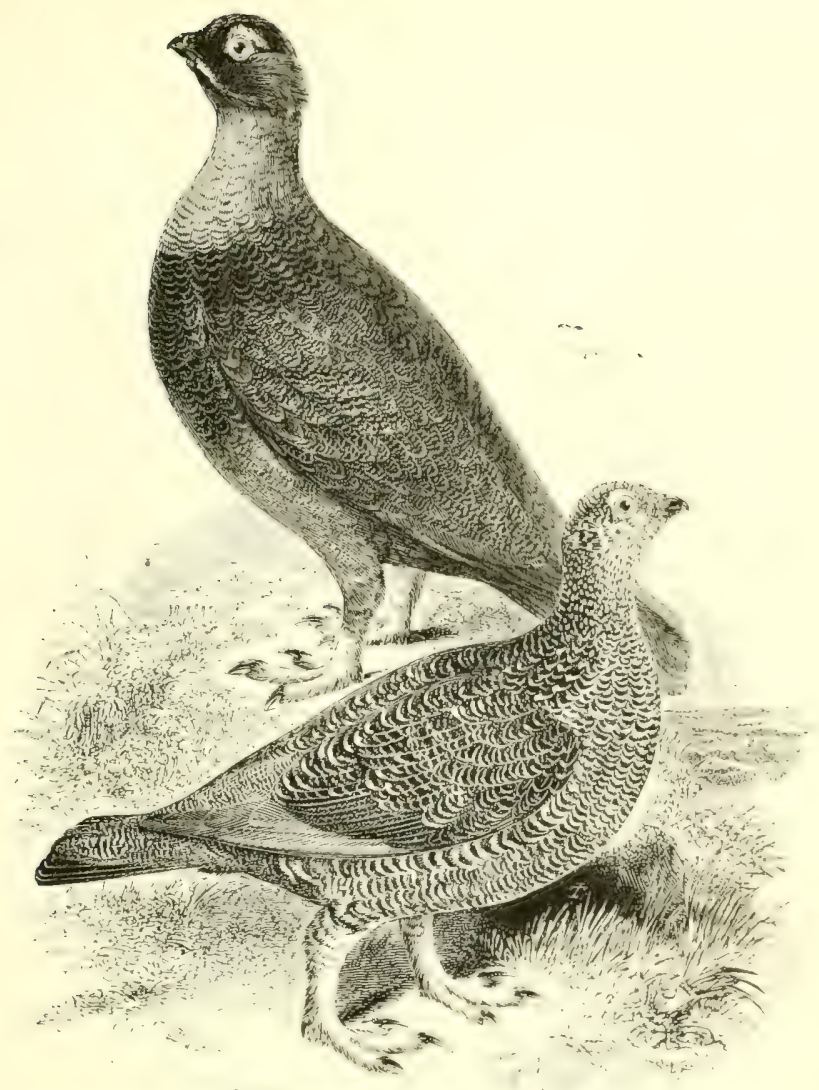

THE RED GROUSE.

LAgópus scóticus (Latham).

This species, indigenous only to the british Islands. is our 1epere sentative of the Willow-(irouse (L. albus), the hatter inhabiting the northern portions of Europe, Asia and America. In Scotland, from which the Red Grouse derives its specific name, it is generally distributed over the moors of the mainland, from the highest point where ling (Calluna) and heath (Eriad) flourish down to the coast-line, being also found in the Inner and most of the Outer Hebrides; while remarkably fine specimens are jwelucel in the Orkneys, though introduction has hitherto prosed a failure in the Shetlands. In England this bird is found from the northern 
counties-especially lorkshire and Derbrshire-down the Pennine range as far as the Trent, as well as in Lancashire, Cheshire, Staffordshire, Shropshire, and on most of the Welsh moors to (ilamorganshire; but to the south-east of these lines it has never succeeded in maintaining itself, though introduced on the heaths of Surrey and elsewhere. It is resident on most of the moorlands and peat-bogs of Ireland, but is far less abundant there than in Scotland or the north of England. About twenty years ago it was acclimatized in the district of Gottenborg, South Sweden.

Red Grouse pair very early in spring, the female making a scanty nest in some depression in the ground, under shelter of a tuft of heather. The eggs, usually $8-10$, though sometimes 15 in number, are of a buffish-white ground-colour, mottled with rich red or brown: average measurements $I^{\circ} 75$ by $I^{\circ} 2$ in. Instances are on record of their having been found as early as Narch 1 th, but incubation does not become general until April. The female sits very close, the male being usually at no great distance, while on the approach of danger he emits a warning kok, kok, kok. He is also in the habit of standing on a hillock and uttering a peculiar crow at dawn, especially on clear frosty mornings; the note of the hen being a strange nasal croak. The young leave the nest soon after they are freed from the shell, and, with their parents, feed on the leaves and fruit of the bilberry \&c., the tips of ling-and heather-shoots, and, occasionally, grain; the principal feeding-time being, as a rule, late in the afternoon. Unlike its congener the Willow-(irouse, our bird has seldom been seen to perch on trees, though it often sits on earth-dykes and walls. In severe snowy weather (irouse are driven from the higher moors to the lowlands, and have been known to wander so far that they seem to have completely lost the bearings of their old haunts. The causes of the disease to which they are subject have been-and still are-much disputed; but there was a severe outbreak as long ago as June i 8 I 5 in the Reay country, Sutherlandshire (Zool. i 887, p. 302).

The plumage varies considerably, especially as regards the under parts, on which a good deal of white is sometimes observed in winter. The male is reddish-brown on the head and neck, and chestnut-brown-barred and speckled with black-on the upper parts; the feathers of the breast being almost black, with white tips. In summer the yeneral colour is lighter. Length 16 in.; wing 8.4 in. The female (represented in the foreground) is rather smaller, and exhibits much more of a yellowish-chestnut tint. The young moult completely in their first autumn. 


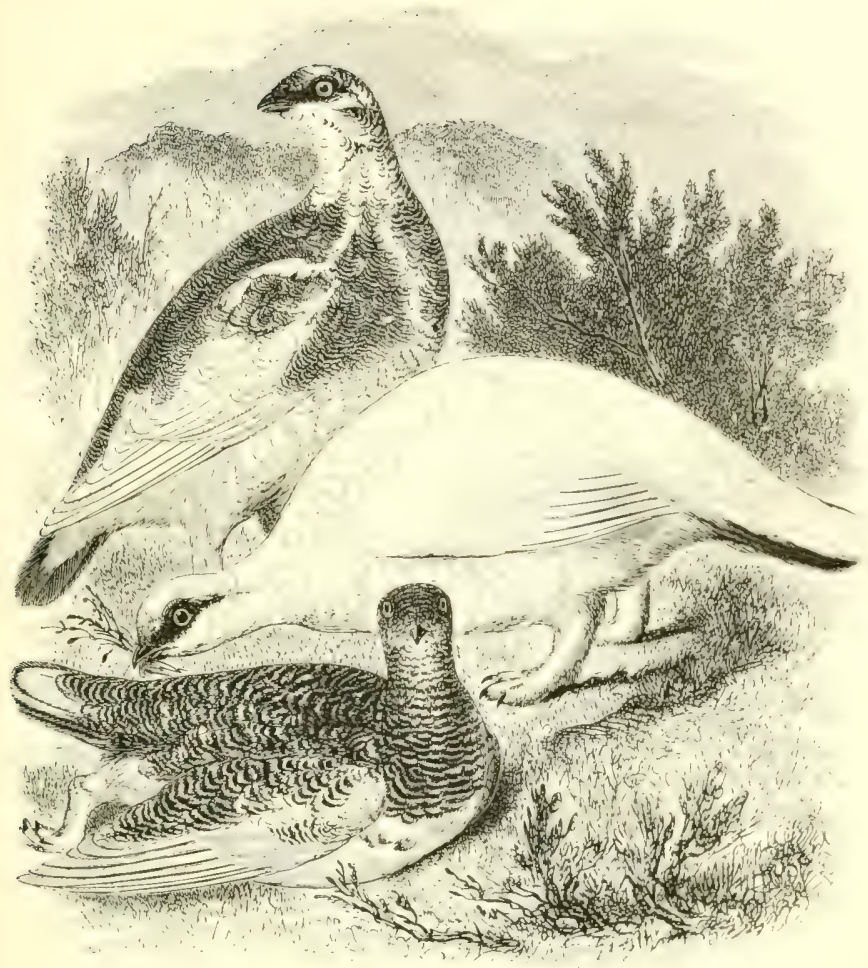

THE P'TARMIGAN.

\section{Lagorus mútus (Montin).}

As regards (ireat Britain, the Ptarmigan is continet to Sicothand: there being no positive evidence of its occurrence in the mountains of Cumberland or Westmorland. Recent investigations by Mr. R. Service (Zool. 1887, pp. 8I-89) have, however, shown that a few existed in the highest portions of Dumfriesshire and Galloway until about 1822, when the last were captured near Sanquhar; though a subsequent attempt by the late Inlice of bucchuch to re-stock that district proved unsuccessful. Owing to re-introduction it is still found in Arran, and a few pairs survive on the Paps of Jura as well as in Islay, while in gradually decreasing numbers it is found in Skye, Harris, and Lewis. From the vicinity of Ben Lomond northward, it inhabits the "region of stones" on the hisher mountain-masses, especially in Perthshire, Murrlectnhire, Inverness 
shire, Ross, and Sutherland, but it is exceedingly local. In Ireland it is quite unknown.

The Ptarmigan is resident in the Lofoden Islands, and on the fells of Scandinavia above the limits of tree-growth, as well as in the loftier portions of Finland, the Kola Peninsula, and the Ural Mountains. It is found in the French, Swiss, and Italian Alps, and in small numbers in Tyrol, Styria, and Carinthia, though no longer in Transylvania; while in the Pyrenees it is tolerably abundant near the snow-line, and it is said to occur in the mountains of the Asturias and Leon. In Asia, our Ptarmigan appears to inbabit the Aitai and some other ranges, and a bird (not in summer dress) obtained near Yokohama in Japan, at an elevation of more than 9,000 ft., is ascribed to this species; but on the lower ground of Northern Siberia and Arctic America, as well as in Greenland and Iceland, its representative is the browner L. rupestris, or some other closely-allied form. In Spitsbergen we find L. hemileucurus, which is larger and fairly distinct.

The nest is a hole scraped in the soil and scantily lined, while the eggs, laid late in May, are 8-1o in number; the ground-colour is, as a rule, rather lighter than in those of the Red Grouse, and they are smaller in size, measuring about $I^{*} 7$ by $I^{\prime} I$ in. In wet or stormy seasons the various families associate or pack by the beginning of August, but otherwise not till winter; they are scarcer on the extreme summits of the mountains than at a lower elevation, and birds shot in the highest situations are usually small in size. The food consists of the fresh green tops of ling $\& \mathrm{c}$., with various kinds of berries; and, like the Red Grouse, the Ptarmigan suffers from disease, at least in Scotland.

The male in summer has a red wattle over each eye; lores, head, shoulders and breast blackish; upper parts, long tail-coverts and flanks finely mottled and barred with greyish-brown; tail-feathers black, tipped with white; belly white. Length $\mathrm{I}_{5}$ in. ; wing $S$ in. The plumage of the female is orange-tawny, barred with black. In both sexes and at all seasons-except for the short time that the young are in nestling plumage - the wings are white, with dark shafts to the quills. In autumn the upper parts are finely vermiculated with slate-grey. In winter boih sexes are white, but the male may be recognized by his black lores and eye-stripes; old females, however, sometimes exhibit the latter. More than nine-tenths of the so-called 'Ptarmigan' sent over to our markets are Willow-Grouse in winter dress: these may be known by their larger size, and as regards the males-by the absence of any black on the lores. 


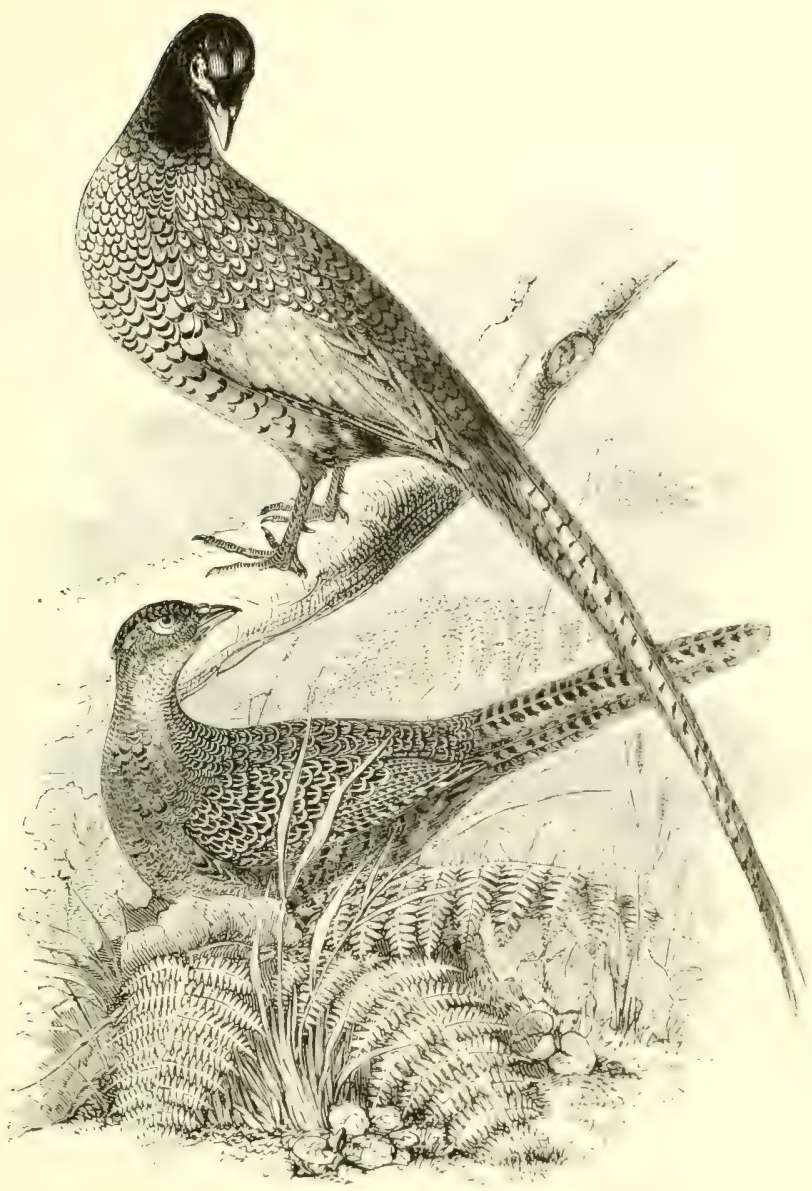

THE PHEASANT.

\section{Phasiánus cólchicus (Linnæus).}

There is evidence that the Pheasant had become naturalized in the south of England before the Norman innasion, though there is no mention of its existence in scotland until 159.4 , or in 1reland? till 1589 ; at the present day, however, it is gencrally distributed throughout the United Kingdom, and it has crem leen acclimatized in some of the Outer Hebrides. Little, if ans, deviation from the typical $P$. colchicus took place up to the end of last century, when the introduction of the Chinese Ring-necked $P$. toriquatus 
commenced, which has left almost indelible marks, especially with regard to the characteristic white collar. Fertile hybrids have also been produced with the beautiful green-tinted Japanese $P$. arersicolor, and the splendid long-tailed Chinese $P$. reeresi; the so-called Bohemian Pheasant being merely a pale buff-coloured variety.

The Pheasant owes its generic and specific names to its traditional introduction from the banks of the Colchian Phasis-the modern Rion which enters the Black Sea near Poti; and there the pure breed is still to be found. Westward, it inhabits portions of Asia Minor, Turkey, Greece, Albania, and Roumelia; but it may be doubted whether it is indigenous to the northward of the Balkans, though found at the present day-under greater or less protection-up to the southern districts of Sweden and Norway, and in nearly every country of Europe. Eastward, its range extends along the southern shores of the Caspian about as far as Astrabad, beyond which a desert cuts it off from the various species which inhabit Afghanistan, Turkestan, Mongolia, and China.

The short crow of the males may be heard in March, when fighting takes place for the possession of the hens, which, as a rule, begin to lay in April. From $10-14$ eggs, measuring about $1 \cdot 85$ by I.45 in., of an olive-brown or sometimes a pale blue colour, are deposited in a slight nest on the ground; but exceptionally squirrels' dreys and former habitations of other birds in trees are selected, while several hens will sometimes sit amicably on the same nest, as they will do with Partridges and domestic fowls. There are also a few authenticated instances where cock birds have been seen incubating, as well as rearing the brood. The natural food consists of grain, berries, acorns and other vegetable matter, with an enormous number of wire-worms and injurious insects; ants and their larve forming the chief sustenance of the young. Water and cover are indispensable, though trees are not absolutely essential for Pheasants, as they do not constantly roost in them during the summer. When well on the wing their pace is tremendous, and they have been seen to fly nearly four miles at a stretch ; they also swim with considerable facility. Hybrids have been produced with several other species of gallinaceous birds; and a partial assumption of the male plumage by females which have ceased to breed is not uncommon.

It is unnecessary to occupy valuable space with a description of this well-known bird, now seldom, if ever, found pure-bred in this country. The average weight of an old cock bird is from $3-3 \frac{1}{2} \mathrm{lbs}$, and of a hen about $2 \frac{1}{2}$ lbs. 


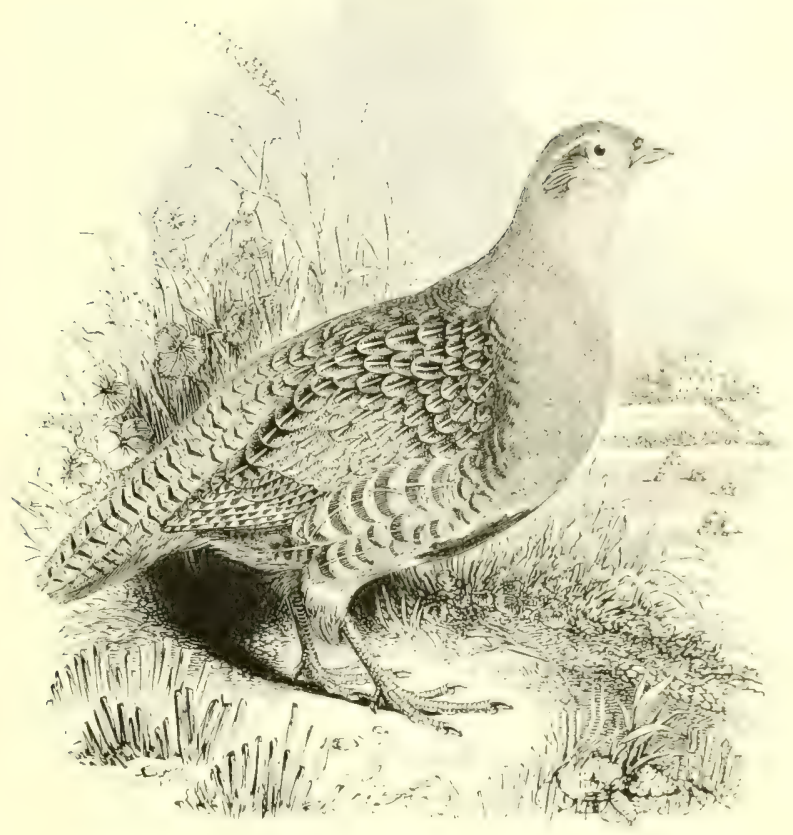

THE COMMON PARTRIITE.

PÉRDIX CINÉREA, I atham.

The Common or (irey Partridge is gentrally distributed throughout the United Kingdom, and nowhere is it more abundant than in those eastern counties of England in which, according to a recent author, "it has been partially exterminated by the Red-legged Partridge, but still occurs locally:" The cultivation of grain is un doubtedly favourable to its increase in number as well as in size, but birds which have fed on heath, whortle-berries \&c., in wild moorland districts are by no means inferior in peint of flavour. In Scotland it is decidedly local, though plentiful on some of the lew grounds; but it is not widely diffused in the Inner I Lebricles. nor does it thrive in the Outer islands, to which, as well als to tixe ()rkncys. it has been introduced. In Ireland its mumbers have diminished of late years, from various causes.

In Norway this species exists under difficulties, owing to the rigour of the winters and the abundance of hirin of freste cepecialls 
the Goshawk; nor can it be said to flourish in any part of Sweden It is found in Denmark, Germany, Holland, Belgium, and in France down to Savoy; but further south it frequents the higher ground, yielding the plains to the Red-legged Partridge. It occurs on both sides of the Pyrenees and as far as the valley of the Douro in the Spanish Peninsula, especially in the moister regions to the west; in Italy it ranges to Naples, and in Central and Eastern Europe it is abundant. iVe trace it to Asia Minor and the mountainous districts of Persia, and it also inhabits the south-west of Siberia, a larger and greyer race being found in the Altai Mountains; while eastward the representative is the smaller $P$. barbata, the male of which has a golden-buff breast, and a deep black horseshoe mark below.

The Partridge often pairs in February, but eggs are seldom laid until the end of April or the beginning of May. From r 2-20 of these are often produced by a single hen, but as many as 33 have been found in one nest, from 23 of which the young were hatched and went off with the old birds, while + of the eggs left behind had live chicks in them. The ustal colour of the shell is olive-brown, but pale blue or whitish varieties are not very uncommon: average measurements $I^{*}+5$ by $\mathrm{I}^{\circ} \mathrm{I} 5 \mathrm{in}$. Incubation lasts twenty-one days, and the young are attended by both parents with great assiduity; I have seen the old birds show a bold front to a Hen-Harrier for several minutes, while covering the retreat of their brood to the shelter of a hedge. The food consists of green leaves, grain, many species of insects, small snails \&c. Breeding takes place in the first spring, but old males are very pugnacious and molest the younger birds, besides taking excellent care of themselves in autumn; the practice of 'driving' has, however, diminished the number of the cocks, and has thus proved beneficial to the general increase of the stock.

The adult male may be distinguished from the female by the brighter yellowish-chestnut on the head and throat, the greyer neck, and the dark brown horse-shoe mark on the lower breast. The legs and feet are bluish-white in the adults, but yellowish brown in the young, which resemble the female in plumage. Average length 12.5 ; wing 6 in. Varieties are very common, but they are mostly found in young birds; in some cases, however, they seem to be connected with the nature of the soil frequented, Partridges from the clay being often poor in colour, while those from the gravel are very warm in tint in any case. In some parts an increasing tendency to a white horse-shoe is apparent. 


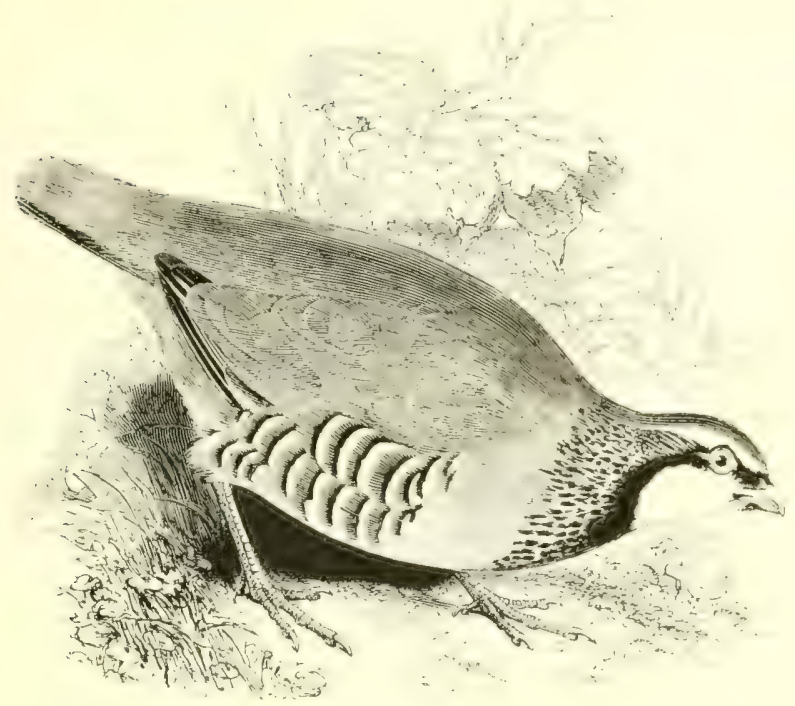

THE RED-LEGGED PAR'TRIDGE.

\section{CÁCCABIS RÚFA (Linnæus).}

This species-often called the French Partridge-belongs to a well-defined group, the members of which resemble each other in their partiality for dry or mountainous districts, their main pattern of coloration, the similarity of the sexes in plumage, and the presence of blunt spurs on the legs of the males. The Red-legged Partridge was successfully acclimatized in England about 1770 , when large numbers of eggs were hatched under domestic fowls in two estates in suffolk; and as the result of this and subsequent introductions it is now thoroughly established, not only in the above county, but also in Norfolk, Iilicolnshire, (ambridse ihire. Essex, some of the Midlands, and on dry ground along the northern side of the Thames valley. Owing to similar but independent centres of dispersal, and a natural tendency on the part of the liris to seck congenial situations, it is also found in many other districts: but under no circumstances has it thriven in the west, or on rich grass-lands; and its stronghold is in East Anglia, where it frequent the higher and less cultivated soils. It has even resisted attempth to exterminate it, made under the belief that it hardsucel the (ire! Partridge, and because its habit of ruming rendered dogs $\mathrm{m}$ 
steady, and precluded the possibility of walking it up ; but since 'driving' became a system the only objection to it is as regards its inferior quality for the table. Attempts at introduction on the mainland of Scotland and in the Orkneys have failed; nor have those made in Ireland since $\mathrm{s} 8_{44}$ been successful. There is not the slightest evidence that this bird ever undertakes long migrations from, or on, the Continent.

Even in the Channel Islands the Ked-legged Partridge appears to be an alien, and in the north of France is rare, while in Belgium it is almost unknown. In the centre, east, and south of France it is generally distributed, and it is the only red-legged species indigenous to the Spanish l'eninsula; but on the Rock of Gibraltar the Barbary Partridge ( $C$. fetrusa), with brown nape and collar, has been introduced from Morocco. Eggs of the latter have occasionally been hatched in England, but the bird has never obtained a footing. The Red-legged Partridge is also found in the Azores, Madeira, and some of the Canaries: no doubt taken there by the early settlers. In the Mlps and the Apennines its eastward progress is barred by the presence of the larger and stronger $C$. savatilis, which also occupies Sicily ; Surdinia is held by the Barbary Partridge, but the Balearic Islands, Elba, Corsica, and part of North-Western Italy are left to the French bird. Lew species have so restricted a natural range, or bear confinement better; thousands of birds being carried about in cages during the greater part of their lives, owing to the southern practice of using them to lure their wild relatives within shot.

The scanty nest is usually on the ground, but not unfrequently in the side or on the top of a stack; the eggs, I $5^{-1} 8$ in number, are yellowish-white, blotched with rufous-brown: average measurements $I^{\circ} 6$ by $I^{\circ} 25$ in. The food consists of leaves, seeds and insects, obtained chiefly on waste land of a drier and more open nature than that frequented by the Grey Partridge. The latter is seldom interfered with; the two species living apart, and rarely interbreeding. The Red-legged Partridge not unfrequently perches on trees, and may often be seen on gates and palings.

The adult male has the bill red; crown grey; a black streak from each eye backwards and downwards to a gorget of the same colour; general upper parts hair-brown; tail-feathers chestnut; throat white; breast pearl-grey; belly fawn-colour; flanks greyish, handsomely barred with black and chestnut; legs red, with rudimentary spurknobs. Length 13.5 in.; wing 6.25 in. The female is rather smaller and duller in colour, and has no knobs on her legs. The young have no grey on the throat and hardly any black on the gorget. 


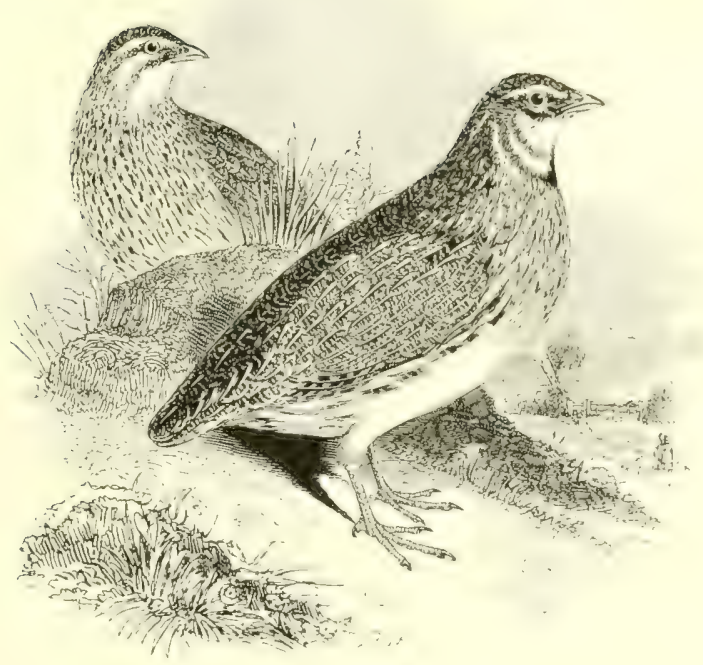

THE QUAIL.

Cotúrnix Commúnis, Bonnaterre.

The Quail is principally a spring-visitor to this country, and the majority leave for the south in October; but in mild winters some remain with us-especially on the west coast of England. and still more so in Ireland. In the latter, indeed, this species is partially resident, though of late years a marked and unaccountahle diminution in its numbers has been noticed. In England, before drainage and high cultivation had broken up the coarse tussocky land in which it delighted, it was far more plentiful than it is at present, particularly in Hertfordshire, Cambridgeshire, suffolk. Norfolk, Lincolnshire $\&$ c.; but from time to time an unusual influx takes place, such as extended in $1 S ; 0$ from East Inglia to Cardigan, Pembroke and Cornwall; while in 1885 a remark able increase was noticed on the high ground along the north side of the valley 'of the Thames and as far as the Severn. Northward, the (2uail gradually becomes less numerous, yet nests have been found in Scotland as far as Caithness, Sutherland, the Orkneys and the Shetlands, several times in the (Huter Hebrides. and not unfrequently in the south-west of the mainland.

In summer the Quail is found in the Feroes, and, though sparingly. 
as far north as lat. $65^{\circ}$ on the Continent, while southwards it becomes more abundant, and immense flocks annually visit the counties bordering on the Mediterranean, especially on the spring migration; upwards of 1 60,000 birds having been netted in a single season on the small island of Capri, in the bay of Naples. The majority pass northwards, but many remain to breed, and a considerable number pass the winter in the south of Europe and North Africa, while in the Canaries, Madeira and the Azores the species is resident. Males from the last have a strong tinge of red on the throatpatch, and examples obtained in Spain \&c. during the winter, are smaller in size and darker in colour than those which arrive from Africa in spring; but space will not allow of further remarks upon the numerous variations. On passage it reaches the extreme south of Africa by the latter part of August, and some are stationary there, nesting in Necember; it occurs in Madagascar and Mauritius, and can be traced northward again to Egypt; while in Palestine, as of old, the Quails come up in the night and cover the land. Across temperate Asia it is generally distributed, breeding as far south as Cashmere, and crossing the Karakoram ( 16,000 ft.) and other ranges, on its way to India, where, as well as in China, it passes the cold season. Insular forms inhabit Japan and Formosa.

The nest-a mere hole scraped in the ground, lined with a few plant-stalks-is usually in a wheat-field, but sometimes in clover or grass; and the eggs, 7 I 2 in number, are yellowish-white, blotched or speckled with umber-brown: average measurements $I^{\circ} \mathrm{I}$ by 9 in. Incubation lasts about three weeks, and two broods, or bailes as they are called, are sometimes reared in the season. The food consists of slugs and insects, plantain, chickweed \&c. - no less than 3.500 seeds of the latter having been found in the crop of a single bird. The male utters a shrill triple note, which is generally ren dered in this country by the words "wet-my-lips;" as a rule he is monogamous.

In appearance the Quail resembles a miniature Partridge. The male (represented in the foreground) is smaller than the female (in the background), and has two dark brown bands descending from the ear-coverts, terminating at the throat in a blackish patch which is not acquired until the second year. Length 7 in. ; wing $4{ }^{\circ} 5$ in.

'Two examples of the Andalucian Hemipode, Tumix syleatica, are said to have been obtained in Oxfordshire, and a third in Yorkshire. No one who knows how sedentary and local this species is, will believe it to be a genuine visitor. 


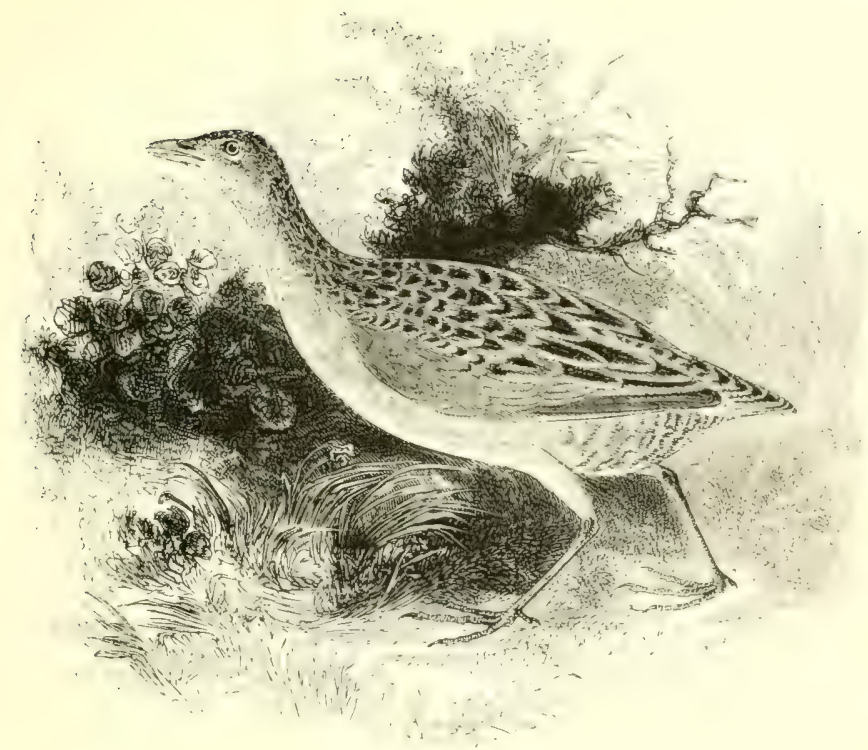

THE LAND-RAIL.

CRéx praténsis, Bechstein.

The Land-Rail, also known as the Corn-Crake, is widely distributed in summer throughout the British Islands; usually making its appearance in the southern counties of England during the last ten days of April, though in Yorkshire and northwards it is seldom heard till the first or second week in May, and only towards the end of that month in the Shetlands. Westward, it has been obtained in St. Kilda, and is common in the Outer Hebrides, where it is probable that a few birds occasionally pass the winter. This is undoubtedly the case in Ireland, and, more rarely, in England, but the majority have taken their departure before ()ctober. Kich pastures are its favourite haunts, but it may be found wherever there is grass-land.

This species occasionally breeds in the Freroes, but its occurrence in Iceland has not been authenticated, though a single example was obtained near (iodthab in Circenland, in r $\$_{5} 5$. Individuals which had, no doubt, availed themselves of the assistance of vessels, have frequently been obtained of late years on the cultem sea-board of the United States; and in ()ctober $18+7$ one was shot in the Bermudas. As a wanderer it has been found in the Azores 
and Madeira, while in the southern countries of Europe it is a bird of regular passage in spring and again in autumn; not nesting, I believe, below the line of the Pyrenees, but continuing its course to the central and northern districts, or even the Arctic circle. In Asia it is found as far east as the Lena, though not recorded from China or Japan ; and it probably inhabits the high lands of Afghanistan and Persia during the summer, inasmuch as it breeds in Western Turkestan. Its principal winter-quarters are in Africa, where it is found down to Natal, and occasionally in Cape Colony.

The nest, composed of dry plants and grasses, is generally among long meadow-grass, where it is often discovered at mowing-time; but it is not unfrequently in standing corn, and thus escapes notice until the brood is safe. The eggs, 7-10 in number, are usually laid towards the end of May or early in June, and are pale reddish-white, spotted with grey and rufous-brown: average measurements $\mathbf{I}^{\circ} 45$ by $I^{\prime} I$ in. 'The 'creaking' call-note uttered by the male-especially towards evening - may easily be imitated by passing the edge of the thumb-nail across the teeth of a comb, and by this means the bird may be lured to within a short distance: the ventriloquial powers attributed to this species are, in my opinion, due to the marvellous rapidity with which it sneaks, unperceived, from one spot to another. It does not take wing readily, and flies slowly, with its legs hanging down; while, if closely pressed, especially if wounded, it will elude even a dog by climbing among tangled bushes, and when captured it will not unfrequently feign death : a device common to other members of the family. The food consists of worms, slugs, insects, small lizards, plants, seeds \&c.; the flesh is highly esteemed for the table.

The adult male has ash-grey patches above each eye and on the cheeks; feathers of the upper parts yellowish-brown with dark centres; wing-coverts and quills chestnut; throat white; breast greyish-buff; belly nearly white in the centre, the flanks broadly barred with cinnamon-brown and buff; bill, legs and feet pale brown. Length II in.; wing $5^{\circ} 2$ in. Females are rather smaller, and, like the young of the year, have the grey on the head and the chestnut on the wings less pronounced. The nestlings, which are at first covered with black down, are able to fly in about six weeks. The usual weight of an adult is about 6 ozs., but a bird of nearly 9 ozs. is on record. Albinoes and other varieties are sometimes met with. 


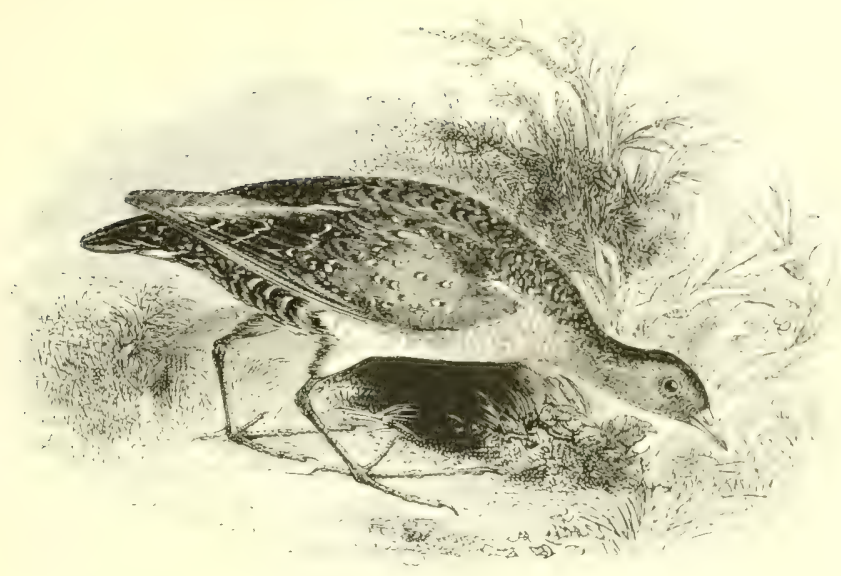

THE SPOTTED CRAKE.

\section{Porzána maruétta (Leach)}

This species, smaller in size than the Land-Rail, is also a summervisitor to the United Kingdom, but owing to the drainage of the fens and the reclamation of marsh-land, it is far less plentiful than formerly. It usually appears in May and departs in ()ctober, but birds have been known to remain till mid-winter, and the occurrences recorded from Norfolk in Narch were more probably due to individuals which had not left the country than to early arrivals. ()wing to its skulking habits, the Spotted Crake is often supposed to be rarer than is really the case; though very local, it breeds in East. Inglia, the Humber, Trent and Solway districts, I)urham and Northumberland, as well as in several of the southern countics, and among the bogs of Breconshire in Wales. On the east side of sirotland it has nested as far north as Elgin, while on migration it has occurred in the (Orkneys and twice in the Shetlands (in ()ctober): on the west it has bred in Dumfriesshire, but has not yet been recorded north of the Clyde. 'To Ireland it is a rare visitor, usually in autumn, but its eggs have been found in Roscommon, and a nestling in Kerry.

Although the Spotted Crake has twice been olbained in (ireenland, it has not yet been noticed in Iceland or the Faroes. On the Continent its northern range extends to about lat. $65^{\circ}$ in Scandinavia, though not quite so far in Russia; and southward, it is generally abundant in suitable lowalities during the summer months; visiting Heligoland on both migrations. especially 
in that of May. In the marshy portions of France, Central Furope, Italy and Sicily it breeds freely, but in the Spanish Peninsula it is chiefly a migrant; as a wanderer it has been obtained in the Canary Islands; while it is found in winter along the whole line of Northern Africa, and as far as Abyssinia. In Asia its summerrange extends eastward to Yarkand and southward to Gilgit, while on its way to India in September it crosses-like the Quail- - the lofty Karakoram range.

The nest, usually placed in a thick reed bed or in a tussock of sedge surrounded by water, is formed externally of long flags, with a cup-shaped centre lined with fine soft grass. The eggs, 8-1o in number, are of an olive-buff ground-colour, spotted and flecked with dark reddish-brown : average measurements $\mathrm{I}_{3} 3$ by 9 in. The young, which are at first covered with lustrous greenish-black down, take to the water very soon after they are hatched. The call-note is a peculiar whuit, whuit. Little can be seen of this species without the assistance of one or more good dogs; though when pursued by them I have seen it flutter up into a tangled growth of brambles, from which it could only be thrashed out with the greatest diffculty: The food consists of worms, slugs, and aquatic insects, with soft vegetable substances.

The adult male has the bill yellowish, tinged with red at the base; eye-stripes, face and throat dull grey; crown dark brown; upper parts generally olive-brown with darker streaks, and minute spots of white, thickest on the neck, and again on the tail-coverts; breast brown, spotted with white: belly dull grey; flanks barred brown and white; legs and feet yellowish-green. Length 9 in. ; wing 4.5 in. The female is slightly smaller and duller in colour. In the young bird the throat is white, and the spots are less pronounced,

A specimen of the Carolina Crake, $P$. carolina, shot near Newbury, Berks, was exhibited at the meeting of the Zoological Society, February i t th I 865 , by Professor Newton, who remarked upon the powers of endurance in their tlight of various members of the family Rallidx, and upon the capture of this species on one occasion in Greenland. The adult may be distinguished from the European bird by its black face. On the strength of a single occurrence it seems inexpedient to add this native of America to the British list. 


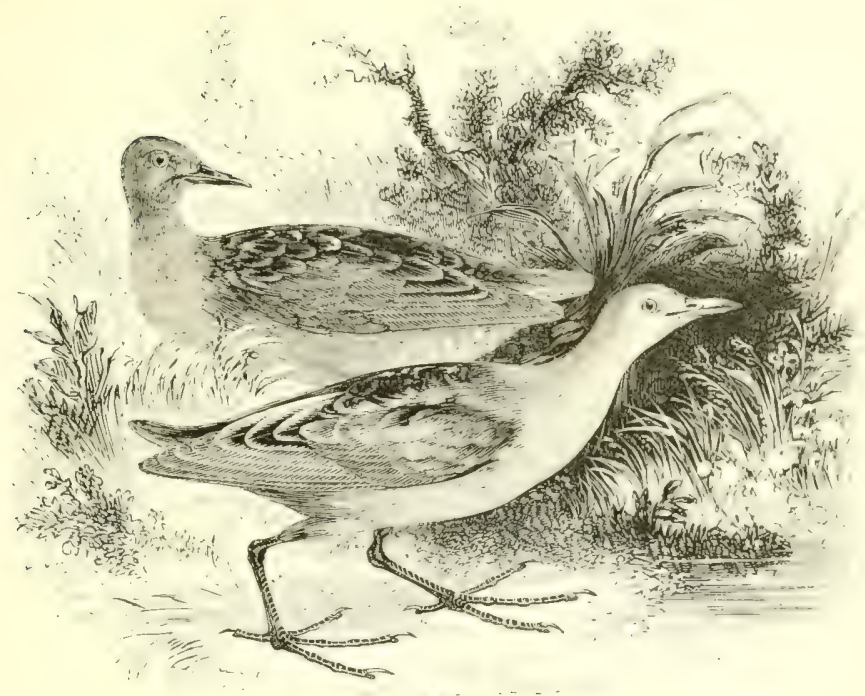

THF, LITTIE CRAKE.

PORZANA PÁRVA (Sicopoli).

This Crake-also called, from its colour, the Olivaceous Gallinule--is, on the whole, a rare visitor to England, though in Norfolk at least eleven authenticated examples have been ohtained since I $8 \mathbf{I} 2$, and a much larger number of such inconspicuous birds must have escaped notice. Specimens have also been recorded from Suffolk, Cambridgeshire, Lincolnshire, Yorkshire (several), I ancashire, Cumberland (one), Oxfordshire, Middlesex, Sussex, I Iants, I orset, Somerset, I)evon and Cornwall; while other countics have no doubt been visited by it, though it has not always been accurately distinguished from the still smaller Baillon's Crake, next in order. As regards Scotland, a specimen preserved by Thomas lidward of Banff in March 1852 is in the collection of Mr. I. H. (iurney : in Ireland, the only authenticated example is one which was shot at Balbriggan in March $185+-a$ bird recorded under this name from Queen's Co. having proved to be a Spotted Crake. 'There is no evidence that it has nested with us, and all its visits have been in spring and autumn.

The Little Crake is said to have bred in the south of Sweden, and on migration it occurs in Ienmark as well as on Heligoland. It nests, somewhat sparingly, from flolstein castward, along the 
southern side of the Bultic as far as Livonia, and in Central Russia; more abundantly in Poland, Southern Germany, AustroHungary, Central France, Savoy and the Rhone valley, and also in Italy down to Sicily; but is as yet only known on passage in the rest of the Mediterranean and in Spain. It is, however, said to be resident in Algeria, though as a matter of fact little is known respecting its distribution in Africa. In the Caspian district it is common in summer; and eastward it can be traced through Persia and Turkestan as far as Gilgit, while it occurs on the lakes of Sind in winter.

A nest found in the Obrez marsh in Slavonia on May $24^{\text {th }}$ I 883 , is described by Mr. W. Eagle Clarke as a depression in the side of a hummock of sedge about six inches above the water, amply lined with short broad pieces of reed-blade, and containing 7 eggs. 'The colour of the latter is pale olive flecked with dull brown; their shape is oval, and in size they somewhat exceed those of Baillon's Crake: average measurements $I{ }^{\prime}$ by $S_{5}$ in. A newly-hatched chick, to which attention was drawn by the loud clear note of the old bird two days later, was "glossy black with a beautiful dark greenish cast, and had bluish-grey legs." The note is a defiant kik, kik, kik. In food and general habits this species resembles its congeners, but Mr. Hume says that it is more insectivorous than Baillon's Crake, adding that he never flushed it from sedge or reed, but found it running over or swimming among the leaves of the lotus and water-lily, while exhibiting less timidity than the smaller species; he also saw it diving several times, apparently in search of food.

The adult male has the leak green, red at the base; irides red; crown and upper surface generally, olive-brown; back with broad black streaks, and a few small white marks, none of which are on the wings; primaries clove-brown on both webs (without any white outer margin to the first as there is in $P$. bailloni); inner secondaries dark brown in the centre, with broad olivaceous edges; tail-feathers with dark brown centres; chin grey; sides of the head, front of neck, breast and belly, slate-grey; thighs, vent and under tail-coverts minutely spotted with white; legs and toes green. Length $S$ in.; wing $t^{*} 2$ in. The female is smaller, and differs in having the space round the eye pearl-grey; crown, nape and sides of the neck, pale brown; chin white; front of neck, breast and belly fulvous buff-colour; flanks and under tail-coverts greyish, with narrow white bars. The young are still paler on the under parts, and more streaked on the flanks. 


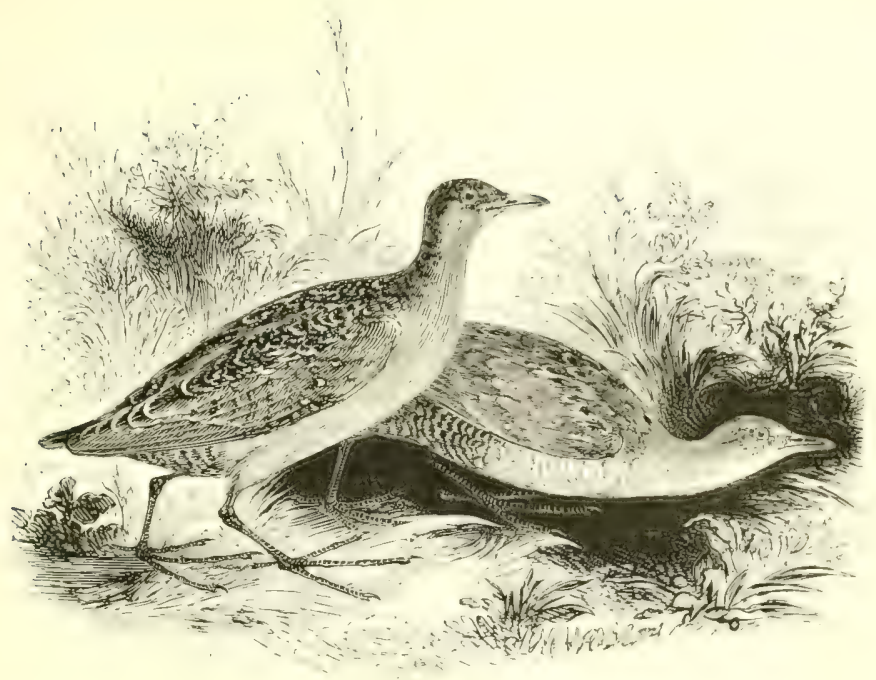

\section{BAILLON'S CRAKE.}

Porzana baillóni (Vieillot).

Baillon's Crake, so named after the distinguished naturalist of Abbeville, is rather more irregular in its visits to England than the Little Crake, and, like that species, is generally observed in spring and autumn; but two nests with eggrs, believed to belong to it, were found in Cambridgeshire in June and August i 858 , while two more were taken near Hickling in Norfolk in June and July I $\$ 66$. There is no evidence that the bird is a resident, though an cxample is said to have been captured on some ice near Cambridge in January I 823. Besides Norfolk, in which about ten specimens have been obtained, it has occurred in suffolk, Derbyshire, Somersetshire, Cornwall, three times in Yorkshire, and once in the Isle of Man. In Scothand once has been recorded by Jardine from Lockerbic, Inumfriesshire, in $18_{42}$, and another (in the Sinclair collection at Thurso) was prob ably killed in sutherland in $18+1$. In Ireland only two atuthenti cated instances are known, both of them from the south.

It is not surprising that Baillon's Crake should occasionally nest with us, for it breeds annually in some parts of Holland, and was, indeed, plentiful in Brabant until the fact beranc known to collectors. In summer it is still numerous in the marshy districts of lirance (especially on the Lower Loire), and round some of the 
Swiss lakes; but it is very irregularly distributed in Germany and is unknown in the Baltic Provinces; M. Taczanowski does not mention its occurrence in Poland; and Mr. W. E. Clarke did not find it in Slavonia, though it appears to be a regular visitor to Lower Hungary, the Black Sea district. and Russia up to about $56^{\circ} \mathrm{N}$. lat. It nests in Portugal and Spain as well as in Northern Italy, while on migration it is found throughout the basin of the Nediterranean, and as a straggler it has occurred in Madeira. In Africa it is widely diffused, breeding as far south as Natal, and has been obtained in Madagascar. Across temperate Asia it ranges from the Caspian to Japan, nesting abundantly in Northern India; and during the cold season it visits Ceylon, the Andaman Islands and Borneo.

The nest, built among reeds or sedge in Europe, but usually in rice-swamps in India, is similar to that of a Moor-hen, and large for the size of the bird: the eggs, $6 \mathrm{~S}$ in number, are olive-brown with darker blotches and streaks-sometimes almost umber-browndarker, as a rule, and rather smaller than those of the Little Crake: average measurements $\mathrm{I}$ in. by $\mathrm{S}$ in. A nestling found by Mr. W. C. 'Tait in June is described as shiny b'ack, with a yellowish bill and greenish slate-coloured legs. It uttered a low piping cry, which was answered by the parent bird close by with a kek-kek-kck; the call-note therefore is similar to that of the preceding species. Baillon's Crake, however. frequents small marshes and pools, especially where there is a fringe of tamarisk or other bushes, and appears to be less partial to meres and open waters than the Iittle Crake. Evening and day-break are almost the only times when it is to be seen, and if disturbed it runs like a water-rat rather than take wing. The food consists of insects and their larvæ, small molluscs, and a little vegetable matter.

The adult male has the bill green, base red; irides red; crown, neck and upper parts generally, warm brown, with flecks of black and white; cheeks, throat and breast slate-grey; flanks and under tail-coverts conspicuously barred with black and white; outer web of first primary white. Length 7 in.; wing 3.5 in. The female has the chin nearly white; the under parts paler grey; the wing-coverts more profusely spotted with white, and the neck streaked with dark brown on a paler ground than in the male. The young bird (in the background; resembles her in the colour of the upper parts, and in the faintness of the white line on the outer web of the first primary; the throat is white, and the under parts are barred with two shades of brown, soon turning to grey in the males. 


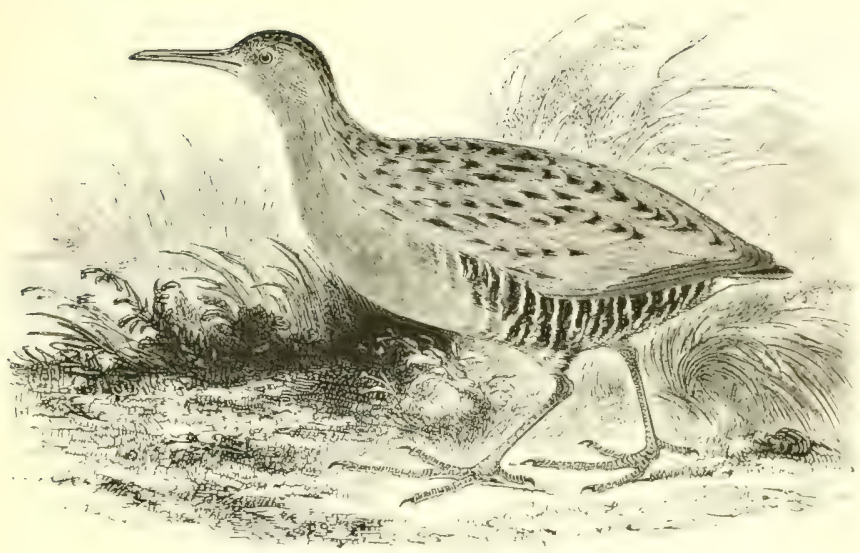

THE WATER-RAIL.

RÁlLUS AQUATicus, Linnæus.

The Water-Rail may be considered a resident in most of the marshy districts of England; but there is evidence that a considerable number of the birds which have been bred in this country move southward in autumn, their piace being taken by emigrants from the north. In the vicinity of the Norfolk 'broads' it is somewhat abundant, and in 1883 upwards of two hundred eggs were received by one dealer from Varmouth, others being supplied as well-a traffic much to be regretted. In Scotland it is found in suitable localities on the mainland, and also on the outlying islands; even passing the winter in the shetlands, where I)r. saxby noticed that, when the frost set in, it would visit enclosed places, such as corn-yards, though he never discovered any grain in the stomaths of the specimens obtained. In Ireland it is also sedentary, though more frequently remarked in winter, when the herbige, which at other times conceals it, is scanty.

This species is only recorded as an autumm-visitor to the liaters, but it appears to remain all the year in Iceland. while on () (n)ber I $5^{\text {th }} 1882$ a single example was obtained as far north as the inland of Jan Mayen. In Norway it has been found up to Ranenfjord (close to the Arctic circle), and near Bergen it is to some extent stationary; but in sweden, except the south we-t, it is only a summervisitor, and it is rare in the Baltic Provinces of Russia, though 
observed as far north as St. Petersburg. In Northern Germany, Denmark, and even in Holland, it is by no means common; but in Belgium, France, and the rest of Europe, it is generally distributed, and in the Caucasus it is found up to a considerable elevation. Eastward we trace it through Turkestan as far as Gilgit; while India, China, Japan, and Southern Siberia are inhabited by closely-allied forms. In Africa it breeds in the marshes of Morocco and Algeria, visiting Egypt and Abyssinia in winter; but in South Africa it is represented by a distinct species, $R$. cerulescens. It has not yet reached the Azores, but an example has been known to settle on a vessel in the Atlantic when 240 miles from the nearest land, and there is a record of more than double that distance.

The nest, which is well concealed in a tussock of sedge, or sometimes among coarse herbage in a willow-bed, is made of flat leaves of the reed; the eggs, 7 -II in number, are pale creamy-white, sparsely flecked with reddish-brown and ash-grey : average measurements $1+$ by $\mathrm{I}$ in. Mr. A. H. Evans obtained some which were slightly incubated as early as April 8th, while fresh clutches are frequently found in June and July, so two broods are no doubt produced in the season. The female, as a rule, slips off and sneaks away on the approach of intruders, but should the clump of sedge containing her nest be surrounded and well beaten out, there is great difficulty in forcing her to take wing ; a solitary person, advancing stealthily can, however, approach sufficiently near for observation, and a dog will often capture a sitting bird. During the breeding-season Water-Rails are very noisy, uttering a loud groaning cro-o-o-an, called 'sharming' in Norfolk. The food consists of aquatic plants, worms, slugs and snails.

The adult male has the bill red; irides hazel; feathers of the crown, hind neck and upper surface olive-brown, with black streaks down the centres ; quills dusky-brown; cheeks, neck, and breast leadgrey; flanks nearly black, barred with white; vert pale buff; legs and feet brownish flesh-colour. Length II $^{\circ}$; wing 475 . The female is duller in colour, and frequently exhibits some distinct white bars on the wing-coverts. The young bird has the under parts of a dull buffish-white, speckled on the throat and barred on the flanks with dark brown; while the upper parts have a more olive tint than in the adult. The nestling is covered with black down. 


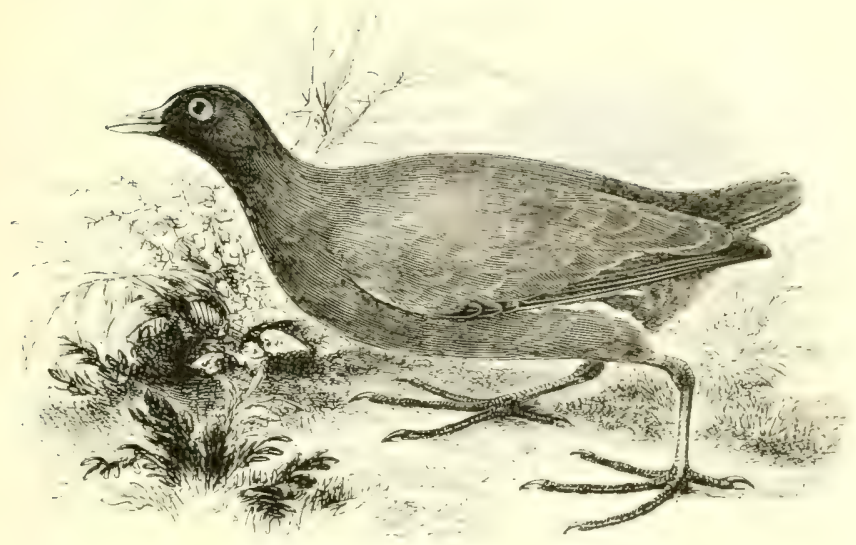

'THE MOOR-HEN.

Crallínula chlóropus (Linnæus).

This familiar species, also known as the Water-hen, is generally distributed throughout the liritish Islands, and is, as a rule, stationary: though a partial migration takes place in winter from the northern districts where the cold weather is severe and continuous. Otherwise the Moor-hen manages to exist very well during frosts, resorting to running streams when ponds are frozen over, and finding shelter in plantations, hedge-rows and thick bushes. Its trivial name had its origin at the time when 'moor' was equivalent to mire or 'marsh.'

The Moor-hen is an irregular visitor to the Froes, and only breeds sparingly in Scandinavia up to lat. $63^{\circ}$, while in Russia it seldom nests as far north ats st. I'etershurg. Throughout the rest of Europe it is more or less common in suitable localities; and it is sedentary in the Canaries, Madeira and the Vores, as well as in Africa north of the Salhara; its numbers in the last being reinforced by migrants from the north in winter. Southward it can be traced along both sides of that continent to Cape colony : hut a remark able island-species, G. nesiotis, is found in the Tristan d'Acunha group, and a separable form, $G$. fyrhwher. inhahits Madagacar, though our bird occurs in Réunion and the Seychelles. From Ceylon and the Philippines northward it is resilent in Asia up t" the main island of Japan, and breeds as tar worth as I ake lanikal in 
Siberia. I closely-allied representative, $G$. salatea, is found in America, and the well-defined $G$. sandricunsis inhabits the Hawaiian Islands; while Gr. tenebrosa, which has no white stripes on the flanks, is the Australian species.

The nest is generally built in wet places, among reeds, sedge and other aquatic plants or the roots of alders; but it is often placed on the low-lying branch of a tree over the water, and exceptionally at an elevation of twenty feet or more from the ground. The materials employed are dry reed-fiags (Ty plac and sedge, matted together, and the birds have been known to raise the structure when an inundation was threatened. The eggs. $;-0$ in number, are buffish-white speckled with reddish-brown : arerage measurements $\mathrm{I} \cdot 65$ by $\mathrm{I} \cdot 2$ in. Incubation, which lasts three weeks, sometimes begins in March, and two if not three broods are produced in the season: the young from the first nest assisting their parents in building another, and even in taking care of the second brood. The Moor-hen usually feeds on slugs, worms, grass, grain when procurable, insects and their larva; but it will also devour the young of other water-fowl, and is very pugnacious towards the latter, as well as to members of its own species. The call-note is a loud crok-rerke, several times repeated, especially towards evening.

The female, which is rather larger and more vividly coloured than the male, has the fore part of the bill yellow, base and frontal plate red; irides reddish-hazel; upper parts chiefly dark olive-brown; head, neck and under parts dark slate-grey, with some white streaks on the flanks; belly and vent greyish; under tail-coverts conspicuously white; legs greenish-yellow, with a red garter above the tarsal joint. Length 13 in.; wing 6.75 . Young birds have the beak, frontal plate, and legs dull green: throat white; under parts ashgrey ; upper surface greyish-olive.

The Purple Gallinule (Porpliyrio curmleus) and the Green-backed (iallinule ( $P$. smarasdonotus) are frequently kept in semi-captivity, and some of the individuals which have from time to time been captured in our Islands have been proved to have escaped; so that it may reasonably be assumed that the others were not genuine visitors. Both species are particularly local inhabitants of the dense swamps of the Mediterranean basin, and neither are addicted to distant migrations. The Martinique Gallinule, $P$. martinicus, a common species in tropical America, is stated by Thompson to have occurred on the south-west coast of Ireland. 


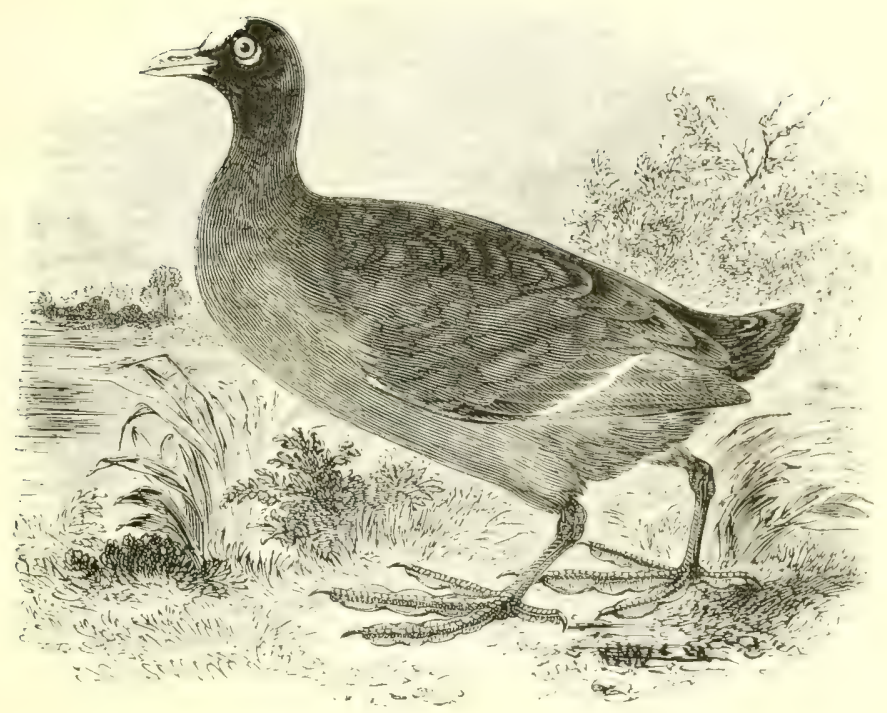

THE COOT.

Fúlica Átra, Linnæus.

The Coot is found upon most of our large ponds, lakes and sluggish rivers throughout the British Islands; though in Fast Anglia, owing to successive drainage of its breeding-haunts, it is less plentiful than it formerly was. It is, however, still abundant on the broads of Norfolk, as well as on Slapton Ley in Devon, where large numbers are killed at the annual battues; also on Southampton Water, and in Poole Ilarbour and other parts of I horsetshire; while on the Nene, in Northamptonshire, Lord Lilford says that it has increased. As a rule it is resident, remaining throughout the winter even in the Hchrides and Orkneys; though only a straggler to the Shetlands. When the inland waters are closed by frost it migrates to tidal estuaries and the sea-coast.

To the Færoes this species is a tolerably regular visitor, and it occasionally wanders to the south-west of Iccland, while a solitary example has even reached Greenland. On the coast of Norway, which is warmed by the (iulf Strearz, the (oot has been found up to $70^{\circ} \mathrm{N}$. lat, and it nests in the southern districts of that country and of Sweden, as well as along the shores of the Baltic, as far as 
St. Petersburg. Southward it is generally distributed over Europe down to the Mediterranean, where, owing to the arrival of migrants from the north, its numbers in winter are sometimes enormous. In the south of the Spanish Peninsula its breeding-range touches that of the Crested Coot, F. cristata, a species which has two bright red caruncles on the frontal plate and is the resident representative throughout Africa; our bird, however, visits the Azores, Madeira, and the Canaries, swarms upon the waters of North Africa and Fogyt in winter, and ranges as far south as the Blue Nile. Eastward, we trace it across temperate Asia to China, and it nests, sparingly, as far south as Cashmere; while in the cold season hundreds of thousands are found on the lakes of Sind, though in other parts of India its distribution is somewhat irregular. Closelyallied forms inhabit Japan, Java, and Australia; and in North America its representative differs chiefly in having a large amount of white on the under tail-coverts.

The nests are strong and compact structures of dry flags, and are usually raised from six to twelve inches above the water on foundations of reeds or tufts of rushes, some of them being so firm as to support the weight of a man seated when up to the knees in water; they are. I believe, often utilized by the Marsh-Harrier. The eggs, 710 in number, are stone-colour, minutely speckled with dark brown : average measurements 2 by $15 \mathrm{in}$. The young, which are hatched towards the end of May, leave their abode after three or four days to follow their parents. In winter, when Coots are in large flocks, they protect themselves against birds of prey by throwing up water with their feet: while they are at all times remarkably wary, for which reason their company is much sought by water-fowl, as they give the alarm by day, when many of the latter are asleep. Hawker says, "If a gentleman wishes to have plenty of wild-fowl on his pond, let him preserve the Cuots, and keep no tame Swans." Their flight is powerful when they are once on the wing, their legs being stretched out behind like those of a Heron; and a wounded bird will scratch like a cat. The food consists of aquatic insects, worms, slugs, and vegetable substances.

The adult has the beak of a pale flesh-colour; the naked patch on the forehead pure white-whence the name 'Bald Coot'; irides crimson; plumage sooty-black below and dark slate-grey above, with a narrow white bar across the wing; legs, toes and webs dark green. Length is in.; wing $S$ in. In the young bird the frontal patch is smaller, the throat is nearly white, and the under parts are grey. 


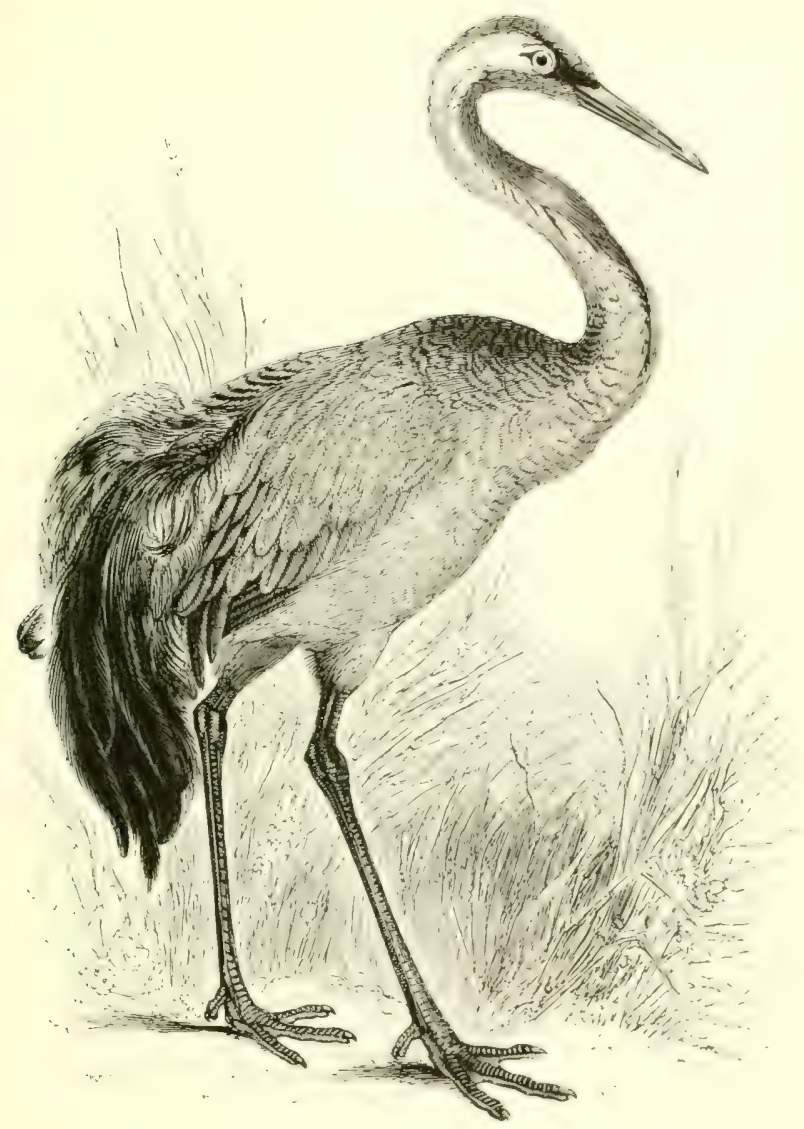

THE CRANE.

Gits commúxis, Bechstein.

There is evidence that until the year I 590 the Crane used to breed in the fens and swamps of the Fastern countics; while its visits in winter continued with regularicy to a hater period, thominh they gradually diminished. In the present century it can only be considered as of irregular occurrence in England, and as still less frequent on the mainland of ficotland: hut a tolerable number have been noticed in the ()rkneys, and even more in the Shetlands. In Ireland few have been obtained : the littest leing an immature male shot in co. Mayo early in January $18 S_{4}$. In esti- 
mating the value of early records respecting its supposed abundance, it must be remembered that the Heron was-and still is-frequently known as the 'Crane.'

On the spring-passage this species sometimes visits the Froes, and wanders as far north as the Varanger-fjord in Norway, while it breeds in the morasses in the south of that country, as well as in Sweden, Lapland, Finland, Russia (down to the Black Sea), Poland (especially on the Tistula), Northern (iermany, Austro-Hungary, the Danubian P'rovinces, 'Turkey, Italy (Tenetia), and Spain (Andalucia). Its loud trumpet-like note may be heard over the greater part of Europe from the beginning of March onward, announcing its return from the southern districts, as well as from Africa, in which its winter range extends to Abyssinia. Eastward we trace it across Siberia to Kamschatka in summer, and to Japan, China, Northern India Sc. during the cold season; while on migration Prjevalski, when at an eleration of I 6.000 feet, observed flock after flock crossing the lofty ranges of Central isia at such an enormous altitude above him that the birds themselves were scarcely visible!

The nest is placed on slightly raised ground in a marsh, and the eggs, usually 2 , though occasionally 3 in number, are of an olivegrey colour, blotched with reddish-brown: average measurements $3 \cdot 8$ by 2.6 in. They are laid towards the end of April in Spain, but in Iapland Wolley did not find them till a month later. The food consists of grass, grain, pulse, acorns, the tubers of the sweet potato, water-melons $\mathbb{E c}$, with bectles and other insects in winter; while in captivity I have seen a Crane capture and swallow a Sparrow.

The adult has a red warty patch on the crown; general plumage slate-grey; inner secondaries long, drooping, and bluish-black in colour. Length +8 in. ; wing $2 \mathrm{I}$ in. The male is larger and rather darker than the female. The young have no red on the head; the upper plumage is greyish-brown, and the hind plumes are short. Breeding does not take place till the third year.

A male example of the l)emoiselle Crane, Grus airgo, is said to have been shot at I)eerness, East Mainland, ()rkney, on May i $4^{\text {th, }}$ I $86_{3}$, a companion bird being pursued, but not obtained (Zool. 1). 8692). This inhabitant of Africa, Asia, and the south of Europe, has wandered as far north as Sweden and Heligoland; it is also frequently kept in confinement. An African Crowned Crane, Balearia parinina, was killed near I)alry, Ayrshire, on Sunday, September I 7 th, I $87 \mathrm{I}$. 


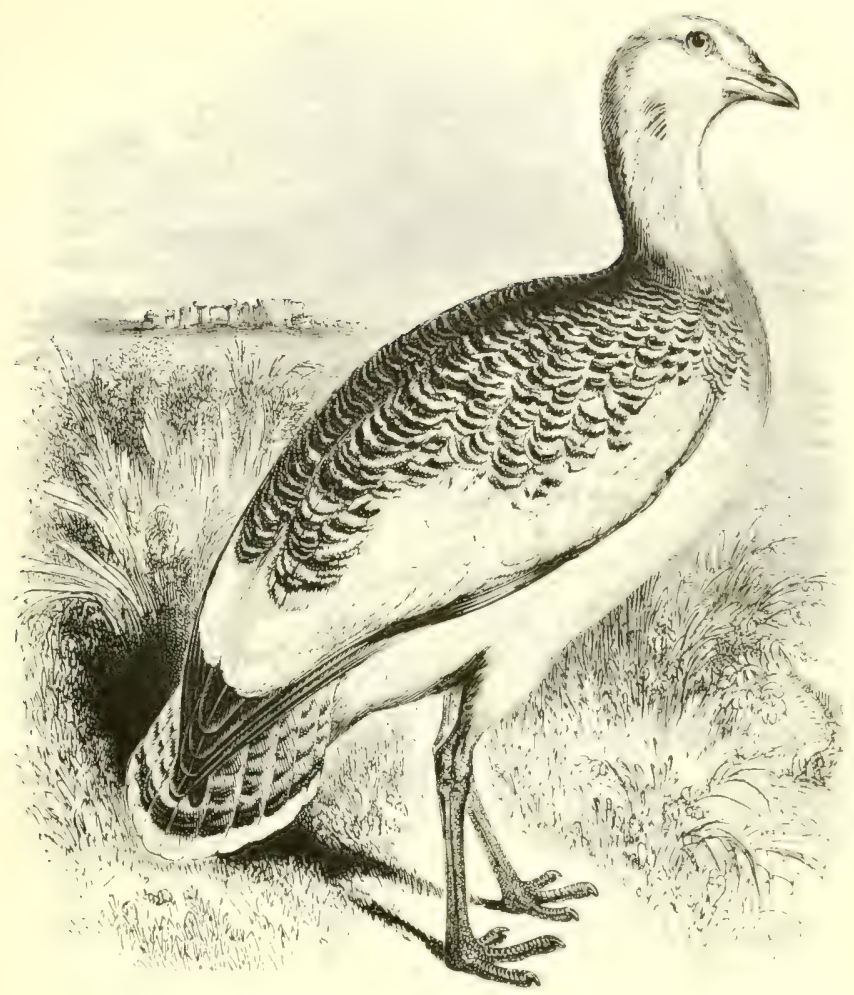

\section{THE GREAT BUS'TARI.}

OTIS TÁRDA, Linnæus.

Until the year ${ }_{5} 26$ the Great Bustard used to breed, sparingly, as far north as the flat portion of the Lothians, on the Scottish side of the Border; and southward it was common on the moors, extensive downs and plains of England, to the Channel. Enclosure, the planting of trees, and the increase of population contributed to the gradual diminution of its numbers, and it passed away, unrecorded, from Berkshire, Hertfordshire, Canibridgeshire, the wolds of Lincolnshire and the downs of sussex, while the first ten years of this century saw the extinction of the birds indigenous to Salisbury P'lain. On the Eastern Wolds of Vorkshire the survivor of former droves was trapped in $18,32-33$; and in Norfolk and Suffolk the last fertile eggs were taken about is s s though a few birds lingered to a somewhat later date. The Bustard is now only an 
irregular wanderer to Great Britain-exceptionally as far north as the Orkneys; the winter of $1870-7 \mathrm{I}$ being signalized by the arrival of a considerable number, while a smaller migration was noticed in England in the winter of $1879-80$, coinciding with a visitation in the northern and central provinces of France.

In Denmark, and in the south of Sweden where it formerly bred, this species is now of only accidental occurrence, and in Russia it is seldom found further north than Moscow, though southward it is plentiful. It is still resident, except in severe winters, on the plains of Germany--especially near Leipzig, and in Poland it is widely distributed; on the steppes of the Danubian and Black Sea districts it becomes abundant, and it is also common in suitable portions of the Spanish Peninsula; but to the rest of Europe it is chiefly a visitor. In Morocco and North Africa generally it is rare. North of the great mountain ranges in Asia, it can be traced to Manchuria, China, and Japan, and a flock has been known to wander as far as the valley of the Indus; but in Eastern Siberia its representative is a very closely-allied species, O. dyborcskii.

In spring the males fight furiously for the possession of the females, but afterwards they live apart in small droves, and towards the end of May they moult their quills, remaining for some time unable to fly; otherwise the liustard is very strong on the wing, and the idea that it habitually secks safety by running is a popular error. The eggs, laid in a bollow scraped in the ground, are 23 in number, and are olive-green blotched with brown: average measurements 3 by $2^{\circ} \mathrm{I}$ in. Incubation, which lasts rather more than three weeks, begins in April in spain, though later in the north; the young are soon able to run and hide themselves. Green corn, peas, clover \&c., are the chief articles of diet, but worms, small mammals and reptiles are also eaten. Old males sometimes weigh upwards of 30 lbs., and their flesh is coarse, but the hens and young are excellent for the table.

The adult male has a tuft of long brisily white feathers at the base of the bill on each side; head bluish-grey; upper surface chiefly ochreous-yellow barred with black; wings white, except the primaries, which are brownish; breast banded with rich chestnut and grey; belly white. Length 45 in.; wing 245 in. The female has no bristles or pectoral band, and is much smaller; wing 19.5 in. The young resemble the hen. In the adult males of this and some other Bustards there is a large sub-lingual air-pouch, which is capable of great dilation during the love-season, though at other times almost invisible. 


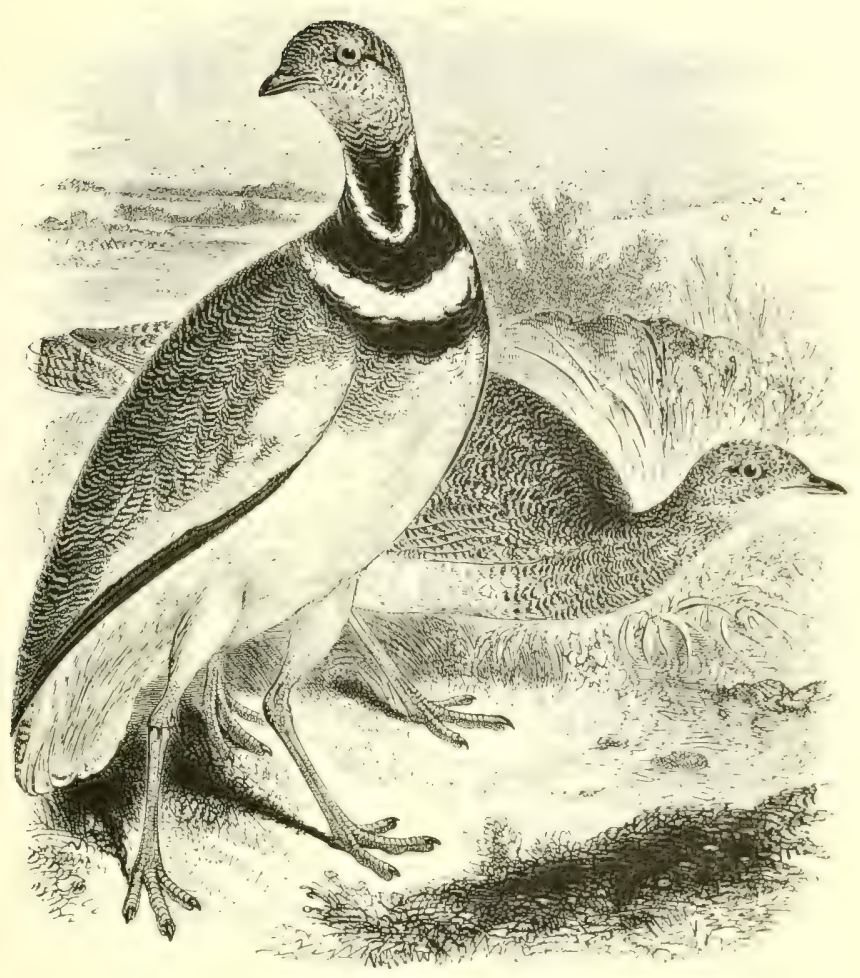

THE LITTLE BUSTARD.

OTIS TÉTRAX, Linnæus.

The Little Bustard was never more than a straggler to the British Islands, and, since its presence was first noticed in $175 \mathrm{I}$, most of the occurrences recorded have been during the colder half of the year. The majority of these have been in the southern counties (notably Cornwall), or in the castern half of lingland (especially in Suffolk, Norfolk, and Vorkshire); while als remards Scotland the four known instances have all been on the east side. In Ireland, two have been obtained in the south and one in co. Mayo, the last in December I $88 ;$.

As a wanderer the Little Bustard has been noticed as far north as Scandinavia, the German side of the Baltic, and the st. l'etersbure district. In May r 883 its nest was found near Fithroflin (nouth of Berlin); while it breeds freely on the undulating plains which struth 
across France from Marne to La Vendée, where it has greatly increased of late years, arriving about the end of March or early in April and leaving in September. In the Spanish Peninsula it is common on broken or rolling ground, above the dead level preferred by its larger congener; but to the north of Italy it is only a visitor, though resident in the south, and in Sicily and Sardinia. In Central Europe it is rare, though still tolerably plentiful along the valley of the Ianube, as well as in the Balkan Peninsula, Turkey, Greece, and Southern Russia. Eastward its range extends to Turkestan, and on migration it is known to cross the lofty Pamir plateau on the way to its winter-quarters in North-western India. In Africa north of the sahara it is abundant, being well known in Algeria and Tunis by the name of "Poule de Carthage."

The male assumes his breeding-plumage in April, at which time he selects a spot about three feet in diameter, on which he passes several hours each day, with head and neck thrown back, wings somewhat extended, and tail erect, pouring forth his peculiar cry of frut, prut, jumping up at the conclusion of each call, and striking the ground in a peculiar manner on his descent. At this season Mr. Ahel Chapman found that the throat became much dilated. Conflicts take place for the females, but instead of uniting in flocks whilst the latter are incubating, each male is to be found in the vicinity of a hen. The nest, slightly made of dry grass, is placed on the ground, among herbage sufficiently high to conceal the bird; the eggs, $3^{-4}$ in number, are of a very glossy olive-brown or pale green, clouded with darker patches, and often beautifully zoned with rufous: average measurements $I^{\circ} 95$ by $I \cdot 5$ in. The first clutch is laid about the end of May, a second being frequently produced in the latter part of July. 'The food consists of herbs, grain, insects, slugs, small snails, frogs, field-mice $\& c$. The male rises with a loud clatter of his wings, but the female sits remarkably close. In autumn the birds unite and form large packs, which afterwards break up into smaller parties.

The male in spring has the cheeks and throat dark grey enclosed by a white loop, below which is a broad collar of black, followed by a band of white and then another of black; crown and general upper plumage sandy-brown, vermiculated with black; wing-coverts and under surface white. In winter the feathers of the neck and breast are sandy-brown streaked with black, as in the female; the latter differs chiefly in having the upper parts blotched-rather than vermiculated-with black. Length 17 in.; wing 9.5 in. The young are like the hen, but rather more barred on the flanks. 


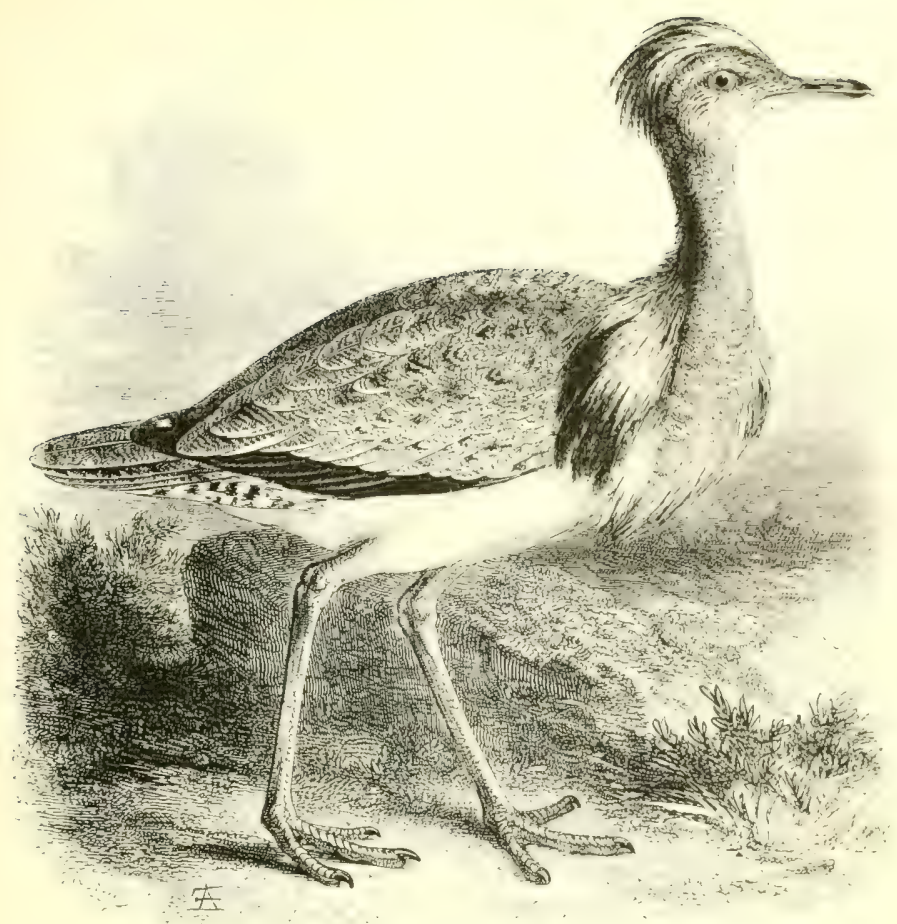

\section{MACQUEEN'S BUSTARI).}

Otis macquenit, J. E. Gray.

This species, which might with advantage be called the Asiatic Ruffed Bustard, nccasionally wanders across Europe, and in October I 847 a bird-now in the Museum of the Philosophical fociety at York-was shot by Mr. G. Hunsley in a stubble field near Kirtenin-Lindsey, Lincolnshire. 'This is the only instance of its occurrence in the British Islands down to the present time.

It is tolerably certain that the five Ruffed Bustards recorded from Northern Germany between the years 1 soo and i $S .47$ wete all examples of $O$. macoutecti, and not of its closely-allied Ifrican representative, $O$. undulata: the existence of two distinct species being unknown to Naumann and others. I genuine Macqueen's isustard, killed near Utrecht in December 1850 , is in the Muscum at I, iden. while three specimens have been obtained in liclyium, one on the Swedish island of Ocland, one (out of a flock of siv) in sichleswiy, 
one in Poland, one in Silesia, one near Helsingfors in Finland, and one in Lironia towards the end of September $\mathbf{1} 850$, the latest occurrence on record. In Italy two females were obtained near Rome in November and Iecember 1859; but in Malta, Sicily, and Southern Spain the bird occasionally met with is the African Ruffed Bustard. In the Aralo-Caspian region Macqueen's Bustard is resident, and eastward we trace it to the steppes near Lake Balkash and to the Altai Mountains; while on migration it crosses the Pamir to pass the cold season in Northern India, where it appears in September and leaves again in March. In the semi-desert districts of Sirsa and Kurrachi, in sind, it is sometimes so abundant that fifty have fallen to a single gun in a day. It is also found in Afghanistan. Paluchistan, and in Pursia from the Gulf of Oman to the Caspian.

I am not aware of any published account of the nidification of this Bustard, though of late years a tolerable number of eggs have been received by Herr Tancre from the vicinity of the Altai range (lat. $50^{\circ} \mathrm{N}$.), in the extreme south of the Russian province of Tomsk. All that I have seen are olive-brown with darker blotches, and with less of a creenish tinge than is found in some of those of the Great Bustard : arerage measurements of 3 (a clutch) in the collection of $\mathrm{Mr}$. E. IBidwell 2.55 by 17 in. P'robably this species is not polygamous, for $1 \mathrm{r}$. Hume never observal any preponderance of females over males. It frequents sandy wastes studded with low bushes, among which it runs with great rapidity. feeding largely on the small fruits of the Bir, the berries of the Gretial, and young shoots of lemon-grass, with a few grasshoppers or beetles. The specimen killed in Lincolnshire had its crop filled with caterpillars of the yellow-underwing moth, small-shelled snails \&c.

The adult male has a crest of white feathers tipped with black, and a ruff, which is chiefly black, on the sides of the neck; upper parts pale buff, fincly vermiculated with black; tail washed with rufous, crossed with three black bars, and tipped with white; throat pale grey; breast bluish-grey: abdomen white. Length 26 in.; wing $15^{\circ} 5 \mathrm{in}$. The female is a little lighter in colour, and has the crest and ruff less dereloped. In the African Ruffed Bustard, O. undulata, the ground-colour is more rufous, the vermiculations are coarser, the tail is broadly crossed with five dark bars, and the elongated feathers of the crest and lower throat are white. The latter species, it may be remarked, is common on Fuerteventura and occurs on Lanzarote, the nearest of the Canary Islands to Africa. 


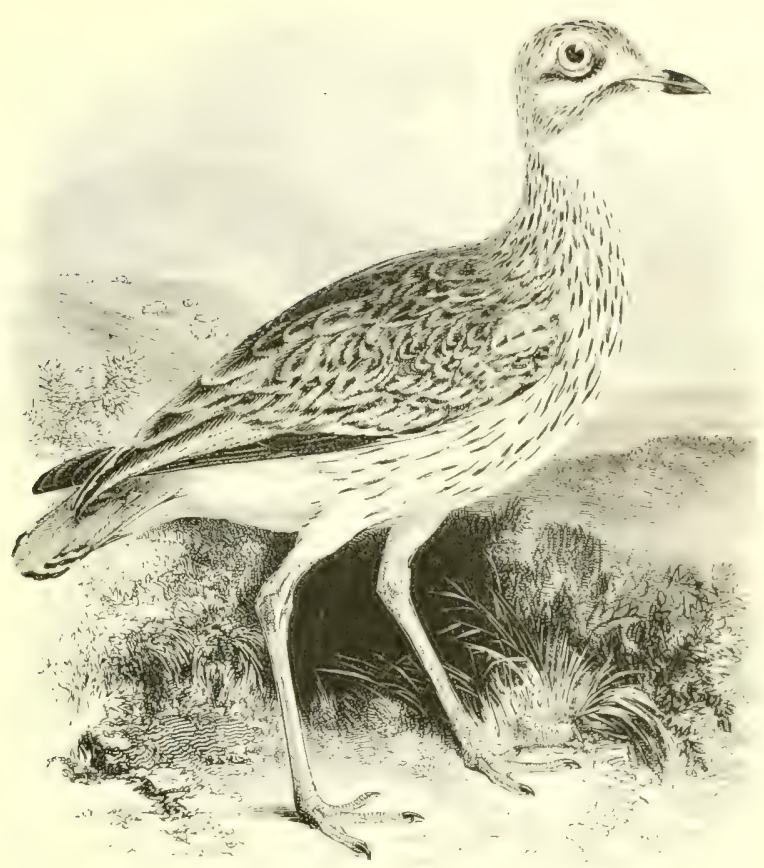

THE STONE-CURIEIV.

CEdicnémus scólopax (S. G. Gmelin).

The Stone-Curlew is often called the Thicknee, owing to the swelling observable at the knee-joints in young birds, which disappears with increasing age; while another name for it is Norfolk Plover, with reference to its comparative abundance on the extensive 'brecks' of East Anglia. As a rule it comes to this country in April, and after assembling in flocks in the early autumn, lcares in October; but in open weather a few have been known to remain until I)ecember, even in Suffolk, while in the mild climate of cornwall and South Devon a tolerable number pass the winter. The localities to which it is partial are chalk downs, open heaths, and dry sandy soils, such as are found in lorset, Wilts, Hants, Susse' Kent (where it breeds down in Romney Marsh as well as on the neighbouring uplands), larkshire and on the north side of the Thames, in Bedfordshire, Ifurtfordshire, ('mbridgeshirc, suffelk and Norfolk. It is also known to have nested in Rutland, Notts, and Worcestershire, and on the wolds of I.incolnshirc and liast 
Yorkshire; but northward it is of very rare occurrence, while west of Herefordshire it is almost unknown. In Scotland one has been obtained near St. Andrews; in Ireland, according to Mr. More, only six or eight examples have been met with.

This species is only a straggler to Denmark, but it breeds, though sparingly, in the northern districts of Germany, and is found in summer throughout the temperate portions of Europe where the localities are suitable; while south of the Alps and the Carpathians it is to a great extent resident, as it also is in the Canaries, and probably in Madeira. It inhabits North Africa, Egypt, and the coast of the Red sea, but in Somali-land its representative is IE. afiinis, clusely related to the widely-distributed South African (E. capinsis. In Asia our bird has not been noticed further north than the wastes near the Saisan Lake (below the Altai range); southward, in . J fuhanistan and India, reaching to Burma, a slightly different form occurs--chiefly on sandy soils, though in Ceylon it also frequents the cinnamon-gardens. Other members of the genus are found in various parts of the African, Indian and Australian regions, as well as in the tropical portions of America.

The cygs, usually 2 in number, are pale clay-brown, spotted and streaked with ash-grey and umber: average measurements $2^{\circ} \mathrm{I}$ by $I_{5}$ in. They are laid in a mere hollow scraped in the moor, or on the sand, among scattered stones, which they much resemble; specimens from arid localities in the south of Europe, Africa, and India being as a rule pale in colour and small in size. The male often incubates during the day. Worms, slugs, and insectsespecially nocturnal beetles-form the principal diet of the StoneCurlew, though it also eats such small mammals as field-mice, as well as frogs and reptiles. Its loud and clear cry is chiefly heard after dusk, and on moonlight nights the birds are very noisy, but during the day they are usually silent.

The adult bird has the beak black at the point, greenish-yellow at the base; irides very large and golden-yellow; feathers of the upper parts pale brown, with dark streaks down the centres; wing-coverts with dull white tips which form two narrow bars, quills nearly black; throat and a streak below the eye, white; neck and breast buff, streaked with dark brown; belly paler; vent and under tail-coverts almost white; legs and feet yellow. Jength $I 7$ in.; wing $9^{\circ} 75$ in. The sexes are alike in plumage; the young are rather duller in colour than the adults, and have more bars on the tail-feathers. 


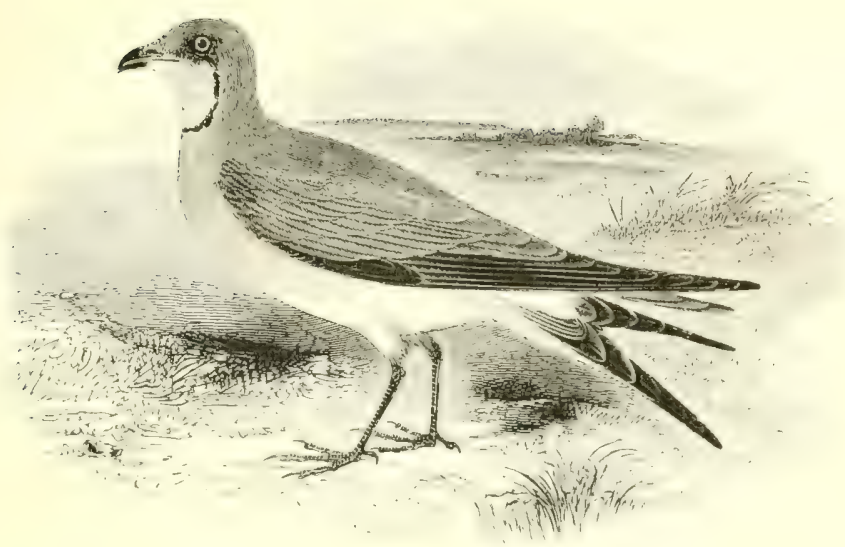

THE PRATINCOLE.

Gíákeola pratíncola (linnæus).

Even to the south of Europe the Pratincole is only a summer visitor, though on both spring and autumn migrations it occasionally wanders to Great Britain. Its occurrence was first noticed in I 807 , when examples were obtained almost simultaneously at ()rmskirk in Lancashire and Bowness in Cumberland, while subsequently four specimens have been taken in Norfolk, one in Cambridgeshire, one in Lincolnshire, three in Yorkshire, one in Northumberland, and one, strange to say, in Unst, the most northern of the Shetland Islands. In the south of England, Hants, I)orset, Wilts, Somerset, Devon and Cornwall have been visited; and a bird has been observed near Hay in Breconshire by Messrs. Baskerville, who were well acquainted with the species. In Ireland one, which was not preserved, is said to have been shot nearly fifty years ago in co. Cork, and the identification was probably correct, for all the evidence that I have been able to collect indicates that this species reaches our shores by traversing the western half of France.

Early in April the Pratincole returns from its winter-quarters in the south to North Africa, where large numbers remain to lirees: while others pass through ligyjt and nest in l'alestinc, I wia Minor, the I)obrudscha, the neighbourlood of Misolonghi in (ircece sicily, the Balearic Islands, and the plains at the mouth of the Guadalquivír in Spain. In other parts of the Mediterranean basin it is 
chiefly known as a migrant, though some may remain on the west coast of Italy, along which the 'Pernice di mare' is well known on passage. It continues its course to the Camargue in the south of France, where again it finds suitable breeding-ground; a few ascending the valley of the Rhone to savoy, and spreading out over the central, western and northern districts of France as far as the mouth of the Somme. In Belgium, Holland, Denmark, and (iermany-according to the latest authorities-it is not known, the mountain ranges of Central Europe forming, apparently, a barrier which it does not cross; and, though found in Austro-Hungary, it is very rare in Poland; while in Southern Russia and on the eastern sicle of the black sea the representative form is $G$. melanoptera, which has black-instead of chestnut - under wing-coverts and axillaries, with no white alar bar. Both of these forms (as well as one that is intermediate) are found in Asia, especially on salt-plains, as far east as the Tian-Shan range; and both occur in South Africa down to Natal in the cold season. There are several other members of the family in the Ethiopian, Indian and East Australian regions, but none are known in the New World.

Early in May the eggs, 2-3 in number, are laid, with their axes parallel, on the sun-dried mud which has been covered with water during the winter-rains; the shell is thin, the form very oval, the ground-colour buff or grey, marbled and zoned with black or purplishbrown spots: average measurements I'I5 by '9 in. The note, when the breeding-place is invaded, is a shrill kia, kia, kiaria; the birds swooping close to the intruder's head, and also cowering over the soil sideways or with extended wings, though this proceeding does not necessarily indicate the proximity of their eggs or young. The flight is very Tern-like, but when on the ground the bird runs with great rapidity. The food-often taken on the wing-consists of insects, especially beetles, grasshoppers and locusts.

The adult has the upper parts clove-brown; tips of secondaries, tail-coverts, and bases of the tail-feathers white; throat buff, enclosed by a narrow black bridle; breast brownish-buff; belly white; axillaries ruddy-chestnut. Length $10^{\circ} 5$; wing 7.5 in. The sexes are alike in plumage. In the young bird the upper parts are much mottled and barred with black and grey, and the breast is profusely striped with dark brown. The nestlings are clove-brown with slight mottlings on the upper parts, and white below; they can run, like Plovers, on emerging from the shell. 


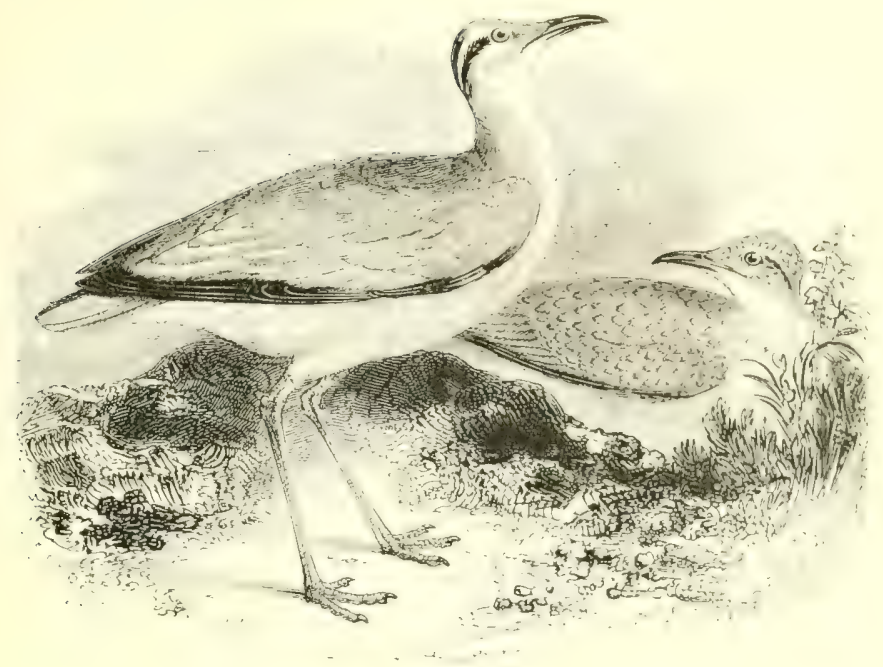

THE CREAM-COLOURED COURSER.

Cursórius gállicus (J. F. Gimelin).

The Cream-coloured Courser is only an irregular wanderer to the countries north of the Mediterranean, and its specific name is purely owing to the fact that the bird was first described from an example killed in France. Although, however, an inhabitant of southern and even desert localities, yet--such are the eccentricities of migration-its visits to (ireat Britain haveloeen, with one doubtul exception, between the early part of October (in which month six individuals are known to have been killed) and December. Kent, Middlesex, Suffolk, Norfolk, i.incolnshire, Vorkshire, Vorthumberland, Cumberland, Leicestershire, 'North Wales' in 1793 and Cardiganshire in October I 886 , ('ornwall, Devon, somerset. 1) rset. Wilts and Hants, may be enumerated among the districts in which it has been identified; about a score of specimens having been obtained altogether, inclusive of one shot on October Sth r 868 in Lanarkshire-the only instance in Scotland. It has not yet been noticed in Ireland. A bird killed about the autumn of 1860 near St. Michaels-in-Wyre, Lancashire, and recorded as a coursert hats since proved to be an example of the Sociable Plover, Vandlus gregarius, to be noticed hereafter. 
As a straggler this species has once occurred in Holland, three or four times in Northern and Central (iermany, and to about the same extent in France. Even to the south of the latter, as well as to Spain and the mainland of Italy, its visits are rare and irregular, though somewhat more frequent in Sicily and Malta; in Bulgaria and the Dobrudscha it is unknown, and it is only a wanderer to the steppes of South Russia. In the west its true home commences at the Canary Islands, on some of which, especially Fuerteventura, the bird is fairly numerous; while eastward it inhabits Africa north of the Sahara - where Canon Tristram obtained the first eggs on record, and southward it is found in Kordofan, as well as on both sides of the Red Sea. Through Arabia we follow it to Persia, Baluchistan, Northern India and Afghanistan; but birds found within the fluctuating Russian frontier near the Murgab have been separated by M. \%aroudnoi as var. logeluluit. Other members of the genus inhabit portions of Asia and Africa ; that most closely allied to the present species being a native of Somali-land.

In the Canaries. Mr. Meade-Waldo obtained young birds by March 23 rd, on the barest parts of the desert, where the stones were mostly small; but in India the laying-season varies from March to August, according to the time of the rains. Most of the eggs in European collections are the produce of a bird which was brought to Favier of Tangiers in I $_{5} 5 \mathrm{I}$ and laid them at irregular intervals until s 859 ; their colour is stone-buff, marbled with purplish-grey and blotched with brown: measurements of one obtained by Canon Tristram I'3 by ros in. Mr. Hume says that those in his large series from the Punjab are rather smaller and darker; his experience and that of other observers is that 2 form the clutch. The food consists of insects and small molluscs. The note emitted by the female is syllabled by Favier as rererer.

The adult has the beak dark brown; irides hazel; forehead and crown of a sandy-buff, turning to grey and deepening to slate-blue margined with black on the nape; from the eye to the nape a white streak, with a narrow black stripe below: upper surface generally sandy-buff; quills, under wing-coverts and axillaries black; under parts pale greyish-buff, gradually passing into white at the vent; legs greyish. The sexes are alike in plumage. Length ro in.; wing 6 in. The young bird (in the background) is more rufous in tint, and has no grey or black on the nape, while the eye-stripe is buff instead of white; the feathers of the throat and the upper parts have dark crescentic markings. 


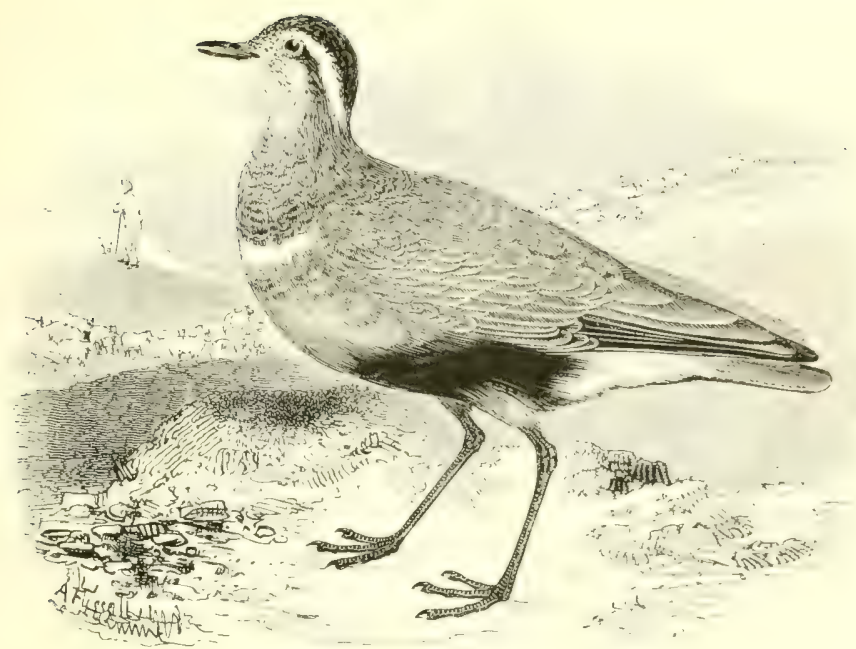

THE DO'TTEREL.

EUdrómias Morinéllus (Linnæus).

The Dotterel usually makes its appearance in the southern and eastern counties of England towards the end of April or early in May, according to the season; leaving for the south in August or the beginning of September. It is somewhat partial to the chaikformation and was formerly abundant along the low hills on the borders of Hertfordshire and Cambridgeshire, on its way to the mountains of the Lake district where it has long been known to breed, although at the present day its numbers are sadly diminisheel. This decrease is not attributable to the greed of the ornithologist or the egg-collector, but to the esteem in which its feathers have been held by anglers for dressing artificial flies; and still more to the slaughter of the bird for the table on its spring passage--a proceed. ing which has barely been checked by an inefficient and feeblyadministered law. On migration the Dotterel often lingers on the marshes-by which I do not mean wet swamps near the sea-coast on both sides of our island, and is of tolerably wide distribution. except in Wales, where it is of very rare occurrence. None remain during summer on the Cheviots, along which the 'trips pass on their way northward in spring; but Mr. survice informs me that a few pairs nest on the (ialloway and l)umfriesshire lills, while further north the bird breeds on the (irampians, especially on the 
borders of Perthshire and Inverness-shire, as well as in Ross : perhaps in sutherland. It visits the Orkneys and Shetlands, but has not yet been recorded from the Outer Hebrides, and is of rare occurrence on the west side of Scotland. In Ireland it is decidedly uncommon at any season.

Is a wanderer this species has been observed in Novaya Zemlya, and it breeds in considerable numbers on the fells of Norway and sweden; also throughout the tundras of European and Asiatic Russia as far as Bering sea, and in the mountain regions of the Ala-tau and other ranges in Eastern Siberia. It is not known to visit Mongrolia, but it panses through Western Turkestan and occurs in Persia, while Palestine, Egypt and Northem Africa appear to constitute its principal winter-quarters, where it is very abundant. Throughout the Mediterranean hasin it is only a migrant, as it is over the central part of the Comtinent, with the exception of the highlands of 'Transylyania, Styria and Bohemia, on which its eggs and young have been taken.

Mr. lirank Nicholson, who has been in the habit of exploring the lake district for more than thirty years, says that the Iyotterel usually lays its egrgs, never exceeding 3 in number, in a depression of the short dense grass, a little below the summits of the mountains; their colour is yellowish-olive, blotched and spotted with brownish-black, and the average measurements are $r \cdot 6$ by $I^{\prime} \mathrm{I}$ in. Inculation seldom begins lefore the first or second week in June. The food consists of wireworms, beetles and other insects. The trivial as well as the scientific name of this bird refers to its supposed stupidity and the ease with which it allows itself to be approached by a fowler with a net, while watching and even imitating his movements.

The adult has the crown nearly black, bordered by a broad white loop which runs backwards from each eye and round the nape; feathers of the upper parts ash-brown, with paler edges and rufous margins to the inner secondaries; tail-feathers-except the central pair-broadly tipped with white; chin and throat dull white; breastfeathers ash-brown, tipped with black at their junction with a white gorget, followed by warm chestnut on the lower breast and flanks; belly black; tail-coverts white; axillaries greyish. Females are somewhat larger and brighter than males. Length 9 in.; wing 6 in. The young bird has the feathers of the crown and upper parts margined with rufous-buff, especially the long inner secondaries; breast mottled with greyish-brown, and with little indication of the white gorget; remaining under parts dull white. 


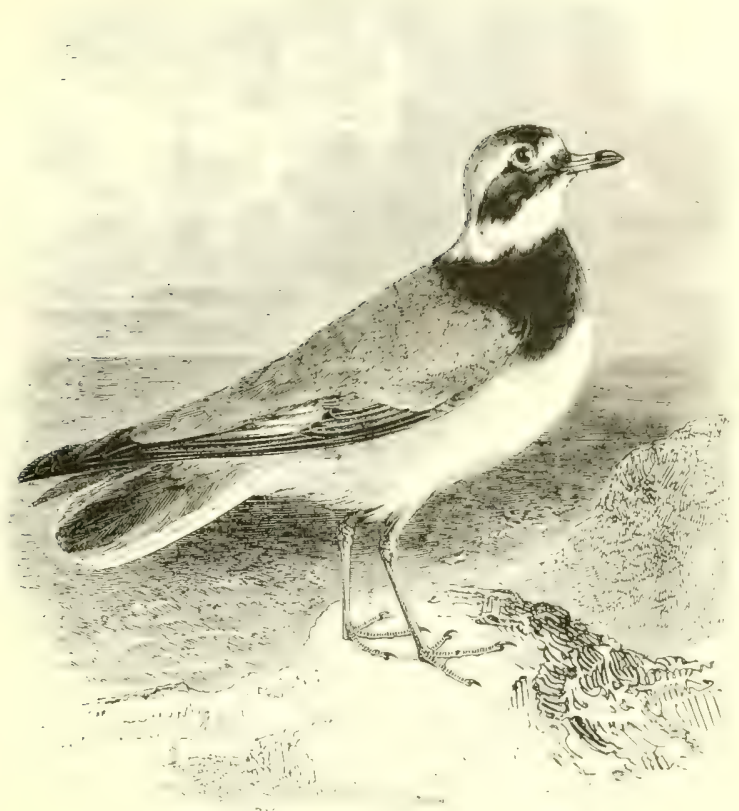

THE, RINGED PLOVER.

\section{Aigmalítis hiatícula (Linnæus).}

This bird is sometimes called the Ringed Ilotterel a name to be deprecated as having led to confusion with the preceding speciesand locally 'Stone-hatch' or 'Sand-litk.' Throughout the IBritish Islands the Ringed Plover is generally distributed along the that portions of the coast, as well as on sandy warrens and inland lakes at some distance from the sea, while on migration it is alsu found by the banks of rivers. The birds which are more or less resident here, and on the ofposite shores of lirunce and Holland. as well as those which arrive from the north in autumn, are larger, more bullet-headed, and duller in the colour of the mantle than those which come from the south in spring, and leave us after a short stay-of which, perhaps, a few remain to breed in Kent and Sussex. Many individuals of this smaller race have been errone.

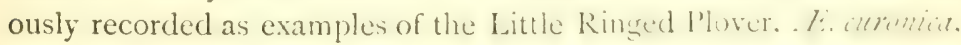
which wili be discussed next.

In summer the Ringed Plover has been found on Jan Mayen, and even at lat. $80^{\circ} 45^{\prime}$ (beyond Spitsbergen), as well as up to $79^{\prime}$ 
in (rreenland and on the opposite side of Smith's Sound; but in America its representative is .E. simifalmata, a smaller species with more developed webs between the toes. In Iceland our bird arrives in May and leaves in September, while on the Continent it inhabits most suitable localities, becoming rarer in the interior of compact countries like Russia, and more abundant in those which present a varied coast line, or are intersected by large rivers. It occurs in Novaya Zemlya, and along the northern shores of the Old World as far as Bering Strait: from which regions it emigrates on the approach of winter The small race already mentioned breeds down to Madeira, the Canaries and Northern Africa, visiting the extreme south of that continent and also Egypt in the cold season; in Central Asia it nests on the large salt lakes down to Turkestan, and it occasionally wanders to the north of India; while Gould states that he received a specimen from Port Stevens, Australia.

The nest is usually a mere shallow cavity in the sand, sometimes lined with small stones, but Col. H. W. Feilden has recorded an exceptional instance in which the green fleshy leaves and stems of Atriplex littoralis were employed. Laying becomes general by the middle of $A$ pril, and two broods are usually produced in the season, freshly-hatched young being often found in the first week of August. The eggs are 4 in number, pear-shaped, and of a stone-buff colour, spotted with black: arerage measurements $I^{\circ}+$ by $\mathrm{r}$ in. Various devices are practised by the parents to divert attention from their nestlings, though the latter can run as soon as they emerge from the shell, and are not easily scen, owing to the similarity of their colour to the surroundings. The food consists of worms, insects, and thinskinned crustaceans, such as shrimps, sanc-hoppers \&c., particles of grit being taken to aid digestion. The usual note is a melodious whistle, and the alarm-cry may be syllabled as pen-y.et, but during the pairing-season the cock has a distinct love-call.

The adult male in spring has the forehead and a stripe behind each eye white; fore-crown, lores and sub-ocular region black; chin, throat and neck white, followed by a black collar, broadest on the breast; nape and upper parts hair-brown, with a narrow white alar bar; outer tail-feathers chiefly white, the rest brown with white tips; lower breast and belly white; bill black at the point, yellow at the base; legs orange. Length 775 ; wing 55 in., in the smaller Continental form only 5 in. The female has the black collar less defined, and in winter both sexes are duller in colour. The young bird has the beak blackish, no black band on the fore-crown: loral stripe and gorget dusky brown; legs pale yellow. 


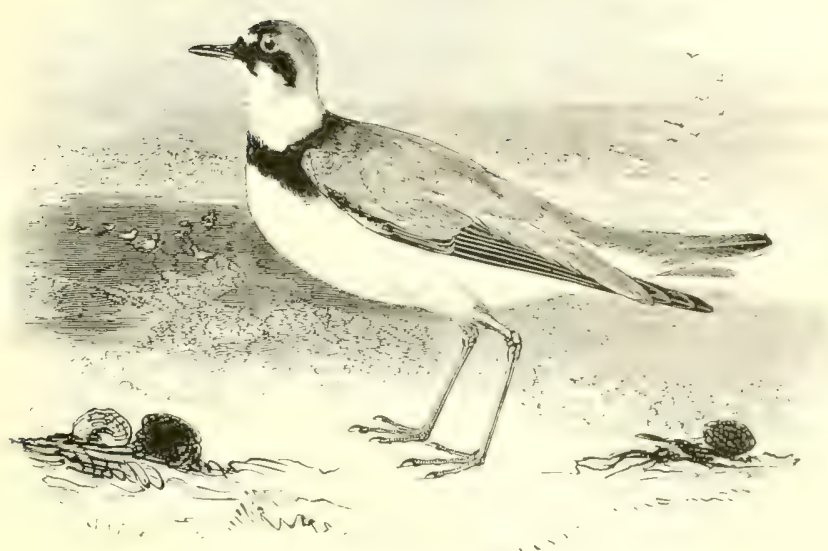

THE LITTLE RINGED PLOVER.

Egialitis curónica (J. F. Gmelin).

The true Little Ringed Plover is one of the rarest of our occasional visitors, and the genuine instances of its occurrence appear to be the following: Years ago I oubleday ohtained an example at Shoreham in Sussex, and Mr. W. Borrer has another, shot near the mouth of Chichester Harbour, in May; Rodd's collection contains one killed on October $23 \mathrm{rd} 1863$, at Trescoe in the ticilly Islands: while on Kingsbury Reservoir in Middlesex, in August 1 \$\$ 64, Mr. Harting and Mr. R. H. Nitford each obtained an immature bircl. Others have been recorded from time to time in "The Zoologist" and elsewhere, but all those which have been submitted to com petent authorities have proved to be specimens of the small continental form of the Ringed Plover, and some, indeed, are now candidly admitted by their possessors to belong to that species. The distinctions between the two are mentioned at the end of this article.

It is somewhat remarkable that the Little Ringed l'losur should so seldom visit us, inasmuch as the bird has been recorded from the Frroes, and is said by Mr. B. Gröndal to be a wanderer to Iceland, while, according to Bogdanow, it occurs sparingly ats fur north as $64-66^{\circ} \mathrm{N}$. lat. in Russia and Asiatic Siberia. It owes its specific name to its occurrence in courland, and it hecels alum 
dantly in Poland and (iermany, less plentifully in Scandinavia and Denmark, and seldom in Holland and Belgium, where localities suited to its tastes are wanting. It does not affect the open seacoast, preferring expanses of sandy soil by inland lakes or large rivers, and these it finds in some parts of France, the Spanish Peninsula, Italy, the south of Europe generally, and Northern Africa. In Asia, besides siberia as already mentioned, it nests in 'lurkestan up to an altitude of 4.000 feet, China anci Japan; it visits India as far as ceylon during the cold season, and ranges southward to the Moluccas and New Guinea. In Africa it has been recorded from as far down as . Iozambique on the east and the Gaboon on the west. A small Plorer, said to have been obtained at San Francisco, was described as a new species by Mr. Ridgway, under the name of .E. mirorhynihr, and subsequently identified by him with - F. curmila ; but he now considers it very doubtful whether the locality given on the label was correct.

The usual breeding-places of this bird are sandy islets and strips of waste land overgrown with coarse wiry grass on the margins of rivers; also the dried-up beds of winter-torrents and elevated stony plains. Incubation seldom begins before the latter half of May, when the eggs, 4 in number, are laid in a slight hollow; their colour is pale stone-buff, with minute dark brown spots and streaks, very different from the bolder markings prevalent in the preceding species: average measurements $I^{\prime} I_{5}$ by 85 in. The usual note is rendered by Naumann as die or deä; but the lovecall, chiefly uttered by the male when on the wing, is a more prolonged trill. The food consists of water-beetles and other insects, in search of which the bird has been observed to turn over small stones.

The adult Iittle Ringed I'lover is smaller in size, slenderer in form, and one-fourth less in weight than . E. licaticiula; the shafts of the primaries are all dusky, except the outer one which is white, whereas in the larger species there are flecks of white on the shafts which form a conspicuous bar when the wing is extended; the general colour of the upper parts is even paler in E. curonica than it is in Continental examples of the Ringed Plover. In spring the eyelids are golden yellow, and the legs are of a pale ochre colour. Length 6.5 in.; wing +5 in. The young exhibit a more decidedly sandy tint on the upper parts than do those of the Ringed Plover, and the down of the nestlings is more distinctly buff. 


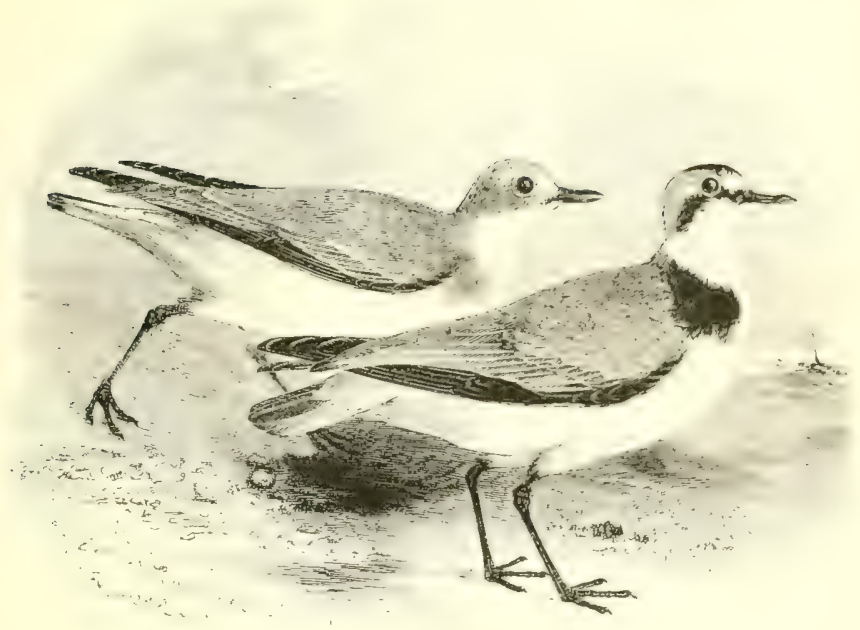

THE KENTISH PLOVER.

EGialitis caxtí́Na (Latham).

The Kentish Plover, easily recognizable by its inconplete pectoral band, arrives on the shores of England in . Ipril, and departs, as a rule, in September; but individuals, which were probably migrants from the Continent, have been obtained on the east coast in October ; Bridlington in Yorkshire being the most northern locality in which it has been noticed, while it is of rare occurrence in Lincolnshire, though more frequent in Norfolk and Suffolk. On the shingle-beaches of Kent (whence it was first described), as well as in Sussex, it formerly bred in considerable numbers, but sad havoc has since been made there by collectors. Westward its appearance is unusual, and only a few specimens are recorded from Devon and Cornwall ; but in the Channel Islands it is not uncommon, especially on Guernsey and the neighbouring islets. To Ireland it is a very rare visitor.

With the exception of a recent occurrence in Norway mentioned by Prof. Collett, this species has not been olscrred above the south districts of Sweden, and it is rare on the lialtic coast of (icrmany ; but in Denmark, Holland and Belgium it is fairiy numerous, while in France and the Spanish Peninsulit it is abunclant, both on the sea-shore and on brackish lagoons at some distance inland. It 
appears to be resident in the Azores, Madeira, the Canaries, and throughout the basin of the Mediteranean; while in winter it has been found in Africa as far south as Cape Colony. In summer it frequents the Black, Caspian and Aral Seas, as well as the salt lakes of Turkestan, Daüria and Mongolia, migrating in the cold weather to Japan, China, the Malay Peninsula, Burma and India; there are, however, several closely-allied species in the south and east of the ()ld World which cause difficulty in defining its winter-range with accuracy. In America the representative is .E. nizosa, which has white-and not black-lores when in breeding-plumage.

Towards the end of May, in warm seasons, the eggs are laid in a small hollow in the sand, or among fine shingle and broken shells, often in a nearly upright position, the points being buried and the thick ends just showing above the loose soil. They seldom exceed 3 in number-though I have found + in Spain and also in the Channel Islands and are rough in texture, and of a yellowish stone-colour, spotted and characteristically scraisled with black: average measurements $I^{\prime} 2$ by 9 in. Mr. H. 1 . Dombrain says that occasionally they are deposited on a heap of sea-weed thrown up by a very high tide. If disturbed when sitting, the bird will run a few yards, fly a little, then drop and run again, uttering a plaintive note; but when the young are hatched it sweeps closely round, accompanying each stroke of the wing by a sharp whistle, then dropping suddenly and cowering with expanded wings and tail. The food is similar to that of the Ringed Plover.

The adult male in spring has the forehead and a broad line above each eye white; lores and a stripe behind the eye black; forecrown black: top of the head and nape reddish-brown; neck-all round-and the entire under parts, white; on each side of the neck a black patch which is not continued to the breast; upper parts -including the three central pairs of tail-feathers - hair-brown with darker shafts; outer tail-feathers white; bill, legs and feet black. Length nearly 7 in.; wing +25 in. The female has no black on the fore-crown, her neck-patches are brown instead of black, and her colours are less bright. The young resemble the female, while the downy nestlings are more rufous than those of the Ringed Plover. The illustration represents an adult male in summer, and a young bird in autumn plumage. 


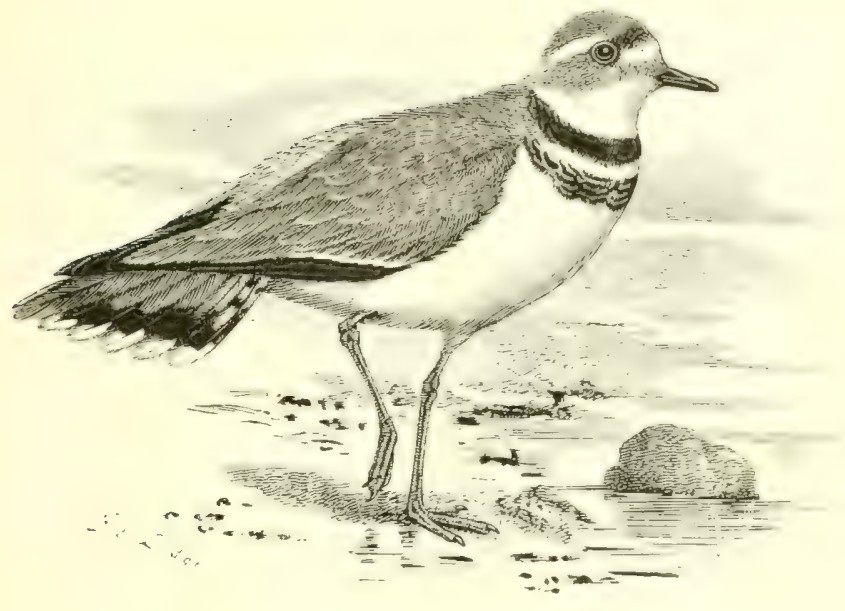

THE KILLDEER PLOTER.

Ágialitis Vocífera (Linnæus).

In I 862 a mounted example of this American bird was identified by Mr. P. L. Sclater, who was informed by Mr. J. R. Wise that it had been killed in April I 857 near Christchurch in Hampshire; but as corroborative evidence of this was wanting and the specimen had changed hands during the interval, I did not consider it advisable to include the species in the $4^{\text {th }}$ Fdition of 'Yarrell,' while later investigation has led me to doubt the accuracy of the assertion. Sulse quently, as stated in the preface to the above work, Mr. Ienkirson shot a bird, which I afterwards examined, on lanuary 15th 18.55 . at Tresco in the Scilly Islands (Zool. x885, p. I I 3 ).

The Killdeer Plover has not yet been recognind on the mainland of Europe, though, according to Mr. I. I. Johmson, it has been obtained on the island of Madeiri. In America it is widely dis tributed, breeding southward from the plain of the sarkitchewan (where it arrives about April 20 th) as far as Mexico: its migration. extending to the Bermudas, the West Indies gencrally, and tropical America down to Colombia. In California and the southern furtion of the United States it is resident or only partially migratory: while even as far north as Long Island it has been met with up to the end of November and often makes its reappearance quite carly in the 
spring. In New England it is by no means plentiful, its line of passage being more to the west; but exceptionally it visits Maine, large flocks having been observed near Portland between 28 th-3oth November i 888 .

The nest is usually a mere hollow in the ground, without any lining beyond a few bits of dry grass, or fragments of small shells arranged in the form of a ring. The eggs, + in number, are pear-shaped, and of a creamy-white colour blotched with dark purplish-brown, much resembling those of our Ringed Plover, though larger in size: average measurements $\mathrm{I} \cdot 6$ by $\mathrm{I}^{\prime} \mathrm{I}$ in. During incubation the parents sit in turns upon their eggs, nor do they leave them by night or day unless disturbed, in which case they are very noisy and resort to the usual manouvres to divert the attention of the intruder. The note-to which the species owes its name -resembles the syllables kill-dic rapidly enunciated, generally in a loud clear tone, which often startles wild-fowl and renders this Plover an object of dislike to the native hunter. The food consists of worms, insects and small crustaceans, chiefly obtained on inland pools and swamps; the actual sea-coast being rarely frequented by the bird, although it may be found on the neighbouring lagoons or backwaters.

The adult has the forehead and a streak behind the eye white; fore-crown banded with black; lores, crown, nape and upper parts umber-brown, with rufous margins to some of the long secondaries; alar bar and portions of the quills white; rump, tail-coverts, and basal portion of the long tail-feathers rufous, the subterminal portions of the latter being barred with black and tipped with white; throat and under parts white, with two black bands across the chest; bill black; legs yellowish-grey. Length $9{ }^{\circ}$ : wing 6.5 in. The sexes are alike in plumage; the young are more conspicuously marked with pale rufous on the upper parts. The characteristics of the Killdeer as compared with the Ringed Plover are its larger size and proportionally longer tail and legs, the latter giving it a very graceful appearance.

For many of the above particulars I am indebted to that excellent work 'The Water-birds of North America.' 


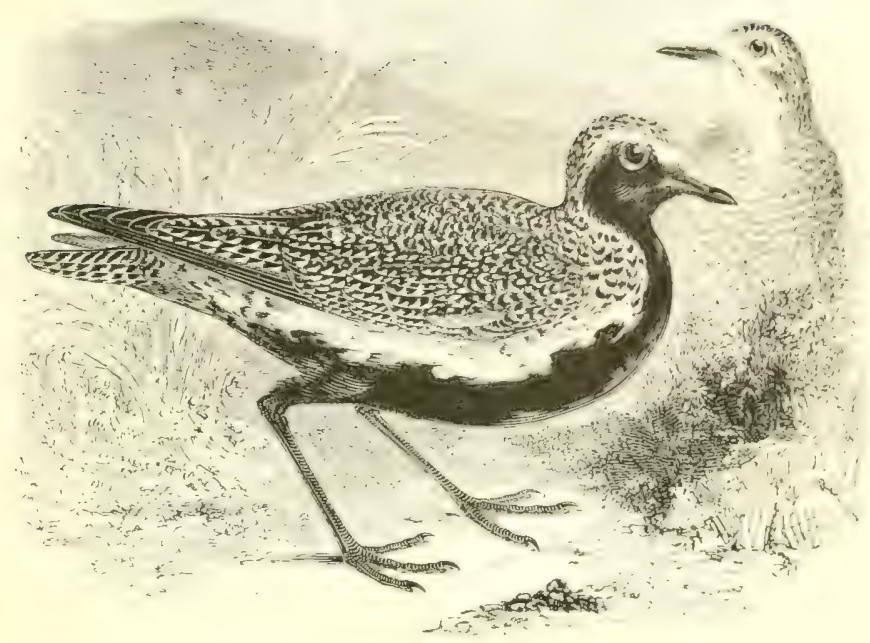

\section{THE GOLDEN PLOVER.}

\section{Charádrius pluviális, Linnæus.}

The Golden Plover is most plentifully and generally distributed in the British Islands on its migrations and during the colder months of the year; the autumnal passage southward opening with a few black-breasted birds early in August, though the large flocks of young seldom arrive till the end of september, and are followed by the adults from October to Nosember. A retum northward is noticed in March, when the birds which have their breeding-places on our moorlands retire from the coasts which they have frequented during the winter; but for long after these have been engaged in the task of inculation, flocks from the south continue to pass upward; the plumage of the later arrivals being, as a rule, far richer in colour than that of our home-keeping individuals. These nest sparingly on the high ground in Devon and somerset, more plentifully in Breconshire with other counties of llales and it.s marches, and in increasing abundance from I) ropthire northwards to Sutherland. On the moors of the Orkneys, Shetlands, and Hebrides this species is common, conomous numbers freclumente the sandy pastures and shores in winter: while in Ireland it lorcels in suitable localities, and rast flocks or "stanch" visit the coants from 
early in autumn onwards, especially when the light of the moon enables them to feed by night.

In summer the (iolden Plover has been found on Ian Mayen and in Greenland, while it is a regular visitor to Iceland, the Froes and Northern Europe; breeding as far south as the moors of Brabant, Luxembourg and (iermany. Over the rest of the Continent it occurs on migration, passing the cold season in the basin of the Mediterranean, and wandering to Madeira as well as down the coast of Africa to Cape Colony. It visits Novaya Zemlya, and inhabits the tundras of Siberia as far east as the I.ena, but beyond the Yenesei the smaller Ch. fulius (the subject of the next article) predominates. In winter it has been found in Turkestan and Baluchistan, but has not yet been recorded from India proper.

The slight and scantily-lined depression which serves for a nest is usually in short grass or heather, but often where the ground is quite bare; the eggs, $t$ in number, are large in proportion to the size of the bird, and are of a yellowish stone-colour handsomely blotched and spotted with rich brownish-black: average measurements 2 by $\mathrm{r}_{4} \mathrm{in}$. Incubation, in which the male occasionally takes part, commences towards the end of April even on the bleak moors of Northumberland, but later in Northern Europe; and the young run as soon as they are hatched, though unable to fly for a month or five weeks. The food consists of insects and their larva, worms, slugs, small molluscs, the fry of the common mussel, and a little vegetable matter. The note is a clear whistling tliii, often heard by night over large towns at the times of passage; the spring-call being described by Mr. A. Chapman as tir $r$ -

In spring the adult male has the forehead white; crown, nape and mantle blackish, profusely spotted with gamboge-yellow, the markings on the inner secondaries being of an oak-leaf pattern; tail barred with brown; above the eye a white line which continues down each side to the reck and even to the flanks; under parts black; axillaries white; bill, legs and feet black; no hind-toe. Length I I in.; wing $7 \cdot 75$ in. The female has usually less black on the breast. After the autumnal-and only complete moult, the under parts are white, tinged with dusky yellowish-brown on the breast, and the upper parts are more yellow than in spring. I have handled a bird in England on February 2oth with nearly black breast. The young resemble their parents in winter-plumage, but are still yellower above; the flanks are more mottled, and the tips of the axillaries are often very distinctly spotted with ash-brown, although the bases of those feathers are white. 


\section{THE LESSER GOLDEN PLOVER.}

\section{Charadrius fúlvus, I. F. Gumciin.}

There are two slightly different forms of this species, one of which is found in the eastern part of Isia while the other inhabits. North America; and inasmuch as individuals referred to both of these have probably been obtained in the British Islands, the above name has been adopted as the least misleading. An example of the Asiatic race was found in Leadenhall Market among a lot of Golden Plovers in December 1874 , and was said to have come from Norfolk; but this alone, however probable, did not suffice to procure the admission of the species to the British list. In the autumn of ${ }_{1} S S 2_{2}$ Mr. J. H. Gurney jun. found another birdthis time of the American form-in the same market; and Mr. J. G. Millais has recorded (Zool. I 886, p. 26) the occurrence of a second American specimen in Perthshire, on August 3rd 1883. On November 26th I887, Mr. Millais received from Stennis in Orkney, in the flesh, one of the Asiatic race; a fact which, considering its importance, might well have been recorded in "The Zoologist' or some scientific journal, and not merely in the columns of 'The Field' newspaper.

A bird ascribed to the American form was obtained on Heligoland in December 1847 by Mr. Gätke. Of the Asiatic race the collection of that distinguished ornithologist contains no fewer than three examples, all captured in summer; while two have becn taken in Malta, one (in the possession of I ord lilford) at Millagia in Spain, and one at Iublin in Poland. This race breeds on the tundras from the Yenesei to Bering Sea and as far south as the moist plains of Mongolia, migrating in winter to ('hina, Iapan, India, the Malay region, Australia, New ' ealand and P'olynesia : it also visits the Prybilof Islands and the coast of Mlaska, while, as might he expected, gradations are found in the racife which lead insensibly to the American form. The latter, which the onitholusists of the United states used to call $C h$. zirsinims, and now term ( $i$. hmimiuss of P. I. S. Miiller, is said to be characterized-at the extreme of its variation-by its larger size on average, relatively shorter inner secondaries, and less brilliant yellow tint. It nests on the Harren grounds' from Alaska to Davis Strait, as well as in the northern 
part of Greenland; while on passage it traverses Canada and the United States, seldom occurring on the coast of California, but rather inclining to the east of the Rocky Mountains. In September and October large flocks often arrive in the Bermudas, the birds being extremely fat and highly appreciated for the table; while on Antigua, Martinique, Barbadoes, and other West Indian Islands, they are sometimes so tame or exhausted that they can be knocked down with sticks and stones. The migrations extend through tropical America to Buenos Ayres on the east side and Chili on the west.

A nest of the Asiatic bird which Mr. Seebohm found on the Yenesei, was upon a piece of turfy land overgrown with moss and lichen, and was a mere hollow in the ground, lined with broken stalks of reindeer moss; the eggs, + in number, resemble those of the Golden Plover, but are slightly smaller; Mr. Mactarlane, in his notes respecting the nidification of the American form on the barren grounds, gives the average measurements as $\mathrm{I}^{\circ} \mathrm{9}$ by $\mathrm{r}^{\circ} 3 \mathrm{in}$. The habits and food of this bird are also similar to those of its congener; but its note, according to Mr. Seebohm, is more like that of the Grey Plover, being a plaintive kï, sometimes $k l-\bar{\varepsilon} \bar{c}$, and often the treble $k l-\bar{e} \bar{c}-k \ddot{o}$.

In the breeding-season this species only differs from the Golden Plover in being smaller and in having the axillaries smoke-grey to their buses instead of white; the above distinctions existing at all seasons of the year. The winter-plumage, however, according to Mr. Seebohm, "differs widely from that of the Golden Plover, though it resembles very closely that of the Grey Plover, the spotted feathers of the upper parts being replaced by feathers having yellow margins. Young in first plumage resemble on their upper parts adults in spring-plumage, except that the tail-feathers, instead of being dark brown with transverse bars of pale brown, are uniform dark brown with marginal yellow spots." Average length of the Asiatic race 9 in., wing 6.5 in.; of the American 9.5, wing 7 in.

It has not been considered necessary to give an illustration of this species. 


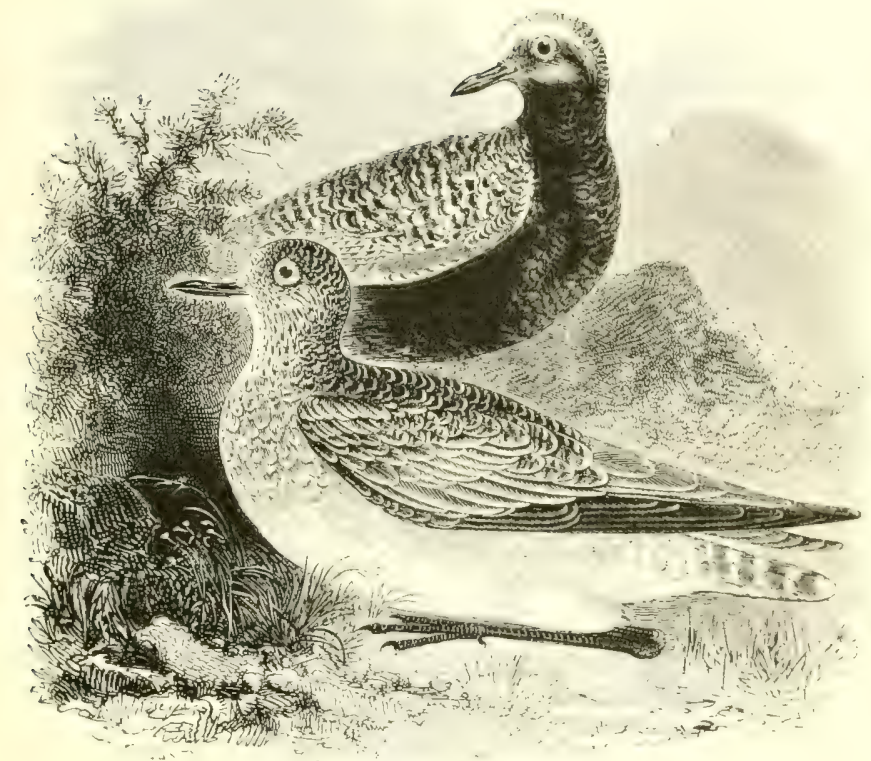

THE GREY PLOVER.

\section{Squatárola helvética (Limnæus).}

This is a larger bird than the Colden Plover, with a more robust bill, and may be recognized on the wing by its litick avillarics as well as its white tail-coverts; while in the hand the presence of a distinct hind-tor is an unfailing characteristic. Numerically it is less abundant than that species, and is, as a rule, more restricted to the sea-coast and vicinity during its visits, which extend from carly in autumn till late in spring. A few black-breasted birds return from their northern quarters by the end of July or beginning of August: the majority of the young arrive in Suptember, and the bulk of the adults come in October and November, after completing their moult. Large numbers spend the winter here, and flocks of a score to a hundred may be seen on the seatshore and mudflats in spring up to the end of May, by which time the black breast has been assumed; while birds which are not breding remain till fune and even July. Though a regular visitant to Ircland, it is less numerouts there than in Great Britain, in which, again, it is more ahumblum on 
the east than on the west coast, becoming decidedly rare in the Outer Hebrides.

The (irey Plover has not been observed in Iceland, and as yet there is no absolute proof of its supposed breeding on the fells of scandinavia. In I875 Messrs. Seebohm and Harvie-Brown found it nesting on the tundras of the Petchora in European Siberia, while further east Dr. von Middendorff had already obtained its eggs on the Taimyr Peninsula in lat. $74^{\circ}$, and on the Boganida in 7 $\mathrm{I}^{\circ} \mathrm{N}$.; its summer-range extending to Kamschatka. On migration it visits the greater part of Asia, Australia, Tasmania, Madagascar, and both sides of Africa. In the Canaries, and along the whole coast-line of Europe, ii occurs on passage; a limited number also rrossing the Continent by way of the valleys of the Rhine and the Rhone-in fact it owes the specific name hictictica to the earliest described specimens having been procured by Réaumur in Switzerland; while another route followed is along the Volga and Kama rivers. Though somewhat rare in (ireenland, it is generally distributed during summer over the barren grounds of Arctic Imerica, and its winter-range reaches southward to Guatemala.

The nest is a slight hollow in the moor; the eggs from ten identified clutches obtained on the Petchora between June zand and July 1 th are described by Mr. Secbohm as 4 in number, intermediate in ground-colour between typical specimens of those oi the (rolden l'lover and the I apwing, the blotching being similar: average measurements $\mathrm{I} \%$ by $\mathrm{I}+\mathrm{in}$. The alarm-note is a plaintive krip, sometimes combined with a double klie-ecp; while during the time that the bird is on our coasts its usual call may be syllabled by $t l-i-i h$, in a much sharper key than that of the Golden Plover. The food consists of worms, marine insects and their larvæ, small molluscs and sea-weed; its flesh is not esteemed for the table.

The adult male in breeding-plumage has the fore-crown white; upper parts mottled and barred with brownish-black and white, the latter predominating in the tail-feathers; lores, cheeks, throat, neck and breast black ; vent and under tail-coverts white; axillaries black; biil, legs and feet blackish. I.ength 12 in.; wing 8 in. In the female the black is less pronounced. After the autumn moult the under parts are chiefly white, and the upper plumage has a more ashy appearance, especially in the female. The young are thickly streaked with brownish-grey about the head and neck, and the upper parts exhibit some yellow spots, which have, however, almost disappeared by the end of December; the axillaries are only dark brown, not black. 


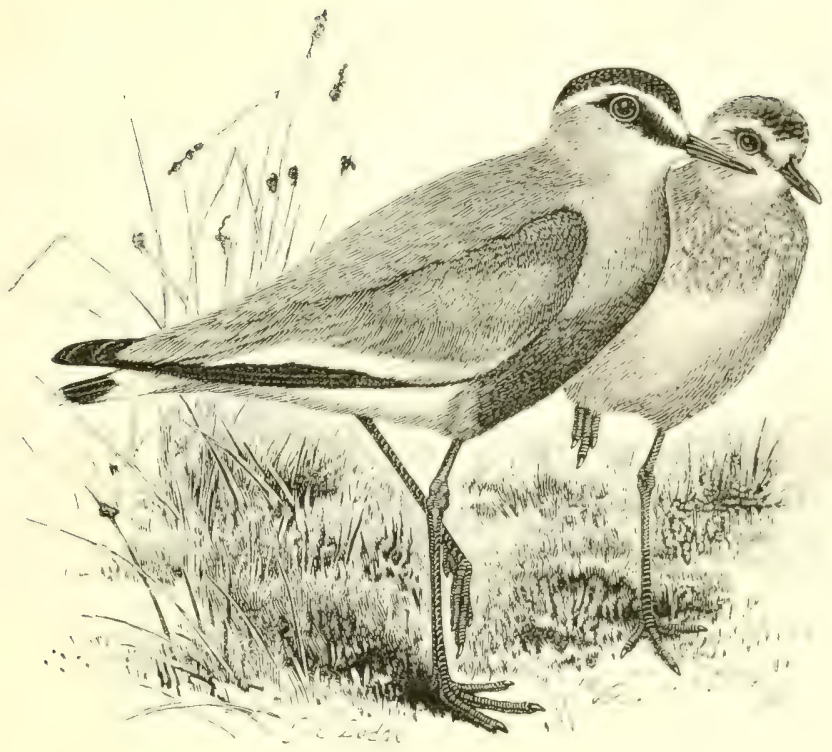

THE SOCIABLE I'LOVER.

\section{VANéltus Gregárius (Pallas).}

In the autumn of the year I 860 or thereabouts, an immature example of this south-eastern species was shot from among a flock of I apwings, near St. Michaelson- Myre in I ancashire: and havins: been subsequently placed in a case with many other stuffed biris which impeded the view, it was erroneously recorded as a Creamcoloured Courser by Mr. F. S. Mitchell. It afterwards came into the possession of Mr. W. H. !loeg, when it was correctly identified, and was exhibited by Mr. Seebohm at a meeting of the \%oolengical Soclety of London on November zoth isss. Its jedigree alpuarto be perfectly satisfactory.

The Sociable Plover has not yet been olserved in Heligoland or the northern part of Western Europe, but as long ago as March 1838 an adult (figured by Bonaparte) was shot near kome, where a young female was obtained in November is; 2 , while a thirel example. was killed near Sienna in the spring of 1856 . On the Riviera, an adult male was taken near Nice in April $188_{3}$. At Cadiz, in February 1868, I found in the market a bird-too advanced for preservation - in the plumage of the first year, a stage then little 
known, but with which I happened to be familiar, having recently received from the Crimea the specimen figured in the background of the present illustration. The bird has not actually been killed in Poland, but near Lublin in September I8+2 Prof. Taczanowski identified two adults--which he was unable to shoot-in company with some Golden Plovers. From Bulgaria or the Dobrudscha this species has not yet been recorded, but it inhabits the steppes of the Crimea and of the district between the Don, the Volga and the Caucasus, though not ranging further north than lat. $53^{\circ}$ according to Bogdanow. Eastward, it is met with in the Aralo-Caspian region, and in Turkestan as far as Lake Saisan; crossing the Pimir plateau in September to the dry uplands of Sind and the sandy plains of India, and wandering southward to Ceylon in the cold season, when it also visits Arabia, Egypt, Nubia and Abyssinia.

Details respecting the nidification of this species are wanting, but eggs obtained through the Moravian colony at Sarepta, on the Volga, are rather paler than those of the Lapwing and less thickly spotted. 'The food consists of spiders, grasshoppers, beetles and their larvæ. Von Heuglin, who had opportunities of observing this bird in Kordofan and Sennaar, says that it frequented sandy localities and ground that had been burnt; it was, as a rule, quite silent, but every now and then he heard it utter a short, shrill whistle.

The adult has the crown of the head glossy-black, enclosed by a broad white band which starts from the base of the bill and runs backwards above each eye to the nape; lores and a narrow streak behind each eye black; nape and mantle ash-grey, rather browner on the wing-coverts; secondaries conspicuously white, quills chiefly black; tail-feathers white, with a subterminal band of dark brown on all except the outer pair; chin white; cheeks and sides of the throat pale buff; breast ash-grey; turning to black on the abdomen, followed by rich chestnut-red on the flanks and vent; axillaries and under tail-coverts white; bill, legs and feet black. Length I 3 in.; wing $S$ in. The sexes scarcely differ in plumage. The young bird has the crown dark brown, with a buffish-white circlet; cheeks and nape dull buff striped with brown; breast rather distinctly marked with 'arrow-heads' of ash-grey; abdomen dull white, with a little chestnut above the vent; the tro outer pairs of tail-feathers white; axillaries and under wing-coverts white, as in the adult.

This species is often placed in the genus Chettusia, but for the purpose of the present work I have thought best to unite it with Vanellus, inasmuch as it has a hind-toe. 


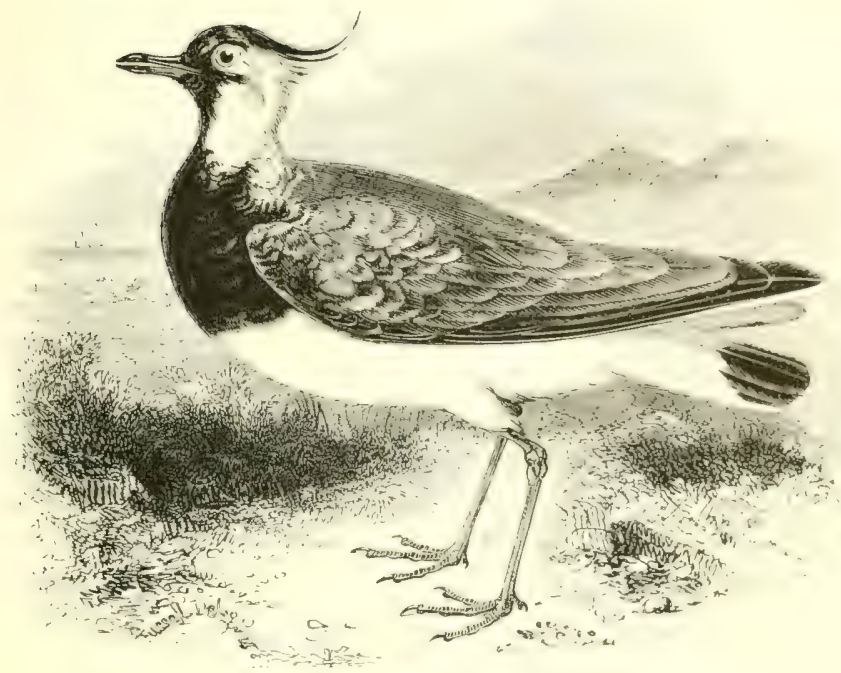

\section{THE LAPIVING.}

VANÉLlus VUlgáRIS, Bechstein.

The Iapwing, also called the Peewit, owes the first name to the slow flapping of its rounded pinions, while the latter is obviously derived from the bird's familiar cry. Throughout the British Islands it is generally distributed and, as a rule, resident: though partial emigration from the north takes place in severe weather. Its favourite resorts are marshy pastures and moorlands. but its breeding-grounds, even when on flats, are usually above the risk of inundation, though its range on the mountains seldom infringes upon that of the Golden Plover. In England, drainage and the increasic of cultivation have tended to diminish its numbers, allowing for the large flocks which annually arrive from the Continent in autumn: but in Scotland it is abundant, and is on the increase in many parts of the north as well as in the Shetiands. In Ireland it is very common, but Sir R. Payne-Gallwey states that its eggs are not collected or appreciated there as they are in (ireat liritain, althoush the birds are freely netted for the table.

This species is only a visitor to the Froes and Iceland, occasionally wandering to Jan Mayen and (ircenland: lout it lorecels in Northern Europe up to the Arctic circle, and is toleratly flentibul 
in Norway and Southern Sweden in summer. The majority of the eggs sent to this country are from the Netherlands and North Germany, where they are systematically gathered up to a date which is fixed by law. In suitable localities it nests throughout the Continent down to the extreme south of Spain, as it does, sparingly, in North Africa and Egypt; while its migrations extend westward to the Azores, and a wanderer has recently been recorded by Col. Feilden from Barbadoes. It is found across Asia as far north as lat. 65 (Bogdanow); its southern breeding-limits being on the humid plains of Mongolia, and on the Tian-shan range up to an elevation of about $\mathrm{II}, 000 \mathrm{ft}$. ; in winter it is also met with in the Indian region down to about $25^{\circ} \mathrm{N}$. lat.

The eggs, normally + but occasionally 5 in number, vary in ground-colour from olive-green to stone-buff, grey, or even pale blue, the blotches being blackish-brown: average measurements I. 6 by $\mathrm{I}^{\prime} \mathrm{3}$ in. They are seldom to be met with before the latter part of March, April being the usual month for laying, but they may be found fresh through May and into June. Amost any depression in turf, fallow-land, dried mud or shingle, suffices for their reception, a fow bents ace placed crosswise being added, usually during the progress of incubation. The female runs silently from her nest when approached, and it is the male which indulges in such frantic swoops and twirls, accompanied by noisy cries; though when the young are hatched both parents practise every artifice to allure man or deg from their brood. 'The 'false' nests often found are scraped out by the cock in turning round, when showing off to the female. On the approach of winter large flocks are formed, which break up in the following spring: they fly in lines with great regularity. The food consists of worms, slugs and insects; and, though inferior to the Golden Plover, the Lapwing is not to be despised for the table.

The adult male in breeding-plumage has the crown and the long movable crest greenish-black; sides of the neck whitish; upper parts metallic-green, glossed with purple and copper-colour; quills chiefly black, the tips of the three outer pairs greyish; tail-feathers white, with a broad subterminal band of black, except on the outer pair ; face, throat and upper breast bluish-black; belly and axillaries white; upper and under tail-coverts fawn-colour. Length I 2 in.; wing 9 in. The mature female does not differ in plumage, but younger hens show some white on the chin; in winter that part as well as the throat are white in both sexes. The young bird has a shorter crest and the dorsal feathers are edged with greyish-buff. 


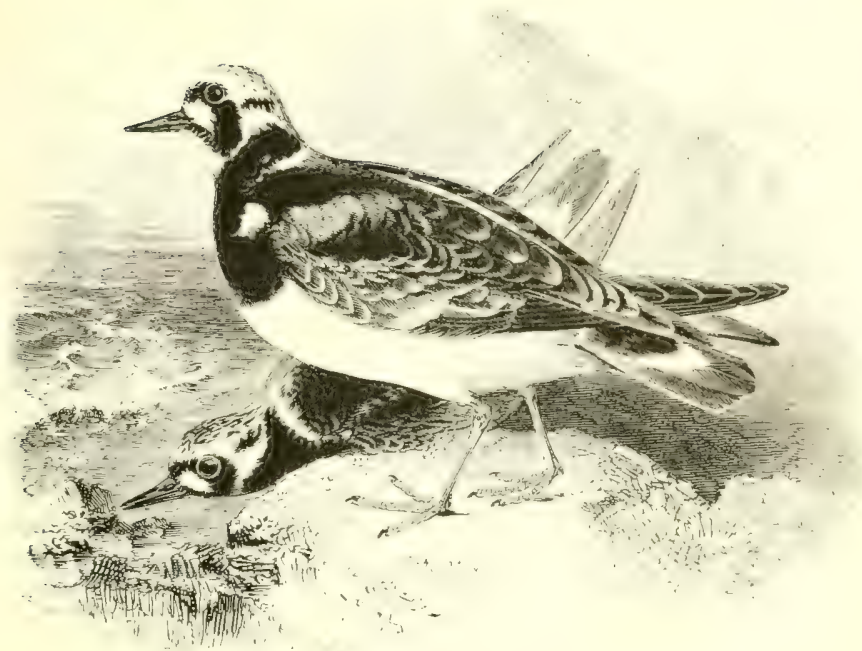

THE TURNSTONE.

Strépsilas intérpres (Linnæus).

This species, conspicuous by the variety of its plumage, is a regular visitor to our sea-coasts, and at times to the margins of lakes and large rivers. Young birds make their appearance by the latter part of July, but the bulk of the migrants from the north do not arrive till August; comparatively few remaining on the east coast of England after the autumn, though on the southern coasts, and still more in the mild climate of the west, many stay through. out the winter. In May the return northward takes place, yet occasionally birds in nuptial dress, sometimes in pairs, remain during the summer in localities apparently suitable for reproduction ; but authenticated eggs have not yet been obtained in any part of the United Kingdom, though diligent search might possibly be rewarded among the islands of Scotland, or on the decply-indented shores of the west of Ireland, where the bird is at all times far more plentiful than in England.

The Turnstone breeds in Greenland, Iceland (where it is sedentary) and perhaps in the Firoes; but its lest known and most accessible nesting-places are on the coasts and intumels of Scandinavia, Denmark, and of the lialtic. It has eccurred on lan Mayen, Spitsbergen and Novaya \%mlya, and is found in summer along the northern coast of Siberia as far as licring Straits: while 
during the cold season its range extends over Asia, and down to Australia, Tasmania, New Zealand, Polynesia, South America and the African region. Mr. Godman believes that the Turnstone breeds in the Azores, and it may possibly do so in the Canaries, while Mr. Tait says that in Portugal it is usually seen near the mouth of the Douro "from the beginning of April till the middle of September," adding that in the summer of $\mathrm{r} S 69$ a young bird was brought to him alive and kept in a cage for many months; no eggs have, however, been taken south of the Baltic. On migration the Turnstone is found along the entire coast line of Europe and on many inland waters, and it is generally distributed in North America, brecding in the Arctic regions; but $S$. melaneceptalus, a second member of this small genus, is also found in Alaska and California.

The nest is a shallow depression, lined with a few dry leaves and bents, under the shelter of such bushes or scanty herbage as grow on the coasts of the northern seas, or upon ledges of rock on their islets. The exrst, $f$ in number, are very distinct from those of any other species, being of a greenish-grey colour, spotted and streaked somewhat spirally with bluish-ash and brown: average measurements $\mathrm{r} \cdot 6$ by $\mathrm{I} \cdot \mathrm{I}$ in. Incubation, shared by both sexes, takes place about the middle of June, only one brood being reared in the season. The Turnstone feeds chiefly on small crustaceans and molluscs, in search of which it may. be seen-sometimes in parties --turning over stones or examining sea-weed, whence its Norfolk name of 'Tangle-picker.' It is easily tamed, and Mr. Tait has given an interesting account of the manner in which his captive bird called down a Whimbrel with which it afterwards lived (Ibis, $\left.1 S_{7}, \mathrm{p} .3 S_{7}\right)$. The note is a clear whistle, but a loud twittering is often uttered by the bird when on the wing.

In spring, as shown in the illustration, the adult male has the head, neck, upper breast and shoulders variegated with black and white: mantle streaked with chestnut and black ; rump conspicuously white, followed by a dark brown patch on the coverts, most of the tail-feathers being of the same colour; under parts white; legs and feet orange-red, hind-toe turning inwards and not backwards. Length 9 in.; wing 6 in. The female is slightly duller in colour, and in autumn the chestnut tint is much reduced in both sexes. The young bird has the forehead and cheeks brown, collar dark umber, merely a buffish tint to the margins of the wing-coverts and secondaries, feathers of the back tipped with dull white. 


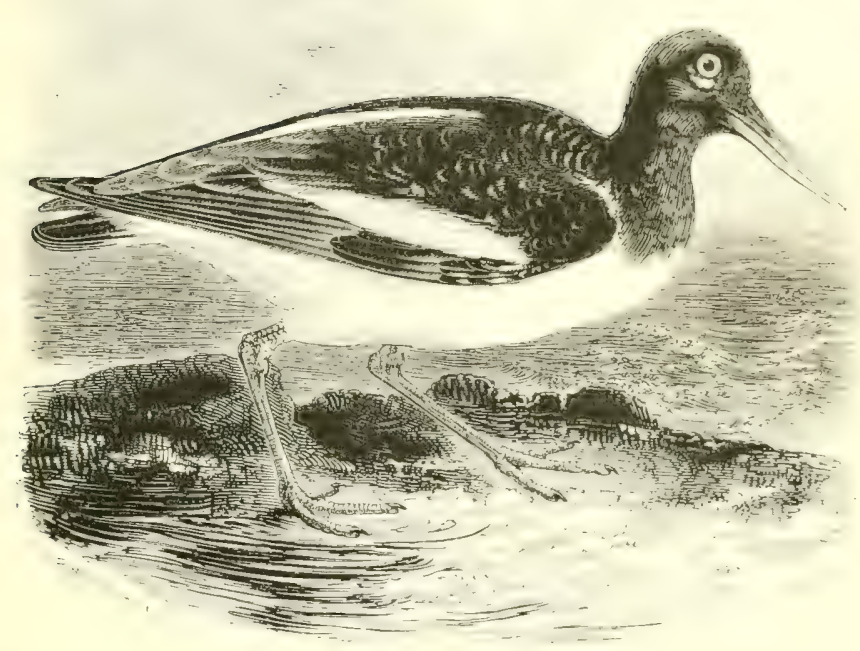

THE OYSTER-CATCHER.

H宅natopus óstralegus, Linnæus.

The Oyster-catcher inhabits the shores of Great Britain and Ireland throughout the year, exhibiting a marked prefurence for sandy bays, stretches of low flat rocks mixed with shingle, and mussel-scalps; but it often occurs inland, and in sicotland it nest. on all the large rivers and many of their tributaries on the east side, and along the Lochy in the west. In autumn the birds which have bred in the north pass southwards, and a certain influx of visitors from the Continent takes place, so that large flocks may be seen from that time onwards along the coasts. ()wing to the black and white in its plumage a common name is - scall'ic, while I think that 'catcher' is an old English corruption of the Dutch ackster (magpie); another equally appropriate term bing - Inssicl pirker."

To Greenland this species is merely a stragegler, but it is reident in the southern districts of Iceland, and occurs in summer on the coasts of Europe, from the North (ape to the delta of the Rhone and the head of the Adriatic. Throughout the erealere fort of the 
Mediterranean basin, however, it is principally a migrant; but it occurs on many of the inland waters of the Continent, and along the large rivers of Russia, as well as on the northern shores of the Black and Caspian Seas, whence it retreats in winter. The Arctic circle forms the northern limit of its range in Asia during the summer, a questionably distinct form being found in Eastern Siberia, Japan and China; but our bird risits Burnia, Ceylon. India, Baluchistan and Persia during cold weather, its migrations extending down the Red Sea to Mozambique on the east side of Africa, and to Senegambia on the west. Its representative in the southern half of that continent is, however, H. capensis, a black species which wanders northward to the Canaries. There are several other members of this cosmopolitan genus, three or four of them being confined to America.

The eggs, usually 3 but sometimes + in number, are yellowish stone-colour, spotted and scrolled with ash-grey and dark brown: average measurements $2 \cdot 2$ by 1.5 in. They are commonly laid on shingle or among sand-hills, and frequently on a pavement of small fragments of shells or on a tussock of sea-pink growing upon a narrow ledge of rock: but I have seen them on the sumnit of a lofty 'stack,' and in the previously robbed nest of a Herring-Gull, while they have been found in meadows far from the sea, and Prof. Collett mentions a clutch laid in a cavity at the top of a felled pine. Incubation becomes general in the latter part of May, and lasts about three weeks. On rocky coasts each pair inhabits a certain district, but on flat shores considerable numbers may be found associated, and their noise is perfectly deafening when the young are just hatched, the old birds flying close round the head of an intruder, except where they have been much disturbed. At other times the Oyster-catcher is remarkably wary, and alarms every other bird in the neighbourhood with its shrill kcep, keep. It swims well and sometimes takes to the water of its own accord. Mussels, whelks, and limpets are neatly scooped from their shells by the bird's powerful bill; annelids, crustaceans, small fish and marine plants being also eaten.

The arrangement of the black-and-white plumage of the adult is shown in the engraving; bill orange-yellow; irides crimson; legs and toes livid flesh-colour. Whole length $16.5 \mathrm{in}$.; wing $99^{\circ} 75$ in. From autumn to spring the front and sides of the neck are white, and the bill is horn-coloured towards the tip. The young have the feathers of the back and wings margined with brown. 


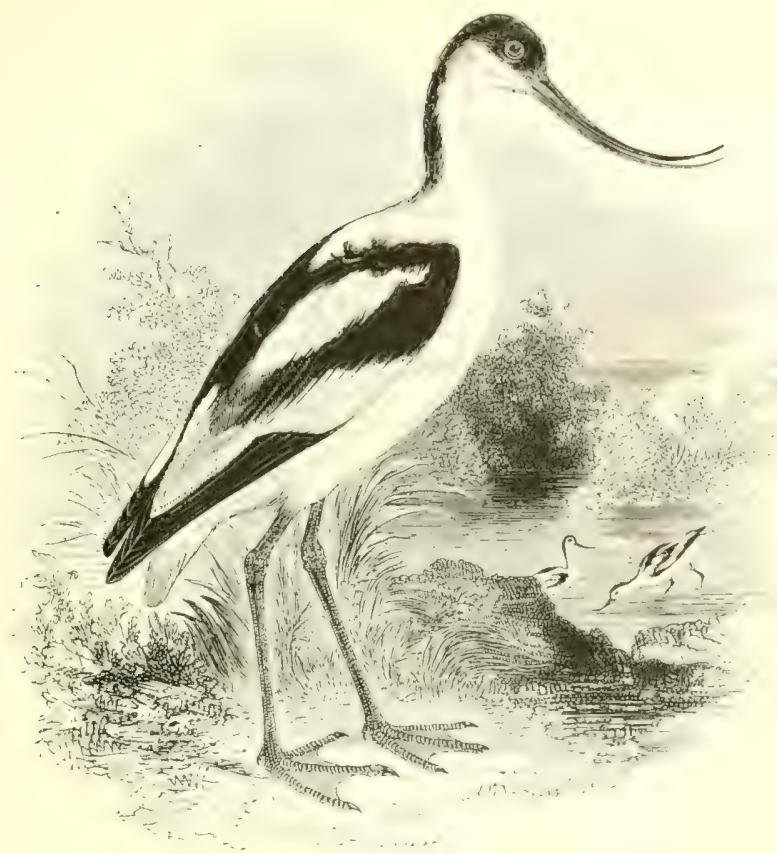

THE AVOCET.

RECURVIRÓSTRA AVOcÉTTA, Linnæus.

This remarkable bird was formerly a regular summer-visitor to our shores, breeding in considerable numbers in such suitable locilities as the coast and estuaries of the Humber district, I incolnshire, Norfolk and Suffolk. Reclamation of fen-land gradually circumscribed its haunts; a large colony at Salthouse was destroyed, as Mr. I. II. Gurney was informed, in consequence of the demand (especially from Newcastle) for Avocet's feathers for dressing artificial flies: and egg-collectors also contributed to the decrease of the specics, which by 182.4 had probably ceased to nest in England. Simall flocks still arrive in May, and occasionally in autumn, but thic formet are never allowed to breed, for the amasser of liritish-killed specimens offers to the local gunners inducements which far exceed the amount of any fine and costs that would be impresed, eren in the problematical event of the offender's conviction under the fectble Wild Birds' Preservation Act. On the south coast the Avocet used to nest on the flat shores of Kent and Sussex, to which it is now only a visitor; while on the west side it is of rare occurrence, 
and in the Solway district is unknown. North of the Humber and along the east coast of Scotland it is seldom seen, though stragglers have been met with in the Shetlands, Orkneys and Outer Hebrides. In Ireland its exceptional visits have been chiefly to the south, but once to the estuary of the Moy in the west.

The Avocet still finds breeding-places in some districts of Denmark and along the southein shores of the Baltic, as well as in the Frisian Islands and on the coast of Holland; while southward, the delta of the Rhone in France and that of the Guadalquivír in Spain may be mentioned. On migration it is met with on the coasts and inland waters of the greater part of the Continent, and it is to some extent resident in the basin of the Mediterranean, becoming abundant on the margins of the Black, Caspian and Aral Seas; while eastward it extends across temperate Asia to Daüria and Mongolia in summer, and as far south as Ceylon in winter. In Africa it is found down to Damara-land and Cape Colony-in both of which it is said to nest, and it occurs in Madagascar. Representative species inhabit North America, the Andes of South America, and the Australian region.

The eggs are laid in May, on bare cracked mud near water, in some slight depression in the sand, or amongst scanty herbage; their number is normally $3-4$, and in colour they are clay-buff, blotched and spotted with black: measurements about 2 by ${ }^{\circ} 5$ in. The usual note is a clear kluit, whence the bird takes its Dutch name. The Italian designation 'arocetta' and the Spanish 'boceta' are probably derived from hocinctta or some similar colloquial diminutive of the classical bucina (a curved trumpet), with reference to the shape of the bill. To obtain the worms, aquatic insects and thin-skinned crustaceans on which the bird chiefly feeds, this peculiar beak is employed with a sideways scooping action, which leaves characteristic marks on the soft mud or sand, whence come the provincial names of 'cobbler's-awl duck,' 'scooper,' and 'shoeing-horn;' while from its cry the Avocet was formerly known as the 'yelper,' 'barker,' and 'clinker.'

The slender, pointed, and flexible bill is black, and resembles two thin, flat pieces of whalebone coming to a point and turning upwards; the irides are reddish-brown; the plumage of the adult is black and white, disposed as shown in the engraving; the legs and toes are pale blue. Whole length nearly 18 in. ; wing 8.5 in. In the young bird the dark portions of the plumage are tinged with brown and edged with rufous. The bill is distinctly upcurved in the nestling of only a day or two old. 


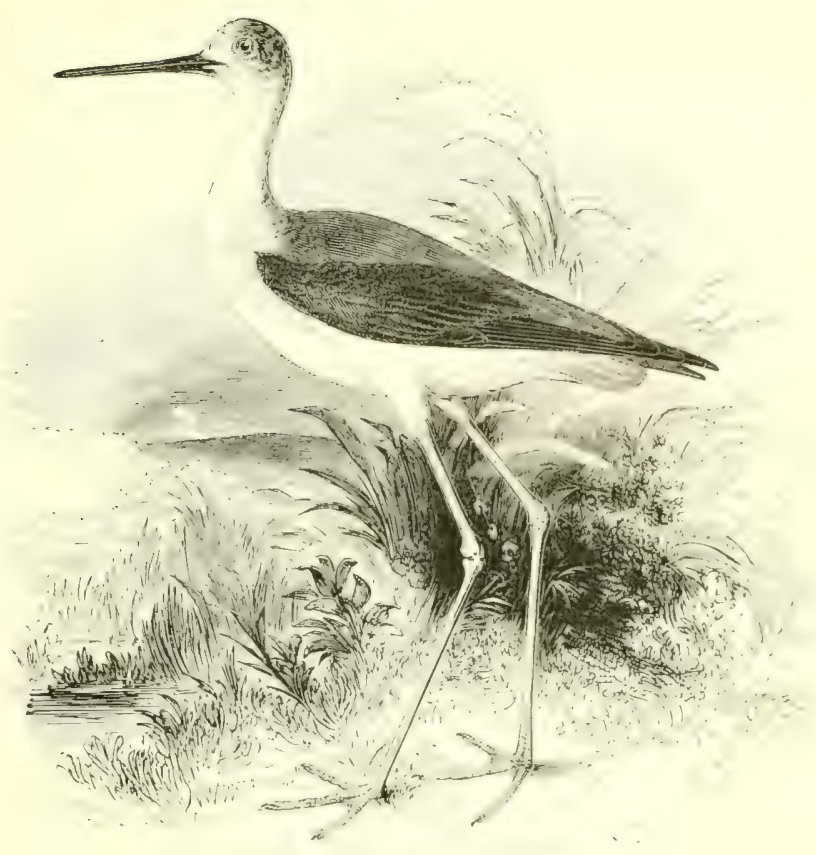

BLACK-IVINGEI) STILT.

Himántopus cándidus, Bonnaterre.

The occurrence of the Black-winged stilt in the British Island; was noticed as long ago as $\mathrm{I}_{6} 4$ by Sir Robert Sibbald, who described and figured one of two examples which had been shot at a lake near the town of Dumfries. Since that date a few more have been obtained or observed, at long intervals, on the mainland of Scotland as well as in the Orkneys and Shetlands; while two are recorded from Yorkshire, one from Lincolnshire, and one from Notts: but it is only on reaching Norfolk-where twelve in all have been taken-that the species becomes fairly frequent. Suffolk, Oxfordshire, Gloucestershire and a few inland counties have alio been visited, while in the south of England, from kent to Cornwall. a good many specimens have been procured from time to time: on the west side, however, it is very rare, theugh Montagu mentions one from Anglesea. In Ireland it has been met with on five or six occasions. As a rule the occurrences in the British Islands have 
been in the months of May, June and July, only a few being observed in autumn.

To Denmark, Germany, Holland and the north of France the Black-winged Stilt is only a straggler, but-like the Avocet-it breeds sparingly on the Neuseidler See in Hungary, more freely in the Camargue at the mouth of the Rhone, and abundantly in the marismas of Southern Spain, as well as in the marshes of Sicily, and on the low shores of the Black, Caspian and Aral Seas. It also nests freely by the lakes of North Africa, though even there, as well as in the Canaries and throughout the basin of the Mediterranean, the bird is almost entirely a migrant, arriving in March or April and seldom remaining after the end of November. In winter it is found down both sides of Africa and in Madagascar; while in Asia it inhabits the warm and temperate regions, large numbers breeding in some parts of the north of India, and also in Ceylon.

The cggs, full clutches of which I have found plentiful in the south of Spain by May 4 th, are usually + in number, and are of a warm stone-colour with hieroglyphic-like scrollings and blotches of black: average measurements $I^{7} 7$ by $1 \cdot 25$ in. By the pools in the marismas they were placed in a slight nest of bents by the side of a tuft of rushes, often so near the water as to be coated with mud from the birds' feet; but on the lower and wetter ground Mr. Abel Chapman met with more solid structures, while on the lagoons of the Black Sea Messrs. Seebohm and Young observed nests from two to four inches high. Col. I.egge found great variety in the sites chosen in Ceylon. The food consists of small univalves, gnats, flies, beetles and aquatic insects, in pursuit of which the bird wades up to its knees in shallow water. The note is a clear pee, pee, pee, and when the eggs or young are approached, suritt, guriet, guret, sharply reiterated. At such times the old birds fly close round the head of the trespasser on their territory, hovering with slow beats of their wings, and dangling their long legs, which are carried straight out during the ordinary flight.

The male in first breeding-dress has the nape and hind-neck black ; mantle and wings greenish-black ; tail grey ; rest of plumage white, with an evanescent fink tinge; old males have pure white heads, and exhibit no black streak down the neck. Bill black, irides red, legs and feet pink. Length from base of bill to tip of wings 14 in. ; wing 9.5 in. ; legs 10 in. The female has a somewhat browner mantle. The young bird has the nape, hind-neck and shoulders grey; back and inner secondaries ash-brown; quills brownish-black. 


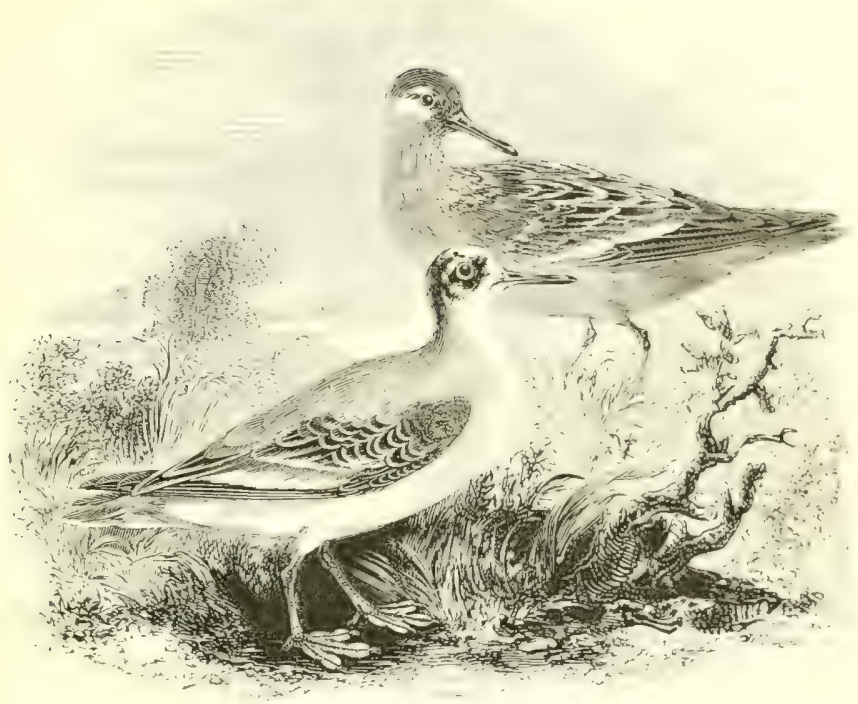

THE GREY PHALAROPE.

Phaláropus fulicárius (Linnæus).

The Grey Phalarope owes its trivial name to the plumage in which it usually visits us, for during the breeding-season the prevailing colour is deep chestnut. At irregular intervals-chiefly in autumn and winter, though occasionally in spring - it makes its appearance upon the shores of England, the favoured counties being those to the south east, south and, in a less derree, the southwest. Mr. J. H. Gurney jun. estimates that during the great immigration between August zoth and Octoluer Sth s $\$(6)$, upwark of 500 were slaughtered, and of these about 250 in Sussex, few birds touching the coast to the north of Rambate. A visitation of some importance in I 869 was almost confined to the south, as was also a smaller one in the autumn of 1886 . On the east of England this Phalarope seldom alights above Norfolk, but in scotlind, accord. ing to Gray, it visits all the shores from lierwick to the (rokneys: it is, however, seldom met with in Sutherland and has not yet been recorded from the Outer Hebrales, thutsh tound within their line. In Ireland it is rare; a few were obtained in the south in the autumn of $\mathbf{r} 886$. Many individuals of this tame and confiding species have been killed far inland by the siele of hakic or 1 math: 
and even on the coast its favourite haunts are pools of fresh or brackish water sheltered from the sea.

The breeding-range of the Grey Phalarope appears to be circumpolar. Its eggs were found by Dr. von Middendorff in Arctic Siberia, and have also been obtained in Spitsbergen and Iceland, but the majority of those sent to collectors of late years are from the districts of Upernavik and Egedesminde in Greenland. Our Arctic explorers have noticed the bird as far nurth as $S 2^{\circ} 30^{\prime}$, and it is abundant in summer on the shores of Alaska, as well as on the Asiatic side of Bering Sea and on all the islands to the northward. In winter its migrations have been known to extend to New Zealand and Chili; in the Indian region it has occurred as far south as Bombay, though its regular lines of passage across Asia have yet to be learned; in Europe, though missing the Volga valley, it is found on many inland waters and on all the coasts down to the Mediterranean; while it also visits North $\Lambda$ frica.

Courtship, assiduously conducted by the female, takes place on the return of the birds to their breeding-grounds about the middle of May, and early in June the eggs, 4 in number, are laid in a scantily-lined hollow of a knoll near some small pool in the spongy peat or moss; these are olive-buff, thickly blotched with umberbrown-less pointed, more bolảly marked, and rather larger than those of the Red-necked Phalarope : average measurements $I^{\prime 2} 2$ by .87 in. Incubation is chiefly performed by the male; the young are on the wing by the middle of July, and depart by the end of August. The food consists of small crustaceans and marine animals, the latter obtained by the birds whilst swimming buoyantly on the waves, sometimes hundreds of miles from land. The note is a sharp tweet, but the female sometimes utters a low clink, clink.

The female, which is larger and handsomer than the male, hasin breeding time-the beak orange-yellow; base of bill and crown blackish; cheeks distinctly white; under parts reddish-chestnut; feathers of the mantle nearly black, with broad rufous margins; wing-coverts lead-grey tipped with white; legs, feet and lobed membranes yellow. This stage is shown by the bird in the background. Length 8.25 in. ; wing 4.75 in. The male is duller, and has the white on the cheeks less defined. In autumn the chestnut gradually disappears; by winter the under surface has become pure white, the back pearl-grey, and the once rufous margins are white, the bill is black, the forehead white, and a black streak runs backwards from the eye; the bird in the foreground is in this stage. The young resemble the adults in autumn plumage. 


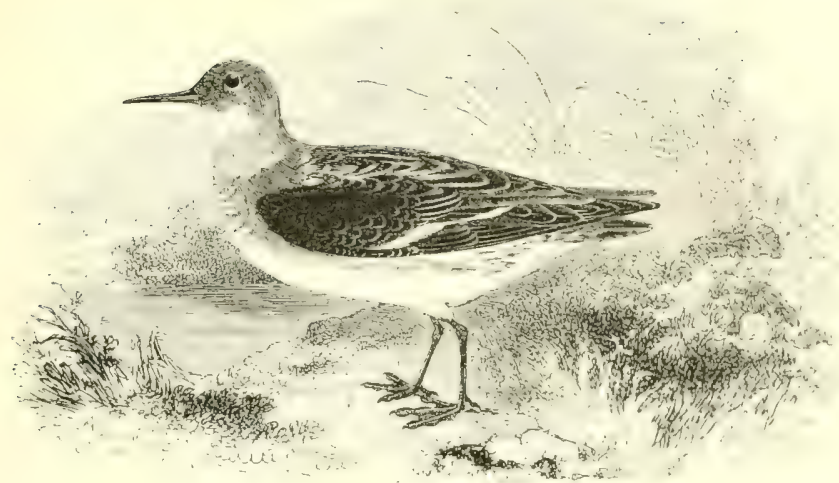

THE RED-NECKEI) PHALAROPE.

Phalaropus hyperbóreus (Linnæus).

The visits of the Red-necked Phalarope to England are even more irregular than those of the preceding species, and although the bird has become more frequent in Norfolk since 1870 , it is at all times less numerically abundant, and seldom wanders far inland: its occurrence being chiefly on the autumn migration. Along the east side of Scotland it is decidedly rare, nor is it at all common on the west; although a few pairs - the remnant of many-still nest in the Shetlands, Orkneys and Outer Hebrides, in localities which are protected from-or undiscovered by-the trading collector. The arrival from the south takes place in the latter part of May, and ly August both old and young have departed. In Ireland, strange to say, the bird has not yet been observed; and altogether the manner in which it avoids the greater part of the British Islands on its passage to and from its summer haunts is somewhat remarkable.

This species breeds in the Fraroes, Iceland, the south of (ireenland, Northern Scandinavia and above the forest-growth on the Dovrefjeld, in Novaya Zemlya, siberia to Bering seal, Kamschatka. and on the high ground by the Sea of Okhotsk. In Mlaskia and throughout the Arctic regions of America it is very albundant, and there again it nests by some of the lakes in the mountain ranges, als well as on the flat coast; while in winter or on passage it has been found down to the Bermudas in the Atlantic and cren to Chili in the South Pacific. In the old World its migrations extend to the Indo-Malayan region, China and Japan, its line through ('entral . Isia crossing the Pamir range. Unlike its congener, it avails itscli of the 
route by the valley of the Volga-especially in spring, visiting the Black Sea district and some of the inland waters of Central Europe, and it occurs irregularly in the Mediterranean basin ; it is, however, rare to the west of Italy, though it has once been obtained in Morocco. It is seldom found on the western and northern coasts of France or on the shores of Holland and Germany; but towards the northeast end of the Baltic it is not uncommon on the autumn passage.

The nest is in a tuft of grass in a wet place, and the eggs, 4 in number, are often rather greener in ground-colour and blacker in their markings than those of the Grey Phalarope, as well as smaller and somewhat more pointed: average measurements $I^{\prime} 15$ by .82 in. The male takes a considerable share in the duties of incubation, and after the young are hatched both parents display great anxiety, hovering close round the intruder. The note is a low metallic pleip, plict. The food consists of small crustaceans, marine insects, worms \&c.: while, like the former species, the bird swims well, though it has not been noticed quite so far from land.

In summer the adult female has the head, hind-neck, and shoulders lead-grey; the feathers of the back and wings somewhat clarker, with a mixture of jale rufous; tips of the wing-coverts and secondaries white, forming a bar; tail-feathers brownish-grey, the middle pair darkest ; chin pure white; sides and front of the neck chestnut; centre of the neck and upper breast lead-grey; under parts white; bill black; legs, feet and lobes greenish. Whole length $7.75 \mathrm{in.}$; wing $+35 \mathrm{in}$. The male is slightly smaller, and has the colours on the head and neck much duller and less sharply contrasted. In winter the forehead and the greater part of the crown are white: nape, and a streak through the eye sooty-brown; dorsal feathers margined with white; cheeks and under parts nearly pure white. The young in autumn have rufous and greyish-white margins to the upper feathers, but afterwards resemble the parents; their feet are yellowish and their toes are much less lobed.

The third and largest member of the genus, Ph. wilsoni, is confined to America, where it chiefly inhabits the interior. Mr. J. Whitaker of Rainworth, Notts, possesses a specimen which he believes to have been shot 'some years ago' in Leicestershire (P.Z.S. I S86, p. 297). A separate genus, Steganopus, has been devised for this species, which has a long slender bill, like our Red-necked Phalarope; while some ornithologists, especially those in America, place the Grey Phalarope in a third genus, Crymophilus. 


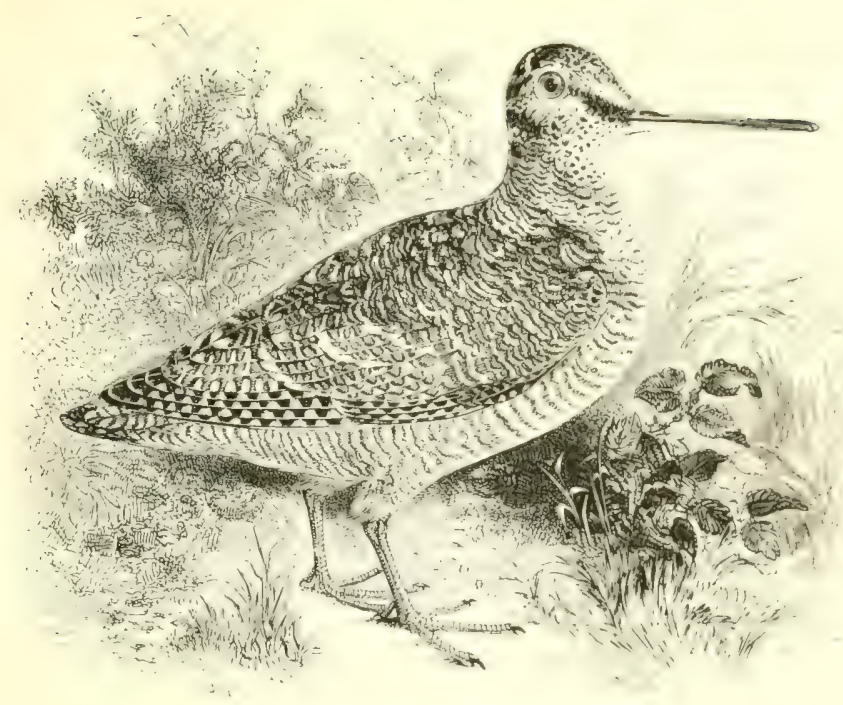

THE WOODCOCK.

\section{SCólOPAX RUSTícula, Linnæus.}

The annual 'flights' of this well-known species usually make their appearance in October, a return migration northwards being noticed in March, by which time the birds which intend to loreed in our islands have betaken themselves to suitable coverts. Of late years, owing to the increase of plantations-especially of comifers-in the vicinity of cultivated ground, the number of those which remain has been greatly augmented: nests having been found in all parts of England, and probably of Scotland and Ireland, except on some of the barest islands. It is said that early in autumn the home-bred birds disappear from their haunts, few, if any. heing seen until the October influx, and they are supposed to have ledt the country; but it may be questioned whether their disiplearance is not attributable to self-effacement during the moult. Mismation takes place by night, when castualties against the lanterni wi lighthouses and vessels are not unfrequent. Birds have often been known to alight with the wind in a quarter directly opluned (o) the direction whence they might be expected : lut this is prolully duc to the existence of different currents of air in the more elevated strata through which they have been passing.

The Woodcock has only once been obtained in the firroes and 
has not occurred in Iceland, though met with as a straggler in Newfoundland and on the Atlantic coast of the United States. The majority nest in the vast forests of Scandinavia and Russia; a smaller number breeding over the rest of Europe - up to the limit of tree-growth-as far south as Northern Italy, Transylvania, the Balkans and the Caucasus. On both sides of the Mediterranean basin the bird is chiefly found in winter, when it is plentiful in suitable localities; but in the wooded mountains of the Canaries, Madeira and the Azores it is resident. Persia and India are only visited during the cold season, though it breeds in the Himalayas at an elevation of $10,000 \mathrm{ft}$, and in the Japanese group as far south as the great volcano of Fujisan: while northward it inhabits the Bureja Mountains, the high land about Lake Baikal and the entire wooded region of Siberia, during the summer.

The eggs - often laid early in March, though more frequently in April-are usually + in number; they are slightly pyriform, and of a yellowish-white colour, blotched with ash-grey and two shades of reddish-brown: average measurements $\mathrm{I}^{\prime} 75$ by $\mathrm{I} \cdot 3$ in. The nest is merely a depression in some sheltered place, a lining of dead leaves being added during the progress of incubation. It is notorious that the female often remores her young, although the manner has been much disputed; the balance of evidence appears to be that the nestling is clasped between the thighs of the old bird and pressed close up to her body, sometimes even to the base of the bill. During the day the Woodcock rests in dry grassy bottoms, or beneath thick bushes-such as holly or laurel, but at dusk and early in the morning, especially during breeding-time, the male persistently follows certain tracks along glades in woods-often called 'cock-roads'-uttering a deep as well as a whistling note; similar routes are also traversed by both sexes on their way to and from their feeding-grounds. Worms, when procuralsle, are devoured in almost incredible quantities, while beetles and other insects, small crustaceans, and even mussels, are also eaten ; and I have watched a bird obtaining its food under circumstances which, if narrated, would not conduce to a taste for 'trail.' Few birds exceed i 5 ozs. in weight, though such are on record.

The general colour of the upper plumage is reddish-brown vermiculated with black, and that of the under parts wood-brown with darker bars. Externally the sexes are absolutely alike, but the spring dress is paler than that of autumn; there is, however, great individual variation. Total length 14.5 in.; wing 8 in. Partial albinisms are not uncommon. 


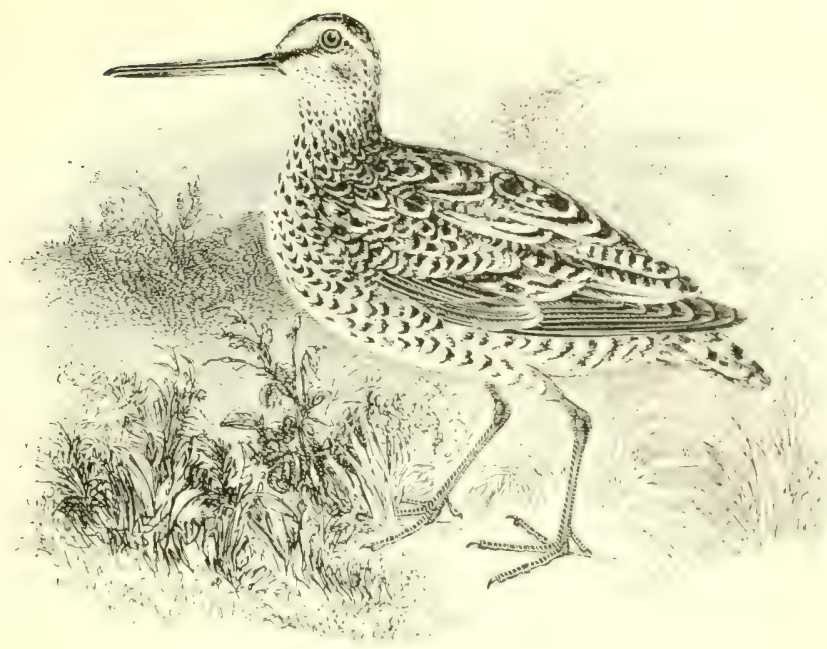

'THE GREAT SNIPE.

Gallinágo major (J. F. Gimelin).

The Great, I)ouble, or Solitary Snipe as it is often called, is an annual visitor in small numbers to the eastern and southern portions of England: its arrivals-chiefly those of young birdsbeing generally between the middle of August and the middle of October. In the central and western districts it is far less frequent : while as regards the spring migration only a single instance is cited by Stevenson-an adult, shot as it alighted on larmouth beach. Two were killed near Glasgow on May I6th I8S5, as recorded by Mr. William Evans, who adds that, as far as he knows. only seven or eight authentic specimens have been obtained in the whole of Scotland. Mr. Williams, the Well-known taxidermist in Dublin, states (Zool. I $8 S 9$, p. 33 ) that one was shot in co. (ialway on October I th isSS, being only the second example which has come under his notice in Ireland, though at least a dozcn large specimens of the Common snipe have been forwarded to him for preservation, under the belief that they belonged to the rarer species; a third was killed on Achill Island in November 1 sis.s.

In summer this species is found in the lowlands and also on the fells of Scandinavia up to about $70 \mathrm{~N}$. lat., and brecels in l en mark-rather freely in Jutland, some parts of Northern (icmany. and, sparingly, in Holland. In the marshy districts of Holand to the east of the Vistula, as well as in Russia down to ahout lat. 50, it 
nests in considerable numbers, and Messrs. Seebohm and HarvieBrown found it in abundance as far north as the delta of the Petchora. Over the rest of Europe it occurs on passage, though scarcely known in the west of France, and uncommon in spain; but to the east of the Rhone valley we begin to find it equally frequent in spring and autumn, while it is distinctly more numerous on the vernal migration in Italy, Malta and Albania. It occurs in North Africa from Morocco to ligglt, and passes southward to the Transraal and Nital, arriving in september and October and departing for the north in April, in which month it has also been obtained in I amara-land on the west side. In Asia it has been found across siberia as far as the lenesei, and southward to the Tian shan range, 'Turkestan. Persia \&c., but has not yet been recorded from India or China.

The nest is a mere hollow in some hillock above the level of the marsh; the eggs. + in number, are of a greyish-buff with pale purplish underlying blotches and bold characteristic purplish-brown surface-markings: average measurements 1 's by 125 in. Incubation begins at the end of May or early in June, lasting eighteen days; and the young, which run as soon as hatched, are ready to fly by the middle of August. The food consists of the larve of insectsespecially of the genus Tifuld-small slugs and worms, with, according to P'rof. Collett, a few small stones. In autumn, when the bird is often a perfect ball of fat, it weighs from 7 to 10 ozs. Many examples have been shot from grass-fields, heather, potato-patches in a sandy soil, barley-larers, turnips. and similar situations, drier than those frequented by Common Snipe; and though often found in couples it is seldom, if ever, in 'whisps': its flight is steadier and heavier than that of its congeners, and the tail is expanded like a fan.

The adult may be distinguished from the Common Snipe by its larger size. proportionately shorter legs and bill, more boldly barred under parts, and especially by the very much greater amount of aithite in the tail-fathirs, which are normally if (exceptionally is during the moult) and not it in number. In the young bird the tail-feathers are barred across both webs, but their ground-colour is of a pure white or buff, and not mottled as in the Common snipe: the markings on the breast and flanks are more arrowheaded in shape than those of the adult. Length 10.5 in.; wing 55 in. The sexes are alike in plumage. 


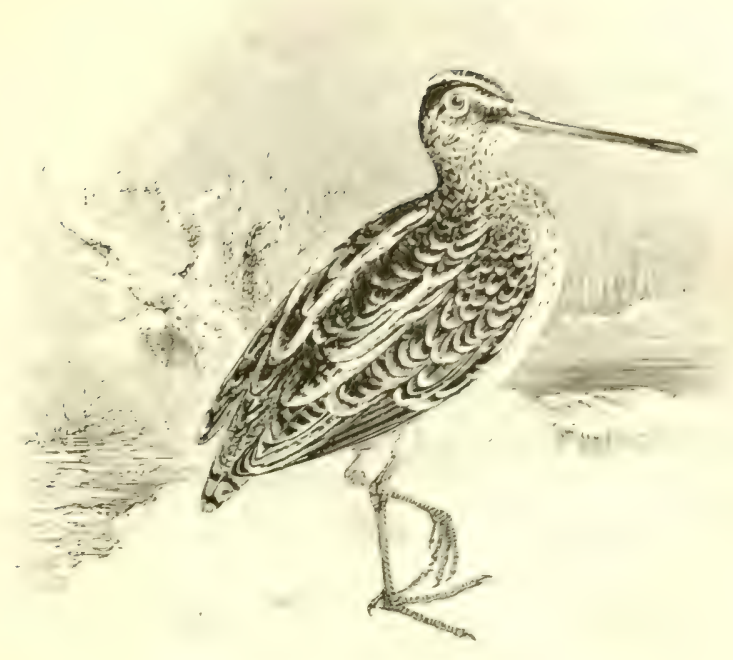

\section{THE COMMON SNIPE.}

\section{Gallinago crifístis (Frenzel).}

This species still breeds in Eneland and Wale werever drain. age has not abolished the localities suited tor its habits. and it in comparatively abundant in the marnes of suffolk, Norbolk and Lincolnshire, while generally distriluted on the northern ure irlund. and up to a considerable clevation in Fcotland and Irelans. Th.e: birds produced in the british Islands are few, howe:er, compared to those which annually visit us in Orteber and lowenlier, when many are killed by striking asainst the lanterns of lifhehou.. . These migrants, though they frequently shift their sround under the influence of the weather, often rumain through the winter till Warn.

The Common snipe is said to have ocrurred in south firewulenes. and is fairly abundant in Iccland and the Feroes. while in summer it is met with throughout nortiurm and temperate Euroges: it west. ing-range reaching to the marslics of Norhern Italy. () fanase or as a winter-visitor it is found in the Atlantic Islands and down to the African side of the Merliterrancan hasin, ascending the Niy. valiey to Nubia and Abysinia, and extending if range on the wat

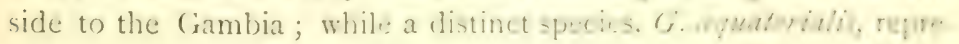
sents it in South Africa. In Asia, it breeds from $70^{\circ} \mathrm{N}$. in Siberia 
down to the lofty table-lands of Yarkand, crosses the great central ranges on migration, and is distributed in winter nearly to the equator. A closely-allied species with i 8 tail-feathers inhabits North America.

During the breeding-season the Snipe produces while on the wing-especially towards evening - a drumming or 'bleating' sound, which appears to be chiefly due to the action of the wings, slightly assisted by the expanded tail-feathers. In April, though exceptionally in March, its slight nest in the side of a tuft of grass or bunch of rushes is prepared; the eggs-usually 4 in number and very large for the size of the bird-being yellowish- or greenish-white, blotched somewhat obliquely with several shades of brown : average measurements I 6 by I'I in. The alarm-note, scape, scape, and chip, chip, is as well known as the zig-zag flight of the bird on being flushed; when feeding, however, the Snipe may be approached unawares, and will then try to escape notice by squatting; occasionally it perches on trees \& $\mathrm{c}$., though the fact has been dogmatically disputed by persons of limited experience. As its food consists of worms, insects and small molluscs, the Snipe often becomes very thin during a continuance of frost; its average weight is 4 ozs.

A detailed description is rendered unnecessary by the wood-cut; tail-feathers $\mathrm{I} 4$ in number; length of body 8 in. ; wing 5 in. It will be more interesting to give a vignette of the so-called Sabine's snipe, now generally admitted to be a melanism and seldom found outside the British Islands. The numerous variations in plumage have led to the creation of several bad species.

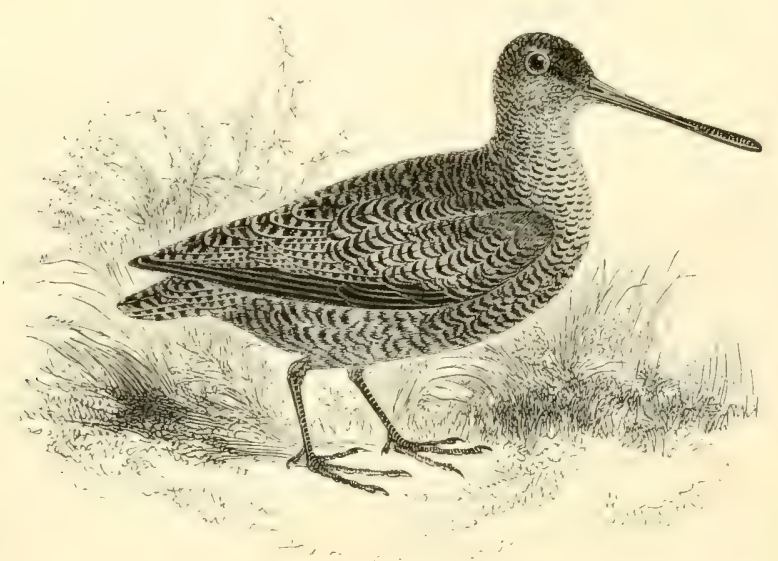




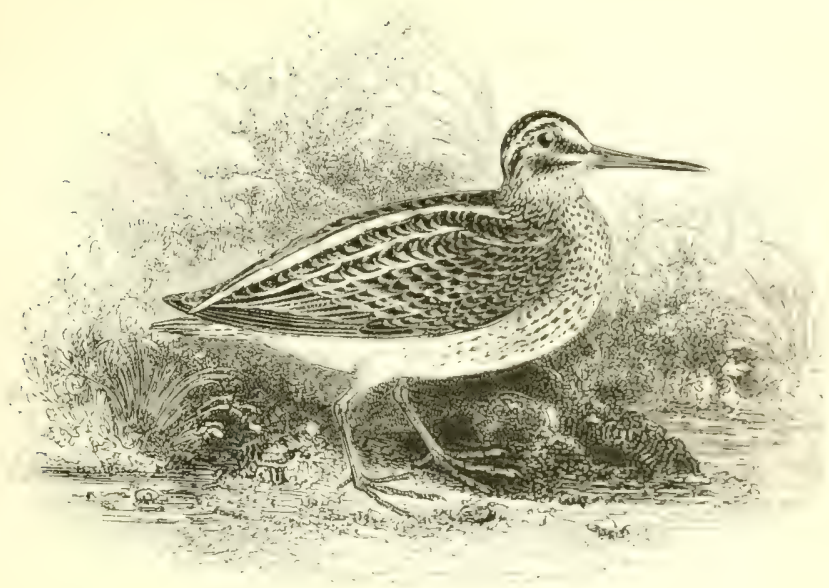

THE JACK SNIPE.

Gallinago gallínula, Linnæus.

The Jack Snipe seldom appears in the British Islands before the middle of September, and the heaviest arrivals take place in October, at which time it sometimes strikes against lighthouses, though with less frequency than the Common snipe. Isefore its departure northwards in April its plumage has assumed all the bloom and brilliancy of the approaching nuptial period, while the fact that a few individuals have been known to remain till late in spring and even through the summer, has given rise to suppositions that it might breed with us; there is not, however, a single wellauthenticated instance of its having done so in any part of the United Kingdom. During the colder months of the year its distribution is general, and though less numerous than the Common Snipe, it is far more ubiquitous, while exhibiting a marked preference for certain localities.

In summer this species inhabits Scandinavia, especially to the north of the Arctic circle, and in Western Rusia it nests as far south as St. Petersburg, though east of Archangel it appoars to lie unfrequent, and Messrs, Seebohm and Harvie-lirown did not observe it on the I.ower Petchora. Putting aside unsulstantiated assertions respecting its supposed breeding below lat. $55^{\circ}$. it may be described as a bird of passage over the remaincler of the fon tinent, becoming very numerous in the south-in some yars even more so than the Common snipe-during winter, at which scison it 
visits North Africa and Egypt, where it sometimes remains as late as May; it also ascends the Nile to Abyssinia. In Asia it breets on the tundras of Siberia as far north as lat. $70^{\circ}$, migrating to Japan and even Formosa in the cold season, as weil as to Tenasserim and the rest of the Indian region, Persia, and Turkestan; as yet, however, it has not been traced across the Pamir or other lofty ranges.

For details of the nidification of this, as of many other species, we are indebted to John Wolley, who found the bird breeding in the latter half of June on the marsh of Muonioniska in Lapland. The nests are described as being loosely made of little pieces of grass, equisetum, and a few old leaves of the dwarf birch, placed in a dry sedgy or grassy spot close to more open swamp. The Jack Snipe weighs about 2 ozs., yet its + eggs weigh more than $\mathrm{I} \frac{1}{2} \mathrm{oz}$.; these, so disproportionate to the size of the bird, are yellowish-olive spotted and streaked with brown, the latter colour being somewhat more predominant than in those of the Common Snipe; they are also rather smaller, averaging $\mathrm{r} / 5$ by $\mathrm{r}$ in. During the breedingseason the Jack Snipe makes a 'drumming' noise, which Wolley likens "to the cantering of a horse over a hard hollow road: it came in fours with a similar cadence, and a like clear yet hollow sound." Its food consists of larvæ of insects, beetles \&c., always accompanied by a little grit. A continuance of severe weather does not impoverish this bird, and between the fattest of several Jacks and the leanest of some Common Snipes (weighed the same day) I have found a difference of only ${ }_{3}^{1} \mathrm{oz}$. in favour of the larger species.

The adult male in breeding-plumage exhibits a large amount of metallic-green and purple on the upper parts; the female is, on the average, a trifle larger in size but not so bright in colour. In winter the reddish-brown of the upper parts is obscured by a tinge of grey: while in the young bird the green and purple reflections are wanting. Tarieties are very uncommon, but a melanism shot near Staines is recorded by Mr. F. Bond. Length of body 6.25 in.; wing 425 in. The tail-feathers are only 12 in number, for which reason, supplemented by the fact that there are two notches on each side of the posterior margin of the breast-bone-the Common Snipe having but one-this species has been placed apart by some ornithologists in the genus Limnocryptes. 


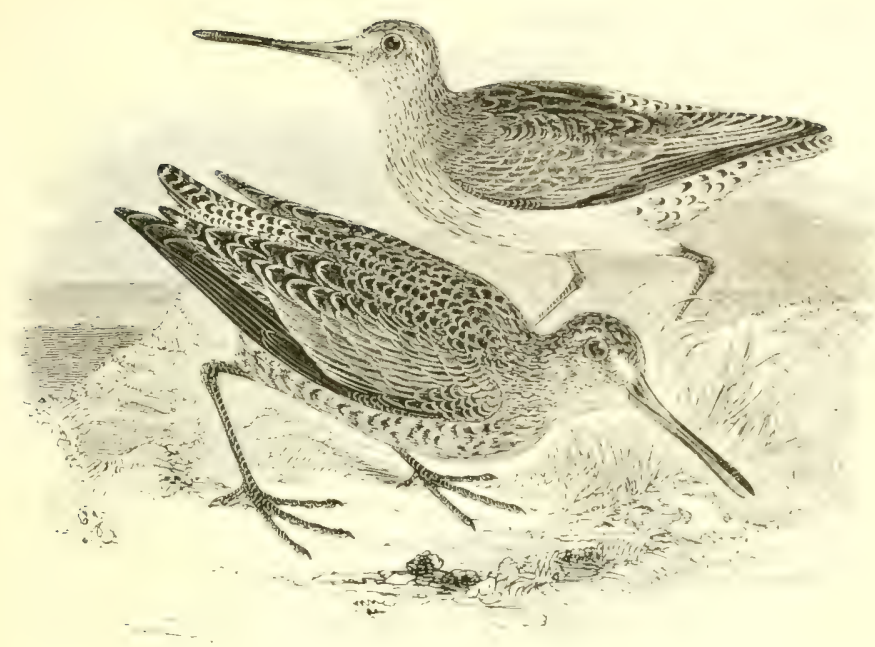

THE RED-BREASTED SNIPE.

\section{Macrorhámphus gríseus (J. F. Gmelin).}

The occurrence of this American species in Great Britain was first noticed by Montagu, who described and figured-under the name of Brown Snipe-a bird killed in Deronshire in Octoher of some year prior to $\mathrm{ISO}$, and now in the British Museum. Two more specimens are said to have been procured in the above county; and one has been shot in the scilly Islands: Middlescx has produced two, Norfolk three, Lincolnshire one (on August I 5 th 1S82), Lancashire one (now in the Preston Museum); and on the Cumberland side of the Solway a young bird, afterwards in Heyshams collection, was taken on September $25^{\text {th }}$ i $\$ 35$. All these have heen obtained in autumn, and most of them in the month of ()ctuber. In Scotland, according to Gray, one was shot near Largo in September $\mathbf{r} 867$, and a bird which has been correctly identified is said to have been killed in Lanarkshire. There are some other records which are open to question. In Ireland no example has yet been met with.

On the mainland of Europe the Red-breasted snipe has only been found in Picardy and Normandy ; while on the other sicle of the North Atlantic it is of rare occurrence in the seruth of (ircenland. It breeds on the vast morasses round Hudson biay, and ahout as fir south as lat. $44^{\lrcorner}$, migrating along the cart colst: but west of the 
Mississippi valley a slightly larger form prevails, with somewhat longer bill and brighter coloration in summer, and for this many American ornithologists have adopted the name scolopaceus, either specifically or sub-specifically. Both forms occur in winter in the Gulf States and among the West Indian Islands, while it is admitted that birds undistinguishable from those of the Atlantic race occur on the barren-grounds and in Alaska-the summer-quarters of the western form-as well as down the Pacific side of America. For the purposes of the present work we may unite the two under one heading and say that the Red-breasted Snipe breeds throughout the Fur countries, migrating in winter as far south as Brazil on the east side and Chili on the west, while a few wanderers cross the Pacific to Japan and North-eastern Siberia. Its spring arrival on Long Island, near New York-where it is known by the name of 'Dowitcher'takes place towards the end of April, and within a month the most northern of its breeding-grounds have been reached.

According to Messrs. Dall, Mackarlane, Nelson and others, the eggs, 4 in number, are laid in June in some slight hollow in a tussock near a like or marsh-pool ; their colour is greenish-grey or brownish-olive, blotched with dark umber: average measurements I.75 by $\mathrm{I}_{2} 2 \mathrm{in}$. The young are full-grown and on the wing by the end of July, and early in August the adults begin to lose their red breeding-plumage, while by September they have fully assumed their grey winter garb, and have formed large flocks. Owing to its tameness this species affords no sport, and if disturbed merely utters a short aicit on taking flight, soon settling down again by the side of the water, in which it seeks the small insects, worms and marine bivalves which constitute its food.

This bird is rather larger than the Common Snipe, and may be recognized at all seasons by the pure white shaft of the first primary, the white axillaries and lower back, and the black-and-white bars on the upper tail-coverts. In summer the upper as well as the under parts are suffused with pale chestnut, and the central tailfeathers are barred with black on a rufous ground, the outer pairs being marbled with black and white; bill dark olive; irides reddishhazel; legs and feet pale olive. Whole length ro-r I in.; wing 5.5 in. The sexes are alike in plumage. The young are much greyer than the adults, and only the margins of the feathers of the mantle are rufous. In winter the general plumage is grey, and except for its size and length of bill the bird is then just like a Dunlin in the dress of that season. 


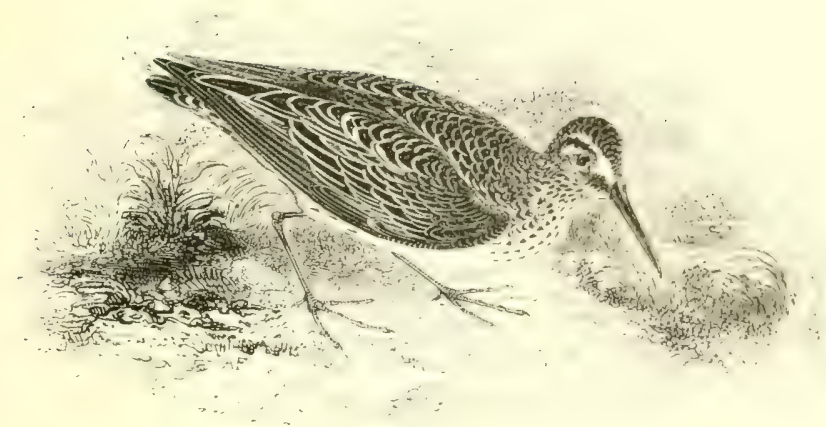

THE BROAD-BILLED SANDPIPER.

\section{LmíCOIA PLATYRHÝNCHA (Temminck).}

The Broad-billed sandpiper was first made known as a visitor to the British Islands by Hoy, who recorded an example shot on May $25^{\text {th }}$ i 836 , on Breydon Broad, Norfolk: a locality which afforded another on May $25^{\text {th }}$ I $\$ 56$, and a third on April $23 \mathrm{rd}$ ISOS. Mr. IV. Borrer has a specimen obtained near shoreham, in (Oetober I $S_{45}$; and Sir H. S. Boynton possesses one killed at Hornsen MI Tue. Yorkshire, in April I $86_{3}$; while lastly, on August i 3 th is 8 ;. Mr. II. Burton killed one near Rye. Accoräing to Thompson one was procured in Belfast Bay, Ireland, on October $4^{\text {th }} \mathrm{I} 844$.

It is evident that our islands lie outside the ordinary route takin by this species; yet it breeds no further off than the fells of Scandinavia, and visits the coasts and inland waters of Ienmark, Germany, France and Switzerland. As jet it has not leen noticu? in the Spanish Peninsula, but in Italy its occurrences, thrush irregular, are not unfrequent, large flocks-which have probably made use of the Brenner Pass-sometimes alighting in the marihes of Venetia. From Finland and the tundras of European Kusial, where it also nests, a more easterly line of thight brings it to the blark Sea and the Aralo-Caspian region, while it is found durine winter m some parts of the Mediterranean basin, including the shoren of Nouth Africa as far as Egypt. Strange to say, it has not been met with ly any explorers in the Arctic portions of Isiatic siberia, hut sever in obtained a specimen on the l'amir, and the hird is commm in 
winter on the coast of Sind. It occurs again on Lake Baikal, and commonly on the Sea of Okhotsk, visiting Japan, China, the Philippines, Burma, and Eastern India; while, after another great gap in its distribution, we find it at Madagascar, of course during the cold season.

Its nesting habits were first made known to English readers by the late Richard Dann, who found small colonies of this Sandpiper in the grassy morasses of Lulea- and Tornea-Lapmark, as well as at about 3,000 feet above sea-level on the Dovrefjeld. Wolley's explorations subsequently rendered us familiar with series of its eggs, which vary in colour from rich chocolate to pale hair-brown mottled with umber : average measurements $1^{\prime} 2$ by 9 . According to Mr. Mitchell the lining of the nest - which is placed in a tussock of grass-is suited to the colour of the eggs, the darkest ones being laid on the brown withered leaves of the mountain-willow, and the lighter ones on grass; he found them on the Dovrefjeld as early as May i 5 th, but in Lapland the latter part of June is the usual time for laying. The bird sits very close and, when flushed, usually drops again a short distance off ; early in the season, however, it soars high in the air, rising and falling suddenly, like a snipe, and repeating the note too- $\pi 00$, rapidly. The food consists of insects and their larvæ.

The adult in breeding-plumage has the feathers of the crown, shoulders and mantle very dark brown variegated with white and rufous, the latter colour predominating on the margins of the long inner secondaries; quills and central tail-feathers blackish, outer tail-feathers pale ash-brown; throat and breast white, tinged with rufous and spotted with dark brown, as are also the flanks; belly white; bill high at the base, very flat and wide, and rather abruptly decurved near the tip; legs and feet dark olive. The sexes are alike in plumage, but the female is slightly larger; whole length $6.5 \mathrm{in}$., wing $4.25 \mathrm{in}$. In the young the upper feathers are more broadly margined with greyish-white. In winter the general upper plumage is ash-grey, very similar to that of our Dunlin; but a distinctive characteristic is the small amount of white on the secondaries and the sides of the upper tail-coverts. 


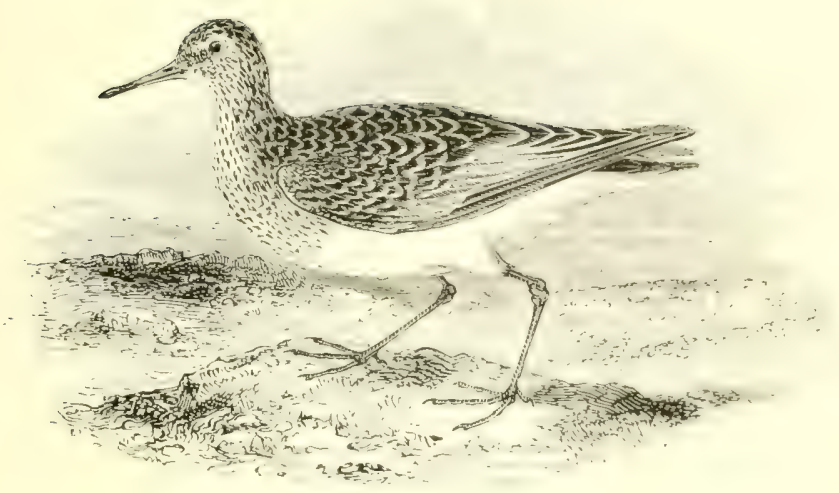

THE PECTORAL SANDPIPER.

Trínga maCuláta, Vieillot.

The Pectoral Sandpiper has been observed in the British Islands with far more frequency than any other American species of wader. The first authenticated specimen was shot in October i $S_{3} \circ$, on Breydon Broad, Norfolk, in which county three more have since been obtained; Suffolk can claim one, Yorkshire three, I) urham two, and Northumberland one-the last (now in possession of Mr. C. M. Adamson) on June 27 th 1853 . There are also records of one from Eastbourne in Sussex, two from North I levon, one from lialmouth in Cornwall, and four from the sicilly Islands-amonis the last an example on May 27 th 1840 . The only instance known on the west coast is that of a young female, shot in Cumberland on ()ctober ISth IS8S. In Scotland, an immature bird was killed at I on mouth, Aberdeenshire, on October and $1 \$ 6_{7}$, and another (identified by $M r$. Harting) near Loch Lomond, on November zth ISSz: while as regards Ireland, Mr. Williams of I)ublin found in the market a remarkably fat male, sent from l'ortumna, co. (ialway, with a lot of Snipe, in October Iss8. Except where otherwise mentioned, all the above occurrences have taken place in autumn or winter.

This species has not as yet been met with on the Continent of Europe, nor does it appear to have crossed from the American side of Bering Strait to Asia, although its old World representative, T. acuminata, does occasionally visit Alaska. In summer it is widely, though somewhat irregularly, distributed across the hurren. grounds, from Point Barrow and the mouth of the liken (o) Hul-en 
Bay; while on migration it is common throughout the Dominion of Canada and the United States, except on the coast of the Pacific; ranging to the Bermudas, Bahamas and West Indies generally, and as far south as Patagonia and Chili. As a straggler it has occurred in Greenland.

The breeding-habits of the Pectoral Sandpipe: were practically unknown until the United States Expedition to Point Barrow in Alaska, when, in $\mathrm{I} S S_{2}$ and $\mathrm{I} S S_{3}$, eighteen sets of eggs were obtained, each complete clutch consisting of 4 . These are described by Mr. John Murdoch as having a drab or greenish groundcolour, blotched with umber-brown: average measurements $\mathrm{I}^{\circ} 5$ by $I$ I in. 'The nest is always built in the grass, in some high and dry locality-never in the black clay and moss, or in the marsh, like that of the Phalaropes. The birds pair soon after their arrival towards the end of ILay or early in June, when the male may be seen taking short. low flights, with the wings held high and beaten stiffly, while the throat is puffed out to its fullest extent (whence the name l'ectoral), and a muffled hoo, hoo, hoo, hoo, is often repeated. After the breeding-season the adults keep very quiet, and they appear to slip away, without collecting into flocks, as soon as the young are able to take care of themselves; the latter, however, begin to form in packs about August roth, and stay for several days before taking thicir departure for the south, a few remaining till the first week in september. At that time the usual note is a single trieet. The lood consists of insects-especially coleoptera-and sea-weed, on which the birds become remarkably fat.

The adult has the feathers of the upper parts dark brown with buff and rufous margins: seconderies with but little white on their edges; munp and tail-currts duskl-frotin ; central tail-feathers dark brown, the rest ash-brown with paler margins; throat and face dull white striped with hair-brown; breast buffish, profusely streaked with 'arrow-head' markings; under parts white. The sexes do not differ in plumage. Length $8 \cdot 75$; wing 5.25 in. The young bird has the feathers of the mantle broadly edged with rufous, and merely stripes instead of 'arrow-heads' on the breast. 


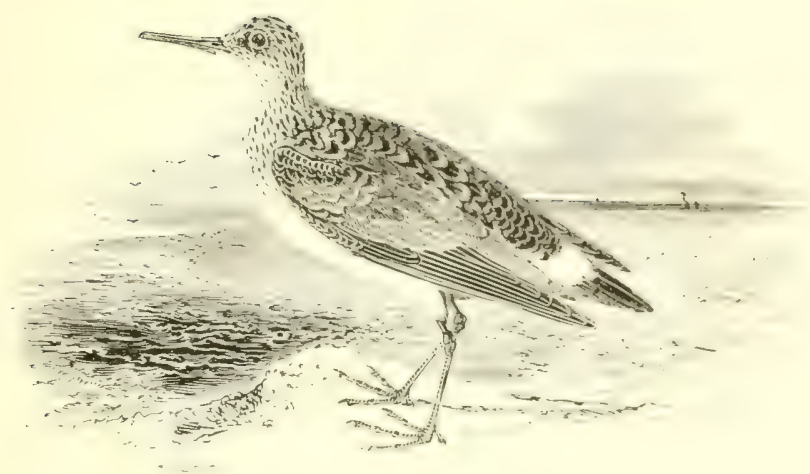

BONAPARTE'S SANDPIPER.

TriNGa FUSCICÓllis, Vieillot.

This is another American bird, which may always be distinguished from the Dunlin by its shorter bill and wolite rump. The first British example on record was shot prior to 1839 , in Shropshire, while subsequently three others have been obtained in Cornwall, two in the Scilly Islands, four at Instow in North l)evon, two in Sussex, and one at Kingsbury Reservoir in Middlesex. There is also a specimen in the Museum at Belfast which is belicted to have been killed near that city.

On the Continent of Europe this Sandpiper has not yet been observed, for the $T$. schinzi of Brehm and some other ornitholusints is a small form of the Dunlin; our bird is, however, the T. schinzi of Bonaparte, and under the name of Schinz's Sandpiper was figured and described in the rst, and and 3r.t liditions of "limell." It is said to have occurred at Reykjavik, Iceland, in June s sio. and is certainly found in Greenland early in the autumn, while sencrally distributed during summer throughout the Aretic regions of Anerica as far west as the Mackenzic region, where it breds abumblantly: but in Alaska it is rare, only two specinnens having leen wheined by Mr. Murdoch at Point Barrow. On migration it is common in the Mississippi valley, and along the whole Atlantic coast to Florida; ranging southward to the llest Indies, cintral lumera.

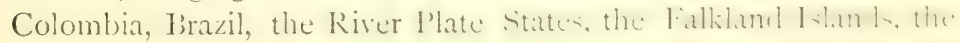
Straits of Magellan, and, on the Pacific side, to P'eru and Chili. 
Authenticated eggs obtained by Mr. MacFarlane on the barrengrounds near the Arctic coast, have a rufous-drab ground-colour, and are boldly blotched with dark brown, especially at the larger end : average measurements 135 by 95 in. The complete clutch consists of 4 , and the nest is a mere depression in the ground, lined with a few decayed leares. Dr. E. Coues says he has frequently observed this bird on rocky shores covered with sea-weed and moist with the falling spray; and that of all American Sandpipers it is the most gentle and confiding. When startled, it emits a soft, low riect, different from the note of any other wader, flying off in very compact flocks in a vacillating manner, alternately showing the upper and under parts, and being easily recognized on the wing by the conspicuously white upper tail-coverts. It usually associates with Semipalmated Sandpipers and Ring-Plovers, and, in common with other small species, is known by the name of 'peep'; Rodd remarked that the call of those killed in Cornwall was shorter and sharper than that of the Iunlin. The food consists of insects, small crustaceans, marine animals \&c., and with us, as in America, the bird appears to be partial to rocks which are covered with seaweed and slope down to the water.

The adult in summer has a white streak over the eye; feathers of the upper parts ash-brown with dark centres, the edges being grey and rufous; quills dusky-brown; rump dark ash-brown; upper tail-coierts chiefly wlite, though-streaked laterally with brown, the central pair-which are not conspicuous-being dark; the two central tail-feathers dark brown, pointed, and longer than the rest, which are ash-brown; chin white; cheeks, neck, upper breast and flanks greyish-white, speckled and streaked with duskybrown; axillaries, belly and under tail-coverts white; bill very short, straight, and nearly black; legs and feet dark olive. The female is a trifle the larger and more richly coloured. Length 7.5 ; wing $4.8 \mathrm{in}$. In winter the mantle is brownish-grey, and the streaks on the breast \&c. are less sharply defined. The young are more mottled with white and rufous on the back, while the throat and breast are suffused with buff. 


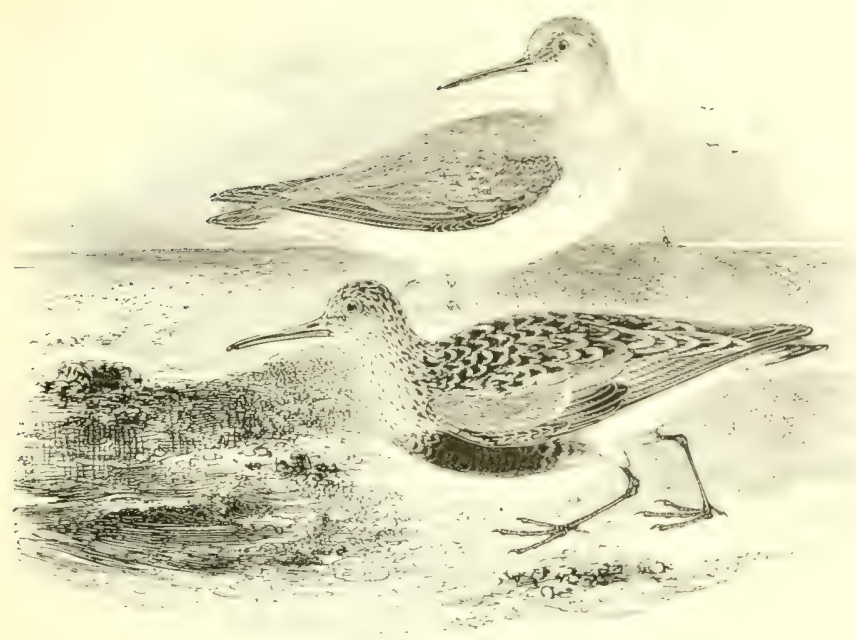

THE DUNLIN.

Tringa alpína, Linnæus.

The Dunlin is the most numerous of the Sandpipers which frequent our shores and tidal rivers, where it may be found throughout the year; for although many of the adults retire inland for nestingpurposes, their place is taken in summer by immature birds. Its favourite breeding-quarters are wild and often elevated moorlands, which are comparatively rare in the south of England; but nests have been found in Cornwall and Devon, and I have seen the young hardly able to fly on Exmoor in Somerset. Satistactory evidence is wanting as regards Wales, but the species breeds sparscly in the marshes of the Dee in Cheshire, more frecly in Lancashire and Yorkshire, and in some numbers on the mosses on both sides of the Solway; while on the east side its egrgs have been obtannel in Lincolnshire, and a few pairs are scattered over the moors further north, up to the Cheviots. In Scotland, where suitable situations are abundant, the bird is gencrally distributul on the mainland-though local in sutherland, and is rather plicntiful on many of the islands as far as the shetlands. Is regardis Irchand. it is only known to nest-in small numbers-in the north west, but in autumn and winter it frequents the coasts in thousands.

The Dunlin varies considerably in size, length of bill, and colluter of plumage, and even in the Paliearctic: resion there aplecar (1) tee two races: a large and northern one of duller tints, and a smaller 
brighter bird to which Brehm applied the name T. schinsi. North American individuals are characterized, as a rule, by their larger size. longer bills, and more rufous summer-plumage, but in sketching the geographical distribution I shall consider these as merely forms of one species. With this proviso it may be said that the Dunlin breeds in the Færoes and also in Iceland, while it is widely diffused in Scandinavia and on the tundras of Russia, its northern range extending to Noraya Zemlya. It also nests in Denmark and along the Baltic coast of Northern Germany; according to Prof. (iiglioli it undoubtedly breeds in the marshes of Venetia in Northern Italy; and Mr. Abel Chapman shot a bird from its exgs in the extreme south of Spain. During the colder months of the year the Dunlin is met with on all the sea-shores and many of the inland waters of Furope, as well as in the Canaries and Northern Africa : its migrations reaching down the east side of that continent as far as Zanzibar. In summer it inhabits the Arctic portions of Situria in Asia, and it winters in China and many districts of the Indian region. In America it nests in the north, descending on the Pacific littoral to California and on the Atlantic to the Wesi Indies; it is also found in Greenland.

Early in May on the salt-marshes, though somewhat later on the fells, the I unlin forms its slight nest, often in a tussock of long coarse grass, or among sea-pinks, short heather ¿c. ; the eggs, 4 in number, are greenish-white, blotched and spotted with two shades of reddish-brown: average measurements $1: 35$ by 95 in. During the pairing-season the birds soar to a moderate height, uttering a somewhat prolonged datic ; but in autumn, when in flocks, a distinct fum may be heard, from which this species derives one of its local names; it is also called 'Ox-bird' and 'Sea-snipe.' The food consists of worms, small crustaceans, and marine insects.

The adult in spring (represented in the foreground) has the crown of the head rufous, streaked with black; mantle chestnut, variegated with black; rest of the upper plumage chiefly ash-grey; throat and upper breast greyish-white with dark stripes; lower breast black; belly white. As a rule the females are larger and have longer bills than the males. Average length $S$ in. ; wing 4.55 in. In the young the feathers of the head and back have large black centres and rufous margins, the chin is white, and the upper breast is tawny-buff with dark streaks which enlarge to spots on the lower breast and flanks; belly nearly white. In winter the adults are chiefly ashcolour above, with a distinct white alar bar, and their under parts are white with a mottied greyish band on the lower neck. 


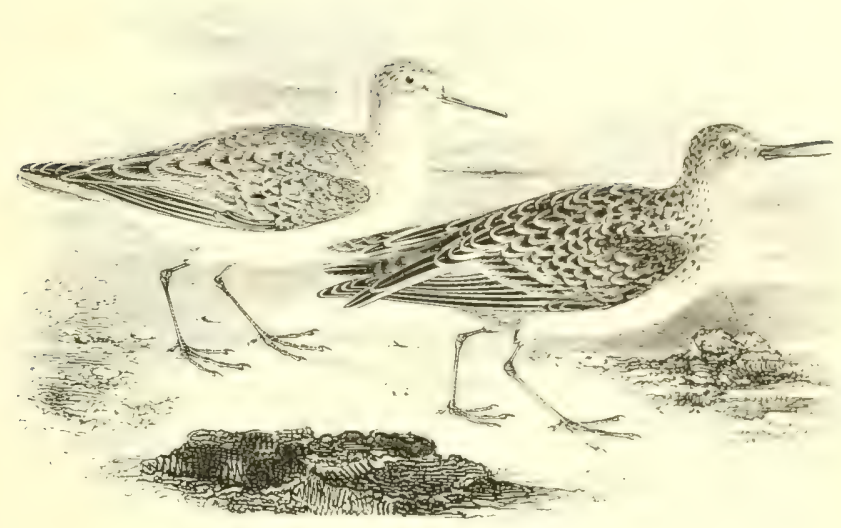

'THE LITTLE S'TINT.

T'Ringa minúta, Leisler.

The Little Stint arrives on the east side of England every autumn, and again on the passage northward in spring, its numbers on the mud-flats of Nurfolk being sometimes considerable; but on the whole the British Islands appear to lie on the outskirts of the chief line of flight pursued by this somewhat eastern species. On the south coast it is not very common, while westward its occurrences are decidedly irregular, the sandy flats of Lancashire and of the Solway district being the localities it most affects. Further north it is as yet unknown on the west side of Scotland, while trustworthy evidence is desirable respecting its reported visiti to the Orkneys and Shetlands: it is undoubtedly rare in sutherland, and even on the east it does not seem to be frequent. According to Mr. More it is to be met with every autumn in Ireland, chiefly along the north-east shore, but is nowhere plentiful.

On its autumnal migration this species visits the greater part of Europe, and, except on the west coast of lirance, it is almost as abundant on the spring passage. It does not appear to winter in any numbers on the northern side of the Mediterranean, theugh man remain in Morocco, Algeria and Esypt: but the majority make for the extreme south of Africa, the suychelles, Irabia, and the cutine Indian region, traversing, on their way to the latter, the great ranges of Central Asia. The breeding-grounds of the Little Stim were first discovered by Ir. von Middendorff, as far east as the 
Taimyr river in Asiatic Siberia, in lat. $74^{\prime} \mathrm{N}$.; in the summer of I 872 . Messrs. Alston and Harvie-Brown obtained a bird in nuptial dress at the mouth of the Dwina, while Prof. Collett found the species common on the Porsanger-fjord in Norway, showing that its range extended further to the westward than had previously been supposed; and in July I8/5 Messrs. Seebohm and Harvie-Brown were the first to take the eggs in Europe, near the mouth of the Petchora. Nesting-places have since been discovered by Mr. Henke near Archangel, by Mr. E. Rae in the Kola Peninsula, by Prof. Collett in Northern Norway, and by Dr. O. Finsch near the Kara Culf; while eggs were brought to Mr. Seebohm on the Yenesei, thus connecting the chain from the westward with the Taimyr. Birds found on the Lena delta and further east in Siberia have redder breasts in breeding-plumage, though undistinguishable in winter, and have been distinguished as $T$. ruficollis.

The nests found by Messrs. Seebohm and Harvie-Brown were mere hollows in the moor, scantily lined with dead leaves \&c. ; the eggs, + in number, are in every respect miniatures of those of the I) unlin: average measurements $\mathrm{I}$ by $75 \mathrm{in}$. Incubation was far adranced by July zand, the date of their discovery. The female appears to be very quiet and tame when at the nest, from which, however, she sometimes endeavours to divert attention by feigning lameness; her note is described as a sharp wick, but in autumn, when the birds are in flocks, their call resembles the confused chirping of grasshoppers or crickets. Aquatic insects, small crustaceans, worms, molluscs, and occasionally the seeds of plants, constitute the food of this species.

The adult in summer-plumage (represented in the foreground) has the upper parts variegated with rufous and black, like a Dunlin; chin white; throat and upper breast tinged with rufous and speckled with dark brown; under parts white; bill, legs and feet black. Length $6 \mathrm{in}$; wing 375 in. The female is slightly larger than the male. After the autumn moult there is no red on the throat, and the upper parts are of an ashy-brown, though always with more rufous than is the case in Temminck's Stint. The young have the feathers of the back edged with buffish-white; the legs and feet are blackish even from the nestling stage. As pointed out by Mr. Harting, the Little Stint is a miniature Dunlin (except for the black breast); Temminck's Stint is a small edition of the Common Sandpiper. 


\section{THE AMERICAN STINT.}

TRINGA MINUTILla (Vieillot).

The American Stint has been obtained in this country on two occasions. The first example was shot on a piece of wet grassland adjoining the sea-shore in Mount's Bay, Cornwall, on October Ioth $\mathbf{1} 8_{53}$, by IV. S. Vingoe, who showed it to J. E. Rodd, by whom it was recorded in 'The Zoologist,' p. 4297 ; the occurrence being also noticed under the name of Tringa fusilla in the l'reface

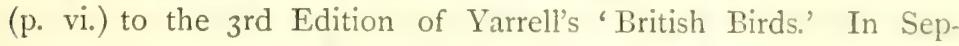
tember I 869 a second example was killed on Northam Burrows, near Bideford, by Mr. Rickards of Clifton (Zool. S.S. 1. 2025), who brought the freshly-skinned specimen to Mr. Harting for his inspection, and its identity has been rouched for by that competent authority (Hbk. Brit. Birds, p. I +3 ). The species has, therefore, as good a claim to be noticed in this work as many other stragglers: but it has not been considered necessary to figure it, as an engraving would not adequately show the points of difference between it and the Little Stint. The American bird is rather smaller, with a proportionately longer bill, and is conspicuously darker at all seasons; in the breeding-plumage the fore part of the chest is ashy-buff, with distinct spots of dark brown-not rufous with tiny dots as in T. mimuta; and the legs are dusky olive-brown, whereas n T. minuta they are black.

This small Stint, called by American ornithologists the Least Sandpiper, is widely distributed throughout the Arctic portions of the New World, breeding as far south as Sable Island-a little below Nova Scotia, as well as in Newfoundland, Labmalor, and the higher regions generally to Alaska. I limited number winter in the Gulf States, but the majority pass onward to Mexico, the West Indies, Central America and Brazil. In autumn larse flucks take an easterly direction as far as the Bermudas, while on the west side the species is extremely common in Suthern ('alifornia.

A nest found in Labrador by ludubon is described as a hollow lined with a few blades of dry srass, the bocality cheren luing under the lee of a small rock, expused to all the heat the sun can afford in that country. The eggs, 4 in number, are of a rich cream-yellow tint, blotched and dotted with rery dark umber. 
especially at the larger end: specimens in Mr. Dresser's collection measure I by $S$ in. Of twenty nests found on the barren-grounds by Mr. MacFarlane, all but six were taken between June 2 ist and 3 oth. The food consists of earth-worms, small crustaceans and marine insects. The note is a shrill twitter, resembling the syllables peep-peet.

The adult in breeding-plumage has the feathers on the head and mack hlackish, slightly edged with rufous; hind-neck ashy, varied with rufous: wing-coverts ash-grey, exteriorly margined with buff, greater coverts with white edges, which form an indistinct alar bar; quills ash-brown, blacker towards their tips, the shafts whitishbrown, with the exception of the outermost which is chiefly white and only dusky towards the extremity; lower back and rump deep black: tail-feathers pale ash-grey, the middle pair elongated and blackish like the rump; lores, eyebrows, and sides of the face whitish; throat white: chest ashy, mottled with dark brown in the centres of some of the feathers; rest of the under surface white: under wing-coverts whitish, some of the lower ones mottled with hrown; bill nearly black; legs dusky olivebrown; iris dark hazel. Externally there is no material difference between the sexes. Total length about 5.5 in.; wing 3.5 in. In autumn some of the feathers of the back and scapulars have pale grey edges. The winter-plumage is ash-grey abore, some of the dorsal feathers being dark purplish-brown in the centre and margined with white; the lower part of back and the rump are blackish; the wing-coverts like the back, the greater coverts clearer brown, and indistinctly tipped with white; rest of the plumage as in summer. The Semipalmated sandpiper. $T$. pusilla, another very common and widelydistributed species in America, may always be distinguished from the present by having the anterior toes webbed at the base. 


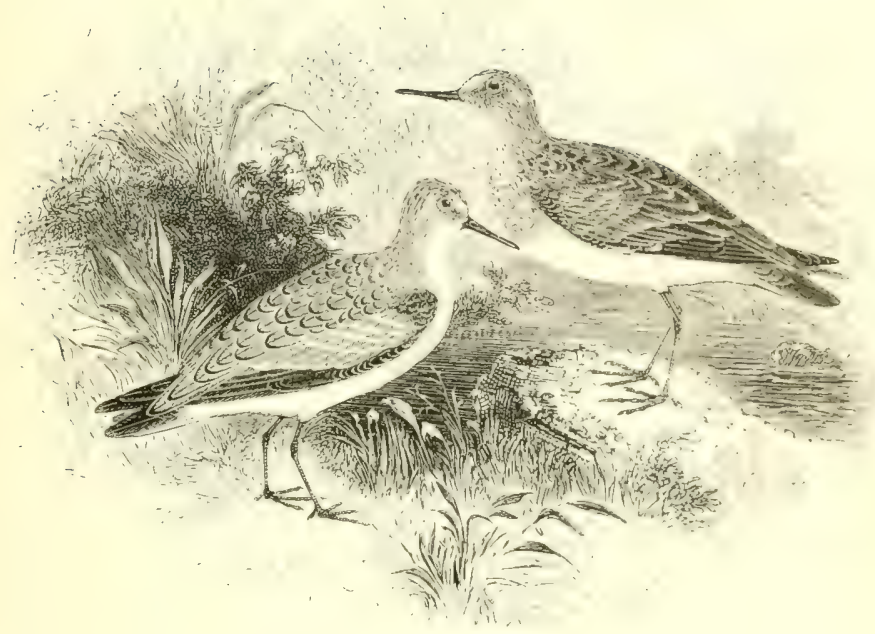

\section{'TEMMINCK'S STINT.}

TRINGA TEMMíncki, Leister.

Though less rare on migration than was formerly supposed. this species is more irregular than the Little Stint in its visits to (ireat Britain, notwithstanding that its western breeding-grounds are at no great distance from our northern shores. There is, howcur, only one very questionable record of its occurrence in Caithness, while few examples, and those at long intervals, have been obtained on the east coast of England between Northumberland and the south of Lincolnshire, in autumn. In Norfolk a good many have been met with at that season-one as late as November 23 rdwhile about ten have been procured on the return passage in May: thence it can be traced along the rest of the eastern sca-board and the whole of the Channel to Cornwall and the scilly Inlinds. It has also been found inland, as at Kingsbury Reservoir in Middlesex, Foulmire in Cambridgeshire, Mansfield Reservoir in Nottinghamshire, Ribbleton MIoor in Iancashire \&c. : but on the west side it is very rare, and only four, or perhaps six instances are on record from the entire Solway district. According to 'Thompson a specimen was procured near Tralee in Ircland in January I $8+8$; a very remarkable date, inasmuch as. with this 
exception, the bird has not been known to remain during the winter in the United Kingdom.

Temminck's Stint breeds in the northern districts of Norway, and in those parts of Sweden, Russia, and Siberia in Asia which lie beyond the limits of forest-growth; also, it is said, in the Stanowoi Mountains. Its reported occurrence in Japan is the result of an erroneous identification, but it visits China on its migrations-which extend to the Malay Archipelago-crosses the Central Asian tableland to India, and descends both sides of Africa to lat. $10^{\circ} \mathrm{N}$. on the east side, and to Senegambia on the west. A considerable number, however, spend the winter in the Mediterranean basin, and on passage it is found on the shores as well as on many of the inland waters of Europe; it is, in fact, far more partial than the Little Stint to rivers, lakes and ponds.

The nidification of this species was first made known to us by Wolley, who found the bird breeding, somewhat locally, to the north of the Crulf of Bothnia. The nest, seldom far from water, is a scantily-lined depression in sedge, rushes or short grass ; the eggs, 4 in number, vary from pale buff to greenish-grey, blotched with several shades of brown : average measurements $I^{\prime} I$ by $S$ in. Prof. Collett says he has never found the females near the nest or young, and the brooding-birds which he shot were all males with large incubation-spots. In the courting-season both birds may be seen hovering or floating in the air like butterflies, uttering a song which has been compared to that of the Grasshopper-Warbler: the usual call-note in autumn is a sharp ftirr. The food consists of worms, marine insects and larwe of Staplyylinide, fragments of grit being taken to aid digestion.

The adult in summer-plumage has the feathers of the upper parts greyish-brown with darker streaks, and with broad blackish bars on the mantle; the shaft of the outer primary nearly white, the other shafts dusky, like the rest of the quills; wing-coverts tipped with white; the two outer pairs of tail-feathers white; throat and breast buffish-brown with darker streaks; under parts and axillaries white; bill blackish; legs and feet greenish-brown. Length 6 in. ; wing 3.8 in. The sexes are alike in plumage. After the autumn moult the dark markings on the back are lost, and the general colour is very similar to that of the Common Sandpiper. In young birds the upper feathers are tipped with grey; the breast shows few spots; the outer tail-feathers are less purely white, and the legs are yellowish. 


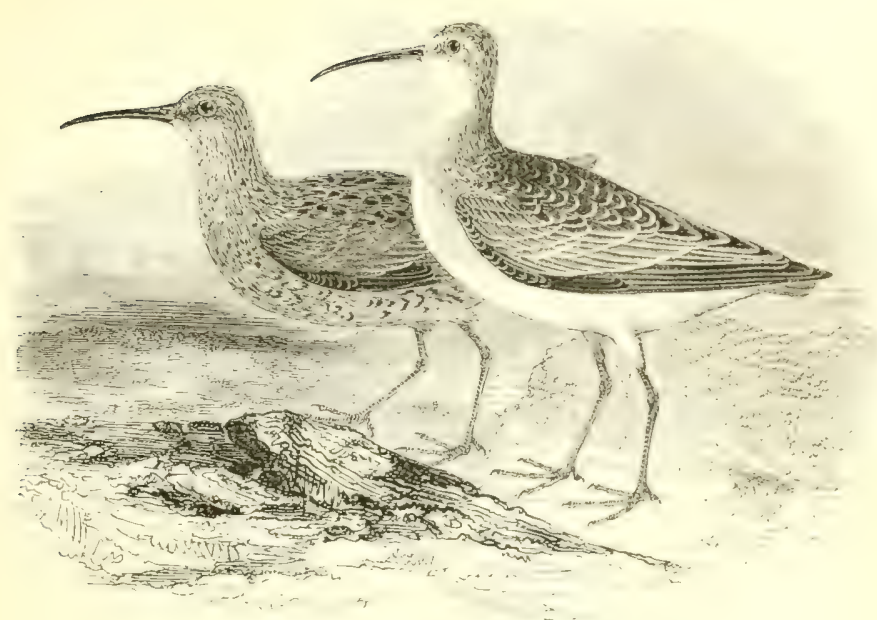

THE CURLEW-SANDPIPER.

Tringa subarquáta (Güldenstädt).

This species, which derives its name from the fact of its decurved bill resembling that of the Curlew, is an annual visitor-though in varying numbers - to suitable parts of the coast of (ireat Britain, especially the estuaries of the east side of Scothand, Nonthumberland, the Humber district, Norfolk, Kent, Sussex, Hants, I) rset, and westward to Cornwall, while it may also be found on inland waters. On the west it is decidedly less frequent, and its occurrence in the north of Scotland, the Orkneys and Shetlands is exceptional. The principal influx-chiefly of young birds-takes place in August and September, the journey southward being resumed by the end of October; but in Ireland, where the CurlewSandpiper occurs every autumn, it has been known to remain in the southern counties until November or even December. On the spring passage it has been met with as early as March I 9 th, and birds in their red summer-dress continue to pass northwards till June; R. Gray has even cited a supposed instance of its brecting in Scotland, though there is no evidence that the precies wats correctiy identified, and as a matter of fact the exgre, like those of the linnt. are still unknown.

The Curlew-Sandpiper has not yet been obtaines in the Futere, Iceland, Greenland, or Spitsbergen, while in Scandinavia and cecn in Finland it is principally olserved on the antummal migratin 1 . 
being very rare in spring. It occurs near Archangel, and Mr. Seebohm shot a female on July I 5 th at the mouth of the Petchora out of a small flock, while on the Yenesei, much further east, he killed a bird in nuptial dress close to the Arctic circle on June I 5 th ; but he did not reach its nesting-ground, and Dr. Finsch's statement that he had found the downy young on the Yalmal Peninsula was afterwards corrected. Dr. von Middendorff was nearly successful, for he observed the bird dispersed over the tundras of the Taimyr in lat. $74^{\circ} \mathrm{N}$. in June, and secured a female with a partiallyshelled egg in her oviduct; Dr. Bunge noticed migrants passing over the Lena delta, probably on their way to the Liakov Islands; the 'Vega' expedition obtained a specimen close to Bering Strait on June 6 th ${ } S_{79}$ : and by a strange coincidence Mr. J. Murdoch procured the first Maskan example at Point Barrow on June 6 th $188_{3}$. With this exception, the species is unknown in Arctic America, while it is of rare occurrence on the Atlantic sea-board of the United States. Returning to Europe, we find the Curlew-Sandpiper as a migrant on all the coasts and along several valley-routes, displaying its richest red plumage on the spring passage through the basin of the Mediterranean. In winter it is found down to Cape Colony and Tasmania, and all orer the Indian region, the mountainranges of Central Asia offering no barrier to its progress.

This bird is generally found in small flocks on sand-banks, ooze and salt-marshes, occasionally associating with other members of the family, though as a rule it keeps somewhat apart. Col. I.egge observed that it does not run about as much as its smaller relatives, and feeds more after the manner of a Sandpiper than of a sint. Its flight is very strong, especially down wind, the white rump being then conspicuous. The note is somewhat louder than that of the Dunlin; the food consists of aquatic insects, small crustaceans, and worms.

The adult in summer-plumage has the head, neck and mantle chestnut, streaked and barred with black and grey; upper tail-coverts white tinged with buff, and broadly barred with black; quills and tail-feathers ash-grey; under parts chestnut-red, slightly barred with dark brown and grey on the abdomen and flanks. After the autumn moult the rufous colour is lost, and the under parts become white. Length 8.5 in., wing 5 in.; females being rather larger than males. The young bird (figured in the foreground) has the upper feathers margined with buff; tail-coverts white; throat and upper breast tinged with buff, and streaked with pale brown; remaining under parts white; bill at first shorter and less decurved than in the adult. 


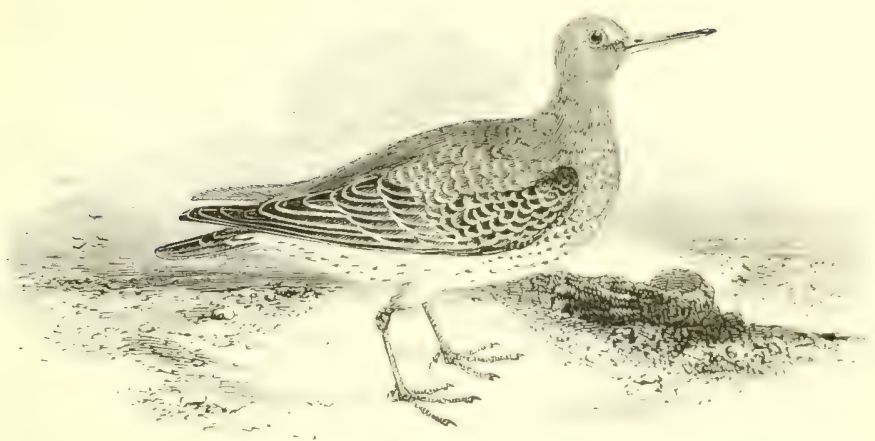

THE PURPLE SANDPIPER.

'TRINGA striátA, Linnzeus.

The Purple Sandpiper is widely distributed alung the coast of Great Britain from September until the following spring, and exceptionally it has even been found inland; but its marked preference is for those rocky shores on which large masses of sea-weed are exposed at low water. Young, scarcely able to fly, have been obtained on the Farne Islands, where they are supposed to have been hatched, while adults have been observed in the Outer Hebrides and other northern localities as late as the end of May; there is even strong presumptive evidence that the bird nests on the high ground in the Shetlands, though identified eggs have not yet been oltitined. On the rugged portions of the Irish coast it is met with in winter, and $I$ found it, still in small flocks, on May $15^{\text {th }}$ in co. Donegal.

This species breeds in considerable numbers no furtler off than the Freroes, especially on Sandoe; while in Iceland, (ireenland, Spitsbergen, Novaya Zemlya, and throughout the greater part of the Arctic regions, it is the most plentiful of its genus. Owing to the influence of the warm (iulf Stream, it is resident or only partially migratory on the coast of Norway, and is even found on the shores of Sweden during winter, though not common at any season far up the Baltic; while southward, we trace it on lassage along the Atlantic sea-board down to Morocco. It may possibly nest high up) in the mountains on some of the Azores, as Mr. Godman shot a male in full summer-plumage in June on litores. In the Mediterranean it is of unusual occurrence, and XI. Alkiton has not met with it on the Black Sea. To the east of Noraya \%emiya the low tuniras 
of Arctic Siberia are unsuited to its habits, and it is rare or very local until Bering Strait is reached. American ornithologists assert that the birds found in that region-inclusive of Alaska-belong to a distinct species, $T$. concsi, while yet a third, $T$. ptilocnemis, is restricted to the Prybilof Islands; .Ir. Seebohm, however, has a Purple Sandpiper from the Kuril group. Its range in western Arctic America is, therefore, uncertain, but our bird undoubtedly breeds in the north-eastern portion, migrating in winter to the Great Iakes, Middle States and, exceptionally, to the Bermudas.

In the circumpolar regions the nest is frequently placed close to the sta-shore, but in the Froes Wolley-and afterwards Col. Feilden - found it on the fells; one being taken by the latter on May zoth, when deep snow was still lying in the sheltered spots and the tops of the hills were white. It is sometimes a tolerably compact structure and placed rather deep in the ground; the eggs, 4 in number, vary from pale green to olive or dull buff, with purplish under-shell markings and reddish-brown surface-blotches: average measurements $\mathrm{r}+45$ by $\mathrm{I}$ in. Prof. Collett says that in Finmark he found only males in attendance on the broods. In summer its food consists chiefly of insects, and in winter the bird may be seen on the rocks amidst the drenching spray, searching for small crustaceans and molluscs among the sea-werd: while, owing to its tameness, few Sandpipers can be more clusely observed. It swims well and voluntarily; the note is a wect-zoit.

The adult in summer has the upper parts dark brownish-grey; the feathers of the mantle nearly black, spotted with rufous and tipped with buffish-white; the 7 th-gth secondaries chiefly white; rump, tail-coverts and central tail-feathers sooty-brown, remaining tail-feathers ashy; throat, neck and breast greyish, obscured with dusky-brown streaks; abdomen whiter, and the flanks spotted with dark brown; legs and feet ochreous-yellow, the hind-toe directed inwards. Length $8: 25 \mathrm{in}$., wing $5 \mathrm{in}$.; females being rather larger than males. In the young bird the feathers of the mantle and breast have crescentic white edges, which wear off later. In winter the upper parts are very sooty in hue, and the breast is dark ash-brown with only faint striations or mottlings, while on the flanks the markings are bolder. The species may be easily recognized by its dark colour, short legs, and generally 'dumpy' appearance. 


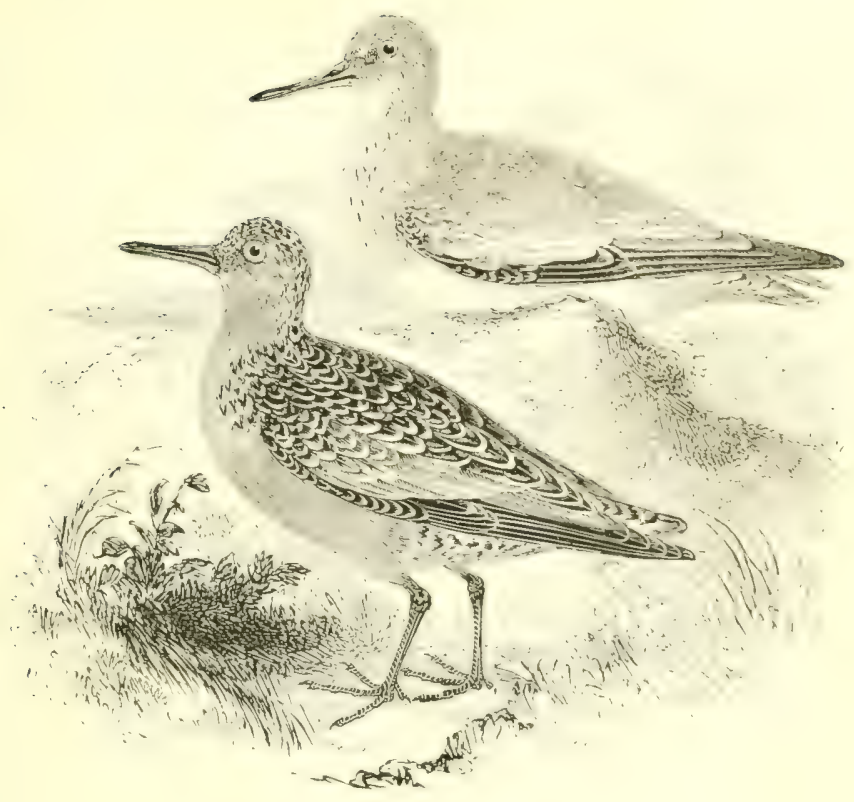

THE KNOT.

Tringa Canútus, Linnæus.

The Knot has long been known as a regular visitor to the Iritish coasts, its name being popularly supposed to hase originated from the esteem in which the bird was held by King Cinute, while down to the end of the 17 th century it was captured in nets and systematically fattened for the table. Flocks of young make their appearance early in August, the adults arriving, as a rule, somewhat later, while a considerable number often remain with us until the following May. 'They are then joined lyy migrants which have developed in a higher degree the rich red tints of the nuptialdress under the influence of a southern climate, and all, cxcept a few barren birds, depart for the far north. Nowhere in Great lirituin is the Knot more abundant than on the cxtensive sancl-banks and mud-flats of the estuaries on the cast, but in the 1lebrides and down the west of Scotland it is comparatively rare, cxcept on the Solway, where vast flocks are met with; it is again plluntiful in suitable situations from Lancashire to Comwall. Large numbers are found in Ireland during the colder months.

To Iceland and the south of (ireenland the linot is a vi-itur on 
the way to its breeding-grounds, which, according to the earlier Arctic explorers, were found on Melville Peninsula, and also-much further to the north-west-on Melville Island, one of the North Georgian or Parry group, whence no identified eggs, however, appear to have been brought back. In i $876 \mathrm{Col}$. Feilden, naturalist to H.M.S. 'Alert,' searched in vain for them, but on July 3 oth a male and three nestlings were obtained near a small lake on Grinnell Land in lat. $S z^{\circ} 33^{\prime} \mathrm{N}$, while Mr. Chichester Hart, naturalist to H.M.S. 'I iscovery,' captured a brood of four in lat. $8 \mathbf{I}^{\circ} 44^{\prime}$ on the inth, three more being taken next day: a beautiful group of the old and young is in the British Museum. An assertion in "The Auk' that the egg had been obtained on Lieut. Greeley's expedition requires confirmation. West of the Parry Islands the Knot can be traced to Alaska, where it is not plentiful; but in Arctic Siberia its representative is $T$. crassirostris, which has a black breast in summer; our bird being of very rare or irregular occurrence, though it has been recorded from I)aüria, China and Japan. Mr. Seebohm did not meet with it on the Yenesei or the Petchora, nor has it been found in Noraya Zemlya or Spitsbergen. On migration it visits the coasts of Europe, and the west side of Africa to Damara-land, but is seldom observed in the Indian region, though it goes as far south as Australia and New Zealand. In America it is well known on passage along the Atlantic sea-board, and has been found in Jamaica, while a single specimen has been obtained in Brazil.

The birds observed by Col. Feilden on and after July $5^{\text {th }}$ were feeding eagerly on the buds of Sirvifraga oppositifolia, while the stomach of one killed at Discovery Bay contained two caterpillars of Dasjefirat sronlandia, one bee, and pieces of an Alga; in this country small bivalves are freely eaten. The Knot is remarkably gregarious, and the young are very unsuspicious on their arrival; no wader strikes the lighthouses more frequently.

The adult in breeding-dress (in the foreground) has the crown and neck reddish-brown with darker streaks; feathers of the mantle blackish, spotted with chestnut and margined with white; tail-coverts white barred with black ; cheeks, throat and breast chestnut; flanks, vent and under tail-coverts whitish, mottled with black. Length Io in.; wing $6.5 \mathrm{in.}$ In winter the upper parts are ash-grey, and the under parts are white with grey flecks. In the young bird the feathers of the mantle have crescentic ash-coloured bars and dull white tips, the under parts having a buffish tinge; the legs and feet are dull olive. Mr. F. Bond has an albino shot near Maldon. 


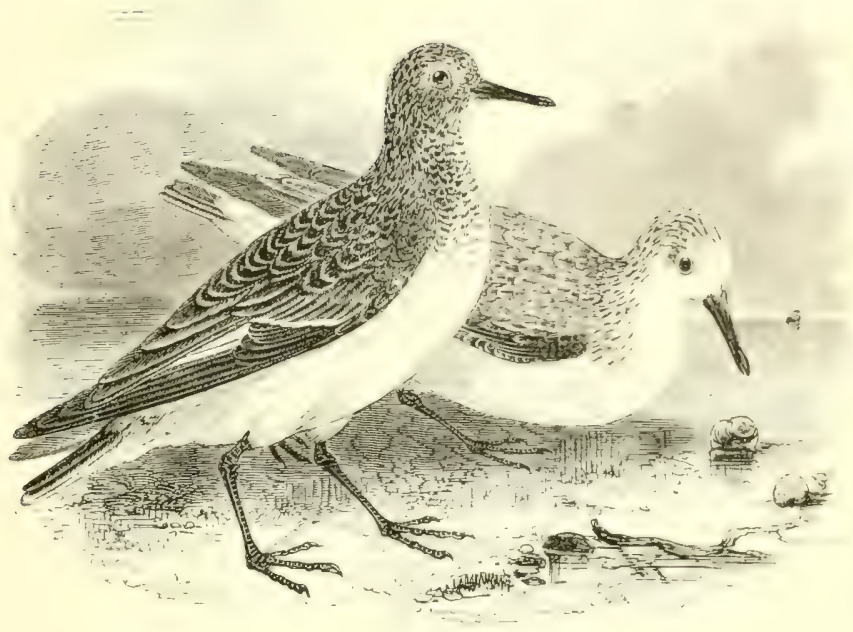

THE SANDERLING.

\section{CÁlidris arenária (Linnæus).}

This species - easily recognizable by the absence of a hind-toeusually arrives on the coasts of the United Kingdom by the midelle of August, and, contrary to the rule among waders, the early flocks frequently consist of old as well as young birds. Throughout the autumn it is plentiful on the sandy portions of our shores. though less numerous on the mud-flats, and it occasionally visits large expanses of water inland; comparatively few, however, remain on any part of our coasts throughout the entire winter. By April the return passage-in smaller numbers-commences; birds in full breeding-dress being observed through Maty and even in Iune.

To the Freroes the sanderling is a somewhat rare migrant, but it undoubtedly nests in some districts of Icclind: and ten exys were obtained by the German expedition on Sabine Island. Iiant Greenland, while on the west side nestlings have becu captured near Godthaab, and also in $S_{\mathrm{I}}{ }^{\circ} 3 S^{\prime} \mathrm{N}$. by I) r. Iicsisels of the 'P'olaris.' Col. Feilden shot a male from two exgs in lat. 82.3 .3 ' on June 2 , th 1876 in Smith Sound, where the bird was not uncommon : Saltine has recorded it as breeding freely on the Parry Ishands : and Mr. MacFarlane killed a female from the firat authenticated ey.s. on the 
barren-grounds near Anderson River. ilestward, it ranges to North Alaska, and, following up its circumpolar distribution, it has been found on the Liakov Islands, Taimyr Peninsula, Yenesei delta, Waigats and Novaya Zemlya, and probably breeds near the mouth of the Petchora. Except in the Baltic, where it is scarce, the Sanderling is tolerably common on passage along the coasts of Europe and of the Atlantic Islands, a certain number wintering in the basin of the Mediterranean, while others continue southward to Cape Colony and Natal; it is plentiful from the Persian Gulf to Ceylon, Borneo and Java, and visits China, Japan, the Kurils, and the Hawaiian Islands. In America, south of its summer-haunts, it is found down to Patagonia and Chili.

The nest found by Col. Feilden was a depression in the centre of a recumbent plant of arctic-willow, on a gravel-ridge several hundred fect above the sea; the eggs were greenish-buff spotted with brown, resembling pale specimens of those of the Curlew in miniature: measurements $\mathrm{I}^{*}+$ by $\mathrm{I}$ in. Like the Knot, this species was feeding at its breeding grounds on the buds of Saxifraga oppositifolic and also on insects, but the stomachs of birds shot in this country generally contain slender sea-worms, small bivalves and crustaceans, with a little gravel. The fat on the body is sometimes nearly a quarter of an inch in thickness. The Sanderling not unfrequently associates with the smaller I'lovers which frequent sandy shores, and sometimes with I unlins; it may, however, be easily recognized by the conspicuous whiteness of its under parts. The note is' a shrill wick.

The adult in summer-dress (represented in the foreground) has the feathers of the upper surface black or dark brown in their centre, edged or spotted with rufous and slightly tipped with grey; a good deal of white at the bases of the inner primaries and along the edges of the greater wing-coverts; central tail-coverts mottled like the hack, but those on each side conspicuously white; face, neck and upper breast pale chestnut, spotted with dark brown; remaining under parts pure white; bill black; legs and feet dark olive. Length $8 \mathrm{in}$; wing $4^{\circ} 7$ in. The female is slightly larger than the male. By the latter part of August the rufous tints on the back have nearly disappeared, leaving the black markings very distinct; by the end of October the upper plumage is chiefly ashgrey and all the under surface is white. In the young bird the upper feathers are tinged and variegated with buff, traces of the same colour appcaring on the sides of the neck and breast. 


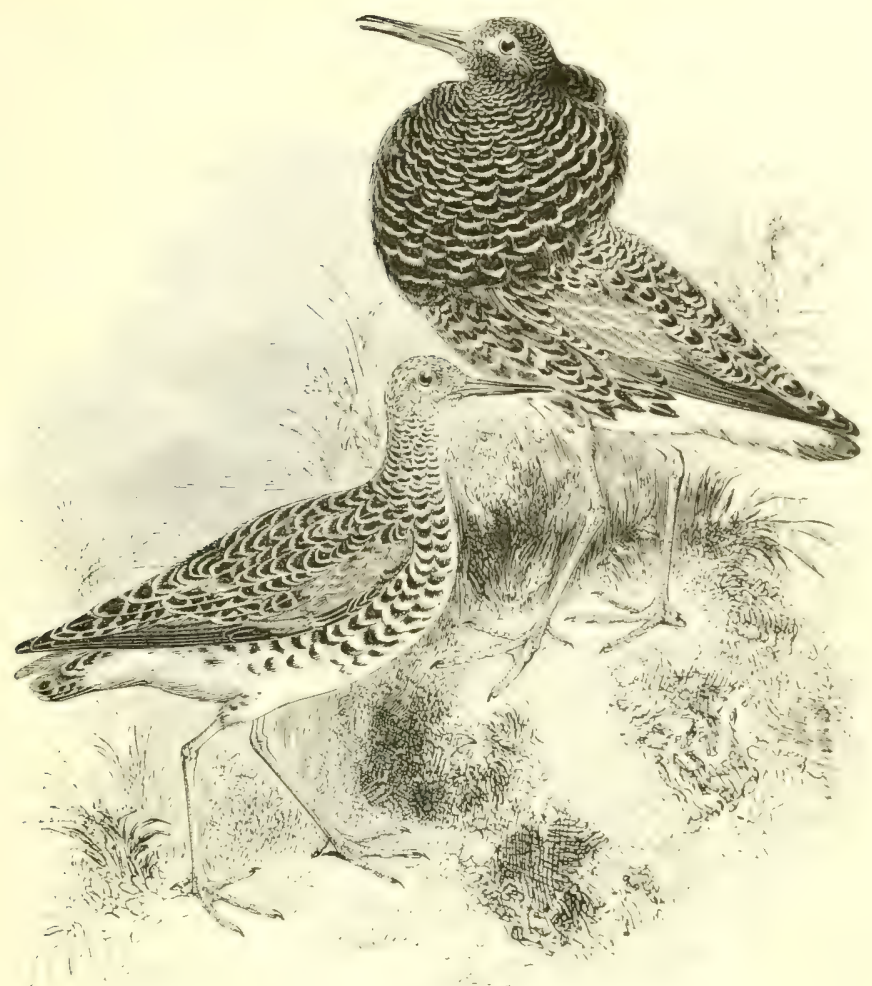

THE RUFF.

\section{Machétes pÚGNax (Linnæus).}

The Rufi and Reeve-the latter being the name applied to the female-used formerly to breed in many of the marshy districts of England; but drainage, and the practice of capturing the bircls cor the table in springs, when game is out of season, have so far diminished their numbers that they are now little more than visitors on the spring migration, and again more abundantly in autumn; a few being occasionally met with during the winter. In Lincolnshire, where the species was once plentiful, a female was shot from her nestin defiance of the law-in I882, and in Norfolk a few harassed birds sometimes rear their broods in spite of the cndearours of collectors to obtain the adults with the eggi. In the west of England the Ruff is decidedly raser than on the east, and the same may be said of Scotland, where it occurs from licrwiksthe to the (r)ken 
and Shetlands, but has only just been noticed in the Outer Hebrides. In Ireland it is of uncommon occurrence-mostly in autumn.

As a straggler this species has been met with in the Faroes and Iceland, occasionally in Canada and some of the Eastern Lnited States, once in Barbadoes, and once on the Upper Orinoco in South America. It breeds far north in Scandinavia and Russia, thence southward, in Poland, Germany, Holland, Belgium and the north of France, while on migration it is found over the rest of Europe; its winter-range commencing on the southern side of the Mediterranean, touching Madeira, and extending down both sides of Africa to Cape Colony. In Asiatic Siberia the Ruff nests up to $75^{\circ} \mathrm{N}$. lat., while during the cold season it visits Japan, Burma, India and 'Turkestan, at times wandering to Borneo.

Ruffs are polygamous, and in spring they hill, that is, they assemble upon knolls of ground, where, erecting the long feathers, from which their name is derived, they spar-bill to bill-ostentatiously, but with little damage to themselves, for the females. The latter make their nests about the middle of May in tussocks of grass on the driest part of wet swamps; the eggs, 4 in number, are greyish-green, blotched and spotted with reddish-brown: average measurements I.S by $\mathrm{I}^{\circ} \mathrm{z}$ in. The males keep apart and appear to take no share in rearing the joung, which are somewhat less able to take care of themselves than are the nestling; of most waders; but in autumn flocks are formed, sometimes of very large numbers. The food consists largely of insects and their larva, worms \&c., but seeds of aquatic plants, rice and other vegetable substances are freely eaten, while in confinement the birds used to be fattened on boiled wheat or bread-and-milk. The note is a low kack, kick, kack.

In spring the males shed the feathers of the face, caruncles taking their place, curled tufts of feathers appear on the sides of the head, and a shield-like erectile ruff is developed by the beginning of May, lasting through June. Every variety of purplish-black, chestnut, grey and white is shown on this ruff and also on the feathers of the back, each bird annually regaining the same colour. Length about 12 in., wing $7 \cdot 25$ in. ; ordinary weight 6 ozs., but of a fatted bird io ozs. After the moult the male resembles the female (in the foreground) in plumage, though he is about one-third larger ; the neck and upper breast are buff, lower breast and belly dull white; primaries dusky-brown, feathers of the back dark brown with buff margins; the latter being especially conspicuous in young birds. Length of the female ro in., wing $6 \mathrm{in}$. 


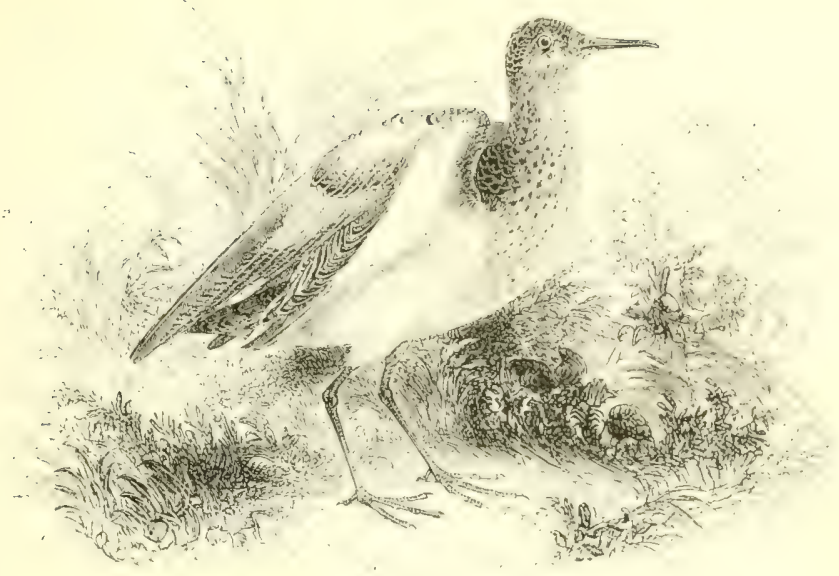

THE BUFF-BREASTED SANDPIPER.

Tringítes Ruféscens (Vieillot).

An example of this American species was shot near Melbourne in Cambridgeshire, when in company with some Dotterels, early in September I \$26, while four others have subsequently been obtained in Norfolk, one in Sussex, four in Cornwall and the Scilly Islands, one at Lundy Island in the Bristol Channel, and one, recorded by Messrs. Nacpherson and Duckworth, at Burgh marsh in Cumberland in September $S_{7} 6$. All the above occurrences have been in autumn; but a male is said to have been killed at Formby, Lancashire, in May I 829 . As regards a supposed Caithness specimen mentioned by Gray, Messrs. Harvie-13rown and Buckley merely remark significantly that the species is on I)r. Sinclair's list! In example shot near Ioublin is in the Museum of that city, and two (one of which I have examined) were killed in the l'cople's Park, Belfast, in October I 864 . The only authenticated instance in Europe-beyond the British Islands-is that of a bird obtained on Heligoland on May gth 18.47 and now in the collection of Mr. Gätke.

In summer the Buff-breasted Sandpiper inhabits the Arctic end sub-Arctic portions of the American continent. I female olutained by Dr. Rae on June r,th at Repulse liay, in the south of Melville Peninsula, is in the British Museum, as are also examples from fiort Simpson; many sets of eggs were taken by Mr. Mac Farlane (m the barren-grounds of the Anderson River district, and Mr. Mtirtorh 
met with this species nesting plentifully at Point Barrow in Northern Alaska, though on the Yukon and southwards to Sitka it appears to be uncommon. Mr. E. W. Nelson found it rather numerous on August Ist ISSo on the north coast of Siberia to the west of Koliuchin Bay, and says that the birds were evidently on their breeding-grounds there; while Dr. von Middendorff has recorded an example from the Sea of Okhotsk, shot on June 30 th. On migration it is found throughout the I'nited States, though irregularly and rather sparsely in the north-east; becoming more plentiful in Iouisiana (where the specimen which Vieillot described was oltained), and thence southward to Mexico. It visits the Bermudas, Cuba, Trinidad, and probably other islands in the West Indies, passing the winter in South America down the Rio de la Plata.

Ir. Murdoch notes the arrival at l'oint Barrow as from June 6th to Sth, the birds frequenting the drier portions of the tundras, and depositing their eggs, 4 in number, in a shallow depression lined with a little moss. When at Washington, I had the pleasure of inspecting the superb series obtained by Mr. MacFarlane, and certainly the eggs of few waders present such beauty or variety; the prevailing ground-colour is pale buff or olive, the underlying markings being lavender-grey, and the blotches rich reddish-brown to black: average measurements $\mathrm{I} 45$ by $\mathrm{I}$ in. As a rule the species is remarkably quiet, even at the season of courtship, though at times two males will meet and go through a performance of sparring or showing-off, while a solitary bird may often be seen walking about with one wing extended high in the air. Early in August the migration southward takes place; and as the food consists of beetles, grasshoppers and other insects which are plentiful in autumn, the bird becomes remarkably fat, and is much esteemed for the table. The note is a faint treeet.

The Buff-breasted Sandpiper may easily be recognized by the beautilul black marblings on the under side of the primaries and secondarics: these markings being much more pronouriced in the adults than in the young. The upper parts are buffish-brown mottled with black, a slight greenish tinge showing on the tips of the primaries and on the central tail-feathers, the other tail-feathers being somewhat barred towards the tips; the under parts are rufous-buff, with a few black spots on the throat and sides of the breast. In the young the feathers of the upper parts are broadly edged with dull white, the under parts are paler, and the spots are smaller. Longth $S$ in., wing 5.25 . Superficially the bird is not unlike a Ruff, though much smaller than even a Reeve. 


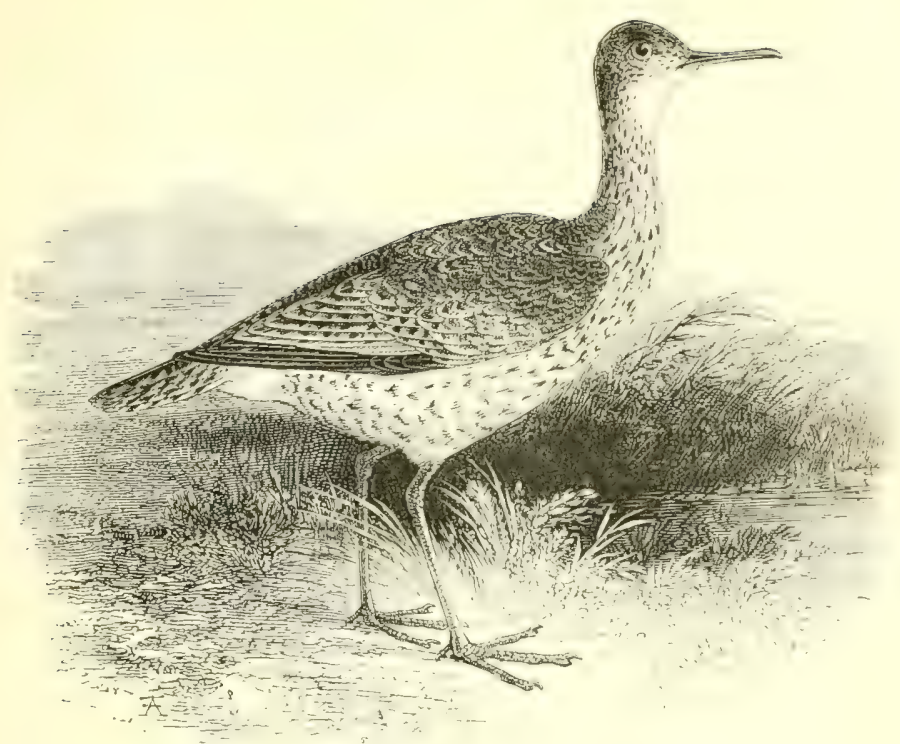

BARTRAM'S SANDPIPER.

Bartrámia longicáuda (Bechstein).

The first authenticated occurrence of this larger wanderer from America was near Warwick at the end of October I85I; a second example (in the collection of Mr. J. H. Gurney) was killed in a ploughed field in Cambridgeshire on December $124 h$ I 855 ; one, now in the Taunton Museum, appears to have been obtained more than forty years ago on the banks of the l'arret in somersetshire; Dr. Bullmore has a Cornish specimen shot on November $13^{\text {th }}$ I 865, and Dr. Leverton of Truro has another taken in October I883; Mr. G. Bolam acquired one from the sea-banks of Northumberland on November 2 Ist is 79; and a freshly-killed specimen, purchased in Leadenhall Market and said to come from I,incolnshire, was identified by Mr. IIarting on ()ctober 27 th i $\$ S O$. Mr. More has examined a bird said to have been sent to a l bullin gamedealer from Ballinasloe, co. Galway, in the autumn of $x 855$, and believes the statement to be correct.

There are several records of the visits of Bartram's sundpiper to the Continent, but the only satisfactory instancess are tho:c of a bircl killed in Liguria in 1859 (now in the Museo Civico at (icmoa), and another obtained at Malta on November i 7 th i 865 by Mr. C. A. 
Wright, who afterwards presented it to the Museum at Florence. In America this species is generally distributed over the United States from Pennsylvania and Illinois westward to the great plains at the foot of the Rocky Mountains, where it is known as the "Prairie Pigeon'; while northward it is met with in Canada-being very abundant on the plains of Saskatchewan, and has even been found breeding at Fort Yukon in Alaska, within the Arctic circle. It has also been recorded from Colville Bay, British Columbia, though otherwise unknown to the west of the 'great divide' On the spring migration vast flocks pass through Kansas, Nebraska, Minnesota and Dakota; while the return passage southward commences as early as July and continues during the autumn; extending to the Mermudas, the Southern States, Mexico, the West Indies, and throughout tropical America down to Buenos Ayres on the east side, and Chili on the west.

Hilly grass-lands are the favourite haunts of this bird, for which reason it is known in the United States as the Upland-, Field-, or Cirass-Plover. The nest is a mere hollow-often in a ploughed field - with only a few grass stems or leaves to keep the egrgs from the damp soil ; these, + in number, and laid early in June, are pinkish clay-colour blotched with pale purple and umber-brown: average measurements 1.8 by $\mathrm{I}, 35$ in. Only one brood is reared in the year, and the young are somewhat helpless and clumsy. The note is a soft mellow whistle, whence the bird derives its Louisiana name of 'Papabot.' 'The food, consisting of beetles, grasshoppers and other insects, small snails, earth-worms \&c., appears to be very fattening, and in autumn the bird is much prized by epicures.

The adult in summer has the head, neck and breast pale rufous, with black markings which assume the form of arrow-heads on the lower breast; chin, orbits, belly and vent white; upper parts streaked and mottled with black and white on a reddish-brown ground; inner webs of primaries conspicuously barred; tail-long and wedge-shaped when closed-of a pale orange-brown barred with black, the middle feathers having dusky centres; under surface of the wings barred with black and white. Length 12 in.; wing 6.75 in. The female is slightly larger than the male. The winter-plumage is rather paler; and immature birds have the feathers of the back more margined with rufous-buff. It will be observed that the tail is barred as in Totanus, and not plain as in Tringa. 


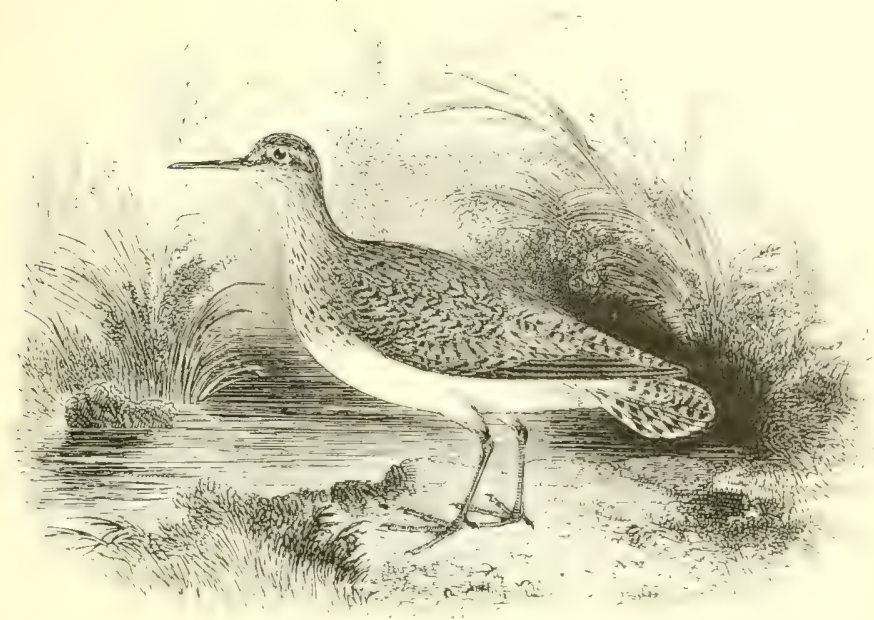

THE COMMON SANDPIPER.

Tótanus hypoléucus (Linnæus).

This species, often called the Summer-Snipe, is a regular visitor to the British Islands, usually appearing in April and leaving arain by the end of September, though a few birds occasionally remain till November. Inasmuch as its favourite haunts are the gravelly margins of lakes or of running water, and islets of shingle with scanty herbage in trout-streams, this Sandpiper is chiefly seen on migration in the south-east of England; but it breeds, sparingly, along the moorland brooks of Cornwall, I levon and Somerset, and perhaps in Dorset, Sussex, Kent and Buckinghamshire. In Wales, and in fact west of the Severn and north of the Trent, it is well known; while in Scotland it is to be found on almost crery loch and burn throughout the mainland, ranging to the Outer Hebrides, Orkneys and Shetlands. It is generally distributed in Ireland.

In summer this Sandpiper is plentiful from the Arctic circle down to the Pyrenees, Alps, Carpathians, and mountains of (ireece and Turkey, while a small number breed in Spain, the Canaries, Madeira, and the Mediterranean basin. In the last, however, the species is better known in winter, at which season it ascends the Nile valley to Abyssinia, and can be traced along the entire coast-line of Africa, as well as to Madagascar Lc. In Asia it is found from the Arctic circle southwards, crossing the great mountain 
barrier at an elevation of $17,000 \mathrm{ft}$. and even breeding in the Himalayas; its winter-range extending over the Indian, Malayan and Australian regions, down to Tasmania.

The nest, which is often a tolerably firm structure of grass, dry leaves, bits of rush $\&$, is generally placed under the shelter of a tuft of herbage or of the broad leaves of the butter-burr; near fresh water, or on the shingle of some islet; sometimes on the bare rock. The eggs, 4 in number, are usually reddish-white, rather minutely spotted with two shades of brown, but nccasionally the groundcolour is pale bluish : average measurements $\mathrm{I}^{*}+5$ by $\mathrm{I}$ in. Incubation commences by the middle of May, but fresh eggs may be found nearly a month later; while every stratagem is tried by the female to divert attention from her nest or young, though the latter can run as soon as they are hatched and show great aptitude in concealing themselves. When on the ground, this bird is in constant motion, flirting the tail up and down, or stretching out and withdrawing the head and neck: it also often alights on fences and bushes, and swims well. In spring it rises in the air, trilling a pleasing song, but the usual note is a piping whict, whet, whet. The food consists of worms and insects.

The adult in summer has the upjer parts of a bronze-brown, minutely flecked and barred with umber; outer pairs of tail-fe athers tipped with white and barred with black, the rest chiefly bronzebrown; chin white; sides of the neck and breast pale ash with dusky streaks; under parts white. Length $S$ in.; wing 425 in. After the autumn moult the upper parts are more uniform in colour. The young have the upper feathers margined with buff, and no dark streaks down the middle of the throat.

The American Spotted Sandpiper, T. macularius, was allowed to retain its place as a British bird in the $4^{\text {th }}$ Ed. of 'Yarrell,' because, among the numerous recorded instances of its occurrence, there were just two which could not with certainty be attributed to ignorance or fraud. Until some trustworthy person can produce a specimen which he has shot, I think that the species has no claim to be considered as one of our visitors; and credulous collectors of 'British-killed'specimens will do well to read the investigations of MIr. J. H. Gurney jun. in his 'Rambles of a Naturalist,' p. 255, or the amusing exposure of a dealer's tricks in Mr. C. M. Adamson's 'More Scraps about Birds,' p. 263. The American bird has all the secondaries broadly barred with ash-brown, while in the Common Sandpiper the 8 th and 9 th are nearly white. 


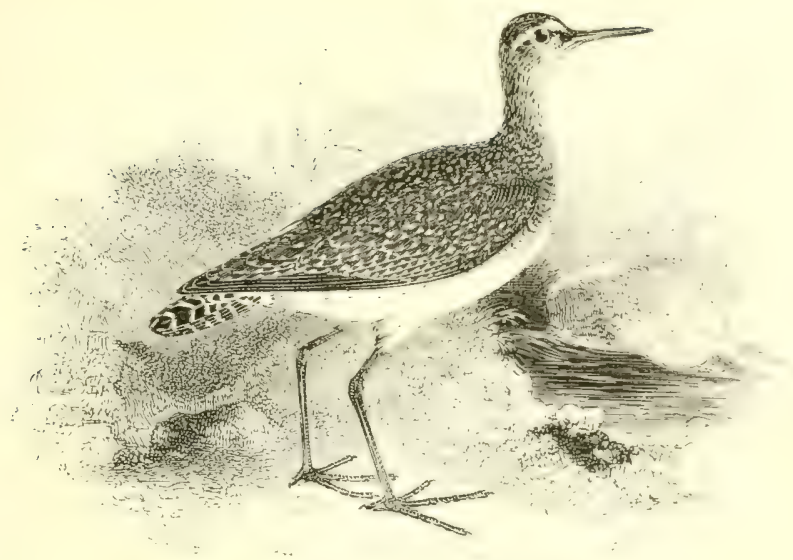

THE WOOD-SANDPIPER.

Totanus gláreola (J. F. Gmelin).

This bird is by no means so regular in its visits as the next species, with which it was formerly confounded, and the main loody of migrants hardly reaches our shores; but in autumn small flocks - consisting almost invariably of young - are met with on the east side of England, and in less numbers in the south, as well as in muddy situations far inland. In Cornwall examples also occur on the vernal passage, having been noticed there as early as April i 5 th, and a few adults alight in East Anglia in spring, while on June $3 \mathrm{rd}$ I853 Mr. John Hancock obtained a male bird, nest and egrs on the now drained Prestwick Car, in Northumberland, which was probably a regular breeding-place in former years. In scotland it appears to have been obtained in Mid-Lothian and Aberdeenshire, and Mr. Bond received eggs which he considered to be well-autherticated from the vicinity of Elgin, but on the west coast only one occurrence-on the banks of the Clyde-is substantiated. Along that side of England also the bird is rery rare, even in such congenial situations as the flat shores of the Solway and of Lancashire: in Ireland the first-and up to the present time the only-specimen was shot in co. Wicklow on August 23rd 1885.

The Wood-Sandpiper is only a wanderer to the Firoes, but during the summer it is one of the commonest waders in Forthern Europe, breeding down to the valley of the lanube, and probably in some parts of North Italy, while on Nay $2 S t h$ is 80 I shot a 
female which had evidently been incubating, on the edge of a wooded marsh near Aranjuez in Central Spain. Over the rest of the Continent it is well known on passage, it winters down to the Cape in Africa, and throughout the entire Indian region, while its breeding-range in Asia stretches from the great mountain-ranges northward to the Taimyr, and eastward to Kamschatka.

Observers of the Wood-Sandpiper in its haunts agree in stating that the nest is rarely to be found without difficulty, being well concealed in some depression on tolerably dry ground, though not far from water, and leing usually amongst bog-myrtle, stunted heath, sedge. or other coarse vegetation. The eggs, 4 in number, are often pale green in ground-colour, though sometimes buffish-white, and are speckled and blotched with reddish-brown, especially at the broader end: average measurements $\mathrm{I} 5$ by $\mathrm{I}$ in. Incubation begins about the middle of May in Holland, though later in the north : the male indulging in 'fllay' similar to that of the Common sandpiper during courtship, and uttering a tremulous note, lecro, live) : lut when alamed the cry is a sharp siti, giff. Like its convener, this bird often perches on bushes, trees or stakes. It feeds on worms, small molluses, inicets and their larre, and a disagreeable musky odour often pervades its flesh.

This species is a little smaller than the (ireen Sandpiper, but with a proportionately longer tarsus; and has the upper parts streaked with olive-brown, the margin of each feather of the mantle showing buttish-white spots which are elongated and well defined in the young, smaller and triangular in the adult; quills dusky, the outer 'me with a whitic shaft (not dusky as in the Green Sandpiper); upper tail-coverts white with narrow dark shaft-flecks; outer tail-feathers white. with bars on both webs in the young and on the outer web only in the adult, the remaining feathers being distinctly barred; neck, throat and breast dull white, thickly streaked with ash-brown, the flanks being barred with the same colour; axillaries white, merely Hickd with borin; abdomen white; legs and feet yellowisholive. Length nearly 9 in., wing 5 in.

Illustrations of the characteristic axillaries and tail-feathers of this and of the Green Sandpiper are given on p. 598. 


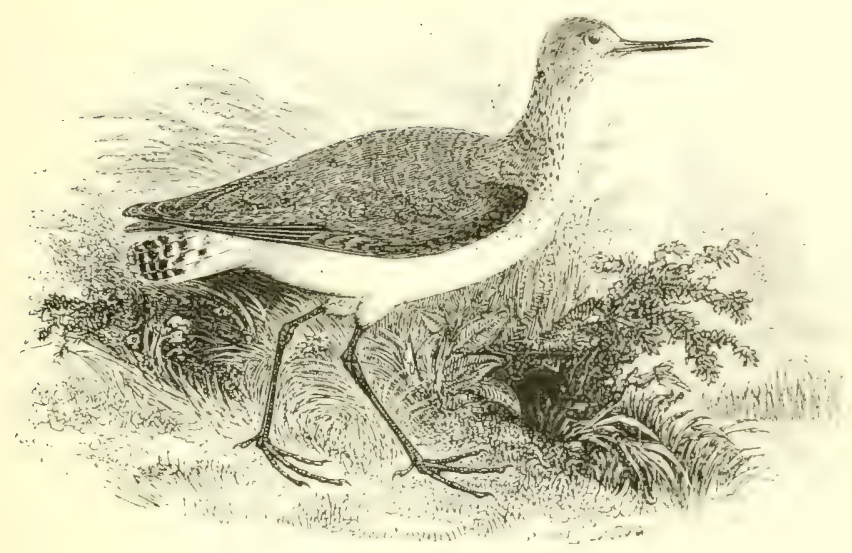

THE GREEN SANDPIPER.

Totanus óchropus (Linnæus).

The Green Sandpiper is not uncommon on the spring as well as on the autumnal migration in many parts of England and Wales, where it is sometimes met with in the depth of winter, continuing in good condition when Snipes are lean. It is, indeed, seldom absunt from some of our streams except during June and July, while even in those months single birds, pairs or small parties have been noticed, especially in Sussex, Norfolk and Yorkshire; and since the fact has been made known that it habitually lays its exgs in old nests in trees, there appears to be considerable probability - though as yet no proof - that it may occasionally breed with us. On the east side of Scotland it is of fairly frequent occurrence, but in the north it is very rare, while its presence in the island groups has not yet been recorded, and it is seldom met with on the west coast, except in the Solway district. To Ireland its visits are unfrequent, wen in autumn.

This species is found nesting in marshy woods, from the vicinity of the Arctic circle southward to Central Russia, Poland and (icrmany, and reaching as far west as Holstein : while over the rest of the Continent it is well known as a migrant, and 1 have an adult female from Málaga, in the south of Spain, shot as late as June 24 th. From autumn to spring it is abundant in suitable lecalitics from Morocco to Egypt; and, though not traced beyond Anerella wn the west side of Africa, it ascends the Nile valley to Abyssinia, con- 
tinuing its course through the Lake district to Cape Colony. In summer it is found throughout Asia from the Arctic circle to the great mountain ranges, while from July onwards it visits the rest of that continent down to Burma.

The remarkable deviation of the Green Sandpiper from the nesting-habits of other waders was first brought before the notice of the majority of British readers by Prof. Newton (P.Z.S. I $86_{3}$, pp. 529-532); but an intimation of its preference for trees had been given in 'Naumannia' for $\mathrm{I}_{5} \mathrm{I}-52$, and Forester Hinz had communicated full details (J. f. O. IS62, p. 460 ) respecting its nidification as observed in Pomerania from isis. The eggs, sometimes laid as early as April 16 th, have often been found in old squirrels' drey's, or the nests of Song- and Missel-Thrushes, Blackbirds, Jays and Wood-Pigeons: occasionally on the ground, or on moss-covered stumps, broken-down trees, and spines heaped upon branches of firs-at elevations reaching to 35 feet, but always in proximity to pools. The exgss are pale greenish-grey, with small purplishbrown spots, and are normally + in number; though, as is the case with some other waders, 7 have been found together, doubtless the produce of two females: average measurements $\mathbf{I} 55$ by $\mathbf{I}^{\cdot} \mathbf{I}$ in. IIcodland streams and ponds, jeaty swamps and meadow-drains are the favourite haunts of this species, rather than the vicinity of the sea. It is generally observed alone or in pairs, at most in family parties; while it frequently shifts its feeding-grounds for no assignable reason. The flight is rapid and glancing; the note is a shrill tui-tui-tui. The food consists chiefly of insects, small red worms and fresh-water snaiis; the flesh has a disagreeable musky odour, like that of the preceding species.

The adult is larger than the Wood-Sandpiper, and rather greener in tint, with fewer spots on the upper parts, whiter tail-coverts, much broader black bars on the central tail-fiathers, pure white belly and under tail-coverts, and brimish-llack awillaries with narrow angular hars of white: these distinctive characters are figured on p. 598 . Length 9.5 in. ; wing 5.5 in. The young show less of the metallicgreen tinge on the upper parts, while the spots are fewer and less purely white.

The Green Sandpiper has only one large notch on each side of the posterior margin of the sternum, and was therefore placed in a separate genus, Hilodromas, by Kaup, who further created Rhya. cophilus for the Wood-Sandpiper. 


\section{THE SOLITARY SANDPIPER.}

\section{TOTANus solitárius (Wilson).}

A specimen of this American species was recorded by Gray in 'The Ibis' for 1870 (p. 292), as having been killed some years pre. viously on the banks of the Clyde. In 'The Zoologist' for 1882 (p. 432), Mr. T. Cornish stated that on September 2 ist of that year, an example, now in the collection of Mr. Dorrien Smith, was shot in the Scilly Islands; and he subsequently identified another (Zool. I885, p. 113) which was obtained in a marsh near Marazion in Cornwall-according to the sale-catalogue of Mr. Vingoe's collec tion, in October ISS+. These have been identified by competent authorities, and the Solitary Sandpiper must therefore be included among the occasional wanderers to Great Britain, though an illustration of it is not considered necessary, inasmuch as its distinctive characteristics could not be shown therein.

In America the 'Wood-Tattler,' as it is often called, appears to be generally distributed during the breeding-season from the vicinity of the Arctic circle southward to about $44^{\circ} \mathrm{N}$. lat, and across the continent from the Atlantic to the Lower Jukon in Alaskia. Many ornithologists have observed it in summer, and Mr. Nelson has several times taken the young when just able to fly in Illinois, yut nothing is known of its nidification, for the description and dimensions griten by the late Dr. Brewer of an egg taken in Vermont and ascritsed to this species indicatis a strong probability of some error. The spring arrival in the United States takes place in May, while the return migration begins in July in the northern districts, and excn in the south few individuals remain after October. On passage this birc! visits the Bermudas, the West Indies, Mexico and (entral Ancrica, but its principal winter quarters are further south, in lirazil, l'araguay and the River Plate States.

The Solitary Sandpiper is so named because it is generally found alone or in pairs on its journeys, when it is not unfrequent hy pools and rivulets; but for a short time after the young are hathed small family parties are formed. 1)uring the summer the lirel appear to be partial to small ponds surrounded ly dense forest. and it then resorts to decayed logs for the purpose of procuring srubs. lnu at 
other times it probes the soft mud for worms and minute crustaceans. The note is a sharp whistle.

This species is about the same size as the Wood-Sandpiper, but its upper parts are even less spotted than those of the Green Sandpiper; the tail-coicrts and ientral pair of rectrices are chiefly olinebrowin, only minutely flecked with white, while all the remaining tail-fiathers are boldly barred with black and white on both awels; the head, neck and under parts are much the same as in the Common Sandpiper; the axillaries are barred angularly with black and white in nearly equal proportions. Length $S^{\circ} 25$ in. ; wing $5^{\circ} 2$ in. Its nearest ally is our (rreen sandpiper, and, like that species, it has only one large notch on each side of the posterior margin of the sternum.

The upper figures represent, respectively, a feather from the axillaries and one from the middle of the tail of the Wood-Sandpiper: below them are similar feathers from the (ircen Sandpiper. The axillaries of the solitary Sandpiper resemble those of the latter in pattern, but the white bars are much broader.
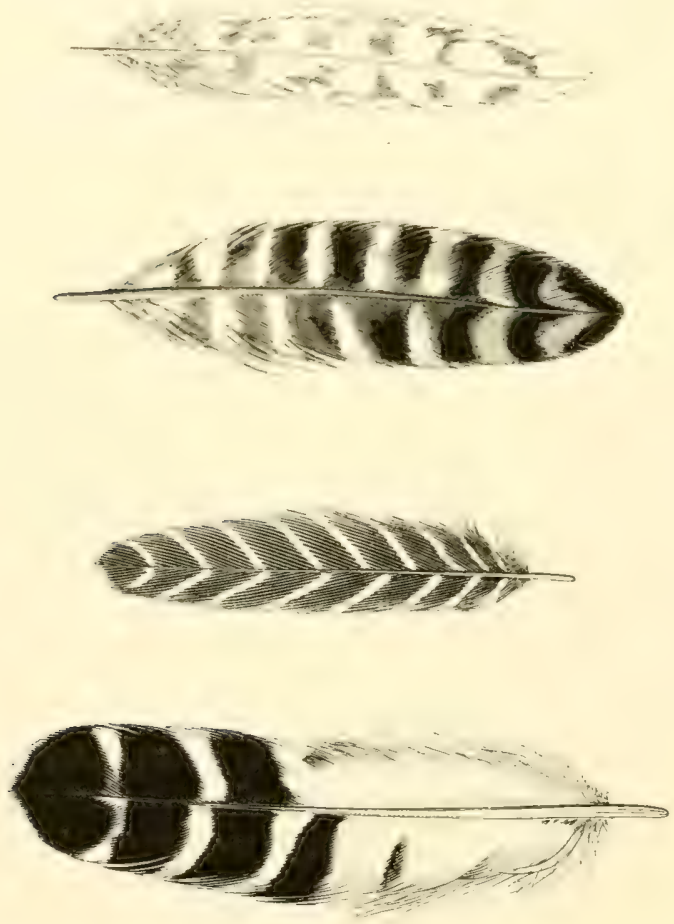


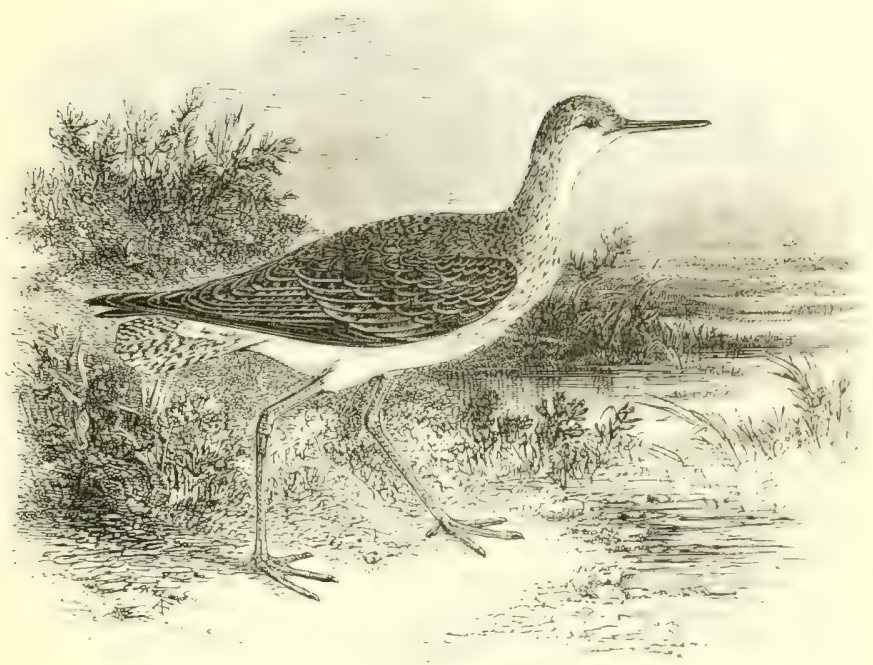

THE YEILOWSHANK.

Totanus flávipes (J. F. Gimelin).

This is another of those American species which occasionally find their way to this side of the Atlantic. The first British-killed example on record was obtained at Misson in Nottinghamshire, by some wild-fowlers who used to send their birds to Doncaster; and having thus reached Hugh Reid, the well-known taxidemist, it was next sold to Sir II. M. E. Milner; it forms the subject of the present illustration and is now in the Leeds Nuseum. I second gonuine specimen was shot by E. Vingoe on September rath $187 \mathrm{I}$, on a salt-marsh near Marazion in Comwall. as stated by Rodd (\%ool. s.S. p. 2807) with ample diagnosis and details.

As a straggler the Yellowshank has occurred in Creenland; but its breeding-grounds are in North America from IIudson bay to Alaska, extending as far south as I ake superior, and prerhaps to the vicinity of Chicago, where Mr. Nelson found the young barely able to fly on July ist $S_{74}$. On passage this species is generally distributed throughout the greater part of the L'nited States, and is abundant along the valley of the Mississippi, though of compratively rare occurrence to the west of the Rocky MIountains. It visits the Bermudas, Bahamas, and IV est Indies generally, as well as the 
mainland of tropical America, wintering as far south as the Chupat valley in Patagonia-where Durnford found it common during November-and also in Chili.

According to Messrs. Kennicott, MacFarlane and others, the nest is a simple depression scantily lined with dead leaves \&c., near the edge of a marsh or pool. The eggs are $t$ in number, and those which I examined in the Smithsonian Institution at Washington were creamy-buff, boldly blotched with chocolate-brown and umber: average measurements 1.65 by $I^{\prime} I_{1}$ in. The food consists of insects and their larve, small crustaceans, worms \&c.; and in its general habits this species resenibles other Sandpipers.

The adult in summer has the crown and nape greyish-white streaked with black; mantle ash-brown with ragged blotches of black which have a tendency to form regular transverse bars on the scapulars and secondaries; upper tail-coverts pure white with dusky bars; tail-feathers white, with numerous ash-coloured bands-broadest on the central pairs-across both webs; chin and neck white, the latter thickly streaked with wood-brown; under parts white; axillarics white, hrred with ash-colum ; bill black and very slender; legs and feet bright yellow. Length $10^{7}, 5$ in. ; wing 6 in. In winter the streaks are almost absent from the head, neck and throat; the young resemble the adults in wintcr, but are more or less tinged with pale brown on the upper parts.

As the immature Redshank, with pale yellow legs, has several times been mistaken for the lellowshank, it may be pointed out that $T$. Harifes has a much more slender bill, a longer tarsus, and distinctly barred axillaries.

On May i $3^{\text {th }}$ ISS9, while this sheet was in the press, the late Mr. Vingoe's collection was sold at Stevens' auction-rooms, when the specimen of the Vellowshank from Marazion obtained the price of $\mathcal{E}_{5}$. r 5 s. $6 d$., and the Solitary Sandpiper referred to on p. 597

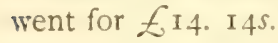




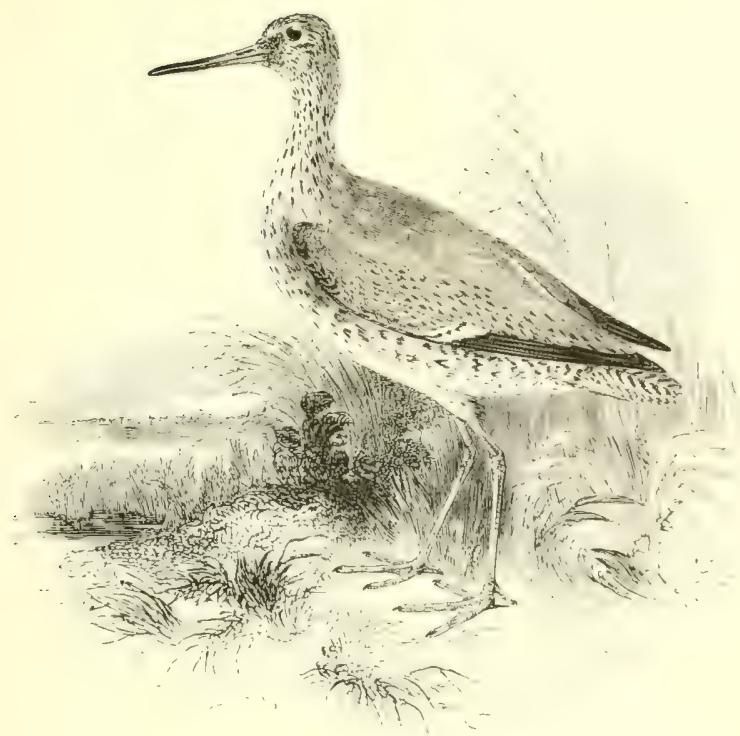

THE COMMON REDSHANK.

T'OTANUS CÁLIDRIS (Linnæus).

In spite of drainage and modem improvements the Redshank may still be found breeding in most of the marshy districts of England and, sparsely, in Wales; usually making its apprearance inland from the middle of March onwards. Early in autumn it begins to resort to the coast, where it is joined by large numbers of migrants from the Continent; but on the approach of cold weather the majority pass southward, although during open winters birds may be found throughout the year, especially in the south and west. In Scotland it is generally distributed and abundant as far as the Shetlands, but in most of the Outer Hebrides it appears to be rare In Ireland it is fairly numerous during the summer, while plentiful at other times of the year along the sea-board, especially on the bays of the west, where large expanses covered with Zisterat marivit are left by the receding tide.

This species breeds in the Freroes, Iceland, scandinavia u! to $70^{\circ} \mathrm{N}$. lat., and as far north as Archangel in Russia; south of which it is found nesting in suitable localities throughout Europe, and also in Morocco. It visits the Canaries, and migrate's duwn the west side of Africa to Cape Coluny, while on the east we trace 
it through Abyssinia to Natal. In Asia it barely ranges north of lat. $55^{\circ}$ in Siberia, and during the summer it chiefly inhabits the elevated table-lands from Persia to Mongolia ; on passage it occurs in Japan, China, the Philippines, Borneo and Java, and it is plentiful throughout the Indian region during the cold season.

The Redshank frequently breeds in small communities, the nest being in the centre of a tuft of rushes or of long grass, the entwined blades of which conceal from view the + eggs within; these are of a yellowish stone-colour blotched with purpish-brown, and measure about $\mathrm{I}^{7} 75 \mathrm{by} \mathrm{I}=\mathrm{in}$. In the south they are often laid during the first week in April, but may be found fresh until the iniddle of May-or even later in the north: incubation lasting about sixteen days. When the nest is approached the bird is very noisy and practises many artifices to allure the intruder from the neighbourhood; while at other times it causes much annoyance to sportsmen by flying round and frightening everything by its shrill note, which has obtained for it the local name of to.k in East Anglia and tolk in Scandinavia. In spring the male has a peculiar love-song, and Stevenson has seen him uttering it while running along the top bar of a gate, pirouetting and bowing like an amorous pigeon; occasionally too the bird perches on trees. It dires when wounded, and has been seen to swim to shallow water on the other side of a creek rather than rise and fly across. Its flight is quick though somewhat wavering, the white band on the extended wing being very conspicuous. The food consists of aquatic insects, annelids, worms, crustaceans, and small molluscs. During seven or eight months of the year this species frequents the margins of salt or brackish waters.

The adult in summer has the upper parts pale brown, profusely streaked and barred with umber; secondaries nearly white; rump white with a few dusky flecks; tail-feathers white, barred with blackish, and with a tinge of pale brown on the central pairs; under parts white, streaked on the neck and breast and barred on the flanks and axillaries with umber; legs and feet bright orange-red. Length I I in., wing $6.2 \mathrm{in}$; the female being rather larger than the male. In winter the bird has the upper parts ash-colour, the rump white, and the under parts nearly so, with a few ashy streaks and spots on the neck and breast; axillaries pure white. In the young the legs are lemon-yellow. 


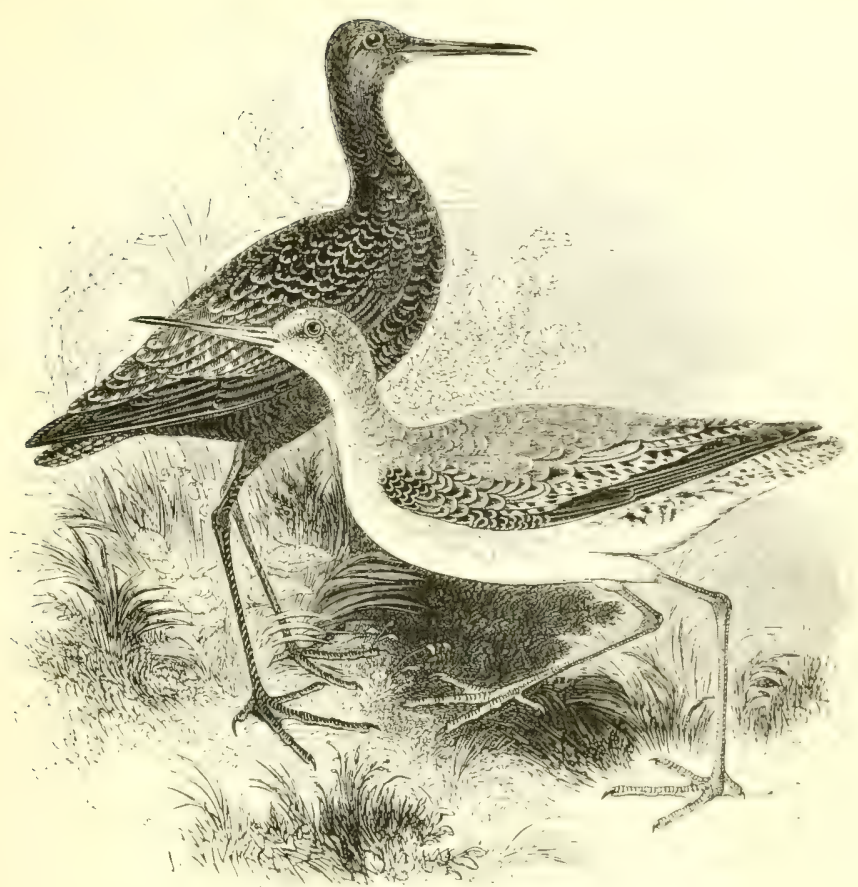

THE SPOTTED REDSHANK.

'Totanus fúscus (Linnæus).

On the autumn migration the Spotted or i)usky Redshank is of somewhat irregular-though not altogether unfrequen-occurence in Norfolk and other eastern counties, and birds assuming the breeding-dress are still more common there in spring; lout southward, even in the mild climate of Comwall, this specices is selclom met with, and on the west side it is rare at any season. It is partial to fresh or slightly brackish water, and has been found as far inland as Nottinghamshire, but north of the Humber it is almost unknown in England. It has occurred in Aberdeenshire and lianffshirc, but Messrs. Harvie-Brown and Buckley have not met with it in caith ness, Sutherland, or the Outer Hebrides, and its reported aprearance in the Orkneys requires confirmation. while on the ticettish side of the Solway Mr. Service is only aware of a single instance. In Ireland one has been obtained nuar liclfast: and butwenthe ycars I $\$ 67$ and $\mathbf{s} S S S$ Mr. R. Warren, of Ballina, has killed two and has seen a few others on the Moy estuary, in autumn and winter. 
In summer this species inhabits the northern portions of Scandimavia and Russia; the birds which intend to nest there arriving in May, though migrants have been noticed passing northwards over Heligoland as late as June $i_{7}$ th. It crosses the Continent by several routes, its winter quarters commencing in the basin of the Mediterranean and extending to Cape Colony. In Asiatic Siberia it is somewhat irregularly distributed, but Dr. von Middendorff found it breeding on the Boganida, while eastward it ranges to Kamschatka; and during the cold season it visits Japan, China, Burma, India \&c.

I'or details respecting the nidification British ornithologists are indebted to Wolley, who observed the Spotted Redshank in Finland in 1854 . It applears to choose the driest situations, such as the tops of long hills covered with scattered timber-many hundreds of yards from any marsh: and there, in some slight depression among the scanty vegetation, it deposits towards the end of May its 4 eggs, which vary in ground-colour from a yellowish-olive to a beautiful sea-green, and are blotched with sereral shades of brown and black: average measurements $\mathrm{I}_{5} \mathrm{~S}_{5}$ by $1 \cdot 25$ in. The bird sits very close, its white back being conspicuous as it crouches with its neck drawn in, and on rising it flies round with an occasional tjeuty, or stands upon the top) of a neighbouring tree, showing the full length of its slender legs, neck and bill. It becomes very demonstrative when the young are hatched, and probably carries them down to the marsh, as they are found there while still small. The food consists of worms, beetles and other insects, univalves \&c. ; chiefly obtained near fresh water, to which, as already observed, this species is far more partial than the Common Redshank.

The adult male in summer (figured in the background) has the general plumage of a sooty-black hue, excepting the white rump and the barred upper tail-coverts; the female is rather larger and often has a white chin, the under parts being paler and more mottled; bill nearly black, red at the base of the lower mandible; legs and feet claret-red. Average length $\mathrm{I}_{3}$; wing $6.6 \mathrm{in}$. After the autumn moult the upper parts are chiefly ash-coloured, more mottled with white than in the Common Redshank, while the tail-feathers are much darker; the secondaries are thickly barred with dusky on both webs; the neck is ash-colour, the under parts are dull white, and the axillaries white. The young have the upper surface tinged with brown, the under parts clouded with ash-grey, and the legs orange-yellow. 


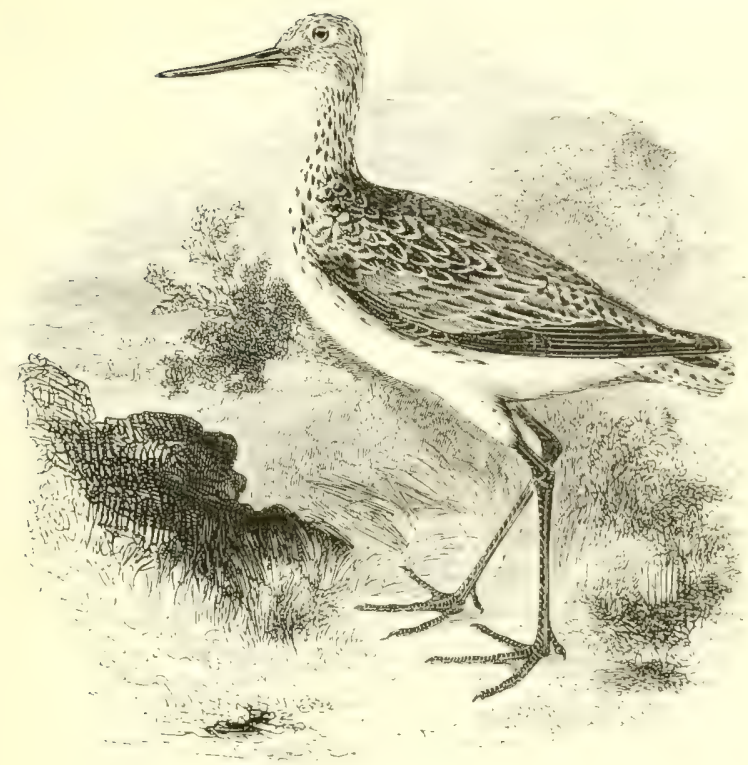

THE GREENSHANK.

\section{Totanus canéscens (J. F. Gmelin).}

The Greenshank occurs annually though in small numbers on the shores and many of the inland waters of (ireat Britain, during the spring and autumn migrations, but even in the south it is seldom met with in December or January. In Ireland, however, it remains the entire winter, especially in cos. Mayo and Cork, and its absence is very brief, inasmuch as some birds make their appearance early in July while the majority have arrived by the end of that month (R. Warren); nevertheless it has not been known to breed in that island. In Scotland it was discorered nesting by Macrillivray in the Outer Hebrides, where, according to Messrs. Harvie-Brown and Buckley, only a few pairs are now to be found-the same holding true of Skye and some of the inner islands; but on the mainland. as $I$ am told by the former gentleman, its breeding area is increasing and extends over portions of Caithness, Sutherland, Ross, Inverness, Argyle, and the north of Perthshire, while Mr. Service thinkis that a small number inhabit the (ialloway hills. Saxby's statements respecting the finding of its exgs in shetland remain uncorroburated by later observers, and information is scanty as regards the ()rkneys. This species is a regular summer-visitor to the fells and moratsics 
of Scandinaria, Northern Russia, and Siberia in Asia as far east as the Stanowoi Mountains; while its winter range extends over the greater part of the eastern hemisphere down to the Australian region. On $i a y z S_{\text {th }} S_{3} 2$ Audubon obtained three specimens in Florida, but since that date the bird has not been noticed in North America : though examples, said to be from Buenos Ayres and Chili, are in the Leiden Museum. It is well known on the coasts and inland waters of Europe, especially on the autumnal passage, and considerable numbers go no further in winter than the basin of the Mediterranean.

The nest is often at some distance from water, or even on dry ground among scattered pine-trees, but in scotland it is generally near the edge of a loch or other fresh water. Mr. Buckley mentions finding three eggrs between two stones on May 2 th 1869 , and on passing the spot on May 26 th i 8 ; I he saw the bird sitting so closely between the same two stones that she did not move until touched with the point of a fishing-rod. The eggs, normally + in number, are of a warm stone-colour, with blotches of purplish-grey and spots of rich brown: average measurements $\mathrm{I}^{\circ} 9$ by $\mathrm{I}^{\prime} 3$ in. When its haunts are approached, and especially after the young are hatched, the (ireenshank is very vociferous, uttering a loud chec-ricet, chec-wect, and swooping round the head of the intruder: at other times it has a strong and rapid flight, while it also perches on trees. It feeds on small fish and spawn, crustaceans, molluscs, worms and beetles, often searching for the latter in meadows frequented by cattle.

The adult male in summer has the head and neck greyish-white streaked with blackish-brown; feathers of the mantle and secondaries nearly black, edged with pale grey; rump pure white; tail-feathers white, mottled and barred with dusky-brown; under parts white streaked and spotted with ash-brown on the throat, breast and flanks; bill slightly upcurved and blackish; legs and feet olive-green. Total length 14 in.; wing $7 \cdot 25$ in. In winter the upper parts are greyer and the under surface is pure white. The immature bird has tawny margins to the dorsal feathers, while the chest and flanks are minutely pencilled with blackish-grey.

It is asserted in Littleboy's 'Birds of Hertfordshire' that a MarshSandpiper, T. stagnatilis, was shot near Tring Reservoirs in October I $8_{7}$ by Mr. Walter Rothschild, but the owner has hitherto been invited in vain to submit this treasure to competent authorities. This Greenshank in miniature has been known to visit Heligoland and Northern France. 


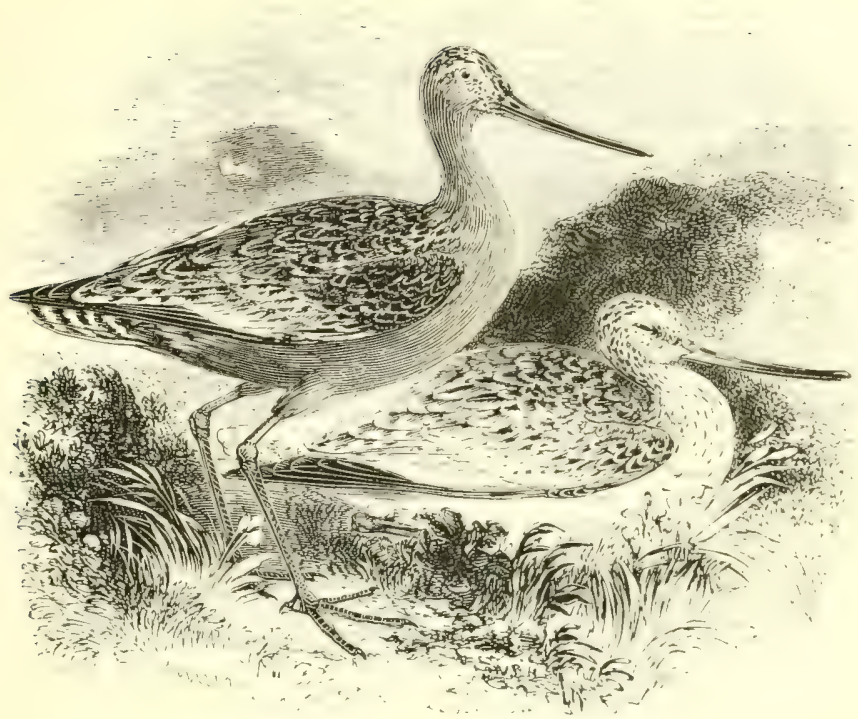

THE BAR-TAILED GOI)WIT.

\section{Linósa LaPPónica (Linnæus).}

The Bar-tailed Crodwit is a regular visitor to our estuaries, sandbanks and mud-flats in spring and autumn; young buff-breasted birds, which are at first very tame, often beginning to arrive by the latter part of August. Mr. Abel Chapman states that on the coast of Northumberland it may be found "thousands strong, throughout the hardest winters and most protracted frosts," but in I.incolnshire, Norfolk, and southward to the Channel, observers asree that comparatively few are to be met with in winter; on the other hand, numbers in the red breeding-plumage occur in the south on the spring migration, especially in Norfolk-where, from the date of their arrival, the Izth of May is called by the broydon gunners 'Godwit day' - though the bird is almost unknown to the north of the Humber at that season. In Scotland it occurs on the east coast as late as December, but on the west it appears to be wery local, having chiefly been observed in the sound of Harris, and again on the Solway. It is tolerably comnon during autumn and winter in Ireland, where, according to Mr. Warren, large flocks beyin to arrive on the west coast in March, and increase in numbers "I] (1) April, while many birds in the pale plumage of immaturity remain till nearly the middle of June. 
As a straggler the Bar-tailed Godwit has recently been recorded trom the Færoes, but its breeding-range barely extends as far west as Finmark; and though Wolley obtained the eggs in the Muonio district of Lapland, yet even there he appears to have been only on the outskirts, while no other Englishman has added to our knowledge of its nidification. Messrs. Harvie-Brown and Seebohm only once observed it on the Petchora, and the latter merely obtained a solitary example on the Venesei, in about $70^{\circ} 35^{\prime} \mathrm{N}$. lat. East of the Taimyr Peninsula we find a race which is more streaked and barred with brown on the rump, and is known by those who admit its specific distinctness as L. uroprisirlis; this extends to the Sea of ()khotsk in summer, migrating to Japan, China, the Malay Archipelagn, Australia and New Zealand. In Europe our typical form is irregularly distributed during the cold season down to the Mediterranean basin, and in Africa it can be traced to the Gambia on the west and the Somali country on the east; while in Asia it is a wintervisitor to the Mekran coast and the mouth of the Indus, and has been obtained in Nepal, but its line of flight does not appear to cross the great central mountains.

Figgs obtained by Wolley in Finland, and figured by Hewitson, are light olive-green, blotched and streaked with brown; they measure $2 \cdot 1$ by $1+5$, being similar to, but rather smaller than, those of the Black-tailed (iodwit, the next species. The food consists of aquatic insects, worms, small crustaceans and molluscs. The note is syllabled by Mr. Harting as lou-cy, loutcel, and by this the bird when in winter dress may often be distinguished from the Whimbrel at a distance.

In summer the adult male (in the foreground) lias the head, neck and under parts chestnut-red, with dark streaks from the crown to the sides of the breast; mantle variegated with wood-brown and black; rump white with brown streaks; tail buffish-white, barred with dark brown. Length $15 \mathrm{in}$; wing $8 \mathrm{in}$. The female is larger, but her colours are paler. After the autumn moult the under parts are chiefly white, with a few dark streaks on the neck and breast ; the upper parts are brownish-grey, which becomes ashy in winter; and the true rectrices are chiefly ash-grey with dark shaftstreaks: the long tail-coverts are, however, distinctly barred, so that, in ordinary parlance, the term 'bar-tailed' is at no season a misnomer. The young have broad bars-retained through the winteron the tail-feathers; the upper prarts are tinged with buff and checquered with two shades of brown, and the under surface is dull buff with dusky streaks. 


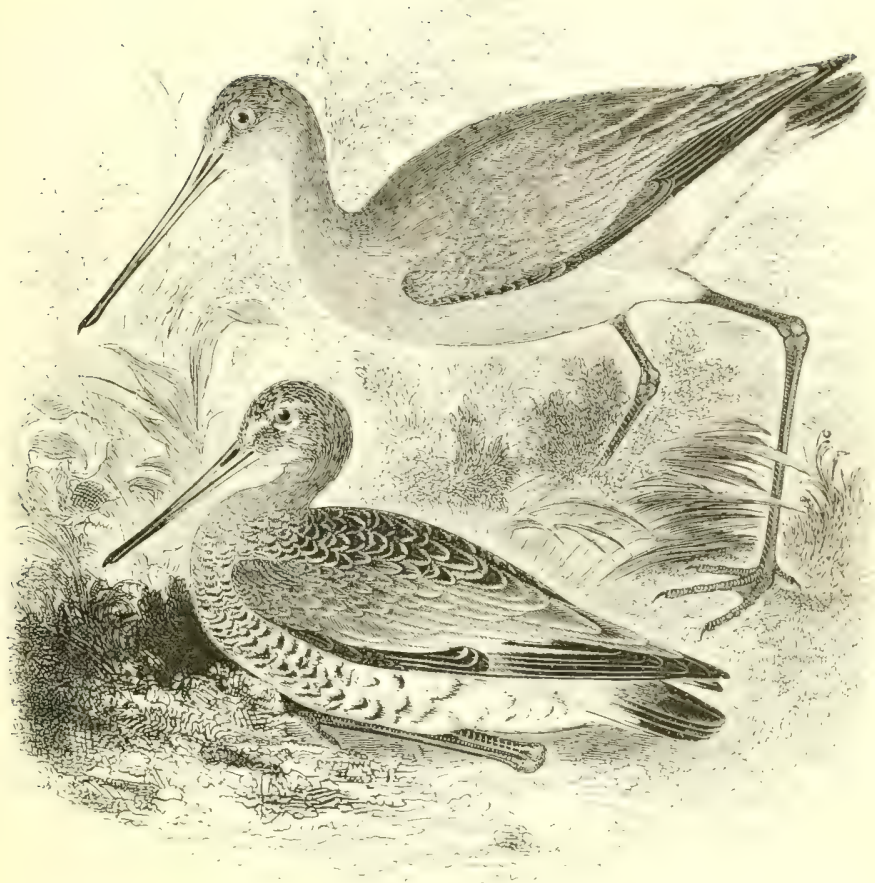

THE BLACK-TAILED GODWIT.

Linósa bélgica (J. F. Gmelín).

At the present day this species is chiefly a visitor to our islands on the spring and autumn migrations, a few individuals being some times observed in winter; but down to the year i $\$ 20$ it used to brocel in the fens of Lincolnshire and the Isle of Ely, while eggs were taken in Norfolk as recently as is +7 . The passage suuthward com. mences in August, and that in spring takes place from April to May; but at no season is this bird so numerous as the Bar-tailed Godwit, and north of the Humber its occurrence is rery irregular. On the west it visits the coast of Iancashire in small partics every autumn, but even the marshes of the Solway seldom attract it, while further north it is almost unknown, and on the calst side of soutlunt its appearance is unfrequent. In Ireland it is schlom met with in the fall, and only exceptionally in spring. 
The Ilack-tailed Godwit has been known to nest in the Færoes, and does so annually in the south-east of Iceland, where it is known by the name of jadrakan or 'earth-raker.' On the Continent it breeds sparsely as far north as lat. $64^{\circ}-65^{\circ}$ in Scandinavia and Russia, plentifully in Poland, sparingly again in Silesia, and-where the localities are suitable - in Northern Germany, Denmark, Holland and Belgium; but elsewhere it is chiefly known on migration, in the course of which it occurs in the Canaries and Madeira, its winterquarters commencing in the basin of the Mediterranean and extending to Abyssinia. In Asia it is found in Western Siberia south of lat. $60^{\circ}$ as far as the valley of the Ob, and through Turkestan to the Altai, ranging down to Ceylon in winter; while east of the Lena a larger form-distinguished by separatists as L. melamuroïdes -inhabits Eastern Siberia and Kamschatka in summer, passing through Japan and China to Australia and Polynesia during the colder months. The reported occurrence of the Black-tailed Codwit in (ireenland is open to question, and in North America its representative is L. Indsonica, which is smaller and has dark brown instead of white axillaries.

The nest is a slightly-lined hollow among coarse herbage; the eggs, 4 in number, are pear-shaped, and of a pale olive colour with brown spots: average measurements $2 \cdot 2$ by $r_{5}$ in. 'The only note which I heard on the breeding-grounds in Holland was a peculiar yelp, but one syllabled as grutto is said to be uttered. The food consists of insects and their larve, worms \&c.

The adult male in summer (figured in the foreground) has the head, neck and breast reddish-fawn colour, with dark markings on the crown and blackish bars on the lower breast; mantle brown, mottled with black; wing-bar conspicuously white; rump white; tail-feathers black-except their bases, which are white; belly whitish, barred with dark brown. Length r6 in.; wing 9 in. The female is decidedly larger, though there is great individual variation; her tints are duller. In winter the general colour is ash-brown above and greyish-ash below, the vent being white. The young are similar, but early in autumn they are tinged with rufous on the neck.

The specific name belgica is based upon a full description, with an excellent coloured plate, in Nozeman's 'Nederlandsche Vogelen'; while the term agocthala, which has often been employed, was originally bestowed on the preceding species. 


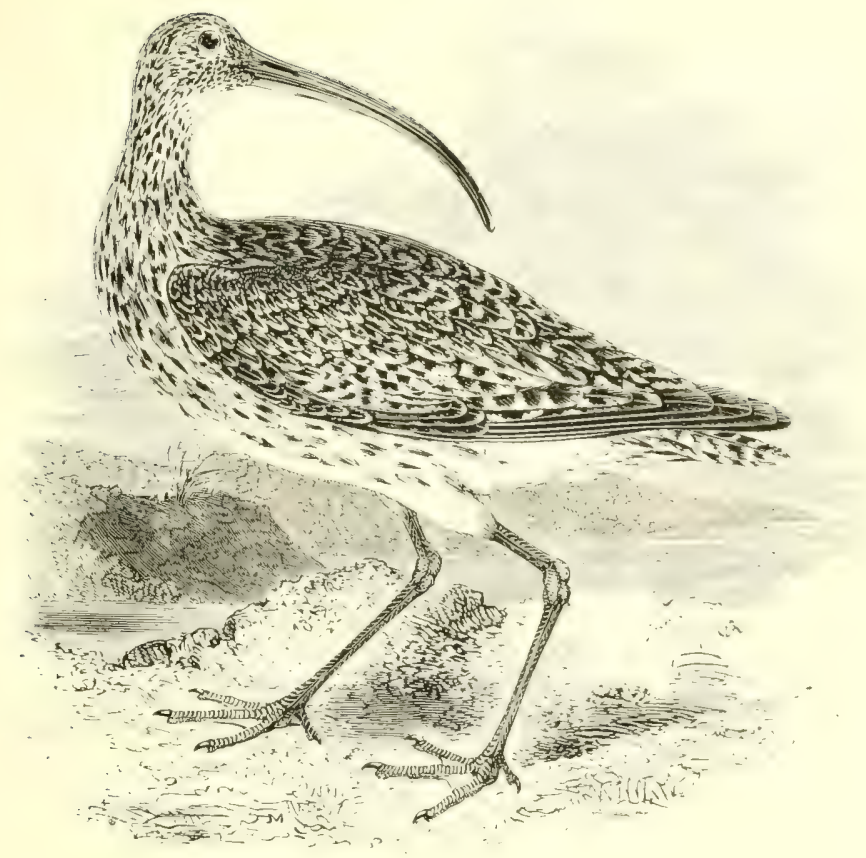

THE COMMON CURLEW.

\section{Numénius arquáta (Linnæus).}

Wherever sand and mud-flats or rocks covered with sea-weed are left bare by the receding tide, there the Curlew is to be found during the entire year; for even in spring, when the adults retire inland, their places are taken by immature birds which remain during the summer. It still breeds on the moors of Cornwall, Devon and Somerset, sparingly in I)orset, Wilts and Hants, frecly in Wales and the neighbouring counties, and on the high ground northwards (including the Isle of Man) as far as the liorder, while we also find it on low-lying heaths, such as Thorne Waste in Lincolnshire. It is even more generally distributed over the mainland of Scotland, as well as in the Orkneys and Shetlands, but is not positively known to nest in the Outer Hebrides, though it occurs there in winter. In Ireland it is common throughout the year.

The Curlew is only a straggler to the Froes and Iceland, where it is represented in summer by the Whimber ; lout it brecels more or less plentifully in Scandinavia, Russia, Poland, North (icrmany, 
Denmark. Holland and Flanders, as well as on some of the wastes of Britanny. Mr. Gätke has described the immense flights which cross Heligoland on migration, and throughout Central and Southern Europe this species is well known on passage, ranging as far west as the Azores; it winters in Africa from the Mediterranean to Damara-land and Natal, and risits Madagascar. As regards Asia, the birds found between the Caspian and Lake Baikal exhibit more white on the rump and axillaries than our western form-though they intergrade with it, and these have been specifically distinguished as .1. lineatus: Eastem Siberia, again, is inhabited by 1. armpw, a valid species-characterized by a broadly-barred rump-which visits Australia in winter. The American representative of our bird is the large 1 . lentirestris, which has rufous axillaric: In the Mediterranean basin and in Southern Russia we find a small Curlew, .1. temuliustris, no larger than the Whimbrel, with which it has been confounded: quite unnecessarily, for it has a striated crown and its axillaries are pure white.

The ofen, unconcealed nest is placed indifferently upon dry bare ground or in heather, grass or hogr and the tharge pear-shaped egess. which are olive-green bloteled with brown, and measure about 275 by 10 in., have been found near Carlisle early in April, while on the high moors of Northumberland incubation is not unfrequent by the end of that month. Mr. A. Chapman has remarked that the young selcom go far from the nest for the first few days. As long as the latter remain on the moors and pastures their diet consists of herries. worms, snails, spiders, insects $\mathbf{c c}_{\mathrm{c}}$, and in early autumn the hirds are excellent eating; but after they have resorted to the seashore and fed on crustaceans and marine animals they become unpalatahle. The Curlew has often been seen to perch on tall trees: its flight is rapid-a wedge-shaped formation being assumed by flocks: while it is not only remarkably wary, but seems to take pleasure in alarming every living creature within hearing of its shrill contr-li: : in the breeding-time, however, it has a peculiar rippling note.

The adult in spring-plumage has the feathers of the crown and upper parts pale brown, with darker central streaks; rump and upper tail-coverts white, the latter streaked with dark brown towards their tips: tail-feathers barred with dark brown and dull white; under parts pale brown-nearly white on the belly-streaked with dark brown. The female is the larger and has the longer bill. Whole length $2 \mathrm{I}-26$ in. ; wing $\mathrm{II}^{\circ} 5$ to $\mathrm{I} 2 \cdot 25$ in. In winter the under parts are almost white; and in the young bird they are washed with buff. The Curlew does not breed until its second spring, 


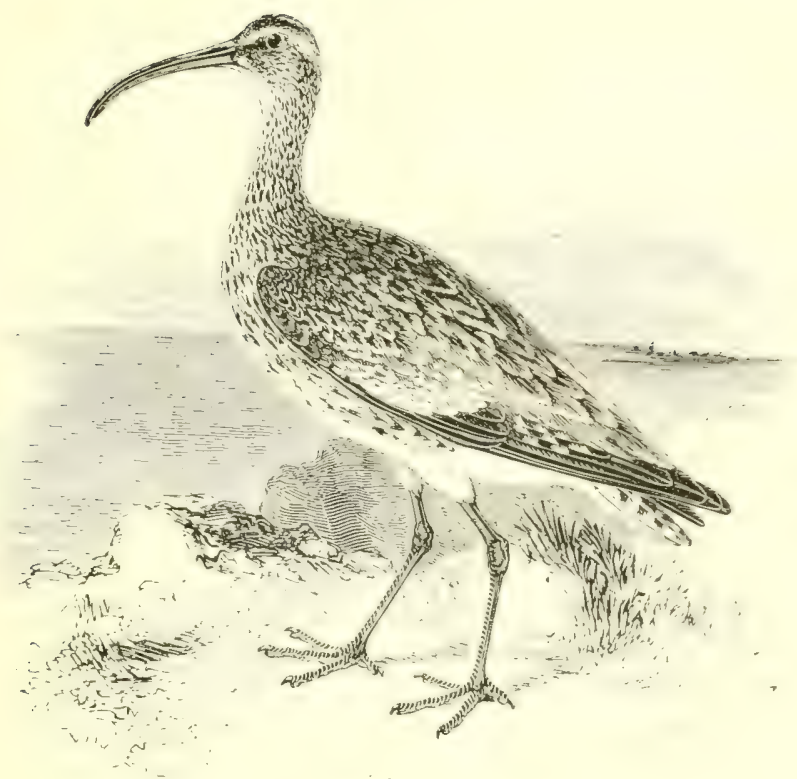

THE WHLMBREL.

Numexius pháopus (Linnæus).

The Whimbrel sometimes makes its appearance on our shores in the early part of April, but the main body of migrants northward arrive in May, with a regularity which has procured for this species the name of 'May-bird' in Cornwall, Hants, Norfolk and other counties. A small number of immature individuals remain on our coasts during the summer, while by the latter part of July the return passage - commencing with the young - sets in, and continues through the autumn; at the latter season, however, the birds usually fly very high and seldom remain for long, few being met with after the end of September. None are known to lirect on the mainland of Scotland, but a small number nest on some of the Orkneys and a good many do so on several of the sibetlancis: while a pair or two inhabit North Ronay in the Outer Hebrides, and on its travels-especially in spring - the bird passes throusth the (ather islands of that group. In Ireland also it is most abundant on the spring migration, but has never been known to breed.

In the Faroes and Iceland, as already mentioned, the IIthimbul 
takes the place of the Curlew from April or May till September, and it occasionally wanders to Greenland. In Scandinavia it nests on the fells and to the north of the limits of forest-growth; but in the Arctic and sub-Arctic regions of Russia it appears to be very local, while over the greater part of Siberia in Asia we find a race in which the adults have more streaks on the rump than even young birds of our western furm. This eastern representative, which has been separated specifically as .l. írriestus of Scopoli, migrates southward to New Guinea; but our typical bird visits a considerable portion of the Indian region, as well as Mauritius and Madagascar, and in Africa is found down to Cape Colony. Its wanderings extend westward to the Azores, and on passage it is found over Europe as far as the Mediterranean, though it seldom occurs far inland. Its American representative is $N$. Iudsonicuswith rufous axillaries, which has once been obtained in the southwest of Spain.

A shallow depression in the soil serres to contain the 4 eggs, which are usually laid from the latter part of May to the middle of June: they are of two shades of olive-green, blotched with brown: average measurements $2+$ by 155 in. The Whimbrel is very pugnacious at its breeding-place, and I have seen it attack the Arctic skua, while Col. Feilden has observed it driving away the I,esser lihack-backed (iulls, uttering its trilling cry, tctty, tetty, tetty, tet, as it darted to and fro with arrow-like flight. Its food consists of small crustaceans, insects, worms, and land-shells, such as Hilix crictorum, while it is said to be partial to bilberries, for it is much more of a land-feeder than the Curlew. Owing to its note, 'Titterel' is a common name for this bird in Sussex, and in the south and west Whimbrels are often spoken of as 'the Seven Whistlers,' the rippling whistle being repeated seven times.

This species is much smaller than the Curlew, from which it further differs characteristically in the markings of the head, the crown being dark brown with a broad pale streak down the middle; the general hue of the upper parts is darker, though otherwise the general plumage is similar; the axillaries are white, barred with brown. Length $16-18$ in.; wing about 10 in.; the female being larger than the male. The young are spotted on the back and barred on the wing-coverts and secondaries with buffish-white, a remarkably checquered appearance being thus produced; the rump is more or less streaked; the axillaries are only slightly barred, but the dark transverse markings on the tail-feathers are more numerous and defined than in the adults. 


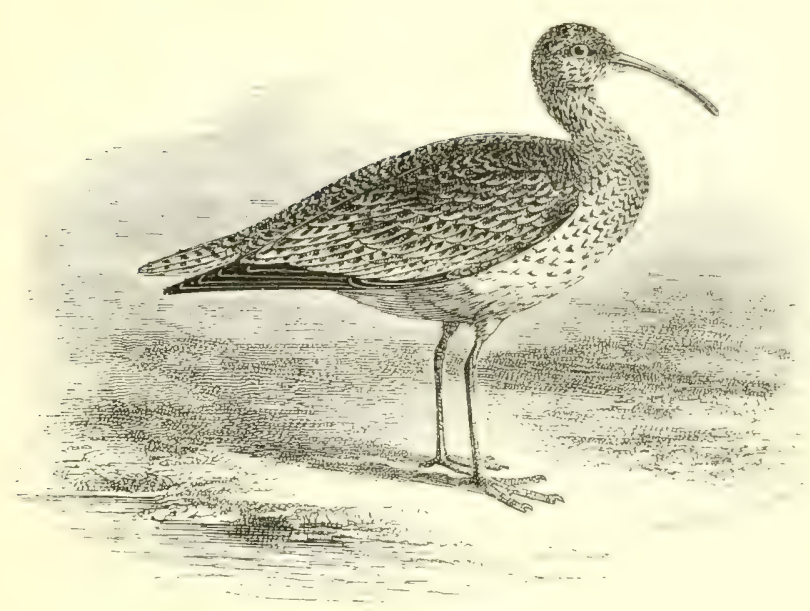

THE ESKIMO CURLEW.

Numenius boreális (J. R. Forster).

This small American species is an occasional straggler to the British Islands, the first instance on record being that of a bircl which was killed in Kincardineshire on September 6th 1855 . On September 29 th 1879 another, shot in Aberdeenshire, was sent for preservation to MIr. G. Sim, who also received an adult male from Kincardineshire on September 2ist i SSO. An txample, said to have been forwarded from sligo, was purchased in l)ublin market on October 2 Ist I 870 , and afterwards presented by Sir Victor Brooke to the Museum of that city. According to the late Dr. Churchill Babington, two were obtained near Woodbridge in suffulk in November $\mathrm{I}_{5} 2$, only one of which is now in existence; while he adds, on Hele's authority, that a bird, which was not preserved, was killed on the river Alde some few years before 1870 . 'The latest occurrence is that mentioned by Mr. Thomas Comish, at Tresen in the Scilly Islands, on September Ioth 1887 .

The Eskimo Curlew appears to be merely a visitor to (ireenland, but is widely distributed during the summer throughout the Aretic regions of America from Hudson bay to Alaska : only a few, however, remain to breed in the latter as far south as St. Michael's though northward this is the most abundant member of the senus. It has wandered to the Pribilov Islands, but its representative in Northern Siberia-and southward to Australia in winter-is 
1. minutus of Gould, a slightly smaller species, which has paler and less barred under parts, and morcover has the back of the tarsus scutellated like the front-as in Totmmus; in the American bird the hind tarsus is reticulated, as in other members of the genus Aumenius. Although the Eskimo Curlew has been obtained in the Galípagos Islands, and also on the coast of Chili, it does not appear to pass down the Pacific sea-board of North America; its line of flight being rather to the eastward of the Rocky Mountains. Immense numbers migrate through the Mississippi valley, but none winter there, nor is a long stay made in any part of the United States to the north of Texas; some visit the Bermudas, while others yass southward as far as Patagonia and the Falkland Islands.

Mr. MacFarlane describes the nests, which he found between June zoth and July roth, as mere hollows in the barren-grounds; the eggs, + in number, are olive-drab or light ash-green, blotched with various shades of brown: average measurements 2 by $1 \cdot 5 \mathrm{in}$. In autumn the bird feeds freely on crowberries, and is so partial to a species of snail found on low rocks and mud-flats that Dr. Elliott Coues has seen flocks hovering distractedly over a party of gunners stationed on ground where these molluscs abounded. The note is an often-repeated soft, mellow whistle; the flight is straight and very swift.

The points which distinguish this species from its nearest ally, I. mimutus, have already been indicated; its other diagnostic characteristics are: primaries with scarcely a trace of bars, no white on the rump, under parts buff with transverse 'arrow-head' markings, axillaries chestnut barred with brown. Length 14 in.; wing 8.25 in. As Mr. Seebohm has pointed out in his work on the 'Charadriida,' the pale stripe down the centre of the dark crown is sufficiently defined to show that this species belongs to the group of Whimbrels rather than that of Curlews; but I do not consider it expedient to follow his example and change a long-accepted name. 


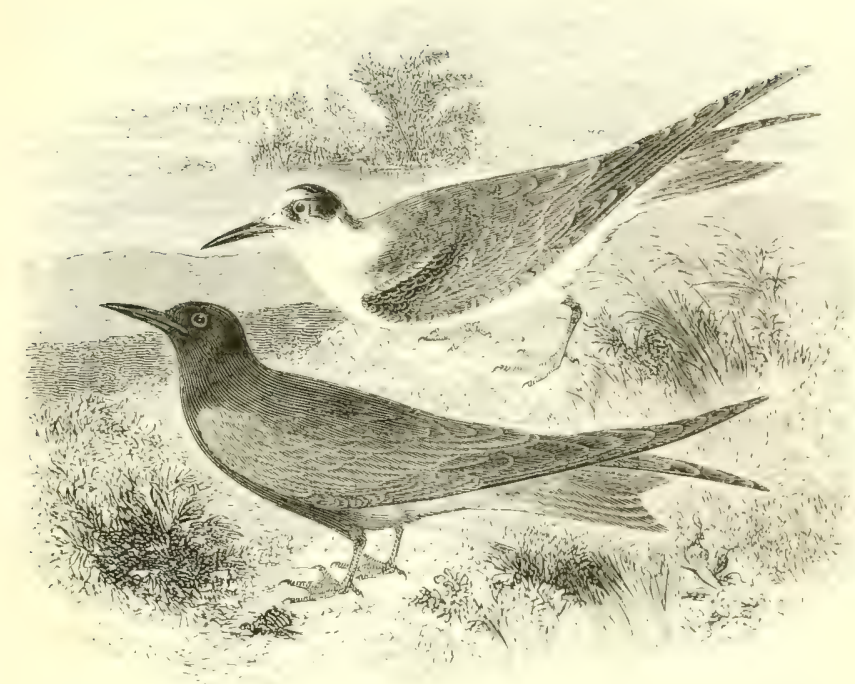

THE BLACK TERN.

\section{HYDROCHELÍDON NIGRA (Linnzeus).}

The Black Tern was a regular spring-visitor to England before drainage had done away with most of the fens and wet marshes to which it used to resort for breeding-purposes; but even in Norfolk the last eggs on record were taken as long ago as 1858 , though early in the century the nests of the 'Blue Darr,' as the bird was called, might have been found in hundreds on the alder-swamps. In Lincolnshire it is possible that a pair or two of the "Car-Swallow' may still be seen during the summer; but otherwise this species chiefly frequents our eastern and southern coasts, rivers and inland waters in April and May; while in August the young begin to make their appearance, and a few birds remain in the south-west as late as November. In the west of England it is rare, even on the marshes of the Solway, where, however, its eggs are said to have been taken in 1855 ; and though it has been met with on Loch Lomond and other waters in the lowlands of Scotland, it is as yet unknown in the Hebrides or the Orkneys. On the east it seldom occurs northward of the IJumber: sashe, howcrer. has stated that he once observed it in the shetlands, which is not improblathe. inas much as a wanderer was cbtained in the lareses in september s stio. 
The irregular occurrences recorded from Ireland are chiefly those of immature birds in autumn.

This species is not known to breed north of about lat. $60^{\circ}$ in the Baltic, the (iulf of Finland or Russia, but over the rest of the Continent it is abundant in suitable localities down to the Mediterranean; it also nests in the marshes of North Africa. Even in winter it does not seem to go further south than the Cameroons ( $t^{\circ}$ N. lat.), whence I have an example; all the specimens recorded under the name of $H$. nir from I)amara-land on the west side or the Transvaal on the east, having proved to be H. leucoptcra, the next species. As reyards Asia, Drs. Radde and Walter do not record the Black Tern from the district between the Caspian and the Merv oasis, and there is no authentic instance of its occurrence in India or China. It inhabits America, from Canada in summer to Chili in winter, the adults found there being, as a rule, of a browener black on the under parts than any European specimens, though some are identical with ours.

Irom about the third week in May this bird may be found in colonies on wet marshes or by shallow pools, making its nest of decayed plants on heaps of wrack which rise and fall with the water, or on the firmer hummocks of the bog. The eggs, 3 in number, are ochreous-clay, olive-brown or olive-green in ground-colour, boldly blotched with darker brown: arerage measurements $\mathrm{r} .45$ by $\mathrm{r}$ in. The Black Tern feeds chielly on aquatic insects, many of whichsuch as dragon-flies--it takes on the wing, and MIr. F. S. Mitchell has watched it swooping down upon the field-crickets (Acheta camfestris) during their momentary appearance at the entrances of their burrows; it is also very partial to leeches, and will take small fish \&c. The note is a shrill crick, crick.

The adult in nuptial-dress (figured in the foreground) has the head and neck dark lead-grey, nearly black on the crown and nape; back, wings and tail slate-grey, the latter slightly forked; throat, breast and belly dark lead-grey ; under wing-coverts pale grey; vent white; bill black; legs and feet short, reddish-brown. Females have usually lighter coloured under parts than males. Length $\mathrm{o}$ in. ; wing 8.5 in. After the autumn moult the forehead, throat and nape are white, as are also the under parts for a short time-though usually barred with grey. The young bird (in the background) is mottled with brown on the head and mantle, but by the following spring the upper parts have become lead-grey, with a darker line remaining along the carpal joint; the full dress is not acquired till the second spring, when breeding takes piace. 


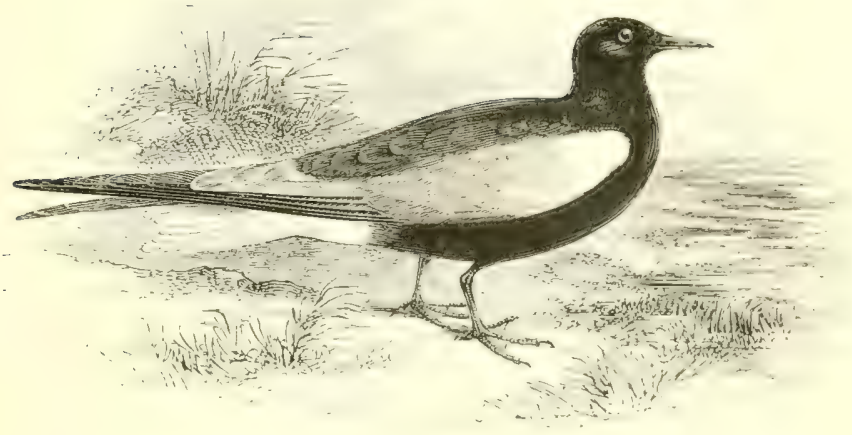

THE WHITE-WINGED BLACK TERN.

\section{Hydrochelidon i.eucóptera (Schinz).}

This species, which has a more south-easterly habitat than the Black Tern, is an irregular visitor to our shores on migration especially during May and June, in which months a good many examples have been obtained of late years in Norfolk, while others have occurred on the coasts of Susses, Hants, Dorset, Cornwall and the Scilly Islands, northward in lorkshire and I)urham, and inland near Coventry: The first British specimen on record was, however, shot in Iublin Bay, Ireland, in October I $\$_{4} \mathrm{I}$, and I have eximined a bird in full moult killed at Ilfracombe, North I evon, early in November 1870 ; these being the only autumnal instances known to me. Besides the former, two more have been obtained in Ireland, but in spring.

The White-winged Black Tern has only once been known to wander as far as Lund in sweden, and its northern breeding-limits appear to be in the governments of Lublin and Siedlec in Poland, south of which it is by no means uncommon on some of the marshes of Central and South-eastern Europe. It probably nests in Sicily, as well as near Massaciuccoli and Venice on the mainland of Italy, which it visits on migration; it frepuents the ('amarsuce, ascends the valley of the Rhone to Savoy and Central France, and passes along the east coast of suain in considurable numbers. though seldom seen in the south-west and not recorded ly. Mr. Tait from Portugal. In Western Morocco it is hardly known, but it is said to breed in Mlgeria and I.owur Egypt, while in wintur it is 
found in flocks on the marshes and 'vless' of Africa down to the Transvaal and Damara-land. I)uring summer it inhabits the temperate regions of Asia from the Caspian to the Amoor, Mongolia and Northern China; wintering as far south as Celebes, and visiting Ceylon, though rare on the mainland of India. 'Two examples in full nuptial dress were shot in the province of Nelson, New Zealand, on December I th 1 S6S; and in North America an adult female was obtained on Iake Koskonong, Wisconsin, on July 5 th 1873 .

This gregarious species nests in marshes, and may sometimes be found in company with the Black Tern, as in Central Europe, in which the latter is in the ascendant; but in southern Russia large and distinct colonies are formed. The egers. deposited on floating vegetation in May or June, are 3 in number, and resemble those of the preceding species: average measurements 1.35 by $\mathrm{I}$ in. Its light is more rapid and its cry is said to be har.her than that of its congener; the food consists of dragon-flies and other aquatic insects.

'The adult in summer has the head, neck and back glossy black, in strong contrast to the white on the carpal joint of the wing; greater wing-coverts grey, and secondaries lead-grey; primaries frosted with pearl-grey, which soun wears off, leaving the webs sootyblack; upper tail-coverts and tail jure white, the latter very slightly forked; under parts black, with a brownish tinge on the abdomen; vent white; under wing-coverts and axillaries black; bill livid red; legs and feet orange-red, the webs very much indented. Length 9.5 in. ; wing $S: 25$ in. After the autumm moult the hital, neck, and under farts inclusive of the wink-tirts are white, and the mantle and tail are grey. The young bird-which resembles the adult in winter-plumage, though at first mottled with brown on the upper parts, may be distinguished from the immature $H$. nitra by its shorter bill, longer toes with more deeply incised webs, paler rump and tail, and more defined wedge of white on the inner webs of each primary: Neither the feathers on the carpal joint nor those of the tail become pure white until the third year.

The late G. R. (rray erroneously identified this species with the Stcma nigra which Linnitus described as "found on the small reedy islands about Upsala," and which was, of course, the Black Tern. Being considered an authority on nomenclature, especially by foreigners, his unfortunate precedent has been only too widely followed, and has occasioned much confusion. 


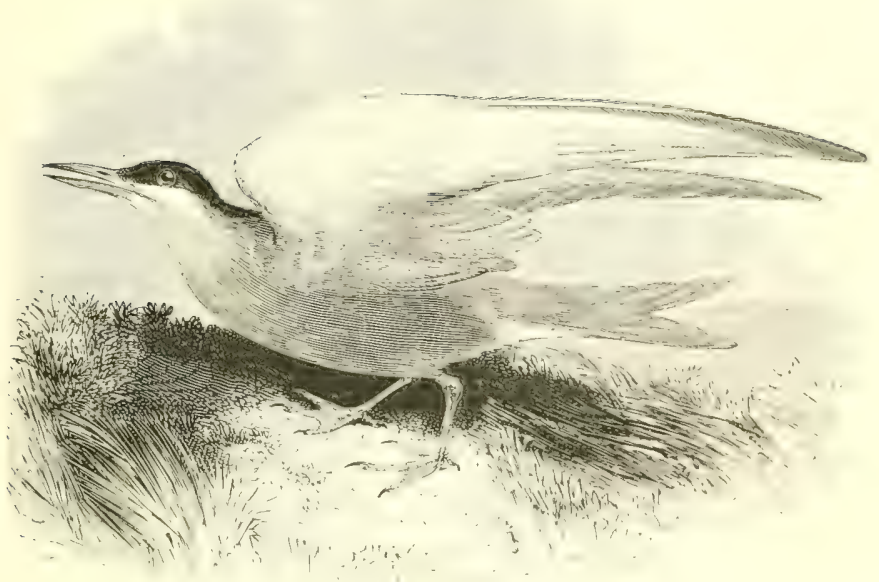

THE WHISKERED TERN.

Hydrochelidon híbrida (Pallas).

The Whiskered Tern has an even less northerly range than the preceding species, and only wanders to our islands at long intervals. It was first recognized by Heysham, who selected the subject of the above illustration from some sea-birds which hatd been shot at I,yme in Dorsetshire towards the end of August $1 \$_{3} 6$; in september $1 \$_{30}$ one (in the Warren collection at the I)ublin Museum) was oldained at the mouth of the Liffey; a third was killed, according to Mr. Southwell, near Hornby' ('astle, Vorkshire, in is +2 : an adult female containing advanced ora was shot on Hickling liroad, Norfolk, om June I 7 th $\mathrm{I} 847$, and is in the collection of Mr. J. H. Gurney; an immature example was procured at the end of August ${ }_{1} S_{5} \mathrm{r}$, near Tresco, in the Scilly Islands; and lastly, an adult picked up on the water near Plymouth--alive but apparenty exhausted-in Mily I $865_{5}$, was presented to me by my late friend the much regretted Mr. J. Gatcombe.

This Tern is a very rare straggler to Northern Germany; nor does it often wander up the valley of the Rhone, though it still breeds sparingly in the delta of that river. Large numbers arrive by the middle of April in the marshes of the south-west of Spain; and, though only known on passage in Italy, there are imprortant colunicis 
in the swamps of the Danube, as well as in Turkey, Greece and the southern districts of Russia, while a few pairs occasionally nest as far north as the morasses near Lublin in Poland. In North Africa, from Morocco to Egypt, the Whiskered Tern is abundant in suitable localities, and in the months of our winter it has been found-in immature dress as well as in full breeding.plumage - as far south as Damara-land, the Transvaal and the Orange Free State, so that it probably nests in the southern half of that continent. In Asia it is distributed from the Mediterranean to Mongolia, and nests plentifully in Northern India, while southward we trace it to Celebes. There again we meet with birds which I believe to have been bred in Australia, and these. in their winter-dress, are slightly paler than our northern examples, although I can find no difference between adults in nuptial dress from (lueensland and from Europe.

Like its congeners, this Tern breeds in colonies; its nest being often a large mass of tangled growing weeds pulled together on the surface of the water. The egiss, 3 in number, are usually of a pale green ground-colour, though sometimes stone-grey or buff, spotted, blotched, or scrolled with brown and black: average measurements I 55 by $\mathrm{I}^{\circ} 5$ in. In Europe incubation commences in May, but July is the usual month in India. The food consists of dragon-flies, grasshoppers, caterpillars, aquatic bectles \&c., as well as of newts, small fish and frogs. The flight is buoyant, but not very swift.

The adult in breeding-plumage has the forehead, crown and nape black, contrasting with a broad stripe of white which runs backwards from the base of the bill, and forms the whisker or moustache from which the bird derives its name; upper parts slate-grey, darker on the shoulders and primaries, except when the latter are frosted with pearl-grey; chin and throat greyish-white; breast slate-grey ; abdomen and flanks nearly black; under wing-coverts pure white; axillaries white, sometimes tinged with grey; bill blood-red; legs, feet and webs vermilion. Length I $_{5}$ in.; wing 9.25 in. Indian birds, which are probably almost sedentary, are smaller than Western examples, which evidently take long journeys to South Africa. In winter the forehead and under parts are white; the crown, nape and ear-coverts being only streaked with black; while the mantle is paler than in summer, and is sometimes a delicate pearl-grey. The summer-dress is assumed by a moult, which commences in February or March.

This and the two foregoing species constitute the natural subdivision of "Marsh-Terns." 


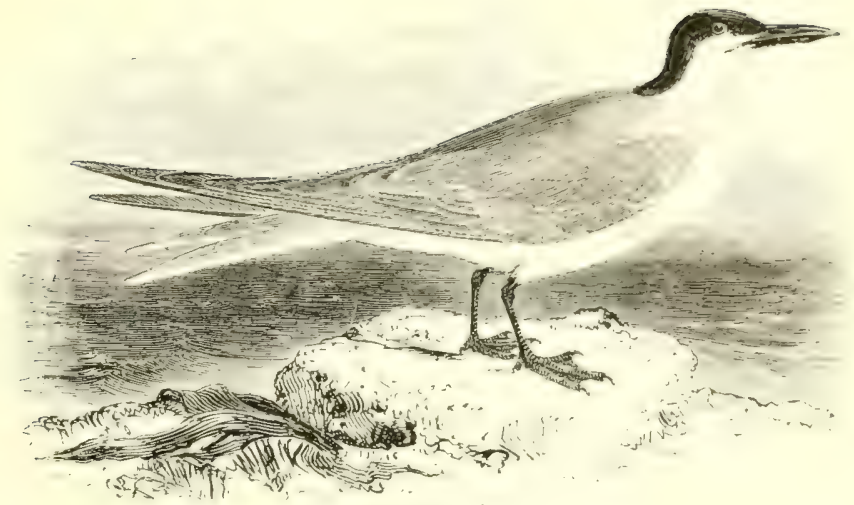

THE GULL-BILLED TERN.

Stérna Ánglica, Montagu.

This species was first made known by Montagu, from specimens shot in Sussex, and in ignorance of its being a mere visitor to our shores, he bestowed upon it the inappropriate name of anglica. Since the date of his discovery examples have been obtained as far north as Blackpool in Lancashire and the vicinity of Leeds in Jorkshire; but Norfolk, where no fewer than eight have been taken, has naturally proved the most attractive county to this migrant, while there are records of one from Hunstanton in Norfolk, one from Kent, three from Sussex, and one each from Christchurch in Hants, Plymouth in Devon, Penzance in Cornwall, and Tresco in Scillyalmost all of them in spring or summer. In Ireland an immature bird was shot on Belfast Lough towards the end of September ysS;.

It is not remarkable that this widely-distributed Tern should occasionally visit England, seeing that it annually repairs to the Island of Sylt and a few spots on the west coast of 1)enmark. In the Netherlands, Central Europe generally, and the north of France, it is only of accidental occurrence, but it breeds at the mouth of the Rhone, and abundantly along the coast of Spain, especially on the sand-banks between Cadiz and the l'ortuguese fronticr: and, though chiefly a migrant in Italy, it nests on the salt lagoons of Greece, Asia Minor, and the Black and Caspian Suas. In similar situations it is plentiful from . Yorocco to Egry,t and the Red sica: whilst in Asia it is found in summer as far north as the lloang-ho valley in Mongolia, and also breeds on the islande of the I'ersian 
Gulf. In the cold season it visits China, the Eastern Archipelago, India and Cerlon; in the latter the northern birds meet with individuals of a slightly paler race which breeds in Australia and was distinguished by (iould as S. macrotarsa. In America the Gullbilled Tern nests along the east coast from New Jersey to Texas, as well as in the Bahamas, Cuba \&c., and probably on the back-waters near Santa Catarina in Brazil, while it ranges as far south as Patagonia. On the Pacific side Mr. Salvin obtained it in Guatemala.

A slight hollow scratched in the earth or sand, lined with a few fragments of sea-weed or dried grass, serves as the receptacle for the eggrs. which are 2 or 3 in number; their ground-colour is usually pale buff-occasionally of a pale greenish tint which soon fadesblotched and spotted with several shades of brown: average measurements 2 by $1+\mathrm{in}$. I) uring the breeding-season the note resembles the syllables ihi-ah. but at other times the bird utters a laughing af, af, af, like a ciull. In Ceylon Col. Legge found it feeding on frogs, crabs and fish: in Egypt Ton Heuglin observed it darting into the dense smoke of a prairie fire in pursuit of locusts; and in Algeria Mr. Salvin noticed it hovering over grass fields, and pouncing upon grasshoppers and beetles; it also captures many species of insects on the wing. Its tlight is graceful but not very rapid, the long wings being plied with measured steady strokes.

The adult in summer has the forehead, crown and nape jet black; upper parts pale grey. except where the frosting has been rubbed off the primaries, which are then darker, especially on the edges of the inner webs; under parts pure white; bill black, very stout and strong; legs and feet black, with a tinge of red. Length I5.5; wing 13 in. In winter the head is white, with ash-grey streaks, some of which unite and form patches on the eye and ear-coverts. The young bird is mottled and striped with brown, tinged with buff on the upper parts, while the bill and legs are brown; and even in the second year, when breeding takes place, the latter are still livid. The bill is subject to great individual variation, but is generally largest in males; the feet are almost as fully webbed as in the true Sea-Terns; the tail is short, and the lateral feathers are slightly rounded, though more pointed than in the Marsh-Terns. This species was made the type and sole representative of the genus Gilochelidon by Brehm, who further devised Sylochelidon for the. Caspian Tern. 


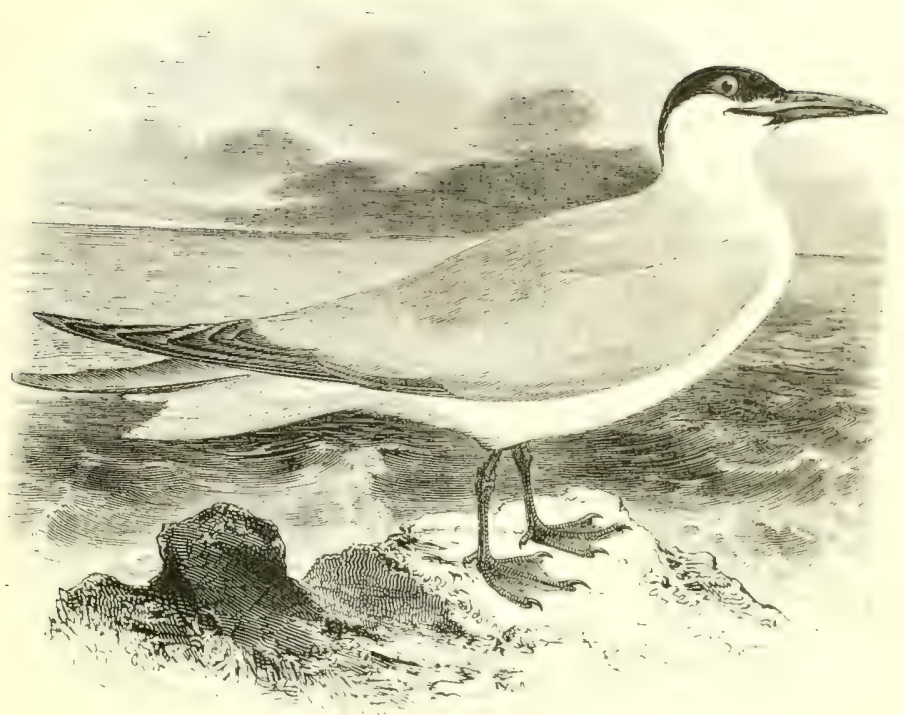

\section{THE; CASPIAN TERN.}

Sterna cáspia, Pallas.

This fine Tern, the largest member of the genus, is of more irregular appearance on the coast of England than might reasonably be expected, seeing that some of its breeding-places are at no great distance. According to an excellent summary of its occurrences by Mr. J. H. Gurney, jun. (Zool. 1887, p. 457), nine examples have been obtained - and others have been observed - on the coast of Norfolk between i S25 and i S60; while eight have been killed, at various times and places, in Suffolk, Kent, I orset, Lincolnshire and Yorkshire. Mr. E. Bidwell, whose identilication may be trusted, saw an individual of this species near the forne Islancls on June 6 th I $S S \circ$; and although the species has not yet been recorded from Scotland, a male was shot at Taagoe in the faroes on May Ioth 1887 , as stated by Col. H. W. Feilden.

The Caspian Tern breeds in colonies - which have seriously diminished of late years-on the sandy shores and islands of the basin of the Baltic; but its best-known haunt is the island of Sylt, to the west of Schleswig, though I believe that some nest still nearer to us, namely on the const of Holland to the south of the Naas, for I saw six adults flying in pairs and evidently going out to 
fish, in the carly dawn of July 9th i $S_{75}$. On the waters of France, Switzerland and the interior of the Continent it is only known as a straggler. but it breeds on the eastern shores of Spain as well as on some small islands near Sardinia, while generally distributed throughout the Nediterranean; it also nests by the Black and Caspian Seas, from the latter of which it was first recorded by Pallas. It arrives at the northern limit of its range in spring, departing for the south in autumn; but is, apparently, a resident on the northern littoral of Africa, and southward along both sides of that continent, as far as Cape Colony. In Asia it can be traced from the Caspian to China, and-crossing the lofty mountain chain on its migrations - it visits India and liuma in winter; moreover it breeds in the Persian (iulf as well as in Ceylon. It also inhabits Australia and New Zealand: while in America it is found from Labrador on the east, and the Yukon on the west, down to Mexico.

The Caspian Tern deposits its eggs in May or June on ine bare sand, in a slight hollow which is occasionally lined with pieces of shell or a few bents; they are $2-3$ in number, and in colour stone-buff, spotted and scrolled with ash-grey and dark brown : average measure ments 2.55 by 1.7 in. The ordinary food consists of fish. The note is a loud, harsh kriki-kra, uttered freely by the bird when its breeding-haunts are invaded. This species is nearly as partial to brackish lakes as to the sea-shore, and when searching for food it has a characteristic halit of keeping its bill pointed downwards, almost at a right angle to its body.

The adult in summer-plumage has the bill vermilion-red; crown and nape glossy-black; neck and under parts pure white; upper parts pale french-grey, curker at the tips of the primaries where the frosting is quickly worn off ; tail white with a greyish tinge, and only slightly forked; legs and feet black. Average length $20 \mathrm{in}$., wing Ió in. ; the male being larger than the female and having a stronger bill. In winter the crown is streaked with black, and there is a dark patch behind the ear-coverts. The young bird has the forehead and crown white; upper surface mottled with ash-brown; quills ash-grey; bill dull red, horn-coloured at the tip. 


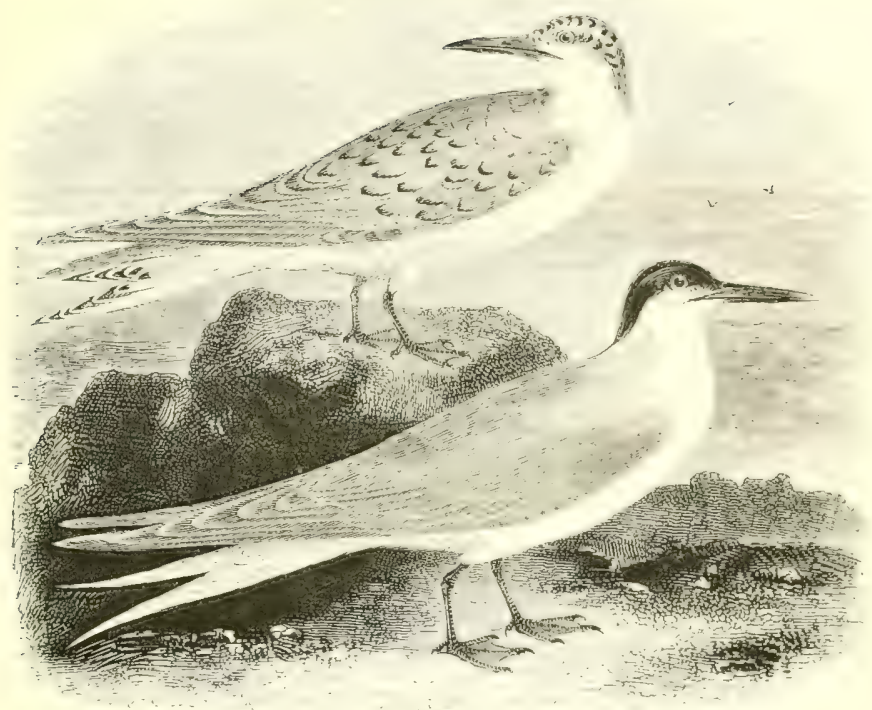

THE SANDIVICH TERN.

Sterna Cantíaca, J. F. Gmelin.

The Sandwich Tern, which derives its name from the place where it was first observed in 1784 , is a regular visitor to the British Islands; arriving in some localities towards the end of March (though usually in April, or not till May on the east coast), and leaving for the south early in autumn. When persecuted, it not unfrequently changes its breeding-grounds, and ornithologists who have recently explored the silly Islands have failed to find it there in summer, while particulars respecting Kent, Essex or Suffolk might prove prejudicial; but a large and well-known colony inhabits the Farne Islands, and on the west a limited number nest on Walney Island off Lancashire, and at Ravenglass in Cumberland. Beyond the Solway a few pairs are found on the coast of Kirkcud. brightshire, and, according to Cray, some frequent Loch I.omond: while on the east of Scotland there are breeding-places up to the mouth of the Findhorn. In Ireland there is a carefully protected site near Ballina, described by Mr. R. Warren (Zool. I877, p. I01), and some others are probably in existence.

This species is seldom found northward of Denmark and is almost unknown in the Baltic, but on the low coasts and some of the islands of the North Sien, from Iutland to the Netherlands, it 
nests in large colonies. On migration it visits the shores of France, and there are probably some settlements in the north-west; while it is common in Spain on passage, where some remain to breed, as they also do in Sardinia, and perhaps in Sicily. Further up. the Mediterranean it is comparatively rare, but it is plentiful by the Black and Caspian Seas, and eastward it is found along the Arabian and Persian coasts as far as Kurachee in Sind. It nests in the Canaries, frequents the northern waters of Africa, and goes down the west in winter as far as Cape Colony. In America this 'Tern-formerly' distinguished as Stirna acuflatida-inhabits the Atlantic sea-board from New England southward to HondurasMr. Salvin having found it breeding in the latter, and also noticed it on both coasts of Guatemala; while in winter it visits Brazil.

The nests are frequently mere shallow holes scratched in the sand among sea-campion or other plants, but on Walney Island and elsewhere tolerably solid structures of bents have been noticed. The eggs are usually 2 , rarely 3 in number: but in large colonies birds not unfrequently lay in one another's nests, and I once found two eggs of this species and one belonging to the Arctic or the Common Tern in the same hollow of a mass of sea-tang on the Farne Islands. Many are of a rich yellowish-stone colour, thickly scrolled and spotted with ash-grey, orange-brown and deep redbrown, but in others the ground-colour is creamy-white: average measurements $2 \mathrm{in.}$ by $\mathrm{I}_{5} \mathrm{in}$. liy fishermen this species is called, far excillini', 'the Tern, all other species passing under the general name of 'Sea-Swallows icc. It subsists chiefly' upon fisl, the sandlance and young gar-fish forming the principal supply. Its flight is strong and rapid, the bird making a great advance at each stroke of the pinions; and, except when engaged in incubation, it is usually on the wing, uttering at intervals a hoarse and grating cry, kirhitt, kirhitt, audible at a long distance.

The adult in summer has the bill chiefly black, yellow at the tip ; forehead, crown and elongated nuchal feathers black; mantle pearlgrey; quills rather darker on the portion of the web next to the white shaft, but pure white on the greater part of the inner web down to the very tip; rump and tail white; throat and under parts white, often suffused with a lovely salmon-pink; legs and feet black. By the end of August a great deal of the black on the forehead has disappeared, but the nape is mottled throughout the winter. Length 16 in., wing 12 in. The young (in the background) has the head barred with black and white; the back, wing-coverts and tail-feathers varied with angular lines of black. 


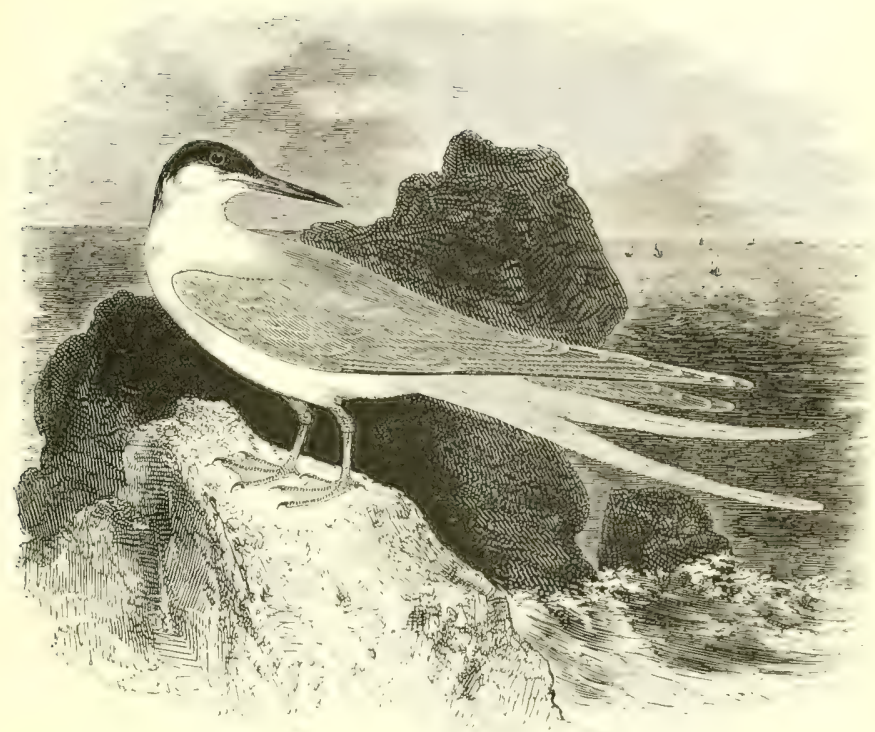

THE ROSEATE TERN.

\section{Sterna dougálll, Montagu.}

This slender and elegant species was discovered on the Cumbraes in the Firth of Clyde by Dr. MacDougall of Glasgow, who sent a specimen to Montagu. Selby subsequently found it breeding in some numbers on the Farne Islands, which were afterwards almost deserted, but where of late years several pairs have again been noticed; and although some were shot in 1880 by one of the Trinity lighthouse-keepers in defiance of the law, there is now a prospect of efficient private protection. Foulney and Walney Islands on the Lancashire coast, as well as some of the Scilly Islands, were formerly frequented by the bird, though of late it has seldom buen observed in any of those localities. I am inclined to attribute its diminution in a great measure to the increase of the larger strongerbilled Common Tern, before which, as l)r. Iureau informs me of his own knowledge, three colonies of the Roseate T'ern have successively given way on the coast of Irittany in the course of a few years. Indiscriminate egging on the prart of fishermen has undoubtedly been very prejudicial, especially as revards some former suttlements in the north of Ireland; while the havec caused by gunners, who used to shoot all kinds of Terns for sport or for plumes for 
ladies' hats, has doubtless affected the Roseate to a slight degree. It must, however, be remembered that this species only arrives towards the end of May, and leares much sooner than the other Terns-as soon as ever its young can fly; in fact, I do not remember to have seen more than two or three immature birds killed within our four seas, though adults are occasiunally obtained on migration.

The Roseate Tern is an oceanic and southern species, and is not known beyond $57^{\circ} \mathrm{N}$. lat., being merely a straggler to the coasts of the North Sea. It has several colonies on the west side of France, and a few examples have been obtained in the Mediterranean; while we trace it to the Azores, and across the Atlantic-by way of the Bermudas - to America. There it is found breeding along the east coast from New England to Honduras, and throughout the West Indies, though it has not yet leen obtained on the Pacific sea-board. It has been recorded in error from the south-west of Africa, but I have specimens in full breeding-plumage from Cape Colony and Natal: while by way of Madagascar we trace it through the Indian Ocean to Ceylon and the Andaman Islands, in both of which it nests, as it also does in Northern Australia and in the New Caledonia group.

The eggs, $2-3$ in number, are laid on the ground, and vary from creamy-white to buffish-brown in colour, blotched and clouded with bluish-grey and rich brown; they are as a rule somewhat more elongated than those of the Arctic 'Tern, and measure about $I$ ' 7 by $I^{\prime}{ }_{5}$ in. The food cunsists of fish obtained from the sea, which this species almost exclusively affects, seldom eren visiting a salt lagoon. In flight, except when the bird is turning or hovering, the two long tail-feathers are carried close together. The note is a rather peculiar harsh crake.

The Roseate Tern owes its name to the beautiful though evanescent pink tinge on its under parts; the mantle is of a paler grey than in the Arctic or Common Terns, and-except in old birdsthis grey extends to the tail-feathers; in the primaries the white inner marsins are wiell difined to the rery tifs and eqen a little way up the outer a'clls: more so than in the much larger Sandwich Tern. This is an infallible distinction for young as well as old birds; another characteristic is the comparative shortness of the wing. Early in the breeding-season the bill is orange at the base, but soon becomes chiefly or wholly black; the legs and feet are red. In winter the forehead is nearly white. Length $15.5 \mathrm{in}$, wing $9 \mathrm{in}$. 


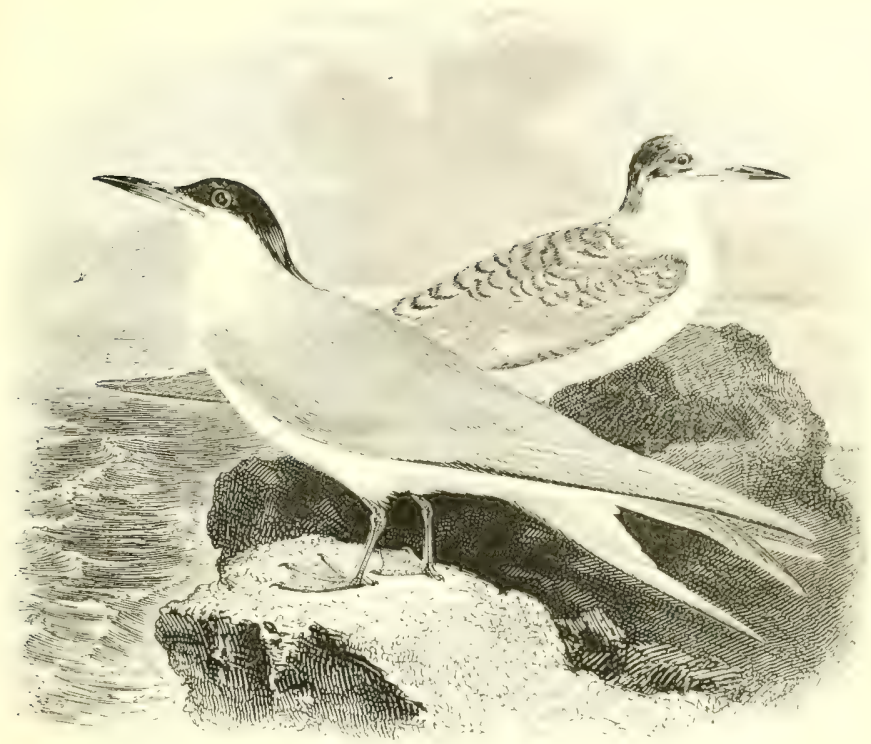

\section{THE COMMON TERN.}

Sterna fluviátilis, Naumann.

The Common Tern is deservedly so named as regards the greater part of the British Islands, but there is considerable difficulty in sketching its northern summer-range with exactitude, owing to the fact that this over-laps the southerly limits of the Arctic Tern. Broadly speaking, I believe that the Common Tern is the predominant species along the shores of the Channel and on the west side of Great Britain as far north as the Isle of skye; while on the east it is found from Kent to the Moray Firth, and was the only species that I observed near Nairn during August i $\$ \$ 5$. Continuing northwards, we find it yielding numerically to the Arctic Tern, and showing a liking for fresh-water lochs or estuaries rather than for exposed islands, though Mr. Harvie-Brown states that in ${ }_{1} 88_{5}$ it was nesting abundantly at the west end of the I'entland skerries, while the eastern was occupied by a colony of Arctic Terns. I have no conclusive evidence of the occurrence of the Common Tern in the Shetlands, Orkneys or Outer Ilebrides. When the two species inhabit the same area, they frequently shift their ground from year to year in a most confusing mamner, and this, no doubt, led so accurate an observer as MIr. E. Booth to miss secing the (ommon 
Tern on the Farnes, where large colonies undoubtedly breed in some seasons. In Ireland it is the more plentiful bird in the south, while it appears to rival the Arctic Tern in the north, and there also it frequently nests by the margin of fresh water It usually comes to us at some time in May, the autumnal misration lasting from August to October, and on passage it may often be observed on rivers and inland waters, even on the Serpentine \&c. in London.

l)uring the warmer months this species is widely distributed on the coasts, rivers and lakes of Europe, from Norway to the Mediterranean, Ilack and Caspian suas, and thence westward to the islands of the Atlantic. Across that ocean we find it abundant in North Anerica, from Labrador to Tcxas, but it has not yet been recorded from the Pacific. Returning to the eastern hemisphere, we trace it down the west side of Africa to Accra in winter; and in Asia it is found in summer on the low land from the Caspian to Mers, but on the elevated lakes of Cashmere, Tibet and Southem Siberia it is represented by S. tiltetant, which has a darker general hut, a more vinous tint on the under parts, and smaller bill and feet; this form visits Ceylon and South Africa in winter.

'The eggs, usually 3 in number, are laid on sand, shingle, dry wrack or even short herbage near water, a few crossed bents being occasionally added; they vary in colour from dull grey to stone-buff. blotched with bluish-ash and dark brown: average measurements $\mathrm{I} \mathrm{t}$ by $\mathrm{I} \cdot \mathrm{I}$ in. In cold seasons few birds have begun laying by the last days of May, and incubation does not become general until June. On the approach of an intruder the parents utter a sharp firre, and when their young are hatched they will often skim over the spot and drop small fish close to the nestlings, whose mottled colour renders them almost indistinguishable from the surrounding shingle. The food consists chiefly of young coal-fish and sand-eels, with shrimps and other crustaceans.

The adult in summer has the bill orange-red, horn-colour at the tip ; head and nape black; mantle pearl-grey ; rump and tail white, except the two lateral pairs of streamers which are grey on the outer webs; under parts nearly white, with a vinaceous-grey tinge on the breast and abdomen; legs and feet orange-red. In winter the forehead is sprinkled with white. Length $\mathrm{I}_{4} \cdot 25 \mathrm{in}$, wing $10^{\circ} 75 \mathrm{in}$. The young bird has the crown and nape streaked with blackish-brown; mantle barred with ash-brown, which gradually disappears till only a dark band along the carpal joint remains; tail-feathers grey on their outer webs; under suríace white; bill, legs and feet reddish-yellow, turning nearly black in winter. 


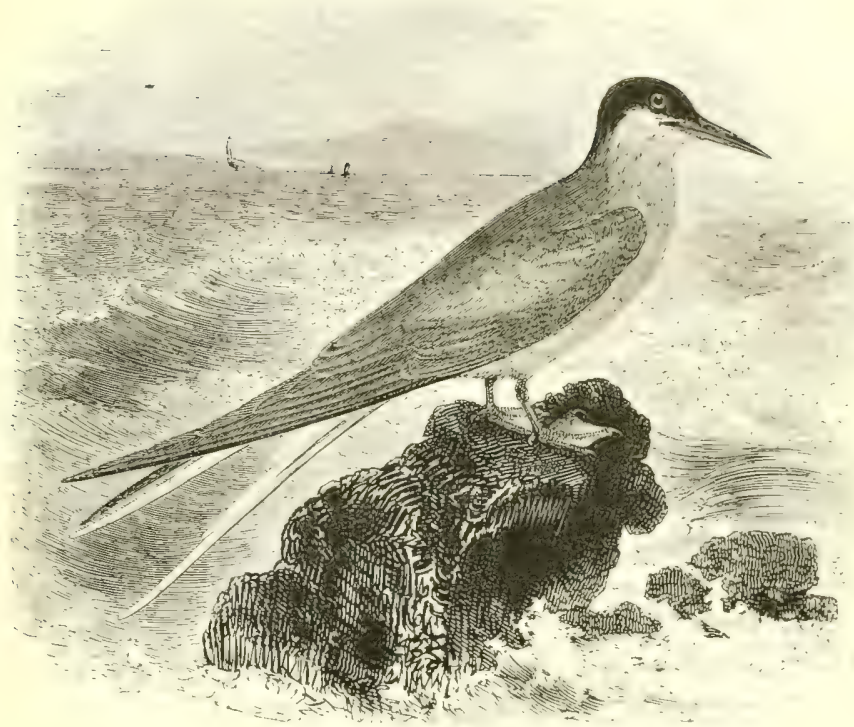

'THE ARCTIC 'IERN.

Sterna Macrúra, Naumann.

This northern representative of the preceding species is the only Tern that nests in the Shetlands, while southward, if not absolutely the sole member of the genus, it is at least predominant in the Orkneys, the Outer Hebrides, and along the west coast of Scotland, down to the Isle of Skye. On the east of Great Britain, though not paramount, it breeds in considerable numbers down to the Farne Islands, and, sparingly, to the mouth of the Humber, south of which it is only known on passage. In the west of England it nests-or used to nest-on Walney, where, however, the Common Tern appears to outnumber it in some years; and the same must now be said of the Scilly Islands, on which, according to Rodd, the Arctic Tern was formerly in the ascendant. In Ireland it frequents the north and west, from Antrim to (ialway and Kerry, but details are wanting. On migration, of course, it is found on all cur shores, but identified specimens have rarely been obtained inland.

Beyond the British Islands the Arctic Tern occurs in abundanct? -during the short summer of the northern regions as far as human foot has trod; for Col. Feilden, when with H.M.... "Alert, found it nesting above lat. $\mathrm{S}_{1}^{\circ} \mathrm{N}$, and I'arry's expedition observed it beyond 
Spitsbergen; while in Asia as well ar in America it is completely circumpolar in its range. On migration we trace it along the Atlantic sea-hoard to the Canaries and the Azores - a straggler occa sionally penetrating into the Mediterranean as far as Italy; it descends the coast of Africa to Table Bay, and I have a specimen which flew on board I.ord Crawford's yacht "Tenus " far to the south-east of Madagascar. The islands of the Southern Ocean are inhabited by two nearly-allied but well-defined species, while there is a third representative in South America; on the west coast, however, StaffCommr. NacFarlane, when in H.M.S. 'Constance,' obtained a genuine Arctic 'Tern off Arica. It breeds plentifully in Alaska, and occurs in Kamschatka and Amur-land: though there-as well as in Japan, and in Siberia as far as I ake [Baikal -the representative species is $S$. longifinnis, which has a black bill, small dark brown legs and feet, and grey under surface.

The eggrs, laid in a mere depression of the sand or scanty herbage, or even on the bare rock just above reach of the waves, are sometimes 3 but often only 2 in number; they are slightly smaller than those of the Common 'Tern, measuring about $\mathrm{I} \cdot 6$ by $\mathrm{I}$ in., and are subject to rather more variation in coloura a pale bluish-green being frequent, while a rich ochre-red with rufous-brown spots is occasionally found. In defence of its nest the bird is very bold, striking the intruder sharply with its beak, and a flock has been seen to mol and drown a Hooded Crow. In food and general habits it does not differ materially from the preceding species, and both may be seen dashing down with such force as to raise a cloud of spray, which momentarily hides them from the view of any one on nearly the same level; but, from an eminence, I have never witnessed complete submersion, though in this respect the experience of the Rev. H. A. Macpherson differs from mine.

The adult in summer may be distinguished from the Common Tern by its blood-red bill, distinctly pearl-grey under parts (without any vinaceous tint), and longer lateral tail-feathers. At all ages its shorter tarsi are characteristic, though the difference is not invariably so great as some writers have supposed; a better distinction being the narroiness and pale colour of the stripe next the shaft on the inner well of each of the long primarics; this stripe being much broader in S. furiutilis. The young of both species go through similar seasonal changes. The legs and feet are coral-red in spring -duller in the young-and nearly black in winter. Birds a year or more old have a dark bar on the carpal joint until the autumn moult ; they breed the following June. Length 145 in. ; wing 10 in. 


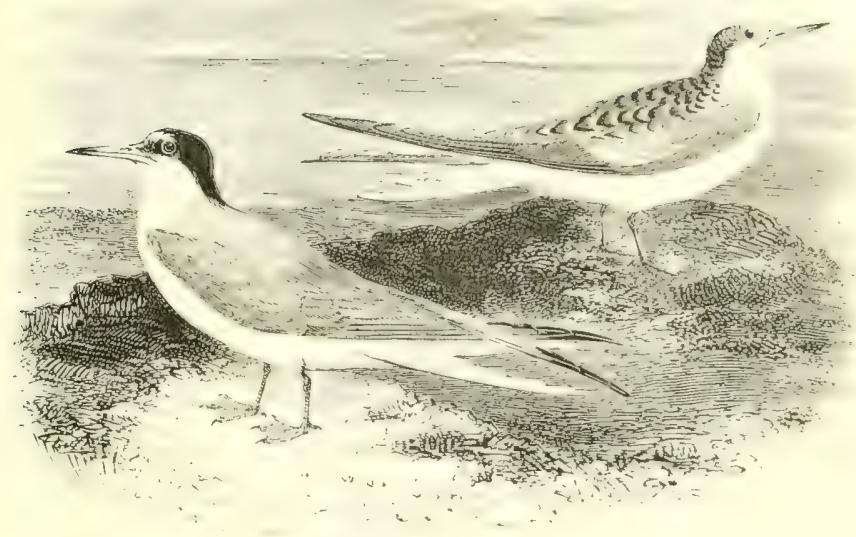

THE LITTIE TERN.

STERNA MinútA, Linnæus.

Early in May this smallest of the British Terns makes its appearance on our coasts, especially on those which present low flat shores covered with sand, broken shells and shingle. In such localities it may be found along the English Channel and from Kent northward to the Humber, but the smali colony which Selby found on the coast of Northumberland opposite Holy Island, has ceased to exist for many years. Mr. Wm. Evans informs me that this is also true of Gullane in Haddingtonshire, but the bird still nests near the mouth of the Tay and in Aberdeenshire; though only a pair or two can be recorded from the south-east of Sutherland and none from the west, while recent authorities have not observed the species in the Orkneys, Outer Hebrides, or Skye. Southward there are small settlements along the west side down to the Solway, below which, except where persecuted-as in I ancashire-the Little Tern breeds in suitable localities as far as Cornwall. In Ireland it nests in many places, though seldom in large numbers. Is a rule it leaves us in September or early in October, but a laggard has been obtained in the third week of December.

The Iittle 'Tern seldom occurs in the northern part of the lialtic, but is abundant on the south shore of that sea, and follows the course of the large rivers for so great a distance-nesting on their 
islands and sand-banks - that it may be said to extend across the Continent to the Mediterranean, Black and Caspian Seas; while it also frequents the Atlantic coast. It breeds in l.ower Egypt and, perhaps, in the Red Sea, and in winter descends the west side of Africa to Cape Colony. Along the Asian plateau it can be traced to Central India, but in Ceylon, China, and the eastern region generaily it is represented by $S$. sincusis, which is rather larger and has white shafts to all its primaries. In North America we find $S$. antillarmm, with dark shafts-as in our bird-but with a grey rump and very little black at the tip of the bill; while on the east side of South America, ascending the great rivers for thousands of miles, S. suferiliaris-with stout and wholly yellow bill-is the representative species. All these, and some other small Terns with white foreheads, have been placed by many systematists in the genus Stermula.

The eggs, usually 2 though often 3 in number, are stone-colour -occasionally with a bluish tinge-spotted with ash-grey and dark brown: their average measurements are $\mathrm{I}^{\prime} 35$ by 95 in., and they are laid on the bare shingle or soil towards the end of May or early in June. Far from showing fear when its haunts are approached, the bird advances with rapid beats of its long pinions, uttering a peculiarly sharp pime, and will frequently settle on its rest. It feeds on small surface-swimming fish and their fry, as well as shrimps and similar crustaceans; and, like other Terns, it may often be seen swimming or resting on the water.

The adult in summer has the bill orange-yellow tipped with black; forehead white, loral stripe, crown and nape black; mantle pearl-grey ; wing-feathers grey, with white margins to the inner webs, and with dark shafts to the two outer quills, which are, moreover, ash-grey; tail and entire under parts white; legs and feet orange. Length 9 in., wing 6.75 in. In winter the black on the head is duller in colour. The young bird (figured in the background) has the bill dark brown at the tip, paler at the base; forehead, crown and nape tinged with buff and streaked with blackish-brown; mantle dull grey, tinged with buff and mottled with umber; tail-feathers greyish-white, slightly freckled with brown near the tips. The black loral streak is not well defined until after the second moult, up to which a dark line on the carpal joint with a grey tinge on the rump and tail-feathers remain to indicate immaturity; breeding takes place the following spring. 


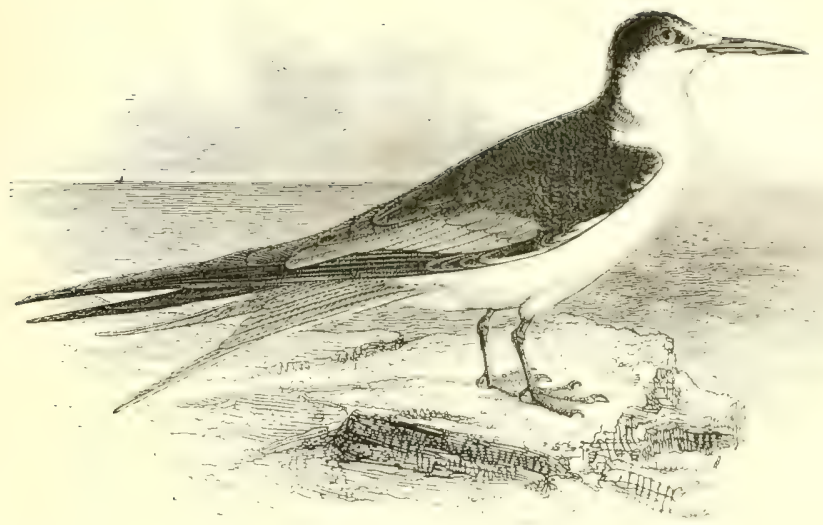

THE SOOTY TERN.

Sierra fuliginósA, J. F. Gmelín.

The specimen figured is said to have been shot in October i $S_{52}$ at Tutbury, near Burton-on-Trent, and having been purchased by Mr. H. W. Desweux, of Drakelow Hall, it was exhibited by Yarrell at a meeting of the Linnean Society in February I 853. MIr. J. E. Harting has stated in 'The Field' that he examined in the flesh an example killed on June 2 rst is69, near Wallingford in lierksinire; and Mr. A. C. Foot of Bath sent me an adult, with the information that it was caught alive, after wet and windy weather, about three miles from that city on Octoher $4^{\text {th }}$ or 5 th 1885 , and was seen in the flesh by the Rev. Leonard Blomefield as well as by the Librarian of the Museum. Other birds recorded by this name have proved to be Black Terns.

On the Continent, this species has been noticed as a wanderer on three occasions. Naumann states that one was obtained near Magdeburg; Degland and Gerbe mention an adult male, now in the Lille Museum, taken alive but exhausted near Verdun on June ${ }_{5} 5_{\text {th }} 1854$; and one, now in the Museum at Florence, was captured on October 28 th 1862 in a trout-net in Piedmont.

The Sooty Tern has been known to occur about a dozen times as far north as the New England states, and occasionally visits the Bermudas; but it is not found in any numbers on the American sea-board above Florida and the Bahamas, south of which it is generally distributed throughout the llest Indies, especially on the low islands known as 'Cays.' In the Pacific it breeds from I.ower 
California to Polynesia, where the coral 'atolls' and other islands offer numerous localities suited to its habits; there are many wellknown stations on the reefs which girdle Australia; and northward we trace it through the Fastern Archipelago to China and the southern part of Japan. It occurs in Ceylon, the Laccadive Islands, the Persian (julf and the Red Sea : and southward, throughout the Indian Ocean by way of the Chagos group, Mauritius, Rodriguez \&c., to Madagascar. Off the west of Africa a small number frequent St. Helena, and immense colonies, which have been repeatedly described as 'Wide-awake Fairs,' are found on that great volcanic cinder-heap, the Island of Ascension.

I believe that normally each female only incubates a single egr at a time, but two or even three eggs have been found in the same slight hollow in the soil which serves for a nest, and, owing to the way in which these are collected for cating-200 dozen being sometimes picked up in a morning at Iscension-there is some difficulty in ascertaining the true complement. The colour is pinkish-cream or bluish-white, with an endless variety of lavender and chestnutred blotches, and the shell is smonth (whereas in the egg of the Noddy-a bird often found breeding in the same localities-the surface is of a rough chalky nature): arerage measurements 2 by $\mathbf{I} 5$ in. As soon as the young can fly, they and their parents go off to sea, where they feed upon small fish and marine animals; according to some observers, this species is crepuscular in its habits.

The adult has the forehead, eye-brows, sicles of the neck, and entire under parts white; loral streaks, crown and nape deep black; remaining upper parts chiefly sooty-black, the two long outer tailfeathers white on their outer webs; bill, legs and feet black. Length 16 in., wing I 5 in. The young bird has the under parts sooty-brown; and the upper surface of a darker hue, with whitish tips to nearly all the feathers except the primaries.

I have examined a specimen of the Smaller Sooty Tern, $S$. ancisthita of Scopoli. which is said-and, I believe, with truthto have been captured on one of the light-ships at the mouth of the Thames in September IS75 (Zool. I $S_{77}$, p. 213); the evidence is, however, slightly imperfect. This species is browner on the upper parts, has a longer white stripe over the eye, a greyer tint on the neck, and less fully-webbed feet than the above; while the young bird has white under parts. 


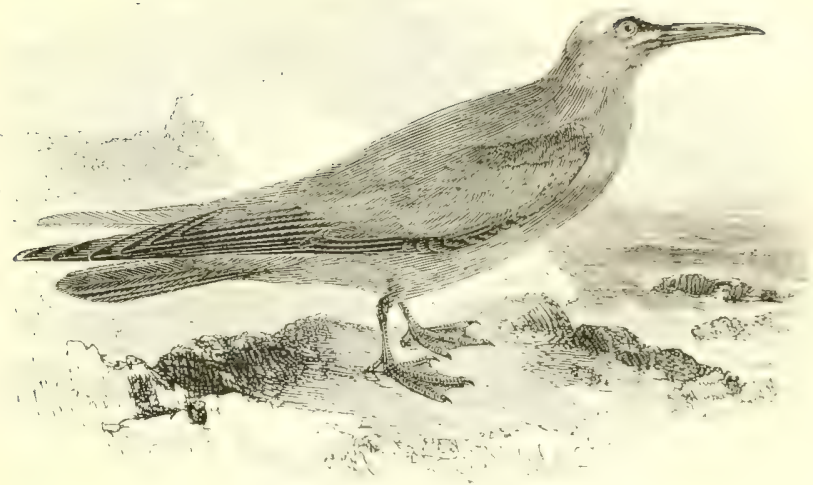

THE NODDY TERN.

Anous stólidus (Linnæus).

Two examples of this pelagic species are recorded by $\mathrm{WW}$. Thompson (Mag. Zool. \& Bot. i. p. 549) as haring been obtained between the Tuskar Lighthouse-off the coast of Wexford-and the Bay of Dublin, about the year $I \delta_{3}$, and one of these is in the Science and Art Museum of the above capital. Some later reports of birds which were identified on the wing as belonging to this species either refer to the Arctic Skua or are unworthy of serious consideration. No other specimens are known to have been taken in the British Islands or on the Continent.

The Noddy is-like the Sooty Tern-of general distribution throughout the tropics; some of its best known breeding-grounds being in the Tortugas group off the const of Floridi, the Bahambs, and many of the Cays of the II est Indies, as well as on both sides of Central America. In the Atlantic it was found by the 'Challenger' Expedition residing as far south as the sturm-beaten Inaccessible Island, off Tristan d'Acunha; while in the l'acific it visits Chili, and wanders to New Zealand. On the islands and coasts of Polynesia and Australia it is found breeding in most of the localities mentioned when treating of the Sonty Tem, though often slightly apart from that species: and it equally nocurs throughout the Indian and African seas, breeding on the Iaccadives, the islands of the Red Sea, St. Helena, Ascension, and other places.

Contrary to the habit of all other Terns, this and most of the members of the genus Anews malie a nest. which is often of large 
size and is built of dry grass, bits of sea-weed, twigs, fish-bones \&c., not interworen but laid in a heap, with merely a slight cavity for the egg. The top of a cocoa-nut tree or the outer branches of mangroves are often selected, while in some places the nests are on shelving rocks beneath overhanging cliffs, and, more rarely, on patches of sand or grassy slopes. Audubon, who is responsible for the statement that the Sooty Tern habitually lays three eggs, also asserts that the complement is the same in the case of the Noddy, but other observers in all parts of the tropics are unanimous in stating that this species never has more than one. The shell has a somewhat dull and rough surface, and is ruddy-white or buff in colour, sparely blotched and freckled with reddish-brown: average measurements 2 by $\mathrm{r}_{4}$ in. The yolk is bright yellow, whereas in the egg of the sooty: Tern it is deep orange-red. In the northern hemisphere breeding takes place in May or June, but in the southern tropic there is great irregularity, and fresh eggsmay be found from September to January. As soon as the young are able to fly the birds disperse orer the ocean, and when fatigued they frequently settle on vessels, exhibiting a stupidity or indifference which has procured for this species its trivial as well as its scientific name. The food consists of small fish, molluscs, medusæ \&c.

The adult has the forehead and crown grey, and the upper parts sooty-brown, rather darker on the wings; there is, however, some difference in the above tints according to season, locality and the age of the individual. Mature specimens soon after the moult are nearly black on the lores and throat, while in younger birds those parts are paler; the under parts are browner than the back; the bill is black; and the legs and feet are reddish-brown, with full webs, which are yellowish in life. Length 16 in., wing I I in. The young bird has the forehead white, slightly speckled with brown, while both upper and under parts are dull umber. In this and other members of the genus the tail is graduated-not forked, the central tail-feathers being the longest. Two smaller and quite distinct species of Noddy are also found. within the tropics; while in Polynesian and Australian waters there are yet two others, very closely related, but characterized by their nearly uniform grey colour and still smaller size.

Owing to a practical joke, which afterwards became a fraud, Thompson was led to include the Swift Tern, S. bergii of Lichtenstein (S. z'elox of Ruippell) in his 'Birds of Ireland'; it is a purely tropical species. 


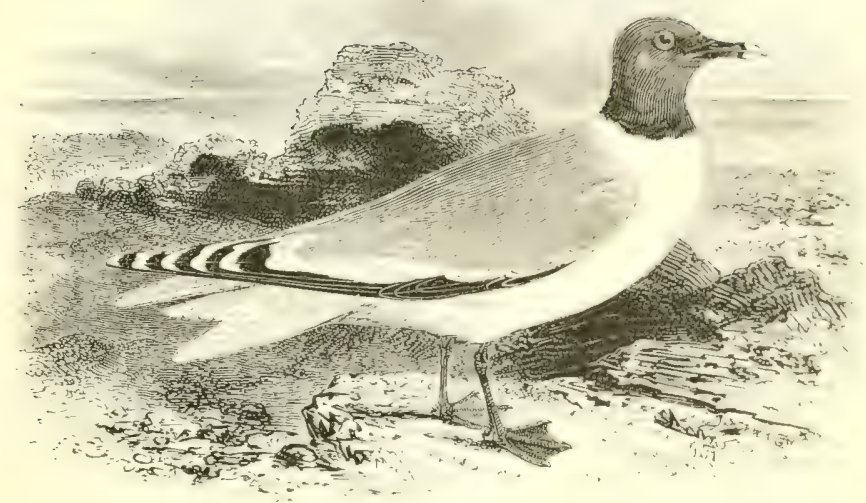

S.DIINES GLIS.

Xéma sabínir (Joseph Sabine).

This small and beatiful fork-tailed Gull is another of the species first recognized in the United Kingdom by Thompson, who described an immature example shot in Bulfast Bay in September I822; since which date about a dozen specimens have been taken in Ireland. Many more are on record from various counties of England and Wales, and a few from Scotland-all of these having occurred between August and December; while, with the exception of two adults in summer-plumage obtained, respectively, at Bricllington in Yorkshire and on the Island of Mull, they have proved to be young birds.

Strange as it may appear, this almost circumpolar species was not noticed in Norway till Uctober i $\$ 86$, but it had long been known as a straggler to the islands and shores of the (ierman Ocean and the north-west coast of France. It was discovered-on the expedition of ISIS in search of a north-west passage-by the late sir Edward Sabine, who found it nesting in lat. $7529^{\prime} \mathrm{X}$. on the west side of Greenland, and it is now known to breed throughout the Arctic regions of America from liaffin lay to Alaska: whence we trace it in summer across the high latitudes of Asia as far as the Taimyr peninsula, where Dr. von Midelendorff obtained its esps. It has not, however, been recorded from Norayia Zemlya or Iran. Josef Land, and appears to be rare or very local in Spitsbergen, while 
it is merely a visitor to Jan Mayen. In the Atlantic it has not been met with further south than the Bermudas; but in the Pacific it not only crosses the equator, but goes as far as $12{ }^{\circ} \mathrm{S}$., two nearly adult specimens in winter-plumage having been presented to me by Capt. A. H. Markham, R.N., from Callao Bay, where Staff-Commr. MacFarlane afterwards found it in swarms during the month of February. It thereby overlaps the habitat of the far larger I. furcata, another fork-tailed species, only three examples of which are known.

The eggs, 2 in number, are laid on the bare ground, or on dry tussocks in marshes near the sea-frequently in proximity to those of the Arctic Tern, with which species this Gull often associates; their colour is dull brownish-olive with somewhat darker blotches near the larger end, much like those of the Arctic Skua in miniature: average measurements $\mathrm{I}^{\prime} 7$ by $1.3 \mathrm{in}$. The nestlings, which are hatched towards the end of July, are at first mottled with brown and dull yellow. The food consists of small fish, crustaceans, worms, insects and their larve; the note is harsh and clicking.

The illustration of the adult in summer-plumage renders a detailed description unnecessary : the head and neck are lead-grey, encircled by a black collar, and the mantle is slate-colour. Length $\mathrm{I}_{4}$ in.; wing $10: 75$ in. In winter the crown and forehead are white, but there is more or less black on the nape. The young bird in the plumage of the first autumn (iigured below) is ash-coloured on the upper parts, barred with brown and dull white; and, when still younger, has a dark gorget.

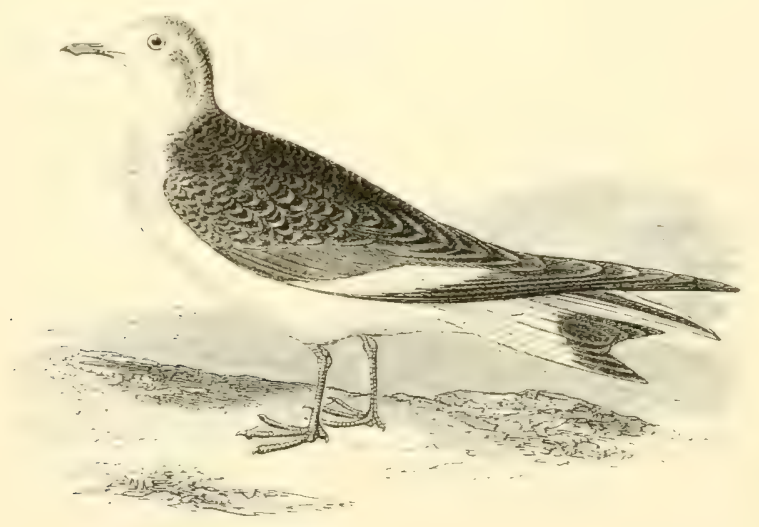




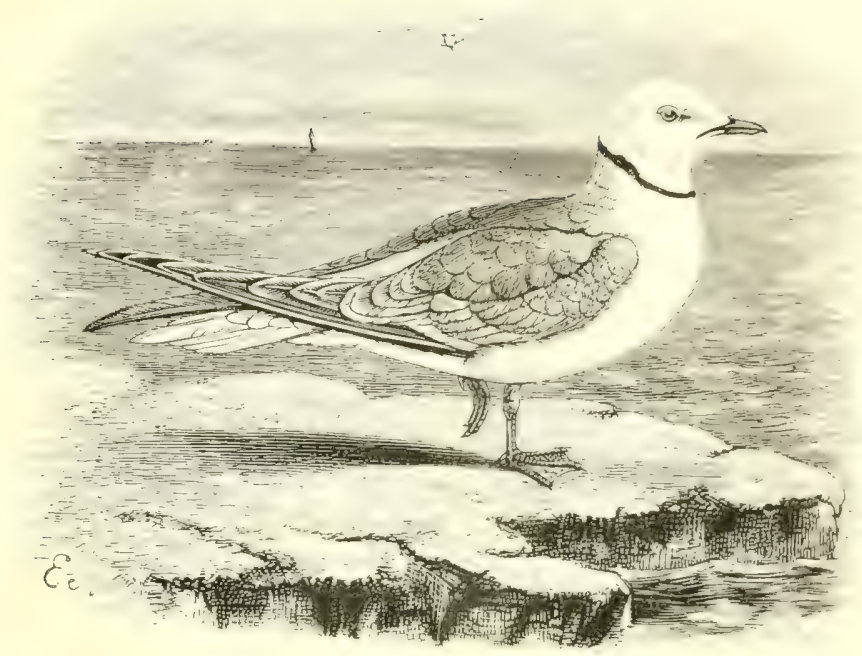

THE WEDGE-TAILED GULL.

Rhodostéthia Rósea, Macgillivray.

An example in winter-plumage, which passed through the hands of (iraham, the somewhat notorious bird-stuffer of York, is said to have been shot near Tadcaster in I ecember i $S_{4} 6$ or February is 4 , and, having been purchased by the late Sir Wm. M. E. MIilner, is now in the Museum of Leeds. According to several experts, it presents the appearance of a specimen which has been mounted from a relaxed skin and not direct from 'the flesh'; but inasmuch as this Arctic species has undoulstedly wandered in winter to Heli. goland and the Faroes, there is at least no inherent imprubulility of its occurrence in Yorkshire, and it has been generally admitted to the British list.

This beautiful rose-breasted Guil was discovered on June $23 \mathrm{rd}$ I823 on Melville Peninsula, during Parry's second cxpedition, and was subsequently observed at Felix Harlour, Boothia : while scoural examples were seen to the north of Spitsbergen on Parry's boatvoyage, as well as in Hinlopen Strait. At long intervals șix specimens have been obtained in Greenland, and two-in immature plumage-in the Mainz Museum are said to have come from Kamschatka. The Austro-Hungarian cyedition procurcel whe on Franz-Josef Land, and Baron ron Nordenskiöld's party in the

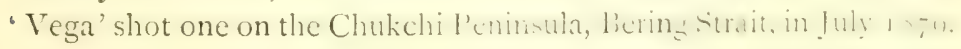


In October of the same year Mr. Newromb, naturalist to the illfated 'Jeannette,' killed eight off North-eastern Siberia, and during the fearful march of the shipwrecked crew to the Lena, he saved three specimens by carrying them inside his shirt beneath his beltflattened shapeless skins which I handled with reverence at Washington, for such an instance of bull-dog tenacity is unparalleled in the annals of collecting. A few others have since been obtained at the mouth of the Lena, but it was reserved for the American expedition to Point Barrow in Alaska to find this species during September and Octuber of $\mathbf{I} S S_{1}$ and of $I S \$ 2$ in large numbers; pointing to the probability of there being an important breeding-place on some undiscovered land to the northward of Wrangel Island or thereabouts, and perhaps in the Liakoff Islands. Mr. E. Nelson procured a bird at St. Michaels. Alaska, and a fine adult-one of two sent from Disco in (ircenland in 18.5 - has been presented by Mr. Seebohm to the Jiritish Museum. Not only are some rash statements that the eng had been taken at the same time as the latter (P.Z... I 886, p. Sz; luk IsS6, p. 273) unconfirmed, but the circumstances, the description, and a coloured photograph of the egg in question all indicate that it was probably that of Sabine's Gull.

The breeding-habits of this small species-often called Ross's Gull, after its discoverer the late Sir James C. Ross-are still unknown; and until the above appearance of flocks at Point Barrow, only 23 specimens were ascertained to be in existence. The flight is described as peculiarly graceful and wavering; I can find no details respecting the food.

The adult in summer has the under parts white, suffused with rose or salmon coluur; head and neck white, with a few black feathers near the eye, and a narrow collar of the same colour; mantle pale pearl-grey; outer web of first primary black, secondaries and inner primaries tipped with rosy--white; tail wedge-shaped and pure white; bill black (even smaller than represented in the engraving); legs and feet red. I.ength 13.5 in. ; wing ro in. In winter there is no black collar. By September 2 ist the young bird is greyish on the crown and nape as well as on the mantle, though the wing-coverts and inner secondaries are still umber-brown with pale margins; the three outer primaries are black on both sides of the shafts, and all up to the $7_{\text {th }}$ are tipped or barred with the same colour; the central - and projecting-feathers of the tail are broadly banded with brownish-black. 


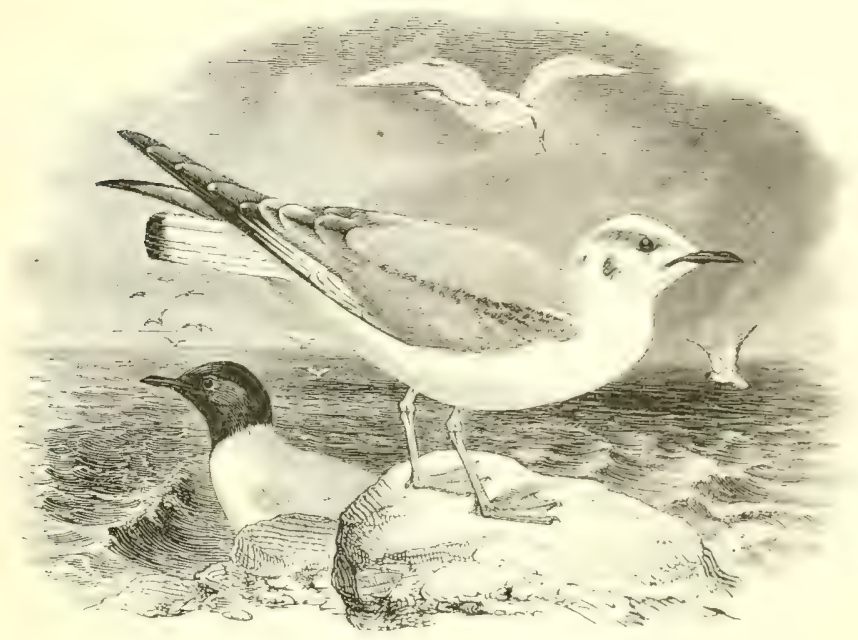

BONAPARTE'S GULL.

LÁRUS PHILADÉlPhia (Ord).

It is to Thompson again that we are indebted for the first notice of the occurrence of this species in the British Islands; he having correctly identified an example obtained near lielfast in Ireland on February Ist I $8_{4} 8$, and brought to him before it was skinned. In Scotland an adult, which I exhibited at a mecting of the \%oological Society of London in I $S S_{4}$, was shot on $I$, $($ ch $I$. (mond about the end of April 1850 by Sir George H. Leith-lBuchanan: while in Englard one was killed in Falmouth harbour on January fth and another at Penryn - close by-on Jannary roth $\mathbf{1 8 6 5}$, and one early in November I87o at St. Leonards in Sussex. Mr. Gätke informs me that he has an adult taken on Heligoland in the depth of winter about forty years ago, but otherwise there appears to be no authentic record of the appearance of this bird in Europe.

In summer Bonaparte's (Gull is wildely distributed over the lakes and wooded regions of the Fur countries of North America, from a little within the Arctic circle down to about $60^{\circ} \mathrm{N}$. lat.; but it does not visit the ice-fringed shores to the northward, and is of very rare occurrence in licring sia. though not uncommon alongs the Yukon and on the marshes at the mouth of that great river. On migration it frequents the l'acifie const as far south at sian lecilu in California, as well as many of the inland waters of the United States, while on the east side it is abundant and of regular occur- 
rence down to South Carolina, and occasionally visits the Bermudas; it is, however, rare on the (julf side of Florida, and has not yet been obtained in the West Indies. With the first genial weather in April and throughout the greater part of May there is a succession of birds passing northward:; the earlier ones being adults, while the later arrivals are birds of the previous year, some of which linger on the coast-marshes all the summer. Richardson, who found this species breeding in the vicinity of (ireat Bear Lake, says that it is seen there as soon as the first pouls are thawed, and before the ground is denuded of snow.

The alove explorer and Messrs. Mac Farlane, Kennicott \&c. agree in stating that Bonaprarte's Gull iuilds in colonies, placing its nest, which is composed of sticks, grass, moss itc., on the branches of some bush or tree-ofen a spruce-fir-at elevations varying from four to twenty feet: in some districts, however, it appears to breed in marshes, and, presumably, on the ground. The eggs, 2-3 in number, are dull olive-colour. spotted, scrolled and zoned with brown: average measurements 19 by $\mathrm{r}+\mathrm{in.}$, though there is considerable variation in a large series. The food consists of small fish, crustaceans, insects and their larrex; the flight is buoyant and Tern-like; and the note is described as a "sharp but rather faint squeak."

The adult in summer has a slate or greyish-black hood, pearl-grey mantle, and white tail and under parts; the outer web of the first primary and the unds of the first five black, the remainder of those feathers being white-or greyish--on the inner webs; biil black; legs and feet orange-red. The sexes are alike in plumage, and the statements of Audubon and Bonaparte that the female has a brown hood are inexplicable. In winter the head is nearly white. The bird figured on the rock is an immature specimen in its first winter; the transitional stages are similar to those in other Gulls, and I need merely state that at all ases this species may be distinguished by the white marsins to the inner with of the two onter primaries. Length $14^{\circ} 5$ in. ; wing $10^{\circ} 25$ in.

The American Laughing Gull, L. atricilla, was added to the British list by Montagu in error, as indicated by his description of the bird obtained at Winchelsea. This species is stouter than our L. ridibuntus, has a blacker hood and darker mantle, and may always be distinguished by its black outer primaries. 


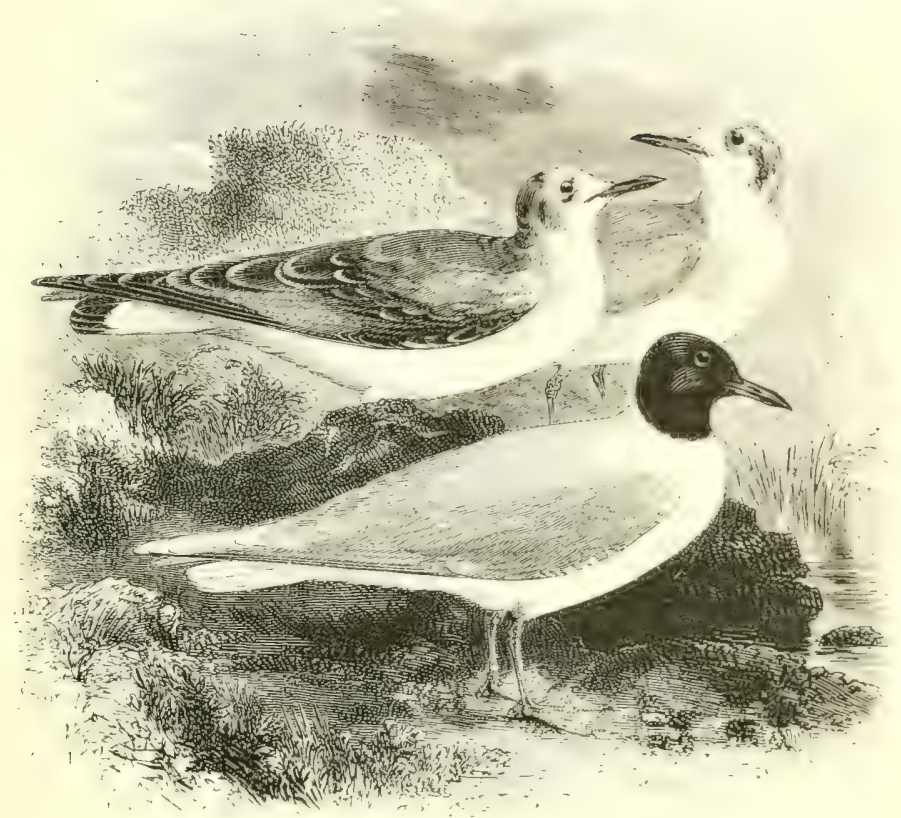

THE LITTLE GULL.

LARUS MiNútus, Pallas.

This species, the smallest member of the genus, was introduces? to the British list by Montagu, who described and figured a youms bird shot near Chelsea prior to $18 \mathrm{I} 3$. ()ther specimens were subsequently obtained from time to time, while in $1 S 66$, and again in Is6s. the Little Gull appeared on the coast of Yorkshire in numbers till then unprecedented, though they were far cxcceded along the entire east side of England during the winter of 1 S6o : and again after the heary easterly gales in February i $\$ 70$, when the proportion of aclults to young birds was unusually large. It has also occurred along the Channel as far as Cornwall, but seldom visits Hales, Lancishire or the Solway district. Along the west of Scotland it has appeared at intervals as far as Skye and North Uist, but on the east, as might be expected, the bird is more frequently met with, and has been recorded from the Border to the Shetlands. 'T'o Ireland it is an infrequent visitor in autumn and winter. 
The Little ciull was obtained in the Firoes for the first time in February isS6, and has only recently been noticed in the south of Norway; but according to Nilsson it formerly bred in Gottland, and it annually visits the cousts and islands of the Baltic. Its nearest nesting-places are probably those in the morasses of Esthonia, and between Lake Ladoga and Archangel; but large colonies are to be found among the swamps of the Lral, and the bird remains until somewhat late in spring in Southern Russia and the Black Sea district, though not positively known to breed there. On migration and in winter it visits the inland waters as well as the coasts of Europe, down to the Mediturranean: while it also freguents the northern shores of Africa. In summer it is found across temperate Asia as far north as the Sea of Okhutsk; but, with one exception, it has not been known to cross the great central ranges to India. According to Mr. W: I Jutcher an immature example was shot on Iong Island, New York State, about September i $5_{\text {th }}$ ISS7 (Auk I888, p. I 7 I).

Mr. W. Meves of Stockholm, who found a large colony of 'Schieks' - as the Russians call the Little Gulls - near Lake I adoga, describes the nests as being placed on almost floating islets of tangled plants, and built of leaves and grass. The eggs, usually 3 but occasionally + in number, are olive-green or pale brown, rather minutely spotted and sparsely blotehed with umber: average

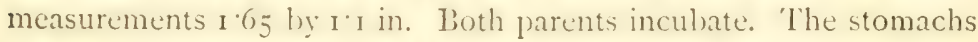
of the birds examined by Mr. Meves contained chiefly small fish, insects being only found in a few.

The adult in summer-plumage (figured in the foreground) has the under parts white suffused with pink; mantle pale grey; primaries broadly tipped with white and deroid of dark bars, the under side black-a consujicuous characteristic when the bird is flying; hood black; bill reddish-brown; legs and fuet vermilion. In winter the head is white, more or less streaked with ash-colour on the nape, as shown in the hindermost figure. Length $\mathrm{I} 2$ in., wing $8 \cdot 75$ in. A young bird (in the centre) shot in November had the upper parts mottled with dark brown, and a band of the same colour at the tip of the tail. In the immature stage the primaries are blackish-brownexcept on the inner webs where they are chiefly white-and the under side of the wing is white; the bill is blackish and the feet are yellow. The nape becomes dark grey the first spring; but the dark markings on the shoulders and tail remain till after the second moult. 


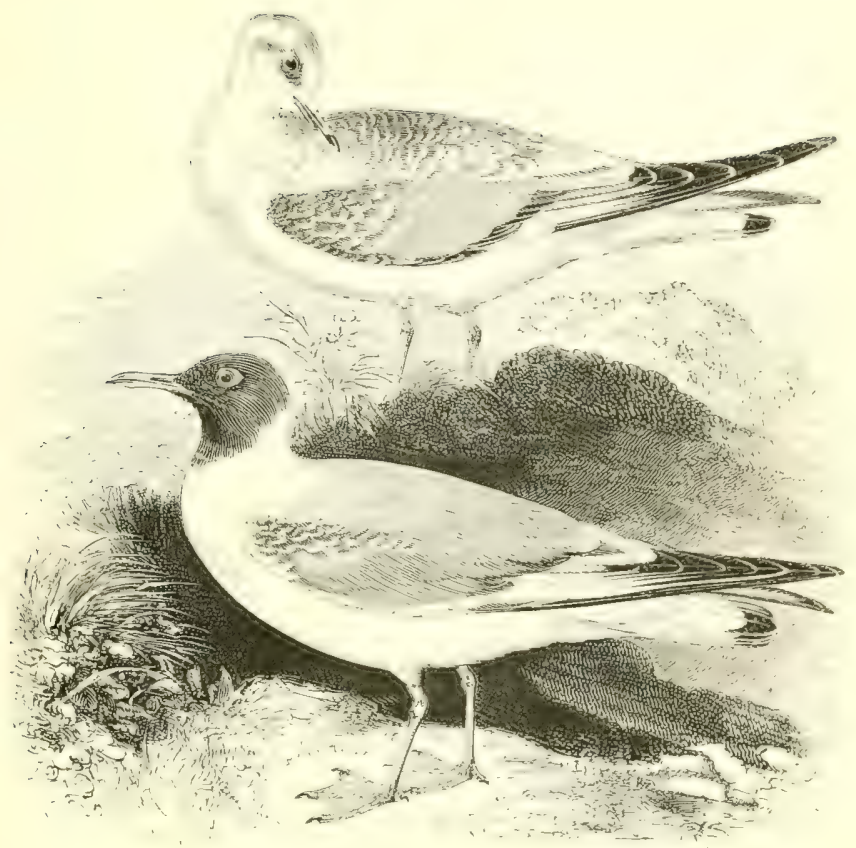

THE BI.ACK-HEADED GUI.L.

LARUS RIDIBÚNDUS, Linnæus.

This species-which might more appropriately be called the Brown-headed Gull, for the hood is certainly not black-is gencrally distributed throughout the year on the flat portions of our shores, resorting in spring to marshy situations near the sea-coast and of fen to inland meres. I) rainage, cultivation, commerce (as in the tuwn of Fleetwood), and other causes, have led to the destruction of many 'gulleries,' though the birds have simply' luetaken themsclves to other situations, and are probably as numerous as ever. 'The most western colony appears to be in the vicinity of Poole in I)rrect: there is-or was-one in Romney Marsh in Kent; several, as Mr. Miller Christy tells me, are to be found on the coast of lissex; and there are two or three in Norfolk, including the well-known ticoulton Mere. At least one important settlement is near liriger in l.incolnshire, and there are smaller ones in Yorkshire; those of Norbury and Aqualate Mere in stafforishire have lecen celuhated for ecmturies; while northward, there are screral -including Walney Inimel 
-in Lancashire, and a considerable number in Cumberland and Northumberland. In icotland they are even more plentiful, some of the largest being near Glasgow, at Inchmoin on Loch I.omond, and in Perthshire, Moray and Elginshire, while smaller ones are found as far north as the Shetlands; a stray bird has even been obtained in St. Kilda, the most western locality on record. In Ireland this is perhaps the commonest of the genus.

The Black-beaded Gull nests in one locality in the Froes, and sparingly in Southern Norway and Sweden, but in Russia it extends to Archangel, becoming abundant southward. It is widely distributed over the rest of Europe down to the Mediterranean, where its must southern breeding-haunt appears to be in the island of Sardinia ; in winter it ascends the Nile to Nubia, visits the Red Sea, and ranges from Palestine to the P'ersian (iulf and the coast of India. On the elevated mountain lakes of the great Asian plateau its representative in summer is the somewhat larger L. lirmmeicipluains, which has a paler hood and a different wingpattern; our bird, however, inhabits the temperate portions of Siberia as far as the Sea of Okhotsk, and is plentiful in the lower portions of Japan and China, especially during the cold season.

The nests, built of sedse, flags $\mathrm{dc}$, are placed on clumps of rushes, grass-tussocks, masses of boy-bean, or on the bare ground; the eggs, normally 3 in number, though + are sometimes found, vary from an olive-brown to a palc green, blue, or even salmon groundcolour, with blotches of black and dark brown : average measurements 2.2 by $15 \mathrm{in}$. In ordinary seasons laying begins by April 1 Sth, the eggs being systematically collected for eating in many places until some time in May. To the farmer this Gull is a benefactor, devouring large numbers of grubs and worms, while it has been seen to capture cockchafers and moths on the wing; in fact it is almost omnivorous. From its hoarse cackle it is often called the Laughing Gull; also the 'Peewit' or 'Peewit-Gull.'

The adult in spring-plumage has a dark brown hood-which is lost in winter; french-grey mantle; white tail and under parts, the latter with a pink tinge; outer frimaries characterized by white centre's and dark maryins to the inner wels. The bird figured in front shows traces of immaturity in the dark tip to the tail and the brown mottlings on the wing-coverts. Length 16 in., wing 12 in. The young bird is shown in the background; its outer primaries are chiefly dark brown, but at an early period a streak of white, which increases in size with age, makes its appearance along the middle of the inner web. 


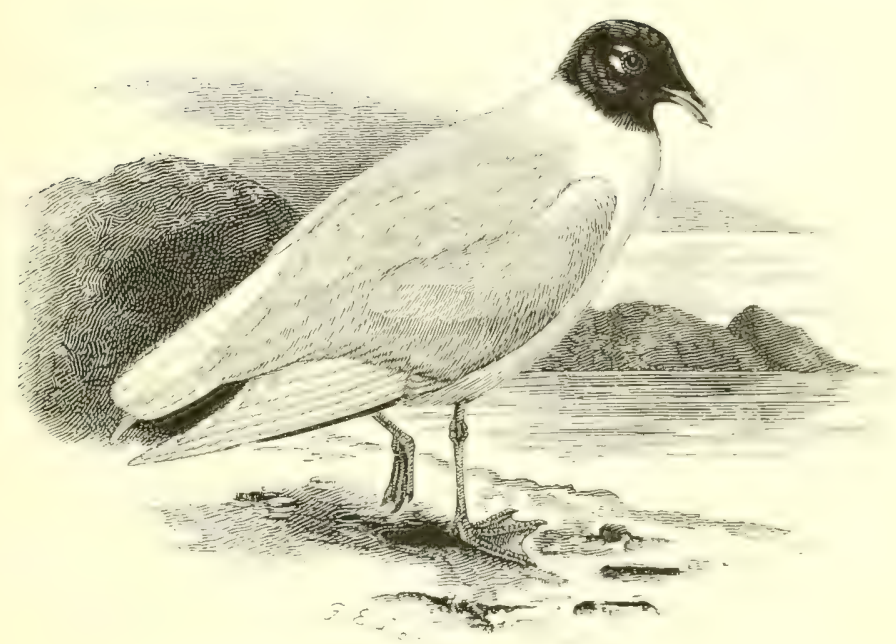

THE MEDITERRANEAN BLACK-HEADED GULI.

\section{LARUS MÉLANOCÉPHALUS, Natterer.}

On December 26th I S86, Mr. G. Smith of Great Yarmouth informed me that he had just received an adult example of this species in winter-plumage, shot on Breydon Broad; the bird was examined in the flesh by Messrs. Southwell, J. H. Gurney jun. and others, and I subsequently exhibited it at a meeting of the \%oological Society of London. This is the first authenticated instance of the occurrence of the Mediterranean Biack-headed (iull in the British Islands, but there is an immature specimen in the liritish Museum, which is said (and, I believe, with truth) to have been shot in January I 866 , near Barking Creek on the Thames; this, however, was not correctly identified until I saw it in $187 \mathrm{I}$, and, considering the possibility of some accidental exchange during the interval. I did not feel justified in including the species in the fth edition of 'Yarrell.' A description of its characteristics was, however, girem in that work, and led to the identification of the Breydon bird.

As a straggler this Gull has been obtained at the mouth of the Somme in the north of France, whence a southerly gale would soon bring it to our coasts; and I believe that it is found nearly crery scar at the mouth of the Gironde, while I think there must be some breeding-place along the low shores to the southward, an I olserved about a score of birds during the first weck of March 1 sisz, at it. 
Jean-de-Luz, ten miles south of Biarritz. In is6S I met with it, apparently breeding, on the marshes below Huelva in the southwest of Spain, and birds-with eggs said to belong to them were brought to me from the low islets at the mouth of the Guadalquivir, where, on May gth $1 S S_{3}$, Mr. Abel Chapman shot a bird and obtained two clutches; while in May of the present year (ISS9) Messrs. H. E. Iresser and Hanbury Barclay found a considerable colony in that locality. Many breeding-places doubtless exist in the Mediterranean, as the bird is plentiful, but none are positively known until the vicinity of Sinyma is reached; there are also some on the shores of the Black Sea.

Mr. I)resser tells me that the nests were fairly solid structures of small twigs, and were placed on the mud, generally under or near low scrubby bushes: the eggs, from 23 in number, are rather paler and more inclined to stone-colour than those of L. riditundus, though very similar in general appearance, and, strange to say, they are slightly smaller: average measurements 2 by $x^{*}+$ in. In Spain, and also in the Black sea, colonies of this species are generally close to those of the Slendur-billed (iull, L. vilustes, a bird which lays much larger eggrs-like light varicties of those of the Sandwich Tern in colour-and resembles I. ridilumitus in the pattern of its long wings, though it differs from it in never assuming a hood.

The adult in breeding-plumage has the head jet-black; mantle grey, of about the same tint as in L. rititumdus; primaries greyishwhite with merely a narrow black streak along the outer web of the first ; tail and under parts white; bill coral-red with a darkish band in front of the angle; legs yellowish-brown. Length $\mathrm{I} 7 \mathrm{in.}$; wing I I $5 \mathrm{in.}$ Birds which have assumed the black hood for the first time exhibit black streaks next the shafts of primaries $1-3$ and black bars on $I-5$ until the following autumn. In winter, as usual, the hood disappears, and the head is merely streaked with dark brown, thickest about the eye and the ear-coverts. In the bird of the year, like that in the British section of our Natural History Museum, the first fie frimaries have the outer webs, the shafts, and the greater portion of the imner withs dark brown on both upper and under sides, with nearly withite cdses; whereas in the young of L. rilibundus the shafts and contiguous portions of the inner webs are white with dark margins. On the wing, when seen from below, these distinctions are very noticeable; as is also the greater robustness of the bill in L. melanocephalus. 


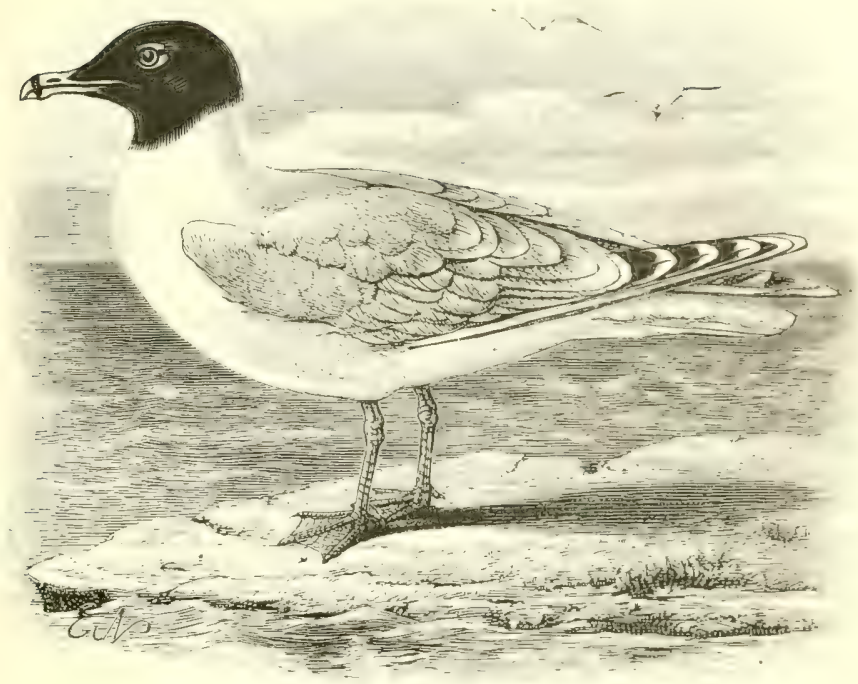

THE GREAT BLACK-HEADED GULL.

\section{LARUS ICHTHYÁËTUS, Pallas.}

An example of this south-eastern species-which almost attains the dimensions of our ( ircat Black-backed ( iull-was recorded by Mr. F. W. L. Ross (Anr. \& Mag. N. H. (3) iv. p. 467) as having been shot off Exmouth, about the end of May or early in June 1859 , when in company with a flock of ordinary members of the family. This bird, now in the Exeter Museum, is an adult in summer plumage; its history appears to be satisfactory, and it cannot be suspecterl of having escaped from continement, for no instance is known of this species having been in captivity.

Even in the Mediterramean the (ireat Black-headed crull is only found in the extreme eastern portion known as the Levant, where it has been met with in Cyprus, and on the shores and lakes of Palestine. It is common in Egypt and as far up the Nile as Nubia : while it occurs in the Ked sea, the l'ersian (iulf, and thence along the coast-line to India. In the Black Sea it is decidedly rare, but it breeds in great numbers on the seal Islands in the ciapian and on the low-lying shores of that sea, as well as on the lakes of Turkestan; while 1)r. Finsch noted its arrival on the Ala-Kul-a little to the east of Iake balkash-on May oth, and om the saism. Nor early in June. I'rjevalsky observed it on the Koko- lor 100 
E. long.), an elevated lake in the mountain range between Mongolia and China; and it is probably found throughout Tibet in summer, as it passes over Gilgit on its way to India, where it frequents the rivers and coasts down to Ceylon and Burma during the cold season. It is unknown on the Amoor or along the sea-board of China, and Cassin's record from Japan is the result of an erroneous identification.

Little is known respecting the breeding habits of this bird, though numbers of its eggs have been received through the Moravian colony at Sarepta on the Lower Volga; these, laid on the bare sand, are 3 in number, and stone-drab in colour, boldly streaked and blotched with umber and black: average measurements 2.95 by 2 in. The cry is described as a harsh and raven-like croak; the food consists of fish, crustaceans, locusts, reptiles \&c.

The adult in breeding-plumage has the head jet-black; mantle of a darker grey than in L. ridilundus; secondaries with broad white tips, which form a conspicuous alar bar: primaries chiefly white, barred with black from the ist to the $5^{\text {th }}$ and slightly on the Gth; tail and under parts white: bill orange-yellow, red at the angle and zoned with black; legs and feet greenish-yellow, webs orange. There is considerable variation in size, and females are often so much smaller than males as to have given rise to the belief that they belonged to a distinct species; length of a male $27 \mathrm{in}$., wing 19 in. In winter the head is merely streaked with blackish. The young bird is mottled with brown on the upper parts, and the primaries are dusky-brown; it may be distinguished from members of the Herring-Cull group of the same size by the white marsins to the secumdaries, extending for a long way up both aicls ; also by the uniformity in the dark band which crosses the tail, this band being mottled and broken up in other species. The nestling differs from that of almost all the Gulls in being of an unspotted greyish-white above, and clearer white below.

The Ciulls with hoods have been separated from the rest under various generic names. The least objectionable is Chröcocthalus of Eyton, based upon "coloured hood, small size, and more naked tibia"; but the second qualification does not suit the above gigantic species, for which therefore, Kaup created the genus Ichthyaitus. No term can be more inadmissible than . Yema, as it should only be applied to a Gull with a forked tail. 


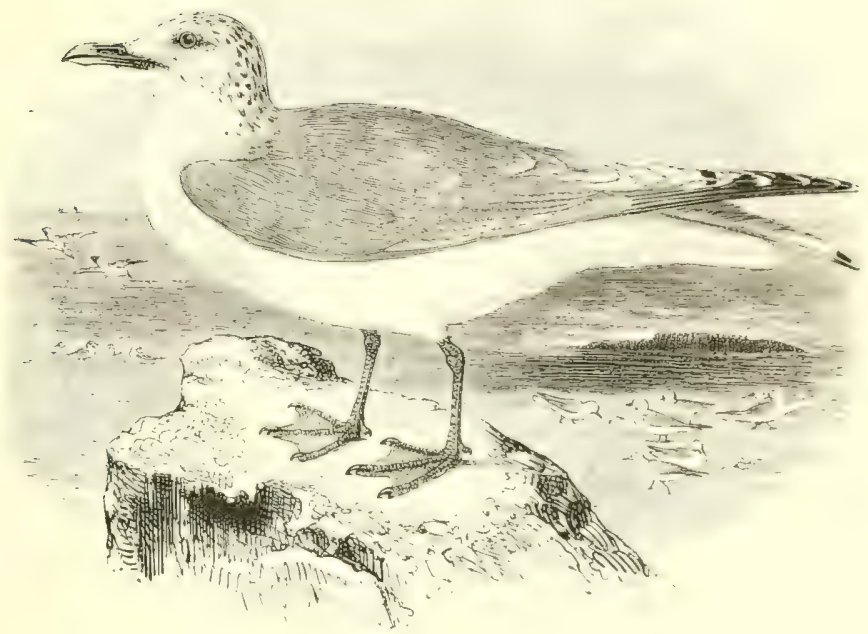

THE COMMON GULL.

LARUs cáxus, Linnæus.

The trivial name of this species has led to many errors as regards England and Wales, for although the bird is certainly 'common' on the coasts from autumn to spring, and is frequently seen inland, yet in April the adults pass northwards, and I am not aware of a single breeding-place south of the Border; as, however, it nests on the Scottish side of the Solway, an exception may, perhaps. have to be made in time to come as regard; England in that particular district. Northward the 'Blue Maa, as it is appropriately called, is found breeding in abundance on the coasts of Scotland, as well ats the fresh-water lochs on its moors including the Hebrides, ()rkneys and Shetlands; though comparatively rare in summer along these portions of the east coast which are precipitous, and therefore unsuitable. In Ireland the 'common' Gull of the peasantry is generally $L$. ridibundus, but there is evidence that $L$. camus has nested on some inland lakes in Donegal, while Mr. R. Warren found a small colony on Lough Talt, co. Sligo, in the summer of 1855 , and in 1882 he discovered another on a lough in co. Mayo: in winter the bird is plentiful by the sea.

The Common Gull is only a spring visitor to the Frroes, and 
MIr. B. Gröndal does not include it among the birds of Iceland; but it is numerous in Norway up to the North Cape, as well as in Sweden, and in Northern and Central Russia. During the colder months it occurs on the shores, lakes and rivers of the rest of Europe down to the Mediterranean; also on the African side of the latter as far as the suez Canal. In summer it inhabits Siberia in Asia, where the birds are, as a rule, larger and darker on the mantle than western examples: while in winter it frequents the Japanese and Chinese waters. In North America, from the Pacific to Great Bear Lake, it is represented by a slightly smaller species, L. brachyrhinchus; but throughout the rest of that continent we find L. delenaternsis, a rather larger bird, with a paler mantle and a doubly zoned bill : an immature example of L. camus was, however, obtained in Labrador on August 2 Ist i 860.

Grassy islands and sides of lochs, or slopes facing the sea and often not far above high-water, are favourite resorts of this species; and there it breeds in colonies, making a somewhat large nest of seaweeds, grass, heather ic. The egrge, normally 3 in number, are olive-brown in ground-colour, spotted and streaked with blackish; but pale blue, straw-coloured and light green varieties are not uncommon: average measurements $2 \cdot 25$ by $\mathrm{I}_{5} \mathrm{in}$. As a rule this Gull does not go far from land, and owing to its being one of the first to seek the shore on the approach of coarse weather it has been made the subject of many rhymes and poetical allusions. It feeds on small fish, molluscs, crustaceans \&c., and may frequently be seen picking up srubs on the furrows in company with Rooks, while it will sometimes eat grain.

The adult in summer has the head, tail, and entire under parts white: mantle of a deeper grey than in any other medium-sized species except the Kittiwake; in the primaries, which are comparatively long, the three outer pairs are dull black on the lower portions, with large white 'mirrors' near the tips on the Ist and and and even on the 3 rd in mature birds, while in the rest pale grey predominates-the black merely forming a bar-and all except the Ist are broadly tipped with white; bill greenish at the base, rich yellow towards the point; legs and feet greenish-yellow in summer, darker in winter. Average length I $\$ .5$ in. ; wing I 4 in. In winter the head and neck are streaked and spotted with ash-brown, as shown in the illustration. In the young bird the primaries and the broad tail-band are dark brown; the under side of the wing is mottled with brown, whereas in L. riditundus it is greyish-white. 


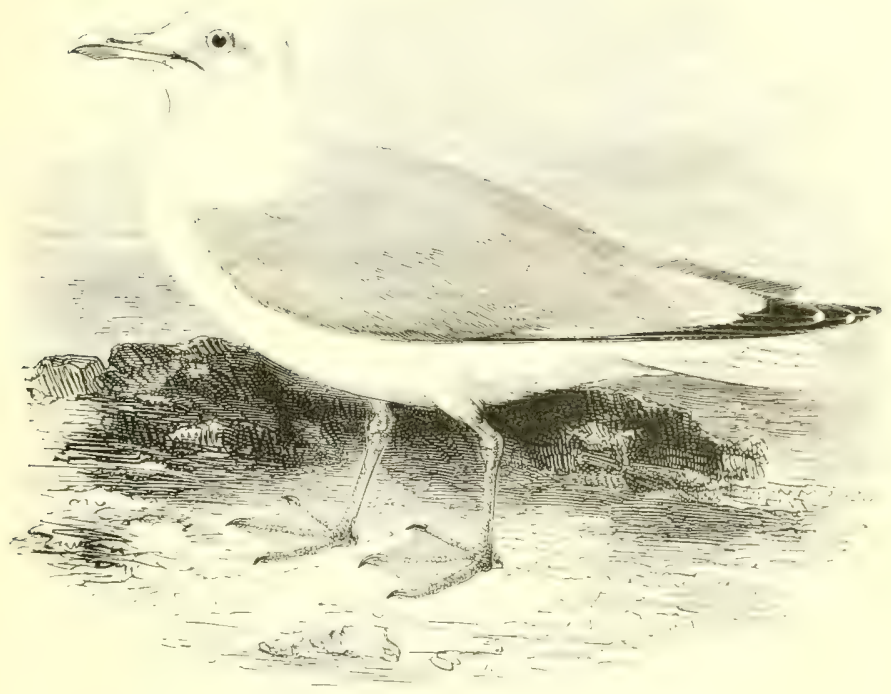

THE HERRING-GULL.

\section{LARUS ARgentátus, J. F. Gmelin.}

The Herring-Gull is the most widely distributed member of the family on the coasts of the British Islands; breeding wherever precipitous cliffs or isolated 'stacks' afford a suitable refuge. Occasionally, as on Foulshaw Moss in Westmoreland, it resorts to low marshy ground, and colonies may also be found on islets in lochs in some parts of Scotland, though such situations are ustally left to the Black-backed and Common Gulls.

This species is abundant on the coasts of scandinavia and the Baltic, while immense numbers nest on some of the low frisian Islands-especially on Sylt, where from 40,000-50,000 eggst are taken for eating in a season; and southward it ranges down the western sea-board of Europe, stretching out to the Azores. T'urning from the foggy North Allantic to the more sumny shores of the Spanish Peninsula and the Mediterranean, we find a resident sub-species, L. cachinnans of Pallas, characterized by a darker mantle, lemon-yellow legs and feet, and an orlital-ring of a decp orange-red; this form extends from the black sea and the Canpian northward to Archangel, and castward to the lacific, visiting the 
coasts of Arabia, India, China and Japan in winter. In Northern Siberia, however, from the I'etchora to the Lena delta, the representative during the summer months is L. affinis of Reinhardt: a fairly defined species, with yellow legs and feet and with a mantle almost as dark as in some examples of our Lesser Black-backed Gull, though the outer primaries exhibit in the basal portion that characteristic grey "wedge ' which is not found in $L$. fuscus. This Siberian Herring-Gull passes the summer in the then continuous light of the Arctic resions, and the winter in the sunshine of the south of Europe, Isia ic. : it has occurred several times on Heligoland, once in Holland, once in (ireenland, and may very likely visit the British Islands. In the eastern portion of North America our Herring-(iull has been found on the consts and inland waters from Melville Peninsula to the Gulf of Mexico.

The nest, formed of grass, is usually on the ledges of cliffs, but may also be on flat ground-or eien on trees, in some parts of North America where the lird has been plundered by fishermen. The eggs, often laid by the frrst week in May, and usually 3 in number, are light olivelorown, blutched and spotted with dark umber: but the ground-colour is sometimes green, pale blue, or ochre-yellow: average measurements 2.9 by $195 \mathrm{in}$. This species may sometimes be seen searching for worms, slugs, grubs $\mathbb{i c}$. inland, while it devours newly-sown grain, and freely scoops out the bulbs of turnips; its principal food, however, is obtained along the shore or on the sea, and its trivial name is supposed to be owing to its habit of following shoals of herring-fry. Like other large Gulls, it is a great robber of egers : and when, at some noted and accessible breeding-place of sea-fowl, such as Lundy Island, a gun is fired by a tourist-party for the childish pleasure of seeing an immense number of birds on the wing, then is the opportunity of the Herring-Gulls, and every unprotected egg of Guillemot or Gannet is swept from the ledges in an instant !

The adult in summer has the head, tail and under parts white; mantle french-grey; secondaries tipped with white; outer primaries chiefly black, with white tips and large sub-apical 'mirrors,' while a pale grey 'wedge' runs down the inner webs, increasing in size on the inner primaries successively, until the grey becomes the predominating colour; bill yellow, red at the angle; orbital-ring pale yellow; legs and feet flesh.colour. Length $22-24$ in., wing $16.5^{-}$ I 7.25 in. ; the male being larger than the female. In winter the head and neck are streaked with grey. The young are mottled with brown, and full plumage is not acquired (in captivity) until the fifth year. 


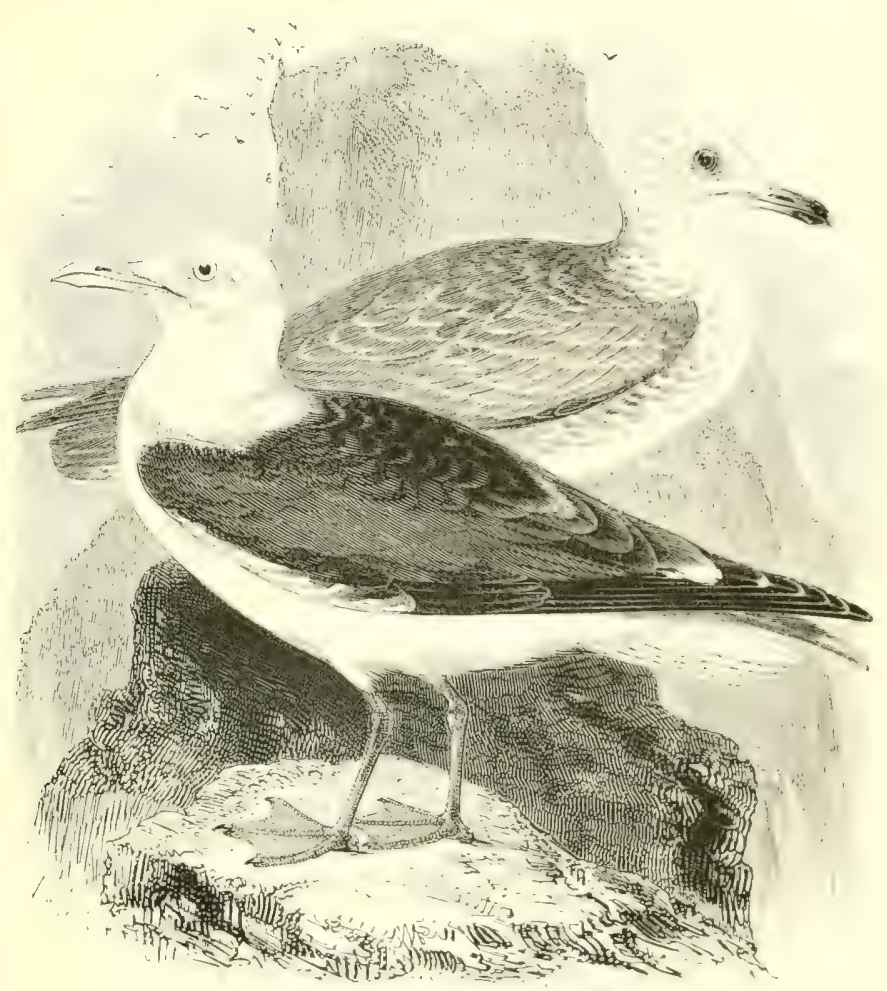

THE I,ESSER BIACK-BACKED GULL.

LARUS FÚSCUS, Linnæus.

Though resident all the year in the British Islands, except, perhaps, in the north, this species is more local than the HerringGull in its distribution during the breeding scason, owing to its liking for grassy slopes, flat-topped islands or stacks of rock, rather than for precipitous cliffs. In the south of England its nestingplaces are confined to Ilevon and Cornwall : colonics evist in II ales and the Isle of Man; on the 'mosses' and 'flows' of Cumberland it is so abundant that measures have to be taken to prevent its undue increase; and, though banished as much as jossible from the moors of Northumberland, large numbers nest on the Farne I lands. In Scotland closely-packed settlements may be found-far too plentifully for game-preservers -up to the northermmost shetlands: especially along the western coast, within the shclter of the Uuter Hebrides, though on the far side of that group the lleming (iull 
predominates. In Ireland few breeding-places are known, but the species is found throughout the year.

The I.esser Black-backed (iull is numerous during the summer in the Froes, and along the coast of Norway; but it migrates southward on the a!proach of winter, as it does from the shores of the Baltic, on whicis it is found, but is not known to nest. Small colonies exist on some of the Channel Islands and probably along the western sea-hoard of France; Col. Irby states that a few pairs remain to breed on the shores of Morocco in . April ; and the bird has been traced to the Canaries, Madeira and Senegal. In the Mediterranean it occurs chiefly during the colder months, yet is said to nest in sicily and sardinia ; while evidence is imperfect as regards the 13!ack Sea; though castward, its representative is certainly the siberian Herring-(iull : birds with mantles of the deepest black and brilliantly vellow feet are, however, resident on the Nile and the Red Sea, and limin l'asha is said to have recently obtained a specimen on the Allert Nyanza. The southern hemisphere is inhabited by L. deminiemms, intermediate in size between this and the (ireat Black-backed (iull ; the Californian L. actitenlatis is nearer akin to the Herring-Gulls.

The nest is made of grass, bits of sea-weed, ic., and the egrgs, generally laid in the latter half of May, are usually 3 in number; they are somewhat smaller on average than those of the HerringGull, and exhibit greater variation in their ground-colour: measurements about $2 \cdot S$ by $\mathrm{I}^{\circ}$ in. The food consists chiefly of fish and small crabs, the indigestible portions of which are thrown up in large pellets, while MIr. 'T. F. Buckley has found similar castings composed of the husks of grain : the bird is, however, omnivorous, and very injurious to the eggs and young of moorland-game and water-fowl.

The adult in summer is white, except on the mantle; which varies from slate-grey to black; the three outer primaries are of a duskyblack which becomes paler towards the edges of the inner webs, though there is no grey 'wedge'; a sub-apical white mirror exists on the ist and-in mature birds - on the snd quill ; the legs and feet are yellow, and the relative shortness of the latter is characteristic. In winter the head and neck are streaked with dusky-brown. Length of a male 23 in., wing 16 in. ; the female is usually smaller. The young bird is very similar to the immature Herring-Gull, but the general tint of the upper parts is darker and the primaries are a nearly uniform black; the lower part of the tail is crossed by a black band, which gradually breaks up into mottlings and disappears with increasing age; the !egs and feet are at first light brown. 


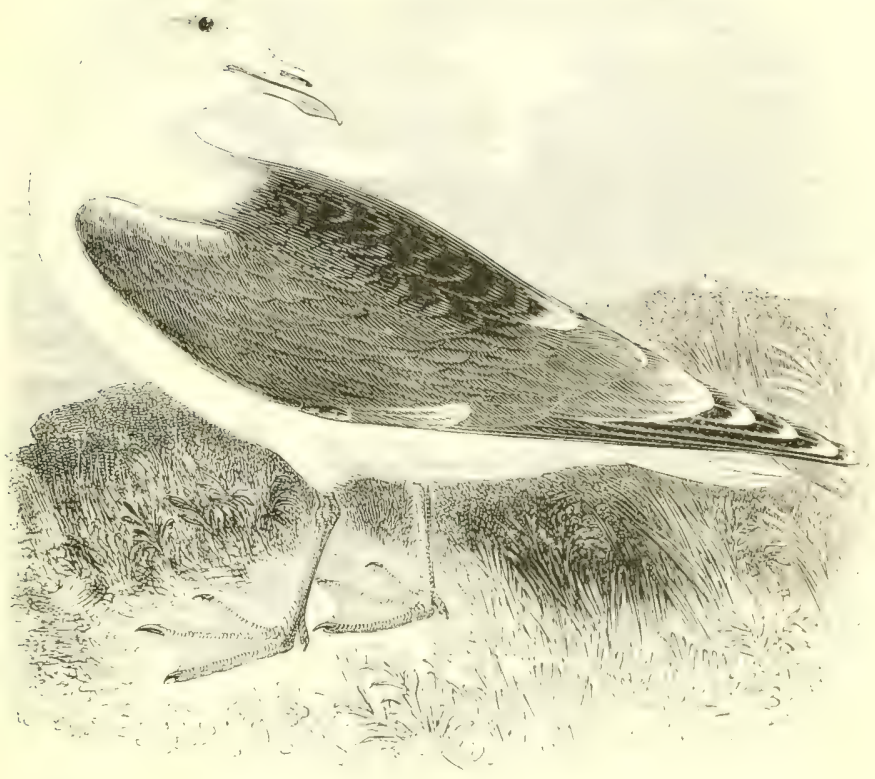

THE GREAT BLACK-BACKED GULL.

LARUS MARínUS, Linnæus.

As a breeding-species this is by no means plentiful in England, though birds in various stages of immaturity may be seen on our coasts at all seasons-sometimes in considerable flocks-until the first appearance of black on the mantle in the third year, after which there is a tendency to separation into pairs. At the present day a few only nest on the cliffs of Dorsetshire, Lundy Island, Cornwall, Scilly, Wales, and, perhaps, on the Isle of Man; but in 1885 about fifteen couples inhabited the flows in the neighbourhood of the Solway, though on the east of England no breeding-place is known. In Scotland this rapacious Gull is far more abundant, especially on the deeply indented coasts and inlinde of the north and west, and above all in the Outer Hebrides, where colonies of twenty to twenty-five pairs may be found; it also resorts, there and elsewhere, to islets in mountain lakes, and lofty hill-tops. In Ireland it is not met with in such assemblages, but is widely distributed. 
The Great 13lack-backed (sull is rusident in the Faroes and Iceland, and is pientiful during the summer on the coasts of the North Sea. Sicandinavia, and Russia, ranging as far east as the delta of the Putchora. Southward, no nesting-places are known on the Continent, except in the north-west of France: though the bird occurs in winter down to the Canaries, and is met with-usually in immature plumage - on the Mediterranean and Black Seas, as well as inland waters. Across the North Atlantic it is found breeding in Danish (ireenland up to $6.5 \mathrm{~N}$. lat., and has been observed in Baffin Bay; while southward, it nests in Labrador and Maine, occurs on the great lakes, and visits the liermudas and Florida in winter. Both sides of bering sea are frequented by L. sichistisugus of Siejneger, a new and little-known species which may be roughly described as intermediate between L. marimus and L. affinis; but Mr. Seebohm has given me a bird from Hakodadi-in the North Island of Japan-which I identified some years ago as a (rreat Black-backed Gull : and even now, in spite of the discovery of L. schistisugres so near, and the apparent gap in the distribution of L. marinus, I cannot refer this example to any other species. Attention is specially called to the range of this (iull, respecting which we are rather more than usually ignorant.

The nest is frequently on some isolated stack of rock or on an islet in a loch: and the eggs, laid in May, are never more than 3 and often only $z$ in number, while I have several times known only $\mathbf{I}$ to be laid; their colour is stone buff, boldly blotched with dark grey and umber: average measurements 3 by $z^{\prime} \mathrm{I}$ in. Nothing in the way of animal food comes amiss to this predacious species, whether it be sickly or injured ewes, weakly lambs, young or wounded waterfowl and game, eggs, or carrion. The majestic flight, large size, and loud querulous note of this species render it easy of recognition on the wing.

In the adult the outer primary has a large white tip, though in younger birds this 'mirror' is crossed by a narrow black bar-as it is in all examples on the snd: while mature birds have a distinct grey 'wedge' on the inner webs, indicating that the affinities of this species are with the Herring-(iulls, and not with the Lesser Black-backed Gull. Bill yellow, red at the angle; legs and feet flesh-colour. Length of a male $30 \mathrm{in}$., wing 20 in.; the female being smaller. The young bird is paler in ground-colour than immature L. argentatus, and has more sharply defined mottlings. 


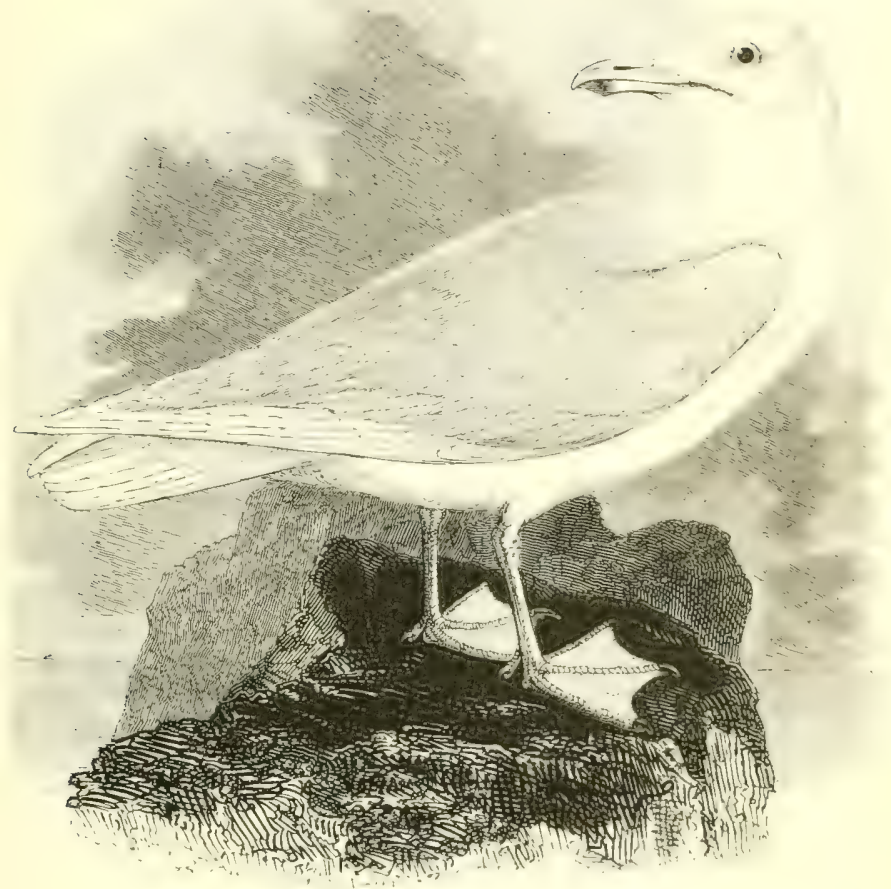

THE GLAUCOUS GULI.

\section{Larus glaúcus. O. Fabricius.}

This large white-winged Gull-equal in size to the preceding species, is a visitor to our islands during the colder months of the year, especially to the northern districts; but although sometimes observed in the Shetlands until June. it has never been known to breed there, or even in the Freroes. In severe winters it is sometimes abundant in (ireat Britain, immature birds, of course, forming the majority; but south of Norfolk it is of irrerglar appearance. and in the west of England it is rare, although, as it happens, the subject of the illustration was shot on the Severn in the winter of I840. In Ireland it is seldom met with.

The Glaucous Gull is common and resident in Iceland, and is found during summer throughout the entire circmulular regions of the Old and the New World; but it alsandons the highest hatiudes 
during the winter time, when its migrations extend as far south as the Straits of Gibraltar, the Mediterranean and Black Seas, and Vedo Bay in Japan. Mr. Ridgway has distinguished the (ilaucous Gull of Alaska by the name of L. bamoriamus, but I can see nothing exceptional in specimens from the North Pacific, the Arctic regions of America, or Greenland; and in winter this (xull visits the great lakes and the Mississippi valley as well as the east coast, Texas being its southern limit. In the Pacific-north of lat. $40^{\circ}$-we find a very distinct and slightly smaller species, $L$. slanciscens, with primaries chequered with pale grey-not black, as in the Herring-(jull. A larger indisidual-as yet unique-from . llaska, has been named L. Ne/soni by Mr. Henshaw; and on the cast side of Baffin Bay, migrating to New lork State in winter, there is a small species, I. Kumlitni, which may lest be described as forming another link between the group of Herring-and of white-winged ciulls.

The nest is made on projecting ledges of lofty cliffs or on the shore, according to circumstances; the eggs, usually laid in June, are stone-culour, spotted with ash-grey and brown: averagre measurements 20 by 2 in. The (ilaucous (jull has several times bred and reared its young in the Gardens of the \%oological society of London. It is ommivorous as regards diet ; in South (ireenland, during August and September, the berries of Empetrum nigrum are largely consumed by the immature birds. From its overbearing nature this species has long been known as 'the Burgomaster' among whalers and sealers.

The adult in summer is white, except the mantle which is pale pearl-grey; the primaries reach but little beyond the tail ; the bill is yellow, orange at the angle; the legs and fuet are bright pink. In winter the head and neck are streaked with ash-grey. Length of a male 32 in., wing 19 in. : fumales are often much smaller. The young bird is mottled with ash-brown on a creamy ground, becoming lighter at each moult, until, just before assuming the pearl-grey mantle, it becomes white for a short time. In this state it was formerly supposed to be a distinct species, which Richardson named L. hutchinsi; but its identity is now fully established, and I have watched every change of plumage in the birds brought up in the Zoological Gardens. The bill is brown and the legs and feet are livid flesh-colour in the immature bird. 


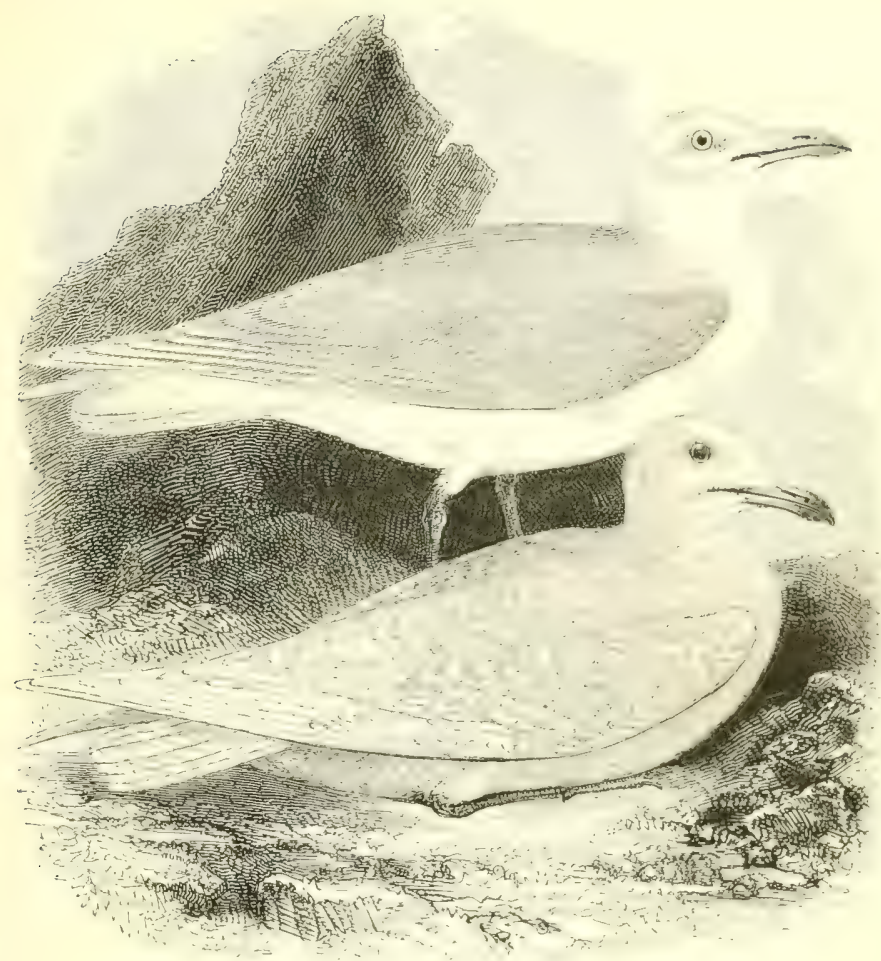

THE ICELAND GULI.

LARUS lEUCÓPTERUS, Faber.

This smaller white-winged species-which bears about the same proportion to the Glaucous that the Iesser Black-backed does to the Great Black-backed (iull-was first recognized in the British Islands by the late Dr. Lawrence Edmonston of Unst in Shetland, and is now known as a tolerably frequent, though irresular, visitor to the sea-board of Scotland in cold weather. The winter of I872-3, which was remarkable for an unusual advent of Glaucous Gulls in the Firth of Forth, was still more so for the influx of Iceland Gulls, many of them leeing adults: and, though this hirel is natura!ly rarer on the English shores, a larese number reached Cornwall in January and February of the latter year, while in $187+5$, after long-continued sales, both young and old were filenti. ful on the coast of south I)eron. On its migration northwards this 
bird has been observed by Mr. Cordeaux in the Humber district as late as April 1 Sth. In Ireland it has but seldom been recognized, and chiefly on the estuary of the Moy.

The Iceland (iull sometimes wanders to the Freroes; but, strange to say, the island from which it derives its trivial name is only inhabited ly it from September to May, during which period it is also found on the coasts of Norway, the North Sea, and the northwest of France. The correctness of its identification in Novaya Zemlya is questionable. During the breeding-season it appears to be confined to (ireenland and the Arctic regions of America, though in the latter our naturalists did not observe it in Smith Sound during the expedition of $\mathrm{I}_{75}-6$; thence westward we trace it to Alaska, where-and throughout Eering sea-it is, according to Mr. E. W. Nelson, the most numerous of the family. In winter it ranges southward to California, and on the Asiatic side of the Pacific an example was obtained by Capt. Blakiston at Yezo in Japan. Returning to America, it is of rezular occurrence as far south as Lake Michigan during the colder months.

The nest is often placed upon ledges of lofty cliffs; but in Alaska small islets are much frequented, and Mr. I)all found the eggs laid in shallow depressions in the sandy beaches of the Yukon, early in June. These are $2-3$ in number, and are of a greenish stone-colour blotched with brown: average measurements $2 \cdot 75$ by $\mathrm{I} \cdot S$ in. The food consists chicfly of small fish, but crustaceans as well as refuse are greedily deroured, and saxby noticed a partiality for oats and other vegretable substances. The flight is lighter and more elegant than that of the (ilaucous Gull-as might be expected from the fact that the Icelander has much longer wings in proportion to its bulk; and Mr. Harvie-Brown has remarked that when resting upon a mud-bank it has a neater and more slender appearance and stands higher on its legs.

The adult in summer has the bill yellow, red at the angle; mantle pale grey; secondaries tipped with white which forms a band contrasting with the grey; rest of the plumage white; legs and feet yellowish flesh-colour. Length $22 \mathrm{in}$., wing $16-\mathrm{r} 7 \mathrm{in}$. l)uring the winter months the head and neck are spotted and streaked with grey. The young bird is at first somewhat darker than the immature L. glaucus, but is otherwise similar, and goes through the same stages till maturity is attained in the fourth year. 


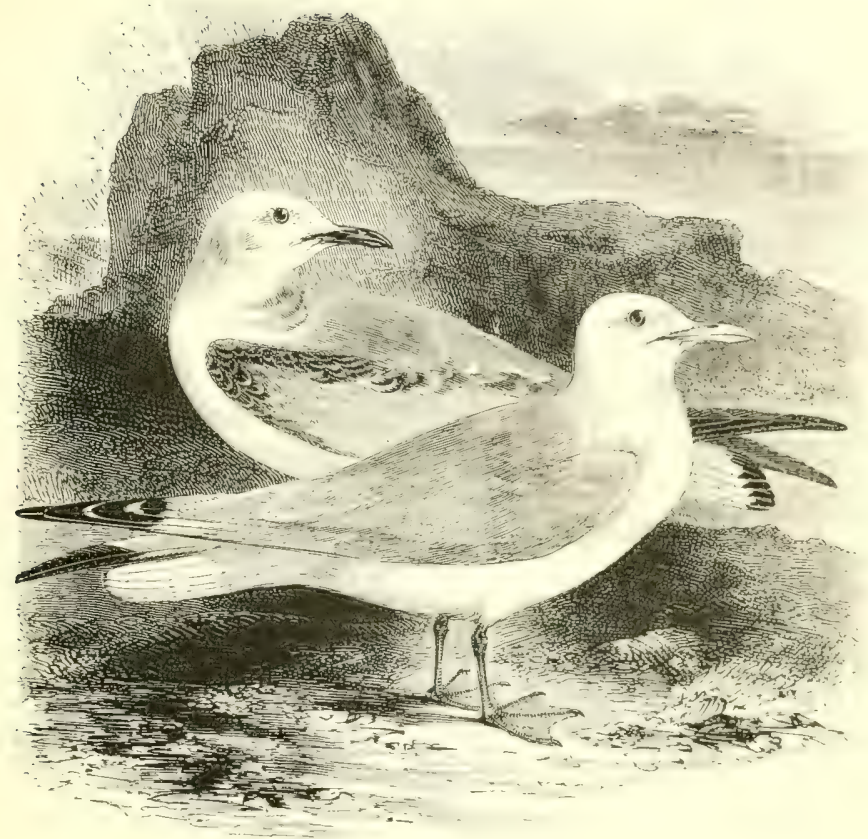

THE KITTIIAKE GULI.

\section{Ríssa TRIDÁCTYLA (Linnæus).}

The Kittiwake-characterized by an obsolete hind-toe-is to be found in British waters throughout the year, resorting in summer to jagged cliffs, where immense numbers may often be found breeding in close proximity. There are colonies on I undy Island off North Devon, the Scilly Islands, Wales, the Isle of Man, Flamborough Head and the Farne Islands: and, on the east side of Scotland, at the Bass Rock, the Isle of May, and Dunbuy in Aberdeenshire: while in the Orkneys and the Shetlands thousands of birds whiten the precipices. In the west these assemblages are cuen more numerous, and the 'gullery' on the Shiant Islands is the most extensive within my knowledge. In Ireland, too, this Gull is extremely plentiful on the precipitous portions of the sea-boarl.

On the Continent the Kittiwake is not known to nest further south than Brittany, but in winter it ascends the Garonne as far as Toulouse, and thence probably proceeds to the Meuliterrancan, where it is not uncommon; it also visits the Black and Caspian 
Seas. Its southern range appears to extend to the Canaries on this side of the Atlantic, and to the Burmudas on the other; while northward, heyond the British Islands, this (xull breeds in myriads on the cliffs of the Faroes, Iceland, Norway-where a vast colony exists near the North Cape, Spitshergen, Noraya Zemlya, Franz-Josef I and, and wherever suitable lccalities present themselves in the Siberian Arctic Ocean. 'Turning westward, we find it abundant in (ireenland, and throughout the northern portions of America above the Gulf of the St. Lawrence, as far as licring Sea. There individuals are found in which the hind-toe is not quite obsolete and is occasionally terminated by a minute nail ; though this peculiarity is not always of equal extent on both feet of the same bird, nor is it confined to examples from that district. The area between Alaski and Kamschatkil is also, however, inhabited by a perfectly distinct species, $R$. lrovirestris of Brandt, which may at once be recusnized by its oranere-red legs and feet, and darker mantle.

The nests usually of sea-weed or bents, and exceptionally of such 'flotsam' as tobacco-are placed on narrow ledges of rocks; and I have seen some which were not more than 5 feet above highwater mark, though the topmost might be hundreds of feet higher. The egres, 2,3 in number, vary from greyish-white to olive-buff, blotched and zoned with ash-erey and rich brown: average measurements 2 I 5 hy 1 \% in. They are sellom laid until the latter part of May, so that many of the young can scarcely fly-while others are still in the nest when the sea Birds Protection Act expires on August Ist : and thousanc's are then slaughtered to provide plumes for ladies' hats. The food comsists of fish and marine animals; sea-water is drunk in preference to fresh; and marked birds have been known to follow vessels across the North Atlantic. The name is derived from the note, as are those of 'Hacket' and 'Ilacklet'; the young bird is often called 'Tarrock.'

The adult in summer has the bill greenish-yellow; mantle deep grey ; primaries black on the lower portion from the ist to the 5 th, being barred with black on the 6th; head, neck, tail and under parts white; legs and feet blackish. Length 15.5 in., wing 12 in. In winter the nape and hind-neck are grey, like the mantle. The young bird has the bill black; nape greyish; shoulders, wingcoverts and inner secondaries thickly spotted with brownish-black; Ist to $4_{\text {th }}$ quills blackish on the outer and on part of the inner web; tail barred with dull brown near the tip ; legs and feet brown until complete maturity is attained. 


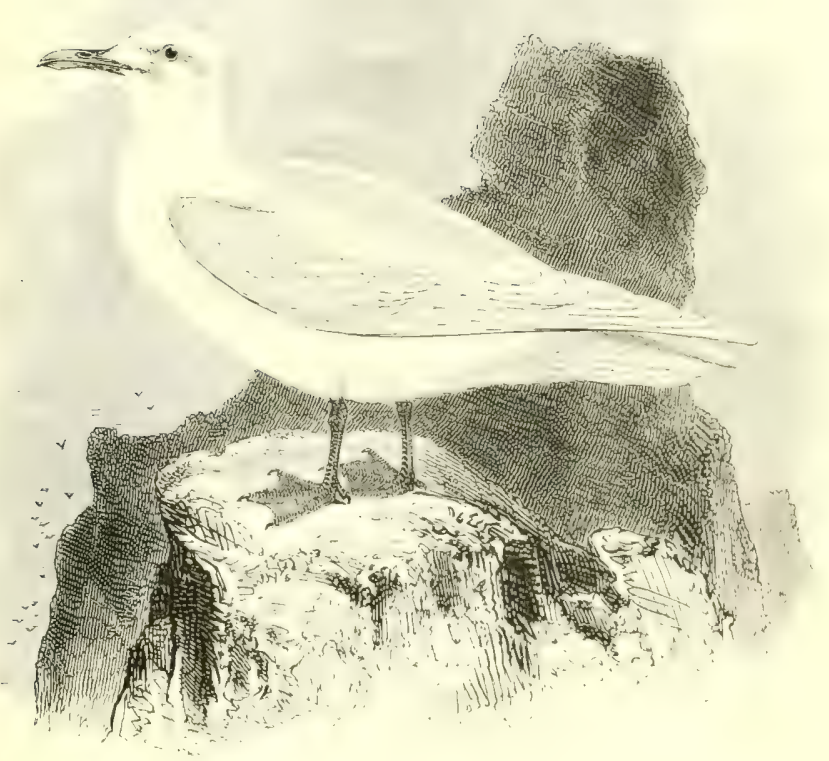

THE IVORY GULL.

\section{PÁGophila EBúrNeA (Phipps).}

The first British specimen of this truly Arctic (iull was oftanincel by the late Dr. Lawrence Edmonston during the wintur of $\mathrm{I} \$ 22$, in the Shetland Islands, where this species has suldiequently lecen met with on several occasions. Four examples have been recorded from the Orkneys, one of them as late in spring as May; while southward, Sutherland, Caithness, banffshire and Abercleenshire have been visited, and six or seven birds have been killed in south-western waters, chicfly off the Firth of ("lyde. In England this Gull is, naturally, more frequent in the north than in the south; but its migrations have extended to the ('hamnel and ('ormwall: while in Ireland two birds have been taken and others have becu observed. Altogether we may consider that about thirty specimens have been procured in the liritish Islands, and, of thesc, rather more than half appear to have been adults.

The Ivory Gull has been noticed on the coasts of Northern 
Furope down to the mouth of the Somme in France, and is said to have occurred near Lausanne in switzerland; but even during the cold months it is only a straggler southward of the Arctic circle, and was not identified in Iceland until April is 79 . In the high northern latitudes it is now known to be completely circumpolar in its range, for the recent American expeditions to Point Barrow and Bering sea met with it in those parts-where it had not previously been observed, though tolerably common on the Asiatic coast and off the islands to the northward. Almost all the Arctic explorers have recorded it: Richardson found it breeding in about $122^{\circ} \mathrm{W}$. long. : Sir I eopold II. ('lintock obtained a single eggr (now in the T)ublin Museum) from a nest on Prince P'atrick's Island in I I $6^{2} \mathrm{~W}$.; and Col. Feilden saw a pair on a lofty and inaccessible cliff in Smith sound, on August yoth is 75 . In liaffin bay it is plentiful, and adults as well as immature birds are annually obtained in Greenland; while in winter they appear to wander as far south as New Brunswick. The best known brecding-places are, however, in Spitsbergen and Franz-Josef I and, and the bird doubtless nests in the west and north of Novaya \%emlya. where Capt. A. H. Markham, R.N., found it plentiful.

The nest, composed of mosi, sea-weed and drift, is placed on ledges of precipices, or on the ground a little above high-water mark, according to convenience; the egess, which never exceed 2 in number, are very similar to those of $L$. canus, and measure about $2{ }^{\circ} 5$ by $I^{\circ} 7$ in. In 'The Ibis,' I888, pp. $440-443$, Prof. R. Collett has given a description of a fine series, with a coloured illustration of two eggrs and of a downy nestling. The food consists largely of marine animals and the droppings of walruses and seals, but the 'krang' or flensed carcases of whales \&c. are greedily devoured. Col. Feilden says that this bird has a shrill note, not unlike that of the Irctic Tern, and also that in its flight it resembles a Tern rather than a Gull.

The adult in summer has the entire plumage white, slightly rosy in life; the bill greenish-grey at the base; legs and feet black, the hind-toe strongly developed and connected with the tarsus by a well-defined web. I.ength of a male I 8 in., wing 13 in. ; the female is smaller. The young bird is dark grey on the face and chin, and is spotted with black on the back, wing-coverts, tips of the primaries and tail-feathers, as well as on the upper and under tail-coverts. The downy nestling is white. 


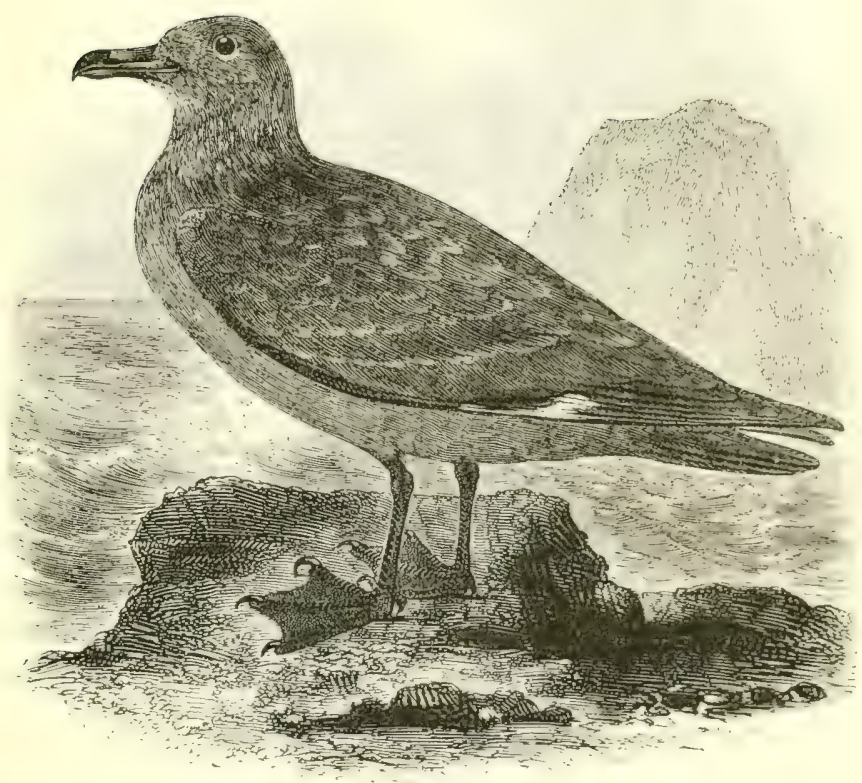

\section{THE GREAT SKUA.}

Stercorárius CATARrháctes (I innæus).

This fine species is the largest Furopean representative of the small group of Parasitic Gulls, the members of which obtain their food chiefly by robbing the smaller or more cowardly sci-fowl. In the British Islands the only breeding-places of the Great Sikua or 'Bonxie' are in the Shetlands, where a well-known colony on Lnst, and another on Foula may be mentioned, at both of which the lird is protected as far as possible. It seldom visits the Orkneys or the ()uter Hebrides, and is decidedly scarce along the west side of frotland, though occasionally met with on the cast during the colder months : and the same may be said of Fingland, down to and throughout the Channel: but it seems to be rarer than is really the case, berause it frequents the fishing-grounds far out at sea, where the (iulls which it robs are plentiful; exceptionally, after severe weather, it hati licen met with inland. In Ireland it is almost unknown.

The Great Skua breeds in the Feroc Islands, though dimininhed in numbers by the "neb-toll' to which ripacious birds are sulject: 
while in Iceland it is still abundant on the Testmanna Islands, and has four or five other settlements. There is no evidence of its nesting within Norwegian waters, where it is scarce at any season; and although it can be traced southward in winter to the Straits of Gibraltar, or a little further, it seldom enters the Mediterranean; it has, however, wandered to the lakes of Switzerland, and in I $\$ S 2$ to the province of Terona. It is very rare in South Greenland, but appears to breed on some islands to the north of Hudson Strait, and is not uncommon on the fishing-banks down to New England in winter; its reported occurrence across the Fur regions and in the North Pacific is, however, unconfirmed by any recent explorer. On both sides of South America, from I 2 S. lat. to the Straits of Magellan, its representative is S. ihilinsis, which has bright chestnut under parts and axillaries; while in the Falkland Islands and throughout the Southern Occan we find S. antarticus, a stouter, sooty-brown species.

The nest-a carity in the moss and heather of the highest moorlands-is prepared in the latter half of May; and the eggs, never more than 2 in number, are olive-brown with darker markings: average measurements $2 \cdot 8$ by 2 in. When handling a nestling, I found the parents unremitting in their assaults; they came down at full speed, almost skimning the ground, until, at about fifteen yards' distance, the strong feet with their hooked claws were lowered and held stiffly out-producing for the moment a very ungainly appearance: but on quickly raising the hand or stick, the bird rose again, the whirr and vibration of its pinions being distinctly heard and felt. The stomachs of a pair which were shot on the Faroes were full of the flesh of the Kittiwake, and the castings consisted of the bones and feathers of that bird; Heysham has recorded the capture of an adult in the act of killing a Herring-Gull, while fish and offal are often eaten. 'The cry is Skui, skui; whence the bird's name.

The adult has the head and throat dark brown mottled with rufous; nape covered with yellowish-brown acuminate feathers; upper parts dark brown, mottled with chestnut and dull white; quills umber-brown, with white hases--conspicuous in flight; under parts rufous-brown; under wing-coverts blackish; bill, legs and feet black, the claws hooked and sharp. Length $24^{-25} \mathrm{in}$., wing 16 in. The sexes are alike externally; the young bird scarcely differing from the adults except in the greater freshness of its plumage. Melanistic varieties are occasionally met with. 


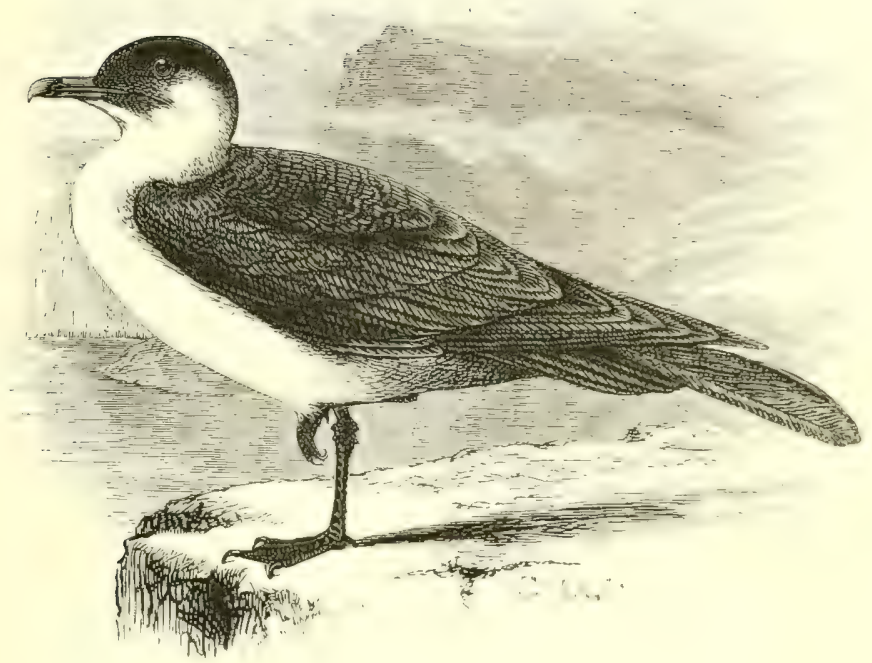

THE POMATORHINE SKUA.

Stercorarius pomatorhínus (Temminck).

This species is of tolerably regular occurrence on the coasts of Great Britain-especially along the eastern sea-board, on which a remarkably large migration was noticed in the autumn of $18 ; 9$, and another, slightly smaller and less extensive, in ()ctoler r sso. Some individuals remain all the winter on our southern shores, and, after severe gales, have been met with far inland; lut comparatively few are seen on the spring passage. In Ircland the appearance of this bird is more irregular.

The Pomatorhine Skua is merely a visitor to the northern coists (uf Europe, and has not even been found breuding on splitslereren, Franz-Josef Land or Nowaya 7.emlya; lut it probably nests all alomer the tundras of Asiatic siberia, where 1)r. ron Middendorfi obtainerl its eggs on the Taimyr in lat. $74^{\circ} \mathrm{N}$. It is common on both sides of Bering Sea, especially at the mouth of the lukon in . Makka, and thence is said to occur across the Arctic resions to baftin bay : while in Greenland it appears to breed in colonies northward of liscelen. 
minde. On migration it has been obtained as far south as Cape York in Australia, Walvisch Bay in South Africa ( $23 \mathrm{~S}$. lat.), and Callao in Peru $\left(12^{\circ} \mathrm{S}\right.$.) : while it has, of course, been recorded from numerous intermediate localities.

The 2 eggs, deposited in a mere depression of the moss, are of an olive-brown with darker blotches, and measure about $2^{\circ}+5$ by $\mathrm{I}^{\prime} 7 \mathrm{in}$. Like the rest of the group, this Skua plunders the Terns and Gulls, devours 'krang' or any animal matter cast up by the sea, while it also preys freely on lemmings.

The adult has the front and crown of the head sooty-black; neck white, with straw-coluured acuminate feathers; upper parts chiefly umber-brown, the two central tail-feathers projecting + in. and being tritisted rerticully; loreant dull white; flanks and abdomen brown. Length $2 \mathrm{I}$ in., wing $r+25$ in. Younger examples have a brown pectoral band, more or less striated under parts, barred tail-coverts, and central tail-feathers but little elongated. The bird of the year (represented below) is brown, mottled and barred with dull rufous. Melanistic varieties are not uncommon.

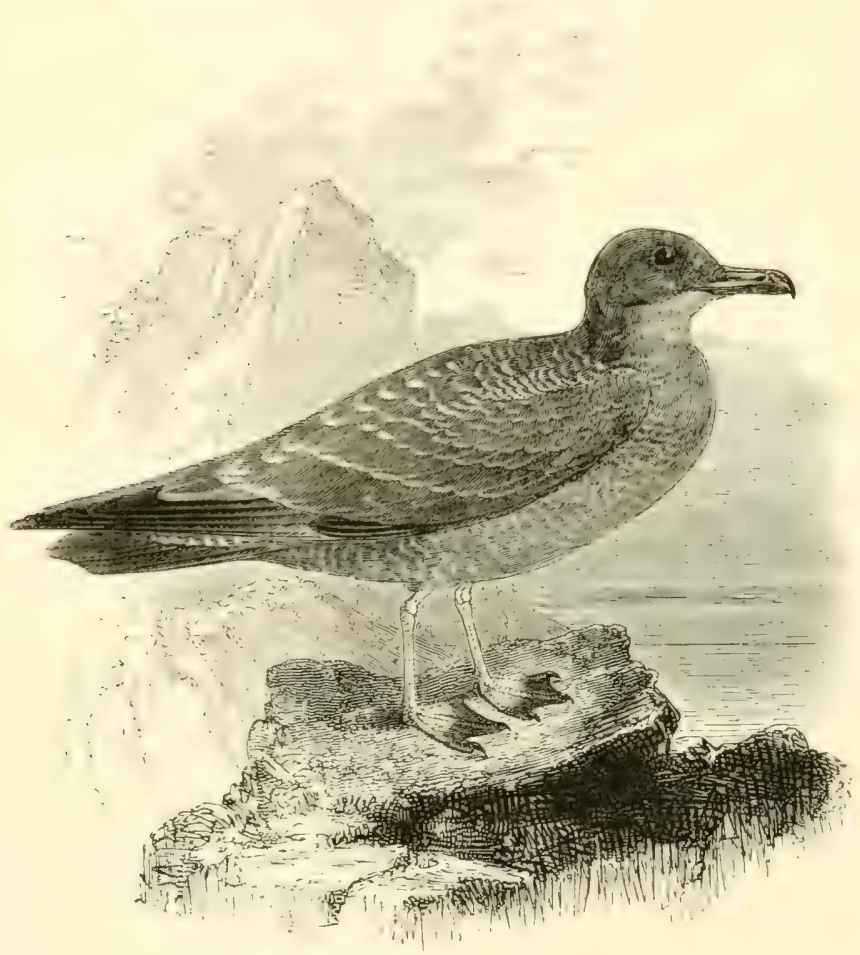




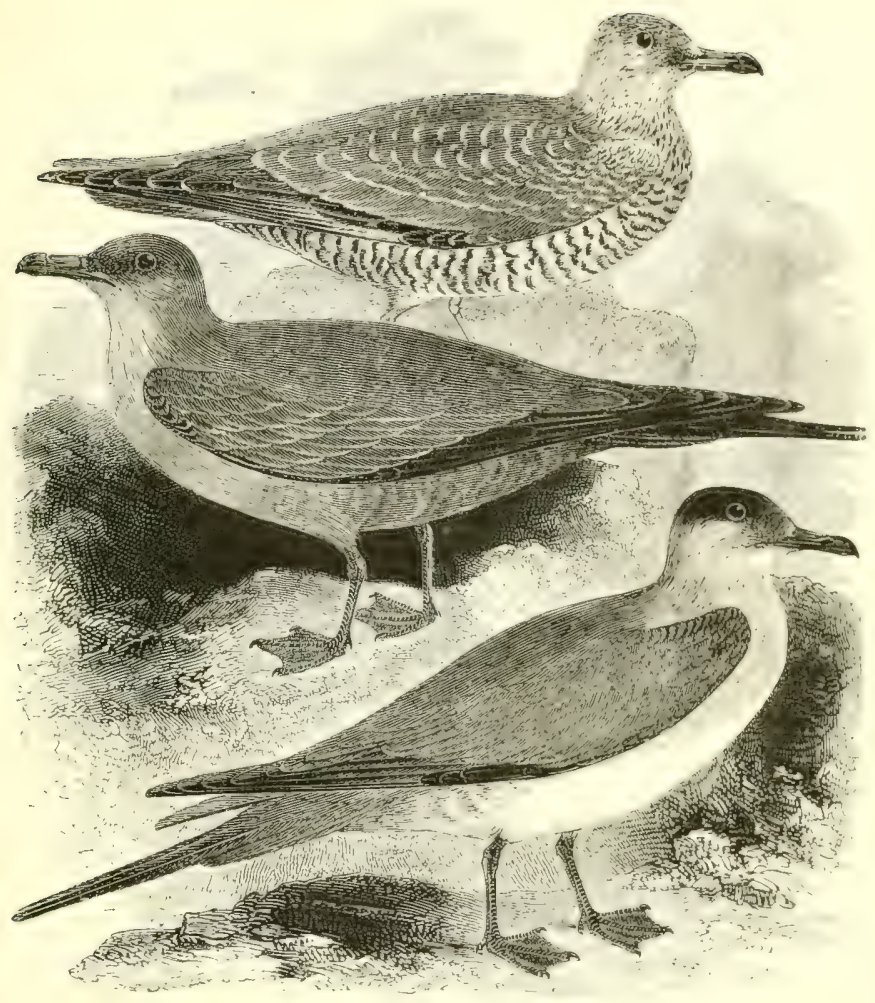

THE ARCTIC OR RICHARISSON'S SKUA.

\section{Stercorariús CRepidátus (J. F. Gmelin).}

The second English name is strictly applicable to a dark form of this bird; but it is often employed, and has the murit of being distinctive, whereas the first has occasionally been confurred on the next species. The Arctic Skua breeds on some of the shotlands. and there are several colonies in the Orkneys, while on the mainland a pair or two may still be found in sutherland and ('aithness: it also nests at a few spots in the Outer Helurides, and very sparingly on the Inner islands. On migration it is not uncommon along both sides of Scotland, as well as down the east (oast of England, hut it is less frequent in the (hanncl, while comparatively irregular in the western sea. To Ireland it is a periodical visitor; and it has occasionally been met with on inland waters in various parts of the British Islands. 
There are two very distinct varieties of the Arctic Skua, the one being entirely sooty, while the other has light under parts; but the latter pairs with whole-coloured birds as well as with those like itself, the dark-coloured birds also mating. The extreme and intermediate forms are found nesting on our northern islands, the Færoes, Iceland, the coasts of Scandinavia, Russia, and probably Novaya Zemlya; but the sooty bird has not been observed on Spitsbergen, and all the specimens from the far north of America are whitebreasted; which looks as if the dark variety was sub-arctic. At all events, this form predominates in the south, whereas the whitebreasted race increases in numbers to the northward until it attains to the ascendency; in America again, below the Arctic circle, both are met with. As a breeding species this skua may be broadly described as sub-arctic and circumpolar; in the cold season it frequents the coasts of Europe, Africa down to the Cape of Good Hope, the Persian Gulf and vicinity, the North P'acific, and the Atlantic as far south as Rio de Janeiro, while it has occurred several times in New Zealand.

The eggs, 2 in number, are laid in a hollow of the moorland moss ; they are of an olive-green colour, blotched with dark brown, and measure about $2 \cdot 3$ by $1.6 \mathrm{in}$. The flight of this Skua is rapid, although somewhat devious; and any intrusion upon the breedingground is resented by swoops - directed from behind or sideways, for although the bird will actually strike with its wing, I have never seen it make a front-attack. 'The cry is a plaintive mee, sometimes a sharp) mec-ázith. This species feeds principally upon fish, obtained by robbing the smaller Gulls, but it also preys upon wounded or disabled birds, is said to plunder the eggs of other sea-fowl, and has been known to pick up worms and molluscs. It does not dive, but has frequently been observed to settle on the water.

The lowest figure is that of an adult-but not very mature-example of the intermediate form; in many, as already observed, the throat and breast are white, and not shaded with brown. The middle bird may be said to belong to the dark race, though more sooty individuals are to be met with. Between the above there is every gradation; but all have a yellow tinge on the acuminate feathers of the cheeks and neck, and are umber-brown on the upper parts. Length 20 in., wing 1375 . The young bird (at the top) I consider to be the offspring of light-coloured parents; the progeny of a dark pair is much more sooty, with merely rufous edges to the upper feathers. 


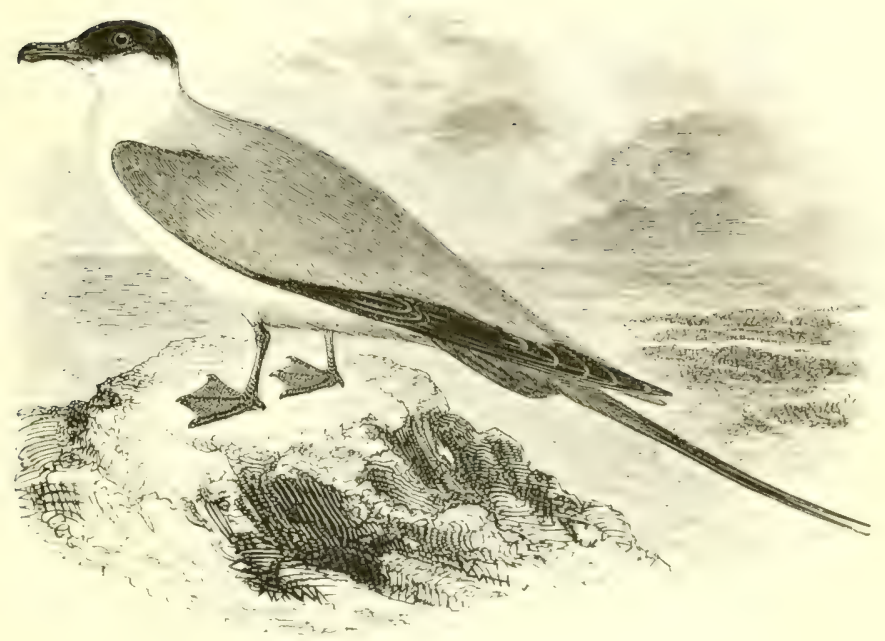

THE LONG-TAILED OR BUFFON'S SKUA.

\section{Stercorarius parasíticus (Linnæus).}

This circumpolar species-rather smaller and much more attenuated than the preceding-is only an irregular migrant to the liritish Islands; and, though naturally more frequent in the north than in the south, it has never occurred in any numbers in sicotland duriner the cold season. On the east side of England, however, it is comparatively common, especially between the mouth of the lices and Flamborough Head, and many--some of them adults-were killed during the great storms of (October $18 ; 9$; while, though rarer as we proceed southward, it is also met with along the channel. The went appears to be seldom visited; yet old hirds have occurrel there in spring on several occasions, one being shot in Cornwall as late as June $4^{\text {th }} 1877$, and another in Cumberland on June $3 \mathrm{rd} \mathrm{I885}$. In Ireland it has been noticed in autumm, and, sparingly; in spring.

The Long-tailed Skua does not breed in the Frees or Iceland; but in Norway a few pairs inhabit the I wrefjeld abowe the limit of forest-growth, while Wolley, Wheclwright and others found comiklerable numbers nesting on the fells of sweelinh I...phlmel to the mom of lat. $68^{\circ}$. It visits Spitsbergen, which, however, appears to be less suited to its requirements than Noray / emlya, where Capr. 
A. H. Markham R.N. obtained a nestling, now in my possession. Eastward, this species can be traced across the tundras of Siberia to Bering Sea, and is widely distributed throughout the Arctic regions of America; Col. Feilden met with no other Skua in Smith Sound, and it also breeds in Greenland. On migration it ranges southward as far as the Mediterranean, and down to about $40^{\circ} \mathrm{N}$. lat. on the east of America, as well as on the Pacific side.

The eggs-usually 2 in number-are laid on the ground in some slight hollow, and are smaller, greener, and more scrolled than those of the Arctic Skua, which they otherwise resemble: average measurements 2 by $\mathrm{I}_{4} 4$ in. The birds are very bold when their nest is approached, and utter a loud shrieking note; the flight is remarkably swift and elegant. In summer, crowberries are largely consumed by the young; at other times beetles, crustaceans, worms, small birds, fish robbed from other Gulls or Terns, and lemmings, form the diet of this species, with a preference for the last.

The adult has the upper part of the head dark brown; neck nearly encircled with buffish-yellow; back and central tail-feathers of a greyer brown than in the Arctic Skua; wings and the shorter tail-feathers dark brown; breast chiefly white; flanks and belly greyish-brown; bill dark horn-colour; legs olive-grey; feet black. Length 23 in., including the long tail-feathers, which sometimes project as much as 9 in. in the male and 7 in the female; wing nearly $\mathrm{I}_{2}$ in. Immature birds are barred with greyish-brown and white on both upper and under parts-especially on the breast, flanks and tail-coverts. The young of the year are subject to a little variation in tint, especially on the lower surface, but are always greyer and less rufous than examples of the Arctic Skua. The readiest distinction at any age is, however, to be found in the shafts of the primaries; these are all white in the Arctic Skua, whereas in the Long tailed Skua the two outer ones only on each side are whitc, the rest being dusky: this fact was distinctly indicated by Linnæus in his description.

In the young of this and of the two preceding species the interdigital webs are parti-coloured, as shown in the vignette of the Pomatorhine Skua (p. 674). This peculiarity led Banks to confer the name crepidatus (sandalled) on the Arctic Skua, but Gmelin was the first to describe that species. 


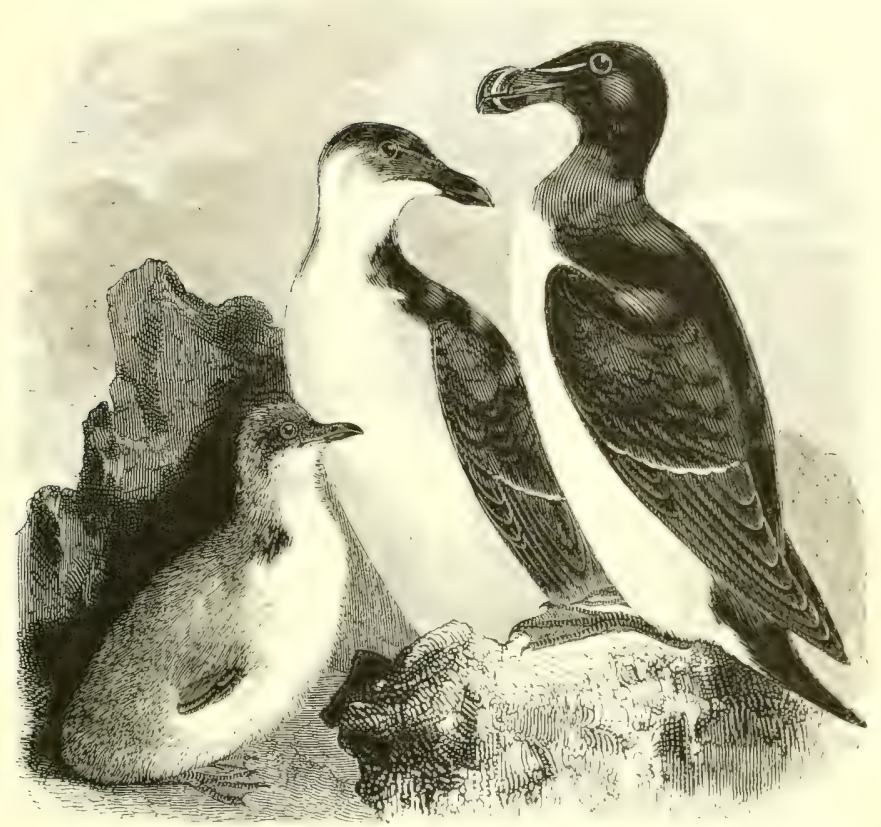

THE RAZOR-BILI.

Alca tórda, Linnæus.

The Alcida-or Auks-are pelagic birds endowed with great powers of swimming and diving: they are only found within the higher or the temperate regions of the Northern hemisphere, and have little structural affinity with the Sphenisidic-or true I'engruins -of the Southern oceans, though they are frequently assuciated with them, owing to a confusion of popular names and a certain superficial resemblance. The Razor-bill is one of the best known members of the family, and, together with the Common (ivillemot and the Puffin, may be seen in the tide-way off our coasts throughout the year; but all three species can be best observed during the breeding-season, when they assemble by hundreds and thousands on suitable cliffs, isolated stacks, and islands. They usually arrive in the latter part of Narch or carly in April, and after the duties of incubation are over they return to the sea, accompanied by their young. The Razor-bill is, however, less plentiful than the (ivillemot or the Puffin, and is rather more partial to sheitered waters. 
This Auk breeds in the Færoes and in Iceland, and on the cliffs of Scandinavia up to $69^{\circ} \mathrm{N}$. lat.; it also appears to reach Jan Mayen, but is unknown on Spitsbergen. Southward it is found in summer down to Brittany; while in winter it goes up the Mediterranean to the Adriatic and Malta, though the majority keep well out in the Atlantic as far as the Canaries, unless driven into bays by stormy weather. It also resorts to the west coast of Greenland up to about lat. $70^{-}$, as well as to the shores of Labrador, the Gulf of St. Lawrence, and the Bay of Fundy; but it seldom attains the American side of Davis Strait, and has not been met with in the Arctic waters to the westward; nor is there any proof of its occurrence in the Pacific.

The Razor-biil deposits a single egg, choosing, if possible, some crevice, or at least an over-hung ledge; though in default of these it will make use of an open shelf, like a (itullemot. When brooding it couches along--not across-the egg, its mate often standing near; and both sexes incubate, though the male may be seen to bring food to the sitting female. 'The eggs, often laid by the middle of May, are not so pear-shaped as those of the (ivillemot and seldom show the faintest tinge of ureen: they are usually white or pale chocolatebrown, blotched and often zoned with mahogany-colour or black: average measurements 2.8 by $\mathrm{i}^{\circ} \mathrm{g}$ in. On holding the empty shell against the light the inside lining-membrane shows green: whereas in that of the Guillemot it appears to be yellowish-zihte, except when overpowered by the green of the shell itself. The young flutter from the rocks to the sea, or are taken by the neck and carried down by the parents : they are at first very loth to follow the old bird in diving, and remain crying plaintively on the surface of the water. The food consists of small fish (which are carried diagonally in the bill-not at right angles, as by the Puffin) and crustaceans. The Razor-bill utters a peculiar grunting or groaning, especially when sitting; on the water it may be distinguished from the Guillemot, at a distance, by its upturned tail.

The adult (figured on the right) is chiefly greenish-black above, deep brown on the throat, and white below; in winter the upper parts lose the greenish gloss, and the throat, fore-neck and cheeks are white, Length 17 in., wing $75^{\circ}$. A young bird killed in December (central figure) has the bill smooth and black without any white groove on either mandible, and shows only a faint white line from the top of the bill to the eye; its plumage resembles that of the adult in winter. I do not think that breeding takes place until the bird is nearly two years old. 


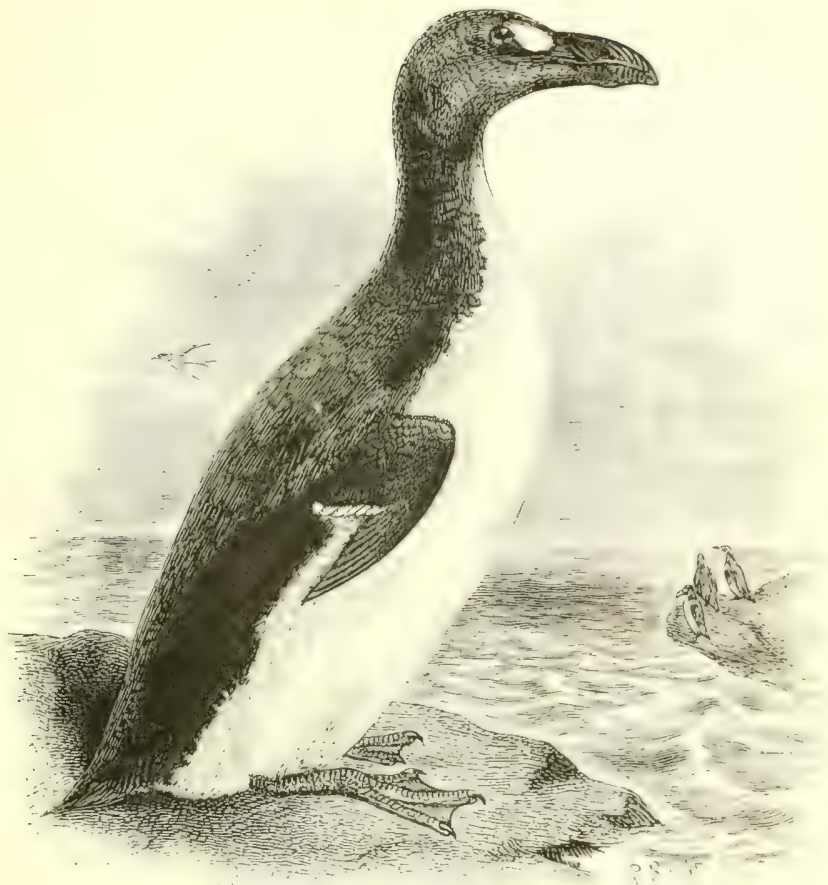

THE GREAT AUK.

AlCa impénvis, Linnæus.

This species, also called the Gare-fowl, is now supposed to be extinct - and with good reason, for the latest examples were obtaincd off Iceland in I 844 , since which the bird has been assiduously but vainly sought. It formerly inhabited the shores of Iccland, the Furoes, and the Scandinavian coast of the North sear ; while its presence in the Outer Hebrides had been on record since i 6s.4. though the hird had evidently become very rare in Scottish waters by the beginning of the present century. An adult male-now in the British Museum, and from which the above illustration is taken-was obtained by Bullock in ISI 2 from Papa Westra, in the Orkneys; in August $182 \mathrm{I}$ or $\mathrm{x} 822$, Fleming received a live bird which had been captured on St. Kilda; and in May I $34+$ another-now in the Museum of Trinity College, Dublin-was also taken alive at the mouth of Waterford Harbour. No other liritish specincens are in existence; but Mr. Henry livan; who has repeaterlly vinited the it. 
Kilda group, has collected strong evidence that about i $8_{4} 0$ a bird was secured on the grassy slopes of stack-an-Armin; being killed three days afterwards as a witch, in consequence of a storm which frightened its captors. Remains have been found in Caithness, Argyllshire, and some old sea-caves in Durham.

Nowhere was the (ireat Auk so abundant as in the neighbourhood of Newfoundland--especially on Funk Island, where numerous bones and even natural mummies have heen found, as well as the remains of the rude stone enclosures or 'pounds' into which--between the sixteenth and eighteenth centuries - the birds used to be driven by French and other fishermen, who afterwards salted them down for food. The Penguin or I'in-wing, as it was called (probably from the shortness of its wings and not from fincuis, fat), also frequented the coast of Labrador, and was recorded by Catesby from the waters of Carolina in winter. Passing northwards, there is no proof that the Great Auk has been obtained within the Arctic circle; or even above $65^{\circ} 20^{\prime}$, on some islands near the east coast of Greenland, now blocked by drift ice. Off the south west of Iceland, which has furnished the majority of the skins and eggs existing in collections, there were three skerries where it appears to have bred; one of these-the (icirfuglasker, near Reykjanes-disappeared during a submarine eruption in $I_{3}$ o, aftur the colony on it had been nearly extirpated; Eldey or the Meal-sack was systematically robbed until the two last birds were taken alive in June $18_{44}$; and there can now he little hope that a remnant has taken refuge on the surfencircled Geirfugladrángr. A graphic description by Professor Newton, of his rescarches and those of Wolley in Iceland, is to be found in 'The Ibis' for I86r, pp. 374-399.

The eggs resemble those of the Razor-bill in general coloration, but some of them exhibit a distinctly green tinge, as well as an approach to the scrolling observable in those of the Guillemot: average measurements $4^{\circ} 9$ by 2.7 in. About seventy of these, and seventy-seven skins or mounted birds, appear to be in existence. The food is said to have consisted chiefly of fish; and the bird's powers of swimming and diving have been described as remarkable. The note was a low croak.

As shown by the engraving, the bird in summer plumage is chiefly black above and white below; Fleming's description shows that after the autumn moult the throat and fore-neck became white. Length 32 in. ; the longest feather of the wing only +25 in. It is, of course, the incapacity for flight which has been the main cause of the destruction of this species. 


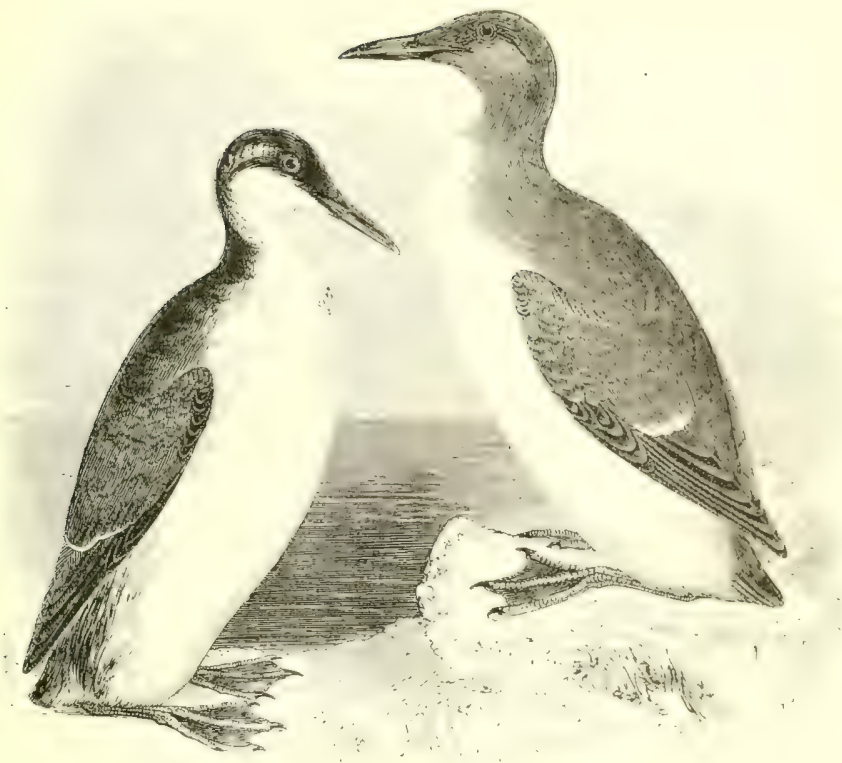

'THE COMIION GUILIENIOT.

Uria TRólle (Linnæeus).

The Common Guillemot is more numerous than the Razor-bill, which it resembles in the localities it frequents, the times of its arrival and departure, its manners, habits and food. Near Flamborough, and at other large and accessible colonies, its eggs are collected during the seanon in vast quantities; chicfly, it is said, on account of the albumen, which is used for clarifying wine and in the preparation of patent leather. Except where extirpated by persecution, settlements may be found on suitable sea-cliffs throughout the British Islands.

This species abounds in the Froes, the south of Iceland, and Norway as far east as the V'aranger-fjord: while, owing to the inluence of the ciulf Stream, it ranges northward to Bear Islanch. In the Lultic it breeds on Bornholm : there are colonies on Heligeland, as well at on the northern and western coasts of France; and Mr. Tait has recently obtained its ewg fir m the Jerlengas Islanels off the mouth of the Tagus. It seldom enters the Mediterranean, but frequents the Atlantic down to about lat. $30^{\circ}$ in winter; and on the American 
side it breeds from New England northwards to lat. $64^{\circ}$. A form with a somewhat stronger bill inhabits the North Pacific.

Like the Razor-bill, the Guillemot lays only a single egg, but this is of large size, and very variable in colour; being generally of a fine bluish-green, more or less blotched and streaked with dark reddish-brown or black: sometimes it is white scrolled with brown, and often of a plain green or white without any streaks or blotches, while a rich reddish-brown varicty is less commonly found. The form is that of an elongated pear, and the average measurements are $3.25 \mathrm{in}$. by $2 \mathrm{in}$. The bird usually sits facing the cliff, holding the egr between her legs, with its point outwards; if robbed she will lay at least one more-similar in character. Plenty of young are.on the sea by the third week in July, and by the end of August or early in september both parents and offspring have quitted the rocks for the year. In England this species is often called 'Murre' from the hoarse murmuring emitted by the multitudes assembled at their breeding-haunts; by fishermen it is known as 'Scout,' 'Marrot' or 'Tinkershere'; and the young bird is often called 'Willock' from its cry-whence, probably, the French-derived word Guillemot. ('onsiderable force is exercised in diving and the wings are used for propulsion under water.

'The adult in spring-plumage (on the right) has the head, neck and upper parts of a brown which is very variable in tint; under-surface white; bill, legs and fect blackish; webs olive. I.ength of a male about $\mathrm{s} S$ in., wing 755 ; the female being rather smaller. In winter the throat becomes white or is mottled irregularly with brown; as in the young bird on the left, which has yellowish webs to its feet.

The Ringed or Bridled (ivillemot, figured below, is now generally admitted to be a variety, with an unusual development of white round the eye and along the crease or furrow behind it.

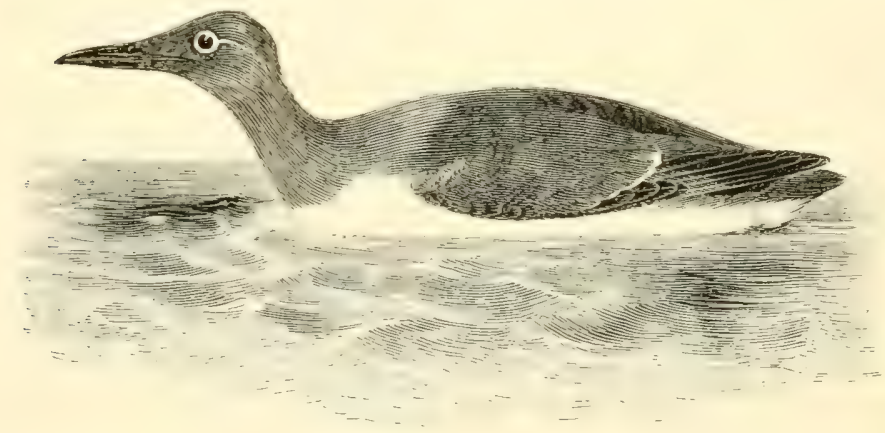




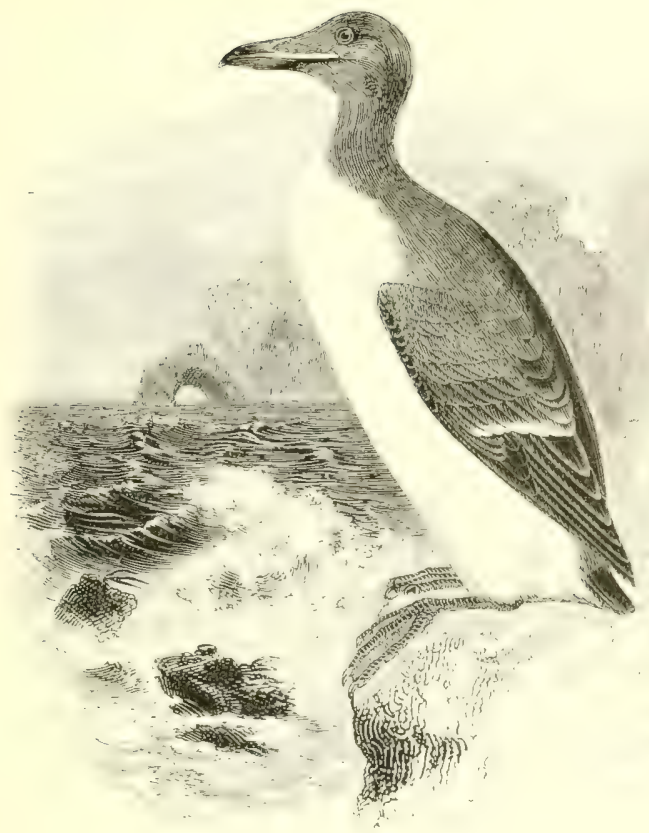

\section{BRÜNICH'S GUILLEMOT.}

URIA BRUENNICHI, E. Sabine.

This species may be distinguished from the preceding by its largur size, as well as by its stouter and deeper bill-for which reason it has been called the Thick-billed Guillemot; it is also blacker in plumage on the upper parts. It has been included in the British list upon somewhat slight eridence, for no competent obecrers have met with it on the coasts of Ireland, the Shetlands, the St. Kilda group, or in other places where it is said to have occurred. There is, however, a probability that a specimen found by Macgillivray among some skins belonging to the late Mr. Wilsom, janitor to the University of Edinburgh, was sent from the Orkneys; and also that an example was obtained off the mouth of the () rwell in sulfoll : while it is not unlikely that this species should wander to British waters, seeing that Mr. L. Hargitt's collection contains a bird whith was undoubtedly killed near Hâvre in lirance.

Brïnich's Guillemot is a straggler to the coasts of the North Sea during winter, and sometimes visits the higher latitudes of Vormay in considerable numbers: but it has not yot lecen rocosnizat in the 
Fxroes, and even in Iceland it is almost confined to the northern districts. In Greenland it breeds above lat. 6+, and Col. Feilden has described (Zool. 1878, p. 380 ) his visit to a vast colony or "loomery" in the clifis of Sanderson's Hope-over a thousand feet in height - a little to the south of Lpernavik; he also observed two individuals in August as far nurth as lat. 79 , after which this bird was not seen again until the return of the "Alert to navigable water south of Cape Sabine. It abounds on Jan Mayen, Spitsbergen ard Franz-Josef Iand, and on the open water round the last Mr. B. I. cigh smith met with it as early as the beginning of March; it is also plentiful on Norara Zemlya and throughout the Arctic Ocean as far as the waters to the north of Bering strait. In Bering Sea and the North Pacific, American naturalists distinguish a subspecies, which they call (ria ameitur arra ; but on the Atlantic :eaboard the typical form is far more abundant than the Common Guillemot as a breeding-species down to the (iulf of St. Lawrence, while its winter range extends to New Jersey.

The eggs are, as a rule, somewhat thicker and blunter than those of the Common (iuillemot, while in the green varieties that colour is perhaps a trifle more pronounced. In food and habits, so far as is known, this species does not differ materially from its congener.

The adult in summer has the beak black, with a whitish line along the citse of the uffer manditle from the nestrits to the grape; crown of the head and nape black, with a greenish gloss; remaining upper parts duller black: secondaries tipiped with white; throat and foreneck deep-brown, as in the Razor-bill; under parts white-that colour running more to a point in front of the neck than in the Common Guillemot, in which the white usually terminates in a rounded arch. I.ength of a male $\mathrm{s} S \mathrm{in}$. ; wing 8.25 in. ; the female being rather smaller. 'The dark throat is lost in winter, as it is in $U$. troile; in the young bird the bill is much smaller than in the adult.

It has recently been asserted that the type of the grenus Uria is the next species, $U$. srylle; but it appears to me that Brisson has undoubtedly indicated $C$ : troile ( $C f$. Ornithologie, vi., p. 70 ); consequently those who desire to separate the Black Guillemots must adopt Ceppluts for them. 


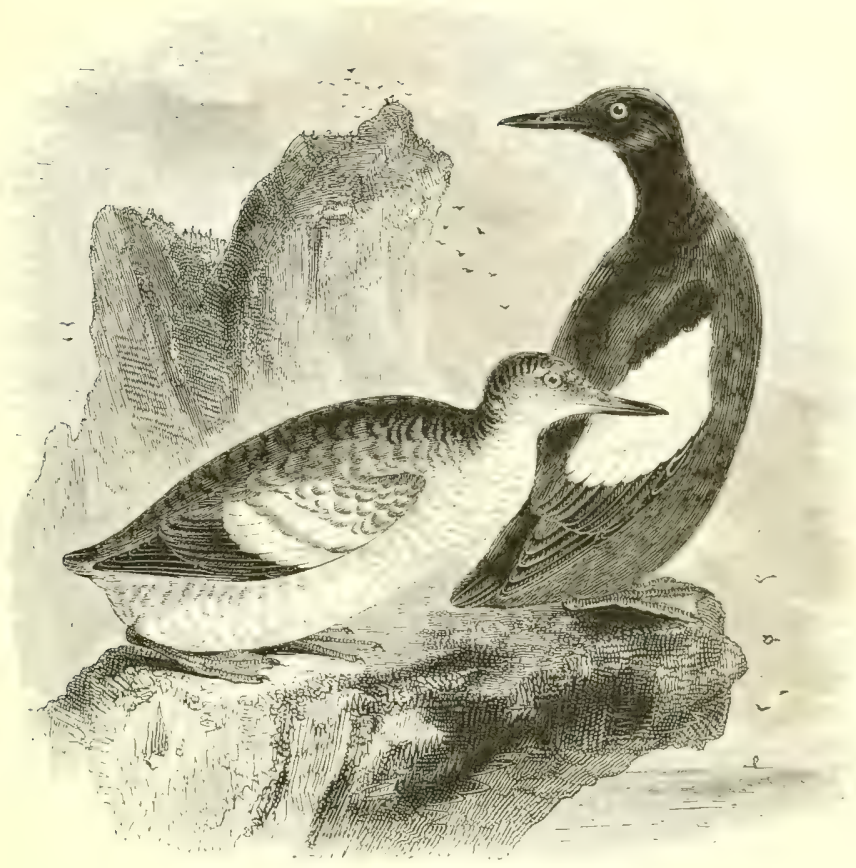

THE BLACK (:UILLEMOT.

URIA GRÝLLE (Linnæus).

The Black Guillemot is chiefly an inhabitant of our northern waters, and its occurrences on the east coast of England or as far south as the Channel are infrequent, even in winter. At the present day it is not known to breed in Wales or in Cumberland, though a few pairs still (I888) resort to the Isle of Man; but across the Irish Sea it is-or was-found sparsely on the rocky portions of cos. Dublin and Wicklow, as well as in co. Waterford, and lecomes more numerous in the western and northern districts of the sister island. In Scotland, it appears to have abandoned, of late years, some localities on the east side where it formerly nested : lut it is common about the red sandstone cliffs near I luncanshy Head in (aithnens. as well as on the west coast of Sutherland, while it may be called abundant in the Hebrides especially on the Lecrib lilands in l.wh Snizort, Skye ; it is likewise plentiful in the Orkneys and the Shetlands, where it is generally known as the 'Tystie.'

This species breeds in the Færoes, Scandinaria, I)enmark, and 
some parts of the Baltic, as well as in the IThite Sea as far as Onega ; while on the other side of the Atlantic, we find it from Massachusetts to South Greenland. 'The birds obtained by Col. Feilden in Smith sound, north of lat. $S z^{\circ}$, belong to the form distinguished as Crit mantti, in which the bases of the feathers forming the wingspot are pure white and the black has a green tinge: it abounds in the waters of sipitsbergen, Novaya Zemlya and the high north generally: This race appears to exterd to llering Sea, where it meets with $U$. wlumbu, another very near ally; while somewhat further south-ranging to Japan in winter-the representative is $U$. carbo, which has no white on the wings.

As already indicated, the Black (ivillemots have been separated from other Auks and have been placed in the genus Cepplums; and they uncloubtedly differ from other members of the family, in that they lay 2 eggs. These are deposited in crevices of cliffs or, occasionally, of old ruins, as well as on the bare ground under blocks of stone or among large boulders, sometines a hundred yards inland: their colour is white-slightly tinged with green or blue-spotted with ash-grey and several shades of brown : average measurements $2 \cdot 3$ by $I \cdot 5$ in. The yolk is of a very deep orange-red colour. The birds return to their accustomed haunts year after year, and both sexes undoubtedly take part in the duties of incubation. Dunn and saxby state, from observation in shetland, that the young never leave the nest until perfectly fledged and able: to provide for themselves: after which they are abandoned by their parents. The food is small fish and fry; crustaceans \& $\mathbb{E}$. : the cry is shrill but rather plaintive.

The adult in spring has the beak black, inside of the mouth reddish-orange; irides brown; plumage sooty-black, except a patch on the wing-coverts, which is white with a black bar--often concealedon the basal portion; legs vermilion-red. The sexes are alike in plumage; length $\mathrm{x}_{4}$, wing $6.5 \mathrm{in}$. After the autumn moult the crown is white marked with black; the back is barred with black and white, while the rump and under jarts are nearly white. The young bird, which resembles the adult in winter-dress, has the irides dark brown; bill blackish-grey; inside of the mouth pale orange; tarsi and feet deep brown; but by the end of September the inside of the mouth has changed to brownish-pink, and the legs and feet to a deeper tint; while in December the colour of these parts differs only in degree from that of the adults. By the end of June the bird has acquired its full plumage, and is undistinguishable from the adult (Saxby). Varieties are occasionally met with. 


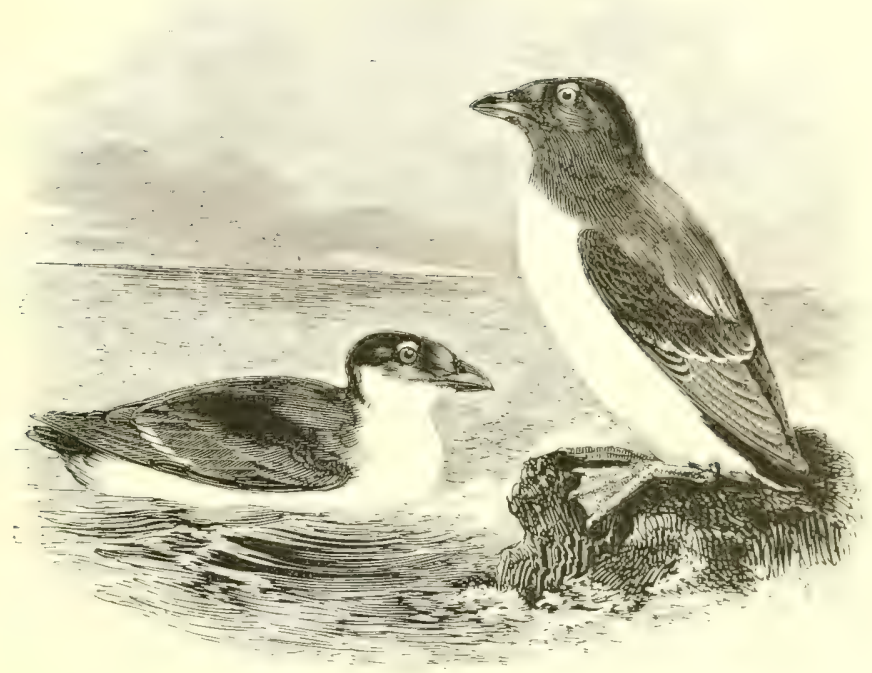

THE LITTLE AUK.

Mérgulus álle (Linnæus).

This species-also called the Rotche or Rotge, names apparently of Scandinavian origin - is a tolerably regular winter-visitor to the northern coasts of the British Islands; and, though less frequent southward, it occurs as far as the Channel; while, after stormy weather, examples have been obtained some distance up the Thames. as well as at many places inland. Birds in full summer-plumage are sometimes observed here; and on August 5th I886 I distinctly saw an adult with its young near the island of Pabbay in the Outer Hebrides, not more than twenty yards from the steamer 'Hebridean.' On the approach of a vessel this bird has a peculiar way of splashing along the surface of the water-as if unable to fly-and then diving through the crest of an advancing wave; it swims rather deep, and very much "by the stern," as Mr. Abel Chapman has remarked; so that, apart from its diminutive size, it is easily recognizable.

During the colder months the Little Auk frequents the North Sea, and the Atlantic as far south as the Azores and the Canaries: but although resident in Iceland throushout the vear, its only Lrecdingplace there appears to be on Grimsey, in the extreme north. On 
and about Spitsbergen-from lat. $73^{\circ} \mathrm{N}$. to the drift ice at $S z^{\circ}-$ its numbers are almost incredible, and Mr. B. Leigh Smith observed it as early as March on the open water off Franz-Josef Land; while it is common on the west side of Novaya Zemlya, though not known eastward of the Kara Sea. In Greenland large colonies exist from lat. $68^{\circ}$ northward nearly to $79^{\circ}$, beyond which Col. Feilden did not observe this species, nor has it been recognized in the Arctic regions to the westward of Baffin Bay ; and it is not found in Bering Sea or the Pacific. In winter it ranges as far south as New Jersey; being well known to American fishermen as the "Icebird,' from its partiality to the vicinity of bergs \&c. ; and even by August i 5 th is $S_{4}$, I passed through a flock in the Gulf of St. Iawrence, where, at that time, there happened to be an unusual quantity of ice.

The single egg is deprosited in holes and tunnels under stonesso far in that the Arctic foxes cannot reach it-or in cliffs up to 2,000 fect above sea-level: it is of a pale greenish-blue colour, sometimes faintly spotted and scrolled with red: average measurements I.9 by $\mathrm{I}^{\prime} 25 \mathrm{in}$. Col. Feilden found the nestlings just hatched on July 2 Sth; and subsequently noticed that the parents had their cheeks distended with a reddish substance, consisting of immense numbers of minute crustaceans, which were evidently food for the young; in winter the bird feeds on animal offal, and is then fond of staying close to fishing-vessels at anchor.

The adult has the beak leaden-black; the irides hazel; a small white spot over the eye; the head and upper parts chiefly black; chin and throat black in summer, white in winter, and mottled with black and white in spring and autumn : breast and belly white ; legs and toes livid-brown, webs darker. Length $S_{5} 5 \mathrm{in}$., wing $4.5 \mathrm{in}$. The young bird resembles the adult in winter-plumage. Albino and isabelline varieties are sometimes met with.

In the Southern Hemisphere there is a genus of small oceanic Petrels (Pelecanoildes), the members of which bear a strong superficial resemblance to the Little Auk in size, form, colour, and mode of flight; but on close examination, they may at once be recognized by their tubular nostrils. 


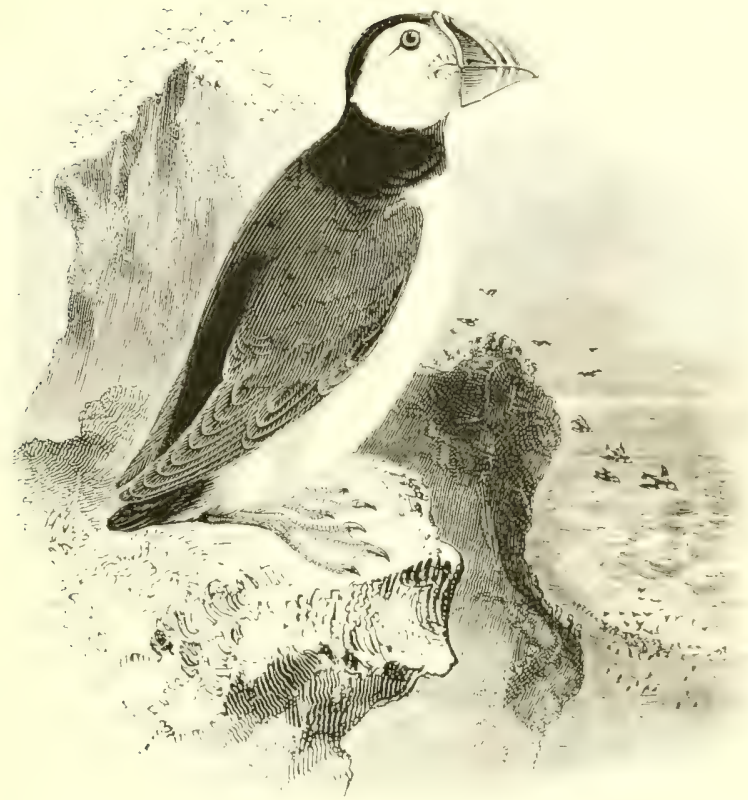

THE PUFFIN.

FratérCula árctica (Linnæus).

The Puffin is the sole representative in the Atlantic of a wellmarked genus, whose three other members are confined to the North Pacific - the head-quarters of the Alcida. Even in winter it is seldom absent altogether from British waters; while from the end of March to early in April or May-according to latitude-it begins to return to its breeding-places, which it leaves with stcat regularity in the latter part of August. At the present day comparatively few nest in the Isle of Wight, Dorsetshire, Devon or Cornwall; but numbers loreed in the sicilly Islands, and mriwh burrow in the slopes of Lundy Island, which received its name cins puffin, $c y$ island) from the Scandinavian rovers who formerly reviled there. Many haunts exist in Wales, as well as a few in the Isle of Man; but on the east side of England the cliffs near Flamborough, and some of the Farne Islands, are the only resorts known. In Scotland large colonies are very plentiful, and the swarms of birds going and coming round many of the islands in the Hebrides make the horizon quite hazy: while the sume may le sarl of the wilder parts of Ireland. During stormy weather the I'uffin 
is freguently driven far inland, and not lone ago an individual flew through an open window in Brook Street, London.

This species is the most abundant of the rock-birds which risit the Færoes, and there are vast colonies on the coast of Norwayespecially north of the Arctic circle, as well as in Iceland. A large race from splitsteren hat been distinguished by some omitholergrists as 1 : statilis: and it is probably this which occurs sparingly in Insaya Zemlya, and more plentifully on the coast of Greenland up to $70^{\circ} \mathrm{N}$. lat. Southward, our form breeds on the Atlantic coast of America down to the Bay of Fundy, misrating in winter as far as Massachusetts. Returning to kurope: we find the Puffin nestine on many of the smaller Channel Islands, as well as on the coast of France, especially in Brittany; I observed numbers off the rocky licerlengas Islands near the mouth of the Tagus, on June 8 th I868; and the bird is not uncommon during winter in the Mediterranean, as far east as Sicily.

In May a single egy is deposited in the fissure of a cliff, or at some distance down a burrow in the short turf or loose soil; it is at first of a dull white, freckled or even zoned with pale brown or lilac: but the rough srannlar shell soon becomes stained: arerage measurements 2.25 by $\mathrm{x} \cdot 6 \mathrm{in}$. Incubation lasts a month, and the ne-tlings-covered at first with black down-remain for about three weeks in their retreat: being fed with herrine-fry and other small fish, which are carried transiersely in the bills of their parents-as many as eight at a time. Marine insects and crustaceans are also eaten : the birds going out to procure food with sreat regularity, and flying long distances-sonetimes fifty miles-to obtain it. When on land they rest on the whole length of the foot and heel, and walk with a waddling gait: but they tly rapidly; and can swim and dive well. They fight fiercely, holding each other till both are drowned rather than let go. 'Sea-Parrot' and 'Coulter-neb' are among the commonest of the English local names: in Gaelic and Erse, 'Boujir.'

A detailed description of the adult in summer is rendered unnecessary by the figure: in autumn the homy frontal sheath of the bill is shed in several pieces, and the bill is consequently much smaller in winter, as well as dulier in colour. Average length I 2 in., wing 6 in.; spitsbergen examples being larger. The young bird has a smaller and shallower bill; the sides of the head are deeper grey, and the space in front of the eye is sooty-black; in some cases the dark face is partially retained when the bird begins to breed, in its third year. Albinisms are not rare. 


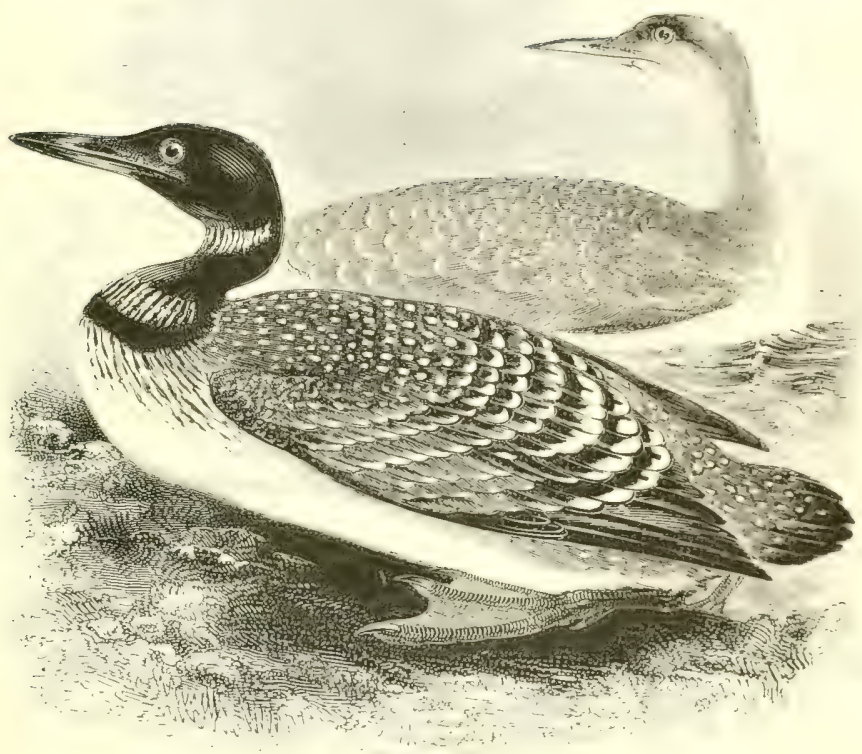

\section{THE GREAT NORTHERN DIVER.}

Colyimes glaciális, Linnæus.

This fine bird (sometimes called the Immer-or Ember-Goose) is the largest of the three Divers which are of regular occurrence in British waters. The young generally come close to the shore, and are therefore more frequently obtained on our estuaries and in our narrow seas than the adults; though these are occasionally abundant off South Devon and Cornwall, as well as in the Irish Channel and along the west of Scotland, even as late as the month of June. From the north-west of the latter, indeed, they are seldom long absent, and there are substantial grounds for believing that a few pairs have bred in the Shetlands; Saxby having seen the bird in summer on a loch in Yell, whence he obtained eggs which could not - from their size-be those of any other species: the Black-throated Diver being as yet unknown in that group. On July inth is 79 an adult flew past my boat in Sulemvoe, almost within gunshot: 
and on the 28 th, a few hours before leaving Lerwick. I was assured on good authority that a very young specimen had just been brought in alive by the 'Farl of Zetland,' a small steamer which then served the northern islands. There are many instances of the occurrence of this species during migration on lakes and meres in various parts of the United Kingdom.

In winter the Great Northern Diver is found along the Atlantic sea-board of Europe, while it also risits the Mediterranean and Black Seas: and immature birds are often found on inland waters. It is well known in the Froes and Norway from autumn to spring, but it seldom goes far up the Baltic; and in the Arctic portions of European Russia and of Asiatic Siberia its representative appears to be $C$. adamsi, the next species. In Iceland our Diver is abundant, one or two pairs nesting on nearly every lake; and it also breeds plentifully in the southern districts of Creenland: while in North America, where it is known as the Loon, it is found in summer throughout the Fur countries below the Arctic circle, and down to Maine. At Great Slave Iake it meets with C. adamsi, which is its representative to the northward and westward; in winter it ranges southward to Mexico.

The nest-always near fresh water, on a small island or the margin of a lake or pond-is usually composed of flattened herbage and moss, though sometimes the eggs are laid on the bare ground. 'These, normally 2 in number, are of an olive-brown, with a few darker spots : average measurements 3.5 by $2.5 \mathrm{in}$. A distinct track is often made by the bird's sliding and floundering progress to and from the water ; and safety is usually sought by diving rather than by taking wing. The food is chiefly fish, and a specimen has been captured in the meshes of a trammel-net 30 fathoms below the surface of the sea. The cry-frequently uttered by night-is a weird and melancholy howl; a low croak is also emitted.

The adult has the bill black; irides red; head and neck black, glossed with purple on the upper throat and with green on the lower neck; about 12 white streaks on the upper throat-band and 18 on the lower; mantle black spotted with white; belly chiefly white. Length from 30 to 33 in., wing $3_{3}-\mathrm{I}$.4 in.; males being decidedly larger than females and often weighing upwards of $8 \mathrm{lbs}$. here, while reaching 15 lbs. in America. In winter the black throat-bands are lost for a short time. The young bird has the feathers of the upper parts greyish-black, with paler margins; under surface dull white; bill brownish horn-colour. 


\section{THE WHITE-BILLED NORTHERN DIVER.}

Colymbes adanisi, G. R. Gray.

This Diver is the Arctic representative of the preceding species, from which it differs in several important particulars. The bill, which is yellowish-white at all seasons, is deeper and has the under mandible remarkably upcurved from the angle; the head and upper neck are glossed with green, while the lower neck is tinged with purple (the reverse being the arrangement in the (ireat Northern I)iver): the streaks on the upper throat-band are only 6 in number, with 10 on the lower one; the white spots on the scapulars are larger-while those on the flanks and upper tail-coverts are smaller-than in the sub-Arctic species; and finally, this high northern form is superior in size. Early in the spring of 1852 an example, which is now in the collection of Mr. J. H. Gurney, was shot at Pakefield near Iowestoft, and the late Dr. Churchill Babington has figured an immature specimen in his 'Birds of Suffolk,' believed to be from that county; while one in winter-plumage, in the Museum at Newcastle, was certainly shot on the Northumbrian coast, according to MIr. John Hancock. Some of the distinctive features of this species had attracted the attention of the late Sir James Clark Ross, who virtually discovered this bird on Boothia in I $\$_{3} \circ$, though (iray only named it in 1859 ; but until Mr. Seebohm worked out and summarized the points of difference (Zool. r884, p. I 40 ), its claims to recognition were somewhat coldly received. Other examples have doubtless been overlooked; and an unusually large bird with white mandibles, shot by Mr. E. 'T. Booth on Hickling Broad in I)ecember I 872 , may have belonged to this species.

During the breeding-season the White-billed I liver appears to be circumpolar in its distribution. It is probably this large species and not $C$. glacialis - that is found on the istand of Jan Mayen, and has been observed in splitsbergen, Noraga \%cmlya, and Mreti Russia generally. In Asiatic Siburia it was described to Mr. Sicebohm by the natives as frequenting the tumelra lakes on the lenesci, and I)r. von Middendorff states that the l)ivers he obtained on the Taimyr peninsula had yellowinh-white bills: while castward it cam be traced to Bering Sea and its islands, and to Alaska. In the 
latter it is at least predominant, but further south, as well as in the Great Slave Iake district, it meets with $C$. rlacialis; no intermediate forms being known. In winter it ranges through the North Pacific down to Japan ; while, as already indicated, it is found throughout America to the north of the Arctic circle, in summer.

No special description of the breeding-habits or eggs of this species is given by Messrs. Nelson, MacFarlane or other explorers of the Fur countries, but in all probability they do not differ from those of the (ireat Northern I)irer. The 'laugh' is said to be somewhat harsher than that of its congener. The distinctions between the two species have already been mentioned.

The form and structure of the legs and fect in these Divers and also in the Grebes - are worthy of attention; for though almost useless on land, these members are most efficient instruments in the water. The bones, which are broad and flat, are almost as thin as the blade of a knife, so that when the backward stroke in swimming is given, the whole surface of these bones and their investing membranes is brought to bear against the water: but when the leg is advanced, in order to renew the impulse, the sharp edges only are opposed to the fluid: the position as well as the partially rotatory motion reminding the observer of the action of oars in rowing when "feathered." Those who have the opportunity of examining the legs of a liver-in a recently-killed specimen, while all the parts retain their perfect fexibility-will find a beautiful example of animal mechanics. The figure below represents the form of the foot in this genus.

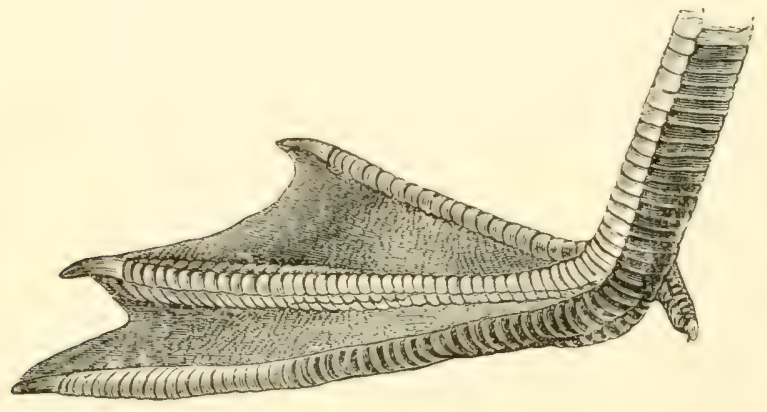




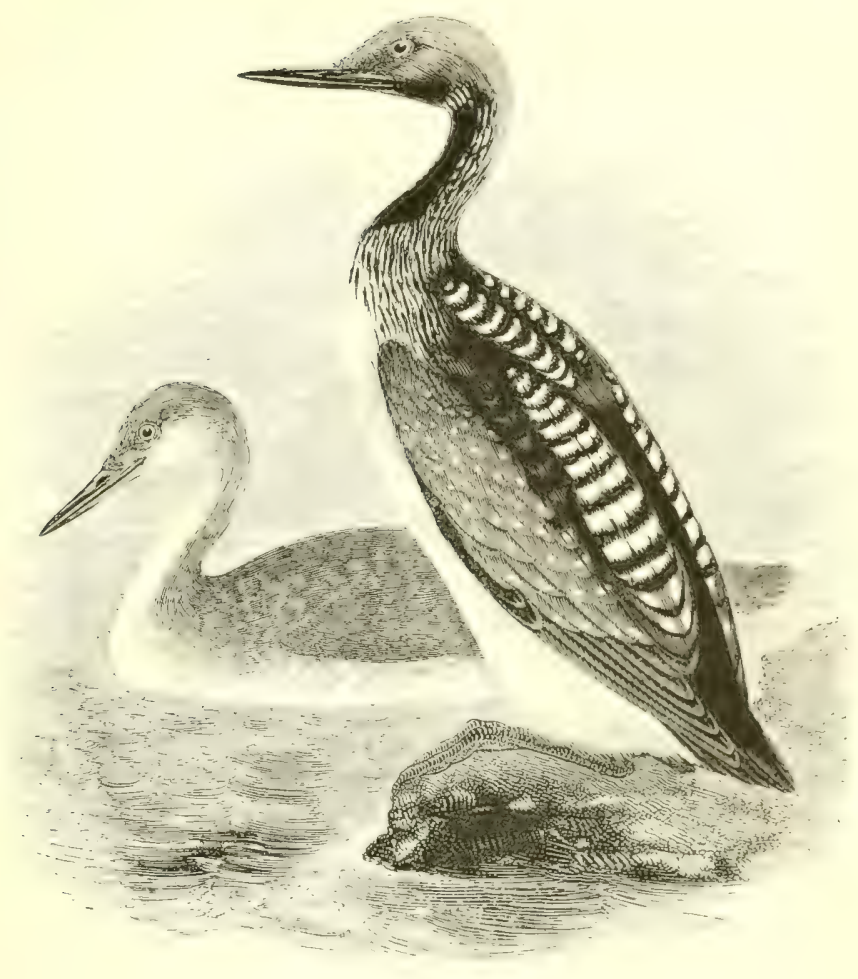

THE BLACK-THROATED DIVER.

\section{Colymbus Árcticus, Linnæus.}

The Black-throated Diver is by far the rarest of the three species which annually visit the coasts of England in winter; and the examples obtained generally prove to be immature birds, although adults are sometimes met with as far south as the Channcl, and westward to the estuary of the Dart in Devon. Few occurrences are known in Ireland at any season, though two birds with full black throats have been recorded as late as the month of April by Mr. R. Warren from the mouth of the Moy, and by Mr. L. Patterson from the neighbourhood of bellat. In Gotland, at lom. ago as $18_{34}$ this Diver was shown by Jardine and Selby to be a breeding-species in sutherland, where it is now known to be litentiful. especially in the north-west; while a pair of birds - with their nest cut out from the soil-procured in Caithness by Col. L. H. L. Irby' and Capt. S. G. Reid, fill an attractive case in the British Museum. 
Several of the lochs of Inverness-shire, Perthshire, Ross, and Argyll, as well as many in the Outer Hebrides, afford congenial summerquarters, and Mr. T. E. Buckley observed birds during May, June and July on some of the lakes of Rousay, in the Orkneys; this species has not, however, been identified in the Shetlands at any season.

In winter the Black-throated I)iver has been met with on the coasts and inland waters of the Continent down to the Mediterranean, though it is decidedly rare south of the German side of the Baltic, where it breeds. Northward and eastward it is very abundant in summer on the lakes of Scandinaria, Finland and Russia; while it ranges across Siberia to the Pacific, and risits Japan in winter. The bird which predominates in Alaska and California is considered to have passed the "incipient stage" by the authors of 'The Water-birds of North America,' who distinguish it specifically as Erinater pacificus; though they admit that our C. articus is also found in Alaska and throughout the Fur countries to Hudson Bay. It is known to range northwards to Melville Peninsula, and southward to lake Michigan in winter; but it has not yet been proved to occur in (ireenland or Iceland, and there is a doubt as regards Spitsbergen.

In Scotland the margin of a green island in some fresh-water loch is almost invariably selected; the eggs, 2 in number, being laid in May, on the bare soil or on some crushed vegetable matter; they vary in colour from olive- to russet-brown, with sparse spots of black or umber : average measurements 3 by 2 in. In the Petchora district Messrs. Seebohm and Harvie-Brown found a large floating nest, partially supported by aquatic plants. The cry is loud and discordant, the flight is said to be unusually rapid, and the food consists chiefly of fish.

The adult in summer has the crown and hind-neck ash-grey; upper parts nearly black, barred and spotted with white; chin and throat purplish-black, with an intermediate half-collar of short white streaks; sides of the neck striped with black and white; under parts white; bill black; irides red; legs and feet brown. Length about 26 in. ; wing $\mathrm{II}^{\circ} 5$ in. Females are but slightly smaller than males, and both sexes, when mature, have black throats. The young bird has the hind-neck of a much purer grey than in the immature Northern Diver, which it otherwise resembles in its general plumage; it is, however, decidedly smaller. 


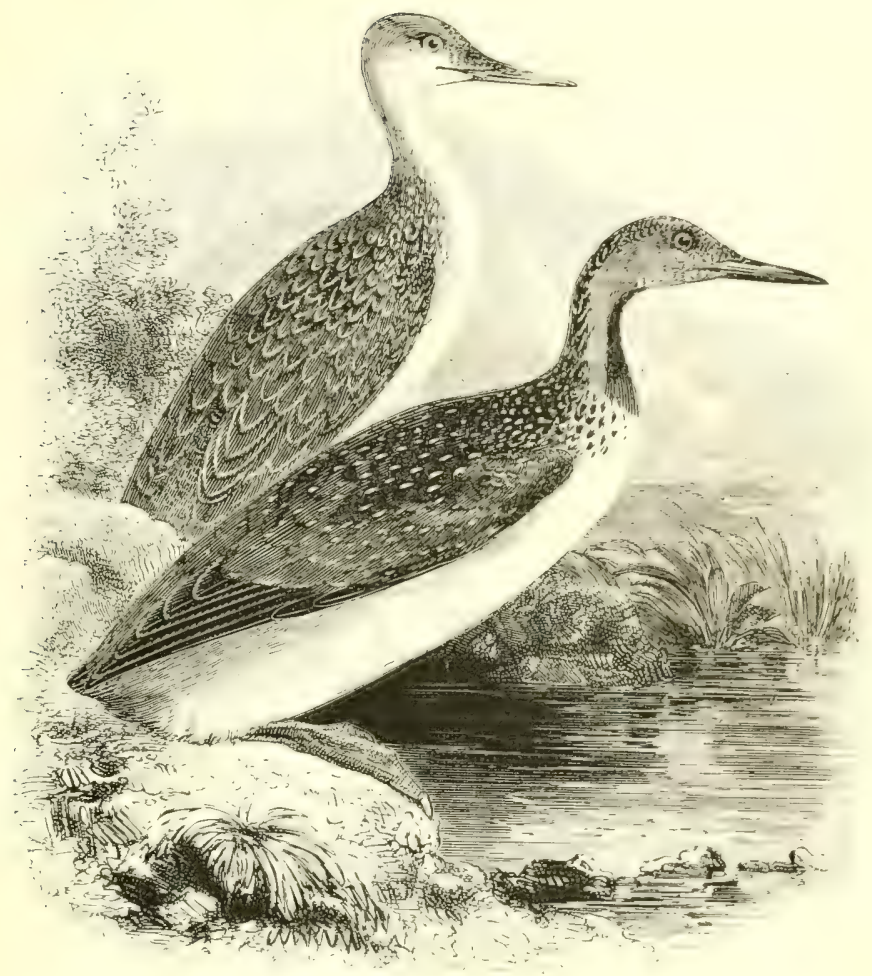

THE RED-THROATED IIIVER.

Colymbus septéntrionális. Linnæeus.

This species is the smallest as well as the most abundant member of the genus; immature birds and-in fewer numbers-adults with the white throats characteristic of winter-plumase buing found on all the coasts of the British Islands from autumn to spring. In May. examples with red throats are noticed, increasing in frequency as we proceed northwards; while in Scotland we find this Diver breeding, in variable though sometimes consideralle numbers, in most-if not all-of the Hebrides, and on the mainland from Argyllshire upwards, as well as in the Orkncyss and Shetlands. To Ireland it is a regular visitor during the cold season, and a few pairs have recently been found nesting on some of the loughs in Donegal. In pursuit of fish it frepuents estuaries and is oficn met with far up rivers, sometimes occurring on inland waters in winter as well as in summer. 
Northward the Red-throated I) iver has been observed up to lat. $S_{2}=$, while it breeds plentifully in spitsbergen, and, in a word, throughout the Arctic and sub-Arctic regrions of Europe, Asia and America. In Europe its migrations extend to the Mediterranean, Jiack and Caspian Seas, though the bird is less frequently noticed on inland waters than its congeners; and Mr. (iittite has recorded, under date of Hecember zand IS79, a wonderful passage- "almost by the million"- - off Heligoland. Fon Heuglin says that he has seen immature examples on the lagoons of Lower Egypt in winter; at which season the range of this species reaches Japan, China and Furmosa in Asia, and Maryland in America.

When breeding, this bird freguents more retired spots than the Black-throated biver, and prefers the margins of small tarns or even pools-often at a considerable elevation-to islands in a large loch. Sometimes there is a slight nest-border of heather or bents, but usually the esys, 2 in number, are laid on the bare soii or trodden-down turf, so close to the water's edge that they are often moist underneath; their colour varies from olive to pale brown, spotted with umber: and their average measurements are $2 \%, 5$ by I.S in.: in Scotland they may be found fresh from the middle of May to a month later. More than one pair of birds seldom inhabit the same piece of water: but on the l'orsanger Fjord, in West Finmark, I'rof. (collett discovered fifteen nests in half an hour, and also found that the male shares the duties of incubation. When disturbed from her eggs, the female glides into the water, and at first swims very low; then, bending her head and neck forward, disappears with a gentle plunge which hardly leaves a ripple: but I have noticed that if my stay near her nest was prolonged, she would swim high, snapping her mandibles and turning her lead with a jerky action, and occasionally stopping to drink. The note is a harsh kark, kurk, kakera, and is supposed to foretell wet or stormy weather; for which reason the bird is widely known as the 'Rain-goose.' The food consists chiefly of fish.

The adult is figured in the foreground; the sexes being alike in plumage, though the female is somewhat the smaller: average length $23 \mathrm{in}$., wing $\mathrm{II}$ in. In autumn the red throat is lost for a short time. The young bird (shown in the background) has the feathers of the upper parts edged with white. Albinos are occasionally met with. 


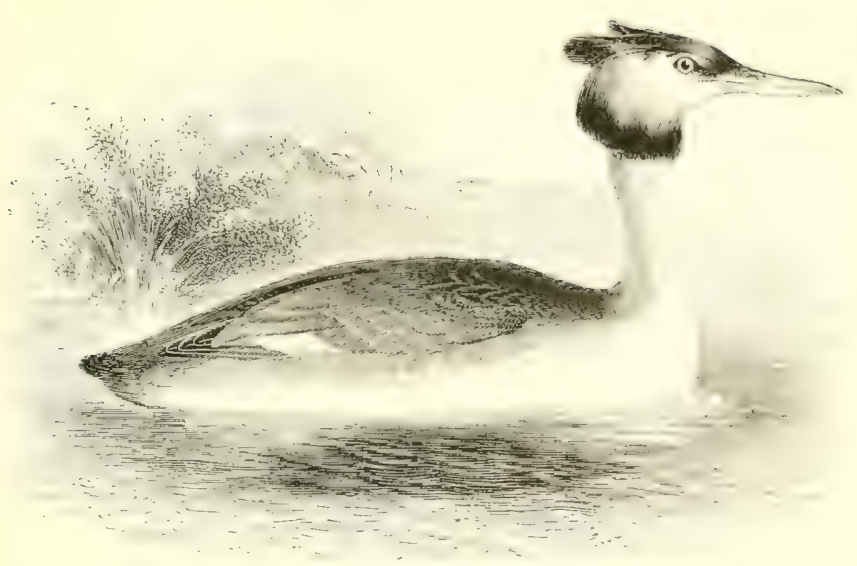

THE GRFAT CRESTED GREBE.

Podícipes cristátus (Linnæus).

The Great Crested Grebe is more or less resident in England and Wales on extensive sheets of water partially overgrown with reeds; such as the 'broads' of Norfolk, the meres of Yorkshire, Shropshire, Cheshire and Lancashire, the lakes of Breconshire, and similar localities. Northward, Mr. R. H. Read has recently found it breeding in the vicinity of the Clyde, but otherwise it is rare in Scotland, and has not been met with in the Outer Hebrides, though said to have wandered to the Shetlands. In Ireland it nests on several fresh-water lakes, especially in the district round Lough Neagh; and on many parts of the British coasts it may be met with in winter, when driven by frost from inland waters. In Norfolk it is generally called a 'Loon,' in Lincolnshire it was formerly know'n as a 'Gaunt,' and in the north-east of Ireland its name is 'MLulrooken.'

This large species is only a straggler to the Froes, and an accidental visitor to Norway; but it breeds in Southern Sweden, Denmark, and on both sides of the Baltic-becoming carcectinnly abundant in some parts of Russia, Poland and Germany. Southward, it nests in suitable localities down to the Mediterranean, as well as in North Africa, Palestine, Northern India, Central Asia, China and Japan; while it is also plentiful and resident in South Africa, some parts of Australia, and in New Zealand. It has not, however, been found in North America, where all the birds recorded as $P$. cristatus have hitherto proved to be examples of $P$. srisifisint or some other species. 
The nest is usually a patch of wet sedge or other aquatic plants floating on the surface of the water; the eggs-laid in May and seldom, if ever, mure than 4 in number-are of a chalky-white (with a green lining membrane) when fresh, but soon become ochreousbrown from contact with decomposing vegetable matter: average measurements $2 \cdot 2$ by $\mathrm{I}_{5} \mathrm{in}$. The female frequently covers them with sedge on leaving her nest. Both parents are very careful of their young, which repose upon their lacks just behind the insertion of the wings, and they feed them with young eels and other small fish, crustaceans icc. ; tadpoles and frogs are also eaten, while feathers are frequently swallowed and brought up in castings, together with fish-bones and other indigestible substances. This bird may often be seen flying, at a considerable height, like a wild duck; its note is a harsh croak.

The adult male in summer has the crown and crest dark brown; cheeks white; tipjet chestnut, blackish at the margin; upper parts dark brown; carpals and secondaries white-very conspicuous in flight; under parts silky-white. Length $22 \mathrm{in}$., wing $S$ in. Females are rather smaller, and have the tippet and crest less developed; in winter these ornaments are absent for a time in both sexes. Little crest or chestnut-colour is shown by the young until their second year. The curiously striped nestling is figured below.

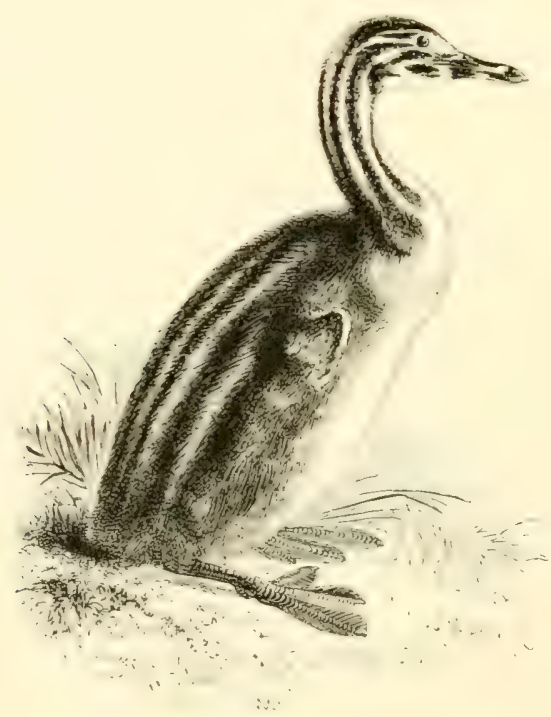




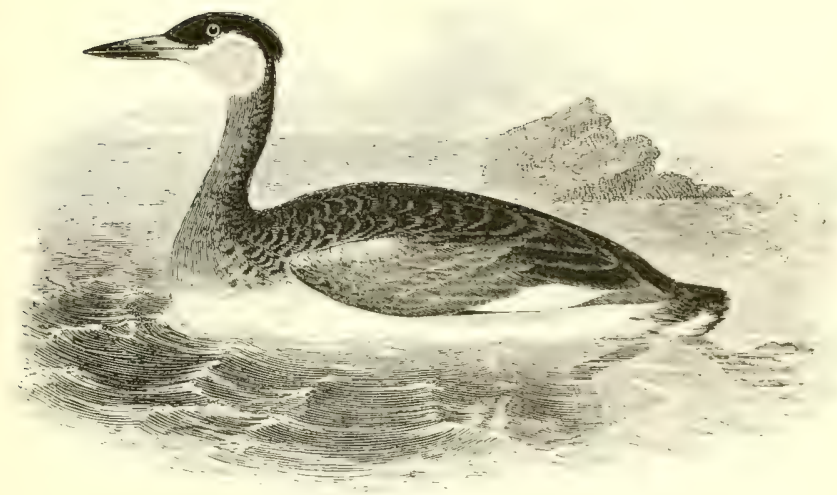

THE RED-NECKED GREBE.

Podicipes griseígena (Boddaert).

The Red-necked Grebe is tolerably common in suitable localities along the eastern coast of Great Britain from autumn to spring, and examples are sometimes obtained in breeding-plumage: lut in the Channel its occurrence is more irregular until we reach Cornwall, where, according to Rodd, this species is not unfrequently met with. Turning northwards, it is decidedly rare along the west side of England and Scotland, while as yet unrecorded from the Outer Hebrides; it has, however, been taken in the ()rkneys and Shetlands. In Ireland only five or six birds have been recognized - at long intervals - on the eastern and southern coasts.

This Grebe is resident in the southern districts of Norway; and it breeds abundantly on some of the waters of Denmark and Northern Germany, whence, however, it migrates in autumn and visits our eastern shores. It is also plentiful throughout the Iialtic. and as far north as the reedy lakes at the head of the Gulf of Bothnia; while in Russia it is found nesting from Irchangel to the Black and Caspian Seas. Over the rest of Europe it is chiefly known as a migrant, ranging as far south as the Mediterranean: yet it visits North Africa, and in Norocco Col. Irby has seen birds so young that they must have been reared in that country. In Asia it appears to be found as far east as Turkistan, where-acomeling to Severtzoff - it meets with a larger form, distinguished hy some ornithologists as C. Molboelli; this race inhabits Eastern Siberia, the North Pacific, North America in general, and (ircen- 
land-where it was first discriminated by Reinhardt. A bird obtained in Iceland in Iecember I $S S_{5}$ probably belongs to this form.

The nest is a floating structure similar to that of the preceding species, in the company of which the Red-necked Grebe may often be found breeding in Northern Germany; the eggs are dull white, and elliptical in shape, as are those of all the members of this genus : average measurements 2 by $\mathrm{r}_{3} 3 \mathrm{in}$. The note is said to be somewhat louder than that of its larger congener, which this bird resembles in its general habits, diving-powers and food.

The adult has the bill dark horn-colour, yellow at the base; irides yellowish-white: crown, nape and hind-neck blackish; feathers of the cheeks, chin and throat grey, with white margins which form a strongly contristed streak lilliw the eye ; upper parts dark brown, with a conspicuous white patch on the secondaries; neck in front rich chestnut-red; breast and belly silky-white. l.ength $16.5 \mathrm{in}$, wing $;$ in. In winter the throat is greyish-white; as it also is in young birds, which are duller in general colour.

The figure below shows the form of the foot in the Grebe.

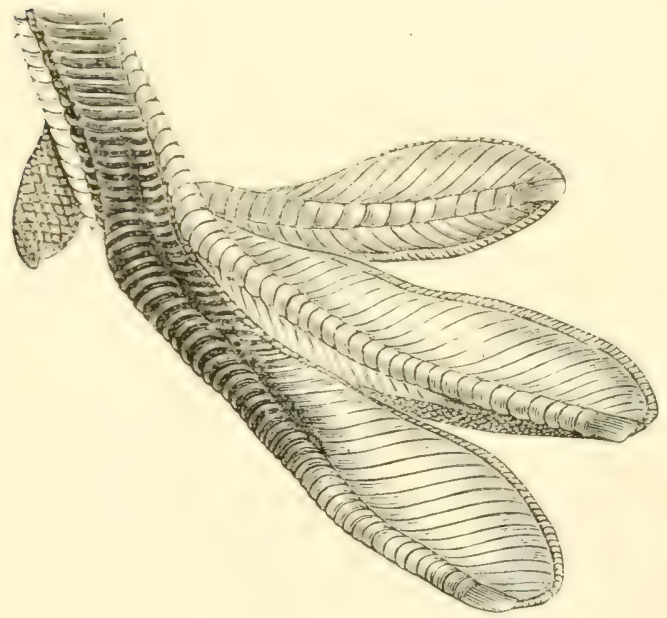




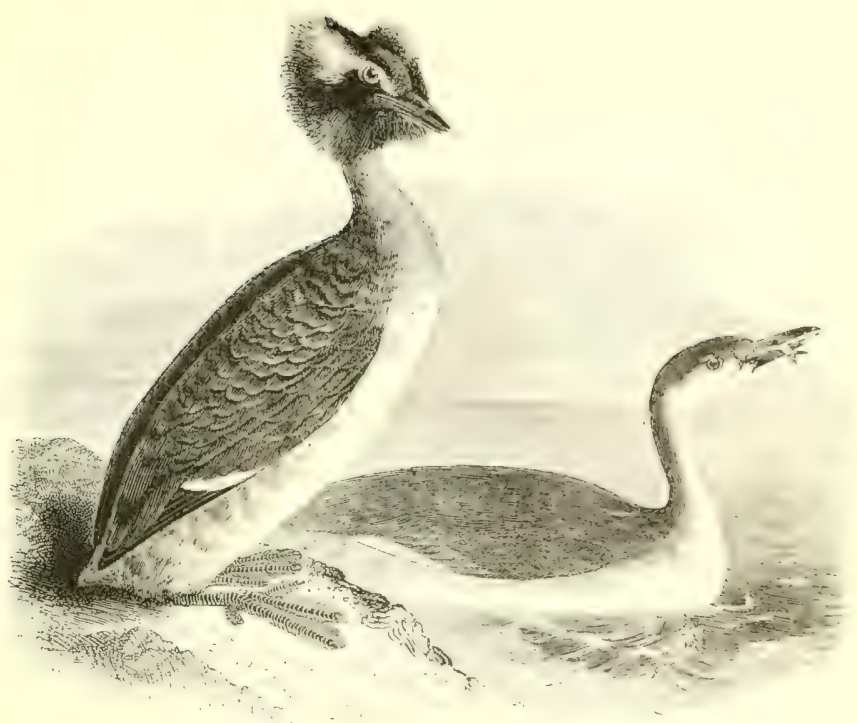

THE SLAVONIAN OR HORNED GREBE.

\section{Podicipes aurítus (Limneus).}

The Slavonian Grebe is a northern species, and its occurrence on the southern and western coasts of England is irregular even in winter; but on the east it is frequently met with from autumn to spring, especially in Norfolk and at the mouth of the Humber, as well as further north. In Scotland it is generally distributed on both sides, and in the Hebrides, Orkneys and Shetlands it is even common; while there can be no reasonable doubt that one or two pairs have been in the habit of nesting. for many years past on some fresh-water lochs near Gairloch in Ross-shire, where the birds have been watched by Messrs. E. T. Booth, John H. Dixon, H. E. Dresser and others. According to MIr. A. G. More, this Grebe is a regular winter-visitor to Ireland, in small numbers; but Mr. R. Warren has seldom observed it on the estuary of the Moy, in the west.

This species is only found in the Færoes on migration, but it breeds regularly in Iceland. Scandinasia and Russia, and sprarily in Denmark; while in the coller menths it is known throughut the rest of Europe, down to the Mediterranean, where, however, it is rare. In Asia, it ranges across Siberia to Japan, and about as far south as lat. $24^{\circ}$ during the cold season; in America, it is common 
in Alaska and throughout the Fur countries in summer, visiting the northern portions of the Lnited States in winter, and occasionally wandering to the Bermudas. Young birds have been met with in the southern part of Greenland.

The nest, which is rather large and floats on the surface of the water, is composed of reeds and other aquatic plants; the eggs, $2-4$ in number, are of a bluish-white colour when first laid, though they soon become stained : average measurements I'75 by I'25 in. The female dives with the young under her wings, and Proctor observed that the position of the nestlings was with their heads towards the tail of the parent bird, their bills resting upon her back. Messrs. Slater and Carter repeatedly noticed the adults swimming under water after leaving the nest: their legs-being practically terminal instead of lateral memlers-giving them somewhat the appearance of large frogs. The food of this species is similar to that of its congeners.

The adult in summer-plumage (figured on the left) has a tuft of clongated pale chestnut feathers on each side of the head; crown, forelead, chin and tippet black : upuer parts dark brown ; secondarics chiefly rithite, inctht the thrie cuter anes, whith are mainly dusky, like the primaries; neck, breast and flanks warm chestnut; belly white; bill straight, nearly black, except the tip which is whitish; irides red; legs and toes dark ureenish-brown cutside, ycllower on the inner surface. I.ength 13.5 in. ; wing 5.5 in. The male is the larger and has more dereloped head-ormament;, but otherwise the sexes are alike externally. After the autumn moult the irides are paler, the crest and tuft are absent, and the under parts are chiefly white, the throat and flanks being streaked with dusky-grey. The young resemble the adults in winter-plumage.

It is unfortunate that the specific name auritus, which Linnaus undoubtedly used for the Slavonian Grebe, should have been diverted by Latham and others to the next species; thereby causing great confusion. 


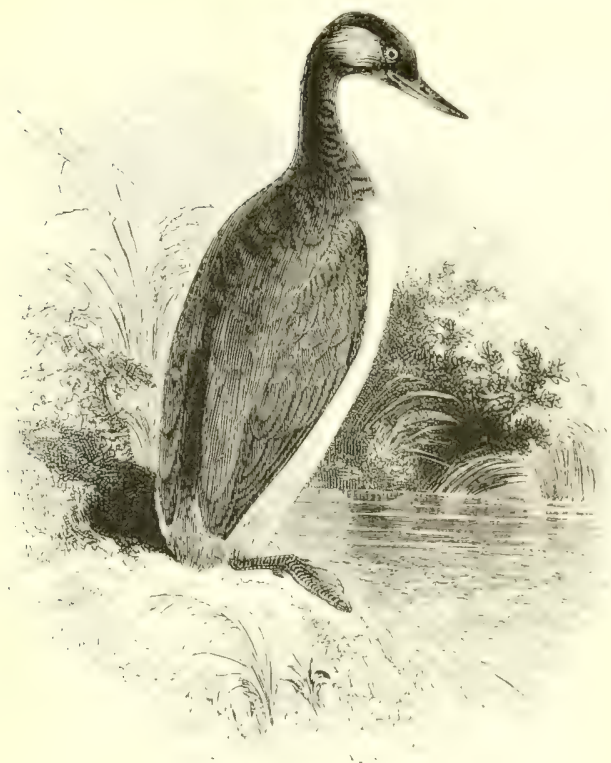

\section{THE BLACK-NECKED OR EAREI GREBE.}

Podicipes nigricóllis, C. L. Brehm.

This Grebe is rather smaller than the preceding species, and is its very opposite as regards distribution; for this is essentially a southern bird which occasionally pushes its migrations in spring and summer as far to the north-west as the British Islands, while it also visits us - though far more rarely-in autumn and winter, to escape the severe cold of the Continent. Birds in complete breeding-dress have been obtained, at intervals, in most of our southern counties, and rather plentifully in suffolk and Norfolk: there is, indeed, strong presumptive evidence that the species hats bred in the latter, for MIr. F. T. Booth had "a full-pllumaged adult and a couple of downy mites" brought to him by a marshman some years ago ( $C f$. Tr. Norfolk \& N. Nat. Soc. vol. iv. p. 4i6, footnote). As we continue northward, we find this Grebe becoming scarcer, though it can be traced to the Orkneys; but on the west of scotland the only authenticated occurrencen appear tor be these of an adult on Loch Sunart in the spring of I $\$ 66$ and a pair shot at Castledykes pool on the Nith. A few instances are on record from Cumberland, and one from the Isle of Man, but the bird is undoubtedly rare on the west side of Ingland; while in Ireland (wo) 
examples in full plumage have been obtained in June, and a few birds appear to have been met with during the colder months.

The Black-necked Grebe is merely a wanderer to the southern portions of Scandinavia; but as regards I enmark, Benzon assured Mr. I)resser that it bred regularly near Thy, in the north-west of Jutland, though neither P'rof. Lütken nor Mr. Oluf Winge confirm this statement. Southward it is found nesting in suitable localities throughout the greater part of Europe, becoming abundant in the countries bordering the Mediterranean and Black Seas; it is even more plentiful in North Africa, and ranges southward to the Cape; while in Asia it is widely distributed over the temperate regions as far as the Piacific. and down to about $22 \mathrm{X}$. lat. in winter. In North America it is represented by a closely-allied but distinguishable species, I'. arlifurmizus, which has hardly any white on the innermost primary and little on the two first secondaries. Neither species is found in Greenland, but Mr. P. (iröndal insists that the true Blacknecked circbe as well as the slavonian-has occurred in Iceland.

Canon Tristram found this species on Iake Halloula in Algeria, "in socicties more densely crowded than any rookery"; the nests being "raised on artificial islets, frequently almost touching each other, and sometimes piled on stout foundations rising from more than a yard uncler water." Lenzon states that in I)enmark the nests were not floating amongst the reeds, but were on tussocks at the edge of the lake, though in places where the water was deep and clear; they were made chiefly of "moss" [sic], with which the female covers up her egss on leaving them. These are originally yellowish-white, but are often stained dark brown : arerage measurements 1.65 by $I^{\circ} 15$ in. The note is described by Naumann as a soft lich or-in the parring season-lidder, reiterated; the food consists of fish, crustaceans, coleopterous insects \&c. The late Mr. (iatcombe told me that he had seen this Grebe and others dive with a leap when in deep water, as a Shag does.

The adlult in summer has the head and neck black, with a triangular patch of long hair-like feathers of a golden chestnut colour on the ear-coverts; upper parts dark brown; sciondaries almost entivily white to their tips, while there is also a great deal of white on the fonr inner frimarie's; breast and belly white, flanks dull chestnut; bill black, upcurved in front of the angle. Whole length $12 \mathrm{in.}$; wing 5 in. After the autumn moult the ear-tufis and black on the throat are lost, only a dusky hand remaining on the latter; the plumage of the young resembles that of the adults in winter. 


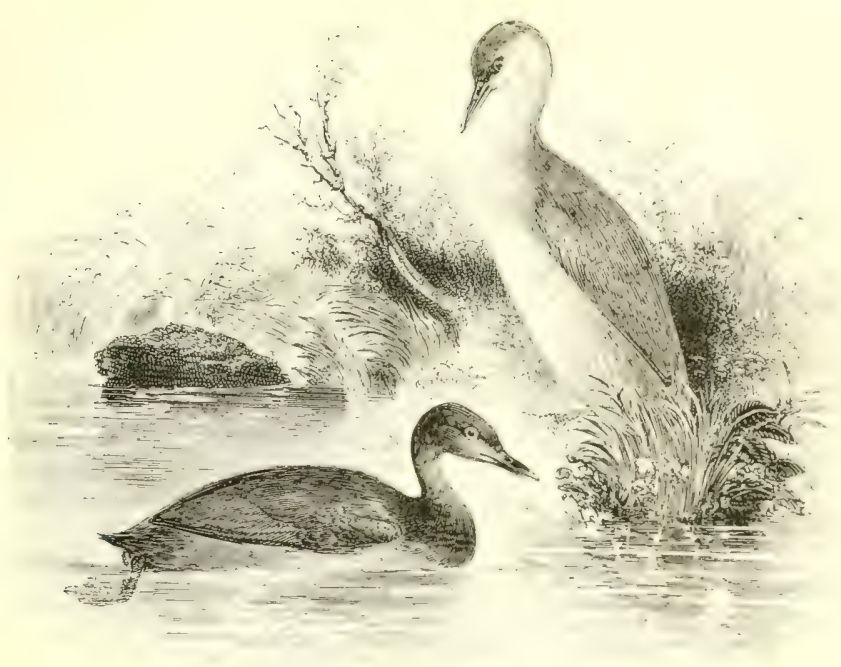

THE LITTLE GREBE.

Podicipes fluviátilis (Tunstall).

This species-familiarly known as the Dabchick-is generally distributed and resident on the reedy streams, lakes and ponds of England; it may even be found nesting on some of the omamental waters of London, notably in St. James's Park. In Scotland it is less plentiful, though found northward to the Shetlands and westward to the Outer Hebrides, while it breeds up to an elevation of 2,000 feet or even more in the Highlands; it is, hovever, more frequently noticed in winter, when there is less chance of concealment, and when the freezing of inland waters drives it to the coast. In Irelund it is common.

The Little Grebe is seldom met with in the Froes and has not yet been recorded from Iceland; while, though Norway is unker the influence of the Gulf Stream, its range there does not entund above lat. $62^{\circ}$. On both sides of the Baltic it is rare, even in summer; but it is of tolerably general distribution wer the ret of the Continent, and it is resident in the south; as well as in North Africa. The same may be said of South Africa and Madagascar; temperate Asia, as far west as China and Japan, and the country southward to Ceylon and Burma; the Malay archipelago and Northern Australia. In the south of the latter and in New Zealand, as well as in North America, it is represented by wther sperici: 
The nest-which is somewhat large, considering the size of the bird-iscomposed of and moored to aquatic plants; and in it from 4-6 eggs are deposited between April and August; two clutches being cften produced in the season. Their colour is white, until stained adventitiously; and their average measurements are $\mathbf{r} \cdot 6$ by I in.; the sitting bird, on leaving the nest, covers them with weeds plucked by her bill. The food is usually small fish, insects and vegetable matter, but in winter marine animals are often consumed. Like other Grebes, this species swallows feathers; while it carries its young on its back, as already described. The note is a whit, whit.

The adult in summer (represented swimming in the foreground) has the head, neck and upler parts dark brown; very little white on the secondaries; chin black; cheeks, throat and sides of the neck reddish-chestnut; under parts chiefly greyish-white; flanks dusky-brown; bill hurn-culour, yellowish-green at ihe gape; irides reddish-brown; legs and toes dull green. Length $9^{\circ} 5$; wing $4^{\circ} 25 \mathrm{im}$. In winter the chin is white, and the head and neck are ash- or clove-brown, the general colour being paler. The young are still lighter in tint.

In 'Research' for January ist i\$S9, Mr. R. Newstead, curator of the Chester Museum, called attention to some interesting points in the anatomy of this (ircbe and some others. The fibula is not fused to the tibia, but is connected with it along the whole length by a very strong ligament, so that by taking hold of the foot the tibia can be made to rotate; while there is a perforated and grooved bone at the back of the tars()-metatarsus, which has three perforations and carries eight tendons. For diagrams illustrative of the above I am indebted to I)r. W. H. Dobie, of Chester.

An example of the American Pied-billed Grebe (Podilymlus podiceps)-so young that it exhibited longitudinal stripes on the neck-was exhibited by Mr. R. Bowdler Sharpe at the meeting of the Zoological Society of London on June 2 ISt I $S S I$, and was stated to have been killed near Weymouth in the previous Fanuary! (See Mr. J. F. Harting's remarks in 'The Zoologist,' I SS I, p. 334.) 


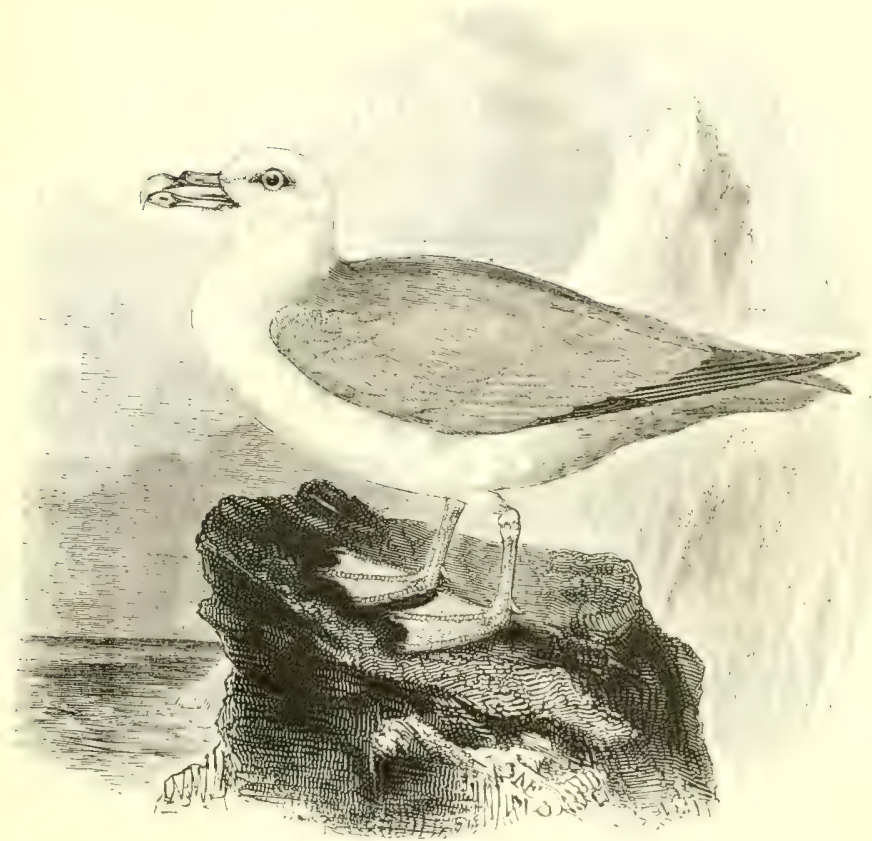

'THE FULMAR.

\section{Fúlaarus glaciális (Linnæus).}

This Petrel is seldom met with near the southern and western coasts of England except during the colder months, and even then chiefly after tempestuous weather, when it is sometimes driven far inland; but on the fishing-grounds about thirty miles off the east coast it is by no means uncommon, and, when the herring-nets are being hauled, birds are sometimes taken by the hand, owing to their voracity. In Ireland few examples have actually been obtained, but I have seen plenty within eight hours' distance (by steamer) of Lough Foyle, when going to and returning from America. In Scotland the Fulmar is frequently observed in winter; it has long been known to breed in the St. Kilda group, while recent evidence points to the establishment of colonics on the Flannans and North Ronay; and in the Shetlands, since June 1878 it has nested on Foula, where it appears to be increasing.

In the Feroes, where the fulmar wats first noticed as a breedinsspecies about $\mathrm{r}_{3} \mathrm{y}$, it is now common. Si) far, all the birds foumel 
nesting have white under parts, and their young in first plumage resemble them-as I pointed out in 'Yarrell,' vol. iv. p. 5, as long ago as $I S S_{4}$; but northward, a form with greyish under parts is also observed, and the two forms are distributed in a somewhat perplexing manner. In Iceland-where the species is very common-the grey race is said to predominate at Grimsey and in the rorth; the same is the case on the wertern side of Davis Strait and Baffin liay, though at Ovifak in (ireenland the light-breasted bird nests in myriads; round Spitsbergen both forms are numerous; and one or both are found on Novaya \%emlya and Franz-Josef Land, though neither can be traced castward of the Kara Sea. In Bering Sea and the North Pacific again, we meet with a light and also a very dark variety, which American ornithologrists distinguish sub-specifically. In winter the Fulmar has been met with about as far south as lat. $43^{\circ}$ in European waters, while in America it is well known on the fishing-banks off Massachusetts and Mainc as the 'Noddy.'

The single egg is laicl an a ledge or in a slight excavation on the grassy sheli of a lofty cliff: its shell-which is roughly granulated and has a strong musky smell-1s at first pure white, with occasionally a few minute reddish-bruwn spots: average measurements 2.9 by 2 in. Large numbers of birds are annually taken by the St. Kildans, who make use of the clear amber-coloured oil which the bird vomits on being seized, and with which it nourishes the young. The Fulmar is a constant attendant on whalers, sealers \&c.-who know it as the "Mollimoke" -in orkler to obtain fatty substances and animal offal ; but I never saw it take any while on the wing, and it always settles on the water to feed. like an Albatross. The pinions are often flapped slowly in an owl-like manner, but in scudding they are held very straight-a peculiarity by which it may easily be distinguished from a Gull at a distance. I have recently seen a statement that the Fulmar "is supposed to be one of the most numerous birds in the world "; but I am not aware of any valid foundation for this belief.

The adult has the front part of the bill yellow, sides yellowishwhite, tubular ridge olive-colour; mantle and tail grey, quills dusky; head, neck and under parts usually white in European specimens, but of varying shades of grey-as already observed-in many northern examples, some of these being occasionally obtained in the British Islands; legs and feet ash-colour. Length 19 in.; wing $12.5 \mathrm{in}$. The young bird is slightly smaller and has a darker bill; that part is also darker in the grey form. 


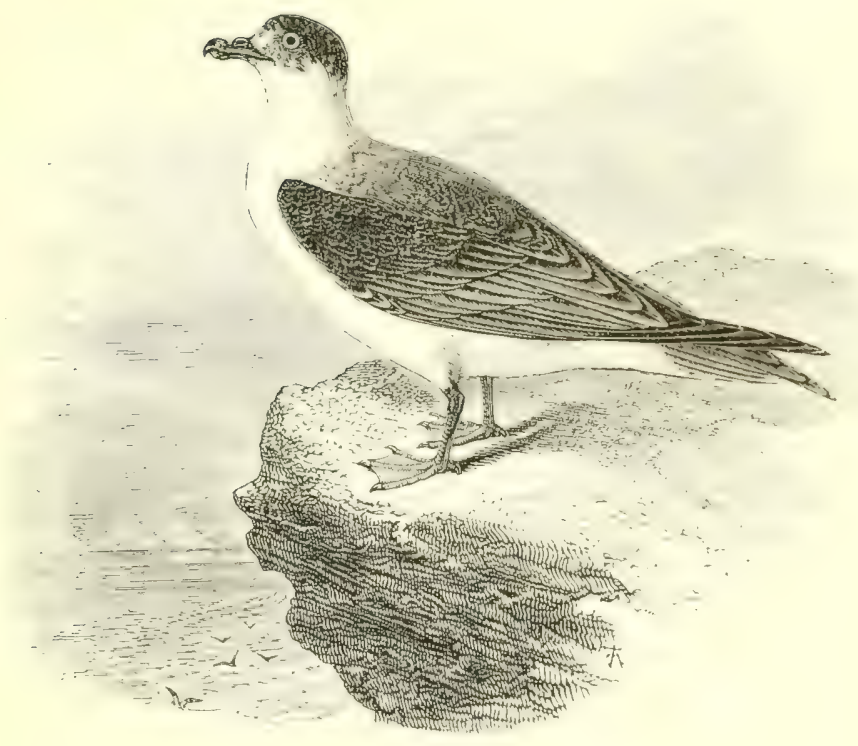

THE CAPPEI) PETREL.

CEstrélata hesitáta (Kuhl).

The subject of the illustration was observed by a boy in March or April 1850 , on a heath at Southacre, near Swaffham in Norfolk, flapping for some time from one furze-bush to another, until it got into one of them, and was secured; when, although exhausted, it had strength enough remaining to bite the hand of its captor, who thereupon killed it. The late Mr. Newcome, of Hockwold Hall, near Brandon, fortunately happened at the time to be hawking in the neighbourhood of Swaffham; and his falconer, John Madden, observing the boy with the dead lird, procurcel it from him, and brought it to his master, by whom it was skinned and mounted, and in whose collection it found a place. A detailed account of this bird, with two illustrations, is given by l'rofessor Newton in 'The Zoologist' for 1 $852, \mathrm{p} .3691$.

In the Museum at Boulogne there is a Capped Petrel said to have been shot near that town many years ago by its donor, a sportsman long since deceased; and Mr. W. Eagle Clarke has identified a specimen in the linda-P'esth Muscum which, actording to Dr. Madarász, was killed near Zolinki in North Hungary in I 870 ; but in neither case can the pedigree be considered quite 
satisfactory. No other occurrences are recorded from Europe, and in fact little is known of the distribution or head-quarters of this species. An example from Hayti is in the British Museum; Paris luas three obtained by I:Herminier in the island of Guadaloupe, where, however, Mr. Ober failed to rediscover the bird; there is a fourth in Paris and a fitth is in Leiden, from unknown localities; while in the United States a wounded individual was picked up on a salt lagoon on the east side of Florida in $1 S_{f} 6$, and another was shot on Long Island in July i 850 , after a severe storm.

It is almost unnecessary to add that we have no information respecting the breeding-habits of this species, but it probably resorts to burrows in the mountains of tropical islands. Many of the Petrels appear to frequent the land merely for the purposes of reproduction, after which they disperse over the ocean and can seldom be obtained or identified: while their breeding-seasons seem so little subject to rule (within the tropics) that the best period for search cannot be laid down. In case any of my readers should ever have the opportunity of landing on any of the small islands nearest the coast of Brazil known as Trinidad, Martin las Sc., in about $20^{\circ} 30^{\prime} \mathrm{S}$. lat. and 20) 11 . lone, they will probably make some interesting discoveries in Petrels, even if they do not meet with this particular species. It is no doubt nocturnal in its habits.

The adult has the beak black; crown and nape dark brown, cheeks and ear-coverts reyer; mantle dark brown; rump and tailcoverts white; central tail-fuathers chiefly brownish-black, the rest more or less white on their basal portions, but broadly edged with brown; forehead and under purts white; legs and feet duskyyellow. Length i 6 in., wing 12.25 in. The immature bird is believed to be mottled with brown on the forehead and to be duller in tint on the upper parts.

An example of the Petrel familiarly known as the Cape Pigeon (Daption cafonsis), is recorded by Mr. A. G. More (Ibis, ISS2, p. $\left.3 f^{6}\right)$ as having been shot near I) ublin on the zoth October I 88 I ; and Degland and Gerbe state that three specimens have been obtained in France. There does not, however, appear to be any adequate reason for including this species among the Birds of Great Britain, or even of Europe, for its home is essentially the southern hemisphere; and although it is known to follow ships, for the sake of food, for a considerable distance, yet it is equally certain that many birds, captured with hook and line, are then carried far beyond their usual area before being restored to liberty. 


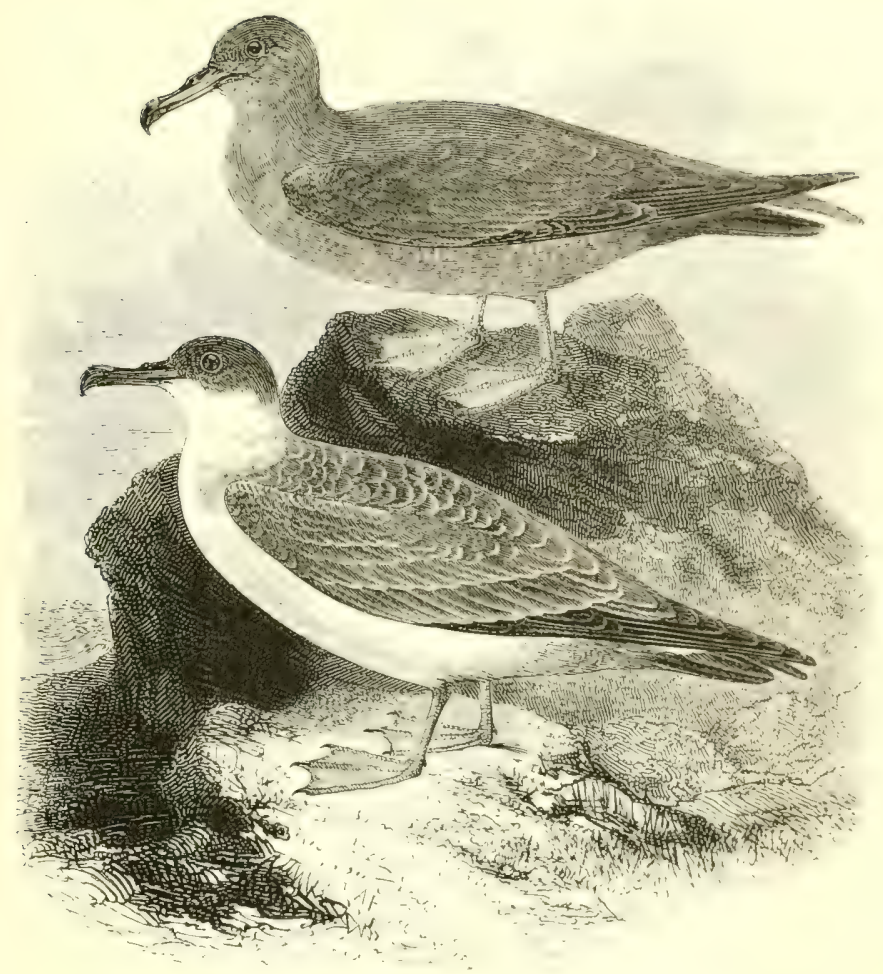

THE GREAT SHEARIATER。

Puffínus Mujor, F. Faber.

The Great Shearwater-represented by the lower figure in the illustration-is an irregular autumnal visitor to the British coasts; sometimes making its apjearance in considerable numbers from August onwards off Cornwall and the sicilly Islands, where it is called the 'Hackbolt.' It is also not unfrequent near I)evon and Dorset, and in the latter it has been obtained as early as the month of June; but on the east coast it is comparatively rare, though, according to Mr. Corleaux, many were seen off Flamborough in September I881. In Scotland, the Rev. H. A. Macpherson found a dead bird at I.owersill in Skye, on July $\mathrm{r}_{3}$ th 15.55 : and I saw a large shearwater-probally this species-in the sound of Harris on August 6th i 886. On the shores of Ireland it has been captured on sereral occasions. and under the name of "Ha: 
down' it appears to be well known to the fishermen, who sometimes take it with a hook.

Mr. (siitke informs me that a flock occurred off Heligoland many years ago, since which time he has only obtained a single example; but this species has seldom been noticed in the Faroes or Iceland; howerer it undoubtedly visits the south of Greenland, though Reinhardt was mistaken in supposing that it bred there. Capt. J. IV. Collins state's that it arrives on the fishing-grounds off New England and Irritish North America in . Lay, remaining there till October or November-according to the time of the first snow; and, although in the course of thirty years experience in taking these birds for hait he must have seen thousands opened, he never found one which slowed any signs of breeding. It traverses the Atlantic and pro. bably resorts to some of the islands in the southern ()ean for the Iurposes of reproduction: specimens having been obtained at Tierra del Fueso, and also near the ('apie of (rood Hope. In the Azores, as well as on the islets near Madeira and the Canaries, the resident species is $I$ '. Kuhli (identical with $I$. buralis of Cory), which visits the western coasts of France and the Peninsula, and is abundant throughout the Mediterrancan; the latter species is of a much paler brown on the upper parts, and has a yellow-coloured and deeper bill.

Nothing is known of the nidification of the (ireat shearwater, for the egg from the Madciran lesertas figured by Hewitson is that of $P$. Kullit. The food consists chietly of squid, and Mr. Gurney found the horny jaws of small cuttle-fish in the stomach of a bird shot near Flamborvugh ; but any animal substance is greedily swallowed, and, as already mentioned, this species is systematically taken with a hook to furnish bait for fisl. When alighting it strikes the water with great violence-in a manner quite different from that of a Gull--and then dives; pursuing its jrey under water with great rapidity, and often tearing bait from the fishermen's hooks. When crossing the Atlantic it may be seen skimming the surface of the water without any apparent effort, alternately poised on either wing; but at times it flaps its pinions freely.

The adult has the bill dark brown; head and nape ash-brown; neck whitish, when fully extended in Hight; feathers of the mantle ash-brown with paler edges; quills and tail-feathers blackish; tailcoverts mottled brown and white; under parts white, with some pale brown running up the centre of the abdomen and on the thighs; legs and feet pinkish-white in life, drying yellow. Length i 8 in. ; wing $\mathrm{I}_{3}$ in. 


\section{THE SOOTY SHEARWATER.}

Puffinus gríseus (J. F. Gmelin).

The Sooty Shearwater-represented by the upper figure in the woodcut on P. 7I5 - was until recently considered to be the young of the Great Shearwater, and there is consequently great difficulty in saying to which of these species many of the earlier records refer. Identified examples have been obtained-in our summer and autumn - at North Berwick in sicotland and along the cast const of England, especially off Yorkshire; while several have been taken in the Channel as far west as Cornwall, though the bird is evidently less abundant there than its larger congener. In Ireland specimens have been secured on the coast of Kerry and in Belfast Lough, while others have been observed.

This species visits the northern coasts of France, and has oc. curred more than once in the Færoes. It is generally distributed over the North Atlantic, and is well known as the 'Black Hagdon' on the North American fishing-banks, where, however, Capt. Collins says it is far less plentiful than the Great Shearwater. Like the latter, it has its breeding-haunts in the southern hemisphere, and it is from the Chatham group and New Zealand that we derive our imperfect knowledge of its nidification; while, in the Pacific, it ranges northward to California and the Kuril Islands during the summer.

According to the experience of Mr. Travers in the Chatham Islands, this species makes a burrow in peaty ground-rumning horizontally for about three or four feet and then turning to the right or left; while a slight nest of twigs and leaves at the extremity serves as a receptacle for the single white egg. The dimensions of the latter appear to be about $2^{\circ} 6$ by $I^{\prime} 7$ in., but there are sereral closely-allied Petrels which breed in those parts, and it is not yet quite certain that the veritable egg of this species has been measured, though numbers must have been taken. The male assists in the work of incubation, and the young birds, which are very fat, are esteemed a delicacy by the Maories, who hold them over their mouths in order to swallow the oily matter which is dis- 
gorged. The old birds roost on the shore, and are very noisy during the night. The food of this species is probably of the same nature as that of its congeners.

The adult has the bill dark brown, paler at the base of the lower mandible; head, neck and back dark brown, with lighter margins to the feathers of the latter: quills and tail-feathers blackish; under parts of a rather greyer brown, each feather being paler in the centre than at the edge; legs brown on the outer side and yellowish within. Average length 1725 ; wing 1275 to $13 \cdot 25$ in. The young scarcely differ from the adults, except in greater freshness of plumage; and this remark applies to nearly all the l'etrels. (On the wing this bird looks very black at a distance. 


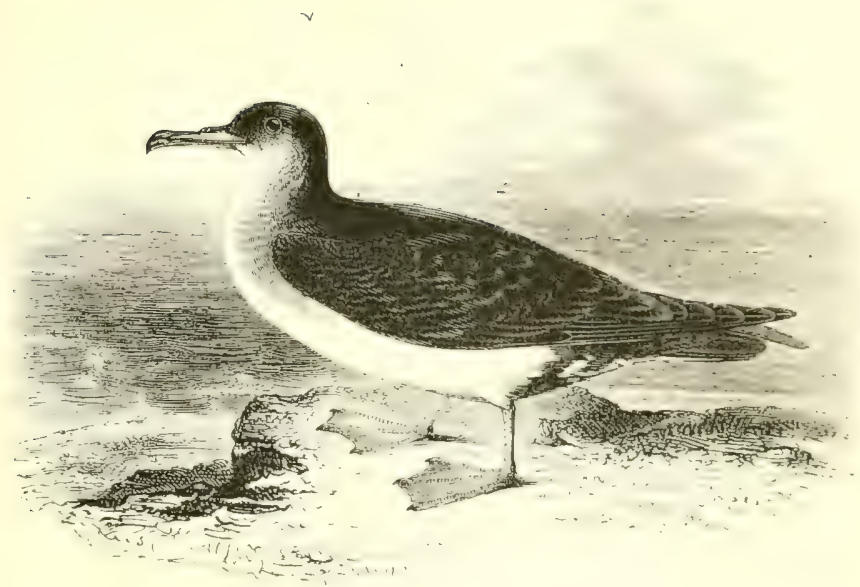

THE MANX SHEARWATER.

Puffinus anglórum (Temminck).

This species is widely distributed over British waters throughout the year; while it breeds on many of the most retired parts of our coasts, especially on islands with turfy slopes and on lofty cliffs with ledges, in which it burrows. It owes its trivial name to Ray, who calls it the 'Puffin of the Iske of Man' in Willughby's "Ornitholosy. and until a comparatively recent date it was abundant on the 'Calf' of Man. Southward it nests on the coast of Wales, notably on Skomer off Pembrokeshire: perhaps also on Lundy, where it is well known as the 'Cuckle'; and off Cornwall, where it is termed 'Skidden' and 'Crew, it breeds in the scilly group. On the cast side of the mainland of (ireat liritain no nesting-places are known, thoush the bird is plentiful, especially near fishing-hanks: but there are several in the Orkneys and Shetlands, where the 'Lyrie,' as the bird is called, is highly appreciated as an article of food by the natives, who are amusingly secretive and even wilfully inaccurate on the subject. A colony exists on Eigg, and there are several which are smaller in other islands of the Inner Hebrides, as well as a few in the Outer group. In Ireland, Rathlin liland, the islets and conts of Donegal, the Skelligs off Kerry, and some stations in the St. George's Channel ma be mentioned; and there are jrobalily many others. In Erse and Gaelic the bird's usual name is 'Fachach.'

This shearwater breeds in considerathenembers in the liveress.and 
is met with on the coast of Norway, as well as throughout the North Sea; it is also plentiful in the south-west of Iceland, and is said to have occurred in Creenland. There is a large settlensent on one of the Channel Islands, and southward this species appears to breed in the Azores. Madeira, and the Canaries; while throughout the Mediterranean and in the Black Sea it is represented by $P$. yclkemun of Acerbi (the 'ime damnée' of the Bosphorus), which is characterized by a large amount of brown striation on the under tail-coverts and exhibits a more dusky tint on the upper parts. In American waters the IIanx Shearwater appears to be rare, and Capt. Collins has not observed it on the fishing-grounds; but I saw two examples nutside the straits of Belle Isle on August i $3^{-1}$ th Is + , looking wery black as compared with the Great Shearwater. It is said to have nested in the Bermudas.

The single white erg is deposited in a slight nest of dry grass at the end of a burrow, and is smooth in texture, with less of the musky odour which is so obrusive in that of the Fulmar: average measurements $2+4$ by $16_{5} \mathrm{in}$. Incubation, in which the male takes part, sometimes commences early in May, and the nestling remains in its home until long after it is fully fledged, becoming enormously fat. The food com-ists of surface-fish, offal, small cuttle-fish \&c. ; the oil romited by the hird is green, but leaves a yellow stain. The flight is rapid and skimming, but - contrary to a popular idea-this species often settles on the water, and it dives freely, though only remaining uncer water for a short time. It is undoubtedly nocturnal or crepuscular in its general habits, but occasionally large flocks may besen by day. The note is a ilik-cuck-oin, generally repeated three times.

The adult has the bill blackish-brown, paler at the base; crown, nape, and upper parts sooty-hlack; under parts white; sides of the neck mottled with greyish-brorn; behind the thighs a patch of sooty-brown: leys and feet yellowish flesh-colour, the outer toes darker. Total length $\mathrm{r}_{5}$ in.; wing $9{ }^{\circ} 5$ in. The young bird resembles the adult and has white under parts, but occasionally examples with sooty lower surfaces are met with. 


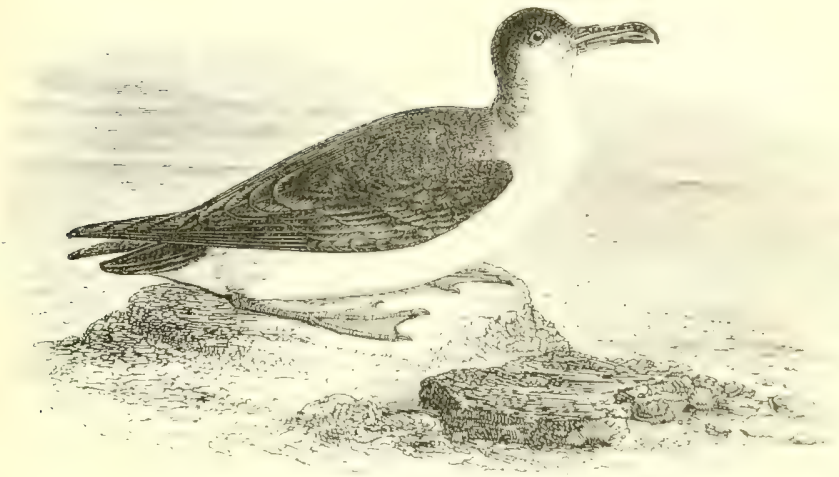

THE DUSKY SHEARIVATER.

Puffinus obscúrus (J. F. Gmelin).

The subject of our illustration was brought to Yarrell by Mr. I3. Blackburn of Valentia Harbour in co. Kerry, who afterwards sent a note to the effect that the bird flew on board a small sloop in that vicinity late in the evening of May i ith $\mathrm{S}_{53}$. This specimen was exhibited at a meeting of the Linnean Society in the following Junce. In 'The Zoologist' for I $S_{5} S$ the late $M I r$. H. Stevenson stated that he had examined a second example, which was found dead on the larsham estate near Bungay in Suffolk, about April roth of the above year; and this, after being lost to sight for some time, was rediscovered through his investigations, aided by those of Messrs. J. II. Gurney jun. and Hartcup; it was exhibited by Mr. Osbert Salvin, at a meeting of the Zoological Society on May I 6 th is 8.8 . According to the original account, the bird had probably been driven inland by a gale and had come in contact with a tree, since it had a wouncl on one side of the head as if from a violent blow.

This small Shearwater frequents the Canaries, Madeira, and perhaps the Azores; its nearest breedingr-place to our shores being on

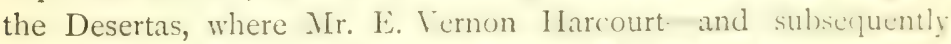
Mr. Hurrell-obtained birds and exgss. Crossing the Atlantic, we trace the species to the Bermudas, the lahamas and Harbaluss. in the last of which Col. Feilden recently found it nesting. (On the first, however, where it was formerly very abundant and known as the 'Cahow, Capt. S. G. Reid says that it has now almost cciscel in lureed : 
but on the uninhabited 'cays' in the Bahamas group the 'Pimlico' -as it is called-is still plentiful. Northward it has been known to wander as far as New Jersey; while southward it is found in the West Indies generally; beyond the above area, and over a large portion of the Pacific, several closely allied and imperfectly known species are met with, and it is desirable to await the result of Mr. Salvin's determination in his promised monograph before saying more. Possibly the unsatisfactory name discurus (which was originally applied to a bird from Christmas Island, in the middle of the Pacific) may have to be relinquished for the Atlantic bird, and auduboni of Finsch substituted; but seeing that the former has served for many years and has been generally accepted, there seems no immediate need of alteration.

The egg is laid in a burrow or hole among the rocks, and is pure white: average measurements 2 in. by ${ }^{2}+$ in. During the daytime this Shearwater remains in its retreat, and it is so thoroughly nocturnal that Capt. Reid was aware of only one instance of an example being seen on the wing in Bermudian waters; its parasites have no eyes, and belong to a group peculiar to night-1iying birds. There is consequently great difficulty in estimating the range ; added to which, very inaccessible places are often selected for breeding. Col. Feilden has given a description (Ibis, r $\$ 89, \mathrm{p} .60$ ) of his visit to one of these -the Bird-rock off Barbadoes, a mushroomshaped mass of coral limestone, surrounded by surf, through which the natives swim to collect the nestlings for food. The stomachs of the birds examined contained remains of cephalopods and fish.

The adult resembles the Manx Shearwater, but is much smaller: average length I I-I 2 in., wing 775 in. : specimens from the Desertas being less than those from Barbadoes. The bill is black and slender; the upper parts are of a dark sooty-black, with a bluish tinge on the mantle, while there are some slate-coloured bars on the flanks and under tail-coverts; the latter, as well as all the lower surface being chiefly white. (Birds from New Zealand and Samoa -assigned to this species-have the under tail-corerts dusky.) 


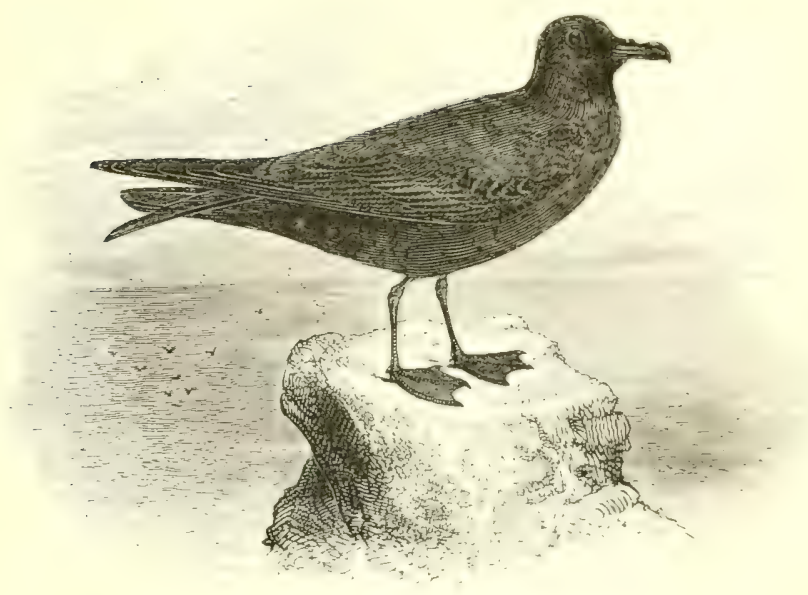

BULIVER'S PETREL.

Bulwéria columeína (Moquin-Tandon).

The only authentic instance of the occurrence of this species in Great Britain is that of an example found dead on the banks of the Ure near Tanfield in Yorkshire on May Sth i $S_{37}$, which was brought to Capt. Dalton (son of the Col. Dalton who provided licwick with the Storm-Petrel figured in his 'British Birds'). This specimen was described and figured by (Fould in Pt. xxii. of his "Birds of Ituropec $\left(\mathrm{I} \delta_{37}\right)$; but he did not include the species in his "Mirds of (ircat Britain' (IS73) and omitted all mention of his former sponsurship in the Introduction, which made me once suspect that later infurmation had cast some doubt on the statement. However, Messrs. IV. Mangle Clarke and James Carter took considerable pains to investisate the matter, and were successful in tracing the identical bird. which is now in the Museum at York. Further details are given in the

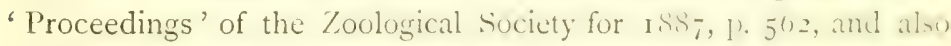
in 'The Naturalist' for I 888 , p. I56.

An example in the Leiden Museum is said to have come from Greenland, but Reinhardt informed Mr. I'. E. Irutie that he thousht it might be from one of the Moravian settlements in I.airadur: in any case this bird has seldom been met with beyond the ricinity of the Canaries, Madeira and l'orto Santo. The first publishedacoome of it is given by Jardine and Selly (Ill. ()rn. ii. pl. (15), who confered

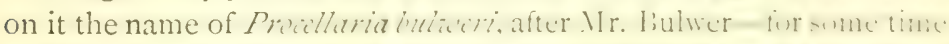
a resident in Madeira, to whom they were indelited for the yea inen 
they described and figured. Webb, Berthelot and Moquin-Tandon state ('Ornithologie Canarienne,' $\mathrm{I} \mathrm{S}_{4} \mathrm{I}$ ) that it is very common on the small island of Alegranza, where it breeds in holes in the rocks, and is known by the name of 'perrito,' or 'little dog,' from its cry.

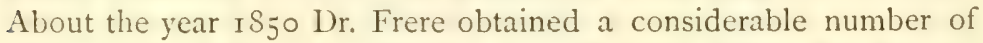
birds and eggs from the Desertas, near Madeira, where Mr. Hurrell also took a good many in $\mathrm{I}_{5} \mathrm{I}$; while Mr. F. D. Godman gives (Ibis, IS $72, \mathrm{p} .162$ ) the following account of his visit to those rocky uninhabited islands in $187 \mathrm{r}:-$

"We found plenty of Bulwer's Petrels sitting on their eggs, which were in holes or under rocks, and usually about as far in as one could reach with one's arm. They build no nest, but lay their eggs on the bare rock. I did not find more than one egg in each nest. I secured several birds and eggs, and kept some of the former alive. It is curious to watch them crawling along the ground; for they cannot fly unless they get to the edge of a rock; they waddle along on their feet, and, when they come to a steep place, use the sharp-pointed hook of their beaks to draw themselves up with. They seem to dislike the light, and hide themselves under a rock or crawl into a hole as soon as possible; I never saw one of this species flying about in the daytime, though some of the smaller ones are common enough." The egg is pure white : average measurements I ' 75 by I' 25 in.

The adult has the bill black; irides deep brown ; plumage almost uniform brownish-black, rather paler on the edges of the great wingcoverts; tail much graduated and cuneate; legs and toes reddishbrown, webs dusky. I.ength $10.5 \mathrm{in}$, wing $S \mathrm{in}$. This is a highly specialized form, with only one near ally, Bulüeria macgillizrayi, from the waters of the Fiji group; it is perhaps nearer to (Estrclate than to any other genus. 


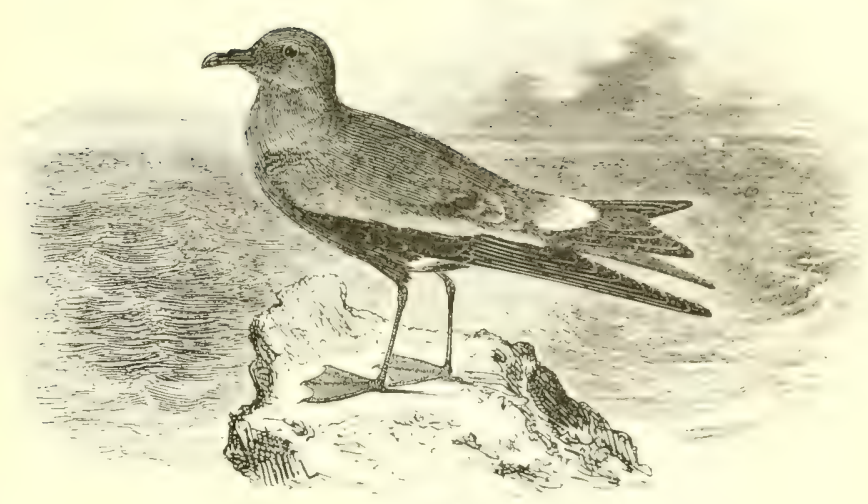

THE FORK-TAILED PETREL.

\section{OCEANódRoMa LEUCORRHóa (Vieillot).}

This species-sometimes called Leach's Petrel-was first made known as a British bird by Bullock, who obtained it at St. Kilda in I 8 I . Subsequently it has often been noticed within our waters, and it is now met with almost annually on the east coast of England, as well as inland; this is especially the case after northerly and westerly autumnal gales, from which Mr. Cordeaux infers that birds are driven right across the country. Off Cornwall it is quite as common in some winters as the Storm-Petrel, and it may lu sait to have occurred in almost every maritime county of (ircat liritain. In $\mathbf{I} S_{47}$ it was found breeding in the st. Kilda groul, and later investigations have shown that further colonies exist on North kony and several islands in the Outer Hebrides; while ere long the speries will probably be found nesting on some of the Inner islands. In Ireland it is frequent, and in I \$\$6 its egg was obtained by Mr. K. I. Ussher from one of the IBlasquets, off co. Kerry, the must western land (with the exception of Iceland) - bulonging to Eurum the birds having subsequently been taken as well as their eggs.

The Fork-tailed Petrel has wandered to the coast of Norway; but, strange to say, it has only twice been met with on Heligulam? though storm-driven individuals have been taken on the (with if Germany, Holland, Belgium, France, l'ortugal, and cren as far up the Mediterranean as Sicily; while Mr. E. Vicnon IIm urt 
states that this species reaches Madeira. On the further side of the North Atlantic, it has been known to visit Iceland and Greenland; and it is common in America from Labrador to the Bay of Fundy, ranging southward to Virginia in winter. It is also found throughout the North Pacific, nesting from California northward to the Aleutian Islands, as well as on the Commander and Kuril groups nearer Asia ; and it visits Japan. Three other Petrels with forked tails likewise inhabit the above Ocean, and belong to this well-defined genus.

The egg-white, freckled and zoned with minute rusty spots, and measuring about $\mathrm{I}^{\circ} 3$ by $97 \mathrm{in.}$ - is laid in a burrow or hole of some kind; usually in the first half of June. Mrr. John Swinburne-and afterwards Mr. Harvie-Brown-found a large colony nesting in the ruins of a deserted village on North Ronay; and there the latter also obtained three Storm-Petrels, though these did not appear to have eggs. All the Fork-tailed Petrels proved on dissection to be females, but on Grand Menan and other islands in the Bay of Fundy, where this species is very abundant, investigations have proved that the male takes part in incubation. When dragged from their holes the birds showed little disposition to fly, being apparently dazed by the light of day, and when released they invariably sought for some dark retreat. The food consists of small molluscs, crustaceans, and any greasy substances found floating on the water. The note resembles the syllables pezur-zeit, pewor-zuit.

The adult has the general plumage dark leaden-black above and sooty-black below, with a shade of ash-colour on the wing-coverts and the margins of the secondaries - which gives the bird a greyer appearance on the wing than the Storm-Petrel; upper tail-coverts chiefly white; tail sooty-black and considerably forked; bill black, legs and feet dusky. Length 75 in. ; wing 6 in. The nestling is covered with long sooty down, which makes it resemble a little long-haired mouse rather than a bird, as neither wings nor bill are visible. 


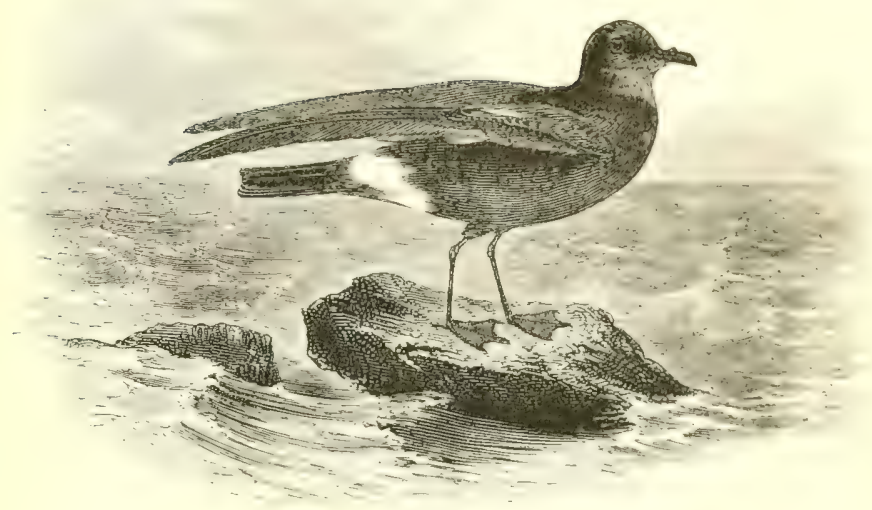

THE STORMI-PETREL.

Procellária pelágica, Linnæus.

The Storm-Petrel is generally distributed througlout British waters, and during rough weather is often met with inland, especially at the time of the autumnal migration, when individuals are frequently taken while fluttering against the lanterns of light-houses and light-ships. Unusual numbers occurred between October $27^{\text {th }}$ and November $4^{\text {th }}$ I $S S_{3}$ on the east side of England; and in ISS6, according to Mr. Harvie-Brown, "a regular stream of migration of Petrels seems to have taken place with the 'great rush' of other species on the 5th-6th of October, as they were reported from sereral stations "-in scotland. The same writer adduces evidence that this bird remained on South Uist during November, December, and January ISz2-23; though as a rule it does not voluntarily approach the land until May. In Scotland and Ireland its breeding-places are numerous, owing to the abundance of low islets and other suitable situations; there are several on the coast of Wales and in the Scilly Islands, and a few pairs are believed to nest on Lundy; eastward of which no resorts are known in England.

Southward, this species breeds in the Channel Islands and along the coast of Brittany, as well as on both sides of the Mediterranean as far as the Ionian Sea; while storm-dricen examples have been obtained far inland on the Continent. It visits the Mrores, Mateira 
and the Canaries, and has been traced down the coast of Africa as far as Cape Town, during our winter months. Returning northward, we find it nesting plentifully in the Færoes, and it occurs on the coast of Norway up to lat. $69^{\circ}$; it also ranges to Iceland, Southern Greenland, the Bay of Fundy and Newfoundland, but is not known to breed along the American sea-board.

As a rule the Storm-Petrel does not begin to lay until the second half of June, and a young bird has been found in the nest as late as October I Sth. A slight bed of stalks of plants is sometimes made at the end of a burrow in turfy soil, or beneath stones, or in crevices of rocks; but the single white egg-often faintly spotted with rusty dots - is usually laid on the bare soil : average measure. ments I'I5 in. by $8_{5}$ in. A strong odour of musk pervades the burrow and its contents. The food consists of crustaceans, molluscs, small fish, and fatty matter of any kind; the last being frequently obtained by following in the wake of vessels. In steamers it is difficult to capture this and similar species, but when a sailing ship is going slowly through the water it is not at all difficult to entangle them by trailing long threads-slightly weighted at the end-from the taffrail; sailors, however, consider this proceeding unlucky, although they do not necessarily connect the appearance of these birds with foul weather. In captivity the Storm-Petrel has been kept alive on oil for three weeks. By sea-faring folk, this and other members of the genus are known as 'Mother Carey's Chickens' (perhaps a corruption of Hater cara); while their habit of paddling along the waves is supposed to have been the origin of the word Petrel-after the Apostle Peter, who essayed to walk on the water.

The adult has the upper parts black, except the tail-coverts which are white at their bases, while the edges of the wing-coverts are slightly edged with white; under surface sooty-black, sides of vent white; bill, legs and feet black. Length 6 in.; wing $4^{\cdot} 6$ in. The young bird is rather browner, and shows little or no white on the wingcoverts or vent. Mr. J. H. Gurney jun. has an albino example. 


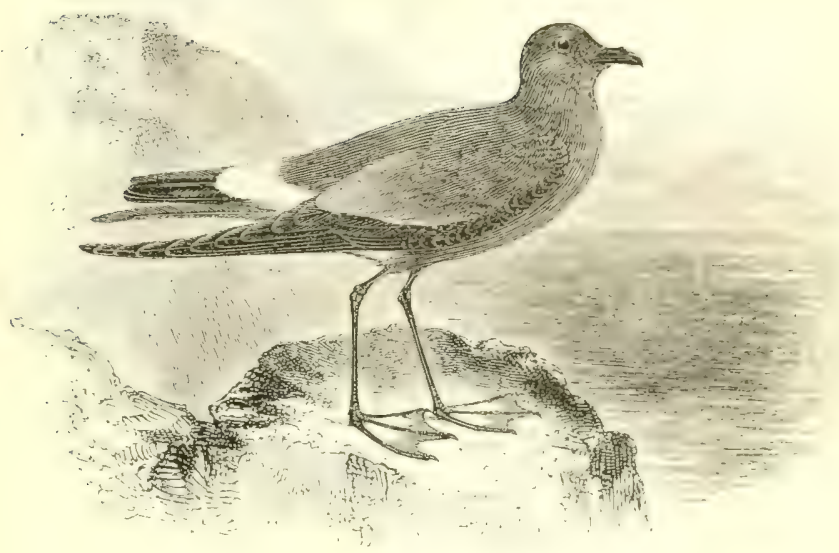

\section{WILSON'S PETREL.}

Oceanítes oceánicus (Kuhl).

This remarkably long-legged I'etrel was noticed and figured as Procellaria pelagica by Wilson (Am. Orn. vii. p. 90, pl. 1x. fig. 6), under the impression that it was identical with the bird just described, but the earliest scientific description of it was given by Kuhl in $1 \$ 20$. In $\mathrm{S}_{24}$ Bonaparte published a memoir on this and three more species, with the distinctive characters, measurements, and figures of cach: and, in ignorance of Kuhl's name, proposed to call this bird f'retlaria wilsoni, in honour of the distinguished ornithologist, whose name can, however, only be handed down to posterity in the trivial appellation. In his memoir Bonaparte says, "I have never learnt that it has been seen on the coasts of Europe. I killed onc, that had probably strayed, near the Azores"; and this appears to be the first printed notice of the occurrence of Wilson's Petrel on the European side of the Atlantic. As regards the British Islands, Gould observed this species in abundance off the I.and"s lind in May ${ }_{1} 8_{3} 8$, and in November of the same year the specimen now figured was found dead near l'olperro in (ornwall: an example has been picked up near Chippenham in II iltshire: two have hecn obtained near Freshwater in the Isle of Wight the last in the autumn of ISSS); the late Mr. F. liond recorded one from sursex: one was shot near Halifax in Yorkshire in Normber $187+$ and two 
appear to have occurred in Cumberland, the latest of these in I88I. As yet there is no record of this species in Scotland; and as regards Ireland, all that can be said is that a specimen was presented to Thompson in August $\mathrm{J} S_{4} \circ$ by Glennon of Dublin, who believed it to have been obtained in that country.

In France, two examples are said to have been taken in the Gulf of Gascony in December $S_{5}$, and one from Guétary near Biarritz (December $3^{\text {rd }} \mathrm{I}_{7} \mathbf{z}_{2}$ ) is in the collection of Dr. Marmottan at Paris. Stragglers have occurred on the coast of Provence, and I possess a female captured off Málaga on August 7 th I 873 ; while Dr. Salvadori has identified a specimen-in the University Museum of Cagliarisaid to have been obtained off Sardinia. Mr. Godman found this Petrel common in summer about the Azores, and it has been procured in many localities on the west coast of Africa down to the Cape of (rood Hope; four examples were obtained by the 'Challenger' Expedition, off the Antarctic ice barrier on February I th IS 7 ; the Rev. A. E. Eaton, naturalist to the Transit-of-Venus Expedition, found it breeding on Kerguelen Island ; and it appears to extend over the South Atlantic to Australia and New Zealand, as well as across the South Pacific to Chili and I'eru. In the North Atlantic it is common along the American coasts, visiting the West Indies and Mexico.

Nine eggs brought from Kierguelen by Mr. Eaton and described by me (l'hil. Trans. clxvii. p. 164) are of a dull white colour, with minute purplish-red spots which usually form a zone at the broader end : average measurements $I^{\prime} 3$ by 9 in. They were laid in January and February, in crevices and holes among shattered rocks or large boulders. The birds arrived at their nesting-places in the latter part of the previous November, but comparatively little was seen of them by day, though towards evening they used to fly over the water like swallows, or follow the course of the valleys far away into the country. In food and general habits this resembles other small species; in its anatomy, however, both Garrod and Forbes considered that it differed so widely from the majority of the Petrels as to be entitled to rank in a separate family-Oceanitida.

This bird is sooty-black above and below, with greyish-white edges to the wing-coverts and inner secondaries, white upper tailcoverts and thigh-patches, and a little white at the base of the outer tail-feathers; the bill, legs and toes are black, and the webs of the latter are yellow at their bases. Total length $7^{\circ} 5$ in., wing 6 in., tarsus $\mathrm{I}_{4} 4$ in. 


\section{A P P E N D I X.}

Black-throated Thrush (p. q).

In 'The Ibis' for October, I889, Lt.-Col. H. M. DrummondHay states that he has traced and identified an example of this species, shot by Mr. Robert Gloag after a prolonged snowstorm, on the banks of the Tay, a little below Perth, in February I879. It was then in company with another bird of the same kind, and has been presented to the Museum of the Perthshire Society of Natural Science.

Ring-OUzel (p. I5).

Prof. J. W. H. Trail states that this species breeds-or has bred-among the hills of Mainland or Pomona, in the Orkneys, which I had excepted. The statement that it "is entirely absent from our islands during the winter" (i.e. after Christmas) requires modification, as there is evidence that in some localities the bird has been found all the year round.

Desert WheAtear (p. 25).

Since the article on this bird was written, a third British specimen-apparently a young male-was shot near Arbroath on December 28 th 1887 , and was exhibited at a meeting of the Zoological Society of London on March 6th I888, on bebalf of Lt.-Col. H. M. Drummond-Hay, who published details in 'The Ibis,' ISSS, p. 283 .

REDSTART (p. 3I).

This species bred and reared its young at Powerscourt, co. Wicklow, in the summer of 1885 ; and since that date it has nested annually in that district.

Black Redstart (p. 33).

Mr. R. J. Ussher informs me that this bird is not infrequent in winter on the east and south coasts of Ireland, 
and has been obtained as far west as the Blasquets, off co. Kerry. As regards a nest and two eggs (in the British Nuseum) taken near Chelmsford in Essex and ascribed to this species (Zool. I888, p. 390), I have examined the specimens, and think that the whole evidence is strong, though not conclusive.

Bluethroat (p. 35).

Mr. Joseph Agnew-whose admirable returns from the Isle of May are well known to all students of the Migration Reports-has signalized his transfer to the Monach Island light-house in the Outer Hebrides by obtaining a male of this species on October I Ith I888. It arrived with Redstarts, in a gale for the N. and N.E. with snow and hail showers, and was two days on the island before it died (Harvie-Brown and Buckley, 'Fauna of Outer Hebrides,' p. 252).

BARRED WARBLER (p. 5I).

A young male was shot by Mr. George l'ower at Blakeney in Norfolk on September Iolh i SSS, after easterly winds; making the fifth example obtained in Great Britain.

ICTERINE WARBLER (p. 69).

Mr. C. M. Adamson has shown me an adult male shot in a garden close to Newcastle-on-Tyne, on June 20 th 1889. Mr. Cordeaux has suggested that the bird figured was probably an example of Hypolais polyglotta, and not of $H$. icterina, in which the wings reach nearly to the middle of the tail. If this had been noticed in time another illustration would have been given.

WadL-Creeper (p. I I I).

The dimensions were accidentally omitted: they are-length of body $5^{\circ} 5$ in., wing $3^{\circ} 9$ in.

Red-Breasted Flycatcher (p. 153).

A young bird was killed by striking against the lantern of the Arklow (South) light-ship, seven miles from the coast of Wexford, on October $23 \mathrm{rd} 1887$, and was forwarded to Mr. R. M. Barrington (Zool. i 888, p. 39r). To the examples already recorded from Trescoe, in the Scilly Islands, a third should be added, namely one sent to Vingoe in October I863, and not mentioned by Rodd; it is now in the collection of Mr. J. H. Gurney jun. A specimen was obtained in Holland on September 23 rd I 888 . 
Crossilll (p. r93).

Waterford must be added to the Irish counties in which this species has bred; Mr. Ussher having obtained a nest, with four much incubated eggs, for the British Museum, on March 23 rd I889. An example of the large-billed race known as the Parrot-Crossbill was shot on Lord Rosse's demesne, Parsonstown, last January (Zool. i889, p. I 8 I).

Brandt's Siberian Bunting, Emberisa cioïdes.

In June I 888 Mr. R. W. Chase of Birmingham purchased a young male of this species, said to have been taken near Flamborough in October 1887 and to have been mounted from the flesh by Mr. Matthew Bailey, who did not know the bird and was quite ignorant of the interest attaching to it. This is set forth by Canon 'Tristram in "The İbis' for July I 889 (p. 293), where an adult male from Krasnoyarsk is figured; but Mr. Seebohm remarks (tom. cit. p. 296) that the Flamborough bird approaches rather nearer to the Chinese sub-species Emberiza cioiddes castaneiceps than to the typical Siberian form. As a mere detail, it may be mentioned that in 'The Naturalist' for I $S S$ ? (p. I I3) the date of capture is given as November I 886.

Ortolan Bunting (p. 205).

From the Migration Report for 1885 (p. 26) it would appear that two Ortolan Buntings frequented the Isle of May, in the Firth of Forth, from April 23rd to May 2nd, when one of them was shot.

Snow Bunting (p. 215).

In June i 888 Mr. John Young found a nest of this species, with 5 eggs, in Sutherland.

JAY (p. 225).

Mr. Ussher says that in Ireland the stronghold of this specic's is in the basin of the Suir, the Barrow and the Nore, beyond which its range is not extensive.

Great Spotted Woodpecker (p. 265).

The Rev. H. A. Macpherson has recorded an example from Skye, shot in October I886 (Zool. I S89, P. 269).

Cuckoo (p. 277).

Through inadvertence, I omitted to state that Mr. John Hancock saw the nestling cuckoo begin to eject the young of the Hedge-Sparrow when the former had only been hatched about thirty hours (Nat. Hist. 'Trans. Northumb. \& Durham, viii. P. 213). 
Scops-Owl (p. 297).

Add, a specimen obtained in co. Wexford on May 3 Ist I 889 , now in the Science and Art Museum, Dublin (Zool. I $\left.889, \mathrm{p} .3^{\mathrm{I}} 3\right)$.

Hoвby (p. 337).

Sir Edward Newton writes that on August 29th i $S_{7} 7$ he saw at Kinnaird House-about half-way between Dunkeld and Grandtully-nailed to the keeper's "larder," an old Hobby with three young, the latter nearly full-grown and fledged, but with the down still hanging to their heads and backs; the keeper said he got them that summer from a nest in a tree (Zool. 1889, p. 32).

Red-Footed Falcon (p. 339).

Mr. William Evans reminds me that in addition to the Aberdeenshire occurrence cited, there is a young female in the Edinburgh Museum which was killed at Kinghorn, Fife, on September zoth ISSO; and a male passing into adult plumage was shot near Jedburgh in $r 888$.

Gannet (p. 353).

Mr. Ussher informs me that the colony on the Bull Rock is a small one as compared with that on the Little Skellig; but Mr. R. M. Barrington states that many birds were driven away from the former by blasting operations, during the erection of the light-house.

Purple Heron (p. 357).

Mr. W. Evans writes that a young female specimen, shot near Prestonpans in October 1872 , is now in his collection.

Airerican Bittern (p. 373).

Mr. W. Evans has examined the so-called example, recorded in 'The Field' of March $4^{\text {th }} 187 \mathrm{I}$, from the Pentland Hills, and informs me that it is only a Common Bittern.

White-Fronted Goose (p. 387 ).

In the south of Ireland this species can only be called abundant during severe frosts (Ussher).

Bean Goose (p. 389 ).

Less plentiful in the south of Ireland than the preceding species (Ussher).

SHELd-Duck (p. 407).

Exceptionally, hybrids between this species and the Mallard have been produced in confinement (Zool. x889, pp. 260, 3I4). 
Ruddy Sheid-Dưck (p. 409).

The specimen ascribed to Perthshire was obtained in For farshire, though it is in the Perth Muscum. In addition to the examples recorded from the Shannon in the summer of $\mathbf{1} 886$, one was shot (out of a flock of six) at Kinsale and one (out of three) in the north of co. Cork, about the same time.

Shoveler (p. 4I5).

I intimated that this Duck probably bred in the marshes on the Cumberland side of the Solway, and Messrs. Macpherson and Duckworth have subsequently shown this to be the case.

Scaup Duck (p. 437).

As regards Mr. A. C. Stark's very positive and detailed account (Pr. R. Phys. Soc. Edin. vii. p. 203) of the breeding of this species on Loch Leven, Mr. IV. Evans informs me that he subsequently accompanied Mr. Stark to that spot several times, and they failed to identify a single Scaup; though Tufted Ducks were abundant : as they had been for years previously.

GOLDEN-EyE (p. 439).

The Rev. H. H. Slater has received specimens from Iceland, where Barrow's Golden-eye had previously been considered to be the only representative of the genus Clángula.

Turtle-Dove (p. 473).

Mr. Ussher considers that this species is only found in very small numbers, even in the wooded districts of Ireland.

Pallasis Sand-Grouse (p. 475).

The Rev. H. A. Macpherson has recently published (July I889) an account of the visitation of this species to Scotland in $\mathrm{I} 888$, prepared chiefly from information collected by Professor Newton and Mr. J. A. HarvieBrown. There is strong evidence that nestlings were found, and at the Meeting of the British Association at Newcastle, on September I ath, Professor Newton exhibited a downy chick taken alive in the north-east of Scotland early in August ISS9.

Pratincole (p. 5 I 7 ).

The record of an occurrence in Northumberland is an error; on the other hand, Surrey should be added to the list of counties visited. 
Red-breasted Snipe (p. 56r).

A young bird labelled 'Largo, Fife, I $\$ 67$ ' was purchased at the sale of the late Sir IV. Jardine's collection by the Rev. H. A. Macpherson, who presented it to the Edinburgh Museum.

Curlew-Sandpiper (p. 577).

As regards the occurrence of this species in the south of Ireland, Mr. Ussher informs me that he is not aware of a single instance in co. Waterford, nor did Dr. Birkett notice it there during his experience of fifty years.

Comion Tern (p. 63r).

Mr. Harvie-Brown informs me that on Haskeir off Canna, where he saw only Arctic Terns in 1879 , he found the Common Tern predominating in $\mathrm{I} 889$; and $\mathrm{I}$ have received independent evidence on this point from Mr. Henry Evans.

Arctic Tern (p. 633).

Mr. Ussher states that this species breeds on the Keragh Islands off co. Wexford, Puffin Island off Kerry, and on some islands in Bantry Bay. Mr. A. H. Evans writes to me that he has watched this Tern diving completely under water.

Comion Gull (p. 655).

Mr. H. M. Wallis has recently found this species nesting in various parts of Donegal, and Mr. R. M. Barrington has discovered a small colony on one of the Blasquets, off Kerry.

Lesser Black-Backed Gull (p. 659).

Mr. Ussher mentions the Saltees, High Island near Castle Townsend, and Puffin Island off Kerry as breeding-haunts.

Pomatorhine Skua (p. 673).

Although there is no published record of the nesting of this species on Novaya Zemlya, yet Col. H. W. Feilden informs me that Capt. A. H. Markham, R.N., mentioned it in his journal as breeding commonly, and on July 5 th 1879 he took an egg on Berg Island, which has been sent for my inspection; it is a very long specimen and measures $2^{\circ} 6$ by $\mathrm{I}^{\circ} \mathrm{\gamma}$ in. 


\section{N D E X.}

(The English names of the species which are not admitted to the Iritish List are placed within square brackets.)

Aberdevine, 167

'Abubilla,' 276

Acanthis, xvi

Acanthis bella, I8o

— brvirostris, IS6

- cannabina, $\mathbf{1} 79$

- exilipes, I8 $\mathbf{I}$

- flavirostris, 185

fringillirostris, $\mathbf{I}$ So

holboclli, I81

- hornemanni, ISI

- linaria, I8I

rostrata, I $8 \mathrm{I}$

mefescens, $18_{3}$

ACANTHYLLIS, xix

Acantryllis caudacuta, 255

ACCENTOR, xii

Accentor, Alpine, 87

Hedge-, 85

Accentor collaris, $\delta_{7}$

modularis, 85

ACCENTORIN/E, xii, 85

ACCipiter, xxiv

Accipiter brevipes, 324

nisus, 323

ACCIPITRES, xxiii

ACredula, xiii

Acredula caudata, 93

irbii, 93

var. caucasica, 94

rosea, 93

tephronota, 94

Acrocepilalus, xii
Acrocephalus aquaticus, 79

— palustris, 73

—. ploragmitis, 77

- stentorens, 76

- streperzes, $7 \mathrm{I}$

- turdoüdes, 75

Ä̈DON, xii

Aëdon familiaris, 68

- galactodes, 67

Egialitis, xxxiii

Es gialitis cantiana, 527

- curonica, 525

- Miaticula, 523

- microrhyncha, 526 nivosa, 528

simipalmata, $5^{24}$

vocifera, 529

Agelaus phanicuse, 216

Aix sponsin, 420

ALAUDA, xix

Alauda artioria, 24I

——ariensis, 239

— brachydactyla, 245

_ calandra, $24 \mathrm{~S}$

- cristata, 243

- sibirica, 247

ALAUDIDA, xix, 239

Arca, xxxviii

Alca impinnis, 681

_ torda, 679

ALCEDINID E, $\mathrm{xx}, 269$

ArCEDO, $\mathrm{xx}$

Alcido busalensis, 270 
Alcedo ispida, 269

- pallasi, 270

ALCID A, xxxviii, 679

ALECTORIDES, xxxii

'Alza-cola,' Alza-rabo,' 68

'Âme damnée,' 720

Ammer, 20I

AMPELID E, xv, I 47

AMpelis, xv

Ampelis cedrorum, $\mathbf{1 4 8}$

- garrulues, 147

_- phanicoptera, $\mathrm{I}_{4} 8$

ANAS, xxvii

Anas boscas, 4 II

- discors, 422

obsczera, 4I 2

strepera, 4I3

ANATID E, xxvii, 385

Anorthura troglodytes, Ios

ANoüs, xxxvi

Anous stolidus, 639

ANSERES, xxvi

ANSER, xxvi

Anser albifrons, 387,734

- brachyoryynchus, 391

- cinerizs, 385

cysnoides, 390

- erythopus, 388,392

- gambeli, $38 \mathrm{~S}$

- mobrirostris, 386 segetuml, 389,734

Antrius, xiv

Anthus bertheloti, I25

— blakistoni, I34

-.-- campestris, I 29

cervintzs, 127

japoniculs, 134

Indovicianus, I34

maculatus, 124

obsczumes, I35

— pemnsyleanicus, I34

- pratensis, 125

- richardi, I3I

mestris, I35

spipoletta, I33

trivialis, 123

AQU1LA, xxiii

Aquila chrysaitus, 3I7

_- clanga, 316

mavia, 3I 5

orientalis, 316

- pennata, 314

Archibutco, 314
ARDEA, XXV

Ardea alba, 359

- nubulcas, 363

- candidissima, 362

- cinerea, 355

coromanda, 364

egretta, 360

- culophotes, 362

- sar zetta, $36 \mathbf{1}$

- purpurea, 357, 734

ralloides, 365

ARDEIDE, XXv, 355

ARDETTA, xxv

Ardetta minuta, 369

- podicipes, 370

- sinensis, 370

Asio, xxii

Asio accipitrinus, 285

- caponsis, 286

- otus, $2 S_{3}$

- wilsonianus, 284

Astur, xxiv

Astur atricapillus, 322

- palambarius, 321

Athene, xxii

Athene bactriana, 292

-.. slaux, 292

- Meritionalis, 292

- noctua, 291

Auk, Great, 68I

— Little, 689

Avocet, 545

' Bald Pate,' 428

Balearica pavonina, 508

'Barker' (Avocet), 546

Barn-Ow], 28I

BARTKAMIA, XXXv

Bartrania longicauda, 589

'Beam-bird ' (Spotted Flycatcher), 150

Bee-eater, 273

- [Blue-tailed], 274

BERNICLA, xxvii

Bernicla brenta, 399

- canadensis, 400

- lencopsis, 397

_uigricass, 399

- meficolis, 395

'Billy-biter' (Blue Titmouse), IO2

Bittern, American, 373, 734

- Common, $37 \mathrm{I}$

Little, 369

Blackbird, 13 
Blackcap, 47

Black-cock, 479

'Black Curlew' (Glossy Ibis), 379

'Blue-Darr' (Black Tern), $6 \mathbf{1 7}$

'Blue Felt' (Fieldfare), 7

'Blue Maa' (Common Gull), 655

'Blue Rock' (Rock Dove), 469

Bluethroat, 35, 732

—_ Red-spotted, 35. 36

IVhite-spotted, 36

'Bonxie' (Great Sliua). 67 I

Botaurus, xxy

Botaurus lentiginosus, 373, 734

— stellaris, $37 \mathrm{I}$

'Bottle-Tit' (Long-tailed T.). 94

'Boujir' (Puffin), 692

Brambling, 177

'Broad-bill' (Shoveler), 4I 5

Bubo xxii

Bubo ascalaphuss, 300

_- ignavus, 299

-n maculosus, 300

- sibriricus, 300

— turcomantus, 300

—uirginianus, 300

Budytes, 122

[Bulbul, South African], I26

Bullfinch, I 87

Bulweria, xxxix

Butweria colombina, 723

-__ macsillivrayi, 724

Bunting, Black-headed, I97

_- Brandt's Siberian, 733 Cirl, 203

_- Common, 199

_ Corn-, 199

_._ Lapland, 2 I 3

Little, 209

Ortolan, 2ะ5, 733

Reed-, 2 I I

Rustic, 207

Snow-, 21 5, 733

Yellow, $20 \mathrm{I}$

'Bunting-Lark' (Corn-13unting), 199

'Burgomaster' (Glaucous Gull), 664

'Burrow-Duck' (Sheld-Duck), 408

'Bush-Chats,' 26

Bustard, Asiatic Ruffed, $5^{13}$

- Great, 509

Little, 5 I I

Macqueen's, 513

Butcher-bird (Gt. Grey Shrike), I 40

BuTEO, xxiii
Buteo desertomm, 3 I

- lazsopus, $3 \mathrm{I}_{3}$

- sancti-johannis, 314 vulgaris, $3 \mathbf{I} \mathbf{I}$

'Butter-ball' (Buffel-headed Duck), 442

'Butter-bump' (Bittern), 37 I

Buzzard, Common, 3 II

— Honey-. 329

Moor-, 305

— Rough-legged, $3^{I} 3$

Caccabis, $\mathrm{xxx}$

Caccabis petrosa, 490

- mufa, 489

- saxatilis, 490

Calandrella batica, 246

__ minor, 246

- pispoletta, 246

Calcarius, xvii

Calcarius lapponicus, $2 \mathrm{I} 3$

CAlmuris, xxxy

Calidris arenaria, $5^{\delta_{3}}$

'Calloo' (Long-tailed Duck), 443

['Cape Pigeon'], 7 I4

Capercaillie, 477

CAPRIMULGID E, xix, 257

CAPrinulgus, xix

Caprimuisus agyptius, 260

— europieus, 257

—urficollis, 259

Cakduelis, xvi

Carduclis canicps, $\mathbf{1} 66$

_- ilegans, 165

- major, 166

Carpodacus, 190

Carrion-Crow, 233

[Cedar-bird], 148

Ceppluzs, 686, 688

CERTHIs, xiv

Certhia brachyodactyla, Ion

$\longrightarrow$ costie, IO9

- familiaris, 109

_- familiaris antricana, 110

CERTHIIDA Xiv, IO9

Ceryle alcyon, 270

Chaffinch, 175

CIIARADRIID.E, xxxii, 519

CinRADRIUs, xxxiii

Charadrius dominicus, 533

- fulvus, 533

__ pluivalis, $53 \mathrm{I}$

- virginicus, 533

'Chat,' 26, $7 \mathrm{~S}$

Cuelinos, $x v$ 
Chelidon castmiriensis, I5T

— lagopoda, 157

- urbica, 157

Chen, xxvii

Chen albatus, 394

- ccrulescens, 394

hyperborezus, 393

- - rossi, 394

Chenalopex cogyptiaca, 400

Chettusia, 538

Chiffchaff, 6I

Chough, 22I

- [Alpine], 222

Chroicocephalzes, 654

Cirrysonitris, xvi

Chrysomitris spinoides, 168

- spinus, 167

'Churn-owl' (Nightjar), $25 \mathrm{~S}$

Ciconia, xxy

Ciconia alba, 375

- boyciana, 376

- migra, 377

CICONIIDE, $\mathrm{xxr}, 375$

CINCLID E, xii, 89

Crnclus, xii

Cinclus albicollis, 90

- aqualicus, 89

—_cashmiriensis, 90

-_ melanogaster, 89

- minor, 90

Circus, xxiii

Circus ceruginosus, 305

- cineracens, 309

cyenezes, 307

- hadsonizes, 308

Cirl Bunting, 203

Clangula, xxviii

Clangula albcola, 44I

- slaucion, 439, 735 islandica, 439

'Clinker' (Avocet), 546

Coal-Titmouse, 97

'Cobbler's-awl Duck' (Avocet), 546

Coccothraustes, $x \mathrm{v}$

Coccothraustes humii, 164

- japoniczes, 164

- vulgaris, 163

Coccystes, xxi

Coccystes glandarius, 279

Coccyzns americanus, 280

- erythropthalmus, 280

Cock of the Wood (Capercaillie), 477

Colaptes auratus, 268
Columba, axix

Columba eversmanni, 470

- intermedia, 472

livia, 47 I

anas, 469 palumbus, 467

COLUMBI, xxix

COLUMBIDE, xxix, 467

COLYMBID E, xxxviii, 693

Colymbes, xxxviii

Colymbus adamsi, 695

—arcticus, 697

- glacialis, 693

- holboelli, 703

_.. septintrionalis, 699

Coot, 505

CoRACias, $\mathrm{xx}$

Coracias garmlues, $27 \mathrm{I}$

- indicus, 272 leucocephalus, 272

CORACIID E, $\mathrm{xx}, 27 \mathrm{I}$

Cormorant, Black, 349 Common, 349

Crested, 35 I

Great, 349

Green, 35 I

Corn-Bunting, 199

Corn-Crake, 493

CORVID E, xviii, 221

CORVUS, xviii

Corvins affuis, 232

- corax, 23I

- comix, 235

- corone, 233

daüriczes, 230

frusileus, 237

-monedula, 229

pastinator, 238

tingitannes, 232

umbrimus, 232

Cosmonetta, xxviii

Cosmonetta histrionica, 445

Cotile, $\mathrm{xy}$

Cotile riparia, I 59

- mepestris, 160

Coturnix, $\mathrm{xxx}$

Coturnix commanzis, 49I

'Coulter-neb' (Puffin), 692

Courser, Cream-coloured, 5 I 9

Crake, Baillon's, 499

Corn-, 493

Little, 497

Spotted, 495 
Crane, 507

- [African Crowned], $50 \mathrm{~S}$ [Demoiselle], 508

Creeper, Tree-, Io9 Wall-, III, 732

'Crew' (Manx Shearwater), 7 I9

Crex, xxxi

Crex pratensis, 493

'Crick,' 'Cricket Teal' (Garganey), 424

Crithasra chrysopysa, I70

Crossbill, I93, 733

— European White-winged, I95

Parrot-, 194, 733

Two-barred, 195

Crow, Carrion-, 233

Grey, 235

Hooded, 235

'Royston,' 235

'Cuckle' (Manx Shearwater), 7 r9

Cuckoo, 277, 733

- [American Black-billed], 2SO [American Yellow-billed], 280

- Great Spotted, 279

'Cuckoo's-leader,'-mate(Wryneck),26I

CUCULIDE, xxi, 277

Cuculus, xxi

Cuculus canorus, 277,733 hepaticus, 278

Curlew, Common, 6I I Eskimo, 6I5 Stone-, 515

Curlew-Sandpiper, 577, 736

Cursorius, xxxii

Cursorizus gallicus, 5 I9

- var. bogolubovi, 520

Cushat, 467

Cyanecula, xi

Cyanecula lencocyana, 36 succica, 35,732 wolfi, 36

Cyanospiza ciris, I70

Cygnus, xxvii

Cygnus americanzes, 404

- bewicki, 403

buccinator, 404

immuatabilis, 406

mizesicus, 401

olor, 405

CyMochorea, xxxix

CYPSELID E, xix, 25I

Cypselus, xix

Cypselus affinis, 252
Cypselus afus, $25 \mathrm{I}$

- melba, 253

- pallidus, 252

- unicolor, 252

Dabchick, 709

DAFILA, xxvii

Dafila acuta, 417

Dalmatian Regulus, 60

Daption capensis, 7I4

Daulias, xi

Daulias grolzii, 39

- lusciniar, 39

- philomela, 40

DENDROCOPUS, $\mathrm{xx}$

Dindrocopus lenconotus, 266

— major, 265, 733

- medizes, 266

- minor, 267

- mumidicus, 266

- pubescens, 268 villosus, 266

'Deviling' (Swift), 25I

Dipper, 89

- Black-bellied, 89

'Diver,' 35 I

Diver, Black-throated, 697

_- Great Northern, 693

— Red-throated, 699

_- White-billed Northem, 695

Dotterel, 52I

— Ringed, 523

Dove, Ring-, 467

— Rock-, $47 \mathrm{I}$

— Stock-, 469

Turtle-, $473,7.35$

Duck, 'Bimaculated,' 420

_- Buffel-headed, $4+\mathrm{r}$

Burrow-, 408

- Common Sheld-, 407, 734

— Lider, 447

- Ferruginous, 433

- (iolden-eye, 439, 735

- Harlequin, 445

- Long-tailed, $4+3$

[American Summer-], 420

Pintail, 417

Ruddy Sheld-, 409, 735

Scaup, 437, 735

'Spirit' (Buffel-headed), $4+2$ 'Sipoon-bill' (Sl:oveler), 415

_ Steller's Western, 451

_ _ Tufted, 435 
Duck, 'Whew' (TVigeon), 426

- White-eyed, 433

Wild, $41 \mathrm{I}$

'Dun-bird' (Pochard), 429

Dunlin, 569

'Dunnock,' 'Dykie' (Hedge-Sparrow), 85

Eagle, 'Black' (Golden), 3I 8

_- Cinereous, 319

Golden, 317

Sea, 319

Spotted, 315

White-tailed, 3 I 9

Eagle-Owl, 299

Ectopistes migratorius, 474

Egret, Little, 36I .

Eider Duck, 447

— King, 449

Steller's, 451

Elanoides furcatus, 328

Elanus carulezs, 328

'Ember-Goose' (G. N. Diver), 693

EMrerizA, xvii

Emberiza castaneiceps, 733

— cioïdes, 733

cirluss, 203

citrinella, 201

casia, $20 \mathrm{r}$

hortulana, 205, 733

melanocephala, 197

miliaria, 199

palustris, 212

- passerina, 212

- pusilla, 209

pyrrhuloüdes, 212

restica, 207

schaniclus, $2 \mathrm{II}$

EMberizin.E, xvii, 197

ERITHaces, xi

Erithacus hyrcanzs, 38

-n nubecula, 37

Erne, 3 I9

EUdROMIAs, xxxii

Eudromias morinellus, 521

'Fachach' (Manx Shearwater), 719

Falco, xxiv

Falco asalon, 34I

- amerensis, 340

anatum, 336

barbarzes, 336

candicans, 331
Falco cenchwis, 345

- columbarius, 34I

cuvieri, 338

gyrfalco, 334

holboelli, 334

islandus, 333

pekinensis, 346

peregrinus, 335

- punicus, 336

- severzts, $33 \mathrm{~S}$

- sparverius, 344

- subbuteo, 337,734

timmunculus, 343

vespertinus, 339, 734

Falcon, Greenland, 331

- 'Gyr,' 33 I

_ Iceland, 333

- Peregrine, 335

- Red-footed, 339, 734

_- 'Stone' (Merlin), 342 White, 332

FALCONID E, xxiii, 305

'Feather-poke'(Long-tailed Titmouse), 94

'Felfer, Felt' (Fieldfare), 7

'Fern-owl' (Nightjar), 258

Fieldfare, 7

Finch, Citril, I 70

_- Mountain, I77

'Firetail' (Redstart), 32

Flamingo, $38_{3}$

Flycatcher [American Red-eyed], I46

— Pied, $15 \mathrm{I}$

— Red-breasted, 153, 732 Spotted, I49

_- [White-collared], I 52

Fratercula, xxxviii

Fratercula arctica, 691

_ glacialis, 692

FRINGILLA, xvi

Fringilla calebs, I 75

- maderensis, I76

- montifringilla, 177

- moreleti, 176

_ spodiogenys, I76

teydea, 176

tintillon, 176

FRINGILLID/E, xv, I6I

FRINGILLINE, $x$

Fulica, xxxi

Fultia atra, 505

- cristata, 506

FULICARIÆ, xxxi 
Fuliguline, 429

Fuligula, xxviii

Fuligula affunis, $43 \mathrm{~S}$

- americana, 430

cristata, 435

ferina, 429

ferinoides, 430

homeyeri, 430

- marila, 437, 735

— mariloïdes, 438

- nyroca, 433

- mina, $43 \mathrm{I}$

Fulmar, 7 I 1

Fulmarus, xxxix

Fulmanus glacialis, 7 I I

Gadwall, 4I3

GALLINE, xxx

Gallinago, xxxiy

Gallinago aruatorialis, 557

- calestis, 557

- sallimula, 559

-...- major, 555

Gallinula, xxxi

Gallinula chloropus, 503

_- galatea (read galeata), 504

nesiotis, 503

pyrmorrhoa, 503

sandricensis, $5 \mathrm{O}_{4}$

tenebrosa, 504

Gallinule [Green-backed], 504

[Martinique], 504

Olivaceous, 497

[Purple], 504

Gannet, 353, 734

Garden-IVarbler, 49

'Gare-fowl' (Great Auk), 68 I

Garganey, 423

Garrulus, xviii

Garrulus brandti, 226

cervicalis, 226

slandarizes, 225, 733

'Gaunt' (Great Crested Grebc), 70I

GAVIE, xxxvi

Gecinus, $x x$

Gecinus canues, 264

- sharpii, 264

vaillanii, 264

viritis, 263

Geocichla, I I

Gelochetidon, 624

Giareola, xxxii

Glareola melanoptere, 5 IS
Glareola pratincolit, 517, 735

GLAREOLID I, xxxii, 5 I7

Glead, Gled (Kite), 325

Goatsucker, 258

Godwit, Bar-tailed, 607

- Black-tailed, 609

Grolden-eye, 439, 735

-_ [Barrow's], 439

Goldfinch, 165

Goosander, 459

Goose, Bean, 389,734

- Bernacle, 397

- Brent, 399

- [Canada], 400

- [Chinese], 390

- [Eyptian], 400

- Grey Lag-, 385

_L Laughing, 387

_ Lesser White-fronted, $38 S$

—_ Pink-footed, 39 I

— Red-breasted, 395

_ 'Road-,' 'Root-' (Brent), 400

_ Snow, 393

'Solan' (Gannet), 333

[Spur-winged], 400

'IVare' (Brent), 400

- White-fronted, 387,734

Gos-Hawk, 32 I, 336

- [American], 322

[Grackle, Americin Rustic], 216

Gracula religiosa, 2 I6

'Grass-chat' (Winchat), aS

Grasshopper-WVarbler, SI

Grebe, Black-necked, 707

— Eared, 707

- Great Crested, 7OI

—_ Horned, 705

Little, 709

- [Pied-billed, American], 7ro

_- Red-necked, 703

— Slavonian, 705

Greenfinch, $16 \mathbf{I}$

Greenshank, 605

Grey-hen, 479

Griffon-Vulture, 30I

Grosbeak, P'ine, I II Scarlet, IS9

Grouse, Black, 479

- Red, ${ }_{4} \mathrm{SI}$

Pallas's Sand-, 475, 735

Three-toed Sancl-, 476, 735

Wood-, 477

GRUID.J, xxxii, 507 
GRUs, xxxii

Grus commmis, 507

- virgo, 508

Guillemot, Black, 687

- Bridled, $68_{4}$

Briinnich's, 685

Common, 683, 736

Ringed, 684

Thick-billed, 685

Gull [American Laughing], 650

- Black-headed, 649

- Bonaparte's, 645

- Brown-headed, 649

- Common, 655, 736

- Glaucous, 663

—_ Great Black-backed, 66I

- Great Black-headed, 653

- Herring-, $657^{\circ}$

- Iceland, 665

- Ivory, 669

- Kittiwake, 667

- Lesser Black-backed, 659, 736

- Little, 647

- Mediterranean Black-headed, 65I 'Peewit,' 650

- Ross's, 644

- Sabine's, 64I

Wedge-tailed, 643

Gulls, Parasitic, 67I

Gyps, xxiii

Gyps fulvus, $30 \mathrm{I}$

- himalayensis, 302 kolbi, 302

' Hackbolt,' 7 I 5

'Hacket,' 'Hacklet,' 668

Hematopus, xxxiii

Hamatopres capensis, 544 ostralegus, 543

'Hagdown,' 715

Haltażtus, xxiii

Haliaëtus albicilla, $3 \mathbf{1 9}$

- lencocephalus, 320

HARELDA, xxviii

Harelda glacialis, 443

Harrier, Hen-, 307

- Marsh-, 305

_- Montagu's, 309 'Ring-tail,' 308

Hawfinch, 163

Hawk, Gos-, 32 I, 336

—_ 'Hunting,' 336

'Mullet-' (Osprey), 347
Hawk, 'Passage,' 335

—_ 'Red,' 335

- Sparrow-, 323

Hawk-Owl, 295

'Hay-bird' (Willow-Wren), 64

'Hazel Linnet' (Lesser Whitethroat), 44

'Heath-poult,' 479

Hedge-Accentor, 85

Hedge-Sparrow, 85

Helodromas, 596

[Hemipode, Andalucian], 492

Hen-Harrier, 307

HERODIONES, xxy

Heron, Buff-backed, 363

- Common, 355

- Great White, 359

- Night-, 367

- Purple, 357, 734

- Squacco, 365

Herring-Gull, 657

Hierofalco, 33I

'Hill Lintie' (Twite), I85

Iimantopus, xxxiv

Himantopus candidus, 547

HIRUNDINIDÆ, xv, 155

HIRUNDO, xv

Hirundo erythrogaster, I 55

- horreorum, I 55

—— rustica, I 55

- savignii, 156

Hobby, 337, 734

- Orange-legged, 339

'Hohltaube' (Stock-Dove), 469

'Holm-screech' (Mistle-thrush), 2

Honey-Buzzard, 329

Hoopoe, 275

House-Sparrow, I 7 I

'Huldue' (Stock-Dove), 469

HYDROCHELIDON, XXXVi

Hydrocheliáon hybrida, $62 \mathrm{I}$

_- leucoptera, $6 \mathbf{I 9}$

- nigra, $6 \mathbf{I} 7$

HypolaIs, xii

Hypolais icterina, 69, 732

- polyglotta, 70

Hypotriorchis, 337

IBIDID E, xxvi, 379

Ibis, Glossy, 379

'Immer-Goose,' 693

[Indian Mynah], 216

IYYNGIN E, xx, 26I 
$\mathrm{I} \ddot{\mathrm{Y} N \mathrm{NX}} \mathrm{xx}$

Jünx torquilla, 26 I

Jackdaw, 229

Jay, 225, 733

Kestrel, 343

Lesser, 345

King Eider, 449

Kingfisher, 269

- [Belted], 270

Kite, 325

- Black, 327

__ [Black-winged], $32 \mathrm{~S}$

'Red,' 325

[Swallow-tailed], $32 \mathrm{~S}$

Knot, 58 r

LAGOPUS, xxx

Lagopus albues, $48 \mathrm{I}$

… hemitizucums, $4 \mathrm{~S}_{4}$

- mutus, 483

- nupestris, 484 scoticus, $48 \mathrm{I}$

Land-Rail, 493

LANIID A, xiv, I39

LANIUS, xiv

Lanizes algeriensis, $\mathbf{1} 40$

—_ollurio, I43

_- excubitor, 139

- homeyeri, $\mathbf{1 4 0}$

- leucopteruse, 139

- major, I39

- meridionalis, $\mathbf{1} 40$ minor, I4I

- pomeramis, I45

Lapwing, 539

LARIDE, xxxvi, 6I?

Lark [Calandra], 248 Crested, 243

- Shore-, 249

- Short-toed, 245

White-winged, 247

LARUS, xxxvii

Larzes affinis, 658

- argentatus, 657

- atricilla, 646

- barrovianus, 66.4

- brachyrluynchus, 656 brunneicephahus, 650 cachinnans, 657 canues, 655,736

- delawarensis, 656
Larus dominicanus, 660

- fuscus, 659,736

- selastes, 652

- slauciscens, $66_{4}$

- slaucus, $66_{3}$

- Mutchinsi, $66_{4}$

- ichthyaitus, 653

- Kumlieni, 664

- leucopterus, $66_{5}$

— marimus, 66 1

-.. melanocephalus, 651

—_ minutus, 647

- nilsoni, 664

- occidintalis, 660

- philadiphia, 645

—- ridibundus, 649 schistisagus, 662

LIGURINUS, XV

Ligurinus aurantiienteris, 162

Chloris, $\mathbf{1} 6 \mathbf{I}$

- chloroticus, 161

sinicus, 162

LIMIICOLA, xxxy

LIMICOLA; xxxii

Limicola platyrhyncha, 563

Limnocryptes, 560

Limosa, xxxvi

Limosa asoceptrala, 610

-_..-belgica, 609

- hudsonica, $6 \mathrm{IO}$

—_apponica, 607

- milanuroüdes, 6 10

-uropygialis, 608

Linaria canescens, ISI

'Ling-bird' (Aleadow-l'ipit), I 25

Linnet, 179

- Brown, 179

- Green, I6I

- Grey, 179

'Hazel-' 44

Mountain, I \$5

Red, I79

'Liver,' 379

LOCUSTELLA, xii

Iocustella lanciolata, S2

__ luscinioide's, $S_{3}$

- Maria, S1

- stramineia, $\mathrm{S}_{2}$

Loon, 701

Loxis, xvii

Loxia lifasciata, 195

- curirostra, 193, 733 liucoptcra, 195 
Loxia pityopsittacus, 194, 733

'Lyrie' (Manx Shearwater), 7 I9

Machetes, $\mathrm{xxxy}$

Machetes pugnax, 585

Macrorhamphus, xxxiv

Macrorhamphus grisezes, 561, 736

Magpie, 227

Mallard, 4 I I

Mareca, xxviii

Mareca americana, 427

- penelope, 425

'Marrot' (Guillemot), 684

Marsh-Harrier, ,305

'Marsh-Terns,' 61 7, 622

Marsh-Titmouse, 99

Marsh-Warbler, 73

Martin, House-Martin, 157

- [American Purple], ${ }_{5} \mathrm{~S}$

- Sand-, 159

Mavis, 3, 'Mawvis,' 4

'May-bird' (Whimbrel), 6I 3

Meadow-Pipit, 125

Melanocorypha, 248

Merganser, Hooded, 465

- Red-breasted, 46 I

Mergulus, xxxviii

Mergulus alle, 689

Mergus, xxix

Mergus albellus, 463

- cusullatus, 465

- merganser, 459 serrator, 461

Merlin, 34I

MEROPIDA, $x x, 273$

Merops, $\mathrm{xx}$

Merops apiaster, 273

-.-persicus, 274

- philippinus, 274

Milvus, xxiv

Miluns cegyptizes, 326, 328

- govinda, 328

- ictinus, 325

melanotis, 328 migrans, 327

Missel-Thrush (lege Mistle-Thrush), I

Mistletoe-Thrush, 2

[Mocking-Bird], 70

'Mollimoke '(Fulmar), 7 I 2

Monticola, x

Monticola cyanus, I7, 18

- saxatilis, I7

Moor-Buzzard, 305
Moor-hen, 503

'Morillon' (Golden-eye), 439

'Moss-cheeper' (Meadow-Pipit), r25

Motacilla, xiv

Motacilla alba, II 5

— borealis, I 20

- cinereicapilla, 120

- feldegri, 120

- fava, I 19

- lugubris, II 3

- melanocephala, $\mathbf{2} 20$

- melanope, 117

- paradoxa, I20

- raii, $12 \mathrm{I}$

- taivana, I22

- viridis, 120

- xanthophrys, I2O

- yamilli, $\mathrm{I}_{3} 3$

MOTACILLID E, xiv, II3

'Mother Carey's Chickens,' 728

Mountain-Finch, I 77

'Mullet-Hawk' (Osprey), 347

'Mulrooken ' (Gt. Crested Grebe), 7o I

'Murre,' 684

Muscicara, xv

Muscicapa atricapilla, I5I

- collaris, 152

_- grisola, 149

-. parva, $\times 53,732$

MUSCICAPIDE, xv, I49

'Mussel-picker' (Oyster-catcher), 543

Neorhron, xxiii

Neophron percnopterus, 303

'Nettle-creeper,' 42

'Night-hawk' (Nightjar), 258

Night-Heron, 367

Nightingale, 39

Nightjar, 257

- Egyptian, 260 Isabelline, 260

- Red-necked, 259

'Noddy,' 712

Nucifraga, xviii

Nucifraga caryocatactes, 223

- hemispila, 224

- multipunctata, 224

Numenius, xxxvi

Numenius arquata, 6 I I borealis, 6I 5 cyanopus, 61 2 hudsonicus, 6I 4 lineatus, 612 
Numenius lonsirostris, 6 I2

- minutus, 616 phaopus, 6I 3

- temuirostris, 612

- variegatus, 6I4

'Nun' (Smew), 463

Nutcracker, 223

'Nuthack,' 106

Nuthatch, I05

' Nutjobber,' Io6

Nyctala, xxii

Nyctala acadica, 290

- richardsoni, 290 tengmalmi, 289

NycteA, xxii

Nyctea scandiaca, 293

Nycticorax, xxy

Nycticorax caledonicus, 368 griseus, 367

OCEanites, $x 1$

Ocranites oceanicus, 729

Oceanodroma (see Errata)

Oceanodrona lincorraoa, 725

ODONTOGLOSSE, Xxvi

CEDEMIA, xxix

Edemia americana, 454

- fusca, 455

- nigra, 453

- perspicillata, 457

-.. veluetina, 456

CEDICNEMID E, xxxii, 515

QEDicnearus, xxxii

Edicnemus affunis, 516

- capensis, $5 \mathbf{1 6}$

- - scolopax, 515

CEstrelata, xxxix

Estrelata hesitata, 713

'Old Squaw,' 444

Oriole, Golden, 137

ORIOLID $\mathrm{E}$, Xiv, 137

OrIOlus, xiv

Oriolus galbula, I 37

- kundoo, $\mathrm{I}_{3} 8$

Ortolan, 205, 733

Osprey, 347

OTIDID E, xxxii, 509

OTIS, xxxii

Otis dyboziskii, 510

- macqueni, $5^{1} 3$

tarda, 509

tetrax, 5 I I

unilulate, $5 \mathrm{I} 3$
OTOCORYS, xix

Otocory's alpistris, 2.49

- bilophar, 250

- longirastris, 250

- penicillata, 249

- peregrina, 250

Ouzel, Ring-, I 5, 73 I

—, Water-, 89

'Oven-bird' (Willow. Wren), 64

Owl, liarn-, 2SI

- Brown, 287

— Church-, 2SI

—_Eagle-, 299

- I Iawk-, 295

_Little, 29I

- Long-eared, $28_{3}$

- Scops-, 297, 734

- Short-eared, 285

— Snowy, 293

- Tawny, 287

- Tengmalm's, 289

— White, 2SI

Wood-, $2 S_{7}$

__ 'Woodlcock-', 285

'Ox-bird,' 570

'Oxeye' (Gt. 'Titmouse), 95

Oyster-catcher, $5+3$

PAgOPhila, xxxyii

Pagophila dinmeda, 609

Pandion, xxiv

Pandion haliaitus, 347

PANURID.E, xiii, 9I

P'ANURUS, xiii

l'anumus biarmicus, 9I

PARIDK, xiii, 93

Partridge, Common, 487

- [Barbary], 490

_ 'French,' 489

- Grey, 487

— Recl-legged, 4 S9

PARUS, xiii

I'arus alcer, 97

— borealis, 100

- britannicus, 97

- cieruleuts, 101

- cristatus, $\mathrm{IO}_{3}$

- cyctmus, 102

- cyrioles, 95

- Midourit, $9 \mathrm{~S}$

- Iusuliris, 100

— major, 95

— michalouslit, os 
Parus minor, 95

- palustris, 99
- persicues, IOI
- pleskiz, IO2
teneriffi, IOI
ultramarimus, IOI

[Passenger-Pigeon], 474

PASSERES, $x$

PASSER, xvi

Passer domesticus, I7 I

— Mispaniolensis, I72

- indicus, I 7 I

- italice, $17 \mathrm{I}$

- montanus, 173

_ - var. malaccensis, I74

Pastor, xviii

Pastor rosezes, 219

'Peep,' 568

Peewit, 539

'Peewit-Gull,' 650

PELECANID E, xxiv, 349

Perdix, $\mathrm{xxx}$

Perdix barbata, 488

- cinerea, 487

Pernis, xxiv

Pemis apizonus, 329

- ptilorhynchus, 330

Petrel, Bulwer's, 723

- Capped, 7I3

Fork-tailed, 725

- Leach's, 725

- Storm-, 727

— Wilson's, 729

Pitalacrocorax, xxiv

Phalacrocorax carbo, 349

- desmaresti, $35^{2}$

- graculues, $35 \mathrm{I}$

-.. nove-Yollandia, 350

Phalarope, Grey, 549

—_ Red-necked, 55I

Phalaropus, xxxiv

Phalaropus fulicarius, 549

hyperborezus, 55 I

vilsoni, $55^{2}$

PHASIANID E, xxx, 485

Phasianus, xxx

Phasianus colchicus, 485

- reevesi, 486

- torquatus, 485

Pheasant, 485

PHCENICOPTERID E, xxvi, $38_{3}$
Phenicopterus, xxvi

Phonicoptemes roseus, $38_{3}$

Phylloscopus, xii

Pliylloscopus bonellii, 66

- Inumii, 60

- proregulus, 60

- rufus, $6 \mathrm{I}$

- sibilatrix, 65

— supercilioszes, 59

- tristis, $6 \mathbf{I}$

- trochilus, 63

PICA, xviii

Pica mantritanica, 228

- muttalli, 228 mestica, 227

PICARIE, xix, 25 I

I'ICII). I, XX

PICINE, $\mathrm{xx}, 263$

Picoüdes tridactylues, 268

Picus martius, 268

Pigeon [American Passenger-], 474

- 'Cape,' 7 I 4

— Wood-, 467

Pine-Grosbeak, I9I

Pinicola, 192

Pipit, Meadow-, 125

- Red-throated, I27

Richard's, I3I

Rock-, 135

- Tawny, I29

-Tree-, 123

W Water-, 133

Platalea, xxvi

Platalea leucorodia, 38 $\mathbf{I}$

_- temirostris, 382

PLATALEIDE, xxvi, $3{ }^{8}$ I

Plectroplianes, xvii

Plectrophenax, xvii

Plectrophenax nivalis, 215

Plectropterns gambensis, 400

Plegadis, xxvi, 379

Plegadis falcinellus, 379

- guarauna, $3^{80}$

Plover, Golden, 53 I

- - Grey, 535

Kentish, 527

Killdeer, 529

Lesser Golden, 533

Little Ringed, 525

- Norfolk, 5 I 5

Ringed, 523

Sociable, 537

Pochard, 429 
Iochard, 'Paget's,' 43 '

Red-crested, 43I

PODICIPEDIDE, xxxviii, 70I

Podicipes, xxxviii

Palicipe's auritus, 705

— califormicus, 708

cristatzes, 701

fluviatilis, 709

sriseigena, 703

- nisricollis, 707

Podilymbus podicips, 7 Io

'Poker,' Red-eyed, red-headed, 429

Porphyrio carulezs, 504

- martinicus, 504

-.. smaragitonotus, 504

Porzana, xxxi

Poracna bailloni, 499

- carolina, 496

maruetta, 495 parva, 497

'Poule de Carthage,' 512

PRATINCOl.A, xi

Pratincola hemprichi, 2)

- matrar, 29

- nubitra, 27

- nubicola, 29

torquata, 29

Pratincole, 5I 7, 735

Procellaria, xxxix

Procellaria bulueri, 723

— pelasica, 727 wilsoni, 729

PROCELLARIID E; , xxxix, 7 II

Progne purpurea, I 58

Ptarmigan, $4 \delta_{3}$

PTEROCLETES, xxix

PTEROCLID E, xxix, 475

P'uffin, 69I

'Puffin of the Isle of Man,' 719

Puffinus, xxxix

Puffinus anglorum, 719

- borcalis, 716

sriscus, 717

- kuhli, 716

— major, 715

- obscurtes, $72 \mathrm{I}$

- yelkouan, 720

'Purga-bueyes,' 364

'Purre,' 570

Pyenonotzes capensis, 136

PYGOPODES, xxxviii

PYRRIOCORAX, xviii

Pyrricocorax alpinus, 222
Pyrrhocorax sraculus, 221

Pyrriuld, xvii

I'yrrhula enucliator, IOI

- erythrina, is9

- izropaca, 187

—- major; 187

- murinus, ISS

Pyrrhulorhyncha, 2 I2

Quail, 49I

(Uueest, 467

QuerquedulA, xxviii

Querquilula carolininsis, 420, 421

- circia, 423

- crecca, 419 discors, 422

Kail, Land-, 493

-... Water-, 50 I

- Rain-bird' (Green Woodpecker), 264

'Rain-Goose' (G. N. Diver), 700

RALLID $\mathrm{E}, \mathrm{xxxi}, 493$

Rallus, xxxi

liallus aquaticus, 50 I carulescens, 502

'Rattle-wing' (Golden-cye), 4.40

Raven, 23I

Razor-bill, 679

RECURVIROSTRA, xxxiv

licurvirostra avocetta, 545

Redbreast, 37

'Red craking reed-wren,' $S_{4}$

Redpoll, Lesser, $\mathrm{I}_{3}$

-_. Mealy, I $8 \mathbf{I}$

'Stone-', I 82

Redshank, Common, 601

_.. Dusky, 603

__ Spotted, 603

Redsiart, 31, 731

_. Black, 33, $73 \mathbf{1}$

kedwing, 5

Reed-Bunting, 2I I

'Reed-P'heasant' (Bearded Tit), 92

'Reed-Sparrow,' 2 II

Reed-Warbler, 71 Great, 75

'Reel-bird ' (Savi's Warbler), St

- Reeler' (Grasshopper Wiarbler), Si

Reeve, $58_{5}$

Regulus, xi

R'cumlus calcundula, $5^{S}$

-... cristalus, 55

___ var, aะoricus, 56 
Regulus cristatues var. japonicus, 56

— ignicapillus, 57

maderensis, 58

- modestus, 60

- toneriffer, $5^{8}$

RHODOSTETHIA, xxxvii

Rhodostethica rosea, 643

Rhyacophilus, 596

Ring-Dove, 467

Ring-Ouzel, I5, 73I

RissA, xxxvii

Rissa brevirostris, 668 tridactyla, 667

Robin, 37 [American], Io

Rock-Dove, 47 I

Rock-Pipit, I35

Rock-Thrush, 17

Roller, 271 [Blue], I 7, IS

-. [Abyssinian], 272

Rook, 237

'Rotche,' 'Rotge,' 689

Ruff, 585

Russet-Chat, 24

Ruticilla, xi

Ruticilla cairit, 34

- mesolenia, 32

ochrurzes, 32

- phanicurzts, 3I, 73I

_nufventris, 32

— suecica, $3^{6}$ titys, 33, 731

Sanderling, $5^{8} 3$

Sand-Grouse, Pallas's or Three-toed, 475,735

'Sand-lark,' 523

Sand-Martin, I 59

Sandpiper, Bartram's, 589

__ Bonaparte's, 567

_ Broad-billed, 563

— Buff-brensted, $5^{87}$

Common, 591

Curlew-, 577, 736

- Green, 595

L Least, 573

- [Marsh-], 606

- Pectoral, 565

_- Purple, 579

__ Solitary, 597

... [American Spotted], 592

_. Wood-, 593
SAXicola, xi

Saxicola albicollis, 24

- azcrita, 24

- deserti, 25, 73I

isabellina, $2 \mathbf{I}$

melanoleuca, 23

ananthe, 19

rufa, 24

stapazina, 23, 25, 26

'Scarf,' 'Scart,' 35 I

Scaup, 437, 735

[American or Lesser], 438

Scolecopliagzes fermengineus, 216

SCOLOPACID E, xxxiv, 545

SCOLOPAX, xxxiv

Scolopax rusticula, 553

'Scooper' (Avocet), 546

Scops, xxii

Scops asio, 298

- gize, 297,734

Scops-Owl, 297, 734

Scoter, Common, 453

- Surf-, 457

Velvet-, 455

'Scout' (Guillemot), 684

'Screecher' (Swift), 25I

'Sea-Parrot' (Puffin), 692

'Sea Pheasant' (Long-tailed Duck),

\section{7}

'Sea-Pie' (Oyster-Catcher), 543

'Sea-Snipe' (Dunlin), 570

'Sea-Swallows' (Terns), 628

Sedge-bird, 77 , infra

Sedge-Warbler, 77

— Great, 76

Serin, 169

Serinus, xvi

Serinus canaria, I70

- canicollis, 170

- canonicus, 169

- hortulanus, 169

- ictereses, I 70

-

'Seven Whistlers' (Whimbrel), 6I4

Shag, 35I

Shearwater, Dusky, 72 I

- Great, 715

- Manx, 7 I 9

Sooty, 7 I 7

'Sheld-Duck' (Merganser), 46 I

Sheld-Duck, Common, 407, 734

—— Ruddy, 409, 735 
'Shoeing-horn' (Avocet), 546

Shore-Lark, 249

'Shovelard,' 'Shoveler' (Spoonbill), $38 \mathrm{I}$

Shoveler (Duck), 4I 5, 735

Shrike, Great Grey, 139

— Lesser Grey, r4I

- Red-backed, 143

W Woodchat, 145

'Shuffle-wing' (Hedge-Sparrow), 85

[Siberian Thrush], 12

Siskin, I67

SitTA, xiii

Sitta cesia, 105

- cashmirensis, 106

- eleropiea, 105

- rupico!a, 106 7uhiteheadi, 106

SITTIDE, xiii, TO5

'Skidden' (Manx Shearwater), 7 I9

Skua, Arctic, 675

- Buffon's, 677

-_ Great, 671

___ Long-tailed, 677

- Pomatorhine, 673, 736

— Richardson's, 675

Skylark, 239

'Smee,' 463, infra

Smew, 463

—_ 'Red-headed,' 463

'Smokie (Hedge-Sparrow), 85

'Snake-Bird' (Wryneck), 262

Snipe, Common, 557

- Double, 555

Great, 555

- Jack, 559

- - Red-breasted, 56r, 736

Sabine's, $55^{8}$

' Sea-' (Dunlin), 570

Solitary, 555

Summer (Com. Sandpiper), 59I

Snow-Bunting, 215, 733

Snow-Goose, 393

'Solitary Thrush' (Starling), 218

Somateria, xxviii

Somateria dresseri, 448

- mollissima, 447

-v-nigrum, $44 \mathrm{~S}$

spectabilis, 449

- stelleri, $45 \mathrm{I}$

Song-Thrush, 3

'South-southerly' (Long-tailed D.),
Sparrow-Hawk, 323

Sparrow, Hedge-, $S_{5}$

—- House-, I7 I

- Tree-, 173

- [White-throated-], I 70

Spatula, xxvii

Spatula clypeata, 415.735

'Spear-WVigeon' (Merganser), 46r

'Spink' (Chaffinch), I76

'Spirit-Duck' (Buffel-headed D.) 415

Spoonbill, $38 \mathrm{r}$

'Spoonbill' (Shoveler Duck), 415

'Spottvogel,' 7o

'Sprosser,' 40

Squatarola, xxxiii

Squatarola helvetica, 535

Starling, 217

- [American Resl-winged], $2 \mathbf{1} 6$

- [Meadow], 216

Rose-coloured, 219

STEGANOPODES, xxiv

StercorariUs, xxxvii

Stercorarius antarcticus, 672

— catarrhactes, $67 \mathrm{I}$

- chilensis, 672

crepidatus, 675

parasiticus, 677

- pomatorhizizes, 673, 736

STERNA, xxxvi

Sterna acuflavida, 628

-..-ancestheta, 638

- anslica, 623

- antillarum, 636

- bergii, 640

- cantiaca, 627

caspia, 625

dongalli, 629

— Auviatilis, 631,736

- fuliginosa, 637

- longifennis, 634

macrotarsa, 624

macruma, 633, 736

minuta, 635

sinensis, 636

- superciliaris, 636

- tibetana, 632

- velox, 640

Sternula, 636

Stilt, Black-winged, 547

Stint, American, 573

— Little, 571

Temminck's, 575

Stock-Dove, 469 
Stonechat, 29

Stone-Curlew, 5 I 5

'Stone-hatch' (Ringed Plover), 523

'Stone-Redpoll,' I 82

Stork, Black, 377

White, 375

'Storm-cock' (Mistle-Thrush), 2

Strepsilas, xxiiii

Strepsilas interpres, 54 I

- melanocephalus, 542

STRIGES, xxi

STRIGIDÆ, xxi, 28I

STRIX, xxi

Strix flammea, $28 \mathrm{r}$

- passerina, 292

Sturnella magna, 216

STURNID E, xvii, 217

STURNUS, xvii

Sturmus purpurascens, 2I8

- unicolor, $2 \mathrm{I} 8$

vulgaris, 217

SulA, xxiv

Sula bassana, 353, 734

capensis, 354

Surf-Scoter, 457

SURNIA, xxii

Sumia doliata, 296

- funerea, 295

- ulula caparoch, 295

Swallow, 155

- [American Tree-], 158

Swan, Bewick's, 403

- Mute, 405

[Polish], 406

Tame, 405

[Trumpeter], 404

-Whistling, 40I

Wild, 40I

Swift, 25 I

- Alpine, 253

- Needle-tailed, 255

Sylochelidon, 624

Sylvia, xi

Sylvia affinis, 44

- althea, 44

- atricapilla, 47

- cinerea, $4 \mathbf{I}$

- conspicillata, 42

curruca, 43

fuscipilea, $4 \mathbf{1}$

hortensis, 49

jerdoni, 46

minuscala, 44
Sylvia nisoria, 51, 732

-_orphea, 45

- $\operatorname{sarda}, 54$

- zudata, 53

Syluirne, xi, 4 I

SYRNIUM, xxii

Syrnium aluco, 287

nivicolum, 288

Syrrhaptes, xxix

Syrrhaptes paradoxus, 475, 735

- thibetams, 476

Tachycineta bicolor, I 58

TADORNA, xxvii

Tadoma cana, $4 \mathrm{IO}$

- casarca, 409, 735

- comuta, 407, 734

' 'Tangle-picker' (Turnstnne), 542

'Tarrock' (Kittiwake), 668

'Tassel,' 336

Teal, 4 I9

_ Blue-winged, 422

'Cricket,' 424

_- Green-winged, 42 I

—_ Summer-, 423

Tern, Arctic, 633, 736

- Black, 617

- Caspian, 625

- Common, 631, 736

- Gull-billed, 623

- Little, 635

— Noddy, 639

- Roseate, 629

— Sandwich, 627

- Sooty, 637,

—_ [Smaller Sooty], 638

[Swift], 640

Whiskered, 62I

—_ White-winged Black, 6 I9

Terns, Marsh-, 622

TETRAO, xxx

Tetrao tetrix, 479

— urogalloïdes, 478

zerogallues, 477

TETRAONIDE, $\mathrm{xxx}, 477$

Thicknee, $5^{\text {I } 5}$

Throstle, 3

Thrush [American Migratory], ro

— Black-throated, 9, 73I

-_ [Blue Rock-], I7, I8

_ 'Golden,' I2

- [Gold-vented], I 36 Missel-(lege Mistle-), I 
Thrush, Mistletoe-, 2

- Rock, 17

- [Siherian], I2

- Song-, 3

White's, I I

TICHODROMA, xiv

Tichodroma meraria, II I, 732

'Tiercel,' 336

'Tinkershere' (Guillemot), 68+

Tit-lark, 'Titling,' I 25

Titmouse, Bearded, gI

- Blue, Ior

Coal-, 97

Crested, I03

Great, 95

__ Long-tailed, 93

_- Marsh-, 99

'Titterel' (Whimbrel), 6I

'Tolk,' 'Took,' 602

Totanus, xxxy

Totanus calidris, 6 ก

- canescins, 605

- flavipe's, 599

fuscus, 603

-... Slaniola, 593

- hypoliucus, $59 \mathrm{I}$

- macularizes, 592

ochropus, 595

solitarius, 597

stagnatilis, 606

Tree-Creeper, 109

Tree-Pipit, I 23

Tree-Sparrow, I 73

TRINGA, XXXY

Tringe acuminate, 565

_ـ alpina, 569

- canutus, $58 \mathrm{I}$

- coutesi, 580

crassirostris, $5 \mathrm{~S} 2$

fuscicollis, 567

maculata, 565

minuta. 57 I

minutilla, 573

pilocnemis, 580

pusilla, 573

meficollis, 572

schinzi, 567, 570

striata, 579

subarquala, 577,736

timmincki, 575

Troglonytes, xiii

Troglodytes bergensis, 10 : borialis, 107
Troslodyte's hivtinsis, 107

- pallidus, 108

— parvulus, 107

TROGLODYTID E, xiii, ro

TrRygites, Xxxv

Tryngites rufescents, $5 S_{7}$

TUBINARES, Xxxix

TURDIDE, $x$

TURDIXE, $x, I$

Turius, $x$

Turdus alpestris, 16

- atrigularis, 9, 731

- hadgsoni, 2

- iliacus, 5

- lunulatus, 12

- merula, $\mathrm{I}_{3}$

-... misyatorius, 10

- musicus, 3

- pilaris, 7

- muficollis, 10

- sibinius, 12

-... torquatus, 15, 731

- varizes, $\mathbf{I} \mathbf{I}$

- viscizortus, I

Tumix sylvatica, 492

Tumstone, 541

Turtle-Dove, 473,735

TURTUR, xxix

Turtur communis, 473, 735

-.. isabellinus, 474

- oriencalis, 474

-... risorius, 474

Twite, 185

'Tystie' (Black Guillemot), 68';

'Uinilo' (Smew), 464

UPUPA, xxi

Upupa ipsps, 275

UPUPID.E, xxi, 275

URIA. xxxviii

Uria brunnichi, 655

— carbo, $68 \mathrm{~s}$

- columba. 688

— grylle. $68_{7}$

—_ lomitia arra, 656

_-_ mandti, 68S

- troile, $68_{3}$

Urinator paciffus, 698

VANeldus, xxxiii

Vamellus gregarius, 537

-... vulgaris, 539

Velvet-Sicoter, 455 
'Verderolle,' 74

Vireo olivacents, 146

Vulture, Egyptian, 303 Griffon-, 301

VULTURID E, xxiii, 30I

'Wachholder-drossel ' (Fieldfare), S Wagtail, Blue-headed, II 9

—_ Grey, II 7, I22

- Pied, II 3

White, II 5

Yellow, I2I

Wall-Creeper, II I , 732

Warbler, Aquatic, 79

_L Barred, 51, 732

'Barred Willow, 60

1)artfurt. 53

Garden-, 49

Great Reed-, Great Sedge-, 75

Grasshopper-, SI

Icterine, 69, 732

- Marsh-, 73

- Orphean, 45

- Reed-, 7 I

Rufous, 67

Savi's, 83

Sedge-, 77

Thrush-like, 76

Yellow-browed, 59

'Water-blackbird,' '-colly,' '-crow,

'-ouzel' (Dipper), 89

Water-hen, 503

Water-Pipit, I33

Water-Rail, 50 I

Wiaxwing, I47

Wheatear, I9

- Black-throated, 23

- Desert, 25, 73I

- Isabelline, 2 I

'Whew-Duck,' 'Whewer' (Wigeon), 426

Whimbrel, 613

Whinchat, 27

'Whistler' (Golden-eye), 440

'Whitc-rumps' (Wheatears), 20

Whitethroat, Greater, 4I, 44

- Lesser, 43, 44

Whooper, $40 \mathrm{I}$

'Wide-awake' (Sooty Tern), 638

Wigeon, 425
Wigeon, American, 427

_- 'Spear' (Merganser), 46r

'Willock' (Guillemot), 684

Willow-Wren, 63

Windhover (Kestrel), 343

'Wood-ape' (Little Bittern), 370

Woodchat, I45

Woodcock, 553

' Woodcock-Ow1,' 285

Wood-Grouse. 477

Woodlark, 24I

Woodpecker [American Spotted] 268

- [Black], 268

- [Downy], 268

- [Golden-winged], 268

- Great Spotted, 265, 733

- Green, 263

-_- [Hairy], 266

- Lesser Spotted, 267

- [Middle Spotted], 266

-__ [Northern Three-toed], 268

- [White-backed], 266

Wood-Pigeon, 467

Wood-Sandpiper, 593

'Wood-Tattler,' 597

'Woodweele' (Green Woodpr.), 264

Wood-Wren, 65

Wren, 107

- Fire-crested, 57

- Golden-crested, 55

- [Ruby-crowned], 58

- [St. Kilda], IO7

—Willow-, 63

- Wood-, 65

'Writing-lark' (Yellow Bunting), 202

Wryneck, 26I

XeMa, xxxvii, 654

Xema furcata, 642 sabinizi, 64I

'Yaffle' (Green Woodpecker), 264

Yellow-Hammer, 20I

'Yellow-neb Lintie' ('Twite) I 85

Yellowshank, 599

'Yelper' (Avocet), 546

'Zizi' (Cirl Bunting), 204

Zonotrichia albicollis, I7o 







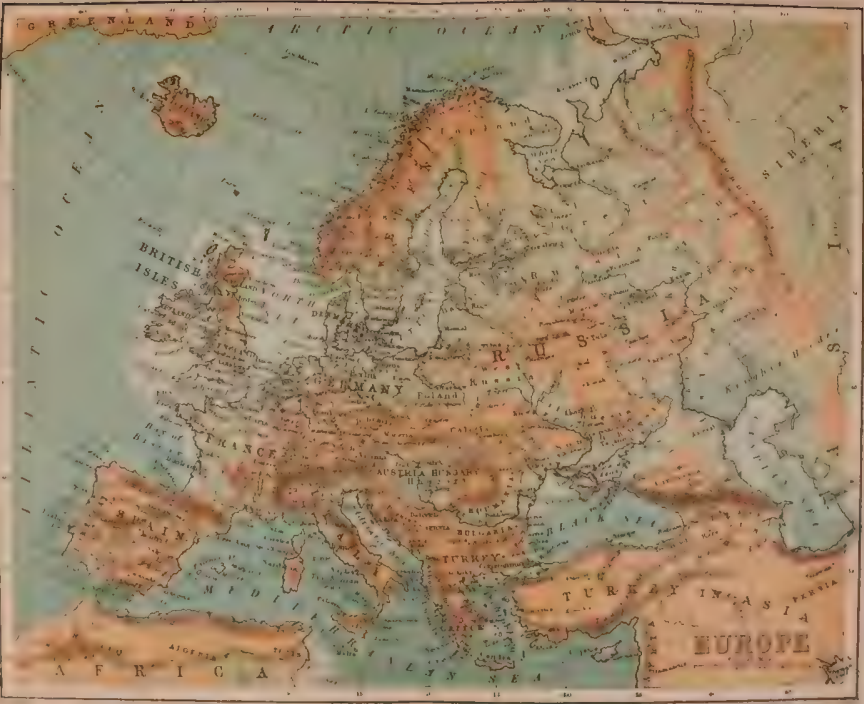







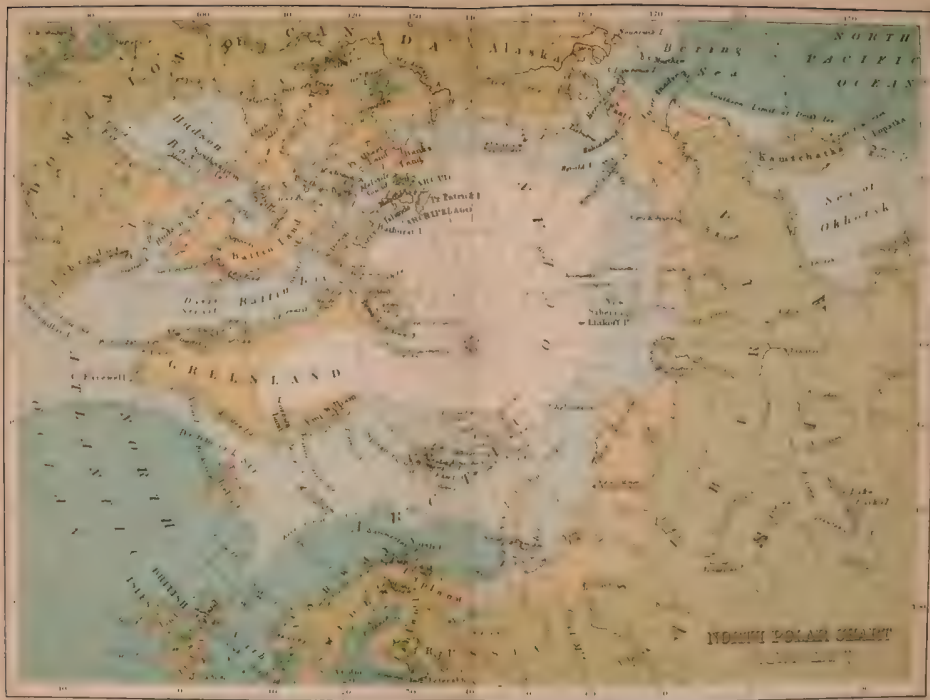







\section{ILLUSTRATED MANUAL}

OF
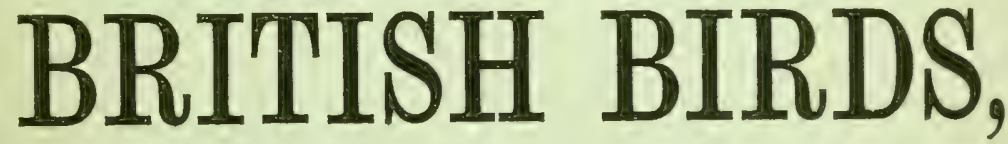

BY

Howard SAUNdERS, F.L.S., F.Z.S., \&C.,

Editor of the Third ANd Fourth Volumes of "Yarrell's History of British Birds," FOURTH EDITION.

WITH ILLUSTRATIONS OF NEARLY EVERY SPECIES.

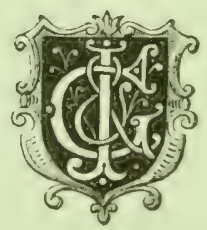

LONDON :

GURNEY \& JACKSON, I, PATEROATHR ROW.

(SUCCESSORS TO Mr. VAN VOORST.) 


\section{REMARKS AND ADDITIONS.}

$-0-$

THE following Remarks are in answer to correspondents :-

The scientific arrangement followed in this work is mainly in accordance with that of 'The List of British Birds compiled by a Committee of $t$ )" British Ornithologists' Union,' in which, again, the sequence is almost identical with that in Mr. Dresser's 'Birds of Europe.' Whatever may be the differences of opinion respecting the relative position of some of the Families in the Order Passeres, authorities in Europe and America are fairly agreed that the highest Avian development is attained in that Order, which should, therefore, occupy the first place in a descending arrangement or the last in an ascending one. By following the scheme so sanctioned, we at least make some approach to uniformity, and to this end I have, in the Passeres, subordinated my own views to those of the majority on unessential points.

It should be remembered that this work is only a Manual, intended to convey as much information as may be practicable in one volume; but those who require a greater amount of detail than is consistent with the plan of limiting each species to 2 pp., must be referred to "Yarrell's History of British Birds," 4th Edition.

The characteristics of the Orders, Families and Genera will be given in the Introduction.

Round lrackets. indicate that the describer of the species did not employ the generic name now adopted. the tail.

The length of a bird is measured from the base of the bill to the tip of

DESERT WHEATEAR. - Since the article was printed, a bird, apparently a young male, was shot near Arbroath on December 28 th, 1887 , and exhibited at a meeting of the Zoological Society of London on March 6th, 1888, on behalf of Lt.-Col. H. M. Drummond Hay, who published details in 'The Ibis,' I 888 , p. 283.

REDSTART,-I have lately received satisfactory evidence that this species bred and reared its young at Powerscourt, co. Wicklow, in the summer of 1885 ; while several examples of this hitherto rare visitor to Ireland were obtained in $\mathrm{I} 886$.

H. S. 







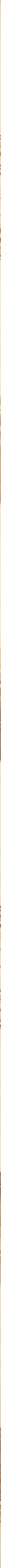




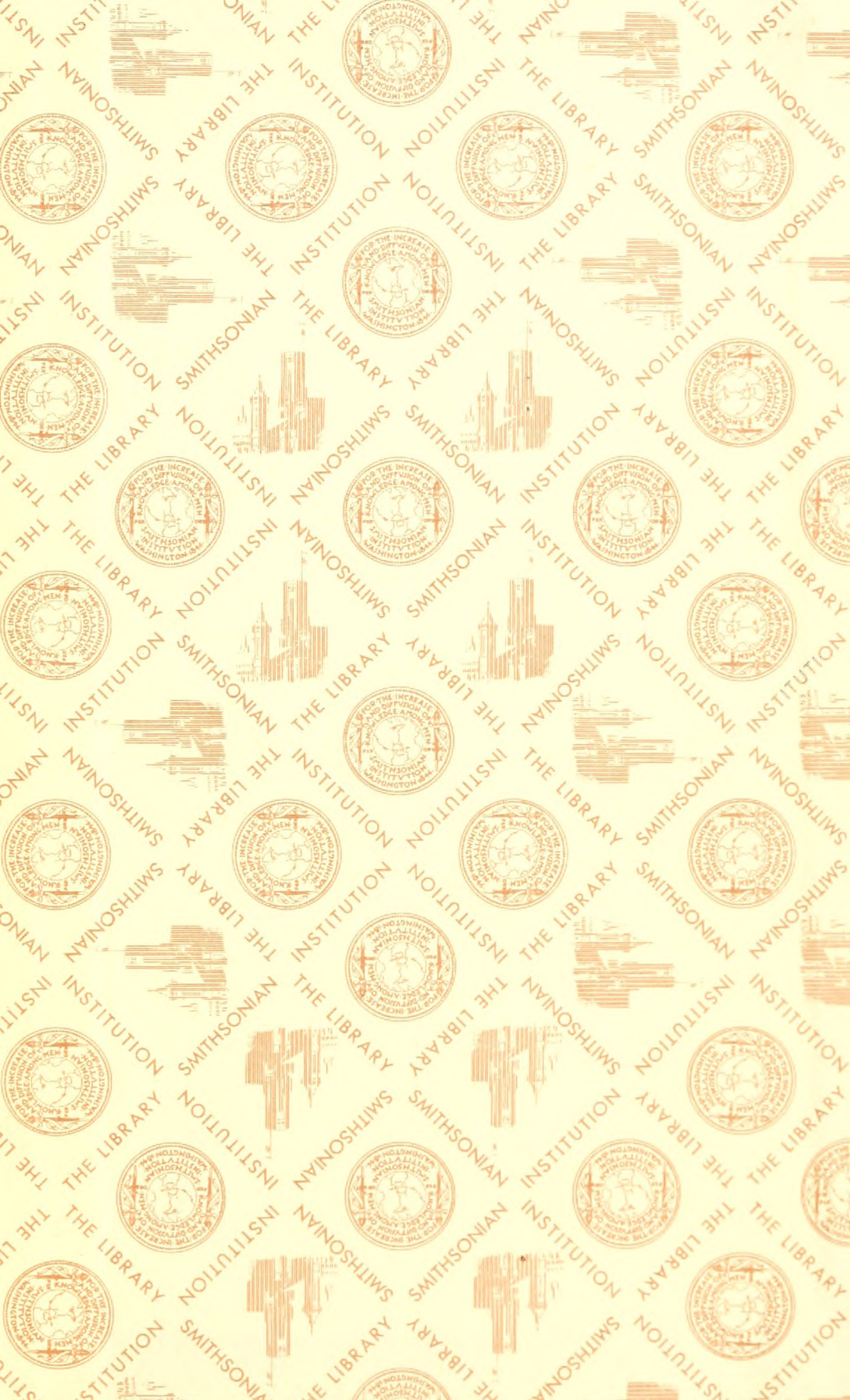


SMITHSONIAN INSTITUTION LIBRARIES

nhbird QL690.G7\$35

An illustrated manual of British birds. 